




\section{anales}

de la unínersidad

de alicante

\section{historia mediedal}




\section{ANALES DE LA UNIVERSIDAD DE ALICANTE HISTORIA MEDIEVAL}

Coordinador: Juan Antonio BARRIO BARRIO

Director: José HINOJOSA MONTALVO

Secretaria: María Luisa CABANES CATALÁ

Comité de Redacción:

Ramón BALDAQUÍ ESCANDELL Juan Antonio BARRIO BARRIO María Desamparados CABANES PECOURT José Vicente CABEZUELO PLIEGO Juan Manuel DEL ESTAL. Miguel Ángel LADERO QUESADA Verónica MATEO RIPOLL Ángel-Luis MOLINA MOLINA

SECRETARIADO DE PUBLICACIONES

UNIVERSIDAD DE ALICANTE 


\author{
JUAN ANTONIO BARRIO BARRIO \\ JOSÉ VICENTE CABEZUELO PLIEGO \\ JUAN FRANCISCO JIMÉNEZ ALCÁZAR, eds.
}

\title{
Congreso Internacional
}

\section{Jaime II}

\section{años después}

Actas

ALICANTE

1997 


\section{ÍNDICE}

\section{PONENCIAS}

\section{Emili BALAGUER I PERIGÜELL}

Arnau de Vilanova. La medicina, la ciencia y la técnica en tiempos de Jaime II

Humberto BAQUERO MORENO

Relações entre os reinos peninsulares (1290-1330) ................................. 29 Juan Antonio BARRIO BARRIO

Las rentas reales en la procuración de Orihuela, 1305-1324 Agustín BERMÚDEZ AZNAR

Una perspectiva jurídica sobre la donación del reino de Murcia a Jaime II de Aragón José Vicente CABEZUELO PLIEGO

El poder real en la Murcia aragonesa a través del oficio de la procuración, 1296-1304

Francisco Javier DÍEZ DE REVENGA

Don Juan Manuel: realidad textual y originalidad creadora Odico ENGELS

Las monarquías. Europa Occidental en la transición del s. XIII al s. XIV .... Juan Manuel DEL ESTAL GUTIÉRREZ

El itinerario de Jaime II de Aragón en la conquista del reino castellano de

Murcia (1296-1301)

Maria Teresa FERRER I MALLOL

Els sarraïns del regne de Múrcia durant la conquesta de Jaume II (1296-1304) Manuel GONZÁLEZ JIMÉNEZ

La sucesión al trono de Castilla: 1275-1304 ... José HINOJOSA MONTALVO

Las fronteras del Reino de Valencia en tiempos de Jaime II Juan Francisco JIMÉNEZ ALCÁZAR

La frontera occidental del Reino de Murcia en el contexto de la intervención

aragonesa: defensa y repoblación (1270-1340).

Miguel-Ángel LADERO QUESADA

La situación política de Castilla a fines del siglo XIII 
Ángel Luis MOLINA MOLINA

El Reino de Murcia durante la dominación aragonesa (1296-1305)

Regina SAINZ DE LA MAZA LASOLI

Los Santiaguistas del Reino de Murcia durante la ocupación aragonesa (1296-1304)

Esteban SARASA SÁNCHEZ

El reino de Aragón en la época de Jaime II (1291-1327)

Juan TORRES FONTES

Problemática Murcia-Don Juan Manuel en la minoría de Alfonso XI

Yom TOV ASSIS

Jaime ll y los judíos en la Corona de Aragón

Francisco de Asís VEAS ARTESEROS

La población de Lorca en la época de Jaime II. Aproximación a su estudio ..

\section{COMUNICACIONES}

\section{El contexto mediterráneo}

Juan Antonio BARRIO BARRIO, José Vicente CABEZUELO PLIEGO y José HINOJOSA MONTALVO

La contribución de la Procuración de Orihuela en la conquista de Cerdeña .. Andrés DÍAZ BORRÁS

Los antecedentes trecentistas del Corso murciano. Las vinculaciones del corsario Martín Sánchez con las autoridades de Valencia en las postrimerías del reinado de Jaime el Justo

Gabriel GONZÁLEZ MAURAZOS

La documentación diplomática entre la Corona de Aragón y el Sultanato Mameluco durante el reinado de Jaime II: Un ejemplo de las transformaciones en las relaciones internacionales del ámbito Mediterráneo en la Baja Edad Media

Mª Dolores LÓPEZ PÉREZ

De nuevo sobre la "guerra del Estrecho»: la contribución financiera del reino de Valencia en la última fase del conflicto (1332-1344) Miguel MARZAL GARCÍA-QUISMONDO

La perspectiva catalano-aragonesa de D. Jaime de Sicilia Josefina MUTGÉ I VIVES

Activitat piràtica entre catalano-aragonesos i castellans a la mediterrània occidental durant el regnat de Jaume II

Pedro Carlos PICATOSTE NAVARRO

Intereses transalpinos de Jaime II en la época de la conquista del Reino de Murcia. La donación de los calatravos al Infante Juan en 1304 
Rica AMRÁN-TEDGHI

El papel de Ceuta en la política exterior de Jaime II de Aragón

Roser SALICRÚ I LLUCH

Notícies de Genovesos al regne de Múrcia al tombant del segle XIII .....

Consuelo VARA IZQUIERDA

Relaciones políticas y comerciales de Jaime II de Aragón

Mercè VILADRICH

Noves dades sobre les relacions entre el soldà del Caire al-Nāșir Muḥammad

Ibn Sayf al-dīn Qalāwūn i el rei Jaume II

\section{La Corona de Aragón y los Estados peninsulares}

\section{Carlos BARQUERO GOÑI}

Actuaciones de Jaime II en las encomiendas hospitalarias de la Castellanía de Amposta: una aproximación

José María DE FRANCISCO OLMOS

Jaime II y la "Constitución» de la Corona de Aragón

Antonio LINAJE CONDE y Adela TARIFA FERNÁNDEZ

Sobre el concepto y la evolución de la frontera en los reinos hispánicos peninsulares. Entre Úbeda y Sepúlveda

\section{La Frontera en los reinos de Murcia, Valencia y Granada}

Clara ALARCÓN RUIZ, Julio NAVARRO MOLTÓ y Rafaela VIDAL FERNÁNDEZ

Capítulos entre Murcia y Orihuela: relaciones de Frontera (1427)

Concha ALFARO BAENA

Castril: de Hișn frontero a señorío bajomedieval

Presencia de navarros y vascos en la repoblación del reino de Murcia ......

$M^{a}$ Desamparados MARTíNEZ SAN PEDRO

Jaime II y la cruzada de Almería

Enrique VARELA AGÜÍ

La estructura castral santiaguista en la Sierra de Segura durante el

siglo XIII: aproximación a su tipología

Carles VELA I AULESA

Per ço com gran fretura és de vianda en la nostra host. L'avituallament de

l'exèrcit de Jaume II en la campanya de Múrcia (1296)

\section{Las repercusiones de la intervención de Jaime II en el reino de Murcia}

\section{Antonio CARRASCO RODRÍGUEZ}

Los orígenes del pleito del Obispado de Orihuela (siglos XIII-XIV) 
Francisco de MOXÓ Y MONTOLÍU

¿Torrellas o Torrijos? En torno a la ubicación de la Sentencia de $1304 \ldots . .$. 643 Enrique CUTILLAS BERNAL

La Feria de Alicante (1296-1804)

$M^{\text {a }}$ Magdalena MARTÍNEZ ALMIRA

Derechos y privilegios de los mudéjares de las tierras alicantinas en la documentación de Jaime $\|$

Don Juan Manuel y Arnau de Vilanova: la cultura y la ciencia en tiempos de Jaime II

Manuel A. RODRÍGUEZ DE LA PEÑA

Hesper, El Vestro y el Vespertilio. Elementos de continuidad entre el milenarismo staúfico y el ciclo profético de imperio aragonés 


\section{Internacional}

\section{Jaime II}

años despues? elllllit)
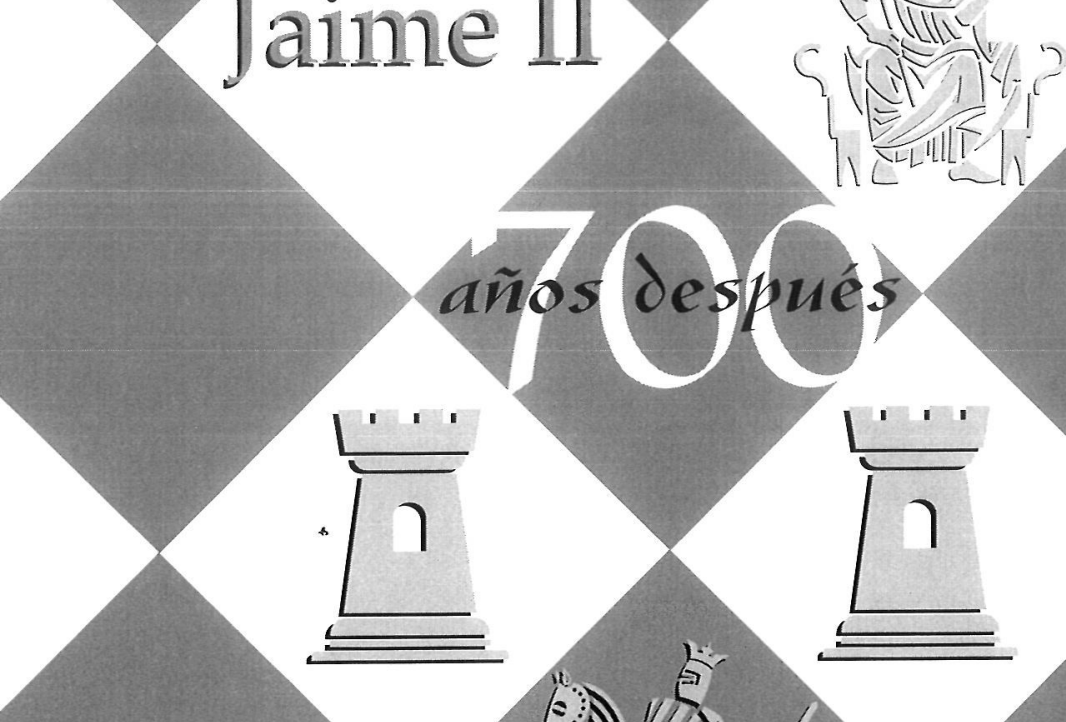

$$
\text { ponenctas }
$$





\title{
ARNAU DE VILANOVA. LA MEDICINA, LA CIENCIA Y LA TÉCNICA EN TIEMPOS DE JAIME II
}

\author{
Emili BALAGUER I PERIGÜELL \\ Catedrático de Historia de la Ciencia
}

Cuando a mediados del siglo XIII, Jaume I conquista el territorio que se configura como Reino de Valencia en el seno de la Corona de Aragón, comienza a iniciarse el segundo de los períodos que suele distinguirse en la actividad científica, desarrollada en Europa occidental, a lo largo de la edad media: el proceso de asimilación, a través de los textos árabes, del saber clásico griego y helenístico enriquecidas en el mundo islámico por aportaciones originales y elementos de la ciencia clásica india.

Este proceso que se inició principalmente con las traducciones de textos astronómicos y matemáticos realizados en los monasterios catalanes de Vic y Ripoll, cuyos abades mantuvieron contacto con la Córdoba del califato, mediante la ayuda de los mozárabes; y en el campo médico por las realizadas en la ciudad italiana de Salerno, primera escuela médica laica de la Europa medieval. Pero desde mediados del siglo XII, fue indiscutiblemente Toledo la capital fundamental de la transmisión al occidente europeo del saber greco-árabe.

Pero además durante los siglos XI y XII, la Península lbérica se convirtió en el escenario más importante de la cultura islámica, tanto en el campo de las matemáticas, la astronomía, la geografía, etc. como en el de la botánica, la agronomía y la medicina (Averroes y Avenzoar). Las aportaciones fueron tan importantes que este período andalusí constituye una etapa con personalidad propia en la historia de la ciencia.

El actual territorio valenciano permaneció al margen de este proceso, ocupado por grupos berberiscos en los que apenas debieron tener vigencia los elementos árabes, destruyeron la organización sociopolítica visigoda, implantando una sociedad primitiva casi exclusivamente rural. Sólo a partir del siglo XI, con la constitución de los reinos de Taifas, fundamentalmente los de Valencia y Denia, se detecta una recuperación de la actividad científica. 
El núcleo de mayor importancia fue Denia, sobre todo a partir del siglo XI en el reinado de Muŷāhid. En la corte de este monarca, que poseía una sólida preparación cultural, se reunieron científicos e intelectuales procedentes de diferentes lugares de al-Andalus. Entre ellos cabe destacar al astrónomo Ahmad Ibn al Saffār, autor de un tratado sobre el astrolabio, traducido al catalán por Millàs Vallicrosa, y que tuvo gran difusión tanto en el mundo árabe como en el latino.

Después de haberse formado en el Oriente islámico, se instaló en Denia el médico Abu Marwan ibn Zuhr, que alcanzó gran prestigio como clínico, Su hijo Abü-'Ală'zuh (el Albuleizar de los latinos), es autor de diversas obras de las cuales una monografía sobre la litiasis renal y otra sobre la higiene individual, sólo se conserva el texto latino. La obra más destacada, editada en árabe y francés en 1911 por G. Colin, es la titulada Tadhkira, compendio de medicina práctica con una orientación puramente galénica y ambientalista en la mejor tradición hipocrática. La dedica a su hijo, Abū Mazwān ibn Zuhr (el Avenzoar latino), que a su vez es autor de la más importante contribución andalusí a la medicina clínica, sólo comparable a la de Rhazes.

Mención especial merece Abū-s-Salt Umayya, nacido y residente en Denia hasta los veinte años. Se trata del tipo de médico con una amplia preparación intelectual, científica y técnica, característica del mundo árabe medieval. La numerosa producción escrita de Abu-s-Salt comprende una tratado de geometría, otro de astronomía y una monografía sobre el ecuatorio, un instrumento de invención andalusí para calcular la posición de los planetas. Su principal obra médica es un tratado de medicamentos simples, estudiado en 1883 por M. Steinschneider partiendo de un ejemplar manuscrito, al que recientemente se ha sumado otro descubierto por F. Giron y L. García Ballesta. Se le considera como un hito importante en la trayectoria de la farmacoterapia al al-Andalus y fue traducido al hebreo por Jehuda Ben Salomon Natan y al latín por Arnau de Vilanova. Es autor, también, de un estudio sobre geografía física y la cultura de Egipto, de un tratado de lógica, de una epístola sobre la música y de una antología de poemas de autores andalusís.

En el reino de Taifas de Valencia, las figuras más tempranas dignas de mención fueron el constructor de instrumentos astronómicos Ibn Sā id al-Shali, que desarrolló su actividad en la segunda mitad del siglo XI, autor de uno de los primeros globos celestes que se conservan. Fue construido en Valencia en el 1102 y actualmente se encuentra en el Museo de Historia de la Ciencia en Florencia. Junto al-Shalí, hemos de mencionar al matemático Ibn Sayyid al-Kallu, que desde los años centrales del siglo XI hasta su muerte, que J. Vernet sitúa hacia 1119 en Játiva, contribuyó a la teoría pitagorística de los números procedente de Nicómaco de Gerasa, matemático griego del siglo II y que destacó muy especialmente como geómetra, sobre todo en relación con las Crónicas de Apolonio de Pérgamo, el gran título helenístico de la disciplina.

El principal discípulo de al-Kalbū fue el zaragozano lbn Baŷya (el Avempace latino) autor de varios tratados científicos y ampliamente conocido por sus obras filosóficas, en especial la traducida al castellano con el título de Régimen del solitario, que tuvo una gran influencia en el pensamiento europeo no sólo en la edad media sino, incluso, en los primeros tiempos modernos. Después de un largo peregrinaje por la Península 
Ibérica y el norte de África, Avempace residió, durante la segunda década del siglo XII en Valencia y Játiva, donde fue acusado de hereje.

Coetáneo de al-Kalbū, fue el médico valenciano 'Abd-al Wadūd b Abd-al Malik, autor de una obra en defensa de la medicina científica, contra los teólogos que la consideraban un desafío de la omnipotencia divina y contra las prácticas empíricas sin fundamento racional. García Ballester ha destacado el interés de este texto para conocer los problemas sociales, económicos y éticos del ejercicio médico en el mundo islámico.

En el ocaso del dominio musulmán en territorios valencianos, J. Vernet ha estudiado un grupo de científicos, fundamentalmente matemáticos, que desde finales del-siglo XI, hasta la primera mitad del siglo XIII, suponen una verdadera avanzada, en dicha área, en el panorama general andalusí. La conquista cristiana obligó a muchos de ellos a emigrar a Granada, Sevilla u otras localidades meridionales. Algunos murieron poco antes de ver destruido su mundo sociopolítico y cultural. Es el caso del médico alcireño ibn Tumlus, autor de un libro parcialmente editado y traducido por $M$. Asin Palacios, con el título de Introducción al arte de la lógica, que murió en su ciudad natal en 1223; y del matemático saguntino al-Quda ci, muerto en Valencia en 1230.

La conquista por Jaime I significó un cambio drástico en la sociedad valenciana de mediados del siglo XIII. La entrada de una nueva cultura - la cristiana - en el seno de la cultura islámica, hasta ese momento hegemónica, conllevó la presencia de elementos nuevos no sólo en los contenidos científicos sino también en el modo de concebirlos. Pero no olvidemos que tanto en la sociedad islámica - que va a ser profundamente alterada- como en la nueva sociedad cristiana que se inicia en 1238, existió la cultura judía. A partir de los años de la conquista, la sociedad valenciana medieval sólo podrá entenderse teniendo en cuenta este entramado complejo de tres culturas.

A pesar del trauma de la conquista, la comunidad mudéjar valenciana conservó estructuras que permitieron un cierto nivel cultural. Es el caso de las «aljamas» independientes como lugares privilegiados donde las leyes y costumbres islámicas continuaban vigentes, asesoradas por una asamblea de notables. En estos momentos no debe confundir «las aljamas» con lo que más adelante serás las «morerías», verdaderos ghettos para mantener aislada a la comunidad musulmana. Mikel de Epalza interpreta esas asambleas como el grupo de notables que entregaron cada una de las plazas, por lo cual fueron elevados por los cristianos a un cuerpo parecido al de los consejo municipales. Por otra parte las ansias evangelizadoras de las primeras jerarquías eclesiásticas, tampoco parece ser tuvieron éxito y buena prueba de ello, es la desaparición en 1314 de las escuelas de árabe y hebreo, fundadas en Játiva veinticinco años antes para la formación de misiones. Sin embargo, los musulmanes valencianos no tuvieron una «madrasa» o centro de estudios islámicos, como la tuvieron los de Zaragoza, con influencia en todo el Reino de Aragón, donde se enseñó medicina hasta finales del siglo XV.

La degradación de la cultura musulmana en el Reino de Valencia, no fue tan rápida como se creía y a pesar de las prohibiciones legales, como la de 1388, que no permitía a los médicos musulmanes asistir a enfermos cristianos, sus servicios fueron soli- 
citados por municipios, hospitales, nobles y reyes. Por ejemplo, Juan I solicitó en 1387 desde Barcelona, la presencia del médico valenciano Abrahim y el Hospital de la Reina de la ciudad de Valencia, encargó a un "metge moro l'assistència a un pobre malalt, i va destacar que va ser més eficaç que el metge cristià assalariat de manera regular» (J.M. López Piñero y V. Navarro).

Un segundo aspecto de la actividad científica de los mudéjares valencianos, fue la desarrollada por los alfaquíes que mantuvieron relaciones con la cultura del mundo islámico del norte de África y del Oriente. Como ejemplo notable nos referiremos al alfaquí de Paterna, que en los años centrales del siglo $X V$, aprovechando un viaje a $E I$ Cairo - el importante centro de ciencia islámica del Mediterráneo oriental— se trajo consigo un manuscrito científico innovador en el campo de la trigonometría y que permitía mediante un instrumento utilizado por los astrónomos de El Cairo, conocido como sexagenarium y mediante la aplicación gráfica de fórmulas trigonométricas, dentro de la astronomía ptolemaica, calculaba las ecuaciones del centro de la tierra y el argumento de los planetas. Fue traducido al catalán en Paterna en 1456 y al latín por el médico valenciano Joan de Bosnia, uno de los miembros fundadores de la Escuela de Cirugía Valenciana en 1462.

Sin embargo, es preciso matizar los comportamientos en la actividad científica ya que de hecho las tres culturas presentes en tierras valencianas no se comportan como departamentos estancos. Si en el mundo cristiano despertó gran interés, incluso en fechas tardías como ya hemos visto, algunos aspectos de la ciencia árabe; la corriente contraria también tuvo lugar. La asimilación de la ciencia greco-árabe por la cultura latina y su estructuración entorno a planteamientos cristianos, el llamado movimiento escolástico; tuvo su influencia en la cultura árabe. Un ejemplo paradigmático es la trayectoria del médico Muhammad al-Safra, nacido a finales del siglo XIII en la pequeña señoría musulmana de Crevillente y residió en ella hasta su desaparición en 1318. Fue autor de un tratado de cirugía basado principalmente en la obra de Albucasis, cuyo contenido amplió en diversos temas, y en la misma línea que éste denunció las prácticas empíricas sin preparación cultural. La relación de al-Saafra con la cultura científica cristiana consistió no sólo en tener un maestro cristiano, un tal Bernard, sino en que su obra responde a lo que García Ballester llama el «reflujo de la escolástica» ya que algunos autores musulmanes, como el médico de Crevillente, asimilaban los planteamientos cristianos bajomedievales.

Los judíos constituyeron en la baja edad media valenciana una minoría que aumentó su importancia a lo largo de siglo y medio que siguió a la conquista, a causa de la mayor permisividad cristiana en este período, en comparación a la intolerancia almohade anterior. En el Llibre del Repartiment figuran tres alfaquíes judíos, médicos, vinculados a la casa real. Aunque en el sínodo de la iglesia valenciana de 1263 se acordó «que cap clergue ni laic demane en les seues malalties un metge jueu o en reba medicació", algunos de los alfaquíes judíos ejercieron complejas funciones en el seno del círculo real. Samuel Abenmenassé, fue nombrado por Pedro III en 1279, médico real e intérprete oficial del árabe. Poseyó estos cargos hasta 1286 en que pasa a ejercerlo en la corte del infante Alfonso, hasta que le sucedió en estas funciones el 
judío catalán Baoudavid Bonsenyor. Jahudá Bonsenyor, hermano de éste, realizó los mismos servicios en la corte de Jaime II. El cargo de intérprete de árabe no se limitaba a funciones puramente administrativas o diplomáticas, sino que se implicaba también en el campo científico, como lo demuestra la traducción que Jahudá hizo para Jaime II, del árabe al catalán, de la obra de Albucasis y como estuvo de atento este monarca, mediante el alfaquí, a la literatura médica árabe existente en sus reinos, de la cual intentó dotar al reciente Estudio General de Lérida.

La actividad de Samuel Abenmenassé en la corte, justo los mismos años que Arnau de Vilanova vivía en Valencia y Barcelona - también en el círculo cortesano de esta ciudad-sugiere una posible relación entre los dos. Mucho más si se considera que fue durante estos años que Arnau tradujo del árabe al latín diversos escritos médicos, entre ellos el tratado sobre medicamentos simples del médico valenciano Abu Salt, ya citado anteriormente.

La situación de la minoría judía empeoró drásticamente a finales del siglo XIV, especialmente a partir de los asaltos de la judería y las matanzas de 1391. La progresiva intolerancia desde estos acontecimientos obligó a mucha gente a exilarse, otros se convirtieron al cristianismo aunque sólo fuera por guardar las apariencias y con la exclusiva finalidad de poder integrarse en la sociedad cristiana, lo que podemos ejemplificar en el médico setabense Lluis Alcanyis, primer catedrático de medicina de la Universidad de Valencia y autor de un Regiment preservatiu i curatiu de la pestilència, cuyo trágico final fue ser condenado a la hoguera.

Mientras que en la Europa occidental cristiana, el proceso de transmisión de la ciencia greco-árabe, culmina, en parte, en la creación de una nueva institución para su cultivo y transmisión, el Studium generale o universidad; el modelo de enseñanza implantado en el Reino de Valencia, por los Furs de Jaime I debía ajustarse al conocido como «modelo abierto» de origen islámico: «Tot clergue o altre hom pusque franchament e sens tot servei e tribut tenir estudi de gramatica e de totes altres arts e de fisica (medicina) e de dret civil e canonich en tot loch per tota la ciutat». No obstante, la iglesia mostró muy pronto su interés por controlar la cultura. Con esta intención se fundó en 1254 en la catedral de Valencia una escuela de gramática, además de conseguir nueve años más tarde un privilegio pontificio para fundar un Studium generale, que quedó en mero proyecto. La iniciativa partió de Andreu Albalat, que ocupó la sede episcopal valenciana desde 1248 hasta 1276 y que García Ballester considera posible que interviniera en favor del mencionado privilegio, ya que el 1245 vivía en Roma. Albalat participaba de la mentalidad de los dominicos de la época, que había encabezado san Alberto Magno, favorable a la ciencia desde los supuestos aristotélicos. Durante su estancia en Roma hizo amistad con Teodorico Borgognoni, también dominico y autor del primer tratado de cirugía importante aparecido en el ambiente de la Universidad de Bolonia, basado directamente en la obra de Albucasis. La versión definitiva de esa cirugía fue redactada a instancias de Andreu Albalat y dedicada por su autor al obispo de Valencia.

El sucesor de Albalat en la sede episcopal valenciana, Jaspert de Botonac, mantuvo también una postura favorable a la ciencia, lo que justifica el hecho de que Arnau 
de Vilanova le dedicara la obra De improbatione maleficorum. Sin embargo en el siglo siguiente se detecta, entre algunos representantes del mundo eclesiástico valenciano, una actitud de reserva hacia la autonomía del pensamiento racional y un mayor énfasis en la necesaria subordinación del pensamiento científico a la teología. Debió influir en esta actitud las condenas por el obispo de París, Etienn Tempier, de una larga lista de postulados aristotélicos considerados contrarios a la fe cristiana; así como la vinculación de ciertas materias como la alquimia y la astrología a la tradición cultural árabe. Los principales representantes en Valencia de esa actitud fueron el franciscano Francesc Eiximenis y los dominicos san Vicent Ferrer y Antoni Canals. Fueron hombres prácticos que supieron construir, mediante la predicación y su comprometida implicación en la vida más real e íntima de la ciudad de Valencia, un puente entre las ideas teológicas conservadoras y el pueblo, tanto el patriciado como en el resto de la población. Es en este contexto en el que hay que situar los consejos de Eiximenis a los hijos del patriciado urbano valenciano, previniéndoles contra el estudio de «artes liberales» como la aritmética, la geometría, la astronomía, etc., por no ser ciencias religiosas y conllevar el peligro de perder la fe y pasarse a «serraïns»; san Vicent Ferrer, prior del influyente convento dominico de Valencia, no dudó en condenar a Aristóteles y Plantón al infierno; e igualmente el dominico Antoni Canals, que insistió en la inestabilidad de una fe basada en los estudios y la lectura de libros. Dentro de este ambiente, no podemos olvidar las recomendaciones del obispo de Valencia, en 1399, al abad del monasterio de San Jerónimo de Gandía cuando le puso en guardia contra la "ciencia luliana» y le aconsejó "no recurrir a los laberintos de la ciencia, sino a la instrucción moral...».

Investigaciones sobre el siglo XIV valenciano, han puesto de manifiesto la existencia en la ciudad de Valencia, a partir ya de los años finales del siglo XIII, de un grupo social muy vigoroso que dotó de un fuerte dinamismo a la vida social y económica valenciana. Un grupo social que, como en otras ciudades europeas, se hizo con el gobierno de la ciudad y que estuvo formado por artesanos, mercaderes, profesionales y rentistas no nobles: los civi Valentie o "ciutadans de València» de los documentos bajomedievales. Ese grupo social estuvo especialmente preocupado por los problemas médicos e incluso, tomó partido muy pronto (1329) por el modelo escolástico de profesional médico salido de aulas universitarias. Fue también el grupo social responsable de cierto grado de medicalización que tuvo lugar en la Valencia bajomedieval, es decir, de la paulatina conversión de la salud en un problema técnicamente médico. A ellos se debió la introducción de una serie de medidas, algunas de cierta audacia tecnológica, que fueron más allá del individuo y de los estrechos círculos cortesanos - adinerados: control de alimentos, medidas para evitar la contaminación del agua de uso doméstico, así como para procurar la evacuación de aguas sucias y limpieza de basuras, desecación de marjales, control de los profesionales sanitarios, introducción de profesionales médicos en los hospitales, etc.

Desde su monopolio del poder municipal, esta oligarquía se posicionó a favor de la institucionalización de la enseñanza, la cultura y la ciencia, como ya hemos indicado anteriormente, de acuerdo con el modelo universitario. Los nuevos fueros de Alfonso I (1329) consagraron la sanción normativa de este modelo; a pesar de ello, el nuevo 
proyecto de fundar un studium generale (1373), se frustró una fez más. La pugna entre la iglesia y la oligarquía urbana en torno al control de la enseñanza, fue, sin duda, uno de los factores determinantes que provocaron que Valencia no tuviera un Studium generale durante la baja edad media. Frente a las escuelas catedralicia y conventuales, el municipio tenía «escoles de gramatica e logica e de altres arts», que van a ser dotadas de un local propio en 1374 y unificadas, sin tomar en consideración la opinión del obispo, en 1411. Un acontecimiento de mayor importancia fue la creación en 1462 de la escuela de cirugía, de la que hablaremos luego, el desarrollo de la misma corresponde ya al período protorrenacentista.

Al complejo panorama bajomedieval que acabamos de describir, hay que añadir la enseñanza en Valencia de las doctrinas de Ramón Lull. Un primer lulismo entroncará muy pronto con la espiritualidad arnaldiana y a pesar de los esfuerzos del inquisidor de la Corona de Aragón Nicolau Eimeric y la ofensiva de los religiosos opuestos al cultivo de la ciencia; no conseguirán impedir que en 1369, Pedro III, concediera un privilegio a Berenguer Fluviá para enseñarlas en el campo de la filosofía, la astronomía, la medicina y dar el título de maestros en estas materias. Como han estudiado L. Comenge y T. y J. Carreras Artau el centro principal del poderoso movimiento lulista fue la ciudad de Valencia y la primera institución docente lulista fue la escuela dirigida en Alcoy por Pere Rosell, amparándose en el privilegio de Pedro III.

La producción científica de los cristianos valencianos a lo largo de la baja edad media, se llevó a cabo, como es lógico, paralelamente a la trayectoria de los condicionamientos socioculturales y políticos que sumariamente acabamos de recordar. Comenzó siendo la propia de una zona de frontera o regne de croada, como le gusta decir a R.I. Burns, la de unos territorios conquistados por las armas dominando la población autóctona que progresivamente se irá degradando hasta su expulsión definitiva. Los descendientes de los conquistadores irán progresivamente integrando la actividad científica de los cristianos valencianos en el mundo europeo occidental, no sólo en cuanto a su organización, sino también en lo relacionado con el producto. Ahora bien, conviene recordar que esta integración no fue completa hasta el período renacentista.

Desde esta perspectiva podemos distinguir dos etapas en la producción científica de los cristianos valencianos a lo largo de la baja edad media. La primera abarca desde la conquista a finales del siglo XIV y se caracteriza por una estrecha vinculación con la universidad de Montpellier, perteneciente a la Corona de Aragón, quedando en un segundo plano la universidad de Lérida, fundada por Jaime II (1300). En este período la convivencia con los musulmanes y judíos todavía tiene un peso importante. La segunda etapa comprende desde finales del siglo XIV, coincidiendo con la desarticulación de la comunidad judía y de que Montpellier deja de pertenecer a la Corona de Aragón, hasta las décadas centrales del siglo XV. En este período, aunque no se rompe definitivamente las relaciones con Montpellier, pasaron a primer término como modelo de organización para la oligarquía urbana local, las universidades de Bolonia, Pisa, Siena y Padua.

La primera etapa se inició con la producción de Arnau de Vilanova, la figura más importante con gran diferencia de todo el período medieval. 
Arnau fue miembro de una familia catalana, hijo quizá de aquellos primeros repobladores del recién conquistado Reino de Valencia, donde parece que nació entre 1238 y 1240 . Si discutible es el lugar de su nacimiento, no cabe la menor duda sobre su vinculación a Valencia, ciudad en la que poseía importantes bienes, amigos y seguidores; a la que volvió repetidamente a lo largo de su vida y donde fue asignado por Clemente $\mathrm{V}$ al nombrarle clérigo de la diócesis valentina.

Según su propio testimonio, sabemos que comenzó su formación con los predicadores, estudió medicina en Montpellier hacia los años sesenta y allí se casó con Agnés de Blasi, hija de un famoso comerciante, J.A. Paniagua, uno de los principales especialistas en este autor, no cree que ampliara su formación en Nápoles, como algunos han sostenido, sino que ejercería como médico en Valencia hasta su marcha a Barcelona, en 1281, como médico de cámara del rey Pedro III.

Hacia 1289 inició su colaboración con la universidad de Montpellier, si bien no fue hasta 1295 cuando manifestó un claro interés por instalarse allí, constituyendo un patrimonio y, paralelamente abandonó la gestión de sus negocios en Valencia en manos de procuradores. En 1309 abandonó la Universidad, el mismo año que su amigo, el papa Clemente $\mathrm{V}$ promulgó una bula que ordenaba el plan de estudios médicos en Montpellier y en cuya gestación fue fundamental la influencia de Arnau, médico suyo en aquella época.

Una desgraciada intervención ante la Curia de Avignon en verano de 1309, donde expuso sus conocidas y controvertidas opiniones religiosas, le supuso el ostracismo y la animadversión del su principal valedor y protector, el rey Jaime II. Arnau se instaló junto a Federico III, rey de Sicilia y el más ilustre seguidor de las propuestas espirituales de este autor, hasta su muerte, ocurrida frente a Génova el 6 de septiembre de 1311, cuando se dirigía a Avignon.

J.A. Paniagua ha puesto de relieve la trascendencia de la personalidad de Arnau: «Ningún otro comparable a él se encuentra en el conjunto de los reinos de la Reconquista, y muy pocos se le asemejan en la España musulmana y en la Cristiandad medieval. La figura de Mestre Arnau de Vilanova destaca claramente como una de las más notables y representativas de la ciencia médica en el ámbito entero de la Edad Media universal».

Arnau aparece como un hombre de frontera, que manifestó una clara vinculación al arabismo y al escolasticismo. El saber escolástico estaba fundamentado en el criterio de autoridad, según el cual, las afirmaciones de los clásicos no necesitaban ser contrastadas con la realidad. En tal ambiente, el descubrimiento de la ciencia árabe comportó una auténtica revolución mental, ya que se constituyó como nueva autoridad, planteando al hombre medieval la necesidad de conciliar entre las contradicciones existentes en las opiniones de autoridades igualmente respetables mediante una hábil utilización de la ratio.

Así fue acuñando el método de las questiones disputata para la enseñanza, según el cual se discutía sobre una base textual, utilizando la lógica deductiva.

La labor científica de Arnau fue desarrollada fuera de Valencia y se caracterizó por su vinculación total al movimiento escolástico. Por un lado, contribuyó a ampliar el 
conocimiento clásico mediante la traducción del Liber de viribus cordis de Avicena y el Liber de rigore et tremore et iectigatione et spasmo de Galeno. Por otro, fue uno de los principales introductores del llamado "nuevo Galeno" en las facultades de medicina europeas, tal y como ha puesto de relieve L. García Ballester.

Su nombramiento como médico de cámara iba a ofrecer la posibilidad de iniciar su actividad científica, pues Pedro III marchó al año siguiente (1282) a Sicilia para ser coronado rey. Buen conocedor del árabe, aprovechó las posibilidades que le ofrecían la rica biblioteca de la corte y, posiblemente, la presencia de Samuel Abenmenassé. La inmensa tarea llevada a cabo por las escuelas de traductores, dio lugar a que el trabajo de Arnau hubiera de reducirse a textos secundarios, aunque de indudable valor, que completaron el proceso de recuperación del saber greco-árabe.

Ahora bien, los escritos que le dieron auténtica fama, fueron sus obras originales y versiones de textos hipocráticos y galénicos elaboradas, en su mayor parte, en Montpellier durante su etapa universitaria.

A mediados del siglo XII, parece que el Corpus Toletanum ya estaba plenamente asimilado en Montpellier, con lo que se añadía la filosofía natural de Aristóteles y el Canon de Avicena a la formación del médico.

A finales del siglo XIII, es decir, en la época en que Arnau enseñaba, confluyeron en Montpellier dos tradiciones renovadoras: el arabismo, de honda raíz montepelusana, y el escolasticismo médico italiano de la bolonia de Taddeo Alderotti y en la que el Canon era fuertemente cuestionado como texto central para la enseñanza. Así se cerró el proceso de asimilación plena del galenismo iniciado con la Escuela de Traductores de Toledo, con lo que se perfeccionaron enormemente los conocimientos sobre la fisiología, patología, clínica y terapéutica galénicas entre los profesores universitarios. L. García Ballester centra el protagonismo de Arnau en cuatro puntos: su labor universitaria de comentarista de los tratados de Galeno; su aportación a la empresa de transmisión, en la que fue fundamental su conocimiento directo de las fuentes árabes; su intervención en las ordenaciones que regularon los estudios médicos de Montepellier desde 1309, y su indiferencia o conformismo ante la obra morfológica de Galeno.

Parte de sus escritos respondían a un esquema metodológico basado en la total confianza en la vía experimental, al permitir conocer lo sensible en su manifestación concreta, frente a la razón que sólo nos informa de las propiedades comunes. Tal confianza debía ir acompañada de una cautela frente a los resultados, pues el proceso experimental está sujeto a multitud de factores que pueden perturbarlo. Por último, una prudente actitud ante la autoridad científica, que le empujó a condenar los excesos de la especulación filosófica —en especial de los averroístas- y las síntesis médicas demasiado elaboradas -el Canon principalmente- pues coartaban la necesaria curiosidad de acudir a los textos originales. Por ello, algunas de sus obras manifiestan un claro sentido polémico.

Tal actitud se manifestó también en sus escritos de práctica terapéutica, donde dictaba sensatas dietas, recomendaba medicamentos de propiedades suficientemente comprobadas y se mostraba contrario a los abusos de las sangrías.

Arnau defendía que Hipócrates y Galeno habían transmitido la técnica y el método 
idóneos para el mantenimiento y restablecimiento de la salud, objetivo prioritario de la medicina. Por ello, desplegó una interesante actividad como comentarista, que en el caso de Hipócrates se limitó a la Articella. Ante la evidente insuficiencia de estos textos para cumplir su propósito, dedicó una gran atención a las obras patológicas y clínicas de Galeno, adelantándose a los esfuerzos boloñeses en varias décadas. Podemos destacar su versión $D e$ inequali intemperie, breve tratado galénico, al que hizo un comentario extenso y complejo, abordando el concepto de complexión patológica -fundamental en la patología humoralista- pues lo concibió como una introducción a los dos grandes textos terapéuticos de Galeno: De simplicibus medicinis y De ingenio sanitatis, este último también comentado por él.

Llama la atención el empeño que Arnau pareció mostrar en evitar al máximo la difusión de estos escritos, con el fin de ocultar información a sus enemigos académicos, los averroistas, quienes constituían un importante grupo de presión universitario.

Entre sus trabajos originales destacan el Speculum medicinae. Obra de madurez, aparece como uno de sus libros más extensos e importantes, donde se refleja claramente la doctrina médica de su autor, Se trata de un texto de medicina básica donde ofrece un resumen de fisiología, higiene fundamental, farmacología general y psicopatología básica. Su intención es puramente didáctica, exponiendo y completando de forma sencilla y clara las propuestas galénicas.

Este texto se complementa con las Medicationis parabolae, las cuales tuvieron una inmensa difusión. De forma aforística, estudia los modos de enfermar generales, las enfermedades simples y algunos consejos terapéuticos.

La farmacología fue la disciplina que posiblemente mayor prestigio concedió al médico valenciano. Hallamos escritos de base teórica, como el ortodoxamente galénico De simplicibus; y de contenido eminentemente práctico, como el De gradibus. En este famoso tratado propuso la aplicación del cálculo matemático para determinar la dosificación de los medicamentos compuestos, siguiendo los métodos del Al-Kindi.

La obra de mayor difusión fue el Antidotarium auténtica enciclopedia que incluye varios capítulos de farmacología general, seguidos de un importante apartado prácti$\mathrm{co}$, donde se indica la definición, composición y procedimiento de confección de multitud de electuarios, píldoras, jarabes, emplastos, etc. Esta colección de fórmulas parece responder a una reelaboración del Antidotarium Nicolai, quizá el escrito original más famoso salido de la escuela de Salerno.

Por último, el Regimen sanitatis fue el texto de Arnau más conocido. En efecto, el médico valenciano se convirtió en uno de los clásicos de la literatura higiénico-dietética medieval. Este género alcanzó una gran popularidad por la escasez de remedios específicos de tratamiento con que contaba la medicina de aquel período.

Llama la atención que un tratado de higiene individual confeccionado expresamente para la persona del rey Jaime II, alcanzase tan gran reputación y difusión. Trata su autor aspectos tales como las características idóneas del lugar donde instalar la corte, de los cuidados personales - ejercicios físicos, aseo, estados de vigilia y sueño, emociones - y régimen alimenticio - cualidades salutíferas de los principales alimentos y bebidas-. El libro está escrito en un lenguaje sencillo y escueto, despojado de 
toda erudición, manifestando la inmensa capacidad de Arnau para hacerle comprender por los profanos. Esta claridad de estilo, unido a la utilidad de su doctrina, explican que fuera uno de los textos más leídos de la Edad Media.

Arnau aparece, pues, como uno de los médicos más famosos, tanto desde su faceta de médico práctico, como en la académica. Sus obras fueron copiadas y estudiadas profusamente y, tras la implantación de la imprenta, fue el autor más editado antes de 1500 (se imprimieron seis veces sus Opera omnia, que recogían sesenta tratados). J.A. Paniagua ha desvelado las claves que explican las causas de su inmenso prestigio, hasta el punto que son apócrifas la mitad de las páginas de sus obras completas editadas durante el Renacimiento.

Nos hallamos ante un autor que abordó una gran variedad de temas, tratándolos todos ellos con singular competencia. Por otro lado, su personalidad responde perfectamente a la convulsionada época en que vivió. Fue el maestro más ilustre de la más prestigiosa escuela de medicina. Sus curaciones sensacionales le ganaron el favor de papas y monarcas, lo que le ofreció una cierta impunidad para publicar sus ideas religiosas, que participaban en los ideales espirituales y de pobreza propugnados por los fraticelos. Arnau fue un hombre de una gran influencia, pero su osadía le valió el ostracismo en los últimos años de su vida y la condena inquisitorial a sus doctrinas religiosas, tras su muerte y la de sus protectores (1316 y 1318). Nada pudieron hacer para evitarlo sus albaceas y seguidores en Valencia, tal y como ha demostrado M. Rodrigo Lizondo.

De lo anteriormente expuesto, no es difícil comprender que Arnau fuese convertido en un personaje legendario, a quien se atribuyó todo tipo de escritos, especialmente alquímicos. Tal «conversión» sufrieron también Ramón Llull y Roger Bacon, figuras coetáneas suyas y de características similares.

La historiografía contemporánea está realizando una rigurosa tarea de expurgo de los numerosos textos falsamente atribuidos al médico valenciano. J.A. Paniagua ha puesto de relieve que de la producción auténticamente original "se desprende una doctrina científica armónica y coherente". Es la expresión del saber impartido en Montpellier, centro de la medicina escolástica basada en la tradición galénica e impulsora de la recuperación del sistema hipocrático-galénico, frente a los seguidores de la sistematización avicenista.

Agustín Rubio y Mateu Rodrigo han destacado la clara influencia de las doctrinas religiosas del médico valenciano entre las capas burguesas ciudadanas, donde alcanzaron gran popularidad las propuestas espirituales de los Beguins, agrupaciones de laicos con ideales espiritualistas, cuya principal actividad era la atención a los pobres en los hospitales. Entre las propuestas de Arnau, una de las más repetidas era la llamada a la caridad hospitalaria y a la construcción de hospitales. En este ambiente, se integran la fundación del Hospital de En Clapers por Bernat de Clapers, uno de los procuradores en la gestión de los negocios de Arnau de Vilanova y hombre vinculado estrechamente al círculo de sus seguidores en la ciudad, en el que también se movió Guillem Ramón Catalá, fundador del Hospital dels Beguins. Hay que destacar que tales fundaciones respondieron asimismo a la convicción de la eficacia de la tarea hospita- 
laria en el proceso de asentamiento de la cultura cristiana entre la mayoría musulmana.

El segundo período en que hemos dividido la actividad científica cristiana en la Valencia bajomedieval, si bien no se interrumpen las relaciones de valencianos con la Universidad de Montpelier, como ya hemos indicado, sí es cierto, que pasan a primer plano las universidades italianas. La principal aportación de las primeras generaciones italianizantes no se dieron en el terreno de la producción escrita, sino en la fundación del colegio de cirugía al que ya hemos aludido. Desde 1433 que existía el gremio de cirujanos de Valencia, pero es en 1462 cuando consigue que el municipio creara una lectura o escola de cirugía y que fuera obligatoria la asistencia para conseguir la licencia municipal correspondiente. La iniciativa partió de médicos universitarios de mentalidad avanzada, algunos de edad madura como el examinador Lluis Dalmau, que fue el primer profesor, el ya mencionado Joan de Bosnia; otros, todavía muy jóvenes, como es el caso de Lluis Alcanyis y Pere Pintor que centraron su actividad en la transición de siglo XV al XVI. El 1478 l'escola, obtuvo la autorización real para disecar cadáveres humanos, hecho de trascendental importancia y que puede considerarse como el punto de partida del posterior florecimiento de la escuela anatómica valenciana. Al integrarse esta institución a la Universidad de Valencia, ejemplo paradigmático de las universidades de tipo municipal, lo que representó la culminación del poder ascendente de la oligarquía urbana en la actividad docente, cultural y científica; esta Universidad se convirtió en una de las primeras de Europa que dispuso de una cátedra de cirugía.

El interés de los reyes de la Corona de Aragón por los estudios universitarios fue grande en personas tales como Jaime II, Alfonso el Benigno, Pedro el Ceremonioso y Martín el Humano. El mismo interés detectamos entre los burgueses que dirigieron la vida ciudadana de Valencia; un patriciado urbano que hizo de la actividad mercantil y del desarrollo del comercio, el eje en torno al que giró la vida social de Valencia, y que estableció relaciones normales con todo el Mediterráneo, desde Beirut y Alejandría a Marsella y Barcelona, y con todo el Atlántico, desde Sevilla y Lisboa a Brujas. Ello le dotó de un evidente cosmopolitismo. A ello se añadió la valoración positiva de la ciencia («molt honren e enoblexen ciutat hòmens ornats de siència») (1401), como pone de relieve el epistolario de los «jurats» de la ciudad de Valencia, recientemente editado (A. Rubio). Si la corona y el patriciado urbano participaron de semejante actitud, ¿por qué siguió manteniéndose el modelo arcaico de la libertad de enseñanza (modelo abierto), en fuerte contraste con la penetración que la ciencia escolástica consiguió en la sociedad valenciana de los siglo XIV y XV, y que nos es conocida a través de las bibliotecas, que se nos han conservado, de médicos y burgueses? Dado el estado actual de las investigaciones, no podemos responder con un mínimo de rigor a estas preguntas. Lo que sí, creo, podemos afirmar es que no existió ciencia en los doscientos cincuenta años que siguieron a la conquista de Valencia por Jaime I, acorde con la situación estratégica de la ciudad (desde el punto de vista geográfico, social y demográfico), y con sus relaciones nacionales e internacionales. Seré más preciso: durante ese período, la sociedad valenciana —algunos de sus miembros-consumió 
ciencia (ciencia hecha fuera de sus territorios), pero no creó ciencia. A pesar de que en la segunda mitad del siglo XV se crearon estructuras propicias para ello. La inexistencia de un Estudio General en Valencia condenó a ésta a lo que con expresión actual llamaríamos provincialismo científico. Sólo salió de esta situación en la transición del siglo XV al XVI, con la creación del Estudi General. Será a partir de esos años cuando detectaremos una actividad científica propiamente dicha.

La actitud de la Iglesia y de las órdenes mendicantes valencianas, posiblemente desempeñaran un papel de cierta relevancia en la situación que hemos descrito.

Ello no quiere decir que la universidad, con su secuela de producción científica, dejara de tener presencia en Valencia. Ahora bien, fue una presencia indirecta. Valencia se ofreció a la universidad escolástica como un mercado donde colocar sus productos; sea en forma de profesionales (teólogos, juristas, médicos, graduados en artes), sea en forma de compradores de libros. Valencia, pues, consumió ciencia, pero no la creó. Los ejemplos más claros los tenemos en las figuras valencianas que participaron en el proceso de creación científico-médica. Nos referimos a los médicos Arnau de Vilanova (c. 1240-1311), Berenguer Eimerich (c. 1290-c. 1356), Nadal Lambrí (m.c. 1395), Joan de Bosnia (fl. 1463-84). Todos ellos estuvieron vinculados a centros universitarios y de ellos recibieron el estímulo intelectual. Arnau de Vilanova y Berenguer Eimerich lo estuvieron a Montpellier, Nadal Lambrí a Lérida, de donde fue catedrático. Antes hemos mencionado el pequeño escrito de Arnau dedicado al obispo de Valencia, Jaspert de Botonac, en lo que parece un reconocimiento a la curiosidad científica del prelado y a una posible actividad de patronazgo; toda su obra restante médica y de filosofía natural, desde sus traducciones de obras médicas islámicas hasta sus comentarios escolásticos y sus escritos clínicos más aplicados, no parece tuvieran nada que ver con el ambiente intelectual o social valencianos, pese al íntimo contacto que mantuvo con la ciudad y con los miembros de su patriciado urbano. Igual podemos decir de Berenguer Eimerich, cuyas obras tienen todas un claro perfil universitario, y de las que nos consta que, una al menos, fue realizada por directa petición de Bernardo de Gordón, su maestro y compañero de claustro de Arnau en Montpellier. Nadal Lambrí, natural de Morella, se formó en Montpellier y Lleida; en esta ciudad ejerció la medicina y de su facultad de medicina fue profesor, participando activamente en las disputas científicas en torno a la doctrina de los tratados medicinales y contribuyendo a ellas con una obra, por desgracia perdida (L. García Ballester, M. R. Mc.Vaugh).

\section{REFERENCIAS BIBLIOGRÁFICAS}

CARDONER Y PLANAS, A. (1973), Història de la Medicina a la Corona d'Aragó (11621479), Barcelona, Scientia.

CARRERAS ARTAU, J. (1935), La llibreria d'Arnau de Vilanova. Analecta Sacra Tarraconensis, 11, 63-84.

CARRERAS ARTAU, J. (1950), L'epistolari d'Arnau de Vilanova, Barcelona, Institut d'Estudis Catalans. 
COLIN, G. (1911), La Tedkira d'Abu-l Ala, publiée et traduite..., Paris, Publs. de l'École Supérieure de Lettres d'Alger.

COMENGE, L. (1897), La Medicina en el Reino de Aragón. Siglo XIV. El Siglo Médico, 44, 449-459, 481-484, 497-501, 513-517, 529-533, 545-549, 561-566.

FAURADO DE SAINT GERMAIN, L. (1950), Un lunario valenciano cuatrocentista. Boletín de la Real academia de Buenas Letras de Barcelona, 23, 9-48.

FRANCO SÁNCHEZ, F. y CABELLO, M.S. (1990), Muhammad AS-Safra, el médico y su época, Alicante, Universidad de Alicante.

GALLENT MARCO, M. (1985), El gremi de cirurgians de València: (1310-1499) procés de constitució. Afers, 1, 249-269.

GARCÍA BALLESTER, L. (1982), Arnau de Vilanova (c. 1240-1311) y la reforma de los estudios médicos en Montpellier (1309): el Hipócrates latino y la introducción del nuevo Galeno, Dynamis, 2, 97-158.

GARCÍA BALLESTER, L. (1988), La medicina Valenciana medieval, València, Eds. Alfons El Magnànim, I.V.E.I.

GARCÍA BALLESTER, L.; MC. VAUGH, M.R. y RUBIO, A. (1984), Medical Licensing and Learning in Fourteenth Century Valencia. Transanctions of the American Philosophical Society, 79/6, 1-128.

GARCÍA BALLESTER, L.; PANIAGUA, J.A.; MCVAUCH, M.R. y RUBIO, A. (dirs.) (19751993), Arnaldi de Villanova Opera Medica Omnia, Granada-Barcelona, Universidad de Granada-Universidad de Barcelona.

GARCÍA BALLESTER, L. (1989), La ciencia en Valencia después de la conquista. En:

En torno al 750 aniversario. Antecedentes y consecuencias de la conquista de Valencia, València, Consell Valencià de Cultura, Vol. II, pp. 239-254.

LÓPEZ PIÑERO, J.M. y NAVARRO BROTONS, V. (1995), Història de la Ciència al Pais Valencià, València, Edicions Alfons el Magnànim.

MILLÁS VALLICROSA, J.M. (1960), En torno a las tablas astronómicas del rey Pedro IV de Aragón. En: Nuevos estudios sobre la historia de la ciencia española, BarceIona, C.S.I.G., pp. 279-285.

PANIAGUA ARELLANO, J.A. (1969), El maestro Arnau de Vilanova, médico, Valencia, Cátedra e Instituto de Historia de la Medicina.

PANIAGUA ARELLANO, J.A. (1994), Studia Arnaldina. Trabajos en torno a la obra médica de Arnau de Vilanova, c. 1240-1311 Barcelona, Fundación Uriach.

POULLE, E. (1966), Théorie des planètes et trigonommetrie u Xve siècle, d'aprés un équatoire inédite, la sexagenarium. Journal del Savants, 3, 129-161.

PUIG OLIVER, J. de (1980), El procés dels lul.listes valencias contra Nicolau Eimeric en el marc del Cisma d'Occident. Butlletí de la Societat Castellonense de Cultura, $56,319-463$.

ROMANO, D. (1956), Los hermanos Abenmenassé al servicio del Pedro el Grande de Aragón. En: Homenaje a Millás Vallicrosa, Barcelona, C.S.I.C., Vol. II, pp. 243-292. RUBIO VELA, A. (1984), Pobreza, enfermedad y asistencia hospitalaria en la Velencia del siglo XVI. València, Institució Alfons el Magnànim.

SALAVERT FABIANI, V.L. (1988), Los saberes médicos y su enseñanza (Baja Edad 
Media). En: J.M. López Piñero (dir.). Historia de la Medicina Valenciana, Valencia, Vicent García Editores S.A., pp. 71-87.

STEINSCHNEIDER, M. (1883), Aben's-Salt (gest. 1134) und sine Simplicia. Ecin Beitrag Zur Heilmittellehre der Araber. Archiv für pathologischesn Anatomie und Physiologie, 94, 28-65.

VERNET, J. (1989), La ciència abans de la conquesta. En: En torno al 750 aniversario. antecedentes y consecuencias de la conquista de Valencia, València, Consell Valencià de Cultura, Vol. II, pp. 227-239. 



\title{
RELAÇÕES ENTRE OS REINOS PENINSULARES $(1290-1330)$
}

\author{
Humberto BAQUERO MORENO
}

Universidade de Porto

Parece não haver margem para dúvidas que a política de $D$. Dinis se insere numa conjuntura que implica um estreito relacionamento com os estados peninsulares: Castela e Aragão. Em conformidade com as principais linhas apontadas pela moderna historiografia portuguesa, a razão principal deve-se sobretudo à circunstância deste reinado, iniciado após a morte do seu progenitor D. Afonso III, ocorrida em 16 de Fevereiro de 1279, se caracterizar por uma acentuada estabilidade interna, resultante duma autoridade régia incontestada, em contraste com o estado geral em que se encontrava o reino de Castela, onde imperava um acentuado clima de ingovernabilidade e de permanentes conflitos sociais'.

Um dos primeiros grandes sucessos da política externa portuguesa consiste na realização do casamento entre o monarca e D. Isabel, filha de Pedro III de Aragão. Tratou-se, com efeito, dum êxito da diplomacia portuguesa, tendo o bom resultado das diligências encetadas pertencido aos procuradores do rei, João Velho, João Martins e Vasco Pires, seus vassalos, a quem coube negociar as cláusulas do matrimónio e simultâneamente receberem a noiva, por palavras de presente, legitimados pela procuração que Ihes havia sido outorgada pelo rei de Portugal em 12 de Novembro de $1280^{2}$.

A missão realizada pelos embaixadores portugueses revestia algum melindre na medida em que a princesa aragonesa era requestada por outros embaixadores dos

1 Sobre esta matéria veja-se a síntese de José MATTOSO in «História de Portugal», vol. II, Lisboa, 1992 , pp. 148 e seg.

2 Arquivo Nacional da Torre do Tombo (A.N.T.T.), Chancelaria de D. Dinis, hivro 1, fol. 42. 
reis de França e de Inglaterra, cujo objectivo visava o mesmo desiderato em benefício de seus filhos herdeiros ${ }^{3}$.

Por decisão assumida por Pedro III, foi outorgada em 11 de Fevereiro de 1282 a carta real em que se concretizava o casamento entre D. Dinis e D. Isabel. O monarca português procedia à doação a sua noiva, em arras, de doze castelos e três vilas. Em conformidade com os itinerários sabe-se que D. Dinis se encontrava em Trancoso, em Junho de 1282, vila cuja doação fez a sua mulher no dia 26 desse mesmo ano. As bodas efectuaram-se nessa localidade, onde ambos permaneceram até aos primeiros dias de Agosto 4 .

Aos desígnios políticos de Portugal interessava este matrimónio, não só porque D. Isabel usufruía do maior prestigio pelas suas excelsas qualidades, mas ainda devido ao peso estratégico de Aragão, tanto do ponto de vista político como económico, e dum modo particular ao posterior protagonismo de Jaime II (1291-1327) sobre o espaço do mar Mediterrâneo.

Os anos que se seguem, e sobre os quais não nos iremos deter, caracterizam-se pela guerra civil em Castela, que coloca Afonso o Sábio contra o príncipe D. Sancho. Entre os principais eventos cumpre destacar a embaixada enviada a Castelo por D. Dinis, após Abril de 1284, a dar os pêsames a Sancho IV pelo falecimento de seu pai e a felicitá-lo pela sua elevação ao trono. Um facto, contudo, contribuiu para a irritação do monarca português: a intitulação pelo soberano de Castela de rei do Algarve ${ }^{5}$.

Apesar deste e doutros percalces as relações entre D. Dinis e D. Sancho podemse considerar estáveis, indo ao ponto de ambos se associarem para durante a primavera e o verão de 1289 combaterem o rei aragonês, não se importando o rei de Portugal que o prejudicado era o seu próprio cunhado. A concertação da aliança em curso surgira da entrevista realizada entre ambos os monarcas, no Sabugal, no mês de Dezembro de 1288. As boas relações existentes entre ambos os lados apenas viriam a esmorecer em 1293, quando D. Dinis protege D. João Nunes de Lara na sua contenda com o monarca castelhano, situação que se agrava ainda mais quando este decide casar seu filho, o futuro rei Fernando IV, com a filha de Felipe o Belo, rei da França ${ }^{6}$.

Sancho IV morre em 25 Abril de 1295, implicando o seu falecimento uma acentuada turbulência no reino de Castela. Um pouco antes do seu passamento determinara no seu testamento que se devolvessem com a maior brevidade, ao rei $\mathrm{D}$. Dinis, as vilas de Serpa, Moura, Mourão, Aroche e Aracena, as quais haviam sido injustamente arrebatadas a Portugal e se encontravam indevidamente retidas pelos castelhanos ${ }^{7}$.

Ainda pela mesma altura faz mercê à sua sobrinha infanta D. Branca, filha de D. Dinis, de todo o património existente entre Badajoz e Aroche, preocupado o monarca castelhano pelo seu bem estar material. De notar que esta doação foi efectuada

3 Ruy DE PINA, Crónica de D. Dínis, Porto, 1945, cap. II, pp. 11-12.

4 Itinerário del-rei D. Dinis (1279-1325), Lisboa, 1962, p. 17.

5 . VISCONDE DE SANTAREM, Quadro elementar das relações políticas e diplomáticas de Portugal, tomo I, Paris, 1842, p. 113.

6 José MATTOSO, ob. cit., p. 150.

7 VISCONDE DE SANTAREM, ob. cit., pp. 115-116. 
em o dia 24 de Abril, precisamente um dia antes do falecimento do monarca, o qual se encontrava em Toledo gravemente enfermo ${ }^{8}$.

Durante a menoridade de Fernando IV, de Castela, que apenas tinha nove anos, a tutoria de sua mãe D. Maria de Molina, que assumiu as funções de regente desse reino veio a ser contestada pelos infantes $D$. João, irmão de Sancho IV e D. Henrique, irmão de Afonso o Sábio. Pertenceu a D. João a tarefa de procurar o auxilio do rei português para o que se deslocou à cidade da Guarda com a finalidade de selar um pacto com D. Dinis. Este deve ter-se verificado em finais de Julho, altura em que o monarca se demorou nessa cidade, tendo ficado acordado que o rei português apoiaria as pretensões do infante $\mathrm{D}$. João no seu desiderato de ocupar o trono de Leão, cuja integração com Castela se verificara em $1230 \mathrm{com}$ Fernando III, o Santo ${ }^{9}$.

$\mathrm{Na}$ sequência do mencionado encontro entre D. Dinis e D. João, Portugal declara guerra a Castela, incumbindo os seus embaixadores de a anunciarem junto de Fernando IV. Nas cortes que entretanto se realizavam em Valladolid causou entre os presentes enorme impressão o anúncio do rei português, tanto mais que havia plena consciência das dificuldades que revesteria uma guerra com Portugal. Após a audição dos mensageiros portugueses pertenceu ao infante D. Henrique a iniciativa de se entrevistar com o rei D. Dinis. De observar que nessas cortes o referido infante fora designado tutor de seu sobrinho, o rei D. Fernando IV, o que the conferia legitimidade para negociar com o monarca português, evitando um confronto militar ${ }^{10}$.

$\mathrm{Na}$ entrevista celebrada na cidade da Guarda em 6 de Setembro de 1295, D. Henrique era portador duma carta em que se comprometia em nome de Castela, a proceder à devolução de diversas terras que foram sempre pertença de Portugal e que por isso mesmo deviam ser entregues. Constava desse documento de devolução a restituição das vilas de Serpa e Moura, com os seus termos e castelos. Com base na reinvindicação de D. Dinis, comprometia-se D. Henrique a entregar Aroche e Aracena, dando assim cumprimento a uma cláusula contida no testamento de Sancho IV ${ }^{11}$.

Coube ao infante D. João ratificar em 4 de Outubro de 1295, por carta passada desde Ciudad Rodrigo, o convénio que fora estabelecido com o rei português. Assim, em 20 de Outubro o rei D. Dinis recebeu as vilas de Moura e Serpa, o castelo de Noudar, inserido no termo de Moura e ainda o castelo de Mourão. A devolução destas localidades e fortalezas deixava em aberto um problema: a necessidade urgente de delimitar com precisão a linha da fronteira, com o objectivo de incorporar no reino de Portugal muitas terras que devido a uma indefinição da fronteira se consideravam usurpadas. A entrega seria feita ao porteiro da coroa João Rodrigues, que por seu turno as daria ao cavaleiro Nuno Fernandes Cogominho, que assumiria a sua posse em nome do rei D. Dinis ${ }^{12}$.

8 A.N.T.T., Gaveta XVIII, maço 9, no 1. Publicado em As Gavetas da Torre do Tombo, vol. IX, Lisboa, 1971, pp. 408-410.

9 VISCONDE DE SANTAREM, ob. cit., p. 116.

10 Fortunato DE ALMEIDA, História de Portugal, vol. I, Coimbra, 1922, pp. 242-243.

11 A.N.T.T., Direitos Reais, livro 3, fol. 138.

12 A.N.T.T., Gaveta XIV, maço 4, n 17 Documento publicado em As Gavetas da Torre do Tombo, vol. III, Lisboa, 1963, p. 614. 
Em 20 de Outubro o rei Fernando IV e o infante D. Henrique comprometiam-se por carta, junto de D. Dínis, a entregar-lhe os castelos e vilas de Aroche e Aracena. $O$ prazo de entrega decorria entre 28 de Setembro de 1296 e 28 de Março do ano seguinte ${ }^{13}$.

A proposta em apreço causou a maior irritação no monarca português que via nesta atitude uma manobra dilatória para atrasar a entrega dessas importantes localidades estratégicas. Esta equivocidade teve como consequência que em Janeiro de 1296 se tenha constituído uma liga que visava desmembrar os estados de Fernando IV. Entrava na sua composição o rei de Aragão, Jaime II, e seu irmão o infante D. Pedro, cunhados do rei D. Dinis; D. Afonso de Lacerda, primo de Fernando IV e o infante D. João. Em função do compromisso assumido este último governaria o reino de Leão, Galiza e Asturias, enquanto D. Afonso tomaria conta do trono de Castela e da Andaluzia. A Jaime ll caberia o reino de Murcia. De notar que tanto D. João como D. Afonso chegaram a ser proclamados monarcas ${ }^{14}$.

Nos primórdios do mês de Janeiro de 1296 o infante D. João entra em território português e alia-se com D. Dinis, o qual se mostra disponível para o auxiliar na conquista do reino de Leão, no qual se auto-proclamara monarca. Dentro da mesma lógica o rei de Portugal entra no pacto celebrado, em 21 de Janeiro, em Bordalva, o qual confederava os acima mencionados castelhanos e aragonese ${ }^{15}$.

A entrada do exército português deu-se em terras de Castela no mês de Setembro de 1296, actuando D. Dinis como aliado dos infantes D. João e D. Afonso de Lacerda. O rei português «com suas gentes bem ordenadas emtrou em Castella por as comarquas de Cidade Rodrigo e de Ledesma e na frontarja os portugueses tomaram por força hu castello que dizem Torres e mataram todollos contrarios que nelle acharam. $E$ dy foy el Rey Dom Dinis fazendo crua guerra sem algua resistencia nem contradicam quarenta legoas de Castella atee o lugar de Symancas que he duas legoas de Valhadolid honde el Rey dom Fernando estaua. E a tençam de todos era que elRey dom Dinis ho hya çerquar para que repartyam suas estançias de que a hua parte dauam a el Rey dom Dinis e a outra com a gente dAragam e dom Afonso de Lacerda que era com elle e contra el Rey dom Fernando" ${ }^{16}$.

Com a entrada do inverno, o rei $\mathrm{D}$. Dinis teve receio que os castelhanos the cortassem a passagem do rio Douro, pelo que de seguida inverteu a marcha e regressou por Medina del Campo a Portugal, apoderando-se da comarca de Riba Côa, que pertencia na altura a Castela ${ }^{17}$.

No âmbito dos acontecimentos o infante D. João, intitulado rei da Galiza e de Leão, outorgou uma carta em 19 de Novembro de 1296, na qual se declarava que tinha

13 A.N.T.T., Gaveta XIV, maço 8, no 24. Publicado em As Gavetas da Torre do Tombo, vol. III, pp. 796-797.

14 José MATTOSO, ob. cit., p. 150.

15 Jerónimo ZURITA, Anales de la Coroa de Aragon, vol. II, livro 5, cap. 20, Zaragoza, 1977, p. 494.

16 Ruy DE PINA, ob. cit., cap. VIII, p. 44.

17 Fortunato DE ALMEIDA, ob. cit., p. 243. 
recebido de D. Dinis a quantia de $\mathbf{3 1 5 . 0 0 0}$ maravedis leoneses pela compra da cidade e do castelo de Coria ${ }^{18}$.

Com a finalidade de evitar um conflito aberto com Portugal realizam-se em Zamora cortes nas quais se acordou o cumprimento do testamento de Sancho IV no respeitante às terras devolvidas a Portugal, do mesmo modo que se assentou no casamento do primogénito $\mathrm{D}$. Afonso com $\mathrm{D}$. Beatriz de Castela. As decisões acordadas em Zamora foram de imediato transmitidas a D. Dinis, obstando-se deste modo a que fosse desencadeada uma nova invasão em Castela. Entre as propostas de paz figurava o casamento de Fernando IV de Castela, apenas com onze anos, com D. Constança, filha do rei $D$. Dinis, com somente sete anos. Outro dos consórcios seria entre o herdeiro do trono português D. Afonso, com sete anos e D. Beatriz, irmã de Fernando IV, que ainda não completara os quatro anos ${ }^{19}$.

Uma carta de Fernando IV de Castela, datada de 28 de Agosto de 1297, propunha ao rei português que se fizesse uma troca entre os castelos e lugares ocupados na sua incursão por terras de Ribacôa. Eram estes os que integravam a irmandade dos sete castelos pertencentes às vilas de Sabugal, Alfaiates, Vilar Maior, Almeida, CasteloBom, Castelo-Rodrigo e Castelo-Melhor. O escambo implicava o reconhecimento de os direitos de Fernando IV sobre diversas vilas e castelos raianos ${ }^{20}$.

Em função de um conjunto de diligências prévias chegou-se à celebração do tratado de Alcañizes em 12 de Setembro de 1297. As cláusulas de convénio estabeleciam os direitos de Portugal à posse dos castelos ocupados em Ribacôa e ainda ao castelo de Monforte. Outros castelos localizados no Alentejo ficariam sob a soberania portuguesa como era o caso de Campomaior, Ouguela, Olivença e São Felix dos Galegos. Acrescentavam-se a estas concessões os castelos de Moura e Serpa, que apesar de terem sido cedidos em 1295, ainda não tinham sido devolvidos. Por seu turno Portugal renunciava à posse dos castelos de Aroche e de Aracena e ainda aos castelos de Valencia de Alcantara, Ferreira e Esparregal, que se encontravam na posse da ordem de Alcantara ${ }^{21}$.

Nesse mesmo dia, em Alcañizes, procedia-se à ratificação do tratado celebrado em Fevereiro, relativamente aos casamentos acordados. Em 15 de Setembro, Fernando IV fez a promessa que o bispo de Badajoz daria outorga à doação que fizera a D. Dinis da via de Campomaior, pelos direitos que esse prelado possuía sobre essa vila ${ }^{22}$.

Efectivamente, em 30 de Outubro de 1297, o rei de Portugal procedeu ao auto de

18 A.N.T.T., Gaveta XIV maço 1, $\mathrm{n}^{\circ}$ 10. Publicado em As Gavetas da Torre do Tombo, vol. III, p. 587.

19 VISCONDE DE SANTAREM, ob. cit., p. 120.

20 A.N.T.T., Livro de Extras, fol. $188 \mathrm{v}$.

21 A.N.T.T., Gaveta XVIII, maço 9, n 13. Publicado em As Gavetas da Torre do Tombo, vol. IX, Lisboa, 1971, pp. 500-504.

22 A.N.T.T., Gaveta XVIII, maço 10, n² 9. Publicado em As Gavetas da Torre do Tombo, vol. IX, pp. 535-536. 
posse dos lugares de Campomaior e de Ouguela, dando-se assim cabal cumprimento aos acordos estabelecidos entre ambas as partes ${ }^{23}$.

Entretanto, os nobres e homens bons reunidos nas cortes de Valladolid, produziram uma carta em 12 de Maio de 1298, através da qual requeriam o auxílio de D. Dinis para combater o infante $D$. João e os partidários que o apoiavam. $O$ documento em apreço exprimia a ansiedade pela situação de guerra civil que o reino de Castela atravessava ao por-se em causa a autoridade de Fernando IV. Dando sequência ao pedido de auxilio o monarca português dirigiu-se para Castela à frente do seu exército, tendo-se encontrado em Toro com o infante $D$. Henrique, que se mostrava de extrema duplicidade em toda esta conjuntura. $O$ rei de Portugal propôs à rainha-regente $\mathrm{D}$. Maria de Molina, que reconhecesse D. João como rei de Galiza, no que deparou com a sua recusa. Frustrados os seus intentos regressou a Portugal, tendo permanecido no Sabugal durante todo o mês de Agosto e na primeira quinzena de Setembro a aguardar o desenrolar dos acontecimentos em Castela, os quais entretanto não se alteraram ${ }^{24}$.

No decurso do mês de Janeiro de 1300 o rei D. Dinis enviou uma embaixada a Castela com a finalidade de se entrevistar com o rei Fernando IV e D. Maria de Molina. $O$ encontro teve lugar em Palencia, resultando dos contactos estabelecidos a confirmação dos casamentos do rei de Castela com D. Constança e do herdeiro ao trono de Portugal com D. Beatriz ${ }^{25}$.

Dando seguimento ao acordado, D. Dinis dirigiu-se para Ciudad Rodrigo, no mês de Março de 1300, tendo-se entrevistado com os reis de Castela com a finalidade de repartir as despesas na obtenção das bulas que concediam a dispensa de parentesco com o fim de viabilizar os casamentos acordados em Alcañizes. Em conformidade com as diligências efectuadas foram concedidas as bulas necessárias para a efectivação do casamento entre Fernando IV e D. Beatriz, o que veio a acontecer em Janeiro de $1302^{26}$.

No contexto da diplomacia peninsular D. Dinis enviou, em Novembro de 1300, uma embaixada a Jaime II de Aragão, sendo embaixador o conde João Afonso de Albuquerque, o qual tinha por missão encontrar-se em primeiro lugar com a rainha Maria de Molina, precisamente com a finalidade de se conseguir uma aliança entre os monarcas de Castela e Aragão. Em resposta Jaime II enviou como embaixador a Ramon de Monros, o qual era portador de diversas cartas para D. Dinis, em que lhe requeria, que no caso de o monarca português empreendesse uma viagem a Aragão se fizesse acompanhar de sua mulher D. Isabel. Outras cartas do rei de Aragão foram enviadas ao príncipe $D$. Afonso e a outros fidalgos e prelados portugueses ${ }^{27}$.

23 A.N.T.T., Gaveta XVIII, maço 2, nº 9. Publicado em As Gavetas da Torre do Tombo, vol. IX, pp. 410-414.

24 A.N.T.T., Gaveta XVIII, maço 3, n²1. Publicado em As Gavetas da Torre do Tombo, vol. VIII, Lisboa, 1970, pp. 298-299.

25 VISCONDE DE SANTAREM, ob. cit., p. 125.

26 José MATTOSO, ob. cit., p. 152.

27 Jerónimo ZURITA, ob. cit., vol. II, livro 5, cap. 45, pp. 590-591. 
Entretanto, a seguir ao mês de Agosto de 1302, o rei D. Dinis enviou uma embaixada a Castela chefiada pelo conde de Barcelos, com o objectivo de se consumarem as bodas matrimoniais entre Fernando IV e D. Constança, que alcançara a idade própria para a sua concretização, o que aliás veio a acontecer ${ }^{28}$.

A troca de mensagens diplomáticas acentuou-se durante 1303. Jaime II enviou uma embaixada a Portugal constituída por Domingos Garcia de Echauri, Ramon de Monros e João Garcez de Alagon, a qual tinha como missão alcançar uma trégua tripartida entre o monarca de Aragão, D. Dinis e o infante D. Afonso, que pretendia ser rei de Castela. Contudo para impedir que esta aliança se consumasse, Fernando IV enviou a Portugal como seu embaixador ao infante $\mathrm{D}$. João, instando o estreitamento de laços políticos entre os dois reinos em detrimento de Aragão. Como resultado destas diligências efectua-se no mês de Março de 1303, em Badajoz, uma entrevista entre D. Dinis e Fernando IV, da qual resultou que o monarca castelhano concedeu uma avultada soma de dinheiro ao rei de Portugal ${ }^{29}$.

Este encontro régio que se ficou devendo à oposição do infante $D$. Henrique ao rei de Castela, traduziu-se no empréstimo de um milhão de maravedis ao monarca português, que em troca se comprometia a auxiliar militarmente a Fernando IV ${ }^{30}$.

$A$ influência de $D$. Dinis surge-nos de um modo manifesto na contenda que opunha Castela e Aragão a propósito da disputa que se travava desde 1296 por causa da ocupação, por parte destes, de Murcia e Alicante. Uma embaixada aragonesa chegada a Portugal em Junho de 1303 viabilizou uma trégua entre os três reinos, difícil de conseguir, devido às ambições do infante $\mathrm{D}$. Fernando de Lacerda ao trono castelhano e às mencionadas disputas territoriais. Uma outra embaixada de Jaime II enviada a Portugal fazia saber que existia uma aliança entre Aragão e o referido infante, pelo que não podia haver qualquer paz ou trégua sem o seu consentimento. Prometia, contudo, entrevistar-se com ele para se alcançar a necessária concórdia ${ }^{31}$.

A natureza destas embaixadas com carácter contraditório, conduz Jerónimo Zurita a produzir este saboroso comentário alusivo a Jaime II: - «Y asi andaba el rey en un mismo tiempo entreteniendo a los unos y a los otros para sacar el mejor partido que pudiese ${ }^{32}$.

Com o propósito de atenuar a tensão política, Jaime II, por carta de 21 de Abril de 1304, declara que não irá atacar alguns castelos pertencentes à soberania de Castela, por os mesmos se encontrarem sob a protecção do rei $D$. Dinis, do bispo de Zaragoza, e de o tio do monarca de Castela, o infante D. João ${ }^{33}$.

Em Julho de 1304 o rei D. Dinis dirige-se através da Guarda à fronteira leonesacastelhana. A comitiva régia integrava à volta de um milhar de fidalgos, destacando-se a presença da rainha $\mathrm{D}$. Isabel, do irmão do rei, o infante $\mathrm{D}$. Afonso, do seu filho ilegí-

28 VISCONDE DE SANTAREM, ob. cit., pp. 126-127.

29 Idem, Ibidem, p. 127.

30 José MATTOSO, ob. cit., p. 152.

31 Jerónimo ZURITA, ob. cit, livro 5, cap. 59, vol. II, pp. 642.

32 Idem, Ibidem.

33 A.N.T.T., Chancelaria de D. Dinis, livro 5, fol. 2. 
timo D. Pedro de Barcelos e de Pero Afonso de Albuquerque. Ao chegar D. Dinis à Guarda recebeu a visita de representante do rei Fernando IV, o escrivão da puridade, Diogo Garcia de Toledo, que tinha por incumbência acompanhar o monarca português na sua visita a Castela. Durante a sua digressão por terras castelhanas nunca D. Dinis consentiu que alguém da comitiva se hospedasse nalguma localidade, recorrendo a tendas de campanha e adquirindo por dinheiro as vitualhas necessárias para a manutenção dos acompanhantes e das montadas ${ }^{34}$.

D. Dinis chegou a Roa e entrevistou-se com o seu genro Fernando IV, seguindo na sua companhia para Agreda. Entretanto Jaime II aguardava o rei de Portugal em Torrellas, na fronteira do seu reino entre Agreda e Tarazona. $O$ encontro verificou-se em princípios de Agosto, sendo grande a recepção que o aragonês fez a D. Dinis e a sua irmã Santa Isabel. No dia 8 desse mês o rei português conjuntamente com o infante D. João e o bispo de Zaragoza, dom Jimeno de Luna, lavrou a sentença sobre a contenda que dividia os reis de Aragão e Castela acerca da posse de Murcia. Em conformidade com a mesma pertenceriam ao reino de Aragão as localidades de Cartagena, Elche e Alicante, ficando na posse da Castela, Murcia e Molinaseca, além dos seus termos. Fernando IV ratificou em 9 de Agosto na presença de todos a sentença em apreço e prestou homenagem ao rei de Aragão ${ }^{35}$.

Com a presença dos monarcas dos três reinos realizaram-se grandes festas em Tarazona, localidade em que Fernando IV ratificou a cedência que Afonso o Sábio fizera a D. Dinis do reino do Algarve. Uma estreita aliança foi celebrada entre os três monarcas, a qual abrangia o rei de Granada que era vassalo de Fernando IV. Concluídas as cerimónias os reis de Castela e de Portugal regressaram juntos, enquanto Jaime II partiu para Zaragoza ${ }^{36}$.

Decorridos alguns anos, em 15 de Fevereiro de 1312, veio a Portugal uma embaixada enviada por Jaime II. Um dos objectivos que a determinou visava a realização do casamento de sua filha Violante del Bar com um infante português. Outra das questões a tratar prendia-se com a restituição a Portugal de Serpa, Moura, Aroche e Aracena, uma antiga questão que se vinha arrastando. Em aberto existia uma queixa de Fernando IV, em que o mesmo recordava que durante a sua menoridade o rei português se apoderara dessas localidades e das terras de Ribacôa, do que se sentia muito prejudicado. Para obviar a esta contenda Jaime Il enviou a seu irmão, dom João de Aragão, para que se encontrasse uma solução. Dom Dinis consentiu nesta arbitragem e colocou os castelos de Castelo Mendo, Sortelha e Segura sob sua tutela. Um dos embaixadores que representou os interesses do rei de Portugal foi Ramon de Cardona, que era cunhado de Jaime II, por se encontrar casado com sua irmã Dona Beatriz ${ }^{37}$.

No meio desta contenda, travada em Agosto de 1312, o rei de Castela invocava os seus direitos à posse dos castelos de Moura e Serpa, dos sete catelos de Ribacôa e

34 Jerónimo ZURITA, ob. cit, vol. II, livro 5, cap. 56, pp. 668-669.

35 Idem, Ibidem, pp. 669-671.

36 Idem, Ibidem, pp. 671-673,

37 Idem, Ibidem, cap. 97, pp. 759-760. 
Monforte, e ainda os castelos de Olivença, Campomaior, San Feliçes de los Gallegos e Ouguela. Alegava que os dois primeiros pertenceram a Castela durante dezassete anos e os últimos mais de cem anos. Na sua resposta, o rei de Portugal declarava que tanto Serpa como Moura eram terras conquistadas pelos seus antecessores aos mouros, até que Afonso o Sábio as conquistou por força a Afonso III, a braços com a guerra civil na sequência da deposição de Sancho II. Também as terras de Ribacôa eram da conquista dos reis de Portugal até à ocupação dos castelhanos. Igualmente considerava que os castelhanos Ihes haviam usurpado Valencia de Alcantara, Herrera, Esparregal e Ayamonte, localidades estas que foram cedidas a Castela por acordo de Fernando IV e D. Dinis. Também este monarca renunciou à posse de Aroche e Aracena por escambo com Olivença, Ouguela, Campomaior e São Felices de los Gallegos ${ }^{38}$.

Lembravam, ainda, os portugueses, que através do acordo matrimonial, a propósito do casamento de D. Afonso III, com a filha de Afonso X, Dona Beatriz, estabeleciase a cláusula que tendo um filho de ambos, sete anos, receberia o reino do Algarve, o que apenas veio a concretizar-se com Fernando IV ${ }^{39}$.

Em 9 de Setembro de 1312 faleceu o rei de Castela. Sua mulher D. Beatriz enviou a seu pai $D$. Dinis a notícia de tão infausto acontecimento, o que interrompia as negociações em curso ${ }^{40}$.

No início do ano seguinte chegou a Portugal uma embaixada de Jaime II, na qual se solicitava a D. Dinis que o infante D. Pedro de Castela fosse nomeado tutor de Afonso $\mathrm{XI}$, que ficara menor por falecimento de Fernando IV. A pretensão visava o propósito de que o jovem rei fosse criado por sua mãe D. Constança. Essa conjuntura apresentava-se complicada face à divisão reinante. Segundo Zurita «los hechos vinieron en tanta discordia y rompimiento que ni los infantes se pudieron concertar ni mucho menos el reino; y unas ciudades y villas tomaron por tutor el infante don Pedro con la reina doña Maria y otros al infante dom Juan con la reina doña Costanza; y asi en lugar de un tutor hubo diversos señores. $Y$ estaba la tierra en grande escandalo y confusion $»^{41}$.

Com a guerra civil de 1319-1325 que opõe D. Dinis a seu filho D. Afonso, Portugal perde influência na cena internacional, a braços com uma grave crise interna. Sintomática é a entrevista do herdeiro ao trono de Portugal com a rainha de Castela, Maria de Molina, em Fuente Grimaldo, em que acordam que esta escreva a D. Dinis, requerendo-lhe que abandone o trono a favor de seu filho ${ }^{42}$.

Na sequência desse acordo a rainha Maria de Molina escreve com efeito em 1319, ao rei D. Dinis, para que renuncie ao poder. Em resposta o monarca português dirigese a essa senhora regeitando categoricamente a proposta. Do mesmo modo envia à rainha os seus pêsames pelo falecimento dos infantes $\mathrm{D}$. Pedro e D. João ${ }^{43}$.

38 Idem, Ibidem, p. 761.

39 VISCONDE DE SANTAREM, ob. cit., p. 137.

40 Idem, Ibidem.

41 Jerónimo ZURITA, ob. cit., vol. II, livro 5, cap. 102, pp. 775-776.

42 VISCONDE DE SANTAREM, ob. cit, pp. 138-139.

43 Idem, Ibidem, p. 139. 
Desgostoso o rei $D$. Dinis com o comportamento rebelde de seu filho, 0 infante $D$. Afonso, queixou-se em 1321 a Jaime II, o qual para atalhar o mal e alcançar a concordia enviou a Portugal como seu emissário, a seu irmão D. Sancho. Por seu turno o mencionado infante queixou-se de seu pai a seu tio, o rei de Aragão, acusando o progenitor de ser o culpado do clima de dessassossego que se vivia no reino ${ }^{44}$.

D. Dinis faleceu em 7 de Janeiro de 1325. Após a sua morte vieram a Portugal algumas embaixadas a apresentar os pêsames pelo seu desaparecimento. De Castela manifestaram as suas condolências à rainha viúva $D$. Isabel e ao novo rei $D$. Afonso IV, que foi felicitado pela sua elevação ao trono ${ }^{45}$.

Penalizado Jaime II com o sucedido enviou desde Valencia um seu emissário, o cavaleiro Lope Alvarez de Espejo, que em seu nome apresentou as suas condolências e efectuou diligências para a reconciliação entre o novo rei e seu irmão, o infante D. Afonso Sanches ${ }^{46}$.

A seguir a Fevereiro de 1325, o rei de Aragão solicitou a seu sobrinho Afonso IV, que the emprestasse dinheiro para a guerra de Cerdenha, conhecedor que seu pai $D$. Dinis deixara um avultado tesouro ${ }^{47}$.

Com toda a probabilidade, ainda neste mesmo ano, o rei D. Afonso IV enviou a Barcelona como seu embaixador a Lopo Fernandes Pacheco. A missão tinha como finalidade tratar do casamento com $D$. Branca, que era noiva prometida do infante português D. Pedro, filho de D. Afonso IV, com D. João, senhor de Biscaía ${ }^{48}$.

No ano de 1326 verifica-se que Afonso XI de Castela efectua diligências no sentido de se casar com Dona Maria, filha de D. Afonso IV, repudiando para o efeito a filha de D. João Manuel que era neta do rei de Aragão. No termo do mês de Novembro do ano em apreço, o rei de Aragão enviou como embaixador a Portugal a D. Ximeno de Tobia, o qual tinha por missão conseguir junto de $D$. Afonso IV que este escrevesse ao papa para que o mesmo concedesse a dispensa do casamento entre D. Branca e D. João. De igual modo o embaixador aragonês deveria solicitar, em nome do seu monarca e do de Portugal, a ratificação das pazes celebradas entre eles, Fernando IV e o infante D. João. D. Afonso IV recébeu a embaixada aragonesa quando se encontrava em Estremoz, em 22 de Dezembro, ficando acordado guardarem-se as cláusulas do tratado de amizade que existia entre Portugal e Aragão ${ }^{49}$.

Em Setembro de 1327, o rei de Portugal enviou como seu embaixador à corte aragonesa, a Lourenço Gomes de Abreu. O encontro entre o emissário de $\mathrm{D}$. Afonso IV e Jaime II deu-se, em 18 de Outubro, deste ano, na cidade de Barcelona. Segundo a carta de crença do representante diplomático referia-se que entre os reis de Portugal e de Castela se tinha concertado o casamento entre a infanta D. Maria, filha do referido monarca com o próprio soberano castelhano, o qual desejava romper o seu

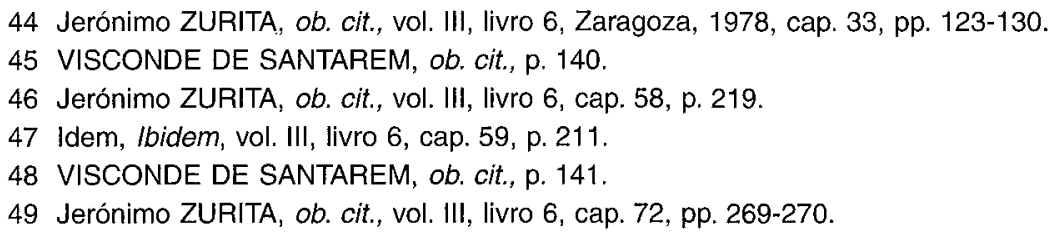

44 Jerónimo ZURITA, ob. cit., vol. III, livro 6, Zaragoza, 1978, cap. 33, pp. 123-130.

45 VISCONDE DE SANTAREM, ob. cit., p. 140.

46 Jerónimo ZURITA, ob. cit., vol. III, livro 6, cap. 58, p. 219.

47 Idem, Ibidem, vol. III, livro 6, cap. 59, p. 211.

48 VISCONDE DE SANTAREM, ob. cit., p. 141.

49 Jerónimo ZURITA, ob. cit., vol. III, livro 6, cap. 72, pp. 269-270. 
matrimónio com D. Constança, neta do rei aragonês. Usando do maior tacto diplomático D. Afonso IV transmitia ao seu homólogo aragonês que tal acontecimento não visava desconsiderá-lo, antes pelo contrário, requeria o seu conselho e consentimento. Com firmeza Jaime II respondia que Afonso IV dispunha do bom senso necessário para entender que esta atitude constituía uma afronta para si, para seus filhos e para sua neta $D$. Constança. Atendendo ainda ao vinculo de amizade que existia entre Portugal e Aragão, este facto representava igualmente uma afronta para a coroa portuguesa, pelo que D. Afonso IV deveria rejeitar categoricamente «tan flacas y coloradas razones las que el rey de Castilla daba para fundar y justificar el divorcio " ${ }^{50}$.

Partiu para Portugal, em Outubro de 1327, o embaixador Boshom Ximenez com a finalidade de evitar o desenlace previsto. A missão traduziusse num insucesso, dado que o rei de Castela estava determinado a repudiar sua mulher. A guerra civil estava desencadeada com a oposição de D. João Manuel, que com a sua hoste combateu o rei de Castela ${ }^{51}$.

No decurso deste mesmo ano o rei castelhano enviou uma missão secreta a Portugal para se inteirar da sensibilidade do monarca português acerca do casamento do próprio soberano de Castela com D. Maria e simultâneamente o divórcio com D. Constança. A reacção de Afonso IV foi muito negativa ao insurgir-se contra o siligismo de que se revestia essa missão, do mesmo modo que defendia que a primeira tarefa a encetar consistia na publicação do divórcio ${ }^{52}$.

Apostado no estreitamento das boas relações com Portugal, Afonso XI, em 18 de Outubro de 1327, passou uma procuração a Pero Ruiz de Villegas e a Fernão Fernandez de Pina, para que com toda a minúcia passassem em revista e ratificassem os acordos celebrados entre os monarcas de Castela e de Portugal, Fernando IV e D. Diniz, respectivamente ${ }^{53}$.

No mesmo dia da procuração o rei de Castela outorgou outra carta aos mesmos procuradores, concedendo-lhes poderes para que pudessem receber por palavras de presente a infante D. Maria, filha do monarca português ${ }^{54}$.

Provávelmente, em Novembro de 1327, nova embaixada de Castela foi enviada por Afonso XI ao rei de Portugal. A proposta visava o casamento do herdeiro do trono português, D. Pedro, com a infanta de Castela D. Branca, impedindo, deste modo, a possibilidade de qualquer aliança entre Portugal e o seu adversário, o infante D. João Manuel. Esta iniciativa deparou com uma recusa de D. Afonso IV, que diferiu a proposta para um encontro pessoal a realizar entre ele e o rei de Castela ${ }^{55}$.

Enquanto se desenvolvia intenso intercâmbio diplomático entre os mencionados reinos de Portugal e Castela falecia em Barcelona, após prolongada doença, no dia 2

50 Idem, Ibidem, vol. III, livro 6, cap. 73, pp. 275-276.

51 Idem, Ibidem.

52 VISCONDE DE SANTAREM, ob. cit, pp. 145-146.

53 A.N.T.T., Gaveta XVIII, maço 11, no 5. Publicado em As Gavetas da Torre do Tombo, vol. IX, pp. 636-657.

54 A.N.T.T., Casa da Coroa, gaveta 17, maço 1.

55 VISCONDE DE SANTAREM, ob. cit., p. 147. 
de Novembro de 1327, o rei de Aragão, Jaime II, com a idade de sessenta e seis anos $^{56}$.

Em 17 de Dezembro de 1327, efectuou-se em Coimbra a celebração de um tratado de paz e amizade entre Afonso XI e Afonso IV, em que se procedia à ratificação de todos os convénios acordados pelos seus progenitores D. Dinis e Fernando IV ${ }^{57}$.

Decorridos alguns dias, em 26 de Dezembro, realiza-se na mesma cidade o tratado de casamento entre D. Maria, filha do rei de Portugal e Afonso XI de Castela ${ }^{58}$.

No ano seguinte, no lugar de Alfaiates deu-se um encontro entre Afonso IV e Afonso $\mathrm{XI}$, tendo-se celebrado as bodas do rei de Castela com a infanta D. Maria de Portugal. Logo de seguida, em Fuente Aguinaldo, efectua-se o casamento entre D. Pedro, herdeiro de Portugal e D. Branca, filha do infante D. Pedro de Castela ${ }^{59}$.

Durante a permanência em Fuente Aguinaldo dos reis de Portugal e de Castela, o primeiro aconselha o segundo que se alie com o novo monarca de Aragão, Afonso IV, para assim deixar isolado a $D$. João Manuel e impedir uma aliança com o aragonês. Para 0 atrair deveria propor-Ihe o casamento com sua irmã $D$. Leonor e de imediato mandar restituir D. Constança a seu pai o infante D. João Manuel ${ }^{60}$.

Tomando a iniciativa os reis de Portugal e de Castela procuram confederar-se com Afonso IV de Aragão, ratificando os acordos anteriores, e levando se possível este monarca a marginalizar ao infante $D$. João Manuel. Essa tentativa não resultou na medida em que o aragonês invocava que antes de mais nada era indispensável a reconciliação entre Afonso XI e o referido infante ${ }^{61}$.

Num esforço de aproximação, Afonso IV de Aragão, por procuração de 25 de Agosto de 1328, designou o membro do seu conselho, Gonçalo Garcia, para que em sua representação alcançasse o acordo de ratificação do tratado de amizade entre os três reinos, Aragão, Castela e Portugal, que tinha sido celebrado em Agreda a 9 de Agosto de 1304. Tal desiderato veio a ser conseguido entre as três partes, em Medina del Campo, em 21 de Outubro de 1328. A ratificação de Afonso IV de Aragão deu-se em 31 de Janeiro de $1329^{62}$.

Fruto desta série de esforços diplomáticos traduziu-se em Agreda, em 5 de Fevereiro de 1329, na efectivação de um tratado de liga entre os monarcas dos três reinos, em cujas cláusulas se estabeleceu um pacto de amizade, mediante o qual se declarou que seriam amigos dos seus amigos e inimigos dos seus inimigos, não consentindo a permanência em seus reinos de adversários mútuos e conjugando esforços no sentido concertar esforços para combater os muçulmanos. Ainda em conformidade com o tratado de paz acordava-se que $\mathrm{D}$. Branca de Castela seria entregue à rainha de Por-

56 Jerónimo ZURITA, ob. cit., vol. III, livro 6, cap. 75, p. 282.

57 VISCONDE DE SANTAREM, ob. cit.

58 A.N.T.T., Casa da Coroa, gaveta 17, maço 1, p. 147.

59 VISCONDE DE SANTAREM, ob. cit., p. 149.

60 Idem, Ibidem, p. 150.

61 Jerónimo ZURITA, ob. cit,, vol. III, livro 6, cap. 79, p. 295.

62 A.N.T.T., Gaveta XVIII, maço 5 n 32. Publicado em As Gavetas da Torre do Tombo, vol. VIII, pp. 566-575. 
tugal, D. Beatriz, até alcançar os doze anos, idade que lhe permitiria contrair casamento com o herdeiro da coroa D. Pedro ${ }^{63}$.

A amizade entre Portugal e Aragão viria a ser selada em 2 de Novembro de 1329 através do representante diplomático de Afonso IV, Lopo Fernandes Pacheco e o rei Afonso IV de Aragão, com a ratificação em Valencia do tratado de Agreda de 9 de Agosto de 1304, uma pedra decisiva que viria a consolidar toda a estratégia política concertada pelos reis D. Dinis, Fernando IV e Jaime $11^{64}$.

Com a ratificação assinalada assiste-se ao coroamento duma política que veio reforçar os laços existentes entre os três reinos, pese embora as vicissitudes entretanto vividas, o que significa que para além das constantes relações entre Portugal e Castela, as mesmas estendiam-se ao reino de Aragão, certamente incrementadas pela constante influência da rainha Santa Isabel, aragonesa, que viveu em Portugal entre 1282 e 1336, mantendo um papel fundamental no estreitamento de contactos entre o espaço atlântico e mediterrânico, tanto no plano afectivo como político.

63 Jerónimo ZURITA, ob. cit., vol. III, livro 7, cap. 7, pp. 321-323.

64 Idem, Ibidem, vol. III, livro 7, cap. 9, p. 329. 



\title{
LAS RENTAS REALES EN LA PROCURACIÓN DE ORIHUELA, 1305-1324
}

\author{
Juan Antonio BARRIO BARRIO \\ Universidad de Alicante
}

\section{EL PATRIMONIO REAL A PRINCIPIOS DEL SIGLO XIV}

Tras la conquista del reino de Murcia en 1296 Jaime II unió las villas reales más importantes como Orihuela, Alicante y Guardamar a la Corona de Aragón. La firma de los tratados de Torrellas y Elche en 1304 y 1305 se plasmó en la definitiva incorporación a la Corona de Aragón de los territorios situados entre Biar y el río Segura. Quedando dentro del patrimonio real localidades como Alicante, Guardamar, y Orihuela. Ello suponía la posibilidad de contar con una mayor cobertura territorial hacia el Mediterráneo con puertos como el de Alicante y el incremento consolidado de la renta recaudada por la Corona por la incorporación al patrimonio real de tierras, rentas, monopolios, jurisdicciones, etc. Coincidiendo en esta franja cronológica con la anexión temporal a la Corona de localidades tradicionalmente señoriales como Elche y Crevillente.

El estudio de las rentas reales en el reinado de Jaime II es una cuestión todavía por abordar, a pesar de los recientes avances en el conocimiento del patrimonio real de la Corona de Aragón en época de Jaume I, Alfonso el Casto, Alfonso el Benigno,

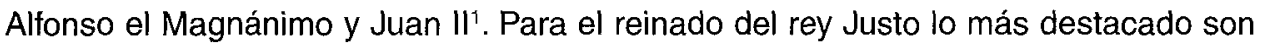

1 GUINOT, E., «El patrimoni reial al Pais Valencià a inicis del segle XV», Anuario de Estudios Medievales, 22 (1992), pp. 581-639. Donde recoge la bibliografía puntual de los estudios sobre el patrimonio real en estos reinados. Para la fiscalidad regia en la Corona de Aragón entre los siglos XII al XIV son imprescindibles los trabajos de Manuel SÁNCHEZ MARTíNEZ, "La fiscalidad real en Cataluña (siglo XIV)", Anuario de Estudios Medievales, 22 (1992), pp. 341-375. Id. "La evolución de la fiscalidad regia en los países de la Corona de Aragón (c.1280-1356)», Europa en los umbrales de la Crisis (1250-1350), Pamplona, 1995, pp. 393-428. Id. El naixement de la fiscalitat d'Estat a Catalunya: segles XII-XIV. Vic, 1995. 
los estudios de Ferrer i Mallol sobre la renta mudéjar ${ }^{2}$ y sobre la organización de la bailía de Orihuela ${ }^{3}$ y la aproximación al estudio de las finanzas de la Corona a principios del siglo XIV realizada por Guilleré.

Nuestro objetivo es realizar un análisis de las rentas reales ordinarias en la procuración de Orihuela entre 1305 y 1324, período comprendido entre el tratado de Elche y la separación de Elche del patrimonio real, a partir de las cuentas conservadas para los años 1316-13245.

Dentro de la organización administrativa emprendida tras la partición del reino de Murcia entre la Corona de Aragón y Castilla por el tratado de Torellas de agosto de 1304, Jaime II nombro al que era baile general del reino de Murcia Ferrer Descortell, nuevo baile general de las tierras dellà Xixona ${ }^{6}$. El baile general era el responsable de la administración del patrimonio real. Tenía que recibir las rentas y los impuestos reales y pagar los gastos de la Corona en la demarcación que administraba, y presentar sus cuentas al Maestro Racional ${ }^{7}$, que era el contador supremo del reino, que fiscalizaba las cuentas de todos los oficiales dependientes de la hacienda regia, como los bailes locales y sus lugartenientes ${ }^{8}$.

Para el estudio de las rentas reales de la bailía dellà Xixona he utilizado como principal fuente las cuentas de la administración de la bailía entre 1316 y 1324 conservadas en el Archivo de la Corona de Aragón y en el Archivo del reino de Valencia?.

Las cuentas del Baile Joan Rolf comprenden desde el día 1 de Mayo del año 1316 hasta diciembre de 1317. Vecino de Alicante había asumido el cargo en agosto de

2 FERRER i MALLOL, Ma.T., Els sarrains de la Corona catalano-aragonesa en el segle XIV. Segregació i discriminació, Barcelona, 1987. Id., La frontera amb I'Islam en el segle XIV. Cristians i sarraïns al Pais Valencià. Barcelona, 1988. Id., Les aljames sarraïnes de la Governació d'Oriola en el segle XIV, Barcelona, 1988.

3 FERRER I MALLOL, Ma.T., "La Batllia general de la part del regne de Valencia dellà Xixona", Anales de la Universidad de Alicante. Historia Medieval, 6 (1987), pp. 279-309.

4 «Les finances de la Couronne d'Aragon au debut du XIV siecle (1300-1310)", Estudios sobre renta, fiscalidad y finanzas en la Cataluña Bajomedieval, Barcelona, 1993, pp. 487-507.

5 Para aquilatar el tema he preferido no incluir el estudio de los subsidios y contribuciones extraordinarias realizadas por las villas reales en el período, como las subvenciones aportadas por las villas de Guardamar, Alicante, Elche y Orihuela a la campaña de Cerdeña comentadas en HINOJOSA MONTALVO, J. y BARRIO BARRIO, J.A., «Las Sisas en la Gobernación de Orihuela durante la Baja Edad Media», Anuario de Estudios Medievales, 22 (1992), pp. 535-579.

6 FERRER I MALLOL, Ma .T., "La Batllia general de la part del regne de Valencia delià Xixona...», pp. 282-283.

7 Ibídem, pp. 279-280.

8 FERRAZ PENELAS, F., Que fue el Maestre Racional. Valencia, 1977, p. 4. MONTAGUT I ESTRAGUÉS, T., El Mestre Racional a la Corona d'Aragó (1283-1419). 2 vols. Barcelona, 1987.

9 Disponemos de las cuentas del año 1316, 1317 y 1324 conservadas en el Archivo de la Corona de Aragón en la sección Maestre Racional, Reial Patrimoni, correspondiente a los registros 1701 y 1702. Mientras que las cuentas de los años $1318,1319,1320,1321$ y 1322 se encuentran en el Archivo del reino de Valencia, en un cuaderno incluido en un registro de la sección de Bailía. 


\section{LOS INGRESOS. LA PARTICIPACIÓN DE LAS VILLAS REALES EN LAS REN- TAS DE LA CORONA}

Uno de los aspectos fundamentales para el estudio del patrimonio real, es conocer el nivel de ingresos, a través de la valoración de la aportación de cada una de las villas reales del territorio, señalando en cada localidad las exacciones que se percibían, el valor de las mismas y la contribución global.

\section{Las rentas de Elche}

Como afirma Ferrer i Mallol Elche fue una villa real bajo dependencia de la Corona desde 1305 a 1324. Destaco en este período ente las villas reales como la más rica e importante de todas ${ }^{12}$. Contaba con la comunidad sarracena más numerosa de la procuración de Orihuela lo que se refleja en el nivel de ingresos, en comparación con lo que se recaudaba en las localidades de Alicante, Orihuela y Guardamar con población cristiana predominante. Una de las rentas más elevadas que recaudaba la Corona en Elche y por ende en todo el territorio de la procuración era la denominada «renta de moros", que comprendía una amplia gama de tributos sobre el individuo y la comunidad y sobre la producción.

La Corona recaudaba en Elche la mayor parte de las rentas en el territorio procuratorial, suponiendo porcentualmente en todo el período estudiado valores entre el 53 y el $79 \%$ sobre el total. Recayendo una buena parte de estas cargas fiscales sobre la comunidad mudéjar. Procedían en su mayor parte de una amplia y variada gama de exacciones sobre el individuo y la comunidad, sobre la posesión de los medios de producción y transformación, sobre la actividad comercial y mercantili ${ }^{13}$ y sobre algunos monopolios cuya gestión se arrendaba anualmente.

Rentas de los moros de Elche. Bajo este concepto se recaudaban, en una sola partida, una serie de rentas sobre la comunidad mudéjar de Elche y que en el período

10 FERRER I MALLOL, Mํ. ${ }^{a}$., “La Batllia general de la part del regne de Valencia dellà Xixona... », pp. 286-287.

11 lbídem, pp. 287-288.

12 FERRER I MALLOL, Ma.T., Les aljames sarraïnes..., p. 11.

13 Seguimos básicamente la tipología establecida por E. GUINOT en Feudalismo en expansión en el norte valenciano. Antecedentes y desarrollo del señorío de la Orden de Montesa. Siglos XIII y XIV, Castelión, 1986, y utilizada por J. HINOJOSA MONTALVO en sus trabajos sobre fiscalidad mudéjar: "Crevillente: una comunidad mudéjar en la Gobernación de Orihuela en el siglo XV», Actas del IV Simposio Internacional de Mudejarismo, Teruel, 1992, pp. 307-317. Id., La moreria de Elche en la Edad Media, Teruel, 1994. Id., "Señorío y fiscalidad mudéjar en el reino de Valencia», Actas del V Simposio Internacional de Mudejarismo, Teruel, 1991, pp. 105-134. Id., "La renta feudal de los mudéjares alicantinos", Señorio y Feudalismo en la Península Ibérica. (ss. XII-XIX), Zaragoza, 1993, vol. II, pp. 105-129. 
estudiado fueron colectadas por Alfons Guillem. Era la renta más importante de Elche. En el libro de cuentas del baile se especifica el significado de cada exacción ${ }^{14}$ :

- El atzaque. Se pagaba por el ganado pequeño dos dineros por cabeza, posiblemente ovino y cabruno. En 1315 ascendió a 500 sueldos anuales. A partir de 1316 la renta quedo integrada en el monto global del tributo de los moros de Elche.

- El almagram. Tributación sobre la posesión de la tierra según la extensión y la calidad de la misma.

- El cabezaje. Impuesto que abonaba cada musulmán varón mayor de dieciséis años y las mujeres viudas. La tarifa establecida era de 5 sueldos por cabeza.

- La alfarda. Era uno de los impuestos comunitarios más importantes de las comunidades mudéjares del reino de Valencia. Consistía en una cantidad fija anual que cada aljama pagaba al rey.

- La alfatrà. Era un impuesto de capitación que gravaba a todos los miembros de la comunidad musulmana con una tarifa de un almud de cebada.

- Los diezmos de la vendimia, del trigo, de la alcandia, de la cebada que pagaban los musulmanes de Elche.

- La alhabeç de las mezquitas. Era una peita que los musulmanes entregaban para la mezquita.

- La albayat. Colectado sobre la tierra de secano que sembraban los mudéjares. En 1315 por este concepto se recaudaron 100 sueldos $^{15}$.

- La venta del agua de Marchena y de las cuatro alquerías utilizada para regar tierras de moros, generaba una renta a la Corona, individualizada en 1315 por un importe de 4.000 sueldos anuales ${ }^{16}$, pero que en las cuentas del período estudiado esta englobada dentro del grupo de exacciones de los moros de Elche.

- Las gallinas. Cada casa habitada por musulmanes debía entregar una gallina o su equivalente en dinero, 6 dineros, al rey cada año ${ }^{17}$.

Diezmos. En 1316 y 1317 se recaudaron una serie de diezmos sobre la producción agraria por separado de la denominada renta de los moros. El diezmo o alfatrà de la cebada consistió en una gravamen de 2 cahíces de cebada por cada centenar. También se cobraron por separado el diezmo del trigo, de la alcandia y del aceite ${ }^{18}$.

Herbaje. Impuesto que se pagaba por la utilización de los pastos ${ }^{19}$. Con una tarifa en 1316 de 11 sueldos por cabeza ${ }^{20}$.

Carnaje. Consistía en una parte del diezmo de los animales nacidos durante el año ${ }^{21}$.

14 La definición de cada una de estas rentas en FERRER I MALLOL, Mª .T., Les aljames sarraïnes...

15 Ibídem, p. 145.

16 FERRER I MALLOL, M…, Les aljames sarraïnes..., p. 145.

17 Ibídem, p. 141.

18 A.C.A. Real Patrimonio, Maestro Racional, Reg. 1701.

19 Del derecho de herbaje cobrado en 1323 se ha descontado el salario del colector, aunque en las cuentas no aparece especificada la cantidad.

20 A.C.A. Real Patrimonio, Maestro Racional, Reg. 1701, f. 3r.

21 En el reino de Valencia era la cuarta parte. GUINOT, E., "El patrimoni reial al Pais Valencià...", p. 598. Desconocemos que porcentaje se aplicaba en Elche, ya que desde la conquista de Jaime II en 
Quirat. Era un derecho que cobraba la Corona a los mudéjares en las villas del reino de Valencia della Xixona por la entrada y salida de mercancías ${ }^{22}$. Según las cuentas de 1316 era el derecho que pagaban los moros por todo lo que compraban y vendían. Además en esta renta se cobraban los censos de tiendas, molinos, hornos, baños y otros derechos y caloñas ${ }^{23}$. Era la segunda renta más importante, y produjo entre 1316 y 1319 ingresos muy superiores a los percibidos por el almojarifazgo ${ }^{24}$.

De la cantidad que recibía el baile en nombre del rey se detraía una cantidad que tomaba el colector de la renta en concepto de retribución y otra por las cantidades que se destinaban a gastos de obras y mantenimiento en los molinos, hornos, tiendas, baños, etc. ${ }^{25}$.

Almojarifazgo. Era el mismo impuesto que el quirat, pero con el nombre de almojarifazgo gravaba a los cristianos. Definido en las cuentas como el derecho que los mercaderes cristianos pagaban en la aduana de Elche ${ }^{26}$. Bajo este concepto se cobraban otros censales que el rey tenía en Elche ${ }^{27}$. Como en el quirat en la cantidad ingresada en las arcas reales se restaba lo que debía cobrar el colector ${ }^{28}$.

En las cuentas de 1318 aparece una anotación que indica que el almojarifazgo lo pagaban también los judíos: «... el dret que alcuns cristians e juheus pagaran el dit any en la dita duana $a b$ alcuns censals..." ${ }^{29}$.

Desde 1320 quirat y almojarifazgo, se cobraron bajo un mismo concepto denominado aduana de Elche $^{30}$.

Derecho del puerto del Cap del Aljup. Se cobraba en el puerto del Cap del Aljup de Elche $^{31}$ a cristianos, moros y judíos por las mercancías que cargaban.

el cobro de la pena del quart la Corona aplico una reducción de la misma a la décima parte, porcentaje que también podía afectar al cobro de ciertas rentas.

22 FERRER I MALLOL, M‥T., Les aljames sarraines..., p. 146.

23 Ibidem, pp. 149-150.

24 A partir de 1320 ambas rentas aparecen unidas como aduana de Elche.

25 A.C.A. Real Patrimonio, Maestro Racional, Reg. 1701, f. 1r.

26 Para el estudio del almojarifazgo en Elche y Alicante vid. HINOJOSA MONTALVO, J., «Un arancel comercial en Alicante y Elche durante la Baja Edad Media: el derecho de Aduana", Anuario de Estudios Medievales, 23 (1993), pp. 57-74.

27 A.C.A. Real Patrimonio, Maestro Racional, Reg. 1701, f. 1r.

28 En 1316 por el cobro del almojarifazgo el colector Bernat Saverdú, que además regentaba la escribanía de la aduana de Elche, recibió por siete meses 58 sueldos 4 dineros, en concepto de los 100 sueldos anuales que cobraba como colector. A.C.A. Real Patrimonio, Maestro Racional, Reg. 1701, f. 1r. FERRER I MALLOL, M‥T., "La Batllia general de la part del regne de Valencia dellà Xixona...».

29 A.R.V. Bailía, Apéndice 61, f. 300r.

30 En 1324 las rentas de la aduana de Elche fueron arrendadas por 17.200 sueldos de los que hubo que descontar por salarios de los guardas que vigilan los caminos 1737 sueldos, por obras y otros gastos 322 sueidos 4 dineros, por las franquicias comerciales concedidas a los vecinos de Barcelona, Mallorca y Gerona 1.865 sueldos 4 dineros y por cantidades pendientes por dicho concepto del año pasado 364 sueldos 9 dineros. A.C.A. Real Patrimonio, Maestro Racional, Reg. 1702.

31 Sobre el puerto medieval de Elche vid. HINOJOSA MONTALVO, J., «El Cap del Aljup, puerto medieval de Elche", Mayurqa. Homenatge a Álvaro Santamaría, 23, Palma de Mallorca, 1989, I, pp. $311-374$. 
«...ço es quels crestians moros e juheus estranys e privats paguen al dit port per les coses e mercaderies que hi carreguen..." ${ }^{32}$.

En 1315 la renta rendía una suma de 2.000 sueldos $^{33}$. En las cuentas de 1316 el colector de dicha renta era Bernat Despuig, que ejercía además la escribanía del puerto ${ }^{34}$ y recibía 400 sueldos que se descontaban del importe recaudado por realizar ambas funciones.

En 1324 se arrendaron las rentas del puerto del Cap del Aljup a Alfonso Guillem por 1.550 sueldos. De esta cantidad la corona recibió una mínima parte que no alcanzo los 200 sueldos, ya que hubo que deducir una serie de gastos que tuvo el arrendatario:

- Por las franquicias comerciales concedidas por la Corona a los vecinos de Barcelona, Gerona y Mallorca 700 sueldos.

- Por el salario del Escribano del Puerto 400 sueldos.

- Por 75 moros que pasaron con el mensajero del rey de Granada con franquicia de pago 256 sueldos 8 dineros $^{35}$.

Con el arrendamiento de las rentas del puerto de Elche la Corona continuo con la tendencia de arrendar las rentas de tipo comercial, como era habitual en Alicante y Orihuela.

Arrendamiento de la Albufera. La Albufera de Elche destaco por su aprovechamiento para actividades pesqueras. Entre 1316 y 1324 fue arrendada por la Corona ${ }^{36}$.

Tahurería. Monopolio que se arrendaba anualmente y que gravaba el juego legal que se celebraba en la tahurería. En 1307 las autoridades locales de Elche solicitaron a Jaime ll la cesión de esta renta y la de la Albufera al municipio para poder destinar el importe de ambas, que los munícipes estimaban en torno a mil sueldos, para la reparación de las murallas de la villa. Petición que fue denegada ${ }^{37}$. La suma de las rentas de la tahurería y de la Albufera en las cuentas de los año 1316-1319 arroja una cifra que se aproxima mucho a la que utilizaron las autoridades municipales de Elche en su solicitud del año $1307^{38}$. De los ingresos de la tahurería se descontaban todos los años 40 sueldos en concepto del alquiler del local donde se jugaba.

Judíos de Elche. Era una renta que pagaban los judíos de Elche y los de Orihuela. Consistía en una tasa anual fijada sobre ambas juderías y que ascendía a 1050 sueldos, pero que fue rebajada por Jaime II a 800 sueldos, de los que 500 correspondían

32 A.C.A. Real Patrimonio, Maestro Racional, Reg. 1701, f. $1 \mathrm{v}$.

33 FERRER I MALLOL, Má.T., Les aljames sarraïnes..., p. 149.

34 FERRER I MALLOL, Mํ.T., "La Batllia general de la part del regne de Valencia dellà Xixona...", p. 303.

35 A.C.A. Real Patrimonio, Maestro Racional, Reg. 1702, f. 3v.

36 En 1316 se arrendó con el march por 1.100 sueldos a un vecino de la localidad.

37 FERRER I MALLOL, M‥T., Organització i defensa d'un territori fronterer. La Governació d'Oriola en el segie XIV. Barcelona, 1990, pp. 167-168. Doc. $n^{\circ}$ 58. (1307, diciembre), pp. 393-394.

38 A.C.A. Real Patrimonio, Maestro Racional, Reg. 1701. A.R.V., Bailía, Apéndice 61, ff. 300r$301 r$. 
a los de Orihuela y 300 a los de Elche, aunque posteriormente, sobre todo a partir de las cuentas de 1320 fue modificado el gravamen proporcional de cada judería pagando los de Orihuela 530 y los de Elche 270.

"Item es çert que los juheus de Oriola e d'Elx solien donar al senyor Reyu per tribut cascun any Mille $L$ solidos dels quals mostraren carta de gracia del dit senyor Rey que no fossen tenguts de pagar per cascun any entre tots mas DCCC sol. dels quals quels DCCC solidos se avengren en axi quels juheus d'Oriola pagasen los D. solidos..." ${ }^{39}$.

Alquería de Beniamor. La alquería de Beniamor a principios del siglo XIV pertenecia al arráez de Crevillente y fue concedida por Jaime II en 1320 a Acard de Mur ${ }^{40}$. En 1318 en las cuentas del Baile una anotación indica que «... veni la alqueria de Beniamor en lo terme de d'Elx la qual era del senyor de Crivillen ensemps ab un Reyal qui es en lo dit loch ço es la renda per cascun any. $\mathrm{MCCl}$ sous». A continuación la siguiente entrada refiere que el Real fue establecido a Alfonso Guillem «ab entrada» de 320 sueldos y con un censo anual de 150 sueldos $^{41}$. En 1320 por la alquería de Beniamor se recaudaron 300 sueldos 3 dineros.

Rentas judiciales de la bailía. Entre las rentas judiciales recaudas por el baile en Elche, destacar la multa impuesta en 1316 a Ricardo Trever, patrón de una nave que cargo mercaderías con la promesa de no llevarlas a tierra de enemigos y las desembarco en Almería y fue condenado por ello a pagar 4.000 sueldos. Restando 200 sueldos en los gastos de los hombres que acudieron a detenerlo sumo 3.800 sueldos.

En 1324 se impuso una multa de 400 sueldos a un patrón de nave de Orihuela que se había comprometido a no llevar sal desde el puerto de Cap de Cervera a Génova ni a Saona, pero fue denunciado por haber llevado la mercancía a la última locali$\operatorname{dad}^{42}$.

Renta judicial del justicia de Elche. De las multas y composiciones que cobraba el justicia se detraía el salario del justicia, el de su asesor y el del entregador, quedando la parte restante para el rey. Sólo hubo ingresos por este concepto en 1320 y ascendieron a 374 sueldos 4 dineros.

\section{Las rentas de Crevillente}

En 1296 Jaime Il incorporaba al patrimonio real de la Corona catalano-aragonesa villas como Alicante y Orihuela, mientras que en localidades señoriales se limito a aceptar la sumisión oficial de sus titulares. Tras asegurar en los primeros días de mayo el control de la comarca de Orihuela el ejército real se dirigió hacia Murcia iniciándose

39 A.C.A. Real Patrimonio, Maestro Racional, Reg. 1701, ff. $1 \mathrm{~V}-2 \mathrm{r}$.

40 FERRER I MALLOL, Mª.T., Les aljames sarraines..., p. 65.

41 A.R.V. Bailía, Apéndice, 61, f. 300.

42 A.C.A. Real Patrimonio, Maestro Racional, Reg. 1702, f. 5 r. 
el 16 de mayo el sitio del castillo de Monteagudo que dominaba la capital y donde recibió el día 17 la sumisión oficial del arráez de Crevillente (Mahomat o Muhammad Abinhudell), titular del señorío de Crevillente y de los lugares de Albatera y de Cox ${ }^{43}$.

Crevillente y Aspe se mantuvieron como señorío feudal respetado por Jaime II, ya que garantizo en 1296 al arráez Muhammad I y a su sucesor la continuidad al frente del señorío. En 1318 con la muerte del sucesor de Muhammad I el lugar fue incorporado al patrimonio real, para ser cedido en los años posteriores a miembros de la familia real. En mayo de 1322 Crevillente fue separado del patrimonio real y concedido al infante Pedro 44 .

Por esta breve incorporación al patrimonio real entre las rentas de Elche se recaudaron en los años 1318, 1319, 1320 y 1321 las rentas de Crevillente por valor de 12.604 sueldos, 30.147 sueldos, 25.448 sueldos y 18138 sueldos respectivamente.

\section{Las rentas de Alicante}

En Alicante y Orihuela a la hora de analizar la fiscalidad regia, se observan unas características propias que diferencian el régimen de exacción fiscal de la Corona en los territorios de la bailía dellà Xixona del de otras localidades del territorio regnícola, por el peso de la conquista castellana de la segunda mitad del siglo XIII y por el predominio de una población cristiana, que en la política repobladora de la monarquía castellana y de la catalano-aragonesa, en una zona de frontera, beneficio a los concejos de estas localidades con diversas exenciones fiscales sobre sus habitantes o con la concesión a las autoridades locales de rentas tan importantes como el tercio diezmo o el cabezaje. Alfonso X concedió al concejo de Alicante el cabezaje en $1261^{45}$ y que se aplicaba a principios del siglo XIV a las obras de las murallas ${ }^{46}$. Además de exenciones a mudéjares y judíos de la questia, alfarda, peita, etc., que luego fueron reconocidas por Jaime $\mathrm{II}^{47}$.

En Alicante predominaba una renta comercial como el almojarifazgo asociado a la importancia mercantil del puerto y dos monopolios como la tahurería y el almudín. La gestión del control del almojarifazgo y de la tahurería se arrendaba todos los años. Los mudéjares alicantinos también contribuían a las rentas de la Corona con impuestos como el cabezaje, la alquieda y las caloñas.

Almojarifazgo y aduana del puerto. Estos dos conceptos se incluyen en los libros de cuentas de la bailía por separado o unidos y siempre como principal tributo que se cobraba sobre la entrada y salida de mercancías y que debía gravar a los comerciantes cristianos, pero suponemos que también a los judíos y musulmanes ${ }^{48}$.

43 FERRER I MALLOL, Mª.T., "Notes sobre la conquesta del Regne de Múrcia por Jaume II (12961304)", en Homenatge a la memòria del Prof. Dr. Emilio Sáez. Barcelona, 1989, p. 33.

44 FERRER I MALLOL, M‥T., Les aljames sarraines..., pp. 16-22 y 33.

45 FERRER I MALLOL, M…, Organització i defensa d'un territori fronterer... p. 170.

46 FERRER I MALLOL, M‥T., Les aljames sarraïnes..., Doc. ํㅜ 80, pp. 243-244.

47 Ibidem, Doc. no 80, pp. 243-244.

48 A no ser que estuvieran exentos, ya que no aparece en las cuentas de Alicante el quirat. 
En las cuentas de 1316-1317 se registra como derecho de aduana del puerto de Alicante y fue arrendado en 1316 a Guillem Monserrat por 6.000 sueldos y en 1317 a Esteve de Rubí por 4.660 sueldos $^{49}$. En las de 1318, 1319, 1320 (4.120 sueldos), 1321 (4.000 sueldos) y 1322 (4.040 sueldos) como almojarifazgo y en las de 1324 como almojarifazgo y aduana al mismo tiempo. En 1324 y como había sucedido en Elche el valor del arrendamiento sufrió un importante descenso, ya que fue tasado en 2.860 sueldos, pero por las franquicias reales concedidas a los operadores mercantiles de Barcelona, Gerona y Mallorca la cantidad ingresada fue de 1356 sueldos 4 dineros, 10 que suponía una considerable merma en los ingresos percibidos por la Corona por este concepto ${ }^{50}$.

Tahurería. Jaime II había concedido en 1304 al consell de Alicante para obras de las murallas el tercio diezmo de las rentas de la tahurería ${ }^{51}$, por lo que el consell de Alicante recibía una parte de las mismas. En los ingresos de 1317 le correspondió el $15 \%$ del valor del arrendamiento ${ }^{52}$.

Açoch y almudín. Las tiendas, obradores y el almudín eran locales que arrendaba la Corona cobrando por su cesión una cantidad anual. El almudín era el edificio donde particulares, mercaderes y panaderos podian almacenar o comercializar el trigo de la villa.

Marchs de plata. El march era el derecho que pagaban los arrendatarios al abonar la cantidad importe del arrendamiento que habían obtenido, y que era del 20 por mil respecto a la cantidad global del arrendamiento ${ }^{53}$.

Cabezaje moros. Como en Elche y el resto de localidades de la procuración era el impuesto que pagaba cada musulmán varón mayor de dieciséis años y las mujeres viudas. La tarifa establecida era de 5 sueldos por cabeza ${ }^{54}$. En Alicante este tributo gravaba a los moros "peons de la orta e del raval"s 5 .

Alquieda. El derecho de alquieda fue percibido por la Corona en Alicante sólo en el año 1319 y por valor de 450 sueldos. En un año en que paradójicamente no se recaudo la renta de caloñas, cabezajes, etc. de los mudéjares en Alicante. Es un tributo mudéjar que Ferrer i Mallol lo define como un impuesto comercial, posiblemente

49 A.C.A. Real Patrimonio, Maestro Racional, Reg. 1701, f. 17v. HINOJOSA MONTALVO, J., «Un arancel comercial en Alicante y Elche durante la Baja Edad Media: el derecho de Aduana", Anuario de Estudios Medievales, 23 (1993), pp. 57-74. FERRER I MALLOL, Mª ${ }^{\mathrm{a}}$.T., Les aljames sarraïnes..., p. 148.

50 A.C.A. Real Patrimonio, Maestro Racional, Reg. 1702, f. 1r.

51 FERRER I MALLOL, Ma.T., Organització i defensa d'un territori fronterer.. p. 170.

52 La tahurería de Alicante fue arrendada en 1317 a Ramón de Montagut por 1650 sueldos de los que la Corona sólo recibió 1.403 sueldos. A.C.A. Real Patrimonio, Maestro Racional, Reg. 1701, f. 5r., 17v. y $29 r$.

53 PILES ROS, L., Apuntes para la historia económico social de Valencia durante el siglo XV. Valencia, 1969, p. 26.

54 FERRER I MALLOL, Mํ.T., Les aljames sarraïnes..., p. 130.

55 En 1316 fueron contabilizados 69 musulmanes varones. Se recaudaron 172 sueldos a razón de 2 sueldos 6 dineros por cabeza, ya que la otra mitad del tributo la recibió el consel/ de Alicante para las obras de las murallas y fueron gravadas 16 moras viudas que a 5 sueldos por cabeza abonaron 80 sueldos. 
sobre el mercado y que en Alicante en 1366 estaba asociado al salmedinatge de los moros $^{56}$.

Caloñas moros. Se recaudo en 1316 como único tributo por valor de 222 sueldos, pero en 1317 se recaudaron las caloñas, el cabezaje y el resto de derechos pagados por los moros de Alicante y de la huerta con un importe de 2.039 sueldos $^{57}$. En 1320 fueron 893 sueldos, en $1321,2.650$ sueldos y en 1324 de 2.807 sueldos $^{58}$.

Renta judicial de la bailía. El baile de Alicante cobro en concepto de renta judicial sobre las multas que había impuesto en 1318, 1.522 sueldos 6 dineros y en 1322 , 2.073 sueldos 7 dineros.

\section{Las rentas de Orihuela}

Orihuela tenía una fiscalidad similar a la de Alicante, con la peculiaridad que en el período estudiado no aparece ningún monopolio real en las cuentas del baile, junto a la ausencia del tercio diezmo. Predominando un impuesto comercial como el almojarifazgo, junto a las cabalgadas y coses vedades, además de las rentas judiciales.

En Orihuela Alfonso X concedió en 1281 el tercio del diezmo al concejo de Orihuela, para la reparación de las iglesias ${ }^{59}$. Además la Corona no percibía la renta de la tahurería, ya que había sido cedida su administración al municipio en época castellana y por que Jaime II en el contexto moralizante de finales del siglo XIII había suprimido la casa de juego ${ }^{60}$. Sancho IV de Castilla había cedido en 1282 al concejo de Orihuela las tahurerías o casas de juego de la villa por tiempo de diez años ${ }^{61}$, y en 1285 realizó una definitiva concesión a perpetuidad. Posteriormente, ya bajo administración catalano-aragonesa Jaime II otorgo en 1296 por un tiempo sujeto a voluntad real esas rentas, siendo poco después las casas de juego suprimidas en el contexto moralizante de la época. Un intento de las autoridades municipales en 1307 por recuperar la tahurería resultó infructuoso por la negativa regia, a pesar de la advertencia de los munícipes de que las prohibiciones no habían menguado la pasión por el juego de los oriolanos y la necesidad del municipio de recaudar esos fondos. En 1325 el Consell de la villa volvió a obtener las rentas de la tahurería, pero al año siguiente el rey redujo su tiempo de vigencia a un sexenio ${ }^{62}$.

56 FERRER I MALLOL, Mํ. ${ }^{2}$., Les aljames sarraïnes..., pp. 145-146.

57 A.C.A. Real Patrimonio, Maestro Racional, Reg. 1701. FERRER I MALLOL, M‥T, Les aljames sarraines..., p. 131.

58 A.C.A. Real Patrimonio, Maestro Racional, Reg. 1701 y 1702 . A.R.V, Bailía, Apéndice 61, ff. $301 \mathrm{r}-302 \mathrm{~V}$.

59 TORRES FONTES, Juan, Colección de documentos para la historia del reino de Murcia. Tomo III. Fueros de Alfonso el sabio a Murcia. Murcia, 1973, Doc. no CXLIX, (1281, marzo, 10), p. 157.

60 BARRIO BARRIO, J.A., «Lo marginal y lo público en Orihuela a través de la acción punitiva del Justicia criminal. 1416-1458», Historia Medieval. Anales de la Universidad de Alicante, 10 (1996), pp. 81-98.

61 ESTAL, J.M., Documentos inéditos de Alfonso $X$ el sabio y del Infante; su hijo Don Sancho. Alicante, 1984. IV parte, Doc. $n^{\circ}$ 8, (1282, mayo, 20), pp. 119-121.

62 FERRER I MALLOL, Mํ.T., Organització i defensa d'un territori fronterer..., pp. 164-165. 
El cabezaje de los mudéjares fue concedido por Jaime II al consell de Orihuela en 1296 para destinarlo a la reparación de murallas y torres ${ }^{63}$.

Almojarifazgo. En Orihuela el derecho de almojarifazgo se cobraba tanto a cristianos, musulmanes y judíos. Se incluían los censales que tenía el rey sobre dicho lugar.

Cabalgadas, cosas vedades y caloñas. Bajo la denominación «derecho que pertenece al señor rey de las cabalgadas que se hacen en tierra de moros del rey Granada, cosas vedades y caloñas» se recaudaron 1371 y 2.686 sueldos en 1316 y 1317 respectivamente, sin volver a aparecer en las cuentas de los años siguientes. A partir de 1318 hay una nueva referencia bajo la denominación «emolumentos de la bailía» o rentas judiciales de la bailía y que debe corresponder al mismo concepto. En Orihuela uno de los ingresos de las rentas reales procedía de las cabalgadas organizadas por los lugares del término de Orihuela, ya que de los los ingresos obtenidos en la misma, un quinto correspondía al rey ${ }^{64}$. En el concepto coses vedades se encuentran una serie de productos que habían sido gravados por Jaime I tras la conquista del reino de Valencia, con un canon por su exportación de la ciudad de Valencia y del reino ${ }^{65}$. El número de productos manifestados en la relación de coses vedades fue aumentando con el paso del tiempo ${ }^{66}$. Se incluían metales preciosos, férreos, materias primas, como el alquitrán, maderas, metales, productos alimenticios, armamento, etc. ${ }^{67}$. En la procuración de Orihuela este derecho lo cobraba el baile y afectaba sobre todo a los productos que salían con destino a Castilla.

Renta judicial del justicia de Orihuela. De la renta judicial del justicia de Orihuela recaudada sobre las multas que el magistrado imponía durante el año de su ejercicio, se descontaba el importe del salario del justicia, el de su asesor y el del entregador así como otros gastos no detallados. En 1304 Jaime II Jaime II fijó el salario del justicia de Orihuela en 500 sueldos y el de su asesor en 300. Para el justicia de Alicante estipuló un salario de 400 sueldos y para su asesor 250 sueldos $^{68}$.

Rentas de Cox y de Albatera. Cuando en 1266 Alfonso X delimito el alfoz o término de Orihuela incluyo los lugares de Cox y Albatera como parte de su término ${ }^{69}$.

\section{Ibídem.}

64 ESTAL, J.M. del, El reino de Murcia bajo Aragón (1296-1305). Corpus documental 1/1. Alicante, 1985. Doc. no 51, (1296, mayo, 14), p. 164. Orden de Jaime Il al caballero Gonzalo de Fontana para que exija el pago del quinto del botín de las cabalgadas realizadas en el término de Orihuela. Doc. $n$ o 71, (1296, mayo, 18) p. 183. Doc. $n^{\circ}$ 81, (1296, mayo, 21), pp. 190-191.

65 Sobre la exportación de productos en Castilla vid. GONZÁLEZ MÍNGUEZ, C., "CCoses vedades" en Castilla y factores determinantes del desarrollo económico de Vitoria en la Baja Edad Media». Boletín «Sancho el Sabio», Año XXIV, Tomo XXIV, 1980, pp. 179-229.

66 En Castilla las primeras listas de artículos cuya exportación estaba prohibida son de época de Alfonso $X$. Como en el reino de Valencia en Castilla el número de productos vedados fue aumentando con el paso del tiempo. Así en las Cortes de 1313 la relación se ha ampliado considerablemente. Ibidem, pp. 183-184.

67 HINOJOSA MONTALVO, J., «Coses vedades», Diccionario histórico de la Comunidad Valenciana, Valencia, 1992.

68 A.C.A. C, reg. 231, f. 56r. (1304, diciembre, 5).

69 TORRES FONTES, J., Codom. T. III. pp. 89-91. 1266, julio, 15. 
En 1296 Albatera y Cox eran lugares señoriales que pertenecían al arráez de Crevillente. En 1318 Jaime Il incorporó el señorío de Crevillente a la Corona hasta que el 22 de mayo de 1322 lo dono al infante Pedro ${ }^{70}$. Tras la desaparición del señorío musulmán de Crevillente en 1318 Jaime II concedió dichos lugares en 1320 a Acard de Mur ${ }^{71}$. A pesar de ello las rentas de Cox y Albatera fueron cobradas por el Baile en 1322 (4.100 sueldos) y 1324 (2000 sueldos) dentro de las rentas del Patrimonio Real. En las cuentas de 1324 la anotación indica que el baile recibe 2.000 sueldos de las rentas de Cox y de Albatera por composición realizada con los herederos del noble Acard de Mur ${ }^{72}$.

Otras rentas. Como rentas de menor importancia señalar el march de plata, como en Alicante, con un valor fijo de 120 sueldos anuales y la renta de los judíos de Orihuela que pagaban un canon fijo anual como sus correligionarios de Elche, y que como hemos destacado anteriormente se repartía entre ambas juderías pagando la de Orihuela 500 sueldos anuales, cifra superior a la de Elche y que apunta la mayor pujanza de la comunidad israelita oriolana.

En 1316 aparece un pago de 84 sueldos en concepto de herbaje, por algunas cabañas que pasaron el puente de dicho lugar y por 14 cabezas que fueron vendidas a un judío y a un moro a razón de 6 sueldos por cabeza.

\section{Las rentas de Guardamar}

Durante el período estudiado Guardamar era una villa real. Según Ferrer i Mallol fue un núcleo exclusivamente cristiano, a pesar de un frustrado intento de Jaime II en 1298 para crear un morería en la localidad ${ }^{73}$.

Por la escasa importancia de Guardamar y al no contar con población sarracena, las rentas se arrendaban anualmente por una cantidad fija. Las rentas recaudadas en esta localidad eran las más bajas de la procuración. En 1316 fueron arrendadas a Bernat Macip vecino del lugar por 1.100 sueldos. El segundo concepto por el que percibía ingresos la Corona era por las rentas judiciales, tanto del justicia como las del baile del lugar. En 1316 se produjo un ingreso excepcional de 1.000 sueldos por la muerte de un musulmán. La pena judicial impuesta a los cristianos culpables del homicidio, ascendía a dos mil sueldos, de los que mil correspondían al rey y la otra mitad a la familia del mudéjar asesinado, que no acepto la indemnización ya que la Suna les prohibía cobrar por la muerte de su familiar ${ }^{74}$.

70 Sobre el señorio musulmán de Crevillente vid. GUICHARD, P., Un señor musulmán en la España cristiana: el «ra'is» de Crevillente (1243-1318). Alicante, 1976. FERRER I MALLOL, Ma.T., Les aljames sarraïnes..., pp. 16-22 y 33-34.

71 FERRER I MALLOL, M…, Les aljames sarraines..., pp. 7-8.

72 A.C.A. Real Patrimonio, Maestro Racional, Reg. 1702.

73 FERRER I MALLOL, Mํ.T., Les aljames sarraines de la Governació d'Oriola en el segle XIV. Barcelona, 1988. p. 5. Id. La frontera amb l'islam en el segle XIV. Cristians i sarraïns al País Valencià. Barcelona, 1988, pp. 6 y 15.

74 A.C.A. Real Patrimonio, Maestro Racional, Reg. 1701, f. 6r. Sobre este episodio vid. FERRER I MALLOL, Mª.T., Les aljames sarraïnes..., p. 166. 
RENTAS REALES DE ELCHE, CREVILLENTE, ALICANTE, ORIHUELA Y GUARDAMAR AÑOS 1316-1319. VALOR PORCENTUAL

\begin{tabular}{|l|c|c|c|c|c|c|c|c|}
\hline RENTAS & \multicolumn{2}{|c|}{$\begin{array}{c}\text { AÑO 1316 } \\
\text { (mayo a diciembre) }\end{array}$} & \multicolumn{2}{|c|}{ AÑO 1317 } & \multicolumn{2}{c|}{ AÑO 1318 } & \multicolumn{2}{c|}{ AÑO 1319 } \\
\hline RENTAS & SUELD & $\%$ & SUELD & $\%$ & SUELD & $\%$ & SUELD & $\%$ \\
\hline Elche & 43.521 & 75,49 & 68.913 & 77,54 & 59.158 & 71,42 & 53.257 & 53,2 \\
\hline Crevillente & - & - & - & - & 12.604 & 15,22 & 30.147 & 30,12 \\
\hline Alicante & 6.208 & 10,77 & 9.692 & 10,91 & 10.244 & 12,37 & 9.160 & 9,15 \\
\hline Orihuela & 5.688 & 9,87 & 8.822 & 9,93 & 8.167 & 9,86 & 6.095 & 6,09 \\
\hline Guardamar & 2.233 & 3,87 & 1.448 & 1,63 & 2.657 & 3,21 & 1.440 & 1,44 \\
\hline TOTAL ABS. & 57.651 & - & 88.875 & - & 82.831 & - & 100.099 & - \\
\hline
\end{tabular}

Fuente: A.C.A. Real Patrimonio, Maestro Racional, Reg. 1701.

RENTAS REALES DE ELCHE, CREVILLENTE, ALICANTE, ORIHUELA Y GUARDAMAR. AÑOS 1320-1324. VALORES PORCENTUALES

\begin{tabular}{|l|r|r|r|r|r|r|r|c|}
\hline RENTAS & \multicolumn{2}{|c|}{ AÑO 1320 } & \multicolumn{2}{c|}{ AÑO 1321 } & \multicolumn{2}{c|}{ AÑO 1322 } & \multicolumn{2}{c|}{ AÑO 1324 } \\
\hline RENTAS & SUELD & $\%$ & SUELD & $\%$ & SUELD & $\%$ & SUELD & $\%$ \\
\hline Elche & 78.869 & 66,19 & 49.695 & 58,45 & 78.052 & 79,23 & 55.257 & 77,07 \\
\hline Crevillente & 25.448 & 21,36 & 18.138 & 21,33 & - & - & - & - \\
\hline Alicante & 7.303 & 6,13 & 9.035 & 10,63 & 8.953 & 9,09 & 6.573 & 9,17 \\
\hline Orihuela & 6.154 & 5,16 & 6.510 & 7,66 & 10.486 & 10,64 & 9.264 & 12,92 \\
\hline Guardamar & 1.379 & 1,16 & 1.640 & 1,93 & 1.020 & 1,04 & 600 & 0,84 \\
\hline TOTAL ABS. & 119.155 & 2 & 85.019 & 1 & 98.512 & 7 & 71.695 & 1 \\
\hline
\end{tabular}

Fuente: A.C.A. Real Patrimonio, Maestro Racional, Reg. 1701. 


\section{Balance global de las rentas reales en la Procuración}

Lo más destacado de las rentas reales en la procuración de Orihuela es el perfil diferenciado que presentan respecto a las del resto de localidades del reino de Valencia, como ya ha sido puesto de manifiesto para inicios del siglo XV por Enric Guinot ${ }^{75}$. Destacar la ausencia en las villas reales de la bailía de tributos habituales en otras localidades reales de la Corona de Aragón y del reino de Valencia como la quèstia/ peita, la cena, o como el yantar o los pedidos castellanos ${ }^{76}$. Fruto de las exenciones $y$ franquicias fiscales de época castellana.

Dentro de la contribución de cada villa al conjunto de rentas reales, destacan las rentas de la villa de Elche, que llegaron a suponer el $79 \%$ del total recaudado. En segundo lugar Crevillente que con su breve incorporación al patrimonio real aporto importantes cantidades al fisco real. Localidades de población cristiana mayoritaria como Alicante y Orihuela realizaban una aportación mucho menor a las arcas reales, mientras que las rentas obtenidas en la pequeña villa de Guardamar no dejaban de ser simbólicas por las exiguas cantidades que se colectaban.

\section{LOS GASTOS}

Los gastos más destacados que tenía que realizar el baile en nombre de la Corona correspondían al pago a los alcaides por la tenencia de los castillos y los salarios de los oficiales reales ${ }^{77}$. Recalcar también las partidas destinadas a provisión de la casa real o para algún miembro de la familia real. En un segundo plano aparecen el pago de violarios y deudas, obras, donaciones y gastos extraordinarios.

El control de los gastos era realizado por el propio rey, que expedía la correspondiente orden al baile estableciendo los pagos fijos que debía realizar en nombre de la Corona. El 18 de diciembre de 1317 Jaume Il tras comprobar los ingresos que se habían producido en las rentas de la bailía dellà Xixona, ordenaba a Jaume Andreu, nombrado ocho días antes como Baile general de dicha demarcación ${ }^{78}$, los pagos que debía realizar en 1318, fijando en primer lugar el pago del salario de cada uno de los alcaides de los castillos reales del territorio y el salario de cada uno de los oficiales reales, escribanos, colectores, la satisfacción de la pensión anual a cada uno de los titulares de violarios comprados por la Corona, etc. ${ }^{79}$.

75 GUINOT, E., «El patrimoni reial al Pais Valencià...», p. 612. Para la fiscalidad real en Cataluña vid. SÁNCHEZ MARTÍNEZ, M., El naixement de la fiscalitat d'Estat a Catalunya (segles XII-XIV), Vic, 1995.

76 Para la fiscalidad real en Castilla vid. LADERO QUESADA, M.A., Fiscalidad y poder real en Castilla (1252-1369), Madrid, 1993.

77 Como ya ha sido puesto de manifiesto para el reino de Valencia y en la primera década del siglo XIV por Christian GUILLERÉ en «Les finances de la Couronne d'Aragon au debut du XIVe siecle...", p. 492.

78 Parece ser que el día 10 de diciembre de 1317 ya había sido nombrado para el cargo. FERRER I MALLOL, Mª.T., "La Batllia general de la part del regne de Valencia dellà Xixona...», pp. 287-288.

79 A.R.V. Bailía, Apéndice 61, ff. 304r-v (1317, diciembre, 18). 


\section{Salarios y tenencias de Castillos}

Sobre el documento citado anteriormente y la comprobación de los gastos realizados por los correspondientes bailes en el período estudiado podemos detallar la partida de gastos fijos de la Corona en pago de tenencia de castillos y salarios a oficiales reales.

En concepto de tenencia de castillos el baile pagaba a cada uno de los alcaides el salario correspondiente. El del castillo de Orihuela cobraba 6.000 sueldos desde 1313. El de Callosa 800 sueldos. El de Guardamar 1.000 sueldos en 1316, cifra que se redujo a 500 a partir de 1318. El alcaide de la calahorra de Elche cobro 1.000 sueldos en el período contabilizado y el de Alicante 5.000 sueldos $^{80}$.

A estas cifras hay que sumar los salarios cobrados anualmente por los oficiales reales. A los titulares que ejercieron la procuración real entre 1316 y 1324 les fue asignado un salario de 4.000 sueldos, excepto Arnau de Torrelles que ocupo el cargo entre 1313 y agosto de 1316 y que tenía asignado un salario de 2.000 sueldos $^{81}$, como queda recogido en las cuentas del baile de $1316^{82}$. El asesor de la procuración disponía entre 1316 y 1324 de un salario diario de 4 sueldos, que correspondía al mantenimiento de dos cabalgaduras, lo que suponía al año un monto de 1460 sueldos $^{83}$.

Asimismo los oficiales de la bailía tenían asignadas unas atribuciones anuales. El titular de la bailía general del reino de Valencia dellà Xixona cobraba 2.000 sueldos anuales desde $1304^{84}$, el baile local de Orihuela 300 , el de Alicante y el de Guardamar 200 cada uno. Jaume Descaplers, vecino de Elche, ocupo la escribanía de la bailía desde 1316 y hasta 1327, con un salario de 200 sueldos $^{85}$. El titular de la bailía general del reino de Valencia, Ferrer Descortell, Baile general del reino de Valencia desde $1316^{86}$, tenía en 1316 y 1317 una asignación de 13.920 sueldos, sobre las rentas de Elche, en concepto de pago de violarios y por la tenencia de algunos castillos del reino ${ }^{87}$ y que no recibió en 1324. El lugarteniente del Baile no obtenía un salario fijo y

80 Sobre el sistema de tenencia y el salario de los alcaides de los castillos de la frontera meridional de Alicante en el siglo XIV vid. FERRER I MALLOL, M․ T., "La tinença a costum d'Espanya en els castells de la frontera meridional valenciana (segle XIV)», Miscel.lània de Textos Medievals, 4 (1988), pp. 1-102.

81 Sobre los procuradores que ejercieron el cargo entre 1316 y 1324 vid. FERRER I MALLOL, Ma.T., Organització i defensa d'un territori fronterer..., pp. 84-115.

82 A.C.A. Real Patrimonio, Maestro Racional, Reg. 1701, f. 8 r.

83 En 1316 el asesor Llorenç Fritós ya recibió este salario que se mantuvo hasta 1324 en que Guillem Mir percibió la misma cantidad. A.C.A. Real Patrimonio, Maestro Racional, Reg. 1701, f. 9v. Reg. 1702, f. 7V.

84 FERRER I MALLOL, M ${ }^{\mathrm{a}}$.T., "La Batllia general de la part del regne de Valencia dellà Xixona...», p. 283.

85 Ibídem, p. 299.

86 FERRER I MALLOL, Ma.T., “La Batllia general de la part del regne de Valencia dellà Xixona...», p. 285.

87 A.C.A. Real Patrimonio, Maestro Racional, Reg. 1701, f. 11v. 
al titular de 1317 Bertomeu Romeu, la Corona le asignó 150 sueldos anuales para mantener al servicio del rey un caballo alforrado ${ }^{88}$.

Con un salario de 10 sueldos diarios el escribano del puerto de Alicante, percibía anualmente la cifra de 304 sueldos, incrementada en 1324 a 400 sueldos.

Desde 1318 la bailía general dellà Xixona contó con un abogado asesor. El nombramiento había sido solicitado por el titular de la bailía ante la necesidad de contar con un jurista. Bernat de Solsona, vecino de Alicante, ejerció desde 1318 con un salario anual de 100 sueldos. El cargo fue sustituido en 1324 , ya que se recupero la figura del Procurador Fiscal en la persona de Guillem Fibla con un salario de 100 sueldos ${ }^{89}$.

Alfonso Guillem colector de los impuestos de los mudéjares de Elche cobro en el período contable 1316-1324, 400 sueldos por su actividad. Le fue concedido el oficio de colector por Jaime II en enero de 1308 y de forma vitalicia en $1311^{90}$. Aunque según María Teresa Ferrer i Mallol Jaime II había pedido en 1313 al Baile General dellà Xixona que permitiese que el oficio fuese ejercido por Juçef Capdepebre. En 1316 como consta en las cuentas del Baile de dicho año Alfonso Guillem seguía ejerciendo su oficio como colector. Entre sus obligaciones estaba la de «... reebre les comptes dels moros en morisc e per fer trasladar en crestianesc les libres de les rendes d'Elx...". Cobraba como recaudador real una gama variada de rentas sobre los mudéjares de Elche, que si no se vendían eran recaudadas por un colector real: Almagram, alfarda, diezmo del pan, del vino y del aceite y otros frutos, agua, cabezaje, albayat, alhabeç de las mezquitas, alfatrà, gallinas y atzaque. En las cuentas de 1323 aparece cobrando un salario Juçef Capdepebre de 150 sueldos por la "turçimanyia» de los moros de Elche. El salario había sido asignado por Jaime II en 1321, en reconocimiento a la tarea que venia realizando desde años como trujamán de los impuestos de los sarracenos ${ }^{91}$.

Los 180 sueldos anuales del alcadí de la aljama de moros de Elche era en concepto de salario por el cargo y por redactar el padrón para la recaudación de la alfarda92.

"Item al alcadi de les moros d'Elx per salari de la dita alcaydia e per escriure los padrons de la alfarda de les moros segons es acostumat... CLXXX solidos" ${ }^{93}$.

Cada año un mudéjar de Elche recibía 100 sueldos por la ayuda que prestaba en el cobro de caloñas e impuestos que gravaban la comunidad mudéjar de Elche.

88 FERRER I MALLOL, $\mathrm{M}^{2}$.T., «La Batllia general de la part del regne de Valencia dellà Xixona...», p. 298. A.C.A. Real Patrimonio, Maestro Racional, Reg. 1701, f. $33 \mathrm{v}$.

89 Ibidem, pp. 298-299. A.C.A. Real Patrimonio, Maestro Racional, Reg. 1702, f. 8r.

90 FERRER I MALLOL, M‥T., Les aljames sarraines..., pp. 176-177 y Doc. $n^{\circ}$ 34, (1308, enero, 16), p. 203-204.

91 FERRER I MALLOL, Mํ.T., Les aljames sarraines..., p. 177.

92 FERRER I MALLOL, Mํ.T., Les aljames sarraines..., p. 178.

93 A.C.A. Real Patrimonio, Maestro Racional, Reg. 1702, f. $7 \mathrm{v}$. 


\begin{tabular}{|c|c|c|c|}
\hline \multirow[t]{2}{*}{ CONCEPTO } & \multicolumn{3}{|c|}{ AÑOS } \\
\hline & 1316 & 1317 & 1324 \\
\hline Alcaide Castillo Orihuela & 6.000 & 6.000 & 6.000 \\
\hline Alcaide Castillo Callosa & 800 & 800 & 800 \\
\hline Alcaide Castillo Guardamar & 1.000 & 1.000 & 500 \\
\hline Alcaide Calahorra Elche & 1.000 & 1.000 & 1.000 \\
\hline Alcaide Castillo Alicante & 5.000 & 5.000 & 5.000 \\
\hline Salario Procurador & 2.000 & 4.000 & 4.000 \\
\hline Asesor de la Procuración & 1.460 & 1.460 & 1.460 \\
\hline Baile Gral. Reino Valencia & 13.920 & 13.920 & 一 \\
\hline Baile Gral. dellà Xixona & 2.000 & 2.000 & 2.000 \\
\hline Baile de Orihuela & 300 & 300 & 300 \\
\hline Baile de Alicante & 200 & 200 & 200 \\
\hline Baile Guardamar & 100 & 100 & 100 \\
\hline Escribano de la Bailía & 200 & 200 & 200 \\
\hline Escribanía Puerto Alicante & 304 & 304 & 400 \\
\hline Colector de la renta de los Mudéjares de Elche & 400 & 400 & 400 \\
\hline Alcadí de la Aljama de los moros de Elche & 180 & 180 & 180 \\
\hline $\begin{array}{l}\text { Un moro de Elche que ayuda en la Alfarda y } \\
\text { en las caloñas de los moros }\end{array}$ & 100 & 100 & 100 \\
\hline Guarda del Molinello & - & 200 & 200 \\
\hline Salario Procurador Fiscal & 一 & 一 & 100 \\
\hline Salario de un trujamán & 一 & 一 & 150 \\
\hline TOTAL & 36.964 & 39.164 & 25.090 \\
\hline
\end{tabular}

Fuente: A.C.A. Real Patrimonio, Maestro Racional, Reg. 1701, 1702. A.R.V. Bailía, Apéndice 61, ff. 303r-v. 
"Item an Jahie Alluben moro d'Elx los quals pren cascun any per la ajuda que fa en les calonies e en les alfardes que.ls moros pagen cascun any segons es acostumat... C solidos" ${ }^{94}$.

El molinello era un puesto de vigilancia del camino entre Alicante y Jijona y situado en el límite del término. Al menos desde 1306 el responsable de la custodia del puesto percibía una salario anual de 200 sueldos. Durante el período estudiado ocupo el cargo Pere Miquel de Vaylo entre 1306 y hasta su muerte en 1323. Fue sustituido por su hijo Martí Pérez de Vaylo ${ }^{95}$.

El pago de salarios a los oficiales reales y a los alcaides por la tenencia de castillos supuso en los tres años contabilizados una de las partidas más importantes ya que absorbió en 1316 el $40 \%$ en 1317 el $38 \%$ y en 1324 el $30 \%$ del presupuesto total de gastos.

\section{Provisión de la casa real}

Para provisión de la casa real conocemos para los años 1316 y 1317 una partida anual fija de 31.500 sueldos para gastos de la casa real96.

A partir de 1324 desaparece esta partida y es sustituida por una asignación anual al infante Pedro, de 45.000 sueldos sobre las rentas de Elche, concedida por Jaime II. Aunque el 6 de mayo de dicho año se produjo la donación solemne del lugar al infante Ramón Berenguer, manteniendo el infante Pedro la renta ${ }^{97}$. Mientras que en las cuentas de 1324 se consigna una partida destinada al Infante don Pedro, de 36.300 sueldos que el rey le ha concedido sobre las rentas de Elche, aunque cobro 35.200 sueldos ya que hubo que descontar el pago de un violario.

La partida de gastos dedicada a la casa real era una de la más importantes. En 1316 y 1317 en concepto de provisión real supuso el $40^{\prime} 7$ y el 38'4\% respectivamente. Mientras que en 1324 la cantidad asignada al infante don Pedro represento el $46 \%$ del total de gastos.

La suma de las partidas de salarios y provisión de la casa real representaba en 1316 el $79 \%$, en 1317 el 73 ' $7 \%$ y en 1324 el $76 \%$.

\section{Violarios y deuda}

Todos los años una parte de los gastos de la bailía se empleaban en pagar las pensiones de los violarios que había adquirido la Corona en el territorio. El violario era una modalidad de crédito encubierta, muy parecida al censal, pero que a diferencia

94 A.C.A. Real Patrimonio, Maestro Racional, Reg. 1702, f. $7 \mathrm{~V}$.

95 FERRER I MALLOL, M…, Organització i defensa d'un territori fronterer..., pp. 320-321.

96 Que recaudaba el tesorero real Pere March. Para las partidas contabilizadas de 1316 y 1317 aparecen 20.000 y 30.500 sueldos respectivamente que el baile entrego al tesorero real Pere March para provisión de la casa real.

97 FERRER I MALLOL, Mª.T., Les aljames sarraines..., pp. 34-35. 
VIOLARIOS CARGADOS POR LA CORONA A CARGO DE LAS RENTAS DE LA BAILÍA.

DATOS DEL AÑO 1316-1324

\begin{tabular}{|c|c|c|c|}
\hline \multirow[t]{2}{*}{ BENEFICIARIO } & \multicolumn{3}{|c|}{ PENSIÓN ANUAL } \\
\hline & 1316 & 1317 & 1324 \\
\hline Berenguer de Puigmolto & 1.000 & 1.000 & - \\
\hline Pons de Mataro & 1.500 & 1.500 & - \\
\hline Domingo Ponçano & 1.000 & 1.000 & - \\
\hline Joan Galbe & 1.000 & 1.000 & 1.000 \\
\hline Joan Pérez de Vesques & 500 & 500 & 500 \\
\hline Urrigo de Quintanall & 1.000 & 1.000 & 1.000 \\
\hline Pere Andreu d'Odena & 500 & 500 & - \\
\hline Pere Monpaho & 250 & 250 & $\begin{array}{r}243 \mathrm{~s} . \\
4 \mathrm{~d} .\end{array}$ \\
\hline Guillem Soler & 250 & 250 & - \\
\hline $\begin{array}{l}\text { Jaume Masquefa, como proc. de los herederos } \\
\text { de Guillem Paratge }\end{array}$ & - & 一 & 500 \\
\hline TOTAL & 7.000 & 7.000 & $\begin{array}{r}3.243 \mathrm{~s} . \\
4 \mathrm{~d} .\end{array}$ \\
\hline
\end{tabular}

Fuente: A.C.A. Real Patrimonio, Maestro Racional, Reg. 1701, ff. 10v-11r. 20r-21r. Reg. 1702, f. 7 r.

de éste no era perpetuo, sino que el pago de la pensión anual se limitaba a la vida de dos personas señaladas por las partes, siendo frecuente tomar como referencia la vida de miembros de la casa real.

La cifra que debía pagar anualmente el baile de las rentas del territorio a dueños de los violarios en 1316 y 1317 , se elevaba a 7.000 sueldos. Jaime II comunicaba a Jaume Andreu días después de ser nombrado para el cargo de Baile general del reino de Valencia dellà Xixona, el nombre de los dueños de los violarios y de la pensión anual que debía pagar a cada uno de ellos ${ }^{98}$. En 1324 algunos violarios ya se habían extinguido y sólo hay uno nuevo, pasando la cifra global a pagar en concepto de pensiones de 7.000 a 3.243 sueldos.

98 A.R.V. Bailía, Apéndice 61, ff. 304r-v (1317, diciembre, 18). 
El baile también tenía que hacer frente a diversas deudas de las arcas reales, normalmente a oficiales reales o a servidores de la casa real. En el primer grupo incluir los pagos de 500 sueldos pendientes a un escribano real en 1316 y los 5.000 sueldos que cobro el titular de la bailía en 1317 de un préstamo que había realizado a la Corona. En 1317 y 1324 los pagos por deudas de la Corona fueron superiores a la amortización de las pensiones anuales de los violarios.

\section{Gastos en obras}

Para los tres años que disponemos de cuentas de gastos, las partidas de obras, corresponden a diversas inversiones realizadas en el castillo de Orihuela (463 sueldos en 1316 y 1021 en 1317), el almudín de Alicante (947 sueldos en 1316), el castillo de Alicante con 1591 sueldos en 1317, la torre del cap del Aljup (228 sueldos en 1316 y 1106 en 1324) 99 . Una serie de partidas menores al alcázar de Elche (479 sueldos en 1324), los muros del arrabal de Elche, el castillo de Callosa y el castillo de Guardamar.

\section{Gastos en Administración}

He incluido en este apartado una serie de pequeños y variados gastos destinados al mantenimiento del aparato burocrático de la bailía, siendo los más destacados los correspondientes al pago de las prendas de vestir de los correos, con asientos contables de 85 sueldos por correo, para capa, camisa y pantalones. En 1316 recibieron este pago cinco correos y en 1317 ocho ${ }^{100}$.

Otros gastos en este apartado tuvieron como fin el pago de dietas a oficiales reales como el propio baile o el alcaide del castillo de Orihuela, o el alquiler de casas para almacenar el producto de los diezmos.

Añadir a estos gastos el pago que cada año se realizaba en correos, escrituras y otras "coses necessaries al fet» de la bailia ${ }^{101}$.

\section{Donaciones reales}

Desde el inicio de la conquista del reino de Murcia Jaime It recompenso a diversos caballeros fieles con heredades, rentas o pensiones anuales. Las cuentas estudiadas recogen algunas de estas donaciones efectuadas por Jaime $\|^{102}$. El resto son peque-

99 Las obras de 1324 se realizaron “... en les botigues en que les mercaders meten la roba e mercaderies lurs...», A.C.A. Real Patrimonio, Maestro Racional, Reg. 1702, f. 9 r.

100 En 1317600 sueldos se destinaron al pago de las prendas de vestir de dos escribanos reales.

101 A.C.A. Real Patrimonio, Maestro Racional, Reg. 1701, f. 13r.

102 Felipe Togores recibió 1.000 sueldos para una cabalgadura, aunque sólo en las cuentas de 1316, la entrega de 200 sueldos que tenía pendientes de dicha cantidad. A.C.A. Real Patrimonio, Maestro Racional, Reg. 1701, f. 11v. 
ñas ayudas para mantenimiento de cabalgaduras y donativos reales. Son cifras insignificantes y que suponen unos porcentajes paupérrimos sobre el total de gastos.

\section{Gastos varios}

Uno de los gastos varios era el pago de una cantidad anual fija al Obispo y Capítulo de Cartagena, en concepto de diezmo de las rentas de Elche y del puerto de Santa Pola y que se abonaba en dos plazos de 400 sueldos (habitualmente en Mayo y Octubre) ${ }^{103}$.

En este apartado también hay que incluir diversas compras realizadas por el baile como la de 30 «stores» que se enviaron a Barcelona, o la de 6 «stores» y 2 mesas en 1317.

Determinados pagos extraordinarios engrosan esta partida de varios, como los 579 sueldos que tuvo que abonar en 1317 el baile a un vecino de Alicante, por un caballo que había perdido en Almería al servicio del rey.

También hay que considerar dentro de los gastos los atrasos que resolvía anualmente el baile, como los 3013 sueldos que tenía pendientes de cobro en 1316, ya que en un ejercicio anterior había pagado de su peculio esa cantidad al resultar las cuentas de la bailía deficitarias ${ }^{104}$.

«Item mes en dat lo dit en Johan Raolf los quals li romaseren a cobrar del compte segons que avia mes dat que no avia reebut segons que en to dit compte es declarat...".

Por el mismo motivo en 1324 el baile cobro 1687 sueldos de las cuentas del año anterior ${ }^{105}$.

\section{Balance global de los gastos de las rentas reales en la Procuración}

Lo más reseñable en un balance global sobre el gasto de las rentas reales en la procuración real de Orihuela, es que la mayor parte iban destinadas al pago del salario de alcaides y oficiales reales, así como a miembros de la casa real. Empleándose el resto de partidas en el pago de deudas contraídas en el territorio, pequeños gastos de burocracia, donaciones reales, etc.

El pago de salarios de alcaides y oficiales suponía porcentajes que iban del $30 \%$ de 1324 al $40 \%$ de 1316, mientras que para provisión de la casa real en 1316 y 1317 el porcentaje fue del 38 y el $35 \%$ respectivamente. En 1324 la renta para provisión del infante don Pedro supuso el $46 \%$ de los gastos de las rentas reales del territorio. Por tanto las tres cuartas partes de las rentas reales correspondían al mantenimiento de la administración real en el territorio procuratorial y a la provisión de la casa real. Partidas como las de obras en los castillos tuvieron una mínima significación, ya que la Corona

103 A.C.A. Real Patrimonio, Maestro Racional, Reg. 1701, f. 19v.

104 A.C.A. Real Patrimonio, Maestro Racional, Reg. 1701, f. $11 \mathrm{v}$.

105 A.C.A. Real Patrimonio, Maestro Racional, Reg. Reg. 1702, f. 10r. 
GASTOS EFECTIVOS DE LAS RENTAS REALES. (1316-1324)

${ }^{*}$ = Gastos correspondientes a ocho meses (sólo para 1316)

\begin{tabular}{|c|c|c|c|c|c|c|c|c|c|}
\hline \multirow{3}{*}{ CONCEPTO } & \multicolumn{9}{|c|}{ AÑOS } \\
\hline & \multicolumn{3}{|c|}{$1316^{*}$} & \multicolumn{3}{|c|}{1317} & \multicolumn{3}{|c|}{1324} \\
\hline & SUELD. & D. & $\%$ & SUELD. & D. & $\%$ & SUELD. & D. & $\%$ \\
\hline $\begin{array}{l}\text { Tenencias de } \\
\text { castillos y salarios }\end{array}$ & 22248 & 4 & 40,74 & 35385 & 3 & 38,44 & 22955 & 6 & 30,05 \\
\hline $\begin{array}{l}\text { Provisión de la } \\
\text { Casa Real }\end{array}$ & 20900 & & 38,27 & 32497 & 11 & 35,3 & - & 一 & - \\
\hline $\begin{array}{l}\text { Provisión Infante } \\
\text { D. Pedro }\end{array}$ & - & - & - & 一 & - & 一 & 35200 & 一 & 46,08 \\
\hline Violarios y deuda & 5160 & & 9,45 & 15017 & 9 & 16,32 & 9257 & 10 & 12,12 \\
\hline Obras & 1638 & 3 & 3 & 2813 & 4 & 3,06 & 1960 & 7 & 2,57 \\
\hline $\begin{array}{l}\text { Mantenimiento } \\
\text { burocracia }\end{array}$ & 787 & 3 & 1,44 & 2727 & 1 & 2,96 & 1528 & 9 & 2 \\
\hline Donaciones reales & 200 & - & 0,36 & 1475 & - & 1,6 & 2845 & - & 3,72 \\
\hline Gastos varios & 3675 & 8 & 6,73 & 2127 & - & 2,31 & 2637 & - & 3,45 \\
\hline Subtotal & 54608 & 18 & & 92041 & 28 & & 76382 & 32 & \\
\hline TOTAL & 54609 & 6 & & 92043 & 4 & & 76384 & 8 & \\
\hline
\end{tabular}

Fuente: A.C.A. Real Patrimonio, Maestro Racional, Reg. 1701 y 1702. Elaboración propia.

había concedido a las villas reales del territorio determinadas rentas como el cabezaje - la tahurería para que pudieran invertir lo recaudado en obras de muros y torres.

Como apunte final destacar que la principal prioridad de la Corona en el gasto de las rentas en el territorio, fue librar cada año puntualmente el salario de los alcaides de los respectivos castillos. Por ello Jaime II en la orden remitida al inicio de su mandato al baile general Jaume Andreu, situaba en la prelación de gastos en primer lugar el salario de cada uno de los alcaides. En las cuentas de gastos se señala siempre en primer lugar el pago a los alcaides por la tenencia de los castillos, que se solía satisfacer integro durante el ejerció anual del cargo. El pago de los salarios a los oficiales reales resulto más irregular, lo que demuestra que en el gobierno del territorio la principal prioridad de la Corona era asegurar el control de los castillos.

Durante el período estudiado Jaume II pudo asegurar en la procuración de Orihuela el control militar y la administración real gracias a las rentas cobradas en el territorio. Además desvió una parte sustanciosa de las mismas a engrosar las arcas de la Corona o las de algún miembro destacado de la familia real como el infante don Pedro. 


\title{
UNA PERSPECTIVA JURÍDICA SOBRE LA DONACIÓN DEL REINO DE MURCIA A JAIME II DE ARAGÓN
}

\author{
Agustín BERMÚDEZ AZNAR
}

\section{EL ESTADO DE LA CUESTIÓN}

El tema de la conquista y anexión del reino de Murcia a la corona de Aragón ha sido objeto de una continuada atención historiográfica. El propio relato de los más destacados acontecimientos se encuentra ya en la mera narración cronística del suceso ${ }^{1}$, pero es que, además, disponemos de la documentación de la época en actualizada edición ${ }^{2}$ y de numerosos estudios que, incluso en nuestros días, siguen ofreciendo nuevas perspectivas y enfoques ${ }^{3}$.

1 Entre dichas crónicas destacan por su minuciosidad las aragonesas; especialmente la de R. MUNTANER (ed. de F. Soldevila en Les grandes croniques, Barcelona, 1971, cap. CLXXXVIII, pp. 834 y ss.) y la de J. ZURITA, Anales de la corona de Aragón (ed. de A. Canellas López, Zaragoza, 1969, lib. V, cap. XXI, pp. 501 y ss.).

2 Resultan fundamentales: la Colección de documentos para la historia del reino de Murcia. Documentos del siglo XIII, ed. de J. Torres Fontes, Murcia, 1969; El reino de Murcia bajo Aragón (12961305). Corpus documental, ed. de J.M. del Estal, vol. $1 / 1$, Alicante, 1985, y vol. I/2, Alicante, 1990. (En adelante esta colección será citada: J.M. del Estal, 1/1 O l/2).

En un contexto más amplio siguen aportando documentos de interés los clásicos estudios de M. GAIBROIS DE BALLESTEROS, Historia del reinado de Sancho IV de Castilla, Madrid 1922-1929, y A. BENAVIDES, Memorias del reinado de Don Fernando IV de Castilla, Madrid 1860. En un segundo plano se encuentran algunos documentos de interés en A. GIMÉNEZ SOLER, Don Juan Manuel, Zaragoza, 1932.

3 Entre ellos cabe mencionar: J. M. DEL ESTAL, Conquista y anexión de las tierras de Alicante, Elche, Orihuela y Guardamar al reino de Valencia por Jaime I/ de Aragón (1296-1308), Alicante, 1982; M.T. FERRER Y MALLOL, "Notes sobre la conquesta de Murcia per Jaume II (1296-1304)", en el Homenatge a la memòria del Prof. Emilio Sáez. Aplec d'estudis dels seus deixebles i col-laboradors. 
Pero, frente a todo ello, la valoración jurídica de la anexión no ha merecido tanto interés bibliográfico. $Y$ ello no cabe justificarlo por la menor entidad del tema; por el contrario, puede afirmarse que, en buena medida, el proceso de incorporación aragonesa gira en torno al eje articulador que jurídicamente supone una donación, esto es, un acuerdo de voluntades tendente a producir la traslación de un dominio. Desde este supuesto se comprende que Jaime II no dejase de esgrimir en ningún momento la donación como el instrumento jurídico legitimador de su presencia en las tierras del levante castellano.

En la documentación de la época ha quedado clara constancia de la importancia que se le asignó por todos a la donación. Así, al pedir D. Jaime a Da Yolanda Manuel y a su marido el infante $D$. Alfonso de Portugal que reconociesen su soberanía en relación con los señoríos murcianos que poseían, les argumenta que lo hace porque le es «feita donaçión purament entre vivos del reino de Murçia, con su carta, por la qual cosa el dito regno perteneçe a Nos, e Nos somos venidos agora en el dito Regno por omperar e reçebir aquél así como a cosa nuestra» ${ }^{4}$. Igualmente, en 1296, el arraez de Crevillente Mahomat Abenhudell justifica su sumisión «cercioratus plenarie de donatione et concesione facta vobis ilustrissimo domino Jacobo... irrevocabiliter inter vivos de toto Regno Murcie... per illustrissimum dominum Alfonso... per hostensionem instrumenti publici de donatione et concesione ${ }^{5}$. De forma similar, los vecinos de Orihuela rinden pleito-homenaje a Jaime II «per rao de la donatio al dito senyor Rey en Jacme feta purament et entre vius per lo molt alt senyor Namfos, per la graçia de Deu, rey de Castella... segons que es contengut en la carta publica de la dita donatio, bollada amb bolla de plomb ${ }^{6}$.

Pero, no cabe duda que una donación como la del reino de Murcia constituyó un acto jurídico complejo, en el que cada uno de sus principales elementos componentes: donante, objeto donado y donatario aglutinaron en torno suyo abundantes y no fácilmente resolubles problemas.

\section{EL DONANTE: D. ALFONSO DE LA CERDA}

\section{Legitimidad de su titularidad}

La primera problemática a tratar debe referirse a la persona del donante: D. Alfonso de la Cerda, hijo del infante D. Fernando de Castilla. Y la crucial cuestión que a él

Barcelona, 1989, pp. 27-44; A. MASIÁ DE ROS, Relación castellano-aragonesa desde Jaime Il a Pedro el Ceremonioso, Barcelona, 1994; E. GUINOT, Els limits del Regne, Valencia, 1995, especialmente el cap. 7 , pp. 103-115.

4 1296-abril-28. Huerta de Almoradí. Carta de Don Jaime II al infante D. Alfonso de Portugal. (En J.M. DEL ESTAL, I/1, doc. 8 y $1 / 2$, doc. 12).

5 1296-mayo-17. Huerta de Murcia. Acta de sumisión del arraez de Crevillente Mahomat Abenhudell a Jaime II reconociéndole como soberano del reino de Murcia. (En J.M. DEL ESTAL, I/1, doc. 66).

6 1296-mayo-11. Orihuela. Pleito-homenaje de la villa de Orihuela a Jaime II de Aragón. (En J.M. DEL ESTAL, I/1, doc.18). 
afecta respecto a la donación es la legitimidad de su título de propiedad o señorío sobre el reino de Murcia. Se trata obviamente de un problema complejo y difícil, pues está conectado y es consecuencia de la conflictividad sucesoria desencadenada tras la muerte del príncipe heredero D. Fernando?.

A este respecto, y enfocando el tema tan sólo en la vertiente que es objeto de nuestro interés y no en la globalidad del debate, cabe puntualizar que, como tópicamente se viene repitiendo, según el Derecho tradicional castellano la muerte en 1275 del heredero al trono de Castilla, sin haber accedido a la titularidad real, no transmitía derechos al trono a sus sucesores; por eso, el texto legal castellano posiblemente vigente en ese momento, el Espéculo, no contemplaba, al abordar el supuesto, la posible existencia de un derecho de representación por parte de los sucesores del difunto ${ }^{8}$. Sin embargo, el gran texto legal alfonsino, las Partidas, sí recoge este principio de representación especificando que "si el hijo mayor muriese antes que heredase, si hubiera hijo o hija de su mujer legítima, que aquel o aquella lo hubiese (el reino) y no otro»'; lo que ocurre es que resulta dudoso y problemático aceptar la vigencia en dicha fecha de este último texto ${ }^{10}$. En cualquier caso es lo cierto que, no sin dilación y vacilaciones, Alfonso $X$ hará jurar como heredero a su segundo hijo, el infante $D$. Sancho, siguiendo, en definitiva, la normativa tradicional castellana y dándose, en teoría, por acabado el tema. De esta forma terminaban las aspiraciones a ocupar el trono castellano por parte de D. Alfonso, el hijo mayor del infante fallecido; por lo menos aquí terminarían sus derechos al mismo por el mecanismo de la sucesión forzosa.

Pero posteriores acontecimientos políticos volverían a reabrir el tema sucesorio desde un planteamiento jurídico distinto: Se trata de la rebelión del legítimo heredero, el infante $D$. Sancho, contra su padre, el rey Alfonso $X$, acontecimiento igualmente complejo y oscuro. El hecho es que esta situación repercutió en el tema sucesorio ya que si bien la sucesión del infante tenía carácter forzoso no lo es menos que cabía su exclusión en caso de mediar justa y grave causa. Y la concurrencia de estas circunstancias fue lo que llevó al rey Alfonso $X$ a desheredar solemnemente a su hijo el 8 de octubre de $1282^{11}$. Tan grave medida fue ratificada en el testamento del monarca de 8

7 E. BENITO RUANO, «El problema sucesorio de Castilla a la muerte de D.Fernando de la Cerda», en VII Centenario del Infante Don Fernando de la Cerda. Jornadas de Estudio. Ciudad Real, 1976, pp. 217-225.

8 Así, en Il.16.1 el texto legal se limita a declarar tan sólo que «el fijo mayor del rey deue heredar el señorío de su padre». (Seguimos la edición de G. Martínez Díez, Ávila, 1985).

9 II.15.2.

10 Parece inoperante respecto al tema aquí tratado entrar en el complejo y debatido problema del inicio de la vigencia legal de las Partidas. Véase como opinión recogida en una actualizada obra de conjunto: Salvador DE MOXÓ, “La época de Alfonso X», en Historia de España dirigida por J.M. Jover Zamora. Tomo XIII, vol.: «La expansión peninsular y mediterránea. La corona de Castilla». Madrid, 1990; especialmente el cap. VII: «La sucesión de Castilla», pp. 200 y 204.En el mismo sentido: M. GONZÁLEZ JIMÉNEZ, Alfonso X (1252-1284). Palencia, 1993, p. 129.

11 Un amplio comentario y glosa del documento se encontrará en A. BALLESTEROS BERETTA, Alfonso $X$ el Sabio, Barcelona, 1963, p. 992.

La legalidad de la medida a tenor del Espéculo II.6.2 era inequívoca: «e deven ser deseredados 
de noviembre de 1283, alegando el intento del infante de despojar a su propio padre de sus reinos y señoríos. Y por si se abrigaba alguna duda al respecto, el rey ratifica su decisión en su codicilo de 1284 ya que por medio del mismo era también dado desheredar ${ }^{12}$.

Pues bien, en consonancia con cuanto antecede, y desde un plano teórico-jurídico, la vía de acceso al trono de Castilla, que se le había cerrado a D. Alfonso de la Cerda por el mecanismo de la sucesión forzosa, se le abría ahora de nuevo; esta posibilidad se basaba en su nombramiento como heredero testamentario por parte de su abuelo, el rey Alfonso $X$, una vez desheredado Don Sancho.

No obstante todo ello, y como es bien sabido, D. Sancho, públicamente maldecido y desheredado por su padre, accede de facto al trono de Castilla, y como tal es jurado y reconocido por todos.

\section{El uso, reconocimiento y capacidad real del donante}

La ocupación del trono de Castilla por Sancho IV no impidió que terminasen las reivindicaciones del primogénito del fallecido infante $\mathrm{D}$. Fernando. Muy por el contrario, D. Alfonso de la Cerda mantuvo en todo momento sus legítimas aspiraciones al trono de Castilla amparándose en la voluntad testamentaria de su abuelo Alfonso $X$. En consecuencia, utilizó la correspondiente y tradicional titulación real, incluso llegando como tal a suscribir tratados de paz y alianza ${ }^{13}$. Ese tratamiento le es reconocido además por algún soberano extranjero ${ }^{14}$, pero, sobre todo, por Jaime II, quien suele dirigirse a él como «llustrem Dominum Alfonsum, Regem Castelle» o como «muy noble y muy honrrado Don Alfonso, por la gracia de Dios, Rey de Castilla...» ${ }^{15}$; en contrapartida y coherentemente, Jaime II calificará a Fernando IV como "Don Ferrando qu' es diu Rey de Castiella» o «Ferdinandus qui se dicit Regem Castelle, natus quodam dopni Sancii de Castella» ${ }^{16}$.

Es más, en dos ocasiones Don Alfonso será formalmente proclamado rey de Castilla.

de todo cuanto que ovieren por siempre, e áyalo el rey para darlo o para fazer dello lo que quisiere». También Partidas VI.7.4 permitía de forma genérica que el padre desheredase al hijo que "le buscase tan mal porque el padre oviese a perder gran partida de lo suyo e menoscabar".

12 Los comentarios y referencias de A. Ballesteros a estos testamentos pueden verse en su obra Alfonso $X$ el Sabio, ob. cit., pp. 1000 y 1050 respectivamente.

Partidas VI.12.2 también permitía desheredar en codicilo.

13 1301-septiembre-10. Zaragoza. Tratado de paz entre Don Alfonso de la Cerda y el rey de Granada Muahmmad II. (En J.M. DEL ESTAL, 1/2, doc. 202).

14 1300-marzo-28. Carta del sultán de Egipto a Don Alfonso, rey de Castilla. (J.M. DEL ESTAL, I/2, doc.112).

15 Son múltiples los ejemplos documentales aducibles a este respecto. Sin ánimo de exhaustividad, véanse algunos de ellos en J.M. DEL ESTAL, I/1, doc. 80; y I/2, docs. 5, 44, 45, 90, 91, 98, 99 y 228.

16 Entre los ejemplos documentales citables véanse en J.M. DEL ESTAL, $1 / 1$, doc. 68 ; y $1 / 2$ docs. 168, 169, 193 y 204. También se encuentra alguna similar referencia en A. JIMÉNEZ SOLER, Don Juan Manuel, ob. cit., doc. LXXXII. 
Una en Jaca, en 1288, y otra en Sahagún, en 1296; en ambas se realizó una ceremonia formal de aclamación por parte de un grupo de nobles castellanos leales a su causa $^{17}$. Obvia y consecuentemente con todo ello D. Alfonso no llegó en ningún momento a renunciar formalmente a su dignidad real y a sus derechos al trono castellano; precisamente por eso una de las cláusulas de los acuerdos arbitrales de Torrellas de 1304 estableció "que el dicho Don Alonso dexe la voz de Rey de Castilla y de León, como se llama Rey, et las armas derechas et sello de Rey"18.

Así pues, Don Alfonso siempre se creyó legítimo rey y consiguientemente legítimo detentador del señorío sobre las tierras de la corona de Castilla. $Y$ dentro del conjunto de prerrogativas reales a él inherentes, $D$. Alfonso de la Cerda, en cuanto pretendido rey castellano, tenía la tradicional facultad de hacer donaciones; tal disponía la legislación ${ }^{19}$ y tal era, y había sido, la práctica en la vida política castellana. Por ello nada de extraño puede encontrarse en el hecho de que $D$. Alfonso, en uso de sus legítimas prerrogativas reales, done uno de los territorios de su señorío, el reino de Murcia, al Rey de Aragón, su pariente y, sobre todo, su continuo valedor.

\section{LA DONACIÓN DEL REINO DE MURCIA}

\section{Licitud de la donación de un reino}

El objeto de la generosa donación por parte de D. Alfonso era nada menos que de todo un reino, el reino de Murcia. Pero la magnitud de la donación es tal que cabe preguntarse sobre la licitud de donar uno de los componentes territoriales de la corona de Castilla, con la violación que ello podía suponer del principio de la indivisibilidad del patrimonio territorial de la corona que se heredaba.

En el orden de los principios, el propio Alfonso X se había mostrado contrario a cualquier práctica que pudiera comportar una desmembración del patrimonio territorial de la corona. Ya en 1255, con motivo del juramento de su hija $D^{\text {a }}$ Berenguela como presunta heredera de la corona castellana, el monarca hace especial hincapié en este extremo ${ }^{20}$. Posteriormente, en su magna obra legal, las Partidas, se establece que el rey y todos los del reino deben «guardar que el señorío sea todavía uno, e non consientan en ninguna manera que se enajene nin se departa» ${ }^{21}$.

17 J.M. DEL ESTAL, Conquista y anexión del reino de Murcia, ob. cit., pp. 160 y 166. Para una más amplia contextualización histórica de la crisis civil castellana véase. C. GONZÁLEZ MíNGUEZ: Fernando IV (1295-1312). Palencia, 1995, pp. 13-146.

18 En A. BENAVIDES, Memorias del reinado de D. Fernando IV, ob. cit., vol. II, doc. 280; J.M. DEL ESTAL, I/1, doc. 214.

19 Partidas, II.1.8, II.5.15 y V.4.9 contemplan la posibilidad de generosas donaciones reales, aunque sin llegar nunca a preveer la amplitud de la que nos ocupa.

20 W. PISKORSKI, Las Cortes de Castilla. Ed. facs. Barcelona, 1977. Ap. I, pp. 196-197.

21 II.15.5. Este argumento se vuelve a reiterar en II.15.2 al tratar de «como el fijo mayor ha adelantamiento e mayoría sobre los otros hermanos». 
Sin embargo, en los planteamientos teóricos de la política castellana sorprende constatar como se cuenta habitualmente con los reinos para resolver los más variados problemas políticos. Así, siguiendo con el ejemplo suministrado por el propio Alfonso $\mathrm{X}$, el monarca castellano, para condescender a las presiones de Felipe III de Francia en favor de los infantes de la Cerda, decide separar a Jaén y concederlo como reino vasallo a Don Alfonso ${ }^{22}$; la tajante oposición del heredero, el infante D. Sancho, hace fracasar el plan. Mas tarde, en 1283, al desheredar en Sevilla a D. Sancho e instituir como heredero a D. Alfonso de la Cerda, el viejo monarca castellano dona los reinos de Sevilla-Badajoz a su hermano, el infante $D$. Juan, y el reino de Murcia a su otro hermano el infante D. Jaime ${ }^{23}$; es cierto que ambos territorios tenían la condición de reinos vasallos de Castilla, pero no lo es menos que se trata de un débil vínculo, tendente a superar formalmente la posible objeción que pudiera hacerse de ir contra el mencionado principio de indivisibilidad del territorio de la corona castellana.

Con estos próximos antecedentes nada de extraño hay en que, pocos años después, se vuelva a utilizar el fraccionamiento territorial de la corona castellana como instrumento negociador para conseguir componendas políticas que ayuden a resolver problemas coyunturales. Así, el 21 de enero de 1296 tiene lugar en la localidad de Ariza un peculiar reparto teórico de la corona castellana entre Don Alfonso de la Cerda y su tío, el infante D. Juan; por él se adjudican al infante $D$. Juan los reinos de León, Galicia y Sevilla, y a D. Alfonso los de Castilla, Toledo Córdoba, Murcia y Jaén ${ }^{24}$; de la trascendencia práctica de este reparto puede juzgarse a tenor de la proclamación real de D. Juan en León y de D. Alfonso en Sahagún, ceremonias ambas celebradas ese mismo año de 1296. Posteriormente, el 26 de junio de 1303, cuando ya decae claramente la estrella política del pretendiente rey $D$. Alfonso, en una reunión también habida en Ariza entre Jaime II, el infante D. Enrique, D. Diego López de Haro, su hijo y D. Juan Manuel para intentar una vez más buscar una solución negociada al conflicto castellano, se adopta entre otros acuerdos el de conseguir de D. Fernando IV de Castilla la concesión para $\mathrm{D}$. Alfonso de la Cerda del reino de Jaén y algunas otras villas ${ }^{25}$.

Aunque es evidente que todos estos proyectos y propuestas en ningún momento llegaron a materializarse, es lo cierto también que son denotadoras de la viabilidad con la que teóricamente se planteaba la posibilidad de donar un reino.

22 Los detalles sobre la entrevista de Bayona de 1280 pueden encontrarse en A. BALLESTEROS BERETTA, Alfonso $X$ el Sabio, ob. cit., p. 928.

23 A. BALLESTEROS BERETTA, Alfonso $X$ el Sabio, ob. cit., pp. 1053-1054. Véase la interpretación que del alcance de estas donaciones hace M. GONZÁLEZ JIMÉNEZ, Alfonso X, ob. cit., pp. 152 y 153.

24 J.M. DEL ESTAL, Conquista y anexión, ob. cit., p. 165.

25 1303-junio-20. Ariza. Alianza realizada entre D. Enrique, D. Diego López de Haro, D. Juan Manuel y D. Jaime II, el infante D. Alfonso y el infante D. Fernando. (En A. BENAVIDES, Memorias de Fernando IV de Castilla, ob. cit., vol. II, doc. 234. Véase también el vol. I, pp. 15 y 29). 


\section{Formalización de la donación}

En dos ocasiones tiene formalmente lugar la donación del reino de Murcia por parte del pretendiente y titulado rey de Castilla D. Alfonso de la Cerda.

La primera se hace a favor de $D$. Alfonso de Aragón en documento expedido en Calatayud el 26 de junio de 1289.

Este documento comienza con la titulación real del donante, a la que sigue la motivación de la liberalidad que la provoca (ayuda especial prestada para ganar sus reinos empleando sus vasallos y tesoros), la calificación del acto jurídico (donación) y su duración («por agora e pora todos los tiempos»).

En cuanto al objeto donado, tras denominarlo globalizadamente (el reino de Murcia y su señorío) pasa a detallarlo a partir de tres niveles: físico, personal y material; respecto al primero incluye los mares, ríos, aguas, montes, llanos, ciudades (especifica las de Murcia y Cartagena), villas, lugares, castillos y fortalezas; respecto al componente personal alude expresamente a los hombres, caballeros, infanzones, dueñas, ciudadanos, clérigos y habitantes cristianos, judíos y moros; en relación al elemento material se conceden las rentas, pechos, pedidos y derechos debidos por razón del señorío.

Los derechos incluidos en la donación son también objeto de minuciosa relación. Ante todo el donante declara hacer al donatario rey y señor del objeto donado, es decir del ámbito físico (reino, ciudades, villas y lugares), del poblacional (los habitantes, ciudadanos, caballeros y otros hombres) y del elemento material (rentas y derechos que a los reyes de Castilla tradicionalmente le correspondieron). Al propio tiempo se reconoce en el donatario su capacidad plena para dar, vender y cambiar lo que estime oportuno, sin que por lo tanto el donante se haga reserva alguna en ninguna proporción, renunciando expresamente a cualquier derecho o señorío que le pudiera corresponder. En consecuencia, el donante pone al donatario en señorío y derecho del bien donado, y manda a todos los ricos hombres, caballeros, dueñas, infanzones, clérigos, ciudadanos y hombres del reino de Murcia que lo tengan desde ese momento por su rey y señor, absolviéndoles, para facilitar ese reconocimiento, de toda fe, homenaje y naturaleza que le hubieran prestado o le fueran debidos.

Entre las cláusulas complementarias contenidas en el documento figuran las promisorias de no retener el donante nada del reino, y de que cuanto de alguna manera le pueda venir o percibir será desde ahora en voz del nuevo rey. También figuran las cláusulas de no retrocesión e irrevocabilidad de la donación, y una serie de cláusulas asegurativas: de reconocimiento y homenaje, de observancia de lo estipulado (ratificado con juramento sobre la cruz) y de formalidad escrita, mediante la expedición de carta sellada.

Con la obligada datación, relación de testigos, etc., termina este importante documento ${ }^{26}$.

26 En J.M. DEL ESTAL, $1 / 1$, doc. 1. 
Respecto a la segunda donación, la efectuada a Jaime II en Ariza el 21 de enero de 1296, debió tener un contenido similar a la anterior y pudo ser efectiva y nuevamente formalizada en documento, ya que tanto D. Alfonso de la Cerda ${ }^{27}$, como D. Jaime $\|^{28}$ aludirán a dicho instrumento jurídico.

Conviene tener en cuenta que con la mera expedición del documento de donación tan sólo se cumplía por parte del donante una de las formalidades del acto jurídico (tal vez la más importante), pero restaban, sin embargo, otras que, con carácter complementario, contribuían también a su perfeccionamiento. Las que se encuentran en la donación del reino de Murcia fueron: la notificación de la donación a terceros interesados, el mandato de su cumplimiento, y el público reconocimiento de la misma.

El testimonio más elocuente de la notificación de la donación a posibles terceros implicados, unida a la orden de su cumplimiento, es una carta de Don Alfonso dirigida al concejo de Orihuela el 3 de febrero de 1296; en ella le comunica la donación que ha realizado, ordena obediencia al nuevo titular, el rey de Aragón, y les absuelve expresamente de la fe, jura, homenaje, fidelidad y naturaleza que a él le fuera debida como rey de Castilla ${ }^{29}$.

El reconocimiento ostensible y público de la donación por parte de $\mathrm{D}$. Alfonso de la Cerda consistió en la supresión de su titularidad real sobre Murcia en cuantos documentos expide desde ese momento, manteniendo obviamente los restantes títulos reales en el inicio de todas sus cartas.

\section{EL DONATARIO: DON JAIME II DE ARAGÓN}

En principio, hay que presumir en el donatario la concurrencia de los elementales requisitos legales que le capacitaban para recibir la donación. Tan sólo podrían plantearse dudas referidas a su condición de no natural, requisito éste nada superfluo en un caso en que el bien donado era un reino. A este respecto cabe considerar que tal exigencia no debía tener un carácter taxativo, pues en otras parcelas del Derecho público castellano su operatividad era escasa; tal es el caso frecuentísimo de los matrimonios reales e incluso también el de los derechos sucesorios. A este último respecto debe recordarse que entre las previsiones sucesorias del propio Alfonso $X$ figuraba la de llamar a la sucesión de la corona de Castilla, si ello fuera preciso, al propio rey de Francia, Felipe III ${ }^{30}$.

27 "Como Nos ayamos dado el Regno de Murcia... por nuestras cartas seelladas con nuestra bulla de plomo colgada». (En J.M. DEL ESTAL, l/1, doc. 3).

28 1296-abril-28. Huerta de Almoradí. Carta de Jaime II al infante portugués Don Alfonso: "A Nos feita donaçión purament entre vivos del Regno de Murçia con su carta». (En J.M. DEL ESTAL, 1/1, doc.8).

29 Véase la nota 27.

30 En A. BALLESTEROS BERETTA, Alfonso $X$ el Sabio, ob. cit., p. 1007. 


\section{La aceptación de la donación}

Si bien no tenemos constancia de una declaración expresa de Jaime II respecto a su aceptación de la donación, la misma puede inferirse desde el primer momento de incidentales referencias documentales. Por ejemplo, la contenida en una carta de 28 de abril de 1296 en la que el monarca aragonés declara a $D^{\mathbf{a}}$ Yolanda de Portugal que por la donación que se le ha realizado «el dito regno perteneçe a Nos... e Nos somos venidos agora en el dito Regno por reçebir aquél así como a cosa nuestra»; o también en la alusión contenida en la carta de Jaime II dirigida al conde de Ampurias donde expresamente alude al «regnum nostrum Murcie» ${ }^{31}$.

Pero son más bien ciertas actuaciones del mencionado rey las que inequívocamente permiten inferir su actitud. La primera es la incorporación que hace del título de rey de Murcia en todos los documentos emanados de su Cancillería; su ubicación la hará tras el de Valencia, siguiéndole después el de conde de Barcelona ${ }^{32}$. La segunda es la notificación que personalmente hace a cuantos puedan estar implicados en el tema de la concesión y su nueva condición de rey de Murcia; a tales efectos es de mencionar la carta dirigida a su consejero Bernat de Sarriá el 17 de febrero de 1296, notificándole la terminación de las negociaciones y mandándole se disponga a ocupar por la fuerza las plazas y lugares del reino de Murcia ${ }^{33}$; en el mismo sentido se expresa al infante D. Alfonso de Portugal al pedirle su reconocimiento como rey y señor del reino de Murcia por cuantos castillos y lugares allí tenía ${ }^{34}$.

\section{Ocupación y reconocimiento}

La ocupación de la donación efectuada era en el terreno práctico el gran problema a resolver ya que, como es obvio, se dona un reino perteneciente a la corona de Castilla, a la que habitantes, ciudades, villas, lugares, castillos, fortalezas y señoríos enclavados en el reino murciano reconocen como legítima entidad soberana.

En este sentido, la actitud táctica de D. Jaime fue clara. Comenzó anteponiendo el despliegue de un contingente militar para asediar y ocupar, si fuera necesario, cada localidad o enclave militar que se le opusiera; al propio tiempo, se sirvió de un amplio conjunto de medidas pacíficas, que desde las más duras amenazas podían llegar a

31 «Por la qual cosa (donación) el dito Regno perteneçe a Nos, e Nos somos venidos agora en el dito Regno por omperar e reçebir aquél, así como a cosa nuestra». (En J.M. DEL ESTAL, 1/1, doc. 8, y $1 / 2$, doc. 193 respectivamente).

32 Así, pues, la titulación real pasa de la tradicional: «Don Jaime, por la gracia de Dios, Rey de Aragón, de Mallorcas, et de Valencia, et conde de Barcelona» (documento de 1296-abril-29, en J.M. DEL ESTAL, I/1, doc. 9) a la de «En Jacme, por la gracia de Deu, Rey d' Aragó, de Mallorques, de Valentia, de Murçia et Comte de Barcelona» (documento de 1296-mayo-11, en J.M. DEL. ESTAL, I/1, doc. 18).

33 J.M. DEL. ESTAL, $1 / 1$, doc. 5.

34 «Porque vos requerimos e vos amonestamos que vos nos ayades e nos obedescades por aquello que tenedes en el Regno de Murçia, como a señor e rey del Regno de Murçia». (En J.M. DEL ESTAL, $1 / 1$, doc. 8). 
las más generosas promesas; de esta forma se trató de evitar el efectivo uso de las armas y la consecución del tan deseado reconocimiento ${ }^{35}$.

Respecto a la actuación militar sólo hubo algún combate aislado (por ejemplo el mantenido ante el castillo de Alicante) bastando, en general, el asedio formal como medio intimidatorio. Respecto a las medidas pacíficas, Jaime II dio muestras de su acrisolada habilidad diplomática y negociadora; en esta táctica los instrumentos más utilizados fueron la expedición de salvoconductos que facilitaran mantener entrevistas negociadoras ${ }^{36}$, el establecimiento de treguas que permitieran a las poblaciones asediadas recapacitar sobre su decisión ${ }^{37}, y$, cuando no hubo más remedio, el uso de conminaciones y amenazas, sobre todo de expropiación de heredamientos ${ }^{38}$.

Fruto de la eficacia de todas estas medidas fue que el monarca aragonés consiguiera poco a poco tomar posesión del reino donado y obtener el reconocimiento de su soberanía y señorío por parte de las autoridades militares, núcleos poblacionales y señoríos asentados en el reino de Murcia.

En cuanto a los primeros, el reconocimiento de los responsables de las instalaciones militares resultaba fundamental. Pero no todos los alcaides de castillos y fortalezas reaccionaron del mismo modo; los hubo que, como el alcaide de Alicante Nicolás Pérez, se opuso hasta el final y murió en la refriega; otros, sin embargo, tras una más o menos corta resistencia terminaron doblegándose y reconociendo la soberanía aragonesa. En consonancia con dichas actitudes el tratamiento que les dispensó Jaime II fue muy variado; en los casos de mayor colaboración y rápido reconocimiento se les recompensó, cuando menos, con la confirmación en el oficio (circunstancia ésta que debió ser uno de los señuelos de la negociación ${ }^{39}$; en otros casos la pérdida del cargo e, incluso, la sanción fueron inevitables ${ }^{40}$.

35 El detalle de la progresiva ocupación de cada plaza y las medidas adoptadas al efecto pueden seguirse con detalle en J.M. DEL ESTAL, Conquista y anexión, ob. cit., pp. 183-268.

36 Pueden servir como ejemplo los salvoconductos otorgados en mayo de 1296 al alcaide de Alhama, de Monteagudo y de Chocos. (En J.M. DEL ESTAL, 1/1, docs. 59, 70 y 84 respectivamente).

37 Así, entre otras, las dadas a Cartagena en 22 de mayo de 1296, (en J.M. DEL ESTAL, I/1, doc. 87). Pero posiblemente las más reiteradas y complejas fueron las concedidas a Don Juan Manuel por su señorío de Elche en 17 de mayo de 1296, 27 de julio de 1296 y, sobre todo, de 9 de mayo de 1303. (En J.M. DEL ESTAL I/1, docs. 57, 124 y 195 respectivamente).Véase también R. CHAVÁS, "Treguas de Don Jaime Il de Aragón con el noble Don Juan Manuel, hijo del infante Don Manuel», en Boletín de la Real Academia de la Historia, 28 (1896), pp. 433-440.

38 Resulta paradigmático a estos efectos la carta de Jaime II a Lorca el 17 de diciembre de 1300. (En J.M. DEL ESTAL, 1/2, doc. 129).

39 Tal fue el caso, entre otros, de Miguel García, alcaide de Abanilla (J.M. DEL ESTAL, Conquista y anexión, ob. cit., p. 215), Pedro Roys de San Cebrián, alcaide del castillo de Orihuela (ibídem, p. 221), Juan Fernández de Gomariz, alcaide del castillo de Monteagudo (ibídem, p. 240), Pedro Zapata, alcaide del castillo de Mula (ibídem, p. 252) y Romeu de Merimond, alcaide del castillo de Cartagena (ibídem, p. 254).

40 Así actuó Jaime II contra el alcaide castellano de Callosa, Fernando Pérez de Gurmesal, a quien no sólo destituye sino que también sanciona con la confiscación de sus bienes. Otro tanto le ocurrió al alcaide del Castillo de Cartagena, Sancho Díaz de Bustamante. (En J.M. DEL ESTAL, Conquista y anexión, ob. cit., pp. 214 y 257). 
En relación a los núcleos poblacionales, el reconocimiento se produce tras la consiguiente negociación y promesas del nuevo monarca de respetar las personas de los pobladores, sus privilegios y propiedades. Tal ocurre con algunos ejemplos documentados que disponemos de Orihuela, Murcia y Elche; en todos ellos, un grupo de procuradores o miembros del concejo, dotados de los consiguientes poderes al efecto acudian ante el monarca o su representante para prestarle el obligado homenaje y reconocimiento. En Orihuela, en concreto, el acto se realiza por el concejo reunido en la Iglesia de San Salvador, haciéndole a Jaime II homenaje «de boca y de manos» como a su rey y señor natural ${ }^{41}$. También de Lorca conocemos los nombres de sus representantes que llevaron a cabo el "sacramentum fidelitatis et homagium ore et manibus Bernardo de Serriano, nomine Domini Regis, et recognoverunt dictum dominum regem pro rege et domino regni Murcie» ${ }^{42}$.

Por último, como ejemplo elocuente del reconocimiento por parte de un lugar de señorío, disponemos del acta por la que Mahomat Abenhudell, ra'is de Crevillente, «recognoscens in verum et naturalem dominum meum vos predictum dominum regem Jacobum ${ }^{43}$.

\section{Los actos de disposición del donatario}

A partir del reconocimiento de Jaime Il como nuevo señor, éste, en uso de la soberanía que detenta sobre el territorio, realiza toda una serie de actos de disposición de índole muy diversa.

En primer lugar se encuentran toda una serie de concesiones privilegiadas a colectividades urbanas y confesionales. Respecto a las primeras fueron muy numerosos los privilegios de todo tipo concedidos a ciudades y villas que, tras la oportuna negociación terminan reconociéndole como rey; la recompensa real consistió las más de las veces en la confirmación de sus propiedades, los indultos por encausaciones civiles o criminales, libertad de tránsito por los reinos, etc. ${ }^{44}$. Otro tanto ocurre con las comunidades confesionales. A las comunidades de mudéjares se les suelen dar seguridades personales y patrimoniales para evitar que huyan y se despueblen los lugares donde habitan ${ }^{45}$; además de ello se les reconocen sus propios tribunales para el cono-

41 1296-mayo-11. Orihuela. Reconocimiento de Jaime II como rey de Murcia por el concejo de Orihuela. (En J.M. DEL ESTAL, I/1, doc. 18).

42 1300-diciembre-19. Lorca. Relación de caballeros lorquinos que prestaron homenaje a Jaime II. (En J.M. DEL ESTAL, I/2, doc. 132).

43 1296-mayo-17. Ante el castillo de Monteagudo. Acta se sumisión de Mahomat Abenhudell, arraez y señor de Crevillente, reconociendo a Jaime II como soberano del Reino de Murcia y su señor natural. (En J.M. DEL ESTAL, I/1, doc. 66).

44 Un buen ejemplo de este tipo de medidas nos to suministran las efectuadas por Jaime II para Orihuela el 11 de mayo de 1296 y que se recogen en J.M. DEL ESTAL, I/1, docs. 16-34.

45 Véanse a este respecto las garantías generales reflejadas en una carta real de Jaime II a todos los mudéjares del reino de Murcia el 20 de mayo de 1296. (En J.M. DEL ESTAL, 1/1, doc.79).

Las hay también referidas específicamente a los sarracenos de Alguazas, Cartagena, Petrel y Elche. (En J.M. DEL ESTAL, 1/1, docs. 75, 97, 59 y 189 respectivamente). 
cimiento de sus causas ${ }^{46}$, la celebración de mercado semanal ${ }^{47}$, exenciones de servicios personales ${ }^{48}$, exenciones impositivas ${ }^{49}$, etc. Menos abundantes fueron, pero tampoco faltaron, las disposiciones referidas a judíos: extensión a los mismos de los privilegios concedidos a los vecinos de la localidad ${ }^{50}$, exención del “ius hospiti ${ }^{51}$, libertad de tránsito ${ }^{52}$, etc.

Dentro de las concesiones privilegiadas menudearon las de carácter estrictamente personal. En algunos casos se trata de licencias militares ${ }^{53}$, en otras son salvoconductos, como el concedido al Adelantado del Reino de Murcia, D. Juan Sánchez de Ayala para abandonar con su familia y enseres el reino de Murcia en un plazo de tiempo determinado ${ }^{54}$; no faltan tampoco perdones e indultos a inculpados ${ }^{55}$. Pero en la mayoría de las ocasiones estos privilegios contienen recompensas a los leales colaboradores a la causa aragonesa; estas recompensas fueron, sobre todo, inmuebles que habían sido confiscados a sus anteriores propietarios por traición o por no haber reconocido a tiempo la soberanía del nuevo monarca ${ }^{56}$; en menor proporción también se efec-

46 A efectos judiciales y procesales son importantes dos disposiciones de Jaime II. En una, de 23 de mayo de 1296, nombra al ra'is de Crevillente como juez ordinario de todos los sarracenos moradores de Crevillente, Alicante, Orihuela, Guardamar y Beniopa, (en J.M. DEL ESTAL, I/2, doc. 51). La otra se refiere específicamente a la aljama sarracena de Alicante para que sus causas sean sustanciadas según la çunna, (en J.M. DEL ESTAL, Alicante, de villa a ciudad 1252-1490, Alicante, 1990, doc. 45).

47 El 19 de febrero de 1298 Jaime II concede a los sarracenos de Guardamar la celebración de un mercado semanal. (En J.M. DEL ESTAL, 1/1, doc. 161).

48 Una exención de la prestación de servicio militar a los mudéjares de la Arrixaca y huerta de Murcia es la concedida por Jaime II el 25 de abril de 1303. (En J.M. DEL ESTAL, 1/1, doc. 193).

49 En 1303 Jaime II eximirá de cabezaje y alfarda a los mudéjares de la Arrixaca y huerta de Murcia y también a los de Elche. A estos últimos les eximirá además de la tarchana. (En J.M. DEL ESTAL, $\mathrm{I} / 1$, doc. 188,190 y 191 respectivamente).

50 Tal hace Jaime II respecto a los judios de Alicante el 9 de febrero de 1298. (En J.M. DEL ESTAL, I/1, doc. 160).

51 Esta exención referida a la aljama de judíos de Murcia respecto a los miembros de la familia real es ratificada por Jaime II el 3 de junio de 1296. (En J.M. DEL ESTAL, I/1, doc. 98).

52 Un ejemplo contundente de esta libertad de desplazamiento lo muestra el privilegio de guiatge y salvoconducto dado por Jaime II para los judíos de Cartagena el 3 de junio de 1296. (En J.M. DEL ESTAL, $1 / 1$, doc. 97).

53 Se trata de licencias para permitir el regreso a casa de hombres de armas ya en grupos ya aisladamente. (Véanse, por ejemplo, las concedidas por Jaime ll los días 14,15 y 17 de mayo de 1296, recogidas en la obra de J.M. DEL ESTAL, I/2, docs. 34, 36 y 38; también en $1 / 1$, doc. 53).

54 En J.M. DEL ESTAL, $1 / 2$, doc. 37.

55 Así los concedidos el 16 de mayo de 1296 a dos vecinos de Alicante, Julián y Pedro Martínez de Alcañiz. (En J.M. DEL ESTAL, l/1, docs. 54 y 55).

$56 \mathrm{La}$ documentación recoge variados ejemplos de estas concesiones inmobiliarias efectuadas por Jaime II a sus leales colaboradores. Véanse en J.M. DEL ESTAL, I/1, docs. 11, 93 111, 112, 113, $123,131,133,135$, y en $1 / 2$, docs. $27,29,30,31,35,101,102,256,257,258,259,261,262$ y 271. 
tuaron concesiones de rentas ${ }^{57}$ e incluso de oficios ${ }^{58}$. Los destinatarios de todas estas medidas casi siempre eran cristianos, y cuando aparecen destinatarios mudéjares suelen ser de alto nivel social, como el arraez de la Arrixaca de Murcia $^{59}$ o la esposa del ra'is de Crevillente ${ }^{60}$.

Otra prototípica manifestación de la soberanía del nuevo titular fue el ejercicio de una ordinaria actividad legislativa. En este sentido, la emanada de Jaime II tuvo en principio la pretensión de infundir confianza a la población y facilitar al máximo su aceptación de la soberanía aragonesa; para lograrlo se mantuvieron incólumes los fueros, privilegios, exenciones y costumbres locales, muchos de ellos conseguidos y disfrutados ya desde época de Alfonso X. Esta medida debió aplicarse de forma radical tan sólo en un primer momento, y se intentaría con ella no sólo facilitar el suave tránsito a la nueva soberanía sino también ganar tiempo mientras que se elaboraba un marco legal más amplio, al parecer inspirado en la legislación vigente en el reino de Valencia. El caso de Murcia es a tales efectos paradigmático: la ciudad, tras reconocer a Jaime II, recibe una primera confirmación de su tradicional Derecho, para señalársele como supletorio el Fuero de Valencia en tanto que se realizaba para ella una específica recopilación; ésta fue efectivamente sancionada por el monarca el 25 de octubre de 1297, y aunque no se conoce el texto completo de la misma su entronque con la legislación valenciana es incuestionable ${ }^{61}$.

En cuanto al aparato institucional de gobierno y administración, el original castellano es sustituido por el aragonés. A nivel territorial tal ocurre con el Adelantamiento del Reino de Murcia, que es transmutado ahora por una Procuración General del Reino de Murcia ${ }^{62}$. Otro tanto cabría decir respecto al oficio de Bayle General del Reino de

57 Suelen ser, en su mayoría, rentas anuales renovables a beneplácito real; excepcionalmente las hay vitalicias, y en un caso se concede una renta diaria de carácter vitalicio. (En J.M. DEL ESTAL, $\mathrm{l} / 1$, docs. $134,135,136,138,139,140,145$, y I/2, docs. 67 y 68 ).

58 1296-agosto-4. Jaime Il otorga a Juan de Marsella el oficio de corredor en Orihuela; tiene carácter vitalicio y de recompensa a los servicios prestados. (En J.M. DEL ESTAL, I/2, doc. 65).

59 La concesión que le hace Jaime II en 1296 de un horno, casa urbanas y seis fanegas de tierra de cultivo puede verse en J.M. DEL. ESTAL, $1 / 1$, doc. 92.

60 Jaime II le confirma el heredamiento que le había legado en Murcia su padre, el rey moro Aliafar. (En J.M. DEL ESTAL, 172, doc. 52).

61 En este sentido resultan muy elocuentes tres misivas de Jaime II. La primera de 3 de julio de 1296 está dirigida al justicia de Murcia, mandándole servirse de los fueros otorgados a la ciudad por Alfonso $X$ y sus sucesores en tanto se lleva a cabo una "compilatio Fori Murcie»; en caso de no encontrarse solución legal en los mencionados textos se recurriría a los Furs de Valencia. La segunda carta, de la misma fecha que la anterior, está dirigida a los juristas Martín de Dios y Juan Meeyani, encomendándoles la realización de una compilación del Fuero de Murcia. La tercera, de 25 de octubre de 1297, es una provisión real dirigida a sus súbditos del reino de Murcia notificándoles haber sancionado el Forum Murcie. (En J.M. DEL ESTAL, l/1, docs. 113,114 y 148 respectivamente). Véase también sobre toda esta temática: J.M. DEL ESTAL, “El Fuero y las Constitutiones Regni Murcje de Jaime II de Aragón (1296-1301)", en Anales de la Universidad de Alicante. Historia Medieval, 8 (1990-91), pp. 19-56.

62 El tránsito institucional se produce pronto. El 23 de mayo de 1296 Jaime II nombra a su hermanastro Jaime Pérez como Procurador General del Reino de Murcia, (en J.M. DEL ESTAL, 1/1, doc. 
Murcia $^{63}$, institución prototípica de la corona aragonesa, y por lo tanto hasta ese momento desconocida en los organigramas castellano-murcianos. A nivel local los cambios son también notables; así, y por no citar sino algunas de las más conocidas instituciones locales, los alcaldes y alguaciles de los núcleos poblacionales castellanos son sustituidos por justicias, jurados, baile y almotacén de las localidades aragonesas $^{64}$. Es posible, por último, que el cambio afectara menos a las autoridades militares, entre las que destacarían los alcaides; todo parece indicar que éstos mantendrían un ámbito competencial similar basado en el común vínculo de derechos y obligaciones generados por las relaciones vasalláticas; buena prueba de ello lo constituye el hecho de que la mayoría de los alcaides que se someten sin ofrecer resistencia son confirmados en su cargo por el nuevo monarca aragonés ${ }^{65}$.

En suma, la donación del reino de Murcia constituyó el pretexto e instrumento jurídico que, revalidado por la efectiva ocupación militar y reconocimiento formal, contribuyó a operar el tránsito de la soberanía castellana a la soberanía aragonesa. Un tránsito evidentemente coyuntural que la sentencia de Torrellas-Elche se encargaría de precisar en lo territorial y consolidar en lo temporal.

91). A partir de él se sucederán en el cargo D. Jaime de Xérica, Bernat de Sarriá, Bernat de Cruylles, Pedro de Monteagudo, etc.

63 Desde mayo de 1296 menudea la documentación sobre actuaciones de Bernat Colomet como Bayle General del Reino de Murcia; y desde 1301 ocurre otro tanto con su sucesor Ferrer Descortell. (J.M. DEL ESTAL, I/1, docs. 112, 129, 152, 171, y l/2, docs. 44, 45, 46, 47, 48 y 84).

64 Véase la carta privilegio de Jaime II a la villa de Alicante para que nombre justicia, jurados y almotacén en sustitución de los alcaldes y alguaciles, (en J.M. DEL ESTAL, 1/1, doc. 118). Sobre bayles locales la documentación también es abundante; respecto al de Alicante, por ejemplo, véanse las referencias de J.M. DEL ESTAL, Alicante de villa a ciudad, ob. cit., docs. 37, 39, 62, y 66.

65 Véase la nota 39. 


\title{
EL PODER REAL EN LA MURCIA ARAGONESA A TRAVÉS DEL OFICIO DE LA PROCURACIÓN, 1296-1304
}

\author{
José Vicente CABEZUELO PLIEGO \\ Universidad de Alicante
}

En la primavera de 1296 Jaime II llevó a cabo una campaña militar por tierra y por mar que le permitió en breve tiempo conquistar el reino de Murcia castellano'. Frente a otros momentos en los que las relaciones entre las coronas de Castilla y Aragón propiciaban el enfrentamiento armado, no fueron, sin embargo, los primeros años del reinado de Jaime II tiempos que presupusiesen inestabilidades diplomáticas conducentes a crisis bélicas. Aunque lo cierto es que las tierras murcianas habian de ser, casi necesariamente, fuente de conflicto entre ambas potencias peninsulares atendiendo a que en ellas convergían las líneas de expansión de la cristiandad hispana frente al Islam, apareciendo la región desde un principio como objetivo fundamental ${ }^{2}$. Pese a su inicial dominio castellano, la Corona de Aragón siempre tuvo en consideración, ora subjetiva ora objetivamente, este espacio, que defendió como suyo e incluso

1 Acerca de la conquista del reino de Murcia por Jaime II cfr. ESTAL GUTIÉRREZ, J.M. del, Conquista y anexión de las tierras de Alicante, Elche, Orihuela y Guardamar al Reino de Valencia por Jaime // de Aragón (1296-1308). Alicante Medieval en la Proyección expansionista de Aragón, desde la hegemonía castellana a su incorporación formal al Reino de Valencia (1243-1308), Alicante, 1982. 1d. Corpus Documental del reino de Murcia bajo la soberania de Aragón (1296-1304/5). Coleccion de Documentos Medievales Alicantinos 1/1, Alicante, 1985. Id., El reino de Murcia bajo Aragón (12961305). Colección documental del medievo alicantino. Corpus Documental $1 / 2$, Alicante, 1990. FERRER i MALLOL, Mª.T., "Notes sobre la conquesta del regne de Múrcia per Jaume II (1296-1304)", en Homenatge a la memória del Prof. Emilio Sáez. Aplec d'estudis dels seus deixebles y col.laboradors, Barcelona, 1989, pp. 27-44.

2 BEJARANO RUBIO, A., «La frontera del reino de Murcia en la política castellano-aragonesa del siglo XIIl», en Alfonso X el Sabio, vida, obra y época, I, Madrid, 1989, pp. 199-212. 
repobló con sus gentes ${ }^{3}$. Algunos contemporáneos de los acontecimientos creyeron encontrar razones que avalaban el interés catalano-aragonés por Murcia. Lo cierto es que si la política de Jaime I aparentemente reforzó la línea de Almizra como mojón meridional con la vecina Castilla, la de sus sucesores en el trono se orientó a su traslado hasta el contacto directo con Granada. Pedro el Grande y Alfonso el Liberal contaron con una importante baza a su favor, los infantes de la Cerda, quienes, protegidos desde 1277 en la Corona de Aragón de su tío Sancho IV, obtuvieron en ella los apoyos necesarios para intentar recuperar el trono castellano a cambio de la cesión del reino de Murcia. El primer paso lo dio Alfonso III, quien al permitir la coronación de Alfonso de la Cerda en Jaca como rey de Castilla obtuvo en compensación el reino de Murcia en 1289. Este acto nominal fue llevado al terreno de la práctica por Jaime II, cuando, solventados todos sus problemas internacionales, se decidió por la recuperación de ese territorio.

Incorporado el reino de Murcia a la soberanía del rey Justo como un territorio más - así lo pone de relieve su intitulación durante el período en cuestión: “... rex Aragonum, Valencie, Murcie ac comes Barchinone...»-, Jaime II aplicó en él el mismo sistema de administración pública utilizado en el resto de sus dominios, quedando obviamente relegado el castellano. Los gobiernos municipal y territorial fueron ordenados empleando la fórmula política que regía en la Corona de Aragón, y así, mientras que en las villas los tres pilares básicos de su gobierno eran Jurados-Justicia-Consejo, el espacio regnícola quedó desde el punto de vista gubernativo y administrativo en manos de un procurador real y de un baile general, encargados respectivamente del gobierno y de la administración del real patrimonio, ambos bajo el control directo del rey ${ }^{4}$. No se innovó, pues, a la hora de proceder al reordenamiento político del nuevo reino.

Conviene recordar que la conquista del espacio murciano fue una acción personal del rey de Aragón, quien cargó sobre sus hombros todo el peso de la campaña llegando incluso a poner en peligro su vida en más de una ocasión. Lo cierto es que fue durante su estancia en estas tierras, todavía inconclusa la conquista, cuando asentó las bases del gobierno territorial murciano en su ausencia. El 31 de mayo de 1296, recién conquistada la villa de Mula, fue creada la Bailía General bajo la dirección de Bernat Colomet ${ }^{5}$. Unos días antes, tras la rendición de la capital del reino, era la

3 Acerca de este tema cf. TORRES FONTES, J., La reconquista de Murcia en 1266 por Jaime I de Aragón, Murcia, 1987, en concreto de la página 109 en adelante.

4 FERRER i MALLOL, $M^{a}$.T., «La Batllia General de la part del regne de València dellà Xixona», en Anales de la Universidad de Alicante. Historia Medieval, 6, Alicante, 1987-1988, pp. 279-309. Id., Organització i defensa d'un territori fronterer. La Governació d'Oriola en el segle XIV, Barcelona, 1990, pp. 3-59.

5 Con un salario de dos mil sueldos anuales. ACA, C, reg. 340 , f. 94 r. 
Procuración la institución creada y concedida a un hermano de Jaime II, Jaime Pérez ${ }^{6}$. Magistratura sobre la que vamos a reflexionar en estas páginas.

El origen y desarrollo de la Procuración en la Corona de Aragón como institución de gobierno estuvo íntimamente ligado a la expansión territorial y a la imposibilidad del príncipe para proceder personalmente al control político y administrativo de los nuevos espacios ${ }^{7}$. A fin de solventar estos problemas se procedió al empleo de fórmulas gubernativas de carácter público basadas en la idea de la representación ${ }^{8}$, apareciendo entonces delegados reales al frente de dichas entidades con la misión principal de administrar justicia y proceder a su gobierno en nombre del promotor ${ }^{9}$. De ahí que algún foralista, caso del aragonés Bardají, opinase con bastante razón que tales funcionarios fueron creados por el rey, y nunca por ley de ningún tipo ${ }^{10}$.

Murcia y su reino quedaron convertidos de inmediato en una Procuración, en un distrito administrativo como los existentes en el resto de tierras de la Corona de Aragón sustentados en territorios históricos con entidad propia: reinos, condados. Si bien, no hubo que esperar la ausencia del rey, como sucediese en el reino de Valencia ${ }^{11}$, para conocer de este oficio en Murcia. Cargo, por otro lado, de muy similares características al existente en estas tierras durante la dominacjón castellana: el adelantado, tal y como ha afirmado J. M. Pérez-Prendes ${ }^{12}$, y como creyeron los habitantes de esas tierras, caso de las gentes de Novelda, aljama situada en el espacio que conquistara

6 ACA, C, reg. 340, f. 105v. (1296, mayo, 23). ESTAL. GUTIÉRREZ, J.M. del, Conquista y anexión de las tierras..., p. 247. Id., El reino de Murcia bajo Aragón... l/1, doc. nº 91. FERRER i MALLOL, Mª.T, Organització i defensa..., p. 15 y doc. $n^{\circ} 4$.

7 LALINDE ABADÍA, J., "Ensayo de tipología orgánica de la administración en la historia de España", estratto dagli Annali della Fondazione italiana per la storia amministrativa, 4, Milano, 1967, pp. 10-11 y 13-14. CABEZUELO PLIEGO, J.V., Poder público y administración territorial en el reino de Valencia, 1239-1349. El oficio de la Procuración, Tesis Doctoral inédita, Facultad de Filosofía y Letras, Universidad de Alicante, 1996, I, pp. 113-121.

8 LALINDE ABADÍA, J., "Virreyes y lugartenientes medievales en la Corona de Aragón", en Cuadernos de Historia de España, XXXI-XXXII, Buenos Aires, 1960, p. 99. Id., Derecho histórico Español, Barcelona, 1981, p. 322. PÉREZ BUSTAMENTE, «El Gobierno y la administración de los territorios de la Corona de Aragón bajo Jaime I el Conquistador y su comparación con el régimen de Castilla y Navarra", en $X$ Congreso de Historia de la Corona de Aragón, Zaragoza, 1980, pp. 515-516.

9 MONSALVO ANTÓN, J.Ma., "Poder político y aparatos de estado en la Castilla bajomedieval. Consideraciones sobre su problemática», en Studia Historica, IV, Salamanca, 1986, p. 121.

10 BARDAXI, I. de, Tractatus de officio Gubernationis seu Procurationis Generalis regni Aragonum, Zaragoza, 1592, secunda quaestio, $\mathrm{n}^{\circ} 1$, 3, 4-6 y quarta quaestio, $\mathrm{n}^{\circ} 6$.

11 CABEZUELO PLIEGO, J.V., Poder público y administración territorial..., I, p. 128.

12 «De esta forma resulta que "adelantado" viene a ser, dentro de la estructura político-administrativa del reino castellano, algo al modo del "locum tenens", del "gerens vices", que se va a usar en Cataluña». PÉREZ-PRENDES Y MUÑOZ DE ARRACÓ, J.M., “Fazer justicia. Notas sobre actuación gubernativa medieval», en Moneda y crédito. Revista de Economía, Homenaje a Don José Antonio Rubio Sacristán, II, 129, p. 77. Acerca de los adelantados murcianos anteriores a la conquista aragonesa, cf. TORRES FONTES, J., "Los adelantados mayores del reino de Murcia en el siglo XIII», en Colección de Documentos para la Historia del Reino de Murcia, V, Documentos de Fernando IV, Murcia, 1980, pp. XV-XXII. 
Jaime II en 1296, quienes a finales del siglo XIV todavía asimilaban Adelantamiento con lo que ellos denominaban "offici de Governador» ${ }^{13}$, o de procurador, para entendernos mejor.

Las amplias competencias con que contó hicieron del oficio el más importante tras la Curia regia ${ }^{14}$, pues sus titulares, pese a no contar con poderes absolutos, se convirtieron en las cabezas visibles de la administración civil, militar y judicial del territorio que administraban; poder que en algún momento vieron acrecentado tras la obtención de comisiones para proceder en determinados asuntos que no podían atender de ordinario $^{15}$.

Pese a que los estudios sobre la Procuración dentro de los territorios que compusieron la antigua Corona de Aragón no han sido hasta la fecha objetivo preferencial en la investigación histórica ${ }^{16}$, curiosamente la Procuración del reino de Murcia, pese a sus escasos ocho años de existencia, cuenta con uno de los análisis más completos, al tiempo que pioneros, sobre la temática. Empleando un discurso diacrónico su autora, M‥ T. Ferrer i Mallol, conocedora como nadie de la problemática histórica de estas tierras, reflexiona acerca del devenir de la magistratura en cuestión a través de la acción de gobierno de sus titulares. Es por ello que nos sentimos liberados de tratar de forma prolija en estas páginas ciertos aspectos sometidos a análisis por la citada historiadora. Nuestra intención será, más bien, la de acercarnos a la magistratura desde una perspectiva sincrónica y globalizadora que analice características generales y privativas al tiempo que competencias y limitaciones a sus actuaciones antes que trayectorias personales de quienes rigieron sus destinos.

\section{CARACTERES GENERALES DE LA PROCURACIÓN MURCIANA}

Cuando aparece la Procuración en el reino de Murcia se trataba de un oficio consolidado en la Corona de Aragón, aunque relativamente. Ya desde tiempos de Jaime 1 los dominios del rey fueron gobernados a través de procuradores. Del mismo modo actuaron sus sucesores, Pedro III y Alfonso III. Pero la magistratura, si la analizamos en su estructura general, o las magistraturas, si lo hacemos desde una óptica territorial, lejos de presentar un modelo unitario de funcionamiento se mostraban muy heterogéneas en lo estructural y en lo espacial, pues tan pronto encontramos momen-

13 CABEZUELO PLIEGO, J.V., Poder público y administración territorial..., I, pp. 115-116.

14 MATHEU i SANZ, LI., Tractatus de regimine urbis et regni Valentiae, Valencia, 1654, cap. II, sent. III, $\mathrm{n}^{\circ} 42$.

15 Por ejemplo, la concesión de salvoconductos, como la otorgada por Jaime Il a Bernat de Sarrià en la primavera de 1300 en favor de los vecinos de Lorca y Mula, poblaciones en esos momentos rebeldes, que quisiesen pasar al servicio del rey de Aragón. ACA, C, reg. 197, f. 99r. (1300, abril, 1).

16 Es curioso, a la vez que sintomático, que transcurridas más de tres décadas el trabajo de J. Lalinde sobre la Gobernación siga siendo obra de referencia obligada a la hora de plantearse cualquier estudio sobre el tema en cualquier territorio de la Corona de Aragón, no sólo por su vigencia científica, que la posee, sino también porque es la única obra existente que aborda y analiza el problema. LALINDE ABADÍA, J., La Gobernación General en la Corona de Aragón, Zaragoza, 1963. 
tos en los que el sistema procuratorial tiende a la unidad de gobierno, como sucede en Aragón, Cataluña y Valencia a principios de las décadas de 1270 y 1290 con hijo y nieto respectivamente de Jaime I, ambos infantes de nombre Pedro, como otros, en ese mismo espacio temporal, en que los territorios pierden tal conexión y quedan administrados por personajes vinculados tan sólo al rey, e incluso momentos en que el marco geopolítico de aplicación del modelo procuratorial, reinos y condados, se quebranta para duplicarse, aunque por breve tiempo, como sucede en Valencia donde en 1286 el reino queda dividido por la línea del Júcar en dos distritos procuratoriales, citra et ultra Xucharum ${ }^{17}$.

Si esto es en cuanto a la institución, otro tanto ocurre en lo referente a sus titulares. En este punto es conveniente advertir que prácticamente hasta finales del siglo XIII la magistratura conoció momentos en que tuvo carácter de Lugartenencia en el pleno sentido jurídico del término, con lo que quienes la desempeñaban no eran sino alter ego reales en el territorio a regentar ${ }^{18}$. Mientras que en otros tal intitulación, originaria por otro lado del oficio, evoluciona en concepto hasta el punto de solaparse y convirtiese en sinónimo perfecto de Procuración, de ahí que durante todo el período en cuestión hablemos de locum tenens y procurator refiriéndonos incluso a un mismo oficial, como ocurre en Valencia con Pere Ferrando, nominado en 1267 «procuratorem sive tenentem locum nostrum in eodem regnos ${ }^{19}$.

En consecuencia, cuando a mediados de la última década del Doscientos acontece la conquista e incorporación murciana a la Corona de Aragón y la introducción en este nuevo territorio de la Procuración como fórmula política, la magistratura, como concepto, se hallaba en una fase todavía formativa. Va a ser precisamente Jaime II quien en estos momentos establezca las bases sobre las que habría de asentar la institución. Y así, de un momento, designado por Lalinde como «sistema procuratorial inorgánico» en cuanto carente de normativa establecida, se alcanzó entre 1299 y 1302 a lo que también el citado historiador denominó como «régimen de la Procuración General» y que nacía para dar cobertura legal a la participación del primogénito en las tareas de gobierno. El heredero al trono, convertido en procurador general de la Corona, pasaba a administrar los distintos territorios a través de representantes vinculados a su persona, denominados gerentes vices procuratoris o portants veus de procurador, con las mismas funciones que los antiguos procuradores designados por el rey. Sin embargo, esta nueva forma gubernativa no se aplicó de modo instantáneo en todos los territorios de la Corona, pues ni Murcia ni Valencia quedaron incluidas dentro de ese régimen. Frente a lo que acontecía a principios del Trescientos en Aragón y Cataluña, donde Lope de Gurrea y Bernat de Fonollar aparecen como vicegerentes del primogénito, en Valencia y en Murcia los titulares de la Procuración, Bertran de Canelles y Pere de Montagut, nominados en abril de 1303, lo eran por y en nombre

17 Ibidem, pp. 28-38.

18 LALINDE ABADÍA, J., «Virreyes y Lugartenientes medievales...», pp. 99-105. Id., La Gobernación General..., pp. 35-37. Para el reino de Valencia cf. CABEZUELO PLIEGO, J.V., Poder público y administración territorial..., I, pp. 203, 254 y II, pp. 753-757.

19 CABEZUELO PLIEGO, J.V., Poder público y administración territorial..., I, p. 158. 
del rey ${ }^{20}$. De ahí que el reino de Murcia nunca conociese del nuevo sistema de la Procuración General, ni tampoco el de Valencia hasta 1309, manteniéndose ambos durante todo ese tiempo en la misma dinámica de vinculación en exclusividad con el rey. A la pregunta de por qué no se introdujo el nuevo sistema en todos los territorios al unísono, quedando fuera Murcia y Valencia, en la actualidad sólo se puede responder con hipótesis. Una de ellas, con posibles visos de veracidad, quizá fuese la inestabilidad bélica de ambos reinos, sobre todo el murciano, frente a toda clase de peligros exteriores, "Tanto como la lógica de estrenar un sistema administrativo en el marco de unos territorios muy asentados en sus raíces, política e incluso geográficamente, como era el caso de Aragón y Cataluña, frente a espacios inestables en los que, quizá otra vez, se requiriese la efectividad de los modelos ${ }^{21}$.

\section{Número y condición de los procuradores murcianos}

Cinco fueron los oficiales que ocuparon la Procuración del reino de Murcia entre los veranos de 1296 y de 1304: Jaime Pérez ${ }^{22}$, Jaime de Jérica ${ }^{23}$, Bernat de Sarriàa ${ }^{24}$, Bernat de Cruilles ${ }^{25}$ y Pere de Montagut ${ }^{26}$. Número elevado si tenemos en cuenta la brevedad del dominio aragonés en estas tierras, pero que se entiende al tratarse de cargos de responsabilidad sujetos al beneplácito real, con lo que el rey removía discreccionalmente a sus titulares, bien porque el momento requiriese de un hombre con características distintas a las ofrecidas por quien en esos instantes ocupaba la magistratura, o bien para ofrecerles otros destinos ${ }^{27}$. A excepción de Jaime de Jérica,

$20 \ll . .$. comitimus sive comendamus vobis officium Procuracionis regni nostri... Ita quod vos sitis procurator noster in ipso regno et exerceatis bene et fideliter ad honorem et fidelitatem nostram ipsum officium", es lo que se lee en el nombramiento de ambos. Cfr. ACA, C, reg. 231, f. 53r.-v. (1303, abril, 29). FERRER i MALLOL, Ma.T., Organització i defensa..., doc. no 28 para el nombramiento del procurador murciano, y ACA, C, reg. 231, f. 35r. (1303, abril, 30), para el valenciano.

21 CABEZUELO PLIEGO, J.V., Poder público y administración territorial..., I, pp. 347-348.

22 ACA, C, reg. 340, f. 87r. (1296, mayo, 23). ESTAL GUTIÉRREZ, J.M. del, El reino de Murcia.. $1 / 1$, doc. no 91 .

23 ACA, C, reg. 196, f. 183r. (1298, abril, 9). FERRER i MALLOL, Ma.T., Organització i defensa..., doc. $n^{\circ} 14$.

24 Apéndice documental, doc. no 4. FERRER i MALLOL, M‥T., Organització i defensa..., doc. nº 16

25 ACA, C, reg. 231, f. 51r. (1303, abril, 3). LALINDE ABADÍA, J., La Gobernación General..., doc. $\mathrm{n}^{\mathrm{o}} \mathrm{XI}$.

26 ACA, C, reg. 231 , f. 53r.-v. (1303, abril, 29). FERRER i MALLOL, M².T., Organització i defensa..., doc. $n^{\circ} 28$.

27 Esto fue lo sucedido con Bernat de Sarrià, a quien Jaime II destituye tras haber recibido innumerables quejas de sus gobernados, y así se lo comunica en carta privada. ACA, C, reg. 231, ff. 51v.52 r. (1303, abril, 3). Si bien, la razón oficial que ofrece el rey a su sustituto en la Procuración, Bernat de Cruïlles, es que le ha removido del cargo porque le necesitaba a su lado. ACA, C, reg. 231, f. 51r. (1303, abril, 3). Cf. LALINDE ABADIA, J., La Gobernación General..., docs. no XI y XII. ESTAL GUTIÉRREZ, J.M. del, El reino de Murcia bajo Aragón... l/1, docs. $n^{\circ} 229$ y 230. FERRER i MALLOL, M. ${ }^{a}$ T, Organització $i$ defensa..., pp. 42-43 y doc. no 25. CABEZUELO PLIEGO, J.V., Poder público y administración territorial..., II, pp. 662-663. 
el resto fueron procuradores privativos del territorio murciano, compartiendo el de Jérica su responsabilidad con el reino de Valencia. Asimismo, todos ellos contaron con idénticas prerrogativas procuratoriales, salvando la excepción de Bernat de Cruilles, sustituto de Bernat de Sarrià, quien alcanzaba el oficio en la primavera de 1303 investido de caracteres de lugarteniente ${ }^{28}$.

a. Obligación del procurador era la de hacer residencia personal en el territorio que hubiera de administrar. Muy pocos datos son los que tenemos a este respecto acerca de los procuradores murcianos. Imaginamos que Murcia sería la ciudad elegida a tal efecto, por razón de su condición capitalina, como lo era Valencia, aun desconociendo el emplazamiento exacto de la casa-residencia y del inmueble habilitado como Curia o tribunal procuratorial —de no ser el mismo-; ello pese a la obligatoriedad de estos oficiales de viajar por todo el reino. Únicamente conocemos una noticia tardía, de 1303, por la que Jaime II ordenaba al entonces procurador Pere de Montagut recibir en su nombre y custodiar el castillo de Molina. Además de proveer lo necesario para su defensa, el rey quería que Montagut llevase su residencia hasta él para custodiarlo mejor ${ }^{29}$. Otros procuradores, como Jaime de Jérica o Bernat de Sarrià, también obtuvieron alcaidías de castillos - Orihuela y Alicante respectivamente- durante su gestión al frente de la Procuración, que en algún caso abandonaron finalizada ésta ${ }^{30}$, desconociendo si residieron o no en ellos ${ }^{31}$. Encontramos paralelos a este tipo de residencia castrense en la vecina Valencia, en donde Pere de Queralt obtuvo las casas del castillo de Corbera para morar con su familia mientras ocupase el cargo; así como

28 Podría entenderse que se trata de dos oficios diferentes, desde la teoría del Derecho, dado que Jaime II en ningún momento entrega a Bernat de Cruilles la Procuración del reino de Murcia sino "nostre lloc en aquell regne». Si bien, equipara perfectamente ambas situaciones cuando indica que el nombramiento alcanzado por Cruilles deviene por la imposibilidad de que pueda quedar vacante la Procuración murciana. ACA, C, reg. 231, f. 51v. (1303, abril, 3). ESTAL GUTIÉRREZ, J.M. del, El reino de Murcia bajo Aragón... 1/1, doc. $\mathrm{n}^{\circ} 231$. Es claro, entonces, que aun con distinta intitulación y posiblemente con alguna competencia más, Bernat de Cruilles habría de realizar el mismo trabajo que sus antecesores los procuradores, pues su misión fundamental era administrar justicia y mantener el territorio en paz.

Es importante referir que la presencia de Bernat de Cruilles en suelo murciano no derivó de su nombramiento como lugarteniente real, sino que fue anterior a éste. En febrero de ese mismo año Jaime II envía a este noble a Murcia para coordinar la defensa del reino ante un supuesto ataque castellano, comunicando su presencia al procurador y a las autoridades municipales murcianas para que le reconociesen tal función. La entrega de esa misión a Cruilles, que podía desempeñar perfectamente el procurador por ser parte de su cometido, hacía que los días de Bernat de Sarrià al frente de la institución estuvisen contados. ACA, C, reg. 126, ff. 285v.-286r. (1303, febrero, 10).

29 Apéndice documental, doc. $n^{0}$ 7. FERRER i MALLOL, Mํ.T., Organització i defensa.., p. 52.

30 Como sucedió al señor de Jérica, que hubo de restituir la plaza a Bernat de Cruilles y ésta hacer lo propio a Guillem de Vilaragut, que era a quien el rey había designado como alcaide. ACA, C, reg. 197, f. 99v. (1300, abril, 1).

31 Bernat de Sarrià parece que no residió en Alicante, donde tenía un sustituto. FERRER i MALLOL, $M^{a}$.T., «La tinença a costum d'Espanya en els castells de la frontera meridional valenciana (segle XIII)", en Miscel.lània de Textos Medievals, 4, Barcelona, 1988, p. 17. 
también en las tierras dellà Sexona, donde existía una estrecha vinculación entre Procuración y alcaidía de la fortaleza oriolana ${ }^{32}$.

b. Era igualmente obligación de los oficiales adscritos a la Procuración murciana el juramento de la observancia de los fueros y privilegios del territorio sujeto a su administración. Así quedó establecido por Jaime II en Murcia cuando al confirmar distintos privilegios y franquezas de la capital del reino a solicitud de sus habitantes, en agosto de 1296, dispuso que cada procurador al principio de su administración y gobierno jurase ante el Consell de la ciudad de Murcia, en el altar de la iglesia de Santa María "sedis Murcie» el cumplimiento y la defensa de dicha normativa ${ }^{33}$. Era costumbre que los titulares de la Procuración hiciesen jura de reconocimiento de la legislación vigente así como de privilegios, franquezas, usos y costumbres privativos de cada uno de los territorios ${ }^{34}$, prestación que se consideraba garantía sobre su buena gestión ${ }^{35}$. Su no ejecución «implicaba la ilegalidad de las acciones emprendidas en nombre del oficio ${ }^{36}$ al tiempo que su remoción de él. La conexión en este punto con el reino de Valencia es total, pues aquí el procurador también había de realizar el acto de jura ante Consell de la capital del reino si hablamos de la Procuración citra, y ante el de Orihuela si nos referimos a las tierras ultra Sexonam ${ }^{37}$. Del otro tipo de garantía, la prestación de fermançes e manposters a fin de rendir cuentas ante sus gobernados una vez finalizado el ejercicio del cargo, no tenemos noticia alguna, aunque no dudamos de su existencia ${ }^{38}$.

c. Los oficiales de la Procuración vieron satisfecha la prestación de sus servicios con la recepción de un salario anual sobre diversos conceptos, pudiendo además obtener cantidades extraordinarias a añadir al monto salarial que no eran más que incrementos encubiertos del mismo, tal y como ocurría en la Procuración valenciana ${ }^{39}$. Solamente conocemos una noticia, aunque ya tardía, donde se refleja el salario anual del regente de la magistratura murciana, que puede servir de paralelo a la hora de extrapolarlo al resto de gobiernos procuratoriales, aunque con las lógicas prevenciones, como ocurre en la vecina Valencia donde el emolumento procuratorial no alcanza una homogeneidad numérica ni de procedencia hasta la década de 1320 , cuando ya el reino se ha incorporado plenamente al régimen de la Procuración General. Se trata

32 CABEZUELO PLIEGO, J.V., Poder público y administración territorial..., II, p. 675. FERRER i MALLOL, Ma. T., «La tinença a costum d'Espanya...", pp. 16-18 y 47-48.

33 ACA, C, reg. 194, ff. 226r.-227r. (1296, agosto, 3).

34 Para Valencia cf. CABEZUELO PLIEGO, J.V., Poder público y administración territorial..., II, pp. 664-671.

35 LALINDE ABADÍA, J., Los medios personales de gestión del poder público en la Historia Española, Madrid, 1970, pp. 111-112. PÉREZ BUSTAMANTE, R., «El juramento de los oficiales del reino de Castilla, 1252-1474", en Moneda y Crédito. Revista de Economía, Homenaje a Don José Antonio Rubio Sacristán, Madrid, 1974, p. 211.

36 CABEZUELO PLIEGO, J.V., Poder público y administración territorial..., II, p. 667.

37 Ibidem, pp. 668-669.

38 Acerca del control sobre los oficiales de la Procuración valenciana cfr. ibídem, II, pp. 942-952.

39 Ibídem, II, pp. 679-713. 
de Pere de Montagut, a quien se le concede un salario anual de siete mil sueldos, más una cantidad extraordinaria de mil sueldos a añadir a esa suma mientras desempeñase el oficio ${ }^{40}$.

\section{Defender y juzgar: competencias del oficio de la Procuración}

La Procuración del reino de Murcia, al igual que sus paralelos en el resto de territorios de la antigua Corona de Aragón, fue creada para que desde ella se velase por la integridad territorial del espacio administrado, la seguridad interior al tiempo que «la defensa del buen estado de la cosa pública y de los intereses del rey a través de una intervención pacificadora al tiempo que punitiva" que "permitió a sus titulares actuar de una u otra forma sobre prácticamente todos los habitantes del reino, naturales 0 foráneos, moros, cristianos o judíos, hombres o mujeres, clérigos o laicos, realengos o señoriales $"{ }^{41}$. Con el fin de poner en práctica tales tareas, los reyes dotaron al oficio de amplios poderes, convirtiéndole en el vértice de la administración pública regnícola. A tal amplitud en el terreno de las competencias se unía para magnificarla la arbitrariedad con la que los oficiales de la Procuración ejercían su oficio. Será precisamente en estos instantes, en los albores del reinado de Jaime II, cuando desde la Curia regia se procediese, muy tibiamente, a marcar los perfiles jurisdiccionales de la magistratura. La breve andadura de la Procuración murciana conoció de esta política de mayor control real, si bien las características sociopolíticas del nuevo reino, en pie de guerra y con una numerosa población castellana hacia la que la nueva autoridad mostraba sus reservas, y no gratuitamente ${ }^{42}$, conferían a la Procuración una potencialidad jurisdiccional quizá mayor que en otros reinos, o si no eso una mayor permisibilidad por parte del poder real frente a acciones de dudosa justificación teórica de parte del procurador.

Del análisis de los nombramientos procuratoriales murcianos entre 1296 y 1304 sólo derivan rasgos generales de su quehacer oficial, mientras que ya en un terreno

40 ACA, C, reg. 231, f. 53v. (1303, abril, 29). A este mismo oficial, tras la partición del reino de Murcia en Torrellas, se le redujo el sueldo a la mitad, dado que era la mitad del territorio la que había de atender. ACA, C, reg. 231, f. 56r.-v. (1304, diciembre, 7). FERRER i MALLOL, Ma.T., Organització $i$ defensa..., doc. $\mathrm{n}^{\circ} 45$.

41 CABEZUELO PLIEGO, J.V., «Reflexiones en torno al oficio de la Procuración como instrumento de la acción regia para el gobierno político del reino de Valencia. 1239-1348», en Anales de la Universidad de Alicante. Historia Medieval, 10, Alicante, 1994-1995, p. 23.

42 La existencia de enemigos de Jaime II dentro del territorio murciano, que salian ocultamente del reino hacia Castilla para tratar contra los intereses del rey de Aragón, así como la entrada, también clandestina, de castellanos a Murcia con el mismo propósito, es un hecho desde la conquista, quedando los oficiales de la Procuración con la responsabilidad de descubrirlos y castigarlos. ACA, $C$, reg. 112 , f. 28v. (1298, junio, 19). Los peligros que suponía a la estabilidad política del nuevo reino la existencia de una población hostil llevaron a Jaime II a tomar una drástica solución: la expulsión de todos los castellanos del territorio murciano, aunque con las lógicas excepciones; medida aplaudida por el entonces procurador Bernat de Sarrià. ACA, C, reg. 118, f. 15r.-v. (1301, febrero, 21). FERRER i MALLOL, Ma.T., Organització i defensa..., p. 34 y doc. no 19. 
más particular a través del análisis de sus actuaciones concretas podemos construir una casuística de intervenciones privativas ex oficio. Desde el primero de los parámetros la misión principal de la institución sería militar y judicial. Así se desprende de la primera credencial de nombramiento que conocemos, la de Jaime de Jérica de abril de $1298^{43}$, donde se apunta la facultad para conocer de las segundas apelaciones, tal y como correspondía al oficio por haberlas detentado sus predecesores en el cargo, así como también la obligatoriedad de observar el derecho y hacer justicia. Por recibir nombramiento sobre los reinos de Valencia y Murcia, entendemos que al hablar de predecesores se entiende valencianos y murcianos. De Jaime Pérez, primer procurador del reino de Murcia, no tenemos la carta de promoción al cargo, pero sí de su antecesor valenciano, Jaspert de Castellnou, quien recibe la Procura cuatro meses después que Jaime Pérez, y a quien igualmente se le otorgan las segundas apelacio$n{ }^{44}$, por lo que pensamos que Jaime Pérez también contaría con ellas. A toda esa carga judicial se añade también la castrense, dado que en la notificación que Jaime II dirigió a Murcia acerca del nombramiento del señor de Jérica como nuevo procurador del territorio subrayaba su carácter de «procuratorem et gubernatorem ac defensorem» y su función militar — «ut regnum nostrum Murcie ab hostibus potenter et viriliter deffendatur et possit in statu tranquillo et pacifico remanere" - ${ }^{45}$. El nombramiento de Bernat de Sarrià de abril de 1300 va en la misma dirección ${ }^{46}$. Sin embargo, no los de sus sucesores, pues ni en el de Pere de Montagut ${ }^{47}$, ni en el de Bernat de Cruïlles ${ }^{48}$ hay mención explícita al conocimiento de las segundas apelaciones ${ }^{49}$, aunque recordemos que este último tenía carácter de lugarteniente y ni siquiera llegó a ejercer como tal.

Defender y juzgar eran, como queda dicho, los principales cometidos de los regen-

43 ACA, C, reg. 196, f. 183r. (1298, abril, 8). FERRER i MALLOL, M‥T., Organització i defensa..., doc. $\mathrm{n}^{\circ}$ 14. CABEZUELO PLIEGO, J.V., Poder público y administración territorial..., I, p. 261 y II, p. 764 y doc. $n^{\circ} 47$

44 ACA, C, reg. 194, f. 284r. (1296, octubre, 8). CABEZUELO PLIEGO, J.V., Poder público y administración territorial..., I, p. 255 y II, p. 764 y doc. no 45 .

45 ACA, C, reg. 111, f. 295r. (1298, mayo, 16). TORRES FONTES, J., Colección de Documentos para la Historia del reino de Murcia, II, Documentos del siglo XIII, Murcia, 1969, doc. $\mathrm{n}^{\circ} \mathrm{CXXXI}$. ESTAL GUTIÉRREZ, J.M. del, El reino de Murcia bajo Aragón... l/1, doc. $n^{\circ} 163$.

46 Apéndice documental, doc. ํㅜ 4. FERRER i MALLOL, Mํ.T., Organització $i$ defensa..., p. 23 y doc. $\mathrm{n}^{\mathrm{0}} 16$.

$47 \mathrm{Ni}$ en su primer nombramiento como procurador del reino de Murcia -ACA, C, reg. 231, f. 53r.-v. (1303, abril, 29) - , ni tampoco en el segundo ya como procurador de las tierras allende Jijona -ACA, C, reg. 231, f. 56r.-v. (1304, diciembre, 17)-.

48 ACA, C, reg. 231, f. 51r. (1303, abril, 3). LALINDE ABADÍA, J., La Gobernación General..., pp.

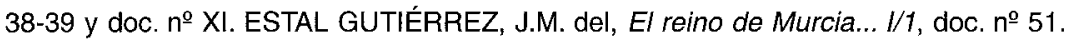

49 Es curioso que el sucesor de Montagut, Gombau d'Entença, y el de éste, Juan Jiménez de Urrea, recibiesen de nuevo las segundas apelaciones, pudiendo ejercer sus atribuciones a ambos lados de la línea de Almizra. Cfr. ACA, C, reg. 231, f. 38v. (1305, marzo, 11) y ACA, C, reg. 232, f. $317 \mathrm{v}$. (1309, marzo, 30). FERRER i MALLOL, Mํ.T., Organització i defensa..., doc. $n^{\circ} 46$. CABEZUELO PLIEGO, J.V., Poder público y administración territorial..., I, p. 307 y II, p. 767. 
tes de la Procuración ${ }^{50}$. Si bien, la amplitud de estos verbos no creemos que permita hacerse una idea, ni siquiera remota, acerca de cual sería el área de influencia jurisdiccional de la magistratura en el reino de Murcia. La literatura jurídica tampoco podrá dar luz a esta cuestión, pues a diferencia de lo ocurrido en otros territorios de la Corona de Aragón donde diversos foralistas se interesaron por el oficio, alcanzando a escribir sugestivas páginas sobre su función que en su conjugación de aciertos, errores y omisiones han servido de base a ulteriores investigaciones ${ }^{51}$, lo efímero de la institución en estas tierras hizo que nada de esto ocurriese. Habrá de ser, pues, el Archivo el único soporte semántico de tales voces.

Inmediato a la conquista Jaime II dispuso la compilación de una normativa legal privativa para los murcianos, conocida como Fuero de Murcia, vigente a partir de finales de octubre de $1296^{52}$. Este código, dividido en cuatro libros, se convertía en la columna vertebral de la nueva sociedad murciana al tornarse en rector de las relaciones sociales de sus miembros. En él, lógicamente, aparecian recogidas noticias rela-

50 En 1302 Jaime II comunicaba a diversos municipios del reino de Murcia que todos los asuntos concernientes a la defensa de ese reino los había confiado entre otros, al procurador. ACA, C, reg. 123 , f. 4v. (1302, febrero, 14). Mientras que dos años después, y tras conocer una entrada aragonesa en tierras granadinas protagonizada por Pere de Montagut junto al maestre de la Orden del Temple y al-Abbas ibn Rahu, un marroquí que por entonces se hallaba a su servicio, el rey dirigía al procurador murciano las siguientes palabras: «... circa tuicionem et diligentem custodiam dicti regni nostri Murcie sitis sollicitis... prout de vobis confidimus et speramus". ACA, C, reg. 235, f. 78r. (1304, mayo, 31). Cf. para el reino de Valencia, CABEZUELO PLIEGO, J.V., Poder público y administración territorial..., II, pp. 771-773.

51 Para Valencia, cfr. el Stil de la Governació en diversas ediciones, algunas de ellas comentadas: Furs e Ordinations fetes per los gloriosos reis d'Aragó als regnícoles del Regne de València, Valencia, Imprenta de Lamberto Palmart, 1482, ed. facsímil, Universidad de Valencia, 1977, pp. 519521. FERRÁN SALVADOR, V., Amaldo Juan y su Stil de la Governatio. Transcripción y notas biográficas, Valencia, 1936. LALINDE ABADÍA, J. V., La Gobernación General.., pp. 395-397. CABEZUELO PLIEGO, J.V., Poder público y administración territorial..., II, pp. 718-735. También resultan interesantes la apreciciones realizadas por BELLUGA, P. Speculum Principum, Venecia, 1580. TARAZONA, P. H., Institucions dels furs, y privilegis del regne de Valencia. Eo summari e reportori de aquells, Valencia, 1580. Copia facsímil, Valencia, 1976; y MATHEU SANZ, LI., Tractatus de regimine urbis et regni Valentiae, Valencia, 1654.

Para Aragón resulta de obligada consulta el trabajo de BARDAXI, I. de, Tractatus de officio Gubernationis...

Para Cataluña y las tierras ultrapirenáicas, son de especial interés BOSCH, A., Summari, Index o Epitome dels admirables e nobilissims titols de honor de Cathalunya, Roselló e Cerdanya, Perpignan, 1628. FERRER, M., Recoliectio per me... Doctorem Regii Consilii (ad memoriam tantum et pro faciliore materiae instigationae) facta de casibus in quibus Gubernator Cathaloniae consueverunt et possunt exercere jurisdictionem, Domino Rege et eius Locumtenente generalis absentibus a Cathaloniae, Barcelona, 1647. ALART, B., Privilèges e titres relatifs au franchises, institutions et proprietés communales de Roussillon et de Cerdagne, depuis le XI siècle jusqu'a l'an 1660, Perpignan, 1878.

52 ESTAL GUTIÉRREZ, J.M. del, "El Fuero y las "Constitutiones regni Murcie" de Jaime II de Aragón (1296-1301)", en Anales de la Universidad de Alicante. Historia Medieval, 8, Alicante, 19901991, pp. 19-29. 
tivas a la naturaleza y funcionamiento de las distintas oficialías regnícolas, siendo obviamente la Procuración una de las que sería tratada de forma más prolija en el texto legal. Lo cierto es que tal compilación no ha llegado a nosotros, aunque sí una addenda de 1301 que sobre la base de los furs de València corregía y complementaba el contenido del fuero de 1296. Estas «declaraciones, addiciones, correcciones, substracciones et mutilaciones", como las llamó Jaime II, contemplaron varios items donde se hacía referencia a algunos aspectos de tipo jurídico y procesal en los que el procurador se muestra bien como la autoridad regnícola con competencias exclusivas, o bien con cierto nivel de participación ${ }^{53}$. El documento recoge como competencias privativas del procurador las consideradas como regalías: crimen de lesa majestad, falsa moneda, sellos o cartas reales así como actuación contra oficiales reales. Del mismo modo le facultaba para estar presente en la resolución de pleitos civiles y criminales que correspondiesen a los justicias ciudadanos, e incluso sentenciarlos siempre que se encontrase presente en la villa o lugar, aunque en este caso sus sentencias habrian de ser anotadas en los libros de la Curia del justicia. Quedaban a su arbitrio las causas de viudas, huérfanos y miserables, así como los procesos contra oficiales reales, pasados y presentes. Quedarían asimismo dentro de su jurisdicción el conocimiento y punición de todas las causas de extranjeros, así como las demandas y requisiciones judiciales existentes entre estas personas o de regnícolas hacia ellas; no en el supuesto de que fuesen ellas las que solicitasen justicias contra vecinos, pues en este caso sería el justicia local quien habría de intervenir. Finalmente, el texto legal subraya la cualidad de juez de apelaciones que tiene el procurador cuando se indica que las segundas apelaciones dirigidas al rey, no encontrándose éste en el reino de Murcia, habrían de ser conocidas y sentenciadas por el procurador. En el caso de primera apelación a sentencias del procurador aquélla habría de ser conocida por otro juez para evitar que los habitantes del territorio murciano hubiesen de salir a pleitear a otras partes.

No obstante las atribuciones puestas de manifiesto en este documento, el análisis de las actuaciones concretas permite ampliar de forma considerable su número, al tiempo que matizar ciertas competencias contenidas en el Fuero que serán modificadas a posteriori. A través de ellas podemos elaborar una relación general de temáticas de adscripción privativa o tangencial a la Procuración murciana, muy cercana a la propuesta por nosotros en un trabajo sobre esta magistratura en el reino de Valen$\mathrm{cia}^{54}$, que permiten seguir definiendo al procurador, en palabras de J. Lalinde, como "una mezcla de juez, ejecutor de órdenes regias y jefe de milicias» 55 . De tal forma que su tremenda actividad militar en defensa del territorio encomendado, frente a enemigos exteriores e interiores, descansaba en amplias atribuciones judiciales que le con-

53 ACA, C, reg. 198, ff. 262r.-265r. (1301, febrero, 18). ESTAL GUTIÉRREZ, J.M. del, «El Fuero y las "Constitutiones...", pp. 29-36 y doc. no 8 .

54 CABEZUELO PLIEGO, J.V., Poder público y administración territorial..., II, pp. 776-927.

55 LALINDE ABADÍA, J., La Gobernación General..., p. 76. 
vertían en el magistrado supremo del reino; facultades ambas que difícilmente aparecen disociadas. He aquí la potencia del oficio.

Como jefe militar del reino de Murcia poseía potestad para:

- dirigir la hueste regnícola y disponer aquello que considerase oportuno en defensa del espacio murciano ${ }^{56}$,

- convocar las tropas realengas y de feudatarios ${ }^{57}$.

- embargar bienes de los enemigos y distribuirlos entre los afectos a la causa del rey de Aragón, bien por orden de éste bien de motu proprio ${ }^{58}$, atendiendo a distintos

56 El procurador contaba con una hueste propia a su servicio, no demasiado numerosa, aunque como dice $M^{a}$.T. Ferrer «important perque el formaven homes a cavall de plena dedicació a la professió militar». Si atendemos únicamente a la cifra señalada en la credencial de nombramiento de Pere de Montagut, de abril de 1303, así como a la expuesta en mayo de ese año donde se refería una relación de servidores reales en Murcia, el contingente procuratorial era de diez caballeros, cuatro armados y seis alforrados, con un salario de mil sueldos anuales los primeros y de quinientos los segundos. ACA, C, reg. 231, f. 53r.-v. (1303, abril, 29). ACA, C, reg. 231, ff. 52r.-53r. (1303, mayo, 1). ACA, C, reg. 231 , f. 54r. (1303, mayo, 18). FERRER i MALLOL, M‥T., Organització $i$ defensa..., p. 193 y doc. ํㅡ 28 y 32. Si bien, en fechas anteriores sabemos que tuvo a su servicio a cien hombres, cincuenta caballeros y cincuenta peones, con los que debía proceder a la defensa del territorio murciano y de los intereses reales en él. ACA, C, reg. 197, ff. 98v.-99r. (1300, abril, 1). Cf. FERRER i MALLOL, Ma.T., Organització $i$ defensa..., pp. 15-55, páginas en las que se derraman constantes alusiones a este asunto.

Era igualmente misión del procurador mantener puntos de vigilancia diurnos y nocturnos, con cargo a los municipios. ACA, C, reg. 120, f. 233r.-v. (1302, enero, 23). Así como un servicio de espionaje interior y exterior. CABEZUELO PLIEGO, J.V., «Reflexiones en torno al oficio...», p. 24.

Por otra parte, existía una conexión militar muy ímportante entre las Procuraciones murciana y valenciana, y no sólo cuando ambas instituciones fueron regidas por una misma persona, el señor de Jérica. A solicitud de la autoridad militar del reino de Murcia las milicias valencianas dirigidas por su procurador habian de colaborar en la defensa de ese espacio. Cf. ACA, C, reg. 108, f. 185r.-v. (1297, julio, 29). Apéndice documental, doc. $n^{\circ}$ 3. ACA, C, reg. 197, f. 99r. (1300, abril, 1). FERRER i MALLOL, Má.T., Organització $i$ defensa..., p. 17. CABEZUELO PLIEGO, J.V., Poder público y administración territorial..., I, pp. 258-259, 269-270, 278, 280. Tal colaboracionismo procuratorial se mantiene después con respecto a la Procuración de Orihuela. CABEZUELO PLIEGO, J.V., «Precedentes políticos de la Procuración de Orihuela», en Quaderns de Mitjorn, 2, en prensa.

57 Las tropas locales sólo podía convocarlas una vez al año, si bien los procuradores solían saltarse constantemente esta norma, con las consiguientes quejas por parte de los consistorios al rey. $\mathrm{Cf}$. ACA, C, reg. 116, ff. 232r.-233v. ACA, C, reg. 120, f. 234r.-v. (1302, enero, 21). ACA, C, reg. 126, f. 284v. (1303, febrero, 9).

58 En 1301 el procurador quedó con poder para tomar y redistribuir entre fieles a la Corona de Aragón todas aquellas heredades y bienes inmuebles habidos en el reino de Murcia propiedad de peones a quienes les fueron confiscados por ausencia o por rebeldía. La razón de su entrega inmediata era para evitar la despoblación del territorio, pues los agraciados habían de establecer residencia continua en ellos. ACA, C, reg. 198, f. 260r. (1301, febrero, 21). Al año siguiente se dictó una orden para devolver a los sarracenos del lugar de Carchena los bienes que les habian sido tomados por el procurador cuando asaltó y conquistó el lugar por su rebeldía a la soberanía aragonesa. ACA, C, reg. 121 , f. 10 . 
criterios: indemnización por pérdidas ocasionadas por la guerra ${ }^{59}$ o compensación por los servicios prestados ${ }^{60}$,

- recibir el juramento de fidelidad y homenaje feudal de todos los que poseían castillos en nombre del rey. También recibir las plazas para entregarlas a otros alcaides, así como nominar él mismo alcaides ${ }^{61}$,

- supervisar las fortalezas del reino y, caso de resultar necesario, proceder a su abasto y restauración ${ }^{62}, y$

- defender la normativa foral del reino ${ }^{63}$.

Sin perder ese carácter miliciano que infundía respeto y temor entre sus gobernados, el regente de la Procuración contó con importantes atribuciones judiciales que le convertían en juez de apelación y recurso, pudiendo proceder de oficio mediante inquisicions en aquellas causas que eran competencia directa suya ${ }^{64}$. En este terreno, incoaba y resolvía:

- disputas intercomunales por el establecimiento de términos ${ }^{65}$,

— pleitos en los que una de las partes gozaba de la condición de miserabilidad ${ }^{66}$,

- banderías ${ }^{67}$.

59 Sirvan como ejemplo, de los cientos localizados, lo sucedido a Ramon Ferrer, vecino de Alhama, quien había perdido animales por valor de dos mil maravedís castellanos estando en servicio del rey de Aragón. ACA, C, reg. 194, f. 259v. (1296, septiembre, 22). O al caballero Dalmau de Sant Martí, que vio confiscados, como el resto de catalanes residentes en tierra castellana, los bienes que poseía en la ciudad de Sevilla. ACA, C, reg. 194, f. 267v. (1296, octubre, 1).

60 En este punto se valoraba tanto la acción como la calidad social del agraciado. A Sancho Pérez, almogaten que sirvió a Jaime II durante toda la campaña murciana, le fue entregada una heredad cuyas rentas le sirviesen de sustento. ACA, C, reg. 194, f. 259v. (1296, septiembre, 22). Mientras que, por ejemplo, a Pere Jordá habría de entregársele una heredad cuyas rentas no fuesen superiores a seiscientos sueldos anuales. ACA, C, reg. 194, f. 277r. (1296, octubre, 10). La elección del lugar y de la propiedad quedaba al arbitrio del procurador.

61 Sirvan como ejemplos: ACA, C, reg, 197, f. 99v. (1300, abril, 1). ACA, C, reg. 199, f. 86r. (1302, mayo, 31). ACA, C, reg, 201, f. 40v. (1303, febrero, 16). Etc.

62 ACA, C, reg. 198, f. 260r.-v. (1301, febrero, 21). ACA, C, reg. 199, f. 85r. (1302, mayo, 20).

63 Apéndice documental, doc. $\mathrm{n}^{\circ} 2$.

64 CABEZUELO PLIEGO, J.V., Poder público y administración territorial..., II, p. 771.

65 En agosto de 1296 Jaime Pérez, primer procurador murciano, quedó encargado de verificar los términos de la ciudad de Murcia impuestos en su día por Alfonso el Sabio. ACA, C, reg. 194, $f$. 228v. (1296, agosto, 3). FERRER i MALLOL, Ma. T., Organització $i$ defensa..., p. 17. Al año siguiente delimitó perfectamente los términos de la villa de Alicante. ESTAL GUTIÉRREZ, J.M. del, El reino de Murcia bajo Aragón... $/ 1$, doc. $\mathrm{n}^{\mathrm{0}} 143$.

66 Cuando en 1303 Jaime II conoce los atropellos sufridos por Florena Martí, vecina de Guardamar, que se decía persona miserable, a manos de Guillem Paratge, convecino, que se había apropiado de una heredad que reivindicaba la mujer, Jaime II solicita al entonces procurador Bernat de Sarrià que se haga cargo del asunto, "taliter vos habendo in hiis quod predicta mulier, que pauper persona, ut predicitur, et miserabilier est, ius sum consequi valet et habere nec eum duicius opporteat vexari laboribus et expensis set pocius consequi». ACA, C, reg. 118, f. 79r.

67 ACA, C, reg. 108, f. 143v. (1297, julio, 17). 
- delitos contra la Corona: sedición ${ }^{68}$, plagio o collera, defensa de los caminos públicos ${ }^{69}$, herejía, sodomía, falsa moneda y lesa majestad. Al respecto de esta última falta la oligarquía de la capital del reino tenía sus dudas, a finales de 1300 , sobre su vinculación con el oficio de la Procuración, considerando más bien que quedaba dentro de la jurisdicción del justicia civil ${ }^{70}$. La addenda foral de 1301 dejó las cosas en su sitio, tal y como reconocieron esos mismos prohombres en $1303^{71}$.

- etc.

Esos amplísimos poderes convertían a la institución en garante de la cosa pública y de sus gentes. De tal modo que los procuradores podían actuar en labores diplomáticas con personajes, instituciones e incluso con potencias extranjeras que permitiesen acuerdos favorables a los intereses de sus gobernados y por extensión a los reales $^{72}$, procediendo en caso contrario sobre bienes y posesiones de foráneos dentro de su jurisdicción para resarcir pérdidas económicas. Disponían aquellas obras públicas que se consideraban adecuadas para el desarrollo económico de la región, como el trazado de nuevos viales ${ }^{73}$. Procedían igualmente, aunque no de forma privativa, al control de las distintas producciones murcianas en lo relativo a su extracción del territorio, fuese a tierras de la Corona o al extranjero ${ }^{74}$. La Curia de la Procuración tenía, atribuciones sobre el resto de oficiales del reino, además de las procesales aducidas en el Fuero. El baile, por ejemplo, estaba obligado a rendir cuentas ante el procurador del ejercicio de la acción de su oficio, aunque de forma circunstancial ${ }^{75}$. Mientras que los justicias habían de jurar su cargo ante el procurador, hecho que se mantuvo en las

68 El castigo era la expulsión del territorio, como le sucedió a un clérigo de la lglesia de Cartagena. ACA, C, reg. 130, f. 222r. (1303, diciembre, 16). Si bien, en este delito concurría como atenuante el hecho de que los sediciosos fuesen personas pobres y miserables, ya que su condición social y económica, a ojos de la autoridad, no los hacía peligrosos, y como ocurrió con unos vecinos de la ciudad de Murcia se les permitía regresar. ACA, C, reg. 128, f. 135r. (1303, mayo, 15).

$69 \mathrm{El}$ asalto a Pere Andreu, notario de Murcia, en el camino público que comunicaba la capital del reino con Mula -ACA, C, reg. 128, f. 139r-, y el proceso contra Joan Carles, vecino de Orihuela, inculpado de agredir a una mujer en un camino público - ACA, C, reg. 127, f. 284v. (1303, febrero, 9) - fueron llevados por Pere de Montagut, procurador.

70 Apéndice documental, doc. ํㅗ 5 .

71 ACA, C, reg. 129, f. 91r. (1303, septiembre, 16).

72 En 1301 el procurador llevó a efecto una serie de encuentros con un castellano, Gómiz Ferrándiz, con el fin de alcanzar un acuerdo de paz entre Castilla y la Corona de Aragón, que evidentemente puso en conocimiento de Jaime II. ACA, C, reg. 120, f. 142r. (1301, noviembre, 17). En 1304 sucede algo similar, aunque en esta ocasión su interlocutor era granadino. ACA, C, reg. 235, f. 102v. (1304, junio, 29).

73 Así, por ejemplo, en septiembre de 1296 y a solicitud del rey Jaime, disponía que el camino público que transcurría cercano a la población de Callosa lo hiciese por dentro de la villa, obligando a sus viandantes a pasar por él. ACA, C, reg. 194, f. 88r. (1296, septiembre, 10).

74 Como ejemplos véanse: ACA, C, reg. 194, ff. 228v.-229r. (1296, agosto, 3). ACA, C, reg. 121, f. 54r. (1301, junio, 22). ACA, C, reg. 116, f. 311r. (1301, enero, 3). ACA, C, reg. 201, f. 10r. (1303, julio, 7). ACA, C, reg. 129, f. 90r. (1303, septiembre, 16). Etc.

75 ACA, C, reg. 121, f. 79r. (1301, julio, 7). 
tierras dellà Sexona hasta la aplicación a mediados de 1308 de los furs de València, que apuntaban que tal jura se hiciese ante el baile general ${ }^{76}$. Al tiempo que actuar "cum consilio et voluntate procuratoris regni Murcie» cuando juzgasen sobre cosas litigiosas superiores a trescientos sueldos ${ }^{77}$.

Durante la dominación aragonesa de todo el reino de Murcia estas causas fueron campo de actuación ordinaria de la Procuración, así como en los primeros tiempos, después de la sentencia de Torrellas, del espacio denominado ultra Sexonam. No obstante, tras el ingreso de las tierras del norte de ese reino al de Valencia y la aplicación en el mismo del régimen foral valenciano, matizado por los privilegios locales, algunas de esas competencias quedaron en desuso, como el derecho del gobernador a conocer causas correspondientes a los munícipes.

\section{3. «Quod intromettere non debetis». Los límites jurisdiccionales de la Procuración}

Amplias fueron, pues, las competencias de los regentes de la Procuración; la importancia del oficio así lo requería. Pero tal extensión jurisdiccional no alcanzaba el infinito, sino que se veía limitada en atención al resto de poderes que cohabitaban con esta magistratura en el reino de Murcia: territoriales, municipales y señoriales. Lo cierto es que el carácter de representación de la real persona, que el oficio se negaba a abandonar, y la indefinición de sus atribuciones, por inviabilidad manifiesta de reglamentación teórica y por interés de la realeza en que ésta se mantuviese ${ }^{78}$, convirtió al oficio en constante centro de atención por razón de sus constantes altercados jurisdiccionales con otros poderes, que, disfrazados de defensa de sus propias competencias o de falsas creencias en proceder en defensa y seguridad de los intereses reales y de la «cosa pública», servían para afianzar su supremacía al tiempo que para obtener, de forma subrepticia e ilegal, ingresos con que sanear las arcas de su oficio, en unos momentos en que comenzaba a ver peligrar su potencialidad jurisdiccional con el trasvase de ciertas competencias privativas hasta esos momentos hacia otras magistraturas ${ }^{79}$.

76 Así se manifestaba en las quejas de Ferrer Descortell, baile general de las tierras oriolanas, referidas a como tras la elección de justicias municipales el día de Navidad en Orihuela y Elche estos oficiales pasaron a jurar sus respectivos cargos al procurador argumentando privilegio antiguo, a pesar de que los fueros de Valencia indicasen que el receptor del juramento había de ser el baile. Este acto, ilegal según la legislación vigente, hacía peligrar los procesos realizados por esos justicias hasta que no prestasen juramento ante el regente de la Bailía, siendo susceptibles de anulación. Tras tener conocimiento de todo, Jaime ll dio validez a tales procesos y ordenó que en adelante fuese el baile quien recibiese de ordinario el juramento de los justicias ciudadanos. Apéndice documental, doc. $n^{\circ} 10$.

77 Tal y como dispone Jaime II al justicia de la ciudad de Murcia. Apéndice documental, doc. ํㅜ 1.

78 OLLA REPETTO, G., Gli ufficiali regi di Sardegna durante il regno di Alfonso IV, Cagliari, 1969, p. 14. PÉREZ GARCÍA, P., «Origen y configuración de una magistratura urbana de la Valencia foral: el Justicia Criminal», en Estudis. Revista de Historia Moderna, 13, Valencia, 1987, p. 44. Id., El Justicia criminal de la ciudad de Valencia (1479-1707), Valencia, 1991. p. 49. CABEZUELO PLIEGO, J.V., Poder público y administración territorial..., pp. 754-755 y 918.

79 CABEZUELO PLIEGO, J.V., Poder público y administración territorial..., II, pp. 928-941. 
Una de las instituciones que más sufrió las injerencias de la Procuración fue la Bailía General, y precisamente a raíz de la pérdida por parte de aquélla de alguna atribución hasta esos instantes privativa, como fue la actuación sobre las minorías religiosas: moros y judíos. Fue durante el gobierno de Jaime de Jérica cuando éste se quejó a Jaime II de haber disminuido su oficio con la concesión de las causas de sarracenos y judíos a la Bailia General ${ }^{80}$. El rey le respondió que tales causas estaban en poder de la Bailía antes de que él accediese a las Procuras valenciana y murciana, en abril de 1298. De ahi en adelante moros y judíos quedaron dentro de la jurisdicción del baile general. Pero ¿y antes? A Jaime de Jérica le antecedió en el gobierno murciano Jaime Pérez y según lo expuesto por el rey al señor de Jérica sería durante el ejercicio del oficio de aquél cuando supuestamente se produciría el cambio. La pregunta sería ¿actuó alguna vez de oficio sobre estas materias Jaime Pérez? En el estado actual de nuestros conocimientos resulta sumamente arriesgado aventurarnos con un pronunciamiento, afirmativo o negativo, por la dificultad que entraña su justificación. Desde luego la temática queda fuera del arco competencial de la Procuración documentalmente en enero de 1298, cuando Jaime II recriminaba al entonces procurador valenciano vizconde de Castellnou su inmiscusión en estas materias por pertenecer al oficio de la Bailía General ${ }^{81}$. Con anterioridad a esa data observamos intervenciones procuratoriales en materia de minorías, aunque todas ellas relativas a la defensa, individual o colectiva, de sus miembros ${ }^{82}$. Sólo una nos llama la atención en cuanto a susceptible de poder desequilibrar la balanza del lado afirmativo, referente a unos moros apresados por Jaime Pérez como procurador murciano, de nombres Abulfaçen y Uxone, acusados de concubinato, y que Jaime II consideró debían quedar libres al no tener que aplicárseles la ley cristiana. La orden de liberación la recibió Jaime de Jérica, ya que el hermanastro del rey de Aragón optó por mantenerlos en prisión $^{83}$. Lo que no somos capaces de precisar es si la actuación del procurador en este asunto derivó de la filiación religiosa de los delincuentes o de la calidad del delito.

Pero lo cierto es que pese a lo dispuesto en las ordenanzas reales al respecto de esta temática, no faltaron injerencias por parte de la Procuración en asuntos de minorías, casi siempre para tratar de hacerse con unos ingresos suplementarios. Hasta tal punto se vulneraba la legalidad que en 1302 Jaime II hubo de reprender fuertemente a los oficiales de la Procuración, titular y lugarteniente, tras conocer como reclamaban las multas y otras penas en que habían incurrido sarracenos murcianos ${ }^{84}$. La rapacidad de los procuradores les llevó a exigir a los justicias ciudadanos presentar ante

80 Apéndice documental, doc. $n^{\circ}$ 3. FERRER i MALLOL. Mํ.T., Organització i defensa..., p. 22. CABEZUELO PLIEGO, J.V., Poder público y administración territorial..., II, pp. 800-801 y 811-813.

81 ACA, C, reg. 256, f. 6r.-v. (1298, enero, 22).

82 Sirvan como ejemplos: ACA, C, reg. 194, f. 45r.-v. (1296, agosto, 20-21); f. 74r.-v. (1296, septiembre, 2); f. 81v. (1296, septiembre 4 y 8); f. 104r (1296, septiembre, 22); f. 117v. (1296, septiembre, 29). ACA, C, reg. 105, f. 136r. (1296, octubre, 10). Etc.

83 ACA, C, reg. 110, f. 115v. (1298, abril, 13).

84 ACA, C, reg. 199, f. 33v. (1302, enero, 30). 
ellos las cuentas de la gestión de su oficio en lo relativo a rentas, multas, derechos etc., para poder distraer una parte, cuando igualmente correspondían a la Bailía ${ }^{85}$. Hechos que, desgraciadamente para esta institución, no cesaron de ocurrir, como se pone de manifiesto tanto en la Procuración valenciana como en la oriolana ${ }^{86}$.

Los oficiales municipales, reales y señoriales, también conocieron injerencias de este tipo que igualmente soliviantaban las estructuras del gobierno en el reino de Murcia. En unos casos los poderes del municipio se quejaban de inmiscusiones por parte de la Procuración en competencias privativas de carácter judicial; en otros el asunto iba más allá, pues las quejas se dirigían a la no observancia de los propios privilegios locales ${ }^{87}$. E incluso se alcazaba en la pugna, por parte de los regentes de la Procuración, a la remoción de cargos públicos, destitución recriminada desde la Curia regia cuando no estaba avalada por un mandato real ${ }^{88}$. Algunas de estas actuaciones procuratoriales fueron consideradas injerencia al tiempo que menoscabo real a la autoridad municipal, pues habían sido realizadas dentro de las más absoluta legalidad. Esto ocurrió sobre todo tras la aprobación de la addenda foral de 1301, que en opinión de los prohombres de la capital de reino propiciaba la actuación indiscriminada del procurador en campos hasta entonces vedados a su proceder y pertenecientes al municipio. A mediados de 1303 los murcianos levantaron súplica en este sentido, pues aunque sabedores de las competencias inherentes al oficio de la Procuración protestaban ante el deterioro que sufría la institución del Justiciazgo en razón al constante intervencionismo procuratorial sobre causas que correspondían a los justicias, sobre todo cuando en los procesos aparecían familiares o servidores de la Procuración. El choque de poderes, y el consecuente mal gobierno, fue atajado por Jaime II en septiembre de ese año cuando, tras explicar que las enmiendas forales de 1301 habian de servir para corregir anacronismos de la ley fundamental de los murcianos, no para potenciar las atribuciones jurisdiccionales de unas instituciones sobre las competencias de las demás, ordenó que los negocios principales que perteneciesen a los justicias fuesen vistos por ellos, no pudiendo intervenir el procurador salvo en legítima

85 Apéndice documental, doc. $n^{\circ} 6$.

86 CABEZUELO PLIEGO, J.V., Poder público y administración territorial..., II, pp. 935-940.

87 Así se observa en las quejas de municipios como Guardamar, Orihuela, las villas del valle de Elda, Murcia y otros más. Cfr. ACA, C, reg. 116, ff. 233r.-v. (1300, noviembre, 11). ACA, C, reg. 128, f. 171r. (1303, junio, 20). ACA, C, reg. 129, f. 90r.-v. (1303, septiembre, 16). FERRER i MALLOL, Ma.T., Organització i defensa..., pp. 40-41.

88 Tal sucede en Elche, tras el infructusoso intento por parte de Jaime de Jérica de deponer a Joan Bretón de su oficio de merino. ACA, C, reg. 112, f. 62v. (1298, junio, 22). O cuando Pero López de Rufes, alcaide de la Calahorra, ve peligrar su oficio ante las exigencias de Bernat de Sarrià. ACA, C, reg. 116 , f. 37 v. (1300, agosto, 19).

Sin embargo, en la remoción de los cargos públicos de la villa de Elche por el procurador en septiembre de 1296 no hubo reproche alguno de Jaime II, por haber partido de él la orden. La razón de tal mandato estaba en la negativa de uno de los electos a jurar la soberanía del rey de Aragón. ACA, C, reg. 194, f. 82r. (1296, septiembre, 5). FERRER i MALLOL, Ma.T., Organització i defensa..., p. 17. 
apelación ${ }^{89}$; que entendemos, tal y como se recoge en la legislación valenciana, tras sentencia definitiva otorgada por ese tribunal, o bien por resultar negligente o partidista el instructor principal de la causa ${ }^{90}$.

Curioso resulta el ahínco, en algunos casos exagerado, mostrado por los procuradores por defender los intereses reales sobre cualesquiera otros, si lo extrapolamos a actuaciones de esos mismos oficiales, aunque en calidad de personas privadas, dentro de la más absoluta ilegalidad. Frente a actitudes exacerbadas en el cumplimiento del deber, de las que se derivaba un mal uso del poder, como lo ocurrido en el señorío manuelino del Vinalopó a manos de Jaime Pérez en $1297^{91}$, nos encontramos otras con los mismos protagonistas aunque de signo contrario. Posiblemente el caso más sintomático pueda ser el de Bernat de Sarrià, criticado por sus gobernados por su exceso de celo en la defensa de las regalías, que como feudal vulneraba de forma consciente en interés propio, cuando se inhibió en la negativa de sus vasallos sarracenos habitantes en el término de Orihuela a pagar el cabezaje que de antiguo tenían costumbre salvar los moros oriolanos y que se empleaba para la reparación del castillo $^{92}$, o bien cuando a finales de 1302 quiso imponer un impuesto sobre la sal en su señorío de Callosa pese a saber que dicha tasa, conocida como gabela de la sal, era prerrogativa real ${ }^{93}$.

\section{LA CURIA DE LA PROCURACIÓN}

Por debajo del procurador se hizo necesaria la presencia de otros oficiales que, con diferentes tareas, hiciesen funcionar la maquinaria política y judicial del Tribunal, tal y como ocurría en el resto de territorios donde operaba la institución.

\section{Lugartenientes}

El origen del lugarteniente procuratorial se encuentra en el exceso de trabajo que recaía sobre su superior así como en la imposibilidad de éste para diligenciarlo. Vin-

89 ACA, C, reg. 129, f. 91r. (1303, septiembre, 16).

90 CABEZUELO PLIEGO, J.V., Poder público y administración territorial..., II, p. 929.

91 A finales de 1297 don Juan Manuel se quejaba a Jaime Il del incumplimiento de los acuerdos de Elche entre ambos, sintiéndose perjudicado por tal. Algunas de las quejas eran producto de malas acciones del entonces procurador murciano Jaime Pérez, quien había tomado la alfarda de la merindad de los moros de Elche, Aspe, Chinorla y Monóvar por un valor anual de tres mil quinientos sueldos así como diversas cantidades de dinero producto de varios asuntos, procedido a la elección de oficiales y otorgado heredades a voluntad. ACA, C, reg. 106, ff. 93v.-94v. (1297, noviembre, 22). GIMÉNEZ SOLER, A., Don Juan Manuel. Biografía y estudio crítico, Zaragoza, 1932, doc. no XII. ESTAL GUTIÉRREZ, J.M. del, El reino de Murcia bajo Aragón... $/ 1 /$, doc. $n^{\ominus} 151$. FERRER i MALLOL. Ma.T, Organització i defensa..., p. 18.

92 ACA, C, reg. 120 , f. 234r. (1302, enero, 19).

93 Que hubo de revocar tras mandato real de 6 de enero del año siguiente. ACA, C, reg. 126, f. $209 \mathrm{v}$. 
culado a los oficios de alta responsabilidad, como apuntan García de Valdeavellano ${ }^{94}$ - García Marín ${ }^{95}$, las funciones de los lugartenientes eran las mismas que las de sus superiores, desarrolladas, en el caso murciano, sobre el mismo espacio jurisdiccional que los procuradores.

La Procuración del reino de Murcia contó con un único lugarteniente, atendiendo a que el territorio no era demasiado extenso para ser dividido en Lugartenencias, como ocurriese en Valencia. Es posible que naciese de la mano de la magistratura, como sucede con su homólogo de la Bailía ${ }^{96}$, aunque no tenemos noticia alguna de su existencia durante prácticamente el primer año. Las primeras referencias a la Lugartenencia procuratorial murciana las hallamos en la primavera de 1297, cuando en diversos documentos Jaime II se dirige al «nobili et dilecto nostro Jacobo Petri, fratri suo, procuratori regni Murcie, vel eius locumtenentin ${ }^{97}$. A partir de estas fechas las noticias al oficio son habituales. El primer personaje del que conocemos nombre es Joan de Vidaure, que ejerce como lugarteniente durante el gobierno de Jaime de Jérica. Localizamos a Vidaure en calidad de tal ya en fecha tardía, 1300, actuando junto a Bernat de Sarrià, entonces consejero real, y Domingo de Biscarra para tratar de atraer del lado de Jaime II a Pedro Jiménez de Lorca ${ }^{98}$, así como en otras causas ${ }^{99}$. Un año después documentamos regentando ese oficio a Guillem de Vilaragut, ya con Bernat de Sarrià al frente de la magistratura ${ }^{100}$. Vilaragut aparece en el reino de Murcia en los primeros instantes de la conquista ${ }^{101}$, obteniendo en febrero de 1301 la alcaidía de la fortaleza oriolana ${ }^{102}$, que simultaneó con la Lugartenencia hasta su muerte, ocurrida a

94 GARCÍA DE VALDEVELLANO, L., Curso de Historia de las Instituciones Españolas. De los origenes al final de la Edad Media, Madrid, 1970, p. 496.

95 GARCÍA MARÍN, J. M. p. 54 y nota $n^{\mathrm{o}} 103$.

96 ESTAL GUTIÉRREZ, J.M. del, El reino de Murcia bajo Aragón... 1/1, doc. nº 112. (1296, junio, 29).

97 En mayo de 1297 Jaime II se dirige al procurador murciano o a su lugarteniente para comunicarles que en caso de que los vecinos de varias poblaciones - Alcantarilla, Molina, etc. - negasen el homenaje de fidelidad al abad del monasterio cisterciense que se iba a construir en ese reino, procediesen contra ellos confiscando sus bienes para obligarles a realizar dicho acto de reconocimiento. ACA, C, reg. 108, f. 34v. (1297, mayo, 21). Acerca de esta fundación cisterciense cf. SÁINZ DE LA MAZA LASOLI, R., «El monasterio cisterciense del Real de Murcia. Un proyecto fracasado de Jaime II», en Anales de la Universidad de Alicante. Historia Medieval, 9, pp. 179-196

98 A quien caso de aceptar la oferta se le concedería a perpetuidad el lugar de Beniscorna, en el reino de Murcia. ACA, C, reg. 197, f. 73r. (1300, febrero, 17).

99 FERRER i MALLOL, Mํ. T., Organització i defensa..., p. 23.

100 ACA, C, reg. 198, f. 251r. (1301, febrero, 1). ESTAL GUTIÉRREZ, J.M. del. El reino de Murcia bajo Aragón... V/1, doc. $\mathrm{n}^{\circ}$ 124. ACA, C, reg. 198, f. 254r.-v. (1301, febrero, 18). ACA, C, reg. 118, f. 19r. (1301, febrero, 20). ACA, C, reg. 120, f. 258v. (1302, enero, 28). FERRER i MALLOL, Mํ.T., Organització i defensa..., p. 47.

101 FERRER i MALLOL, Ma ${ }^{a}$.T., Organització i defensa..., p. 15.

102 ACA, C, reg. 198, f. 254r.-v. (1301, febrero, 18). FERRER i MALLOL, Ma. T., «La tinença a costum d'Espanya...», pp. 16 y 47. 
mediados del año siguiente ${ }^{103}$. El último personaje que localizamos al frente de este oficio es Berenguer de Puigmoltó, caballero con una gran vinculación con el reino de Murcia $^{104}$ y posteriormente con el territorio de él segregado tras la sentencia de Torrellas, en el que también llegó a ser lugarteniente procuratorial ${ }^{105}$. Su relación con el oficio sólo la constatamos en un documento fechado en mayo de 1303, en el que se refiere a una sentencia dictada «per Berengarium de Podio Moltone, tunc tenentem locum procuratoris dicti regni» ${ }^{106}$, desconociendo si en esos momentos todavía desempeñaba el cargo, aunque sí continuaba al servicio del rey, en nombre de quien poseía dos caballos armados y otros dos alforrados para la defensa del reino de Murcia ${ }^{107}$. Un tiempo después quedó como alcaide de Alhama ${ }^{108}$.

\section{El asesor}

Las prerrogativas judiciales de la magistratura, unidas al-desconocimiento de sus titulares de la ciencia jurídica, hicieron necesaria la presencia de un profesional del Derecho, abogado o doctor, que aconsejase al procurador en esta materia a fin de que no se incurriese en ilegalidad en los procesos incoados y sentenciados en ese Tribunal. Hasta tal punto se convierte en imprescindible su concurso que sin él cualquier causa o proceso realizado en la Curia de la Procuración quedaba anulado por defecto de forma. Su misión fundamental era conocer, y en algún caso sentenciar, las causas que fuesen presentadas ante el Tribunal de la Procuración o bien aquéllas otras que iniciara el procurador en nombre del rey ${ }^{109}$.

En cuanto a sus titulares, nombrados siempre por el rey en atención a la importancia del oficio, diremos que la brevedad del gobierno aragonés en el reino de Murcia

103 ACA, C, reg. 199, f. 88r. (1302, junio, 13). FERRER i MALLOL, Mํ.T., "La tinença a costum d'Espanya...», docs, no 2 y 3 .

104 Apareció, junto a otros muchos caballeros, entre la tropa que entró en el reino de Murcia en 1296 y pronto obtuvo favores reales por su arrojo. Alcanzó el justiciazgo alicantino, la merindad de la villa de Elche y posteriormente la alcaidía del castillo de Orihuela. Así como también diversas posesiones territoriales en el reino de Murcia. ACA, C, reg. 108, f. 143v. (1297, julio, 17). ACA, C, reg. 112, f. 267v. (1298, junio, 22). ACA, C, reg. 198, f. 267r. (1301, febrero, 25). ACA, C, reg. 199, f. 86r. (1302, mayo, 31). FERRER i MALLOL, Mํ.T., Organització i defensa..., pp. 64-65. Id., "La tinença a costum d'Espanya...", p. 47.

105 Cf. FERRER i MALLOL, M‥T., Organització i defensa..., pp. 63-72.

106 ACA, C, reg. 128, f. 139r. (1303, mayo, 18).

107 ACA, C, reg. 231, f. 54r. (1303, mayo, 18). FERRER i MALLOL, Mํ. T., Organització i defensa..., doc. $\mathrm{n}^{\mathrm{0}} 32$.

108 ACA, C, reg. 201, f. 96v. (1304, febrero, 1). FERRER i MALLOL, Mํ.T., Organització i defensa..., p. 65.

109 Cf. ALANYA, L. (ed.), Aureum opus regalium privilegiorum civitatis et regni Valentie cum historia cristianisimi regis Jacobi ipsius primi conquistatoris, Valencia, 1515, reimpresión facsímil Valencia, 1972, con índices preparados por CABANES PECOURT, M.D., f. 77v. BARDAXI, I. de, Tractatus de officio Gubernationis..., 2, pp. 170-171, 173-175. FERRER i MALLOL, Mํ..T., Organització i defensa..., p. 148. CABEZUELO PLIEGO, J.V., Poder público y administración territorial..., II, pp. 963-995. 
hizo que fueran escasamente media docena los letrados que ocuparon el cargo, removidos en cada ocasión que cambiaba el titular de la magistratura. El primero que conocemos en el oficio es García Munyoz, nominado asesor de la institución que entonces regía Jaime Pérez el 21 de agosto de 1296, habiendo sido con anterioridad juez de la Curia regia, por lo que le suponemos hombre de gran prestigio en el campo de las leyes ${ }^{110}$. Quizá ejerciese el oficio hasta primeros de 1298 , pero no más allá, pues cuando Jaime de Jérica unifica en sus manos las Procuraciones de Valencia y Murcia es otro juez real, Guillem de Jàfer, quien se hace con él, en concreto el 1 de mayo, apareciendo como "assessoris Procuracionis regnorum Valencie et Murcie»"11. Si bien, es posible que durante el gobierno del señor de Jérica existiesen dos Asesorías atendiendo a que eran dos las magistraturas que regía, una en cada reino. Esto es así porque con fecha de julio de 1300, cuando al frente de la Procuración murciana se encuentra Bernat de Sarrià, éste recibe una orden de Jaime ll para salvar a Joan de Meyà el salario adeudado durante los dos años que ocupó el cargo de asesor de Jaime de Jérica, a razón de mil sueldos anuales. El hecho de que Meyà hubiese colaborado con Jaime de Jérica, de que percibiese el dinero en moneda murciana, no valenciana $^{112}$, y de que fuese uno de los compiladores de los fueros murcianos ${ }^{113}$, nos hace pensar en la idea de la doble Asesoría, por otra parte lógica al pensar que la prestación de servicios, por razones de presencia física, en un solo Tribunal había de colapsar necesariamente el otro, ante la imposibilidad legal de poder sacar causas fuera de los reinos y la no existencia de huellas de lugartenientes del asesor.

Tras la destitución del señor de Jérica se regresa al sistema de gobierno unipersonal y uniterritorial, y así al tiempo que el vizconde de Castellnou se hace con la Procura valenciana, Bernat de Sarrià ocupa la murciana. Veintidós días después del nombramiento de Sarrià encontramos en la Asesoría a Bernat Benet ${ }^{114}$, que se mantuvo más de tres años en el desempeño del cargo hasta ser sustituido por otro letrado, Nicolau Porcel, en mayo de 1303, quien como su antecesor obtenía el oficio de «iudicatus seu assessor Procuracionis regni Murcie» a beneplácito, con un salario anual de mil quinientos sueldos valencianos - superior al obtenido por Meyà- sobre las rentas del reino, habiéndole de ser abonado por el baile general ${ }^{115}$. Días antes había sido nominado procurador Pere de Montagut. Porcel fue reprendido fuertemente por Jaime II en septiembre de ese año al conocer que, no contento con el salario que percibía, extorsionaba a quienes acudían al Tribunal de la Procuración exigiendo a cada una de las partes en litigio seis dineros por libra, lo que iba claramente contra fueros, usos y costumbres de los murcianos, ya que la percepción de su salario ordinario le vedaba

110 ACA, C, reg. 194, f. 243r. FERRER i MALLOL, M‥T., Organització i defensa..., p. 148.

111 ACA, C, reg. 196, f. 212r.-v. FERRER i MALLOL, Mª.T., Organització i defensa..., p. 148.

112 CABEZUELO PLIEGO, J.V., Poder público y administración territorial..., Il, pp. 976 y 988.

113 ESTAL GUTIÉRREZ, J.M. del, El reino de Murcia bajo Aragón... l/1, docs. no 114 y 148. ld., «El fuero y las "Constitutiones...», pp. 25-27.

114 ACA, C, reg. 197, f. 110r.

115 ACA, C, reg. 231, f. 53v. (1303, mayo, 17). FERRER i MALLOL, Mª.T., Organització $i$ defensa.., pp. 148-149. 
tomar numerario por el desempeño de su oficio ${ }^{116}$. No sabemos si por este hecho, por otro lado desgraciadamente habitual y que revela las dificultades para la percepción del salario ${ }^{117}$, o por otra razón que desconocemos, Nicolau Porcel fue depuesto de la Asesoría, entregada en diciembre de ese año a Guillem Mir, letrado de la capital del reino, con los mismos derechos aunque con un salario sensiblemente inferior, mil sueldos anuales ${ }^{118}$, quien ya en enero del año siguiente se quejaba de la dificultades en la recepción del monto salarial así como de otros derechos que habían de llegar a sus manos por razón de su oficio' ${ }^{19}$.

Tras la sentencia de Torrellas de agosto de 1304 y la división del reino de Murcia en dos mitades, Guillem Mir continuó ejerciendo sus funciones como asesor en la mitad norte, en la Procuración ultra Sexonam, con capital en Orihuela, aunque con un salario reducido en un cincuenta por ciento ${ }^{120}$.

\section{El escribano}

La misión principal del escribano era la de realizar todas las actas, cartas o escrituras concernientes al oficio de la Procuración, así como proceder a su custodia junto con la del sello de la magistratura' ${ }^{121}$. Posiblemente, como ocurría en el reino de Valencia, hubiera de asistir al procurador cuando éste se decantaba por pactar composiciones económicas con los delincuentes para así anotar la cantidad obtenida por esa vía en los libros de la Escribanía ${ }^{122}$.

Conocemos bien poco del oficio y de sus titulares durante el gobierno aragonés de Murcia. Si trasladamos a la Escribanía procuratorial una orden real dirigida a los munícipes murcianos pocos meses después de la conquista, todos los documentos y cartas públicas habían de ser redactadas en «vulgar, per la part que les gens pus clarament o entenen ${ }^{123}$. En cuanto a quiénes la desempeñaron, sabemos que tras acceder a la Procuración Jaime de Jérica, pretendió sustituir a los escribanos de las Curias de Valencia y de Murcia, a lo que Jaime II se negó en razón a que éstos, que habían obtenido el cargo con anterioridad a la presencia en el oficio del señor de Jérica, prestaban un buen servicio en él ${ }^{124}$. No tenemos ninguna credencial de nombramiento

116 ACA, C, reg. 129, f. 90v. (1303, septiembre, 16).

117 CABEZUELO PLIEGO, J.V., Poder público y administración territorial..., ll, pp. 979-982.

118 Apéndice documental, doc. nำ.

119 ACA, C, reg. 131, f. 56v. (1304, enero, 8).

120 Que le fue incrementado con un ingreso extraordinario de doscientos sueldos para «auxilium expensarum domus vestre" sobre las multas y otros derechos del justicia oriolano. ACA, C, reg. 231, f. 56v. (1304, diciembre, 5). ACA, C, reg. 231, f. 59v. (1308, agosto, 26). FERRER i MALLOL, $M^{2}$. T, Organització $i$ defensa..., p. 149.

121 FERRER i MALLOL, M‥T., Organització i defensa.., p. 151. CABEZUELO PLIEGO, J.V., Poder público y administración territorial..., II, pp. 996-999.

122 CABEZUELO PLIEGO, J.V., Poder público y administración territorial..., II, p. 999-1000.

123 ESTAL GUTIÉRREZ, J.M. del, El reino de Murcia bajo Aragón... V/1, doc. n 141. (1296, agosto, 29$)$.

124 Apéndice documental, doc. $n^{\circ} 3$. 
de escribano de la Procuración entre 1296 y 1304, pero sí indicios de personas que ejercieron como tal. Uno de ellos es Pere Ça Muntcada, de quien Jaime II apunta en junio de 1302 que es «scriptor dilecti consiliarii nostri Bernardi de Sarriano, procuratoris regni Murcie» ${ }^{125}$. Otro sería Pere Andreu, un notario de la ciudad de Murcia, que según refería el rey a Pere de Montagut había estado a las órdenes de su antecesor en el cargo, Bernat de Sarrià, quien le envió al asedio del castillo de Mula para redactar los documentos necesarios sobre los pactos habidos entre Sarrià y los comendadores santiaguistas, sufriendo en su viaje un ataque y heridas de azagaya ${ }^{126}$.

\section{Otros cargos}

Junto a asesor y escribano, oficios de carácter técnico para los que se requería una cierta cualificación profesional, el Tribunal de la Procuración contó con otros cargos de tipo ejecutivo, dado que su misión principal era poner en práctica las órdenes que les dictasen sus superiores. Se trata de porteros, correos, alguaciles, corredores... Sólo tenemos noticia de uno estos oficiales, y muy tardía; se trata del nombramiento en febrero de 1304 de Arnau de Milleres como alguacil de la Procuración murciana de por vida ${ }^{127}$, cuando a ésta escasamente le restaba seis meses de existencia.

125 ACA, C, reg. 124, f. 188r.-v. (1302, junio, 8).

126 ACA,$C$, reg. 128, f. 138r. Debe tratarse del mismo Pere Andreu a quien Jaime II concedió durante el asedio al castillo de Orihuela una serie de posesiones en la ciudad y huerta de Murcia a perpetuidad por su fidelidad a la causa del rey de Aragón. ACA, C, reg. 194, f. 247v. (1296, mayo, 10).

127 Apéndice documental, doc. ํำ 9. FERRER I MALLOL, Mํ..T., Organització $i$ defensa..., p. 152. 


\section{APÉNDICE DOCUMENTAL ${ }^{128}$}

1296, agosto, 3. Valencia.

Jaime I/ dispone que el justicia de la ciudad de Murcia pueda juzgar hasta trescientos sueldos. Cuando la cosa litigiosa supere ese valor sólo lo podrá hacer con la aquiescencia del procurador del reino.

ACA, C, reg. 194, f. $227 \mathrm{v}$.

\section{Civitatis Murcie ${ }^{129}$}

Noverint universi quod nos, Jacobus, Dei gracia rex Aragonum, Maioricarum, Valencie et Murcie ac comes Barchinone, volumus, concedimus et ordinamus quod iusticia civitatis Murcie possit super penis pecuniariis et caloniis per quaslibet personas dicto iusticie racione dicti officii dandis et solvendis qualibet racione ascendentibus ad summam trescentorum solidorum regalium et infra moderari et inde remissionem moderare facere ante sentenciam et post prout ei racionabiliter videbitur faciendum. Super caloniis vero ascendentibus ultra summam trescentorum solidorum dicte monete cuiuscumque fuerit quantitatis possit dictus iusticia moderari et remissionem inde moderare facere racionabiliter cum consilio et voluntate procuratoris regni Murcie, sine cuius consilio et voluntate ultra dictam quantitatem trescentorum solidorum moderari seu remissionem aliquam facere non presumat. Nos enim moderacionem et remissionem quam dictus iusticia per se de caloniis et penis predictis ascendentibus ad summam trescentorum solidorum et infra et cum consilio et voluntate dicti procuratoris de caloniis et penis ascendentibus ultra dictam summam trescentorum solidorum fecerit, ut est dictum, obtinere volumus robur perpetue firmitatis. Mandantes procuratoribus, iusticiis, baiulis et universis aliis officialibus et subditis nostris, presentibus et futuris, quod presentem concessionem et ordinacionem nostram firmam habeant et observent et non contraveniant nec aliquem contravenire permittant aliqua racione. Predictam autem concessionem et ordinacionem durare solummodo volumus et valere dum de nostre fuerit beneplacito voluntatis.

Data Murcie, IIIำ nonas augusti, anno Domini $\mathrm{M}^{\circ} \mathrm{CC}^{\circ} \mathrm{X} \mathrm{XC}^{\circ}$ sexto.

128 Agradezco a la Dra. Regina Sáinz de la Maza, del Consejo Superior de Investigaciones Científicas, la revisión de este apéndice documental y sus acertadas puntualizaciones paleográficas.

129 Letra no contemporánea. 
1297, julio, 27. Lérida.

Jaime Il ordena a Jaime Pérez, procurador del reino de Murcia, que obligue a las autoridades municipales de la villa de Orihuela a aceptar como norma legal el Fuero de Murcia.

$A C A, C$, reg. 108 , f. 171 r.

Jacobus, et cetera, viro nobili et dilecto Jacobo Petri, fratri et procuratori regni Murcie, salutem et dileccionem. Cum nos ad communem et utilem statum tocius regni Murcie foros generales et communes toti regno provide et cum magna deliberacione ad proborum hominum instanciam civitatis et regni predicti duxerimus statuendos, ad quorum observacionem omnes habitantes in regno predicto tenentur eciam obligantur, qui fori iam tam in civitate quam in aliis locis regni ipsius ab hominibus observantur, exceptis probis hominibus Oriole, qui eos, ut intelleximus, renuunt observare. Et non sicut pars conveniens immo turpis que suo non congruit universo, idcirco vobis dicimus et mandamus firmiter et dictricte quatenus homines loci predicti de Oriola ad observacionem ipsorum fororum modis quibus peteritis compellatis.

Data llerde, $\mathrm{VI}^{\circ}$ kalendas augusti, anno Domini $\mathrm{M}^{\circ} \mathrm{CC}^{\circ} \mathrm{XC}^{\circ}$ septimo.

Petrus Marchi.

\section{3}

1299, junio, 10. Nápoles.

Jaime II acusa recibo a Jaime de Jérica, procurador de los reinos de Valencia y de Murcia, de las distintas cartas de él recibidas y le contesta a ciertos interrogantes expresados en ellas acerca del oficio de la Procuración.

ACA, C, reg. 113, ff. 164v.-165r.

Jacobus, et cetera, viro nobili et dilecto Jacobo, domino de Xerica, procuratori regnorum Valencie et Murcie, et cetera. Receptis litteris vestris nuper nobis transmissis et hiis que continebantur in eis plenarie intellectis, sic vobis duximus respondendum quod placuit nobis multum de significata nobis in eis tranquillitate et statu pacifico regnorum Valencie et Murcie et vestram preterea diligenciam comandamus. Ad id autem quod nobis per ipsas vestras litteras intimastis quod cum hoc anno induxissetis exercitum hominibus regni Valencie ut sequerentur vos ad dampnificandum et offendendum hostes nostros dum in regnum Murcie accederetis et quod illi de civitate excusarunt se ex indultis eis privilegis quod non tenebantur ire in exercitum nisi nobiscum insimul et illi de regno dixerunt se facturos sicuti illi de civitate, respondemus vobis quod si illi de civitate ex predictis eis indultis privilegiis possunt se racionabiliter excusare de non eundo in exercitum nisi tantum nobiscum gravamur, tamen et displicet nobis si alii de 
regno quos non credimus ex privilegiis vel alia iusta causa posse racionabiliter excusari ab ipso exercitu faciendo non fuerunt vos secuti in exercitum supradictum et eos proptera debite corrigemus loco et tempore opportunis. Ad alia vero que nobis per ipsas literas scripssistis nos subtraxisse comisso vobis officio procuratoris sarracenos et iudeos, custodiam rerum prohibitarum et ea comisisse baiulis nostris generalibus dictorum regnorum tam in civili quam criminali noveritis quod antequam vobis dictum procuratoris comisissemus officium, predictam custodiam sarracenos et iudeos tanquam ad officia dictarum Baiuliarum spectancia mandaveramus per eosdem baiulos cum baiulis eisdem insimul procurari. Cum intencionis nostre non fuerit nec est subtrahere seu diminuere aliqua de dictis officiis que noscantur ad ea racionabiliter pertinere, verumtamen nos dante Domino intendimus esse in brevi in partibus ipsis et tunc certificari plenius ad que officiorum ipsorum predicta spectare noscantur super eis deliberabimus quod fuerit racionis. Ad alia autem que de Scribaniis Procuracionum ipsarum nobis scripsistis, respodemus vobis quod cum nos antequam predicta Procuracionum officia vobis comissa fuissent, Scribanias ipsas quibusdam benemeritis duxerimus concedendas eas a manibus eorum revocari non expedit dum bene et legaliter se habeant in eisdem. Ad alia vero que super mitenda illuc peccunia pro negociis et serviciis nostris nobis per predictas vestras litteras scripssistis, respondemus vobis quod cum dominus Papa non satisfecerit nobis de quantitate peccunie in qua nobis tenebatur pro prosecucione negocii Sicilie quod habuimus, nullam illuc ad presens mitere possumus peccunie quantitatem set in antea curabimus ad partes ipsas transmitere // illam quam poterimus peccunie quantitatem. Ad ea vero que super emendis equorum et aliorum animalium illorum de comitiva vestra nobis per ipsas vestras literas scripsistis, quia certum est nobis baiulos nostros regnorum ipsorum nullam de iuribus et proventibus officiorum Baiuliarum ipsarum recipere peccunie quantitatem propter plures et diversas asignaciones factas per nos diversis personis in iuribus et proventibus ipsis eis ad presens super hiis non scribimus, set cum nos in partibus nostris presentes fuerimus quod, ut predicitur, dante Domino erit in brevi, sit circa emendam equorum et aliorum animalium predictorum providere curabimus quod vos et illi de familia vestra contentos vos poteritis reputare, petitas autem literas ad fratrem Romeum, de Ordine Minorum, et alios manumissores illustris infantis dopni Petri, bone memorie fratris nostri, super prorrogacione solucionis facienda de precio castrorum dicti fratris nostri per ammiratum emptorum, licet alias iam super hoc eis scripsserimus vobis ad presens per portitorem presencium destinamus. Ad ea autem que alie vestre litere continebant super facto Ferdinandi, fratris nostri, respondemus vobis quod providimus supersederi in negocio ipso in negocio ipso (sic) usque quo nos simus in partibus ipsis presentes et tunc super ipso negocio vobiscum confferre intendimus et facere quod nobis decencius visum fuerit expedire. Circa vero statum pacificum et tranquillum regnorum nostrorum vestro regimine comissorum sic prudenter et sollicite intendatis quod fideles nostri sub vestro bono regimine in statu gaudeant pacifico et tranquillo vosque possitis proptera nobis occurrere merito comendandus. Et ut in columitate et statu persone nostre quem audire prosperum perebtatis, valeatis plenius informari. Scire vos volumus quod per Dei graciam plenam fruimur corporis sospitant.

Data Neapoli, IIII- idus iunii, anno Domini $\mathrm{M}^{\circ} \mathrm{CC}^{\circ} \mathrm{XC}^{\circ}$ nono. 
[1300, abril, 1. Barcelona].

Jaime II pone al servicio de Bernat de Sarrià, procurador del reino de Murcia, a cincuenta caballeros y cincuenta peones para la defensa del territorio murciano además de la hueste que ya reside en él.

ACA, C, reg. 197, f. 98v

\section{Eiusdem $^{130}$}

Jacobus, et cetera, dilecto consiliario suo Bernardo de Serriano, procuratori regni Murcie, salutem et cetera. Cum ultra illam equitum et peditum comitivam que ad stipendia nostra in regno Murcie moratur ad presens pro tuiciori et fortiori deffensione dicti regni Murcie quinquaginta equites et quinquaginta pedites per vos in dicto regno ad servicium nostrum retinere providimus et velimus, ideo dicimus et mandamus vobis quatenus dictos quinquaginta equites et quinquaginta pedites sub stipendiis sive solidis Curie nostre in nostrum servicium teneatis in regno predicto. Nos enim volumus et concedimus per presentes quod cuilibet equiti tenenti equm armatum cum tribus equitaturis ultra lipsum/ equm armatum dentur et solvantur octo solidos regalium Valencie pro unoquoque die, et cuilibet tenenti equm alforratum cum duabus equitaturis ultra ipsum equm alforratum dentur et solvantur sex solidos pro die, et cuilibet peditum predictorum octo denarii eiusdem monete. Verum, si dictus eques tenens equm armatum non haberet nisi tres equitaturas, dentur eidem sex solidos tamen monete predicte et sic descensive secundum quod tenebit equitaturas. Et si ille qui equm alforratum tenuerit non habuerit nisi duas equitaturas, dentur sibi quatuor solidos tamen monete iamdicte, et sic descensive secundum quod tenebit equitaturas.

Data ut supra. [Barchinone, kalendas aprilis, anno Domini $\mathrm{M}^{\circ} \mathrm{CCC}^{-}$]. Idem.

1300, noviembre, 11. Valencia.

Jaime Il ordena a Bernat de Sarrià, procurador del reino de Murcia, sobreseer ciertos procesos y esperar hasta que él acudiese a ese territorio tras haber recibido una queja de las autoridades municipales murcianas en el sentido de que actuaba contra fueros y privilegios de la ciudad y reino.

ACA, C, reg. 116, f. 232r.

Letra no contemporánea. 
Bernardo de Serriano, procuratori regni Murcie, et cetera. Constituti ante nostram presenciam nuncii seu procuratores universitatis civitatis Murcie nobis exposuerunt conquerendo quod vos gravatis eosdem contra forum et racionem et etiam contra privilegia sua et observancia eorumdem super hiis casibus, videlicet qui sequntur. Primo quod compellitis quosdam homines civitatis Murcie qui sunt super facto criminis lese maiestatis, ut dicitur, accusati, ad respondendum coram vobis super eo cum non teneantur respondere in casu predicto ni coram iusticia civitatis Murcie. Secundario quod capitis seu capi facitis in dicta civitate aliquos homines extraneos qui sunt de quibusdam maleficiis seu excessibus accusati, cum iuxta forum et privilegia dicte civitati concessa non teneantur nec coram eiusdem iusticia respondere. Tercio quod facitis cognosci de secundariis appellacionibus cum iuxta forum predictum, nisi per nos personaliter cognosci, non debeat de eisdem. Quarto quod cum ipsi iuxta eorum privilegia non teneantur servire cum equis armatis pro hereditamentis que diversa fuerunt pro cavalleriis, compellitis ipsos ad serviendum cum equis armatis pro hereditamentis superius nominatis. Quinto quod cum ipsi non teneantur iuxta eorum privilegia facere exercitum, nisi semel in anno, compellitis ipsos ad faciendum dictum exercitum contra privilegia supradicta. Sexto quod sarraceni qui consueverunt morari in la Rexaca et in alqueriis orte regni Murcie habent deserere ipsa loca et inde affugere propter multas oppressiones et gravamina que inferris seu inferri facitis eisdem. Quare vobis dicimus et mandamus quatenus super predictis et quolibet predictorum supersedeatis procedere ac procedi facere donec nos fuerimus in regno Murcie personaliter constituti, et siquam pignora ab eis tenetis seu capi fecistis racione predicta ea incontinenti restituatis eisdem ac restitui faciatis.

Data ut supra. [Valencie, III idus novembris, anno Domini Mo trecentesimo]. Idem.

1302, enero, 30. Valencia.

Jaime Il ordena a Bernat de Sarrià, procurador del reino de Murcia, no inmiscuirse en la jurisdicción ordinaria del baile general del territorio.

ACA, C, reg. 199, ff. 33v.-34r.

Dilecto consiliario suo Bernardo de Serriano, procuratori regni Murcie, vel eius locumtenenti ac alii cuicumque procuratori qui pro tempore fuerit, salutem et dileccionem. Cum ad officium baiuli nostri regni Murcie specialiter pertineat audire // compotum a iusticiis civitatis et aliorum locorum regni predicti de omnibus redditibus, caloniis et proventibus ac iuribus iusticiarum locorum predictorum ac exigere et recipere nomine nostro quicquid ex ipsis iuribus remanet solvere salariis iusticiarum et assessorum, et vos, ut intelleximus, intromitatis vos de premissis. Ideo vobis dicimus et mandamus quatenus de hiis vos ulterius nullatenus intromitatis sed hec expediri permitatis percipi et haberi per baiulum antedictum. Nos enim per presentem mandamus iusticiis dicti 
regni, presentibus et qui pro tempore fuerint, ut cum dicto baiulo computent et ipsi baiulo et non vobis nec altri cuicumque respondeant et satisfaciant de premissis.

Data Valencie, IIII kalendas febroarii, anno quo supra. [millesimo CCCํㅜ primo] Bernardus de Aversone, mandato domini episcopi.

\section{7}

1303, septiembre, 16. Caspe.

Jaime Il concede a Pere de Montagut, procurador del reino de Valencia, el castillo de Molina y le ordena que traslade su residencia a él.

ACA, C, reg. 201, f. 40v.

Jacobus, et cetera, dilecto suo Petro de Monteacuto, procuratori regni Murcie, salutem et cetera. Significamus vobis quod Eymericus de Bellovicino, procuratori nomine dilecti consiliarii nostri Bernardi de Serriano, reddit nobis verbo castrum de Molina, quod memoratus Bernardus tenebat pro nobis. Nosque sicut providimus et ordinamus quod castrum predictum de Molina tradatur vobis nomine nostro, eapropter vobis dicimus et mandamus quatenus dictum castrum de Molina \recipiatis/ et, cum ipsum realiter et potenter receperitis, nos de reddicione ipsius castri habebimus pro contentis ac prefato Bernardo inde quitium appellamus. Quod castrum, cum receperitis illud diligenter teneatis et custodiatis aut teneri et custodiri diligenter faciatis, prout melius ad servicium nostrum videbitis expedire, preterea nos de retinencia dicti castri vobis, prout oportunum fuerit, curabimus providere. Quicquid autem circa hec faceritis nobis continuo intimare curetis preterea placeret nobis et teneremus pro bono quod ex quo receperitis dictum castrum in et vestrum domicilium transferatis ac in eodem meiorem residenciam faceritis ut ipse locus melioramentum inde reciperet et diligencius custodiretur.

Data in loco de Casp, XVIa kalendas octobris, anno quo supra.

Bernardus de Aversone, mandato regio.

\section{8}

1303, diciembre, 17. Valencia.

Jaime concede a Guillem Mir, letrado de la ciudad de Murcia, la Asesoría de la Procuración del reino de Murcia con los derechos acostumbrados y un salario anual de mil sueldos valencianos.

ACA, C, reg. 201, f. 68 r.

Nos, Jacobus, Dei gracia rex Aragonum, et cetera. Attendentes sufficienciam et industriam vestri, Guillermi Mir, iurisperiti Murcie, vobis officium Assessorie Procuracionis regni Murcie usque ad nostrum beneplacitum duximus comittendum, ita quod vos sitis assessor procuratoris dicti regni et exerceatis officium ipsius bene et legaliter. Nos enim 
mandamus per presentes procuratori et universis et singulis dicti regni quod vos pro assessore habeant dum nobis placuerit, ut est dictum, denique volumus et concedimus vobis quod habeatis et percipiatis quolibet anno pro salario seu labore vestro mille solidos regalium Valencie quos vobis solvi mandamus per baiulum regni nostri predicti de redditibus et exitibus et aliis iuribus eiusdem regni. Mandantes per presentes Ferrario de Cortilio, baiulo dicti regni, quod de redditibus et exitibus ipsius regni solvat vobis dictos mille solidos annuatim dum fueritis in officio antedicto et apochas recepturus de quantitatibus quas vobis pro inde duxerit exsolvendas.

Data Valencie, $X V I^{\circ}$ kalendas ianuarii, anno Domini $\mathrm{M}^{\circ} \mathrm{CCC}^{\circ}$ tercio.

Petrus de Monello, mandato regio.

1304, febrero, 16. Valencia.

Jaime Il concede a Arnau de Milleres el oficio de alguacil del procurador del reino de Murcia de por vida, con los derechos y el salario habituales.

ACA, C, reg. 231 , f. $54 \mathrm{v}$.

Nos, Jacobus, et cetera, confidentes de fide et legalitate tui, Arnaldo de Milleres, te ad officium alhuatziri procuratoris regni Murcie dum vixeritis providimus statuendum, ita quod tu sis alhuatzirius dicti procuratoris et exerceas pro nobis officium ipsum bene et legaliter dum tibi fuerit vita comes. Nos enim volumus et concedimus tibi quod habeas et percipias racione ipsius officii ea iura que per alios predecessores tuos in dicto officio sunt recipi consueta. Mandantes per presentes procuratori et universis aliis officialibus et subditis nostris regni predicti quod te pro alhuatzirio habeant et tibi de hiis de quibus predecessoribus tuis in dicto officio respondere consueverunt et debent, respondant dum vixeritis, ut est dictum.

Data Valencie, XVo kalendas marcii, anno predicto. [ $\mathrm{M}^{\circ} \mathrm{CCC} \mathrm{CC}^{\mathrm{O}} \mathrm{I}^{\circ}$ ].

Bernardus de Aversone, mandato regio facto cum littera secreta.

1309, febrero, 25. Barcelona.

Jaime II reconoce que desde la recepción de los fueros de Valencia por las comunidades situadas al sur de Jijona los justicias ciudadanos deben prestar juramento ante el baile general del distrito y no ante el procurador, como era costumbre antes.

ACA, C, reg. 231 , f. $60 \mathrm{v}$.

Jacobus, et cetera, fideli suo Ferrario de Cortilio, baiulo nostro in parte regni Valencie, et cetera. Recepimus litteram vestram per quam significastis nobis quod homines de Oriola et homines Elchii elegerunt iusticias in locis ipsis die nativitatis Domini proxime 
nunc transacte et quod, licet iuxta forum Valencie ipsi iusticie in posse vestro die eadem deberent iurare et vos circa hoc requisivissetis eosdem, dicti tamen homines fecerunt iurare ipsos iusticias in posse procuratoris nostri, ut iuxta eorum privilegia antiquitus, ut asseritur, facere consueverant quodque post dies aliquos ad vestri instanciam prefati homines, recognoscentes forum Valencie in prestacione iuramenti predicti non fuisse servatum, recurrerunt ad vos ut reciperetis iuramentum a iusticiis supradictis et petierunt ac vos rogarunt instanter ut a nobis obtineretis litteram per quam concederemus ut processus coram dictis iusticiis seu per eos facti seu faciendi propter non observatum forum in prestacione iuramentorum, predictorum non possent ullo tempore anullari. Unde premissis plenarie intellectis, quia pro parte dictorum hominum suplicastis nobis ut huiusmodi litteram concedere et vobis dirigere dignaremur, volentes dicti supplicacioni annuere, per presentem litteram volumus et concedimus quod racione prescripta processus aliqui facti vel faciendi per dictos iusticias vel eorum alterum revocari non possint seu aliquatenus anullari dum modo iidem iusticie statim receptis presentibus dictum iuramentum in posse vestro faciant, nisi iam ipsum fecerint, videlicet in posse vestro ut est de foro Valencie faciendum. Quodquidem iuramentum volumus decetero fieri in posse vestro seu alterius qui pro tempore baiulus noster in ipsis partibus fuerit per iusticias locorum predictorum cum electi fuerint iuxta forum.

Data Barchinone, Vo kalendas marcii, anno Domini Mํ CCCo octavo.

Bernardus de Aversone, mandato regio. 


\title{
DON JUAN MANUEL: REALIDAD TEXTUAL Y ORIGINALIDAD CREADORA
}

\author{
Francisco Javier DÍEZ DE REVENGA \\ Universidad de Murcia
}

Se han estudiado ya en este congreso numerosos aspectos de la época del rey aragonés Jaime II, que sin duda han dilucidado muchos pormenores poco conocidos de tan interesante período de la historia medieval, que importa, y de forma decisiva a las actuales regiones de Valencia y Murcia, y que tanto tiene que ver con ciudades muy importantes de estas regiones como son la propia Murcia, Alicante, Lorca, Orihuela, Cartagena y tantos otros territorios de frontera de los reinos de Murcia, Valencia y Granada. Territorios que Don Juan Manuel, protagonista de estas páginas, conocía muy bien y tal como dejó claro en tempranas y singulares descripciones, presentes en el Libro de la caza, comenzando por Villena, la mejor zona para la caza de garzas, ánades, con halcones y con azores, perdices, codornices, flamencos, liebres y conejos. De allí, a Elda y Novelda, Vinalopó abajo, hasta llegar a la laguna de Santa Pola, rica en aves acuáticas. Luego Crevillente, Albatera, la huerta de Orihuela, cuya fragosidad dificulta el ejercicio de tan señorial deporte, como ocurre en Monteagudo y en su almarjal. Otro almarjal, el de Cartagena, será rico en aves como todo el Valle del Guadalentín y Lorca. Y don Juan Manuel se complacerá en dejarnos un relato ameno de sus aficiones deportivas y de su dominio del terreno.

Era la del nieto de San Fernando una época especialmente revuelta y todos los historiadores han sido unánimes en señalar las dificultades que asolaban estas tierras durante aquellos años cruciales. Nuestro personaje era muy especial: levantisco aristócrata, orgulloso de su estirpe real, contribuyó y mucho al desarrollo de estos territorios, pero también es muy cierto que su contribución trajo consigo muy complejos problemas. Su figura atraviesa los años de la época de Jaime II de Aragón, su suegro y protector, con quien se alió para defenderse de sus propios parientes, su sobrino Fernando IV de Castilla y su sobrino nieto Alfonso XI. Está presente también en la de 
Alfonso IV de Aragón, que le concedió el título de Príncipe de Villena, y en la de Pedro IV, que le otorgó el de Duque de Villena. La corte de Jaime II fue la que le abrevió el nombre y le dio justamente éste que ahora utilizamos y con el que todos le conocemos, como si se tratase de un nombre y un apellido modernos: Don Juan Manuel. Tal denominación, debida a la comodidad de la cancillería aragonesa, como sabemos, era impensable en Castilla, donde siempre fue nombrado tal como él mismo firmaba: Don Juan, hijo del infante Don Manuel. Traspasa del mismo modo el reinado de varios monarcas castellanos, su primo Sancho IV, el hijo de éste y el nieto (Fernando IV y Alfonso $\mathrm{XI}$ ) en cuyas minoridades ejerció su influencia e incluso la regencia en la del segundo de ellos, y en cuyas mayorías provocó disensiones y conflictos de lo más variado y diverso, sufrió persecución y a punto estuvo de ser asesinado por orden de su sobrino nieto, el rey Alfonso XI.

Para los historiadores de la literatura se nos ofrece, sin embargo, muy distinto, como un prudente escritor, embarcado en el proyecto más serio de renovación de las letras castellanas del siglo XIV, actividad en la que ocupa un lugar de honor, porque en él se ha considerado al primer escritor de nuestras letras con conciencia de serlo, al autor de una obra didáctica dechado de prudencia y sabiduría, al renovador de nuestro idioma y al creador de una prosa casi mayor de edad, capaz de expresar conceptos y sentimientos, continuadora de la labor iniciada por el tío de nuestro Príncipe y rey Alfonso $X$ el Sabio.

No me voy a referir, desde luego a su figura histórica. Otros lo han hecho y con títulos más que sobrados. Han aportado documentación inédita y han abierto caminos, desde los trazados, hace ya muchos años, por Giménez Soler, cuyo nombre siempre ha de ser recordado al comienzo de cualquier estudio sobre Don Juan Manuel'. Hemos de señalar, como complemento de las referencias bibliográficas más conocidas, que muy recientemente, en la década de los ochenta, Don Juan Manuel recibió, como personaje histórico, estadista y político, atención por parte de prestigiosos historiadores, que documentaron sus difíciles relaciones con los territorios y los concejos de las regiones fronterizas de su adelantamiento. Aurelio Pretel ${ }^{2}$, el año del centenario, 1982, dedicó un voluminoso libro al que él llamaba «el señor de la llanura» y sus relaciones con las comarcas de la actual provincia de Albacete, mientras Juan Torres Fontes, en ese mismo año del centenario, estudiaba las «tensiones y conflictos», con el concejo murciano ${ }^{3}$, que ampliaba, en otro artículo de 1986, al señorío de Cartagena ${ }^{4}$. En el libro del Centenario, que llevaron a cabo la Universidad de Murcia y la Academia

1 Andrés GIMÉNEZ SOLER, Don Juan Manuel: biografía y estudio crítico, La Académica, Zaragoza, 1932.

2 Aurelio PRETEL, Don Juan Manuel, señor de la llanura: repoblación y gobierno de la Mancha albacetense en la primera mitad del siglo XIV, Instituto de Estudios Albacetenses, Albacete, 1982.

3 Juan TORRES FONTES, «Murcia y don Juan Manuel: tensiones y conflictos», Don Juan Manuel VII Centenario, Universidad de Murcia-Academia Alfonso X el Sabio, Murcia, 1982, pp. 17-26.

4 Juan TORRES FONTES, "Don Juan Manuel señor de Cartagena", Estudios en homenaje a Don Claudio Sánchez Albornoz en sus noventa años, Facultad de Filosofía y Letras, Universidad de Buenos Aires, 1983-1986, IV, pp. 35-57. 
Alfonso $\mathrm{X}$ el Sabio, se contó con granados especialistas que abordaron otros aspectos históricos, especialmente Julio Valdeón ${ }^{5}$ y Reinaldo Ayerbe-Chaux, encargado de examinar las complejas relaciones de Don Juan Manuel con la Corona de Aragón ${ }^{6}$. A todos ellos me remito.

$Y$ me van a permitir que tampoco haga en este breve espacio temporal de que dispongo ningún panorama general sobre la cultura o la literatura de la época de Don Juan Manuel, porque está hecho en muchos lugares. Les puedo citar multitud de estudios y libros. Si quieren ustedes saber de la relación de Don Juan Manuel con estas tierras, también es un aspecto muy estudiado. Ángel Luis Molina y yo, hace ya muchísimos años, estudiamos las tierras murcianas de Don Juan Manuel a través del Libro de la caza y en la Historia de la Literatura Murciana, que publicamos Mariano de Paco y yo en $1989^{\circ}$, hablamos de la relación con Murcia de don Juan Manuel, desde el punto de vista literario. Ángel Luis Molina estudiaría también los dominios del mal llamado infante y otros estudios relacionarían con Murcia su actividad ${ }^{9}$. No voy a volver sobre cosas estudiadas, lo que constituiría una falta de respeto hacia ustedes, que no voy a cometer. Prefiero, sin embargo, y en justa compensación, hacer lo que aquel bondadoso cristiano que en vez de dar como limosna el pescado al hambriento, le daba la caña con qué pescarlo. Y mi contribución a este congreso no va a pasar de ser una caña en forma de valoración de las últimas aportaciones a la realidad textual de la obra juanmanuelina, es decir dónde y con qué confianza pueden leerse sus obras, a tenor de las últimas y más recientes aportaciones en este terreno. Pero no por ello renunciaré a hacer al final una justificada valoración literaria de nuestro Don Juan Manuel.

Prefiero, entonces, reflexionar en esta ponencia sobre los instrumentos y documentos que han mejorado nuestras posibilidades de acceso a los textos de Don Juan Manuel en los años que han transcurrido desde el Centenario hasta hoy, es decir, desde 1982 a 1996. Y hay que señalar en primer lugar que la penuria de textos de las obras juanmanuelinas antes del Centenario era alarmante. Un autor tan significativo como él no contaba con textos que pudiesen ser fiables y era una verdadera pena, que salvo la edición del Libro de Patronio o El Conde Lucanor que Blecua había hecho estupendamente para Clásicos Castalia ${ }^{10}$, ninguna de las demás obras se podían

5 Julio VALDEÓN BARUQUE, “Don Juan Manuel y Peñafiel», Don Juan Manuel VII Centenario, Unizersidad de Murcia-Academia Alfonso X el Sabio, Murcia, 1982, pp. 385-395.

6 Reinaldo AYREBE-CHAUX, «Don Juan Manuel y la Corona de Aragón. La realidad política y el ideal de los tratados", Don Juan Manuel VII Centenario, Universidad de Murcia-Academia Alfonso $X$ el Sabio, Murcia, 1982, pp. 17-26.

7 Francisco Javier DÍEZ DE REVENGA y Ángel Luis MOLINA MOLINA, «Don Juan Manuel y el reino de Murcia: notas al Libro de la caza", Miscelánea Medieval Murciana, 1, 1973, pp. 9-48.

8 Francisco Javier DÍEZ DE REVENGA y Mariano DE PACO, Historia de la Literatura Murciana, Universidad de Murcia-Academia Alfonso X el Sabio-Editora Regional de Murcia, Murcia, 1989.

9 Ángel Luis MOLINA MOLINA, "Los dominios de Don Juan Manuel», Don Juan Manue/ VII Centenario, Universidad de Murcia-Academia Alfonso X el Sabio, Murcia, 1982, pp. 215-226.

10 DON JUAN MANUEL, El Conde Lucanor, Castalia, Madrid, 2ª edición, Madrid, 1971. 
consultar con una mínima coherencia y con una imprescindible seguridad de que lo que estábamos leyendo era lo que Don Juan Manuel había escrito. Era penosa, por ejemplo, la edición del Libro de la caza, que había hecho Castro y Calvo ${ }^{11}$. Otras ediciones eran inasequibles o inencontrables. El resto de las obras de Don Juan Manuel era imposible de consultar.

Pero, por fortuna para los estudiosos de la literatura de Don Juan Manuel, el prestigioso e incansable filólogo, profesor José Manuel Blecua, dio a conocer en 1981 y 1983, por fin, su edición de las Obras completas ${ }^{12}$ del hijo del infante Don Manuel, en dos volúmenes, cuyos resultados textuales y bibliográficos hemos, hoy, de celebrar, ya que nos permiten asegurar que en los últimos años, se ha dado un gran avance en el campo de las ediciones del Príncipe de Villena. Hemos visto, casi coincidiendo con el centenario, aparecer esta edición de las Obras completas hecha por José Manuel Blecua, lo que ha supuesto, en el campo del estudio de los textos juanmanuelinos, un avance absolutamente singular. Blecua no lleva a cabo una edición al uso. Prefiere concentrar todos sus esfuerzos en cuidar al máximo el texto. Y merece la pena que nos detengamos en por qué esta edición es tan valiosa. En primer lugar porque es la obra de toda una vida. Él lo explica bien en la introducción y a ella remitimos. Comenzó su trabajo en los años treinta, $y$, de hecho, publicó una edición del Libro infinido en 1938 , en Zaragoza ${ }^{13}$. Pero, a pesar de que siempre siguió trabajando sobre los textos del ilustre autor medieval, diversos proyectos de otros investigadores le hacían desistir de trabajar en Don Juan Manuel. Pero desde los años cincuenta todo estaba abandonado, $y$, tras recuperar la tarea, se decide finalmente a editar todos los textos que no aparecen ya hasta las fechas, antes señaladas, de 1981-1983. La edición comprende un primer volumen con el Libro del Caballero y del Escudero, Libro de las armas, Libro enfenido, Libro de los estados, Tratado de la Asunción de la Virgen María y Libro de la Caza, mientras que el segundo volumen recoge El Conde Lucanor y la Crónica abreviada. Para todos los textos, Blecua se sirve del conocido manuscrito de la Biblioteca Nacional de Madrid (el 6376), mientras que para la Crónica abreviada utiliza el manuscrito de la misma Biblioteca, número 1356. En el caso de El Conde Lucanor, que, como se sabe, cuenta con otros manuscritos, especialmente señalables el Códice de Puñonrostro de la Real Academia Española y el manuscrito de la Real Academia de la Historia, Blecua ha utilizado todos ellos así como la edición de Argote de Molina.

Ver reunidos en una misma edición, admirablemente impresa, perfectamente justificada, y con un aparato crítico exhaustivo, todas las obras de Don Juan Manuel fue un gran alivio para los estudiosos de la obra literaria de este gran escritor que tanto

11 DON JUAN MANUEL, Libro de la caza, edición de José María Castro y Calvo, C.S.I.C., Bar* celona, 1945.

12 DON JUAN MANUEL, Obras completas, edición de José Manuel Blecua, Gredos, Madrid, 19811983.

13 DON JUAN MANUEL, Libro Infinido. Tratado de la Asunción de la Virgen, edición de José Manuel Blecua, Universidad, Zaragoza, 1937-1938, pp. 2-28 y 165-208. Reedición en Universidad de Granada, Granada, 1952. 
veló porque su obra llegara a nosotros de la mejor forma posible. La desgracia que impidió durante siglos que esta decisión de Don Juan Manuel tuviese frutos, por fin se veía superada.

Posteriormente, un especialista antes citado, Reinaldo Ayerbe-Chaux ha publicado en 1989 una edición de Cinco tratados ${ }^{14}$, que merece también un detenido comentario.

Reinaldo Ayerbe-Chaux ha demostrado a lo largo de numerosos artículos y algún libro anterior (El Conde Lucanor. Materia tradicional y originalidad creadora ${ }^{15}$ ) su fidelidad al estudio de Don Juan Manuel y su acertada dedicación al conocimiento del magnate y escritor castellano del siglo XIV. Por ello, no nos puede extrañar la calidad, precisión, cuidado y documentación con que ha llevado a cabo la edición de algunas de las obras de este interesante autor medieval español. En concreto se trata de cinco de sus tratados: el Libro del cavallero et del escudero, el Libro de las tres razones, el Libro enfenido, el Tratado de la Asunción de la Virgen y el Libro de la caça. Cinco obras de las que existían algunas ediciones anteriores, en las que se habían venido perpetuando errores de trascripción, excepción hecha de la gran edición de José Manuel Blecua (Madrid, 1981-1983). El procedimiento utilizado por Ayerbe-Chaux para conseguir un texto depurado y evitar los errores anteriores ha consistido en trascribir directamente del famoso Ms. 6376 de la Biblioteca Nacional de Madrid sin tener en cuenta las trascripciones realizadas por otros. Y una vez llevada a cabo, resueltos los habituales problemas paleográficos y establecida la puntuación, ha cotejado su texto con la que se considera la edición más respetada del noble castellano, la antes citada de José Manuel Blecua. A partir de ahí ha adoptado las lecturas de Blecua que ha considerado mejores, siempre que no se ha coincidido en las mismas, indicándolo en tales casos en el aparato de notas.

Precede a la edición un estudio preliminar muy completo, informativo y valioso, tanto sobre la figura de don Juan Manuel como sobre su obra partiendo de datos ya conocidos que van siendo enriquecidos con las últimas aportaciones de la bibliografía especializada y del propio autor de la edición. Ayerbe-Chaux es cuidadoso y honesto hasta el extremo de reconocer su error al haber designado en el pasado a don Juan Manuel con el título de «infante», que el noble castellano jamás ostentó. Ahora podría documentar tal aspecto consultando el estudio sobre el particular, que hice en colaboración con María Concepción Ruiz Abellán sobre «Denominación y títulos de Don Juan Manuel» ${ }^{16}$. De su reflexión sobre la personalidad de Don Juan Manuel interesa mucho su opinión sobre el lugar excepcional que ocupa el autor en la literatura medieval, ya que por su condición de político, de hombre de mundo que podríamos decir utilizando una expresión actual, su experiencia contaba mucho en sus obras.

14 Juan Manuel, Cinco Tratados. edición de Reinaldo Ayerbe-Chaux, The Hispanic Seminary for Medieval Studies, Madison, 1989.

15 Reinaldo AYERBE-CHAUX, El Conde Lucanor. Materia tradicional y originalidad creadora, Porrúa-Turranzas, Madrid, 1975.

16 Francisco Javier DÍEZ DE REVENGA y María Concepción RUIZ ABELLÁN, «Denominación y títulos de Don Juan Manuel», Miscelánea Medieval Murciana, 8, 1981, pp. 9-29. 
Mucho más amplio, original y completo es el estudio dedicado a cada uno de los cinco tratados. En el dedicado al Libro del cavallero et del escudero se plantea el análisis partiendo del fondo histórico que supone la caballería y del fondo literario que constituyen los libros de esta especialidad, para finalizar centrando el análisis de la obra en relación con la propia vida del autor y destacando que en la época más tormentosa de su existencia fue cuando don Juan Manuel escribió sus obras más conseguidas, como este Libro del cavallero et del escudero. En el de Las tres razones o Libro de las armas valora especialmente la mezcla de historia y leyenda y la «fluidez deliciosa» de la narración, mientras que en torno al Libro enfenido reivindica su importancia dentro de la obra de don Juan Manuel sobre todo por la relación planteada y tan interesante autor-obra-destinatario. Sobre el Tratado de la Asunçión de la Virgen valora su condición de documento histórico sobre las creencias religiosas de la época y su calidad de páginas últimas del autor, «dictadas por el corazón y por un tierno afecto a la Virgen». El estudio más extenso es el dedicado, por último, al Libro de la caza, encuadrado en los tratados de ceterería a que tan aficionados eran los nobles y grandes señores en la Edad Media. Plantea Ayerbe-Chaux en esta ocasión con todo detalle la cuestión de la autoría directa del libro, que atribuye, tras examinar todas las posibilidades y variados argumentos, a la cancillería del príncipe castellano, aunque advirtiendo que tal supuesto sólo es aplicable al Libro de la caza y no a obras más maduras, y más personales, como el Libro de los Estados y El Conde Lucanor.

Los textos de cada uno de los cinco tratados van acompañados de interesantes notas que atienden a dos aspectos: al textual, antes citado, y a la explicación de los textos con múltiples referencias de carácter histórico, literario, cultural y bibliográfico. Sin ser desmedido en la cuestión, el editor cuida atender a los aspectos más concretos de una forma muy sintética, de manera que no se produzca farragosa erudición, antes bien un material explicativo muy claro y conciso. Tal apartado informativo se completa con la presencia de un muy amplio glosario final, muy útil ante la dificultad que pudieran plantear algunas lecturas. Subrayemos, por último, las referencias bibliográficas que sobre los estudios en torno a don Juan Manuel realiza el editor. Son muy completas igualmente. La bibliografía en torno al autor, además de ser muy amplia, se halla dispersa por todas partes del mundo, ya que ha sido objeto de la atención de hispanistas de este y del otro lado del Atlántico. Ayerbe-Chaux ha incorporado a su obra la cita de trabajos a veces publicados en no muy difundidos medios publicísticos.

Se trata por tanto de una obra muy completa en todos sus aspectos que une, a todas las cualidades que hemos señalado de carácter científico, la grata y manejable presentación del volumen, que sin duda está contribuyendo, por todo ello, en gran manera a la difusión de la obra menos conocida del autor de El Conde Lucanor en los medios hispanísticos no sólo americanos. Ayerbe-Chaux une a su bibliografía juanmanuelina, muy estimada por la crítica precedente, esta cuidada edición que pone de relieve su buen hacer, su preparación y su inteligencia en el manejo de textos que tanta dificultad presentan para el estudioso y para el lector en general.

Nos vamos a referir, finalmente, a una edición, aun más reciente, de 1992-1994, que sirve para conocer muy bien algunos aspectos de la cultura escrita del siglo de 
Don Juan Manuel y pone a disposición de los lectores uno de los códices que contiene su Libro de Patronio o El Conde Lucanor. Estoy aludiendo a la edición del Códice de Puñonrostro ${ }^{17}$, que llevaron a cabo la Real Academia Española, la Universidad de Murcia y la Asamblea Regional en 1992 con un breve prólogo de José Manuel Blecua. A esta edición siguió la publicación de una edición y trascripción de este códice publicada en 1994 por la Asamblea y la Universidad, al cuidado de Juan Torres Fontes, Ángel Luis Molina Molina, Francisco Veas Arteseros y Juan Francisco Jiménez Alcá$z^{2}{ }^{18}$. El Códice de Puñonrostro como nos refieren sus editores es un valioso manuscrito que contiene, además de El Conde Lucanor, el texto del Sendebar, colección de cuentos mandada traducir por el Infante Don Fadrique, hermano de Alfonso X el Sabio, y tío de Don Juan Manuel. Se trata de uno de los textos de narrativa medieval en castellano más interesantes de todo el período desde el punto de vista del desarrollo de la narrativa en las literaturas modernas. Completan el códice varios textos más: una explicación del Padre Nuestro, el testamento de Alonso de Cuenca, físico del rey, una epístola de San Bernardo a San Ambrosio y un tratado de moral, religión y ciencias, en forma de diálogo. El códice puede fecharse a finales del siglo XIV.

Con todos estos textos, recientemente publicados, ya estamos en condiciones de leer a la figura más importante de la literatura peninsular de la primera mitad del siglo XIV junto al Arcipreste de Hita, un poeta, vinculado todavía al mester de clerecía, que nace a finales del siglo XIII, como Don Juan Manuel, y que deja un sólo libro, El libro de Buen Amor, joya literaria, muy diferente de la colección cuentística del sobrino de Alfonso $X$, pero coincidente en algunos puntos, especialmente en contener la herencia del relato breve, del cuento y del apólogo oriental, trasmitido a través de la cultura árabe, que, sin duda, es la mejor aportación juanmanuelina. Esa herencia conecta a Don Juan Manuel con el gran esplendor del cuento europeo del siglo XIV, cuyas máximas figuras son Giovanni Boccaccio con su Decameron y Geoffrey Chaucer con sus Cuentos de Canterbury.

Querría, para terminar esta intervención, hacer referencia, como he anunciado, a un aspecto estrictamente literario, que es muy representativo de la literatura ejercida por el Arcipreste de Hita y Don Juan Manuel. Y para ello, vamos a tomar como ejemplo, que comentaremos, una lectura, una lectura cualquiera, que naturalmente no vamos a hacer en este momento, pero que todos podemos recordar. Tomemos como ejemplo, uno de los apólogos más conocidos, el cuento XXXV de El Conde Lucanor, «De lo que aconteció a un mancebo que casó con una mujer muy fuerte y muy brava". Todos somos capaces de recordar ahora mismo el cuento. El Conde Lucanor pide a Patronio, como es habitual, que resuelva un problema de sus estados, en este caso el de un criado suyo que pretenden casarlo con una mujer muy rica pero también muy

17 Códice de Puñonrostro. El Conde Lucanor y otros textos medievales, edición de José Manuel Blecua, Real Academia Española-Universidad de Murcia-Asamblea Regional de Murcia, 1992.

18 Códice de Puñonrostro. El Conde Lucanor y otros textos medievales, edición y trascripción de Juan Torres Fontes, Ángel Luis Molina Molina, Francisco Veas Arteseros y Juan Francisco Jiménez Alcázar, Universidad de Murcia-Asamblea Regional de Murcia, 1994. 
brava. Patronio le cuenta para ayudarle un cuento, cuya tradición oriental se manifiesta desde el principio, el del «fijo de un hombre bueno que era moro», al que casaron con una mujer «muy fuerte y muy brava». La noche de bodas, el joven casado, va pidiendo de forma sucesiva a todos los animales de la casa que le den agua para las manos, y conforme cada uno de ellos (perro, gato y caballo) no lo hace, los va apuñalando y despedazando de la forma más sañuda que pudiera imaginarse, ante el espanto de la recién casada, que va poco a poco perdiendo su bravura. Cuando llega el momento en que le pide el agua a la esposa, ésta sin rechistar se la da, con lo que queda totalmente amansada y el mancebo triunfador. A la mañana siguiente, la familia conoce sin salir de su sorpresa lo sucedido, y, a los pocos días, intenta el padre de la novia, ya en su casa, mostrarse igualmente fiero con su esposa, y para ello mata, con similares intenciones, un gallo, pero la mujer le avisa que ya es demasiado tarde, "ca ya bien nos conocemos». «Et porque don Johan lo tuvo por buen enxiemplo, fízolo escribir en este libro et fizo estos versos que dicen así»:

Si al comienzo no muestras quién eres

nunca podrás después cuando quisieres.

Es este cuento del Libro de Patronio o El Conde Lucanor un producto muy de su tiempo. Las colecciones de relatos, ejemplos o apólogos, proliferan durante toda la Edad Media, siguiendo corrientes orientales y alimentándose de temas clásicos o procedentes de la propia tradición indoeuropea. El Conde Lucanor es vivo ejemplo de esta tendencia y primer libro español donde se narran los cuentos ya con un criterio artístico, con una voluntad de estilo, con un afán de perfección no sólo al escoger los relatos sino también en el momento de escribirlos. El esquema estructural del cuento de «El mancebo que casó con una mujer muy fuerte y muy brava» es idéntico a los demás aparecidos en el resto de la colección: el conde Lucanor, ante un problema planteado por el gobierno de su casa, pide consejo a su ayo Patronio, que le responde con un cuento alusivo al problema que tiene que dilucidar. Finalizará el relato con la aplicación al caso y la obtención de una moraleja expresada en un pareado final. Es claro, pues, que el afán didáctico-moral preside la narración del autor, como todas las del libro, aunque en este caso, el tema no sea propiamente moral en abstracto, sino aplicado a la conducta matrimonial ante el caso particular de la mujer brava.

Las preocupaciones de Don Juan Manuel en todo el libro responden a muy diversos asuntos: la vanidad, la hipocresía, la pobreza, los engaños que puede sufrir el ser humano. Son todos sus temas, por tanto, de carácter moral, pero don Juan los trata con singular originalidad, con rasgos muy personales y no es el menor de éstos el manejo de la ironía, y la gracia y la amabilidad marcan la temperatura de casi todos estos apólogos. Tales rasgos artísticos están patentes en este cuento, cuyo tono irónico se ve reflejado en el gusto por la hipérbole, como en los bárbaros sacrificios de los animales, descritos con inusitada plasticidad. E incluso la feliz ironía final dota al relato de indudable gracia, sobre todo en la final alusión al intento de repetir la experiencia por parte del suegro del mancebo. Constituye éste el contrapunto de la acción 
principal del cuento, logrando así completar las posibilidades morales del ejemplo —una positiva, el nuevo esposo; y otra negativa, el suegro- para llegar a la moraleja después de haber ejemplificado los dos extremos de una realidad, moraleja expresada en los dos versos que constituyen el tercer estrato narrativo, representada por la voz del narrador principal, es decir, el propio Don Juan Manuel.

Una cuestión muy interesante, y de la que se ha ocupado una muy importante biografía es la de la tradicionalidad del cuento. Por supuesto, éste se encuentra, con su historia, en colecciones de apólogos, y pertenece al folklore oriental. El origen concreto de esta historia es persa y su resonancia posterior contará nada menos que, entre otras muchas versiones, con una de las mejores comedias de William Shakespeare, The Taming of the Shrew, que hemos traducido al castellano como La doma de la bravía o La fierecilla domada. Pero también es muy interesante, quizá más, la tradicionalidad de los procedimientos y las estructuras narrativas. $Y$ a ello nos vamos a referir brevemente.

Los cuentos empiezan a hacerse presentes en la literatura castellana de la época a mediados del siglo XIII. Es de suponer que en las largas noches del invierno, en las tertulias de las grandes casas, de los campamentos militares, en las reuniones en las plazas de los pueblos, en los viajes, en los descansos en las posadas, se contasen cuentos. Y por ello, no es de extrañar que Alfonso $X$ el Sabio mandase traducir la primera colección importante de cuentos que se conoce en castellano, el libro del Calila e Dimna, ejemplo que fue seguido por su levantisco hermano el infante Don Fadrique, que mandó traducir, como ya sabemos, el Libro de los engaños e assayamientos de las mujeres o Sendebar. Tanto el Calila e Dimna como el Sendebar se caracterizan por contener relatos con estructura repetitiva, como la tiene éste de Don Juan Manuel, del "Mancebo que casó con una mujer muy fuerte e muy brava". En el Sendebar hay un cuento que tiene este mismo efecto de carambola: "Oí decir que un cazador que andaba cazando por el monte, halló en un árbol un enjambre, y tomólo y metiólo en un odre que tenía para traer su agua; y este cazador tenía un perro, y traíalo consigo; y trajo la miel a un mercader de una aldea que era cerca de aquel monte para la vender. Y cuando el cazador abrió el odre para lo mostrar al tendero, cayó de él una gota y posóse en ella una abeja; y aquel tendero tenía un gato, y dio un salto en la abeja y matóla; el perro del cazador dio un salto sobre el gato y lo mató; y vino el dueño del gato y mató al perro; y entonces levantóse el dueño del perro y mató al tendero, porque le matara el perro; y entonces vinieron los de la aldea del tendero y mataron al cazador dueño del perro y vinieron los de la aldea del cazador a los del tendero, y tomáronse unos con otros y matáronse todos, que no fincó y ninguno; y se mataron unos con otros por una gota de miel». En una carta del murciano Alonso Fajardo, ya en siglo XV, se recoge este mismo clímax de horrores o efecto carambola: "Soez cosa es un clavo y por él se pierde una herradura, y por una herradura un caballo, y por un caballo una hueste y por una hueste, una ciudad y un reino» ${ }^{19}$.

19 Sendebar, edición de José Fradejas Lebrero, Editora Nacional, Madrid, 1981, p. 91. 
En el caso del cuento de Don Juan Manuel que ahora comentamos, el diseño repetitivo nos conduce rápidamente al momento clave del relato: aquel en que para dominar a su mujer el marido pide agua para las manos a un perro, a un gato y a un caballo. Es obvio que el movimiento repetitivo podría haberse alargado si Don Juan Manuel se hubiera servido de más seres vivos, de más animales que los tenidos en cuenta: un perro, un gato y un cabalio. Pero con poderoso instinto narrativo, con gran sentido de la proporción y del ritmo del cuento, Don Juan Manuel detiene el gracioso mecanismo repetitivo justamente donde convenía ya que de haberse prolongado la lista, se hubiese descendido en el nivel de eficacia narrativa. Como un eco de ese movimiento repetitivo se nos ofrece, al final del cuento, el sacrificio del gallo por el suegro sin resultado alguno. Se trata, como yo le oí explicar a mi maestro el Profesor Mariano Baquero Goyanes ${ }^{20}$, de una especie de festiva coda o cola final que, a la par que introduce una inteligente nota humorística en el relato, refuerza la disposición repetitiva de su estructura.

El genio de Don Juan Manuel, el mismo genio que utilizó para gobernar su Adelantamiento Mayor del Reino de Murcia, le sirvió para configurar el más serio avance que se produce en la prosa literaria medieval en la Península.

20 Aunque lo referido no está en sus páginas, merece consultarse, para cuestiones de narrativa, Mariano Baquero Goyanes, "Perspectivismo en EL Conde Lucanor", Don Juan Manuel VII Centena* rio, Universidad de Murcia-Academia Alfonso X el Sabio, Murcia, 1982, pp. 27-50. 


\title{
LAS MONARQUÍAS. EUROPA OCCIDENTAL EN LA TRANSICIÓN DEL S. XIII AL S. XIV
}

\author{
Odilo ENGELS
}

Si se quieren tratar las monarquías del s. XIII como factores políticos deben considerarse los siguientes fenómenos: en primer lugar, observamos la separación del Estado de la persona del monarca que comenzó a formarse durante el $\mathrm{s}$. XII para perfilarse en el s. XIII. Si durante el s. XII la persona del rey había representado al reino, a lo largo del s. XIII este último apareció como una entidad abstracta y supra-personal. Si en un principio "la corona» representaba el símbolo material de la soberanía, luego pasó a tener un significado de símbolo abstracto. En Inglaterra y Francia la nobleza creía tener que proteger a "la corona», la arbitrariedad del rey, para favorecer a los futuros sucesores al trono. En aquel momento «la corona» representaba los medios de poder, puestos a disposición de la monarquía, con los cuales ésta se mantiene vigente. Desde entonces el monarca utilizaba «la corona» como un símbolo abstracto para definir con ella el conjunto de sus derechos. Evidentemente se mantuvo la preocupación -algo más antigua y no desinteresada, que la nobleza sentía por los medios de poder-casi equivalentes a los derechos de la corona, frente a su cambio de significado. En este sentido dicho desarrollo desembocó en Hungría hacia 1400 en la acentuada oposición de monarquía y corona, representando la corona a la totalidad de la nobleza y no al rey.

Pasamos al segundo fenómeno: el creciente conflicto monarquía-nobleza, y monarquía-ciudades. Todos sabemos que el noble hacía tiempo que estaba obligado frente al soberano al consilium et auxilium, y esto no sólo era obligación a seguir, en guerra o en asistencia al tribunal regio, sino que a su vez el monarca dependía de la aprobación de la nobleza, como por ejemplo, antes de emprender una empresa bélica o la cesión de un territorio de cierta consideración. Este equilibrio más o menos intacto, se tambaleó en el s. XIII. El soberano fortaleció el principio monárquico y adoptó los primeros rasgos absolutistas; se consideraba poseedor de todos los poderes del Estado, 
rindiendo cuentas únicamente ante Dios. La nobleza no se rebeló directamente contra estas ideologías monárquicas, pero utilizaba las debilidades y los fallos políticos del rey para la consecución de sus anhelos de participación.

El ejemplo más cercano, la corona de Aragón, es mejor conocido por ustedes. Es un particular ejemplo de la capacidad de permanencia de la nobleza. Pedro III estuvo casado con Constanza, hija de Manfredo de Sicilia. De ahí su interés por Sicilia como heredero de los Hohenstaufen. A los tres años de ascender al trono, esto le llevó a imponer a su hermano Jaime II de Mallorca las obligaciones feudales sin considerar el último testamento de su padre Jaime el Conquistador. Las Vísperas Sicilianas de 1282 fueron preparadas por él en conspiración con los magnates sicilianos; y pese a que el complot se convirtió apresuradamente en una rebelión abierta, Pedro consiguió que la isla quedara en su poder. Era de esperar que el Papa Martín IV reaccionara con la excomunión de Pedro y con el entredicho de la isla. Sin embargo, el siguiente paso de la "Curia Romana" conllevó serias dificultades, pues consistió en liberar a los ciudadanos de la corona de Aragón de su juramento de fidelidad al rey y ofrecer la corona a un hijo del rey de Francia. Jaime de Mallorca se puso inmediatamente de parte del rey francés, con lo cual las rutas marítimas de Barcelona a Sicilia quedaban amenazadas. Los altos cargos de Aragón se mantuvieron reservados frente a la política mediterránea por lo que Pedro tuvo que unir la empresa siciliana con un viaje-cruzada a Túnez. Ante esta situación, a Pedro no le quedó más elección que declarar mediante un privilegio general el reconocimiento de los derechos especiales de la nobleza aragonesa y de las ciudades, hecho que había sido demandado reiteradamente por los representantes del «Privilegio General» de octubre de 1283, decretado en Zarago$z a, y$ prestar conformidad a una convocatoria periódica de las Cortes, cuyas fechas ya no eran decisión exclusiva del soberano. De forma análoga, aunque no tan general, tuvo que acceder igualmente a las demandas de los representantes de las ciudades catalanas. El hijo de Pedro, Alfonso III, se vio obligado a dar nuevos pasos porque Castilla se aproximaba a la corona francesa, vislumbrándose con ello una guerra entre Aragón y Castilla. No sólo aprobó en las Cortes de Zaragoza de 1287 los privilegios de la Unión concedidos por su padre, que se comprometió a enfrentarse a miembros de la unión aragonesa y de las Cortes, únicamente con la conformidad de Justicia de Aragón; sino que además tuvo que aceptar la posibilidad de que la Unión pudiese derrocarle como rey por motivos legales. En mi opinión ningún otro reino evolucionó tanto en la dirección de una monarquía constitucional. Hablar en términos de fuerza o debilidad del poder real significa quizás no disponer de la adecuada escala de medida; por contra, si se toman en consideración tales hechos bajo el aspecto de colaboración interna para la consecución del equilibrio en reparto de poder, entonces, la corona de Aragón evolucionó conforme a las tendencias de aquel tiempo.

Recordemos la Carta Magna inglesa de 1215. En primer lugar, este documento persiguió el reconocimiento de los derechos que el monarca debía asegurar a los barones, teniendo en cuenta la creciente necesidad de recursos. Esto anuncia el cambio en el comportamiento entre reino, nobleza, iglesia y ciudad. La Constitución de Paper de 1244 no iniciaba orden alguno, sólo era una propuesta que insinuaba sus 
contornos. El rey Enrique III debía ser supervisado en sus negociaciones referentes al reinado por una comisión formada por barones. En las Provisiones de Oxford de 1258, Enrique debía admitir un consejo de 15 miembros, que dirigía la decisión del rey respecto los asuntos del reino inglés. Pero la oposición de la nobleza se dividió cuando el anglofrancés Simón de Monfort se puso al mando de los radicales; a su fallecimiento (1265), en la guerra civil el poder real resurgió aún con más ímpetu de entre las turbulencias. Por un lado el Estatuto de Marlborough (1267) concedía al rey la posibilidad de ejercer la soberanía sin límites ni impedimentos; por el otro lado Enrique garantizaba el mantenimiento de las audiencias de consejos apoyadas en las Provisiones de Marlborough. Así pues, las negociaciones reales, cada vez más complicadas, aumentaban las necesidades de capital del monarca, favoreciendo la disposición a comprometerse. Desde 1272 Eduardo I, hijo de Enrique, no tuvo otra alternativa que perseguir sobre esta base una política de consolidación mediante convenios, aún sin dejar de acentuar sus prerrogativas reales. Sólo así pudo soportar los años difíciles a finales del S. XIII, cuando tuvo que llevar a cabo las costosas guerras de Gales, Escocia y en la Gascuña. No tuvo tanta importancia que la Carta Magna fuera recordada de nuevo en 1297 y 1300 mediante los poderes importantes de la población. Las medidas legales de las regulaciones eran leves. No obstante, se observaba claramente una tendencia a la unión de personas que finalmente formaban las communitas regni, para lo cual fueron admitidos cada vez más representantes del commons. La función del parlamento como origen de consejo y tribunal se extendía hacia una instancia de decisión e indirectamente de control respecto a las cuestiones financieras, y sobre todo para las peticiones de individuos o comunidades.

Francia evolucionó sin obstáculos, aún mostrando una base paralela. Bajo el mandato de Luis IX, el legislativo borgoñés hizo constar en el año 1256 como único monarca de su reino al soberano francés, que no reconocía la superioridad de nadie en los asuntos mundiales; solamente él servía al bienestar público, porque la patria communis era idéntica a su reino por lo que se anteponía a la patria regional. Este concepto sobrepasó la transición al S. XIV, aunque las escalas éticas no fueron tan altas como las que vivió Luis IX. En 1247 este monarca mandaba comisarios a todas las regiones del reino para controlar las actividades de los bailes y de los funcionarios reales con el fin de solventar malentendidos. La repetición anual de dichas visitas intensificaban la reforma del sistema, que quedó reflejado en las ordenanzas sobre obligaciones de los bailes y de la Sennenschale de 1254 y 1256 . No sólo en este caso el rey obraba sin consultar con los barones convencido de que sus deseos coincidían con el bienestar común. Al igual que las ordenanzas del emperador Federico II éstas seguían tratando asuntos morales como juegos de azar o blasfemias y sobre todo particularidades legales como la sustitución del duelo por el procedimiento de inquisición. Estas medidas sólo eran válidas en el reino. Aún así se sobrepasó la frontera, pues se podía apelar al parlamento por falseamiento o negación de derechos en el territorio de un vasallo. En un principio, Luis no violó la juridicialización, pero las numerosas posibilidades de apelar directamente ante el rey reducía notablemente el peso de sus señorías. A esto se suma la formación de los legisladores, sobre todo, aquellos 
juristas formados según el derecho romano. Su creciente número permitió, desde Felipe IV, la organización de cámaras; por consiguiente se consumó paso a paso la separación del poder ejecutivo y la administración. Para que la dirección no pudiese dependizar al soberano, se modificó la "curia regis" mediante su extensión a nuevos grupos, como las ciudades. Cuando se convocaban, era decisión del rey; los participantes de las reuniones se unían en representación de su états; las proposiciones del rey eran asesoradas por separado, al igual que las exposiciones de las conclusiones. Estas últimas no tenían por qué ser aprobadas por el monarca. En comparación con Inglaterra, el monarca francés disfrutaba de un campo de actuación mucho más amplio.

La evolución en Castilla habría sido semejante si la relación con la nobleza no hubiese sido tan tensa. En la Guyenne se formaba una residencia armada, y en Flandes en 1302, un ejército nacional formado por fuerzas ciudadanas se rebelaba destruyendo un ejército real de caballeros. A continuación se han de tener en cuenta las alianzas entre la nobleza por la defensa del centralismo real; pero el sistema de ordenanza sufrió una crisis amenazante en Francia motivada por la guerra de los Cien años a mediados del s. XIV. En Castilla, en cambio, todo pareció ocurrir medio siglo antes. Como personaje clave destaca Alfonso $X$ el Sabio quien se consideraba representante de Dios y sostenía ya pensamientos que Juan Gil de Zamora manifestaba poco después ante Sancho IV. El rey se encontraba entre Dios y el hombre, Dios le ofreció a él los imperios, por lo cual podía esperar de sus habitantes obediencia absoluta y disposición de sacrificio hasta la muerte. No fue el fecho del imperio lo que le trajo dificultades con la nobleza, sino la legislación. La antigua nobleza - como la denominaba Salvador de Moxó- se diferenciaba antes del s. XII por basar su autoridad en dominio y laboriosidad lejos de la corte; pero bajo el imperio de Alfonso VIII tuvo que reunir sus antiguos derechos en el «Fuero viejo". Alfonso $X$ se impuso a esto redactando en 1265 el prólogo y el primer tomo del "Libro del Fuero" de Fernando III con el sentido de aumento de las competencias del poder del rey, sin tomar por ello contacto con la nobleza. Ante este hecho, se encontró con una creciente protesta hasta que en 1272 tuvo que retirar su versión por reconocimiento expreso de los antiguos privilegios. El Orden del rey estaba acompañado de medidas económico-políticas que favorecían a las ciudades en perjuicio de la nobleza, porque amenazaban con romper las estructuras tradicionales monárquicas. Lo mismo sucedía con las medidas de centralización, la curia regis fue transformada en una administración jurídica de la corte y hacia los intereses de la autoridad, la administración financiera fue racionalizada y la administración territorial totalmente reorganizada. Pero no sólo esto llevó a las rebeliones de la nobleza, sino también una lealtad menguante entre las potentes familias nobles. El cambiante comportamiento de Castilla con la corona de Aragón estaba cargado de peligro hacia un pacto entre el monarca y una significativa familia noble o grupo de nobles para perjudicar al monarca. Esta inseguridad culminó en 1275, cuando el futuro sucesor del trono, Fernando de la Cerda, cayó en la batalla contra los moros, y Alfonso $X$ no tuvo en cuenta la descendencia de éste, tal como lo había previsto la corte de Palencia de 1253, sino a su segundo hijo Sancho IV. Como la familia de los Lara apoyaba a los hijos de Fernando, Sancho se afilió con los Haro, rivales de 
los Lara; ya que Haro como soberano de Vizcaya podía darle la oportunidad a Sancho de tomar influencia en el reino de Navarra, el rey de Francia se puso a disposición de los Lara. Con ello el reinado se rebajó literalmente a liderar a una de las partes en la guerra civil. Aún fue peor, porque Alfonso creía tener que ser flexible ante los consejos del rey francés después de que las Cortes de Segovia reconocieran a Sancho como futuro sucesor de la Corona, consideró sus medidas de centralización por transigencia y pensó en el reparto del reino entre Sancho y los hijos de Fernando de la Cerda. Lo único consecuente era que en 1282 en Valladolid Sancho destituyó del cargo a su padre por incapacidad. Por consiguiente, Alfonso desheredó a su hijo y nombró sucesor a su hijo mayor, Fernando, con lo cual demostró lo inútil que había sido su política en los últimos siete años.

Aunque Sancho IV acabó imponiéndose, la cuestión de la sucesión legítima del trono no fue resuelta, y ésto pronunciaba la oposición entre los Haro y los Lara. Desde el punto de vista del s. XIII se podría lamentar que las diferencias, dentro de la familia real, por la inclusión de la nobleza, no permitían al reino llegar a la estabilidad. Desde el punto de vista del s. XIV se reconoce en las turbulencias del saliente s. XIII un comienzo, convertir la nobleza en corte, también llamada «nueva nobleza», que se estableció como servicio en la corte. Para ello se necesitaba en Castilla la nueva dinastía de los Trastámara, que no se vio atacada por la dichosa cuestión del sucesor del trono. Pero no sólo eso, importante fue también la decisión de la evidencia soberana. Se debe conceder el mérito a la monarca María de Molina por haber guardado la corona intacta a su hijo Fernando IV, pero no pudo remediar que, por miedo a perder sus privilegios y en vista de la unión de las ciudades en Hermandades para la mayor fuerza de imposición, que la nobleza sustituyera a los funcionarios reales por representantes propios. Sin tener en cuenta el peligro de caer en una dependencia total, debía surgir la cuestión de la postura del rey en sentido no absolutista. Juan Manuel, un sobrino de Alfonso $X$, no dudaba de la delegación de Dios a través de un monarca y de la obligación de la nobleza respecto de él, pero ésta tenía un derecho, rebelarse contra el rey cuando existiera una gran pérdida de su honor o naciera un daño por su obligación de lealtad. Aquí se presuponía la igualdad de los hombres ante Dios, que permite únicamente diferentes obligaciones dentro de una sociedad, para las cuales existía una misión especial y natural. De esta manera tan moderada, casi humilde de formular estos pensamientos, justificaron la idoneidad del cargo del rey, y efectivamente, Enrique de Trastámara utilizó más tarde este argumento en la toma de la corona.

Pero la teoría del reinado de Castilla no llegó tan lejos como el «Pactismo» de la corona de Aragón. En su obra más importante «Lo Crestià» el franciscano valenciano Francesc Eiximenis subordinó al rey a las leyes y encontró en las Cortes el órgano en cuya jurisdicción caía el poder de veredicto y castigo en caso de incumplimiento de las leyes por parte del soberano, ya que éstas convirtieron al rey en su monarca y así podían destituirlo. Según su punto de vista el núcleo de las Cortes estaba formado por la totalidad de las ciudades; en las regiones valenciano-catalanas dominaba casi una tendencia republicana. En Castilla en cambio se consideró la violenta supresión de 
Pedro el Cruel mediante un tiranicidio como salida excepcional. Ya la reducción de las asambleas populares a cabildos, con los funcionarios reales como regidores en segundo plano, reducción realizada por Alfonso XI con el fin de favorecer un control estabilizado desde la Corte, muestra claràmente cómo se interrumpió el camino hacia una monarquía constitucional.

Para demostrar que las tensiones internas no eran sólo consecuencia del constante crecimiento de necesidades financieras y de una administración cada vez más complicada, deberíamos considerar al papado de aquellos tiempos. Como el papado tenía los mismos ideales monárquicos que los soberanos de aquel entonces, no es de extrañar que apoyara a ciertos monarcas en sus diferencias con la nobleza. Aquí debe bastar con el ejemplo de Navarra. Con el fuerte aumento del «Fuero Antiguo", creado en 1238 como meta, tuvo Teobaldo II que jurar en 1253 antes de su proclamación que respetaría todos los derechos y libertades de los habitantes y anularía todas las injusticias implantadas por sus antecesores. Solamente después de su juramento los navarros estaban dispuestos a hacer su juramento de fidelidad. Si además se le acerca a la justificación histórica de los «Fueros Generales», de que los montanyeses hubieron reconquistado su país con sus propios medios a los sarracenos y luego elegido un rey, que primero tuvo que jurar sus derechos, entonces el monarca aparece, independientemente a la monarquía hereditaria, como un delegado del pueblo. Fue razón suficiente para el Papa Inocencio IV para tomar en 1255 a Teobaldo II bajo su protección y autorizar al obispo a desligar al rey del juramento de la coronación, con lo cual se reducía la capacidad del ejercicio de su cargo.

Precisamente Inocencio IV mostraba comprensión por la difícil situación del rey de Navarra; él mismo no nombró ningún cardenal durante su pontificado, porque éstos ya no se consideraban como súbditos del cargo papal. Con ello surgió paulatinamente un contrapeso al plenitudo potestati. Ya bajo Inocencio III los canonistas pedían un cambio en el comportamiento de la autoridad y en el nombramiento del Papa. ¿Acaso justificaba la ilimitada autoridad del Papa poder conceder permisos según le venían en gana, o debía respetar las normas del plenitudo potestati en cada nombramiento. Inocencio IV, excelente jurista, desarrolló a partir de un ejemplo de la historia de Aragón una primera solución: los religiosos hacían votos de pobreza y soltería según mandaban las reglas de su orden. El Papa podía dispensar de esto si la boda del monje fuera la única solución para continuar la dinastía. Las utilitas de la generalidad podían anteponerse al bonum individual del voto. Inocencio sólo podía llegar a esta conclusión porque diferenciaba muy bien entre derecho divino, derecho natural y derecho positivo. Los decretalistas entre los canonistas, defensores activos de la autoridad papal, encontraron en los decretistas, que se consideraban como las fuentes principales de las decisiones del concilio, un competidor con posiciones contrarias. Éstos perseguían la idea que el Vicarius Christi fuera una fuente de derechos ilimitada, en que quedan recogidos todos los derechos positivos; éstos se hacían cargo de difundir aspectos morales como otros criterios de conclusión. Desde siempre debía cuestionarse ante el otorgamiento de una dispensa si la decisión estaba permitida, si era adecuada y si servía al amor, para que correspondiera a las utilitas. El tercer punto, las caritas. Éstas 
eran cada vez más importantes porque asociados al scandalum resultaban negativas. Si un obispo antepusiera una peregrinación, cuya finalidad se había perdido prematuramente desde le punto de vista de las Utilitas formales, podría argumentarse una dispensa, pero no se podría remediar la impresión de un scandalum si se tratara de un novicio. En tal caso por el amor al prójimo se concibe una dispensa.

Un amplio consenso entre decretalistas y decretistas se encontró a lo largo del s. $X V$. En estos tiempos los cardenales volvieron a encontrar el camino a la reducida escala de su declaración. Una característica de la idealización del Papa es la amenaza de independencia de éste por seguir, medidas positivistas. Otra característica es volver a llevarla a su origen adaptándola a su correspondiente estructura. Con ello se reflejaba la crisis con sus motivaciones opuestas en las monarquías occidentales. Intentando reunir todo ello en un punto, la crisis queda reducida a la oposición entre la persistencia del derecho consagrado y la cuestión de si la autoridad o la institución es capaz de realizar una función práctica, y en qué medida.

Debemos tener en cuenta un tercer fenómeno: la casa real. No es igualable a una dinastía y tampoco es idéntica al reino. Como ejemplo, la corona de Aragón, donde antes se formaron los elementos de una casa real. Pero tanto ella, la corona de Aragón, como los reyes de Castilla, antes de los Trastámara, carecía de un identificativo dinástico que reuniese a todos los miembros, como por ejemplo, Kapetinger, Habsburger, Plantagenet, etc...

Comencemos aun así por la corona de Aragón. Ya en el s. XII, después del que Ramón Berenguer III adquiriese el condado de Provenza mediante su boda en 1112, la manera de pensar en las casas nobles de los condes de Barcelona jugó un papel importante. Así pues, de aquí en adelante, valía como una provisión para el segundo hijo, con derecho a reversión del cargo principal, en caso de que la familia se quedase sin herencia. La casa de Barcelona perdió prácticamente la Provenza cuando en 1245 Beatriz de Provenza, hija heredera, contrajo matrimonio con el hermano del rey Carlos de Anjou y éste le jurase fidelidad. En 1137 se constituyó la unión de Aragón y Cataluña. Mientras Ramón Berenguer vivía, la futura relación legal de la dos naciones quedaba indefinida. Ya porque el conde de Barcelona como princeps era solamente el delegado de su esposa Petronila, era inimaginable que las estructuras internas de los dos países se asemejaran. Pero tampoco se intentó realizar tal acercamiento bajo el reinado de Alfonso II, ya que al parecer la idiosincrasia de las dos naciones de la Corona era independiente de las características biológicas de las familias soberanas en sentido de una institución suprapersonal. El estado todavía en auge de la casa noble era incapaz de homologar los diferentes documentos legales, aun procediendo de territorios vecinos. Sólo así se puede entender la inhabitual transición de Ramón Berenguer IV a Alfonso II. Ramón Berenguer asignó a su hijo mayor, también llamado Ramón, en el testamento Aragón y Cataluña, y a su hijo segundo Pedro el condado de Rosellón y Cerdeña así como los derechos sobre Carcascana y Narbona. En cambio Petronila pensaba en el destino de la dignidad real de su casa paterna, porque en su testamento de 1164 llamó a su mayor Ildefonsus, y al que el padre llamaba Pedro, apareció con el nombre de Ramón Berenguer. Inequívocamente los dos hijos, de la casa de Barce- 
lona y de la casa de Aragón, debían seguir siendo los dirigentes; para el padre la tradición de Barcelona tenía prioridad, en cambio la madre pensaba con más previsión. Con los cambios de nombre en relación a los dos países, Aragón, con su dignidad consagrada no sólo recibía prioridad, sino también cambió el nombre de Pedro por Alfonso. Pedro debío recordar al Batallador cuando este legó su reino impropiamente a las Órdenes Militares, cosa que también podía haberse tenido en cuenta para la elección del nombre de Ramiro, padre de Petronila; aunque éste como religioso debió haberse dispuesto para la continuación de la dinastía ya que también resultaba idóneo para un recuerdo glorioso. Al menos en la casa real se observaba una fusión que creó un símbolo estable. Hasta entonces San Juan de la Peña era para los reyes de Aragón sinónimo de sepultura y Ripoll para los condes catalanes, sobre todo para la casa de Barcelona. En cambio Alfonso II creó en Poblet un monumento fúnebre para todos los monarcas de la Corona.

Elegir Poblet, en el obispado de Tarragona, no fue mera coincidencia. En 1170 Alfonso Il le escribió a Guillermo de Tarragona que la ciudad de Tarragona caput totius regni mei fore dinoscitur..., qui eam destruit, caput meum destruit. Esto parece ser la clave de la estructura interna de la corona de Aragón. Pocos años antes de la muerte de Ramón Berenguer IV se establecieron apostólicamente las fronteras de la provincia eclesiástica de Tarragona. Se orientaban, con pocas excepciones, según los límites de Tarraconensis de la antigüedad tardía. Su parte norte, que pertenecía a la provincia eclesiástica de Narbona, se agregaba a la casa de Barcelona; molestamente se desviaba a la frontera provincial para no dividir el condado de Cerdeña. Esto también explica la situación de Mallorca. Jaime I legó en su último testamento la isla como reino propio de su hijo, también llamado Jaime, y le concedió poderes de la corona al norte de las cimas de los Pirineos. Jaime II debía poseer las partes en tierra firme como feudo de los condes de Barcelona, y sin dependencia feudal las islas de Mallorca y Menorca. Aunque en el año 483 tuvieron obispo propio no fue así en las listas de firma del Collectio Hispana. La jurisdicción de aquellos lugares fue prometida mediante privilegios papales en 898 al obispo de Gerona y en 1068 al obispo de Barcelona. Después de la reconquista de Mallorca, Jaime l estableció una sede episcopal en Palma, mientras que los obispos de Tarragona, Barcelona y Gerona bloquearon mutuamente sus derechos sobre Mallorca mediante una inútil disputa y el Papa estaba dispuesto a ligar el nuevo obispado inmediatamente a la sede papal. Cuando la causa siciliana envió ayuda, el camino hacia un reinado independiente mallorquín quedaba abierto. Pero la idea del derecho sobre la casa era tan fuerte que Pedro III indicó con el poder de sus títulos un rex Maioricarum en 1276 un día antes de su coronación en Zaragoza; esto es, agregó Mallorca a la corona de Aragón, y en 1276 obligó a su hermano con el contrato de Montpellier a reconocer su dependencia feudal. En el s. XIV el feudo al parecer y en vista de su extensión a Cerdeña y Córcega, ofrecía poca seguridad; además el contrato de unión de 1309 concedía la soberanía sobre Aragón, Cataluña y Valencia a una única persona, por lo cual en 1349 a través de Pedro se sometía Mallorca eliminándose como reino. De aquí en adelante se representaba su población en las Cortes de Barcelona. 
De esta manera Sicilia perduraba como única línea colateral de la casa de Barcelona hasta que Martín, por entonces rey de Sicilia, tomaba en 1396 la corona de Aragón tras la repentina muerte de su hermano Juan I y unificaba en 1409 en Sicilia la isla a la Corona tras la muerte de su hijo Juan. Las vísperas sicilianas de 1282 están en relación causal con Carlos I de Anjou. Éste hermano del rey francés Luis IX es un claro ejemplo de la defensa del establecimiento de una casa real de rango superior. El condado de Anjou que Felipe IX arrebató en 1204 en unión con el condado de Maine de los Plantagenets constituyó el punto de partida de un reino disperso formado por elementos pertenecientes a distintas bases jurídicas. Anjou tuvo en 1246 a su hermano Carlos como vasallo de la Corona cuando se casó con Beatriz, hija heredera de la Provenza. La ya esperada adquisición de Provenza - situada en el Imperio y perteneciente a la casa de Barcelona- debía ser ligada a los paisajes franceses. Carlos aún no se disponía a desligarse de la casa real francesa; llevaba en su emblema a lo largo de su vida los lírios dorados de los Anjou, que como Anjou, representaba también las posteriores ramificaciones en los Balcanes y en Hungría, aunque ya no tenía nada que ver con el condado francés. La autocomprensión se transformaba de la misma manera que el punto esencial de la soberanía de la Provenza se trasladaba a Italia. En 1253 se le ofreció a Carlos por primera vez el reinado de Sicilia, pero en el sur de Italia aún mandaban los Hohenstaufen y los papas negociaban con la corte real inglesa por encargo de Sicilia, atrasando así la llegada de la corona de Sicilia hasta 1266. En Roma la simpatía por los Anjou no era uniforme; por eso Carlos se preocupaba por obtener fama entre los senadores en Roma, que finalmente consiguió en 1268 tras el triunfo sobre los Conrados, y que tras varios asaltos también obtuvo en 1269 del Papa por la vicaría del Imperio de los Toscana. Proclamar rey de Cerdeña a su segundo hijo debía haber sido una medida de resistencia contra Jaime II, pero el compromiso matrimonial de Carlos de Salerno con la hija heredera de Esteban IV de Hungría y el del heredero de la corona húngara Ladislao con la tercera hija de Carlos de Anjou debía provocar presión sobre Bizancio, pero que esto iniciara la línea colateral húngara de los Anjou no se podía saber. Al mismo tiempo Carlos hacía planes matrimoniales con los monarcas de Siberia y Bulgaria casando en 1271 a su hijo Felipe, rey de Cerdeña, con la hija heredera de los condes de Achaia. Tras la muerte del basileo Miguel II en 1272 los habitantes de Albania aceptaron a Carlos como siguiente rey, con lo que se fijó la posterior línea albánica de los Anjou. Se puede observar como fue cercado sistemáticamente Bizancio; y de hecho en 1273 Beatriz, segunda hija de Carlos, tuvo que casarse con el hijo mayor del emperador titular latino de Constantinopla. No es de extrañar que los bizantinos afrontaban en 1274 la demanda de la unión eclesiástica, lo que significaba un mayor apoyo contra los Anjou. Pero para Carlos, Bizancio no era el propósito definitivo, sino Jerusalén; pues Carlos compró a principios del año 1277 a María de Antioquía, que buscaba hacer valer sus derechos contra el rey Hugo III de Chipre ante la corona de Jerusalén, este título. No era más que un título, pero tenía un gran valor ideológico para los Anjou.

Carlos de Anjou se hizo cargo del regnum siciliano a expensas de los Hohenstaufen. Lo que el papado no podía prever, es que Carlos no se hizo cargo sólo del reino, sino 
también de la supraestructura ideológica; esto equivale a ser la última estación antes del salto sobre el mar hasta tierra santa. La cruzada del emperador Enrique IV, y sobre todo la de su hijo Federico II no servía tanto a la liberación de la tumba santa, como al cumplimiento de la profecía del emperador en la antigüedad tardía. En la visita de Federico II al santo sepulcro, éste inició el comienzo del imperio mesiano y de la era de paz escatológica. A diferencia de Federico II, no hubo declaraciones en esta dirección por parte de Carlos de Anjou, pero estos pensamientos no eran inusuales en los contemporáneos de la segunda mitad del s. XIII, y mediante ello también pusieron en contacto a miembros de la casa de Barcelona.

Para poder enfrentrarse con las mismas armas a Alfonso $X$ de Castilla, que como nieto del rey Felipe de Suabia tenía derecho sobre la herencia de los Hohenstaufen, Jaime I casó en 1262 a su hijo Pedro, sucesor del trono con Constanża, hija del rey Manfredo. Como se mostró varios años después, era la única superviviente heredera de los Hohenstaufen y supuso hasta cierto punto la legitimación para la adquisición de Sicilia, que fue tomada en el s. XII como objetivo. La víspera siciliana era el vehículo decisivo que paró la expansión de los Anjou y facilitó la supremacía de la casa de Barcelona, aunque el papado hizo todo lo posible por eliminar la dinastía de los Hohenstaufen. Lo que es menos conocido es que todo este proceso mostró también la parte de la vertiente del derecho familiar. Debe destacarse que Jaime II de Aragón consiguió en 1297 la investidura del reino de Cerdeña de Bonifacio VII y su hermano Federico III de Sicilia accedió a la petición de ayuda basilea, estableció en la vecindad de Achaia los ducados de Atenas y Neopatra e impuso, en contra de la voluntad de la compañía catalana, la liga feudal de los dos ducados al reino de Sicilia. ¿Es absurda la suposición de poder ver en parte un cuidadoso traspaso del entendimiento de la casa de Anjou. ¿O, mejor dicho, apropiarse del mundo imaginado por los Hohenstaufen? Porque, en cierta manera, ese tuvo que ser también el modelo de Cortes de Anjou.

Ya el nombre Federico es digno de atención. Era un nombre característico de los Hohenstaufen, que de los hermanos menores de Alfonso $X$, salvo Enrique, llevaba Federico, llamado Fradique, quién luchó al lado de Manfredo en 1266, y después de la derrota de Benevent huyó a Túnez, y de allí regresa a Sicilia, maquinando en 1267 una, para los Anjou, peligrosa revuelta. El hermano de éste, Jaime II, no quería libertarle en 1291 para Sicilia cuando él mismo tuvo que subir al trono a Alfonso III; Sicilia debía quedar directamente unida a la corona de Aragón, pero la tuvo que rechazar totalmente en 1295 en el tratado de Anagni, para evitar tanto la excomunión papal como la presión francesa y castellana, la isla de Sicilia en beneficio del poder papal. Se le adjudicó como número de orden III, lo cual como rey de Sicilia no le correspondía en absoluto. El número de orden II le correspondía al Hohenstaufen Federico, por su Kaiserorgnung. En ése número de orden también debía pensar Federico III, al que el día de su coronación al almirante aragonés Roger de Lauria, ante los estamentos sicilianos, declaró ser aquel Federico del que las profecías hablaban como Advenimiento y Señor del Imperio y de la mayor parte de la Tierra. Él por su parte se manifestaba en favor de la paz y la Concordia de la Cristiandad, con el fin de reconquistar la tierra santa. Escribió a su hermano Jaime II con la certeza de que el hundimiento 
del linaje galo de los Anjou estaba cercano. Esto es comprensible por el transfondo escatológico con la espera del fin del mundo. El franciscano Petrus Johannis Olivi denomina ya poco antes de 1298 a Federico Il como el «último emperador», que había perseguido a la Iglesia y volvería a perseguirla, si como afirmaban distintas profecías, resucitaba. Incluso Alfonso $X$ de Castilla fue insultado como anticristo por Gerardo de San Donnino, porque fluía sangre de los Hohenstaufen por sus venas. En el lado opuesto Federico II era considerado como un reformador de una iglesia desmoralizada, y a ella apelaba Federico III seguramente con un peyorativo dedo índice señalando a los Anjou. Pues también ellos habían sido incluidos en la espera del fin del mundo y precisamente como contrafigura de los Hohenstaufen. Ya que el canónigo de Colonia, Alejandro de Roes escribía hacia 1281 que del linaje de Carlomagno y de la casa real francesa surgiría un emperador llamado Carlos, que dominaría toda Europa y renovaría tanto al reino como a la iglesia. Después de él nadie reinaría, pues habría llegado el fin del mundo.

Carlos I de Anjou fue bautizado con el nombre de Esteban, tuvo que aceptar el nombre de Carlos aun antes de la adquisición del condado de Provenza, por lo visto porque debía resaltar la tardía inclusión de los Kapetinger en la descendencia de los carolingnos. Ya de manera modificada aparece este motivo en el año 1281. El nieto de Carlos se llamó Carlos Martell nombrado así —como así se pensó entonces- en memoria del patriarca de los carolignos. Y Carlos Martell se casó con Clemencia, la hija del rey alemán Rodolfo de Austria. Sobre todo traía la desposada el regnum Arelatense como dote, formalmente todavía en reino del Imperio, que a largo plazo debía proporcionar a los Anjou un paso al Imperio occidental.

Los franceses y Carlos de Anjou estaban acostumbrados a la sucesión hereditaria, pero el Imperio occidental era un imperio electivo, a lo que justamente en aquella década daban gran importancia los príncipes electores. Le negaron al rey alemán el dinero para un viaje a Roma para su coronación imperial, ya que al emperador electo no se le podía negar la elección de su hijo como sucesor. Pero el círculo de candidatos era limitado, ya que sólo entraban candidatos de linaje aptos para ser reyes. Por ello sólo se turnaban los Austria, los Wittelsbacher y los Luxemburgo en la posesión de la corona alemana. Los Austria descienden de Rodolfo de Rhreinfelden, el antirey del emperador Enrique IV; pero esto debió ser subrayado claramente, ya que el otro candidato a la elección de 1273, Otocar de Bohemia, incluso se había burlado de la insignificancia de los Austria. Por ello en las vísperas de la coronación, Rodolfo de Austria cambió el nombre de su esposa e hija, ambas llamadas Gertrudis, a Inés y Ana respectivamente; pues así se llamaban en 1218 las últimas herederas de la casa ducal de Zähringer, que había heredado en el s. XI de Rodolfo de Rheinfelden, quién había sido bendecido con una hija. Algo parecido observamos en la casa de los Luxenburgo. Carlos IV fue bautizado bajo el nombre de Wenceslao en 1316, y utilizó reiteradas veces este nombre como rey de Bohemia; pero en 1323, cuando fue desposado en París con la hija de Carlos de Valois, tomó el nombre de Carlos, probablemente porque tanto su padre, el rey Juan de Bohemia, hijo del emperador Enrique VII, como también su suegro aspiraban a conseguir la corona imperial, por lo que podía 
confiar en aspirar a dicha corona imperial algún día. El nuevo nombre señala sin lugar a dudas a Carlomago. En 1347 Carlos IV recibió en Praga la corona del Santo Wescenlao, a la que nunca renunció, y se hizo nombrar rey de Alemania en 1349 en Frankfurt, y un mes después se hizo coronar en Aquisgrán. En memoria de su elección hizo instalar en una pared libre de adornos de la catedral de Frankfurt situada a la derecha del coro, por encima de los asiento, una representación metafórica de Carlomagno y justo enfrente, a la izquierda del coro, a sí mismo. De camino a Aquisgrán hizo erigir una estatua de Carlomagno en la torre sur de la catedral de Colonia, y en Aquisgrán encargó la construcción de un coro gótico en la vieja iglesia imperial de los carolingios, imitando a la Chapelle Royal de Paris. Se había hecho artificialmente un descendiente de los carolingios, lo mismo que ya hiciere Carlos de Anjou cien años antes.

Algo más fácil lo tuvo la casa de Wittelsbach. De su casa ducal bávara descendía Isabel, esposa del rey Conrado IV, inmediato sucesor de Federico II. Poco después del nacimiento de Conradín, último heredero masculino de los Hohenstaufen, murió Conrado, en 1258 y la viuda de éste se casó con el conde del Tirol. Conradín quedó bajo la tutela de los Wittelbacher bávaros, que se sentían los protectores del legado alemán de los Hohenstaufen en el sur de Italia. Los Wittelsbacher le prometieron ayudar a formar su ejército, así como administrar sus bienes y territorios en el sur de Alemania en su ausencia, si éste les legaba los títulos de esa zona en caso de que Conradín que por aquel entonces no tenía hijos legítimos no regresase vivo de la atrevida empresa de Italia. Como esto de hecho ocurrió, pudieron considerarse realmente como continuación de la casa de Hohenstaufen.

Todo esto parece algo aventuresco, pues la consanguinidad ya solo juega un papel parcial en esta manera de pensar y querer hacer política. El derecho familiar abarcaba más, la sucesión en el cargo o la toma de posesión de una gran parte del legado material podía sustituir o suplir la escasez de consanguinidad. Los Austria fueron los que más lejos llevaron esta práctica, difundiendo hacia 1300 la leyenda de que descendían los de Colonna, sabiendo que éstos ya afirmaron en el s. XI ser descendientes de la casa imperial juliana, esto es, descender del César. Cuanto más alta era la meta política más atractivo debía ser el modelo de una casa soberana más antigua que legitimara el incremento de dignidad y en el incremento de la extensión territorial.

A raíz de los tres fenómenos observamos dos tendencias históricas de las instituciones, que se hicieron notables en toda Europa occidental a lo largo de toda la Alta Edad Media. Por un lado vemos la transpersonalización del reinado en reinados regionales, que se manifiesta en que el monarca debía compartir parcialmente su derecho a gobernar la población. En tanto en cuanto en esto existe el germen de la soberanía popular, dicha tendencia tendrá, desde un punto de vista histórico, un gran futuro. Por otro lado dicha característica suprapersonal dificulta la variación de las fronteras; el paso de Alicante del reino de Murcia al reino de Valencia —estudiado detenidamente por Juan Manuel del Estal- o la incorporación de Mallorca al principado catalán parecen ser más bien excepciones a esta tendencia. Sobre esto destaca - esto sería lo segundo- la parte dinástica del soberano, que aporta a la participación periférica de 
la población en el gobierno una mayor movilidad y sobre todo un radio de acción realmente europeo. Sólo el hecho de que la variedad de títulos legales pudieron ser implantados en otro plano jurídico sin cambios, permitió la creación de grandes reinos, por ejemplo desde la Provenza hasta los Balcanes del cercano Oriente, o desde el condado de Luxemburgo, entre la frontera franco-alemana, pasando por Bohemia hasta Polonia y Hungría, o desde el alto Rín pasando por Austria hacia Bohemia y Hungría. Aquí se miraba hacia atrás, pues se necesitaba la legitimación dada por una destacada personalidad de la historia, que se tratara como si fuera el fundador del linaje. Estas dos actitudes, una mirando al pasado y otra al futuro, es naturalmente propia de todas las épocas pero nunca en los extremos en los que se manifestó en la alta Edad Media de los s. XIII y s. XIV.

Traducción: Victoria Miralles 



\title{
EL ITINERARIO DE JAIME II DE ARAGÓN EN LA CONQUISTA DEL REINO CASTELLANO DE MURCIA (1296-1301)
}

\author{
Juan Manuel DEL ESTAL GUTIÉRREZ
}

Universidad de Alicante

El desarrollo de este tema admite la posibilidad de dos tratamientos diferentes. Uno: el seguimiento documental, día a día, de las andanzas y quehacer del monarca, Jaime II de Aragón, a través de los documentos reales de su cancillería (Registros, Cartas Reales y Pergaminos) del quinquenio empleado en la conquista y sometimiento casi total del Reino castellano de Murcia (1296-1301).

Y otro: el estudio y exposición de la importancia y necesidad historiográfica del mismo; la metodología y mecánica seguidas en su elaboración; y, por último, su especial interés y utilidad singular para el correcto seguimiento puntual de la campaña militar aragonesa antedicha. El camino por el que hemos optado ha sido el de la fusión de entrambos extremos apuntados, cuidando de subrayar en un amplio Anexo documental los sucesos de mayor relevancia e interés al respecto.

\section{IMPORTANCIA Y NECESIDAD DEL CITADO ITINERARIO}

EI ITINERARIO de Jaime II de Aragón viene constituyendo lamentablemente una laguna inexcusable en la historiografía medieval de aquella corona.

Es curioso constatar cómo Jaime $\mathrm{ll}$, que fue uno de los monarcas más sobresalientes en la política territorial expansionista de la Casa de Aragón, por la conquista y anexión a la misma de los Reinos de Murcia y de Cerdeña, más los Ducados de Neopatria y Atenas, siga hasta la fecha todavía sin contar con la publicación de su propio Itinerario.

Y es aun más sorprendente todavía que no cuente siquiera con la publicación al 
menos de algún Itinerario parcial, como su propio padre, Pedro III el Grande, con el de sus Viajes a Berbería y Sicilia, y su mismo nieto, Pedro IV el Ceremonioso, con el Itinerario de su viaje a Cerdeña o el de antes de ceñir la corona, el Itinerario del Infante Pedro.

$\mathrm{Y}$ Jaime II de Aragón pudo haber sido muy bien objeto de numerosos Itinerarios parciales, como el correspondiente, por citar tan solo unos pocos, a la Conquista y anexión del reino castellano de Murcia a la corona de Aragón (1296-1304),tema que hoy ocupa la atención principal de este Congreso; o el de la Infeudación papal del reino de Cerdeña a Jaime II de Aragón por Bonifacio VIII (1297) y el de su Conquista ulterior (1324 y años siguientes) por su hijo el Infante D.Alfonso, gracias a la singular ayuda paterna armada; o el Itinerario de su viaje a Roma y firma del Tratado de Anagni (1297/98), con el papa Bonifacio VIII, Felipe IV de Francia y el rey de Nápoles, Carlos II de Anjou ${ }_{3}$ o el Itinerario de su expedición marítima a Sicilia, contra su rey, Federico III, su hermano, en cumplimiento de lo estipulado en el citado Tratado de Anagni, en el que Jaime II se comprometió a arrebatar el reino de Sicilia a su hermano y devolverlo a la Iglesia Romana, a cambio de la susodicha infeudación papal del reino de Cerdeña, periplo que ocupó bien catorce meses (1298/99) al monarca aragonés, aunque infructuosamente; $y$, por último, entre tantos otros posible Itinerarios parciales, el Itinerario de las negociaciones castallano-aragonesas en agosto del 1304 y mayo del 1305, encaminadas, como es sabido, a poner fin a la ya larga contienda armada entre ambas coronas, mediante el Fallo Arbitral de Torrellas y el Acuerdo de Elche.

Pero ninguno de los referidos períodos, así como otros muchos de su largo reinado (junio 1291-noviembre 1327), mereció hasta la fecha los honores ni siquiera de un Itinerario parcial y cuanto menos de su Itinerario total.

Jaime II continúa siendo todavía en lo concerniente a Itinerarios la gran excepción de los monarcas de la corona de Aragón. Ya que desde su abuelo, Jaime I el Conquistador, hasta su biznieto, Martín I el Humano, el último dinasta de la Casa de Barcelona, todos los soberanos de la misma cuentan con la publicación de su propio Itinerario, total o parcial, en el espacio de casi dos siglos (1213-1410).

La relación bibliográfica de los Itinerarios publicados de los monarcas de la Casa de Aragón, nos muestra con diafanidad evidente la inexplicable inexistencia del Itinerario de Jaime II entre los aparecidos.

Anotamos seguidamente los ITINERARIOS de los monarcas de la Casa de Aragón publicados hasta la fecha:

\section{Jaime I el Conquistador (1213-1276).}

MIRET I SANS, J., Itinerari del Rei en Jacme lo Conqueridor, Barcelona, 1918. GUAL CAMARENA, J.M. y ZAFRA, J., Aportaciones al ltinerario de Jaime I, $\mathrm{X}$ Congreso de Historia de la Corona de Aragón, II, Zaragoza, 1980, pp. 81-88.

\section{Pedro III el Grande (1276-1285).}

MIRET I SANS, J., «Viatges del'Infant en Pere, fill de Jaume I en 1268-1269», Butlletí 
del Centre Excursionista de Catalunya, XVIII, Barcelona, 1908.

MIRET I SANS, J, «Notes sobre l'expedició del Rei en Pere el Gran a Barbería, 1281-1282", Boletín de la Real Academia de Buenas Letras, XIV, Barcelona, 1914. SOLDEVILA, F., «Pere el Gran», Memories del Institut d'Estudis Catalans, IV, Barcelona, pp. 2-6.

Alfonso III el Liberal (1285-1291).

PARPAL MARQUÉS, J., «Itinerario que siguió Alfonso III de Aragón en la conquista de Menorca», Revista Menorca, Maó, 1898, pp. 134-136 (conquista año 1287). CARRERAS Y CANDI, F., «ltinerari del Rei N'Anfos II lo Liberal», Boletín de la Real Academia de Buenas Letras de Barcelona, X, Barcelona, 1931, pp. 61-83.

Jaime II de Aragón (1291-1327).

Todavía sin Itinerario.

\section{Alfonso IV el Benigno (1327-1335).}

MIRET I SANS, J., «ltinerario del Rey Alfonso III de Cataluña, IV de Aragón. El conquistador de Cerdeña", Boletín de la Real Academia de Buenas Letras de Barcelona, V, Año IX, Núm. 34, Barcelona, 1909, pp. 3-15, 57-71, 114-123.

\section{Pedro IV el Ceremonioso (1335-1387).}

GIMÉNEZ SOLER, A., «El viaje de Pedro IV a Cerdeña en 1354», Boletín de la Real Academia de Buenas Letras de Barcelona, V, Barcelona, 1909-1910, pp. 93, 171-199, 287-298, 521-524.

GIRONA I LLAGOSTERA, D., «Itinerari de l'Infant Pere (desprès Rei Pere III)», Estudis Universitaris Catalans, 18, Barcelona, 1933, pp. 336-355; 19, Barcelona, 1934, pp. 81-262.

Juan I el Cazador (1387-1396).

GIRONA I LLAGOSTERA, D., Itinerari de l'Infant En Joan, Actas y Memorias del III Congreso de la Corona de Aragón, Valencia, 1923.

GIRONA I LLAGOSTERA, D., «Itinerari del Rei En Joan I (1387-1396)», Estudis Universitaris Catalans, XIII-XV, Barcelona, 1928-1930. Extracto publicado aparte, Barcelona, 1931, p. 281.

\section{Martín I el Humano (1396-1410).}

GIRONA I LLAGOSTERA, D., «Itinerari del Rei En Martí (1396-1410)», Anuari de I'Institut d'Estudis Catalans, IV y V, Barcelona, 1911 y 1914. Edición en un solo volumen, Barcelona, 1916, en $251 \mathrm{pp}$.

A la vista de la relación historiográfica que antecede, acerca de los ITINERARIOS publicados hasta la fecha, concernientes a los monarcas aragoneses de la Casa de Barcelona, desde el 1313 al 1410, se hace harto penosa y sorprendente la inexisten- 
cia del Itínerario correspondiente a Jaime II el Justo, monarca que tanto sobresalió en la política territorial expansionista, así marítima como terrestre, de la Corona de Aragón.

Pues ajustándonos tan solo al tema principal, que hoy atrae la atención de este Congreso de Jaime II setecientos años después (1296-1996), a él se debe fundamentalmente la Conquista y anexión del Reino castellano de Murcia a su corona, en el quinquenio del 1296 al 1301 y la Incorporación oficial definitiva de la región centroseptentrional de Alicante al Reino de Valencia, por la Sentencia Arbitral de Torrellas (1304) y el Acuerdo de Elche, el 1305, creándose en tal ocasión la Procuración General de Orihuela o Tierras del Reino de Valencia ultra Sexonam. Tierras que por cierto recibieron de la generosa mano de este monarca su propia Constitución o Carta Magna, el año 1308, por la que se regirían en lo sucesivo todos sus vecinos, al par que por los Furs Valencianos y sus propios privilegios, hasta la supresión borbónica de los mismos por el decreto de Nova Planta del $1707^{1}$.

Fueros que no podemos olvidar que refunden sustancialmente el Fuero Real y demás fueros que sucesivamente promulgara el Rey Alfonso $X$ el Sabio a favor del Reino de Murcia y correspondientes villas septentrionales de Alicante, Orihuela, Elche y Guardamar del Segura, al lado de los ya citados Furs Valencianos, más los cuantiosos privilegios reales de Jaime II emanados tan profusamente a favor de las mismas ${ }^{2}$.

Tales fueros reales constituyeron todos juntos como el cedazo o entramado legal, por el que se rigieron estas villas alicantinas, dentro ya del marco constitucional del reino de Valencia, en el que siguieron vigentes como el Llibre dels furs i Usatges d'Oriola i Alacant por espacio de casi cuatro siglos, hasta la promulgación borbónica antes citada del 1707.

Datos todos éstos que nos revelan ampliamente la importancia y necesidad de la elaboración del ITINERARIO de Jaime II de Aragón, en el período concerniente al menos al tema primordial de este Congreso, con referencia a la conquista e incorporación del Reino castellano de Murcia a la Corona de Aragón, durante los años en los

1 ESTAL, Juan Manuel del, Alicante de villa a ciudad (1252-1490). Colección documental del Medievo Alicantino (CODOMA) III, Alicante, 1990, pp. 34-43 y 285-289. ÍDEM, «El fuero y las = Constitutiones Regni Murcie = de Jaime II de Aragón, 1296-1301», Historia Medieval. Anales de la Universidad de Alicante, 8, Dpto. Hist. Medieval, Alicante, 1990/91, pp. 19-56, passim.

2 ESTAL, J.M. del, Conquista y anexión de la tierras de Alicante al Reino de Valencia por Jaime Il de Aragón (1296-1308), Alicante, CAPA, Núm. 87, 1982; ÍDEM, Libro de los primitivos privilegios de Alfonso $X$ el Sabio a Alicante. Estudio histórico-crítico y edición facsímil, Madrid, EDILAN, 1984; IDEM, Documentos inéditos de Alfonso $X$ el Sabio y de su hijo, el Infante D. Sancho. Estudio, transcripción y facsímiles, Alicante, 1984; ÍDEM, El Reino de Murcia bajo Aragón, 1296-1305. Corpus documental (CODOMA) I/1, Instituto Juan Gil Albert, Alicante, 1985; ÍDEM, I/2, Alicante, 1990; ÍDEM, CODOMA II, años 1305-1380, Universidad Alicante, edic. microficha, 1988; ÍDEM, "CARTA MAGNA O FUERO de Jaime II de Aragón a las villas de Orihuela, Alicante, Elche y Guardamar, (1308)", Alicante, Papeles Alicantinos, Núm. 30, Alicante, 1988; ÍDEM, “Orihuela de villa a ciudad». Compendio de una historia bicentenaria desde Alfonso el Sabio de Castilla al Rey Magnánimo, Alfonso V de Aragón, (1243/381437/38), Alicante, 1996. 
que más activamente se desarrolló la campaña militar aragonesa, desde la primavera, sobretodo, del 1296 a la segunda quincena de enero del año $1301^{3}$.

$Y$ a este período concreto nos ceñiremos fundamentalmente en esta Comunicación, añadiendo a modo de Apéndice final un extracto del Itinerario de Jaime II de Aragón, ceñido a los hechos más notables y salientes, de la referida campaña militar de conquista del reino castellano de Murcia.

\section{METODOLOGÍA Y MECÁNICA SEGUIDAS EN LA ELABORACIÓN DEL MISMO}

Con referencia a la metodología empleada en la composición de este ITINERA$\mathrm{RIO}$, correspondiente a la conquista y anexión del reino castellano de Murcia por Jaime Il a la corona de Aragón, queremos subrayar que, pese al elevado número de fuentes documentales, impresas, del reinado de este monarca, a primera vista numerosas, no son ni con mucho suficientes para la ejecución completa de dicho itinerario, por cuanto resultan bastante escasos los días calendados de ese período de los cinco años referidos (febrero 1296-enero 1301), viéndonos por ello obligados a recurrir por fuerza mayor a las fuentes manuscritas e inéditas, en las más de las veces.

Tan sólo con la ayuda de éstas nos ha sido posible acceder a la identificación mayoritaria de la datación crónica y tópica de las andanzas del monarca de Aragón en todos y cada uno de los días de su largo reinado, permitiéndonos situarlo con exactitud en el tiempo y lugar precisos. Tan complejo cometido nos ha sido realizable solamente a través de los Registros de cancillería principalmente, al lado del muy elevado número de Cartas y Pergaminos Reales, depositados prioritariamente en el Archivo de la Corona de Aragón (Barcelona), concernientes al período estudiado.

A estas fuentes manuscritas e inéditas citadas, hay que agregar otras, también numerosas y manuscritas, guardadas en no pocos archivos nacionales y extranjeros, regionales, catedralicios y municipales, en cuyos numerosos fondos hemos podido recabar los datos indispensables para la confección de un calendario crónico-tópico antes apuntado. Por cuanto se hace bien patente la masa asaz voluminosa de documentación manuscrita que hay que hojear y ojear doblemente, removiendo folios y ver y volver a ver una y más veces dicha documentación, existente en los diferentes archivos referidos, al objeto de conseguir la información deseada.

Entraña esta obra de auténtico matiz heurístico una tarea de investigación documental, tan ardua y laboriosa, que, con referencia a un Itinerario no parcial, sino total, de Jaime II de Aragón, al igual que ocurre con el Itinerario completo de Pedro IV el Ceremonioso, precisa de la dedicación casi de por vida de una sola persona, para poder llevarlo a cabo satisfactoriamente. Así lo expresaba un experimentado maestro en estas lides, hace ya más de medio siglo, en los siguientes términos: "D'altres, com els Itineraris de Jaume II i el de Pere III el Cerimoniós, la revisió de centenars de regis-

3 ESTAL, J.M. del, "Nuevos datos sobre la capitulación y conquista aragonesa de Lorca", (amplio anexo documental), Homenaje al Prof. D. JUAN TORRES FONTES, Universidad de Murcia, 1987, pp. 431-464, passim. 
tres i la recerca i compulsació de milers de documents exigeisen per cada un d'ells la labor de tota la vida (y prosigue explicitando un voto personal). Aixó no contrastant, és d'esperar que hi haurà estudiosos qui non dubtaran d'esmerçar llur treball abnegat en la confecció dels Itineraris dels nostres comtes-reis, qui manquen a la història integral de Catalunya» ${ }^{4}$.

Y transcurrido más de medio siglo, hemos de seguir confesando, apenados, que tanto Pedro IV como Jaime II de Aragón, a excepción de unos pocos años calendados del primero, continúan esperando todavía uno y otro la confección y publicación de su respectivo Itinerario completo y total.

Por todo ello, nos es muy grato poder comunicar a los estudiosos de Jaime II en este Congreso, que tenemos ya ultimado el Itinerario de Jaime II de Aragón (12911327), completo y presentado a la Institució Valenciana d'Estudis i Investigació (IVEI) de la Generalitat Valenciana y Diputación Provincial de Valencia, a la espera tan sólo de su pronta publicación.

Con referencia ahora a la mecánica y técnica personal que hemos seguido en la elaboración del referido Itinerario, así total como parcial, cual es el caso de este último en la presente Comunicación, se ha optado por el método más usual y práctico en esta clase de trabajos, teniendo en cuenta siempre la mayor comodidad y utilidad práctica del usuario habitual.

Se ha buscado por ello preferentemente brindar al lector en todo momento una visión sinóptica de los días del mes en cada página, con la indicación simultánea y sucesiva para cada día de la datación crónica y tópica a la vez, fuente documental de referencia y una breve regesta del documento utilizado ${ }^{5}$.

Habida cuenta de la no poca complejidad existente en la confección de un Itinerario real, hemos estimado útil y esclarecedor, explicar la mecánica concreta, que en nuestro caso particular, nos ha servido a efectos de comodidad y rapidez muy positivamente en trasladar al papel los resultados diarios de la consulta documental.

Así por ejemplo, antes de iniciar en el archivo la lectura de un determinado registro de cancillería, nos impusimos la tarea práctica de trazar en un folio para cada mes del año, en columnas paralelas descendentes, los datos correspondientes a la calendación romana en la primera; los referentes al día del mes y de la semana, en la segunda y tercera; la datación tópica, en la cuarta; la referencia documental, en la quinta y, por último, la regesta o resumen del documento citado, en la sexta columna.

Método que nos resultó muy práctico, por cierto, y cómodo de verdad, por obviarnos las molestias sin número de tener que trasladar en cada documento la datación romana a la moderna. Trabajo que se repetiría miles de veces, al tener que efectuar en cada momento el cálculo de los referidos traslados cronísticos. $Y$ hay que observar que el reinado tan largo de Jaime $\|$ de Aragón alcanzó casi los 37 años de gobierno

4 GIRONA I LLAGOSTERA, Daniel, «Itinerari del Rei En Joan I, 1387-1396», Revista d'Estudis Universitaris Catalans, XIII-XV, Barcelona, 1928-1930 y extracto en separata, Barcelona, 1931, p. 4.

5 Una ejemplificación de lo dicho puede comprobarla el lector consultando el Anexo documental del Itinerario parcial con que concluye este trabajo. 
(junio 1291-noviembre 1327), que suman con creces la elevada cifra de los 13.000 días.

El folio en cuestión podría presentarse en forma similar al patrón siguiente:

AÑo 1296

\begin{tabular}{|c|c|c|c|c|c|}
\hline Calend. rom & abril & día sem. & Lugar & Ref $f^{\mathrm{a}}$ dtal. & Regesta \\
\hline $\begin{array}{l}\text { kls } \\
\text { aprilis }\end{array}$ & 1 & domingo & Valencia & ACA reg. 104 & $\begin{array}{l}\text { Jaime II dispone preparativos } \\
\text { conquista reino cast }{ }^{\circ} \text { Murcia }\end{array}$ \\
\hline $\begin{array}{l}\text { pridie non. } \\
\text { aprilis }\end{array}$ & 4 & miérc & Valencia & r. 104 f. $1 \mathrm{v}$ & Carta en igual sentido \\
\hline nonas apr. & 5 & jueves & Valencia & r. 104 f. $1 \mathrm{r}$ & Ídem \\
\hline $\begin{array}{l}\text { VI idus } \\
\text { aprilis }\end{array}$ & 8 & dom $^{\circ}$ & Valencia & r. 104 f. $5 v-6 r$ & Ídem \\
\hline Idus apr. & 13 & viern & Valencia & r. 104 f. $17 \mathrm{v}$ & Ídem \\
\hline $\begin{array}{l}X V I I I \text { kls } \\
\text { madii }\end{array}$ & 14 & sab & Valencia & r. 104 f. $19 r$ & $\begin{array}{l}\text { Jaime II a su consejero real } \\
\text { sobre conqt }{ }^{\mathrm{a}} \text { reino Murcia }\end{array}$ \\
\hline $\begin{array}{l}X \text { kls } \\
\text { madii }\end{array}$ & 22 & dom $^{\circ}$ & Alicante & r. 340 f. $55 \mathrm{v}$ & $\begin{array}{l}\text { Jaime II somete castillo y } \\
\text { villa de Alicante }\end{array}$ \\
\hline $\begin{array}{l}\text { VI kls } \\
\text { madii }\end{array}$ & 26 & juev & $\begin{array}{l}\text { Guardamar } \\
\text { de Segura }\end{array}$ & r. 340 f. $6 r$ & $\begin{array}{l}\text { Jaime II ocupa el castillo y } \\
\text { lugar de Guardamar }\end{array}$ \\
\hline $\begin{array}{l}\text { II kls } \\
\text { madii }\end{array}$ & 30 & lun & Almoradí & r. 340 f. $52 \mathrm{r}$ & $\begin{array}{l}\text { Conquista del lugar de } \\
\text { Almoradí }\end{array}$ \\
\hline $\begin{array}{l}\text { pridie kls } \\
\text { madii }\end{array}$ & 30 & lun & $\begin{array}{l}\text { Real de } \\
\text { Orihuela }\end{array}$ & r. 340 f. $4 \mathrm{v}$ & $\begin{array}{l}\text { Jaime II inicia asedio del } \\
\text { castillo y villa de Orihuela }\end{array}$ \\
\hline
\end{tabular}

\section{Particular interés y utilidad del presente Itinerario}

La condición itinerante de Jaime II de Aragón, en perenne desplazamiento por lugares diferentes dentro y fuera de su corona, persiguiendo siempre escuchar y atender in situ personalmente los problemas diversos de sus gentes, lo convirtió en un incansable y permanente viajero, consiguiendo que tan sorprendente movilidad real dote a su Itinerario de un interés excepcional. Ya que gracias al mismo podemos situar al monarca, en cada uno de los momentos de su largo reinado y de modo especial en el quinquenio dedicado a la conquista y anexión del reino castellano de Murcia a su corona (1296-1301), el que hoy ocupa a este Congreso particularmente, en el espacio y tiempo precisos, a través de la doble datación crónica y tópica consignadas en los documentos reales.

Tal Itinerario suministra además el adecuado marco cronológico y toponímico a un sinfín de actos oficiales del monarca, referentes ya a privilegios, cartas, donaciones, franquicias, sanciones, fueros e instituciones reales, etc., que por uno u otro motivo carecen a veces en su transmisión documental, publicada o inédita aun, de la correspondiente datación crónico-tópica, posibilitándonos de esta suerte la identificación 
correcta de la misma, pues tanto una como otra se complementan entre sí y yuxtaponen habitualmente.

Por cuanto la ausencia, desaparición y falta de una de ellas, puede llegar a suplirse por la presencia documental de la otra, llegando por su medio a la identificación de entrambas o a la exclusión a veces de una de ellas, por no encajar de forma alguna en el contexto, debiendo en este caso ser desechada y sustituida por la datación correcta. Por tal procedimiento puede llegarse a averiguar una fecha no expresada, así como el lugar de datación tampoco referido, a base tan solo de la referencia explicitada de una de las dos dataciones aludidas. Ya que la datación crónica puede averiguarse, aunque no vaya expresada en el texto, por la datación tópica y viceversa, no pocas veces.

Por todo ello la utilidad del Itinerario de Jaime II de Aragón es manifiesta para situar al monarca en un momento dado en el lugar preciso, aunque éste no se halle expresado en el documento y otro tanto puede afirmarse acerca de la fecha exacta en que se emanó un documento real, aunque ésta no figure en el mismo.

$Y$ en no pocos casos el presente Itinerario nos ayudará a detectar el error de ciertos autores, incluso consagrados, en la datación ya crónica o tópica equivocadas. La presentación de algunos ejemplos concretos nos ayudará positivamente a comprender mejor la utilidad del susodicho Itinerario.

Resulta que un error en la datación crónica de un determinado documento, conlleva idéntico error en la datación tópica también, como ocurre al ilustre historiador y documentalista ANTONIO BENAVIDES ${ }^{6}$, quien, al fechar los documentos 81 y 84 en los días 4 y 18 de febrero respectivamente del año 1297, en Alhama de Segura (Murcia), el primero, y en Valencia el segundo, se equivoca de lleno, por hallarse Jaime II de Aragón en las fechas referidas en Roma, huésped del papa Bonifacio VIII, para negociar el espinoso asunto de la devolución del Reino de Sicilia a la Iglesia Romana, a cambio de la infeudación papal de los Reinos de Córcega y Cerdeña, feudatarios a su vez de la Sede Apostólica.

El citado historiador no tuvo en cuenta la datación por la Era Incarnationis, en el Estilo florentino, de la cancillería de Aragón, debiendo añadir una unidad a la cifra del año en cuestión, como ya es sabido, desde el uno de enero al veinticuatro de marzo, por lo que el año correcto documentado por él no es el 1297, sino el 12987. Lo que hubiera podido obviarse fácilmente de haber tenido a la mano el Itinerario de Jaime II. De donde se desprende la importancia y utilidad del mismo.

$Y$ otro tanto ocurre con el no menos conocido archivero del ACA, MANUEL DE BOFARULL Y DE SARTORIO ${ }^{8}$, al asignar erróneamente también la datación tópica de Valencia al documento citado, cuando escribe: «Dat. Valentie VI idus madii an. dni. $M$

6 Crónica de Fernando IV de Castilla. // Colección diplomática, Madrid, 1860, dctos. 81 y 84.

7 "Datum in castro de Alfama pridie nonas februarii an.dni. M CC XC VII» ACA, C, reg. 256, f. 182r y reg. 195, f. 123r: «Dat. Valentie XII kls martii an. dni. M CC XC VIl», fechas correspondientes al 4 y 18 de febrero del año 1298.

8 Colección de Documentos Inéditos de la Corona de Aragón (CODOIN-ACA), vol. 42, dło. 375 , Barcelona, 1876. 
CC XC VIIl', datación que no se ajusta a la realidad histórica, por encontrarse Jaime II aquel 10 de mayo del año 1298, no en Valencia, sino en Barcelona ${ }^{9}$.

De igual modo yerra otro destacado historiador, de la estirpe benemérita de los BOFARULL, de nombre ANTONIO DE BOFARULL I BROCA ${ }^{10}$, al situar a Jaime $\|$ en Valencia, el dos de febrero del año 1299, cuando en realidad por aquellas fechas se encontraba bien lejos de allí, en Milazzo (Sicilia), dirigiendo la operación militar, ya aludida, contra su hermano, Federico $\mathrm{III}^{11}$.

Este mismo autor escribe en otro lugar, erróneamente también, que Jaime II de

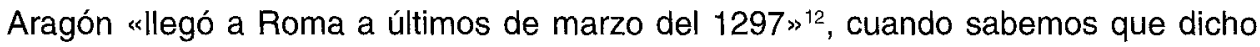
monarca se hallaba en la Ciudad Eterna ya desde dos meses antes, llegando a la misma el 14 de enero de aquel año exactamente ${ }^{13}$, convirtiéndose en huésped de Bonifacio VIII, como ya queda expuesto anteriormente.

De forma similar yerra otro ilustre historiador alemán, JOHAN VINCKE ${ }^{14}$, al asignar al documento 10 de su Colección Documental la doble datación crónica y tópica equivocadas: Valencia, 13 de marzo del 1317, cuando en realidad el documento citado reza exactamente: Dat. Valentie III idus martii anno domini M CCC XVIII5, datación que corresponde no al año 1317 , sino al $1318^{16}$. Y por lo demás Jaime II en la fecha apuntada por VINCKE no se hallaba en Valencia, sino en Barcelona ${ }^{17}$. Lapsus en el que no hubiera incurrido por cierto el citado historiador, de haber tenido a la vista el ITINERARIO de dicho monarca, por donde se desprende la importancia y necesidad de la publicación del mismo.

La utilidad de este Itinerario resulta manifiesta para la identificación precisa de un determinado topónimo, cual es el caso de la confusión por un destacadísimo investigador de la historia de este período ${ }^{18}$, del Castillo de Lort (EI LLOR, La Segarra, Lérida) con el Castillo de Lorca (Murcia), al escribir: «Sembla que Jaume II tornà a fer una breu escapada al regne de Mùrcia a primers de juliol de 1297; el 4 d'aquest mes almenys era en el setge de Lorca». Dato éste imposible de encajar en el Itinerario del monarca aragonés, a quien resultaba materialmente imposible realizar un desplazamiento de

9 «Datum Barchinone sexto idus madii an. dni. M CC XC VIII», ACA, C, reg. 324, f. 276v.

10 Historia crítica de Cataluña, Barcelona, 1876, vol. IV, pp. 64-65.

11 «Dat. in portu Melacii IV nonas februarii anno domini M CC XC VIII», ACA, C, reg. 265, f. 119r.

12 Historia crít. de Cataluña, IV, p. 51.

13 «Dat. Rome XIX kalendas februarii anno domini M CC XC VI», ACA, C, reg. 321, f. 55r.

14 "Königtum und Sklaverei im aragonischem Staatenbund während de 14. Jahrhunderts", Spanische Forschungen der Görresgesellschaft, erste Reihe. Gesammelte Aufsätze zur Kulturgeschichte Spaniens, 25 Bund, Münster im Westfallen, 1970, p. 46.

15 ACA, C, reg. 215, f. 260r.

16 Por seguir la cancillería de Aragón, como ya es sabido, la Era Incarnationis, en el Estilo Florentino, debiendo añadirse una cifra más al año expresado, desde el 1 de enero al 24 de marzo.

17 «Dat. Barchinone III idus martii anno domini M CCC XVI», ACA, C, reg. 162, f. $6 r$.

18 FERRER I MALLOL, M" Teresa, "Notes sobre la conquesta del Regne de Murcia per Jaume II (1296-1304)", Homenatge a la memòria del Prof. Dr. EMILIO SAEZ. Aplec d'Estuis dels seus deixebles i col-laboradors, Barcelona, 1989, Universidad de Barcelona. Centre d'Estudis medievals de Catalunya. Institució Milà i Fontanals (CSIC), pp. 27-44; p. citada, 39. 
más de 700 kilómetros, desde el castillo aludido de El Llor, en la provincia de Lérida, al de Lorca, en la región meridional de la provincia de Murcia, en un mismo día, ya que el 4 de julio de aquel año está poniendo sitio al castillo leridano de Lort, El Llor ${ }^{19}$, al igual que el día anterior, 3 de julio ${ }^{20}$, y el día $5^{21}$, resultándole al monarca de todo punto imposible encontrarse el mismo día en dos lugares tan distantes entre sí. La existencia del Itinerario de Jaime II de Aragón hubiera hecho imposible tal confusión.

Es útil así mismo también el presente Itinerario para resolver las dudas de algún notable medievalista ${ }^{22}$, quien, al situar la documentación a Jaime II en un mismo día (14 mayo 1296) en dos lugares distintos, si bien cercanos, a menos de 10 kilómetros de distancia, la villa de Orihuela y el castillo murciano de Monteagudo $^{23}$, y al esotro día (el 15), de nuevo en Orihuela ${ }^{24}$, y al siguiente (día 16) en Murcia ${ }^{25}$, atribuye a un error del escribano la datación tópica del día 14 ante el castillo de Monteagudo ${ }^{26}, 10$ que a decir verdad no implica necesariamente un lapsus del escribano, si se tiene en cuenta la distancia tan reducida entre ambos lugares (10 kms. escasos), perfectamente recorribles en una misma jornada (menos de $20 \mathrm{kms}$. con ida y regreso).

Puede ayudarnos también este Itinerario a corregir en determinados casos los datos biográficos de un personaje célebre en la historia peninsular, como es el caso puntual del arzobispo de Tarragona, D. Rodrigo, cuyo fallecimiento lo apunta erróneamente un ilustre historiador ${ }^{27}$, el 16 de diciembre del año $1307^{28}$, fecha que en modo alguno se ajusta a la realidad histórica, ya que Jaime II le dirige una carta personal, muchos meses después, el 21 de agosto del $1308^{29}$, demostración fehaciente de que regía aun por estas fechas la metrópoli de Tarragona.

Tras esta breve exposición de los tres puntos fundamentales enunciados, los que

19 «Dat. in obsidione castri de Lort IV nonas julii anno domini M CC XC VII», ACA, C, reg. 264, f. 36v. Carta de Jaime II al veguer de Don Juan Manuel en Villena, Pedro Escriba.

20 «Dat. in obsidione castri de Lort V nonas julii an. dni. M CC XC VII». ACA, C, reg. 252, f. 167r. Carta a su hermano, Federico III de Sicilia.

21 "Dat. in obsidione castri de Lort III nonas julii anno domini M CC XC VII». ACA, C, reg. 252, f. 167r. Jaime II a su hermano Federico III de Sicilia.

22 FERRER I MALLOL, o.c., p. 35.

23 Ibid.: «el 14 de maig el rei era a Oriola, però el mateix dia era també al campament daval del castell de Monteagudo, a la vora de Mùrcia».

24 ACA, C, reg. 340, f. 87r: «Dat. Oriole idibus julii anno domini M CC XC VI».

25 ACA, C, reg. 340, f. 69v: «Dat. en la Huerta de Murcia, juxta castrum de Montagut, XVI dias andados del mes de mayo en el anyo de nuestro senyor M CC noventa e seys".

26 FERRER I MALLOL, o.c., p. 35: «Sembla, doncs, que hi ha d'haver un error de datació a la carta del dia 14 de maig, que situa al rei a Monteagudo". $Y$ añade seguidamente una conclusión a nuestro juicio erronea: «perquè de fet el monarca no es mogué d'Oriola fins el 15 o el 16 de maig», ya que la doble datación tópica, alterna, consignada, se explica perfectamente por la distancia tan corta referida, salvable muy bien una y más veces en un solo día.

27 EUBEL, Hierarchi catholica Medii Aevi, Münster im Westfallen, reed. 1913, I, p. 479.

28 "Obiit Rodericus archiepiscopus Tarrachonensis (1307 decembris 16)», 0.c., ibid.

29 «Roderico archiepiscopo Tarrachonensi... Dat. Valentie XII kalendas septembris anno domini M CCC octavo", ACA, C, reg. 140, f. 150r. 
a su vez estimamos más destacables en nuestro Itinerario documental, sobre la conquista por Jaime II de Aragón del reino castellano de Murcia, a saber: su importancia y necesidad, la metodología y mecánica seguidas en su elaboración, más el interés y utilidad del mismo, nos permitimos añadir a continuación como un muestrario o selección del mismo, a modo de colofón de todo lo expuesto, un Anexo final.

En dicho anexo o Itinerario parcial de Jaime II hemos procurado dispensar particular atención a la campaña militar del monarca aragonés en la conquista del mencionado reino murciano, durante el período aproximado de cinco años, desde febrero del 1296 a enero del 1301, tratando de subrayar los sucesos de mayor interés al respecto.

Hemos estimado oportuno también presentar a modo de preludio anticipado de dicha conquista, las gestiones realizadas por Jaime II ante los alcaides castellanos de los castillos de Alicante (Nicolás Pérez de Murcia), de Orihuela (Pedro Roiz de Sant Cebrian) del castillo murciano de Monteagudo (Juan Fernández de Gomariz) y del castillo de Cartagena (Sancho Díez de Bustamante), con una antelación de casi nueve meses antes de dicha conquista, encaminadas directamente a conseguir de los mismos la entrega pacífica de los castillos citados, con la prestación consiguiente del homenaje vasallático debido, en consecuencia a la violación por su rey, Sancho IV, del Pacto o Concordia de Monteagudo-Soria (29 noviembre 1291).

En carta personal a los susodichos alcaides castellanos advertía Jaime II, el 5 de agosto del año $1295^{30}$, que, ante una eventual respuesta negativa suya, procedería a arrebatarles por la fuerza las fortalezas citadas, en claro presagio de la guerra que tal recusación iba a desencadenar entre las coronas de Castilla y Aragón.

No hemos descuidado tampoco en nuestro Itinerario el dedicar cierta atención al periplo marítimo, que efectuó por tres veces, en este período, Jaime II, a Roma y curia papal de Bonifacio VIII (enero-abril 1297); al Reino de Nápoles y corte de Carlos II de Anjou, su suegro (julio-agosto 1298 y marzo-junio 1299); y al Reino de Sicilia (agostodiciembre 1298 y enero-marzo y julio-agosto 1299), en miras a recabar de su hermano, Federico III de Sicilia, la renuncia a aquel reino en beneficio de la Iglesia Romana, en base al ya citado Tratado de Anagni (1297), por entrañar todo ello el alejamiento del monarca de Aragón del escenario peninsular, dentro del período estudiado (12961301), en la campaña militar emprendida por Jaime II para someter el reino castellano de Murcia e incorporarlo a su corona.

30 Consúltense dichas cartas en el citado Anexo documental o Itinerario parcial de Jaime II de Aragón, en la fecha indicada. 


\section{ANEXO DOCUMENTAL}

Itinerario parcial de Jaime II de Aragón (1296-1301)

Mes Lugar Ref dtal. Regesta

\section{Año 1295}

\section{Agosto}

5

Barcelona

ACA CRD Jaime II caj. $1, \mathrm{n}^{\circ} 250^{31}$

5

Barcelona ACA CRD Jaime II

caj. $1, \mathrm{n}^{\circ}=247$

5

5

5

Barcelona CRD Jaime II

5

Barcelona caj. $1, n^{\circ} 237$

caj. $1, \mathrm{n}^{\mathrm{o}} 248$

CRD Jaime III

caj. $1, n^{\circ} 277^{32}$

$$
\text { caj. 1, ne } 237
$$

CRD Jaime II
CRD Jaime II

caj. $1, n^{\circ} 238^{33}$
Orden al alcaide del castillo de Orihuela, Pedro Roiz de Sant Cebrian, de entregarle la fortaleza por violación de su rey, Sancho IV, de la Concordia de Monteagudo - Soria- 29 nov. 1291.

Carta en idéntico sentido al alcaide del castillo murciano de Monteagudo, Juan Fernández de Gomáriz.

Ídem al alcaide del castillo de Cartagena, Sancho Díez de Bustamante.

Ídem al alcaide del castillo de Alicante, Nicolá Pérez de Murcia.

Ídem al alcaide aragonés del castillo de Fita, en rehén de Castilla, Rodrigo Martínez de Guadalajara, liberándolo del vasallaje al rey castellano.

Id. al alcaide aragonés de los castillos de Cervera, Alfaro y Agreda, Alfonso de Haro, en liberación del vasallaje a Castilla ${ }^{34}$.

31 ESTAL, J.M. del, El reino de Murcia bajo Aragón, 1296-1304/5, l/1, Alicant 1985, pp. 109-110 y $12-15$.

32 ESTAL, El reino de Murcia bajo Aragón, l/1, pp. 11-20.

33 Ibid., pp. 11-15.

34 Actitud que entraña una abierta determinación aragonesa de ruptura con Castilla y por ende una resuelta disposición de Jaime II a ocupar los citados castillos murcianos, si sus alcaides respectivos no se aprestaban a acatarlo como legítimo soberano suyo y su señor natural.

Era en suma la declaración anticipada de guerra a Castilla por el reino de Murcia, donado reiteradamente en tres ocasiones sucesivas (1289 y 1296) por el infante don Alfonso de la Cerda a la corona de Aragón. ESTAL, J.M. del, Conquista y anexión de la tierras de Alicante al reino de Valencia por Jaime /l de Aragón, Alicante, 1982, pp. 160-171 y 325-329. 


\section{Año 1296}

\section{Febrero}

17 Cetina (Z) ACA, C, r. 252 f. $230 r^{35}$ Jaime II notifica a Bernat de Sarrià donación del reino de Murcia por inf. d. Alfonso de la Cerda y el ultimatum al rey Fernando IV de entregarlo en 15 días so pena de ocuparlo por la fuerza.

Notifica Jaime II a su consejero, Bernat de Sarrià, y a Pedro de Llibià, baile general del reino de Valencia, el envío a Murcia de Bernat Merçer para ganar ciertos prohombres a la causa de Aragón ${ }^{36}$.

22 Zaragoza Reg. 252 f. 231r

Orden a Bernat de Sarrià de hacer armar diez galeras en astilleros de Valencia, Barcelona y Mallorca ${ }^{37}$.

$22^{38}$ Zaragoza Reg. 252 f. 130v-131r Reg. 340 f. $63 r-v$

Encomienda Jaime II a Berenguer de Vilaragut y Ramón de Manresa asunto galeras en Barcelona; a Pedro de Foces en Mallorca y al canciller, Ramón Despont, en Valencia, donde era obispo.

\section{Marzo}

4 dom $^{\circ}$ Zaragoza Reg. 103 f. 264 r

Dat. Cesarauguste IV nonas martii a.d. MCCXCV.

Reg. 263 f. $264 v$

Jaime II ruega al papa Bonifacio VIII el abono de las $12.000 \mathrm{lib}$. tournesas por renunciar al reino de Sicilia en favor de la Iglesia Romana.

35 FERRER I MALLOL, o.c., pp. 29, 42-43; ESTAL, El reino de Murcia..., I/2, Alicante, 1990, pp. 16-18.

36 FERRER I MALLOL, o.c., pp. 29 y $42-43$.

37 Ibid., pp. 30 y 43-44; ESTAL, ibid., pp. 17-18.

38 Queremos significar aquí que en los años bisiestos, los día 24 y 25 de febrero, al contar este mes con 29 días, se explicitan en la calendación romana bis VI kls martii (el 24) y VI kls martil (el 25) respectivamente, derivando de aquf́ la denominación de año bisiesto. 
Jaime II interesa al ra'is de Crevillente, Muhammad ibn Hudayr, en la conquista del reino de Murcia por su condición de vasallo de Aragón.

Alicante ?

ACA, C, r. 340 De regno Murcie, f. $6 r$

aunque no haya constancia documental.

Alicante

Reg. 340 f. $6 r$

Este día recibió ya el monarca de Aragón el homenaje vasallático de Guillem de Folch en casa de Ramon Ça Costa en Alicante ${ }^{39}$.

Gestión de una tregua de 26 días con el merino mayor de D. Juan Manuel, Sancho Ximenes de Lanclares, en miras a su acatamiento como soberano del reino de Murcia $^{40}$.

Nombramiento de Bernat Bonivery como notario público «totius regni Murcie»"1.

Reg. 340 f. 5r-6r Donación a Guillem Durfort, consejero real, de un heredamiento en La Daya, entre Almoradí y Orihuela, confiscado anteriormente al castellano Fernando Pérez de Guzmán por su rebeldía contra Aragón ${ }^{42}$.

Reg. 194 f. 214r-v Se confirma la donación anterior en premio a los servicios prestados a Jaime I, su abuelo, a Pedro III, su padre, y a Alfonso III, su hermano ${ }^{43}$.

Conmina al inf. D. Alfonso de Portugal y espo-

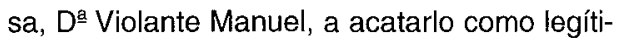
mo soberano del reino de Murcia.

39 A partir de esta fecha procedió ya Jaime II a la provisión de los cargos públicos de alcaide, baile y justicia en el castillo y villa de Alicante en los caballeros Pedro de Urtx, Raimundo de Capiath y Berenguer de Puigmoltó. ESTAL, El reino de Murcia..., 1/1, pp. 21-22.

40 ESTAL, ibid., pp. 74-77.

41 Ibid., pp. 26, 113 not. 1.

42 Ibid., pp. 113-116.

43 Ibid., pp. 116-118. 
29 dom $^{\circ}$ Almoradí Reg. 340 f. $3 \mathrm{v}$

29

Almoradí (A) ACA, C, r. 340 f. $51 \mathrm{r}$

Almoradí

Reg. 340 f. $288 r$

30

Almoradi

Reg. 340 T. $288 \mathrm{r}$ de varios heredamientos en Murcia, confisca- dos a Fernando Pérez Cantador, mayordomo del adelantado por Castilla en el reino de Mur- cia, D. Juan Sánchez de Ayala, por su rebeldía contra Aragón ${ }^{46}$.

30 lu Huerta de Reg. 340 f. 52r
Almoradí

30

Real ante Reg. 340 f. 288r

Orihuela

\section{Mayo}

1

Real ante Reg. $340 \mathrm{f} .11 \mathrm{r}$

Almoradí

1

Real ante Reg. 340 f. $13 \mathrm{~V}$

Orihuela
Donación a su portero real, Bernat de Genebret,

Ordena al consell de Guardamar efectuar entrega de todo el grano acopiado en la iglesia del lugar ${ }^{44}$.

Al expirar la tregua con D. Juan Manuel el 19 mayo ruega Jaime II a su merino mayor, Sancho Ximenes de Lanclares elija lugar de encuentro con su enviado, Pedro de Llibià, para entregarle la plaza de Elche ${ }^{45}$.

\section{contra Aragon}

Jaime II acoge bajo su tutela real al noble don Juan García de Loaysa, as como a los hombres y mujeres de los castillos de Bañeres y Petrer, señoríos suyos ${ }^{47}$.

Sienta este día sus reales Jaime II ya dentro del propio término de Orihuela ${ }^{48}$.

Inicio del cerco de Orihuela desde el campamento ante Almoradí ${ }^{49}$.

Acampa Jaime II ante el castillo y villa de Orihuela ${ }^{50}$.

44 Ibid., pp. 120-121. Jaime II nombró alcaide de Guardamar a Galcerand de Rosanes, quien desempeñó un papel sobresaliente en la recaudación de vituallas para la tropa aragonesa ocupada en la conquista del reino castellano de Murcia.

45 ESTAL, El reino de Murcia..., l/1, p. 76.

46 Ibid., pp. 121-123.

47 Ibid., 1/2, Alicante, 1990, pp. 28-29: «Dat. in orta de Almoradi in regno Murcie».

48 "Dat, in casis termino de Oriola in Regno murcie tertio kls madii anno domini M CC XC VI». ESTAL, ibid., $1 / 1$, dto. 30 , p. 121.

49 "Dat. in castris apud locum de Almoradino»; "Dat. in orta de Almoradino» ibid.

50 «Dat, in obsidione de Oriola kls madii anno domini M CC XC VI», ibid 
Al ra'is de Crevillente, Muhammad ibn Hudayr, que permita a los mudéjares de Alicante, allí refugiados, en su señorío regresar a la villa alicantina con sus haberes ${ }^{51}$.

$8 \mathrm{ma}$ Asedio de Reg. 340 f. 29r Orihuela

10

Asedio de ACA, perg. 642

Orihuela de Jaime II

$11 \quad$ Orihuela

Reg. 194 f. $238 r$
Al portero real, Bernat de Genebret, que provea de vituallas al alcaide del castillo de Callosa de Segura, Bernat de Pujades ${ }^{52}$.

El alcaide del castillo de Abanilla (MU), Miguel García, acata soberanía de Jaime Il en el reino de Murcia, respetando el señorío de su señor, Guillem de Rocafull ${ }^{53}$.

Jaime II dentro ya de Orihuela confirma a sus vecinos el título de propiedad de sus casas y hacienda.

11 Orihuela

Arch.Mun.Orih. (AMO) Pleito-homenaje de la corporación municipal de Lib. priv., MS 2588, Orihuela, 38 miembros, a Jaime II, en la iglesia fols, $15 r-16 r$ del Salvador, acatándolo como legítimo soberano y su señor natural ${ }^{54}$.

12

Orihuela Reg. 340 f. $35 r$

Donación a Berenguer de Liminyana, vecino de Orihuela, de los lugares de Xacara y Xacarella por los servicios prestados.

12 Orihuela Reg. 340 f. $58 \mathrm{r}$

Conmina al alcaide del castillo murciano de Monteagudo, Juan Fernández de Gomáriz, a hacerle entrega del mismo.

13 dom $^{\circ}$ Orihuela Reg. 340 f. $66 \mathrm{v}$

Al alcaide del castillo de Alicante, Pedro de Urtx, que imponga a un cautivo castigo ejemplar por insultos a los vecinos del lugar.

Constituye bailes de la villa de Orihuela a los vecinos Pedro Rosselly y Guillem Parratge con el compromiso de acopiar el mayor volumen posible de vituallas ${ }^{55}$.

51 «Dada en el çerco de Oriola, quatro dias andados del mes de mayo en el anyo de nostre senyor M CC XC sies». ESTAL, El reino de Murcia bajo Aragón..., 1/2, pp. $29-30$.

52 ibid., l/1, p. 32.

53 TORRES FONTES, Juan, CODOM II, n CXIX, pp. 121-122; ESTAL, ibid. $1 / 1$, pp. 35-36.

54 TORRES FONTES, ibid. ESTAL, ibid. 1/1, pp. 129-132. El castillo en cambio de Orihuela, regido por el alcaide Pedro Roiz de Sant Cebrian, no se rindió hasta más tarde, el 21 de junio, jueves, tras cumplirse el plazo acordado de 40 días. ESTAL, ibid., pp. 40-41.

55 ESTAL, El reino de Murcia..., 1/1, pp. 158-159. 
$14 \mathrm{lu}$

Real ante Reg. 340 f. 66r Monteagudo

15

Orihuela

Reg. 340 f. $63 \mathrm{v}$

16

Real ante Reg. 340 f. $78 \mathrm{v}$
castillo de
Monteagudo

16

Huerta de Reg. 340 f. $69 \mathrm{v}$ Murcia ante castillo de

Monteagudo

16

Ídem

Reg. 340 f. $66 \mathrm{r}-\mathrm{v}$

17

Ídem

Reg. 25 f. 282 r

17

Ídem
Al caballero Gonzalo de Fontana sobre el cobro del quinto de las cabalgadas en el término de Orihuela ${ }^{56}$.

A los alcaides de Alicante y Guardamar, Raimundo de Urtx y Galcerand de Rosanes que no estorben el regreso a casa del caballero Exerio Pérez de Oza con seis hombres suyos ${ }^{57}$.

Al alcaide del castillo de Alicante, Raimundo de Urtx, y al justicia del mismo, Raimundo Castellan sobre el indulto a Julián y Pedro Martínez de Alcañiz, vecinos del lugar ${ }^{58}$.

Se congratula ante el rey de Granada, Muhammad II, por la paz firmada entre ambos, dos días antes ${ }^{59}$.

Salvoconducto real a favor del adelantado por Castilla en el reino de Murcia, Juan Sánchez de Ayala, para que pueda abandonar indemne aquel reino con su mujer e hijos, en el plazo de diez días ${ }^{60}$.

Acta de sumisión y vasallaje del ra'is de Crevillente, Muhammad ibn Hudayr, a Jaime II como soberano legítimo del reino de Murcia ${ }^{61}$

Prórroga del plazo primitivo de 30 días a 42 para entregarle el alcázar intraurbano de Murcia, regido por el alcaide Martín Fernández debiendo librarlo a su enviado Bernat de Sarrià ${ }^{62}$.

56 Ibid., p. 164. El mismo día 14 se desplazó Jaime II de Orihuela al asedio del castillo de Monteagudo, regresando de nuevo a Orihuela, debido a la corta distancia de apenas diez kilómetros.

57 ESTAL, ibid., pp. 43-44.

58 La datación tópica de los días 16 al 18 de mayo se expresa indistintamente por la cancillería de Aragón en los términos siguientes: "dat. apud Montem Acutum»; "dat. en la huerta de Murcia juxta castrum de Montagut»; "escrita en la orta de Murcia prop lo castell de Montagut»; «dat. in campis juxta castrum de Monte Acuto"; "dada en la orta de Murcia prope locum de Monteagut»; "dat. in orta Murcie juxta locum qui dicitur Montagut». ESTAL, ibid. I/1, pp. 167-183; 1/2, pp. 44-46.

59 ESTAL, ibid. $1 / 1$, pp. 169-170.

$60 \mathrm{Ibid} . \mathrm{I} / 2$, pp. $44-45$.

61 lbid., pp. 50 y $176-179$.

62 ESTAL, El reino de Murcia..., l/1, pp. 180-181. 
Salvoconducto a favor del alcaide del castillo de Murcia Monteagudo, Juan Fernández de Gomáriz, para llegarse indemne a su presencia para negociar la entrega del castillo ${ }^{63}$.

$19 \mathrm{sab}$ Murcia

Reg. 340 f. $74 r$ y $75 r$

Tras la entrevista con Juan Fernández de Gomáriz, Jaime II no obtuvo aún la capitulación del castillo de Monteagudo, hasta 21 de junio, pudiendo ocupar sin embargo la ciudad de Murcia en este día ${ }^{64}$.

20 dom $^{\circ}$ Murcia Reg. 340 f. $76 \mathrm{v}$

Jaime II pide al noble castellano don Juan García de Loaysa, tenente del castillo de Petrer y vasallo del infante D.Alfonso de Portugal y de su esposa $D^{\mathbf{a}}$ Violante Manuel, que lo acate como soberano del reino de Murcia y señor suyo natural ${ }^{65}$.

20 dom $^{\circ}$ Murcia

Reg. 340 f. $76 r$

A petición del ra'is de Crevillente, Muhammad ibn Hudayr, Jaime II acogió bajo su tutela real «a todos los moros del Regno nuestro de Murcia» ${ }^{66}$.

$21 \quad$ Murcia

Reg. 340 f. $79 r$

Embajada aragonesa del abad de Foix, Jofré de Cruilles, ante D. Alfonso de la Cerda, «rey de Castiella».

Mayo

22

Murcia

Reg. 340 f. $80 \mathrm{~V}$

Embajada de Jaime II en el franciscano fray Pedro ante el concejo de Lorca para recabar su acatamiento y vasallaje.

63 Ibid., pp. 182-183.

64 La entrada de Jaime II en la ciudad de Murcia no supuso la rendición del castillo intraurbano - Alcazar-Kibir, cuyo alcaide Martín Fernández no capitularía tampoco aquel día y fue objeto de varios emplazamiento o treguas hasta mediados de junio, fecha en que acató la soberanía del monarca aragonés. ESTAL, ibid., pp. 40-42 y 61-64.

65 ESTAL, ibid., pp. 67-69 y 188-189. En idénticos términos dirigió sendas cartas al citado infante D. Alfonso de Portugal y esposa.

66 Por estas mismas fechas habían acatado a Jaime ll como rey legítimo de Murcia y señor suyo natural los lugares Murcianos de la cuenca alta y media del Segura, más los lugares del valle alto y medio de su afluente, el río Mundo, destacando entre otros Hellín, Calasparra, Cieza, Ricote, Archena, Lorquí, Ceutí, Las Alguazas y Molina Seca, acogiéndolos de igual modo bajo su protección real el monarca aragonés. ESTAL, ibid., p. 48. 
Nombra a Jaime Pérez, señor de Segorbe, su hermano, procurador general de reino de Mur$\mathrm{cia}^{67}$.

Constituye al ra'is de Crevillente, Muhammad ibn Hudayr, juez ordinario de los mudéjares del reino de Murcia ${ }^{68}$.

$24 \quad$ Murcia

Reg. 340 f. $107 v-108 r$

Confirma la posesión de un horno de pan y cier ta casas al arráez de la Arrixaca de Murcia, Abenhayça.

28

Sitio de Reg. 340 f. 258v

Mula (MU)

Inicia el asedio de la villa y castillo de Mula, capitulando al día siguiente ${ }^{69}$.

30

Mula

Reg. 340 f. 112 r

Al proveedor de vituallas de la casa real, Guillem Columer, que le haga llegar del mejor caldo de la tierra ${ }^{70}$.

31 ju Mula

Reg. 340 f. $115 r$

Homenaje del alcaide del castillo de Mula, Pedro Zapata, al rey de Aragón ${ }^{71}$.

A punto de cumplirse la tregua acordada con D.Juan Manuel (próximo 2 junio, sábado) ordena al procurador general, Jaime Pérez, que proceda contra él y su señorío de Elche con máxima dureza ${ }^{72}$.

\section{Junio}

67 ESTAL, El reino de Murcia..., I/1, pp. 197-198.

68 "ut sitis judex sarracenorum Regni nostri Murcie». Ibid., pp. 51-52.

69 lbid., pp. 199-200.

70 «de meliori vino quod inveneritis», ibid., p. 200.

71 Poco después tornó a rebelarse de nuevo este alcaide contra Aragón no logrando someterlo Jaime II hasta el 1303, FERRER I MALLOL, "Notes sobre la conquesta del regne de Murcia...», pp. 36 y 40 .

72 "post predictam diem sabbati facietis et fieri faciatis malum et dampnum quodcunque poteritis in loco Eltx et hominibus habitantibus in eo et bona eorum", ESTAL, ibid., pp. 201 y 74-85. 
Inicio del asedio al castillo y villa de Lorca, que Lorca (MU)

3 dom $^{\circ} \quad$ Sitio de Lorca Reg. 340 f. 284 r

Confirma al alcaide de la ciudad de Cartagena, Romeu de Morimond, en su cargo, por entregarle la plaza antes de caducar la tregua el 27 de mayo $^{74}$.

Constituye delegado real al caballero, Ferran Garçes de Rueda, para recibir el homenaje de los moros de los castillos de Axpe, Monóvar y Chinosa y jurarlos al ra'is de Crevillente, Muhammdad ibn Hudayr ${ }^{75}$.

$9 \mathrm{sab} \quad$ Murcia Reg. 340 f. $139 \mathrm{v}$

Al rey de Nápoles, Carlos II de Anjou, su suegro, que facilite a Galcerand de Montoliu llegar hasta el almirante Roger de Lauria en el Reino de Sicilia

10 dom $^{\circ}$ Murcia

Reg. 340 f. $132 r$

Al conde de Urgel, Ermengol, prohibiéndole enrolarse en la armada de Federico III de Sicilia $^{76}$.

Orihuela

Reg. 340 f. 130 r

Al rey de Nápoles, Carlos II de Anjou, comunicándole el envío a Cataluña de una galera armada para reclutar ballesteros por Federico III de Sicilia, lo que no puede tolerarse por contravenir el Tratado de Anagni ${ }^{77}$.

12 Sitio de Elche Reg. 340 f. $129 \mathrm{~V}$

Tras el incumplimiento de las treguas firmadas por el noble D.Juan Manuel, decide Jaime II sitiar la villa de Elche.

73 No volviendo a reanudar el sitio hasta mediados de diciembre del 1300, mes en que lograría su capitulación definitiva. ESTAL, "Nuevos datos sobre la capitulación y conquista aragonesa de Lorca», Homenaje al Prof. D. JUAN TORRES FONTES, Universidad de Murcia, 1987, pp. 431-464.

74 ESTAL, El reino de Murcia..., 1/1, pp. 70-73. El alcaide del castillo de Cartagena, Sancho Díaz de Bustamante, en cambio no acató la soberanía de Aragón hasta más tarde, el 23 de julio siguiente.

75 Ibid., p. 60. Este mismo día recibió Jaime II también el homenaje del noble D. Juan García de Loaysa por la tenencia del castillo de Petrel. FERRER I MALLOL, o.c., p. 38.

76 Por contravenir ala Paz de Anagni del 1395, ESTAL, ibid., pp. 206-207.

77 lbid., pp. 209-210. 
16 sab Sitio de Elche Reg. 340 f. 122r

18

Sitio de Elche Reg. 340 f. $150 \mathrm{~V}$

21 ju Sitio de Elche Reg. 340 f. 182v-183r

24 dom $^{\circ}$ Sitio de Elche Reg. 340 f. 168r, 180r

29

Sitio de Elche Reg. 340 f. 182v-183r

25

Sitio de Elche Reg. 340 f. 171r

30 sab Sitio de Elche Reg. 340 f. 185r, 187r
A su consejero real, Bernat de Sarrià, que impida a Carroç el embarque en el puerto ilicitano del Al-Ajub embarcar con sus hombres armados rumbo Sicilia en ayuda de Federico III, su hermano ${ }^{78}$.

Al procurador general de reino de Murcia, Jaime Pérez, que esté en Orihuela el día 21, jueves, por expirar ese día la tregua dada al alcaide de su castillo, Pedro Roiz de Sant Cebrian, para hacerse cargo del mismo ${ }^{79} 80$.

En premio a la entrega del castillo de Orihuela Jaime II confirmó a su alcaide, Pedro Roiz de Sant Cebrian, en el cargo.

Dat.al setge de Eltx XXIV dies andados del mes de juny de l'anyo de $n$. seynor M CC XC VI.

Al baile general del reino de Murcia, Bernat Colomer, que, transcurrido sin éxito el plazo dado, le envíe una relación de los castellanos insumjsos para proceder a la incautación de sus bienes en dicho reino ${ }^{81}$.

Al noble Jaspert, vizconde de Castellnou, al frente de la tropa aragonesa ante Villena, que inflija daños a las tierras de D. Juan Manuel por su insumisión ${ }^{82}$.

Dat. in obsidione de Eltx pridie kalendas julii anno domini $\mathrm{M} \mathrm{CC} \mathrm{XC} \mathrm{Vl}$, asedio que se prolongaría hasta la firma de una Tregua por 7 años el 27 de julio ${ }^{83}$.

78 ESTAL, El reino de Murcia..., V/1, pp. 213-214.

79 Ibid., pp. 215-216.

80 Ibid., pp. 41-42.

81 lbid., pp. 218-219.

82 «e que talets e cremets allí tot ello que potets e que hi fasats con maior tala e maior mal puscats", ESTAL, Ibid., pp. 79-80.

83 lbid., pp. $71-85$ y 212-241. 


\section{Julio}

1 dom $^{\circ} \quad$ Sitio de Elche Reg. 194 f. $246 \mathrm{r}$

Reg. 340 f. $191 \mathrm{r}$

3

Sitio de Elche Reg. 340 f. $191 \mathrm{v}$

$11 \mathrm{mi}$ Sitio de Elche Reg. 340 f. $183 \mathrm{v}$

$18 \mathrm{mi}$ Sitio de Elche Reg. 340 f. 240r, 152r

$23 \mathrm{lu}$

$27 \mathrm{vi}$

Sitio de Elche Arch. Cat. Valencia, perg. 0567

$29 \mathrm{dom}^{\circ}$ Elche

Reg. 340 f. $266 \mathrm{r}$

30

Murcia

Reg. 340 f. $269 r$
Donación de amplios heredamientos al caballero Ferran Garçes de Rueda por los muchos servicios prestados.

Al justicia de la ciudad de Murcia, Pedro Jiménez de Spilonga, que, mientras se compila el Fuero Nuevo, siga sirviéndose de los fueros alfonsinos y donde éstos no basten, recurra a los furs valencianos ${ }^{84}$.

Confirma a la ciudad de Cartagena sus fueros.

Al arzobispo de Tarragona, D. Rodrigo, que cuide de restaurar el orden en la metrópoli.

Compromiso formal de Jaime II de no separar jamás el castillo y villa de Alicante de la corona de Aragón ${ }^{85}$.

Tregua por siete años entre Jaime II y D. Juan Manuel hasta que cumpla 21 años (9.V.1303) ${ }^{86}$.

Jaime II dentro ya de Elche: «Dat. in Eltxio IV kalendas augusti anno dni.M CC XC Vl».

Jaime II se traslada a Murcia para proseguir la conquista del reino.

\section{Agosto}

4 sab Murcia

4

Orihuela

Reg, 194 f. 236v
Reg. 263 f. 114r, 280v Tras la confirmación a Murcia de todos sus fueros abandona la capital.

Al baile general del reino de Murcia, Bernat Colomer, que dé posesión de un heredamiento en Beni-Totana (MU) a Hugo de Solanis, confiscado a Aldolza López, dama de cámara de la reina $\mathrm{D}^{\mathrm{a}}$ María de Molina ${ }^{87}$.

84 ESTAL, El reino de Murcia..., 1/1, pp. 119-120; ÍDEM, «El fuero y las -Constitutiones regni Murcie- de Jaime II de Aragón, 1296-1301 ", Anales de la Universidad de Alicante, $H^{a}$ Medieval, 8, 1991, pp. 19-56.

85 ESTAL, El reino de Murcia, l/1, pp. 225-228. En la misma fecha confirmó a la villa de Alicante todos los fueros y libertades de que disfrutara hasta la fecha, ibid. pp. 223-225.

86 Ibid., pp. 80-85.

87 lbid., p. 246. 
$5 \mathrm{lu} \quad$ Alicante

12 dom $^{\circ}$ Valencia

Reg. 263 f. $115 \mathrm{v}$

$16 \mathrm{ju} \quad$ Valencia Reg. $104 \mathrm{f.} \mathrm{34r}$

21 ma Valencia Reg. 194 f. $248 \mathrm{~V}$

\section{Noviembre}

1 ju Barcelona Reg. 194 f. $313 r-v$

18 dom $^{\circ}$ Cadaqués Reg. 321 f. $10 \mathrm{~V}$

puerto (GE) Dat. in portu de

Cadaqués
Esta primera quincena del mes la dedicó Jaime Il a preparar su viaje marítimo a Roma, donde residió por espacio de más de tres meses, huésped del papa Bonifacio VIII.

Al obispo de Zaragoza, D. Ximeno de Luna, que dote al clérigo Raimundo de un beneficio eclesiástico en el arciprestazgo de Teruel para ayudarlo en sus estudios en Montpellier ${ }^{90}$.

88 ESTAL, El reino de Murcia, 1/1, pp. 246-247; ÍDEM, «Erección por Jaime II de una feria en Alicante», Revista IDEA (Instituto de Estud. Alicantinos), 16, 1975, pp. 153-174; iDEM, «Mercados y ferias medievales en Alicante...", IDEA, 35, Alicante, 1982, pp. 35-38.

89 Permaneció el monarca aragonés en la capital del Turia por espacio de casi dos meses, hasta el 13 de octubre, reg. 263 f. 156v: «Dat. Valentie III idus octobris anno dni. M CC XC VI».

90 Zarpa del puerto de Cadaqués Jaime II rumbo la corte papal de Bonifacio VIII en Roma y Anagni, adonde no llegó hasta el 14 de enero del 1297, tocando los los puertos de Port Vendres (Vallespir, r. 321 f. 20r, el 4 dic.); el día 8 en Aigües Mortes (Gard, Languedoc, r. 321 f. 21 r); el 11 en Marsella (r. 321 f. 21v); el 21 «in portu de Olig» (r. 321 f. 23v); el 28 dic. en Alfic (r. 321 f. 22 r); el 1 de enero de 1297 ante Orbetello, en la Toscana (dat. in mari ante portum de Sancto Stefano, r. $321 \mathrm{f.} 22 \mathrm{v}$ ); el 2 en Civitavèchia (dat. in Civitate Veteri, r. 321 f. 22v) y por fin Roma, el 14 de enero del 1297 (dat. Rome XIX kls februarii an. dni. M CC XC VI, 1297). 


\section{Enero}

16 ma Roma Reg. 321 f. $25 \mathrm{v}$

20 dom $^{\circ}$ Roma

Reg. 321 f. 30 r

Reg. 321 f. $32 v$

5 ma Roma

7 ju Roma

Reg. 321 f. $34 v$

\section{Marzo}

3 dom $^{\circ} \quad$ Roma

Reg. 321 f. $42 r$

10 dom $^{\circ}$ Roma

Reg. 321 f. $45 r$

19 ma Roma

reg. 321 f. $49 v$

31 dom $^{\circ}$ Roma reg. 321 f. $51 \mathrm{v}$
Al almirante Roger de Lauria que acuda a su presencia en Roma para tomar el mando de la armada de Aragón contra Federico III de Sicilia, por lo que le otorga «in feudum castrum et villam de Cocentayna» $(A)$.

Nombra al jurisperito aragonés, Juan, notario real y jefe de la escribanía de la Çalmedina de Zaragoza en régimen vitalicio.

A Romeu de Morimond que tome a su mando las 12 galeras armadas del rey de Nápoles, Carlos II de Anjou, y se sume a las de Aragón, surtas en Gaeta.

Nombra a Bernat de Sarrià almirante de toda la armada de la corona de Aragón ${ }^{91}$.

Al procurador general del reino de Murcia, Jaime Pérez, que dé posesión de cierto heredamiento en Orihuela a Pedro de Verduno.

Al maestre de la orden del Templo en Aragón y Cataluña, Berenguer de Cardona, que no permita la extracción de vituallas del término de Peñíscola (CS).

A Bernat de Sarrià, almirante de la armada de la corona, que ponga al frente de alguna de las galeras contra Sicilia a Bernardo de faro.

Sustituye a Gay Sexmundi cónsul de catalanes en Pisa por Simone Arlotti.

91 «Almirante regnorum nostrorum Aragonum, Maiorice, Valentie et Murcie ac comitatus Barchinone, remoto quolibet alio in dicto officio admirantie constituto", ACA, C, reg. $321 \mathrm{f} .34 \mathrm{v}$. 
4 ju Roma

Reg. 341 f. $2 r-6 r$

5

Roma

Reg. 321 f. 54r-v

7 dom $^{\circ} \quad$ Roma

8

Civitavec- Reg. 321 f. 56v, 59v chia (1)

13 sab Civitavecchia Reg. 321 f. 59r

$18 \mathrm{ju}$

In mari entre Reg. 321 f. 60r

Civitavecchia

y Marsella

$25 \mathrm{ju} \quad$ Barcelona Reg. $311 \mathrm{f}$. 207r

\section{Mayo}

$7 \mathrm{ma} \quad$ Barcelona reg. 324 f. $231 \mathrm{v}$

$23 \mathrm{ma}$ Lérida Reg. 108 f. 34v
Infeudación papal de Jaime II por Bonifacio VIII del reino insular de Córcega y Cerdeña, a cambio de la cesión del reino de Sicilia a la iglesia de Roma, gobernado a la sazón por Federico $1 \|^{92}$.

Al rey de Nápoles, Carlos II de Anjou, su suegro, so bre el matrimonio de su hijo, Roberto, duque de Calabria, con la infanta Yolanda, hermana del rey deAragón ${ }^{93}$.

Ultimo día de estancia en Roma de Jaime II de Aragón $n^{94}$.

Al podestà y senado pisano sobre ciertas irregularidades financieras del mercader catalán, Berenguer Mata, vecino de Montblanc (T).

Encarga al almirante Ro ger de Lauria negociar con Federico III la devolución del reino de Sicilia a la iglesia romana.

Al maestre de la Orden del Hospital de San Juan de Jerusalén, Guillem de Villaroers, acerca del negocio confiado.

Jaime II está de nuevo en esta ciudad, de regreso de su periplo marítimo a Roma.

Acerca de ciertos disturbios originados por la sucesión en el condado del Pallars.

Jaime II nombra al abad del monasterio cisterciense de Santes Creus $(T)$ capellán mayor de la Capilla Real.

92 Comprometiéndose Jaime II a llevar a cabo dicha empresa con las armas, si fuera preciso, como ocurrió de hecho. SALAVERT Y ROCA, Vic., Cerdeña y la expansión mediterránea de la corona de Aragón, 1297-1314, II, Madrid, 1956, pp. 22-30.

93 Ibid., pp. 31-32.

94 «Dat. Rome VII idus aprilis anno dni. M CC XC VII», r. 321 f. 60 r. 
Junio

$5 \mathrm{mi} \quad$ Lérida

Reg. 252 f. $163 \mathrm{v}$

Al papa Bonifacio VIII sobre el asunto del reino de Sicilia y la resistencia de su hermano, Federico III, a renunciar al mismo.

18 ma Vila de Reg. 195 f. 29v

De camino Jaime II a poner sitio a los castillos Estarás (L) de La Cuba (HU) y de El Llor $(L)^{95}$.

$20 \mathrm{ju} \quad$ Sitio del Reg. 311 f. 19r "dat. in obsidione castri de La Cuba (p.j. castillo de Barbastro-Huesca) XII kls julii anno dni. M CC XC VII».

$22 \mathrm{sab}$ Sitio al

Reg. 311 f. $30 \mathrm{r}$ castillo de El Llor (L) Inicia el asedio a este castillo de Lort (E) Llor, La Segarra, L) ${ }^{96}$.

Julio

$2 \mathrm{ma}$

Sitio al

Reg. 195 f. $63 r$

astillo de

El Llor

Prosigue Jaime II el asedio al castillo de El Llor (castrum de Lort) iniciado el 22 de junio pasa$\mathrm{do}^{97}$.

3 Sitio castillo Reg. 252 f. 167r El Llor

Continúa el asedio al castillo de El Llor ${ }^{98}$.

4

Sitio El Llor Reg. 264 f. 36v

Al veguer de D. Juan Manuel en Villena, Pedro Escriba $^{99}$.

5 vi Sitio castillo Reg. 252 f. $157 \mathrm{r}$

A Federico III acerca de su obligada renuncia El Llor al reino de Sicilia a tenor del Tratado de Anagni ${ }^{100}$.

7 dom $^{\circ} \quad$ Sitio al Reg. 252 f. $167 v-168 r$ castillo de El Llor

Expone a su hermano Federico III las causas de empuñar las armas contra él, de no acceder al beneplácito del papa Bonifacio $\mathrm{VIII}^{101}$.

95 «Dat. apud villam de Estars XIV kls julii an. dni. M CC XC VII».

96 «Dat. in obsidione castri de Lort X kalendas julii an. dni. M CC XC VII», reg. 311 f. 30r. Asedio que mantuvo Jaime II por casi dos meses, sin abandonar la provincia de Lérida, hasta el 29 de agosto del mismo año, cuando lo encontramos ya en Huesca.

97 «Dat. in obsidione castri de Lort VI nonas julii an. dni. M CC XC VIl», reg. 195 f. 63 r.

98 "Dat. in obsidione castri de Lort $V$ nonas julii an. dni. M CC XC VII".

99 «Dat. in obsidione castri de Lort IV nonas julii an. dni. M CC XC VII».

100 SALAVERT Y ROCA, o.c., Il, pp. 30-32.

101 Ibid., pp. 32-34. 
25 ju Lérida

Reg. 264 f. 51r-52v

Reg. 252 f. $174 \mathrm{v}$

\section{Agosto}

$19 \mathrm{lu}$

Lérida

Reg. 264 f. 70r

25 dom $^{\circ}$ Lérida

Reg. 264 f. $72 \mathrm{r}$

Reg. 311 f. 172r

Reg. 311 f. $195 \mathrm{v}$

14 sab Zaragoza

Reg. 109 f. $311 \mathrm{v}$

Reg. 195 f. $70 v-71 \mathrm{r}$

\section{Septiembre}

1 dom $^{\circ}$ Huesca

Reg. 195 f. $70 \mathrm{v}-71 \mathrm{r}$

Ruega al Capítulo provincial de la Orden de Predicadores en Valencia que sustituya en Murcia los frailes castellanófilos por otros fieles a la causa de Aragón.

Permaneció el monarca en esta ciudad casi dos meses, hasta el 16 de noviembre.

\section{Octubre}

6 dom $^{\circ}$ Teruel

Reg. 106 f. $15 r-v$

Notifica al juez eclesiástico de Tarragona, Fernando Juanes, el levantamiento papal de la excomunión al veguer de la ciudad, Bernat de Fonollar.

$31 \mathrm{ju}$ Teruel Reg. 106 f. $61 \mathrm{v}$

Ordena al obispo de Cartagena, D.Rodrigo, retirar el entredicho al justicia de Murcia, Pedro Jiménez de Spilonga ${ }^{102}$.

102 Incurso en la pena eclesiástica por haber detenido dentro del recinto sagrado al reo de homicidio, Pedro Sánchez, pese a haberse ajustado en tal acción al vigente fuero de Murcia. 


\section{Noviembre}

3 dom $^{\circ} \quad$ Teruel

Reg. 899

(erróneamente de

Pedro IV) f. 150r
Jaime II concede a la villa de Alicante franquicia de lezda y peaje por contribuir a la obra de la Torre del Molinell, lugar de control aduanero entre Valencia y Alicante ${ }^{103}$.

\section{Noviembre}

$16 \mathrm{sab}$ Valencia Reg. 264 f. 140r

Jaime II fija su residencia en esta ciudad, donde permanecerá el resto del año, hasta mediados de enero siguiente.

19

Valencia Reg. 324 f. $243 r$

Convenciones entre Carlos II de Nápoles y Jaime II de Aragón, su yerno, contra Federico III de Sicilia ${ }^{104}$.

\section{Año 1298}

\section{Enero}

$14 \mathrm{ma}$ Jijona (A) Reg. 195 f. $117 \mathrm{v}$

Jaime II reanuda de nuevo la campaña militar en el reino de Murcia para someter los lugares rebeldes de Alhma, Lorca, Mula y Alcalá etc.

$18 \mathrm{sab}$ Asedio al Arch.R.V., castillo de reg.c. 611 f. 198r Alhama (MU)

Nombra al caballero de Verona, Lorenzo de Scala alcaide del castillo de Almizra

\section{Febrero}

$1 \mathrm{sab} \quad$ Sitio al castillo de Alhama

3 lu Castillo de Reg. 256 f. 182r Alhama

$6 \mathrm{ju} \quad$ Murcia
Reg. 196 f. $131 \mathrm{r}$

Reg. 256 f. $30 v-31 v$

Reg. 195 f. $119 r$
Prosigue el asedio al castillo de Alhama: «in obsidione castri de Alfama" y otorga franquicia de ancoraje a las naves que atraquen en el puerto de Alicante.

Al rey de Granada, Muhammad II, congratulándose de la capitulación del castillo de Alahma ${ }^{105}$.

Confirma a Muhammad ibn Hudayr en el cargo de ra'is de Crevillente ${ }^{106}$.

103 ESTAL, El reino de Murcia, 1/1, pp. 274-278; ÍDEM, Documentos inéditos de Alfonso $X$ el Sabio y del infante su hijo D. Sancho, Alicante, 1984, pp. 28-38.

104 MIQUEL ROSELL, F.J., Regesta de Letras Pontificias del archivo de la corona de Aragón, Barcelona, 1948, no 295, pp. 157-158.

105 ESTAL, ibid., pp. 289-290.

106 lbid., pp. 290-291. 
Agradece a los comendadores santiaguistas de no 10 Ricote, Fernando Pérez, de Cieza, Juan Traslado del a.1757 Martínez y de Aledo, Pay Ferrándiz, los servicios prestados a la causa de Aragón ${ }^{107}$.

\section{Abril}

18 vie Sant Mateu del Maestrat (CS)

Reg. 264 f. 305v Hace alto en este lugar en su camino de regreso a Barcelona.

25 vie Barcelona Reg. 319 f. $13 r$

De vuelta a esta ciudad Jaime II prepara su próximo viaje marítimo extrapeninsular a Nápoles y Sicilia adonde zarpará el 10 de junio, con ánimo de cumplimentar la voluntad papal, aunque sin éxito, por espacio de año y medio, no regresando a Barcelona hasta octubre del 1299.

\section{Año 1299}

\section{Mayo}

6 ma Nápoles Reg. 265 f. 178r

Residió aquí Jaime II, con su esposa Da Blanca de Anjou, huésped de su suegro, Carlos II, cuatro meses (24.7-14. 8, 1298 y 21.3-26.6, 1299), preparando y ejecutando expedición militar al reino de Sicilia (26.6-14.8, 1299), pero $\sin$ éxito ${ }^{108}$.

\section{Junio}

19 vie Anagni (I)

Arch.Vat., reg.49 f.179

Huésped Jaime II del Papa Bonifacio VIII obtuno ${ }^{\circ} \mathrm{Clll}^{109}$ vo subsidios diocesanos para la empresa militar de Sicilia.

29 lu Amalfi (I) Reg. 113 f. $175 \mathrm{r}$

Reanuda navegación hacia Sicilia, notificando a su suegro, Carlos II de Anjou, la salida.

107 TORRES FONTES, Juan, CODOM, II, núm. CXXVIII, pp. 132-133; ESTAL, ibídem, pp. 292-293.

108 No explicitamos con detalle este periplo marítimo de Jaime II, por rebasar los límites del tema de esta Comunicación, remitiendo al lector interesado en ello a nuestro ITINERARIO completo de este monarca, que esperamos salga en breve su publicación.Durante su estancia en Nápoles dio a luz su esposa al futuro Alfonso IV de Aragón.

109 Edic. DIGART, G., Les Registres de Boniface VIII, II, Paris, 1884-1939, no 3083, col. 420. 
Julio

9 ju Cabo de ACA, CRD Jaime II

Orlando $\quad n^{\circ} 387$

(Sicilia)

\section{Agosto}

4 ma Puerto de Reg. 265 f. 215r

Milazzo (I)

$13 \mathrm{ju} \quad$ Castillo de Reg. 197 f. 30v

San Marco (I)

$31 \mathrm{lu} \quad$ Pozzuoli (I) Reg. 265 f. 225v

\section{Septiembre}

3 ju

Puerto de Reg. 265 f. 222 r
S. Felice de
Circeo (I)

13 dom $^{\circ}$ Puerto de Pisa (I)

$19 \mathrm{sab}$ Puerto de Tolon (FR)

25 vie Puerto de Reg. 265 f. 241v

'Aigle,

Marsella (FR)

\section{Octubre}

1 ju Castillo de Reg. 265 f. 267r

Blanes (GE)

$3 \mathrm{sab} \quad$ Barcelona reg. $265 \mathrm{f.} 232 \mathrm{r}$
Notifica a Bonifacio VIII haber arribado al caput de Orlando y derrotado a Federico III.

Comunica al duque de Calabria, Roberto de Anjou, el triunfo habido en el cabo Orlando de Sicilia sobre Federico III.

«Dat.in litore maris prope castrum Sancti Marciidus augusti an.dni.M CCXC IX»110.

Camino de regreso a Barcelona.
En el golfo de Gaeta, rumbo a España.

Reg. 265 f. 225V Dat. apud portum Pisanum idus septembris an.dni. M CC XC IX, donde permaneció una semana, hasta el día 16.

Reg. $265 \mathrm{f.262r}$ In mari in Provincia (Provenza) in portu de Oliulas, hoy Toulon, XIII kls octobris a.d. MCCXCIX.

In portu vocato de Aquila in Provincia (Provenza) hoy Carry le-Rouet al NW de Marsella.
Dat. in mari ante castrum de Blanis (Blanes, Gerona).

Arribo final de Jaime II a Barcelona, tras el peripio marítimo de casi año y medio por Nápoles y Sicilia.

110 Ante las persistentes dificultades de someter a su hermano, Federico III y devolver aquel reino de Sicilia a la iglesia romana, Jaime II decidió abandonar la empresa militar y emprender el regreso a Barcelona. 
Al procurador general de los reinos de Valencia y Murcia, Jaime de Jérica, encomendándole los noble oriolanos Juan de Rocafull e hijo, Guillem. Jaime II residirá ahora en Barcelona por más de medio año, hasta el 23 de abril del 1300.

23 vie Barcelona Arch.Mun.Elche (AME) La reina $D^{\mathrm{a}}$ Blanca de Anjou confirma fueros y Arm.2, codice, franquezas de Orihuela ${ }^{111}$.

$n^{\circ} X X X V, f . X X X \mid X r$

\section{Año 1300}

\section{Mayo}

15 dom $^{\circ}$ Lérida

Reg. 332 f.51v

Nueva convocatoria de los nobles de Aragón por Jaime II para someter los pocos castillos rebeldes del reino de Murcia, sobretodo los de Lorca, Mula y Alcalá entre otros.

31 ma Lérida

Reg.332 f. 53r, 57v

Orden a los barones de Aragón de presentarse el próximo 10 de julio en Visiedo y Calamocha, con sus hombres de armas, para someter los focos rebeldes murcianos.

\section{Junio}

$28 \mathrm{ma}$ Teruel

Reg. 332 f. $57 \mathrm{r}-\mathrm{v}$

Al noble don Pedro Cornell que acuda a renirse con él en Visiedo con todos sus hombres de armas.

Julio
1 vie Teruel $\quad \begin{aligned} & \text { Reg. } 266 \text { f. } 258 r-259 r \\ & \text { Reg. } 332 \text { f. } 59 r\end{aligned}$

Al procurador general de Aragón, Lope Ferrench de Luna, que esté en guardia contra ataque eventual castellano de su frontera.

15 vie Daroca Reg. 332 f. 73 r

Convocatoria del procurador general de Aragón, Lope Ferrench de Luna, a las cortes de aragón el 8 de agosto próximo.

111 ESTAL, El reino de Murcia, l/1, pp. 299-300. 


\section{Agosto}

$1 \mathrm{lu}$

Alagón (Z) Reg. 332 f. 68r-69r

$17 \mathrm{mi} \quad$ Zaragoza Reg. $332 \mathrm{f.} 75 \mathrm{r}$

\section{Septiembre}

16 vie Zaragoza Reg. 332 f. $70 \mathrm{r}$

\section{Octubre}

9 dom $^{\circ}$ Calatayud(Z) Reg. 325 f. 3r-v

$12 \mathrm{mi}$ Calatayud Reg. 116 f. 196v

12

Calatayud Reg. 332 f. 112r-v

Reg. 332 f. $120 \mathrm{~V}$

4 vie Valencia

$$
\text { Reg. } 332 \text { f. } 120 \mathrm{~V}
$$

6 dom $^{\circ} \quad$ Valencia

Reg. 332 f. $122 r$

f. $120 \mathrm{~V}$

f. $121 \mathrm{r}-\mathrm{V}$
Al procurador de Aragón, Lope Ferrench de Luna, que esté preparado para rechazar un ataque eventual de Fernando IV a su frontera.

Mandato a los maestres de las ordenes Militares del Templo, Santiago, Calatrava y castellanía sanjuanista de Amposta de hallarse vigilantes contra una incursión castellana inminente.

Al sobrejuntero de Zaragoza, Rodrigo, que tenga bien alertados a los vecinos de Velilla de Ebro contra un eventual ataque castellano.

A los colectores de la gabelas de la sal en Zaragoza que hagan saber las condiciones de compraventa de aquel producto en un bando.

Al procurador general del reino de Murcia, Bernat de Sarrià, que esté en guardia contra un ataque eventual castellano.

A los feuadatarios de la corona de aragón que acudan a Valencia con sus huestes el 11 de noviembre.

Al noble Juan García Jofré de Loaysa, lugarteniente del infante D. Alfonso de Portugal en los castillos de Elda y Novelda, que provea de los hombres armados solicicitados por Bernat de Sarrià $^{112}$.

Resuelto Jaime II a sofocar de una vez los focos aún rebeldes a su causa, los castillos de Lorca, Mula y Alcalá, entre otros, convocó un cuantioso contingente armado en Cocentaina (A) bien equipados de caballos, armas, aparatos de guerra y provisiones para cuatro meses.

112 ESTAL, El reino de Murcia, l/2, Alicante, 1990, p. 111. 
6 dom $^{\circ}$ Valencia Reg.332 f. $125 \mathrm{r}-\mathrm{v}$

$8 \mathrm{ma}$ Valencia Reg. $332 \mathrm{f.} 121 \mathrm{r}$

9

Valencia

reg. 332 f. $121 \mathrm{r}$

13 dom $^{\circ}$ Valencia

reg. 332 f. $125 r$

$17 \mathrm{ju} \quad$ Valencia Reg. $332 \mathrm{f} .123 \mathrm{r}$ f. $124 \mathrm{~V}$

18 dom $^{\circ}$ Valencia
Reg. 332 f. $124 \mathrm{v}$
En iguales términos se dirigió a los consells valencianos de Museros, Massamagrell, Vilafames, Massanassa, Albaida y Xirivella, ordenándoles poner los hombres de armas solicitados a disposicición de Bernat de Sarrià ${ }^{113}$.

A los comendadores santiaguistas de Cieza, Ricote y Aledo en el reino de Murcia, señores Juan Martínez, Fernando Pérez y Pay Fernández respectivamente, que urjan el pago del monedaje a sus vecinos y entregarlo a Pedro Escribano, para ayuda campaña militar murciana $^{114}$.

A todos los oficiales del reino de Valencia que activen con diligencia la mayor leva posible de hombres de armas para sofocar los focos aun rebeldes del reino de Murcia $^{115}$.

Igual mandato de leva a los lugares valencianos de Alcira, Játiva, Gandía, Pego, Beniopa, Pop, Gallinera y Ebbo, a través de su portero Miguel del Real, provistos también de víveres para cuatro meses.

Al justicia, jurados y comunidad de Ademuz (V) que recluten hombres de armas, bien equipados de caballos y aparatos de guerra, con provisiones para cuatro meses y se sumen en Alicante al grueso militar real el uno de diciembre próximo.

Al procurador general del reino de Murcia, Bernat de Sarrià, que haga una leva de hombres de armas en Alicante, debidamente equipados, de los que lleve él la mitad y el resto lo sumará el monarca al grueso de su expedición personal.

113 Ibid., pp. 112-113.

114 ESTAL, El reino de Murcia, l/2, pp. 114-115.

115 Ibid., pp. 115-116. 


\section{Diciembre}

$17 \mathrm{sab}$ Real ante Reg. $293 \mathrm{f.} 1 \mathrm{r}$ Lorca (MU)

18 dom $^{\circ}$ Lorca

19

Lorca

Reg. 293 f. $4 r$

24 sab Lorca

Reg. 293 f. $25 r$

$28 \mathrm{mi} \quad$ Lorca Reg. 293 f. 25r-v

Reg. 293 f. $19 \mathrm{v}$
Conmina Jaime II al alcaide del castillo de Lorca, Nuño Pérez, a la entrega de la Torre Alfonsí o del homenaje, tras haberse consumido los plazos otorgados de 50 y 60 dias, so pena de confiscar a los defensores sus casas $y$ haciendas ${ }^{116}$.

Reg. 293 f. $17 r-25 r$

Acta de Capitulación del castillo y villa de Lorca, suscrita por su alcaide, Núño Pérez, y el de la villa, López Fernán dez, aunque en precario ${ }^{117}$.

Compromiso de Jaime II ante el maestre santiaguista, Juan Osores, de acojer bajo su tutela regia las encomiendas de Ricote, Cieza y Aledo, durante la conquista del reino de Mur$\mathrm{Cia}^{118}$.

Al comendador santiaguista de Moratalla, Juan Alvarez, emplazándolo a prestarle el homenaje debido antes de 20 días por hallarse enclavada su encomienda dentro delreino de Murcia $^{119}$.

Pendiente Jaime II del abastecimiento de Lorca, impone a sus oficiales que no estorben a sus en viados regios, Jaime Peregrín y Juan Cayrat, descargar sus viandas en los puertos de Cartagena, Aguilas, Guardamar y Alicante ${ }^{120}$.

Ultimatum de Jaime II al alcaide del castillo, Nuño Pérez, y demás defensores del mismo, de entregarlo al dia siguiente, 29 , so pena de males mayores ${ }^{121}$.

116 ESTAL, "Nuevos datos sobre la capitulación y conquista aragonesa de Lorca", Homenaje al Prof. don JUAN TORRES FONTES, Universidad de Murcia, 1987, I, pp. 432 y 441; ÍDEM, El reino de Murcia, l/2, p. 122.

117 Se comprometían ambos alcaides a desalojar y entregar villa y castillo con sus tres torres, la principal o Alfonsina, la del Espolón y la de Guillen Pérez de Pina en el plazo máximo de 50 días, compromiso que incumplió particularmente el susodicho alcaide del castillo Nuño Pérez, por lo que Jaime Il hubo de actuar en consecuencia, ESTAL, “Nuevos datos sobre la capitulación...», pp. 432$433,442-447$.

118 Ibid., pp. 433-434 y 447-448; ÍDEM, El reino de Murcia, I/2, p. 130.

119 lbid., pp. 435 y 455-456.

120 Ibid., pp. 437 y 456-457; ESTAL, El reino de Murcia, I/2, p. 140.

121 Ibid., pp. 436-437 y 457. Y la amenaza surtió por fin su efecto. 
Jaime II confirma al alcaide, López Fernández, de la villa de Lorca y su concejo los fueros de que disfrutara hasta la fecha ${ }^{122}$.

\section{Año 1301}

\section{Enero}

3 ma Murcia

Reg. 332 f. $127 \mathrm{v}$

Ante la dilación de entrega de la Torre Alfonsina del castillo de Lorca por su alcaide Nuño Pérez, Jaime II hubo de reclutar nuevos combatientes, acudiendo a la leva de mudéjares en el medio y bajo Vinalopó ${ }^{123}$.

5 ju Murcia

Reg. 332 f. $128 r-v$

Próxima la fecha cuaresmal de la celebración de cortes en Cataluña, Jaime II notifica al conde de Ampurias, Ponç Hugonis el aplazamiento de las mismas a causa de hallarse ocupado en la dura empresa de someter los focos aun rebeldes de la Torre Alfonsina de Lorca, del castillo de Mu la y el de Alcalá ${ }^{124}$.

$11 \mathrm{mi} \quad$ Murcia Reg. 332 f. $127 \mathrm{v}$

Al noble D.Juan García de Loaysa que haga llegar cuanto antes a las fuerzas sitiadoras del castillo de Mula los mudéjares convenidos de Elda y Novelda ${ }^{125}$.

122 Sin hacer otro tanto al alcaide del castillo de Lorca, Nuño Pérez, por haber incumplido el ultimatum de entregarle la Torre Alfonsina o del Homenaje, ESTAL, El reino de Murcia, 1/2, pp. 143144; ÍDEM, «Nuevos datos sobre la capitulación...», pp. 436-437 y 469-460.

123 En este sentido convocó a filas, urgiéndoles incorporarse a la tropa concentrada frente a los focos Murcianos aún rebeldes de los castillos de Lorca, Mula y Alcalá, a los mudéjares de las aljamas sarracenas de Elda, Novelda y Elche, ESTAL, El reino de Murcia, I/2, p. 145.

124 Ibid., pp. 146-147. En idénticos términos se dirigió a los condes del Pallars, de Urgel y a otros numerosos nobles catalanes.

125 Ibid., p. 148: "Dehim vos e manam vos que vos manets per vostra letra als dits moros que els que vinguen en la dita ost de Mula sens tota tregua... Dada en Murcia XI dies anats del mes de gener en l'ayn damunt dit». 


\section{Año 1301}

\section{Enero}

13 vie Murcia

Reg. 118 f. $2 r$

Al procurador general del reino de Valencia, Jaspert, vizconde de Castellnou y comandante en jefe de la tropa asediante el castillo de Lorca, que, concluyendo la tregua otorgada al alcaide del castillo de Lorca, Nuño Pérez el domingo próximo (15.J.1301), deberá urgir la entrega de la Torre Alfonsina sin próroga alguna ulterior ${ }^{126}$.

$14 \mathrm{sab}$ Murcia Reg. $332 \mathrm{f.} 129 \mathrm{r}$

En la espera de que el alcaide del castillo de Lorca, Nuño Pérez, le haga entrega por fin de la Torre del homenaje del mismo o Alfonsina, despacha Jaime II numerosas cartas a los procuradores, bailes, justicias y demás oficiales de la corona que apoyen el acopio de viandas con destino al castillo y villa de Lorca $^{127}$.

$17 \mathrm{ma} \quad$ Murcia Reg. 332 f. $149 \mathrm{v}$

A los ricos-hombres y prelados del reino de Aragón que proporcionen a sus enviados, $\mathrm{Pe}$ dro de Roda y Juan de Roquefort el volumen mayor posible de vituallas para los castillos recien sometidos y necesitados del reino de Murcia.

16-20 enero

Núño Pérez entendió que no podía dilatar más la entrega de la Torre Alfonsina y la entregó.

126 «por aquesto decimos e mandamos vos que requirades a Nuño Pereç e los otros sobreditos, dia domingo primero que viene (15 enero), en el qual se cumplen los ditos $X V$ dias, que nos desemperen la dita Torre Alfonsia, segunt puesto es en las ditas convinencias. Essi ellos un otro alongamiento entendieren, no ge les consintades de un dia ni de una ora, antes queremos e mandamos firmement e expressa de sos pena de la nostra graçia e merçé, que tantost pensedes de enantar contra las rahenas e contra Nuño Pereç e los otros sobditos sin ninguna mercé, assi como contra aquellos que crebantan fe e prometimiento que fazen a seynor, a que a otros sea siempre escarmiento e exiemplo». ESTAL, El reino de Murcia, 1/2, pp. 148-149; ÍDEM, «Nuevos datos sobre la capitulación...», p. 440.

127 ESTAL, El reino de Murcia, pp. 150-155. 


\section{Año 1301}

\section{Enero}

$18 \mathrm{mi} \quad$ Murcia Reg. 332 f. $149 \mathrm{r}$

Orden de Jaime II al portero real, Juan de Roquefort, que se haga cargo con el repostero de la reina, $D^{\text {a }}$ Blanca de Anjou Pedro de Roda, del transporte de las viandas acopiadas en Aragón para avituallamiento de los castillos necesitados del reino de Murcia ${ }^{128}$.

$21 \mathrm{sab}$ Murcia Reg. 198 f. $244 \mathrm{r}$

Tras la entrega por fin de la Torre Alfonsina de castillo de Lorca por su alcaide, Nuño Pérez, el rey de Aragón procedió a confirmar a la villa y castillo de Lorca todos sus fueros y libertades de los que disfrutara anteriormente bajo la soberanía castellana, en premio al juramento de vasallaje y fidelidad prestados ${ }^{129}$. Concluía así el asedio más largo y duro de Jaime II en la conquista del reino castellano de Murcia, restándole tan solo por someter las plazas de Mula y Alcalá, y muy pocas otras de menor importancia.

128 ESTAL, El reino de Murcia, 1/2, p. 155.

129 «laudamus etconfirmamus vobis universis et singulis fidelibus vestris, fidelibus nostris habitatoribus... castri et ville de Lorcha et terminorum suorum et vestris successoribus in perpetuum privilegia, libertates, franchitates et inmunitates, foros ac bonos usus et bonas consuetudines ac etiam donationes, quas obtinuistis a regibus Castelle, antecessoribus nostris in regno Murcie, prout hec in cartis quas inde habetis plurimum continetur et prout ex ipsis melius usi estis. Mandantes per presens privilegium nostrum procuratori regni predicti, necnon justiciis, bajulis eiusdem et universis aliis officialibus nostris... quod hanc, approbationem et confirmationem nostram firmam habeant, teneant et observent ac inviolabiliter faciant observari...», ESTAL, El reino de Murcia, 1/2, pp. 156-157. 



\title{
ELS SARRAIINS DEL REGNE DE MÚRCIA DURANT LA CONQUESTA DE JAUME II (1296-1304)
}

\author{
Maria Teresa FERRER I MALLOL \\ Institució Milà i Fontanals. CSIC
}

Amb la conquesta del regne de Múrcia per Jaume II durant la guerra contra Castella de 1296-1304, la Corona catalano-aragonesa incorporava un altre regne amb una proporció molt important de població sarraïna. Com al regne de València, una gran part de la població auctòctona de religió islàmica havia romàs al regne, tant a conseqüència del protectorat de Castella acordat a Alcaraz, el 1243, com per les capitulacions pactades amb Jaume I quan aquest monarca conquerí el regne després de la sublevació del 1264'. Malgrat que les primeres operacions militars castellanes de mitjan segle XIII i la conquesta de Jaume I havien provocat l'emigració d'un nombre molt considerable de sarraïns murcians, eren encara una minoria important, bé que en regressió.

Sembla que els castellans no posaven gaires obstacles a l'emigració dels sarraïns cap a Granada; el fet que els deixessin vendre els seus béns a cristians facilitava la marxa del sector més benestant2; altrament, algunes mesures preses a Castella contra els sarraïns degueren accentuar la incomoditat que sentien sota domini cristià $i$ potser n'estimularen l'emigració. Em refereixo concretament a dues qüestions posades en evidència pel Prof. Torres-Fontes: en primer lloc, les restriccions imposades a la pràctica religiosa ja durant el regnat d'Alfons el Savi, concretament la prohibició de la crida de la salà, és a dir, la crida a l'oració que feia el muetzí des dels minarets de les mesquites $^{3}$; era una manifestació religiosa amb la qual la població islàmica se sentia

Cf. sobre aquest tema l'excel-lent treball del Prof. J. TORRES FONTES, La reconquista de Murcia en 1266 por Jaime I de Aragón, Murcia, Patronato de Cultura de la Excma. Diputación Provincial de Murcia, 1967.

2 J. TORRES FONTES, "Los mudéjares murcianos en el siglo XIIl», Murgetana, XVII (1961) p. 9.

3 Ibidem, p. 21. 
molt identificada, però que desvetllava una hostilitat manifesta en la Església, que s'esforçà a fer-la prohibir en terres cristianes, cosa que no aconseguí a la Corona catalano-aragonesa fins el $1318^{4}$. Per les reaccions que aquesta prohibició suscità entre els sarraïns d'aquest darrer estat, podem suposar el malcontentament que degué provocar a Castella. En segon lloc, la prohibició de tenir propietats, decidida a les Corts de Valladolid del $1293^{5}$, degué suposar un altre cop molt dur per a la població islàmica sotmesa a Castella i potser influí, com diu Guichard, en l'actitud favorable a Jaume II que la comunitat musulmana adoptà arran de la invasió del regne de Múrcia ${ }^{6}$.

Veurem ara on s'assentava la població islàmica en aquest territori. A la part septentrional del regne, la població cristiana es concentrava a la plana litoral, mentre que la vall del Vinalopó era majoritàriament de població sarrainna: comprenia la moreria urbana i l'horta d'Elx, Crevillent, Elda, Novelda, Petrer, Xinosa, Monòver i Asp. Fora d'aquest nucli més compacte, l'horta d'Oriola també comptava amb un nombre considerable d'habitants sarraïns i la vila tenia una moreria urbana, bé que força més reduïda que la d'Elx; a l'horta d'Alacant i a la moreria d'aquesta vila hi vivien, igualment, petites comunitats sarraines.

A la part meridional del regne -l'actual província de Múrcia - el litoral era molt despoblat; I'únic nucli destacable, malgrat que era de dimensions reduïdes, era Cartagena, amb una petita moreria. La població cristiana es concentrava a la ciutat de Múrcia i a les viles de Lorca i Mula, mentre que els sarraïns predominaven a la vall de Ricote, a l'horta i al camp de Múrcia i a la mateixa capital, que comptava amb una moreria important; cal esmentar també un petit nucli sarraí a Mula ${ }^{7}$, mentre que no he trobat cap notícia relativa a Lorca. La vall de Ricote comprenia diversos nuclis habitats: Ricote, Blanca, Abarán, Ulea, Ojós, Asuete o Villanueva. A l'horta i camp de Múrcia, sabem que comptaven amb població sarraïna Lorquí, Ceutí, Molina, Alguazas - conegudes a la documentació catalana com les Alguastes- Pliego i Albudeite, Alcantarilla, Cotillas etc., a més de Favanella —Abanilla en castellà-, que els primers temps quedà lligada a la Corona catalano-aragonesa, i Fortuna ${ }^{8}$, que eren els nuclis més pròxims a la frontera quan el regne es dividí.

4 M.T. FERRER I MALLOL, Els sarrains de la Corona catalano-aragonesa en el segle XIV. Segregació i discriminació, Barcelona, CSIC. Institució Milà i Fontanals, 1987, pp. 88-95.

5 J. TORRES FONTES, Los mudéjares murcianos en el siglo XIII, pp. $24-25$.

6 P. GUICHARD, Un señor musulmán en la España cristiana: el «ra'is de Crevillente (1243-1318), Alacant, 1976, pp. 26-27.

7 Sembla que en altre temps Mula havia tingut una moreria important: J. TORRES FONTES, Los mudéjares murcianos en el siglo XIII, pp. 26-27.

8 Sobre el lloc de Fortuna cf. J. TORRES FONTES, "Fortuna en los siglos XIII y XIV", Murgetana, XXVIII (1968), pp. 47-102.

9 Cf. les panoràmiques generals dels moros murcians durant la baixa Edat Mitjana traçades per J. TORRES FONTES, "Los mudéjares murcianos en la Edad Media», III Simposio Internacional de Mudejarismo (Teruel, 1984). Actas, Terol, Instituto de Estudios Turolenses, 1986, pp. 55-66, i a «Los mudéjares murcianos: economía y sociedad", a IV Simposio Internacional de Mudejarismo: Economía (Teruel, 1987), Terol, Instituto de Estudios Turolenses, 1992, pp. 365-393, així com «Murcia Medieval. Testimonio documental. VIII. Los mudéjares», Murgetana, 59 (1980), pp. 115-158. També A. L. MOLINA 
M'ocuparé només dels sarraïns durant els anys de la guerra. M'ha semblat que així el meu treball serà més homogeni perquè, altrament, tindria molta documentació per a la part septentrional de l'antic regne i poca, o no gens original, per a la part meridional. Aquesta decisió farà que em limiti, especialment, als efectes de la guerra sobre les diverses comunitats sarraïnes.

\section{LA GUERRA, CAUSA DE DESPOBLACIÓ}

La guerra de 1296-1304, com totes les guerres, afectà la minoria sarraïna i provocà un descens demogràfic. Alguns sarraïns degueren morir en les operacions bèl.liques, uns altres foren capturats i, en virtut del principi pel qual tot sarrai suposadament rebel quedava reduït a captivitat, foren venuts i portats sovint lluny de les seves terres; d'altres sarraïns emigraren cap al regne de València, fora de l'àrea de guerra ${ }^{10}$, i altres, si els fou possible, fugiren a Granada. Cal tenir en compte que les guerres eren sempre d'efectes més desastrosos per a les minories, sarraïns i jueus, que no pas per als cristians, perquè eren les víctimes preferides dels excessos dels soldats.

Acabada la guerra, una carta de Ferran IV dóna testimoni d'aquesta minva de la població sarraïna a la part del regne de Múrcia que tornà a mans de Castella: «por razón de las guerras e de los otros males que son acaescidos en tierra de Murcia, la mayor parte de los moros son muertos e los otros fuydos, por las quales cosas la tierra es muy despoblada e menguada dellos" $" 11$.

L'inici de les operacions bèl-liques provocà una desbandada entre els sarraïns, principalment entre els que vivien a les zones rurals, per a refugiar-se a indrets considerats més segurs: Els primers afectats foren els moros d'Alacant; ni els que vivien a la rodalia ni els que vivien al raval de la vila no podien comptar amb la protecció de les muralles de la ciutat, on en temps de guerra la presència dels sarraïns no era gaire apreciada per la manca de confiança en la seva lleialtat.

Fora dels murs protectors, els esperaven tota mena de desgràcies: la mort, la captura i la reducció a la servitud. Un exèrcit en campanya era sempre perillós, oimés per als sarraïns, que eren ciutadans de segona. Els sarraïns d'Alacant, doncs, anaren a refugiar-se a Crevillent, el darrer senyoriu que s'havia mantingut en mans d'un noble musulmà, l'arrais de Crevillent, de qui esperaven protecció; ell podia negociar amb el rei i ja es devia saber que havia estat visitat pels emissaris de Jaume ${ }^{1{ }^{12}}$.

MOLINA, La vida en Murcia a finales de la Edad media, Academia Alfonso X el Sabio, discurso de recepción, Múrcia, 1983, i “Los mudéjares en el reino de Murcia", Áreas, 14 (1992), pp. 91-106.

10 És el cas, per exemple, d'Ahayan Huarat Façon, que marxà a viure a València amb la mare, la germana, la muller i un fill des de Crevillent, on residia: ACA, C, reg. 198 v. (1296, juliol, 6).

11 J. TORRES FONTES, Los mudéjares murcianos, p. 27.

12 P. GUICHARD, Un señor musulmán en la España cristiana, p. 22; J.M. del ESTAL, "Vasallaje del señorío musulmán de Crevillente a Jaime II de Aragón», Sharq Al-Andalus. Estudios Árabes, 2 (1985), doc. V; M.T. FERRER I MALLOL, Les aljames sarraines de la governació d'Oriola en el segle XIV, Barcelona, Institució Milà i Fontanals, 1988, p. 16 i doc. 1, i J.M. del ESTAL, El reino de Murcia bajo Aragón (1296-1305). Corpus documental, I/2, Alacant, Instituto de Cultura «Juan Gil-Albert», Di- 
Molts més sarraïns, com també els cristians, abandonaren les cases i degueren amagar-se a les muntanyes, fugint dels almogàvers i de la gent de guerra, o bé marxaren a Elx, que essent senyoriu de don Juan Manuel, de la família reial castellana, els devia semblar més segur, $O$ als dominis dels ordes militars. Després tornaren als llocs ocupats per Jaume II, des que hi hagué ordre. El mes de maig de 1296, quan ja es devia veure pròxim l'atac a Elx, moros d'aquesta vila fugiren cap a Alacant, que ja era en poder de Jaume II i on no calia témer cap episodi bèl-lic ${ }^{13}$.

Hi ha nombrosos testimonis de captures de sarraïns; si havien estat fetes violant guiatges atorgats pel rei i algú amb influència s'encarregà de reclamar-los, els afectats aconseguiren la llibertat. És el cas de dos sarrains innominats presos per Ato de Lisón i que pel juny de 1296 eren en poder de Bernat Pujades, alcaid del castell de Callosa. L'arrais de Crevillent els reclamà a Jaume $\mathrm{II} \mathrm{i}$ el rei ordenà que fossin retornats ${ }^{14}$. Pel maig, una cavalcada pel terme d'Albudeite produí almenys 80 sarraïns captius i que Jaume II autoritzà que fossin venuts perquè, quan foren presos, aquest lloc estava en guerra amb ell15. Dels sarrains portats a Oriola per l'adalil Vicenç de Xixona, que havien estat presos en una cavalcada per Ceutí, Lorquí i les Alguazas, els capturats en aquest darrer lloc hagueren de ser alliberats perquè el rei no volia causar perjudicis al seu conseller Ramon de Manresa, a qui havia donat el $l \operatorname{loc}^{16}$. Hi ha constància, en canvi, que els procedents de Lorquí foren venuts ${ }^{17}$; la licitud de la captura d'algun altre presoner, pres igualment per Vicenç de Xixona, fou objecte d'una llarga controvèrsia perquè en el moment de la captura no es veia prou clar si ja era vigent el guiatge atorgat pel rei als sarraïns d'Asp ${ }^{18}$. També Ferran Garcés de Rueda reclamà per la captura de quatre sarraïns de l'alqueria de Catral, al terme d'Oriola, que el rei li havia donat. A la darreria de juliol, n'havia recuperats dos ${ }^{19}$.

Alguns membres de l'exèrcit enviaren els captius aconseguits cap al seu lloc

putación de Alicante, 1990, 1/2, doc. 18. Pel que fa als emissaris enviats a l'arrais, abans de la invasió, cf. M.T. FERRER I MALLOL, Notes sobre la conquesta del regne de Múrcia per Jaume II (1296-1304), a Homenatge a la memòria del Prof. Dr. Emilio Sáez. Aplec d'estudis dels seus deixebles i col.laboradors, Barcelona, Universitat de Barcelona, Centre d'Estudis Medievals de Catalunya i Institució Milà i Fontanals, 1989 , p. 30.

13 A. GIMÉNEZ SOLER, Don Juan Manuel. Biografía y estudio crítico, Saragossa, 1932, doc. 63. M. del ESTAL, Vasallaje del señorío musulmán de Crevillente a Jaime Il de Aragón, doc. II; M.T. FERRER I MALLOL, Les aljames sarraines, pp. 50-51 i doc. 3, 15 i 16; J. M. del ESTAL, El reino de Murcia bajo Aragón, 1/2, doc. 23.

14 ACA, C, reg. 340, f. 130 v. (1296, juny, 13).

15 ACA, C, reg. 340 , f. 85 v. (1296, maig, 22).

16 ACA, C, reg. 340, f. 71 r. (1296, maig, 17), publ. per J. M. del ESTAL, El reino de Murcia bajo la soberanía de Aragón (1296-1304/1305). Corpus documental, Alacant, Instituto de Estudios Juan Gil Albert, 1985, $1 / 1$, doc. 64

17 Ibidem, f. 73 r. i v. (1296, maig, 17 i 18).

18 ACA, C, reg. 340, f. 201 v (1296, juliol, 7) i reg. 104, f. 29 r.-v., 36 r., 55 r. (1296, agost, 11, 16, 21). Cit. el primer per P. GUICHARD, Un señor musulmán en la España cristiana, p. 27.

19 M.T. FERRER I MALLOL, La frontera amb l'slam en el segle XIV. Cristians i sarrains al País Valencià, Barcelona, Institució Milà i Fontanals. CSIC, 1988, doc. 6. 
d'origen, com Gil de Jaca, que envià una nena sarraïna de sis anys cap a Aragó amb el seu escuder Joan Ferrer ${ }^{20}$. Altres, com Pere de Montagut de Carlet, foren autoritzats a vendre els captius aconseguits, considerats de bona guerra, en aquest cas dues sarraïnes, Nussa i Çofra, i un sarraï, Mafumet ${ }^{21}$. Sabem que molts dels sarraïns capturats foren retinguts a Oriola, a Guardamar i a Alacant, d'on alguns intentaren fugir ${ }^{22}$. A vegades, alguns sarraïns foren tan desgraciats que, havent estat capturats pels castellans i portats a una de les viles que resistiren, la seva situació resultà consolidada per ignorància quan la vila fou presa per Jaume Il. És el que li esdevingué a Façén, un moro de la Reixaca de Múrcia, que pel gener de 1301 encara era presoner a Lorca perquè un clergue del Iloc, callant el seu origen, havia sol-licitat a Jaume II que I'hi donés. Només quan el pare de Façén, Mahomet, es presentà al rei, que es trobava llavors a Múrcia i, plorant, li explicà el cas del seu fill, el monarca ordenà desfer aquest greuge tan $\operatorname{gros}^{23}$.

Una de les primeres preocupacions de govern de Jaume II, a mesura que anava adquirint territori del regne, fou la de tranquil.litzar els camperols sarraïns, que posà sota el seu guiatge perquè tornessin a les seves cases i reprenguessin les tasques agrícoles. Com que la intervenció de l'arrais de Crevillent els donava més confiança, Jaume II autoritzà aquest personatge a assegurar tots els sarraïns del regne de Múrcia $i$ els seus béns o a donar-los guiatge en nom seu, a fi que tornessin a llurs cases, mentre el reconeguessin com a senyor i rei de Múrcia, tot declarant que els tractaria bé, com ho havien fet els seus predecessors. A precs de l'arrais, el monarca autoritzà també els captius sarraïns que s'havien refugiat a Crevillent a romandre-hi segurs ${ }^{24}$.

Quan el regne estigué pràcticament tot sota control de Jaume II, foren les incursions castellanes les que causaren danys i espant als sarrains i possiblement captius. Una incursió castellana de cap al març de 1303 aterrí els sarraïns de l'horta d'Elx que, segons el rei, eren «fort esmayats», fins a tal punt que en volien marxar. Per tal d'evitarho, el rei demanà a l'arrais de Crevillent que es reunís amb els vells i l'aljama de moros d'Elx i els calmés, prometent-los la tramesa de tropes per a protegir-los i un tracte menys rigorós pel que feia a exaccions reials i peites, a fi que no es moguessin. Assegurava que des de llavors els privilegis els serien observats i no serien «leig menats» ${ }^{25}$.

L'atac sofert havia coincidit amb l'absència, a més, dels moros joves o més preparats per a la guerra que, per ordre de Bernat de Sarrià, participaven en el setge de Mula.

20 Jaume II ordenà als seus oficials que els deixessin passar: ACA, C, reg. 340, f. 154 v. (1296, juny, 18).

21 ACA, C, reg. 105, f. 122 r. (1296, setembre, 24).

$22 \mathrm{ACA}, \mathrm{C}$, reg. 340, ff. $144 \mathrm{r}$. i $149 \mathrm{v}$. Els guardats a Oriola i Guardamar procedien d'Elx i Crevillent.

23 ACA, C, reg. 118, ff. 6 v.-7 r. (1301, gener, 16).

24 P. GUICHARD, Un señor musulmán en la España cristiana, pp. 28-29 i M.T. FERRER I MALLOL, Les aljames sarraïnes, p. 16.

25 ACA, C, reg. 127, f. 52 r. (1303, abril, 1). Cit a M.T. FERRER I MALLOL, Organització i defensa d'un territori fronterer. La Governació d'Oriola en el segle XIV, Barcelona, Institució Milà i Fontanals. CSIC, 1990, p. 42. 
Per això el rei es veié obligat a autoritzar l'arrais de Crevillent a fer tornar els moros que eren a la bastida de Mula per tal que poguessin defensar la seva terra ${ }^{26}$. A més li donà una credencial perquè s'adrecés a tots els moros de Múrcia amb un missatge reial, que no sabem quin devia ésser, però que segur que tenia relació amb aquests problemes $^{27}$.

La contribució a la guerra pesà també sobre la població sarraïna, igual que sobre la població cristiana. Si bé al començament els seus serveis no foren gaire requerits, almenys no pas mentre hi hagué a la regió l'exèrcit que portà a terme la part més important de la conquesta, després la reducció dels efectius provinents dels altres regnes obligà a recórrer als habitants del regne de Múrcia per a mantenir la defensa i per a portar a terme alguna de les campanyes; com els altres súbdits del regne, quedaren obligats a la prestació del servei d'host durant dos mesos. Pel gener de 1298, tenim constància que, als sarraïns d'Alacant, els fou perdonat aquest servei d'host a canvi de traslladar de manera cuitada, de nit i de dia, tota la fusta i aparells d'un giny que es trobava a Alacant fins al setge d'Alhama, mentre que els moros de Múrcia, els d'Oriola, els d'Elx i els d'Alcantarilla foren convocats per ajudar en aquesta tasca i a més per portar-hi una perxa que el rei havia fet tallar a Múrcia ${ }^{28}$.

Però no és fins a l'època de govern del procurador Bernat de Sarrià que les notícies són més abundoses, precisament per l'esforç de guerra que demanà i que provocà queixes en tot el regne ${ }^{29}$. L'any 1301 , sabem que els moros d'Elda, Novelda i Elx foren convocats a l'exèrcit a Mula, però finalment els d'Elda i Novelda aconseguiren la remissió d'aquesta obligació a canvi del pagament de 7.000 sous; havien al.legat, per deslliurarse, la seva pobresa, de manera que hem de suposar que el servei militar els resultava molt més carregós que aquella quantitat, que a més no havien de pagar de manera immediata sinó que tenien temps fins el 24 de juny ${ }^{30}$. L'any 1303 ja hem vist que els moros d'Elx participaven en el setge de Mula i sabem que també ho havien fet els moros d'Alacant; però aquests, pel desembre de 1302, n'havien marxat, sense autorització, fatigats pel llarg setge, i el rei havia hagut de demanar al procurador Bernat de Sarrià que els rebaixés la multa de 100 sous que els havia imposat, perquè no la podien pagar ${ }^{31}$.

Hi havia, encara, altres obligacions militars, les preventives. A Oriola i a Múrcia els sarraïns havien estat obligats, l'any 1302, a col-laborar en el servei d'escoltes i guardes a cavall per a vigilar els camins. Pel gener d'aquest any els moros oriolans protestaven perquè deien que no era costum que ho haguessin de fer, mentre que a

26 ACA, C, reg. 127, f. 52 r.-v. (1303, abril, 1).

27 ACA, C, reg. 307, f. 88 v. (1303, març, 30), publ. per J. M. del ESTAL, El reino de Murcia bajo Aragón, I/2, docs. 224-225.

28 ACA, C, reg. 253 , f. 71 v. i reg. 256, f. 6 v. (1298, gener, 19 i 24)

29 Sobre el govern de Bernat de Sarrià cf. M.T. FERRER, Organització i defensa d'un territori fronterer, pp. 23-48, especialment pp. 27, 39 i 41-42.

$30 \mathrm{ACA}, \mathrm{C}$, reg. 332 , f. 127 v. i 129 r. (1301, gener, 3, 11, 14, 18), publ. per J. M. del ESTAL, El reino de Murcia bajo Aragón, l/2, docs. 146, 148, 154, 156 i 160.

31 ACA, C, reg. 126, f. 190 r.-v. (1302, desembre, 23). 
Múrcia no tenim constància de cap protesta verbal, però sí de fet: marxaven de la ciutat. La reacció de Jaume II fou demanar al procurador que cessés de fer-los exaccions que no podien pagar, perquè no volia que la Reixaca es despoblés ${ }^{32}$.

L'interès per a mantenir la població sarraïna del regne fou visible, a l'obra de govern de Jaume II, des d'un primer moment. Com anirem veient, concedí guiatge als sarraïns que residien al regne $\mathrm{i}$ algunes franquícies temporals d'impostos, extensives també als moros que s'hi establissin. Calia que l'economia del regne tornés a posar-se en marxa després del trasbals de la guerra i de moment, atesa l'escassedat de la població cristiana, els sarraïns eren imprescindibles, especialment a l'àmbit rural, però també per a molts oficis artesanals.

\section{LES COMUNITATS DEL REGNE DE MÚRCIA DURANT LA GUERRA}

\section{Alacant}

Alacant tenia una moreria urbana força reduïda a la darreria del segle XIII; la causa, segurament cal buscar-la en el fet que era una de les viles que s'havien resistit al protectorat castellà imposat pel pacte d'Alcaraz del 1243 i on l'exèrcit d'Alfons el Savi, llavors infant, intervingué amb contundència. Probablement ja llavors la població islàmica sofrí una reducció molt important i segurament fou desposseïda de la terra, puix que tant els documents alfonsins ${ }^{33}$ com els posteriors, quan es refereixen als moros de I'horta d'Alacant, esmenten sempre eixàrics, és a dir, moros que no tenien terres pròpies i que conreaven les dels cristians, amb dret a una part dels fruits. Segons les al.legacions presentades pel justícia d'Alacant en un procés contra sarraïns per homicidi, l'any 1315, els moros que residien a l'horta d'Alacant eren tots eixàrics; cap no tenia heretatges propis, a diferència dels sarraïns d'Elx, d'Oriola o de la vall d'Elda, i eren considerats domèstics dels senyors de qui tenien heretats ${ }^{34}$.

A causa de la sublevació contra el domini castellà el 1264, la comarca d'Alacant degué resultar molt castigada per les ràtzies de l'infant Pere, després Pere el Gran. La conquesta de Jaume I, el 1265-1266, degué acabar de delmar la població mora, especialment en un lloc de pas obligat com Alacant.

La guerra amb Castella, que començà el 1296, trobà, doncs, una població sarraïna afeblida. Davant la perspectiva d'una nova guerra, una part dels moros d'Alacant es refugiaren a Crevillent, com ja hem dit.

Quan la comarca alacantina tornà a quedar assossegada, després de la conquesta per Jaume II, els sarraïns d'Alacant mostraren interès a tornar a llur lloc d'origen i el

32 ACA, C, reg. 120, f. 233 r.-v. (1302, gener, 23) i reg. 124, f. 190 v. (1302, juny, 7). M.T. FERRER, Organització $i$ defensa d'un territori fronterer, pp. 41 i 42.

33 J. TORRES FONTES, La reconquista de Murcia, pp. 37-44 i Colección de documentos para la Historia del reino de Murcia, III. Fueros y Privilegios de Alfonso X el Sabio al reino de Murcia, ed. per J. TORRES FONTES, Múrcia, 1973, pp. LI-LXI i docs. 23, 39, 55, 59 i 60.

34 M.T. FERRER I MALLOL, «Un procés per homicidi entre sarraïns de l'Horta d'Alacant», Sharq al-Andalus, 7 (1990), p. 146. 
seu propòsit fou facilitat pel mateix rei, que concedí guiatge a tots els que s'establissin a l'horta d'Alacant i hi residissin personalment.

Per tal d'incrementar la població sarraïna, Jaume II concedí, a més, franquícia de peita o alfarda durant dos anys als moros que s'establissin a Alacant. Els autoritzà a elegir un altre alamí, si no estaven contents del que tenien, i concedí que l'alamí jutgés les seves causes segons sunna, tal com s'havia fet fins llavors. El rei disposà, a més, que no poguessin ser obligats a fer obres al castell d'Alacant i que tampoc no els poguessin ser confiscats els animals de càrrega per al mateix objectiu. Prohibí a l'alcaid del castell que intervingués en res que els afectés, ja que era el batlle d'Alacant qui se n'havia d'ocupar, i li ordenà que retornés als sarraïns alacantins el bestiar que els havia confiscat pretextant que era de gent d'Elx, els quals estaven en guerra amb Jaume $\|{ }^{35}$.

Potser el raval on vivien els sarraïns d'Alacant resultà destruït per la guerra o potser les autoritats locals consideraren més oportuna una altra ubicació, el cas és que sabem que el 1303 es construïa de nou un raval dels sarraïns a Alacant; sembla que algunes persones en pertorbaven l'edificació perquè pretenien tenir drets en el terreny escollit i calgué que el rei intervingués en la qüestió per encomanar la resolució del litigi a uns prohoms que havien de ser nomenats pel justícia i pels jurats d'Alacant ${ }^{36}$.

Les nostres notícies sobre el nombre aproximat de sarraïns residents a Alacant i al seu terme són molt migrades i es basen en les xifres del cabeçatge. En el meu llibre sobre les aljames sarraïnes de la governació d'Oriola, les vaig analitzar i vaig arribar a la conclusió que, entre el raval i l'horta, els moros d'Alacant no sobrepassaven el miler ${ }^{37}$.

El cabeçatge era l'impost que pagaven els caps de família o membres del mateix grup familiar que tenien béns propis o edat per a treballar. L'any 1261 Alfons $X$ havia concedit aquest tribut al consell d'Alacant, perquè l'esmercés en la construcció de les muralles $i$ en altres despeses municipals ${ }^{38}$; però, com que no havia esmentat totes les diverses categories de contribuents, resultà que els peons de l'horta i les mores vídues de la vila quedaven fora d'aquell privilegi i els trobem pagant el cabeçatge al batlle general, mentre que la resta dels sarraïns, els eixàrics i els botiguers i menestrals, en teoria, l'havien de pagar directament al municipi d'Alacant. Diem en teoria perquè, els anys 1256 i 1257, Alfons el Savi havia concedit als amos cristians que tenien eixàrics sarraïns a les seves terres el delme, l'alfatrà i el cabeçatge dels seus moros ${ }^{39}$.

La contradicció entre els diferents privilegis i la multiplicitat de perceptors del cabeçatge provocà plets entre la vila d'Alacant i diversos senyors. El 1298 n'hi havia un entre Vicenç de Xixona, propietari d'unes alqueries dins el terme d'Alacant per

35 P. GUICHARD, Un señor musulmán en la España cristiana, p. 27, i M.T. FERRER I MALLOL, Les aljames sarraïnes, pp. 53-54, 66-67.

36 ACA, C, reg. 127, f. 108 r. (1303, abril, 24).

37 M.T. FERRER, Les aljames sarraines, pp. 53-54.

38 Ibidem, docs. 59 i 60.

39 Colección de documentos de Murcia, III, docs. 23 i 39. 
donació de Jaume II, i la vila d'Alacant. Vicenç de Xixona assegurava que els sarraïns de les seves alqueries mai no havien pagat el cabeçatge als homes d'Alacant en temps dels anteriors propietaris, que eren García Fernández de Varea i la seva muller dona Elis i després Fernando Rodríguez de Aranguren, mentre que els homes d'Alacant pretenien que els pertocava aquest dret ${ }^{40}$. Creiem que aquestes alqueries eren les d'Alconchel i Aljucén, a l'horta d'Alacant, prop del Moliniello, segurament dins el terme actual de Mutxamel, ja que sabem que limitaven amb la muntanya de Busot ${ }^{41}$. El mateix problema sobre el pagament del cabeçatge es presentà posteriorment també a Agost, cosa que fa pensar que el privilegi d'Alfons el Savi potser no havia tingut una efectivitat real, almenys a les alqueries ${ }^{42}$.

Diverses fonts, algunes de posteriors als anys que estudiem, ens informen de la presència de sarraïns en algunes alqueries de l'horta, Canyelles o Benifageig, Benialí, Benimocrén etc. ${ }^{43}$.

Als llogarrets més grans, els tenim documentats a Agost, a Busot, d'on van marxar tots cap a Granada el 1304, seguint en la retirada els genets granadins que havien envaït aquelles terres meridionals valencianes ${ }^{44}$, i a Nompot o Montfort ${ }^{45}$.

Malgrat l'interès de Jaume II i dels seus successors per a afavorir la residència de moros a Alacant $\mathrm{i}$ al seu terme, la comunitat sarraïna mostrà una progressiva tendència a disminuir. La invasió dels genets granadins, que es produí el 1304, precipità aquesta tendència perquè molts sarraïns de les comarques meridionals valencianes marxaren a Granada amb ells. Més tard, la guerra amb Castella dels dos Peres accentuà la despoblació.

\section{Elx}

Elx era una vila important i rica i també la que tenia un nucli més important de població sarraïna. Pertanyia, en el moment de la conquesta, a don Juan Manuel, de la família reial castellana ${ }^{46}$. Malgrat que, quan van iniciar-se les operacions militars, no fou atacada perquè hi havia negociacions obertes amb don Juan Manuel per al reconeixement de Jaume II com a rei de Múrcia, el fracàs final d'aquestes negociacions provocà que el lloc fos assetjat des del començament del mes de juny de 1296 fins al 27 de juliol, en què se signà una treva que hauria de durar alguns anys.

Com a Alacant, abans que Jaume II no iniciés les operacions militars contra Elx, un bon nombre de sarraïns van abandonar el lloc i es van refugiar a Crevillent, sota la protecció de l'arrais, i a Alacant. Jaume II els concedí dos guiatges, un el 24 de maig

40 ACA, C, reg. 107, f. 251 r. (1298, febrer, 9).

41 Cf. els límits a ACA, C, reg. 340, f. 28 v. (1296, maig, 7).

42 M.T. FERRER, Les aljames sarraines, p. 14 i doc. 72.

43 M.T. FERRER, Un procés per homicidi entre sarraïns de l'Horta d'Alacant, pp. 145-146.

44 M.T. FERRER, Les aljames sarraïnes, p. 54.

45 Ibídem, p. 55.

46 Cf. sobre aquesta etapa: J. HINOJOSA MONTALVO, La morería de Elche en la Edad Media, Terol, Centro de Estudios Mudéjares. Instituto de Estudios Turolenses, 1994, pp. 7-16. 
i un altre el 5 d'agost, aquest darrer perquè poguessin tornar als seus domicilis ${ }^{47}$. El 20 d'agost, Jaume II confirmà als sarraïns d'Elx els privilegis i les donacions que els havien concedit l'infant Manuel $i$ el seu fill don Juan Manuel fins a la data ${ }^{48}$. A més, recomanà al seu germà Jaume Pere, procurador del regne de Múrcia, que els defensés contra qualsevol que intentés maltractar-los i que no els fes pagar cap impost que no paguessin en temps de l'infant don Manuel. Aquell mateix mes d'agost els autoritzà a portar i vendre per tots els seus dominis blat, oli i altres mercaderies, pagant lleudes, peatges $i$ altres drets acostumats, i manà als homes d'Elx que haguessin rebut comandes de sarraïns abans del setge que els les restituïssin ${ }^{49}$.

Basant-me en les informacions que proporcionen els impostos del cabeçatge i de gallines, que no són exactes, vaig calcular que Elx i la seva rodalia tenien de 2.100 a 2.450 habitants sarraïns cap al 1315. Poser eren més en el moment immediatament posterior a la conquesta. A part de la pèrdua de població que pogué suposar la guerra, la incursió de l'exèrcit de Granada, l'any 1304, també tingué una repercussió negativa, ja que sabem que hi havia sarraïns d'Elx entre els que van seguir l'exèrcit nassarita a la retirada.

A Elx, els sarraïns vivien en un raval situat a la part meridional de la vila, al voltant d'una mesquita, ara església de Sant Joan. Bé que una part dels habitants del raval devien dedicar-se a oficis artesanals, sembla que molts vivien de l'agricultura i treballaven terres a cens del rei o del senyor del lloc, a la porció del terme dita Magram.

L'abundància de privilegis i disposicions reials a favor d'aquesta aljama palesen la importància que tenia. Ja el 20 d'agost de 1296, Jaume II confirmà tots els privilegis que li havien estat concedits per l'infant Manuel i pel seu fill don Juan Manuel, però fou l'any 1303 quan el monarca féu un major nombre de concessions: ordenà el respecte dels privilegis que havia confirmat anteriorment i a més concedí als sarraïns que no poguessin ser convocats a exèrcit, llevat del cas que el regne de Múrcia fos envaït per un gran nombre d'enemics i calgués el seu ajut o que ell els ho manés expressament; els concedí igualment que ni cap oficial reial de Múrcia, ni cap cavaller no els pogués prendre les bèsties per portar-les a l'exèrcit; aquesta concessió fou confirmada el 1318, afegint-hi que fins i tot el rei hauria de pagar lloguer per les bèsties que requisés; els condonà el pagament de l'algarfa, que era un dels impostos que gravaven els fruits de la terra, i suprimí la tarcana, que sembla que era un bordell; concedí, als sarraïns que s'establissin a Elx o que hi acudissin a comerciar, que fossin jutjats en les seves causes i plets com els del lloc en igual cas i, per tal d'atreure pobladors sarraïns, concedí franquícia de cabeçatge i d'alfarda durant un any als sarraïns francs que s'hi establissin ${ }^{50}$.

47 M.T.FERRER I MALLOL, «La conquesta de les comarques meridionals valencianes per Jaume II», en curs de publicació a Quaderns del Migjorn; M.T. FERRER, Les aljames sarraïnes, p. 51.

48 J. del ESTAL, Vasallaje, doc. III; M.T. FERRER, Les aljames sarraïnes, p. 60 i doc. 69; J. del ESTAL, El reino de Murcia bajo Aragón, $\mathrm{l} / 2$, doc. 18, amb algunes incorreccions a la transcripció dels noms dels testimonis.

49 ACA, C, reg. 104, f. 45 v. (1296, agost, 20).

50 M.T. FERRER, Les aljames sarraïnes, pp. 47-51 i 60-61. 
Aprofitant el canvi de senyoriu, cristians, jueus i sarraïns d'Elx intentaren escapolirse de l'obligació de pagar delmes i primícies a la seu de Cartagena, però no aconseguiren aquest objectiu, malgrat les males relacions del rei amb el bisbe de Cartagena $i$ altres alts càrrecs eclesiàstics ${ }^{51}$.

Durant els primers mesos de l'any 1303, els sarraïns d'Elx degueren queixar-se de transgressions dels seus usos i costums, perquè Jaume II procurà acontentar-los i féu expedir el mateix dia, el 25 d'abril, tot un seguit de concessions o de recomanacions al batlle general perquè s'informés més a fons de les queixes per tal de poder decidir amb coneixement de causa. Manà, en primer lloc, als col-lectors dels drets d'actuar amb tota la benignitat que els fos possible amb els sarraïns d'Elx $\mathbf{i}$, al batlle general, li ordenà que només els fes pagar cena per al batlle reial una vegada a l'any i no més, com sembla que se'ls exigia, bé que li manava que primer se n'informés. Per a algunes qüestions, els sarraïns d'Elx retreien com a model els temps de l'infant Manuel: s'havien queixat, per exemple, que llavors no pagaven un impost anomenat merinat, que havia creat don Juan Manuel per cobrir la despesa de gent a cavall per a la guarda del Iloc; però, per altra banda, es queixaren que ja en temps de l'infant eren obligats a pagar redempció d'exèrcit, "tarif» i "bera», malgrat que en general els sarraïns no estaven obligats a redempció d'exèrcit; es lamentaven que sota el domini de Jaume Il continuaven aquesta mena d'exaccions; també es queixaven que, quan hom els demanava peites i exaccions, tots eren taxats a abonar-ne una certa part però, com que alguns se n'anaven del lloc sense pagar, la resta era obligada a satisfer la seva part, cosa que trobaven molt injusta; també protestaven perquè hom els exigia impostos de trànsit que abans no pagaven: els demanaven 7 sous si es traslladaven a Múrcia, Lorca o Granada, quan passaven per Oriola, i havien d'abonar 15 diners per cada càrrega d'oli, quan abans només en pagaven un diner lleonès; es planyien encara de ser molestats en l'empriu de les aigües i s'exclamaven d'haver de pagar el delme d'una manera que els resultava més carregosa i cara que abans. Abans, deien, quan anaven a començar la sega o la verema, avisaven els delmers perquè anessin a les eres $i$ a les vinyes a rebre el delme, mentre que ara els delmers no hi volien anar i els demanaven el preu del delme més tard i més car; sembla que els sarraïns d'Elx s'havien queixat de falta d'observança del privilegi concedit per l'infant Manuel, pel qual si un sarraí era processat, havia d'estar pres a la presó dels sarraïns. Aquestes dues darreres qüestions, el rei les atorgà sense més formalitats, mentre que per a la resta en demanà al batlle general més informaciós2.

Alguns mesos més tard, a la darreria de novembre, fou don Juan Manuel mateix qui denuncià intromissions del procurador del regne de Múrcia, Pere de Montagut, en els afers dels moros d'Elx i del seu terme i en els dels moros d'Asp, de Xinosa i de Monòver. Com que Jaume II desitjava mantenir els pactes amb don Juan Manuel, manà a Pere de Montagut que no hi intervingués ${ }^{53}$.

51 ACA, C, reg. 107, f. 222 r. (1299, febrer, 9). El rei es mostrà disposat, més endavant, l'any 1302, a fer estudiar la revisió d'un conveni entre don Juan Manuel i el capítol de Cartagena sobre el pagament del delme: reg. 125, f. 116 r.-v. (1302, octubre, 20).

52 ACA, C, reg. 127, ff. 108 r.-109 v.

53 M.T. FERRER, Organització $i$ defensa d'un territori fronterer, p. 54. 
Del funcionament intern de l'aljama d'Elx en el moment immediatament posterior a la conquesta, no en tenim gaires referències; és més tard, però encara dins del regnat de Jaume II, que les notícies comencen a sovintejar. No m'hi referiré, doncs, ara perquè, a més, tot el que en sé ja ho vaig exposar al meu llibre ${ }^{54}$.

A l'horta d'Elx hi havia moltes alqueries habitades per sarraïns: algunes, com les de Marxena, Terça i Benicuei, devien formar part de l'aljama del raval, però altres, com les de Tres Espilles, Xàrquia i l'Asprella, sembla que formaven aljama a part; hi havia a més algunes alqueries senyorials, com la de Beniabez, o les de Beniamor i Saoní o Saonei, que pertanyien a l'arrais de Crevillent; tenim encara notícia de les de Rabat, Beniboc etc., però són notícies molt poc explícites ${ }^{55}$.

\section{Crevillent}

Crevillent era el centre del senyoriu de la família·ibn Hudayr. Pierre Guichard ha estudiat aquesta família, la seva influència, les seves possessions ${ }^{56}$; el Prof. del Estal i jo mateixa hem afegit noves dades per al coneixement d'aquest senyoriu singular. En el moment de la conquesta per Jaume Il ostentaven el títol d'arrais de Crevillent Ahmad i Muhammad, que eren oncle i nebot ${ }^{57}$. Tant l'un com l'altre mostraren bona predisposició a acceptar la senyoria de Jaume II i a fer-la acceptar pels sarraïns de les localitats veïnes. El 17 de maig, Muhammad reconegué Jaume II com a rei, després de les negociacions dutes a terme per Ahmad $i$, el 23, el rei confirmà a aquest darrer la possessió de Crevillent, Coix i Albatera i, a més, concedí Beniopa, prop de Gandia, amb caràcter vitalici segons uns documents a Ahmad $i$ segons uns altres a Muhammad $^{58}$.

Com ja he dit, Crevillent es convertí en refugi dels sarraïns d'Oriola, d'Albatera, de Coix, d'Elx i d'Alacant, que temien ser victimes dels abusos dels soldats. L'arrais Muhammad fou autoritzat pel mateix rei a assegurar les persones $i$ els béns dels sarraïns que tornaven als llocs de residència, amb la condició que reconeguessin prèviament Jaume II com a rei de Múrcia, cosa que investia l'arrais d'una gran autoritat, mentre que l'altre arrais, Ahmad, era honorat amb el càrrec de jutge dels sarraïns del

54 M.T. FERRER, Les aljames sarraïnes, pp. 61-63.

55 M.T. FERRER, Les aljames sarraïnes, pp. 12-13 i 64-65.

56 P. GUICHARD, Un señor musulmán en la España cristiana, ja citat.

57 Quan, a la darreria de desembre de 1297, Ahmad morí, Jaume Il donà el condol a Muhammad per la mort -diu el document- del seu oncle: ACA, C, reg. 107, f. 178 v. (1298, gener, 3). P. Guichard no havia pogut aclarir el parentiu entre l'un arrais I l'altre: P. GUICHARD, Un señor musulmán en la España cristiana, quadre genealògic dels Banu Hudayr, p. 85. També desconeixia la data de la mort d'Ahmad.

58 ACA, C, reg. 25, f. 282 r.-v. publ. per P. GUICHARD, Un señor musulmán en la España cristiana, doc. 1 i pp. 22-23; i reg. 340, f. 107 r. i 108 r.-v. publ. J. M. del ESTAL, Vasallaje del señorio musulmán de Crevillente, docs. VI i IX i El Reino de Murcia, 1/2, docs. 49-50. M.T. FERRER, Les aljames sarraines, p. 17. Sobre el senyoriu dels lbn Hudayr a Beniopa cf. M.V. FEBRER ROMAGUERA, «EI señorío mudéjar de Beniopa (Valencia) en la época de sus arraeces de la familia de ibn Hudayr (1296. 1322)", a IV Simposio Internacional de Mudejarismo: Economia, pp. 351-361. 
regne de Múrcia, des d'Oriola a Alacant i Beniopa, càrrec que sembla que ja havia tingut precedentment. Jaume II confià, a més, a Ahmad, el 4 de juny, els llocs d'Asp, de Monòver i de Xinosa, que es devien haver retut gràcies a la seva mediació ${ }^{9}$.

També li foren confirmats, de manera genèrica, els béns que posseïa a la capital i els que hi tenia la seva muller Abnatalaziz per donació del seu pare, l'exrei sarraí de Múrcia, Muhammad ibn Huddo; més tard, el rei confirmà a l'arrais Ahmad: deu caps de moros eixàrics a la mateixa ciutat, que tenia per concessió dels reis de Castella ${ }^{61}$, i unes cases a la Reixaca que havia comprat a la vídua d'un tal "Suayach», moro de Múrcia, que havien estat confiscades a causa d'una informació proporcionada per Juan Pérez de Tarazona i donades a aquest, provisions que foren anul-lades quan l'arrais es queixà ${ }^{62}$.

Ignorem quines prerrogatives foren reconegudes als arrais de Crevillent; els documents diuen que eren les mateixes que tenien reconegudes en temps passats, és a dir, sota el domini dels reis de Castella. Suposem que devien consistir en cessió d'impostos i de drets jurisdiccionals semblants als que la Corona cedia en senyorius cristians. Dins el pla militar, l'arrais de Crevillent figurà en lloc destacat, per la importància de la seva comitiva - dos cavalls armats i entre vuit i quatre cavalls alforrats-, a la llista dels homes que servien el rei amb cavalls a la frontera ${ }^{63}$.

Probablement els privilegis de què gaudien els arrais devien semblar a alguns nobles i alts oficials poc adequats a llur condició de sarraïns. Pel novembre de 1297, el rei hagué d'advertir al seu germà Jaume Pere, procurador del regne de Múrcia, que fes respectar els béns i privilegis confirmats a l'arrais Ahmad de Crevillent, que es queixava del tracte que rebia. Uns quants anys després, el 1301, calgué fer una recomanació semblant a favor de l'arrais Muhammad ${ }^{64}$.

59 P. GUICHARD, Un señor musulmán en la España cristiana, pp. 23 i 28-29. J.M. del ESTAL, Conquista y anexión de las tierras de Alicante, Elche, Orihuela y Guardamar al reino de Valencia por Jaime // de Aragón (1296-1308), Alacant, Publicaciones de la Obra Social y Cuitural de la Caja de Ahorros Provincial de Alicante, 1982, doc. 5; Vasallaje del señorio musulmán de Crevillente, doc. XI, i El reino de Murcia bajo Aragón, 1/1, doc. 79; M.T. FERRER, Les aljames sarraïnes, pp. 16-17 i docs. 6 , 7, 13; J.M. del ESTAL, El reino de Murcia bajo Aragón, 1/2, docs. 51 i 58, aquest darrer amb una regesta que no es correspon exactament al contingut del document.

60 ACA, C, reg. 340, f. 107 r.-v. (1296, maig, 23); Cit. per P. GUICHARD, Un señor musulmán en la España cristiana, p. 28 i M.T. FERRER, Les aljames sarraïnes, p. 17. El document de confirmació dels béns d'Abnatalaziz ha estat publicat per J. M. del ESTAL, Vasallaje del señorio musulmán de Crevillente, doc. VIII, i El reino de Murcia, I/2, doc. 52.

61 ACA, C, reg. 106, f. 129 r. (1297, desembre, 7).

62 ACA, C, reg. 106, f. 101 r. (1297, novembre, 27), però el rei féu que els alcadís i jurisperits cristians de Múrcia informessin sobre la qüestió: ACA, C, reg. 106, f. 117 r. (1297, desembre, 5).

63 P. GUICHARD, Un señor musulmán en la España cristiana, p. 30, i M.T. FERRER, "La tinença a costum d'Espanya en els castells de la frontera meridional valenciana (segle XIV)", Miscel.lània de Textos medievals, 4. La frontera terrestre i marítima amb I'lslam, Barcelona, CSIC.Institució Milà i Fontanals, 1988, doc. 4 i M.T. FERRER, Organització i defensa d'un territori fronterer, doc. 32 . El nombre de cavalls alforrats era de vuit a l'ordinació del primer de maig de 1303 i fou rebaixada a quatre a la del 18 de maig.

64 M.T. FERRER, Les aljames sarraïnes, p. 17. 
Després de la mort d'Ahmad, continuà com a arrais el seu nebot Muhammad, mentre que el fill d'Ahmad, Muhammad, veia reconegudes tant la dignitat d'arrais com les propietats del seu pare, Crevillent, Coix, Albatera i els béns de Múrcia, bé que l'altre Muhammad continuà ostentant el títol d'arrais. La identitat de nom fa difícil destriar les activitats de l'un i de l'altre, però creiem que fou el més gran qui tingué el govern efectiu de Crevillent i qui fou nomenat, l'any 1301, jutge dels sarraïns de la Reixaca de Múrcia i, el 1305, jutge dels sarraïns de les terres dellà Xixona. També degué ser ell mateix el destinatari d'una carta en la qual Jaume II, abans d'emprendre un viatge per a entrevistar-se amb el Papa, l'any 1305, deia que comptava amb ell per tal de guardar la terra durant la seva absència ${ }^{65}$.

Efectivament, després de la conquesta del regne de Múrcia, el paper de l'arrais de Crevillent continuà essent molt important com a intermediari amb Granada o com a font d'informació sobre les intencions de la cort granadina, on l'arras, per indicació de rei o per iniciativa pròpia, enviava sovint emissaris o espies ${ }^{66}$. L'any 1318 , el senyoriu fou annexionat a la Corona.

El fet que Crevillent fos lloc de senyoriu fa que no tinguem dades ni de població ni pràcticament d'activitats, ja que ens manca la documentació fiscal que, encara que sigui de manera ocasional, trobem en altres casos.

\section{La vall d'Elda}

Monòver i Xinosa. Ambdós llocs, i la torre de Salines, havien pertangut a don Juan Manuel. Durant la conquesta del regne de Múrcia foren ocupats per Ferran Garcés de Rueda. No tenim constància que els habitants sarraïns d'aquests llocs rebessin cap guiatge fins que Jaume II no en concedí un, el darrer dia de juliol de 1296, a tots els sarraïns que anessin a residir al regne de Múrcia i, en particular, a Elx, Xinosa, Monòver i Salines, mentre paguessin els drets acostumats ${ }^{67}$. Jaume II confià, de moment, tots dos llocs a l'arrais de Crevillent, però després de la partició del regne de Múrcia, l'any 1304, de la delimitació i de la pèrdua de la propietat d'aquests llocs per part de don Juan Manuel, Jaume II els concedí, amb caràcter vitalici, al seu conseller Gonçalvo Garcia ${ }^{68}$.

Monòver i Xinosa, com a llocs de senyoriu, són pobres en documentació fiscal i, per tant, no tenim dades de població ni pràcticament d'activitats. Sabem només que l'any 1301 el rei volia recaptar en aquests dos llocs i a Asp l'impost de la cena, que havia cobrat en passar per Elx, però que amb les presses per arribar a Múrcia no havia pogut demanar-lo a aquests altres llocs ${ }^{69}$.

65 M.T. FERRER, Les aljames sarraines, pp. 16-18. Doc.de confirmació a favor de Muhammad II publ. per J. M. del ESTAL, El reino de Murcia, 1/1, doc. 158, i 1/2, doc. 105, on no se cita ni a ell mateix.

66 M.T. FERRER, Les aljames sarraines, pp. 16-18.

67 M.T. FERRER, Les aljames sarraines, p. 22 i doc. 16.

68 M.T. FERRER, Les aljames sarraïnes, pp. 22-23.

69 ACA, C, reg. 332, f. 129 v. (1301, gener, 24), publ. per J. M. del ESTAL, El reino de Murcia bajo Aragón, 1/2, doc. 161. 
Petrer. Petrer, un llogarret de població predominantment sarraïna, era domini de la família Garcia de Loaysa el moment de la conquesta del regne de Múrcia per Jaume II i continuà a les seves mans. Malgrat que Joan Garcia de Loaysa semblava disposat a reconèixer Jaume II, finalment allargà la prestació d'homenatge perquè volgué fer-la de manera acordada amb don Juan Manuel i especialment amb Violant Manuel, germana de don Juan Manuel i el seu marit, l'infant Alfons de Portugal, dels quals era procurador a les seves poblacions d'Elda i Novelda. Finalment prestà homenatge el 4 de juny de 1296, però des del mes d'abril era sota guiatge ${ }^{70}$. El fet que Petrer no entrés a la guerra i estigués sota guiatge pràcticament des del començament de les operacions militars, estalvià als seus habitants molts sofriments. El 5 de juny, després del reconeixement de Jaume II per Garcia de Loaysa, els moros de Petrer reberen un nou guiatge, el definitiu ${ }^{71}$.

Sembla, però, que els sarrains van considerar la guerra com una mena d'alliberament total de les seves obligacions anteriors respecte a Joan Garcia de Loaysa, que devien conceptuar persona lligada al règim anterior, i es negaren a pagar-li les peites i els tributs deguts a l'alcaid. La reacció del rei fou la de donar suport a l'autoritat de Joan Garcia de Loaysa $\mathrm{i}$ ordenà als seus oficials que obliguessin els moros a pagar ${ }^{72}$.

Com que Petrer era lloc de senyoriu, no tenim dades ni de població ni pràcticament d'activitats, ja que ens manca la documentació fiscal, com ens passa a Crevillent, a Monòver i a Xinosa. Sabem, però, que els Loaysa tingueren dificultats per a mantenir la població sarraïna dins el seu domini. El 1309, els moros de Petrer feren arribar queixes a Jaume II perquè Joan Garcia no respectava els privilegis atorgats pels seus antecessors i per ell mateix i no els permetia de vendre llurs propietats ni traslladar-se a viure al domini reial ${ }^{73}$. Probablement, les ofertes de rebaixes d'impostos als qui s'establissin a les moreries reials havien causat impacte a Petrer.

Elda i Novelda. En el moment de la conquesta del regne de Múrcia per Jaume II, Elda i Novelda pertanyien a la infanta Violant, esposa de l'infant Alfons de Portugal. La sentència arbitral de Torrellas del 1304, que acabà la guerra, atribuí aquests llocs a Jaume II i es pactà una indemnització per als infants de Portugal, a càrrec del rei de Castella ${ }^{74}$.

No tenim notícia de concessió de privilegis a aquests dos llocs reials, fora d'un guiatge concedit el 1296 als sarraïns d'Elda i Novelda, mentre el rei negociava que els infants de Portugal el reconeguessin com a rei de Múrcia $^{75}$.

70 M.T. FERRER I MALLOL, «La conquesta de les comarques meridionals valencianes per Jaume I\}», en curs de publicació a Quaderns del Migjorn.

71 J. M. del ESTAL, El Reino de Murcia bajo Aragón, I/1, doc. 59.

72 ACA, C, reg. 340, f. 157 r. (1296, juny, 20).

73 M.T. FERRER, Les aljames sarraïnes, p. 78.

74 A. GIMÉNEZ SOLER, Don Juan Manuel, pp. 34-35 i docs. CVII, CVIII, CX, CXI, CXVI, CXXVII i CXXXVIII, J. M. del ESTAL, Obra de los reyes D. Dionis e Isabel de Portugal y de los infantes $D$. Alfonso y $D^{a}$ Yolanda Manuel en la conquista y sumisión del Reino de Murcia a la Corona de Aragón, a «Actas das II Jornadas Luso-Espanholas de História Medieval», I, Porto, 1987, pp. 147-158, i M.T. FERRER, Les aljames sarraines, pp. 32-33.

75 M.T. FERRER, Les aljames sarraïnes, doc. 14. 
Joan Garcia de Loaysa, el senyor de la veïna població de Petrer, a qui ens acabem de referir, actuava com a procurador dels infants i es va trobar aquí amb el mateix problema que havia hagut d'afrontar a Petrer i que ja hem comentat, és a dir, que els sarraîns es van considerar alliberats per la guerra de complir les seves obligacions anteriors respecte a Joan Garcia de Loaysa, que era l'alcaid de tots dos llocs, i es negaren a pagar-li les peites i els tributs deguts per aquest càrrec. La reacció del rei, com ja hem dit, fou la de donar suport a l'autoritat de Joan Garcia de Loaysa també a Elda i a Novelda i ordenà als seus oficials que obliguessin els moros a pagar ${ }^{76}$.

Malgrat aquest intent de defugir la seva autoritat, Joan Garcia de Loaysa continuà preocupant-se pels moros d'Elda i Novelda i, pel setembre, demanà protecció per a ambdós llocs. Jaume II la concedí i ordenà al seu germà Jaume Pere, procurador del regne de Múrcia, que no permetés que se'ls fes cap mal7 ${ }^{77}$. No coneixem cap altra intervenció reial a favor dels moros d'Elda i de Novelda fins al febrer de 1301, en què manà a Bernat de Sarrià, llavors procurador del regne, que els tractés favorablement $i$ els defensés ${ }^{78}$. Dos anys després, pel juny de 1303, hagué d'amonestar el nou procurador, Pere de Montagut, perquè els demanava exaccions inusuals ${ }^{79}$.

L'administració de les rendes d'Elda i de Novelda durant el període de la guerra comportà alguns problemes. Sembla que el responsable de la gestió dels comptes fou Huçmen Abencaçila o Abentaçila, sarraí de Novelda. Al començament de l'any 1301, Jaume II l'havia convocat i li havia atorgat guiatge sens dubte per a parlar d'aquesta qüestió ${ }^{80}$; poc després, el rei manà als moros d'Elda i de Novelda de posar a la disposició de l'infant Alfons de Portugal els 7.000 sous reials de Múrcia que ell els havia demanat anteriorment ${ }^{81}$; però les dificultats varen venir després de la pau amb Castella, perquè l'infant de Portugal volia cobrar les seves rendes endarrerides i demanava a Garcia de Loaysa que obligués Huçmen a retre comptes. Com que sembla que els mètodes usats per Garcia de Loaysa eren força expeditius i molestos per a Huçmen, aquest demanà la intervenció de l'arrais de Crevillent a favor seu que, al seu torn, féu que el rei el defensés; però després, com que els infants de Portugal també sol.licitaren la intervenció de Jaume II perquè Huçmen retés comptes, el rei es veié obligat a manar al procurador Pere de Montagut que l'obligués a retre'ls a Garcia de Loaysa. Les reclamacions de l'infant Alfons de Portugal es feren extensives després a altres administradors anteriors, com un tal Açmet, fill de Melic, sarraí d'Elda i altres persones, tant cristians com sarraïns, que s'havien absentat del regne per no retre comptes. L'infant de Portugal exigí, fins i tot al mateix Garcia de Loaysa, que retés comptes, ja que havia rebut

76 ACA, C, reg. 340, f. 157 r. (1296, juny, 20).

77 ACA, C, reg. 104, f. 83 v. (1296, setembre, 8).

78 ACA, C, reg. 254, f. 35 r. (1301, febrer, 24), publ. per J. M. del ESTAL, El reino de Murcia bajo Aragón, 1/2, doc. 196.

79 ACA, C, reg. 128, f. 171 r. (1303, juny, 20).

80 ACA, C, reg. 116, f. 306 v. i reg. 118 f. 2 r. (1301, gener, 3 i 13).

81 ACA, C, reg. 254, f. 35 r. (1301, febrer, 23), publ. per J. M. del ESTAL, El reino de Murcia bajo Aragón, 1/2, doc. 195. 
les rendes en nom seu i a més havia venut alguns castells seus $i$ a aquest fi envià a la Corona catalano-aragonesa Arias Cabral ${ }^{82}$.

No sembla pas que la persecució a Uçmen Abentaçila perquè retés comptes afectés gaire la seva credibilitat davant de don Juan Manuel, germà de la infanta de Portugal, ja que fou ell la persona escollida per a organitzar la pobla de moros que volia fer a Alarcón ${ }^{83}$.

Segons els càlculs que vam fer a base de l'impost del cabeçatge i de l'impost de gallines, tots dos del 1315, Elda devia comptar amb 1.200 habitants sarraïns, aproximadament, mentre que Novelda en devia tenir entre 850 i $900^{84}$.

Asp. Asp pertanyia en el moment de la conquesta a don Juan Manuel, però la població, habitada gairebé exclusivament per sarraïns, acceptà la senyoria de Jaume II molt abans que don Juan pactés la treva, com Monòver i Xinosa, el 4 de juny de 1296. El govern del lloc fou confiat, de moment, a l'arrais de Crevillent. Després de la sentència arbitral de Torrellas, el lloc passà al patrimoni reial ${ }^{85}$.

Segons els càlculs que vam fer a base de l'impost del cabeçatge i de l'impost de gallines, tots dos del 1315, Asp devia comptar amb uns 650 habitants sarraïns, aproximadament ${ }^{86}$.

\section{Oriola}

Oriola era vila reial. En el moment de la conquesta per Jaume II sembla que devien viure a la vila d'Oriola, en un raval extramurs, prop del pont, un nombre encara considerable de sarraïns. Joan Baptista Vilar va aventurar la xifra de 1.650 habitants sarraïns per a la vila i el terme. A mitjan segle XIV no sembla que fossin més d'uns 200, si ens basem en l'impost del cabeçatge; a tot el terme devien ser llavors uns 600 , si tenim en compte que hom considerava que, a la Daia, li corresponia de pagar un terç de limpost.

La població sarraïna d'Oriola anà disminuint durant tota la primera meitat del segle XIV i, després de la guerra amb Castella dita dels dos Peres, la moreria d'Oriola desaparegué. Respecte a l'organització interna de l'aljama, me'n vaig ocupar al meu llibre i no repetiré ara les dades exposades allà ${ }^{87}$.

Les petites comunitats de l'horta depenien teòricament de l'aljama d'Oriola, bé que estaven molt condicionades pel senyoriu al qual pertanyien, tal com ho proven les resistències a contribuir en els impostos d'Oriola, com aquesta vila pretenia.

82 ACA, C, reg. 133, f. 76 r. i f. 116 v. (1304, agost, 23 i novembre, 24), reg. 134, f. 136 v. i 234 r.i v. (1304, novembre, 12 i 1305, febrer, 28), reg. 235, f. 153 r. (1304, novembre, 12), reg. 136, f. 204 r. (1305, setembre, 13) i A. GIMÉNEZ SOLER, Don Juan Manuel, doc. CV, pp. 307-308.

83 ACA, C, reg. 203, f. 138 r. i 142 r. (1306, abril, 9 i 10), cf. M.T. FERRER, Les aljames sarraïnes, p.45.

84 M.T. FERRER, Les aljames sarraïnes, pp. 48-49 i 73.

85 M.T. FERRER I MALLOL, «La conquesta de les comarques meridionals valencianes per Jaume Il», en curs de publicació a Quaderns del Migjorn, i M.T. FERRER, Les aljames sarraïnes, pp. 32-33.

86 M.T. FERRER, Les aljames sarraïnes, pp. 48-49.

87 M.T. FERRER, Les aljames sarraïnes, pp. 55-59 i doc. 4. 
Entre aquestes aldees de l'horta destacava Almoradí, de població mixta de cristians i sarraïns, bé que dins el terme hi predominaven els sarraïns, especialment a la Daia. Aquest lloc, que pertanyia a Fernando Pérez de Guzmán, fou donat pel rei al seu conseller Guillem Durfort ja el 27 d'abril. El 10 de maig, quan el monarca ja havia adquirit Oriola i el terme es podia considerar segur, demanà als habitants cristians i sarraïns del lloc i de la rodalia d'Almoradí que tornessin a residir-hi, els posà sota el seu guiatge $i$ els manà que obeïssin Guillem Durfort ${ }^{88}$.

L'alqueria de Catral, on també residien un nombre indeterminat de sarraïns, fou donada pel rei al seu fidel servidor Ferran Garcés de Rueda, que havia tingut un paper important en les negociacions amb l'arrais de Crevillent $\mathrm{i}$ altres senyors del regne. La primera donació, condicionada per la possibilitat que els propietaris reconeguessin Jaume II com a rei de Múrcia, es produí el 25 de maig, quan el monarca li concedí les possessions dels hereus d'Alemany de Puig i d'Alfonso García de Panpliga, que tenien tots dos part de Catral, a més d'altres propietats a Ceutí, Elx, Múrcia i Villena; la donació definitiva tingué lloc el primer de juliol, quan el mes de temps donat als cavallers $i$ propietaris del regne de Múrcia per a reconèixer Jaume II com a rei havia passat sobradament ${ }^{89}$; posteriorment vengué el lloc a Bernat de Sarrià, a qui Pere de Montagut, procurador del regne, l'embargà entre 1304 i 1305, segurament per procedir a la restitució dels béns confiscats als castellans durant la guerra, restitució pactada a la pau amb Castella ${ }^{90}$; com a senyor de Catral, Ferran Garcés de Rueda s'ocupà de buscar i reclamar els sarraïns d'aquesta alqueria que havien estat capturats durant les operacions bèl.liques, abans del mes de juliol de $1296^{91}$.

Albatera i Coix, de població sarraïna, pertanyien a l'arrais de Crevillent. El 14 de maig, Jaume II concedí guiatge als moros d'aquests llocs, juntament amb els de Crevillent, perquè hi poguessin tornar i poguessin dedicar-se novament a les tasques agrícoles i poc després, el 23 del mateix mes, confirmà a l'arrais la possessió d'aquests llocs ${ }^{92}$.

Redovà també era de senyoriu i de població majoritàriament sarraïna. Havia pertangut al noble castellà Rodrigo Iñíguez $i$ als seus fills, als quals l'alqueria fou confiscada per Jaume II, que la concedí el 1296 a Ramon Sacoma, un veí d'Alacant que havia col-laborat amb les seves tropes en la presa d'Alacant. També devien ser de població sarraïna Xàcara i Xacarella, confiscades a Pero i a Munyo Díaz i donades a Berenguer de Liminyana, d'Oriola, Algorfa, que pertanyia a l'orde de Santiago, Orxell etc. ${ }^{93}$.

88 Ibídem, pp. 6-8 I doc. 2. La donació de la Dala a Guillem Durfort fou publicada per J. M. del ESTAL, Corpus documental del reino de Murcia bajo la soberanía de Aragón (1296-1304/5). Colección de Documentos Medievales Alicantinos, 1/1, Alacant, 1985, doc. 7, que publica al doc. 6 el mateix document en la versió del reg. 340.

89 ACA, C, reg. 340, f. 97 v. (1296, maig, 25) i reg. 194, ff. 245 v.-246 r. (1296, juliol, 1).

90 M.T. FERRER, Les aljames sarraines, p. 7.

91 M.T. FERRER I MALLOL, La frontera amb l'Islam, doc. 6.

92 M.T. FERRER I MALLOL, Les aljames sarraïnes, doc. 5 i p. 17.

93 Ibidem, pp. 9-10. 
Favanella, situada al límit entre els termes municipals d'Oriola i Múrcia, era una aldea de població predominantment sarraïna, que fou disputada, acabada la guerra, entre tots dos municipis, que exhibien, l'un i l'altre, privilegis dels reis de Castella atribuint-la al terme respectiu ${ }^{94}$. En nom de Guillem de Rocafull, que era el senyor del lloc, el regia Miquel Garcia, alcaid del castell. Els sarraïns n'estaven queixosos, però ignorem quines eren les ofenses que els havia fet; si més no, pel gener de 1301 es negaven a obeir-lo i a pagar-li les rendes; a més, amenaçaven abandonar el lloc i traslladar-se a viure en uns altres indrets. Jaume II hagué de demanar-los que no marxessin, prometent-los que no se'ls faria cap injúria, però els ordenà que obeïssin l'alcaid i li paguessin les rendes. A l'alcaid, el rei li perdonà tot el que hagués fet malament fins al gener de 1301, però l'advertí que en el futur hauria de respondre del que els fes davant els oficials reials ${ }^{95}$.

Pel que fa als impostos, els sarraïns d'Oriola pagaven també el cabeçatge. Jaume Il el donà al municipi perquè en destinés el producte a les obres de reparació $i$ construcció de les muralles, bé que una tercera part s'havia d'esmerçar en la reparació del castell. Sembla que el rei no féu altra cosa, en realitat, que confirmar el que ja s'havia establert a la vila en temps dels reis de Castella. Com a Alacant, a Oriola també es reivindicà el cabeçatge de les aldees pròximes, com la Daia, que al.legava immunitat, - Catral. L'any 1302, els sarraïns d'aquestes alqueries, que pertanyien llavors a Bernat de Sarrià, s'havien negat a pagar la part que els pertocava en la peita, conjuntament amb els sarraïns d'Oriola. En aquest cas, el rei ordenà que fossin obligats a pagar ${ }^{96}$. Finalment, l'any 1314, Jaume II concedí l'impost al que era llavors el senyor del Iloc, Gonçalvo Garcia ${ }^{97}$.

En concepte d'alfarda o peita, els sarraïns d'Oriola pagaren 3.000 sous de reials, l'any $1312^{98}$. Suposo que devia ser la quantitat habitual, al començament del segle XIV, perquè era una quantitat fixa, com la quèstia dels cristians, que es repartia internament a l'aljama segons la riquesa de cadascun. Aquests eren, amb el quirat, els impostos més importants dels que pagaven els sarraïns, però en trobem poques notícies durant els anys de la guerra.

Cal fer esment encara de les prestacions de treball. L'any 1296, el rei els demanà de contribuir amb una persona per cada casa, amb una bèstia, un dia cada setmana,

94 M.T. FERRER I MALLOL, Abanilla y Jumilla en la Corona catalano-aragonesa (s. XIV), a Homenaje al Profesor Juan Torres Fontes, Murcia, Universidad de Murcia-Academia Alfonso X el Sabio, 1987, pp. 484-490. Sobre Favanella cf. també l'estudi més general de J. TORRES FONTES, El señorío de Abanilla, Múrcia, Patronato de Cultura de la Excma. Diputación de Murcia, 1962.

95 ACA, C, reg. 116, ff. 313 v. i 314 r. (1301, gener, 4 i 5).

96 ACA, C, reg. 120, f. 234 r. (1302, gener, 19). Publ. seguint la versió d'un còdex guardat a Oriola per J. M. del ESTAL, El reino de Murcia bajo Aragón, I/1, doc. 183. Publ. també per M. L. CABANES CATALÀ, El còdex d'Elx, Elx, Ajuntament d'Elx i Generalitat de València. Consell Valencià de Cultura, 1995, doc. [IXC], p. 233. Sabem que Bernat de Sarrià posseïa Catral, comprada a Ferran Garcés de Rueda, i la Daia, comprada a Guillem Durfort: M.T. FERRER, Les aljames sarraines, pp. 7-8 i Organització i defensa d'un territori fronterer, p. 36, 41 i 48 i ACA, C, reg. 131, ff. 5 v. 6 r. (1304, gener, 6).

97 M.T. FERRER, Les aljames sarraines, pp. 132-133.

98 ACA, C, reg. 326, f. 86 r. 
per a obres que feia a Callosa, que sabem que eren un forn i un camí. Més tard, rectificà aquesta petició per errònia i aclarí que la contribució era d'un dia cada mes ${ }^{99}$.

\section{Múrcia}

Sens dubte, Múrcia i la seva horta acollien encara una comunitat de sarraïns prou notable a la fi del segle XIII, malgrat la pèrdua de població experimentada després de la revolta.

Era presidida per un príncep de la dinastia lbn Hud, que havia estat respectada per Alfons $X$ el Savi, a precs del rei de Granada; aquest príncep era conegut pel títol d'exrei de Múrcia o bé de rei de la Reixaca de Múrcia, el barri on havien estat relegats els moros de la capital.

Segons la crònica d'Alfons el Savi, després de la submissió que acabà la revolta de 1264-1265, Alfons X nomenà rei moro de Múrcia Muhammad ibn Hud i li concedí la tercera part de les rendes del regne de Múrcia; Muhammad passà a viure a la Reixaca, on havia estat concentrada la població musulmana, i se li concedí per a allotjarse el palau Saguir. De les propietats que conservà en un primer moment, en va anar perdent una bona part, inclòs el palau Saguir, al mateix temps que disminuïa la població sarraïna, que continuà emigrant cap a Granada ${ }^{100}$. Poc abans que esclatés la guerra, l'any 1295, Ferran IV havia autoritzat el rei de la Reixaca perquè vengués els seus béns en el regne de Múrcia i Abrahim Aboçac ibn Hud havia usat aquest permís per a vendre el lloc de Fortuna a un veí de Múrcia, Aparici de Nompot, que en realitat comprava en nom del seu gendre Pere Giralt. Jaume II, a petició d'aquest darrer, confirmà la venda el 10 de juny de 1296, quan ja s'havia apoderat d'una bona part del regne ${ }^{101}$.

Després de la capitulació de Múrcia, el 19 de maig de 1296, Jaume II volgué mantenir la preeminència $i$ els privilegis de què havia gaudit la família ibn Hud $i$ una de les primeres coses que va fer fou confirmar, ja el 21 de maig, alguns d'aquests privilegis a favor d'Abutzac ibn Hud, que era el titular llavors de la dinastia hudita. Li donà, concretament, la justícia sobre els sarraïns de Múrcia, la vuitena part de les rendes de l'almoixerifat de Múrcia i el dret del mercat de les bèsties que, segons el privilegi de Jaume II, eren les coses que el rei Alfons de Castella li havia concedit després de perdonar-los l'error de la insurrecció aconsellada pel rei de Granada, en paraules del mateix document. Ignorem si aquestes rendes eren la meitat del total de les de Múrcia que, segons la Crònica d'Alfons $X$, aquest rei donà al rei de la Reixaca, però no sembla pas que ho fossin en aquest moment; de tota manera, eren una bona renda ${ }^{102}$.

99 ACA, C, reg. 104, f. 88 r. (1296, setembre, 10) i reg. 109, f. 284 v. (1297, agost, 30).

100 J. TORRES FONTES, «Los mudéjares murcianos en el siglo XIII», Murgetana, XVII (1961), pp. 7-9 de l'extret.

101 ACA, C, reg. 340, f. 149 v. (1296, juny, 10). Cf. l'autorització del rei Ferran al rei de la Reixaca $i$ altres documents relatius a la venda de Fortuna a J. TORRES FONTES, Fortuna, docs. 2-4.

102 ACA, C, reg. 340, f. 166 v. (1296, maig, 21). Comentat molt breument per P. GUICHARD, Un señor musulmán en la España cristiana, p. 27. 
Sorprenentment, el 22 de juny, en una carta demanant que fossin buscats dos captius negres musulmans, que es creia que s'havien refugiat a la Reixaca, el rei esmentà com a rei dels moros de la Reixaca de Múrcia Mahomet Aboabdilla, que havia estat el primer titular després de la insurrecció; suposem que es tracta d'un error ${ }^{103}$. Un any més tard, quan tornem a trobar mencionat el rei de la Reixaca, és esmentat altra vegada Abutzac, bé que el nom pren la forma més simple d'Açac. Abutzac havia protestat perquè per a collectar les rendes que hem esmentat abans havia comptat sempre amb un escrivà seu que exercia la seva tasca juntament amb l'almoixerif; però llavors Bernat Colomet, que era el batlle general del regne de Múrcia, no permetia l'actuació d'aquest escrivà. Jaume II manà al batlle general que l'autoritzés de la manera acostumada $i$ que respectés els privilegis que li havia atorgat ${ }^{104}$.

També és el mateix Abutzac el personatge a qui el rei reconegué el dret de tenir en servei de la Corona deu cavallers sarraïns amb cavall $i$ armes, estipendiats per l'erari públic. Pel juliol de 1297, Jaume II ordenà al batlle general que li pagués el que li era degut per aquest concepte, ja que només li havien estat pagats 800 sous reials. L'ordre valia tant per al passat com per al futur, és a dir, el batlle li hauria de pagar regularment el salari militar ${ }^{105}$. Suposo que el rei de la Reixaca degué morir per aquest temps, perquè el seu nom desapareix dels documents. Quan, pel maig de 1303, Jaume II envià al batlle general Ferrer Descortell la lista de la gent d'armes que era al seu servei a Múrcia, el rei de la Reixaca ja no hi apareix amb els seus deu cavalls armats, mentre que sí que hi surt l'arrais de Crevillent amb dos cavalls armats i quatre d'alforrats ${ }^{106}$. És possible que la desaparició del rei de la Reixaca sigui anterior al mes d'abril de 1301; crec que és significatiu que en aquest moment l'arrais de Crevillent, Muhammad, fos nomenat jutge dels sarraïns de la Reixaca ${ }^{107}$, atès que, com sabem, la justícia sobre els moros era un dels privilegis de què gaudia Abutzac. Cal no oblidar que la família dels ibn Hudayr estava emparentada amb els ibn Hud. Una filla de Muhammad ibn Hud, Abnatalaziz, era la muller de l'anterior arrais, Ahmad, que era el personatge més notable entre els moros del regne; un home, a més de la plena confiança de Jaume II.

Segurament era un germà d'Abutzac l'arrais Abonega o Abenayça. Immediatament després de l'ocupació de Múrcia, pel maig de 1296, el rei li confirmà la possessió d'un forn que tenia a la Reixaca i de sis faneques de terra prop de Múrcia ${ }^{108}$, i l'any 1301 li atorgà franquícia d'impostos per aquest mateix forn en consideració als serveis que li havia prestat amb un cavall alforrat ${ }^{109}$,

Pel que fa als sarraïns de la Reixaca, no hi ha gaires documents que els afectin en

103 ACA, C, reg. 340, f. 165 r. (1296, juny, 22).

104 ACA, C, reg. 253, f. 45 v. (1297, juliol, 3).

105 ACA, C, reg. 253, f. 45 v. (1297, juliol, 3).

106 M.T. FERRER, Organització i defensa, doc. 32.

107 ACA, C, reg. 198, f. 281 v. (1301, abril, 18); vegeu més amunt quan parlo de l'arrais de Crevillent.

108 ACA, C, reg. 340, ff. 107 v.-108 r. (1296, maig, 24), publ. per J. M. del ESTAL, El reino de Murcia bajo Aragón, 1/1, doc. 92.

109 ACA, C, reg. 198, f. 255 r. (1301, febrer, 15). 
els primers temps; probablement tot passava a través de l'exrei de Múrcia. No trobem cap guiatge als sarraïns de la Reixaca fins a la confirmació dels privilegis de Múrcia, que inclogué un assegurament als sarraïns $i$ jueus que prestessin obediència a Jaume II ${ }^{110}$. Poc després, el 20 d'agost, el rei els afavorí amb una rebaixa de 800 sous reials del cabeçatge de les vídues sarraïnes, del cabeçatge dels sarraïns i d'altres peites, durant un període de deu anys; amb aquesta concessió els volia compensar pels danys rebuts en temps passat ${ }^{111}$. El mateix mes ordenà al seu germà Jaume Pere, procurador del regne de Múrcia, que defensés els moros de la Reixaca contra els que els volguessin injuriar o molestar, sempre que estiguessin disposats a fer dret als querellants contra ells ${ }^{112}$.

Una nova intervenció del rei a favor dels sarraïns de la Reixaca es produí el setembre del mateix any, perquè s'havien queixat que el batlle de la ciutat de Múrcia els impedia de fer talles entre ells per a recollir els diners necessaris per a afrontar algunes despeses que havien de fer. La resposta del rei fou també la de fer respectar els costums dels sarraïns ${ }^{113}$.

Bernat Colomet obtingué una clarificació de les seves funcions respecte als sarrains pel setembre de 1296. El rei declarà que ningú més que ell no podia intervenir en les qüestions que afectessin jueus i sarraïns del regne de Múrcia; els altres oficials havien d'abstenir-se d'intervenir-hi' ${ }^{114}$. Però no pas sempre el batlle obtingué l'aprovació reial en la seva gestió de les qüestions sarraïnes. Pel juliol de 1297, el rei desaprovà l'organització d'una tarcana o bordell per a meretrius sarraïnes a la Reixaca i ordenà tancar-la i expulsar-ne les dones ${ }^{115}$.

Durant els anys següents, les notícies que tenim dels moros de la Reixaca, com a col-lectiu, són pràcticament inexistents, llevat d'algunes de referents a convocatòries a l'exèrcit que ja he comentat.

Noves queixes arribaren, per l'abril de 1303, ara dins l'esfera de poder del batlle general, Ferrer Descortell. Els sarraïns es queixaven perquè el sabasala, el mostassà i l'alcadí eren obligats a pagar el cabeçatge, quan n'eren exempts; el rei els donà la raó i manà que no els fos exigit; una altra queixa era que per Pasqua pagaven per cap un almud de gra del que compressin per a menjar aquell dia; però els col.lectors els demanaven no pas un almud del gra que compraven aquell dia, que suposem que intel.ligentment devien procurar que fos un gra de baixa qualitat, sinó que el demanaven gairebé tot de blat; d'aquesta queixa, el rei volgué rebre'n més informació abans de decidir. També el mateix dia el rei manà que fos respectat el privilegi que tenien de ser empresonats a la presó dels sarraïns ${ }^{116} \mathrm{i}$, per tal de repoblar la Reixaca, concedí que

110 ACA, C, reg. 194, f. 226 r.-v. (1296, agost, 3).

111 ACA, C, reg. 194, f. 242 r. (1296, agost, 20). Cit per P. GUICHARD, Un señor musulmán en la España cristiana, p. 27.

112 ACA, C, reg. 104, f. 45 r. (1296, agost, 21).

113 ACA, C, reg. 104, f. 101 r. (1296, setembre, 21).

114 ACA, C, reg. 104, f. 107 v. (1296, setembre, 22).

115 ACA, C, reg. 253, f. 45 v. (1297, juliol, 3).

116 ACA, C, reg. 127, f. 109 v. (1303, abril, 25). 
els sarraïns forasters que s'hi instal.lessin per a residir-hi, almenys un any, gaudissin d'exempció de cabeçatge i alfarda durant aquest any ${ }^{117}$. Pocs dies després el rei confirmà l'arrais de Crevillent com a jutge dels sarraïns de la Reixaca de Múrcia i altres llocs del regne ${ }^{118}$. Suposo que aquesta acumulació de decisions favorables als moros de la Reixaca degué correspondre a l'arribada d'algun missatger de l'aljama amb un memorial de queixes i peticions a la cort, a València, o potser fou el mateix arrais qui exercí la seva influència prop del rei a favor dels moros de Múrcia. En qualsevol cas, les queixes són molt interessants per a completar la nostra informació sobre alguns impostos, com el de l'almud de gra per cap, que podria ésser l'alfatrà 119.

Cal dir que també he trobat algunes notícies sobre l'alfòndec de Múrcia, on s'hostatjaven els sarraïns forasters, que fou concedit, juntament amb l'escrivania de la duana o pes, a Arnau d'Esparraguera ${ }^{120}$. Més endavant, sabem que les rendes de l'alfòndec, juntament amb altres, serviren per a garantir una pensió de 1000 sous barcelonins anuals que havia de rebre Berenguer de Miramon, ciutadà de Múrcia; aquestes altres rendes que servien de garantia eren l'almoixerifat i un dret anomenat la "partaça», que pagaven els sarraïns estrangers pels animals carregats de mercaderia quan sortien de la ciutat de Múrcia ${ }^{121}$. També tenim constància de la concessió de l'escrivania dels sarraïns de Múrcia a Joan Pere de Maylén, un home de la casa del $\mathrm{rei}^{122}$.

Personatges notables que trobem esmentats són per exemple Mahomet Alhale, mestre alarif dels sarraïns de Múrcia, a qui fou concedida franquícia de peita el 1298. Un altre mestre, de qui no podem llegir el nom, rebé un donatiu de 55 sous reials de Múrcia sobre la peita ${ }^{123}$. També tenim notícia d'un mercader de Múrcia que havia anat al Marroc sense llicència, una terra amb la qual no hi havia pau, bé que tampoc en aquell moment no hi havia hostilitats obertes, i que quan en tornà fou empresonat, per aquesta raó, a València. El mercader en qüestió, del qual no sabem el nom, es beneficià del fet que els mercaders de Barcelona, de València i d'altres llocs dels regnes de Jaume II s'interessaren perquè fos alliberat, ja que temien que Abenjacob no exercís alguna represàlia contra els mercaders catalans i valencians que eren en aquell moment al Marroc ${ }^{124}$.

117 ACA, C, reg. 200, f. 214 v. (1303, abril, 25), publ. per J. M. del ESTAL, El reino de Murcia, doc. 188.

118 ACA, C, reg. 127 , f. 114 r. (1303, abril, 28).

119 A la part septentrional de l'antic regne de Múrcia aquest impost es consolidà amb la petició d'un almud d'ordi per cap: M.T. FERRER, Les aljames sarraïnes, pp. 46-48 i 133; J. HINOJOSA MONTALVO, "Crevillente: una comunidad mudéjar en la Gobernación de Orihuela en el siglo XV", a IV Simposio Internacional de mudejarismo: Economía, pp. 310-312

120 ACA, C, reg. 340, f. 147 v. (1296, juny, 16).

121 ACA, C, reg. 256, f. 40 r.-v. (1298, febrer, 8).

122 ACA, C, reg. 196, f. 191 v. (1298, febrer, 23).

123 ACA, C, reg. 196, ff. 129 v.-130 r. i v. (1298, febrer, 7).

124 ACA, C, reg. 128 , f. 215 r. (1303, juliol, 18). 
Les comunitats sarraïnes de l'horta de Múrcia varen patir força la guerra. Ja m'he referit al començament als captius que foren presos a Albudeite. El 13 de juny, el rei posà sota el seu guiatge tant els moros de Pliego com els d'Albudeite, però no els serví de gaire perquè pocs dies després sofriren una cavalcada dels homes de Lorca, que lluitaven encara pel rei de Castella ${ }^{125}$.

Una altra cavalcada de l'adalil Vicenç de Xixona per Ceutí i Lorquí durant el mes de maig de 1296 aconseguí també, com ja hem dit més amunt, diversos captius sarraïns, el nombre dels quals no és especificat. El rei consentí la venda dels de Ceutí i Lorquí, però no d'alguns moros d'Alguazas que també havien estat presos, en part perquè el lloc pertanyia a la seva tia, la reina Violant, i en part perquè l'havia concedit al seu conseller Ramon de Manresa ${ }^{126}$. El 13 de maig, un sarraí d'Alguazas de Molina, anomenat Açmet Acurubi, obtingué un guiatge particular per a anar i venir a Múrcia 0 a Alguazas, amb bestiar $i$ altres coses ${ }^{127}$, i el 19 tots els sarraïns del lloc obtingueren guiatge per a les seves terres i per a les persones i per a circular i residir en qualsevol lloc que volguessin del regne de Múrcia ${ }^{128}$. Un mes després el rei encara s'ocupà novament dels sarraïns de les Alguazas, ara perquè s'havien queixat que hom no els deixava usar l'aigua, com acostumaven en temps passat, i que per aquesta causa els seus conreus resultaven perjudicats; el rei manà al batlle de Múrcia que els deixés usar l'aigua segons el costum ${ }^{129}$.

Els sarraïns de les Alguazas foren afortunats perquè el projecte reial de fundar un monestir al Real de Múrcia dependent de Santes Creus féu que el monarca afavorís els llocs que donava al monestir, entre els quals figurava les Alguazas. Així, doncs, per l'octubre de 1297 manà al procurador que els sarraïns del monestir no fossin obligats a contribuir pels béns que tenien a l'almoixerif de la Reixaca de Múrcia i, quan pel desembre d'aquell any els sarraïns hagueren de refugiar-se a Múrcia per viure segurs, ja que els castellans feien cavalcades pel territori, també els defensà contra la pretensió del batlle i de l'almoixerif de fer-los pagar el cabeçatge, com si hi visquessin de manera permanent ${ }^{130}$. Però el 1298 calgué una nova intervenció del rei perquè Santes Creus

125 ACA, C, reg. 340, ff. 149 r. (1296, juny, 13)i 168 r. (1296, juny, 24). La vila de Pliego ja havia rebut abans un altre guiatge, el 20 de maig, però no esmentava els moros: ibídem, $f$. 77 r.

126 ACA, C, reg. 340 , f. 71 r. i 73 r.-v (1296, maig, 17 i 18), aquest darrer publ. per. J.M. del ESTAL, El Reino de Murcia bajo Aragón (1296-1305). Corpus documental, 1/1, doc. 64 i 1/2, doc. 39. Cf. la concessió a Ramon de Manresa a ibídem, doc. 29. Sobre el senyoriu de la reina Violant sobre Alguazas cf J. TORRES FONTES, «El señorío de Alguazas en la Edad Media», Murgetana, XLIX (1977), pp. $81-114$ i concretament pp. 85-90.

127 ACA, C, reg. 340, f. 75 r. (1296, maig, 13).

128 ACA, C, reg. 340, f. 75 r. (1296, maig, 19), publ. per J. M. del ESTAL, El reino de Murcia bajo Aragón, $1 / 1$, doc. 75 .

129 ACA, C, reg. 340, f. 177 r. (1296, juny, 27).

130 ACA, C, reg. 106, ff. 91 r.-v. (1297, octubre, 30), i 135 r. (1297, desembre, 10), cit. R. SÁINZ DE LA MAZA LASOLI, «EI monasterio cisterciense del real de Murcia. Un proyecto fracasado de Jaime Il», Anales de la Universidad de Alicante. Historia Medieval, 9 (1992-93), p. 184. 
s'havia queixat de l'actuació de mestre Bernat, l'almoixerif de la Reixaca de Múrcia, que havia pres al monestir els impostos d'alfatrà i cabeçatge que tenia sobre els sarraïns de les Alguazas i el quirat que tenia sobre els sarraïns de Monteagudo ${ }^{131}$. Els sarraïns que habitaven a les Alguazas, però a la part que pertanyia a Ramon de Manresa, també obtingueren alguns favors, com el de no haver d'acudir a l'exèrcit i no haver de deixar les seves bèsties ${ }^{132}$.

\section{Cartagena}

Tenim molt poques notícies dels moros que vivien a Cartagena. El 3 de juny de 1296 Jaume II concedí un guiatge conjunt a tots els veïns de Cartagena, tant als cristians, com als sarraïns i als jueus, i franquícia i llibertat de moviments per a persones i mercaderies per tot el regne. El guiatge comportava al mateix temps la suspensió de totes les accions judicials pendents per actes i crims comesos amb anterioritat sota règim castellà. Un mes després, Jaume II confirmà al municipi de Cartagena i a tots els veïns, cristians, sarraïns i jueus, els furs i les franquícies concedits pels reis de Castella ${ }^{133}$.

Sabem que, a la primeria de juliol de 1296, alguns prohoms de Cartagena havien intercedit prop del rei, que es trobava al setge d'Elx, perquè perdonés als sarraïns de Cartagena alguns impostos que el seu representant a la vila els exigia. Els prohoms asseguraven que els moros es trobaven en una gran misèria i que no podien pagar $i$, per això, el rei ordenà de sobreseure l'exacció fins que ell no tornés a Múrcia i decidís sobre el cas ${ }^{134}$.

És tot el que en sabem.

\section{Mula}

Tampoc no és gaire més el que sabem dels moros de Mula, que ensimaginem que devien ser pocs. El privilegi de confirmació per part de Jaume II dels privilegis, donacions, bons usos i costums, que els reis de Castella havien concedit als veïns de Mula, esmenta els sarraïns al costat dels cristians $i$ jueus ${ }^{135}$. Sembla que en altre temps Mula havia tingut una moreria important, però durant els anys dels quals ens ocupem a penes si és esmentada; acabada la guerra, Mula sol.licità de repoblar la seva moreria amb seixanta casats d'altra procedència ${ }^{136}$.

131 ACA, C, reg. 110, f. 53 r. (1298, març, 31).

132 ACA, C, reg. 111, f. 215 v. (1298, maig, 19).

133 ACA, C, reg. 340, ff. 240 v. -241 r. i 283 v.-284 r. (1296, juny, 3 i juiol, 15), publ. per J.M. del ESTAL, El reino de Murcia bajo Aragón, l/1, docs. 97 i 117.

134 ACA, C, reg. 340 , f. 214 r. (1296, juliol, 10).

135 ACA, C, reg. 340, f. 280 v. (1296, agost, 2), publ. per J. M. del ESTAL, El reino de Murcia, I/ 1, doc. 126.

136 J. TORRES FONTES, Los mudéjares murcianos en el siglo XIII, pp. 26-27. 
Durant la guerra, únicament hi ha constància de mesures preses contra un jueu de Mula, Abulfacem, que vivia en concubinatge amb una sarraïna, anomenada Axona. El procurador de Jaume II, el seu germà Jaume Pere, els havia empresonats, però el rei manà que fossin deslliurats perquè, no essent cristians, opinava que no s'havia d'intervenir en l'afer i l'any següent repetí el manament a Jaume de Xèrica, que succeí en el càrrec el seu germà ${ }^{137}$.

\section{Els llocs dels ordes militars}

Als llocs dels ordes militars, especialment els de l'orde de Santiago, era on segurament, fora de la capital, es concentrava un nombre major de sarraïns, juntament amb Alguazas, Ceutí i Lorquí. Les negociacions amb l'orde de Santiago per al reconeixement de Jaume II s'allargaren un quant temps, però mentrestant els frares de l'orde i els seus moros reberen un guiatge del rei. Un primer guiatge fou expedit el 25 de maig per als llocs de Ricote, Cieza, Aledo i Ojós, durant el termini de trenta dies que el rei donava als naturals del regne per a decidir si el reconeixien com a rei o no ${ }^{138}$. L'11 de juny Ferran Pérez, comanador de Ricote, i Joan Martínez, comanador de Cieza, juraren tenir pel rei Cieza, Aledo, Negra i Ojós i Ricote ${ }^{139}$. El dia abans, quan el reconeixement ja era imminent, Jaume Il confirmà als llocs de l'orde els furs, privilegis, franquícies, llibertats, donacions i costums concedits pel rei Alfons i pels seus successors a l'orde a Múrcia, amb les mateixes obligacions de serveis en pau i en guerra pels castells que tenia al regne; el dia 12 el rei concedí un nou guiatge als frares de l'orde i als seus moros al regne de Múrcia i, el 26 del mateix mes, comunicà a les places granadines frontereres de Vélez el Blanco i Vélez el Rubio que els llocs de l'orde de Santiago l'havien reconegut com a rei i, per tant, demanà que no fossin atacats $^{140}$. Els qui, en canvi, no observaren la pau amb Granada foren els súbdits de l'orde, que lluitaren contra genets de Granada que havien fet una cavalcada contra Castella i que, tornant, havien passat per Cieza, on algun fou mort i altres foren retinguts $^{141}$. Problemes semblants es repetiren l'any 1300 a Aledo, amb moros almogàvers de Vélez Blanco, a Totana, on homes d'Aledo degollaren dos granadins, $\mathrm{i}$ a Hellín, on foren retinguts dos granadins més ${ }^{142}$.

A la darreria de desembre de l'any 1300 , sembla que havia corregut entre els moros de la vall de Ricote el rumor que Jaume II i la seva gent estarien contra ells; segons el comanador Ferran Pérez, ell els havia convençut que no es moguessin, quan presumiblement pensaven de fugir cap algun altre lloc més segur, ja que eren sota el guiatge reial. El rei es felicità que fos així en carta al comanador i tornà a confirmar

137 ACA, C, reg. 110, f. 34 v. (1297, març, 26) i 115 v. (1298, abril, 13).

138 ACA, C, reg. 340, f. 93 v. (1296, maig, 25). Cf. més informació sobre tot el que es refereix a l'orde de Santiago a R. SÁINZ DE LA MAZA LASOLI, La orden de Santiago en aquest mateix volum.

139 ACA, C, cr Jaume II, caixa 152, núm. 834.

140 ACA, C, reg. 340, ff. 127 v. i 128 r. (1296, juny, 10 i 12) i f. 177 r. (1296, juny, 26).

141 ACA, C, reg. 107, f. 219 r. (1298, febrer, 11).

142 ACA, C, cr Jaume II, caixa 122, núm. 1423. 
que els moros no havien de témer res. Probablement, els rumors venien del descontentament dels oficials reials envers el comanador, que no solament no col-laborava en la guerra quan se li demanava sinó que ajudava els enemics. El rei li recordà el jurament i l'homenatge que havia prestat i estigué disposat a parlar amb ell d'una possible retirada del regne, donant-li un termini per a tornar els castells al mestre de l'orde, tal com el comanador de Ricote mateix li havia proposat ${ }^{143}$.

Malgrat el canvi de comanador, que efectivament es portà a terme, la inquietud entre els moros de la vall de Ricote no desaparegué. Per tal de resoldre el conflicte, el procurador del regne, Bernat de Sarrià, s'entrevistà a Múrcia amb l'arrais de Crevillent i amb l'ambaixador de Granada, Çahat Acaybilli, i s'hi acordà que els moros de la vall lliuressin quaranta rehenes que servirien de garantia que no acollirien ni ajudarien de dit ni de fet el rei de Castella i la seva gent, ans el contrari, que li farien guerra. Si no complien la seva paraula, les rehenes quedaven per al rej ${ }^{144}$.

Durant l'any 1303 tornem a tenir notícies de la vall de Ricote i de les altres possessions de l'orde de Santiago. Sabem, per exemple, que el rei tornà a posar sota el seu guiatge la vall, Ojós, Negra i Cieza; la repetició dels guiatges fa sospitar que hi havia hagut, novament, tensions a la vall; altrament, el guiatge no hauria estat necessari $i$, potser per tal de no provocar-ne més, el rei recomanà al batlle general, Ferrer Descortell, que no exigís l'impost de cenes als llocs de l'orde de Santiago si no les pagaven en temps dels reis de Castella ${ }^{145}$.

Pel que fa a les possessions dels Hospitalers, sabem que el castell d'Archena es mantenia rebel a Jaume II l'any 1301, però que els sarraîns que vivien al terme sí que havien acceptat la seva sobirania i s'havien refugiat a Molina Seca; per aquesta causa el rei manà a Bernat de Sarrià que els restituís el blat $i$ altres fruits que havia pres en el transcurs d'una cavalcada a les heretats del terme que pertanyien als dits sarraïns, perquè no eren rebels ${ }^{146}$.

\section{LA PARTICIÓ DEL REGNE}

Després de la pau amb Castella, el 8 d'agost de 1304, només la meitat aproximadament del regne quedà en poder de la Corona catalano-aragonesa, però tenim la impressió que era en aquest territori on hi havia els nuclis més importants de sarraïns, a les comarques d'Elx i de Crevillent, de la vall d'Elda i de Novelda i a les hortes d'Oriola i Alacant i a les seves moreries urbanes.

143 ACA, C, reg. 293, f. 29 r. (1300, desembre, 28), publ. per J. M. del ESTAL, "Nuevos datos sobre la capitulación y conquista aragonesa de Lorca", a Homenaje al profesor J. Torres Fontes, Múrcia, Universidad de Murcia-Academia Alfonso X el Sabio, 1987, I, doc. 14, p. 458 i a El reino de Murcia bajo Aragón, I/2, doc. 144, cal tenir present, però, que la regesta conté errors respecte al contingut del document.

144 ACA, C, cr, caixa 6, núm. 1110, cf. P. GUICHARD, Un señor musulmán, p. 28 i doc. 4, pp. 7374, publ. també per J. M. del ESTAL, El reino de Murcia, doc. 174.

145 ACA, C, reg. 128, f. 143 v. (1303, maig, 26).

146 ACA, C, reg. 121, f. 10 r. (1301, juny). 
Justament a la fi d'agost de 1304, quan anaven a començar els treballs per a la divisió del regne, es produí una incursió granadina per terra i per mar. Per terra, l'exèrcit nassarita arribà fins a Alcoi i a Cocentaina, que foren assetjades perquè Alabbàs Ben Rahú -el mercenari marroquí que havia estat al servei de Jaume II fins pocs mesos abans - participava en l'expedició i sabia prou bé que no eren llocs gaire forts. Per mar, la flota de Granada s'adreçà a Xàbia, a fi d'unir les seves forces amb les de l'exèrcit de terra. Si aquesta conjunció s'hagués portat a terme i la població sarraïna que habitava a les comarques del sud del País Valencià s'hagués revoltat, com esperaven els invasors, la situació hauria resultat molt compromesa per a Jaume II. Però la flota nassarita, a causa d'un temporal, arribà tard a la cita amb l'exèrcit i no el trobà perquè les tropes de terra ja s'havien retirat; la sublevació dels sarraïns autòctons tampoc no fou generalitzada, però alguns — no sabem quants - participaren en els setges de Cocentaina i d'Alcoi i molts més seguiren l'exèrcit nassarita en la retirada: alguns milers de sarraïns del sud del País Valencià i de la vall del Vinalopó i hortes d'Alacant i Oriola ${ }^{147}$.

No tenim constància que el territori murcià actual també hagués resultat afectat per aquest fenomen migratori, però és força probable. Moltes de les notícies sobre aquesta fugida en massa són de l'any 1305, quan la part meridional del regne de Múrcia ja era fora del control de Jaume II, per això la documentació de la cancelleria reial no ens n'informa; però la carta de Ferran IV de Castella, que hem comentat al començament, potser es refereix a aquest fenomen quan esmenta la despoblació causada per la guerra i per la fugida de molts sarraïns ${ }^{148}$.

L'entrada inesperada de l'exèrcit granadí, en un moment en què es creia que hi havia treva, i els incendis, el pillatge i les fugues de tants sarraïns van causar desconcert entre els cristians; però entre els sarraïns va causar potser més desconcert encara la notícia de la pau amb Castella i de la divisió del regne. Els camperols sarraïns eren gent espantadissa; sempre temien efectes dolents per a ells de qualsevol canvi. L'exemple més significatiu el tenim a Elda i a Novelda, on la notícia produí pànic entre els sarraïn, que abandonaren tots dos llocs per a refugiar-se no sabem on. En aquest cas en concret potser temien que retornarien al poder del rei de Castella i que serien castigats per haver obeït Jaume II. Per això, pel novembre de 1304, el rei els notificà que quedaven sota la seva senyoria, els assegurà i els manà que tornessin a llaurar les seves terres, ja que ell els defensaria ${ }^{149}$.

Resumint, doncs, el final d'una guerra, que havia portat tants patiments, no fou tampoc una bona notícia per a molts sarraïns, que temien un altre canvi de senyor; trigaren un cert temps a asserenar-se.

147 M.T. FERRER, La frontera amb l'Islam en el segle XIV, pp. 79-90.

148 Cf. la nota 9.

149 M.T. FERRER, Les aljames sarraïnes, p. 73 i doc. 28. 


\title{
LA SUCESIÓN AL TRONO DE CASTILLA: 1275-1304
}

\author{
Manuel GONZÁLEZ JIMÉNEZ \\ Universidad de Sevilla
}

1. En noviembre de 1386, en pleno avance hacia la meseta de las tropas inglesas y gasconas del príncipe inglés Juan de Gante, desembarcadas meses antes en Galicia, Juan I de Castilla reunió Cortes en Segovia. Debía de hacer frente a una nueva amenaza. Ya no se trataba del enemigo portugués que le había infligido el año anterior la tremenda derrota de Aljubarrota, donde se habían hundido las esperanzas de ser reconocido como rey de Portugal. En esta ocasión venían a su propia casa a disputarle el derecho a ser rey de Castilla.

El origen de este nuevo conflicto es bien conocido: la muerte de Pedro I en Montiel en 1369 había roto la línea legítima de sucesión al trono castellano, para dar paso a la rama bastarda de Alfonso XI, en la persona del conde Enrique de Trastámara. Juan de Gante, que había casado en 1372 con Constanza, hija mayor y heredera de Pedro, habida de su unión - legítima al parecer- con María de Padilla, reclamaba desde entonces los derechos al trono castellano. La derrota de Juan I en Portugal se presentaba como la gran oportunidad para hacer efectivo su sueño'.

Este nuevo problema, añadido al desastre militar del año anterior, llevó a Juan I a plantearse el problema de su propia legitimidad como rey. No es que dudase de ella. Pero debía fundarla sobre bases más sólidas que la brutalidad de un golpe de estado, por más que estuviese justificado por la crueldad del rey asesinado o, como afirmaba la propaganda trastamarista, por el origen espurio de «aquel mal tirano que se llamaba rey», hijo, no de Alfonso XI, sino de un judío llamado Pero Gil. De esta forma, en un

1 La obra fundamental sobre el reinado de Juan I es el libro de Luis SUÁREZ FERNÁNDEZ, Historia del reinado de Juan I de Castilla (Madrid, 1977), refundida en Juan I. 1379-1390 (Palencia, Diputación Provincial, 1994). Sobre Juan de Gante, Anthony GOODMAN, John of Gaunt. The Exercise of Princely Power in Fourteenth-Century Europe (Harlow, Logman, 1992). Ver especialmente, 111-143. 
discurso sorprendente ante los asistentes a las Cortes de Segovia, Juan I declaró, de un plumazo, que todos los reyes anteriores a Enrique II, su padre, debían ser considerados como ilegítimos ya que descendían de Sancho IV que con codiçia desordenada e mala de rregnar, fizo en tal manera que deseredó asu padre en vida, e despues dela muerte del dicho su padre rretuuo al rregno e al senorio por fuerza alos dichos sus sobrinos, los llamados infantes de la Cerda, nietos de Alfonso $\mathrm{X}$ el Sabio?

2. La historia de este conflicto dinástico, desde sus orígenes en 1275 hasta la Sentencia Arbitral de Torrellas, va a ser el tema de esta ponencia. Treinta años de historia, durante los cuales volverá a plantearse una nueva crisis sucesoria, la de la minoría de Fernando IV, ambas enormemente interesantes.

El prof. Sánchez-Arcilla ha afirmado que hasta tiempos de Alfonso XI Castilla careció de una norma precisa que regulase "el orden de sucesión a la corona" " ¿Carecía o no había sido promulgada? Ya lo veremos. De momento recordemos cuál era a mediados del siglo XIII la norma tradicional: primogenitura por línea masculina y, en defecto del primogénito, el mayor de los hijos supervivientes. A falta de hijos varones, podían acceder al trono las mujeres. Estos fueron los principios que rigieron la sucesión al trono durante los siglos XI, XII y XIII, desde la muerte sin sucesión de Sancho II (1072) hasta el accidente que puso fin a la corta vida de Enrique I (1217). Y así hubiera seguido siendo de no haber sido por la recepción en Castilla del ius commune, de la mano, principalmente, de los códigos mandados componer por Alfonso $\mathrm{X}$ el Sabio.

Por lo que hace al asunto que nos ocupa, las Partidas son el texto fundamental, $y$, en ellas, el famoso pasaje de la Partida II, título Xv, ley ii que dice:

«por ende establesçieron que sy fijo varon y non oviese, la fija mayor heredase el rregno, e aun mandaron que sy el fijo mayor moriese ante que heredase, sy dexase fijo o fija que oviese de muger legítima, que aquel o aquella to oviese, e non otro ninguno; pero sy todos estos fallesçiesen deve heredar el rregno el mas propinco pariente que y oviere seyendo omne para ello e non aviendo fecho cosa por que lo deviese perder» ${ }^{4}$.

Muy lejos estaba el Rey Sabio de pensar que esta intrusión en el derecho público de un principio de derecho privado romano (ius representationis) iba a provocar no sólo la división del reino y en el seno su propia familia, sino una guerra civil que sólo interrumpiria el fallecimiento del rey Sabio en abril de 1284.

Dejando aparte, de momento, lo que hubo de personal en el conflicto y ciñéndonos a los aspectos jurídicos de la cuestión, debemos plantearnos ante todo el problema

2 Cortes de los antiguos reinos de León y Castilla [CLC], II (Madrid, Real Academia de la Historia, 1863), 352-354.

3 José SÁNCHEZ-ARCILLA BERNAL, Alfonso XI. 1312-1350 (Palencia, 1996), 32.

4 Partida Segunda de Alfonso $X$ el Sabio. Manuscrito 12794 de la B.N. Edición: Aurora Juárez Blanquer y Antonio Rubio Flores, con estudios de C. Torres Delgado, J. Montoya Martínez, A. Juárez Blanquer y A. Rubio Flores (Granada, 1991), 135. 
de la vigencia o no de las Partidas al producirse en el otoño de 1275 el fallecimiento del primogénito de Alfonso $X$, el infante don Fernando de la Cerda.

Tradicionalmente se viene afirmando que las Partidas no fueron promulgadas en vida de su autor. Sólo alcanzarían vigencia legal en tiempos de su bisnieto Alfonso $X$ $\mathrm{XI}$ quien, en el Ordenamiento de Alcalá de 1348 reconoció las Partidas "como derecho oficial del reino castellano-leonés» ${ }^{5}$. Pero, sin discutir la historicidad de esta sanción alfonsina perfectamente documentada, podríamos preguntarnos si Alfonso $X$ no dio valor de ley, siquiera fuese de forma tácita, a un código en el que tantas ilusiones había depositado. ¿Qué sentido hubiera tenido efectuar tan magna recopilación en la que se invirtió tanto tiempo y dinero sino su efectiva puesta en práctica?

La respuesta no puede ser más que positiva: en vida de Alfonso $X$ las Partidas estuvieron plenamente vigentes, ya sea por su simple promulgación en un acto de la corte del rey, cosa de la que no tenemos constancia o, como quiere O'Callaghan, por el simple hecho de ser las Partidas una revisión ampliada del Espéculo, código que había sido promulgado en Palencia en 1255 y cuya revisión se reservó el rey en el caso de que fuese necesario. Si esto es así, concluye O'Callaghan, las Partidas «no requerían ser promulgadas por separado». Por tanto, «tuvieron fuerza de ley durante el reinado de Alfonso $X{ }^{\circ}$.

Esta tesis podría corroborarse con otros dos argumentos. En el testamento de Alfonso $X$, redactado en Sevilla, el 8 de noviembre de 1282, se incluye un párrafo que puede interpretarse en el sentido propuesto por O'Callaghan:

«E porque es costumbre e derecho natural e otrosy fuero e ley de Espanna que el fijo mayor deue heredar los reynos e el sennorío del padre, non faziendo cosas contra estos derechos sobredichos por que lo aya de perder, por ende, nos, seguiendo esta carrera, después de la muerte de don Fernando, nuestro fijo mayor, como quier que el fijo que él dexasse de su muger de bendiçión, si él vizquiera más que nos, por derecho deue heredar lo suyo, asy commo lo deuía de heredar el padre; mas pues que Dios quiso que saliese del medio que era linea derecha por do desçendía el derecho de nos a los sus fijos, nos catando derecho antiguo e la ley de razón, segund la ley de Espanna, otorgamos <estonçe> e concedimos a don Sancho, nuestro fijo mayor, que lo oviese en lugar de don Fernando, nuestro fijo mayor, porque era más llegado por linea derecha que los nuestros nietos, fijos de don Fernando" ${ }^{7}$.

Aquilino Iglesia ha llamado la atención sobre el hecho de que en el texto que acabamos de leer se hace referencia a dos derechos diferentes: el derecho en virtud del

5 J. SÁNCHEZ-ARCILLA, ob. cit., 282.

6 Joseph F. O'CALLAGHAN, El rey Sabio. El reinado de Alfonso X de Castilla. Trad. de M. González Jiménez (Sevilla, Universidad, 1996), 62.

7 M. GONZÁLEZ JIMÉNEZ (Ed.), Diplomatario Andaluz de Alfonso X (Sevilla, 1991), n. 518, p. 549 . 
cual el hijo del infante debía heredar a su padre y el derecho antiguo al que Alfonso $X$ se acogió para alterar las previsiones sucesorias establecidas por él mismo en las Partidas.

Pero existe otro argumento a favor de la tesis de la vigencia de las Partidas en tiempos de Alfonso $\mathrm{X}$ y, por tanto, del pleno vigor de las disposiciones referentes a la sucesión. Hace muchos años, el prof. MacDonald, experto conocedor de los textos jurídicos alfonsíes y editor reciente del Espéculo, llamaba la atención sobre la existencia de algunos manuscritos de la II Partida en los se alteró el sentido de la ley ii del título xiii de la manera siguiente: donde se lee sy el fijo mayor moriese ante que heredase, sy dexase fijo o fija que oviese de muger legítima, que aquel o aquella lo oviese, e non otro ninguno se hizo una habilidosa alteración/interpolación quedando el texto como sigue:

«si el fijo mayor muriese ante que heredase, si dexase fijo legitimo varon, que lo ouiese, pero si fincare otro fijo varon del rey que aquel to herede et non el nieto" ${ }^{9}$.

¿Qué sentido tendría esta manipulación del texto de las Partidas si no hubiesen tenido vigencia de ley? Evidentemente, ninguno. Por su parte Craddock, estudiando la misma interpolación, realizada según MacDonald en 1276, advierte que también se alteró en el código la edad legal fijada para poder reinar, veinte años, y se rebajó a diecisiete, precisamente la misma que tenía entonces el infante don Sancho ${ }^{10}$. «De esta forma - comenta O'Callaghan-, si el rey fallecía de repente, no habría necesidad de regencia ya que Sancho tenía ya diecisiete años" ${ }^{11}$.

Desde el punto de vista histórico la sucesión de Alfonso $X$ plantea, en general, menos problemas. Uno de ellos — habida cuenta la energía con la que Felipe III de Francia defendió los derechos de sus sobrinos los infantes de la Cerda- es el de la existencia o no de una cláusula en las capitulaciones matrimoniales entre don Fernando de la Cerda y doña Blanca de Francia que estableciese el cumplimiento de las previsiones sucesorias en el orden previsto por las Partidas. El cronista catalán Bernat Desclot señaló a este respecto lo siguiente: avia covinença... que, aprés la mort d'En Ferrando, deguessen ésser sos nobots reis [existía el acuerdo de que después de la muerte de don Fernando, fuesen reyes sus nietos] ${ }^{12}$. Y una versión de la Cuarta Crónica General, de mediados del siglo XV, recoge la misma noticia cuando comenta que

8 Aquilino IGLESIA FERREIRÓS, "La labor legislativa de Alfonso X el Sabio", en España y Europa. Un pasado jurídico común (Murcia, Instituto de Derecho Común, 1986), 586-587.

9 R.S. MACDONALD, "Alfonso the Learned and Succession: A Father's Dilemma», Speculum, vol. XL (1965), 651, nota 11.

10 Jerry R. CRADDOCK, «Dynasty in Dispute: Alfonso $X$ el Sabio and the Succession to the Throne of Castile and León in History and Legend», Viator, 17 (1986), 197-219.

11 J.F. O'CALLAGHAN, EI Rey Sabio, 284.

12 Crònica del rei en Pere [III]. Ed. F. Soldevila, Les quatre grans cròniques (Barcelona, 1983), $454 a-b$. 
"este infante don Ferrando, seyendo infante, casó con la fija del rey de Françia que dezían donna Blanca. E casó con esta postura: que sy oviese en ella fijos, que reynasen en Castilla después dél... E éstos demandaron después el reyno grand tiempos'13.

3. El desarrollo del pleito sucesorio que estas disposiciones provocaron es difícil de resumir en pocas palabras. Intentaré de todas formas ofrecer un relato inteligible de los acontecimientos ${ }^{14}$.

Como dijimos, el problema de la sucesión de Alfonso $X$ se planteó de forma inopinada y, además, en el momento y en las circunstancias menos oportunas. Desde fines de 1274, Alfonso X estaba ausente del reino, tratando en Belcaire con el papa la resolución del fecho del Imperio, en el que había gastado tantas ilusiones, energías y dinero. Fernando de la Cerda había quedado como regente del reino. Fue entonces cuando se produjo la invasión de los benimerines y la ruptura de la tregua que Granada había firmado con Castilla años antes. El infante, que andaba por Valladolid cuando se produjeron estos hechos, se dispuso a acudir a la Frontera, falleciendo de forma inopinada en Villa Real en julio, según unos, o en octubre de 1275, según otros. En ausencia del rey, el infante don Sancho se hizo cargo del gobierno del reino y tomó medidas muy acertadas para contener la amenaza de granadinos y benimerines.

A su regreso de Belcaire sin haber conseguido del papa más que una rotunda negativa a sus pretensiones imperiales, Alfonso $X$ debió afrontar, entre otros problemas, el de la sucesión. La legalidad vigente -las propias leyes que él mismo había elaborado- y hasta los compromisos diplomáticos adquiridos le obligaban a reconocer como sucesor a don Alfonso, primogénito del infante don Fernando de la Cerda. $Y$ un sector de la nobleza, encabezado por el poderoso don Juan Núñez de Lara, señor de Albarracín, exigía que el rey se pronunciase en este sentido. Pero, por otro lado, la mayoría de la nobleza, destacando entre todos don Lope Díaz de Haro, señor de Vizcaya, y la mayoría del reino pedian que se aplicase el derecho tradicional. De la misma opinión era el infante don Manuel, hermano menor de Alfonso $X$ y tío de Sancho, quien, a instancias del monarca, expresó su opinión al respecto con esta bella sentencia que recoge la Crónica de Alfonso $X$ :

«El árbol de los reyes non se pierde por postura nin se deshereda por y al que viene por natura. Et sy el mayor que viene del árbol fallesçe, deve fincar la rama de so él en somo».

Que era lo mismo que decir que ningún tratado o postura podía ir en perjuicio del que por ley natural tiene todos los derechos, y que, por tanto, en faltando el hijo mayor, debía sucederle quien le siguiese en edad.

13 J.R. CRADDOCK, "Cronología de las obras legislativas de Alfonso X el Sabio", Anuario de Historia del Derecho Español, Ll (1981), 403.

14 Sigo de forma resumida lo que expuse en mi libro Alfonso X. 1252-1484 (Palencia, Diputación Provincial, 1993), 123-155. 
Se discute cuál era la opinión de otros miembros de la familia real, especialmente de la reina doña Violante. Se mantuvo al lado del rey mientras se discutieron los derechos de unos y otros, como sucedió en la Cortes de Burgos de 1276 que parece que dieron la razón a don Sancho aunque sin reconocerle aún como el heredero oficial. Esto sucedió en las Cortes de Segovia de 1278.

Entre una y otra reunión de Cortes pasaron en Castilla muchas cosas, y algunas de especial gravedad. Muchos nobles, incluso partidarios destacados de don Sancho, hubieron de exiliarse a Francia, cuyo rey amenazaba con invadir Castilla al frente de un poderoso ejército. Pero lo más grave fue una oscura conjura encabezada por don Fadrique, hermano del rey, que concluyó con la prisión y ajusticiamiento del infante y de don Simón Ruiz de los Cameros. Se discuten los motivos que indujeron al rey para dictar una sentencia tan dura. Basándose en unos pasajes de las Cantigas de Santa María, Kinkade ha hablado de la homosexualidad de ambos personajes ${ }^{15}$. No creo que fuese ésta la causa. Me inclino más bien por pensar que don Fadrique trató, a la vista de lo confuso de la situación, de las dudas de Alfonso $X$ en reconocer oficialmente a Sancho como infante heredero y de la impopularidad creciente del monarca, que había dado ya suficientes muestras de incompetencia política, de dar un golpe de estado y proclamarse él mismo rey 0 , por lo menos, regente hasta tanto se resolviese el problema de la sucesión.

El reconocimiento de Sancho como hijo mayor heredero, en abril de 1278, trajo la tranquilidad al reino, si bien provocó la huida a Aragón de la reina, acompañada de su nuera y de sus nietos los infantes de la Cerda. O'Callaghan piensa que la huida de doña Violante se debió «más a la ruptura de su matrimonio que a su temor por la vida de los infantes de la Cerda» ${ }^{16}$. Si esto es así, no se entiende muy bien por qué la acompañaron la viuda y los hijos de don Fernando de la Cerda. Pero, sea como fuere, el hecho es que a partir de este momento las relaciones entre el rey y su mujer quedaron prácticamente rotas, a pesar del regreso de ésta a Castilla un año y medio después de su partida, cargada de deudas y habiendo dejado en manos de Pedro III de Aragón a los infantes de la Cerda. El infante don Sancho, que satisfizo las deudas de su madre con el dinero que se recaudaba en Castilla para el ejército que sitiaba Algeciras, no fue ajeno del todo a estos hechos. Dadas sus buenas relaciones con el su tío rey aragonés, parece más que probable que la decisión de encerrar a los infantes en Játiva debió contar con la aprobación del infante. De esta forma, alejaba de Castilla a los posibles herederos del rey, al tiempo que ponía en manos de Pedro III una importante baza política que podía emplear en sus difíciles relaciones con Francia.

Por lo que hace a Alfonso X, desde las Cortes de Burgos de 1276, las relaciones con Felipe III de Francia eran especialmente tensas. En 1280 se acercó a Bayona para negociar una solución aceptable del pleito de los infantes de la Cerda. El rey

15 R.P KINKADE, «Alfonso X, Cantiga 235, and the Events of 1269-1278», Speculum 67-2 (1992), 313-318.

16 J.F. O'CALLAGHAN, El Rey Sabio, 293. 
castellano estaba dispuesto a entregar al mayor de sus nietos, Alfonso de la Cerda, el reino de Jaén en concepto de feudo. Felipe III rechazó una oferta tan poco generosa y manifestó exigiendo que, cuando menos, se diese a su sobrino el reino de Castilla o el de León. La propuesta - a todas luces inaceptable para Alfonso X - fue rechazada de plano, con lo que las negociaciones se dieron por rotas.

En octubre de 1281, durante las celebración de una reunión de Cortes en Sevilla, tuvo lugar un duro enfrentamiento entre Alfonso y Sancho, que se negaba en redondo a aceptar cualquier solución al problema que atentase contra la integridad territorial del reino. El infante - que contaba ya con el apoyo de las ciudades y de buena parte de la nobleza y del clero- abandonó la ciudad con el pretexto de negociar una tregua con los granadinos. En realidad, se disponía a ponerse al frente de una sublevación contra el rey. La guerra civil estaba a punto de estallar.

4. Todo conflicto civil plantea al historiador un problema: tratar de ver con claridad los hechos y emitir una opinión objetiva sobre los mismos. En el caso que nos ocupa el problema se complica por la absoluta parcialidad de las fuentes historiográficas conservadas que, en líneas generales, fueron redactadas por autores partidarios 0 simpatizantes de don Sancho. Desde luego, el autor de la última sección de la Crónica de Alfonso $X$ toma partido claramente por el infante. Lo mismo puede decirse del anónimo autor de unos anales del reinado de Alfonso $X^{17}$ y de don Pedro, conde de Barcelos que nos ha transmitido una copia casi literal de la sentencia de la suspensión de Alfonso X en sus funciones de rey, pronunciada en Valladolid en abril de 1282 por el infante don Manuel.

En efecto, para reforzar su posición, Sancho reunió en Valladolid una magna asamblea que, tras breve deliberación, acordó retirar a Alfonso $X$ todos sus poderes y prerrogativas, manteniéndole el título de rey. El texto de la sentencia decía como sigue:

«Por quanto el rey don Alfonso mato a don Fadrique su hermano a don Ximon Ruyz señor de los Cameros e otros muchos fidalgos sin derecho commo non deuia, pierda la justiçia.

E porque deseredo los fijosdalgo de Castilla e de Leon e los çibdadanos e los conçejos, non lo resçiban en las villas nin en las fortalezas e sea deseredado dellas.

E porque despecho la tierra e fizo malas monedas, non le den pechos nin seruiçios nin monedas foreras nin las martiniegas nin otros derechos ningunos de la tierra avnque los demandes ${ }^{18}$.

Ante este acto de rebeldía, la reacción de Alfonso $X$ no pudo ser otra que la de maldecir y desheredar a don Sancho. Y esta maldición parece que le acompañó hasta

17 Cf. M. GONZÁLEZ JIMÉNEZ, "Unos anales del reinado de Alfonso X», Boletín de la Real Academia de la Historia, CXCll (1995), 479-480.

18 Crónica de 1344, cit. por Diego CATALÁN, "Alfonso X historiador», en La Estoria de España de Alfonso X. Creación y evolución (Madrid, 1992), 12. 
la tumba, a pesar de que poco antes de morir el rey su padre manifestase la intención de perdonarle. Pero nunca lo hizo, al menos formalmente, aunque otra cosa diga el cronista. De haber sido así, no tendrían sentido las palabras que según don Juan Manuel pronunció Sancho en su lecho de muerte:

«... bien creed que esta muerte que yo muero non es muerte de dolençia mas muerte que me dan míos pecados et sennaladamente por la maldicion que me dieron mio padre por los muchos mereçimientos que les yo mereci" ${ }^{19}$.

Este asunto de la maldición de Alfonso $\mathrm{X}$-olvidado casi por la historiografía oficial del siglo XIV - resucitó, como hemos visto, de la mano de Juan I en el discurso regio pronunciado ante las Cortes de Segovia. En él no sólo dio por buenos los efectos jurídicos de la maldición alfonsina, sino que reclamó su propia legitimidad acudiendo a su vinculación genealógica con el rey Sabio a través de su madre doña Juana Manuel, nieta del segundo hijo del infante don Fernando, llamado también Fernando como su padre.

De todas formas, quedaba el problema de la ilegalidad de Enrique II, que había sucedido por métodos violentos a su hermanastro Pedro I. Por mucho que la propaganda trastamarista se empeñase en proclamar la ilegitimidad de Pedro l e, incluso, como afirmara Juan I en 1386, en suponer que la bastardía de origen quedaba subsanada por el casamiento con doña Juana Manuel y por haber sido rresçibido e tomado por Rey eneste rregno, la sombra de duda sobre la legitimidad de la nueva dinastía no había desaparecido. Tal vez por ello comenzó a difundirse una supuesta profecía de la que se hicieron eco algunos cronistas y escritores de los siglos XIV y XV.

La profecía en cuestión está relacionada con la supuesta condena que contra Alfonso $X$ pronunció el mismo Dios por haber dicho en público que si hubiera estado al lado de Dios Padre cuando éste hizo el mundo muchas menguas $<q u e>y<$ se $>$ fizieron que non se fizieran. Por esto Dios le anunció que sus descendientes directos perderían el trono y que ello sucedería transcurridas cuatro generaciones a partir de su hijo Sancho ${ }^{20}$.

5. Pero todo esto, con ser interesante, es pura patraña, y la discusión simplemente jurídica contenía de por sí suficientes elementos de controversia como para necesitar de argumentos proféticos que la alentasen. Los hechos, a la altura de 1282, eran éstos: Alfonso $X$, a la vista de la sublevación y traición de su hijo, deroga su nombramiento como heredero - hecho, no lo olvidemos, de acuerdo con el derecho antiguo o tradicional-y retoma su primera intención de aplicar lo dispuesto en las Partidas. Es decir, declara herederos del sennorío mayor de su reino a sus nietos

19 DON JUAN MANUEL, Libro de las armas, en A. GIMÉNEZ SOLER, Don Juan Manuel. Biografía y estudio crítico (Zaragoza, 1932), 689 [53].

20 Cf. M. GONZÁLEZ JIMÉNEZ, «Unos anales del reinado de Alfonso X», 482-486. 
"fijos de don Fernando, nuestro fijo, que fue primero heredero, de guisa que el mayor herede este nuestro sennorío e al otro le faga bien commo conviene, segund el fuero de Espanna manda fazer a los fijos que non han de aver el sennorío mayors ${ }^{21}$.

En el supuesto de que los infantes de la Cerda falleciesen sin dejar herederos, Alfonso $X$ dispuso que heredase el reino el rey de Francia, porque viene derechamente de línea derecha onde nos venimos del emperador de Espanna [Alfonso VII], e es bisnieto del rey don Alfonso de Castilla [Alfonso VIII], bien como nos, ca es nieto de su fija [la infanta doña Blanca, casada con Luis VIII de Francia] $]^{22}$.

Podría argumentarse que esta solución, aparentemente disparatada, es reflejo de una situación familiar que, por doloroso que fuese, Alfonso $X$ se vio obligado a reconocer: que en el otoño de 1282 toda su familia -la reina doña Violante, sus hijos los infantes don Juan, don Pedro y don Jaime, y hasta su hermano el infante don Manuel- estaban del lado del hasta entonces infante heredero don Sancho. En estas circunstancias, y descartado D. Dinís de Portugal, nieto del rey castellano, en razón del origen bastardo de su madre, sólo restaba el rey de Francia.

Ahora bien, lo interesante y hasta cierto punto extraño es que esta previsión sucesoria se mantuviese en la última voluntad o codicilo de Alfonso $X$, redactado el 10 de enero de 1284, cuando ya había vuelto a su obediencia el infante don Juan a quien el rey entregó, en pago de su fidelidad, los reinos de Sevilla y Badajoz. En buena lógica, Alfonso $X$ debería haber dispuesto que los derechos de los infantes de la Cerda pasasen de nuevo a la rama principal del linaje, representada por don Juan, y no a la rama de la casa de Francia, por muy emparentada que estuviese con la de Castilla. De haber sido así, el rey Sabio no hubiera tenido que volver a justificar su decisión argumentando que ninguno non puede dezir con derecho que de nuestro linage sacamos nuestro sennorío nin lo damos a estrannos ${ }^{23}$. $\mathrm{O}$, tal vez, este gesto de aparente inoportunidad política era algo más que un gesto para aplacar las reclamaciones de Francia; era, sin que así fuese formalmente reconocido, el reconocimiento de que la herencia de Alfonso VIII debería haber pasado en su condición de «hija mayor», no a doña Berenguela, madre de Fernando III, sino a su hermana doña Blanca, madre de Luis IX de Francia.

6. La muerte de Alfonso $X$ el 4 de abril de 1284 puso fin a la crisis sucesoria, al menos dentro del reino. El infante don Juan y todos los ricos hombres castellanos que se habían mantenido fieles al rey difunto - y en 1284 eran ya muchos- reconocieron como rey a don Sancho. Antes de que este reconocimiento se produjese, el nuevo monarca - nećesitado de apoyos sobre los que asentar su propia legitimidad- se había hecho coronar rey en Toledo en una ceremonia que tuvo lugar en la catedral y

21 M. GONZÁLEZ JIMÉNEZ (Ed.), Diplomatario Andaluz de Alfonso X, n. 518, p. 553.

22 Id., ibid., p. 554.

23 Diplomatario, n. 520 , p. 561. 
en la que actuaron de oficiantes los obispos de Burgos, Cuenca, Coria y Badajoz. Se trató de un gesto bastante inusual dentro de los ritos sucesorios castellanos. Alfonso $X$ no fue coronado cuando accedió al trono el 1ํ de junio de 1252. Fue, simplemente, alzado o aclamado por el pueblo24. Sancho IV - por razones obvias, tanto de cara al interior como al exterior del reino- no podía contentarse con una simple proclamación, como la que tuvo lugar en Avila, donde se enteró de la muerte de su padre. Debía efectuar -en el mejor de los ámbitos posibles: Toledo, la antigua ciudad donde se coronaban los reyes visigodos-y por la autoridad de cuatro obispos (dos por cada uno de los arzobispados que le eran fieles) un acto público que le presentase ante el reino como el verdadero depositario de la corona real de su padre, esa misma corona a la que Alfonso $X$ se había referido en su codicilo y que debía corresponder a aquél que con derecho e por nos heredare el nuestro sennorío mayor de Castella e de León ${ }^{25}$. Como ha señalado Linehan, «la coronación de Sancho IV fue un acto público tendente a mitigar los efectos de la sentencia de maldición de Alfonso $X$, y venía a proclamar que el nuevo rey había adquirido su reino con derecho. Fue calculada para legitimar su sucesión»²6.

Pero los gestos - y los efectos propagandísticos de los mismos - no concluyeron aquí. Como ha escrito Linehan, «la ceremonia de Toledo no fue una mera coronación. Fue también una ceremonia eclesiástica de coronación, efectuada por cuatro obispos, la primera desde 1135. Además, la reina fue también coronada, probablemente por el propio Sancho" ${ }^{27}$. Evidentemente, estos gestos y ceremonias no resolvieron el problema. Pero sirvieron sin duda para tranquilizar a la opinión pública del reino acerca de la legitimidad de origen del nuevo monarca.

7. La muerte prematura de Sancho IV en 1295, dejando como heredero a Fernando IV, menor de edad, destapó de nuevo la cuestión sucesoria. Ésta había quedado resuelta, en lo que a Francia se refiere, en el tratado de Bayona de 1290, en el que, además de ratificarse lo acordado en Lyon en 1288 respecto a las compensaciones económicas en favor de doña Blanca, viuda de don Fernando de la Cerda, Felipe IV el Hermoso renunció a sus posibles derechos al trono castellano, desentendiéndose "completamente de la causa de los infantes de la Cerda" ${ }^{28}$. A partir de este momento, el valedor de los infantes sería el rey de Aragón, en cuyo reino estaban acogidos desde 1278. Había llegado el momento previsto por Pedro III en que los infantes iban a con-

24 Jofré de Loaysa, testigo presencial del acto, afirma que, tras el entierro de Fernando leuantaron a don Alfonso. Ver el texto en M. GONZÁLEZ JIMÉNEZ, «Andalucía en tiempos de Alfonso X. Estudio histórico", en Diplomatario, xxix.

25 Diplomatario, p. 559.

26 Peter LINEHAN, History and Historians of Medieval Spain (Oxford, Clarendon Press, 1993), 446-447.

27 Ibid., 447.

28 J.M. NIETO SORIA, Sancho IV, 1282-1295 (Palencia, 1994), 104. Publica el texto G. DAUMET, Mémoire sur les relations de la France et la Castile de 1255 à 1320 (Paris, 1914), 200. 
vertirse en pieza de canje en el complicado tablero de la política peninsular y mediterránea de fines del siglo XIII.

En efecto, apenas muerto Sancho IV, el rey aragonés - que hasta entonces había mantenido unas excelentes relaciones con el rey castellano- denunció su acuerdo matrimonial con la infanta Isabel y la devolvió a su madre la regente doña María de Molina. Al mismo tiempo, reconoció como rey de Castilla y León a Alfonso de la Cerda y fraguó una compleja alianza anticastellana en la que entraron, además del infante don Juan, dispuesto siempre a crear problemas, Francia, Portugal y Granada. Fue entonces cuando se planteó la ilegitimidad de Fernando IV, hijo de la unión incestuosa y bígama entre Sancho IV y María de Molina ${ }^{29}$.

No es éste el momento de analizar con detalle el conflicto sobre la sucesión al trono de castellano y que dio lugar a un duro enfrentamiento entre Aragón y Castilla en el curso del cual se produjo la ocupación aragonesa del reino de Murcia y que se prolongaría hasta la Sentencia Arbitral de Torrellas de 1304. Baste recordar que se acordó el reparto del reino entre Alfonso de la Cerda, que recibiría los reinos de Castilla, Toledo, Córdoba y Jaén, el infante don Juan, que sería rey de León, Galicia y Sevilla, y Jaime II de Aragón, a quien Alfonso de la Cerda confirmó la donación del reino de Murcia hecha años antes a su hermano Alfonso III ${ }^{30}$.

Como resultado de todo ello, en la primavera de 1296 se produjo la invasión de Castilla por un ejército aragonés. Mientras el infante don Pedro, hermano de Jaime II, penetraba hasta León, donde fue proclamado rey el infante don Juan, y Alfonso de la Cerda era igualmente proclamado rey de Castilla en Sahagún, Jaime Il procedía a la ocupación del reino de Murcia. La reina regente logró conjurar el peligro, y el ejército invasor, tras fracasar en su intento de apoderarse de la villa de Mayorga de Campos, se retiró a Aragón. No sucedió lo mismo en el sector murciano, que fue totalmente conquistado y retenido por Jaime II hasta 1304.

La resolución de la larga crisis tuvo lugar en la aldea de Torrellas, situada entre Tarazona y Agreda. A las vistas asistieron los reyes de Aragón y Castilla, además de D. Dinis de Portugal, que había sido designado previamente como árbitro del conflicto. Se trataba, por supuesto, de acabar con el enfrentamiento entre Fernando IV y Jaime II. Pero cada uno llevaba a las vistas su propia reclamación. En efecto, lo que de veras importaba a Jaime II era la delineación de una nueva frontera entre los reinos de Valencia y Murcia, adelantándola hasta la línea del río Segura e incorporando a sus reinos, entre otras, las tierras de Alicante, Elda, Novelda, Elche y Orihuela. El objetivo de Fernando IV era conseguir, al precio que fuese, la renuncia del de la Cerda a sus derechos al trono castellano. El acuerdo tuvo, por tanto, dos sacrificados: Alfonso de

29 María de Molina era prima hermana de Alfonso X y, por tanto, tía de Sancho IV. La ruptura de su compromiso matrimonial de éste con Guillerma de Moncada, hija del vizconde Guillermo VII de Bearn, nunca fue reconocida por la Iglesia. No obstante, Fernando IV fue legitimado por Bonifacio VIII en 1301. Cf. P. LINEHAN, ob. cit., 447 y nota 113.

30 La donación fue hecha en Calatayud el 26 de junio de 1289. Publicó el documento A. GIMÉNEZ SOLER, ob. cit., 221-223. Ha vuelto a editarlo J.M. del ESTAL, EI Reino de Murcia bajo Aragón: 12961305. Corpus Documental, I/1 (Alicante, 1985), 107-109. 
la Cerda, que debió contentarse con un importante, aunque disperso, señorío en Castilla, y el reino de Murcia, al que se le amputó el sector más rico y poblado ${ }^{31}$.

A partir de 1304, Alfonso de la Cerda dejó de emplear las armas y sello de Castilla y se integró en los cuadros de la alta nobleza castellana. Mantendría, con todo, y durante mucho tiempo, el resquemor de la derrota. En 1331, rondando ya los sesenta años, en el curso de una emotiva entrevista que tuvo lugar en su señorío de Burguillos, renunció de nuevo a sus derechos al trono castellano en manos de su sobrino Alfonso $\mathrm{Xl}^{32}$. Se cerraba así un largo contencioso que había durado más de cincuenta años. Las Partidas debieron ceder, en este punto concreto, ante el derecho tradicional no escrito que primaba la sucesión dentro de los propios hijos del monarca reinante, prefiriendo al varón sobre la mujer. Sólo tardíamente (1810, constitución de 1812 y Pragmática Sanción de 1830) volvería a estar en pleno vigor la ley $2^{\underline{a}}$ del título 15 de la II Partida ${ }^{33}$. Pero este asunto, me temo, desborda con mucho el ámbito cronológico que ahora nos interesa.

31 Ver sobre esta asunto C. GONZÁlEZ MíNGUEZ, Fernando IV de Castilla (1295-1312). La guerra civil y el predominio de la nobleza (Vitoria, 1976). Del mismo autor, Fernando IV, 1295-1312 (Palencia, 1995).

32 Cf. J. SÁNCHEZ-ARCILLA, ob. cit., 163.

33 Ver los textos en A. GARCÍA GALLO, Manual de Historia del Derecho Español. Il: Antología de Fuentes del Antiguo Derecho (Madrid, 1967), 1232-1235. 


\title{
LAS FRONTERAS DEL REINO DE VALENCIA EN TIEMPOS DE JAIME II
}

\author{
José HINOJOSA MONTALVO \\ Universitat d'Alacant
}

En el mes de febrero de 1245 Jaime I se apoderaba de la plaza de Biar, con lo que prácticamente se daba por finalizada la conquista de las tierras valencianas de Sharq al-Andalus, llegándose a los límites fijados con Castilla para repartirse los territorios musulmanes en anteriores pactos de Tudilén, Cazola y el reciente de Almizrra en 1244', en el que se delimitaba la frontera entre las Coronas de Castilla y de Aragón. Ello no quiere decir que el nuevo reino de Valencia, nacido por la voluntad expresa de Jaime el Conquistador, mantuviera unos límites inamovibles en el tiempo, sino todo lo contrario, ya que a lo largo de dos siglos más se fueron incorporando nuevos espacios territoriales, en particular las comarcas del Alacantí, el alto y el bajo Vinalopó y el bajo Segura, durante el reinado de Jaime $\mathrm{ll}$, en lo que supuso la mayor ampliación territorial del reino desde tiempos de Jaime $\mathrm{l}$.

No vamos a entrar en el análisis pormenorizado del trazado de esta frontera entre Biar y Busot, puesto que disponemos de detallados estudios de J.M. Del Estal ${ }^{2}$, J. Ferrándiz Lozano y el más reciente de E. Guinot en el que analiza los límites del reino de Valencia a lo largo de su historia ${ }^{3}$. Estos límites no respondían a un trazado caprichoso, como pretendía Giménez Soler a principios de este siglo ${ }^{4}$, sino que repo-

1 FERNÁNDEZ LOZANO, José, Data Almizrrano... Siete siglos y medio de historiografía valenciana sobre el Tratado de almizrra (1244-1994), Alicante, 1994.

2 DEL ESTAL, J.M., «Delimitación del término municipal de la villa de Alicante por Alfonso $X$ el Sabio y Jaime II de Aragón (1252-1296)», Item, n. 1, pp. 96-109; Conquista y anexión de las tierras de Alicante, Elche, Orihuela y Guardamar al Reino de Valencia por Jaime I/ de Aragón (1296-1308), Alicante, 1982.

3 GUINOT, E., Els límits del regne, Valencia, 1995, cap. 4, pp. 43-76.

4 GIMÉNEZ SOLER, A., "La Corona de Aragón y Granada», Boletín de la Real Academia de Buenas Letras de Barcelona, julio a septiembre de 1905, pp. 106-107. 
saban sobre unos antecedentes históricos y unas bases geográficas, esto es, la separación entre la parte montañosa y el llano de las tierras que hoy configuran la actual provincia de Alicante. En palabras de E.A. Llobregat «la frontera estuvo en función de la distinción entre llano y montaña ${ }^{5}$, visible para cualquier observador del panorama que se otea desde la cima del castillo de Santa Bárbara en Alicante. La sierra de Alcoy, las de Penya Rubia, l'Arguenya, el Carrascar, el Maigmó y la de Busot eran la barrera que separaba los reinos de Valencia y de Murcia desde 1245.

Aunque la configuración territorial del reino de Valencia no quedará cerrada de forma definitiva hasta finales del siglo XIV, la realidad de 1245 era que la monarquía consideraba finalizada su intervención de conquista en tierras valencianas y el nuevo reino aparecía dotado de unos límites, mencionados expresamente en 1240 en la versión latina de los Furs y de facto, como señala Guinot, tras la ocupación de Biar en febrero de 1245.

En años posteriores, durante el reinado de Jaime I, se fue perfilando la frontera del reino de Valencia en sus zonas limítrofes con Cataluña, Aragón y Castilla, en concreto con este último reino en el tramo desde el Rincón de Ademuz hasta Villena, que eran las zonas con lugares de adscripción más confusa ${ }^{6}$. En cambio la frontera de Valencia con Murcia permaneció inalterada, manteniéndose lo estipulado en el pacto de Almizrra, que incluía para el reino de Valencia las localidades de Biar, Castalla, Tibi, Jijona, Relleu, Orxeta y Finestrat. El barranco del Carritjar, entre las actuales poblaciones de Vila Joiosa y El Campello, marcaba el límite septentrional del término de Alicante y, por tanto, del reino de Murcia.

Las luchas internas y la guerra civil en que se debatió Castilla entre Fernando IV, hijo de Sancho el Bravo, y los infantes de la Cerda, descendientes del primogénito de Alfonso X, permitieron a Jaime II incorporar entre 1296-1304 el reino de Murcia, concedido como recompensa a cambio de la ayuda militar al pretendiente Alfonso de la Cerda. Los trabajos eruditos y detallados de J.M. Del Estal y $\mathrm{M}^{\mathrm{a}} \mathrm{T}$. Ferrer i Mallol ${ }^{7}$ han permitido reconstruir con todo detalle la campaña militar y de ocupación llevada a cabo por Jaime II, testimonio de la vitalidad del reino de Aragón frente a la anarquía castellana y culminación de una expansión territorial anhelada por los monarcas aragoneses y que sólo ahora, ante coyuntura tan propicia, pudo llevarse a cabo. Además de una situación política favorable, influyó también la aceptación mayoritaria de los grupos dirigentes de los más importantes núcleos urbanos murcianos, cuyo sentido «pa-

5 LLOBREGAT, E.A., "Castillos y fronteras medievales en la provincia de Alicante», Castillos de España, 2a época, n 3, (70), Madrid, 1970, pp. 130-137. Lo reproduce FERRÁNDIZ LOZANO, J., Data almizrrano, p. 96.

6 GUINOT, E., Els límits del regne, capítulos 4, 5 y 6 analiza con todo detalle estas rectificaciones territoriales de la frontera valenciana durante la segunda mitad del siglo XIII.

7 DEL ESTAL, J.M., Conquista y anexión de las tierras de Alicante, Elche, Orihuela y Guardamar al reino de Valencia por Jaime I/ de Aragón (1296-1308), Alicante, 1982; Corpus documental del reino de Murcia bajo la soberania de Aragón 81296-1304/5) l/1, Alicante, 1985 y 1/2, Alicante, 1990; FERRER I MALLOL, M‥T., «Notes sobre la conquesta del regne de Múrcia per Jaume II (1296-1304/4)", Homenatge a la memòria del prof. Emilio Sáez. Aplec d'estudis dels seus deixebles i col.laboradors, Barcelona, Universitat-Institució Milà i Fontanals, 1989, pp. 27-44. 
triótico» se apelaba, ya que la mayoría eran oriundos de la Corona de Aragón, así como las garantías de respetar la independencia y neutralidad de las encomiendas de la Orden de Santiago, o la del ra'is de Crevillente, Muhammad Abenhudell, y las de don Juan Manuel.

Sin embargo, una serie de factores aconsejaron y llevaron a Jaime II a buscar la paz: la legitimación de Fernando IV, lo que descartaba la candidatura de Alfonso de la Cerda; la muerte del rey de Granada Muhammad II y el ascenso de Muhammad III, que firmó la paz con Castilla; la rebelión nobiliaria en Aragón, algunos de cuyos miembros más destacados animaban al rey a la paz. Por su parte Fernando IV de Castilla hubo de renunciar a parte del reino de Murcia en aras de pactar con Jaime II, frente a la postura de su madre, María de Molina, partidaria de recuperar todo el reino.

En Torrellas, localidad en la falda del Moncayo, se reunieron el infante don Juan, por Castilla; don Jimeno de Luna, arzobispo de Zaragoza, en representación de Aragón y como árbitro imparcial el rey de Portugal don Dionís. El 8 de agosto de 1304 se firmó la sentencia arbitral que dividía el reino de Murcia en dos partes, fijando como frontera divisoria el bajo Segura, salvo Guardamar y Cartagena, a pesar de estar ubicados en la parte derecha y que ha dado lugar a que algunos autores lo interpretaran como un desconocimiento de la geografía del país por parte de la comisión arbitral. Pero la documentación de la época pone de manifiesto que no había tal desconocimiento sino un conflicto de intereses entre las partes, sobre todo por parte del infante don Juan Manuel, cuyo señorío de Elche había perdido, y la negativa de Castilla, inflexible en mantener Yecla para su corona, por ser villa del citado infante ${ }^{8}$.

El mayor problema radicaba en que la sentencia dejaba sin precisar los límites entre el Segura y Villena, lo que provocó disensiones entre las partes por la adscripción de localidades como Yecla, Abanilla, Jumilla, etc. por lo que hubo que nombrar una nueva comisión para resolver tales diferencias, integrada por el canciller mayor de Fernando IV, Diego García de Toledo, y Gonzalo García por parte de Jaime II. El resultado fue el acuerdo de Elche el 19 de mayo de 1305, en el que la nueva frontera quedaba fijada así: "partiendo de las proximidades de la actual Venta de la Encina, proseguía hacia el sur por el límite comunal que separaba Villena de Almansa, continuaba luego por el de Caudete con Almansa, bordeando después por el sureste por entero el amplio alfoz de Yecla, que se reservaba para Castilla, proseguía a continuación el término comunal de Yecla con Jumilla, para seguir luego el término de Jumilla con Ontur, Tobarra, Hellín y Cieza, para descender seguidamente al Segura, entre los términos de Fortuna y Orihuela, buscando luego el litoral marítimo, entre los concejos de Murcia y Orihuela, alcanzando el Mediterráneo aproximadamente por el límite interprovincial de Alicante y Murcia en la actualidad, entre Pilar de la Horadada y San Pedro del Pinatar" ${ }^{9}$.

8 Puede verse un análisis detallado de las mencionadas sentencia de Torrellas y acuerdo de Elche en la obra de DEL. ESTAL, J.M., Conquista y anexión, pp. 274-282; GUINOT, E., Els límits del regne, pp. 103-115.

9 DEL ESTAL, J.M., "Historia política", en Historia de la provincia de Alicante, Murcia, 1985, p. 228. 
Desde ahora la frontera del reino va a experimentar un salto formidable, desde las sierras de Alcoy, que pasan a ser una frontera interior, administrativa, las comarcas deçà Sexona, a la huerta de Orihuela. La montaña frente al llano. Como núcleos de población más importantes figuraban Orihuela, Alicante y Elche, todos ellos con población mayoritariamente cristiana en tiempos de Jaime II, aunque contaban con morerías urbanas, siendo mayoría la población musulmana en el valle de Elda. El poblamiento de esta zona meridional anexionada a Valencia también presentaba diferencias respecto a las tierras norteñas, pues Alfonso $X$ había dotado a Alicante $y$ Orihuela de extensos alfoces, siguiendo el modelo repoblador castellano, en los que se diseminaban diversas alquerías dependientes del municipio rector. Con la incorporación de esta parte del reino de Murcia el rey de Aragón se convirtió también en el dueño de la mayor parte del territorio, ya que Alicante, Orihuela y Guardamar se incorporaron al realengo, aunque no por mucho tiempo, pues años después pasaron a formar parte de los estados del infante Fernando.

Tras la Sentencia arbitral de Torrellas (1304) y el Acuerdo de Elche (1305) el antiguo reino de Murcia quedó dividido en dos sectores: el septentrional bajo la soberanía aragonesa, y el meridional, con su capital Murcia, bajo la de Castilla. Para las comarcas anexionadas por Jaime II comenzó una etapa de valencianización, las búsqueda de un nombre y de una identidad propios, en unos tiempos en que todavía la repoblación no estaba finalizada y los trasiegos de población hacia el Sur eran constantes.

$M^{\mathrm{a}}$.T. Ferrer ha desbrozado con minuciosidad las denominaciones que la Corona aplicó a estas tierras meridionales alicantinas, al principio definidas como «terre nostre quam habemus ultra Sexonam ${ }^{10}$. La primera línea frontera en Jijona siguió actuando como límite administrativo durante toda la Edad Media: deçà y dellà Sexona. Las aspiraciones de Orihuela a erigirse en capital del territorio, claras ya desde 1307, se vieron cumplidas cuando se creó la gobernación general de Orihuela años más tarde.

La solución final adoptada por Jaime II fue la de encuadrar administrativamente estas tierras en el reino de Valencia entre 1296-1304 en una procuración general enllà Sexona, regida por un Procurator regni Valencie et terre ultra Sexonam, mientras que un baile general ultra Sexonam se encargaba de administrar el patrimonio regio a través de lo que sería la bailía general de Orihuela. La anexión formal de la procuración de Orihuela al reino de Valencia tuvo lugar el 17 de junio de 1308 con la aplicación de los Furs de Valencia como norma legal de todo el territorio, aunque respetando los fueros propios que disfrutaban de la anterior etapa castellana ${ }^{11}$.

Lo cierto es que para propios y extraños estas tierras siguieron teniendo un carácter ambiguo, impreciso, durante buena parte del siglo XIV y en la Crónica de Ramón Muntaner o en la de Pedro el Ceremonioso se las sigue denominando como «regne de Múrcia», como también aparece en documentos de la cancillería real de mediados

10 FERRER I MALLOL, Ma.T., Organització i defensa d'un territori fronterer: La governació d'Oriola en el segle XIV, Barcelona, Institució Milà i Fontanals, 1990, pp. 4-9.

11 DEL ESTAL, J.M., Conquista y anexión, pp. 296-302; FERRER I MALLOL, Ma .T., Organització i defensa, pp. 9-12. 
de siglo, y la antigua frontera de Biar-Castalla-Jijona, seguía teniendo plena vigencia, sobre todo desde el punto de vista de la organización militar del territorio, visible perfectamente en la guerra de los dos Pedros. Estoy de acuerdo con $\mathrm{M}^{\mathrm{a}}$. T. Ferrer cuando afirma que el traspaso del nombre de Valencia a las tierras segregadas del reino de Murcia fue lento, y sólo los fueros, la moneda y las Cortes eran comunes a todo el reino, ya que la administración, el gobierno y la defensa eran independientes en la procuración/gobernación de Orihuela. Medio siglo bajo la Corona de Castilla y los repobladores de origen castellano habían dejado su huella en el territorio, lo hacía diferente, y ello no se borraba de un plumazo. Los reyes de Aragón, por su parte, no lo intentaron nunca, sino que fueron respetuosos con esta personalidad, y a lo largo del siglo XIV vemos como Murcia se castellaniza, mientras Orihuela se valencianiza, aunque siempre quiso mantener su independencia entre ambas capitales. Luego vendría la rivalidad con la emergente Alicante, que también quería ser capital. Pero esta es ya otra historia.

\section{LA FRONTERA CON EL REINO DE GRANADA}

El avance territorial experimentado por el reino de Valencia durante el reinado de Jaime II planteó una nueva realidad fronteriza en el devenir histórico de Valencia, no sólo frente a Castilla, sino frente al Islam granadino, que hasta entonces había quedado relativamente lejano del originario reino de Valencia. A partir de ahora los condicionamientos geoestratégicos y políticos de Valencia con respecto a Granada cambiarán radicalmente, por tierra y por mar, debido al acercamiento físico de la frontera entre ambos reinos. Cierto es que no hubo una frontera directa entre Valencia y Granada, pues el reino de Murcia se interponía entre ambos, pero para las gentes de la época, incluida la monarquía, la frontera, como señala Ferrer i Mallol "era tot el territori que podia ésser amenaçat per una razzia granadina de cinc o sis dies de durada, entre anar i tornar, o pels escamots d'almogàvers, lladres de bestiar i segrestadors de persones". Por tanto podemos hablar con rigor histórico del término frontera, ya que así la utilizaban también las fuentes de la época.

La frontera no fue sólo política sino que tuvo también un variado componente de cariz religioso, económico, social, lingüístico, cultural, etc. cuyo objetivo, como señala Díaz Borrás, no era otro que el arrinconamiento progresivo de las masas musulmanas en beneficio de los planteamientos cristianos $^{12}$, y los moros valencianos fueron conscientes de ello, como pusieron de manifiesto con las armas en la mano en las revueltas del siglo XIII, o de forma silenciosa con la huida clandestina o su marcha a Granada con los ejércitos nazaríes al regreso de sus incursiones por tierras valencianas.

Los recientes estudios, tanto desde la vertiente castellana como desde la granadina, han permitido conocer mejor la problemática político-militar, así como los problemas económicos o sociales generados en torno a la frontera murciana con el reino de

12 DÍAZ BORRÁS, A., Los orígenes de la piratería islámica en Valencia. La ofensiva musulmana trecentista y la reacción cristiana, Barcelona, 1993, p. XIV. 
Granada $^{13}$, pero en el caso del reino de Valencia el panorama historiográfico no presenta un balance tan completo, en buena parte porque el tema sólo ha suscitado el interés de los investigadores de forma consciente y con una metodología adecuada en tiempos recientes ${ }^{14}$, aunque ya el gran cronista que fue $\mathrm{P}$. Bellot, en sus Anales de Orihuela ${ }^{15}$ describió con bastante minuciosidad las incursiones granadinas en tierras de la gobernación de Orihuela, la política municipal de rescate de cautivos, las relaciones entre el consistorio oriolano y localidades como Vélez o Baza, por ejemplo, basándose siempre en las actas municipales de la segunda mitad del siglo XIV y XV, pero dentro de un proyecto de historia en forma de anales, simpiemente narrativo y sin ningún espíritu crítico, sin extraer ninguna conclusión.

Aunque existe documentación relativamente abundante, desde Crónicas a cartas reales y actas municipales, ésta es básicamente cristiana, con escasa aportación granadina, por lo que la visión que se obtiene de la frontera es parcial y «oficial», y si sólo hacemos caso de ella obtendremos una impresión deformada, cuando no sesgada, de lo que fue la frontera. Tengamos en cuenta que a las autoridades cristianas les preocupaba sobre todo la actividad bélica de los jinetes granadinos y sus consecuencias en territorio valenciano, y sólo cuando éstas fueron más importantes o la sensación de peligro fue mayor las fuentes se explayaron un poco más. Las relaciones bélicas entre aragoneses y granadinos en los doscientos cincuenta años de existencia del reino nazarí de Granada, fracasado el proyecto de cruzada contra Almería, se redujeron básicamente a correrías y golpes de mano por ambos bandos, con mayor $o$ menor fortuna, pero en ningún caso se buscaban conquistas territoriales sino botín, sobre todo humano, cautivos, que luego serían utilizados por ambos bandos como fuerza de trabajo, instrumento de trueque o fuente de ingresos a través de los rescates ${ }^{16}$.

Pero la frontera no generó tan sólo una actividad bélica. Hoy, todos cuantos nos acercamos desde una $u$ otra perspectiva a la historia de Granada y de sus vecinos

13 TORRES FONTES, J., "La actividad bélica granadina en la frontera murciana (SS. XIII-XV)», Príncipe de Viana. Homenaje a José María Lacarra, anejo 3, 1986, año XLVII, pp. 721-738;

JIMÉNEZ ALCÁZAR, Juan F., "El hombre y la frontera: Murcia y Granada en época de Enrique IV", Miscelánea Medieval Murciana, XVII, 1992, pp. 77-96.

14 RUZAFA GARCÍA, M., "La frontera de Valencia con Granada: la ruta terrestre (1380-1440)", Andalucía entre Oriente y Occidente (1236-1492). Actas del V Coloquio de Historia Medieval de Anda. lucía, Córdoba, 1988, pp. 659-672.

15 BELLOT, P., Anales de Orihuela (siglos XIV-XVI), Edic. preparada por J. TORRES FONTES, Orihuela, 1954.

16 HINOJOSA MONTALVO, J., "Tácticas de apresamiento de cautivos y su distribución en el mercado valenciano (1410-1434)", Qüestions valencianes, I, Valencia, 1979, pp. 5-44; "Cristianos, mudéjares y granadinos en la gobernación de Orihuela", IV Coloquio de historia medieval andaluza, Almería, 1988, pp. 323-342; DÍAZ BORRÁS, A., Los orígenes de la piratería islámica en Valencia. La ofensiva musulmana trecentista y la reacción cristiana, Barcelona, 1993; "Notas sobre los primeros tiempos de la atención valenciana a la redención de cautivos cristianos (1323-1339)", Estudis Castellonencs, 3, (1986), pp. 147-171; FERRER I MALLOL, Mª.T., "La redempció de captius a la Corona catalano-aragonesa", Anuario de Estudios Medievales, 15, (1985), pp. 237-298. 
cristianos, somos conscientes de que, frente a la imagen distorsionada e interesada de guerra y enfrentamiento con que se quiso presentar este periodo, lo que predominó fue la paz sobre la guerra, la tregua frente al episodio bélico, lo que no excluye que en torno a la frontera se articulara todo un amplio espectro de relaciones sociales y económicas, una mentalidad, la del hombre de frontera, tan peculiar, un paisaje natural moldeado por el hombre, una psicosis o «neurosis granadina», como la calificó J.E. López de Coca, que perduró largo tiempo en los ámbitos fronteros del mediodía valenciano y sobre la que todavía hay que seguir investigando.

Para Torres Fontes la línea fronteriza entre Murcia y Granada estuvo jalonada por una serie de fracasos en el tiempo, desde el fracaso en el intento por mantener la línea del Almanzora, señalada en el tratado de Alcaraz en 1243, al fracaso de la alianza entre Castilla y Aragón contra Granada, y también, que es lo que ahora nos interesa, a lo que considera como fracaso de Jaime II en su intento de anexionar el reino de Murcia a la Corona de Aragón y de llevar la frontera aragonesa al Almanzora, «recuperando la vecindad granadina tan provechosa para sus intereses políticos y económicos" ${ }^{17}$.

En tiempos de Jaime II, a principios del siglo XIV, el reino de Murcia varió mucho en su desarrollo histórico con relación a Granada y a Aragón, pues el área geográfica del reino, que iba desde Biar y el valle de Ayora a la cuenca del Almanzora, se vería reducida por las anexiones de Jaime II en tanto que las emigraciones de los mudéjares murcianos y las posteriores incursiones de los meriniés africanos provocaron un descenso demográfico y una concentración de la población cristiana en los recintos amurallados, despoblándose los campos, lo que no hizo sino favorecer las correrías granadinas por los reinos de Murcia y Valencia. Porque, como ya dijimos, aunque Valencia nunca tuvo una frontera física y política directa con el reino de Granada, ya que entre ambos se interponía Murcia, las propias características geográficas y humanas del territorio murciano, siempre tan falto de gente, propiciaron y permitieron que las incursiones terrestres de los almogávares granadinos llegaran sin excesivos problemas a donde se lo propusieran del reino de Valencia, incluso a los alrededores de la propia capital, como Paterna, o a Xàtiva, Cocentaina, Alcoy, etc. sin ser molestados en numerosas ocasiones.

La incorporación al reino de Valencia por Jaime II de las tierras que configuraron la procuración de Orihuela, luego transformada en gobernación, hizo que estas comarcas, hasta entonces murcianas, siguieran siendo objetivo preferido de los jinetes granadinos. La distancia física entre Granada y Orihuela o Elche siguió siendo la misma, pero ahora dependían del monarca aragonés y el entorno político en el que se iban a mover sus habitantes en sus relaciones con Granada sería diferente, pues ya no formarían parte de la política y estrategia castellana con el reino de Granada, sino de la aragonesa ${ }^{18}$.

17 TORRES FONTES, J., La actividad bélica granadina en la frontera murciana, pp. 722-723.

18 FERRER I MALLOL, M․T., Organització i defensa d'un territori fronteres. La governació d'Oriola en el segle XIV, Barcelona, 1990; "La Batllia general de la part del regne de València dellà Xixona», Anales de la Universidad de Alicante. Historia Medieval, 6 (1987), pp. 279-309. 
Por otra parte, aunque la revuelta de 1264-1265 redujo notablemente la población mudéjar en el reino de Murcia, en la zona anexionada por Jaime ll quedó una importante masa de población musulmana en Elche, Crevillente, las huertas de Orihuela y Alicante, así como en el valle de Elda, donde fueron mayoría hasta $1609^{19}$, si bien la guerra de 1296-1304 hizo que su número disminuyera, por muerte, cautividad o emigración, como también sucedió con las incursiones granadinas de 1304, 1331 y 1332. Ello no fue óbice para que los cristianos siguieran viéndolos con recelo y considerándolos como una peligrosa quinta columna, colaboradora de granadinos y marroquíes en sus algaradas, siendo los moros de las comarcas alicantinas costeras o del interior, desde La Marina al valle del Vinalopó, los que peor fama gozaban, como más tarde en la segunda mitad del siglo XV sucedería con los de Monforte ${ }^{20}$. Todas las tierras situadas dellà Sexona eran consideradas por las autoridades como una zona de alto riesgo con relación a los mudéjares, dada la posibilidad de éstos de huir hacia Granada o al Norte de Africa, como hacían muchos cautivos que querían escapar de sus dueños, o simples moros libres que marchaban clandestinamente a tierra de sus correligionarios para poder vivir el Islam sin trabas ${ }^{21}$. Para evitar tales huidas y la colaboración con espías y salteadores los monarcas limitaron la libertad de movimientos de los mudéjares en todas estas comarcas del mediodía valenciano, debiendo circular con el oportuno salvoconducto real y por los itinerarios expresamente indicados, so pena de caer en cautividad.

A la hora de reconstruir la actividad bélica granadina en la frontera meridional valenciana en estos años finales del siglo XIII y comienzos del XIV tropezamos también con la escasez de fuentes, al no existir documentación municipal de la época, y tener que recurrir sobre todo a la de la cancillería real. Granada nunca tuvo un ejército regular de forma continuada para llevar a cabo una política ofensiva contra Castilla y menos contra Aragón, con quien no tenía frontera directa, pero desde las bases orientales de Baza y Vera podía lanzar sus cabalgadas y correrias sobre territorio murciano y valenciano. En la cabalgada participaban jinetes y peones en número superior al millar, y el objetivo era siempre la destrucción de cuanto encontraran a su paso, desde la tala de cosechas a la quema de caseríos, pero sobre todo, el botín, en particular el ganado, y los cautivos cristianos. Sólo en una ocasión, con el caudillo Ridwan, como veremos, se puso sitio a Guardamar y Elche, ya que la lejanía de las bases y los problemas de intendencia impedían una acción de mayor envergadura ${ }^{22}$.

19 FERRER I MALLOL, Ma - T., La frontera amb l'Islam en el segle XIV. Cristians i sarraïns al País Valencià, Barcelona, 1988, p. 5; Les aljames sarraïnes de la governació d'Oriola en el segle XIV, Barcelona, 1988.

20 FERRER I MALLOL, Ma.T., La frontera amb l'Islam en el segle XIV. Barcelona, 1988. Dedica todo el capítulo 2 al tema de la quinta columna, analizando el sentimiento de solidaridad panislámica, las dificultades de la convivencia cristiano-musulmana y el ataque a las morerías del reino, el control de acceso a los castillos o la libertad de movimientos.

21 FERRER I MALLOL, Ma.T., Els sarrains de la Corona catalano-aragonesa en el segle XIV. Segregació i discriminació, Barcelona, 1987.

22 TORRES FONTES, J., La actividad bélica granadina en la frontera murciana, p. 728. 
A favor de los invasores jugaba el vacío demográfico del territorio, que permitía su paso por el reino de Murcia sin encontrar resistencia, o la colaboración, más o menos interesada, de los mudéjares valencianos, que actuaban como informadores y espías de sus correligionarios granadinos. Los cristianos tenían también sus agentes de información en tierras de Granada, pero a menudo eran falsas o tardías. Esta falta de información y el factor sorpresa, eran decisivas en el éxito de las correrias granadinas, junto con la tardía reacción cristiana, ya que para cuando se habían organizado y preparado para la acción ofensiva las milicias concejiles de Elche u Orihuela, los granadinos ya habían huido con su botín, y pocas veces conseguían derrotarles y recuperar lo perdido.

Realmente podemos afirmar que conocemos con precisión casi diaria los detalles de las relaciones de la Corona de Aragón con el reino de Granada desde el reinado de Jaime II y el resto del siglo XIV gracias a los trabajos de María Teresa Ferrer $i$ Mallol, el más importante de los cuales en esta temática lleva por título La frontera amb l'Islam en el segle XIV. Cristians i sarrains al País Valencià (Barcelona, 1988), así como los de su equipo de trabajo y de Manuel Sánchez, cuya tesis doctoral versó precisamente sobre la Corona de Aragón y Granada ${ }^{23}$, en la Institució Milà i Fontanals del C.S.I.C. en Barcelona. El panorama general que nos ofrece el reinado de Jaime II es el de una alternancia de paz y guerra en la zona de frontera, mantenido mediante una frágil paz que se renovaba con un sistema de treguas de duración quinquenal, que formalmente respetaban las partes interesadas, aún cuando en ocasiones no surtía pleno efecto hasta que los pequeños asuntos pendientes entre las partes no estuvieran del todo solucionados. Por otra parte, no olvidemos que la agresividad y la violencia era algo habitual en la sociedad de la época, que afectaba a todos los estamentos sociales, y que en el caso de la frontera y de la guerra contra el musulmán, contra el infiel, ofrecía posibilidades de promoción social, a través del beneficio obtenido por la guerra, el golpe de mano o el corso.

Del detallado análisis realizado por Ferrer i Mallol de las relaciones de la Corona de Aragón con Granada durante el reinado de Jaime II conviene destacar el establecimiento de una alianza entre Aragón y Granada frente al enemigo común castellano en 1296, a la vez que mantenía buenas relaciones con el sultán marroquí. Pero en 1304 la alianza concertada entre Granada y Castilla dio paso a una serie de incidentes con Aragón, que acabaron en el ataque granadino-marroquí de agosto-septiembre al Sur del reino de Valencia, cuyos episodios más notables fueron el sitio durante tres días, destrucción e incendio de Cocentaina y el saqueo de Alcoy, sin que los cristianos pudieran ofrecer una mínima capacidad ofensiva, limitándose a resistir hasta que Jaime II pudiera organizar el ejército en Valencia. Para entonces los granadinos estaban de regreso a sus bases con un cuantioso botín y, lo que era más novedoso, con numerosos musulmanes valencianos (de Xàtiva, Gandía, Jávea, Orihuela, Alicante)

23 La bibliografía sobre el tema es muy extensa y remito al estudioso al prólogo que le dedica Ma.T. Ferrer i Mallol en su libro La frontera amb l'/slam, o al $n^{\circ} 4$ de la serie "Miscel.lània de Textos Medievals", 4, titulado La frontera terrestre i maritima amb l'/slam, Barcelona, 1988. 
que, galvanizados en su sentir islámico, marcharon con ellos al reino de Granada, aunque aquí las cosas no fueron tan fáciles como esperaban y muchos de ellos regresaron más tarde a sus hogares valencianos tras conseguir el perdón real.

En años sucesivos las alarmas de ataques granadinos a la frontera valenciana menudearon, por suerte la mayoría de las veces infundadas, restableciéndose la paz, alterada ocasionalmente por las capturas por ambos bandos y definitivamente con la cruzada contra Almería en 1309, concluida, tras su fracaso, con un armisticio en diciembre de este año. Las comarcas dellà Sexona no se vieron afectadas directamente por las hostilidades, pero Alicante y Orihuela sirvieron como bases de aprovisionamiento al ejército de Jaime II.

En los años siguientes toda la frontera meridional valenciana vivió un continuo rosario de incidentes, donde los rumores corrían tanto como los jinetes granadinos, los que parecen tener mejor fortuna en sus golpes de mano, en los que obtienen cuantioso botín de hombres y ganado, generando una abundante correspondencia entre Jaime II e Ismail de Granada, en la que el primero le mostraba sus quejas por todos estos ataques, aunque sin conseguir resultados apreciables, lo que dio lugar a la autorización concedida en 1315 por el rey al Consell de Orihuela a tomar represalias contra Granada. Esta será la tónica general durante el resto del reinado de Jaime II, la de una política de treguas, que generó un continuo trasiego de embajadores y mensajeros entre ambas cortes, alterada por toda clase de incidentes fronterizos, imposibles de evitar, por más que Jaime II buscara en todo momento mantener la paz. Su hijo, Alfonso el Benigno, cambiaría esta política por otra abiertamente hostil, de guerra hacia Granada, en alianza con Castilla. Pero el abandono de la coalición por parte de Alfonso XI dejó sólo al monarca aragonés frente a Granada, que supo aprovechar esta coyuntura para lanzar sus jinetes contra la gobernación de Orihuela. Las tropas del caudillo Ridwan en sus campañas de 1331 y 1332 contra Guardamar y Elche causaron enormes daños en todo el territorio, desde el saqueo de la primera, al impresionante botín de cautivos, ganado, y, sobre todo, la huida de numerosos musulmanes de Elche y del valle de Elda, de forma voluntaria o forzada, a Granada con el ejército nazarita. Esta incursión, la más audaz e importante de todas las llevadas a cabo por Granada en tierras valencianas, causó tal impacto en la memoria colectiva de sus gentes, que 130 años después, en 1461, las autoridades de Elche, ante la inquietud desatada en el territorio a raíz de la revuelta catalana, solicitan refuerzos a la reina y le recuerdan el ataque de Ridwan (Reduán) a la villa, aunque ahora se exageran las cifras y se dice que fueron 150.000 los atacantes, que además tuvieron que huir con grandes pérdidas causadas por los ilicitanos, algo que estuvo muy lejos de la realidad, pero que queda como un ejemplo más de manipulación histórica al servicio de la comunidad local y de sus intereses inmediatos, que en este caso no era otro que el conseguir ayuda militar de la señoría ${ }^{24}$.

24 HINOJOSA MONTALVO, J., "Cristianos, mudéjares y granadinos en la Gobernación de Orihuela", Relaciones exteriores del reino de Granada. IV Coloquio de historia medieval andaluza, Almería, 1988, pp. 323-341. 
La frontera con Granada no fue sólo terrestre sino también marítima, y el mar sirvió de eje articulador a unas activas relaciones comerciales entre los reinos de Valencia y Granada ${ }^{25}$, pero también a las acciones de carácter bélico, como por ejemplo la cruzada contra Almería, y sobre todo a la actuación de los piratas y corsarios de uno $u$ otro reino. Digamos que no todos los historiadores están de acuerdo en el concepto de frontera marítima, dado que su carácter es diferente al de la terrestre, ya que si aquí vencieron los cristianos, en el mar la piratería arrinconó a los cristianos peninsulares, por lo que el concepto ideológico de frontera no es aplicable en sentido globalizador ${ }^{26}$.

En esta frontera litoral, que además de geográfica era también ideológica, como ya señalé en otro trabajo específico sobre el tema ${ }^{27}$, las relaciones entre Granada y la Corona de Aragón eran las que marcaban la dinámica de la presencia de piratas granadinos en las costas valencianas, siendo precisamente durante el reinado de Jaime II cuando la monarquía aragonesa prestó mayor atención al tema. Desde principios del siglo XIII la marina musulmana carecía de poder en el área del Mediterráneo occidental y entre 1295 y 1330 el dominio fue claramente cristiano, en concreto de la Corona de los países ribereños de la Corona de Aragón, aunque tras la cruzada de Almería fue perdiendo importancia. Pero el esfuerzo posterior de la cruzada contra Granada entre 1329 y 1333, así como de la campaña del Estrecho, que gravitó en buena medida sobre las arcas valencianas, dejó la capacidad marítimo-militar ofensiva de la marina catalana y valenciana bastante debilitada, aunque quedó claro que tampoco los musulmanes pudieron imponer su dominio en el mar. Lo que hicieron fue cambiar de estrategia, comenzando a partir de ahora una intensa campaña de desgaste de las costas cristianas, en particular las valencianas, mediantes acciones depredatorias de piratería ${ }^{28}$.

A finales del siglo XIII la marina musulmana en el Mediterráneo occidental había quedado arrinconada al área del Estrecho de Gibraltar y la superioridad naval de la Corona de Aragón fue clara, en particular en la etapa entre 1295 y 1330, que es la que aquí nos interesa ${ }^{29}$. El punto final, el de arribada, fue el control del Estrecho por los cristianos, desplazando a los musulmanes. La contrapartida fue el desarrollo de la piratería islámica.

En estos años de Jaime II en el ámbito marítimo hubo una alternancia del uso de

25 HINOJOSA MONTALVO, J., «Las relaciones entre los reinos de Valencia y Granada durante la primera mitad del siglo XV», Estudios de Historia de Valencia, Valencia, 1978, pp. 91-160; “Armamento de naves y comercio con el reino de Granada a principios del siglo XV", $V$ Coloquio de Historia Medieval de Andalucía, Córdoba, 1988, pp. 643-658; "Las relaciones entre Valencia y Granada durante el siglo XV", Estudios sobre Málaga y el reino de Granada en el $V$ Centenario de la conquista, Málaga, 1988, pp. 83-111; RUZAFA GARCíA, M., "Las relaciones económicas entre los mudéjares valencianos y ef reino de Granada en el siglo XV", Relaciones exteriores del reino de Granada. IV Coloquio de Historia Medieval Andaluza, Almería, 1988, pp. 343-382.

26 DÍAZ BORRÁS, A., Los orígenes de la piratería islámica en Valencia, pp. XIV-XV.

27 HINOJOSA MONTALVO, J., "La frontera marítima (ss. XIII-XV)», Actas del Congreso: La frontera: sujeto histórico, Lorca, 1994. En prensa. 
la diplomacia y de la fuerza, proliferando los incidentes de piratas y corsarios cristianos contra los musulmanes, aunque en ningún momento afectaron a los intercambios mercantiles, coexistiendo las flotas comerciales con los barcos corsarios. El objetivo fueron, sobre todo, las escuadras y barcos musulmanes del Norte de Africa y Granada, aunque no podemos hacer un balance detallado de tales actividades. Recordemos, por ejemplo, la captura en 1305 por un leño del conde de Ampurias de 32 granadinos, que fueron vendidos en Castellón, y que fueron devueltos al rey de Granada por Jaime II tras largas negociaciones. Para evitar violaciones de este tipo a las treguas vigentes el rey de Aragón ordenó armar dos leños y una barca, mandada por el valenciano Pere de Ribalta, contra los corsarios catalanes ${ }^{30}$.

Sin embargo, como señala Dufourcq, en el periodo 1310-1330 se percibe un cambio de tendencia en la actitud de marina catalana hacia los paises ribereños musulmanes, sobre los cuales no supo o no pudo mantener la presión marítima adecuada, a la vez que iba emergiendo la marina nazarí. A ello se sumaban otros factores, como el cambio de prioridades en la política exterior de Jaime II, más orientada hacia las islas italianas del Mediterráneo central, igual que los corsarios catalanes, o el abandono de posiciones comerciales por los mercaderes catalanes frente a los italianos. Lo cierto es que desde 1311 las galeras ceutíes se atreven a perseguir a barcos de la Corona de Aragón, en tanto que Barcelona y Valencia deben armar en 1314-1315 embarcaciones para vigilar los mares y perseguir a los piratas, lo que antes no había sucedido, y que era el signo de los nuevos tiempos que se avecinaban. En adelante serian los corsarios valencianos quienes se encargarían de vigilar y proteger las aguas de nuestro litoral de unas embarcaciones musulmanas cada vez más audaces en sus golpes de mano, como lo prueba el ataque y saqueo por la armada nazarí en 1304 de Vila Joiosa, cautivando a más de doscientos vecinos ${ }^{31}$, prosiguiendo a Denia y destruyendo antes el arrabal de Jávea. Por fortuna para los valencianos de la época se trató de un hecho puntual en el espacio y el tiempo, aunque durante todo el reinado de Jaime II no faltaron los avisos y rumores sobre la preparación de armadas granadinas para lanzarse sobre las costas meridionales del reino de Valencia.

28 DÍAZ BORRÁS, A., Problemas marítimos de Valencia a finales de la Edad Media: el corso, la piratería y el cautiverio en su incidencia sobre la dinámica económica: 1400-1480, Valencia, 1988. Editada en microficha; Los origenes de la piratería islámica en Valencia. La ofensiva musulmana trecentista y la reacción cristiana, Barcelona, 1993.

29 El tema lo analizó en profundidad, en numerosos trabajos, DUFOURCQ, Charles-Emmanuel, entre ellos: L'Espagne catalane et le Maghrib aux XIlle et XIV siècles. De la bataille de las Navas de Tolosa (1212) à l'avènement du sultan mèrinide Abou-l-Hasan (1331), Paris, 1966. Hay versión cata* lana: L'expansió catalana a la Mediterrània occidental, segles XIII i XIV, Barcelona, 1969. Los planteamientos de Dufourcq son los seguidos por DÍAZ BORRÁS, A., Los orígenes de la piratería islámica en Valencia, pp. 9-32. Contiene un apéndice bibliográfico muy útil para el tema.

30 FERRER I MALLOL, M‥T., La frontera amb I'Islam en el segle XIV, pp. 92-93, donde analiza estos incidentes con detalle.

31 FERRER I MALLOL, Ma.T., La frontera amb /'slam, pp. 17-72; TORRES DELGADO, C., «El Mediterráneo nazarí: diplomacia y piratería. Siglos XIII-XIV", Anuario de Estudios Medievales, 10, (1980), pp. 227-235; DÍAZ BORRÁS, A., Los orígenes de la piratería islámica en Valencia, pp. 29-30. 
Los actos de piratería comenzaron a dejar sus huellas en la población del mediodía valenciano, perceptible en el aumento del odio hacia los musulmanes, acusados de colaboracionismo con el enemigo, del miedo que se fue difuminando por la sociedad cristiana, temerosa de posibles ataques marítimos y víctima ya habitual de las cabalgadas por tierra, sin olvidar la terrible secuela del problema de los cautivos, una constante en esta sociedad de frontera, que llevó a crear en Valencia una institución específica dedicada a las redención de aquellos que eran capturados en el mar ${ }^{32}$.

Cuando finalice el reinado del rey Justo la frontera marítima de Valencia con Granada habrá experimentado cambios importantes con relación a finales del siglo XIII, cuando los marinos catalanes imponían su fuerza por el Mediterráneo occidental, siendo la aparición de la piratería musulmana, todavía modesta, y el creciente potencial de la escuadra granadina los dos rasgos más sobresalientes. Sus efectos se dejarían sentir en años sucesivos y cuando en 1331 Guardamar fue asaltada y saqueada se vio la precariedad de las defensas del flanco sur valenciano y la necesidad de controlar el área del Estrecho. Este sería el principal problema a resolver por los sucesores de Jaime II.

\section{LAS REPERCUSIONES SOCIO-INSTITUCIONALES DE LA VIOLENCIA FRONTE- RIZA}

La existencia de una frontera, aunque indirecta desde el punto de vista físico, pero real desde la percepción de las gentes de la época, tuvo importantes repercusiones en todo el mediodía valenciano y en facetas tan diversas como la demografía o las instituciones.

En primer lugar sobre las gentes residentes en el territorio, cristianos y musulmanes. Estos últimos, como ya dijimos, vieron descender su número de forma considerable en la procuración de Orihuela desde el reinado de Jaime II, aunque ya existía el precedente de la revuelta de 1264-1265. La guerra de conquista de Jaime II no hizo sino agravar el problema entre 1296-1304, y un testimonio coetáneo era muy claro al señalar que «por razón de las guerras e de los otros males que son acaescidos en tierra de Murcia, la mayor parte de los moros son muertos e los otros fuydos, por las quales cosas la tierra es muy despoblada e menguada dellos ${ }^{33}$.

Las capturas de los almogávares, la emigración legal, o la huida con los ejércitos granadinos provocaron un lento pero continuado descenso de la población musulmana en las principales villas, como fue el caso de Orihuela, Alicante o Elche. El vacío que dejaban los mudéjares en el campo iba siendo colmado poco a poco por los nuevos repobladores cristianos, que se iban instalando en algunas alquerías abandonadas.

32 DÍAZ BORRÁS, A., “Notas sobre los primeros tiempos de la atención valenciana a la redención de cautivos cristianos (1323-1399)», Estudis Castellonencs, 3 (1986), pp. 337-354.

33 TORRES FONTES, J., "Los mudéjares murcianos en el siglo XIII", Murgetana, XVII, (1961), p. 27. Reproduce la cita FERRER I MALLOL, Mํ.T., La frontera amb l'Islam en el segle XIV, p. 6. 
Simultáneamente, las acciones depredatorias de los granadinos en tierras valencianas crearon entre los cristianos un sentimiento de declarada hostilidad hacia los musulmanes, acusados, muchas veces. con fundamento, de connivencia con sus correligionarios, en tanto que los sentimientos de solidaridad panislámica afloraban periódicamente entre los moros valencianos, sobre todo cuando triunfaban los granadinos. La libertad de movimientos para los musulmanes al sur de Jijona o las violencias contra algunas morerías fueron algunas de las inmediatas consecuencias de tan enrarecido clima. El tema lo ha estudiado muy bien $\mathrm{M}^{\mathrm{a}}$. T. Ferrer i Mallol y no insistiré en él ${ }^{34}$.

A pesar de las treguas oficiales, la beligerancia impregnó continuamente la frontera con el Islam, haciendo que la agresividad y la violencia fueran componentes vitales de muchas de sus gentes. La depredación era para muchas de ellas un modo de vida ordinario, una profesión y en la frontera se acogían todo tipo de rufianes y delincuentes, a los que muchas veces se les perdonaban sus delitos a cambio de que se instalaran en aquellas tierras peligrosas. Fue en estas tierras del mediodía valenciano el escenario por excelencia del delito de «plagi» o "collera», consistente en la captura de personas que luego eran vendidas como cautivas o rescatadas a cambio de dinero. Era una actividad a la que se dedicaban habitualmente los almogávares, el otro grupo humano que destacaba por su profesionalidad en la guerra, y que cuando no participaba en las expediciones oficiales contra tierras granadinas se dedicaba al saqueo de las mismas por su cuenta, en busca de cautivos, ganado o cuanto le pudiera reportar un beneficio económico ${ }^{35}$, aunque también podía realizar tareas oficiales, como actividades de espionaje, atalaya, escuchas o correos. Estos microgrupos humanos tenían un funcionamiento directo y espontáneo, de pequeños grupos entre diez y quince hombres, comandados por un almugatèn o un adalid, y los encontramos por igual en Valencia, Murcia o Granada.

Esta violencia fronteriza tenía sus principales víctimas entre los habitantes de estas comarcas o los que transitaban por ellas. La inseguridad, la amenaza a perder la libertad, fue una constante durante toda la baja Edad Media entre las gentes de la gobernación de Orihuela, que debieron acostumbrarse a vivir acompañados de ella, y tanto a título personal, desde el agricultor y el pastor al pescador, como colectivo, como fue el caso de poblaciones enteras como Vila Joiosa o Guardamar que sufrieron sus consecuencias en toda su crudeza. La caída en cautiverio fue la tribulación más penosa con la que debieron enfrentarse las gentes de la época, a ambos lados de la frontera, por supuesto, generando un flujo cotidiano de cautivos y de gentes que acudían a su rescate.

La proximidad de Granada y la vecindad del de Murcia hizo que el espacio meridional valenciano hubiera de organizarse para la guerra. Fue en estas comarcas don-

34 FERRER I MALLOL, Ma.T., La frontera amb I'Islam en el segle XIV, capítulo 5. pp. 17-46.

35 FERRER I MALLOL, M‥T., La frontera amb I'Islam en el segle XIV, capítulo 3, pp. 47-72; Organització i defensa d'un territori fronterer. La governació d'Oriola en el segle XIV, Barcelona, 1990. dedica el capítulo 7 a los almogávares. 
de se registró una mayor actividad bélica en estos siglos, tanto frente a cristianos como a musulmanes, desde la revuelta mudéjar del siglo XIII a la guerra de Castilla en 14291430 , y pocas villas resultaron tan castigadas como Alicante u Orihuela por estos conflictos. La mayoría de los conflictos medievales se reducían a operaciones limitadas en el espacio y en el tiempo, dada la lentitud de avance de los atacantes y la defensa a ultranza de los atacados. De ahí la importancia de mantener un buen sistema de murallas en las villas y que los castillos estuvieran a punto en sus instalaciones y bien avituallados de armas y provisiones.

Lo ideal hubiera sido la construcción de una sólida red de fortificaciones a lo largo de la frontera, pero ello no fue posible por la conjunción de diversos factores, como la debilidad financiera de la monarquía y los municipios, incapaces de emprender obras de envergadura de forma continuada, lo que hacía que la mayoría de los castillos de la región estuvieran en deficientes condiciones y carecieran de guarnición permanente, además de que la diversidad de poderes, el rey o los señores, impedía acciones coordinadas, y la resistencia era aislada. Eran fortalezas de origen islámico, cuyos puntos clave para la Corona de Aragón eran Orihuela y Alicante. Los monarcas fueron conscientes siempre de este papel frontero de las mismas y así lo explicitaron en su documentación, no dudando en calificarlas como "clau del regne», en particular el de Alicante ${ }^{36}$, lo que no impidió que en la guerra de los dos Pedros fueran ocupadas por el monarca castellano, Pedro I. Las alquerías dispersas por el campo eran protegidas por torres, donde se refugiaban sus habitantes en caso de peligro.

En cuanto a la fortificación de los núcleos habitados, sólo Orihuela, Elche y Alicante poseían sólidos recintos amurallados, que en otras localidades, como Guardamar, eran más débiles, lo que valió su ocupación por los granadinos, obligando a posteriores reedificaciones y modificaciones en el poblamiento.

Este clima bélico y de violencia, en particular durante el reinado de Jaime II, motivó la militarización de la sociedad fronteriza, cuyas gentes debían compartir el trabajo con las armas, estar en vigilancia permanente frente a cualquier posible acción por sorpresa del enemigo. La milicia vecinal encuadraba al individuo para las acciones ofensivas o defensivas, y en ninguna otra comarca valenciana como aquí lo militar impregnó de forma tan intensa toda la sociedad, desde el caballero, que gracias a la posesión de caballo y armas monopolizaba los cargos de gobierno municipal, al simple peón, obligado a acudir a la llamada Consell. Como premio, el botín, minuciosamente regulado su reparto, y medio de promoción social.

En cuanto a la frontera marítima, la superioridad de la marina catalana y la acción ofensiva de los corsarios cristianos hacían innecesario durante estos años de finales del siglo XIII y primeras décadas del XIV un sistema de protección costera, aunque el asalto a Guardamar en dos ocasiones demostró la debilidad defensiva en este flanco del litoral. De ahí que cuando aumente la peligrosidad de la piratería granadina y genovesa, ya en la primera mitad del siglo XIV se tome conciencia de adoptar medidas preventivas contra los barcos enemigos, erigiendo torres de defensa, aunque sin

36 HINOJOSA MONTALVO, J., La clau del regne, Alicante, 1990. 
ningún plan preconcebido o articulado, que no llegaría sino más tarde. La noticia más antigua que conozco data de 1337 cuando el infante Ramón Berenguer, señor de Elche, autorizó al Consell ilicitano a construir una torre en la isla de Santa Pola, que era considerada como un refugio para los piratas, aun cuando no se llegó a construir, pues no hay más noticias de ella ${ }^{37}$.

37 HINOJOSA MONTALVO, J., «El Cap del Aljup, puerto medieval de Elche», Homenatge a Álvaro Santamaría, Mayurqa, 23, 1989, I, pp. 311-324; DÍAZ BORRÁS, A., Los orígenes de la piratería islámica en Valencia, pp. 105-110. 


\title{
LA FRONTERA OCCIDENTAL DEL REINO DE MURCIA EN EL CONTEXTO DE LA INTERVENCIÓN ARAGONESA: DEFENSA Y REPOBLACIÓN (1270-1340)
}

\author{
Juan Francisco JIMÉNEZ ALCÁZAR \\ Universidad de Murcia
}

En el plazo aproximado de cinco décadas, desde la mitad del siglo XIII a los comienzos del XIV, el antiguo reino de Murcia, e incluso la tierra cercana a él, contempló su fragmentación de forma abrupta. Por el Poniente, la permanencia del poder nasrí y las circunstancias propias del proceso de conquista por el infante Alfonso derivaron en el trazo de una demarcación forzada en el centro de una gran comarca homogénea. Por el Levante, fueron las complejas relaciones políticas entre Aragón y Castilla, iniciadas un siglo atrás, las que decidieron su conformación definitiva'.

El establecimiento de Castilla en el Reino murciano se vio alterado bruscamente por la agresiva política de "castellanización" de Alfonso $X$. Tras tras la revuelta mudéjar de 1264-66, de forma inmediata se abrió el proceso repoblador en la mayor parte de las ciudades y villas de la demarcación y, paralelamente, el desarrollo institucional que organizaba comunidades y aparato militar. Así, la frontera con los nazaríes granadinos quedaba configurada en torno a unas tierras que dibujaban una línea perpendicular a la costa, partiendo desde las proximidades del puerto de Águilas hasta las defensas castellanas en Huéscar, Cúllar, Galera y Orce. Un punto centralizaba la red defensiva: la villa de Lorca, que además sostenía el paso a las tierras del reino de Murcia, constituido ya como un Adelantamiento, a través del valle del Guadalentín.

1 A pesar del tiempo transcurrido desde su publicación, continúa siendo de obligada referencia el estudio de TORRES FONTES, J., "La delimitación del Sureste peninsular (tratados de partición de la Reconquista)», Anales de la Universidad de Murcia, Curso 1950, pp. 5-32. 
Pero la planificación repobladora chocó con la ofensiva meriní y el inicio de lo que se viene denominando la «Batalla del Estrecho». Como bien es sabido, el proceso repoblador en las zonas más occidentales del reino se había caracterizado por la mayoría castellana, a diferencia de las ciudades orientales que lo fueron por pobladores procedentes de la Corona aragonesa. Prestaremos atención a este hecho cuando perfilemos la peculiaridad de la conquista de Jaime II. Por el momento, aludiremos a esta caracterización de mayoría castellana en la zona occidental por la presencia y configuración de la frontera con Granada. Después de la rebelión mudéjar y el desalojo de la plaza de posibles quintacolumnistas, la demarcación necesitaba, de forma inmediata, de un monto de población que asegurase la posición y la frontera, y no podía ser otro que el formado por contingentes dependientes directamente del soberano de Castilla. Además de este hecho, también hay que tener en cuenta otro tipo de factores interesantes, como la tradicional — que no desacertada - idea de que Jaime I no llegó hasta los límites con Granada y permaneció en las tierras orientales y centrales del reino, así como que Lorca era la plaza situada al Sur de las encomiendas santiaguistas, por lo que recibiría pobladores que continuaban el «circuito fronterizo" en busca de exenciones o sencillamente tierras.

De esta forma, una vez abierto el proceso repoblador en Lorca y con la subsiguiente articulación institucional castellana de la villa, se perfilaba una inflexión en el desarroIlo histórico del territorio ${ }^{2}$. El hecho en su conjunto no deja de tener una importancia capital en el sector, ya que Lorca se configuró como la plaza más decisiva para el mantenimiento fronterizo castellano. Lo había demostrado con la resistencia de Diego Sánchez de Bustamante en la fortaleza durante la rebelión mudéjar, pero con la ofensiva meriní a partir de la década de 1270 va a ser, si cabe, más definitiva. Es obvio que la firme presencia de los norteafricanos y el poder más asentado de los nazaríes colaboró en el afianzamiento de la línea fronteriza con Castilla. Por el momento nos interesa destacar que el mantenimiento granadino condicionó notablemente el desarrollo del reino murciano bajomedieval, ya que se esbozó como la cuña territorial de Castilla entre Aragón y Granada con ribera mediterránea. Este hecho repercutirá de forma intensa en las relaciones entre los tres reinos, debido a que Murcia se encontraba como testigo territorial de la mayor parte de sus contactos directos.

El reino de Murcia era una de las demarcaciones fronterizas de Castilla por antonomasia, marcado por la tan mencionada existencia de una triple frontera: con Granada, con Aragón y con la costa mediterránea. Pero desde el inicio de la repoblación, el sector occidental "sufrió" con mayor rigor la presencia de una frontera militar. La Corona castellana extendía directamente su poder en el sector más meridional de la línea, ya que había delegado la defensa de la zona Norte a las Órdenes del Temple y Santiago. Ésta última había estado avanzando por la Sierra de Segura hasta alcanzar Huéscar en 1241, y recibir un año después Orce y Galera, a la par que, años atrás, también había conseguido el arzobispo de Toledo, D. Rodrigo Jiménez de Rada, conquistar Quesada y buena parte de su entorno, definiendo una línea fronteriza a las puertas de Baza ${ }^{3}$. El poder

2 TORRES FONTES, J., Repartimiento de Lorca, Murcia, edic. 1994.

3 CARRIAZO ARROQUIA, J.M., Colección diplomática de Quesada, Jaén, 1975, pp. L-LIII. 
musulmán tenía en las plazas de Vera, Purchena y la ciudad bastetana los puntales defensivos más importantes, con pequeños puntos avanzados que, con el paso del tiempo, se fueron configurando como la vanguardia defensiva nazarí; es el caso de Huércal y fundamentalmente los Vélez.

En plena etapa de caos político castellano, zenetes veratenses lograron asestar un durísimo golpe a los planes repobladores cristianos; en 1283, una cabalgada en el campo lorquino logró dar muerte a doscientas personas y hacer cautivas a otras tantas. Ya había comenzado el repliegue poblacional del entorno rural al más seguro de las defensas urbanas. Se potenciaba ahora el fenómeno de las despoblaciones, iniciado décadas atrás con el desalojo de los mudéjares de los sectores fronterizos. La cabalgada de 1283 no hizo sino potenciar este proceso. Por aquellos años se asistía a la virulencia de una vida fronteriza muy activa, con golpes de mano, algaras y celadas continuas, y que ya definía el campo como un lugar potencialmente peligroso; por ejemplo, una travesía entre villas podía convertirse en toda una desventura, como en efecto lo fue para Ramón de Mula, cautivado en 1285 cuando se desplazaba desde Lorca hasta Mula ${ }^{4}$.

La única respuesta de los repobladores, articulados ya en concejos y con usos fronterizos defensivos - caso de la obligación de los caballeros villanos de mantener caballo y armas ${ }^{5}$, fue el abandono de la zona o el repliegue a lugares seguros. El ejemplo más conocido es el del obispo de Cartagena que se estableció oficialmente en 1291 en la capital del reino. En los albores de la intervención aragonesa podemos decir que la mayor parte de las zonas cultivadas del sector fronterizo con Granada se habían abandonado, quedando exclusivamente las estrechas franjas de vega en villas como Mula y Lorca como espacios productivos. Incluso se llegaron a desalojar núcleos más pequeños, como Puentes, el enclave más avanzado castellano hacia las tierras orientales nazaries. En esos años, el rey granadino había conseguido recuperar Quesada - 12956 - hasta entonces en poder del arzobispado toledano, y que abría una etapa agresiva de Granada contra Castilla, por la firma de paces entre Jaime II y Muhammad II. Este es el contexto fronterizo en donde hemos de situar el privilegio de 1295, ya con Fernando IV, para que con el sietmo de las cabalgadas se reforzasen las defensas de la villa de Lorca ${ }^{7}$.

La minoría de Fernando IV abrió una época de indolencia monárquíca en Castilla, donde las hermandades hallaron de nuevo un período floreciente. En el reino de Murcia se firmó una hermandad general en octubre de 1295 entre las principales ciudades y villas ${ }^{8}$, y en ella, como no podía ser de otra manera, se garantizaba el señorío de

4 TORRES FONTES, J., Repartimiento de Lorca, pp. 53-54.

5 GONZÁLEZ JIMÉNEZ, M., "Alfonso X y las oligarquías urbanas de caballeros", Glossae, 5-6 (1993-94), p. 200.

6 CARRIAZO ARROQUIA, J.M., ob. cit., pp. LXVIII y ss.

7 TORRES FONTES, J., Documentos de Fernando IV, CODOM V, Murcia, 1980, p. 19.

8 BENAVIDES, A., Memorias de D. Fernando IV de Castilla. Tomo II, RAH, Madrid, 1860, pp. 4650. Al final, hay una nota de Diego Clemencín justificando el espacio en blanco que aparece en el documento, destinado para Orihuela. También se incorporó Cartagena después de formalizada la hermandad: p. 52. 
Fernando IV en tierras murcianas, capítulos equiparables a las firmadas de forma paralela en León y Galicia. De parte lorquina, firmaron Diego Álvarez de Espejo, el adalid Pedro Juan de las Cuevas y Alonso Fernández de la Torre ${ }^{9}$. Poco sospechaban que la amenaza procedería de Aragón tan sólo meses más tarde, y no de Granada ni del interior.

En efecto, los últimos años del siglo XIII vieron que el interés mediterráneo de Jaime II se prolongaba por las tierras murcianas. Para un enfrentamiento abierto con los castellanos era preciso establecer buenas relaciones con los granadinos, acuerdo que debía incluir que los musulmanes actuasen militarmente en la frontera andaluza. Los beneficios para los aragoneses estaban claros, pues se realizaba una maniobra de distracción de contingentes castellanos que pudieran participar en el escenario murciano o en la frontera aragonesa; la ventaja para los nazaríes era que se aseguraba nuevamente la supervivencia del reino granadino. La firma del acuerdo entre Jaime II y Muhammad II en mayo de $1296^{10}$, halla en este contexto su explicación más certera.

Con los aragoneses ya en Murcia, los puntos más occidentales del reino veían que su labor defensiva tenía sentido no sólo contra los nazaríes, sino también contra los aragoneses. Desde la capital, tenemos noticias de que Jaime II envió a un franciscano al concejo de Lorca ${ }^{11}$, sospechamos que con la intención de preparar una capitulación de la villa. Mucho más directo fue el emplazamiento del rey aragonés a Juan Fernández, alcaide del castillo de Chuecos ${ }^{12}$, defensa enclavada entre las sierras de Almenara y Carrasquilla, y que, junto a Tébar, dominaba el único paso accesible desde el puerto costero de Águilas al valle del Guadalentín. En mayo de 1296, Mula había caído en manos aragonesas, aunque Alhama, al pie de Sierra Espuña, aún resistía. Por aquellos mismos días, Jaime II acogía bajo su protección las villas de Cehegín y Caravaca, pertenecientes al Temple ${ }^{13}$, por lo que entendemos que existió un acuerdo en la capitulación pacífica. A pesar de esta capitulación, no vamos a reincidir en la importancia que se le ha dado a la peculiaridad repobladora de esta zona, con la mayoría castellana ya aludida y que llega a mencionar la propia Crónica de Fernando $\mathrm{I}^{14}$.

9 Ibídem, p. 45.

10 Del ESTAL, J.M., El reino de Murcia bajo Aragón (1296-1305). Corpus documental I/1, Alicante, $1985, \mathrm{pp} .164-166$.

11 Ibídem, p. 191.

12 Ibídem, pp. 192-93.

13 Del ESTAL, J.M., El reino de Murcia bajo Aragón (1296-1305). Corpus documental 1/2. Alicante, 1990 , pp. 59-60. Sobre la presencia templaria en la bailía de Caravaca: PASCUAL MARTÍNEZ, L., "Los templarios en el Reino de Murcia», Homenaje al prof. Muñoz Cortés, t. II, Univ. Murcia, 1977, pp. 871-886.

14 Crónica de Fernando IV, edic. de BENAVIDES, A., en: Memorias de Fernando IV de Castilla, tomo I, Madrid, RAH, 1860, pp. 1-243. En la edición de la BAE (Crónicas de los reyes de Castilla, tomo I, Madrid, 1953) en pp. 91-170. 
«E por consejo de los de la tierra, que eran catalanes, dieronsele todas las villas e los castillos, salvo ende Lorca, en que moraban castellanos e otrosi Alcala [Puebla de Mula ${ }^{15}$ e Mula».

Su interés radica en la confirmación y aceptación de unos hechos por parte castellana que, por otro lado y para los fines propagandísticos de la crónica, venían a crear una causa razonable que eximiera a la Corona castellana del fracaso militar y repoblador en el Reino de Murcia, culpando a los propios habitantes de la demarcación.

A principios de junio, Jaime II se encontraba a las puertas de Lorca ${ }^{16}$. El sistema logístico escogido había sido el de apoyo y abastecimiento por mar, con el desembarco en el puerto de Águilas ${ }^{17}$. En estas maniobras observamos la verdadera dimensión de la tregua firmada dos semanas atrás entre Jaime II y Muhammad II, ya que la tregua con los granadinos aseguraba las operaciones marítimas catalanas, sobre todo en latitudes tan cercanas a las tierras nazaríes, y fundamentalmente garantizaba la quietud granadina durante los movimientos terrestres. El fracaso de lo que fue el primer cerco de la plaza lorquina se explica por tres motivos principalmente: por la inexpugnabilidad de las defensas, que procuraban un esfuerzo militar mucho mayor del que había movilizado Jaime II en esta ocasión; en segundo lugar, porque existían problemas logísticos muy complejos, ya que debía mantener lo conquistado a retaguardia; y tercero y consecuencia del anterior, porque estaba asegurando esas conquistas "despejando» los núcleos resistentes, con órdenes de confiscación y expulsión a los que habían huido o resistido ${ }^{18}$.

Las líneas maestras del juego diplomático entre Aragón y Granada condicionaron buena parte de los sucesos fronterizos realizados en este sector. La confirmación de la paz catalano-granadina en septiembre de $1296^{19}$ significaba un mantenimiento de la situación generada tras la invasión en Murcia, intenciones reafirmadas con los contactos de junio del año siguiente entre ambas Coronas, pretendiendo además Jaime II que el sultán nazarí reconociese a Alfonso de la Cerda como rey de Castilla ${ }^{20}$.

Las consecuencias de la intervención aragonesa en el reino murciano no se hicie-

15 Queda demostrada su localización por GONZÁLEZ CASTAÑO, J., Una villa del Reino de Murcia en la Edad Moderna (Mula, 1500-1648), Murcia, 1992.

16 El 4 de junio de 1296 expide una carta desde la huerta de Lorca. Del ESTAL, J.M., El reino de Murcia bajo Aragón (1296-1305). Corpus documental 1/2, p. 60.

17 El 24 de mayo, Jaime II había escrito a su consejero Bernardo de Sarriá indicándole su intención de marchar sobre Lorca dos días después, y con el encargo de que enviase vituallas a Águilas. Ibídem, pp. 56-57.

18 A partir de estas fechas se documentan en el A.C.A., muchas de ellas recogidas en los corpus documentales publicados por J.M. Del Estal, una cantidad notable de cartas de confiscación de bienes a resistentes y otorgamiento de bienes a leales o colaboracionistas.

19 Posiblemente se trate de los mismos capítulos del tratado de mayo. 1296-IX-8. Carta de Jaime II al rey de Granada, diciéndole que ha recibido el tratado de paz ajustado entre los dos, y aplazado para otra época la conclusión de los asuntos pendientes. BENAVIDES, A., Memorias de D. Fernando IV de Castilla, pp. 98-99.

20 Ibídem, p. 124. 
ron esperar, y la más importante, sin duda alguna, fue la anulación de la presencia castellana en el Mediterráneo. La repercusión de ęste hecho en la guerra abierta por el Estrecho era bastante notable para Castilla. Además, la presión iniciada años atrás por nazaríes y meriníes hizo que a la caída de Quesada se le unieran Alcaudete -1300-, Bedmar, Arenas y Locubín -130221 - En el sector murciano, el dominio castellano se seguía restringiendo a Lorca, que permanecía aislada, ya que entre Alcaraz y la villa del Guadalentín, las tropas aragonesas controlaban la bailía de Caravaca. Mula permaneció tan sólo dos años bajo poder aragonés, pues en 1298 la villa se levantó y volvió al señorío de Fernando IV ${ }^{22}$. La caída de Alhama ese mismo año complicó la situación militar del sector, lo que no desahogó la posición lorquina.

Durante cuatro años, la villa lorquina resistió diversos embates aragoneses, por lo que recibió de la Corona dos de los privilegios más conocidos en la Historia de la ciudad. El primero de ellos fue el de acuñación de moneda, concedido en Toro en $1297^{23}$. Las razones de esta concesión las especifica claramente el propio documento: a causa de la guerra que mantenía el rey con el infante $D$. Juan, aspirante al trono D. Alfonso de la Cerda, y de forma fundamental, porque la villa de Lorca esta mucho afincada de guerra de los christianos [aragoneses] et de los moros. No era la primera vez que ante la coyuntura bélica, la Corona delegase esta regalía. Desde el punto de vista estrictamente práctico, la concesión era lógica, ya que Lorca se encontraba aislada, pero también se escondían otras causas relacionadas con motivos económicos más profundos. La moneda que se había ordenado labrar era de «bajísima ley», de dos dineros el maravedí, y pretendía sustituir a la acuñada por Sancho IV (el privilegio menciona incluso la compra de esa moneda para la confección de la nueva), que era de mejor calidad, en un sencillo desarrollo de sustitución de la moneda buena por la mala ${ }^{24}$. Con esta operación se quería evitar la fuga de moneda, a la vez que una medida

21 LADERO QUESADA, M.A., Granada. Historia de un país islámico, Madrid, 1989, p. 144.

22 El 8 de mayo de 1298, Jaime II se dirigió a Jaime de Jérica, Procurador de Murcia, ordenándole recobrar Mula. BENAVIDES, A., Memorias de D. Fernando..., pp. 163-164. De parte castellana, a comienzos de julio, Fernando IV confirmó sus privilegios: TORRES FONTES, J., Documentos de Fernando IV, CODOM V, Murcia, 1980, p. 30. Es interesante observar el papel que en esta sublevación tuvo el comendador santiaguista de Ricote, Fernando Pérez, en respuesta a los términos recriminatorios contenidos en una carta de Jaime II a Juan Osórez como maestre de Santiago a finales de 1300, durante el cerco de Lorca ["que Ferran Perez comendador de la dita val acuylle e recibe nuestros enemigos en los castiellos de la orden e con complio esto fizo nos perder el castiello de Mula"]: Del ESTAL, J.M., El Reino de Murcia bajo Aragón, 1/2, p. 131.

23 Archivo Municipal de Lorca. Lo transcribió ESPÍN RAEL, J., en: Privilegio para labrar moneda en Lorca, dado en Toro, por el rey Fernando IV, en 24 de octubre de la Era de 1335, Lorca, 1936. A raíz de la transcripción del erudito local, con bastantes lagunas, realizó un interesante estudio numismático GIL FARRÉS, O., «En torno del privilegio de Lorca y distinción entre las monedas de vellón de Fernando III y de Fernando IV", Numario Hispánico, V (1956), pp. 263-279. No obstante, el privilegio fue publicado de forma íntegra por TORRES FONTES, J., en: Documentos de Fernando $\mathrm{N}$, pp. 26-30, transcripción que hemos utilizado. Analiza las monedas procedentes de esta acuñación FONTELA BALLESTA, S., Las acuñaciones medievales de Lorca, Lorca, 1995, pp. 61-63.

24 GIL FARRÉS, O., ob. cit., p. 266. 
devaluadora respondía a las necesidades perentorias de liquidez por parte de la Corona. El hecho ayudaba además a mantener en circulación moneda castellana, ya que meses atrás Jaime II había dado licencia para labrar moneda en Alicante ${ }^{25}$.

El segundo de estos privilegios, y mucho más conocido, fue el de 1299. En él, la Corona concedía a la villa diversos castillos del entorno territorial: Caristoy, Calenque, Ugéjar, Amín, Nogalte, Puentes, Celda y Coy ${ }^{26}$. Lo pretendido fue reforzar el sistema defensivo del sector con la centralización del poder militar; no obstante, la desorientación de la Corona era notable, ya que Puentes pertenecía a la jurisdicción de la villa desde la temprana concesión de $1257^{27}$, y Alhama había caído en manos aragonesas hacía un año. Diferente es el caso de $\mathrm{Coy}^{28}$, ya que tras la muerte de su señor, Nicolás Pérez, en 1296 defendiendo la fortaleza alicantina, el enclave creemos que revirtió al patrimonio real.

Cabe ahora preguntarse la efectividad de esta concesión, en primer lugar porque la fortaleza lorquina cayó en manos aragonesas al año siguiente, con lo que se alteraba la ordenación territorial; y segundo, por las consecuencias que se observan con posterioridad al regreso de Lorca a la Corona castellana. El dominio aragonés apenas tuvo consecuencias inmediatas, debido al relativamente corto espacio de tiempo que duró la ocupación - cuatro años-, más cuando hemos de tener en cuenta las condiciones de la capitulación pactada en aquella Navidad de 1300, donde Jaime II respetaba privilegios, fueros y libertades de la villa y concejo; la conclusión más obvia hubiera sido que este privilegio también se hallase entre esas condiciones. Pero en 1304, tras Torrellas, Lorca volvió a manos castellanas. Con el pendón castellano ondeando nuevamente en la fortaleza de la villa, la efectividad del privilegio es muy dudable. Según el perdón de Fernando IV a los vecinos de Lorca, los privilegios se confirmaron, por lo que deberíamos tener en cuenta otra nueva aceptación del privilegio por las autoridades castellanas. Pero sabemos de su inefectividad ya en las primeras décadas del XIV. El profesor Torres Fontes apoya la hipótesis de que fue la posición política de D. Juan Manuel en 1320-30 la que finalmente deshizo la posible realidad del privilegio ${ }^{29}$, opinión que compartimos.

La efectividad más importante del documento fue que en éste se halló la base legal y documental para expandir el alfoz, durante el proceso de ampliación del término jurisdiccional a lo largo de la Baja Edad Media. Por ello, no sorprende su mención y utilización en diversos pleitos muchos años después, ya en los años postreros de la Edad Media. Adquirió otra dimensión a partir del siglo XVII, donde el documento era

25 Del ESTAL, J.M., El Reino de Murcia bajo Aragón, 1/2, pp. 77-79.

26 A.M.L. Pergamino. Publicado por TORRES FONTES, J., en: Repartimiento de Lorca, Murcia, edición de 1977, doc. XXIV, pp. 94-95. Analicé el documento en el amplio contexto de la expansión del alfoz concejil lorquino en: Lorca: ciudad y término (ss. XIII-XVI), Murcia, 1994, pp. 120-121.

27 TORRES FONTES, J., Fueros y privilegios de Alfonso $X$ al Reino de Murcia, CODOM III, Murcia, 1973, pp. 41-43.

28 JIMÉNEZ ALCÁZAR, J.F., «Tierra, propiedad y paisaje agrario en la frontera de Granada: Coy (Lorca, Murcia)", Anales de la Universidad de Alicante, 10 (1994-1995), pp. 169-195.

29 TORRES FONTES, J., Repartimiento de Lorca, Murcia, 1994, p. LXXXIV. 
-como lo es hoy- la enseña y «caballo de batalla» para cronicones y eruditos locales, que cantaron - y cantan- glorias pasadas de la ciudad.

En estos años, la clave de la resistencia lorquina se centraba en la doble vertiente fronteriza que encarnaba la villa y territorio; por un lado la costa, convertida en el único resquicio por el que Castilla se asomaba al Mediterráneo, si bien es cierto que de forma testimonial; y por otro, la frontera terrestre con Granada. Este hecho no es menos importante, ya que era fundamental para los planes expansivos peninsulares de las Coronas aragonesa y castellana.

No vamos a entrar en los sucesos concretos de la capitulación lorquina ${ }^{30}$, sino más bien en el contexto en que se hizo. En primer lugar, hay que tener en cuenta la paz firmada entre Aragón y Granada en febrero de $1300^{31}$, viviendo aún Muhammad II. De ahí que entendamos perfectamente la quietud de las huestes musulmanas en las vísperas del cerco definitivo a Lorca, más cuando en el resto de la frontera castellanogranadina, los nazaríes estaban realizando una presión militar importante, sobre todo en la zona jiennense ${ }^{32}$, cuyo fruto más evidente fue la reconquista granadina de la plaza de Alcaudete.

Para entender perfectamente la caída de Lorca durante el cerco de la Navidad de 1300 , hemos de tener en cuenta dos motivos principales: el papel jugado por D. Juan Manuel, que a la sazón se encontraba refugiado entre los muros de la fortaleza, y, sobre todo, la decisión de los poderosos dominantes del concejo, que al fin y a la postre, aceptaron las condiciones de capitulación ofrecidas por Jaime II. Entre los firmantes podemos observar a individuos pertenecientes a linajes importantes de la villa, como Teruel, Pérez de Tudela, Navarro, Pérez de Meca o Morata ${ }^{33}$. En la confirmación de fueros y libertades dado por Jaime II días después de la cesión de la villa, se contemplaba la atención de la Corona para con los de cavallo ${ }^{34}$, por lo que hemos de tener muy presente la actuación del grupo dominante, aún no definido con precisión, en la capitulación lorquina. La hipótesis parece confirmarse a tenor de las protestas que realizó la ciudad de Orihuela tres años después, por no gozar los caballeros oriolanos el mismo trato de favor que tenían los de Lorca y Murcia ${ }^{35}$. También hay que suponer otro hecho no contemplado en los documentos, y es la perspectiva ofrecida a los vecinos de una futura pertenencia a Aragón. Cierto es que en la villa se dejó sentir rápidamente la concordia granadino-aragonesa, ya que la firma de relaciones

30 Las noticias documentales precisas fueron publicadas por Del ESTAL, J.M., en: «Nuevos datos sobre la capitulación y conquista aragonesa de Lorca», Homenaje al prof. Torres Fontes, vol. I, Univ. Murcia, 1987, pp. 431-464.

31 BENAVIDES, A., Memorias de D. Fernando IV..., pp. 203-205.

32 GONZÁLEZ MÍNGUEZ, C., Fernando IV (1295-1312), Palencia, 1995, p. 65.

33 Del ESTAL, J.M., "Nuevos datos...», pp. 442-447. A Martín de Morata lo podemos ver incluso entre los caballeros alforrats: FERRER I MALLOL, M.T., Organització i defensa d'un territori fronterer. La governació d'Oriola en el segle XIV, Barcelona, CSIC, 1990, pp. 359-361.

34 1300-XII-29, Lorca. Confirmación por Jaime II de los fueros que disfrutaba la villa de Lorca hasta la fecha de su rendición: Del ESTAL, J.M., El Reino de Murcia bajo Aragón, 1/2, pp. 143-44.

35 FERRER I MALLOL, M.T., Organització i defensa..., pp. 352-353. 
comerciales entre ambas coronas en abril de $1301^{36}$, llevaba parejo el paso inevitable de toda afluencia mercantil por Lorca como paso natural.

Con referencia a $\mathrm{D}$. Juan Manuel, es posible que su papel quedase mediatizado o al menos ensombrecido por el protagonismo de los vecinos. Será años más tarde, cuando el autor del Conde Lucanor se «enseñorée» de la villa.

Tras la capitulación de Lorca y la previa caída de Calasparra, Alcaraz se convirtió en la villa-base de frontera del sector Sureste de Castilla frente a Granada, con Mula como vanguardia castellana sobre el núcleo del reino, y Moratalla compartiendo frontera con Aragón -bailía de Caravaca-y Granada. La villa de Lorca, ya bajo dominio aragonés, continuaba manteniendo una doble frontera terrestre, ya que mantenia la granadina y se generaba la septentrional con la vanguardia castellana situada en Mula. Esta villa se convirtió en punto de hostigamiento constante tanto para las tierras bajo dominio aragonés como las de los nazaríes; de ello es buena muestra la petición de Muhammad II a Jaime II de que castigase a Mula por las continuas correrías que realizaban sus vecinos en las zonas orientales granadinas ${ }^{37}$. Lo cierto es que el ambiente de guerra en el reino estaba generalizado, con celadas y algaras constantes por parte de unos y otros ${ }^{38}$.

La estructuración defensiva de la frontera aragonesa con Granada en la zona murciana repetía el sistema castellano, fundamentándose en dos puntos principales: el eje Cahegín-Caravaca al Norte, y Lorca dominando el gran valle de acceso al Levante. El mantenimiento de este esquema defensivo era inevitable y fue llevado a cabo de forma inmediata, habida cuenta que se prolongaba la guerra con Castilla y que se quiso invertir en infraestructuras defensivas y guarnición de Lorca, compuesta en 1303 por cien hombres ${ }^{39}$. En ese mismo año, y coincidiendo con la presencia constante en la villa de Pedro de Monteagudo, Procurador General del Reino, lo que demuestra la importancia estratégica de la plaza, se alude a la necesidad de realizar dos grandes obras en el recinto de la fortaleza, en concreto dos aljibes en las torres Alfonsina y Espolón ${ }^{40}$.

Pero el núcleo principal se asentaba sobre otros enclaves menores, que tejían la tupida red defensiva, como el de Aguaderas, situado también en el valle, y que ya había sido reforzado en tiempos del cerco a Lorca ${ }^{41}$; en este mismo plano se situaban los castillos de Chuecos y Tébar, que capitularon a los pocos días de haber caído la villa lorquina, y que seguirán activos, con una guarnición de 12 hombres.

La utilidad del sistema defensivo se evidenció cuando el sector retomó su

36 MASIÁ, A., Jaume II: Aragó, Granada i Marroc, Barcelona, CSIC, 1989, pp. 118-121.

37 Ibídem, p. 198.

38 Se documentan incluso contingentes musulmanes al servicio de Jaime II que hostigaban toda la tierra circundante que no estaba bajo dominio aragonés, es decir, tierra castellana y también granadina: MASIÁ, M.A., Relación castellano-aragonesa desde Jaime I/ a Pedro el Ceremonioso, vol, I, Barcelona, 1994, p. 144.

39 FERRER I MALLOL, M.T., Organització $i$ defensa..., p. 192.

40 MASIÁ, M.A., Jaume II: Aragó, Granada i Marroc, p. 79.

41 FERRER I MALLOL, M.T., Organització i defensa..., pp. 28-31. 
protagonismo frente a la frontera occidental. La firma de la tregua entre Castilla y Granada en septiembre de 1303 infundió preocupación en las demarcaciones más próximas a la línea ${ }^{42}$, a pesar de las primeras intenciones nazaríes de mantener la tregua con los aragoneses ${ }^{43}$.

Sin embargo, las negociaciones castellano-aragonesas dieron resultado y el acuerdo de Torrellas (8-VIII-1304) precipitó que tan sólo dos días después, la Cancillería de Fernando IV expidiese perdones para Murcia, Lorca, Alhama y Molina ${ }^{44}$. En 1305, este perdón fue confirmado por el rey castellano. Este hecho respondía a la política que se pretendía realizar, de status quo por parte del nuevo adelantado del reino de Murcia, D. Juan Osórez. Lorca sería devuelta a Castilla el 21 de noviembre, la última de toda la serie de devoluciones; la razón no es otra sino que geográficamente era la más lejana de la ruta seguida por el maestre santiaguista y sus mandatarios castellanos.

La Corona castellana retomó el interés por mantener activas las defensas con Granada, aunque de diferente forma a la aragonesa, ya que si ésta había sido de inversión directa, Fernando IV otorgará un nuevo privilegio con el fin de que se autosufragasen las costosas obras ${ }^{45}$. La escasa utilidad de este privilegio va acompañada del fracaso repoblador, que se acentuó tras la ocupación aragonesa. Un buen indicio de este hecho lo ofrece otro privilegio del Emplazado; después de su perdón, dio licencia para reocupar las heredades de los ausentes ${ }^{46}$, lo que significa un proceso de abandono poblacional, desde aquellos que marcharon al llegar los aragoneses, hasta los que huyeron al recuperar la plaza la Corona castellana.

Las relaciones de Castilla con Granada pasarán en los años siguientes por la participación aragonesa, encauzada a través del tratado de Alcalá de Henares. La conquista de Lubrín por el obispo de Cartagena, o la fallida empresa almeriense de Jaime II, fueron acciones ofensivas que no apagaron la presión nazarí en los años siguientes a 1310. Fue precisamente este empuje fronterizo el que proporcionó una nueva configuración de la línea en las dos décadas siguientes, ya que la zona norte santiaguista será reconquistada por los granadinos.

Las treguas de 1310-12 dieron el primer aldabonazo para esa conformación definitiva aludida para este sector, ya que mientras la zona de Cazorla quedó para Castilla, todo el sector sur tornó a manos nazaríes. En esta zona, quedó establecido institucionalmente el arzobispado de Toledo a través del adelantamiento de Cazorla ${ }^{47}$, articulado en una demarcación fronteriza que se extenderá hasta los momentos de la conquista de Baza en 1489. La conquista de Cambil, Alhabar, Belmez -1316 a 1317-y de Tíscar en 1319

42 MASIÁ, M.A., Jaume II: Aragó, Granada i Marroc, pp. 79-81.

43 Ibídem, p. 78.

44 TORRES FONTES, J., Documentos de Fernando $\mathrm{N}$, p. 33, quien recoge también la confirmación de la carta de perdón al concejo de Lorca: p. 45.

45 lbídem, pp. 46-47.

46 Ibídem, p. 48.

47 GARCÍA GUZMÁN, M.M., El Adelantamiento de Cazorla en la Baja Edad Media, Univ. Cádiz, 1985. 
no pudo paliar el desastroso balance en la zona jiennense tras la muerte de los infantes regentes $D$. Juan y $D$. Pedro durante una cabalgada a la Vega granadina.

La otra célula fronteriza, fundamental para la conexión del sector más oriental de la frontera con el núcleo de Castilla, es decir, la zona centralizada por Lorca, estaba controlada por Santiago. Desde que en 1241 Huéscar hubiese caído en manos santiaguistas y al año siguiente, otorgadas a la citada orden las villas de Galera y Orce, todo el sector sufrió una presión muy intensa, ya que abría las puertas de una zona económicamente muy rica en pastizales de invierno. La reacción nazarí tras el desastre de los infantes provocó que en 1324 ismail reconquistara la villa oscense ${ }^{48}$, con el empleo de un ingenio artillero.

La caída de tal enclave provocó una reestructuración de todo el sistema fronterizo, y el planteamiento de la realidad defensiva era procedente para mantener esa estructura. Esta es la explicación más evidente para explicar el nuevo proyecto de repoblación del campo lorquino en 1336, en vísperas del encuentro definitivo en el Salado.

El aspecto del campo lorquino en la primera mitad del XIV era bastante desolador, y si concebimos la frontera como una línea esencialmente humana, la mantenida por Castilla en el sector oriental era de un nivel poblacional muy débil. Por ello, se concibió un nuevo proyecto de repoblación en 1330, paralizado varios años por las maniobras políticas de D. Juan Manuel ${ }^{49}$, y que pretendía dar un nuevo impulso a la instalación de contingentes en la villa. Tras el Salado y la victoria de Sancho Manuel en Velillas -1341-, la frontera se aquietó en las décadas siguientes, no alterada territorialmente hasta la campaña de 1406. Veremos que la actividad fronteriza se concentró en el Norte y Oeste de la línea fronteriza, lo que correspondía a la aludida Banda Morisca de los reinos andaluces. Es la época de la conquista de Alcalá de Benzaide -Alcalá la Real-, y la recuperación de Alcaudete, y de los sitios de las plazas del Estrecho.

Concluyamos diciendo que el sector fronterizo se forjó con las convulsiones interiores más que directas, ya que hemos podido comprobar que no hubo grandes operaciones fronterizas que repercutiesen en cambios sustanciales en la frontera, si exceptuamos la recuperación de Huéscar por Ismail. El proceso repoblador resultó un fracaso, por lo que no hemos de achacar únicamente al desarrollo pestilencial de 1348 como protagonista de la despoblación fronteriza. Es muy significativa la descripción que dio Cánovas Cobeño de la villa de Lorca para estos duros años de implantación castellana y asentamiento fronterizo con Granada; para él, Lorca quedó «reducida a la condición, no de una población regular, sino de una plaza o presidio militar fortificado", realidad que hemos de extender para el resto de núcleos que se mantuvieron habitados.

48 LADERO QUESADA, M.A., Granada..., p. 148.

49 TORRES FONTES, J., Repartimiento de Lorca, 1994, pp. LXXXVI-XC. 
. 


\title{
LA SITUACIÓN POLÍTICA DE CASTILLA A FINES DEL SIGLO XIII
}

\author{
Miguel-Ángel LADERO QUESADA
}

La conquista del reino de Murcia por Jaime II en 1296 y la incorporación de una parte del mismo a la Corona de Aragón, integrándolo en el de Valencia, en 1304, es el objeto o motivo principal de este Congreso y, a siete siglos de distancia, podemos considerarla en sí misma, analizando los detalles de la intervención militar y el juego de relaciones políticas entre los reinos de Aragón, Castilla, Portugal, Granada y Francia que la hicieron posible, o bien podemos situar aquellos acontecimientos en contextos temporales y argumentales mayores, de tipo geohistórico, estructural y coyuntural pero sin perder de vista que los sucesos no fueron consecuencia necesaria 0 resultado ineluctable de esas tendencias y realidades históricas más amplias sino una posibilidad —la que realmente ocurrió — entre otras que también podrían haber ocurrido. Procuraré combinar ambos procedimientos, estudiando la cuestión desde el punto de vista castellano para permitir su contraste con los que han adoptado otros ponentes.

\section{ESTRATEGIAS DE EXPANSIÓN Y COLONIZACIÓN}

La primera intención de control político del Levante andalusí por parte de los reyes de Castilla y León se había manifestado con el establecimiento de protectorado militar y percepción de parias sobre el taifa de Zaragoza, desde los últimos años de Fernando I y en el reinado de Alfonso VI, y con las actividades de este monarca en el S.E. (dominio del enclave de Aledo) y, en especial, del Cid, que bloquea los intentos de cobro de parias y control militar de los condes de Barcelona y domina Valencia durante unos años. El intento se producía dentro de un proyecto político muy ambicioso, que buscaba la sumisión indirecta de los poderes andalusíes a Alfonso VI como Imperator totius Hispaniae. El proyecto terminó definitivamente con la incorporación de aquellas tierras al dominio almorávide, proceso coetáneo a la crisis política que 
padece el reino castellano-leonés tras la muerte de Alfonso VI (1109) y al éxito de Alfonso I de Aragón como conquistador del valle medio del Ebro (toma de Zaragoza, 1118).

Cuando Alfonso VII quiso reconstruir el edificio político del Imperio hispánico, las circunstancias y el reparto de poder habían variado mucho tanto en la España cristiana como en al-Andalus, de modo que una estrategia de control del eje del Sistema Ibérico y de expansión hacia el Levante andalusí tenía que partir de otros supuestos ${ }^{1}$. Al morir Alfonso I de Aragón (1134), intentó por un momento tomar el control de Zaragoza, pero se avino a reconocer el dominio del Regnum Caesaraugustanum por Ramón Berenguer IV como princeps de Aragón por sus esponsales con Petronila, y continuó además otra vía de intervención en al-Andalus, en especial en Levante mediante la protección a Abu Sha'far Ahmad ben Hud, Sayf al-Dawla (Zafadola), hijo del último rey musulmán de Zaragoza. Tras la muerte de éste, en 1146, tomaría su lugar en Murcia y Valencia, Muhammad ben 'Abd Allah ben Sa'ad ben Mardanish, frecuente aliado de Alfonso VII y de sus sucesores contra los almohades hasta su muerte en 1172.

Mientras tanto, se producían los primeros tratados entre Aragón y Castilla destinados a delimitar las futuras zonas de conquista en torno al eje de la cordillera lbérica. En el de Tudellén, 1151, se trató por una parte del reparto de Navarra y, por otra, Alfonso VII reconoció a Ramón Berenguer IV los reinos de Valencia, Denia y Murcia como zonas de su conquista dentro del vasallaje que le prestaba como Imperator totius Hispaniae. En el de Cazola, 1179, donde también debió tratarse de Navarra, Alfonso VIII de Castilla suprimió el vasallaje debido por Alfonso II de Aragón, y le reconoció el reino de Valencia como zona de expansión, pero el de Murcia - al S. de la línea BiarJátiva- sería para Castilla.

En el contenido de estos tratados influían los proyectos a largo plazo pero, sobre todo, las circunstancias próximas y el conocimiento de las propias fuerzas y de los objetivos en los que preferentemente debían emplearse, de modo que interpretarlos con puntos de vista más recientes puede ser inadecuado. Parece bastante claro que, más allá de la cuenca del Ebro y del macizo de Teruel, desaparecía entonces la capacidad real de expansión y colonización territorial catalana y aragonesa -como lo muestra la larga vida del señorío independiente de Albarracín-, y que Alfonso Il estaba interesado con mucha mayor frecuencia en empresas occitánicas y mediterráneas. Alfonso VIII, por el contrario, contaba con recursos militares y de colonización mucho mayores y mantuvo siempre como principal objetivo la expansión territorial en la península.

1 Son muy interesantes las consideraciones que hace J.M. LACARRA DE MIGUEL, "Acerca de las fronteras en el valle del Ebro (siglos VIII-XII)", En la España Medieval, 1 (1980), 181-191. Algunas reflexiones de conjunto en mis trabajos, "Cordillères et fleuves dans la formation de l'Espagne médiévale", en J. Fr. Bergier, ed., Montagnes, Fleuves, Forêts dans l'Histoire. Barrières ou lignes de convergence?, Scripta Mercaturae Verlag, St. Katharinen, 1989, pp. 71-83, y, "Las regiones históricas y su articulación política en la Corona de Castilla durante la Baja Edad Media", En la España Medieval, 15 (1992), 213-147. 
Estas premisas, más la reunificación castellano-leonesa desde 1230, contribuyen a explicar la forma en que se produjeron las grandes conquistas a costa de al-Andalus, entre 1225 y 1265 . El tratado de Almizra (1244) refleja la realidad de las fuerzas y las capacidades en presencia: Fernando III, y en su nombre el infante heredero Alfonso, sujetaba a protectorado al taifa de Murcia y consolidaba el ámbito de expansión fijado en Cazola, al S. del puerto de Biar y de Játiva, no sin algunos roces previos al acuerdo; unos años antes, en 1232, al ofrecer protección al taifa de Niebla, el rey había efectuado una maniobra semejante, destinada a pre-fijar la frontera con Portugal en el Guadiana, pero con este reino no había tratados de reparto tan nítidos que debieran ser objeto de revalidación o cambio.

Jaime I respetó los límites fijados en Almizra cuando entró en Murcia, año 1266, para sofocar la revuelta de los mudéjares, en apoyo de su yerno Alfonso X. Además de cumplir lo pactado, actuaba inteligentemente pues la situación en Valencia era también muy tensa; añadir un nuevo ámbito de responsabilidad habría aumentado la carga a soportar mientras que mantenerlo en manos de un aliado frente al peligro común la disminuía. ¿Tiene este mismo sentido su cooperación a la repoblación de Murcia con colonos catalanes y aragoneses o, por el contrario, era parte de un proyecto de incorporación que entonces se vio frustrado pero que no dejaría de tener repercusiones en los acontecimientos futuros? ¿Corresponden a la realidad o son argumentos creados a posteriori las protestas de nobles catalanes y aragoneses ante la actitud de Jaime I, y la actitud del heredero Pedro, que participó en la campaña y manifestó su deseo de modificar lo tratado en Almizra e incluso de reservar una parte del reino de Granada - la de Almería - a la conquista catalano-aragonesa?

Es muy posible que la breve pero importante obra repobladora de Jaime I en Murcia se inscriba en un proyecto más amplio de control de las costas del SE. peninsular, con o sin dominio político directo. Importa establecer su alcance y dimensiones lo mejor posible, deslindar lo que es propaganda de lo que puede ser realidad, y no inferir de la procedencia de los colonizadores una inmediata consecuencia política; aunque hubieran querido permanecer bajo dominio de Jaime I, lo que no sucedió, ¿hay que suponer que todos ellos o, más bien, sus descendientes, mantenían aquel criterio treinta años después por motivos "nacionales»?, ¿no es preferible pensar que se plantearían la cuestión de acuerdo con criterios prácticos y próximos, de acuerdo con las posibilidades vivas en 1296? La fijación posterior de la frontera, de los poderes y de las poblaciones durante siglos puede llevar a interpretar erróneamente realidades y actitudes anteriores menos sensibles hacia quién fuera el rey titular del poder, siempre que contara con títulos legítimos, actitudes que serían propias tanto de gobernados como de gobernantes: recordemos los proyectos de disgregación de reinos en los testamentos de Jaime $I$, e incluso en el de Alfonso $X$ en el suyo de 1284.

Los estudios de Torres Fontes sobre la repoblación de Murcia muestran, por otra parte, que la de Jaime I fue sólo una de las fases colonizadoras, la segunda entre seis, y no la más importante, destinada a dotar con abundantes tierras a pocos «hombres de valor», en torno a un centenar. En realidad, la llegada de colonos procedentes tanto de Castilla como de la Corona de Aragón fue intensa hasta 1277 y continuó con 
dificultades hasta la última década del siglo, antes de 1296, permitiendo el asentamiento de unos 5.000 vecinos «heredados» con sus familias en todo el reino, procedentes la mitad aproximadamente de la Corona de Aragón y otros tanto de Castilla, instalados principalmente en Murcia, Lorca, Orihuela, Alicante, Elche, Cartagena y Mula, mientras que la cifra de población mudéjar disminuía mucho desde 1277 en adelante ${ }^{2}$. Cuando la sentencia arbitral de Torrellas disponga, en 1304, la partición del reino de Murcia, parece que sus vecinos cristianos, independientemente de su origen, permanecerian en una u otra parte: habría cambios, sin duda, sobre todo en los grupos dominantes, pero no tenemos noticias de emigraciones masivas para ubicar a la población de nuevo según el origen catalano-aragonés o castellano suyo o de sus inmediatos antepasados.

\section{FIN DE LA RECONQUISTA Y CAMBIOS POLÍTICOS ESTRUCTURALES}

Hacia 1264 concluye el tiempo de grandes conquistas, coincidiendo con la frustrada revuelta mudéjar en Andalucía y Murcia y con la nueva definición de las relaciones entre Castilla y el emirato vasallo de Granada. Pasados otros diez o quince años, entre 1275 y 1280 , se puede dar por terminado el proceso colonizador, en sus grandes aspectos, al tiempo que Castilla había de hacer frente a la nueva situación de guerra producida por los desembarcos merinies en el S., entre 1275 y 1286. Así, en el plazo de veinte años, el escenario tradicional de la política castellana durante dos siglos -conquistas y «repoblaciones»- había desaparecido. En relación con este hecho, pero no sólo por causa suya, ocurrieron por entonces cambios fundamentales en las grandes líneas de la organización y de la acción política del reino.

\section{En los orígenes de la crisis}

Hay pocas dudas sobre el hecho de que la capacidad de expansión territorial acompañada de procesos repobladores había alcanzado un límite, hacia 1275, tanto en Castilla como en Aragón o Portugal. Se ha supuesto a menudo que el esfuerzo grande y rápido de colonización alteró y deterioró el equilibrio de las relaciones económicas y sociales, y de la misma población y su reparto, en Castilla, siendo origen de diversas alteraciones políticas favorables, en definitiva, a la oligarquización en el ejercicio del poder y al estallido de crisis empobrecedoras. Que haya habido una crisis estructural entre 1265 y 1330 aproximadamente, parece cierto y general, pero tal vez no lo es buscar la causa única o principal en un hecho tan específico porque fenómenos tales como las alteraciones monetarias, el alza de precios, el reajuste socio-político que afecta a todo el país, o las mismas crisis económicas más profundas afectaron igualmente a otros países que no tenían los problemas de frontera y colonización propios de Castilla.

2 Un resumen de sus trabajos, J. TORRES FONTES, «Los repartimientos murcianos del siglo XIII", en De al-Andalus a la sociedad feudal: los repartimientos bajomedievales, Barcelona, 1990, pp. 71-94. También sus estudios y ediciones, La reconquista de Murcia en 1266 por Jaime I de Aragón, Murcia, 1967, Repartimiento de Lorca, Murcia, 1977, Repartimiento de Orihuela, Murcia, 1988. 
El dominio de las nuevas tierras, e incluso el peligro de la frontera en el S., tenía también aspectos favorables: permitía la colonización y disminuía, con ello, riesgos de superpoblación. Permitía también la plena organización del espacio castellano-leonés, la atribución de tierras, la extensión del sistema urbano y de relaciones mercantiles, el desarrollo de la trashumancia ganadera, la apertura de una fachada marítima de primera categoría económica, como era la Andalucía atlántica, la práctica del oficio militar y la ocupación de rentas, parias y botín por parte de la aristocracia, en relación con él. ¿Por qué hubo de ser todo esto, considerado en sí mismo, sólo una fuente de distorsiones, crisis y retroceso de la riqueza del reino?

Los origenes de la crisis hay que buscarlos más bien en la tensión creada por el proyecto político de incremento del poder en manos de la monarquía, que en Castilla se desarrolla desde el reinado de Alfonso $X$, y en otros aspectos de cambio en los anteriores equilibrios de reparto de poder y renta. También, en la reiteración de problemas sucesorios y minoridades regias entre 1275 y 1325 , que facilitaban los enfrentamientos violentos y la abundancia de abusos y depredaciones con su secuela de ruina, empobrecimiento y despoblación. A esto se añadían las apetencias de los reinos comarcanos, tendentes a disminuir la fuerza política de Castilla. También, la endémica guerra del sur - la llamada «batalla del Estrecho»-, que resultó muy gravosa social y económicamente, sobre todo en Andalucía y, además, frenó y distorsionó el proceso repoblador del sur y sus resultados sobre la propiedad y uso de la tierra.

Los orígenes de la crisis están también, desde luego, en las modificaciones de la estructura económica debidas a la primera gran expansión de la actividad mercantil, tanto interna como exterior, y de los instrumentos monetarios, con desmedidos efectos inflacionistas. Y en la pugna de los grupos sociales con fuerza política por adaptarse a los nuevos modos de percepción de renta y librarse de los malos efectos que provocaba el deterioro o ruina de alguno de los antiguos. $Y$ en los cambios paulatinos en el régimen de explotación de la tierra, que beneficiaban a unos grupos más que a otros. $Y$, posiblemente, en la incidencia especial de calamidades naturales, más frecuentes desde comienzos del siglo XIV -pensemos en la carestía y hambre de 13011302-, que coadyuvaron al comienzo de una larga fase de recesión poblacional.

La valoración combinada de estos factores, y aun de otros, puede ser diversa pero tiene que evitar apriorismos interpretativos. Parece claro que su presencia combinada, en forma de haces cambiantes según lugares y momentos, explica mejor los orígenes y el desarrollo de la crisis que no la apelación a un solo factor dominante, ya sea local o general ${ }^{3}$.

3 Estos aspectos están tratados y anotados con mayor extensión en mi trabajo, «La Corona de Castilla: transformaciones y crisis políticas (1250-1350)", en Europa en los umbrales de la crisis (12501350), Pamplona, 1995, pp. 275-322 (XXI Semana de Estudios Medievales, Estella, 1994). 


\section{El crecimiento del poder real}

Me centraré ahora en cuestiones relativas a los cambios en el ejercicio del poder real y en sus relaciones con la sociedad política porque su conocimiento permitirá explicar mejor el trasfondo de los sucesos ocurridos entre 1295 y 1304.

El ejercicio del poder real entre Alfonso $X$ y Alfonso XI ha abarcado ámbitos relativamente nuevos y se ha practicado en circunstancias distintas a las de tiempos anteriores. Hubo un desarrollo de los fundamentos y los instrumentos del poder, ocurrido dentro del marco de transformaciones amplias en las relaciones entre sociedad y poder real: en la segunda mitad del siglo XIII culminó el desarrollo de lo que se ha venido denominando «Estados estamentales", formados sobre una teoría política que integra diversos estamentos socio-jurídicos y diversas realidades territoriales en un cuerpo común, el reino, cuya cabeza es el monarca. De esta concepción del reino como universitas se deducen unos corolarios de unidad e indivisibilidad del conjunto, de vasallaje natural de todos sus habitantes con respecto al rey, y de justificación del orden social establecido sobre la base de desigualdades y jerarquías regladas para cada estamento, con lo que se legitima a la vez al rey como cabeza sin la que no puede existir el cuerpo político, y a diversos sectores como "sociedad política» cuya participación en el poder es indispensable: la alta nobleza, las jerarquías eclesiásticas, los grupos dominantes en los ámbitos locales. Es, en suma, una concepción política que supera, integrándolas, las diversidades y peculiaridades propias del orden feudal - cuyas manifestaciones son tan diversas en unos y otros reinos- y que sustenta un conjunto de ideas sobre el poder y su ejercicio que no admite criterios de cambio constitucional impuestos por las crisis políticas o las luchas sociales. Pero como éstas existen, los cambios también, sobre todo cuando protagonizaban la demanda grupos sociales con fuerza suficiente para modificar la realidad del poder aunque respetando siempre los fundamentos de su estructura estamental y de su configuración en torno a la realeza.

En el desarrollo del estado monárquico bajomedieval hubo dos posibilidades que desembocaron en resultados relativamente distintos. La primera es la posibilidad autoritaria, que concentra poder en la institución regia: en ella, el rey es el único polo constitucional y ejerce el poder sin limitaciones constitucionales apreciables, aunque las tenga fácticas, y muchas con frecuencia. Desarrolla la posibilidad de un estado más fuerte, compacto y dinámico en el que la potencia regia y su control de algunos resortes de cambio en las relaciones de poder son compatibles con una efectiva supremacía social y política de los grupos dominantes. Frente a este modelo que, en definitiva, permanece más abierto desde el punto de vista regio, la posibilidad pactista se basa en la presencia de dos polos constitucionales, el rey y el reino o sociedad política, compartimentada en varios estamentos con gamas de intereses no coincidentes. La realeza está inserta en unas redes sociopolíticas poco flexibles y de escasa movilidad como tales, a no ser que los grupos dominantes tengan el dinamismo adecuado para promoverla porque, por su parte, la realeza-Estado apenas puede emerger más allá de los intereses estamentales. 
En su caminar político entre los siglos XIII y XVI, Castilla y Portugal se organizaron más bien según el primer modelo y Aragón a tenor del segundo, pero al comenzar la segunda mitad del siglo XIII todo estaba por hacer, a partir de tradiciones y situaciones distintas, cosa que siempre conviene recordar. Alfonso $X$ aprovechó las castellano-leonesas para sentar las bases doctrinales y comenzar el desarrollo institucional de un proyecto político en torno al poder real que llevaba al desarrollo de la soberanía y el absolutismo monárquicos. Las reacciones sociales desde 1272 y las crisis políticas desde 1275 matizaron su desenvolvimiento, que estuvo casi bloqueado en muchos aspectos hasta 1325-1330, y se produjeron reajustes tocantes a la consolidación del poder social -y de la participación política - de la alta nobleza y de las aristocracias locales, poder y participación que se renuevan y desarrollan ampliamente a lo largo de toda la baja Edad Media.

Este análisis de las transformaciones del poder real en aquellos primeros tiempos de cambios y crisis ha de referirse a tres aspectos fundamentales: el desarrollo de las doctrinas políticas y de los fundamentos legales e instituciones de gobierno en primer lugar. La creación de un sistema hacendístico nuevo, en segundo, para considerar por último las características y campos de acción de la política económica regia ${ }^{4}$.

\subsection{Teoría política, leyes, instituciones}

La obra legislativa de Alfonso $X$ tiene una importancia decisiva en la organización y en la misma concepción política de la sociedad bajomedieval castellana. El monarca «no promovió ninguna maniobra formalmente derogatoria del Derecho consuetudinario» (J. M. Pérez-Prendes) pero intentó elaborar una obra legislativa escrita basada en el Derecho Común, capaz de arrinconar al derecho consuetudinario y no escrito en unos casos (Espéculo, Partidas) y de limitar los poderes señoriales y acrecentar los de las ciudades realengas en otros (Fuero Real). La obra legislativa alfonsina hizo crisis en la coyuntura de la revuelta nobiliaria de 1272 pero su influencia perduró: los reyes que le sucedieron se limitaron a legislar por ordenamiento y a menudo sobre cuestiones concretas, y es bien sabido como Alfonso XI, en el promulgado en 1348 ante las Cortes de Alcalá de Henares, fijó el orden de prelación de fuentes jurídicas en su uso por los jueces: primero, la legislación real; segundo, los fueros municipales en uso, salvo «lo modificable a criterio real»; tercero, las Partidas; cuarto, el criterio del rey, en cuanto que sólo a él «corresponde el aclarar, enmendar, suplir e interpretar cualquier laguna de la ley».

4 Resumo puntos de vista y contenidos expresados en otros trabajos míos, especialmente: «La genèse de l'État dans les royaumes hispaniques médiévaux (1250-1450)", en Le premier âge de l'État en Espagne. 1450-1700, Paris, 1989, pp. 9-65, «El ejercicio del poder real en la Corona de Aragón: instituciones e instrumentos de gobierno. Siglos XIV y XV», En la España Medieval (Madrid), 17 (1994), pp. 31-93, "Algunas reflexiones generales sobre los orígenes del Estado Moderno en Europa», en La historia política europea como proceso integrador, Buenos Aires, Asociación Argentina de Profesores Universitarios de Historia de Europa, 1995, pp. 27-46, «Poderes públicos en la Europa medieval (Principados, Reinos y Coronas)", XXIII Semana de Estudios Medievales de Estella, julio 1996 (en prensa), y el ya citado "La Corona de Castilla: transformaciones y crisis políticas...". 
En las Partidas se contiene una exposición doctrinal sobre los fundamentos de la vida política, en especial sobre el oficio regio, y también un «diseño de funciones y competencias sobre el que el rey establece un marco institucional preciso y diversificado de la administración militar, financiera, jurisdiccional y del gobierno de la casa, corte y cancillería" (R. Pérez-Bustamante). En ambos aspectos, los textos alfonsinos abren un tiempo nuevo en la historia castellana -y aun hispánica en general pues las Partidas se tradujeron al catalán y al portugués--, más allá de su vigencia o aplicación. Algo semejante cabe decir en lo que se refiere a la fundamentación de la vida política en una conciencia de identidad que se plasma, aprovechando una ya larga tradición, en la obra historiográfica alfonsí (Estoria de España o Primera Crónica General). Muchas transformaciones de las ideas y las prácticas políticas dependen de este fundamento durante toda la Edad Media tardía, e incluso en los tiempos modernos.

Por otra parte, Alfonso $X$ no fue ese «intelectual inadaptado a la vida activa» política que a menudo se ha imaginado sino el promotor de innovaciones institucionales concretas de primera importancia en todos los ámbitos del gobierno y la administración regios. En lo que se refiere a los oficios de la casa real, conserva los dos principales, Mayordomo y Alférez, al tiempo que potencia o crea otros: en el primer aspecto, el oficio de Repostero Mayor — que cederá mucha de su importancia al de Camarero Mayor en tiempos de Sancho IV-. En el segundo, establece los de Almirante Mayor y Justicia o Alguacil Mayor, así como los Alcaldes de Corte (1274), que debían entender en los llamados «casos de Corte»: la promoción de la justicia regia mediante éstas y otras instituciones es una de las claves principales del programa político alfonsí. La cancillería regia se tecnificó con la creación de los Notarios Mayores de León, Castilla y Andalucía, a los que se añadiría otro para el reino de Toledo en 1295 al comenzar la minoría de Fernando IV, cuando se vino abajo la potencia política del arzobispo de Toledo y canciller mayor, Gonzalo Pérez Gudiel. Alfonso X introdujo también una concepción y un reparto nuevos de las delegaciones territoriales del poder real al crear entre 1253 y 1263 la figura de los Adelantados Mayores de la Frontera (Andalucía), Castilla, León, Murcia y Galicia, sustituyendo en los territorios donde los había antes a los Merinos Mayores. Aunque éstos reaparecen entre 1268 y 1272 y el régimen de Adelantamiento sufre un eclipse temporal, se había creado un marco jurídico-administrativo que llegaría a su madurez un siglo después, en época de Enrique II.

Las reformas alfonsinas abrieron un proceso de institucionalización del ejercicio del poder que continuaría durante toda la baja Edad Media porque subsistieron y fueron objeto de perfeccionamiento en los reinados siguientes. En los inmediatos, apenas encontramos novedades, salvo en lo que se refiere a los intentos de constitución de un Consejo del rey estable en las minoridades de Fernando IV y, en especial, de Alfonso XI, y a la paulatina aparición de la Audiencia en la corte regia, que se detecta en 1312 y, de nuevo, a mediados del siglo XIV.

Las reformas y desarrollos institucionales son característicos de todos los reinos occidentales durante la Edad Media tardía pero la precocidad y energía con que las promovió Alfonso $\mathrm{X}$ en Castilla tienen mucho de singular y contribuyen a explicar, junto con otras causas, la potencia política indiscutida que el poder y la justicia regias 
tuvieron pese a los momentos de debilidad práctica, a los compromisos de facto 0 al control, también fáctico, por otras fuerzas sociopolíticas.

\subsection{Fiscalidad, moneda, política económica}

Por su parte, la creación de un nuevo sistema de Hacienda regia fue un terreno en el que la capacidad de innovación y diseño de un nuevo orden político propia de Alfonso $X$ se manifestó con especial claridad y en el que sus iniciativas tuvieron continuidad e influencia desde el primer momento y proporcionaron a sus sucesores un instrumento político de primera importancia. La obra alfonsina no comenzó, en estos aspectos, de manera escalonada, a partir de 1252, sino abruptamente, para responder a la crisis producida por la revuelta mudéjar de 1264, por el aumento de precios y por el de las necesidades financieras de la monarquía causado por la alianza con Francia — boda del heredero Fernando en 1269-y por los costos del fecho del Imperio. El rey venía obligado a ello, también, porque de la Hacienda regia dependía una parte notable del nivel de rentas de la alta nobleza e incluso de los caballeros ciudadanos, que percibían tierra -en dinero- como vasallos del rey, y participaban por esta vía, y por otras, del poder político regio, y parece claro que esa parte se incrementó en los años que ahora estudiamos, debido al empobrecimiento o quiebra de otras fuentes de renta de la aristocracia.

La secuencia de innovaciones muestra cómo el rey comenzó a pedir y recibir servicios extraordinarios, otorgados por las Cortes, desde 1269. Cómo aumentó enormemente la cabeza de pecho que pagaban los judíos, desde 1280. Cómo hizo respetar las diversas regalías fiscales - salinas, minas-. Cómo conservó para la Corona todos los almojarifazgos del sur, y en su seno comenzaron a percibirse las primeras alcabalas regias sobre las compraventas. Cómo organizó el régimen aduanero con un tipo general del diez por ciento, en especial desde 1268, y estableció al año siguiente un servicio sobre los ganados trashumantes. Además, desde 1265 se consolidó la percepción de ingresos sobre las rentas eclesiásticas y la recaudación de limosnas para la cruzada, mediando permiso pontificio; al primero de ambos aspectos corresponde el cobro de los dos novenos del diezmo eclesiástico (tercias reales) y de décimas sobre el conjunto de la renta eclesiástica.

Así, Alfonso X introducía novedades importantísimas que permitían concentrar más renta en manos del rey $y$, con ello, más medios de poder. Es cierto que su obra hubo de sufrir el contragolpe de las resistencias puestas por el reino en las Cortes, y el de los abusos y anarquía nobiliaria, en especial durante las minoridades regias, debidos en parte a los desajustes que las nuevas formas de percepción y distribución de renta generaban, pero lo cierto es que las clases privilegiadas hubieron de consentir y colaborar en aquel aumento de la presión fiscal, que apenas les afectaba directamente, porque, en definitiva, beneficiaba a su propio nivel de rentas y a su poder. De hecho, todas las iniciativas de Alfonso $X$ sobrevivieron porque los antiguos derechos y rentas ciertas de la Corona estaban ya consignados en su casi totalidad al pago habitual de tierras a nobles vasallos del rey o del heredero del trono, según se demuestra en los 
libros de cuentas de 1290 y 1292, y gran parte de los nuevos ingresos tenían como destino pagar servicios y colaboraciones de miembros de la sociedad política.

Unos decenios más tarde, desde 1333 y 1342, Alfonso XI generalizó el cobro de alcabala, consolidando las esporádicas imposiciones de sisas que habían efectuado Sancho IV y Fernando IV $(1292,1309 . .$.$) , reformó el cobro del monopolio de la sal y$ recuperó la casi totalidad de los montazgos que pagaba el ganado. Es difícil cuantificar la presión fiscal introducida por aquellas reformas. El análisis de las cuentas de 1290-1292 y las de la Frontera de 1294 sugiere que las rentas y derechos ciertos o tradicionales podían ascender a unas 200.000 doblas de oro, con tendencia a disminuir fuertemente debido a las quiebras monetarias. A pesar de este factor, y de las dificultades e irregularidades en el cobro, las novedades hacendísticas habrían permitido multiplicar por tres esta cifra y situar los ingresos anuales de la monarquía en torno a unas 600.000 doblas anuales hacia 1345 .

Las reformas fiscales y sus efectos sobre el orden político y social no pueden comprenderse al margen de otras formas de influencia e intervención política sobre la economía del reino que el mismo Alfonso $X$ también, si no inició, al menos les dio una dimensión y un sesgo nuevos. La intervención más directa se refiere a la moneda, cuya acuñación era regalia efectivamente mantenida. Es posible que los reyes no llegaran a percibir el cúmulo de consecuencias que desencadenaban con sus medidas, salvo en lo relativo al régimen de precios, en el que también procuraron intervenir promulgando tasas $(1252,1258,1268)$, pero la medida principal de Alfonso $X$ fue acuñar en mayor cantidad moneda de vellón e incluso de plata para aumentar la masa monetaria en circulación con piezas más útiles que la de oro para los intercambios interiores y para los tráficos con el exterior. Lo hizo, sin embargo, movido por motivos políticos inmediatos: desde 1258, las pretensiones del rey al título imperial comenzaron a provocar salidas de plata fuera de Castilla. La revuelta contra Granada y la guerra contra Granada de 1264-66 dispararon los gastos militares y llevaron a Alfonso X a acuñar los llamados dineros alfonsíes, moneda de la guerra, blancas o blanquillas, quebrando la ley de la moneda anterior. En 1270-1271 ocurrió otra quiebra al acuñarse los llamados dineros prietos y otra más en 1275 cuando se acuñó moneda nueva blanca: entre 1265 y 1278, la inflación de precios expresados en moneda de vellón fue superior al 500 por 100 . Sancho IV procedió a un nuevo abatimiento o quiebra de moneda al acuñar coronados que recibieron el nombre de novenes, y Fernando IV durante su minoridad disminuyó su ley en una nueva acuñación, acuciado por la escasez de moneda circulante y por el efecto que estaban causando las falsificaciones. Las devaluaciones y la escasez de moneda en uso continuaron al menos hasta 1332.

El medio más simple para medir aquel proceso inflacionario consiste en contemplar cómo evoluciona el valor de la dobla de oro (4.60 g.) expresado en maravedies, pues el maravedí ya en 1268 era una moneda de cuenta, equivalente a 90 blancas. Pues bien, en 1268 la dobla vale legalmente todavía tres mrs., en 1291 de 20 a 22, en 1310,25 y en 1350,35 .

Las medidas hacendísticas y monetarias de Alfonso $X$ se complementan con otras tendentes a regular la actividad mercantil, que son también una novedad desde los 
años sesenta y crean un vínculo entre política regia y realidad económica antes inexistente o mucho más débil. Las actuaciones alfonsíes recaen sobre una actividad mercantil en auge desde las últimas décadas del siglo XII. Ocurre además cuando el fin de la expansión territorial exige una reorganización del conjunto cuya iniciativa sólo puede corresponder a la monarquía, y más teniendo en cuenta sus intereses hacendísticos y monetarios. En líneas generales, la política regia buscaba liberalizar, dar la mayor fluidez posible al tráfico interior de bienes, al tiempo que se establecían claramente las aduanas con el exterior: ambos aspectos podían lesionar intereses de otros poderes, así como la creación y promoción de numerosas ferias en el realengo y la organización de las cañadas de trashumancia ganadera ${ }^{5}$.

\section{Las relaciones entre poder real y sociedad}

En resumen, es difícil sustraerse a la idea de que el conjunto de hechos ocurrido sobre todo entre 1264 y 1281 ha sido más bien una causa que una consecuencia de los procesos de cambios y crisis: aumento de las necesidades financieras de la monarquía, guerras y revueltas, alteraciones monetarias, innovaciones hacendísticas, nueva política económica. Todo ello alteraba las anteriores relaciones entre poder monárquico y sociedad, y los grupos sociales con gran capacidad de intervención o participación en el poder político tenían que reclamar y proponer, de manera más o menos consciente y definida, reorganizaciones del mismo acordes con los intereses no tanto de un individuo o bando sino también de cada grupo como tal. Veamos cómo se abordó esta cuestión por la alta nobleza, por las aristocracias locales y por los dirigentes eclesiásticos.

\subsection{La nobleza}

La alta nobleza pretendió compartir y mediatizar el poder regio pero, en general, no obstaculizó el proceso de renovación y maduración institucional de los órganos de gobierno monárquicos. Ambos aspectos eran compatibles, de modo que no hubo grandes disputas sobre los cambios en lo que podríamos llamar la arquitectura del poder sino en torno a su uso y control. Sucedía aquello en una situación de cambios en el sistema económico y de inevitable transformación de las fuentes de renta, lo que produjo desajustes y tensiones en la relación entre monarquía y nobleza. Ésta actuó formando bandos poco estables, encabezados por parientes del rey o por miembros de las grandes familias que eran, a la vez, altos cortesanos — Lara, Haro-, sin espíritu de grupo homogéneo ni programa común tal como los llegaría a tener la nobleza que comenzó a aglutinarse en torno a Enrique de Trastámara a mediados del siglo XIV. De hecho, los nobles vieron la posibilidad de satisfacer sus aspiraciones más inmediatas

5 Estudio detallado de muchas de estas cuestiones en mis libros, Fiscalidad y poder real en Castilla (1262-1359), Madrid, Universidad Complutense, 1993, y Las ferias de Castilla. Siglos XII a XV, Madrid, Real Academia de la Historia, 1994. 
apoyándose en las disputas internas de la familia real y en las turbulencias de las minoridades regias: en tales circunstancias, era muchas veces más urgente para unos nobles contrapesar el poder de otros que no formar un frente político común ante la realeza comparable al que había conseguido la nobleza de Aragón en 1282. Por todas estas razones, la actitud nobiliaria entre 1272 y 1325 dio lugar a numerosos desórdenes y alteraciones pero sus resultados en cuanto a vincular por pacto a la monarquía en determinadas coordenadas político-jurídicas fueron nulos y, al cabo, ésta sería la fórmula castellana: los nobles se integran en el poder del rey y lo encaminan hacia su beneficio pero no lo limitan jurídicamente como estamento.

Uno de los grandes argumentos de la historia política durante todo el período fueron las reclamaciones económicas de la nobleza, por la necesidad de suplir con entrega de sueldos y mercedes regias, e incluso con cesiones de jurisdicción a favor de diversos señores en algunas aldeas y villas, la escasez de botín y territorio a repartir, a lo que se añadió la exigencia nobiliaria de que la repoblación de las nuevas tierras y el establecimiento de impuestos regios también nuevos no alteraran ni sus privilegios ni el dominio que ejercían sobre sus solariegos campesinos. Así sucedió que en diversas ocasiones, a partir de 1252, aumentaron los reyes las cantidades asignadas a sus vasallos nobles en concepto de sueldo, así como el número de sus beneficiarios, utilizando para ello las rentas ciertas o foreras, los servicios de las Cortes y otros ingresos, y completándolos con entrega de tenencias de castillos, cesión total o parcial de rentas de diversos lugares, más otros procedimientos diversos, en especial, desde tiempos de Sancho IV, la cesión de aldeas en señorío o heredamiento aunque la «señorialización» estaba todavía muy lejos de alcanzar las enormes dimensiones que tendría en época Trastámara.

A partir de 1295, la capacidad fiscal del reino debió disminuir, empobrecido por guerras, exacciones excesivas, rapiñas y malfetrías de poderosos, quiebras anteriores de moneda, cesiones de lugares en heredamiento, y por la coyuntura creada por malas cosechas. Un cálculo de las rentas regias hecho en 1315 reconocía su mengua, pero no por ello es menos significativo: las rentas ciertas o foreras ascendían a 1.600.000 maravedíes más lo de la Frontera, que sería otro millón, y estaba consignado casi todo a sueldo de ricos hombres y caballeros, pero estos sueldos absorbían mucho más y se estimaba que sería preciso un servicio de Cortes de ocho monedas - de un millón de maravedíes cada una - para pagarlos y atender a los gastos, mucho menores, de mantenimiento del rey y su corte. Veinticinco años atrás, cada moneda de un servicio de Cortes rendía 1.5 millones y bastaban cinco monedas para tales menesteres: cuatro para sueldos y una para el gasto de la casa y corte reales.

\subsection{Las aristocracias locales}

Las aristocracias que dominaban los concejos de realengo no eran un conjunto homogéneo en el que las partes aceptaran un programa de acción política común y único. Sin embargo, la actuación colectiva de los concejos, desde mediados del siglo XIII a mediados del XIV, fue mucho más coherente que la de la alta nobleza con la 
idea de conseguir un pacto con los reyes acerca del ejercicio de su poder puesto que les afectaba de manera directa y gravosa al ser ellos el realengo ${ }^{6}$.

Alfonso $X$ había sido un gran coordinador de la vida política concejil: los concejos no actuarían, según su proyecto, como células de acción contrarias o independientes con respecto al poder regio - nunca lo habían sido-sino que dependerían en buena parte de su voluntad y formarían un sector de la sociedad política estrechamente vinculado a él, de modo que sólo a través de las iniciativas de la monarquía se comprenderia la mayor parte de su actividad, ejecutada por grupos de caballeros y hombres buenos, vasallos del rey que ejercerían los principales oficios concejiles. Este diseño político, como otros del Rey Sabjo, hizo crisis desde 1282 pero sería recuperado, en otras circunstancias, por Alfonso $\mathrm{XI}$ al establecer los regimientos durante su reinado efectivo (1325-1350).

Entre tanto, desde el mismo término de la reconquista, las tensiones entre caballeros y común de los vecinos derivaron en luchas intestinas en casi todas las ciudades y villas, bajo la forma de «alzamientos violentos, más o menos simultáneos, realizados al socaire de las luchas políticas que se desarrollaban en el plano de lo nacional, con un visible trasfondo social y con intervención principalísima de los grupos ciudadanos menos favorecidos» (M. C. Carlé). Los reyes apoyaron, generalmente, al «patriciado" de caballeros y hombres buenos, y se apoyaron en él frente a la alta nobleza cuando esto era inevitable: el ejemplo mejor lo proporciona la reina María de Molina y su actitud en 1295-1301, cuando era tutora de Fernando IV, como desde 1315, cuando lo fue de su nieto Alfonso XI.

El resultado final sería el cuasi-monopolio de los gobiernos concejiles por una oligarquía organizada en bandos en cada ciudad, mucho más presta a integrarse en un juego bipolar nobleza-monarquía de la acción política, como portavoz único de su respectiva ciudad, bastante débil, en definitiva, a la hora de reclamar la existencia de formas de participación colectiva en el ejercicio o al menos en el otorgamiento del poder. Pero, antes de que se alcanzara aquella situación a mediados del siglo XIV, los grupos dominantes de las ciudades actuaron con mayor personalidad en la vida política general, en un sentido afecto al poder monárquico pero, al mismo tiempo, intentando limitar al poder regio por vía de pacto político.

Esto se observa claramente al estudiar la formación de Hermandades y las actuaciones de las Cortes desde 1282, fecha de la formación de la primera hermandad general de ciudades, hasta 1325. La hermandad de 1282, a cambio de apoyar al infante Sancho en el ejercicio de la gobernación del reino, reclamó controlar sus actividades militares, judiciales y legislativas, $y$, sobre todo, que no cobrara sin su consentimiento impuestos desaforados, esto es, al margen de las rentas foreras y que restaurara la moneda en su estado anterior a las quiebras. Sancho IV ignoró estas reivindicaciones sin gran dificultad en cuanto accedió al trono pero a su muerte (1295), de nuevo las ciudades de los diversos reinos que componían la corona formaron her-

6 Un análisis de conjunto sobre estas cuestiones en mi artículo, «Monarquía y ciudades de realengo en Castilla. Siglos XIl a XV», Anuario de Estudios Medievales (Barcelona), 24 (1994), 719-774. 
mandades con idénticos fines, apoyadas en una pretensión de control periódico que garantizarían las reuniones anuales de cada Hermandad y una diputación permanente de las Cortes junto al rey. Por último, desde 1313, durante la minoridad de Alfonso $\mathrm{XI}$, se reprodujo el fenómeno de la Hermandad, más maduro en su manifestación, con pretensiones que guardan mucha semejanza con las que nobles y ciudades habían conseguido en Aragón desde 1282. Pero se trataba de fenómenos coyunturales: desde 1325, Alfonso XI, al dar satisfacción por otras vías a las aspiraciones de dominio del poder local de las aristocracias ciudadanas, acabó con las hermandades como fuerza política, aunque pudieron reaparecer con funciones de orden público en otros momentos de crisis del reino.

Las Cortes reunidas muy frecuentemente durante aquellos decenios, dieron fe del nacimiento de las hermandades y las sirvieron de portavoces pero tampoco consiguieron limitar o compartir de forma institucional los poderes legislativos y hacendísticos de la monarquía que las convocaba y otorgaba o no sus peticiones. Ni siquiera pudieron controlar efectivamente la gestión y gasto del dinero procedente de los servicios que otorgaban. Eran una voz 0 , mejor, un conjunto de voces políticas que el monarca no podía ni quería ignorar, tenían en sus manos algunos resortes de poder -la concesión de servicios-, pero nunca consiguieron limitar legalmente los poderes reales ni obtener un campo propio y permanente de ejercicio y administración del poder más allá de sus funciones de consulta y otorgamiento.

\subsection{Los obispos}

La relación entre la monarquía y el alto clero se caracterizó por el apoyo bastante continuo de los obispos y otros dirigentes eclesiásticos a la política regia, a cambio de la protección y defensa del propio fuero o libertas eclesiástica y de sus fuentes de renta, pero esta afirmación general requiere la explicación de numerosos aspectos de detalle: hubo una colaboración evidente en el crecimiento del poder monárquico pero también resistencias y oposiciones o bien lamentos por el ejercicio malo o abusivo del oficio regio. Pero se aceptaron de mejor o peor grado aspectos fácticos del patrocinio regio y se cedieron a la monarquía fuentes de renta muy sustanciosas (tercias reales, décimas y subsidios, contribuciones extraordinarias, predicación de cruzada) ${ }^{7}$.

La monarquía corresponde a la colaboración habitual de los dirigentes eclesiásticos con la protección a aspectos que éstos consideraban de interés primordial para el ejercicio de su propia autoridad, jurisdicción y ministerio religioso, o para la dignidad de su fuero como estamento privilegiado, incluyendo las exenciones y mercedes fiscales. Pero las intervenciones regias en la vida eclesiástica eran muy fuertes y dieron lugar a veces a quejas colectivas del episcopado, de las que son ejemplo notable los

7 El conocimiento de estas realidades en los trabajos de P. LINEHAN, The Spanish Church and the Papacy in the Thirteenth Century, Cambridge, 1971, History and the historians of medieval Spain, Oxford, 1993, y en los de J.M. NIETO SORIA, en especial, Las relaciones entre monarquía y episcopado en Castilla, 1252-1312, Madrid, 1983, y, Iglesia y poder real en Castilla. El episcopado, 12501350, Madrid, 1988. 
gravamina prelatorum de 1262 y 1279, o las quejas, en 1335, por la opresión fiscal causada por Alfonso XI; no obstante, los reyes tomaron habitualmente medida a favor del estamento eclesiástico, por ejemplo Alfonso X entre 1254 y 1257, Sancho IV en 1282, Fernando IV en 1295 y 1311, Alfonso XI en 1315 y 1326. Los ordenamientos reales dejan traslucir que el defecto de poder regio era para los eclesiásticos peor aún que el exceso, sobre todo en una época que padecía ya el deterioro de las rentas basadas en la producción rural -que eran fundamentales para el clero-, como lo muestran las recaudaciones de décimas de 1309-1311, de modo que la sujeción era preferible a la desprotección, entre otras cosas porque el deterioro del nivel de renta se debía más a las dificultades del momento que no a las cesiones a favor de la monarquía o a las exacciones de ésta. Esta actitud general se mantuvo tanto en tiempo de reyes autoritarios y poco proclives a sujetarse a los puntos de vista eclesiásticos, tal sería el caso de Alfonso X o Alfonso XI, como en el de Sancho IV y Fernando IV, cuya necesidad de apoyo en el episcopado fue mayor, especialmente hasta que se consiguieron, en 1301, las bulas papales de reconocimiento de validez al matrimonio del primero de ambos reyes con María de Molina y de legitimación de sus hijos.

\section{COYUNTURAS, HECHOS Y RESULTADOS DE LA ACCIÓN POLÍTICA}

Para explicar adecuadamente la causas que hicieron posible la conquista de Murcia por Jaime II en 1296 no basta con referirse a las de tipo estructural que hasta ahora hemos examinado puesto que sólo señalan cauces y tendencias básicos que condicionaban la acción política. Hay que conocer también en qué circunstancias concretas se desarrollaba ésta y a qué resultados daba lugar en cada momento, analizando al menos el ámbito temporal inmediatamente anterior y los años mismos de la conquista y de sus consecuencias inmediatas, esto es, entre 1275 y 1305 aproximadamente ${ }^{8}$.

\section{Circunstancias generales}

La intensidad y rapidez de los cambios a que se enfrentan los protagonistas es realmente grande pero, por debajo de ellos, hay unas constantes, unos equilibrios en sus relaciones que nadie está en condiciones de romper más allá de ciertos límites. Es lo que sucede, evidentemente, con las cuestiones de frontera entre los reinos peninsulares, aunque en torno a todas ellas $-\mathrm{y}$ aun a la existencia independiente de algunos reinos - había litigios pendientes que alcanzaron solución, casi siempre estable, a lo largo de los treinta años que ahora estudiamos, o en la época inmediatamente posterior - caso de la definitiva reintegración del reino de Mallorca- coinci-

8 Los libros de referencia más completos y de utilidad más inmediata son éstos: M. GONZÁLEZ JIMÉNEZ, Alfonso X (1252-1284), Palencia, 1993. J. O'CALLAGHAN, The Learned King. The Reign of Alfonso $X$ of Castile, Philadelphia, 1993. J.M. NIETO SORIA, Sancho IV. 1284-1295, Palencia, 1994. C. GONZÁLEZ MÍNGUEZ, Fernando IV (1295-1312), Palencia, 1995. A. MASIÁ DE ROS, Relación castellano-aragonesa desde Jaime II a Pedro el Ceremonioso, Barcelona, 1994, 2 vol. 
diendo con la maduración del concepto de Corona regni indivisible, más allá de la persona y de la voluntad de cada rey.

1. En Navarra, la crisis sucesoria de 1274 volvió a activar las viejas aspiraciones anexionistas por parte tanto de Aragón como de Castilla. Jaime I adujo sus derechos dinásticos y un viejo pacto de prohijamiento que había establecido con Sancho VII, pero no pasó a la acción. Castilla, por el contrario, sí lo intentó: el infante Fernando de la Cerda apoyó con las armas al partido que encabezaba García Almoravit. La decisión de la reina navarra Blanca, al concertar el matrimonio de su hija Juana con uno de los hijos de Felipe III de Francia —el futuro Felipe IV-, reforzó decisivamente la influencia francesa en el reino y bastó para detener las pretensiones castellanas, que quedaron en suspenso en 1277, por voluntad de Alfonso X, y así continuaron a pesar del acuerdo secreto de reparto de Navarra establecido en 1281 por el infante heredero de Castilla, Sancho, y por Pedro III de Aragón. Su presencia en Navarra permitiría a Felipe IV jugar un papel aún más activo en el pleito sucesorio castellano de finales del siglo XIII reavivando problemas de frontera que ya serían tratados en su entrevista de Bayona (abril 1290) con Sancho IV pero que no se resolverían hasta diciembre de 1301 , después de fracasar la entrada en Rioja con tropas navarras y aragonesas que había efectuado el noble castellano Juan Núñez de Lara, rebelde a Fernando IV, en mayo de 1299.

2. Para Portugal y Aragón el objetivo estratégico era una modificación limitada de fronteras, que les parecían fijadas en términos demasiado favorables a Castilla. Tal vez considerarían también con agrado una fragmentación interna de la extensa y poderosa corona castellano-leonesa, lo que les permitiría limitar con reinos más reducidos, de potencia similar a la suya, como había ocurrido antes de 1230 , pero esta hipótesis sólo tuvo alguna posibilidad de realización entre 1296 y 1301 y nunca contó con posibilidades efectivas. Dejemos para más adelante el caso aragonés y recordemos muy brevemente que la cuestión fronteriza con Portugal se había planteado de nuevo cuando su rey dejó de prestar vasallaje al castellano por el Algarbe, en 1267 y se resolvió en el tratado de Alcañices (1297), que reconocía a Portugal los términos de Moura, Mourao, Serpa y Olivenza, más los lugares de Riba de Coa (Alfayates, Sabugal, Castel Rodrigo y otros); Dionís I, por su parte, renunció a cualquier otra reclamación territorial, especialmente en Aroche, Aracena y la frontera del Guadiana.

3. El planteamiento de las disputas era totalmente distinto, y mucho más agrio, en la frontera entre Castilla y Granada. El problema fundamental del emirato granadino fue siempre defenderse de Castilla para lo que contó al comienzo con una garantía jurídica, aunque insuficiente, pues había nacido con un pacto de vasallaje de Muhammad I a Fernando III (Jaén, 1246), pero contó, sobre todo, con las dimensiones y características de su territorio, fácilmente defendible, que albergaba además una población densa, en especial después de 1264, superior al comienzo y equivalente, luego, a la de la Andalucía cristiana cuyo apoyo en otras regiones castellanas -en especial las del N. del Tajo- estaba limitado por el hecho mismo de la distancia y por las condiciones en que las guerras se realizaban entonces. Pero, para Castilla, la culminación de las tendencias reconquistadoras y de los esfuerzos para conseguir un 
territorio que pudiera ser organizado sin continuos problemas de frontera, consistía en la conquista de Granada.

Ahora bien, desde 1264 Castilla fue, por diversas circunstancias, incapaz de llevar adelante sus proyectos mientras que los granadinos consiguieron además moverse hasta 1340 en circunstancias generales que favorecían mucho su defensa. El sector más conflictivo de la frontera entre 1275 y 1309 fueron las serranías rondeñas y gaditanas, donde los emires de Granada habían tenido que aceptar, a pesar suyo, la ayuda norteafricana meriní, propiciada además por la actitud insumisa del linaje que gobernaba algunas plazas fuertes del sector, los Asqilula. Para Castilla era un sector clave pues, sin asegurar la paz de frontera, no se podía repoblar gran parte del bajo valle del Guadalquivir, como se demostró durante los desembarcos y ataques de tropas meriníes en $1275,1277,1278$ y 1282 . Evitarlos fue imposible mientras la dinastía meriní tuvo fuerza política y militar en el N. de África pero, al menos, se podían contrapesar aprovechando el enfrentamiento casi continuo entre los sultanes de Granada y Fez, guarneciendo las plazas de frontera como Vejer, Alcalá de los Gazules, Medina Sidonia, Arcos, Morón, Osuna o Estepa, y combinando los ataques terrestres con bloqueos marítimos eventuales que permitieran asediar alguna plaza de desembarco y tomarla: esto es lo que se hizo con Tarifa en 1292 y lo que se intentó en vano hacer con Algeciras en 1278 y 1309. Tarifa fue durante decenios un punto avanzado estratégico en la batalla del Estrecho, para los musulmanes era fundamental recuperarla y para los castellanos costosísimo sostenerla: se estimó en dos millones de maravedíes anuales el gasto en 1293 aunque Alfonso Pérez de Guzmán se hizo cargo de la alcaidía y defensa de la plaza poco después por sólo la tercera parte de esa cantidad.

En la zona fronteriza de Córdoba, Jaén y Murcia, el enfrentamiento entre granadinos y castellanos se producía casi en solitario, aunque es cierto que los meriníes saquearon la campiña cordobesa en sus primeras campañas $(1275,1277)$, y que los reyes de Aragón tenían interés en el S.E., tanto castellano como granadino. Durante la minoridad de Fernando IV, el emir Muhammad II, aliado de Jaime II de Aragón, tomó Alcaudete, Bedmar y Quesada, plazas adelantadas de la frontera giennense, aunque los castellanos las recuperarían en la ofensiva de 1309 a 1312 al tiempo que, aliados esta vez de Jaime II, que asedió Almería en 1309.

4. La política peninsular de los reyes aragoneses estuvo condicionada por el desarrollo de la que llevaron a cabo en el Mediterráneo, especialmente en la cuestión de Sicilia, desde 1282. Las consecuencias de la intervención de Pedro III tras las vísperas sicilianas en los equilibrios políticos de Aragón y Cataluña fue inmediata: la Unión nobiliaria aragonesa consiguió el llamado Privilegio General (3 octubre 1283), mientras que las Cortes catalanas del mismo año obtenían concesiones muy similares del rey. En ambos casos, se quiebra una línea de crecimiento del poder real, al sujetarlo a pacto, y los reyes habrán de tenerlo en cuenta a la hora de emprender acciones exteriores para no tropezar con resistencias o rebeldías internas y para contar con los apoyos financieros y militares necesarios, siempre más limitados de lo que sería su deseo.

Mientras tanto, la reacción pontificia, francesa y angevina era muy fuerte, pero la 
suerte favoreció a Pedro III, al caer preso Carlos de Salerno, hijo del rey de Nápoles $-\mathrm{y}$ de Sicilia-Carlos de Anjou, en 1284. Al año siguiente, fracasaba la expedición francesa a Catảluña destinada a situar en el trono aragonés a Carlos de Valois. Alfonso III, hijo y sucesor de Pedro III en 1285, contó sobre todo con bazas diplomáticas -la prisión de Carlos de Salerno, la retención, como luego veremos, de los castellanos infantes de la Cerda-, y procedió a conquistar Mallorca en 1285-1287 acusando a su rey, Jaime, de haber faltado a sus obligaciones como feudatario. Mientras tanto, un hermano de Alfonso III, también llamado Jaime, rey de hecho en Sicilia, contaba con suficientes fuerzas navales para defender la isla. Entre 1286 y 1291, la querella se desarrolló en escenarios diplomáticos, con ganancias efectivas para Aragón en los tratados de Tarascón (1290) y, ya bajo Jaime II, Anagni (1295), en el que se le otorgó la investidura de Córcega y Cerdeña a cambio de devolver el reino infeudado de Mallorca a su rey y a la renuncia a seguir defendiendo Sicilia, donde reinaba su hermano Fadrique, y de contribuir a la guerra contra él. Pero la situación de Fadrique se consolidó en los años siguientes, hasta la paz de Caltabellota (1302). Lo más importante, desde nuestro punto de vista actual, es que Anagni permitió a Jaime II desvincularse de la anterior actitud que había mantenido, de amistad y apoyo a la postura de Sancho IV de Castilla precisamente cuando la muerte de éste le abría -libre ya de problemas mediterráneos- muy buenas perspectivas para aprovechar la débil situación política de la reina viuda castellana y tutora de Fernando IV, María de Molina.

5. La razón última de esta debilidad hay que buscarla en el pleito sucesorio iniciado con la muerte del infante heredero Fernando de la Cerda en 1275, y en el aprovechamiento de la situación por diversas fuerzas políticas, sobre todo la alta nobleza castellana, para conquistar más poder. Cuando el segundogénito de Alfonso $X$, Sancho, fue reconocido heredero en 1276, los hijos de Fernando - Alfonso y Fernando, los llamados «infantes de la Cerda»- pasaron a Aragón y allí fueron acogidos y retenidos por Pedro III, que vio claramente los beneficios políticos posibles en aquella operación. Juan Núñez de Lara, uno de los principales nobles castellanos, se declaró por los infantes y se exilió por algún tiempo en Francia mientras que Lope Díaz de Haro, señor de Vizcaya, apoyaba a Sancho. En 1280, el rey francés Felipe III sugirió a Alfonso $X$ la posibilidad de crear un reino vasallo en Jaén para Alfonso de la Cerda pero, al exponer públicamente el proyecto, el rey castellano desencadenó la rebeldía de Sancho, que se hizo con el poder pero no pudo impedir que su padre le desheredara en su testamento de noviembre 1283-enero 1284: en él se nombraba heredero del trono a Alfonso de la Cerda, y se establecian dos reinos vasallos con Sevilla y Badajoz, del que sería titular el infante Juan, y Murcia, para el infante Jaime, hijos ambos de Alfonso X. El testamento no se cumplió, pero se había abierto una puerta a ambiciones y proyectos territoriales que no concluyeron en 1284 .

La situación se mantuvo estable durante el reinado de Sancho IV (1284-1295) aunque las amenazas y reivindicaciones seguían latentes mientras se añadía otro peligro: el matrimonio del rey con su pariente María de Molina se había realizado sin dispensa pontificia; ésta no se obtenía con la rapidez deseada ni, por lo tanto, era posible legitimar a los hijos. La muerte prematura de Sancho IV convertiría esta situa- 
ción en un problema añadido de gran importancia porque su hijo y heredero Fernando hubo de comenzar su reinado con solo nueve años y sin legitimar. Antes de que ocurriera tal cosa, las circunstancias no eran tan malas: el poder real se había restablecido, la guerra contra los musulmanes concluía en 1286 y era posible pasar a la ofensiva en 1292 (toma de Tarifa); Sancho se libraba en 1288 de la tutela política de Lope Díaz de Haro y vencía años después revueltas de los Lara — que se habían reconciliado también en 1288- y de su hermano el infante Juan, que se exilió en Fez en 1293.

Volvamos por un momento sobre nuestros pasos para observar cómo la idea de que Murcia era un reino desgajable del conjunto castellano, o una baza en posibles negociaciones, se consideró varias veces en aquellos años. El mismo Alfonso III había propuesto en 1286 que se entregara a Alfonso de la Cerda, y Sancho IV y Felipe IV de Francia así lo acordaron en el tratado de Lyon (julio 1288), añadiendo Villa Real (hoy Ciudad Real); en Lyon se estableció que Alfonso de la Cerda casaría con la infanta Isabel y que, si no dejara Sancho IV herederos legítimos - y entonces no los tenía aún- le sucedería en el trono Alfonso. El tratado franco-castellano apuntaba directamente contra Aragón y Alfonso III reaccionó promoviendo los intereses de Alfonso de la Cerda, al que reconoció como rey de Castilla, mientras que éste, en compensación por su apoyo, le cedía el reino de Murcia. Ninguna de aquellas medidas tuvo efectividad pero se llegó a un estado de guerra entre Castilla y Aragón que concluyó con la muerte de Alfonso III y el giro político de su hermano y sucesor Jaime, que desembocó en alianza - tratado de Monteagudo, noviembre de 1291-y en el proyecto de matrimonio entre el rey aragonés y la infanta Isabel, hija del castellano, de ocho años, que se criaría en casa de su futuro marido, con lo que parecía cesar la hostilidad entre ambos reinos y el apoyo que Aragón venía prestando a Alfonso de la Cerda.

El movimiento de posiciones en aquella partida diplomática era, por lo tanto, muy complejo y fluido, pero es de suponer que con Sancho IV vivo y capaz de movilizar la fuerza militar castellana nunca hubiera obtenido Jaime II lo que consiguió en 1296. La conquista del reino de Murcia no fue consecuencia ineluctable ni del cambio de estructuras de poder ni de la dinámica política concreta, que podían haber dado pie igualmente a otros resultados, sino de la ocasión que se presentó al morir Sancho IV y confluir durante la minoridad de Fernando IV todos los factores de debilidad y todas las dificultades políticas que podían afectar a la realeza castellana, a pesar de los esfuerzos que María de Molina llevó a cabo para limitar sus malos efectos, muy especialmente la revuelta de gran parte de la alta nobleza.

\section{Los sucesos de 1295 a 1305}

1. No es objeto de esta conferencia narrar de nuevo los sucesos políticos de los años 1295 a 1305 sino únicamente explicar mejor el porqué de las acciones y proyectos dentro del cuadro general que hemos expuesto hasta ahora. El perfil de los principales actores se puede trazar con relativa seguridad: la reina María de Molina, tutora 
de Fernando IV, defendía con todas sus fuerzas los derechos de su hijo, comenzando por la integridad del reino, continuaba la acción diplomática ante el Papa, fundamental, para que se reconociera la validez de su matrimonio con Sancho IV y se legitimara a los hijos habidos, y contaba con el apoyo de las ciudades y villas de realengo, principales perjudicadas por la prepotencia de la alta nobleza, y también con el de gran parte del alto clero: los prelados presentes en las Cortes de Valladolid, agosto 1295, reconocieron como rey a Fernando IV, los arzobispos de Toledo Gonzalo Pérez Gudiel y, sobre todo, Gonzalo Díaz Palomeque, trabajaron sucesivamente en Roma por la obtención de las bulas de legitimación hasta que se consiguieron en 1301, mientras que otros obispos actuaban como mediadores entre las partes en conflicto y apoyaban abiertamente a la tutora, por ejemplo los de Osma, Coria, Palencia, Astorga, Sigüenza o Cartagena.

La actitud de los dos infantes castellanos que actúan durante aquellos años sólo puede calificarse de profundamente perjudicial para los intereses del poder regio tal como estaban definidos desde tiempos de Alfonso X, lo que muestra cómo las tendencias a la fragmentación o a otras formas de reparto del poder político comenzaban en el mismo seno de la familia regia para prolongarse y apoyarse en los planteamientos propios de la alta nobleza. El infante Enrique, hermano de Alfonso $X$, regresa a Castilla, sexagenario, cargado de resentimiento y con el fin de conseguir la máxima promoción y medro personal que se le han negado desde que hubo de exiliarse cuarenta años atrás; su capacidad de maniobra, lo coyuntural de sus alianzas, la ausencia de principios estables en su acción, hacen de él un personaje peligroso e imprevisible. Entre sus proyectos más aberrantes figuró el de vender Tarifa a Muhammad II de Granada para alejarlo de la alianza con Jaime II y acabar con el gasto que causaba su sostenimiento; sólo la determinación de Alfonso Pérez de Guzmán, que llegó a entrar en negociaciones directas con Jaime II, y la falta de apoyo que encontró en Andalucía evitaron que tal cosa sucediera, pero María de Molina hubo de otorgar compensaciones: Pérez de Guzmán fue señor de Sanlúcar de Barrameda desde octubre de 1297 y se consolidó como primer noble con señoríos en la frontera de la baja Andalucia9.

El infante Juan, hermano de Sancho IV, autor de revueltas contra el rey, exiliado en Granada desde 1293, jugó abiertamente la carta de Alfonso de la Cerda y se apoyó en Dionís I de Portugal y Jaime II de Aragón para ser proclamado rey de León en abril de 1296. Sólo en junio de 1300 , con la situación en su contra, se avino al reconocimiento de Fernando IV para seguir presente en el escenario político castellano.

Junto a uno u otro infante, y también junto a María de Molina, actúan los miembros de la alta nobleza, con intereses divergentes pero con el objetivo común, que en gran medida consiguieron, de aumentar su poder, sus señoríos y heredamientos y su participación en las fuentes de renta regias. A comienzos de 1296, casi toda la principal nobleza está en contra de Fernando IV: Juan Núñez de Lara lo abandona junto con su

9 Sobre el significado estratégico de Tarifa en aquellos momentos, vid. mi conferencia, "Castilla y la batalla del Estrecho en torno a 1292: la toma de Tarifa", Almoraima. Revista de Estudios Campogibraltareños (Almería), 9 (1993), 15-24. 
pariente Nuño González de Lara para apoyar de nuevo a Alfonso de la Cerda, y también al infante Juan, aunque con reservas, y pelea por sus propios objetivos, entre los que se cuenta el otorgamiento del señorío de Albarracín por Jaime Il. Diego López de Haro hace lo propio, junto con su pariente Juan Alfonso de Haro, pero se mantienen más próximos a María de Molina, y el segundo recibe el señorío de los Cameros a cambio de su fidelidad. Fernán Rodríguez de Castro mantiene el partido del infante en Galicia. Otros nobles como Pedro Díaz de Castañeda, Lope Rodríguez, Ruy Gil de Villalobos o Fernán Ruiz de Saldaña mantienen también una postura inicial de rebeldía que sólo irá modificándose paulatinamente, caso por caso, después del enfrentamiento bélico principal, ocurrido en 1296 , a medida que vayan considerando más conveniente para sus intereses apoyar a Fernando IV.

Las actitudes de Dionís I de Portugal y Jaime II de Aragón son diferentes. Ambos pretendían obtener provecho de la difícil situación castellana pero los objetivos del portugués eran más limitados - la modificación de frontera, el futuro matrimonio entre Fernando IV y su hija Constanza-, los obtuvo ya en las vistas de Ciudad Rodrigo, a mediados de 1295, y sólo el retraso en su cumplimiento le indujo a participar en la guerra, hasta que el tratado de Alcañices (septiembre 1297) resolvió la cuestión y convirtió a Dionís I en un posible mediador, valioso para los intereses de María de Molina.

Jaime II procuró, en cambio, obtener el máximo beneficio de la situación mediante el desarrollo de una acción política muy inteligente, calculadora y flexible, apoyándose en Alfonso de la Cerda, en la alianza con Muhammad II de Granada y, mientras fue posible, con Portugal, en la buena evolución del conflicto siciliano y de sus relaciones con el pontificado, el rey de Francia y los angevinos desde 1295, y, sobre todo, utilizando en su provecho las rebeldías de infantes y nobles castellanos, y el que éstos vieran en la intervención del rey aragonés una forma de mantener su propia influencia y conseguir sus objetivos en contra del partido realista firmemente encabezado por María de Molina. Sólo a medida que evolucionó este último factor tuvo que ir modificando Jaime II su política porque sus medios para llevarla a cabo -recursos militares y económicos- eran muy limitados. Siempre hubo gran distancia entre las pretensiones y las realidades pero, al cabo, fue él quien obtuvo mejores resultados.

2. La devolución de la infanta Isabel a Castilla con ruptura del compromiso matrimonial, a poco de morir Sancho IV, fue señal de lo que se avecinaba pero los acontecimientos decisivos ocurrieron en 1296. Los acuerdos de Bordalba (Ariza, enero) preveían la entrega del trono de Castilla a Alfonso de la Cerda, del de León al infante Juan, y reconocían la cesión de Murcia a Jaime $\|$ e importantes señoríos en el E. de Castilla para su hermano el infante Pedro: Cuenca, Cañete, Alarcón y Moya. La acción militar ocurrió entre abril y agosto: no tuvo resultados decisivos en Tierra de Campos, que era el corazón de la monarquía castellano-leonesa, aunque el infante Juan se proclamara rey en León, pero Jaime II ocupó el reino de Murcia -salvo Lorca, Mula $y$, durante varios meses, Alhama - sin encontrar otra resistencia que la de los alcaides de los alcázares de las principales ciudades, sobre todo en Alicante, y las ofrecidas por Orihuela y por Elche; el asedio de Elche se prolongó más de tres meses mientras se llevaban a cabo negociaciones con los representantes de su señor, Juan Ma- 
nuel, nieto de Alfonso X y Adelantado de Murcia, entonces menor de edad ${ }^{10}$. Los factores que ayudan a entender mejor la facilidad con que Jaime II consiguió su objetivo son: la imposibilidad de enviar refuerzos desde otras partes de Castilla, la falta de autoridad para movilizar milicias concejiles en aquella situación de caos político en la que, además, era de prever el escaso o nulo entusiasmo de una parte de los vecinos por la controvertida causa de Fernando IV, y, además, la escasa capacidad defensiva de Murcia, concentrada además frente a Granada, en Lorca sobre todo —recordemos que esta plaza no se rindió a Jaime II hasta finales de 1299-, ante la amenaza de un ataque de Muhammad II en combinación con el de su aliado coyuntural Jaime II. Por el contrario, en el valle del Duero y en las plazas de la zona de Cuenca, no se obtenía nada pues las circunstancias eran muy distintas, ni llegó a haber en ningún momento durante aquellos años enfrentamientos campales ni, salvo excepciones, asedios de plazas concluidos con éxito por ninguna de las dos partes.

Así, el envite guerrero de 1296 no llegó a tener resultados decisivos. Los aragoneses se retiraron del valle del Duero cuando murió el infante Pedro durante una epidemia en el cerco de Mayorga, que duraba ya cuatro meses. Ni el aragonés y sus aliados ni María de Molina tenían capacidad suficiente para asediar y conquistar plazas contrarias, como se demostró en los años siguientes, ni la mayoría de los nobles estaba dispuesta a choques directos, más allá de escaramuzas o tomas pacíficas de castillos previo acuerdo con el alcaide. Pero las ciudades - salvo León-, y casi todas las villas y lugares obedecían a María de Molina, y los nobles rebeldes comenzarían a hacerlo desde finales de 1296, a medida que recibían compensaciones o veían menos posible el triunfo de Alfonso de la Cerda.

3. Sucede, sin embargo, que los conflictos en aquel tiempo tenían un ritmo de desarrollo lento, por la limitación de los medios disponibles y por el papel que jugaban larguísimas y complicadas negociaciones cuyo curso podía verse alterado en cualquier momento por cambios de alianzas, muertes o sustituciones de protagonistas e incluso, aunque más raramente, por éxitos o fracasos decisivos en el terreno militar. Todavía en el transcurso de 1297, Alfonso de la Cerda pudo instalar una pequeña corte en Almazán, tomada para él por Juan Núñez de Lara y dominar la plaza próxima de Deza, en ambos casos por concesión de los dirigentes locales, pero Jaime II estuvo mucho más interesado en los asuntos del ámbito siciliano entre 1297 y 1300 y no quiso implicarse en nuevas operaciones bélicas, ni siquiera para intentar hacer efectiva la cesión que Alfonso le hacía de Molina, Cuenca, Cañete, Alarcón, Moya y Requena. Al parecer, había conseguido ya sus objetivos territoriales de mayor importancia y prefería la negociación.

Vistas así las cosas, la relativa inhibición de Jaime II, el tratado de Alcañices con

10 J.M. DEL ESTAL, «Problema sucesorio de Castilla y anexión de Alicante a la Corona de Aragón», VII Centenario del Infante don Fernando de la Cerda, Ciudad Real, 1976, pp. 237-263. Conquista y anexión de las tierras de Alicante, Elche, Orihuela y Guardamar al Reino de Valencia por Jaime II de Aragón (1296-1308), Alicante, 1982. «Incidencia del problema sículo-sardo en la conquista del reino de Murcia por Jaime II de Aragón (1296-1304)", XI Congreso de Historia de la Corona de Aragón, Palermo, 1984, pp. 25-70. El Reino de Murcia bajo Aragón (1296-1305). Corpus documental, Alicante, 1985-1990, 2 vol. 
Dionís I, la paulatina y bien remunerada vuelta de nobles a la fidelidad debida a Fernando IV, erosionaron mucho en 1297 la posición de Alfonso de la Cerda y sus aliados aunque continuaran las espadas en alto y hubiera maniobras hostiles destinadas sobre todo al empobrecimiento del adversario: rapiñas, saqueos, falsificaciones monetarias. Quien más padecía era el reino pero, por eso mismo, se consolidaba la posición de María de Molina, que defendía, en nombre de su hijo, la vuelta al orden y el fin de los abusos y malfetrías. Los jalones principales en el lento proceso de restauración fueron éstos: primero, la multiplicación de mercedes a nobles y el aumento de adhesiones desde el otoño de 1297. Segundo, la prisión del último gran rebelde, Juan Núñez de Lara, en mayo de 1299, y su retorno a la fidelidad debida a Fernando IV, con gran provecho de Juan Alfonso y Diego López de Haro, y del infante Enrique. Tercero, la reconciliación y acatamiento al rey por parte del infante Juan, en junio de 1300. Cuarto, el fin de la negociación en Roma y la obtención de las ansiadas bulas de legitimación en septiembre de 1301, coincidiendo con la llegada de Fernando IV a una mayoría de edad que se había retrasado hasta los 16 años. Paralelamente, Felipe IV de Francia aseguraba su intención de no hostilizar al rey castellano.

4. El gran perjudicado por la evolución de los acontecimientos era Alfonso de la Cerda, pero tampoco Jaime II debía esperar nuevas ganancias. Por fin, había conseguido tomar Lorca a finales de 1299 y completar así la principal de ellas, que era el reino de Murcia, pieza clave en futuras negociaciones. Pero no podía ir más allá: a pesar de la marginación temporal a que se vio sometida María de Molina al tomar el gobierno Fernando IV, y del inmediato enfrentamiento por el poder en la corte de dos bandos, encabezado uno por el provecto infante Enrique y los Haro y otro por el infante Juan y los Lara, Jaime II tenía un campo de acción negociadora cada vez más limitado, y pesaba sobre él la actitud levantisca de los nobles aragoneses, que se manifestó en 1301. Poco a poco se aproximaba el fin del conflicto y no surgieron elementos nuevos que alteraran aquella tendencia. Todavía en junio de 1303 (vistas de Ariza), el rey de Aragón, el infante Enrique y los Haro declararon su voluntad de que Alfonso de la Cerda fuera reconocido rey de Jaén y señor de Almazán y otras plazas. El infante Enrique murió en agosto y su partido quedó temporalmente debilitado y disperso. Por otra parte, también en junio se había acordado una tregua entre Castilla y Granada. A fines de año sólo se mantenía rebelde Diego López de Haro y Alfonso de la Cerda, en su refugio de Almazán, únicamente podía esperar las compensaciones limitadas que obtuviera para él Jaime II en un proceso negociador que se anunciaba ya inmediato.

Su resultado fue la sentencia arbitral de Torrellas (agosto de 1304), complementada por el tratado de Elche (mayo de 1305). Con ella terminó la primera de las grandes crisis políticas internas que Castilla padeció a lo largo de casi un siglo, entre 1295 y 1393, la que mayor costo tuvo desde el punto de vista de las pérdidas territoriales, y la primera también en desencadenar un proceso de aumento del poder nobiliario -incluyendo en él los numerosos señoríos que recibió Alfonso de la Cerda, y el comienzo de la prolongada y tortuosa carrera señorial del mal llamado infante Juan Manuel-y otro proceso de empobrecimiento del país, pero en 1304 casi todo podía aún enderezarse según los proyectos políticos que Alfonso $X$ había trazado y comenzado a desarrollar. 
5. En definitiva, se puede suscribir la afirmación de A. Masiá de Ros: en todo este asunto, la ventaja estuvo siempre de parte de Jaime, ayudándole en sus ambiciones sobre Murcia. Se nos podrá objetar que no logró enteramente su objetivo, pero creemos que no es pequeño el éxito conseguido, pues aparte de conservar territorios donados por quien no los poseía, consiguió que su antiguo protegido y aliado fuese dotado por el monarca a quien pretendía despojar... Un pedazo de Murcia a cambio de la paz, quedando además Jaime como árbitro de los destinos peninsulares, no puede ser considerado como un mal negocio ${ }^{11}$.

Un pedazo de Murcia... Tal vez en esta expresión se halla la clave para entender dónde estuvo el daño mayor, y no me refiero tanto al ámbito de la vida política como al de la organización social y económica, que no podría aprovechar las potencialidades de la cuenca del bajo Segura en su conjunto. Además, las comunicaciones de Murcia con el resto de Castilla se veían más dificultadas y disminuían mucho, por una parte, el traspaís y los recursos próximos de que podían disponer los murcianos para la defensa de la frontera con Granada y, por otra, las posibilidades mercantiles castellanas en su fachada mediterránea, donde el puerto principal era Alicante, bien enlazado con el interior por Villena y Almansa, y no Cartagena.

No todo concluyó en 1305: el amplio señorío de Villena, cuyo titular fue don Juan Manuel, nieto de Alfonso X, hasta su muerte en 1348, se reintegró en el espacio político castellano, especialmente desde 1366, manteniendo una gran autonomía. Jumilla y Abanilla fueron conquistadas en la guerra de 1356-1358 y volvieron a formar parte del reino murciano. Pero sería deseable que se estudiaran no sólo las consecuencias políticas de los sucesos de 1296-1304 a lo largo de los siglos XIV y XV sino también, especialmente, las sociales y económicas ${ }^{12}$. Si hubo o no emigraciones y reacomodos importantes de población a causa de la nueva frontera; de qué manera se canalizó el tráfico procedente del reino de Toledo hacia Valencia y Alicante más que hacia Cartagena; en qué medida la partición de 1304 aumentó la marginalidad y dificultó la colonización en una Murcia cuya identidad se basó, a pesar de la lejanía, en su condición castellana, tan celosamente mantenida como lo demuestra hoy el archivo municipal de su capital, que es el más completo y el mejor conservado de toda Castilla para los últimos siglos de la Edad Media.

11 Relación castellano-aragonesa..., p. 125.

12 Vid. los puntos de vista de J. TORRES FONTES, La delimitación del sudeste peninsular. I. Tudilén, Cazola, Almizra, Murcia, 1950, Torrellas-Elche, 1304-1305, Murcia, 1951. Los avatares poIíticos del siglo XIV pueden seguirse en una bibliografía abundante y de calidad. M.T. FERRER I MALLOL, "Abanilla y Jumilla en la Corona catalano-aragonesa (s. XIV)», Homenaje al profesor Juan Torres Fontes, Murcia, I, 1987, pp. 477-490, y, Organització y defensa d'un territori fronterer. La Governació d'Oriola en el segle XIV, Barcelona, 1980. A. PRETEL MARÍN, Don Juan Manuel, señor de la llanura, Albacete, 1982, y, «El cambio dinástico y la crisis de mediados del siglo XIV en el Señorío de Villena», Congreso de Historia del Señorío de Villena, 1987, pp. 305-332. J.L. PASTOR ZAPATA, «Un ejemplo de "apanage" hispánico: el señorío de Villena (1250-1445)", Revista del Instituto de Estudios alicantinos, 31 (1980), pp. 15-40. Una síntesis en Historia de la Provincia de Alicante. III. Edad Media, Murcia, 1985 (pp. 171. 286, "Historia Política», por Juan Manuel del Estal). Y en E. GUINOT RODRÍGUEZ, Els límits del regne. El procés de formació territorial del Pais Valencià medieval (1238-1500), Valencia, 1995. 


\title{
EL REINO DE MURCIA DURANTE LA DOMINACIÓN ARAGONESA (1296-1305)
}

\author{
Ángel Luis MOLINA MOLINA \\ Universidad de Murcia
}

Durante los siglos XII y XIII el reino de Murcia fue territorio disputado por Castilla, que busca una salida al Mediterráneo, y por Aragón, que trata de continuar su expansión territorial hacia el sur y evitar ser rodeado por Castilla. El tratado de Almizra (28-III-1244) suscrito entre el infante Alfonso y Jaime I, para el primero constituyó un éxito y para el segundo fue, en cierto sentido, una decepción, en la medida que el reino de Murcia se encontraba definitivamente en el ámbito geográfico castellano', obligando de esta forma a la Corona de Aragón a buscar la compensación mediante su expansión por el Mediterráneo.

Jaime II tratará de sacar el máximo provecho de las difíciles circunstancias políticas de Castilla durante la minoridad de Fernando IV y de las pretensiones de don Alfonso de la Cerda al trono castellano, para dar un giro radical a la política aragonesa en el Sudeste peninsular'.

Para algunos historiadores la conquista del reino de Murcia por Jaime II, al igual que la anexión de Córcega y Cerdeña, forman parte del proyecto del monarca aragonés de transformar el litoral mediterráneo occidental en una base firme y segura para sus empresas marítimas posteriores, es decir, formaría parte del imperialismo

1 Véanse Julio GONZÁLEZ, Reinado y diplomas de Fernando III, Córdoba, 1980, t. I, pp. 349351. Sobre la incorporación de Murcia al dominio cristiano, Antonio BALLESTEROS BERETTA, La reconquista de Murcia, Madrid, 1943; Juan TORRES FONTES, La reconquista de Murcia en 1266 por Jaime I de Aragón, Murcia, 1967. La evolución de la frontera murciana en el siglo XIIl y los inicios del XIV puede seguirse en Amparo BEJARANO RUBIO, «La frontera del reino de Murcia en la política castellano-aragonesa del siglo XIII», en Miscelánea Medieval Murciana, XIII, 1986, pp. 131-154.

2 César GONZÁlEZ MínguEZ, Fernando IV. 1295-1312, Palencia, 1995, p. 74. 
expansionista, peninsular y mediterráneo, de la corona de Aragón iniciado en $1282^{3}$.

El primer acto de hostilidad de Jaime II fue la devolución a Castilla de la Infanta doña Isabel con el pretexto de que el papa no había otorgado las necesarias bulas de dispensa ${ }^{4}$. En agosto de 1925, enviaría a Fray Domingo de Jaca y Simón Dezlor a la corte castellana para anunciar la anulación del tratado de Monteagudo (firmado en 1291 entre Jaime II y Sancho IV). La difícil situación interna de Castilla impidió dar una respuesta adecuada a tan grande ofensa ${ }^{5}$.

A partir de este momento Jaime II se convirtió en patrocinador de la candidatura de don Alfonso de la Cerda al trono castellano. Por este motivo don Alfonso confirmó a Jaime II la donación de todo el reino de Murcia que había hecho en 1289 a su hermano y antecesor en el trono Alfonso III. Inmediatamente después Jaime II tratará de hacer efectiva la ocupación de dicho reino, y con el hecho consumado de la conquista lograr una ampliación territorial de Aragón $n^{6}$. La crisis interna castellana —minoría de Fernando IV - obligo a doña María de Molina, a resignarse y dar por perdido el reino de Murcia, al menos momentáneamente.

La Crónica de Fernando IV es muy sucinta a la hora de informarnos de la campaña murciana: «E en este tiempo mesmo movió el rey de Aragón con su hueste, e fue al reino de Murcia e por consejo de los de la tierra, que eran catalanes, dieronsele todas las villas e los castillos, salvo ende Lorca, que moraban castellanos, e otro sí Alcalá e Mula» ${ }^{7}$, algunos detalles mas nos proporcionan Ramón Muntaner ${ }^{8}$ y Jerónimo Zurita ${ }^{9}$. La concepción estratégica fue impecable, pues mientras un ejército aragonés al mando del infante don Pedro penetraba en Castilla, el propio Jaime II dirigía otro, apoyado por una flota, hacia el reino de Murcia. La primera ciudad a la que puso cerco fue Alicante, cuyo imponente castillo se rindió a pesar de la tenaz resistencia de su alcaide, Nicolás Pérez de Murcia, que prefirió morir en la lucha antes que rendirse ${ }^{10}$.

3 Juan Manuel del ESTAL, "Incidencia del problema sículo-sardo en la conquista del reino de Murcia por Jaime II de Aragón (1296-1304)", en XI Congreso di Storia della Corona d'Aragona sul tema: La societá mediterranea all'epoca del Vespro, Palermo, 1984, pp. 25-26.

4 Jerónimo ZURITA, Anales de la Corona de Aragón, Zaragoza, 1610, t. l, fol. 358 r.

5 Alguna medida si que se tomó, como se desprende de la carta que Juan Sánchez de Ayala, Adelantado en el reino de Murcia por don Juan Manuel, envió a Bona Junta de las Leyes el 10 de noviembre de 1295, en la que declara la guerra a Jaime II, y le ordena que "por mar con la galiota armada que vos yo dy e fazer guerra e danno quanto pudierdes al rey de Aragon e a las sus gentes». Expedición de corso que debió ser positiva, puesto que el propio Juan Sánchez de Ayala reconocía, el 28 de marzo de 1296, haber recibido de Bona Junta de las Leyes, 3.000 maravedís «por razon de la parte e del derecho que yo devia aver de la ganancia que fiziestes sobre mar con la galiota que vos yo mande armar sobre la tierra del rey de Aragon» (Los documentos están publicados por Andrés GIMÉNEZ SOLER, Don Juan Manuel, Zaragoza, 1932, pp. 223-224, y Juan TORRES FONTES, Documentos de siglo XIII, CODOM, II, Murcia, 1969, pp. 117-118).

6 Juan TORRES FONTES, El señorío de Abanilla, Murcia, 1982, p. 32.

7 Crónica de Fernando IV, B.A.E., Madrid, 1953, p. 103, t. LXVI.

8 Ramón MUNTANER, Crónica, Madrid, 1970, pp. 385-388.

9 Jerónimo ZURITA, ob. cit., fols. 368 r. -369 v.

10 Véanse R. MUNTANER, ob. cit., pp. 386-387; Juan Manuel del ESTAL, Conquista y anexión de las tierras de Alicante, Elche, Orihuela y Guardamar al Reino de Valencia por Jaime Il de Aragón (1296- 
Posteriormente el ejército aragonés se dirigió a Elche, que pertenecía a don Juan Manuel. El asedio comenzó en junio de 1296 y se prolongó durante el mes siguiente. Mientras se completaba el asedio, una parte del ejército se apoderó de Elda, Novelda, Nomport, Aspe, Petrel, La Muela, Crevillente, Abanilla, Callosa y Guardamar.

El 27 de julio llegaron hasta don Jaime dos vasallos de don Juan Manuel —Gómez Fernández y Alfonso García de Pampliega- solicitando una tregua en nombre de su señor, a lo que el monarca accedió hasta que don Juan Manuel cumpliera 20 años.

Anteriormente, en mayo, el concejo de Orihuela reconocía a Jaime II como a su rey. $Y$ en los meses siguientes se apoderaba, prácticamente, de todos las villas y castillos del reino de Murcia, a excepción de Lorca, Alcalá y Mula, sin encontrar resistencia, ni por parte de la población mudéjar, totalmente ajena a la contienda, ni de la población cristiana, cuya densidad era todavía muy débil ${ }^{11}$. En la repoblación habían participado catalanes y aragoneses, que como cabe suponer facilitaron considerablemente la conquista. El licenciado Francisco Cascales escribía al respecto: «Tuvo gran facilidad el Rey en el rendimiento de Murcia, porque los pobladores eran los mas Catalanes y Aragoneses, y en tan poco tiempo como había pasado de la población acá no había perdido la vasija el sabor de la que recibió primero»12. Con su ayuda, el 2 de agosto, Jaime II pudo entrar en Murcia, que se rindió sin presentar combate ${ }^{13}$.

Inmediatamente dispuso guarniciones para asegurar la conquista y premió con señoríos a quienes más se habían distinguido en la lucha, regresando luego a Valencia, donde ya estaba el 18 de agosto de 1296. Nuevamente volvió Jaime II al reino de Murcia, pues el 3-Il-1298, escribía al rey de Granada desde el castillo de Alhama, comunicándole que se había apoderado del mismo: “Aun vos facemos saber que somos venidos al regno de Murcia contra nuestros enemigos de Castilla e asitiamos el castiello de Alhama el qual, loado sea Dios, habemos preso et tenemos, e facemos vos saber porque sabemos que vos placerá» ${ }^{14}$. La conquista del castillo de Alhama, lograda tras largo asedio, sería una nueva base de avance hacia Lorca, la plaza más apetecida por su fortaleza y posición en la frontera con el reino granadino.

La presencia de Jaime II en tierras murcianas tenía también otro objetivo: las en-

1308), Alicante, 1982 y Juan TORRES FONTES, «Nicolás Pérez, alcaide de Alicante», en Murgetana, XXII, pp. 121-129.

11 J. TORRES, “Reconquista y repoblación del reino de Murcia», Actas del Coloquio de la $V$ Asamblea General de la Sociedad Española de Estudios Medievales, Zaragoza, 1991, pp. 248-272.

12 F. CASCALES, Discursos históricos de la muy noble y muy leal ciudad de Murcia, $2^{\mathrm{a}}$ edic., Murcia, 1775, p. 77.

13 Estudios diversos, pero sobre todo la publicación por J. M. del Estal de un Corpus documental de Jaime II relacionado con su intervención armada en el reino de Murcia, permiten seguir, casi día a día y plaza por plaza, la actividad, más política y diplomática, del monarca aragonés para ir consiguiendo sin el empleo de la fuerza, a veces manteniendo prolongados sitios, la ocupación de fortalezas o la aceptación de su soberanía por algunas admitido ante el abandono en que se encontraban y la falta de una hueste castellana que se opusiera a su avance o reforzara guarniciones. El reino de Murcia bajo Aragón (1296-1305), Corpus Documental, 1/1 y 1/2, Alicante, 1985 y 1990.

14 Antonio BENAVIDES, Memorias de D. Fernando IV de Castilla, Madrid, 1860, II, p. 115, y Juan TORRES FONTES, Documentos del siglo XIII, p. 131. 
comiendas santiaguistas. En Elche, el 28 de febrero, escribía al maestre don Juan Osórez pidiéndole que diera orden a los comendadores de Aledo, Cieza y Ricote para que le reconocieran como rey y señor, garantizándoles la posesión de sus encomiendas y ofreciendo su protección. Hubo negativa santiaguista y entonces propuso una nueva fórmula más conciliadora, consistente en que las encomiendas del territorio murciano quedaran dependientes del comentador de Montalbán ${ }^{15}$, súbdito suyo, ante el temor, según manifestaba, de que pudieran perderse para él y para la Orden, porque «por desfayllimiento de guarda et de retenimiento, los ditos castiellos no se ayan de perder a vos et a la Orden», propuesta que tampoco sería aceptada por el maestre de Santiago.

La tercera fase de la intervención de Jaime II en el territorio murciano tiene lugar en el año 1300. De nuevo el objetivo era Lorca, sobre la que tenía puesto cerco y pudo lograr un convenio con su alcaide, el de que si en un plazo determinado no era socorrido, entregaría la fortaleza. La traición del alcaide Nuño Pérez impidió que la ayuda castellana, organizada por doña María de Molina, fuera eficaz y obtuviera el resultado apetecido, puesto que antes de que finalizara el plazo convenido, encontrándose ya las fuerzas castellanas en Alcaraz, se efectúo la entrega.

La presencia del ejército castellano fue suficiente para alejar a las tropas aragonesas, con lo que se impidió que Mula y Alcalá siguieran el mismo camino que Lorca. La actitud de los infantes don Enrique y don Juan, partidarios de llegar a un entendimiento con Aragón, suspendió la continuidad de la campaña, cuando la posición de Jaime II era ya de por sí difícil.

La alianza con Granada permitía e incitaba a que almogávares africanos ocasionaran daños y robos en tierras de las encomiendas santiaguistas, modo indirecto de presionar hacia el reconocimiento de su soberanía, como pretendía Jaime II. En enero de 1301, los vecinos de Aledo protestaban de los perjuicios recibidos, y esta política contra los territorios de la Orden culminó con la ocupación de Cieza por la fuerza. La respuesta fue rápida y poderosa. En abril, Juan Osórez, con 500 caballeros y 4.000 peones, sin sorpresas ni marchas nocturnas, entraba en el reino de Murcia, encaminándose hacia Cieza. Se hizo pública por todo el reino esta proximidad armada de la Orden de Santiago, y el 19 de abril, el gobernador de Murcia convocaba a la defensa de Cieza, enviando por su cuenta 30 ballesteros. La noche del día 22 era asaltada y ocupada, y apresados sus jefes y las fuerzas defensoras que no habían muerto en el combate. Hubo intercambio de cartas entre Jaime II y el maestre, pero la decisión de éste quedó bien clara: "Cieza, punnamosla en cobrar, porque era nuestra», por otra parte, manifestaba que no iría contra él, "salvo si acaeçiese, que el cuerpo del rey don Fernando entrase en el regno de Murcia, en la qual cosa, si acaeçiese, vos daremos a entender en como avemos talante de lo servir»; y le exigía la devolución de su castillo de $\mathrm{Negra}^{16}$.

Por cuarta vez las posiciones encontradas entre unos y otros se pondrían de manifiesto en 1303. Vasallos de la Orden, según queja de Jaime II, "an feyto et fazen

15 Véase Regina SAINZ DE LA MAZA LASOLI, La Orden de Santiago en la Corona de Aragón. La Encomienda de Montalbán (1210-1327), Zaragoza, 1980, pp. 170-177.

16 Juan TORRES FONTES, “Murcia: la conformación de un reino de frontera", en Historia de España Menéndez Pidal, t. XIIl-1, Espasa-Calpe, Madrid, 1990, pp. 480-481. 
cada día muytas terrerias et daynos et agraviamientos a las nuestras gentes del dito regno et viene ende por esto grand destorbo a nos et al dicto regno", insistiendo en su propuesta de que se hiciera cargo de las encomiendas murcianas al comendador de Montalbán y las tuvieran «freyres natales nuestros». Y si, por una parte, advertía que de continuar así las cosas tendría que proceder de otra manera, por otra, ordenaba que se entregara el castillo de Negra al comendador de Ricote, pero, al morir éste por entonces, hizo concesión personal del castillo al comendador de Montalbán. El maestre no estuvo conforme y continuó insistiendo en su devolución, en tanto que gentes de la encomienda de Aledo efectuaban correrías por tierras lorquinas, con robos como el de 80 yeguas y otros animales ${ }^{17}$.

Receloso de la actitud de Muhammad III, que tras la muerte de su padre había firmado treguas por tres años con Castilla y licenciado a los africanos contratados por Muhammad II, e igualmente receloso del maestre de Santiago, cada vez más apremiante en su exigencia de la devolución de Negra, el rey de Aragón recurrió al jefe magrebí Hamu b. Abd al-Haqq b. Rahhu, con quien estaba concertado desde 1300 . El acuerdo de 22 de diciembre de 1303, contenía las siguientes condiciones: entrega del castillo de Negra y los lugares de Ceutí y Lorquí, como base de acampada de sus fuerzas; Ibn Rahhu los recibía «como vasallo de su señor»; entrega un hijo y tres de los jefes de su hueste como rehenes; recibía la seguridad de poder contar con un buen trato y amparo de los aragoneses, facilidad para adquirir provisiones y el quinto que correspondía al rey de las cabalgadas, más los castillos o lugares que pudiera ganar ${ }^{18}$.

Si Ibn Rahhu efectúo dos incursiones que le proporcionaron cuantioso botín, obteniendo unas 50.000 cabezas de ganado en tierras conquenses, aunque perdió parte y sufrió inconvenientes y robos a su vuelta en lugares de don Juan Manuel; y otra al Valle de Purchena junto a freires templarios, el tener que vivir sólo de lo que obtenía en las cabalgadas, hacía difícil su estancia, porque si el maestre del Temple elogiaba su valor y decisión, también ponía de relieve la pobreza y miseria de aquella hueste, merecedora de mayor recompensa, que por su forma de vida era despreciada y odiada en tierras murcianas. Por ello tuvo que sufrir robos y daños en la comarca de $\mathrm{Ne}$ gra, que efectuaban mudéjares de las encomiendas santiaguistas de Aledo y Cieza.

De forma paralela, a lo largo de 1303 , se advierte como se va abriendo paso la idea de que es necesario poner fin a la tensión bélica que había caracterizado las relaciones entre Castilla y Aragón desde 1295. Era manifiesto el cansancio general y el deseo de llegar a un convenio aceptable para todos, ya que la situación no acababa de definirse y menos aún en territorio murciano, cuya inestabilidad e inseguridad sólo podría resolverse con la paz general. Al mismo tiempo, inclinado Fernando IV a la línea política que le aconsejaba el infante don Juan, buscaba igualmente la solución definitiva del problema de los infantes de la Cerda. Y para ello Jaime II formula la propuesta de que tres jueces dieran una sentencia arbitral, aceptándose al rey de Portugal, don Dionis, personaje hábil y tortuoso, para que formara un jurado que diera su

17 Juan TORRES FONTES, «Murcia: la conformación...», p. 482.

18 Juan TORRES FONTES y Ángel Luis MOLINA MOLINA, «Murcia castellana», en Historia de la Región Murciana, t. III, Murcia, 1981, pp. 384-387. 
sentencia en lo que afectaba al reino de Murcia, infantes de la Cerda y todas las cuestiones pendientes entre ambas partes.

A principios de marzo de 1304 en una entrevista en Calatayud entre Jaime II y el infante don Juan, se acordó una reunión entre los reyes de Castilla, Aragón y Portugal, que tendría lugar entre Agreda y Tarazona, para intentar solucionar las diferencias entre Fernando IV y Jaime II; y también se acuerda negociar una tregua entre Castilla y Aragón que duraría al menos hasta el día $1^{\circ}$ de mayo próximo ${ }^{19}$.

En los meses siguientes se producirían diversos encuentros que desembocarían en el compromiso del 20 de abril de 1304, en presencia del notario publico de Tarazona Andrés Pérez de Corvera; por el que el infante don Juan, en nombre del rey de Castilla, y don Alfonso de la Cerda, en el suyo propio, nombraron como árbitros de las diferencias entre Fernando IV y don Alfonso de la Cerda a los reyes de Portugal y Aragón, respectivamente, y se comprometieron a aceptar la sentencia que pronunciaran dentro de un plazo que finalizaba el 15 de agosto. El mismo día y ante el mismo notario, a instancias de Jaime II y de don Alfonso de la Cerda, se redactó el compromiso por el que aceptaban como jueces árbitros de las diferencias entre Jaime II y Fernando IV a don Dionís de Portugal, al infante don Juan y a don Jimeno de Luna, obispo de Zaragoza. Para garantizar que Jaime II aceptaría la sentencia que se dictase entregó a dichos árbitros como rehenes los castillos de Ariza, Verdejo, Somet, Borja y Malón. Lo propio hizo Fernando IV, quien ofreció como rehenes los castillos de Alfaro, Cervera del río Alhama, Ocón, San Esteban de Gozmar y Atienza ${ }^{20}$.

La sentencia arbitral de Torrellas-Elche es la consecuencia natural de la fortaleza alcanzada por la confederación aragonesa y por otro lado, de la crisis interna de Castilla tras la minoría de Fernando IV, así como el cambio de mentalidad, de actuación política y de objetivos concretos que se manifestaban después de las grandes conquistas territoriales del siglo XIII.

Los jueces nombrados para resolver de forma conciliadora las diferencias entre las Coronas de Castilla y Aragón se reunieron en Torrellas, a las faldas del Moncayo, y el día 8 de agosto de 1304 dictaron su parcial decisión. La sentencia señalaba como pertenecientes a Aragón las ciudades de Cartagena, Guardamar, Orihuela, Alicante, Elche, Novelda y la jurisdicción de Villena, cuya propiedad mantendrá don Juan Manuel, lo mismo que Elche. Y ordenaban a Jaime II entregar a Castilla Murcia, Molina Seca, Alcantarilla, Moratalla, Lorca, Alhama, etc.: «assi como taja la agua del Segura fasta el regno de Valencia, entre el mas susano cavo del termino de Villena, sacada la ciudad de Murcia e Molina con sus términos» para Aragón y al oeste y al sur del Segura para Castilla ${ }^{21}$.

Merino Álvarez asegura que la nueva frontera coincidía por el N.E. en la Hitación de Wamba al obispado de Begastri; lo perdido por Castilla era íntegramente la diócesis ilicitana. La inclusión de Cartagena en la parte aragonesa se debía más al interés de Jaime II de poseer un puerto natural que acercara el comercio catalán a los mercados del norte de África, al tiempo que eliminar las posibilidades que el Mediterráneo

19 César GONZÁLEZ MÍNGUEZ, ob. cit., p. 128.

20 César GONZÁLEZ MÍNGUEZ, ob. cit., pp. 129-130.

21 Véase Juan Manuel del ESTAL, Conquista y anexión de las tierras..., p. 275. 
podía ofrecer a Castilla, que a los «errados conocimientos geográficos de la época basados en Ptolomeo, quien había situado a Cartagena más al septentrión de Alicante», como supone Merino ${ }^{22}$.

Los jueces árbitros no sólo se preocupan de fijar la frontera castellano-aragonesa, aunque de forma un tanto imprecisa, sino también de la situación de las personas afectadas por el reparto. En cualquier caso podrían permanecer viviendo en los mismos lugares con todos sus bienes. También se les reconocía absoluta libertad para cambiar de residencia si así lo preferían. Tanto Castilla como Aragón deberían dejar en libertad a todos los cautivos hechos durante la guerra.

Jaime II y Fernando IV deberían otorgar y aprobar la sentencia arbitral en el plazo de tres días, requisito que cumplieron. El análisis del texto de la sentencia, duramente calificado por Francisco Cascales que la consideró injusta ${ }^{23}$, refleja claramente como había triunfado el punto de vista aragonés. Jaime II actuaba desde una posición de fuerza, convertido en árbitro solicitado por las facciones nobiliarias castellanas, y los jueces elegidos obraban en su favor. La conducta del obispo de Zaragoza está justificada, y lo mismo puede decirse de la de don Dionís, para cuyos intereses poco convenía una Castilla demasiado fuerte. Pero el infante don Juan estuvo más motivado por la conservación de su propio poder e influencia que en mantener la integridad territorial de Castilla. Jaime II, como ha destacado Torres Fontes, fue consciente de la monstruosidad que cometía ${ }^{24}$, y por ello dejó a Castilla la parte situada al sur del Segura con Murcia, Molina y Monteagudo. La cesión no fue expresión de generosidad sino de conveniencia, pues si el despojo no fue mayor para Castilla se debió a la paz que ésta había firmado en 1303 con Granada.

El segundo asunto importante tratado en Torrellas trataba de solucionar la cuestión de los infantes de la Cerda ${ }^{25}$. La estancia de los tres reyes peninsulares más importantes del momento en los confines de Castilla y Aragón permitió también la firma de algunos compromisos o acuerdos de paz entre ellos y en las que fue también admitido el rey de Granada, lo que dice mucho sobre la perfecta integración del reino nazari en la política peninsular.

Todo el protocolo de cartas que siguió a la publicación de la sentencia arbitral de Torrellas, refleja la buena disposición que hacia el cumplimiento de la misma mostraron tanto Fernando IV como Jaime II. Pero la delimitación de la frontera murciana se había hecho de una forma muy imprecisa y carente del más mínimo fundamento geográfico, como pudo comprobarse al intentar materializar el reparto de Murcia entre Castilla y Aragón, por lo que la sentencia tuvo desde el primer momento un carácter completamente provisional ${ }^{26}$.

22 Abelardo MERINO ÁlVAREZ, Geografía histórica de la provincia de Murcia, $3^{\text {a }}$ edic., Murcia, 1981, p. 75.

23 Francisco CASCALES, ob. cit., pp. 83-84.

24 Juan TORRES FONTES, "La delimitación del Sudeste Peninsular (Torrellas-Elche, 1304-1305)", en Anales de la Universidad de Murcia, 1951, p. 17 (de la separata).

25 César GONZÁLEZ MíNGUEZ, ob. cit, pp. 136-138.

26 Ch. E. DUFOURCQ, L'Espagne catalane et le Magrib aux XIlle et XIVe siècles, París, 1966, p. 378. 
Como en la sentencia no se indicaba por donde se debía trazar la frontera entre el Segura y Villena, hubo ya entonces discusión entre ambas partes por la posesión de distintos lugares y términos que quedaban sin asignar o imprecisos, como sucedió con Yecla y Jumilla, entre otros. Para resolver dudas y reclamaciones fue preciso nombrar unos encargados -Diego García de Toledo, Canciller de Fernando IV, por parte castellana y Diego García, por parte de Jaime II- que sobre el terreno, llevaran a cabo las delimitaciones entre ambos reinos. Se llegó a un acuerdo -Elche, 19 de mayo de 1305- que fijaba la frontera entre Caudete, perteneciente a Aragón, y Almansa y Pechín, de Castilla. Luego, por entre Jumilla y Letur continuaba para dirigirse a Tobarra, Hellín y Cieza hasta el Segura, exceptuándose a Yecla y su término, que quedaban en propiedad de don Juan Manuel y en jurisdicción del rey de Castilla, formando un enclave dentro del reino de Aragón.

La frontera arrancaba, pues, desde un punto situado, aproximadamente, en las cercanías de la actual Venta la Encina, para seguir por la sierra de las Cabras hasta Cieza y continuar el curso del río Segura entre Beniel y Orihuela hasta Guardamar, que quedaba para Aragón; se segregaba así de la conquista de Alfonso $X$ el Sabio todo el valle de Ayora, donado anteriormente en el tratado de Campillo (1281), los partidos de Villena, Caudete, Jumilla y la casi totalidad de la actual provincia de Alicante ${ }^{27}$.

Abanilla, Jumilla y Villena con sus términos fueron lugares cuya posesión reclamaron continuamente los castellanos y, en diferentes etapas cronológicas, serían reintegradas a su Corona. En cuanto Cartagena, tras la reivindicación que de ella hizo don Juan Manuel, fue cedida a Castilla en el tratado de Elche.

El Profesor Torres Fontes no duda en calificar de disparate geográfico, histórico y político la división en dos partes del valle del Segura. Región bien definida y con características naturales, sociales, económicas y humanas y cuya compacta unidad histórica se había mantenido en todo tiempo hasta entonces. Arbitrariedad que iba a perpetuarse y daría lugar, en determinadas ocasiones, a enfrentamientos entre estas dos zonas tan afines, pues la política se impuso a lo que la naturaleza y el quehacer de los hombres había unido. Supone también la creación de una frontera activa, tanto en la guerra como en la paz, a la que tuvieron que prestar permanente atención los concejos murciano y oriolano, pues las situaciones conflictivas se sucedieron durante más de dos siglos. Y, por otra parte, Aragón no conseguiría dos de los objetivos proyectados en su intervención, ya que Castilla mantenía su litoral mediterráneo y, por otra parte, la posibilidad de frontera territorial con Granada se perdía definitivamente.

En resumen, como afirma Dufourcq, desde el punto de vista territorial y político los acuerdos de Torrellas-Elche constituyeron un error aunque sirvieron para acabar con la tensión bélica existente entre Castilla y Aragón y para estabilizar la frontera entre ambos reinos en la fachada mediterránea, pero al mismo tiempo permitieron al imperialismo barcelonés fortificarse sobre una parte del litoral ibérico de la denominada «Mancha mediterránea».

27 Juan TORRES FONTES, «La delimitación...», pp. 460-461. 


\title{
LOS SANTIAGUISTAS DEL REINO DE MURCIA DURANTE LA OCUPACIÓN ARAGONESA (1296-1304)
}

\author{
Regina SAINZ DE LA MAZA LASOLI \\ Institución Milá y Fontanals. CSIC
}

La donación del reino de Murcia que el 21 de enero de 1296 hizo el infante Alfonso de la Cerda a Jaime II, a cambio de su ayuda para conseguir el trono castellano, fue el punto de partida para que el monarca aragonés hiciera realidad su deseo de ocupación de este reino, aprovechando la minoría de edad de Fernando IV de Castilla. Gran parte del territorio de Murcia quedó bajo poder de Aragón por espacio de ocho años, desde 1296 a 1304, por medio de una gesta que desde diferentes puntos de vista ha sido tratada por varios historiadores. Yo misma, en 1980, y a raíz del estudio que realicé sobre la Orden de Santiago en Aragón, me referí a un aspecto muy concreto de esta ocupación: el del devenir de las encomiendas santiaguistas de Murcia durante dicho periodo ${ }^{1}$. Hoy, 16 años después de aquel primer acercamiento al tema, he querido ocuparme nuevamente de él porque el hallazgo de varios documentos inéditos me ha permitido ampliarlo y estudiarlo en mayor profundidad.

Qué duda cabe, y eso es un hecho conocido, que el señorío de la Orden de Santiago en Murcia, después del de don Juan Manuel, constituía uno de los poderes más importantes que Jaime II debía atraer a su causa, si quería que la ocupación del reino fuese un éxito. Mi propósito en las páginas que siguen será el de analizar, por un lado,

1 R. SAINZ DE LA MAZA LASOLI, La Orden de Santiago en la Corona de Aragón. La Encomienda de Montalbán (1210 1327). Institución Fernando el Católico, Zaragoza, 1980, pp. 170-177. También hacen referencia a los santiaguistas de Murcia bajo este periodo J. TORRES FONTES y A.L. MOLINA MOLINA, Murcia Castellana en Historia de la región murciana, vol. III, Murcia, Ediciones Mediterráneo, 1981, pp. 380-387; M. RODRÍGUEZ LLOPIS, “La expansión territorial castellana sobre la cuenca del Segura (1235-1325)», Miscelánea Medieval Murciana, XII (1985), pp. 118-125; J.M. del ESTAL, Corpus documental del Reino de Murcia bajo la soberanía de Aragón (1296-1304), Alicante, Instituto de Estudios «Juan Gil Albert», 2 vols. 1985 y 1990. 
la política que desarrolló Jaime II para atraer este poder a su causa, y por otro, examinar la reacción y los cambios de comportamiento que tuvieron los santiaguistas de Murcia, ante el cambio que suponía el sometimiento a un nuevo señor.

\section{SUMISIÓN DE LAS ENCOMIENDAS DE RICOTE, CIEZA Y ALEDO}

Las encomiendas santiaguistas en el reino de Murcia se extendían sobre la cuenca del río Segura, y de todas ellas fueron las de Ricote, Cieza y Aledo, más cercanas a la frontera de Aragón, las que quedaron bajo la influencia de este reino, sirviendo, las más alejadas de Segura, Socovos y Moratalla, de límite a la expansión de Jaime II. Pero a todas el monarca pidió la sumisión a medida que efectuaba la ocupación del reino.

La adhesión de las encomiendas de Ricote, Cieza y Aledo a la causa de Aragón no se consiguió por conquista u ocupación militar, que fue la forma adoptada por Jaime II para someter las villas y castillos reales, sino a través de unas negociaciones, que se iniciaron a mediados de mayo de 1296, y para las cuales el monarca se sirvió de su consejero Ferrán Garcés de Rueda².

El primer paso en estas negociaciones lo dio Jaime II el 20 de mayo, es decir, al día siguiente de haber conseguido la capitulación de Murcia. Desde la misma capital, donde el monarca decidió reposar unos días, escribió a Fernando Pérez y a Juan Martínez, comendadores de Ricote y Cieza, respectivamente, anunciándoles la visita de Ferrán Garcés y rogándoles que dieran crédito a todo lo que les diría de su parte; además, el monarca les concedió ya su guiaje para acudir a Murcia y regresar, facilitándoles de esta forma el camino para que no encontrasen obstáculos en el caso de que, tal como deseaba, decidieran prestarle homenaje $e^{3}$. Dos o tres días duraron las conversaciones entre los dos comendadores y Ferrán Garcés, el cual logró que ambos accedieran a presentarse ante el monarca, iniciando el viaje inmediatamente; lo demuestra el hecho de que el día 23 Jaime II volvió a conceder su guiaje a los comendadores, los cuales «venen a nos ab le amat cavaller nostre Ferran Garçés de Roda", garantizándoles también el regreso a sus respectivas encomiendas ${ }^{4}$. El rey les aseguraba, además, cumplir todo lo que Ferrán Garcés les había prometido de su parte, que no podía ser otra cosa que su intención de defenderles.

El día 25 de mayo los comendadores de Rícote y Cieza llegaron a Murcia, donde celebraron su encuentro con Jaime II, el cual les requirió que le obedecieran como a rey y señor. Sin embargo, aquellos le objetaron que no podían prestarle obediencia

2 Jaime ll ya se había servido en otras ocasiones de su consejero Ferrán Garcés de Rueda para obtener la adhesión de otros castillos y lugares. Véase Ma ${ }^{a}$.T. FERRER I MALLOL, «Notes sobre la conquesta del regne de Múrcia per Jaume II (1296-1304)", en Homenatge a la memòria del Prof. Dr. Emilio Sáez, Barcelona, Universitat de Barcelona, Centre d'Estudis Medievals de Catalunya, Institució Milà i Fontanals. CSIC, 1989, pp. 30 y 34, y también La conquesta de les comarques meridionals valencianes per Jaume $/ 1$, en prensa, donde se hace alusión a estas negociaciones.

3 ACA, C, reg. 340, fol. 79r.

4 ACA, C, reg. 340 , fol. $86 \mathrm{~V}$. 
sin licencia expresa del maestre, pidiéndole 30 días para acudir a Castilla con el fin de obtenerla, a lo que el rey accedió, puesto que este era el plazo que iba dando a los habitantes del reino de Murcia para que le reconocieran como rey.

Mientras aquel 25 de mayo los comendadores de Ricote y Cieza iniciaron su viaje a Castilla para presentarse ante el maestre, Jaime II despachaba tres cartas relacionadas con estas negociaciones. Por la primera de ellas otorgaba su guiaje a los lugares de Ricote, Cieza, Ojós y Aledo, para que nadie los dañara durante aquel mes en que los comendadores de Ricote y Cieza, en representación de todos estos lugares, viajaban a Castilla ${ }^{5}$. La segunda carta iba dirigida al propio maestre Juan Osores, y cobra especial interés por constituir el primer contacto que Jaime II establecía con el máximo dirigente de la Orden de Santiago en relación con la ocupación del reino de Murcia. Por ella le hacía saber que Alfonso, al que siempre denomina rey de Castilla, le había hecho donación del reino de Murcia, tras lo cual él había tomado posesión "de la más noble partida d'aquel». Por esta razón, le rogaba que ordenase a los comendadores, que en aquel momento se dirigían a su presencia, y a todos los santiaguistas de Murcia que le obedecieran, a cambio de cuya lealtad él estaba dispuesto a "fazer ben e mercé a los comendadores e los freyres sobredichos, e mandener e deffender a dreyto a ellos e a todos lur bienes que vuestra Orden a en el dito regno de Murcia». El monarca le amenazaba, sin embargo, con actuar contra todos ellos, si no se sometían ${ }^{6}$. Por último, una tercera carta, unida a la anterior y con la misma petición de obediencia, envió Jaime II a Juan Iváñez, comendador mayor de Segura y de todo lo que la Orden de Santiago tenía en el reino de Murcia.

Los comendadores de Ricote y Cieza regresaron de Castilla a principios de junio, antes de que expirase el plazo de un mes que el monarca les había dado para que le prestasen obediencia. Las instrucciones que traían de parte del maestre eran bien claras: se someterían al monarca de Aragón si éste antes aprobaba y confirmaba todos los fueros, privilegios y libertades que los reyes de Castilla habían concedido a los santiaguistas del reino de Murcia hasta la fecha, y esto fue lo que suplicaron a Jaime II que llevara a cabo. El monarca accedió y el 10 de junio confirmaba todos sus privilegios, pero eso sí, con la condición de que le sirvieran e hicieran paz y guerra por él de los castillos y lugares que la Orden de Santiago tenía en dicho reino ${ }^{7}$. Satisfechos ambos comendadores con esta declaración, al día siguiente, II de junio de 1296, en la ciudad de Murcia y en la casa del monarca, juraron obediencia a Jaime II por sus respectivos lugares, así como también por Aledo, Negra, Ojós y demás territorios que tenían en el reino, prometiéndole, tal como les había pedido, hacer por él paz y guerra y todos los servicios que habían prestado a los anteriores soberanos de Murcia ${ }^{8}$.

De esta forma, pues, y después de tres semanas de negociaciones, las encomiendas de Aledo, Cieza y Ricote, comprendiendo esta última las villas de Abarán, Negra,

5 Jaime II también ordenó a sus oficiales y súbditos respetasen el guiaje concedido a los comendadores de Ricote y Cieza: ACA, C, reg. 340, fols. 93r y 97r. (1296, mayo, 25).

6 ACA, C, reg. 340, fol. 92v.

7 ACA, C, reg. 340 , fol. $127 \mathrm{~V}$.

8 Apéndice, doc. 1. 
Ojós y Puerto de la Losilla, se sometieron a Jaime II. Por lo que respecta al resto de las encomiendas santiaguistas del reino de Murcia, el monarca, en espera de su respuesta favorable tras la petición de obediencia que había hecho al comendador mayor de Segura, extensiva a todos ellos, quiso atraerse su fidelidad. Para ello, al día siguiente de recibir el juramento de los comendadores de Ricote y Cieza, otorgó su guiaje a todos los freires de la Orden de Santiago en el reino de Murcia, a sus bienes y a los habitantes de sus lugares, tanto cristianos como sarracenos; de igual forma, el día 14 también concedió guiaje y seguridad a Pedro Fernández, comendador de Moratalla, y a los lugares de Moratalla, Priego y Benizar, con la condición de que no dañasen los lugares del señorío real ${ }^{10}$.

El sometimiento de los santiaguistas de Murcia a Jaime II llevaba emparejado una serie de promesas de fidelidad, defensa y servicio por ambas partes que, como iremos comentando, no siempre se cumplirían. De momento, y por lo que respecta al monarca de Aragón, muy pronto y en diversas ocasiones iba a demostrar que la promesa que acababa de hacer de defender a los santiaguistas era auténtica, pues así le convenía para mantener la adhesión que acababan de otorgarle. Por ejemplo, enterado de que Jaime Pérez, su hermano natural y a quien el 23 de mayo había nombrado procurador del reino de Murcia ${ }^{11}$, se negaba a restituir a Juan Muntaner, comendador de los bienes que la Orden tenía en Orihuela, cierta cantidad de trigo que había tomado del lugar de Algorfa, le ordenó la restitución. El monarca recordó al procurador la protección que acababa de conceder a los santiaguistas de Murcia, por lo que le mandó que no les ocasionara daño alguno ${ }^{12}$. También quiso Jaime II proteger a los freires y lugares de la Orden que ya se habían sometido a su causa, contra posibles ataques de la población sarracena, y así hizo saber a los moros de Vélez Blanco, Vélez Rubio y Negra que el comendador de Ricote le había reconocido por rey y señor del reino de Murcia, por lo que les ordenaba que no le agraviaran, ni a él ni a sus lugares, mandando, además, a los de Negra que entregasen a dicho comendador los derechos que acostumbraban a darle ${ }^{13}$. Otra actitud a favor de los santiaguistas por parte del

9 ACA, C, reg. 340, fol. 128r. (1296, junio, 12). Sobre la presencia de pobladores musulmanes en las encomiendas santiaguistas de Murcia, véase el trabajo de M. RODRíGUEZ LLOPIS, «Repoblación y organización social del espacio en los señoríos santiaguistas del reino de Murcia (1235-1350)", Murguetana, 70 (1986), pp. 5-34.

10 ACA, C, reg. 340 , fol. $134 \mathrm{v}$.

11 Publicado por J.M. del ESTAL, Conquista y anexión de las tierras de Alicante, Elche, Orihuela y Guardamar del reino de Valencia por Jaime /l de Aragón (1296-1308), Alicante, Publ. de la Obra Social y Cultural de la Caja de Ahorros Provincial de Alicante, 1982, doc. 19 y Corpus documental, 1/ 1, doc. 91; también Mํ. T. FERRER I MALLOL, Organització i defensa d'un territori fronterer. La governació d'Oriola en el segle XIV, CSIC, Institució Milà i Fontanals, 1990, doc. 4.

12 ACA, C, reg. 340, fol. 144v. (1296, junio, 15).

13 ACA, C, reg. 340, fol. 177r.-v. (1296, junio, 26). Muy pronto los moros de Vélez Blanco y Vélez Rubio tendrían ocasión de acatar la orden del rey de defender a los santiaguistas, puesto que a mediados de julio y a raíz del ataque perpetrado por moros del reino de Granada a hombres que el comendador de Ricote había enviado de Murcia a Aledo, recibieron instrucciones de Jaime II de capturar a estos moros y obligarles a devolver lo tomado. Las mismas instrucciones dio el rey al alcaide de 
monarca de Aragón fue la de respetar concesiones por ellos otorgadas. Así nos consta que accedió a la súplica que le hizo Pedro Ruiz de San Cebrián, alcaide del castillo de Orihuela, de que se le respetasen los derechos sobre los tercios de las iglesias de Santiago de Murcia y Orihuela, que el maestre de Santiago le había otorgado ${ }^{14}$.

Por último, también tenemos constancia de que, en el mes de julio, los comendadores de Ricote y Cieza acudieron a presencia del rey para quejarse de que, con motivo de la concesión efectuada por el monarca a un vecino de Murcia, llamado Pedro Andrés, éste había recibido unos bienes en la ciudad que eran propiedad de la Orden de Santiago, queja que Jaime II también atendió ${ }^{15}$.

A finales del año 1296 Jaime II podía estar satisfecho. En el terreno militar dominaba casi todo el reino de Murcia, con excepción de Lorca, Alhama y otras pequeñas plazas. En cuanto a la actitud de los santiaguistas, el balance también era positivo: el maestre Juan Osores había adoptado una postura de aparente neutralidad y varias encomiendas del reino le habían reconocido ya como rey. $Y$ así, con este éxito inicial regresó a Valencia, dejando como procurador suyo, como hemos dicho, a Jaime Pérez.

\section{1297. FERNANDO PÉREZ, COMENDADOR DE RICOTE, OBJETO DE POLÉ- MICA}

De esta forma dio comienzo el año 1297, el segundo de la ocupación, con cierta tranquilidad en el terreno militar, que Jaime II aprovechó para dedicarse a asuntos de gobierno.

Pero en relación con los santiaguistas del reino de Murcia, ocurrió a primeros de junio un hecho, desconocido hasta ahora, que mantuvo ocupada la atención y preocupación del monarca aragonés durante un tiempo, y fue la decisión que tomó el maestre Juan Osores de sacar al comendador Fernando Pérez de la encomienda de Ricote para concederla a otro. Fue el propio maestre quien convocó al comendador a Capítulo para comunicarle su destitución, por unas causas que no hemos podido saber. Lo que sí, en cambio, conocemos es cual fue la inmediata reacción de Jaime II, el cual no podía consentir que un comendador, que un año antes le había jurado obediencia y le

Mula Pedro Zapata, a quien además requirió que «no lexedes fasser mal ne danno a los logares de la Orden ne a los habitantes en aquellos, que por nos segurados son »: ACA, C, reg. 340, fol. 237v. (1296, julio, 16).

14 ACA, C, reg. 340, fol. 189v. (1296, junio, 29).

15 El 7 de julio el rey ordenó a Jaime Pérez, procurador del reino de Murcia, hiciera restituir estos bienes a la Orden de Santiago, misión que el 1 de junio del siguiente año, por estar el procurador ocupado en muchos asuntos, encomendó al jurisperito de Murcia Nom de Deu. Ambas cartas en ACA, C, reg. 108 , fol. $82 r .-v$. La concesión efectuada a Pere Andrés, a la que aluden estas cartas y que motivó la queja de los comendadores de Ricote y Cieza, había tenido lugar el 10 de mayo de aquel año, cuando Jaime II, encontrándose en el asedio de Orihuela, le concedió las casas y posesiones que, habiendo pertenecido a un tal Albalat, tenían en aquel momento Guillermo Pérez de Foces y García Gil de Sagra, a quienes el monarca se las confiscó en castigo a su rebeldía: ACA, C, reg. 194, fol. 147v. 
estaba siendo fiel, fuese substituido por otro que tal vez resultase contrario a su causa, y más tratándose de una encomienda de la importancia de la de Ricote. Por ello, al enterarse, rogó inmediatamente al maestre que en consideración suya siguiese manteniendo a Fernando Pérez al frente de la encomienda de Ricote, puesto que era un hombre bueno, en el que se podía confiar y, además, había dirigido la encomienda con lealtad, "assí que danno ni menoscabo no a venido por él al regno nuestro de Murcia». Por esta razón, Jaime Il pidió al maestre que, aún en el caso de que el comportamiento de Fernando Pérez hacia la Orden hubiese sido tal que mereciera su destitución, consintiera al menos en mantenerlo en Ricote hasta que le certificase a quien quería poner al frente de esta encomienda, en cuyo caso, le decía textualmente: "que se haga a nuestra voluntad» ${ }^{16}$.

Firme, pues, en su defensa del comendador, Jaime II ordenó también al procurador del reino de Murcia Juan Pérez, intercediera de su parte ante el maestre a favor de la restitución de la encomienda de Ricote a Fernando Pérez y no consintiera que aquel hiciera cambio alguno sin su licencia y mandato ${ }^{17}$.

Dos meses duró la espera sobre la decisión del maestre, hasta que a finales de agosto éste comunicó a Jaime II que, atendiendo su petición, consentía en mantener a Fernando Pérez al frente de la encomienda de Ricote. El rey agradeció a Juan Osores su cambio de postura y le rogó diera también al comendador las retenencias de los castillos, tal como se acostumbraba, es decir, la provisión de alimentos, guarnición y otras cosas necesarias para su conservación y defensa ${ }^{18}$. Rápidamente el monarca comunicó a Fernando Pérez la decisión del maestre y le pidió su ayuda en la empresa que estaba llevando a cabo en el reino de Murcia $^{19}$, al mismo tiempo que por otra carta le anunciaba, a él y al nuevo comendador de Segura, Lope Fernández, dieran crédito a lo que de su parte les diría su enviado Ferrán Garcés de Rueda ${ }^{20}$. Pero ¿qué misión llevaba a este consejero de Jaime II ante los dos comendadores?

No creemos equivocarnos al pensar que Ferrán Garcés de Rueda, que el año anterior, tal como hemos señalado, había negociado la sumisión de Ricote, Cieza y Aledo, fue enviado en aquellos momentos ante los dos comendadores con la misma misión: obtener, por una parte, de Fernando Pérez la renovación de su lealtad a la causa aragonesa después de haber sido repuesto en la encomienda y, por otra, requerir al comendador de Segura el juramento de obediencia a Jaime II. Así parece

16 Apéndice, doc. 2. Jaime II escribió esta carta durante la breve escapada que realizó a Lorca, con el fin de asediaria.

17 ACA, C, reg. 253, fol. 42v. (1297, junio, 29).

18 Jaime II, agradeciendo al maestre su decisión de mantener a Fernando Pérez en la encomienda de Ricote, le aseguró que «en los feytos vuestros e de la vuestra Orden faremos toda vía de guissa que vos en seredes pagado»: ACA, C, reg. 109, fol. 278r. (1297, agosto, 27). Sobre la retenencia de los castillos en el $s$. XIV véase, Mª.T. FERRER I MALLOL, “La tinença a costum d'Espanya en els castells de la frontera meridional valenciana (segle XIV)», Miscel.lània de Textos Medievals, 4 (1988), pp. $\uparrow-102$.

19 ACA, C, reg. 109, fol. 278r.-v. Publicado por R. SAINZ DE LA MAZA, La Orden de Santiago, doc. 123 y J. M. del Estal, Corpus documental, 1/2, doc. 88.

20 ACA, C, reg. 109, fol. 278v. (1297, agosto, 27). 
indicarlo el hecho de que el día 5 de octubre el monarca, como solía hacer a favor de las villas que le prestaban lealtad, recibió bajo su guiaje y protección especial el lugar de Segura de la Sierra ${ }^{21}$.

\section{LA RETENENCIA DE LOS CASTILLOS SANTIAGUISTAS. INDIFERENCIA DEL MAESTRE}

Superado, pues, el problema que para Jaime II supuso la posible substitución en la encomienda de Ricote de Fernando Pérez, se produjo a comienzos de 1298 la vuelta de Jaime II al reino de Murcia para emprender el asedio de Alhama. Allí se encontraba ya el 4 de enero, día en que, enterado de que el comendador santiaguista de Aledo Pay Ferrándiz quería entrevistarse con él, ordenó a sus oficiales no le hicieran ningún embargo, ni a él ni a sus cabalgaduras ${ }^{22}$.

Desconocemos el motivo de la visita del comendador de Aledo al monarca, pero sí nos consta documentalmente que tanto este comendador, como el repuesto comendador de Ricote Fernando Pérez y también Juan Martínez, comendador de Cieza, seguían manteniendo un comportamiento leal a la causa de Aragón. Así lo reconoció el propio Jaime II, quien, en consideración a la buena disposición de los tres comendadores y para que mejor pudiesen custodiar sus castillos, les prometió 10.000 maravedís procedentes de las rentas de la Orden de Santiago en Murcia, mientras durase la guerra con Castilla, con la posibilidad de darles mayor cantidad si la necesitaban. Además, les aseguró que ni él, ni el procurador en el reino de Murcia, les quitarían sus castillos y lugares y, si alguno lo hacía, él se los devolvería; y por último, y esto es importante, les prevenía de una posible reacción del maestre contraria a ellos, prometiéndoles que, en caso de que esto sucediera, él los defendería enérgicamente: «si forsan magister dicti Ordinis vellet procedere seu procederet ratione premissa contra vos seu aliquem vestrum, nos iurabimus et deffendemus vos totis viribus" ${ }^{23}$.

El contenido de esta carta que el rey envió a los comendadores refleja, por un lado, la situación comprometida de éstos, siempre temerosos de que sus servicios a Jaime II ocasionasen el enojo del maestre, y por otro, la desconfianza que éste inspiraba al rey aragonés, fundamentada, además, en aquella ocasión por el hecho de que

21 ACA, C, reg. 106, fol. 14v. Entre la llegada de Ferrán Garcés ante el comendador de Segura y la concesión del guiaje a este lugar, transcurrieron los 30 días que Jaime Il solía dar a las poblaciones para que decidieran aceptarle como rey de Murcia y prestarle obediencia, lo que seguramente hizo el comendador de Segura durante los primeros días de octubre de 1297.

22 ACA, C, reg. 256, fol. 7r. También nos consta que por las mismas fechas el comendador de Moratalla Juan Álvarez, que se encontraba en Castilla por voluntad de Jaime II, deseaba entrar en Aragón para verse con el comendador de Montalbán García López. El monarca aragonés ordenó a sus oficiales no se lo impidiesen, siempre que no tratase asuntos perjudiciales para el reino: ACA, C, reg, 107 , fol. $187 \mathrm{v}$. (1298, enero, 9).

23 ACA, C, reg. 196, fol. 129r.-v. (1298, febrero, 7). También en AHN, Aledo, cajón 50, núm. 10. En un traslado de 1757. Publicado por J. TORRES FONTES, Colección de documentos para la historia del reino de Murcia. II, Documentos del siglo XIII, (Codom), II, Murcia, Academia de Alfonso X el Sabio, 1969, doc. CXXVIII y J.M. del ESTAL, Corpus documental, 1/1, doc. 159. 
todavía no había atendido la petición que le había hecho en agosto del año anterior de proveer a la retenencia de los castillos santiaguistas de Murcia. Por ello, al día siguiente de hacer todas estas promesas a los comendadores, Jaime II escribió al propio maestre Juan Osores en unos términos bastante duros, que en el fondo eran una auténtica amenaza y una invitación a que abandonase su actitud, tan poco definida. En primer lugar, le exigía una orden a los santiaguistas del reino de Murcia de obediencia a su causa, y después, tras recordarle nuevamente que los castillos de Ricote, Cieza y Aledo, a causa de la guerra con Castilla, precisaban mayor retenencia, le pedía los 10.000 maravedís que le había solicitado, a saber, 6.000 para el de Aledo y 4.000 para el de Cieza, puesto que sólo así, él le garantizaba que estos lugares continuarían bajo la propiedad de la Orden de Santiago; y porque el cumplimiento de estas peticiones no admitía tardanza, le dio 30 días de plazo para que respondiera ${ }^{24}$.

Pero el maestre, obligado a mantener su fidelidad al rey Fernando IV de Castilla, siguió sin enviar el dinero necesario para los mencionados castillos de Murcia, las rentas de los cuales resultaban en aquel momento insuficientes para su defensa. Fue entonces cuando Jaime II, cumplido el plazo que había dado al maestre y buscando una solución intermedia para no tener que cumplir su amenaza de dejar a la Orden sin la posesión de los tres castillos, lo que no hubiera hecho más que empeorar las difíciles relaciones que mantenía con el maestre, gestó la idea ya conocida: que fuese el comendador mayor de Montalbán en Aragón el que se encargase de su custodia. De esta forma se garantizaría la fidelidad de las tres encomiendas de la zona ocupada de Murcia al sacarles de la inmediata sujeción al maestre, consejero, como hemos dicho, del rey de Castilla, circunstancia que siempre suponía una amenaza. Propuesta la idea al propio comendador de Montalbán, a la sazón García López, y habiendo contestado que no efectuaría la guarda de los castillos de Murcia sin orden expresa del maestre, Jaime II escribió nuevamente a éste el 15 de marzo de aquel año de 1298 ofreciéndole una alternativa de actuación: o bien "dedes conseyllo a los ditos castiellos», o bien «mandedes al comendador de Montalbán sobredito que él y dé conseyllo et ayuda, en manera que por deffayllimiento de guarda et de retenimiento los ditos castiellos non se ayan de perder a vos et a la Orden ${ }^{25}$.

Ante la alternativa ofrecida por Jaime II, el maestre prefirió la que dejaba en manos del comendador de Montalbán la ayuda económica a las tres encomiendas de Murcia. Esto es lo que se deduce de la carta que Jaime Il envió a éste el 19 de marzo, pidiéndole que pagase 10.000 sueldos jaqueses a su escribano Bertrán Desvall para la guarda de los castillos de Ricote, Aledo y otros del reino de Murcia, los cuales no podían ya defenderse sin su ayuda ${ }^{26}$; parte de esta cantidad decidió el rey asumirla: él pagaría 4.000 y el comendador 6.000 , como así se lo hizo saber a Jaime Pérez, su

24 ACA, C, reg. 107, fols. 225v.-226r. (1298, febrero, 8). Publicado por R. SAINZ DE LA MAZA, La Orden de Santiago, doc. 125 y J.M. del ESTAL, Corpus documental, 1/2, doc. 106.

25 ACA, C, reg. 110, fol. 33v. (1298, marzo, 15). Publicado por R. SAINZ DE LA MAZA, La Orden de Santiago, doc. 126 y J.M. del ESTAL, Corpus documental, 1/2, doc. 107.

26 ACA, C, reg. 110, fol. 34r. y reg. 264, fol. 252r. Publicado por R. SAINZ DE LA MAZA, La Orden de Santiago, doc. 127 y J.M. del ESTAL, Corpus documental, 1/2, doc. 108. 
procurador en Murcia, a quien anunció que en breve recibiría esta cantidad con destino a la retenencia de los mencionados castillos ${ }^{27}$. Además, para que el comendador de Montalbán no tuviera dificultades en reunir este dinero, mandó a sus oficiales que cuidaran de que los vasallos del comendador pagasen a éste la suma de dinero que les exigiera ${ }^{28}$.

Todas estas instrucciones, encaminadas a la defensa y conservación de las encomiendas santiaguistas de Murcia, fueron completadas con otra orden que dio Jaime II al procurador de este reino y a sus oficiales de mantener y defender a los freires de la Orden de Santiago y sus bienes ${ }^{29}$, sin olvidar tampoco el monarca las encomiendas alejadas de la zona militarmente ocupada, ya que también mandó proteger al comendador de Moratalla Juan Álvarez, siempre y cuando éste correspondiera con su leal$\operatorname{tad}^{30}$.

\section{DETERIORO DE LAS RELACIONES CON LOS SANTIAGUISTAS}

De lo dicho hasta ahora se desprende que las relaciones de Jaime II con los santiaguistas de Murcia, y en especial con el maestre, eran muy delicadas $y$, pese a la buena disposición que hasta aquel momento parecían haber adoptado los comendadores de Ricote, Cieza y Aledo, su comprometida situación, entre la fidelidad que debían al maestre, consejero del rey Fernando IV de Castilla, y la lealtad que habían jurado al monarca de Aragón, hacía que éste no pudiera estar, ni tranquilo ni confiado respecto a ellos, como las circunstancias se lo irían demostrando.

En efecto, nos consta como ya en el mes de febrero de aquel año de 1298 los de Cieza atentaron contra la paz establecida entre Jaime Il y el reino de Granada, al robar y matar a unos jinetes de Granada que, de regreso de Castilla con todo lo que de allí habían extraído, se refugiaron en Cieza confiando en la amistad reinante, suceso que provocó la rápida actuación del monarca aragonés ${ }^{31}$.

Este comportamiento de los de Cieza se sumó a otros sucesos que empezaron a producirse en el reino y que evidenciaban la hostilidad de que empezaban a dar muestra

27 ACA, C, reg. 264, fol. 247r. (1298, marzo, 19).

28 ACA, C, reg. 110, fol. 33v. Publicado por R. SAINZ DE LA MAZA, La Orden de Santiago, doc. 128 y J.M. del ESTAL, Corpus documental, 1/2, doc. 109.

29 ACA, C, reg. 107, fol. 290v. (1298, marzo, 10). Cit. M. RODRíGUEZ LLOPIS, La expansión territorial castellana, p. 121.

30 ACA, C, reg. 107, fol. 246v. (1298, febrero, 9).

31 Jaime II ordenó al procurador del reino de Murcia Jaime Pérez certificase el suceso y obligase a los de Cieza a efectuar enmienda del robo, orden, que al no ser cumplida, tuvo que renovar cuatro meses más tarde al sucesor en la procuración del reino de Murcia Jaume de Xérica: ACA, C, reg. 107, fol. 219 r (1298, febrero, 11) y r. 112, fol. 64 r (1298, junio, 22).

32 Jaime II, desde Nápoles, comunicó al procurador Jaume de Xèrica que le complacían mucho las noticias que le había dado sobre la tranquilidad y estado pacífico en que se encontraban los reinos de Valencia y Murcia: ACA, C, reg. 113, fols. 164v.-165r. (1299, junio, 10). Jaume de Xèrica fue nombrado procurador de los reinos de Valencia y Murcia el 9 de abril de 1298: ACA, C, reg. 196, fol. 183r. Publicado por Ma.T. FERRER I MALLOL, Organització $i$ defensa, doc. 14. 
los pobladores de origen castellano de los lugares ganados para Jaime II, los cuales, alentados por una cierta recuperación en Castilla, negociaban secretamente con este reino. Así, a pesar de que durante los próximos meses la calma en el terreno militar fue una realidad ${ }^{32}$, los movimientos de conspiración en la frontera, protagonizados tanto por castellanos que entraban en Murcia, como por murcianos que entraban en Castilla, empezaron a ser noticia. No faltaron santiaguistas en estas conspiraciones, pues por el mes de octubre de 1299 el monarca se enteró de que algunos freires castellanos de esta Orden pretendían acudir a las tierras del reino, y para evitar los problemas que su presencia podría provocar, ordenó a Lope Ferrench de Luna, procurador de Aragón, y a Jaume de Xèrica, procurador de los reinos de Valencia y Murcia, no se lo permitieran hasta que certificaran este hecho o recibieran otro mandato suyo ${ }^{33}$.

Con la llegada del año 1300 la fuerza del monarca aragonés empezó a debilitarse, haciéndose evidente por un lado la huida mudéjar y por otro la despoblación del reino, cuya procuración fue encomendada a Bernat de Sarrià el 1 de abril de aquel año, en substitución de Jaume de Jèrica ${ }^{34}$. Por lo que se refiere a las relaciones con los santiaguistas, éstas empezaron a hacerse cada vez más difíciles por los continuos agravios que seguían infiriendo a gentes del rey de Granada, pese a la tregua existente entre los dos reinos ${ }^{35}$. Nos consta al respecto que durante aquel año gentes de Aledo degollaron a dos moros de Vélez Blanco ${ }^{36}$, y que también el comendador y hombres de Moratalla capturaron a 14 moros de Granada, nueve de los cuales enviaron a Mallorca, reteniendo a los restantes en Moratalla ${ }^{37}$. Por otra parte, tenemos noticia de que en noviembre las gentes de Aledo, Ricote y Cieza todavía debían al monarca el monedaje, por lo que Jaime II tuvo que ordenar a los comendadores de dichos lugares obligaran a sus gentes a efectuar el pago ${ }^{38}$.

Pero fue sobre todo a partir de mediados de aquel año, a raíz de la convocatoria de tropas que llevó a cabo Bernat de Sarrià, en nombre del monarca aragonés, para el sometimiento de las plazas que le faltaban, cuando los santiaguistas empezaron a inclinarse al lado castellano. Probablemente su cambio de actitud se debió a las noticias que circulaban de una próxima llegada de Fernando IV de Castilla al reino de

33 ACA, C, reg. 114, fol. 51v. (1299, noviembre, 2).

$34 \mathrm{M}^{\mathrm{a}}$.T. FERRER I MALLOL, Organització i defensa, doc. 16.

35 Al enterarse Jaime II de que desde los lugares de las Órdenes en el reino de Murcia se estaba agraviando a los de Granada, con los cuales quería seguir manteniendo la tregua existente, ordenó a su procurador Bernat de Sarrià hiciese enmendar los daños y, en caso de que los de las Órdenes hubiesen asimismo sufrido represalias, pidiera al nuncio del rey de Granada la reparación de los males: ACA, C, reg. 118, fol. 142r. (1300, septiembre, 15). Cit. Mª.T. FERRER I MALLOL, Organització i defensa, p. 43.

36 ACA, c.r Jaime II, caja 122, núm. 1423 (s.f. [1300]).

37 Como Jaime Il y el rey de Granada habían acordado liberar a todos los presos que, desde que firmaron la paz entre ellos, las gentes de ambos reinos habian capturado, Jaime II en aquel momento ordenó al procurador Bernat de Sarrià que liberase a los moros retenidos por el comendador de Moratalla y por los de Aledo: ACA, C, reg. 117, fol. 172r.-v (1300, junio, 4).

38 ACA, C, reg. 332, fol. 121r. (1300, noviembre, 8). Publicado por J.M. del ESTAL, Corpus documental, 1/2, doc. 117 . 
Murcia, pues hay un hecho fácilmente constatable, y es que los momentos de deterioro de las relaciones entre Jaime II y los santiaguistas durante los ocho años de ocupación aragonesa, coinciden con los anuncios de una recuperación castellana o de la venida de Fernando IV. Fuese ésta u otra la razón, lo cierto es que hacia finales de noviembre de aquel año, el maestre, haciéndose seguramente eco del sentir de muchos de sus vasallos, se quejó a Jaime II de que Bernat de Sarrià hubiese requerido la participación de los lugares santiaguistas de Murcia en la guerra contra Castilla. La respuesta del monarca aragonés a Juan Osores fue inmediata y contundente, recordándole que cuando los reyes de Murcia, sus antecesores, dieron estos lugares a la Orden de Santiago, exigieron de ellos fidelidad en la paz y en la guerra, por lo que él, que era rey y señor de este reino, debía ser correspondido por ellos con la misma lealtad; además, le decía que, aún cuando sostenía guerra con Castilla, él no obligaba a los freires y religiosos de Santiago que estaban en Murcia a ir a las huestes y cabalgadas, sino únicamente convocaba a los legos y a los habitantes de los lugares de su Orden, declaración que el mismo día el monarca también transmitió al comendador de Ricote ${ }^{39}$.

Estas quejas de los santiaguistas reflejaban un hecho evidente, como era su resistencia en aquel momento, a prestar ayuda a Jaime II contra los castellanos, que eran a quienes en realidad estaban sirviendo. Esto es lo que el 19 de aquel mismo mes de diciembre, es decir, al día siguiente de la capitulación de Lorca, el monarca aragonés denunció al propio maestre, a quien comunicó que los comendadores y gentes de Ricote, Peña de Ojós, Aledo y Cieza estaban favoreciendo a Castilla al inferir muchos daños a los lugares de Murcia, destacando la traición del comendador de Ricote, Fernando Pérez, el cual, según palabras del monarca, «acuylle e recibe nuestros enemigos en los ditos castiellos de la Orden» y además, y esta es una noticia interesante, «fizo nos perder el castiello de Mula» ${ }^{40}$. Así pues, resulta evidente por esta declaración de Jaime II que a la revuelta y pérdida de esta población, acaecida durante los primeros meses de aquel año, había tenido mucho que ver la actitud desleal y traidora de los santiaguistas, en especial del que presidía una de sus encomiendas más importantes. La conducta de Fernando Pérez en aquellos momentos era bien diferente a la que, según hemos comentado, había mostrado al iniciarse la ocupación aragonesa del reino y que evidencia, como muy bien dice $\mathrm{M}^{\mathrm{a}}$ Teresa Ferrer, que el juramento y homenaje prestados por muchos súbditos del reino de Murcia a Jaime II no fue sinónimo de lealtad, sino de puro oportunismo ${ }^{41}$.

En la carta de denuncia de estos hechos, y en otras que aquel mismo día Jaime II hacía llegar al maestre, pedía a éste que, a causa del mal comportamiento de los

39 Apéndice, doc. 3.

40 ACA, C, reg. 293, fol. 3v. (1300, diciembre, 18). Publicado por J.M. del ESTAL, Corpus documental, 1/2, doc. 134 y "Nuevos datos sobre la capitulación y conquista aragonesa de Lorca», en Homenaje al Profesor Juan Torres Fontes, I, Murcia, Universidad de Murcia, Academia Alfonso X el Sabio, 1987, pp. 431-464, doc. 4.

$41 \mathrm{M}^{\mathrm{a}}$.T. FERRER I MALLOL, La conquesta de les comarques meridionals valencianes per Jaume II, en prensa. 
comendadores citados y para que no le ocasionaran más daños, le hiciese entrega de los castillos de Ricote, Aledo, Cieza y Ojós mientras durase la guerra con Castilla, prometiéndole su devolución en cuanto ésta terminase, y que instalase en ellos por comendador a "algun buen freyre» que se encargase únicamente de administrar sus rentas y al cual hiciese comendador de Montalbán en Aragón, puesto que así «más volenteroso será a guardar el pro de la Orden teniendo la Comendaria de Montalbán». En segundo lugar le rogaba que no sólo expulsara a Fernando Pérez de la encomienda de Ricote, sino que incluso lo hiciera salir del reino de Murcia como castigo por su traición. Y por último le proponía que fuese precisamente Juan López, comendador de Socovos y portador de las cartas, el elegido para dirigir las encomiendas de Murcia juntamente con la de Montalbán, por ser un hombre leal, que había mejorado su encomienda y había hecho mucho bien a la Orden ${ }^{42}$. Precisamente éste tenía que decir al maestre, de parte de Jaime II, que si en el plazo de 30 días no había cumplido sus peticiones, él actuaría contra los castillos y lugares santiaguistas mencionados.

¿Cuál fue la respuesta del maestre a estas propuestas de Jaime II? Los testimonios documentales dejan claro que únicamente a la expulsión de Fernando Pérez de la encomienda de Ricote no puso objeciones, pero no aceptó el resto de las peticiones del monarca de Aragón. En efecto, no tenemos constancia de que Juan Osores se aviniera a perder el gobierno de los castillos de Murcia, dejando al frente de los mismos a meros administradores, puesto que, aparte de la substitución en Ricote, no se produjo en Cieza y Aledo relevo de sus comendadores. Tampoco el comendador de Socovos fue nombrado comendador conjunto de las encomiendas de Murcia y de la Encomienda mayor de Montalbán, sino que a mediados del siguiente año el maestre colocó al frente de esta última a Fortún de Vergua ${ }^{43}$.

En cuanto a la actitud de Fernando Pérez tras la traición que había protagonizado, no se mostró contrario a abandonar la encomienda de Ricote si el rey así lo quería, pero le pidió entrevistarse con él, así como un plazo para poder entregar al maestre los castillos. En la respuesta que Jaime II le dio, le confesó que había sido el procurador del reino de Murcia y otras personas quienes le habían acusado de que no había sido «tan bien levado en los nuestros servicios como avríades podido fer», puesto que cuando requerían su ayuda, siempre encontraba alguna excusa, dando por el contrario favor a sus enemigos. El rey le recordó asimismo, en tono de reproche, el juramento que en su día le había prestado de tenerle por rey de Murcia y que no hubiera debido olvidar, mostrando, eso sí, su complacencia en celebrar la entrevista que le solicitaba, donde tratarían del plazo para que devolviera los castillos y lo que pensaba hacer al respecto ${ }^{44}$. Fernando Pérez abandonó muy pronto la encomienda, siendo

42 ACA, C, reg. 293, fols. 4r.-5r. (1300, diciembre, 19). Cartas publicadas por J.M. del ESTAL, Corpus documental $1 / 2$, docs. 133,135 y 136 y Nuevos datos, docs. 3,5 y 6 .

43 Ver R. SAINZ DE LA MAZA, La Orden de Santiago, pp. 96-98.

44 ACA, C, reg. 293, fol. 29r. (1300, diciembre, 28). Publicado por J.M. del ESTAL, Nuevos datos, doc. 14 y Corpus documental, 1/2, doc. 144. 
sustituido por el hasta entonces comendador de Moratalla Juan Álvarez, qué, además, era aragonés ${ }^{45}$.

\section{1301. ACTIVIDAD MILITAR Y ATAQUE DEL MAESTRE A CIEZA}

En este estado de cosas y tras la rendición de Lorca acaecida el 21 de diciembre, el año 1301 dio comienzo, por una parte, con la orden de Jaime II de expulsión del reino de Murcia de castellanos y gallegos sospechosos ${ }^{46}$, y por otra, con el aviso de que tropas castellanas, dirigidas por el propio rey Fernando IV, iban a llegar al reino de Murcia en socorro de Lorca y Mula. Los llamamientos a combatir de Bernat de Sarrià, procurador del reino, fueron continuos. Uno de los convocados fue el comendador santiaguista de Cieza Juan Martínez y sus gentes, los cuales a principios de enero manifestaron al propio Jaime II su temor de recibir gran daño de los castellanos si acudían a la hueste, inquietud que refleja una vez más su comprometida situación y que el monarca trató de calmar ordenando al procurador que actuara de forma que los de Cieza no sufriesen daño ${ }^{47}$. En cuanto a la encomienda de Aledo sabemos que por aquel mes intervino en escaramuzas, pues si por una parte algunos de sus hombres se apoderaron en Totana de dos acémilas que hombres de Montblanc y Prades habían traído en servicio del monarca, capturando a los acemileros ${ }^{48}$, a fines de mes elevaron sus protestas al monarca por lo daños, pérdidas y menoscabos que habían sufrido por el rey de Granada y pidiéndole poder recuperar todo lo que les había sido tomado ${ }^{49}$. En realidad los agravios eran recíprocos, pues también el rey de Granada se había quejado de los males que los de la Orden inferían a los de su tierra, pidiendo por ello una satisfacción ${ }^{50}$.

El temido ataque del ejército castellano se hizo realidad durante la primera quincena de febrero, pero al haber llegado demasiado tarde para defender Lorca, se marchó tras abastecer Mula y Alcalá, todavía rebeldes a Aragón.

45 El 24 de diciembre Jaime II, quejoso de que Juan Álvarez, comendador de Moratalla, todavía no le había reconocido por rey de Murcia, le convocó a su presencia en un plazo de 20 días para que efectuara el homenaje: ACA, C, reg. 293, fol. 21v. Publicado por J.M. del ESTAL, Nuevos datos, doc. 11 y Corpus documental, 1/2, doc. 141. Sin embargo, ante los acontecimientos producidos por el comportamiento del comendador de Ricote, la entrevista debió traer consigo, no sólo el juramento de obediencia, sino además su traslado al frente de esta encomienda.

$46 \mathrm{M}^{\mathrm{a}}$.T. FERRER I MALLOL, Organització $i$ defensa, pp. 34 y ss.

47 ACA, C, reg. 118, fol. 3V. (1301, enero, 13).

48 ACA, C, reg. 118, fol. 1v. (1301, enero, 11).

49 ACA, c.r. Jaime II, caja, 6, núm. 819. (1301, enero, 27).

50 Es elocuente al respecto la contestación, que a fines de 1300 , dio Jaime II a las querellas presentadas por el rey de Granada por los daños que los santiaguistas le inferían: «entendiemos por el dito Bernat las querellas que vos avíades de los comendadores de los castiellos de las Ordenes. Ond vos fazemos saber que nos avemos feyto venir delant nos el comendador de Moratalla e los otros comandadores, e ellos tanbién an nos mostrado muy grandes querellas que han de los de vuestra tierra, assí que han assegurado muy bien e complidament en nuestro poder que farán luego render e satisfer todo aquello que sean tenidos a vos ni a las vuestras gentes del tiempo de la paz enca, e que vos también que fagades fazer a ellos otro tał»: ACA, C, reg. 334, fol. 6r. (1300, diciembre, 25). 
Una vez pasado el peligro que supuso la pasajera presencia castellana, el afán del procurador Bernat de Sarrià se centró en hacer volver a los santiaguistas rebeldes de Murcia al servicio de Jaime II. Concretamente a primeros de marzo, y tras hablar con los de Cieza, Ojós y con los moros de Ricote, consiguió de todos ellos su promesa de servir al rey de Aragón contra Castilla y de que todo castellano que acudiese a aquellos lugares sería "pres e retengut», a cambio cuya fidelidad el procurador les aseguró que los defendería; los moros de Ricote prometieron, además, la entrega de 40 rehenes ${ }^{51}$.

Los servicios que Bernat de Sarrià estaba prestando a Jaime Il le hicieron merecedor de una recompensa: la concesión que el monarca le hizo de la villa santiaguista de Negra. Fue seguramente este hecho, que suponía el desmembramiento del patrimonio santiaguista de Murcia, unido a la noticia que tuvo el maestre Juan Osores a finales de marzo de que dicho procurador había asediado Ricote y los demás lugares de la Orden, lo que hizo decidir al maestre a ir al reino de Murcia para defenderlos ${ }^{52}$. A mediados de abril se encontraba ya en el reino con unas huestes compuestas por 500 caballeros y 2.000 peones, tal como to comunicaron al rey el concejo de Murcia y Jaime de Besora, lugarteniente del procurador, el cual convocó a todos los vecinos del reino para que estuviesen preparados para rechazar al enemigo y ordenó a los 30 ballesteros enviados por el concejo de Murcia se situasen en Cieza, lugar por donde se temía la invasión ${ }^{53}$. Bernat de Sarriá, por su parte, envió a defender Cieza a Ato de Lesu, el cual se presentó con 20 caballeros, siete suyos y trece de los de Lorca, y 20 peones ${ }^{54}$.

El temor de los de Murcia no era infundado, ya que el día 22 de abril el maestre Juan Osores, con 500 hombres a caballo, 4.000 peones, (más de los que se esperaba), y un número indeterminado de ballesteros, entraron en Cieza por la noche, matando a muchos vecinos y haciendo prisioneros, entre otros, a don Ato de Lesu y a su compañía. El ataque fue comunicado a Jaime II al día siguiente por el concejo de la ciudad de Murcia, el cual avisó al monarca que había muchos más castellanos que se disponían a entrar en el reino ${ }^{55}$.

51 ACA, c.r. Jaime II, caja 89, núm. 10.898. ([1301], marzo, 7 y caja 8, núm. 1110 (1301, marzo, 7). Este último documento está publicado por P. GUICHARD, Un señor musulmán en la España cris* tiana: el «rais» de Crevillente (1243-1318), Alicante, 1976, doc. 4.

52 El 24 de marzo Bernat de Sarrià comunicó a Jaime ll que el maestre de Santiago «era vengut ab gran cavalleria entro a Feylí (Hellín), e fo ver que.y vené, per ço car avia entés que yo era vengut a Ricot e als altres locs dels Ordens e avia entés que.Is teniem asseegats»: ACA, c.r. Jaime II, caja 91, núm. 11.058.

53 ACA, c.r. Jaime II, caja 10, núms 1342 y 1343 (1301, abril, 19).

54 ACA; c.r. Jaime II, caja 112, núm. 325 (s.f.) [1301, abril].

55 «Sennor, a la vostra alta senyoria fem saber que yr dissabte, que fo XXII dies anats del mes de abril, vengueren e plegaren al cortijo de Çeçe el maestre d'Uclés ab çinçents hòmens a cavall e quatre mília peons e més, e ab ballesters de mont que avien, combateren molt regrament el dit cortijo. Et esta nit entraren e preseren aquell et ay y prés el noble don Ato de Lesu que y estave ab companya, et tots quants y eren an presos e cativats e molts morts. Et segons que.ns dien, deven venir e ésser molts grans gens que venen per entrar en esta terra e que volen talar los pans... ": ACA, c.r. Jaime II, caja 10, núm. 1354. (1301, abril, 23). 
El ataque del maestre de Santiago a Cieza dejó sorprendido a Jaime II, quien sólo cuatro días después de producirse escribió a Juan Osores para requerirle que dejase "de fazer mal e dayno a nos o a nuestras gentes e a nuestros regnos", pues de lo contrario él respondería a su rebeldía actuando contra los lugares santiaguistas de Murcia ${ }^{56}$. Pero la carta tenía además otra finalidad: conocer cuáles eran las intenciones futuras del maestre y sobre todo la razón de su ataque, o en palabras del monarca «porqué vos sodes movido a fazer esto». El rey le anunciaba la visita del comendador de Museros García Lorenzo, así como la de Bernat de Sarrià, el cual tenía instrucciones de que si el maestre cumplía lo que en su día le había prometido, se pusieran de acuerdo y entonces no recibiría daño de su parte.

Un mes tardó Juan Osores en contestar al monarca aragonés a través de una carta que refleja el carácter fuerte y obstinado que le dominaba ${ }^{57}$. En ella le decía que no había entrado en Cieza para hacerle mal o "deservirle», sino que "Cieza punnámosla en cobrar, porque era nuestra" y no había ninguna razón que le impidiera conservar lo que le pertenecía. El maestre también se negaba a prestarle el homenaje que le pedía por los castillos, aunque, si le devolvía Negra «et todo lo al que nos fue tomado", le prometía que ni de él ni de sus castillos recibiría daño alguno. Finalmente, le pedía que mandase a sus oficiales que no planteasen pleito alguno hasta que él le enviara a su procurador, ya que sabía que algunos, aprovechando la situación de guerra, se atrevían a pedir propiedades de la Orden sin tener derecho alguno. Estas palabras del maestre indican claramente que el ataque de Juan Osores a Cieza fue una respuesta a la pérdida para la Orden de Santiago de Negra y de otras plazas, así como también una advertencia a Jaime II para que la política que estaba llevando en el reino no comportase la desmembración del patrimonio santiaguista de Murcia, como estaba sucediendo.

\section{TRATOS DE BERNAT DE SARRIÀ CON EL MAESTRE JUAN OSORES. RESTA- BLECIMIENTO DE BUENAS RELACIONES}

El ataque del maestre de Santiago a Cieza y su declaración a Jaime II de que no le haría homenaje por los castillos del reino de Murcia, ponía en serio peligro el apoyo de los santiaguistas de este reino a la causa de Aragón. Por ello el procurador Bernat de Sarrià se propuso inmediatamente continuar negociaciones con todos ellos, y sobre todo con el propio maestre, para renovar su adhesión. A este fin nos consta que, a mediados de mayo, consiguió ya que el comendador de Aledo y sus hombres le hicieran homenaje a él, en nombre de Jaime Il que en aquel momento se hallaba en Lérida, prometiéndole tener a éste por rey de Murcia y luchar contra los enemigos. En cuanto al comendador de Ricote, lo envió a entrevistarse con el maestre para "fer semblatment del castell de Ricote e de la Pena d'Oxoix ${ }^{58}$.

56 ACA, C, reg. 118, fols. 91v.-92r. Publicado por J. TORRES FONTES, Documentos del siglo XIII, núm. CXLVI y R. SAINZ DE LA MAZA, La Orden de Santiago, doc. 141.

57 ACA, c.r. Jaime II, caja 10, núm. 1351. Publicado por J. TORRES FONTES, Documentos del siglo XIII, núm. CXLVII (equivoca la signatura) y R. SAINZ DE LA MAZA, La Orden de Santiago, doc. 142.

58 ACA, c.r. Jaime II, caja 95, núm. 11.611 ([1301], mayo, 27). 
Bernat de Sarrià mantuvo informado a Jaime II de estas negociaciones, el cual le contestó diciéndole que, a pesar de que le parecía muy bien que pusiese a los santiaguistas "en aquella millor guisa que pugats", sin embargo debía ordenar a éstos que, en caso de que Fernando IV acudiese personalmente al reino de Murcia, no deberían acogerle si no querían perder sus lugares ${ }^{59}$.

A primeros de julio el comendador de Ricote Juan Álvarez regresó de Castilla de verse con el maestre, no siendo sin embargo el resultado de la entrevista el que se había pretendido, ya que Juan Osores no sólo no le entregó la Peña de Ojós, sino que había dudado de que Jaime II hubiese mandado decir todo lo que el comendador le había expuesto de su parte. Por ello Bernat de Sarrià decidió enviarle nuevamente ante el maestre para pedirle por segunda vez la Peña de Ojós, así como un mandato a todos los lugares santiaguistas de Murcia de acatamiento a Jaime II. Además, tenemos constancia documental de que el procurador también entró en tratos con el comendador de Socovos Juan López, consiguiendo de él su adhesión a Jaime $\|^{60}$. Sin embargo, a pesar de este logro, Bernat de Sarrià no confiaba demasiado que las gestiones que estaba llevando a cabo para recuperar la fidelidad de los santiaguistas de Murcia lograsen el resultado deseado, y por ello pidió a Jaime II cartas de recomendación para secundar sus peticiones ante el maestre ${ }^{61}$, si bien una de ellas se cumplió por aquellos días: la entrega de Ojós que Juan Osores le hizo a través del comendador de Ricote Juan Álvarez.

Jaime $I I$ accedió inmediatamente a la petición del procurador, y el 19 de aquel mismo mes escribió tres cartas de recomendación. La primera de ellas iba dirigida a Juan López, comendador de Socovos, con la promesa de que haría cumplir todo lo que hubiese tratado con Bernat de Sarrià ${ }^{62}$, y las otras dos iban destinadas al maestre. Por la primera de ellas Jaime II le comunicaba que tendría por firmes todos los tratos que, para el buen estado del reino y de la Orden de Santiago, hiciese con Bernat de Sarrià, a quien debería dar crédito de lo que le diría de su parte ${ }^{63}$. La segunda contenía una promesa del rey aragonés al maestre: que cuando reinase la paz entre él y Castilla le devolvería a los castillos y lugares de Negra y de Peña de Ojós, así como todas las rentas de Negra y de la val de Ricote, asegurándole además guardar y proteger el patrimonio de la Orden como si fuese un bien personal ${ }^{64}$.

59 Las instrucciones que Bernat de Sarrià tenía que dar a los santiaguistas del reino de Murcia de parte de Jaime II eran las siguientes: «vos les declaretz que si don Ferrando, qui.s diu rey de Castella, venia personalment en regne de Múrcia, ne encara ses gens ne sos valedors, que nol.s acuylissen els dits locs, declarant a ells que sien certs que, si u faren, que nós pendriem los lochs que la Orde ha en nostre senyoria on que fossen ": ACA, $C$, reg. 118, fol. 112r. (1301, mayo, 27),

60 Con estas palabras comunicó Bernat de Sarrià al monarca aragonés la fidelidad del comendador de Socovos: «... yo e tractats alcuns feyts ab Johan Lopis, comanador de Socovos, el qual ha voluntat de vos servir e el qual... serà a servey vostre e a profit del regne...»; ACA, c.r. Jaime II, caja 152, núm. 825 ([1301], julio, 10)
61 Ibídem.
62 ACA, C, reg. 334 , fol. $30 \mathrm{v}$.
63 ACA, C, reg. 334, fol. 30r.
64 Apéndice, núm. 4. 
Tras estas negociaciones, que garantizaban de momento la fidelidad de los santiaguistas a cambio de las promesas que el monarca les hacía, un clima de buena relación se estableció entre aquellos y Jaime II, el cual, con el deseo de que se mantuviera, aconsejó a Bernat de Sarrià que las convocatorias de las huestes del reino de Murcia que estaba llevando a cabo no pusieran en guerra a los lugares de las Órdenes ${ }^{65}$. A este estado de buen entendimiento con la Orden de Santiago contribuyó en gran manera el comendador de Ricote Juan Álvarez, aragonés, y que como hemos dicho actuó de interlocutor ante el maestre, haciendo gala de una actitud completamente leal a la causa de Jaime II. Éste, a finales de septiembre, le agradeció los servicios que estaba prestando a Alfonso, rey de Castilla, y le animó a seguir con su actitud, ya que sirviendo al rey Alfonso, le servía a él mismo ${ }^{66}$.

$Y$ es que a Jaime II le interesaba mantener la adhesión de sus incondicionales, puesto que algunos ricoshombres de Aragón ya se habían desavenido de él y la inestabilidad en el reino de Murcia, a causa de la falta de soldados, la escasez de vianda en los castillos y las amenazas continuadas de ataques castellanos, empezaba a ser preocupante, pese a que durante el resto de aquel año se mantuvo una cierta calma militar, así como el buen entendimiento con los santiaguistas.

En efecto, a comienzos del año 1302 Jaime II y el comendador de Ricote, Juan Álvarez, prosiguiendo sus buenas relaciones, se escribieron y enviaron emisarios para tratar asuntos comunes ${ }^{67}$. Sin embargo, a finales de febrero, y por causas que desconocemos, dicho comendador desconfió de Jaime II al creer que estaba poniéndose de acuerdo con Castilla, recelo que transmitió al propio monarca. Éste, para disipar sus dudas y tranquilizarle, le escribió manifestándole lo equivocada que era su sospecha: «nos, adobo nenguno no avemos feyto con Castiella ni vos en tal temer, ante seet cierto que es nuestro entendimiento de perseverar e levar los feytos más enfortidament que nunca en ayudar al muy alto rey don Alfonso de Castiella e infant don Ferrando, su hermano, caros cormanos nuestros, en la demanda que han en Castiella». Por todo ello le instaba a servir a dichos rey e infante, de los cuales, y también de él mismo, recibiría como contrapartida «muyto bien e muyta mercé»» 6 .

No solamente el comendador de Ricote mantenía su lealtad a Jaime II, sino también el comendador de Aledo, Centón Ruiz, al que el monarca agradeció igualmente sus servicios a la causa de Alfonso de la Cerda ${ }^{69}$.

65 ACA, C, reg. 122, fol. 231r.-v (1301, agosto, 29) Cit. Mª̂.T. FERRER I MALLOL, Organització, p. 37.

66 «Sepades que entendiemos que vos servides e punyades servir en aquexas partes al muy noble don Alfonso, rey de Castielia, caro cormano nuestro, e gradezemos vos lo muyto, ond vos rogamos e vos dizimos que al dito rey puynnedes servir quanto podades, que serviendo a ell provides a nos e lo que bien avedes començado, levatlo a cabo adelant, que grant bien vos en verndrá»: ACA, C, reg. 119 , fol. 32r. (1301, septiembre, 29).

67 El 14 de febrero Jaime II escribió a Juan Álvarez, comendador de Ricote, pidiéndole diera crédito a su escudero Rodrigo de Biscarra, que acudía a su presencia para tratar algunos negocios: $A C A, C$, reg. 123 , fol. 5 r.

68 ACA, C, reg. 334, fol. 49r. (1302, febrero, 23).

69 ACA, C, reg. 334, fol. 49v. (1302, febrero, 23). 
El apoyo que Jaime II estaba recibiendo de los santiaguistas en aquellos momentos era realmente importante ante los rumores de que los castellanos se preparaban para entrar en el reino de Murcia durante el próximo verano ${ }^{70}$. El monarca pidió ayuda a sus súbditos, y también a todos los del reino de Castilla «que la boz e carrera del muy noble rey don Alfonso de Castiella querrán tomar ${ }^{71}$, destacando de nuevo en aquellos momentos los servicios que el comendador de Ricote dispensaba a Alfonso de Castilla y que Jaime II le agradeció una vez más ${ }^{72}$.

Los preparativos para una campaña militar prosiguieron durante los primeros meses de 1303, produciéndose el 3 de abril el nombramiento de Pere de Montagut en la procuración del reino de Murcia ${ }^{73}$, en substitución de Bernat de Sarrià, a quien le siguió confiando el asedio de Mula.

Por lo que respecta a los santiaguistas, nos consta que Jaime II continuó protegiéndoles durante toda la primera mitad de aquel año, cursando el día 26 de mayo dos disposiciones a su favor: que en los lugares de la Orden de Santiago en Murcia no se exigieran las cenas, a no ser como se las exigían en época de los reyes de Castilla, y que el procurador y oficiales de Murcia no causasen daño alguno al valle de Ricote, Peña de Ojós, Negra y Cieza, a los que concedía su guiaje ${ }^{74}$. Sin embargo, estas disposiciones no iban a evitar que muy pronto las circunstancias políticas llevasen a los santiaguistas del reino de Murcia a retirar definitivamente su apoyo a Jaime II.

\section{LAS RELACIONES CON LA ORDEN DE SANTIAGO ENTRAN EN CRISIS}

En efecto, los rumores de un ataque castellano aumentaban y en septiembre Bernat de Sarrià informó a Jaime II que, según le habían dicho, Fernando IV de Castilla, personalmente o enviando una compañía, llegaría pronto para recibir el valle de Ricote y todos los demás castillos que las Ordenes tenían en el reino de Murcia ${ }^{75}$. Tal como hemos podido comprobar a través de la documentación, esta noticia coincidió, al igual como había sucedido a mediados de 1300 , con un cambio radical en la conducta de los santiaguistas de Murcia, los cuales, alentados por la anunciada ayuda castellana, decidieron retirar su apoyo a Jaime II. Este cambio de postura se vio favorecido, además, por el fallecimiento del comendador de Ricote Juan Álvarez, aragonés, y que tan buenos servicios le había prestado. Tanto su sucesor Juan López, como los comendadores de Cieza y Aledo, empezaron a causar al reino daños tan graves, que Jaime II no pudo por menos que denunciarlos al propio maestre con estas elocuentes pala-

70 Ante los rumores de los preparativos que se hacían en Castilla, Jaime Il ordenó a su procurador en Murcia Bernat de Sarrià pusiese guardas en los castillos: ACA, C, reg. 123, fol. 37v. (1302, marzo, 8).

71 ACA, C, reg. 123, fols. 102v.-103r. (1302, abril, 19).

72 ACA, C, reg. 123, fol. 103r. (1302, abril, 20).

$73 M^{a}$.T. FERRER, Organització $i$ defensa, doc. 28.

74 ACA, C, reg. 128, fol. 143v. (1303, mayo, 26).

75 ACA, c.r. Jaime II, caja 100, núm. 12.519. Publicado por A. GIMÉNEZ SOLER, Don Juan Manuel, Zaragoza, 1932, doc. LXXXII (parcial) y caja 101, núm. 12.552 ([1303], septiembre, 10). 
bras: «los comendadores qui tienen agora los castiellos de la Orden vuestra que son en el regno nuestro de Murcia, an feyto et fazen cada día muytas terrerías et daynos et agraviamientos a las nuestras gentes del dito regno, et vierne end por esto grant destorbo a nos et mal al dito regno ${ }^{76}$. Concretamente, sabemos que el comendador de Aledo Centón Ruiz y sus gentes, cambiando radicalmente el comportamiento que habían tenido, agraviaban a los de Lorca y daban cobijo en el castillo a almogávares y castellanos, que insidiaban y capturaban a los aragoneses ${ }^{77}$. Otro de los perjudicados por el comportamiento del comendador de Aledo fue Ramón de Mula, a quien sin ninguna razón quitó 80 yeguas y otras bestias que, junto con otros compañeros, sacaba de Castilla, dando muerte a alguno de ellos. Jaime II, quejoso de la actuación del comendador porque había cometido el robo «en deserviçio nuestro", rogó al maestre que le obligase a devolver lo sustraído y le castigase por ello ${ }^{78}$.

Jaime II, aprovechando la notificación que hacía al maestre Juan Osores de los males que los comendadores le estaban causando, le rogó encarecidamente que encomendara estos castillos a freires de Aragón, renovando su propuesta de que fuera el comendador de Montalbán, en aquel momento Artal de Huerta, quien los tuviese, lo que evitaría que se produjesen daños "ni a nos ni a nuestra tierra».

Antes de saber la respuesta del maestre y sin duda para ganarse su favor, Jaime II decidió restituir Negra, que a fines de 1301 había prometido devolver a la Orden cuando reinase la paz con Castilla, lo que todavía no había sucedido. Así pues en septiembre ordenó a Bernat de Sarrià, que como hemos comentado poseía este castillo por la donación que le había hecho en premio a sus servicios, que lo restituyese al comendador de Ricote Juan López $z^{79}$; sin embargo, al fallecer éste por aquellas fechas, el rey ordenó entonces lo entregara al comendador de Montalbán Artal de Huerta, no como a comendador, sino con carácter personal, con lo cual Negra seguía sin ser devuelta a la Orden ${ }^{80}$.

Conocemos la respuesta del maestre Juan Osores a las propuestas de Jaime II a través de una carta que le envió el 30 de diciembre ${ }^{81}$. A través de ella pedía al monarca que tuviera bajo su protección los bienes santiaguistas y le exigía que entregara el castillo de Negra al freire Miguel Pérez, que le enviaba con su carta. Además, como Jaime II, en contra de la política de alianza seguida años atrás con los moros de Ricote, les había aumentado los tributos, le pidió también que no hiciera ni consintiera hacer tuertos a sus vasallos de Ricote, los cuales nunca habían pechado por tener privile-

76 ACA, C, reg. 130 , fol. 170r. (1303, octubre, 29). Publicado por R. SAINZ DE LA MAZA, La Orden de Santiago, doc. 156.

77 Jaime II ordenó al comendador que no consintiera los males que sus gentes estaban infiriendo a los de Lorca: ACA, C, reg. 129, fol. 107v. (1303, octubre, 3)

78 ACA, C, reg. 130, fol. 201r. (1303, diciembre, 1).

79 AHN, carp. 293, núm. 4. Publicado por J. TORRES FONTES, Codom, II, doc. 151.

80 ACA, C, reg. 201, fol. 56v. Publicado por R. SAINZ DE LA MAZA, La Orden de Santiago, doc. 157. El 1 de noviembre Jaime II notificó al comendador de Montalbán Artal de Huerta los ruegos que había hecho al maestre de que le encomendara los castillos de la Orden en el reino de Murcia, así como su decisión de que el castillo de Negra pasase a sus manos: ACA, C, reg. 130, fol. 173r. Publicado por R. SAINZ DE LA MAZA, La Orden de Santiago, doc. 158.

81 Apéndice, núm. 5. 
gios y franquicias. Por último, se excusaba por no poder acudir al reino de Murcia, como era su intención, para verse con el procurador y tratar del comportamiento de sus vasallos, ya que debía acudir rápidamente ante el rey de Portugal que le había convocado, pero le prometía acudir en breve y le aseguraba que todos los lugares de la Orden que estaban bajo su dominio no le harían daño. Con estas palabras el maestre daba su negativa a la propuesta de Jaime II de colocar los castillos santiaguistas de Murcia bajo la dirección de la Encomienda de Montalbán.

Esta carta era ya conocida, pero no así la contestación que Jaime II dio al maestre el 30 de marzo de 1304 y que he tenido la fortuna de encontrar. En primer lugar, a su petición de tener bajo su guarda todo lo que la Orden tenía en su tierra, el monarca le declaraba que ésta había sido siempre su intención, siempre y cuando los santiaguistas actuasen "como fazer deven" y no dañasen su tierra. En cuanto al castillo de Negra, el monarca le decía que en aquel momento no se lo podía entregar, pero que cuando acudiese a Murcia «faremos a aquello que será bien»82. A la tercera petición o advertencia sobre las pechas de sus vasallos, Jaime II manifestaba que de la misma forma que las tenía de las otras Órdenes, las quería tener también de Santiago, a no ser que la Orden de Santiago poseyera privilegios, en cuyo caso le pedía se los mostrase para observarlos. Por último a la afirmación del maestre de que nunca había dejado de servirle y que de sus lugares nunca vendría mal a su tierra, la respuesta de Jaime II contenía una buena dosis de ironía. El rey le rogaba, "pues tan bien lo dezides», que ordenase a sus vasallos del reino de Murcia se comportasen de tal forma que él se sintiera correspondido, y lo sería si él, tal como le había prometido, acudiese al reino de Murcia «e fiziéssedes adobar aquello que Centon Ruiz (comendador de Aledo) e otros han feyto cuentra nos e nuestra tierra e nuestros vassallos" ${ }^{83}$. Con estas palabras Jaime II manifestaba claramente al maestre que a no ser que se presentase y arreglase la situación que sus vasallos estaban provocando en el reino de Murcia, sus argumentos no tenían ni valor ni fiabilidad para él.

Y era lógico, por otra parte, que una vez más Jaime II desconfiara del maestre, ya que por aquel entonces no había cumplido los ruegos que le había hecho de obligar al comendador de Aledo a restituir a Ramón de Mula todo lo sustraído, lo que ocasionó que el monarca ordenase la entrega a éste de la heredad llamada Algorfa, situada en el término de Orihuela y perteneciente a la Orden, para que pudiera explotarla hasta que el comendador le hiciera restitución de lo robado ${ }^{84}$; sin embargo el rey desconocía

82 Unos días antes el freire santiaguista Miguel Pérez de Guasillo pidió a Jaime Il le entregase el lugar de Negra, puesto que el maestre quería "que yo por él lo reçiba»: ACA, c.r. Jaime II, caja 16, núm. 2135 (1304, marzo, 16).

83 Apéndice, núm. 6. También aquel mismo día Jaime ll escribió a Don Juan Manuel, en respuesta a los ruegos que le había hecho a favor de la Orden de Santiago y sus freires. El monarca le contestó diciéndole que, teniendo muy en cuenta sus ruegos, estaba protegiendo el patrimonio de la Orden, si bien que ría que supiera que «en el regno de Murcia algunos freyres e vassallos de la Orden han feyto en deservicio nuestro": ACA, C, reg. 235, fol. 44r. (1304, marzo, 30).

84 La orden de Jaime II a su procurador en Murcia Pere de Montagut de entregar Algorfa a Ramón de Mula fue dada el 15 de febrero: ACA, C, reg. 131, fols. 72v.-73r., orden que le cursó de nuevo el 1 de abril: c.r. Jaime II, caja 18, núm. 2322. 


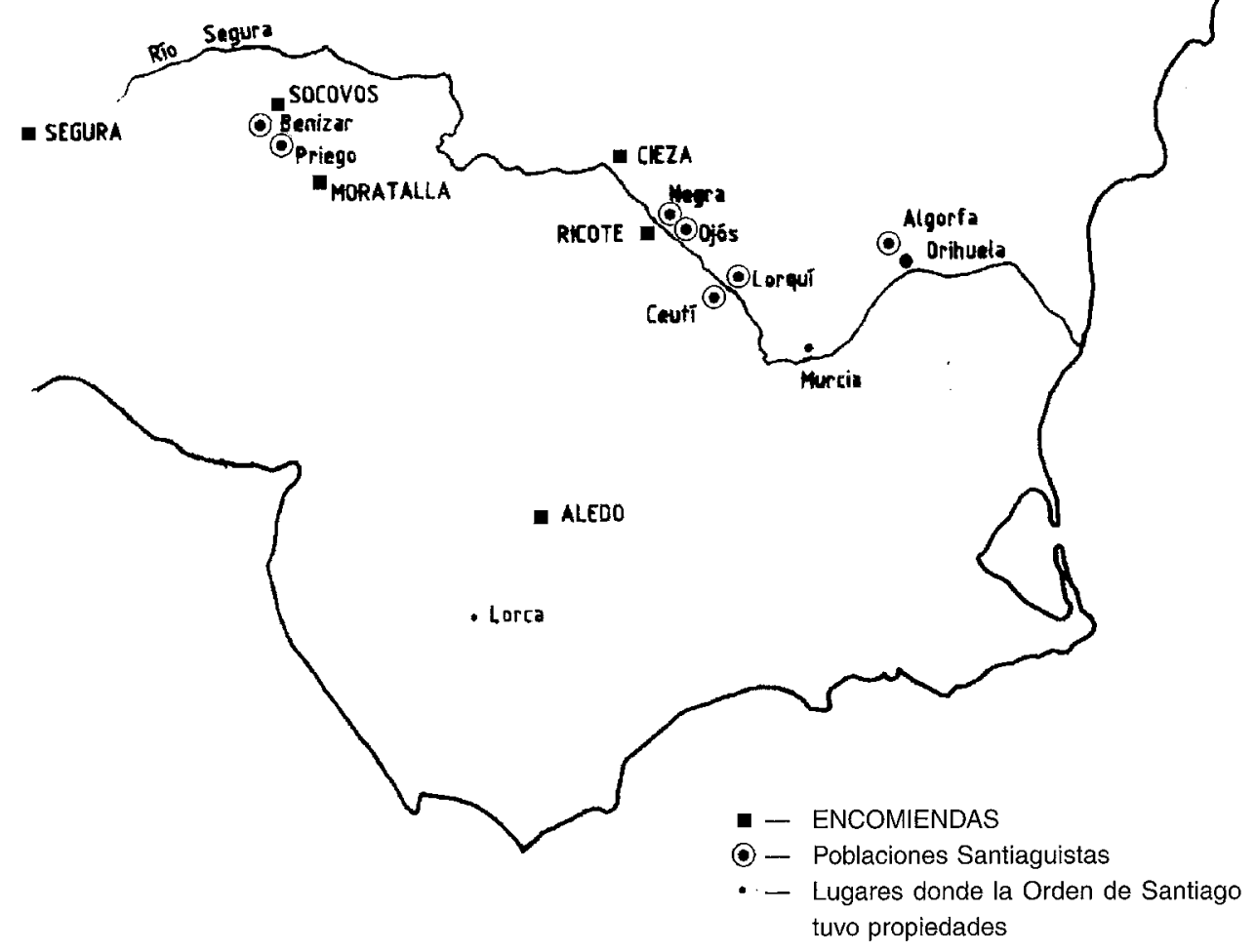

Lugares santiaguistas implicados en la ocupación aragonesa del Reino de Murcia (1296-1304)

que este lugar había sido concedido a violario por el maestre a Juan Muntaner, el cual, lógicamente, protestó, disponiendo entonces el rey la restitución de Algorfa a su propietario y la entrega a Ramón de Mula de otros bienes de Santiago en compensación ${ }^{85}$. Esta indemnización siguió perjudicando el patrimonio santiaguista en el reino de Murcia, por lo que no resulta extraño que aquel año el maestre Juan Osores solicitase a Fernando IV de Castilla poder hacer uso del privilegio que el papa había concedido a la Orden de Santiago en 1287, de predicar y recaudar cruzada para la defensa de varios castillos fronterizos, citándose, entre otros, los de Aledo, Ricote, Peña y Moratalla ${ }^{86}$.

85 ACA, C, reg. 132, fol. 149r.-v. El procurador del reino de Murcia Pere de Montagut sugirió al rey se compensara a Ramón de Mula con bienes de la Orden de Santiago en Lorca, que eran de la encomienda de Aledo y Moratalıa: ACA, c.r. Jaime II, caja 18, núm. 2322 (1304, abril, 4). Juan Muntaner y su mujer doña Alamanda habían recibido por concesión del maestre Juan Osores todo lo que la Orden poseía en Orihuela y en la Algorfa, y ellos, a su vez, donaron a la Orden cuanto poseían en Lorca y su término: AHN, OO.MM. Uclés, carp. 50, vol. I, núm. 9.

86 Ver la bula papa en B. CHAVES, Apuntamiento legal sobre el dominio solar de la Orden de Santiago en todos sus pueblos, El Albir, reimpr. 1975, Barcelona, pp. 194v-195r. Cit. M. RODRÍGUEZ LLOPIS, Repoblación, p.12. El 1 de julio de 1303 Fernando IV de Castilla concedió al maestre Juan 
Vemos, pues, que la inestabilidad que desde comienzos de 1303 estaba ocasionando en el reino de Murcia el señorío de la Orden de Santiago era una realidad, como también la que produjo la intervención de la compañía de jinetes del noble marroquí Alabbàs ben Rahu, a quien Jaime Il el 22 de diciembre del año anterior había encomendado la tarea de hostilizar al enemigo. Las condiciones del establecimiento no sólo eran onerosas para el monarca, sino que hicieron empeorar aún más las relaciones con los santiaguistas, ya que el castillo de Negra y los lugares de Ceutí y Lorquí se entregaron a estos africanos para su establecimiento. Las consecuencias no tardaron en hacerse notar, ya que en abril de 1304 y a raíz de una expedición que ben Rahu iba a efectuar a Castilla, los de Cieza y Aledo avisaron a los castellanos de las intenciones del africano, al que ocasionaron, en especial Cieza, numerosos daños que el propio ben Rahu describió a Jaime $\|^{87}$.

La situación creada, empeorada por el deterioro de las relaciones con el reino de Granada que había firmado la paz con Castilla, la falta de recursos por ambas partes, y el cansancio condujeron a la paz que todos deseaban y que la llegada de la mayoría de edad de Fernando IV iba a facilitar. La sentencia de Torrellas, firmada el 8 de agosto de 1304 decidió la división del reino de Murcia, quedando para Castilla la parte meridional y su capital y para la corona catalano-aragonesa las comarcas septentrionales, que al cabo de pocos años se anexionarían al reino de Valencia.

Precisamente, tras la sentencia de Torrellas, iban a ser dos santiaguistas, el maestre Juan Osores y el comendador de Montalbán Artal de Huerta, quienes actuarían de intermediarios para la devolución de los lugares del reino de Murcia ${ }^{88}$. Artal de Huerta acudió a Murcia el 11 de noviembre para recibir del maestre de santiago, en nombre del rey de Castilla, los castillos y lugares que éste debía entregar a Aragón. Y el maestre Juan Osores, por su parte, fue recibiendo, entre los días 16 y 19 de noviembre los lugares que Jaime II debía devolver a Castilla, recuperando finalmente para su Orden el castillo y villa de Negra tantas veces reclamado ${ }^{89}$.

Así terminó aquel capítulo de la historia del reino de Murcia, ocupado temporalmente por Aragón, mediante la firma de una paz que las palabras de pleitesía que dirigió Jaime II a su antiguo enemigo Fernando IV de Castilla dejaba sellada: «os prometo vos amar e de querer vuestra honrra e vuestra pro, e de ser amigo de vuestros amigos et enemigo de vuestros enemigos... ${ }^{90}$.

Osores, a petición suya, poder recaudar la cruzada. Ver A. BENAVIDES, Memorias de Fernando IV de Castilla, Madrid, 1860, vol. II, doc. CCXXXV.

87 «... porque senyaladament nos fisieron danno y estorvo los de Cieça, en que nos negaron tres cabeças de vacas que les avíamos acomendadas e nunca las podremos aver. Et más, corrieron nos a Negra e no nos podieron façer más danyo, salvo que nos crebantaron ochaenta e tres colmenas e levaron nos una gran pieça de trapo de lienços... »: ACA; c.r. Jaime II, caja 92, núm. 11.186.

88 El 10 de octubre el maestre Juan Osores comunicó a Jaime II que el rey de Castilla le enviaba al reino de Murcia para hacer cumplir las entregas de lugares que ambos debían efectuar. De nuevo, le reiteró su petición de que le devolviera el lugar de Negra: ACA, c.r. Jaime II, caja 17, núm. 2204.

89 Juan TORRES FONTES, Documentos del siglo XIII, docs. CLVI-CLXVII.

90 ACA, c.r. Jaime II, caja 125, núm. 1815. (s.f.) [1304]. 


\section{APÉNDICE DOCUMENTAL}

1296, junio, 11. Murcia.

Fernando Pérez, comendador de Ricote, y Juan Martínez, comendador de Cieza, juran homenaje a Jaime /l por sus respectivos castillos, así como por los de Aledo, Negra, Ojós y demás lugares que tienen en el reino de Murcia.

ACA, c.r. Jaime II, caja 152, núm. 834.

Ferrandus Petri, comendator de Ricoto, Johannes Martini, comendator de Cessa.

In tertio idus iunii, anno Domini $\mathrm{M}^{\circ} \mathrm{CC}^{\circ} \mathrm{XC}^{\circ} \mathrm{VI}^{\circ}$, in civitate Murcie, in domo domini regis, Ferrandus Petri, comendator de Ricoto, Johannes Martini, comendator de Cessa, iuraverunt domino regi tenere dicta castra et alia loca que habent in regno Murcie pro dicto domino rege, e facere pro domino rege predicto de dictis castris, et de castris de Cessa, de Aledo, de Negra et de Penna d'Oxuix, et etiam de aliis locis que ipsi habent in regno Murcie, facere pacem et guerram et omnia alia que facere tenebantur aliis dominis regni predicti Murcie.

(En el margen inferior) Cessa, Aledo, Negra, La Penna de Sux.

\section{2}

1297, junio, 27. Asedio de Lorca.

Jaime II ruega al maestre de Santiago Juan Osores permita a Fernando Pérez, comendador de Ricote, de quien alaba sus virtudes, seguir al frente de esta encomienda, ya que se ha enterado de que quiere destituirle.

ACA, C, reg. 253 , fol. $27 \mathrm{v}$.

Al noble e amado don Johan Osores, maestro de la Horden de la cavallería de Sant Jayme et cetera.

Entendiemos que agora avíades çitado a Ferrant Péreç, comendador de la val de Ricot, a capítol e que allí le avíades tuelta la comanda de Ricot e que la queríades dar a otro. E como el dito Ferrant Pérez sia homne bueno e en qui muyto podría homne fiar, e él la su comanda aya tenido bien e lealment assí que danno ni menoscabo no a venído por él al regno nuestro de Murcia, rogamos vos que por amor de nos embiedes al dito Ferrant Pérez por comendador de Ricot assí como la tenía, et si por ventura por cosas que.I fiçiesse contra la Orden lo avíades a mudar de la dita comanda, que consintades que la tenga el dito Ferrant Pérez entro que nos ayades certifficado a qui 
tenredes por bien de comendarla, que se faga con nuestra voluntat porque nos no end ayamos a aver sospeyta, e gradecer vos lo hemos muyto.

Dada en el sitio del castiello de Lorca, III días por andar del mes de junio et cetera. Petrus Martini, mandato Guillermi Durffortis.

[1300], diciembre, 3. Orxeta.

Jaime II a Juan Osores, maestre de Santiago, acusando recibo de su carta en la que se extrañaba de que Bernat de Sarrià hubiese obligado a los castillos y lugares que la Orden tiene en Murcia a luchar contra los enemigos. El rey le responde que no se ha convocado a los freires y religiosos de la Orden, sino únicamente a los legos y pobladores de los lugares. Bajo los mismos términos al comendador de Ricote.

ACA, C, reg. 254 , fol. 23 r.-v.

Don Jayme et cetera, al honrado don Johan Osores, maestro de la Orden de la cavallería de Sant Yago, salut e dilección.

Recibiemos vuestra carta que agora nos embiastes en razón de los castiellos e lugares que la vuestra Orden ha en el regno de Murcia, los quales requerió Bernat de Serrián, amado conseyllero nuestro, que fiziesces guerra a nuestros enemigos. Ond nos, entendido esto e todo lo al que en la dita carta vuestra nos embiastes dezir, vos respondemos que los reyes del regno de Murcia, antecessores nuestros, quando dieron los logares sobreditos a la vuestra Orden, si retovieron fieldat et paç et guerra, et nos, qui somos rey e sennor del reygno sobredito de Murcia, ayamos e devemos y aver aquella misma fieldat, paç e guerra que los otros reyes y avían. Porque non vos maravilledes en la guerra que avemos con Castiella nos queremos ayudar de los ditos logares, no empero que nos, los freyres ni los religiosos qui son de la dita Orden en los ditos logares mandemos ni fagamos yr en uest ni fer guerra, salvo de los ditos logares e de los homnes legos de aquellos, de los quales nos devemos ayudar et queremos contra nuestros enemigos.

Datum in Orcheta, sub sigillo nostro secreto, $11^{\circ}$ nonas decembris, anno predicto. $\left[\mathrm{M}^{\circ} \mathrm{CCC}\right]$.

Similis fuit facta comendatori de Ricot, verbis competenter mutatis.

1301, julio, 19. Lleida.

Jaime // promete a Juan Osores, maestre de Santiago, que en cuanto reine la paz entre él y Castilla le devolverá el castillo de Negra, que concedió al procurador del reino de Murcia Bernat de Sarrià, y el de Ojós, que el propio maestre ha mandado 
entregar a dicho Bernat por medio del comendador de Ricote Juan Alvarez. También le promete las rentas de Negra y del valle de Ricote, y tener en paz estos lugares.

ACA, C, reg. 334 , fol. 30 r.

Sepan todos quantos esta carta verán que nos, don Jayme, por la gracia de Dios rey de Aragón, de Valencia e de Murcia, conde de Barcelona, prometemos a vos, honrado e religioso don Johan Osorez, maestro de la Orden de la cavallería de Sant Yago, absent, assí como si fuéssedes present, que nos rendremos e livraremos a vos, o a qualquier que será maestro en aquell tiempo, o a los frayres qui por vos o por el maestro qui será en aquel tiempo serán enbiados a reçebir, los castiellos e logares de Negra e de la Peyna de Xoys en aquel tiempo que sea paç entre nos e aquel qui regnará en Castiella, el qual castiello de Negra tiene por nos el amado conseyllero nuestro en Bernat de Serrián, procurador del regno de Murcia, el qual castiello de la Peyna de Xoys vos avedes mandado livrar al dito en Bernat de Serrián por Johan Alvareç, comandador de Ricot. Aún vos prometemos que nos vos mandaremos dar luego e responder de todas las rendas del dito logar de Negra e de la vayl de Ricote tener en patz aquellos logares. Aún vos prometemos que guardaremos todos los logares e bienes e cosas vuestras e de la Orden que son en nuestra senyoría bien, assí como las nuestras cosas propias.

En testimonio de la qual cosa, fiziemos fer esta carta e seellar con nuestro siello colgado.

Dada en Lérida, XIX días andados del mes de julio, en el ayno de Nuestro Senyor de mil e CCC e uno.

Petrus Martin, mandato regio.

1303, diciembre, 30. El Corral.

Juan Osores, maestre de Santiago, a Jaime II, pidiéndole proteja el patrimonio de la Orden en Murcia, le devuelva Negra y no agravie a sus vasallos moros de Ricote contra los privilegios que poseen. El maestre se escusa por no ir a Murcia, prometiendo acudir en breve.

ACA, c.r. Jaime II, caja, 15, núm. 1905.

Cf. doc. 6.

Al muy alto e poderoso sennyor don Jayme, por la gracia de Dios rey de Aragón, de Valencia, Murcia e comte de Barçalonna e de la sancta eglesia de Roma almirán e capital general. Nos, Johan Ossoreç, por la merçé de Dios mayestre de la cavallería de Santiago, besando las vuestras manos com[endamos nos] en vuestra gracia, como de sennyor al qual deseyamos servir. 
Por [vuestra] reyal magestat se conviene fazer ayuda e socorso a las Ordenes e tenerlas en comanda e guiage e non fazerles injuria nin consentir fazer. A vos, sennyor, enviamos mercé pedir que senya la vuestra mercé que todo lo que yes en la vuestra tierra e sennyoría de la nuestra Orden, querades aver en vuestra comanda. Otrosí, sennyor, como vos otras vegadas nos anyades prometido de render el nuestro lugar de Negra, que senya la vuestra mercé que nos lo querades e mandades entregar a este nuestro freyle Miguel Péreç, que a vos enviamos con esta nuestra carta. Otrosí, sennyor, que senya la vuestra mercé que non querades [...] ar nin consintades fazer tuertos nin fuerças a los nuestros vasallos moros de Ricot, como nunca costumpnaron de pechar por razón que los avemos quitos por privilegios e franquezas, mas senya la vuestra mercé que querades sobreser e dexar estas demandas que nos, sennyor, de vos atendemos valer más e aver franquezas e ser mantenidos en aquellas, que non valer menos e ser inniuriados por vos, la qual cosa se conviene fazer a la reyal magestat, e así fuemos mantenidos, sennyor, todos tiempos por los vuestros antecessores, ca, sennyor, nunca fuemos nos en vuestro deservicio. Demás, sennyor, seet cierto que de los lugares que nos avemos en la vuestra senyoría nonca venrá dannyo ni enojo a vos nin a la vuestra tierra, ante avemos mandado e mandamos que senyan a vuestro servicio. Demás, sennyor, sabet que nuestra voluntat era por yr al regnado de Murcia e veernos con vuestro procurador e por darvos dreynto de los nuestros, siquiere freyles, siquiere seglares, e tanbién de Centón como de los otros, mas del rey <de> Portugal oviemos presuradamientre mandado e ymos nos pora él, mas fiamos por Dios que en breu será nuestra tornada e nos yremos pora Murcia por veernos con vuestro procurador e por fazer todas aquellas cosas que nos y fazer devamos.

Dada en El Corral, trinta días de desembre, era de mill e CCC e XLI annos.

1304, marzo, 30. Calatayud.

Jaime II a Juan Osores, maestre de Santiago, acusando recibo de su carta y dándole respuesta a sus peticiones y declaraciones. Entre otras cosas, le pide que acuda a Murcia y enmiende el mal comportamiento que están teniendo sus vasallos en este reino, en especial Centón Ruiz, [comendador de Aledo].

ACA, C, reg. 235 , fols. $43 v .-44 r$.

Cf. doc. 5.

Don Jayme et cetera, al honrrado e religioso varón don Johan Osores, maestro de la cavallería de Sant Yhago, salut e dilección.

Recibiemos vuestra carta que agora nos enviastes e entendiemos muy bien quanto en ella era contenido, a les quales vos respondemos. E primero, a aquello que nos demandastes que queriéssemos aver en nuestra comienda todo lo que la vuestra Orden ha en nuestra tierra, que nos, segunt que pertenexe a nuestra dignidat, queremos aver 
en nuestra comanda et en nuestra protección las Ordenes e lures bienes, las Ordenes catando a nos como fazer deven, e somos ciertos que los officiales de nuestra tierra, hon algo ha de fazer la Orden, vos catarán esto, si de los vuestros lugares e vassallos e tierras non salle mal ni danyo a la nuestra tierra.

Quanto al castiello de Negra, vos respondemos, que assí d'este lugar assí como de otros, aviamos feyto ordinación alguna por buen estamiento del regno de Murcia, por razón de la qual ordinación non podemos agora fazer livrar el castiello segunt que demandantes, mas encerca, si Dios quisiere, nos seremos en el regno de Murcia e estonce faremos hi aquello que será bien.

A lo al de las pechas de los vuestros vassallos, tenemos nos que assí como de las otras Ordenes avemos, nos mayorment por al deffendimiento del dito regno, que assí podamos aver d'ellos; mas si la Orden ha privilegios sobre esto, fazet nos los mostrar et nos observar vos los emos, assí como fazer devemos. Queremos empero que sepades que nos a los vuestros vassallos ni a los moros de Ricot non queremos ni consentiríamos que les fuesse feyto tuerto ninguno ni fuerça, ellos no faziendo porqué.

Quanto a aquello que nos enviastes dezir que nunqua fuestes en nuestro deservicio e que de los lugares que vos avedes en nuestro senyorío nunqua vendrá mal ni danyo a nuestra tierra, es cosa guisada que no se faga, e si d'otra guisa se fazía, non semellaría vuestro ni de la Orden. E pues tan bien lo dezides, rogamos vos que ordenedes de tal manera que los vassallos e freyres vuestros, specialmente del regno de Murcia, sean en tal manera ordenados enca nos e los nuestros officiales e nuestra tierra, que nos devamos seer pagados d'ellos, e seríamos pagados que vos, segunt que en la vuestra carta se contiene, viniéssedes al regno de Murcia e fiziéssedes adobar aquello que Centón Roiç e otros han feyto cuentra nos e nuestra tierra e nuestros vasallos.

Dada en Calataiubi, dos días en la exida del mes de março en el anno de Nuestro Senyor de mil trezientos e quatro. 



\title{
EL REINO DE ARAGÓN EN LA ÉPOCA DE JAIME II (1291-1327)
}

\author{
Esteban SARASA SÁNCHEZ \\ Universidad de Zaragoza
}

La figura y obra de Jaime II ha merecido desde siempre una especial dedicación de los estudiosos que han tratado el tema desde una perspectiva general de la Corona o desde la particular de su entorno familiar ${ }^{1}$. A demás, cuestiones como las relacionadas con la expansión por oriente de los almogávares ${ }^{2}$ o la intervención en Cerdeña ${ }^{3}$ han merecido igualmente la atención en diversas ocasiones.

Sin embargo, faltan estudios adecuados sobre la actuación del monarca en cada uno de sus estados o acerca de la situación de los mismos en su época; además de echarse en falta igualmente un balance global del reinado que sólo la conjunción de los diferentes y heterogéneos trabajos dedicados a esos años permite adelantar como punto de partida para valorar una actuación común o una intervención concreta ${ }^{4}$.

1 MUÑOZ POMER, M.R. y PINILLA PÉREZ DE TUDELA, R.: «Studi e ricerche dedicati a Giacomo II d'Aragona in Spagna (1850-1995)", en Medioevo. Saggi e rassegne 20, Cagliari 1995, pp. 399-460. Todo el volumen está dedicado en varios artículos de diversos autores a la Corona d'Aragona $e$ Mediterraneo. Strategie d'expansione, migrazioni e commerci nell'età di Giacomo II.

2 SARASA, E.: “Los almogávares. Del caudillaje a la república militar», en Historia 16, num. 233, septiembre 1995, pp. 54-58. Aunque, entre otra bibliografía cabe señalar el libro clásico de Ferrán SOLDEVILA, Els almogàvers, Episodis de la Historia 299, Dalmau editor, Barcelona 1952 (1994); así como algunos trabajos de $M^{\text {a }}$ Teresa FERRER.

3 XIV Congresso di Storia della Corona d'Aragona, varios volúmenes, Sassari 1996.

4 MARTíNEZ FERRANDO, J.E.: Jaume // (en Els descendents de Pere el Gran, Història de Catalunya. Biografies Catalanes, vol. 6), Vicens-Vives, Barcelona 1954 (varias reediciones), pp. 59166. Este autor es el primero de los grandes estudiosos del rey y su obra. Entre sus múltiples publicaciones acerca del mismo sobresale por su originalidad, que no se encuentra en otros estudios similares, su libro sobre Jaime // de Aragón. Su vida familiar, C.S.I.C., Barcelona 1948. 
En el caso del reino de Aragón, el reinado de Jaime ll es de los más descuidados; sin embargo remitimos a tres aportaciones de diferente carácter y condición realizadas en los últimos veinte años: los trabajos de Luis González Antón al respecto ${ }^{5}$, las actas del XIV Congreso de la Corona de Aragón celebrado en Cerdeña en 1990 y las páginas que de diversos autores se pueden entresacar sobre la cuestión ${ }^{6}$, y los contenidos de la XXI Semana de Estudios Medievales de Estella del año 1994 dedicada a los umbrales de las crisis entre 1250 y $1350^{7}$. Con lo que ya podemos disponer de una buena base para historiar, analizar y recomponer el reinado de Jaime II en Aragón; sobre todo a partir de 1300, en la segunda parte del mismo, porque la situación cambió con el siglo que dobló este monarca y descompensó la inicial armonía de los dominios del rey, peninsulares e insulares ${ }^{8}$.

Pero existen algunos motivos que acaso justifiquen la escasa dedicación de la historiografía aragonesa, salvo en los casos señalados ${ }^{9}$, a la época de este monarca; tales como la abundancia documental de la Cancillería frente a la escasa documentación local, particular o reinal. Es decir, la necesidad de acudir al Archivo de la Corona de Aragón en Barcelona para tejer un primer entramado que permita después focalizar el interés en una cuestión particular, local o coyuntural ${ }^{10}$. O también, por qué no, el mero hecho, aunque no desdeñable, de coincidir esos años, a caballo del 1300, con el inicio del atraso económico y político de Aragón, el reino interior de la Corona ${ }^{11}$. Y ello a pesar de que Jaime II sobresale, en principio, como pacificador de una situación heredada de sus predecesores tras la guerra civil de la Unión, la división de los aragoneses y el desentendimiento de las empresas mediterráneas; porque, Jaime Il aún logrará reconducir en parte la deteriorada situación y concitar el interés por la empre-

5 Las Uniones aragonesas y las Cortes del Reino (1283-1301), 2 vols. C.E.M.A., Zaragoza 1975; «Las Cortes aragonesas en el reinado de Jaime II», en Anuario de Historia del Derecho Español 1977, pp. 523-682; y «Jaime Il y la afirmación del poder monárquico en Aragón», en A la profesora emérita María Luisa Ledesma Rubio en homenaje académico (Aragón en la Edad Media X-XI) Universidad de Zaragoza 1993, pp. 385-405.

6 Ver nota 3.

7 Europa en los umbrales de la crisis (1250-1350), VV.AA., Gobierno de Navarra, Pamplona 1995.

8 Como a raíz del tratado de Torrellas en 1304, o sentencia arbitrada entre Jaime Il de Aragón y Fernando IV de Castilla, por intervención del rey de Portugal, el infante don Juan (hijo de Alfonso $X$ el Sabio) y el arzobispo de Zaragoza; sobre la influencia en Alicante y la frontera en Murcia de las dos Coronas litigantes; renunciando el aragonés a Murcia pero incluyendo en sus dominios el bajo Segura: desde Alicante hasta Orihuela; con una reafirmación posterior en el tratado de Elche de 1305. Con ello, el rey pudo iniciar su política mediterránea que le llevaría a Cerdeña.

9 Notas 3 y 5 . A partir de ahora fijaremos sobre todo la bibliografía sobre Aragón, pues el libro que contiene esta aportación, ya se refiere en sus páginas a la más completa.

10 La documentación del reinado de Jaime Il es proporcionalmente a los años del mismo muy superior a la de cualquier otro reinado. Sólo en Registros de Cancillería existen catalogados en dicho Archivo 259 registros, sin contar los de las diversas lugartenencias.

11 SARASA, E. y ORCÁSTEGUI, C.: El rechazo de la aventura mediterránea y la manifestación de las contradicciones internas: la consolidación del reino y los comienzos de la crisis (1276-1336), en Historia de Aragón 6, Guara Editorial, Zaragoza 1985, pp. 11-46. 
sa de Cerdeña, en la cual los aragoneses participarán con medios e intervenciones personales ${ }^{12}$.

Es decir, si a Jaime II se le pueden adjudicar los méritos propios de un gran diplomático, de una política expansionista brillante y de una voluntad pacificadora ${ }^{13}$, sin embargo su trayectoria comprende éxitos y fracasos, luces y sombras, que combinan: las decepciones de Almeria o de las Cruzadas ${ }^{14}$; el tratado de Monteagudo (1291) ${ }^{15}$, o la incorporación de Alicante y Murcia a la Corona (1296) ${ }^{16}$.

En este contexto general, Aragón entró en la nueva época con una gran crisis política arrastrada desde $1283^{17}$ y que mostraba las contradicciones internas del sistema ${ }^{18} \mathrm{y}$ el endurecimiento de las relaciones del reino con la monarquía ${ }^{19}$, las consecuencias del final de la "reconquista natural»" ${ }^{20}$, la reconducción institucional ${ }^{21}$, la sensación de abandono de los regnícolas ${ }^{22}$ y la parálisis del crecimiento económica y el inicio de la recesión ${ }^{23}$.

La contestación, la desobediencia civil, las alteraciones y el desentendimiento general fue por entonces la reacción de Aragón ante un experimento inacabado e interrumpido que conllevó al fracaso de un proyecto aragonés, diluido en la concentra-

12 ORCÁSTEGUI, C.: «Contribución económica de los aragoneses a las empresas de Cerdeña (siglo XIV)", en XIV Congresso di Storia della Corona d'Aragona, obra citada, vol. 3, pp. 659-666; y SARASA, E.: «Repercusiones político-sociales en el reino de Aragón de la intervención de la Corona en Cerdeña (siglo XIV)», ibidem, pp. 723-729.

13 "Jaime II y la pacificación del reino", en Historia de Aragón 6 (nota 11), pp. 29-30.

14 MARTÍNEZ FERRANDO, J.E.: «Guerres amb els musulmans de Granada, expedició a Almería» (Jaume II, obra citada, pp. 115-119). Respecto a sus veleidades de cruzado, este autor dice al respecto: «Alguna vegada Jaume II, potser amb excés d'ingenuitat, va intentar de convertir al cristianisme algun dels sobirans mahometans. Tampoc el proselitisme directe que va dur a terme Ramon Llull en alguns viatges que emprengué entre 1292 i 1315 a Tunis i Bugia no tingué cap resultat positiu» (p. 130).

15 Por el tratado de Monteagudo de 1291 se proponía el matrimonio del rey con la hija de Sancho IV de Castilla, buscando el apoyo castellano (matrimonio que no se efectuó); el compromiso de colaborar con Castilla en la lucha contra el Islam benimerín dentro de la política sobre el Estrecho, la ayuda del castellano frente a Francia y un supuesto reparto del norte de Africa en caso de ocupación cristiana por parte de ambas Coronas hispanas. Sin embargo, fracasados los propósitos, el incumplimiento de lo acordado obligó a Jaime II a renunciar a Sicilia en el tratado de Anagni de 1295 y a la herencia de los Hohenstaufen.

16 DEL ESTAL, J.M.: Conquista y anexión de las tierras de Alicante, Elche, Orihuela y Guardamar al reino de Valencia por Jaime II (1296-1308), Valencia 1982; y El reino de Murcia bajo Aragón (12961305). Corpus documental, 2 vols. Alicante 1985 y 1990 respectivamente. Asi como de HINOJOSA MONTALVO, J.: “Anexión del Alicante meridional a la Corona de Aragón» (en Las tierras alicantinas en la Edad Media, Alicante 1995, pp. 30-33).

17 Ver nota 11.

18 Ibidem.

19 Ibidem.

20 Ibidem.

21 lbidem.

22 Ibidem.

23 Ibidem. 
ción del interés de la Corona sobre el Mediterráneo y Levante ${ }^{24}$. Teniendo como resultado la dislocación de intereses de los estados de la Corona y el refuerzo de las instituciones propias y diferenciadas ${ }^{25}$.

De ahí que, en el caso aragonés, la tensión desencadenada hasta entonces se contuvo y soterró en parte por la reconducción institucionaṕ, la superación de la división socia ${ }^{7}$ y el intento de reconstrucción económica ${ }^{28}$. Motivaciones que permitieron al rey pacificar el reino a la vez que aplicar medidas apenas contestadas, pero fortalecedoras del poder regio, tendentes a la recomposición del Patrimonio Rea ${ }^{9}$, la reorganización administrativa ${ }^{30}$, y la fiscalidad ${ }^{\beta 1}$; mientras que facilitó la adopción de soluciones tan dramáticas e impopulares en principio como la disolución de la Orden del Temple ${ }^{32}$, tan arraigada en Aragón, o la implicación aragonesa en la empresa de Cerdeña ${ }^{33}$. Todo lo cual se abordó sobre todo en la segunda parte del reinado de Jaime II, que para Aragón se puede empezar a considerar a partir de 1300, es decir los dos segundos tercios de su mandato ${ }^{34}$.

Esto significa que es a través de los cambios, comportamientos y operaciones reseñadas como se puede abordar, en principio, una valoración global de dicho reinado en Aragón; si bien teniendo en cuenta que pueden quedar otros aspectos complementarios que explican aún mejor el balance, al parecer más bien positivo que negativo, del mismo. La prueba es que, a pesar de las dificultades propias de un contexto internacional y ambiental desfavorable ${ }^{35}$, tras las graves alteraciones y disfunciones de los reinados de Pedro el Grande (1276-1285 $)^{36}$ y Alfonso el Liberal o el Franco $(1285-1291)^{37}$, el tiempo de Jaime II aparece como un paréntesis activo, dinámico y

24 XIV Congresso di Storia della Corona d'Aragona, obra citada.

25 Nota 11.

26 L. GONZÁLEZ ANTÓN, «Las Cortes aragonesas en el reinado de Jaime \|», obra citada.

27 «A pesar de todo, las condiciones fueron favorables a un largo periodo de tregua por parte de la Unión, bajo el ordenamiento de Jaime II..." (SARASA, E.: Sociedad y conflictos sociales en Aragón: siglos XIII-XV, Madrid 1981, p. 51).

28 De lo que las Cortes del periodo son testigo y demostración (GONZÁLEZ ANTÓN, L.: «Las Cortes aragonesas en el reinado de Jaime 1 ").

29 SARASA, E.: "La incidencia del patrimonio real en el tejido social aragonés durante la Baja Edad Media» (en Col.loqui: Corona, municipio i fiscalitat a la Baixa Edat Mitjana, Institut d'Estudis llerdencs, en prensa).

30 SARASA, E. y ORCÁSTEGUI, C.: Historia de Aragón 6, obra citada.

31 SARASA, E.: obra citada en la nota 29.

32 SARASA, E.: «La supresión de la Orden del Temple en Aragón. Proceso y consecuencias» (en Congreso: Las Órdenes Militares en la Península Ibérica, Universidad de Castilla-La Mancha, en prensa).

33 Ver nota 12.

34 GONZÁLEZ ANTÓN, L.: «Las Cortes aragonesas en el reinado de Jaime II».

35 SARASA, E.: Sociedad y conflictos sociales en Aragón; siglos XIII-XV.

36 Ibidem.

37 Ibidem. 
socializador, para recaer después en las crisis propias, conjugadas ahora con las añadidas del siglo XIV, desde los comienzos de Pedro el Ceremonioso ${ }^{38}$.

El elevado número de convocatorias de Cortes para los aragoneses en estos años, ${ }^{39}$ el especial hincapié en dotar al reino de una infraestructura administrativa propia ${ }^{40} \mathrm{o}$ la regulación impositiva de algunas recaudaciones nacidas anteriormente con carácter extraordinario y que ahora se las reconvierte en periódicas ${ }^{41}$, manifiesta al menos que Jaime II, a pesar de sus implicaciones internacionales y peninsulares, y de sus intereses supraterritoriales, atajó la sensación de abandono y desencanto que los regnícolas habían achacado a sus predecesores ${ }^{42}$.

Por otro lado, acaso uno de los grandes logros del monarca fue para Aragón la incorporación de la sociedad aragonesa en su conjunto diferenciado a las estructuras del poder y del gobierno particular del reino; contando con oriundos del país para la ejecución de las misiones propias de la administración real en el mismo. Con lo que se superó la deuda pendiente en este caso por lo que se consideraba como injerencia extraña en los asuntos aragoneses y la falta de correspondencia al respecto ${ }^{43}$. Acaso porque Jaime II inició una política sostenida de gobernar distintamente para cada uno de sus estados ${ }^{44}$, sin menoscabo de una gobernabilidad general pero respetando en cada caso las instituciones propias y las necesidades territoriales ${ }^{45}$.

En efecto, Jaime II atendió en particular al reino de Aragón en un clima de convivencia, confianza y compromiso desconocido hasta entonces después de una segunda mitad del siglo XIII caracterizada por lo contrario y que había puesto en duda tanto el proyecto común de la Corona como la realización particular de Aragón ${ }^{46}$. Se saldaron agravios, se estrecharon diferencias y se articularon los procesos y mecanismos de participación y contribución en la responsabilidad colectiva ${ }^{47}$. $Y$ todo ello $\sin$ los reproches que los aragoneses habían hecho a Pedro el Grande por sus actuaciones mediterráneas ${ }^{48}$.

En definitiva, los treinta y seis años de reinado de Jaime II en Aragón sirvieron sobretodo para reconducir una situación de extrema conflictividad social, de expectativas económicas en suspenso y de retraimiento estamental ${ }^{49}$, hacia la conjunción de

\section{Ibidem.}

39 GONZÁLEZ ANTON, L.: «Las Cortes aragonesas en el reinado de Jaime $\|$ \%.

40 SARASA, E. y ORCÁSTEGUI, C.: Historia de Aragón 6, obra citada.

41 ORCÁSTEGUI, C.: «La reglamentación del monedaje en Aragón en los siglos XIII-XIV», en Aragón en la Edad Media V, Zaragoza 1983, pp. 113-121.

42 SARASA, E. y ORCÁSTEGUI, C.: Historia de Aragón 6, obra citada.

43 Ibidem.

44 Ibidem.

45 Ibidem.

46 Ibidem.

47 Ibidem.

48 SARASA, E.: El privilegio General de Aragón. La defensa de las libertades aragonesas en la Edad Media, Cortes de Aragón, Zaragoza 1984.

49 GONZÁLEZ ANTÓN, L.: obras citadas en la nota 5. 
intereses comunes canalizados por la monarquía a través de un esfuerzo de reinstitucionalización que sentó las bases definitivas de un sistema perdurable ${ }^{50}$.

El arranque de su actitud personal son las primeras Cortes del reinado, inmediatamente estrenado, en 1291, y en las que logra desmontar el movimiento unionista, aislar a la nobleza más contraria a su causa y ganarse a la nobleza inferior y a las universidades ${ }^{51}$.

En dicha asamblea se encontraron los dos propósitos que iban a dirigir la actuación real por un lado y las aspiraciones aragonesas por otro; es decir, la consolidación de la monarquía con la superación del predominio señorial y el protagonismo regular de los sectores no aristocráticos respectivamente ${ }^{52}$. Con lo cual se abrieron unas pautas responsables del resto del mandato en lo que concierne al ideario político del rey y al proyecto del reino ${ }^{53}$. y se afirmaron ambos propósitos en la asamblea de $1300^{54}$. en la que, entre otros logros, obtuvo el soberano un compromiso importante en el beneficio de la sal, que iba a introducir en las Cortes la vertiente económica y fiscal que hasta entonces no se había desarrollado ${ }^{55}$.

No por conocida la cuestión se puede eludir en este punto, el papel jugado por las Cortes a partir de 1300 y a lo largo de los veintisiete años restantes del monarca ${ }^{56}$, ya que fueron la plataforma en la que se vertieron y debatieron los intereses de gobernantes y gobernados a partir del momento de la incorporación de la Iglesia como estamento o «brazo» (el cuarto de Aragón) ${ }^{57}$ y tras el compromiso, incumplido pero presente, de la obligada regularidad en las convocatorias ${ }^{58}$, para las que la imagen de la inversión del deber de asistencia en derecho de presencia puede resultar meramente virtual pero asumible ${ }^{59}$.

Junto a ello, el requerimiento a la Justicia para resolver las diferencias aún belicosas arrastradas desde la Unión y sin acudir a la represión armada significó un avance en los procedimientos de gobierno que asentarían unas nuevas formas de afirmación del poder real, respeto a la legalidad y aprovechamiento de los cauces establecidos, institucionales y judiciales que harian del Justicia mayor del reino, por ejemplo, una figura aprovechable y una referencia obligada en muchas causas hasta entonces diluidas e indefinidas entre la justicia real y la local ${ }^{60}$.

50 lbidem.

51 lbidem.

52 Ibidem.

53 GONZÁLEZ ANTÓN, L.: “Jaime II y la afirmación del poder político en Aragón», obra citada.

54 Ibidem.

55 Ibidem.

56 GONZÁLEZ ANTÓN, L.: "Las Cortes aragonesas en el reinado de Jaime II», obra citada.

57 SARASA, E.: «Las relaciones Iglesia-Estado en Aragón durante la baja Edad Media», en Etat et Eglise dans la genese de I'Etat Moderne, Casa de Velazquez, Madrid 1986, pp. 165-174.

58 SARASA, E.: El Privilegio General de Aragón, obra citada.

59 Ibidem.

60 RODRIGO ESTEVAN, Mำ Luz: Documentos para la historia del Justicia de Aragón, Vol. I. Archivo Histórico de la Corona de Aragón, Justicia de Aragón, Zaragoza 1991 (Jaime II, pp. 30-50). 
Comenzando por las Cortes, recién establecidas constitucionalmente después de una primera fase de formación y consolidación, con la incorporación definitiva de algunas representaciones estamentales — como la Iglesia ${ }^{61}$ o las universidades ${ }^{62}$ con presencia permanente, éstas reflejaron la inquietud ante las deficiencias y carencias financieras de la Corona, la quiebra del potencial económico del reino y la pérdida del poder adquisitivo de los particulares.

En efecto, las Cortes del reinado de Jaime II corroboran la inquietud por las carencias financieras de la Corona a través de algunas actuaciones de las asambleas. En primer lugar se intentó fijar algunas rentas destinadas a la Casa Real, tales como los peajes o las rentas de las salinas y de las aljamas ${ }^{63}$; si bien, en el intento susodicho de recomposición de la Hacienda regia, dispersa y descontrolada hasta la fecha por las múltiples alienaciones y dispendios, sobresale como muestra espectacular la fijación regular del impuesto del monedaje, que se empezó a considerar como ordinario y periódico después de que durante el siglo XIII apenas se respetase y normalizase adecuadamente. Dicha imposición tabulada se regularizó en su percepción y recaudación septenal, así como en cuanto a la infraestructura administrativa necesaria para su mejor control ${ }^{64}$; convirtiéndose en una donación asumida y consentida sin apenas resistencia, con la ventaja de ser, además, muy extensiva, a pesar de las exenciones propias de las clases privilegiadas.

Ahora bien, aparte de esta referencia importante sobre el monedaje, algunas asambleas, como la de 1325, elevaron al monarca las quejas de los súbditos por la «presión fiscal» a la que se veían sometidos con tributaciones concretas.

También el empobrecimiento del reino se hizo manifiesto en estas fechas. Se constata, por ejemplo, un quebranto monetario acusado al intentar fijar la moneda jaquesa confirmada por Jaime I y extremar la persecución de la fabricación de falsa moneda ${ }^{65}$, que, al parecer, se difundía con facilidad.

Otros pormenores, como la fijación del derecho de sucesión ${ }^{66}$ (obligado por la frecuencia de los desheredados), la modificación de las condiciones del préstamo usurario (prohibiéndolo a los cristianos y rebajando al máximo el interés) ${ }^{67}$, el impedimento de los nobles para exigir cenas $u$ otros servicios en las villas del reino $0^{68}$, la persecución de los infractores de pesas y medidas ${ }^{69}$, la prohibición de engrosar las arcas privadas con exacciones ilegales o las trabas interpuestas para el establecimiento de monopo-

61 SARASA, E.: «Las relaciones Iglesia-Estado en Aragón durante la Edad Media», obra citada.

62 GONZÁLEZ ANTÓN, L.: «Las Cortes aragonesas en el reinado de Jaime Il», obra citada.

63 Cortes de 1325.

64 ORCÁSTEGUI, C.: «La reglamentación del impuesto del monedaje en Aragón en los siglos XIII-XIV", obra citada.

65 Fueros de 1300 y 1307, en SAVALL, P. y PENEN, S.: Fueros, Observancias y actos de Corte del reino de Aragón, Zaragoza 1866 (reedición facsimilar, Justicia de Aragón, Zaragoza 1992).

66 Cortes de 1307.

67 Cortes de 1301 y 1307.

68 Cortes de 1300.

69 Cortes de 1307. 
lios en determinadas actividades ${ }^{70}$; demuestran todos ellos las dificultades económicas del territorio aragonés en los primeros años del siglo XIV.

Junto a las medidas adoptadas para evitar fraudes, abusos e ilegalidades jurídicoadministrativas 0 comerciales, existen alusiones a malas cosechas ${ }^{71}$, a irregularidades en la comercialización de paños ${ }^{72}$, al levantamiento de la prohibición de exportar mercaderías reservadas ${ }^{73} \mathrm{o}$ al intento de reducir la mendicidad y los asaltos contra la propiedad que se habían convertido en actividad cotidiana y medio de vida frecuen$\mathrm{te}^{74}$. Testimonios todos ellos de una situación generalizada de crisis económica y social que afectaba a todas las clases sociales.

La actividad foral de la época reflejó igualmente la dificil coyuntura atravesada y una realidad que otras fuentes oficiales no recogen con claridad; buscándose indistintamente soluciones socio-políticas o económicas. Entre las primeras se advierten, por ejemplo, las referidas a inmunidades de los eclesiásticos, fijación de fronteras, exigencia de naturaleza aragonesa para el desempeño de cargos y oficios en la administración y gobierno territorial, determinación de las condiciones necesarias para ostentar la representación municipal, reglamentación de las atribucionés y jurisdicciones de los sobrejunteros (encargados de mantener el orden público y de perseguir a los delincuentes), mayor control para evitar los abusos de jueces y notarios en sus salarios y minutas, interdicción de las reuniones de oficios o protección de las personas y bienes de los guerreros descontrolados ${ }^{75}$.

En lo económico, aparte de que algunas medidas socio-políticas repercutieron indirectamente en ello, la resistencia a la admisión de nuevos impuestos, la fijación de la moneda jaquesa o la permisión de la confiscación de los bienes particulares sólo en caso de manifiesta traición al rey, revelan de igual forma el estado de penuria de los contribuyentes y participantes en actividades libres, fuera del marco señorial.

Tras una situación precedente de alteración unionista, vino un tiempo en el que salieron a la superficie las deficiencias de un sistema económico bajo el que se iban a desarrollar diferencias políticas que Jaime II enterró con su esfuerzo pacificador y con el desvío de la atención hacia el Mediterráneo con la empresa de Cerdeña.

Pero las necesidades de la Corona, del reino y de los particulares afloraron de continuo en estos años. Ya en 1291, 1300 y 1301, las Cortes asumieron el carácter recaudatorio de las mismas, coincidiendo con la institucionalización de las asambleas al completar la participación estamental, regular su periodicidad y ampliar la representación ${ }^{76}$.

Hay, pues, un interés económico añadido a la celebración de Cortes desde 1300; a la vez que, por contra, se retrajo la responsabilidad de las asambleas en asuntos

70 Cortes de 1311.

71 Cortes de 1314.

72 Cortes de 1320.

73 Cortes de 1320.

74 Cortes de 1300 y 1301.

75 Fueros de 1300 y 1325 (SAVALL y PENEN, obra citada).

76 GONZÁLEZ ANTÓN, L.: «Las Cortes aragonesas en el reinado de Jaime Il», obra citada. 
político-dinásticos; si bien respecto a la designación de heredero, juramento de fueros $y$ otras actitudes se advierten ciertos cambios precursores ${ }^{77}$.

Durante el reinado de Jaime II, las Cortes intervinieron en muchas cuestiones internas del reino, pero no en la toma de decisiones políticas o militares, de conquista o treguas; ni siquiera en aquellos casos -Agnani o Caltabellota- en los que se truncaron aspiraciones de la monarquía profundamente sentidas ${ }^{78}$.

Esta indecisión y retraimiento pudo deberse, entre otras razones, a que fue en este reinado de Jaime II cuando el Consejo Real empezó a cobrar capacidad de decisión disputada con las Cortes en cuanto a posturas o confrontaciones políticoexpansionistas se refiere, habiendo sido las Cortes de 1283 la última oportunidad del rey para llevar a cabo una consulta institucional sobre un hecho de importancia. Recuérdese la queja aragonesa por la falta de consejo de Pedro el Grande cuando la campaña de Sicilia, por las repercusiones negativas que los representantes del reino consideraban que podía tener la empresa; postura muy distinta a la que dichos representantes adoptaron después, con Jaime II, con motivo de la ocupación de Cerdeña ${ }^{79}$.

Las Cortes de 1325, con la agudización de la crisis estructural del «reino cabeza de la Corona», fueron especialmente significativas ${ }^{80}$. En primer lugar hay que señalar que Aragón no había visto reunidas sus Cortes desde 1320, mientras que Cataluña - a pesar del interés centrado por entonces en la empresa sarda- había celebrado Cortes en 1321 y en Gerona ${ }^{81}$, preparándose ya la intervención en Cerdeña para la que el infante - futuro Alfonso IV de Aragón-solicitaría de las comunidades ibéricas aragonesas de Calatayud, Teruel y Daroca la correspondiente ayuda ${ }^{82}$.

Pero sucesivas prórrogas en la pretensión de convocar a los aragoneses a Cortes produjeron en este intervalo temporal, abierto desde $1320^{83}-$ y celebrándose las de Barcelona en 1323-, una disidencia interna que precedió a la convocatoria inicial de septiembre de $1324^{84}$, que no sería la definitiva ${ }^{85}$.

77 GONZÁLEZ ANTÓN, L.: «Jaime II y la afirmación del poder monárquico en Aragón», obra citada.

78 Por el tratado de Anagni —firmado en 1295 por Jaime II, Felipe IV de Francia, Carlos II de Nápoles y el papa Bonifacio VIII - se trató de superar la dificultades internacionales surgidas con la conquista aragonesa de Sicilia en 1282 por Pedro lil el Grande. De manera que se levantaron las sentencias contra Aragón de excomunión y entredicho a cambio de que Jaime II retornase Sicilia al papa y Mallorca a su rey Jaime II.

En cuanto a la paz de Caltabellota firmada en 1302 por Carlos II de Anjou y Federico II de Sicilia, aseguraba la independencia sícula, aunque Sicilia quedaría regida por príncipes salidos de la casa de Aragón y constituiría una base importante para el comercio catalán en el Mediterráneo.

79 Ver nota 12.

80 Archivo de la Corona de Aragón (A.C.A.), Registro de Cancillería 308, fols. 250v. a 253v.; y Real Academia de la Historia, Manuscrito A-2 (Colección Salazar), fols. 255-264.

81 Cortes de Cataluña (Real Academia de la Historia), tomo I, pp. 258-272.

82. ZURITA, Anales de la Corona de Aragón, libro VI, capítulo 39.

83 A.C.A. Registro de Cancillería 308, fols. 243-245v.

84 Ibidem, fols. 247-248v.

85 Ibidem, fols. $249-250$. 
Así fue. Una nueva prórroga y la reunión del Consejo Real amplio en Lérida ${ }^{86}$ - para tratar de la oportunidad de recuperar el reino de Mallorca tras la muerte sin heredero del rey Sancho- llevó finalmente al comienzo de las Cortes en Zaragoza, a donde había acudido el rey el 12 de septiembre de aquel año $1325^{87}$; siendo el motivo principal de la convocatoria la resolución pendiente desde 1320 de las reclamaciones sobre el incumplimiento del Privilegio General; reclamaciones a las que el rey dio cumplida respuesta en forma de unas constituciones en veintidós capítulos y que tuvieron amplia repercusión ${ }^{88}$.

Las Cortes de 1325, últimas del reinado, atendieron en sus ordenaciones a las numerosas protestas elevadas a la asamblea sobre política impositiva ${ }^{89}$, que se había ido introduciendo y estrechando a tenor de lo que se podía entender como déficit manifiesto de las finanzas públicas, especialmente por el descontrol de los recursos de la monarquía en el reino $0^{90}$ y en lo que afectaba a Aragón, la decadencia de las aljamas $^{91}$ o la deuda de particulares acumulada, por entonces, y manifiesta reiteradamente en los primeros años de Pedro el Ceremonioso ${ }^{92}$.

Acaso las reclamaciones de estas Cortes ante el rey no eran sino el colofón de una espiral ascendente de avance de las dificultades económicas del reino y de precaución del monarca para frenar el déficit recaudatorio en el mismo. Dichas dificultades habían aparecido ya en 1301 y 1307, cuando se rebajó el límite superior del interés usurario ${ }^{93}$, y prosiguieron en 1311 , cuando se trató de evitar el fraude en la compraventa de paños ${ }^{94}$. así como también en 1320 , al suspender la interdicción de la exportación de ciertas mercancías protegidas ${ }^{95}$.

Junto a estas medidas de urgencia, desde comienzos de siglo también se intentó atajar la proliferación del hurto y la mendicidad como medios de subsistencia habituales ${ }^{96}$. y no tanto como mera marginalidad o indigencia, así como los abusos de los

86 Al que acudieron algunos clérigos y ricoshombres, sólo dos caballeros y dos ciudades aragonesas, frente a una mayor presencia catalana (ZURITA: Anales, libro VI, cap. 57).

87 A.C.A. Registro de Cancillería, 308, fols. 253-253v.

88 Ibidem, fols. 250-253v; y Registro 227, fols. 250-253.

89 SAVALL y PENEN: Fueros, observancias y actos de Corte del reino de Aragón, obra citada, artículos $4,9,10,15,18$ y 25 (pp. 17, 18, 19, 20).

90 ORCÁSTEGUI, C. y SARASA, E.: «El libro-registro de Miguel Royo, merino de Zaragoza en 1301: una fuente para el estudio de la sociedad y economía zaragozanas a comienzos del XIV", en Aragón en la Edad Media IV, Zaragoza 1981, pp. 87-155; y «Miguel Palacín, merino de Zaragoza en el siglo XIV: 1339-1342", Ibidem I, 1977, pp. 51-131.

91 MOTIS, M.A.: «Inicio del declive (judio) en Aragón durante el siglo XIV: Jaime II» (Historia de Aragón 6, pp. 150-154).

92 En los primeros años del reinado de Pedro IV existen muchas peticiones de particulares sobre moratoria de deudas.

93 SAVALL y PENEN: Fueros...I, p. 204 y II, p. 115.

94 Ibidem, I, p. 221.

95 A.C.A.: Registro de Cancillería 247, fol. 174.

96 SAVALL y PENEN, Fueros..., I, pp. 341 y 240. 
poderosos en la exigencia de tributaciones o servicios especiales a las poblaciones del reino ${ }^{97}$.

La importancia de las Cortes de 1325 como punto de referencia para rastrear el proceso de recesión y dificultades económicas inherentes en Aragón, es notoria; teniendo en cuenta, además, el complicado momento que atravesaba la política dinástica y los intereses catalanes en particular, con la apertura del horizonte sardo y la posibilidad de reversión mallorquina a la Corona.

Las dificultades surgidas para controlar eficazmente la administración de los recursos derivados de los derechos y exacciones reales se delatan en los registros de los administradores de dichas rentas ${ }^{98}$, lo cual coincide con la profusión de quejas sobre la intención del soberano de introducir contribuciones desconocidas en el país, o regular decididamente la percepción de algunas que se habían iniciado como excepcionales para transformarse en ordinarias, dada su extensión por todo el territorio y por afectar a buena parte de la población, como sucedió con el monedaje ${ }^{99}$.

A propósito del monedaje, Jaime II había concedido en 1302 la exención del mismo a todas las aljamas de los judíos del reino a petición de los afectados que le venían manifestando su penuria económica ${ }^{100}$; el mismo año en el que el rey concedió asimismo a la Orden del Temple la percepción de la mitad de lo correspondiente a su persona por este concepto en lugares de señorío militar ${ }^{101}$, encargándose un oficial regio y un representante de la milicia templaria de la recaudación; cesión que haría el rey extensible a la orden de San Juan de Jerusalen en las mismas condiciones ${ }^{102}$.

Aunque lo más destacado fue la normativa definitiva que este monarca estableció para la recaudación del monedaje en cuestión, quedando ajustado a la realidad del momento el procedimiento a seguir y las personas a las que les afectaba ${ }^{103}$ : todas de condición o servicio, cristianos y moros, que poseyeran bienes patrimoniales o raices superiores a una estimación de setenta sueldos jaqueses, contribuyedo con un maravedí (siete sueldos de moneda jaquesa) cada siete años; estando exentos los ricohombres, caballeros, infanzones y clérigos en general, salvo que estos dos últimos se dedicasen a negocios o actividades «impropias" de su condición ${ }^{104}$.

Se trataba de ajustar la normativa recaudatoria a la realidad socioeconómica en el nacimiento de una nueva mentalidad fiscal, buscando aproximar la realidad social a la tributaria y aumentar los recursos de la monarquía. Pero junto a las prácticas fiscales reguladoras y normalizadoras del reinado de Jaime $\mathrm{II}$, que tenían como finalidad el

97 Por ejemplo las cenas (SAVALL y PENEN: I, 248).

98 Registros de los Bailes Generales de Aragón: A.C.A., Real Patrimonio, núm. 1688 (año 1310).

99 ORCÁSTEGUI, C.: «La reglamentación del impuesto del monedaje en Aragón en los siglos XIII-XIV", obra citada.

100 A.C.A. Registro de Cancillería 304, fol. I y IV.

101 Ibidem.

102 Ibidem.

103 ORCÁSTEGUI, C.: «La reglamentación...", pp. 118-121. Capitoles de cómo se deve collir el moravedí en Aragón (Biblioteca de El Escorial, manuscrito J-III-21, fols. 145-149).

104 Ibidem. 
evitar el descontrol financiero y el obtener una recaudación mayor en esos años de dificultades, existieron otros indicios que abundan sobre la penuria económica de los contribuyentes ordinarios $u$ ocasionales y la escasa disponibilidad de medios y recursos que heredaron sus sucesores. Dichos indicios son, por ejemplo, la precaria contribución económica de los aragoneses a la empresa de Cerdeña o el descenso en la concesión oficial de mercados y ferias después del auge del siglo XIII'105.

Respecto a la participación contributiva de Aragón a la política expansionista mediterránea, ya desde el comienzo de la ocupación de Cerdeña en 1323, la aportación humana de los aragoneses fue notable en proporción con la menguada contribución económica; viendo en dicha empresa una posibilidad de promoción social que se había desaprovechado, en cambio, cuando la de Sicilia ${ }^{106}$. Lo cual indica, por otra parte, que la nobleza estaba buscando, con este soberano pacificador y diplomático, una ratificación de su preponderancia politico-social en el reino; preponderancia puesta en duda desde finales del siglo XIII por las crisis internas de su clase y la presión del resto social aragonés y del propio rey.

En la preparación previa de la campaña sarda, la disposición real por la que la Iglesia aragonesa debía colaborar a través de la entrega de las décimas durante tres años, apenas fue cumplida ${ }^{107}$. Pero, después, ya en plena urgencia de la recaudación de recursos, lo entregado no correspondió a lo inicialmente calculado y prometido ${ }^{108}$; limitación que también se dio en la participación personal de caballeros con sus mesnadas; dedicándose lo recaudado en Aragón, en buena parte, a la reposición de los préstamos conseguidos por el monarca en Perpignan y Montpellier para la intervención en Cerdeña ${ }^{109}$.

En cuanto al ritmo de creación y autorización de mercados y ferias, que en el siglo XIII había sido constante, se frenó desde comienzos del XIV; conociéndose únicamente, en los años comprendidos, la concesión en 1301 de dos ferias a Tarazona ${ }^{110}$ (para julio y septiembre), otra segunda feria a Monzón en 1311 en septiembre ${ }^{111}$ y la concedida a Huesca en 1326 para el mes de noviembre ${ }^{112}$.

Tras las dificultades derivadas de la recesión económica, la crisis estructural y la división social de finales del siglo XIII y pese a los esfuerzos de Jaime II por superar las causas que habían provocado las mismas (reforzando las instituciones, reconstru-

105 ORCÁSTEGUI, C.: «Ferias y mercados en la Edad Media. Fuentes para su estudio y metodología", en $V$ Jornadas de Metodología de la Investigación Científica sobre Fuentes Aragonesas, Instituto de Ciencias de la Educación y Diputación General de Aragón, Zaragoza 1990, pp. 21-45.

106 SARASA, E.: El Privilegio General de Aragón, obra citada; y obra citada en la nota 12.

107 SALAVERT, V.: Cerdeña y la expansión mediterránea de la Corona de Aragón, 1297-1314, Madrid 1956, vol. II, docs. 48 y 49.

108 De unos 707.500 sueldos jaqueses prometidos no se llegaría ni a la mitad (ORCÁSTEGUI, C.: obra citada en la nota 12 ).

109 Ibidem.

110 A.C.A. Registro de Cancillería 199, fol. 109.

111 Ibidem 16, fol. 202.

112 LALIENA, C.: Documentos municipales de huesca, 1100-1350, Huesca 1988, doc. 122. 
yendo el patrimonio, reordenando la fiscalidad y la administración, y buscando la implicación social en sus proyectos), se puede fijar la atención, finalmente, en cuatro muestras efectivas de la situación latente en este primer tercio del siglo XIV que volvería a explotar con Pedro el Ceremonioso y el rebrote de la Unión: la primera se refiere a la administración de las finanzas reales ${ }^{113}$, la segunda a la situación de las economías señoriales ${ }^{114}$, la tercera a la penuria de particulares o colectivos locales cargados de deudas y con apuros para saldarlas ${ }^{115}$, y la cuatra relacionada con la producción cerealista y su descenso en cantidad y calidad ${ }^{116}$.

La quiebra de las finanzas reales disponibles en Aragón obligó posteriormente a Alfonso IV (1327-1334) a revisar el cómputo y relación de las caballerías distribuidas por el reino ${ }^{117}$, dado el enorme esfuerzo que suponía cumplir con la asignación que correspondía por dicho concepto a ricoshombres y caballeros; revisión que ya Jaime I había intentado hacer en $1271^{118}$. Las protestas de localidades cuyas rentas disfrutaban los nobles sin justificación y la necesidad de regularizar el sistema obligaron a la intervención del rey en el asunto.

En cuanto a las difilcultades señoriales, ejemplos como el de la Orden de Calatrava en Alcañiz son representativos de una situación generalizada, con un crecimiento de la deuda externa, inusual hasta entonces, y un descenso notable de la fiscalidad real correspondiente a dicha Orden ${ }^{119}$ : situación que se dio también en otros señorios religioso-militares que rivalizaron con la nobleza laica y la propia monarquía por el reparto de los beneficios de la tierra ${ }^{120}$, así como en los dominios monásticos aragoneses. En el de San Juan de la Peña en concreto hubo disputas de rentas y propiedades con los nobles, enfrentamientos con poblaciones sometidas a vasallaje por la negativa al pago de tributos y prestaciones personales o controversias provocadas en la venta y circulación de la sal' ${ }^{121}$.

Sobre los apuros de los particulares en poblaciones de realengo y, por lo tanto, no sometidas a la presión señorial, a partir del reinado de Jaime lf, son significativas las

113 Las dificultades en la percepción y administración de las rentas reales en Aragón se manifiesta en los registros de merinos ya mencionados y publicados, nota 90; así como en el del baile de 1310, nota 98 .

114 Las dificultades económicas señoriales se reflejan, entre otros aspectos, en la exigencia indebida de tributos y que las Cortes trataron de impedir desde 1300.

115 La documenmtación municipal de estos años recoge las súplicas de los concejos sobre demoras de contribuciones aún no satisfechas a causa de las dificultades para saldarlas.

116 Cortes de 1314, A.C.A. Registros de Cancillería 308, fols. 233v. y 234.

117 Biblioteca Nacional de Madrid, Manuscrito 746, fols. 239v. a 244.

118 A. CANELLAS, Doce documentos fiscales aragoneses del siglo XIII de la alacena de Zurita, Institución Fernando el Católico, Zaragoza 1983, pags, 8-57.

119 LALIENA, C.: Sistema social, estructura agraria y organización del poder en el bajo Aragón en la Edad Media: siglos XII-XV, I.E.T., Teruel 1975, p. 142.

120 SAINZ DE LA MAZA, R.: La Orden Militar de Santiago en Aragón, Zaragoza 1975, doc. 136.

121 LAPEÑA PAUL, A.I.: El monaterio de San Juan de la Peña en la Edad Media, Zaragoza 1989, pp. 230-248. 
continuas solicitudes y concesiones, en su caso, de moratorias de deudas en ciudades y villas aragonesas: Zaragoza, Sariñena, Huesca, etc. ${ }^{122}$.

$Y$ en lo referido a las cosechas, en las Cortes de 1314 ya se había mencionado la penuria: «quod in toto Aragonum tante urgent victualium penuria et nimia caristia que propter sterilitatem temporis evenerunt quod in eo minime convenit tali tempore generalem curiam celebrare ${ }^{123}$.

A pesar de lo cual, en el reinado de Jaime II en Aragón, las Cortes y el Justicia se fortalecieron, ampliándose competencias y aumentando sus servicios ${ }^{124}$. Los cargos públicos (bailes, merinos y sobrejunteros) se institucionalizaron en sus funciones ${ }^{125}$. El desorden social se contuvo y recondujo hacia la estabilidad superadora de los dos grandes retos del momento: la supresión de la Orden del Temple ${ }^{126}$ y la reanudación de la expansión mediterránea ${ }^{127}$. Y la reconstrucción económica, fiscal y patrimonial se intentó y logró en parte ${ }^{128}$. Aunque, en definitiva, con Pedro el Ceremonioso se vio que la superación de las deficiencias y contradicciones, de las carencias y desequilibrios de los aragoneses con Jaime II fue algo transitorio a pesar de los muchos logros temporales y permanenetes del monarca llamado también el Justo ${ }^{129}$, de la atención prestada a los subditos de su reino continental ${ }^{130}$ y de la trayectoria pacificadora $y$ recomponedora de su gobierno.

La presente es por tanto una mera apuesta por la necesidad de profundizar en el estudio y análisis de lo que supuso el reinado de Jaime II en Aragón dentro de la trayectoria de la monarquía y de la experiencia aragonesa medieval. Porque, de lo antedicho, puede concluirse que el mencionado reinado se desenvolvió en una cuarentena de años aproximadamente que representaron para el reino el final de una época y el comienzo de otra en la que nuevos retos, dificultades y desavenencias provocaron a la larga la vuelta a la guerra civil (la Unión de nuevo en 1347-48), la pérdida de peso político en el conjunto de la Corona (a partir de Pedro IV) y la quiebra del orden social conseguido por Jaime II con la sobreimposición de la alta nobleza, el predominio señorial y la escasa efectividad de los demás sectores sociales (nobleza media, burgueses y gentes de oficio y mercaderes, minorias y funcionariado) que con este monarca habían empezado a despuntar para regresar a la travesía del desierto impuesta por la recuperación del poder nobiliario.

122 A.C.A. Cartas Reales de Pedro el Ceremonioso, núms. 571, 627, 629, 637, 655, 660, 665, 682 y 695 (del comienzo del reinado).

123 A.C.A. Registro de Cancillería 308, fols. 233v. y 234.

124 Ver nota 60 respecto al Justicia.

125 Ver nota 11.

126 Ver nota 32.

127 Ver nota 12.

128 Ver nota 11.

129 SARASA, E.: «El enfrentamiento de Pedro el Ceremonioso con la aristocracia aragonesa: la guerra con la Unión y sus consecuencias", en Pere el Cerimoniós i la seva època, Anuario de Estudios Medievales, Annex 24, Barcelona 1989, pp. 35-45.

130 Ver nota 11. 


\title{
PROBLEMÁTICA MURCIA-DON JUAN MANUEL EN LA MINORÍA DE ALFONSO XI
}

\author{
Juan TORRES FONTES
}

Universidad de Murcia

Murcia y don Juan Manuel protagonizan en dos distintas fases un intenso y estridente periodo de trece años, caracterizado por la continuidad de un enfrentamiento directo que no tendrá fin hasta 1327 , y del mismo serán testigos y, en parte, actores en todo momento, desde posiciones distintas y diversidad de actuaciones, acordes por lo general en cuanto a medidas a adoptar, el infante don Pedro y Jaime II. El primero, como tutor de Alfonso XI, su sobrino, y apoyado por su madre, María de Molina, procuraría en la medida de lo posible atender las demandas de su cuñado, siguiendo las indicaciones de su común suegro Jaime II, pero, sujeto a su deber y rectitud de conducta, no pudo evitar tensas relaciones con don Juan Manuel, amistosas o enfrentadas, ante sus desafueros y permanente empleo de las armas como fuerza coaccionadora. Un perfil, en cierta forma poco novedoso, es el que ofrece Jaime II en estos catorce últimos años de su vida y reinado; el monarca aragonés, puntualmente informado de todo lo que sucedía en Castilla, actuó siempre como buen político, prudente y persuasivo, y más tratándose de un reino ajeno y de la actividad de sus dos yernos, se alejó de todo propósito de sacar utilidad política para su Corona, aunque si intentó convertirse en árbitro de las contiendas y enfrentamientos que mantenían don Pedro y don Juan Manuel, quienes, por otra parte, solicitaron más de una vez sus consejos e intervención, respondiendo Jaime II, por carta o con el envío de emisarios, siempre desde la óptica familiar y empleando un tono paternalista que sólo buscaba el entendimiento y fraternal conexión entre sus yernos. Tampoco faltó correspondencia con doña María de Molina y con el infante don Juan con quienes estaba unido al compartir el mismo deseo de hallar una fórmula que fuese acomodaticia para todos y que trajera, con ello, la paz al reino castellano.

Sin embargo, pese a lo dicho más arriba, conviene esclarecer ahora que el rey de 
Aragón no mantenía la misma relación con el infante don Pedro que con don Juan Manuel. Era más comprensible y cercana la actitud de Jaime II con el infante castellano, tanto como tutor y representante de la autoridad real, como por compartir sus ideas de gobierno e incluso su actividad en la frontera granadina, que tan intensamente atraía a don Pedro. Muy distinta y forzosamente diferente será la que muestre hacia don Juan Manuel, personaje eternamente descontento, rebelde, engañado y desengañado, cuyas imprudencias y malas hechuras recriminaría con dureza en más de una ocasión, aunque, es verdad, siempre utilizando el paliativo de esforzarle en la atención de la mesura, de la paz y del entendimiento con su cuñado, cosa muy beneficiosa para él y para el bien del reino castellano.

En este breve espacio de trece años, que comprende la menor edad de Alfonso XI, en lo referente al orden cultural no contamos con datos suficientes para hacer nada más que dos menciones concretas, pues la situación de Castilla no propiciaba una producción literaria cualificada ni otras manifestaciones de alta valoración. Una es la de don Juan Manuel quién, como últimamente ha dicho Germán Orduña, sólo debió redactar dos obras en estos años: la Crónica Abreviada y el Libro de la Caza, ambos productos obtenidos a base de inspirarse en fuentes alfonsíes. La segunda obra sería reformada tiempo después con una nueva redacción, con lo que adquiriría los procedimientos expositivos de don Juan Manuel en su segunda etapa creativa y, para entonces, de mucha utilidad fue el conocimiento personal que el señor de Villena tenía de todo el Reino de Murcia y restantes posesiones con su variedad de caza, parajes donde abundaba, especies y formas de captura.

Un aspecto a destacar desde los primeros años de su relación con el Reino de Murcia, y que parece oportuno traer aquí, sería la educación muy cuidada que debió recibir y que él mismo consideraría como la más conveniente para los hijos de los nobles: «desque pasaren de cinco años adelant, deven començar poco a poco a les mostrar leer... e este leer deve ser tanto a lo menos fasta que sepan fablar et entender el latin». Todo ello está directamente conectado con su propia experiencia, pues sabemos que a los cinco años era adoctrinado en Elche, que para él era "como regno e señorio apartado... a manera de reyes», por un maestro de Gramática quién, cuando se lleva a efecto la Quinta Partición en el Repartimiento de Orihuela, en Febrero de 1288 , recibe "LX atafullas en Cox, en las fronteras, por rogos et por carta de la condesa et de don lohan, so fijo, et del infante don Manuel». Quedamos sin conocer la identidad del maestro de Gramática que se dedicaba a enseñarle con paciencia, halagos y perseverancia sus primeras letras; se trata de uno de los muchos secretos que don Juan Manuel nunca desveló, como tampoco se conocerán sus lecturas posteriores de las fuentes clásicas, que bien cuidó de ocultar, y esa misma ignorancia tenemos en el protagonismo que pudo tener entonces, como indica Lomax, «una madre italiana cuya influencia sobre el gran escritor queda por calibrar».

Solamente otra figura destaca en el ámbito murciano en estos primeros años del Siglo XIV y es la del historiador Jufré de Loaysa, autor de una "Crónica de los Reyes de Castilla» que, si bien no alcanza en su narración estos años de la minoría de Alfonso $\mathrm{XI}$, si nos dejó una imagen precisa de Castilla la cual, sin variante alguna, cabe 
reproducir como reflejo de cuanto sucedería en estos trece años: «Entonces joh dolor! ningún mercader ni hombre honrado transitaba por Castilla, ni el pastor guardaba sus ganados, ni el buey araba la tierra, sino que las llanuras estaban desiertas, los caminos solitarios, cubiertos de hierbas y frecuentados por liebres más bien que por ganados. Y los hombres no gustaban otra cosa que de muertes, robos y despojos, y muchos que antes solían ganarse el sustento como artesanos o agricultores, convertidos ahora en guerreros, despojaban a cuantos podían, robaban, pasaban a fuego los poblados y ya no se respetaba lugar sagrado, sexo ni edad $u$ orden».

\section{LA DUALIDAD CONCEJO-HERMANDAD DE MURCIAY DON JUAN MANUEL (1313)}

El 9 de Septiembre de 1312 muere Fernando IV y se esfuma el precario orden político logrado algunos años atrás con el inicio de la menor edad de Alfonso XI que comienza con la renovación de un problema que ya se había planteado en la minoría de su padre y que era la falta de una legislación, norma o costumbre afianzada respecto a quien o quienes debían desempeñar la tutoría del monarca. Don Juan Manuel se encontraba en Murcia y tan pronto tuvo noticia del deceso del rey, de quien era mayordomo mayor, se apresuró a marchar a su señorío de Villena con el propósito de dirigirse después a Toledo y permaneciendo a la expectativa de todo lo que pudiera producirse en torno a Alfonso XI, con el firme propósito de hacer valer su alto rango, su pertenencia a la familia real, cuanto había significado su desempeño de la mayordomía mayor del rey, sus posesiones, riqueza y poder. En este contexto, más rápido fue el infante don Pedro quién, atisbando la inevitable confrontación política que iba a producirse en todo el reino castellano, desde Andalucía marchó hacia Toledo y, desde Yébenes, escribía a don Juan Manuel solicitándole con todo fervor su ayuda para conseguir la tutoría de su sobrino y ofreciéndole firmes promesas de futuro como modo de agradecer sus servicios y, días después, desde Ávila, volvía a expresarle su agradecimiento por la seguridad de ayuda que le ofrecía su cuñado.

Promesas y apetencias por ambas partes que habrían de concretarse en la entrevista concertada en Valladolid, el día 8 de Noviembre, entre el maestre de Calatrava, enviado con plenos poderes por el infante don Pedro, y don Juan Manuel. En ella el ofrecimiento del infante era tan generoso y la ambición de don Juan Manuel tan extremada, que sólo un incauto pudiera creer que se hicieran efectivas. Eran éstas: «Que vos tengades en guarda por el dicho rey don Alfonso el regno de Toledo et el regno de Murcia et los obispados de Cuenca et de Siguença, et que ayades y el mismo poder que el dicho infante ouier en lo que fuese tutor, a tanto tienpo como el dicho infante don Pedro terna la dicha tutoria et usara della». Once días más tarde se congratulaba Jaime II de este acuerdo entre sus yernos y escribía a don Juan Manuel felicitándole y animándole a perseverar en el acuerdo por el bien de Castilla.

Mientras tanto, con formaciones ya públicamente declaradas, el infante don Juan asumía el poder en el Reino de León y proclamaba, frente a don Pedro, su propósito de ser también tutor del monarca, a la vez que doña María de Molina cuidaba de su nieto y procuraba aquietar el reino y concertar una concordia que impusiera la paz. 
Seis meses más tarde, el 23 de Mayo, don Juan Manuel denunciaba ante Jaime II la actitud de don Pedro, ya que percibía que las buenas palabras y promesas eran sólo eso y que no tendrían efectividad, tal y como la misma Maria de Molina se lo había hecho ver a la vez que le advertía de que su intención era que ambos infantes se compenetraran y gobernaran los reinos que los aceptaban. Esta vez Jaime II intervino cerca del infante don Pedro y consiguió arrancarle la promesa de poner en manos del arzobispo de Toledo la solución a sus diferencias y recobrar la amistad y confederación perdidas.

El desorden, anarquía, robos, muertes y destrucciones que se extendieron por toda Castilla no tardarían en exigir un resurgimiento de las Hermandades concejiles como único medio de autodefensa; pero, a diferencia de las que se configuraron en 1282, éstas pronto perdieron su independencia por la participación en ellas de la nobleza, ávida de hacerse con el poder. Sin embargo, no sucedió así en Murcia, en donde la Hermandad surge con el firme propósito de sus vecinos de romper el oneroso trato que soportaban de don Juan Manuel y sus vasallos; y tampoco iba a ser una Hermandad en la que se integrarían los demás municipios del reino, como en el Siglo XIII, sino organizada exclusivamente para recobrar su independencia y disfrutar de su fuero y privilegios. En realidad, la sucesión de vejámenes, ocupación de todos los oficios concejiles, exceso de cargas financieras, parcialidad de la justicia y atropellos de todas clases no dejaban otra salida y fueron el detonante de la Hermandad y de los sucesos acaecidos en la capital del adelantamiento murciano.

En fecha anterior a Julio de 1313 se produjo el asalto y parcial destrucción del alcázar de Murcia, puesto bajo el mando de Sancho Manuel, detenidos y después expulsados de la ciudad cuantos partidarios de don Juan Manuel se encontraban en ella. La revuelta debió de ser violenta y la hostilidad se mantuvo por cuanto los «fuera echados", refugiados en Molina Seca, comenzaron a hostigar a todos los que permanecían en la capital, alcanzando los enfrentamientos y acciones gran virulencia y llegando a preocupar a los propios gobernantes oriolanos, como lo prueba que, en el mes de Julio, Arnau de Torrelles pidiese autorización a Jaime Il para reforzar. la vigilancia de las puertas de Orihuela en prevención de las posibles secuelas de la contienda murciana que pudieran llegar hasta ella.

De la situación se hizo eco Jaime II cuando, en Diciembre, amonestaba a su yerno por su conducta: "lo de Murcia nos pesa si algo an feyto no deuidamente encuentra uos. Enpero, sabedes muy bien que Murcia del Rey de Castilla es e, al tienpo que esta agora la tierra, muyto devriades conpensar et non faser ante ellos todo lo que podriades, mas catar servicio del rey e a sosiego de la tierra». La amenaza de don Juan Manuel de ir poderosamente contra Murcia se disipó por la prudencia del rey de Aragón, que estaría al tanto de las causas de la revuelta, tal y como fueron expresadas y justificadas en carta real del año 1317 del infante don Pedro: «Despues que el rey don Ferrando, mio padre, fino aca, que auie y algunos omnes buenos que los pasauan contra las cartas et franquezas et preuillegios et buenos usos et costunbres que auian en tienpo de los reyes onde yo vengo. Et, otrosi, que se mouian a fazer posturas et ordenamientos et usos et costunbres nueuamiente, que nunca fueron, que eran et son contra ellos et contra los dichos sus preuillegios". 
Reconocimiento de la imposibilidad de ganar Murcia por la fuerza sería la firma de una concordia entre Murcia y Cartagena con su castillo. Esta ciudad pasó poco después de 1306 a propiedad de Pedro López de Ayala, alférez y lugarteniente de don Juan Manuel a quien, en Diciembre de 1313, según el "Chronicon Domini Joannis Enmanuelis", la vendió con ciertas condiciones que no se especifican, pero, sin duda, una de ellas serían los plazos para su pago, que terminaría de efectuarse en 1325, tal y como señala el mismo «Chronicon» cuando dice: «En el mes de Junio don Joan pago del todo a Pedro Lopez de Ayala: la deuda que era tenido por razon de la ciudad de Cartagena y dicha ciudad quedo a don Joan sin condicion». La concordia MurciaCartagena se firmaría el 5 de Enero de 1314 y en ella se otorgaban mutua seguridad para personas, ganados y mercancías; obligada salida en apellido para perseguir a malhechores y, por ambas partes, se fijaba una cláusula por la que se estipulaba que si el infante don Pedro no aceptaba este convenio, hecho público, se mantendría por diez días, lo mismo que sucedería por parte de Cartagena y su castillo en la obediencia a don Juan Manuel. Siendo significativo que se incluyan autoridades dependientes de ambos nobles denominados por cada uno de ellos como «nuestro adelantado», indicativo de una situación de separación oficial de la ciudad de Murcia con respecto a su anterior dependencia de don Juan Manuel, que había sido adelantado del reino en el reinado de Fernando IV.

\section{CONTINUIDAD DIFERENCIADORA (1314-1319)}

Las promesas no cumplidas por los tutores de Alfonso XI y la constancia murciana en su negativa a reconocer a don Juan Manuel como adelantado, eran afrentas permanentes que llegarían a exasperar al señor de Villena de tal modo que, sin pensar en sus posibles consecuencias, amenazó a Murcia con permitir el paso libre por Lorca de los granadinos. Pedro López de Ayala, alcaide de Lorca por don Juan Manuel, fue el encargado de comunircarlo así a la Hermandad de Murcia: O se sometían a don Juan Manuel o Murcia quedaría fuera de la tregua que tenía firmada con Ismail de Granada.

El concejo de Murcia recurrió al infante don Pedro y, como en ocasiones anteriores, confiados en la buena acogida que siempre habían encontrado, a Jaime II a quien hicieron saber la amenaza que pesaba sobre ellos. La respuesta del monarca aragonés fue inmediata y escribió a su yerno para hacerle ver que tal amenaza no era buena manera para atraer a los de Murcia a un posible entendimiento y sobre todo para inducirle a pensar en la "carga e infamia vuestra a Dios y al mundo», así como en el escándalo que iba a producir. Escribió también a Murcia para exponer sus dudas: «Sabe Dios si el noble don Johan, fijo del infante don Manuel, ha fecho ni faze ninguna cosa contra vos". Una tercera misiva o emisario envió a Arnau de Torrelles, Procurador General de Orihuela, a quien expresaba su desconfianza de los que pudiera hacer su yerno y le ordenaba que enviase a su lugarteniente, Berenguer de Puigmoltó, con hueste suficiente a Murcia para ayudarles a hacer frente a los posibles ataques granadinos. 
Esta decisión irritó a don Juan Manuel, que no tardó en quejarse a su suegro por el perjuicio que le ocasionaba al consolidar con su actuación la actitud de la Hermandad murciana de no recibirlo por adelantado. Jaime II contestó de inmediato y le dejó bien claro que no lo había hecho por mala voluntad hacia él, sino por «celo de buen amor», indicativo de su propósito de evitar que la torpeza del señor de Villena tuviera efectividad y le perjudicara. $Y$, aún más, su inoportunidad, pues le anunciaba que el infante don Pedro le enviaría un emisario para notificarle el acuerdo de Palazuelos, firmado el 1 de Agosto, por el que se constituía la regencia de Alfonso XI así como el reconocimiento de las respectivas áreas de gobierno, por lo que sería el infante castellano quien podría resolver la contienda que mantenía con Murcia.

Mas, no iba a ser así. Informado don Pedro de la amenaza contra la ciudad de Murcia y las medidas adoptadas por Jaime II, desde Toro atendió la reiterada petición de la Hermandad referente a que les proporcionase un jefe adecuado para que la acaudillara y al frente de su hueste se enfrentase a los granadinos. El 16 de Noviembre Diego López de Haro recibió su nombramiento como adelantado de Murcia e instrucciones precisas de don Pedro para trasladarse a Murcia y poner manos a la obra, cosa que hizo al poco tiempo, pues el día 7 de Diciembre llegaba a su destino portando tres cartas que, al día siguiente, domingo, presentó ante un concejo abierto, totalmente expectante por la llegada de un adelantado que no era delegado de don Juan Manuel. Aparte del documento que contenía su nombramiento, López de Haro mostró la carta por la que don Pedro concedía las escribanías de la ciudad al concejo y, otra tercera, datada en Toro el día 15 de Noviembre, por la que el infante, atendía la petición que Murcia le había formulado para que donase Molina Seca como aldea de la ciudad, tal y como había sido en el reinado de Alfonso X, pues se había convertido, como dice Cascales, en «una ladronera de forajidos», en reducto armado de la gente de don Juan Manuel y desde ella se hacían considerables daños a los vecinos de la capital, por lo que don Pedro indicaba que debían "punnad por quantas partes pudierdes en la ganar... que si uos ganades, que uos la dare». El mismo Cascales nos dice que la hueste murciana pudo ocupar la villa con facilidad por encontrarse desprevenidos sus defensores, tras lo cual fueron expulsados cuantos en ella se hallaban.

Al finalizar 1314 una triple perspectiva de carácter negativo pesaba sobre don Juan Manuel: desconfianza de sus actos y correctivos de Jaime II; recelo y continuidad de falsas promesas de don Pedro y, más que reticencias, enemistad irreductible de la ciudad de Murcia. Ahora el hijo del infante don Manuel buscaría de nuevo la imponderable ayuda del rey de Aragón y, a través de él, la de su cuñado, con objeto de conseguir unos logros que tercamente solicitaba: nombramiento de mayordomo mayor, reintegración del adelantamiento de Murcia con sus rentas y libre entrada de sus vasallos en la capital.

Jaime Il logró persuadir a sus yernos para que acudiesen a una reunión, convocada en Uclés para Enero de 1315, con objeto de alejar dudas, recelos y reticencias. Don Pedro se comprometió a escribir a Murcia y ordenar que recibieran a don Juan Manuel, con promesa de su «segurança» y sin temor a venganzas o represalias; pero, conocedor de la repulsa murciana y no muy decidido a llevar adelante lo convenido, 
trasladó a su suegro la resolución de esta cuestión y le pidió que enviase un emisario a Murcia para que intentara la avenencia y les amenazara con exigir la salida de territorio aragonés de ganados, bienes y personas, así como la prohibición a sus súbditos de toda relación con ellos. La negativa murciana se mantuvo en términos tan tajantes que Pedro Garcés de Castellón, enviado por Jaime II, a su vuelta informó al monarca de la total imposibilidad por entonces de hacer cambiar de opinión a la Hermandad murciana.

La persistente actividad granadina uniría a murcianos y oriolanos para la consecución de acciones conjuntas, aunque sin carácter oficial por la prohibición del rey aragonés, bajo la jefatura de Berenguer de Puigmoltó y del adelantado Diego López de Haro y sin la participación de Pedro López de Ayala, alcaide de Lorca por don Juan Manuel. Quizá la actitud de éste motivaría la carta del infante don Pedro, fechada el 10 de Marzo, alarmado por las noticias que le llegaban desde el reino de Murcia referentes a que algunos no respetaban la tregua firmada con Granada.

En las Cortes de Burgos de este mismo año 1315 fueron aprobados los conciertos de Palazuelos y declarados oficialmente los tutores de Alfonso XI, produciéndose el nombramiento como mayordomo mayor a favor de un hijo del infante don Juan y como adelantado mayor de Murcia a don Juan Manuel. En las Cortes ocurrió un hecho insólito, por cuanto fueron confirmados los fueros y privilegios de todo el reino castellano con excepción de los de Murcia, recabada por don Juan Manuel. La cuestión Rocafull, que se produjo por entonces, alejaría del ámbito cortesano el problema murciano.

Ya en 1316, el infante don Juan logró reconciliar a los enfrentados cuñados, sin nuevas medidas referentes a Murcia, mientras que las relaciones murciano-oriolanas se hacían cada vez más estrechas, hasta el extremo de que Berenguer de Puigmoltó, lugarteniente de Procurador, acudiera ante Jaime II en apoyo de algunas peticiones murcianas y, así, pudo obtener autorización para la saca de armas, hierro y otras mercaderías procedentes de Mallorca cuyo destino oficial era Castilla, pero que, muy probablemente, no saldrían de la frontera murciana y sin duda este suceso se encuentra muy relacionado con la actividad fronteriza frente a los granadinos.

La constancia de don Juan Manuel en reivindicar el adelantamiento y la insistencia de Jaime II en que hubiera una buena relación entre ellos, forzaría a la orden de don Pedro para que fuese aceptado don Juan Manuel, ya nombrado adelantado, y lo que de ello se derivaría, y en caso de negativa concedía autorización a éste "et a todos los concejos de las sus comarcas que los maten et les tomen quanto les fallaren de lo suyo". Pero la actitud de Murcia no cambiaba y el rey de Aragón comunicaba, el 18 de Febrero, a la corte castellana que el concejo murciano se mantenía intransigente, por lo que mandaba a su Procurador de Orihuela que diera un plazo de ocho días para que los vecinos de Murcia salieran de sus tierras con sus pertenencias. Sin embargo, como sucediera dos años antes, esta medida no tendría efecto por la protesta oriolana, más perjudicada, lo que obligaría a dejar en suspenso la orden mediantes sucesivas ampliaciones de plazos; pudiéndose advertir la continuidad de un equívoco entre órdenes oficiales y particulares, en que parecen estar todos involucrados: Jaime II, el 
Procurador de Orihuela, el Infante don Pedro y las autoridades murcianas en espera de otros acontecimientos.

Mientras se mantenían estos escarceos políticos y la polémica Murcia-don Juan Manuel, la frontera murciana seguía activa, en tanto que la división del reino debilitaba sus fuerzas, pues el infante don Pedro operaba en sectores alejados y López de Ayala veía reducida la hueste que guarnecía Lorca. En una incursión fue derrotado y quedó comprometida la fortaleza lorquina por estar "la gente muy esmayada" y con el temor de que los granadinos intentaran ocupar la ciudad, panorama que permaneció hasta que, dos meses más tarde, acudió don Juan Manuel y restableció la situación. El triunfo del señor de Villena fue aprovechado por Jaime II para hacer ver a los tutores de Alfonso XI la necesidad de que don Juan Manuel permaneciera en la frontera con todas las fuerzas murcianas bajo su mando; pero, muy pronto, el veleidoso titular del señorío de Villena se excusó de mantenerse en ella por haber pasado el tiempo en el que sus vasallos obligadamente le prestaban sus servicios y no tener medios propios ni facilitárselos la corte o no contar con la ayuda pontificia.

Frente a ello, se produjo un nuevo cambio en la actitud política del infante don Pedro quién, antes de finalizar el año 1317, atendía las demandas murcianas que denunciaban que hasta 1313 habían estado sometidos a decisiones injustas de vasallos de don Juan Manuel, hombres adictos a su persona que formaban un concejo reducido: los oficios de alcaldes, alguaciles, jurados y almotacenes eran designados por el adelantado, promulgación de ordenamientos y nuevas disposiciones contrarias a su Fuero, privilegios, usos y costumbres, no confirmados en las Cortes de Burgos. No desconocía don Pedro esta situación y las justas pretensiones murcianas, por lo que, dispuesto a atender sus peticiones, desde Ubeda, el 8 de diciembre de 1317, les confirmaba su Fuero y privilegios en nombre de Alfonso XI.

Este vaivén de alternativas contradictorias entre la rectitud de don Pedro y la decisiva influencia de su suegro por atender las reclamaciones de don Juan Manuel, le haría cambiar de nuevo su política respecto a Murcia. Jaime II pudo lograr que sus dos hijas y yernos se reunieran en Ocaña corriendo el mes de Enero de 1318, y en este ambiente familiar aunque un tanto forzado por las circunstancias, don Pedro autorizó de nuevo el empleo de la fuerza para que el señor de Villena intentara someter a los rebeldes murcianos. En el mes de Julio se produjo un encuentro armado del que no parece que salieran muy airosas las huestes del señor de Villena y sin que por ello adelantara en sus pretensiones para ser aceptado.

Al empleo de la fuerza siguió la diplomacia encaminada a hallar una vía pacífica con la que se llegase a la armonía y al entendimiento. El infante pidió a la Hermandad de Murcia que enviase dos «personeros» para tratar con los tutores de Alfonso XI sobre las cuestiones planteadas y alcanzar un acuerdo definitivo. La reunión se celebró en San Esteban del Puerto durante el mes de Mayo de 1319, y don Pedro, una vez llegado el consenso, no tardó en dirigir una carta a Murcia por la que notificaba el acuerdo adoptado y exigiendo su cumplimiento, al tiempo que, en esta densa misiva, especificaba que garantizaba la seguridad de todos los vecinos frente a cualquier represalia de los expulsados de Murcia; perdón y olvido de todo lo pasado; reconoci- 
miento de la legalidad de cuanto se había realizado por los alcaldes, alguaciles, jurados y almotacenes en el desempeño de sus oficios; aceptación de las sentencias de los alcaldes, salvo que hubieran sido dadas contra el Fuero o contra derecho; también quedaban aceptadas las justificaciones presentadas sobre las recaudaciones de las rentas y su gasto, así como la renta de sacas; se dejaban sin efecto ni valor los juramentos, ordenaciones y posturas que entre sí hubieran hecho para no recibir a don Juan Manuel y a sus vasallos, quitos de toda infamia o cualquier otra acusación. Tan sólo no aceptaban su petición de que los pleitos de primera y segunda alzada no conclusos, los terminaran los alcaldes que los habían iniciado.

Con esta larga carta volvieron los «personeros" a Murcia y la presentaron en el concejo abierto convocado para la ocasión, el cual rechazó todas las propuestas del infante castellano por considerar que la aceptación de don Juan Manuel supondría una vuelta atrás y restablecer la situación de 1313, precisamente aquella que motivó la rebelión contra sus "demasías" y, aún más, por el temor de que, pese a todas las promesas, no tardarían en manifestarse los propósitos de revancha y violencia de aquellos que durante siete años habían estado fuera de la ciudad tras haber sido expulsados violentamente de ella.

Siete días más tarde Jaime II expresaba públicamente su pesar por el fracaso de esta nueva propuesta y transmitía a don Juan Manuel su preocupación por cuanto podía hacer, el "enantamiento que entendedes fazer contra ellos porque non uos reçiban por adelantado». Nada haría, entre otras cosas, porque los acontecimientos cambiaron por entero la política castellana.

\section{INQUIETUD, ACTIVIDAD Y CONTRADICCIÓN FRONTERIZA CON GRANADA}

No falta en este breve período histórico de la minoría de Alfonso $\mathrm{XI}$, de división de poderes y debilidad bélica castellana, la obligada referencia, que podría llenar muchas páginas, a la frontera granadino-murciana, siempre activa, amenazante y también perenne factor político-bélico en los enfrentamientos nobiliarios castellanos, cosa que también sucedía en el Reino de Granada, sometido a una continuada guerra civil. El apoyo del infante don Pedro a Nasr, la particular relación de don Juan Manuel con Ismail y su posesión de Lorca, así como las indecisiones de Jaime II que soportaba frecuentes incursiones en territorio oriolano, dejaban la frontera en débiles condiciones de defensa y sería paso fácil para las huestes de Ismail que penetraban por territorio murciano y se plantaban en Orihuela.

Las rupturas de las treguas daban argumentos para las incursiones de fuertes contingentes en una u otra dirección, encaminadas a intentar la ocupación de castillos próximos a la línea divisoria -en 1324 se pierden Huéscar, Galera y Orce, antes el infante don Pedro había ganado Rute, Cambil, Alhabar, Bélmez, Tiscar- y en otras de castigo para asolar el territorio y ahuyentar a los pobladores lejos de ella. Tampoco la firma de treguas impedía la continuidad de estas incursiones, si bien en menor número de combatientes, que se adentraban en busca de botín, más siempre por parte granadina que murciana u oriolana. María Teresa Ferrer nos informa de la repetición 
de estas penetraciones, como la que tuvo lugar en 1314 que supuso la pérdida de 20.000 a 25.000 cabezas de ganado, y que continúan incesantemente en los años siguientes. Frente a ellas, como réplica, se conjuntaron huestes de Orihuela y Murcia a las órdenes de Berenguer de Puigmoltó y del adelantado López de Haro aunque sin mucho éxito, pero mucho peor fue la derrota de Pedro López de Ayala, lugarteniente de don Juan Manuel, que supuso unas fuertes bajas por muerte o cautiverio y que dejó en precaria situación a Lorca hasta que el propio don Juan Manuel, como hemos dicho, pudo hacer desaparecer la persistente amenaza que se cernia sobre el bastión lorquino.

Como exponente de cual era la situación, un documento de 1308, también publicado por la misma investigadora, en el que se relata un suceso que, aunque acaecido años antes de este período que tratamos, no cabe duda que fue uno más y semejante a los muchos que se contabilizan en los cuarenta años siguientes. Según versión del Deán del cabildo catedralicio murciano, entre 30 y 40 granadinos, dirigidos por un hijo del caudillo Zaen, penetraron por el término de Sangonera, a unos 6 kilómetros de Murcia, el 26 de Marzo muy de madrugada, de modo que, cuando había salido el sol, ya tenían recogida una gran presa que el eclesiástico calculaba entre cien y ciento cincuenta cabezas de ganado mayor y cinco a seis mil ovejas y carneros. El comentario del emisario aragonés a Jaime II era que más se hubieran llevado si la niebla no hubiera sido tan densa que les impedía divisar el ganado, ni ver por donde iban; y entre lo que se llevaban y más pesaba al Deán — «mal pecado» fueron sus palabraseran los seiscientos carneros pertenecientes al diezmo eclesiástico.

No hubo hombre, jinete o peón, de Murcia que no saliera en apellido a perseguir a los almogávares, incluso los de la alta clerecía, todos camino de Lorca en donde, al día siguiente, se les agregaron unos 800 hombres de la ciudad. La persecución tuvo éxito y los granadinos fueron alcanzados antes de sobrepasar la extensa zona fronteriza y en el enfrentamiento murió el hijo de Zaen, el adalid granadino para quien no falta un elogio "por ser mançebo nunca vieron un cavallero mas esforçado en una fazienda, ca si entrara por ellos como si fueran ovejas, e de mientre que el se tovo, toda su gente fazian maravillosamente». Un afortunado tiro de ballesta dio con él en tierra y su compañía fue derrotada, con lo que pudieron recuperar el ganado lanar en el que se incluían los seiscientos carneros del diezmo eclesiástico, aunque no sucedió lo mismo con las vacas y yeguas, cuya mayor movilidad les había permitido adentrarlas en territorio granadino. La cabeza del hijo de Zaen sería presentada en Murcia en señal de triunfo y para celebrar la hazaña.

La muerte de los infantes don Pedro y don Juan en la vega de Granada y consiguiente derrota del ejército castellano, no sólo dejó indefensa la frontera, sino que la desmoralización fue grande y, si no tuvo graves e inmediatas consecuencias, fue gracias a la actitud de los concejos andaluces que pudieron firmar una tregua por 8 años, lo mismo que hacía, en 1321, Jaime II al acordar una suspensión de las hostilidades con Granada por espacio de 5 años; pero tanto en una como en otra quedaba fuera el Reino de Murcia, en espera de la decisión de don Juan Manuel, invitado a suscribir la firmada por las ciudades andaluzas. 
Según informaciones de enviados aragoneses, Pedro López de Ayala trataba en Granada la consecución de una tregua para el Reino de Murcia, pero con unas condiciones tan perjudiciales para Aragón que Jaime II, al conocerlas, no pudo por menos que calificarlas de inicuas, ofensivas a Dios y en vituperio de su monarca. Debieron de circular urgentes emisarios aragoneses y la tregua Granada-Murcia se fijaría en los mismos términos normales que las establecidas con Castilla y Aragón. No por eso la frontera quedaría pacificada.

\section{EL «RIEPTO» DE GUILLÉN DE ROCAFULL}

El 1315 se produjo un estridente escándalo que afectó personalmente el honor de don Juan Manuel, conmovió a la corte y nobleza castellana y alcanzó también a la aragonesa. Fue el reto, con denuncia de hechos graves y calificados con duros denuestos aún más estruendosos por don Guillén de Rocafull, señor de Abanilla, ante los tutores de Alfonso XI, a través de cuya Crónica y las cartas publicadas por Giménez Soler permiten conocer las causas y final. Dice la Crónica «andaba don Guillén de Rocafuy diciendo mal et reptando ante el rey a don Joan, fijo del infante Don Manuel, porque decia que le prendiera».

De una anterior y amigable atención de Rocafull con el señor de Villena, pasó todo a una enemistad profunda y duradera que les enfrentaría hasta la muerte. La prisión y cuanto pudo pasar, impulsó al señor de Abanilla a retarlo públicamente en la corte castellana, exponiendo los agravios y tachándolo de cobarde y otros denuestos propios de estos casos, que según los tutores del monarca "auia dicho ante ellos algunas palabras contra don Johan que eran deshonrra de don Johan». Tan injuriosos debieron ser los improperios que el propio infante don Pedro, tutor del rey y también cuñado de don Juan Manuel, airado, ordenó la detención de Rocafull.

Pero si las acusaciones y palabras malsonantes contra el señor de Villena pudieron ser desmedidas, la orden del infante fue considerada como desafuero por la nobleza "por toda la hermandad de la caualleria de Castilla", quienes afrontaron a don Pedro haciéndole patente que el cargo que tenía no le permitía detener a Rocafull y que estaba obligado a oirle, conforme la costumbre de Castilla. Así lo hubo de hacer el tutor del rey: dejar en libertad a don Guillén y mantener el proceso en la corte.

A la natural soberbia de don Juan Manuel se sumó la ira cuando tuvo noticias de la escandalosa denuncia del señor de Abanilla y su única solución, como tantas otras veces, sería acudir a su suegro y exponerle que, según su parecer, no era uso en la corte castellana oír tales palabras y, en el obsesivo orgullo de su linaje, añadía que los tutores de Alfonso XI no habían tenido en cuenta quién era él y quién don Guillén de Rocafull. Miguel Pérez de Arbe, emisario de Jaime II, se presentó ante los tutores castellanos y les expuso la consternación de su soberano y su deseo de encontrar solución satisfactoria para su yerno; además el representante del rey de Aragón debía informarse si el caso era desaforado y si, caso de no serlo, se mantuviera la acusación, exigir seguridad para que don Juan Manuel pudiera contestar el reto y exponer sus razones. Jaime II se equivocaba al creer que todo seguiría adelante, porque su 
intervención no favorecía a su yerno al dejarle en evidencia, lo que después se llamó cobardía.

Aceptada la denuncia de Rocafull y no pudiendo suspender el proceso, todos quedaron expectantes a la espera de los acontecimientos $y$, reiterado el reto por. don Guillén, en el mes de Octubre, sólo quedaba atender la presencia de don Juan Manuel en la corte. De no hacerlo, su honor quedaría maltrecho y, si lo hacía, todo derivaría, según el fuero de Castilla, en un encuentro personal que debía de hacerse públicamente. Contaba don Juan Manuel 33 años y una edad semejante debía tener Rocafull, del que sabemos que en 1308 vivía su padre, y que en 1321 había enviudado y volvería a casar años más tarde. La Crónica alfonsí cuenta como, en fecha cercana, cumplido el plazo de un reto, en la lucha que dos caballeros mantuvieron en Valladolid, mató el "reptador al reptado».

La reina María de Molina, atenta a la inquietud de Jaime II, le escribiría para decirle la inutilidad de sus esfuerzos para disuadir a don Guillén, quién le decía que fueron tantas las cosas «desaguisadas» que hizo contra él, que no podía perdonar ni olvidar; Jaime II contestaba pidiendo seguridad para su yerno de todo peligro para que pudiese marchar a la corte y responder al reto. Los tutores, deseosos de encontrar una solución propicia, por cinco veces prometieron la seguridad solicitada e incluso el infante don Juan ofreció enviar a sus hijos y mil caballeros para que acompañaran al señor de Villena en el viaje, mientras que por su parte, el enviado aragonés, aseguraba a don Jaime que si don Juan Manuel buscara la ayuda de su cuñado, el infante don Pedro le sacaría del mal paso, pero, y son sus palabras, "si esto non se fase creo lo ent sacaran mal si el non responde como deue e si responde aversa a combatir su cuerpo al suyo, segunt costumbre de Castiella». Tal y como indicaba Miguel Pérez de Arbe, sería don Pedro quien ayudaría al señor de Villena a salir lo mejor posible del trance ya que, como dice la Crónica: «troxieron pleytesia con el que non pareciese a los plazos de los pregones et dio el rey por quito a don Joan».

No fue el final. Don Juan Manuel guardó un odio permanente contra Rocafull, una afrenta que no podría olvidar y, cuando cinco años más tarde, alcanza la regencia de Alfonso XI ordenó un proceso en la corte contra Rocafull y su ingreso en prisión. Pero, precavido, don Guillén salió de Castilla e hizo pleito-homenaje a Jaime II por Abanilla reconociéndole como soberano y, para tener una mayor seguridad, hizo donación oficial de su señorío a la Orden de Calatrava. Todavía habría otras vicisitudes posteriores, entre ellas la acaecida en 1327 cuando Alfonso XI incitó a Rocafull para que tomase venganza de los daños y perjuicios que le había ocasionado don Juan Manuel en los años que ejerció la tutoría.

\section{DON JUAN MANUEL. TUTOR DE ALFONSO XI Y ADELANTADO DEL REINO DE MURCIA (1320-1325)}

La inesperada y desastrosa muerte de los infantes don Juan y don Pedro el 24 de Junio de 1319 en la vega de Granada, ocasionó una nueva crisis de gobierno en Castilla, donde había quedado sola doña María de Molina, y significó también la apertura de 
nuevas perspectivas para las insaciables aspiraciones de don Juan Manuel. A ello le alentaría Jaime II tan pronto como supo lo sucedido y, prudentemente, asesoraba a su yerno pidiéndole moderación y a la vez eficaz actividad, haciendo valer «qui sodes e de qual lugar venides... e que Dios vos aya que gradescer ende... ayades buen nonbre e buena fama por el mundo». Días más tarde, el 26 de Julio, le felicitaba por su propósito de asegurar la frontera granadina y, de nuevo, le recomendaba prudencia y le estimulaba a participar en la regencia de Alfonso XI: "si la voluntad fuese de Dios et de las gentes que vos venga de governar los regnos, mucho mejor poderdes servir a Dios et al rey en la frontera et cumplir el buen talant que avedes». El envés de esta nueva situación para don Juan Manuel iba a ser la que se presentaba al concejo de Murcia, muerto don Pedro y falto del apoyo moral, político e incluso bélico que años antes había encontrado en Jaime II, quien en estas circunstancias prestaba toda su ayuda a su yerno, además de que siempre había insistido en que se restablecieran buenas relaciones con él.

Faltan datos, pero cabe deducir que la reacción concejil, tras haber rechazado de plano en los comienzos de este año el acuerdo de San Esteban del Puerto, sería la de plegarse a las circunstancias, porque un periodo de transición y la certidumbre de que don Juan Manuel alcanzaría un lugar destacado en la nueva regencia que habría de formarse en tanto se prolongase la menor edad de Alfonso XI, les obligaba a adelantarse a posibles represalias, por lo que, en Enero de 1320, Gil de Moncada, Berenguer Pujalte y Bernat Mena, enviados de Murcia, se presentaron ante don Juan Manuel y le mostraron la predisposición del concejo murciano a reconocerlo como adelantado. Ahora el señor de Villena podía poner sus condiciones: entrada libre en la ciudad, obediencia a quien designara como su lugarteniente en el adelantamiento, que debía ser vasallo real, y pago de las rentas que se le debían por la tenencia de los castillos a su cargo.

Los murcianos aceptaron y también mostraron su aquiescencia a la jefatura de Alfonso Fernández de Biedma, designado adelantado por don Juan Manuel. En Octubre de este mismo año representantes concejiles, encabezados por Fernández de Biedma, acudieron a Valladolid ante la reina doña María de Molina para obtener la confirmación de sus privilegios y con ella la carta de perdón general por todo cuanto había sucedido en Murcia desde la muerte de Fernando IV hasta la del infante don Pedro. Así se hizo y la abuela del rey, en nombre del monarca, expidió el documento en el que hacía constar todos los hechos tan reiteradamente expuestos en el orden del día de todos los fracasados conciertos de los años anteriores: adelantamiento, «fuera echados», destrucción del alcázar, aprobación de los acuerdos concejiles, sentencias de los alcaldes y todas las demás cuestiones. Sagaz, la reina, encontró una base político-jurídica para exculpar a los murcianos de todo lo pasado y, en nombre de su nieto, decía: «Este perdon les fago yo porque sope yo por cierto que esto que los de Murcia fizieron, que lo fizieron por mandado del infante don Pedro, mio tio e mio tutor, que Dios perdone». Por el bien de todos, reina y madre, hacía recaer en su difunto hijo toda la responsabilidad de lo pasado, era fórmula precisa para la pacificación y convivencia murciana.

En el mes de Noviembre se desplazaron los mismos representantes murcianos a Córdoba con objeto de entrevistarse con don Juan Manuel, que se titulaba ya tutor de 
Alfonso XI y adelantado del Reino de Murcia y, el día 30, mediante juramento solemne, poniendo la mano derecha sobre la Cruz y los Evangelios, prometió olvido de todas las querellas y demandas que podía tener contra la ciudad y sus vecinos, porque, según escribiría, quería poner paz y sosiego en las ciudades y lugares que le habían reconocido como tutor, así como también recordando los servicios que Murcia había prestado a su padre y a él mismo tiempo antes.

En los días siguientes atendió diversas peticiones concejiles y un cuaderno en que se solicitaban innovaciones jurídicas necesarias por no estar contenidas en el Fuero y privilegios de la ciudad. Finalmente, el 10 de Diciembre, todavía en Córdoba, hacía constar que se mantenía en todo lo referente a los acuerdos concertados con el infante don Pedro en San Esteban del Puerto, si bien con ciertas excepciones concernientes al gobierno de la ciudad, volver al régimen mantenido en el reinado de Fernando IV, esto es, no sólo ya la vuelta de los "fuera echados», sino la configuración del órgano concejil que el había establecido, la de sus vasallos y adictos.

Pero la historia de Murcia en el período comprendido entre 1321 y 1325 , al que hay que agregar un apéndice de dos años, puesto que en 1327 se resolvería toda la problemática mantenida por Murcia y don Juan Manuel durante trece años, es prácticamente desconocida. Un silencio casi impenetrable impide conocer hechos, vicisitudes, nombres y desenvolvimiento del concejo en estos cinco años, así como aspectos económicos, demográficos y, en general, el desarrollo de la ciudad en este espacio de tiempo. Sí que se mantenía la inseguridad fronteriza con frecuentes incursiones de almogávares granadinos hasta la firma de la paz de 1321, primero por cinco años y después ampliada por el monarca nasrí a siete, lo que despertó el recelo Pedro López de Ayala por si tenía consecuencias para Aragón, que sólo la había concertado por cinco años, pero la vigencia de la tregua no significaría la desaparición completa de las incursiones de los adalides granadinos. En orden distinto cabe señalar la celebración de un Sínodo Diocesano convocado por el obispo Juan Muñoz Gómez de Hinojosa en 1323, en el que se promulgó un Catecismo, el mismo que Guillermo de Gudín, cardenal de Santa Sabina, aprobó el año anterior en el Concilio de Valladolid, con el doble objetivo de reforma del clero y de costumbres.

A la muerte de María de Molina, el infante don Felipe, don Juan Manuel y don Juan, hijo del infante don Juan, se repartieron el gobierno de Castilla en las zonas geográficas donde habían logrado imponerse y se les mantuvieron adictas. Todo ello en un continuado y largo periodo anárquico, donde el desorden, robos, extorsiones y asaltos se sucedían en todos los reinos de la corona castellana, cuya narración por la Crónica resulta estremecedora y evocadora de los calamitosos años que siguieron a la muerte de Fernando IV y que cabría resumirlo en las palabras que un enviado de Jaime II utilizó para concretar el panorama político castellano: "Todos entre si pugnan por destruirla, que quien mas puede mas lleva e quien menos, lazra (lacera, destruye) e non saben que es justicia nin les place con ella».

Un suceso, que en don Juan Manuel no es insólito y que comenta Giménez Soler, fue una curiosa misiva que Bernardo de Sarriá envió a Jaime II en la que le relataba una doble propuesta del tutor de Alfonso XI, en fechas cercanas a la mayor edad del 
rey. Don Juan Manuel se hacía eco de una supuesta conjura que mantenían algunos consejeros del joven monarca para cuando alcanzara la mayoría de edad, pretendiendo hacerle ver la obligación que tenía de recuperar la parte del Reino de Murcia anexionada a la Corona de Aragón por la sentencia de Torrellas. Y para evitar lo que podía derivar en guerra entre los dos estados, don Juan Manuel proponía concertar el matrimonio de una hija de Jaime II con el monarca castellano y que la infanta llevara como dote dicho territorio, con lo que la paz quedaba asegurada; también, como fiel servidor que se declaraba de su suegro, le sugería la prestación de dos galeras con sus jarcias que don Jaime tenía en Valencia, pues acababa de terminar de pagar la compra de Cartagena, vendida por Pedro López de Ayala, y con ellas, más una nave de tres cubiertas y dos leños armados que estaban en el puerto cartagenero, podría ayudarle en caso de guerra con Castilla. Quien esto decía era por entonces tutor de Alfonso XI y recibió por respuesta un rechazo a tan desmedida propuesta matrimonial, pues Jaime ll dejó bien claro que no cedería ni una alquería de la tierra de Murcia que mantenía con justo título y dejó la cuestión de las dos galeras para un tiempo futuro que no llegaría nunca.

Dos hechos que se sucedieron en Murcia en este mismo año 1325 son exponentes de la tensión y situación insostenible en la que se hallaban los vecinos de Murcia y que agotaría su paciencia ante las exigencias e injusticias de quienes gobernaban la ciudad en nombre de don Juan Manuel. Una tumultuosa rebelión, de la que salió mal herido Sancho Sánchez de Lariega, a quien Jaime II denomina caballero de don Juan Manuel y que era teniente de adelantado de Pedro López de Ayala. El rey de Aragón, por carta fechada en 18 de Febrero, se dirigía a éste para conocer lo ocurrido y en ella habla de «ayuntamiento, alboroço e bullicios e asonamientos fechos en la ciudad contra vos por aquellos que fizieron las dichas feridas". La situación conflictiva, estallido de un odio contenido durante mucho tiempo, pudo ser dominada; pero cuando, meses más tarde, se recibió en Murcia la carta de Alfonso XI en la que notificaba su mayoría de edad y prohibía que se cumplieran las cartas de quienes habían sido sus tutores, el cese de la minoría fue interpretado a que cesaba también el adelantamiento, por lo cual, según carta posterior de Alfonso XI, «alborotaron el pueblo e fezieron conçejo e revocaron las cosas que el dicho don lohan avia fecho». Se restablecería el orden, aunque le costó a Pedro López de Ayala su destitución como lugarteniente de don Juan Manuel en el adelantamiento.

El suceder murciano en estos años tiene un resumen sustancioso en las cartas reales de los años 1325 y 1327, en las don Alfonso se hacía eco de las quejas y querellas expresadas por los enviados murcianos quienes, pese a que don Juan Manuel mantenía su alta posición política en la corte, acrecentada con el compromiso matrimonial de su hija, acudieron a las Cortes de Valladolid, cosa que el señor de Villena no pudo impedir, y allí, ante los ojos y oídos de los asistentes, mostraron sus agravios y quejas, todas ellas escuchadas y aceptadas como verdaderas, que fueron el origen de las disposiciones del rey para poner fin a tal situación, pero su reiteración y exigencias de su cumplimiento muestran su ineficacia al mantenerse el concejo restringido creado por don Juan Manuel y continuar éste como adelantado mayor. 
En estas cartas se hace mención de hombres buenos expulsados de la ciudad por orden de don Juan Manuel, otros alejados por temor a ser muertos; algunos denunciaban su estancia en Orihuela, faltos de bienes y con miedo al regreso. Aún más, se ordenó por pregón salir de la capital y villas del reino a una lista cualificada de vecinos y, tiempo después, nuevos pregones los emplazaban a comparecer ante los tutores en la corte, a la que no acudieron por el peligro y gastos de desplazamiento y por considerar que no se les haría justicia, por lo que sus ausencias darían lugar a las sentencias que decretaban la pérdida de sus bienes. La veracidad de todo sería reconocida por Alfonso $\mathrm{XI}$ : «sabiendo yo que esto que ellos querellan que es notorio e manifiesta cosa».

La contienda Murcia-don Juan Manuel termina en 1327 cuando el señor de Villena se rebeló por la ruptura del compromiso matrimonial de su hija y retenerla el rey en su poder. Sería entonces cuando Alfonso XI reconocería en toda su amplitud las denuncias murcianas: «En tienpos pasados los mas caualleros e escuderos e muchos otros omnes se fezieron vasallos e acostados de don Johan, fijo del infante don Manuel, e con el poder del dicho don Johan todos los fechos de la çibdad auien de pasar por su mano e con esto catauan mas por seruiçio del dicho don Johan, por conplir su talante, que non por el mio seruiçio ni por de vosotros, e que antes se cunplie en Murçia e en el regno las cartas e mandado de don Johan, que las cartas e mio mandado".

Y como punto y final, comenzaba el retorno. El 10 de Octubre de 1327 se presentaba ante el concejo de Murcia Fernán Alfonso, hijo de Rodrigo Alfonso de Magaz, portando una carta real para que lo acogieran en la ciudad, porque siendo vasallo de don Juan Manuel «partiose del dicho don Johan e vinose para mi merçed e es mio vasallo»; sería el primero de una curiosa lista de vasallos y «acostados» del señor de Villena que, en grupo o individualmente, fueron presentándose en los meses e incluso años siguientes con igual solicitud. Se cumplía de esta manera el ordenamiento concejil, ratificado por el rey, por el que se establecía que en Murcia sólo podían vivir y ser vecinos de ella los vasallos reales exclusivamente. Comenzaba un nuevo período histórico de la ciudad de Murcia y su Reino.

Todo daría un vuelco en 1327, año que afectó profundamente a don Juan Manuel. Murió su esposa, Constanza de Aragón; también su suegro, el rey Jaime II; se hace público el nuevo compromiso matrimonial de Alfonso XI con María de Portugal y ve como su hija, no sólo no sube al trono castellano, sino que queda bajo la custodia de su soberano. Un cambio profundo ante la realidad histórica a la que se enfrentaría colérico, amargado y otra vez a la lucha desesperada, destructiva y a la larga inútil.

Hombre de acción, con frecuencia irreflexiva, contradictorio entre su forma de pensar y obrar, sería a raíz de su fracaso político cuando más humano, junto a su incansable actividad político-bélica, tendrá tiempo para atender al bienestar de sus obedientes vasallos del señorío de Villena; también para leer, traducir, reflexionar y exponer por escrito variedad de temas literato-políticos, que señalarían vías de gobierno, de razón de Estado propias de su prosapia y condición, de lo que realmente pensaba pero que por sus ambiciones había combatido y erosionado en años de lucha y expectativa por gozar del poder. Una obra que lo inmortalizaría, haría olvidar su actividad política y lo situaría en la cumbre de la literatura castellana medieval. 


\title{
JAIME II Y LOS JUDÍOS EN LA CORONA DE ARAGÓN
}

\author{
Yom TOV ASSIS \\ Universidad Hebrea de Jerusalén
}

\section{EL REY Y LOS JUDÍOS}

La posición de los judíos en la Corona de Aragón no permaneció constante en los siglos XIII-XIV porque la política de los monarcas con respecto a ellos no fue totalmente consistente. Sin embargo, hay ciertos principios que conservaron su validez hasta las matanzas de 1391. Uno de gran importancia es el que afirma que «judei

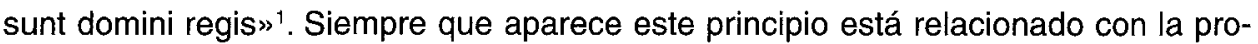
piedad y los bienes y así vemos que los judíos son mencionados como «cofres del senyor Rey», "peculium et thesaurus noster», «tresor e case nostra propia» $y$ «nostrae camerae servi speciales ${ }^{2}$. Al ser propiedad del rey, los judíos gozaban de la protección del monarca ${ }^{3}$. Este es un principio fundamental que todos los reyes-condes mantuvieron desde la época de Ramón Berenguer IV que unió Aragón y Cataluña en 1137. Sin él, la existencia de los judíos en la Corona de Aragón habría corrido peligro. Aunque con el transcurso del tiempo las nuevas condiciones creadas acarrearon cambios en la política judía de la Corona y, por consiguiente, en la posición de los judíos, el

1 T. MIERES, Apparatus super constitutionibus curiarum generalium Cathaloniae, I, Barcelona, 1621, p. 62b; J. BERGUA CAMÓN, «Fueros de Aragón de 1265 a 1381 », Anuario de Derecho Aragonés, $V(1949-50)$, p. 455.

2 J. COROLEU, Documents historichs catalans del sigle XI, Barcelona, 1889, p. 61; F. DE BOFARULL Y SANS, Los judios en el territorio de Barcelona (siglos $X$ al XIII), Reinado de Jaime $I$, 1213-1276, Barcelona, 1910, p. 37.

3 P. CABARTE, Fueros y observaciones del reyno de Aragón, Saragossa, 1624, p. 11b; ACA [=Archivo de la Corona de Aragón], Reg. 43, fo. 30v [=J. RÉGNÉ, History of the Jews in Aragón, ed. Y. Assis, Jerusalem, 1978, no. 1206 (=Régné)]. 
monarca nunca renunció a reivindicar su calidad de propietario de los judíos, lo que contribuyó a la relativa estabilidad de que gozaron los judíos de la Corona hasta 1391.

Desde el punto de vista del rey, los judíos suponían una importante fuente de ingresos. Por eso, en períodos en que las arcas reales estaban casi vacías, normalmente la posición de los judíos se fortaleció. Para el rey, estos últimos suponían un elemento valioso que estaba interesado en conservar y, mejor aún, en aumentar. La famosa invitación que hizo Jaime I a los judíos para que se radicaran en los territorios de la Corona de Aragón y especialmente en el Reino de Valencia, constituye una evidencia clara del valor que otorgaba a sus súbditos judíos ${ }^{4}$. El aliento a la inmigración de judíos a las tierras de la Corona de Aragón, siguió siendo un elemento importante de la política de sus sucesores. Pedro III prosiguió la política de su padre ${ }^{5}$ y Jaime II, además de alentar la inmigración de judíos, prohibió su emigración ${ }^{6}$. El objetivo de prohibir la emigración de judíos era prevenir pérdidas económicas y, por lo tanto, constituía otro aspecto de la misma política de los reyes-condes ${ }^{7}$. Cada judío adicional suponía una ganancia para el tesoro. Todo ataque contra ellos o sus propiedades, conllevaba una reacción inmediata del rey que no quería ver disminuidos sus ingresos. La multa que tenía que pagar el que asesinara o matara accidentalmente a un judío, muestra el valor que este último tenía a ojos del rey y no importa en este contexto si dicha imposición estaba concebida para compensar al rey o para prevenir ataques posteriores ${ }^{8}$. En resumen, el rey tenía para con los judíos la actitud que tiene un propietario con respecto a lo que le pertenece. Cuando el arzobispo de Tarragona intentó impedir en 1300 que los oficiales reales recaudaran impuestos de los judíos locales actuando con ello de acuerdo a la decisión de las Corts de Barcelona, Jaime II expresó su sorpresa ante esta interferencia y declaró que todos los judíos de Cataluña eran propiedad privada suya y que, por lo tanto, tenía derecho a imponerles las cargas fiscales que quisiera ${ }^{9}$. De más está decir que los judíos no podían someterse a ninguna otra jurisdicción sin consentimiento previo del rey ${ }^{10}$.

Durante este período, la vigilancia que el rey ejercía sobre los judíos por considerarlos propiedad suya o parte de su tesoro, redundó en ventaja de ellos. En 1290, Alfonso III detuvo un proceso iniciado por el Conde de Ampurias contra los judíos de

4 J. VILLANUEVA, Viage literario a las iglesias de España, XII, Madrid, 18xx, pp. 327-8; A.P.V. MOREL-FATIO, «Notes et documents pour servir à l'histoire des Juifs des Baléares sous la domination aragonaise du XIlle au Xve siècle", Revue des Etudes Juives, IV (1882), p. 32, no. 1; ACA, Reg. 16, fo. 199 [=Régné 443].

5 Sobre la inmigración de judíos del África del norte, véase ACA, Reg. 40, fo. 80v [=Régné 691 =J.E. MARTÍNEZ FERRANDO, Catálogo de la documentación relativa al antiguo Reino de Valencia, Madrid, 1943, II, no. 332; de judíos de Castilla, véase ACA, Reg. 60, fo. 56v [=Régné 1032].

6 Y. ASSIS, «Juifs de France réfugiés en Aragón (XIIle-XIVe siècles)», Revue des Etudes Juives, CXLII (1983), pp. 294-299; ACA, Reg. 256, fo. 1v [=Régné 2674]; Reg. 195, fo. 120 [=Régné 2675].

7 ACA, Reg. 10, fo. 37 [=Régné 94]; Reg. 56, fo. 59v [=Régné 1337].

8 ACA, Reg. 204, fo. [=Régné 2868]; Reg. 194, fo. 266 [=Régné 2623]; Reg. 197, fo. 19v [=Régné $2720=$ F. BAER, Die Juden im christlichen Spanien, I, Berlin, 1929, no. 142].

9 ACA, Reg. 257, fo. 44v [=Régné 2725].

10 ACA, Reg. 204, fo. 73 [=Régné 2874]. 
sus dominios, argumentando de que sólo el rey tenía autoridad para investigar sus acciones y juzgarlos. Además, el monarca sostenía que los judíos pertenecían a la Corona y que, por consiguiente, cualquier daño que sufrieran atentaría contra sus intereses ${ }^{11}$. La respuesta que Jaime II dio en 1294 a la reina de Castilla que le había pedido que nombrara a Salamón Constantín jutge o rap (juez o rabino) de los judíos de Aragón, es una buena muestra de las ventajas que los judíos podían derivar del hecho de ser propiedad del rey. Este último, que sabía que los judíos se oponían al nombramiento, rechazó la petición de la reina diciendo «... non devedes querer que por un judio perdamos los otros» ${ }^{12}$. De hecho, hizo cuanto pudo por no perder su jurisdicción sobre sus súbditos judíos y actuó con gran diligencia para defenderlos y protegerlos en momentos de peligro. Tomó medidas y ofreció medios para garantizar su bienestar y los estimuló a que se asentaran en sus dominios ${ }^{13}$.

Esta actitud del rey estaba motivada por consideraciones económicas y no tenía nada que ver con sus sentimientos respecto a los judíos. Los verdaderos sentimientos de Jaime II por sus súbditos judíos quedan expresados en una carta que envió a su hija Constanza con ocasión del nacimiento del hijo de esta última en 1321. En ella, el rey la advierte que, en lo que respecta a la educación del recién nacido, no siga el consejo de los judíos como había hecho previamente la infanta en otros terrenos ${ }^{14}$. La carta nos muestra, por una parte, la estrecha relación de ciertos judíos con los miembros de la familia real y, por otra, las reservas y prejuicios personales del rey hacia los judíos tal como los expresaba en su correspondencia privada. Los reyes-condes supieron acallar sus sentimientos personales y tratar a los judíos según los beneficios que el reino pudiera derivar de ellos. La posición de los judíos estaba determinada, en muy buena medida, por los beneficios económicos, reales o imaginarios, que los reyes esperaban poder obtener de ellos.

\section{LOS JUDIOOS Y LA RECONQUISTA}

La posición de los judíos durante los reinados de Jaime I y Pedro III parecía estable y segura; su contribución a la Corona estaba entonces en su momento culminante. Con Jaime I, los judíos fueron considerados un elemento apropiado para colonizar Mallorca y Valencia, zonas que acababan de ser conquistadas y cuya repoblación era vital para el rey desde los puntos de vista demográfico y económico así como por motivos de seguridad. Tras la conquista, especialmente en Mallorca, se produjo una emigración sustancial de musulmanes, población cuya lealtad al monarca era, por otra parte, cuestionable. Los judíos eran candidatos ideales para la colonización y, desde

11 ACA, Reg. 81, fos. 87, 236 [=Régné 2107, 2265].

12 ACA, Reg. 252, fo. 50 [=Régné 2551 =BAER, Die Juden, doc. 136.

13 ACA, Reg. 198, fo. 228 [=Régné 2747]; Reg. 212, fo. 60v [=Régné 3029]; Reg. 216, fo. $24 \mathrm{~V}$ [=Régné 3089]; Reg. fos. 258-9 [=Régné 3057]; Reg. 214, fos. 102v-103 [=Régné 3069].

14 ACA, Reg. 246, fo. 310 [=A. GIMÉNEZ SOLER, D. Juan Manuel: biografía y estudio crítico, Zaragoza, 1932, apéndice, no. 374 =J.E. MARTíNEZ FERRANDO, Jaime II, su vida familiar, II, Barcelona, 1948, doc. 366]. 
el punto de vista del rey, preferibles incluso a los cristianos procedentes de la nobleza catalana o aragonesa que podían resultar rivales políticos. La radicación de judíos en esas zonas no era sólo importante para aumentar la proporción de no musulmanes en los territorios conquistados, sino también para colonizar tierras que los fugitivos habían abandonado o que habían sido confiscadas a manos enemigas. Estimular a que un sector de la población sirviera de elemento colonizador tomando el lugar de los musulmanes a los que se permitió emigrar a Granada y al norte de África, constituyó una de las piedras angulares de la política de la Corona en las nuevas posesiones ${ }^{15}$. La relativa tolerancia que el monarca aragonés había mostrado con los musulmanes, llegó a su fin con las rebeliones de estos últimos ${ }^{16}$ y el rey incrementó las presiones para que los musulmanes emigraran al norte de África ${ }^{17}$ en la misma medida en que estimuló a los judíos a que trasladaran sus hogares a la región y los reemplazaran. La contribución de los judíos a la economía y a la colonización del sur fue sustancial. Lo que es más, Jaime I encontró en Mallorca y en Valencia una pequeña población judía local ${ }^{18}$ cuya afortunada integración fortaleció la posición de los judíos recién llegados ${ }^{19}$.

\section{JUDÍOS AL SERVICIO DEL REY}

Durante el reinado de Pedro III, los esfuerzos y recursos de la política exterior se dirigieron a la expansión por el Mediterráneo incluyendo Sicilia, Malta, Kerkennah, Pantelleria y Jerba. Este cambio puso casi un punto final al cometido que los judíos habian desempeñado en el programa de colonización aunque no en el que jugaban en el terreno económico. La Reconquista catalano-aragonesa quedó interrumpida cuando Castilla conquistó el Reino de Murcia creando un tapón entre la Corona de Aragón y la Andalucía musulmana. Los intereses catalanes se dirigieron allende el mar y habría sido de esperar un cierto deterioro en la posición de los judíos pero, en esa época, estos últimos empezaron a jugar un papel alternativo muy importante para la política del rey. Paralelamente a su vasto programa de expansión territorial y económica, Pedro III tenía el proyecto de establecer un sistema político centralizado, independiente de la nobleza. Con este fin, trató de formar un servicio civil basado en el

15 J. VICENS VIVES, Historia social y económica de España y América, II, Barcelona, 1957-9, pp. 39, 50, 61; J.E. MARTÍNEZ FERRANDO, «Estado actual de los estudios sobre la repoblación en los territorios de la Corona de Aragón (siglos XII-XIV)", VII Congreso de Historia de la Corona de Aragón, I (1962), p. 153; Ch. DUFOURCQ, L'Espagne catalane et le Maghrib, Paris, 1966, p. 154 y en general véase R.I. BURNS, Medieval Colonialism: Postcrusade Exploitation of Islamic Valencia, Princeton, 1975.

16 J. ZURITA Y CASTRO, Anales de la Corona de Aragón, I, Zaragoza, 1610, fo. 167v.

17 ACA, Reg. 9, fo. 28; Reg. 10, fo. 62v; DUFOURCQ, L'Espagne catalane, p. 187.

18 La destrucción de las comunidades judías de al-Andalus fue casi total como consecuencia de la invasión de los Almohades en 1148. Una gran parte de los judíos andaluces se trasladaron al norte, a los reinos hispánicos donde continuaban su tradición y cultura judeo-árabe. Véase Y. ASSIS, "The Judeo-Arabic Tradition in Christian Spain", The Jews of Medieval Islam; Community, Society, \& Identity, ed. D. Frank, Leiden, New York, Köln, 1995, pp. 111-124.

19 VICENS VIVES, Historia social, II, p. 56. 
empleo de oficiales judíos y estuvo a punto de lograrlo ${ }^{20}$. Su elección no es de extrañar. En general, los judíos demostraron poseer muy buenas aptitudes para la administración. Eran totalmente leales al rey y dependían por completo de la Corona. El intento falló cuando la nobleza se negó a enviar tropas para rechazar la invasión francesa de 1283 a no ser que el rey despidiera a sus oficiales judíos. Los despidos echaron abajo el proyecto que, de haber tenido éxito, habría privado a la nobleza de todo poder y posición políticos ${ }^{21}$.

En 1283, Pedro III prometió a los nobles de Aragón, Valencia y Cataluña que, a partir de entonces, no nombraría baile a ningún judío ${ }^{22}$. En diciembre de 1283 , al confirmarse los fueros, reiteró su promesa a los burgueses ciudadanos de Valencia asegurando que ningún judío ejercería la función de baile «nec officium publicum teneat unde super christianum habeat jurisdictionem" ${ }^{23}$. En enero de 1284, se informó a los nobles catalanes de la exclusión final y definitiva de los judíos de todos los cargos públicos ${ }^{24}$. Estas promesas, de hecho, suponían la puesta en práctica de una prohibición que databa de 1228 y prohibía a los judíos ocupar cualquier cargo que les diera competencia judicial sobre cristianos ${ }^{25}$.

No hay que subestimar las serias consecuencias que tuvo para los judíos el que el rey se sometiera a las demandas de la nobleza. Esto último constituyó un cambio decisivo en la historia de los judíos de la Corona de Aragón, el comienzo de su decadencia y la primera etapa de un proceso que culminaría en matanzas, conversiones forzadas y destrucción. Pero la opinión de que la Corona ya no necesitó de los judíos una vez que el proyecto del monarca hubo fracasado, resulta totalmente insostenible ${ }^{26}$. Tanto el propio Pedro III como su sucesor Alfonso III, siguieron utilizando los

20 L. KLÜPFEL, "El règim de la confederació catalano-aragonesa a finals del segle XIII», Revista Jurídica de Catalunya XXXV (1929), pp. 34-40, 195-226, 289-327; XXXVI (1930), pp. 18-37, 97-135, 298-331; J.L. SHNEIDMAN, "The Jews in the Royal Administration of XIIIth Century Aragón», Historia Judaica XXI (1959), pp. 37-52; D. ROMANO, Judios al servicio de Pedro el Grande de Aragón (12761285), Barcelona, 1983; Y. ASSIS, "Diplomáticos judíos de la Corona de Aragón en países islámicos", Sefunot III (18) (1985), pp. 11-34 (en hebreo).

21 SHNEIDMAN, «The Jews in the Royal Administration"; D. ROMANO, "Los funcionarios judios de Pedro el Grande de Aragón", Boletín de Real Academia de Buenas Letras de Barcelona XIX (106970), p. 31; KLÜPFEL, «El règim», XXXV, p. 313.

22 Sobre Aragón, véase J. BERGUA CAMÓN, «Fueros de Aragón de 1265 a 1381 ", Anuario de Derecho Aragonés V (1949-50), p. 455; sobre Valencia, véase ACA, Reg. 62, fo. 18; Reg. 47, fo. 53; sobre Cataluña, véase F. SOLDEVILA, Historia de Catalunya, I, Barcelona, 1962, pp. $362 \mathrm{ff}$.

23 Colección de documentos inéditos del Archivo de la Corona de Aragón, «Procesos de las antiguas Cortes", VI, p. 166.

24 Constitucions y altres drets de Cathalunya, II, Barcelona, 1704 (reedición 1909), p. 49; D. ROMANO, "Los funcionarios judíos de Pedro el Grande de Aragón", Boletín de la Real Academia de Buenas Letras de Barcelona [=BABLB] XIX (1969-70), p. 31.

25 «... ut judei officia judicandi vel puniendi exercere non presumant». Archivo Municipal de Barcelona, Llibre vert, I, fo. 79 .

26 Véase J.L. SHNEIDMAN, «Jews as Royal Bailiffs in XIIIth Century Aragón», Historia Judaica XIX (1957), p. 66. 
servicios de oficiales judíos en los mismos terrenos que antes aunque sin darles el título de baile. En este periodo de transición, los judíos continuaron empleados en la corte hasta que Jaime II cambió su política judía. Lo que es más, los judíos, que seguían siendo propiedad del rey, constituían todavía un elemento valioso. Quedaban varios campos - por ejemplo la medicina y la ciencia así como las finanzas y el sistema tributario- en los que los judíos descollaron hasta el punto de que ni siquiera la nobleza, la Iglesia o la burguesía pudieron prescindir de ellos. Por lo tanto, no es de sorprender que, en momentos en que monarcas de otros países cristianos estaban expulsando a los judíos de sus tierras, los reyes aragoneses recibieran a los refugiados con los brazos abiertos ${ }^{27}$. A la caída de los cortesanos y oficiales judíos de Pedro III no le siguió una decadencia económica de las comunidades judías ni la ausencia de oficiales judíos de la corte anuló la importancia de las comunidades, ya fuera ésta real o imaginaria ${ }^{28}$. El propio rey expresó en varias ocasiones la estima en que los tenía.

\section{LOS OFICIALES JUDIOOS DESPUÉS DE 1283}

En el periodo de transición que va de 1283 a 1291, varios judíos cumplieron misiones políticas y económicas. Entre ellos encontramos a Mossé Ravaya ${ }^{29}$, Muça de Portella ${ }^{30}$, sus hermanos Abraham, Salamón e Ismael y a Aharón ibn Yahia ${ }^{31}$. En esos años, sobresale particularmente la labor de diplomáticos judíos al servicio del rey-conde. Las misiones de estos diplomáticos a tierras musulmanas fueron muy apreciadas. Se les confiaron por su conocimiento del árabe, porque eran expertos en asuntos de los países islámicos en general y porque estaban al corriente de la situación en los reinos musulmanes de España y de África del Norte. Mencionemos entre otros a Abraham ibn Gallel, enviado de Pedro III a Granada en 1280 y $1284^{32}$ que también cumplió misiones diplomáticas para Alfonso III en Marruecos, Tlemecén y Granada ${ }^{33}$; a Vidal de Porta, enviado a Marruecos en $1286^{34}$ y a Samuel Alfaquim, que llevó a cabo misiones diplomáticas en Marruecos y Granada en varias ocasiones ${ }^{35}$. Estos embajado-

27 Y. ASSIS, "Juifs de France réfugiés en Aragón (XIllè-XIVè siècles)», Revue des Etudes Juives CXLII (1983), pp. 209-227.

28 Y. ASSIS, «Los judíos de la Corona de Aragón y sus dominios», El Legado de Sefarad, ed. H. Beinart, I, Jerusalem, 1992, pp. 95-100.

29 ROMANO, «Los funcionarios judíos», pp. 32-33.

30 ROMANO, «Los funcionarios judíos», pp. 33-35; ACA, Reg. 71, fo. 149v [=Régné 1129]; Reg. 58 , fo. 58 , fo. [=Régné 1389 ].

31 ROMANO, "Los funcionarios judios», pp. 35-36; ACA, Reg. 43, fo. 90v [=Régné 1248]; Reg. 57, fos. 144, 188 [=Régné 1397, 1442]; Reg. 57, fo. 222v [=Régné 1457 =MARTíNEZ FERRANDO, Catálogo, II, no. 2298].

32 ACA, Reg. 48, fo. 83v [=A. GIMÉNEZ SOLER, «La Corona de Aragón y Granada», BABLB III (1905-6), pp. 113-114 =Régné 810 \& doc. XII =MARTíNEZ FERRANDO, Catálogo, II, no. 1107].

33 ACA, Reg. 64, fo. [=Régné 1701]; DUFOURCQ, L'Espagne catalane, pp. 211-213, 217.

34 DUFOURCQ, L'Espagne catalane, p. 213.

35 ACA, Reg. 47, fo. 41; DUFOURCQ, L'Espagne catalane, pp. 225-227. 
res tuvieron una influencia en la formación de la política exterior de la Corona con respecto a sus vecinos musulmanes ${ }^{36}$.

Tanto el rey como su familia, siguieron utilizando los servicios de médicos judíos incluso después de 1283. Samuel ibn Menasse, que fue nombrado médico de Pedro III en 1279, continuó en ese cargo hasta octubre de $1285^{37}$. Bondavid Bonsenyor fue médico del infante a partir de $1284^{38}$. En 1287, el médico del infante era un judío llamado Josef ${ }^{39}$. Samue $\left.\right|^{40}$ y Josef de Orta (o Huert) ${ }^{41}$, fueron médicos de Alfonso III.

A finales del siglo 13, tomó cuerpo una nueva política judía. Incluía elementos antiguos y principios nuevos y quedaría en vigor hasta 1391. En general, se mantenían los privilegios existentes pero el cortesano judío no representaba la posición de los judíos en la Corona de Aragón. El cortesano no desapareció totalmente, pero quedó al margen. A partir de entonces fue la aljama la responsable del destino de sus miembros. Esto produjo un cambio enorme en la vida judía en los territorios de la Corona de Aragón. La autoridad de la aljama se hizo más extensiva y por primera vez judíos de las clases inferiores tomaron parte en su administración. Paradójicamente el declive de los cortesanos judíos que habían determinado el carácter del judaísmo catalanoaragonés-valenciano hasta 1283, aumentó el prestigio de la aljama. Los cortesanos judíos que habían sido hasta entonces los dirigentes naturales de la aljama, recibieron un duro golpe y cedieron el lugar a una nueva administración que incluía representantes de las clases inferiores. Esto provocó cambios de largo alcance en la dirección de la aljama como protectora de sus miembros. Este reforzamiento venía a compensar la pérdida del apoyo que previamente le habían proporcionado sus miembros eminentes, quienes la habían representado con éxito y de manera honorable en su calidad de representantes sin nombramiento formal. Simultáneamente, al subir los estratos inferiores - que contribuyeron también a transformar la aljama en el eje de la actividad judía a finales del siglo 13 y principios del 14-judíos capaces y ambiciosos, a quienes a partir de 1283 había quedado vedado el acceso al poder político, volcaron ahora su atención a los asuntos comunitarios. De esa forma, en la vida de los judíos de la Corona de Aragón tuvieron lugar cambios importantes que eran consecuencia de un proceso que se había iniciado en 1283 y que terminó durante el reinado de Jaime II.

36 ASSIS, «Diplomáticos judíos», pp. 11-34.

37 ACA, Reg. 43, fo. 129v [=D. ROMANO, «Los hermanos Abenmenassé al servicio de Pedro el Grande de Aragón", Homenaje a Millás Vallicrosa, II, Barcelona, 1956, doc. I]; Reg. 46, fo. 178v [=Régné 1117].

38 ROMANO, "Los hermanos Abenmenassé», p. 36; ACA, Reg. 62, fo. 109.

39 ACA, Reg. 71, fo. [=Régné 1747].

40 ACA, Reg. 70, fo. 190v [=Régné 1774].

41 ACA, Reg. 75, fos. 28v, $33 v$ [=Régné 1780, 180405]; Reg. 74, fo. 43 [=Régné 1843-4]. Sobre médicos judíos en la Corona de Aragón, véase Y. ASSIS, «Jewish Physicians and Medicine in Medieval Spain", Medicine and Medical Ethics in Medieval and Early Modern Spain, an Intercultural Approach, ed. S.S. Kottek and L. García-Ballester, Jerusalem, 1996, pp. 33-49. 


\section{JAIME II Y LA ALJAMA JUDÍA}

El rey Jaime Il reforzó la aljama como alternativa a los cortesanos porque era consciente de la necesidad de garantizar la seguridad y la existencia misma de los judíos que seguían constituyendo una fuente de ingresos nada despreciable para el tesoro real. Uno de las primeras medidas que tomó el rey a su retorno de Sicilia fue la de iniciar la confirmación de los privilegios de las aljamas, proceso que se prolongaría a lo largo de todo su reinado ${ }^{42}$. Esto se hizo, a petición de las aljamas, por medio de representantes destacados ante la corte y costó a los judíos fuertes sumas de dine$\mathrm{ro}^{43}$. Los privilegios que otorgó Jaime II demuestran el interés del rey por reforzar la autoridad de la aljama. En general, su política consistía en soslayar cualquier prejuicio a la posición de la aljamas y facilitar la existencia de una vida comunitaria acorde con las necesidades de la sociedad judía ${ }^{44}$.

En Elche y Orihuela, al sur de Valencia, territorio conquistado por Jaime II, se volvieron a tomar medidas para renovar el asentamiento de judíos a pequeña escala y el monarca adoptó respecto a ellos la misma política colonizadora que se había seguido en el pasado ${ }^{45}$. También los infantes estimularon a los judíos a radicarse en sus tierras ofreciéndoles amplia autonomía, el derecho para observar los preceptos judíos y condiciones económicas favorables ${ }^{46}$. Esta política judía, que se seguiría hasta 1391, se basaba ante todo en consideraciones económicas. En 1306, cuando las comunidades judías de Europa occidental estaban en proceso de decadencia y extinción, los judíos de la Península Ibérica todavía gozaban del favor de los reyes. De hecho, Jaime II permitió a los exiliados judíos de Francia que se radicaran en su reino y sus motivos eran claramente económicos ${ }^{47}$. El rey seguía contando con el capital judío para sufragar sus empresas. Pidió prestado dinero a judíos para la campaña de Almería en 1309 y recibió de ellos enormes cantidades para adquirir Urgel en 1322. Durante las preparaciones para la campaña de Cerdeña, el rey pidió a los judíos de su reino que contribuyeran con la suma de 500.000 sueldos, que era casi el equivalente de la contribución total de Cataluña entera. Lo que es más, a todos los que participaron en la guerra contra Cerdeña se les concedió una moratoria en las deudas que tenían contraídas con los judíos ${ }^{48}$.

42 ACA, Reg. 191, fos. 27v [=Régné 2392, 2401]; Reg. 192, fos. 54v, 74 [=Régné 2422, 2429]; Reg. 100, fo. 187 [=BAER, Die Juden, doc. 137 = Régné 2629]; Reg. 197, fo. 19v [=BAER, Die Juden, doc. 142 =Régné 2720].

43 ACA, Reg. 192, fo. 74 [=Régné 2429].

44 ACA, Reg. 194, fo. 266 [=Régné 2623]; Reg. 196, fo. 151v [=Régné 2688]; Reg. 212, fo. 145 [=Régné 3037]; Reg. 226, fo. 137v [=Régné 3328].

45 ACA, Reg. 212, fo. 145 [=Régné 3037].

46 ACA, Reg. 383, fos. 40-42 [=BAER, Die Juden, doc. 175].

47 ASSIS, “Juifs de France», pp. 285-322.

48 Sobre Almería véase A. GIMÉNEZ SOLER, El sitio de Almería en 1309, Barcelona, 1904, pp. 90-92; sobre Sardinia, véase A. ARRIBAS I PALA, La conquista de Cerdeña por Jaime I/ de Aragón, Barcelona, 1952, pp. 183-184; J.N. HILLGARTH, The Spanish Kingdoms 1250-1416, Oxford, 1976, p. 240; Y. ASSIS, «Jewish Capital and the Conquest of Sardinia by the Catalans», Italia IX (1990), pp. 7-18. 
Jaime II mantuvo una estrecha relación con eruditos y médicos judíos y estos últimos lo trataron a él y a su familia. Se interesó también por las obras científicas y literarias de los judíos y les encargó la redacción de libros en estos campos del saber. Durante la persecución de los pastoureaux en 1320, tomó medidas para evitar que se extendieran contra los judíos tumultos y ataques como la matanza que tuvo lugar en la comunidad de Montclús ${ }^{49}$.

Jaime II se involucró más en la vida interna de la comunidad y sus actividades cotidianas, que ninguno de sus predecesores. A pesar de ello, se cuidó de no recortar demasiado la autonomía judía. Convenía a sus intereses dejar en manos de la comunidad judía el suficiente poder como para que pudiera cumplir las tareas y obligaciones que tenía contraídas con la Corona. La autonomía judía siguió siendo una condición natural dentro de la estructura de la sociedad medieval y los judíos de los territorios de la Corona de Aragón, con sus normas, leyes, costumbres, idiomas e instituciones distintas de las del resto de la sociedad, estaban todavía más separados de esta última que en ninguna otra parte del mundo medieval. Por eso, cuando el rey sostenía que tenía derecho exclusivo sobre los judíos, su afirmación era más cierta en la Corona de Aragón que en ningún otro país de la Europa cristiana. Jaime ll se opuso a los repetidos intentos de la Iglesia y de la Inquisición de extender sus respectivas jurisdicciones a los judíos, argumentando que "cum non sint de fide seu lege catolica et si in aliquo excesserint contra legem, sint per nos puniendi $»^{50}$. En las circunstancias que acabamos de mencionar, el que Jaime II se inmiscuyera en la autonomía judía apoyando simultáneamente el poder de la comunidad, no resulta tan contradictorio como pudiera parecer a simple vista.

Jaime II jugó un papel muy importante en los cambios que se produjeron en el sistema de gobierno y el liderazgo de la comunidad judía. Interfirió en numerosas ocasiones tanto en el nombramiento como en el despido de dirigentes y funcionarios judíos $^{51}$. Al igual que sus predecesores, Jaime II recompensó a algunos de sus favoritos judíos a expensas de la comunidad, sin tomar en consideración los derechos autonómicos de esta última. El hecho de que diera su apoyo a ciertos judíos individuales que estaban enfrentados con la comunidad, tuvo asimismo un efecto negativo en la autonomía judía ${ }^{52}$. La inmiscusión del rey en los asuntos de la comunidad, solía

49 J. MIRETY SANS, “Le massacre des Juifs de Montclús», Revue des Etudes Juives LIII (1907), pp. 255-266.

50 ACA, Reg. 92, fo. 144 [=BAER, Die Juden, doc. 133]; cf. S. GRAYZEL, «Popes, Jews and Inquisition", A.I. KATSCH and L. NEMOY (ed.), Essays on the Occasion of the Senetieth Anniversary of the Dropsie University (1909-1979), Philadelphia, 1979, pp. 181-182.

51 ACA, Cartas Reales [=CR], Jaime II, Caja 134, no. 198 [=M CINTA MAÑE (ed.), The Jews in the Crown of Aragón, Regesta of the Cartas Reales in the Archivo de la Corona de Aragón, Part I: 10661327, Sources for the History of the Jews in Spain 4, Yom Tov Assis (ed.), no. 408]; Caja 133, no. 343.

52 ACA, Reg. CR, Jaime II, Caja 49, no. 6040 [=CINTA, The Jews in the Crown of Aragón, no. 204]; Caja 133, no. 116 [=CINTA, The Jews in the Crown of Aragón, no. 337]; Caja 43, no. 5331 [=CINTA, The Jews in the Crown of Aragón, no. 188]; Caja 14, no. 1828 [=CINTA, The Jews in the Crown of Aragón, no. 99]; Caja 133, no. 23 [=CINTA, The Jews in the Crown of Aragón, no. 246]; Caja 134, nos. 196, 207 [=CINTA, The Jews in the Crown of Aragón, nos. 407, 416]. 
tener relación con los impuestos. Su intervención no pudo por menos de restringir la autonomía de la comunidad, cuyo prestigio sufrió también del apoyo que el rey prestaba a ciertos contribuyentes individuales a su costa. En ocasiones, la comunidad sufrió severas humillaciones y las medidas que contra ella tomó el monarca, como cerrar las puertas de la judería o hacer detener a sus dirigentes, supusieron un duro golpe a sus derechos ${ }^{53}$. Las excepciones y reducciones fiscales que el monarca concedió a ciertos judíos que normalmente pertenecían a las capas adineradas, no sólo constituian una carga económica, sino también una violación de la jurisdicción comunitaria ${ }^{54}$. La medida de Jaime Il que tuvo un mayor impacto sobre la vida judía fue, sin embargo, la reforma que cambió el régimen interno de las aljamas.

\section{LA LUCHA DE LAS CLASES INFERIORES POR EL PODER}

El malestar social en el seno de las comunidades judías, que había comenzado en Aragón ya durante el reinado de Jaime I, se extendió por toda la Corona. Las reformas que se hicieron en el régimen interno de las aljamas para permitir a los judíos más pobres participar en la administración, no siempre fueron duraderas porque los ricos no escatimaron esfuerzos para expulsar a los representantes de los pobres de los cargos recientemente obtenidos. A pesar de que las familias de la aristocracia judía lograron recuperar una parte del poder que habían perdido, las clases más pobres, que seguían reivindicando sus quejas, no cejaron en su empeño de conseguir una participación en el gobierno comunitario. Su campaña corría pareja con la insatisfacción que su exclusión de los cargos de poder en los municipios, causaba a las clases clases inferiores de la sociedad circundante y no hay duda de que estaba inspirada por ella. La lucha de las clases baja y media judías, dio fruto a partir de principios del siglo 14 cuando la demanda de reformas constitucionales e institucionales se expandió rápidamente. Antes de que esas reformas se produjeran, las relaciones entre las familias más antiguas y adineradas que controlaban la quehilah por una parte y la nueva clase media que se estaba formando junto con los judíos más pobres por otra, era muy tensa y se caracterizaba por las sospechas y la desconfianza mutuas. Jaime II, sin cuya ayuda las clases inferiores nunca habrían podido conseguir ninguna de sus aspiraciones, prestó un apoyo moderado a sus reivindicaciones en una política que estaba dictada por una evaluación pragmática del descontento y de sus consecuencias potenciales.

53 ACA, Reg. 197, fos. 153v-154 [=Régné 2745 =BAER, Die Juden, doc. 146]; Reg. 239, fos. 18v19 [=BAER, Die Juden, doc. 164]; ACA, CR, Jaime II, Caja 134, no. 249 [=CINTA, The Jews in the Crown of Aragón, no. 468]; Caja 10, no. 249 [=CINTA, The Jews in the Crown of Aragón, no. 468]; Caja 10, no. 249 [=CINTA, The Jews in the Crown of Aragón, no. 1328]; Caja 2, no. 420; ACA, Reg. 229, fos. 260v-261, 274v-275 [=Régné 3432, 3436]; Reg. 211, fo. 337v [=Régné 3020].

54 ACA, CR, Jaime II, Caja 35, no. 4423 [=CINTA, The Jews in the Crown of Aragón, no. 153]; Caja 67, no. 8272 [=CINTA, The Jews in the Crown of Aragón, no. 344]; Caja, 80, no. 9731 [=CINTA, The Jews in the Crown of Aragón, no. 472]; Caja 39, no. 4847; Caja 99, no. 12364 [=CINTA, The Jews in the Crown of Aragón, no. 486]; Caja 134, no. 207 [=CINTA, The Jews in the Crown of Aragón, no. 416]; Caja 23, no. 2956; Caja 133, no. 66 [=CINTA, The Jews in the Crown of Aragón, no. 297]; Caja 134, nos. 206, 252 [=CINTA, The Jews in the Crown of Aragón, nos. 415, 471]. 
Entre la élite dirigente y las clases inferiores de Valencia, donde en una fecha tan tardía como 1297 todavía los dirigentes se elegían exclusivamente de las clases altas, reinaba un abierto antagonismo $0^{55}$. Tres años más tarde, durante el reparto de los impuestos reales y comunitarios entre los miembros, los representantes de las clases inferiores se quejaron al rey de que los ricos los oprimían y perjudicaban de distintas maneras. En respuesta, el rey decidió cambiar el sistema impositivo y la estructura del cuerpo encargado de la recaudación de los impuestos. A partir de entonces, la comisión ante la que cada contribuyente tenía que prestar juramento, incluiría un miembro de cada una de las tres clases. Estas tres personas serían elegidas por un concilium de doce miembros compuesto de cuatro representantes de cada clase. Ese mismo concilium o 'eza, junto con los berurim cuya cadencia terminaba, sería el encargado de nombrar a los nuevos berurim ${ }^{56}$. Algo más tarde, se decidió que los berurim salientes no podrían ser reelegidos en los tres años siguientes.

El viejo régimen, que se basaba sobre todo en privilegios que permitían a los oligarcas perpetuar su detentación del poder, no se abolió. La prohibición de elegir berurim a los familiares de los que ya lo eran, supuso asimismo un paso importante. La constitución de 1300 no terminó con las rivalidades y la agitación que reinaban entre los distintos grupos de la aljama de Valencia; pero, aunque fueron necesarias reiteradas intervenciones del monarca, el principio de que las tres clases tenían que estar representadas en todas las instituciones comunitarias, siguió constituyendo un rasgo permanente en la vida de la comunidad ${ }^{57}$.

Lo que sucedió en Valencia forma parte de una fase de agitación general y sentó un precedente que sería seguido por otras comunidades. En la vecina Murviedro el rey intentó poner fin a una larga serie de conflictos decidiendo que se formara un colegio electoral compuesto de seis miembros, dos de cada clase, que sería el encargado de elegir a todos los dirigentes cada dos años ${ }^{58}$. También en diversas comunidades aragonesas se produjeron cambios parecidos. En Huesca ${ }^{59}$, Barbastro ${ }^{60}$, Teruel ${ }^{61}$ y Calatayud $^{62}$, la oposición de las clases más pobres terminó con las oligarquías diri-

55 ACA, Reg. 195, fo. 46 [=Régné 2661].

56 Según las clases inferiores «maiores judei et diviciis opulanti mediocres et minores in eis diversimode agravant et molestant ": ACA, Reg. 197, fos. 153v-154 [=Régné 27745 =BAER, Die Juden, doc. 146].

57 ACA, Reg. 214, fo. 23 [=Régné 3064]; Reg. 229, fo. 274 [=Régné 3434 =BAER, Die Juden, no. $188]$.

58 ACA, Reg. 230, fo. 59 [=Régné 3442].

59 ACA, Reg. 210, fo. 79 [=Régné 2976]; Reg. 225, fo. 280v [=Régné 3299]; R. DEL ARCO, «La aljama judaica de Huesca», Sefarad VIl (1947), pp. 271-301.

60 ACA, Reg. 210, fos. 86-87 [=Régné 2977]; Reg. 229, fos. 177v-178 [=Régné 3404].

61 BAER, Die Juden, doc. 163.

62 Véase la carta enviada por los pobres de Calatayud al rey, ACA, CR, Jaime II, Caja 135, no. 411: «a la vuestra alteça claman merçe, senor, los judios de la mano menuda de Calatayud que sea vuestra merçe que.done... dar una comision general para don Domenge de Tarba que conozca de todos los aferes que son entre nos e los judios mayores porque toda verdat y pueda seyer sabida, senor, e vuestros derechos sean salvos e nos non seamos... enganosament". 
gentes y se abolió su derecho a nombrar a sus propios sucesores en los cargos. La actitud positiva del rey, que estaba dictada por su realismo y pragmatismo políticos, posibilitó los cambios: en todos y cada uno de los casos, los representantes de las clases inferiores se dirigieron a él en demanda de ayuda. A pesar de las fluctuaciones, el logro más importante en este terreno de las clases media y baja, es decir, su derecho a compartir la administración comunitaria eligiendo representantes propios, se mantuvo en muchas comunidades. Pero quedaron vestigios de los privilegios de las familias ricas, y éstos supusieron una continua fuente de disensión en varias comunidades aragonesas ${ }^{63}$.

Las aljamas catalanas no quedaron inmunes al desasosiego social que caracterizó la vida de las comunidades valenciana y aragonesa. En el condado, los cambios más radicales en el sistema de gobierno comunitario se produjeron en 1308 en Lérida donde, en un primer momento, las clases alta y media llegaron a un acuerdo para repartirse entre ellas la administración de la qehilah, dejando fuera a la clase baja. Esta última intensificó su lucha y obtuvo de Jaime II que apoyara las reformas de 1315 que la incluían en el liderazgo comunitario ${ }^{64}$. La medida por la que oficiales que terminaban su cadencia no eran reelegibles en los tres años siguientes, que había sido adoptada para romper el monopolio de la clase alta, causó dificultades en esa comunidad como en todas las demás. Como cada clase estaba representada por el mismo número de personas fuera cual fuese su peso demográfico, a la clase alta no le resultaba fácil proporcionar tantos candidatos. Se intentó solucionar el problema respetando el marco del nuevo principio adoptado, pero el intento falló haciendo fracasar todo el sistema. Todos los esfuerzos por mantener la representación equitativa resultaron infructuosos. Pero la exclusión de las clases inferiores de los cuerpos gobernantes de la comunidad de Lérida después de haber participado en ellos, hay que verla como una excepción a la tendencia general ${ }^{65}$.

Durante el reinado de Jaime II, el régimen comunitario se estabilizó y permaneció casi intacto hasta la víspera de las matanzas de 1391. En muchos aspectos, el reinado de este monarca supuso un cambio decisivo en la historia de los judíos de la Corona de Aragón. Fue en este período cuando el centro de gravedad de la vida judía pasó de los cortesanos judíos a la aljama. El poder y los logros de esta última alcanzaron entonces su punto culminante. No es casualidad que el halajista más grande de la Corona de Aragón y, de hecho, de toda la península, Rabí Shelomo ben Adret, fuera también dirigente del judaísmo catalano-aragonés en la época de Jaime II. El rey mostró gran aprecio por Adret consultándole en diversas ocasiones y el rabino, por su parte, contribuyó en muy buena medida a la organización de la comunidad judía. La vida cultural y religiosa de los judíos de la Corona de Aragón, alcanzó en este reinado sus más altas cimas.

63 ACA, Reg. 227, fo. 191v [=Régné 3333]; Reg. 218, fos. 92v-93 [=Régné 3135 =BAER, Die Juden, doc. 174].

64 Yom Tov ASIBILI, Šeelot u-Tešuvot (Responsa), ed. Y. Kapah, Jerusalem, 1959, no. 114; ACA, Reg. 212, fos. 30v-31 [=Régné 3026]; Reg. 216, fo. 83 [=Régné 3095].

65 ACA, Reg. 216, fos. 84v, 122v-123 [=Régné 3097, 3106]. 


\title{
LA POBLACIÓN DE LORCA EN LA ÉPOCA DE JAIME II. APROXIMACIÓN A SU ESTUDIO
}

\author{
Francisco de Asís VEAS ARTESEROS \\ Universidad de Murcia
}

Los años finales del Siglo XIII y los iniciales del XIV no pueden ser motivo de muchas alegrías para Castilla en donde el desastroso epílogo del reinado de Alfonso $\mathrm{X}$, el mandato de Sancho IV, lleno de condicionamientos que ataron las manos del rey hasta que la enfermedad lo hizo desaparecer, y la minoría de Fernando IV en la que la marea nobiliaria golpeaba las bases del poder monárquico que defendía a ultranza doña María de Molina, eran causa más que suficiente para el desaliento de una población, la de las ciudades, villas y lugares que, si bien es cierto que no entendían de cuestiones de alta política, si tenían la suficiente percepción como para darse cuenta del tinglado que se estaba desarrollando a su alrededor y cuyas consecuencias muchas veces padecian en sus carnes aunque no participasen activamente en ello. Varios años de guerra civil y banderías nobiliarias, guiadas la mayoría de las veces por el sólo deseo de hacer daño en los territorios rivales, dejaban sus secuelas en los campos destruidos, aldeas desoladas y familias diezmadas, bien por las heridas de las armas o por aquellas, menos curables todavía, que ocasionaba el hambre propiciada por la falta de alimentos y las enfermedades que solían acompañar a este tipo de carencias.

Y si eso sucedía en Castilla, en el Reino de Murcia la situación no era mucho mejor pues, a pesar de su alejamiento de los núcleos de poder, también aquí se dejaba sentir la anarquía manifestada, por citar un ejemplo, en la falta de organización defensiva en la frontera granadina, donde la escasez de medios y el desánimo abrieron paso al abandono de la vigilancia militar y a la pérdida del espíritu que llevó a los castellanos casi hasta las mismas puertas de Granada apenas hacia 60 años. Con respecto a Aragón, una frontera entre cristianos y siempre abierta que no separaba dos mundos diferentes en cuanto a raza y religión como sucedía en la granadina, la situación se 
tornó dramática cuando Jaime II, aprovechando las reclamaciones de Alfonso de la Cerda al tambaleante trono en el que estaba sentado Fernando IV, decidió hacer realidad el nunca bien oculto anhelo de rectificar los errores cometidos por Jaime I cuando estampó su sello en los documentos de Almizra y cerró para Aragón la posibilidad de participar en la lucha contra los musulmanes, mediante la invasión del Reino de Murcia que le había donado el nieto de Alfonso X.

En Lorca también se notaron los efectos de una crisis que llegaba a los más lejanos rincones. Ya habían pasado los esperanzadores años en los que Alfonso $X$ se volcó sobre la población y la colmó de mercedes, franquicias, privilegios y donaciones de todo tipo, en atención a la estratégica situación fronteriza de la plaza, y ahora se imponía una realidad muy diferente que echaba por tierra las ilusiones de casi todos. Por una parte, la frontera estaba desguarnecida y los granadinos realizarán profundas incursiones contra las que nada salvo huir se podía hacer, y eso con mucha suerte; por otra, consecuencia de la primera, se produjo una reducción de la superficie cultivada, que se manifestó en una merma de la actividad vinculada al trabajo de la tierra ${ }^{1}$, pues al socaire del clima bélico «no senbravan ni aravan cosa ninguna »², afirmación del murciano Manuel de Arróniz que refleja bien a las claras la situación existente en la zona fronteriza con Granada, donde el temor de un ataque, siempre imprevisto e impredecible, obligaba a la adopción de drásticas medidas de seguridad y, sin duda, la mejor era no salir ni aventurarse para realizar unos trabajos agrícolas en unos campos muy alejados de la sombra protectora de las murallas.

Pero no es solamente eso, sino que al peligro granadino se unen una amplia variedad de factores negativos como las plagas de langosta y las oscilaciones climáticas plasmadas en sequías e inundaciones que tuvieron presencia continuada lo largo de la Baja Edad Media, ocasionando un grave perjuicio a las cosechas y también a las maltrechas economías de los agricultores quienes, en período de sequía, veían como se disparaba el precio del agua para riego, como sucedía en el Siglo XV en el que, en efecto, la comarca lorquina seguía siendo «tierra que llueve poco e tarde e acostunbra llover poco, que por las pocas aguas questa dicha çibdad tiene corrientes e por el poco llouer, que muchos años vale vn hilo de agua para regar con el vn solo dia quinientos e ochoçientos e mil maravedis" ${ }^{3}$. La escasez de agua alcanzaba su punto

1 TORRES FONTES, J. y TORRES SUÁREZ, C., "El campo de Lorca en la primera mitad del Siglo XIV», Miscelánea Medieval Murciana, XI. Murcia, 1984; p. 160.

2 A.M.L. Pleito de Xiquena, fol. 86v.

3 Ibid., fol. 39v. La reiteración en las adversas condiciones climáticas no es más que una ratificación del agobiante problema que plantean, no sólo a nivel de Lorca y su comarca, porque todo el Reino de Murcia es zona "que muy raro y tarde llueva, segund que esto es muy vulgar en toda Castilla, que en este Reyno de Murçia llueue muy poco e tarde». El agua, a lo largo de la Edad Media y todavía hoy, es fundamental para el desarrollo de la población y de la agricultura lorquinas antes y después de la conquista castellana, pues su escasez provocaría una emigración y un abandono de los campos que, faltos de riego, quedarían incultos y yermos, tal y como señala Juan Avellán, procurador de Lorca en el contencioso que la ciudad mantenía con el marqués de Villena sobre la posesión de Xiquena, ya que si «vn solo arroyo de los dichos arroyos le fallesçiese no podria ser de mas vezindad de 
culminante en el estío, cuando se sufrían las temperaturas extremas y las corrientes fluviales terminaban por desaparecer, ocasionando no sólo la pérdida de las cosechas de aquellos productos para los que el riego era vital, sino también problemas para el buen funcionamiento de los nueve molinos con dieciocho ruedas y los dos o tres batanes que estaban en los márgenes del río, de manera que «por las aguas pocas corrientes questa dicha çibdad tiene, los mas de los veranos van a moler los vezinos e moradores desta çibdad a Murçia e a Caravaca»"4.

Causas naturales y humanas que traen consigo una escasez de perspectivas y un horizonte sombrío, desencadenarán una emigración de los repobladores asentados en los sucesivos repartimientos decretados por Alfonso $\mathrm{X}$ y afectarán a la población de la ciudad de Lorca cuya evolución demográfica en los años de tránsito del Siglo XIII al XIV y en la Edad Media en general constituye el objeto del presente estudio, aunque he de apresurarme a decir que es imposible de precisar con exactitud, un objetivo inalcanzable, ya que la falta de documentos que permitan reconstruir totalmente la secuencia poblacional no conduce a otro camino que la aproximación, siempre incompleta, pero acaso útil para dar una idea, aunque fuere muy parcial, de lo que debió ser la realidad.

quatroçientos o quinientos vezinos". Ibid., fol. 22. Alfonso X se da cuenta de ello y, para complementar las aguas del Guadalentín y con ellas el regadío, concede, en 1269, al concejo de Lorca la Fuente del Oro, para que su agua se haga circular por las acequias. TORRES FONTES, J., Repartimiento de Lorca. Murcia, 1994; p. 52.

4 Ibid., fol. 29 y $39 \mathrm{v}$. El traslado a la capital del Reino para realizar la molienda podía estar justificado porque el Segura, pese a estar también afectado por el estiaje, llevaría más caudal que el Guadalentín pues el aporte de sus afluentes es mayor. En cuanto a Caravaca hay que señalar que el agua era más abundante, como lo prueba el hecho de que toda la lana que se producía en Lorca se llevaba a lavar a la sede de la encomienda santiaguista, que era el único lugar en donde había lavaderos de lana que requerían un caudaloso aporte y, por eso mismo, también había molinos en los que los lorquinos podían realizar su molienda. Se trata del agua de las Fuentes de Archivel, situadas en las estribaciones meridionales de la Sierra de Taibilla, hoy término de Caravaca, con las que se proyecto realizar un trasvase hasta Lorca, en donde "La notoria escasez de agua y las necesidades públicas parece que obligaron, en el reinado de Enrique $2^{\circ}$, a pensar en el aumento del pequeño río de esta ciudad". Las obras se iniciaron y por medio de minas, como trabajos preparatorios de captación, se intentó conducir las aguas de las las copiosas fuentes de Caravaca, pero el trabajo se realizó mientras pudieron sostenerlo los lorquinos y una vez agotado el dinero pidieron ayuda a Enrique II, quien contestó que «lo haría luego que se desocupara de la guerra que tenía con los Moros". No llegó la merced del rey y el proyecto se abandonó. Sería tomado de nuevo en 1500 y abandonado más tarde debido, entre otras causas, a la ingente obra que se había de realizar con escasos medios económicos y materiales y también a la tremenda sequía de 1537, que afectó hasta a las mismísimas Fuentes de Archivel. MUSSO Y FONTES, J., Historia de los riegos de Lorca. De los ríos Castril y Guardal o del Canal de Murcia y de los Ojos de Archivel. Murcia, 1847; p. 217. CAPEL SÁEZ, H., Lorca, capital subregional. Lorca, 1969; p. 43. GIL OLCINA, A., El Campo de Lorca. Estudio de Geografía Agraria. Valencia, $1971 ;$ p. 87. 


\section{LORCA 1266-1272. LOS INICIOS DEL POBLAMIENTO CRISTIANO}

La ambiciosa política repobladora de Alfonso $\mathrm{X}$, tendente a establecer en la demarcación lorquina el suficiente y necesario número de pobladores capaz de garantizar la defensa de la frontera y con ella la seguridad del territorio y, también, la continuidad en el cultivo de huertas y campos dejados por los musulmanes emigrados a Granada en los momentos inmediatos al establecimiento del protectorado que emana del pacto de Alcaraz, primero, y de la ocupación, tras la derrota de 1266, después, tiene dos fases claramente diferenciadas y marcadas, una, por los años anteriores a la rebelión mudéjar y, otra, la evolución posterior al fracaso de la revuelta.

La primera etapa de la presencia castellana en Lorca, desde 1244 a 1266, se encuentra muy condicionada por el respeto exacto que don Alfonso, primero como infante y más tarde como rey, impuso respecto a los compromisos adquiridos con los habitantes islámicos de la ciudad, cuyo número no debía ser pequeño si nos atenemos a que Lorca «paresçe syenpre ser de grand vezindad de mayor de dos mil vezinos e al tienpo de los moros de muy mayor vezindad» 5 . Tal afirmación, realizada por Juan Avellán, procurador de Lorca en el litigio que el concejo lorquino mantenía con Diego López Pacheco, marqués de Villena, en 1493, resulta sorprendente, pues, si se aplica el coeficiente 4'5, generalmente usado para el Reino de Murcia, tendremos que se está hablando de 9.000 habitantes - 2.000 vecinos-o más para la fase islámica de Lorca, cifra muy importante y que no parece ajustada a la realidad, aunque la falta de datos imposibilita su cotejo.

Ciertamente, las menciones de Lorca en etapas anteriores a 1243 coinciden en señalar la riqueza y población de la misma. Así al-Ya'qubi la destaca como una de las dos ciudades más importantes de la Región de Tudmir, que contaba con una mezquita mayor y con una numerosa comunidad musulmana ${ }^{6}$. La importancia de sus defensas y la calidad de sus cultivos impresionaba a cualquier viajero como sucedió con alHinyari quien, en el Siglo XII, pasó por esta ciudad y exclama que «nunca vi nada más hermoso que su llanura ni nada más espléndido que su río y los huertos que están en sus riberas. Por lo que respecta a la inexpugnabilidad de su fortaleza, baste decir que ello es tan notorio y conocido que se ha hecho proverbial» ${ }^{7}$. Estas noticias y otras

\section{A.M.L. Pleito de Xiquena, fol. 37v.}

6 Se trata del texto más antiguo que ha llegado hasta nosotros en el que se menciona Lorca. CARMONA GONZÁLEZ, A., «Recorrido por la geografía histórica de la Murcia islámica». En Guía Islámica de la Región de Murcia. Murcia, 1990; p. 18.

7 Descripción recogida por Ibn Sa'id al-Magribi, autor del Siglo XIII. CARMONA GONZÁLEZ, A., «Noticias geográficas árabes referentes al Bilad Tudmir». En Murgetana, 72. Murcia, 1987; pp. 116" 118. Quién más extensamente habla de Lorca es al-Udri: «Información acerca del país de Tudmir: su capital es la ciudad de Lorca... El lugar conocido como al-Fundun tiene las mismas características que el Nilo, sólo se riega una vez y no necesita más... Dicho paraje, que se encuentra en el término de Lorca, tiene dos cauces de agua; si al-Fundun no necesita más riego, dejan pasar el agua por el primer cauce, pero si necesita riego hacen subir las aguas al otro cauce con represas para que se pueda regar". Posiblemente el término al-Fundun proceda del latín fundus «fundo, propiedad, finca» e incor- 
muchas sobre el particular permiten conocer las excelentes cualidades urbanas de la ciudad y la calidad de sus huertas, pero nada en lo que al número de habitantes se refiere; aunque también cabe la posibilidad de que el procurador lorquino al referirse a la población de la Lorca utilizase el término vecinos para indicar el conjunto de personas que, en efecto, habitaban la ciudad, lo cual llevaría a una cifra aceptable de 2.000/2.500 personas que serían las que conformaban la sociedad lorquina de entonces, formada por una mayoría de musulmanes y una minoría de judíos.

Sea como fuere, a partir del establecimiento del protectorado, Lorca va a recibir una nueva población castellana que no representa sino una minoría de carácter fundamentalmente militar, cuya labor esencial era la de constituir la guarnición de la fortaleza y torres. Don Alfonso prestará atención a este grupo reducido de cristianos residentes en el castillo mediante una serie de pequeños repartos de tierras que tienen como objetivo más de servir de gratificación a las guarniciones que desencadenar un crecimiento de la población ${ }^{8}$, algo por entonces muy difícil porque huertas y campos todavía eran propiedad de los musulmanes y a ningún cristiano se le iba a ocurrir salir de la fortaleza y establecerse en el valle para trabajar una tierra que no era suya.

Sin embargo, atento Alfonso $X$ a la repoblación cristiana de la plaza, tal vez pensando en un futuro no muy lejano, tomó una serie de medidas que permitiesen a los castellanos hacerse con el dominio de la tierra sin herir la susceptibilidad de los musulmanes lorquinos, recelosos de que se incumpliesen los acuerdos, dando autorización para que «los vezinos e moradores del conçejo de Lorca... ayan poder de conprar heredamientos de todo moro que uendergelo quisiere en Lorca o en todo su termino, desta guisa: el cauallero que aya poder de conprar heredamiento fasta en dozientos maravedis alfonsis e el peon fasta en çient maravedis alfonsis" ${ }^{9}$. Además de ofrecer estas facilidades para la adquisición de propiedades, el monarca también se preocupó por evitar la desaparición de tierras de cultivo, huerta o campo, que habían sido abandonadas por sus propietarios musulmanes, como sucede con el amplio real y su huerta que el arráez Almoniara poseía en Lorca, en las faldas del castillo y muy cer-

pora la desinencia del aumentativo —ún-, muy utilizada por los hispano-árabes, siendo el significado del topónimo "gran propiedad» y debía tratarse de una buena parte de la huerta de Lorca. CARMONA GONZÁLEZ, A., Recorrido...; pp. 19-20.

8 1257-III-28, Lorca. "Por sabor que he de poblar los alcaçares et la villa de Lorca de cristianos... et porque ayan mas et ualan mas, do et otorgo a todos los cristianos, vezinos et moradores en los alcaçares et en la villa de Lorca, que touieren sus casas mayores hy pobladas con sus cuerpos, todas cosas para sienpre jamas". TORRES FONTES, J., "Fueros y Privilegios de Alfonso $X$ el Sabio al Reino de Murcia», C.O.D.O.M., III. Murcia, 1973. Doc. XXXI.

9 1257-III-28, Lorca. Ibid. Doc. XXX. En función del comprador la tierra quedará como caballería o peonía, que reproducía el esquema social —caballeros, con mayor poder adquisitivo, o peones, de menores ingresos y con menor capacidad de gasto- de quienes integraban la guarnición lorquina. El rey concede plena propiedad de los bienes así adquiridos, pero impone la condición de que el heredamiento no podía ser vendido en un espacio de 10 años. 
cano a unos hornos de yeso, que otorga a Fray Pedro Gallego, obispo de Cartagena ${ }^{10}$, no debiendo ser el único caso.

En realidad estas y otras muchas concesiones del rey castellano indican que la emigración de musulmanes hacia las diversas localidades del reino granadino, cercanas o lejanas de la frontera, se había iniciado, comenzando por aquellos que estaban incómodos con la presencia castellana y tenían medios para dejarlo todo e iniciar una nueva vida en el lado islámico de la divisoria, llevando no sólo a sus propias familias sino también a las de aquellos que estaban al cuidado de sus haciendas y trabajaban sus tierras; la marcha no sería masiva pero ya comenzaba a generar bastantes huecos en la población, merma de brazos para el trabajo agrícola y abandono de unas tierras de cultivo hasta entonces productivas. Por ello, a raíz de la estancia de Alfonso $X$ en Lorca, durante el mes de Marzo de 1257, se aceleró la llegada de nuevas gentes para cubrir esas bajas, lo que se tradujo en un aumento de la población cristiana y en una serie de transformaciones en la localidad, de modo que aquella pequeña guarnición, encerrada en la fortaleza y torres, a las que pronto se sumaría la Alfonsina, sin dejar su función castrense, dio paso a una población cristiana con residencia en la ciudad, fuera ya de los muros del castillo, que no tardaría en constituir un concejo y que, por su diferencia de derechos y obligaciones, distingue a sus habitantes cristianos como vecinos y moradores, lo que es muestra del crecimiento de la población y la puesta en marcha de una organización tendente a la expansión y al dominio"1.

A partir de 1266 se produce el gran cambio, pues Alfonso $X$ no se siente ya obligado a respetar los acuerdos estipulados con los musulmanes en años anteriores, que tan grandes obstáculos habían sido para su política repobladora y, ahora, ya con las manos libres, puede dedicarse a la repoblación de Lorca, ordenando la realización, entre los años 1268 y 1270 , de una nueva partición de huertas y campos en la llanura lorquina con posibilidad de ser regadas, acompañada de numerosas donaciones a instituciones y particulares de aquellas tierras y bienes pertenecientes a los musulmanes huidos o muertos ${ }^{12}$ y de una amplia gama de concesiones ${ }^{13}$.

En efecto, en 1266, el aplastamiento definitivo de la rebelión mudéjar, que en Lorca

10 1257-III-23, Lorca. TORRES FONTES, J., «Documentos de Alfonso X el Sabio». C.O.D.O.M., I. Murcia, 1963. Doc. VII. Todas las concesiones del monarca insisten en la exigencia de que los destinatarios de las mismas residieran de continuo en Lorca para poder gozar de ellas.

11 TORRES FONTES, J., Repartimiento de Lorca; p. XLIV.

12 Así la Orden de Santiago recibe en Lorca "las casas e todo el heredamiento que fue de Abenhamet», 1266-V-21, Sevilla. TORRES FONTES, J., "Documentos...", C.O.D.O.M., I. Doc. XVI. También el Deán de la Iglesia de Cartagena recibió unas casas en Lorca, llamadas de la Peña, y tierras que habían pertenecido a los arrayanes Abenahel, así como tierras sitas en la huerta de Tirieza. TORRES FONTES, J., Repartimiento de Lorca; p. L.

13 1266-VI-7, Sevilla. Eximiendo al concejo de Lorca del pago de diezmos y portazgos de productos como trigo, higos, vino y ganados. También otros dos, otorgados en 1266-IX-9, Sevilla, por los que hacía donación a los vecinos y pobladores de Lorca de los frutos de su término y ordenando que se partiesen por caballerías y peonías, así como de todas las rentas reales de las tiendas, hornos, molinos, baños, alhóndigas, etc. al concejo para que tuviera medios suficientes para guardar la villa. TORRES FONTES, J., “Fueros...», C.O.D.O.M., III. Docs. LXXI, LXXV y LXXVI. 
había tenido un éxito parcial pues los rebeldes no consiguieron hacerse con el control de la fortaleza, presentaba una vertiente negativa plasmada en las numerosas bajas demográficas producidas en la ciudad y campo a causa de la muerte de algunos y la huida masiva de musulmanes, capitaneada por aquellos dirigentes de la revuelta que consiguieron escapar y que más tenían que perder, y seguida por un asustado ejército de familias temerosas de que el triunfo castellano diese paso a una indiscriminada persecución por el mero hecho de ser musulmanes, al margen de su participación o no en la revuelta, lo que no dejaba otra salida que la huida hacia poblaciones limítrofes granadinas como Vélez Blanco, Vélez Rubio, Vera, Mojácar, Baza, etc., en las que unos encontrarían acogida por parte de familiares y amigos, mientras que otros habrían de hacer frente solos al porvenir que se les venía encima, aunque para todos el futuro era incierto porque era verdad que estaban con y entre gente de su propia religión y etnia, pero también lo era que su llegada generaba superpoblación en núcleos urbanos no preparados para recibir un numeroso tropel de gente, malestar e incomodidades que, en ocasiones, encrespaban los ánimos y provocaban reacciones no deseadas y, acaso, injustificadas.

Pero no son solamente musulmanes los que se iban, sino que también había cristianos para quienes la conmoción de la revuelta, el temor de una reacción granadina, la inseguridad de todo tipo y las escasas perspectivas que se ofrecían ante sus ojos, serán motivos más que suficientes para coger familia y enseres y tomar el camino que les aleje a Lorca ${ }^{14}$. La ciudad de Guadalentín se vio privada de la mayoría de sus habitantes musulmanes y de una parte de los castellanos, con lo que los niveles de ocupación urbana debieron descender a estratos muy bajos, sus zonas de huerta abandonadas y una gran superficie de sus campos desierta e inculta; sin embargo, esa situación ahora abría nuevos horizontes para la repoblación, para la llegada y establecimiento de nuevos pobladores que se sumarían a los que habían quedado y que llenarían los hogares abandonados, reforzarían la defensa fronteriza y darían nueva vida a la ciudad y a las tierras de cultivo, asegurando en cierta medida el mantenimiento de la producción en los niveles anteriores a 1266 y, con ello, el alejamiento del peligro de la carestía.

Con tales premisas muy presentes, Alfonso $X$ cursó las órdenes oportunas para que se efectuase una distribución de casas y tierras, la denominada Segunda Partición, realizada entre 1266 y 1270, que supone la llegada de 720 pobladores, siendo la más nutrida, y, poco después, la Tercera Partición, que tiene lugar en 1272 y que aporta otros $153^{15}$. En total vienen a Lorca atraídos por las ventajosas condiciones ofrecidas por el monarca castellano un total de 873 nuevos vecinos que se sumaron a los 90 que, teóricamente, quedaban desde 1266, lo que suma un total de 963 pobladores; datos con los que se puede conjeturar sobre el número aproximado de habitantes que

14 En 1266 se establecieron 107 pobladores en Lorca, de los cuales 17 se marcharon al poco tiempo, ya que en 1272 figuran como ausentes y sus propiedades disponibles. Los motivos para ello no pueden ser otros que la oposición entre la idea que les trajo aquí y la realidad que se encontraron. TORRES FONTES, J., Repartimiento de Lorca; $\mathrm{p}$. XCVI.

15 Ibid.; pp. LII-LXVI y XCVII. 
tenía Lorca, ya que utilizando el mencionado índice de 4'5 resulta un contingente poblacional de 4.333 personas, hombres, mujeres y niños, cifra que, como se puede apreciar, queda muy alejada de los 9.000 habitantes que supuestamente residían en la ciudad durante la época islámica y que, de ser cierta, indicaría una emigración extraordinaria de musulmanes. En todo caso, el número de cristianos ahora reflejado está más cercano a la realidad.

Las palabras de Juan Avellán ante el juez Antón Martínez de Aguilera, en 1493: "por la gran anchura e largura que tiene la dicha çibdad y las sus grandes murallas, que paresçe ser por edificaçion e con casamiento ser e aver sydo todos tienpos de mas de mil e quinientos vezinos arriba ${ }^{16}$, de nuevo permiten hacer un cálculo y llegar a convertir esos 1.500 vecinos en 6.750 habitantes, guarismo que no es, a mi juicio, nada real, pues como ya se ha visto en las sucesivas repoblaciones se contabilizan 4.333 personas y no parece posible creer que en la ciudad de Lorca hubiesen quedado 2.417 habitantes tras la huida de los musulmanes y primeros repobladores ${ }^{17}$. Además, las noticias que presentan un panorama muy poco propicio para el Siglo XIV, en todos los sentidos ${ }^{18}$, no conducen sino a negar las cifras que resultan de las afirmaciones del procurador de Lorca, así como su estabilidad temporal, pues la emigración y las bajas producidas por el curso natural de la vida habían dejado muy mermada la población, lo que llevó a Fernando IV a otorgar al concejo de Lorca todas las propiedades de los ausentes "de aquellos que non moraren y nin tengan y sus casas mayores, segunt su priuillejo manda... et que las puedan dar et partir a pobladores que fagan y uezindat ${ }^{19}$. La situación era realmente angustiosa.

En cualquier caso, los recién llegados, unidos a los que permanecían desde repartimientos anteriores, ampliarían la base de población cristiana que, por estas fechas, era más numerosa que la musulmana, de manera que se ya se había producido una inversión con respecto a la primera fase de la repoblación, y cimentarían la castellanización institucional y social de la ciudad en cuanto los repobladores de procedencia castellana superan a los venidos de otras demarcaciones. Pero las iniciales y optimistas perspectivas dejarán paso al poco tiempo a un fenómeno contrario, porque una cosa es el proyecto, el plan, la ilusión y otra muy diferente la realidad con la

16 A.M.L. Pleito de Xiquena, fol. $21 \mathrm{v}$.

17 No debían ser tampoco 4.333 los habitantes de Lorca. En todo caso la afirmación del procurador lorquino cuando dice que en Lorca "en todos tienpos" residieron 1.500 vecinos se antoja exagerada y formulada en un contexto en el que era necesario acrecentar la importancia de Lorca para demostrar su ascendencia sobre Xiquena y Tirieza y dar al juez una impresión que le inclinase a dar una sentencia favorable al concejo. De nuevo surge la posibilidad de que Juan Avellán identificase vecinos con habitantes y, así, entonces estaría en lo cierto al realizar esa afirmación sobre el mantenimiento de una población cifrada en esas 1.500 personas o más.

18 TORRES FONTES, J. y TORRES SUÁREZ, C., Op. cit.; pp. 155-177, ponen de relieve la situación de despoblación y recesión que vive la ciudad de Lorca, no paliada con una nueva Partición, la Cuarta, efectuada entre 1330 y 1337, que aportó 585 pobladores, unas 2.632 personas, que no fueron suficientes para levantar y mejorar la situación de precariedad existente. TORRES FONTES, J., Repartimiento de Lorca; $\mathrm{p}$. XCVII.

19 TORRES FONTES, J., «Documentos de Fernando IV», C.O.D.O.M. V. Murcia, 1980. Doc. XLIV. 
que diariamente se iban a encontrar y a enfrentar los llegados a Lorca en compañía de sus familias y, pronto, al igual que había sucedido antes, asustados por el constante peligro fronterizo y desilusionados por los escasos rendimientos que la mayoría de las veces sacaban a la tierra, que no compensaban el notable esfuerzo físico y económico que día a día tenían que realizar, a causa de la precariedad de medios y de la indefensión ante las intemperancias climáticas, muchos repobladores abandonaron las tierras recibidas en los repartimientos y los campos quedarán incultos por tiempo a pesar de que, ya tardíamente, en el Siglo XIV se proceda a una nueva Partición que, como queda dicho, no solucionó gran cosa, debido a que, simple y llanamente, las causas que mueven a la huida en busca de lugares y tierras más seguras persistían, como la realidad se encargaba de demostrarlo.

De manera que los que, pese a todo, decidieron permanecer quedaron sujetos a unas condiciones realmente duras que con el tiempo van a curtir y a forjar a los típicos hombres de la frontera, que saldrían a escena años más tarde para amortiguar con sus acciones los desastrosos efectos de las incursiones granadinas, cuyos caudillos, aprovechando el desconcierto que reinaba en Castilla y la situación fronteriza, no encontrarán resistencia cristiana alguna en estos años de tránsito entre siglos y los más perjudicados por la indefensión serán precisamente aquellos cuya máxima aspiración era sobrevivir, cosa de por si bastante difícil.

Un día, quizá de Septiembre, de 1283, varios lorquinos salieron de la ciudad, entre ellos Rodrigo y su hermana Teresa, con objeto de proceder a la vendimia y en esa tarea estaban cuando fueron sorprendidos por Muza Barraham, Zahem y Zahet Azenet y un nutrido contingente de granadinos que cayeron sobre los agricultores, mataron a 200 y llevaron cautivos otros 200 al reino de Granada ${ }^{20}$. Unas 400 bajas son muchas, quizá una cifra exagerada pero indicativa de que una buena parte de los brazos para trabajar las tierras habían sido eliminados o capturados por los granadinos, lo cual traería importantes repercusiones no sólo desde el punto de vista demográfico, sino también productivo y económico, para una población que empezaba a dar síntomas de una gran decadencia, de la que, aunque no tengamos fuentes directas, nos hablan y confirman las indirectas ${ }^{21}$.

20 Rodrigo fue vendido en Vélez Blanco por 5 doblas y Teresa por 10 doblas. El primero permaneció unos días preso en compañía de doña María de Brihuega, otra cautiva, en la ciudad velezana y tras quince días lo llevaron a Guadix y de allí a Granada en donde pasó el invierno y, mediada la Cuaresma, lo llevaron a Almería y allí «metieronlo en fierros et mandaronlo a guardar bestias». Consiguió salir del cautiverio, según él gracias a la intercesión de Santo Domingo, tal y como lo relató al monje Pedro Marín, autor del romanceado texto de los milagros de Santo Domingo. Nada se sabe de la suerte que corrió Teresa. TORRES FONTES, J., Repartimiento de Lorca; p. 54.

21 Uno de los más claros ejemplos de la despoblación a la que se vio sometida la ciudad y término de Lorca se encuentra en la alquería de Guillén Pérez de Pina, uno de cuyos herederos, Alvar Pérez de Pina, obtiene la más alta dotación en el repartimiento de 1272 con dieciséis tahúllas de huerta con árboles, ciento dos tahúllas de tierra de morgón en el fondón de Castalla y otras cincuenta en tierra de fondón. La alquería tan extensa que llegaba hasta Águilas, tenía tierra en cantidad más que suficiente para dar trabajo a bastantes personas, pero su abandono es prueba de que no las 
Llegados a este punto del presente estudio se pueden formular varias cuestiones, ¿Qué quedó del esfuerzo repoblador capitaneado por Alfonso X?, ¿Qué grado de permanencia se registró entre los repobladores? o ¿Disminuyó la población de Lorca hasta un extremo tal que puso en peligro la propia integridad de la demarcación fronteriza a su cargo? Las respuestas son difíciles y nunca completas, aunque los datos aproximados que se pueden obtener apuntan a que a la primera cuestión habría que responder que bastante poco en comparación al despliegue realizado, a la segunda que los niveles de permanencia fueron bajos y a la tercera que sí y que la frontera permaneció incólume porque en Granada los problemas no eran pequeños y los monarcas tenían bastante materia a la que prestar atención en el interior de su reino como para dedicarse a guerras fronterizas, aunque, en este sentido, el tratado de paz firmado entre Jaime II y Muhammad II proporcionará quietud a la frontera y Lorca tendrá un necesario y muy útil respiro. Veamos.

El 18 de Diciembre del año 1300, Jaime II de Aragón se encontraba en Lorca dispuesto a recibir el homenaje del concejo lorquino sobre el cumplimiento de los acuerdos a los que se había llegado para la entrega de la fortaleza y como garantes se presentaron 224 ciudadanos $^{22}$. Pues bien, de entre los contenidos en la larga nómina de lorquinos hay 88 que figuran con los mismos nombres y apellidos en el Repartimiento de Lorca, lo que no puede ofrecer duda ninguna en cuanto a su identificación y que se trate de las mismas personas ${ }^{23}$, es decir el $39 \%$ de los presentados como

había. Finaimente Sancho IV la entregó al concejo porque "esta yerma», al igual que sucedía con otras muchas propiedades, grandes y pequeñas. 1294-X-23, Zamora. CÁNOVAS COBEÑO, F., Historia de la ciudad de Lorca. Lorca, 1980; p. 212. La situación se repite sin cesar, alcanzando su máximo exponente en el reinado de Fernando IV.

22 ESTAL GUTIÉRREZ, J.M. del, El Reino de Murcia bajo Aragón (1296-1305). 2. Alicante, 1990. Doc. 129.

23 El número de identificados puede ser mayor, ya que se aprecian correspondencias de todo tipo que así lo indican, caso, por ejemplo, de Ballestero de Soria, citado en el Repartimiento y Valerio de Soria en 1300; Ballestero no es nombre sino apellido u oficio y puede tratarse de un error del escribano al desarrollar la abreviatura del nombre al escribirlo en el Siglo XVIII, porque la transcripción del Profesor Torres Fontes no ofrece duda. A continuación, como ejemplo de la pauta seguida, se incorpora una relación de correspondencias que ha servido para identificar a varios:

$\begin{array}{ll}\text { Repartimiento } & \mathbf{1 3 0 0} \\ \text { Adán Dotón } & \text { Adán de Oron } \\ \text { Aparicio de Baeza } & \text { Aparicio de Baessa } \\ \text { Arnalt Millorat } & \text { A. Mellorat } \\ \text { Bernat de Figuerola } & \text { Bernando Figuerola } \\ \text { Durán Pérez } & \text { Durant Pereç } \\ \text { Esteban de Toro } & \text { Estheven de Toro } \\ \text { Guillén Borrell } & \text { G. Borrell } \\ \text { Juan Domínguez de Pitarque } & \text { Johan Domingueç de Pitarch }\end{array}$


garantes ante el monarca aragonés habían permanecido en Lorca por lo menos desde 1268-1270, años en los que se efectúa la Segunda Partición, pues en su mayoría figuran encuadrados en ella y, aunque en el texto del Repartimiento la Segunda y la Cuarta Particiones vayan unidas y sin distinción, no es posible admitir que sean pobladores llegados en la Cuarta Partición, pues ésta se realiza en 1336, esto es, treinta y seis años después de la estancia de Jaime II en Lorca, lo que imposibilita cualquier identificación al respecto.

Una estancia de treinta años haciendo frente a todo tipo de vicisitudes, los convierte en unos hombres de peso específico dentro del elenco social representativo de la ciudadanía. De ellos son muy pocos los que figuran en los repartimientos segundo y tercero, como Sancho Palmero, un caballero que había sido heredado en la Segunda Partición con dos caballerías y media en la Cuadrilla de Domingo de Iniesta, y con dos tahúllas, que conformaban una huerta, en la Tercera ${ }^{24}$; también Juan Calafat fue heredado en la Segunda Partición con dos caballerías menos dos ochavas en la acequia del Cañaveral y otra en el fondón, perteneciente a la Cuadrilla de Martín García, y en la Tercera recibió nueve tahúllas para viñas y majuelos ${ }^{25}$.

Lorenzo Rovera
Martín Domínguez de Almohaja
Martín Domínguez de Brihuega
Mateo Valadazote
Pedro Bover
Pedro de Calatayud
Pedro López de Baeza
Pedro Martín de Celha
Pedro Ximénez de Zaragoza
Vengut Rovera

Lorens Rovira
Martín Domingueç de Almoaga
Martín Domingueç de Britega
Matheo de Valadaçot
Pedro Bovet
Pedro Calathayu
Pedro Lopeç de Biessa
Pedro Martínez de Celha
Pedro Ximeno de Zaragoza
Vengut Rovira

También se puede intuir una correspondencia familiar en casos como el citado en el documento de 1300 con el nombre de Paschal Martín de Lorca, ya que en el texto del Repartimiento figuran dos Pascual Martín, padre e hijo, pudiendo el hijo añadir tras el apellido "de Lorca». Lo mismo sucede con Pedro Bover, también padre e hijo. Diferente es la cuestión planteada con el nominado en 1300 como Juan del Seso, porque ahora el problema se centra en que en el Repartimiento figuran dos, pero uno es nieto de Martín Maluenda y el otro lo es de Castejón, por lo que no es posible identificar con exactitud de cual de los dos se trata. Berenguer de Figuerola, citado en 1300, puede ser familia de Bernat de Figuerola o de Guillén de Figuerola, pobladores en la Segunda Partición, pues el apellido aunque frecuente en el Repartimiento no deja de ser poco corriente. Finalmente, M(iguel?) Pérez de Peñafiel, citado en 1300, puede estar emparentado con los repobladores Juan Pérez de Peñafiel y Nuño Pérez de Peñafiel. Vid. TORRES FONTES, J., Repartimiento de Lorca; pp. 11-17, 19, 20, 23, 25, 26, 30, 31 , 34, 35 39, 40, 42, 46. Y ESTAL GUTIÉRREZ, J.M. del, Op. cit; pp. 126 y 127.

24 TORRES FONTES, J., Repartimiento de Lorca; pp. 7, 8 y 24. ESTAL GUTIÉRREZ, J.M. del, Op. cit; p. 125.

25 Ibid.; pp. 8, 30, 31. Ibid:; p. 125. Por su parte, Martín Pérez de Peralta fue el destinatario de una peonía en la Cuadrilla de Buena Fe de Castellot y dos caballerías en la de Domingo Manzanera, todo en la Segunda Partición, y este patrimonio se vio incrementado en 1272 con tres tahúllas de huerta en el pago de Tamarchete y otras quince en tierra de morgón en la Tercera Partición. Ibid; ; pp. 5, 17, 38 y 39. Ibid; p. 127. 
Los heredados solamente en la Tercera Partición son más escasos, lo cual puede resultar comprensible si se atiende al menor número de repobladores llegados - 153y a la marcha de muchos de ellos, de manera que solamente unos pocos de los que quedaron podían, por su posición social representar a la ciudad. Así, se encuentran Pedro Martín y Miguel de Cuenca, residentes en la villa de Puentes, que recibieron cada uno cuatro tahúllas de huerta, sin arbolado, en Tamarchete ${ }^{26}$.

La permanencia de los repobladores a través del tiempo puede verse también a través de sus descendientes, la mayoría de los cuales no solamente consolida el patrimonio obtenido por su progenitor, sino que lo amplían, de manera que pueden llegar a convertirse en familias con una economía y posesiones que permiten el ascenso social basado en una disponibilidad fuerte. Entre todos destaca el caballero Gil de Ricla, personaje con activo protagonismo en la vida ciudadana como lo prueba el hecho de que una de las puertas de la ciudad lleve su nombre, precisamente aquella en la que había una torre donde el concejo celebraba las reuniones antes de trasladarse a la zona de las Plazas, muy cercana al lugar que hoy ocupa el Ayuntamiento ${ }^{27}$. Comenzó con la recepción de cinco caballerías en la Cuadrilla de Guillén de las Cejas y otras dos, "por el rey", en la de Buena Fe de Castellot, todo ello en la Segunda Partición; poco más tarde estos bienes inmuebles se vieron incrementados en la Tercera Partición con seis tahúllas de tierra para cultivar viñas y majuelos ${ }^{28}$. Lo mismo sucede con el también caballero Martín Pérez de Teruel, heredado con 8 tahúllas de viñas en la Tercera Partición, en tanto que su viuda, Olalla, recibía una caballería en la Cuadrilla de Martín García y otra que había pertenecido a Gil de Cuenca en la Cuadrilla de Guillén de los Arcos, todo ello en la Cuarta Partición, la misma en la que sus hijos eran titulares de una caballería y cuarta, cedida a María Alfonso, esposa del molinero Bernat, en la Cuadrilla de Martín García ${ }^{29}$.

También en el seno de instituciones como la Iglesia se manifiesta este fenómeno de la continuidad, caminando en este terreno por los mismos parámetros y proporciones que el resto de los pobladores, aunque, como es lógico, los condicionantes y tareas particulares de los clérigos son diferentes a los del resto, si bien es verdad que los generales les van a afectar, como a todos los lorquinos. En 1300 y para reforzar las seguridades dadas al rey aragonés, se incorpora una representación de la clerecía de la ciudad, capitaneada por el vicario episcopal e integrada por seis clérigos,

26 Ibid.; p. 4. Ibid; pp. 126 y 127. Miguel de Alarcón también era repoblador de Puentes, pero residía en el barrio de Alcalá, recibiendo por ello seis tahúllas de huerta en Marchena. Ibid.; pp. 3 y 8. Ibid:; p. 127.

27 JIMÉNEZ ALCÁZAR, J.F., Lorca. Ciudad y término. Murcia, 1994; p. 99.

28 Sus herederos, ya en la Cuarta Partición fueron heredados dentro de la Cuadrilla de Andreo de las Cejas, con quince caballerías, cinco en la Acequia Alta, otras cinco en el morgón de Tercia y otras tantas en el de La Condomina. Ibid; pp. 7, 11-15, 18 y 36. Ibid.; p. 127.

29 También se puede citar en este contexto a Bartolomé Serrano, quien compartía veintiocho tahúllas de tierra con el pellejero Pedro Visedo, Juan Domínguez de Brihuega, Bernalt de Estella y con Ibáñez de Medinaceli en la Tercera Partición, en tanto que sus herederos recibian una caballería y cuarta en la Cuarta Partición. Ibid; pp. 7, 9, 30-34 y 34. Ibid.; pp. 126 y 127. 
uno por cada parroquia ${ }^{30}$; de todos ellos hay dos que se encuentran identificados con claridad en el texto del Repartimiento. Uno es Ramón Rovira o Ruvira, clérigo llegado a Lorca por los años en que se realiza la Segunda Partición en la que recibió un heredamiento constituido por seis caballerías en la Cuadrilla de Arias Pérez, la misma en la que fue heredado otro compañero de profesión, Martín Pérez de Cuviello, clérigo de San Mateo ${ }^{31}$. El otro clérigo es Pedro Martínez, que solamente compartía con Rovira su vocación sacerdotal y llegar a Lorca por los mismos años, pues su dotación en el Repartimiento está muy lejos de la obtenida por el vicario y hubo de contentarse con una peonía en la Cuadrilla de Mateo Martínez ${ }^{32}$.

Los restantes nombres identificados en el Repartimiento y que personalmente comparecieron ante Bernat de Sarriá, flamante Procurador del Reino de Murcia, recibieron sus heredamientos a lo largo del tiempo en que se llevó a cabo la Segunda Partición. De entre ellos destaca Guillén Azor, un caballero que poseía amplios heredamientos en la Cuadrilla de Andreo de las Cejas, formados a base de dos caballerías y cuarta en la Acequia del Pozo, otras dos caballerías en el Saladar, dos caballerías y cuarta en el almorgón de Tercia, otras dos caballerías en el morgón de la Condomina y otras tantas en los albares de los Alporchones, por lo demás, también era titular de dos caballerías menos cuarta en la Cuadrilla de Buena Fe de Castellot ${ }^{33}$.

30 «Estos que se siguen fizieron segurament a tener e a observar las ditas posturas e cada una daquellas, ço es: Ramon Ruvira, vicario de Lorcha, Sancho Pereç, clerigo, Pedro Martineç, clerigo, Martín Sanchç, clerigo, Miguel Pereç, clerigo, Jayme del Avorero, clerigo, Ramon Martineç, clerigo». ESTAL GUTIÉRREZ, J.M. del, Op. cit; p. 127. Representaba cada uno a su parroquia ya que el numero de seis así parece indicarlo, porque seis eran las colaciones lorquinas: San Pedro, San Juan, Santa María, las tres cercanas al recinto de la fortaleza en la parte alta de la ciudad, y Santiago, San Mateo y San Clemente, situadas en la parte baja de la población.

31 TORRES FONTES, J., Repartimiento de Lorca; p. 27. La trayectoria de Ramón Rovira al servicio de la Iglesia en Lorca terminaría siendo premiada por el prelado cartaginense con su designación como vicario episcopal en la ciudad, cargo que ocupaba en el momento en el que se produjo la llegada de los aragoneses.

32 Ibid; p. 21 . En esta misma Cuadrilla es heredado don Pedro, "clerigo de San Jorge», con dos caballería y media que fueron a parar a manos de Juan López. El ser cura de San Jorge permite identificarlo como venido en la Cuarta Partición ya que, según Cánovas Cobeño en el tiempo de la dominación aragonesa en Lorca, «indudablemente tuvo lugar la fundación de la Iglesia de San Jorge, patrón de dicho reino; fue construida inmediata a la muralla que rodeaba la ciudad y quedó incluida en la Iglesia Mayor de San Patricio, en la capilla del Alcázar». CÁNOVAS COBEÑO, F., Op. cit; p. 216. Otro clérigo citado en 1300 es Jaime del Avorero, cuya ascendencia lorquina es posible, ya que su apellido puede identificarse con el Aorero de dos pobladores de la Segunda Partición, heredados en la misma Cuadrilla: Juan del Aorero y Andrés del Aorero, ambos con una peonía, pero lo que llama la atención es el tratamiento de Don que recibe Andrés, acaso sinónimo de edad avanzada.

33 TORRES FONTES, J., Repartimiento de Lorca; pp. 12-17. ESTAL GUTIÉRREZ, J.M. del, Op. cit; p. 125. La relación de los 88 heredados en los repartimientos y presentes en los actos de Diciembre de 1300, es la siguiente: Miguel de Alarcón, Pascual de Alcañiz, Simón de Alcañiz, Guillén Azor, Aparicio de Baeza, Guillén Borrell, Guillén Bou, Pedro Bovet, Ibáñez de Buendía, Juan Calafat, Pedro de Calatayud, Gil de Caravaca, Bartolomé de Castellot, Buena Fe de Castellot, Aparicio de Cuenca, Miguel de Cuenca, Juan de Chuecos, Juan Daroca, Martín Domínguez de Almohaja, Martín Domínguez 
El jueves, 22 de Diciembre, ya ocupada la fortaleza de Lorca, se procedió a la elección, por parte de los caballeros de la ciudad, de los tres individuos que habían de hacerse cargo, en nombre de Jaime II, de las torres de la fortaleza, quedando la Alfonsina en poder de Alfonso Pérez de Monterroso, la del Espolón fue encomendada a Miguel Rajadel y la de Guillén Pérez de Pina a cargo de Buena Fe de Castellot ${ }^{34}$. Todo ello fue plasmado en otro importante documento que resulta muy útil, ya que ofrece más información sobre el tema objeto del presente trabajo, especialmente en cuanto se refiere a la continuidad familiar de los repobladores asentados en la Segunda Partición, que fueron constituyendo el núcleo esencial de los habitantes de la ciudad, origen del grupo dominante de la misma, lo que se pone de relieve en que de los 33 rehenes que la ciudad entregaba a Jaime II como garantía de la fidelidad de la ciudad y fortaleza, 14 , es decir el $42 \%$ son pobladores registrados en el Repartimiento y de ellos 13 son hijos que se entregan al rey aragonés en lugar de sus padres, hombres ya mayores para entrar en tales situaciones. En cualquier caso, el grupo de rehenes constituye una representación exacta de la configuración social de Lorca, estructurada a base de una concepción militar de caballeros y peones tal y como la había diseñado Alfonso $X$, atendiendo fundamentalmente a las características de la ciudad y del territorio que la circundaba, como lo prueba el hecho de que los 14 identificados en el Repartimiento 10 son caballeros la mayoría de ellos dotados con fuertes dotaciones de tierra.

En realidad, Jaime II tenía necesidad de asegurarse el control de una plaza que tanto esfuerzo le había costado ocupar en cuanto a hombres, dinero y transporte de impedimenta y vituallas, por lo que es lógico que exigiese la entrega como rehenes de personas destacadas de la sociedad lorquina para que garantizasen el cumplimiento de los acuerdos. De ellos solamente incluiré los nominados en el Reparti-

de Brihuega, Juan Domínguez de Pitarque, Adán Dotón, Jaime Escribano, Juan Espinel, Ruy Fernández de la Torre, Bernat de Figuerola, Martín García, Pedro Garcia, Domingo Gonzalo, Miguel de Huesca, Martín de Liria, Pedro López de Baeza, Juan López Navarro, Pedro Martín, Pedro Martínez, Pedro Martínez de Cella, Pedro Martínez de Tarazona, Pascual Mellado, Arnalt Millorat, Domingo de Monzón, Miguel de Morilla, Pedro Morata, Alfonso de Mula, Jaime de Mula, García Muñoz, Jaime Ninot, Pedro Núñez, Jaime de Onteniente, Juan Ortiz, Sancho Palmero, Martín Pascual, Pedro Pascual de la Mata, Durán Pérez, Sancho Pérez, Juan Pérez de Monzón, Martín Pérez de Palencia, Miguel Pérez de Paterna, Martín Pérez de Peralta, Martín Pérez de Teruel, Miguel Pérez de Tudela, Pedro Quipar, Martín de Ribaforada, Gil de Ricla, Lorenzo Rovera, Ramón Roverira, Vengut Rovira, Ibáñez Sancho, Bernat Seguí, Pedro de Segura, Bartolomé Serrano, Domingo Serrano, Juan del Seso, Rodrigo Sevil, Bartolomé de Sevilla, Sancho la Sierra, Martín Soriano, Guillén Talavera, Pedro Tarazona, Fernando de Toledo, Esteban de Toro, Mateo de Valadazote, Bartolomé de Valles, García Vicente, Iñigo de Villafranca, Fernando de Visedo, Martín Ximénez, Pedro Ximénez de Calasanz, Pedro Ximénez de Zaragoza.

34 ESTAL GUTIÉRREZ, J.M. del, Op. cit. Doc. 131, p. 128. De los tres nominados Buena Fe de Castellot es el único que figura en el Repartimiento. Se trata de una persona que formaba parte de lo más acrisolado de la aristocracia lorquina como lo prueba el hecho de que fuese cabeza de una cuadrilla que lleva su nombre, en la que aparece heredado con diez caballerías, cinco que tenía arrendadas a Pedro Mateo de Villar del Saz y otras cinco en la Acequia del Pozo. TORRES FONTES, J., lbid; pp. 16-18. 
miento: «Aquestas son las rafenas dadas al senyor rey por el concejo de Lorcha...: Martin Pereç de Palencia ${ }^{35}$, Berenguer Rovira, fijo de Vengut ${ }^{36}$; Lorençet, fijo de Lorens Ruvira ${ }^{37}$; Dominguelo, fijo de Domingo de Monçon ${ }^{38}$; Gil Sacoma, fijo de Gil de Caravaca $^{39}$; Johan Serrano, fijo de Domingo Serrano ${ }^{40}$; Johan Mellado, fijo de Paschal Mellado $^{41}$; Gonçalvo Ortiç, fijo de Johan Ortiç ${ }^{42}$; Andrenet, fijo de Domingo Gonçalo ${ }^{43}$; Andrés, fijo de Johan de Chocos ${ }^{44}$; Pedro Martin, fijo de Martin Domingueç de Brioga ${ }^{45}$; Alfonsiello, fijo de Durant Pereçc6; Pedro Martineç de Celha ${ }^{47}$; Pedro Ximeneç e Martin Ximeneç, fijos de Martin Ximeno ${ }^{48}$ ». Solamente Domingo Gonzalo y Pedro Martínez

35 Heredado con una caballería en la Cuadrilla de Tomás de Tarazona y otra en la de Domingo de Chuecos. TORRES FONTES, J., Ibid:; pp. 37 y 41.

36 Se trata de Vengut Rovira, heredado con cinco peonías en la Cuadrilla de Andreo de las Cejas, una peonía más otra que compró del adalid Miguel en la Cuadrilla de Ferrán Gómez, media peonía y otra media que poseía por la hija de doña María de las Cuevas en la Cuadrilla de Sebastián de Mora, una peonía en la Cuadrilla de Domingo de Chuecos y otra más en la Cuadrilla de Don Rovera. Ibid:; pp. 12-16, 25-26, 34-35, 40, 46.

37 Lorenzo Rovira contaba con una heredad de dos caballerías en la Cuadrilla de Sebastián de Mora. Ibid:; p. 35.

38 Domingo de Monzón poseía tres peonías y un cuarto y, además, tomaba otra por doña Ramona, tendera, en la Cuadrilla de Guillén de los Arcos. Ibid.; pp. 32-33.

39 Gil de Caravaca, caballero económicamente muy poderoso, había recibido ocho caballerias y dos cuartas en la Cuadrilla de Tomás de Tarazona. Ibid:; pp. 37-38.

40 Domingo Serrano fue heredado con una peonía en la Cuadrilla de Buena Fe de Castellot y con cuatro caballerías en la Cuadrilla de Martín García. Sus herederos, en la Cuarta Partición, figuran como titulares de una caballería y media en la Cuadrilla de Sancho de la Plaza. Ibid.; pp. 17, 30-31 y 43.

41 Pascual Mellado había sido heredado con cinco caballerías en la Cuadrilla de Martín García. lbid; pp. 30-31.

42 Juan Ortiz era titular de una cabaliería y otra que compró a Alfonso de Lorca en la Cuadrilla de Ferrán Gómez, poseyendo también dos caballerias y cuarta en la Cuadrilla de Sancho de la Plaza y una caballería menos cuarta, que perteneció a Bernat Tamarid, en la Cuadrilla Mayor de Don Rovira. Ibid; pp. 25-26, 43-44.

43 Domingo Gonzalo era un cantero que, junto a su suegro, recibió, por carta de Alfonso X, 4 tahúllas de huerta en Tamarchete, más otras quince de morgón y ocho de tierra de fondón, así como las ocho tahúllas que Domingo lbáñez había de entregar a cambio de la tierra que le fue dada para majuelos. También recibió las casas que fueron de don Valero. Ibid.; pp. 4 y 6.

44 Juan de Chocos -o Chuecos - fue heredado con dos caballerías en la Cuadrilla de Mateo Martínez y con cinco caballerías y cuarta en la de Domingo de Chuecos. Ibid.; pp. 21 y 40.

45 Martín Domínguez de Brihuega poseía tres caballerías en la Cuadrilla de Martín García. Ibid.; pp. 30-31.

46 Durán Pérez había sido heredado con dos caballerías en la Cuadrilla de Buena Fe de Castellot. Ibid:; p. 16.

47 Pedro Martínez de Celha -o Cella-, era uno de los 23 pobladores establecidos en el Espolón y por ello obtuvo veinte tahúllas de huerta en Marchena. Ibid.; p. 3.

48 Martín Ximeno era un escribano de Lorca que poseía siete caballerías en la Cuadrilla de Andreo de las Cejas. Más tarde, ya en la Cuarta partición sus hijos recibieron además siete caballerías menos dos cuartas en la Cuadrilla de Arias Pérez y una peonía, más otra que perteneció al ballestero Ramón de Almenar, en la Cuadrilla Mayor de Don Rovira. Ibid.; pp. 11-15, 26, 44-46. 
de Cella fueron heredados en la Tercera Partición, perteneciendo el resto a la Segunda ${ }^{49}$.

De todo lo expuesto hasta ahora, se desprende la conclusión de que los repobladores asentados en Lorca a lo largo de las particiones no permanecen en el territorio mucho tiempo, sino que emigran en gran cantidad, como parece indicarlo la cifra de 88 pobladores presentados como garantes y los 14 que son entregados como rehenes en 1300 , los cuales, suponiendo que fuesen los únicos que habían quedado, representarían 102 pobladores - unos 459 habitantes- cifra muy exigua si se compara con el volumen total de llegados entre 1266 y 1272 que fueron 963 repobladores -4.333 habitantes - y solamente supondrían el 2'3\% del total, y abundando más, si nos ceñimos sólo a la Segunda Partíción tenemos que de los 720 pobladores llegados solamente 85 estaban en 1300 , esto es el $11 \%$ de los integrados en ella, un porcentaje muy bajo de permanencia que, sin duda, no responde a la realidad más absoluta, pero que es muestra de una enorme despoblación que, por lo demás, señalan los documentos. A los 88 hay que añadir los 136 restantes que equivaldrían a 612 habitantes más, en total 1.071 habitantes, cifra, como se ve, muy alejada de las que ya antes he apuntado y que, tal vez, se acerque mucho más a la realidad, siempre incompleta, de los habitantes que tenía Lorca, ya que a estos se sumarían los que no están en el referido documento, de condición social más baja y que representarían un porcentaje imposible de cuantificar, así como las minorías étnicas, sobre todo judíos ya que los musulmanes escaseaban, aunque su aporte conjunto no es significativo.

Por otra parte, también se pone de manifiesto una mayor permanencia de los heredados en la Segunda Partición con respecto a los de la Tercera, cosa lógica puesto que el volumen de repobladores llegados en la Segunda es muy superior y serian éstos quienes, con el transcurso del tiempo y las transformaciones experimentadas en la sociedad lorquina, conseguirían una mayor hegemonía en el seno ciudadano y con ello el acceso al concejo y al gobierno de la ciudad, como sucede con el influyente Íñigo Ximénez ${ }^{50}$ y del también lorquino Pedro Ximénez de Lorca, acaso su herma-

49 En este punto también cabe la posibilidad de añadir algunas identificaciones a base de lazos familiares. Así, Andrés, hermano de Martín de Visiedo, entregado como rehén, puede ser hijo o pariente de Fernando, Gil o Pascual de Visiedo, y aunque la preposición "de» antes del apellido permite excluir de la parentela a Bartolomé Visiedo y al Pellejero Pedro Visiedo, tal exclusión no es total. Lo mismo sucede con «Martín, fijo de Juan de Lavorero», ya que, como he señalado en la Nota 32 de este estudio, en el Repartimiento figura Juan del Aorero, heredado con una peonía en la Cuadrilla de Mateo Martinez, pudiendo tratarse efectivamente de su padre. $Y$, finalmente, «Pedro Martineç, fijo de Buena Fe», que muy posiblemente se trate de Buena Fe de Castellot. Pero, ante la mera suposición, casi certeza, de estas identificaciones, no están incluidos en los arriba reseñados.

50 Heredado con tres caballerías en la Cuadrilla de Ferrán Gómez, llegó a controlar el gobierno municipal y a participar activamente en las tareas repobladoras y, así, poco más tarde «vn aluala, sellado de don Yenego Ximenez, en las espaldas" sirvió de autorización para que Martín Sánchez recibiese tres caballerías en la Cuadrilla de Martín García, tal vez uno de sus colaboradores. El 1305 ya había fallecido por lo que Fernando IV ordena a sus herederos que reconstruyesen los molinos que el difunto poseía, en condominio con el obispo y cabildo, junto al alcázar de Murcia. 1305-II-12, Guadalajara. TORRES FONTES, J., Documentos de Fernando IV. Doc. XXXIV. 
no, quien, tal vez convencido del éxito de las pretensiones aragonesas y de la permanencia definitiva del Reino de Murcia en la corona de Aragón, optó por Jaime II y se convirtió en uno de sus más eficaces instrumentos a la hora de dirigir las operaciones contra Lorca, recibiendo la custodia del castillo y lugar de Aguaderas, recientemente fortificado por Bernat de Sarriá, que puso bajo las órdenes del lorquino 40 hombres a caballo en Julio de 1300 , así como participando en la tala de viñas y campos, fundamentalmente los sembrados de trigo, que Sarriá decretó para que «no hi havia quedar res per talar ${ }^{51}$. Se trataba de evitar la recolección de cereal y acelerar el proceso de rendición de Lorca, que había de estar muy avanzado para cuando Jaime II concluyese las Cortes de Zaragoza y viniese al Reino de Murcia para completar la ocupación. Hasta aquí solamente se han analizado datos y noticias referidos a la población

51 Heredado con siete cabalierías en la Cuadrilla de Domingo de Iniesta, en los años anteriores a la ocupación aragonesa había desempeñado el cargo de arrendador y recaudador de la moneda forera y del almojarifazgo del Reino de Murcia y tuvo enfrentamientos y problemas con las autoridades eclesiásticas porque se negaba a respetar la exención de los clérigos, quienes apelaron ante Fernando IV que, ante las reiteradas quejas del prelado cartaginense, intervino para mitigar el excesivo celo que el de Lorca ponía en su labor y ordenarle que no vulnerase las exenciones de la clarecía. El mismo afán y empeño puso cuando se encontraba ya del bando aragonés capitaneando un grupo de lorquinos entre los que se contaban sus hermanos înigo y Bertrán, «als quals el rei havia de donar sou per deu cavalls armats y deu alforrats» el almocaden Gil Pérez de Enebra, a quien Jaime Il había prometido un heredamiento de 500 sueldos de renta al año, los adalides Juan de Galve, Sanç Garcia y Blasco Miguel, así como otra serie de personas como Bernat Rubio, Juan de Lorca, Miguel de la Losella y otros. Tras la entrega de la ciudad y fortaleza continuó sirviendo en el ejército de guarnición en el Reino de Murcia «Pero Xemenez de Lorcha, II cavalls armats e II cavalls alforrats», durante los años 1303 y 1304. Todo ello fue motivo de que, años antes, fuese acusado de colaboracionista y sufriese la confiscación de dieciséis tahúllas de tierra que poseía en el campo de Lorca así como el desprecio de una buena parte de sus conciudadanos que no compartían su visión de las cosas. Jaime II, premiando su lealtad y buscando su rehabilitación como ciudadano, le otorgó varias casas en el casco urbano de Lorca y diez tahúllas en su termino para compensarle de las pérdidas materiales sufridas. Las otras tendrán más difícil solución como lo prueba el hecho de que, terminada la ocupación y vuelta Lorca al dominio castellano, Pedro Ximénez abandonó la ciudad y Castilla y marchó a vivir al reino de Aragón, muy posiblemente en Orihuela o Valencia, territorios por los que se mueve más frecuentemente y en los que llevaría a cabo actividades comerciales relacionadas con el abastecimiento alimentario, como en Febrero de 1305 cuando obtiene un permiso y salvoconducto real para sacar 300 cahíces de trigo de Orihuela y transportarlos a Valencia, mientras que el día 19 de Mayo de 1305 se encontraba en Elche testificando las modificaciones realizadas en la Sentencia de Torrellas. Su ausencia de tierras lorquinas no duraría mucho tiempo, ya que, siempre con fortuna, buscó la sombra de don Juan Manuel, adelantado mayor del Reino de Murcia, a cuyo servicio lo encontramos en 1307, lo que justifica que al año siguiente se encuentre en Lorca, protegido de toda represalia por el señor de Villena. TORRES FONTES, J., Repartimiento de Lorca; pp. 23-24. 1295-XI-20 y 1295-XI-24, ambas en Medina del Campo, TORRES FONTES, J., Documentos de Fernando IV. Docs. XVII y XIX. 1303-XII-28, Valencia y 1305-II-28, Calatayud, ESTAL GUTIÉRREZ, J.M. del, Op, cit. Docs. 279 y 320. FERRER I MALLOL, M.T., Organització i defensa d'un territori fronterer. La Governació d'Oriola en el segle XIV. Barcelona, 1990; pp. 30, 231, 265 y 291. Docs. 32, 1303-V-18, Valencia; 39, 1304-III-1, Calatayud; y 61, 1308-III-28, Murcia. BENDICHO, V., Chronica de la Muy llustre, Noble y Leal Ciudad de Alicante. Edición a cargo de M. Luisa Cabanes Catalá. Vol. III-2. Alicante, 1991; p. 616. 
que pudo residir en la ciudad de Lorca en los tiempos precedentes a 1300, algunos de ellos muy alejados de lo que debió de ser la realidad y otros más cercanos y por ello más exactos y verosímiles, aunque igualmente incomprobables ni cotejables. Tendría que pasar mucho tiempo y llegar hasta 1498 para encontrar algo más preciso, porque en ese año, con motivo de los enlaces matrimoniales de Isabel y Catalina de Castilla, hijas de los Reyes Católicos, se efectuó una derrama extraordinaria por las poblaciones del Reino en la que estaban obligados a contribuir todos, salvo los clérigos. Pues bien, en el padrón que al efecto se elabora en Lorca se incluyen 1.148 vecinos, de los cuales 30 constan como emigrados, cifra que representa el 2 ' $61 \%$ y que muestra que la emigración desde Lorca es moneda corriente y se prolonga por tiempo. En total son 1.118 los lorquinos obligados a contribuir de su bolsillo a los gastos derivados de las principescas bodas, lo que conduciría, según lo hecho hasta ahora, a unos 5.031 habitantes ${ }^{52}$. En conjunto y a modo de resumen meramente orientativo, se insertan a continuación los datos hasta ahora manejados en el presente estudio:

\begin{tabular}{|c|c|c|c|c|c|c|c|c|}
\hline \multirow{2}{*}{$\begin{array}{l}\text { Años } \\
\text { Vecinos }\end{array}$} & \multirow{2}{*}{$\frac{1245^{53}}{2.000}$} & \multicolumn{2}{|c|}{$12661266 / 70$} & \multirow{2}{*}{$\begin{array}{r}1272 \\
153\end{array}$} & \multicolumn{2}{|c|}{$13001330 / 37$} & \multirow{2}{*}{$\frac{1493^{54}}{1.500}$} & \multirow{2}{*}{$\begin{array}{r}1498 \\
1.118\end{array}$} \\
\hline & & $90^{55}$ & 720 & & 224 & 585 & & \\
\hline Habitantes & 9.000 & 405 & 3.240 & 688 & 1.008 & 2.632 & 6.750 & 5.031 \\
\hline
\end{tabular}

Del cuadro precedente y tomando como base los habitantes de 1498, el dato más fiable, ya que se trata de un padrón de la totalidad de la población, aunque, en este caso como en los anteriores, la correspondencia entre vecinos y habitantes no responde exactamente a la realidad, ya que no hay datos suficientes para analizar con rigor la estructura familiar de la población lorquina, por lo que incluso el coeficiente empleado puede ser erróneo y hay que bajarlo, se llega a una serie de conclusiones. La primera es que hay una enorme diferencia entre 1498 y 1243, una pérdida de 3.969 habitantes que indica, junto con las cantidades expresadas en otros años, que el montante de 9.000 habitantes no es real sino que habría de ser muy inferior.

52 MARTÍNEZ MARTÍNEZ, M., «La población de la ciudad de Lorca en 1498». En Miscelánea Medieval Murciana, XII. Murcia, 1985; p. 31. Lorca era la segunda ciudad del Reino de Murcia en cuanto a población se refiere después de la capital que, a fines de la Edad Media, contaba con un contin. gente situado entre 8.000 y 10.000 habitantes. TORRES FONTES, J., Estampas de la vida en Murcia en el reinado de los Reyes Católicos. La Población. Murcia, 1984; pp. 227-235.

53 Según las afirmaciones de Juan Avellán. Se ha estàblecido el año 1245 como el final de Lorca con población solamente islámica, pues por estas fechas ya había cristianos ocupando el alcázar.

54 Las cantidades asignadas a 1493 corresponden a toda la etapa cristiana en la que, a tenor de lo dicho por el procurador de Lorca en el pleito de Xiquena, Lorca mantuvo una cifra de población estabilizada y nunca inferior a los 1.500 vecinos y figuran en ese año por ser la fecha en la que realizó tal aserto.

55 En 1266 ilegaron a Lorca 107 pobladores, pero se han descontado para realizar el cómputo los 17 que se sabe que emigraron a los pocos años. 
Otra es que entre 1266 y 1272 poblaban en Lorca 4.333 habitantes cristianos, muchos de los cuales, como ya se ha dicho, tomaron otros rumbos y se alejaron del valle del Guadalentín en busca de una mayor seguridad y mejores posibilidades. La inmensa mayoría de los que permanecieron y que figuran entre los 224 de 1300 fueron heredados en la Segunda Partición y no hay nadie de la efectuada en 1266, pioneros con un enorme trabajo que hacer con escasos medios y abundantes incomodidades y adversidades, lo que puede indicar que el número de emigrados había sido mayor de los 17 apuntados, o bien que en ese espacio de tiempo de siete años la muerte se había llevado por delante a muchos de ellos y, también, a la escasa entidad social de los llegados que no llegan a alcanzar los puestos de importancia en la sociedad, como sucede en la Segunda, debido al carácter de los primeros pobladores cuya labor esencial era servir de guarnición en la fortaleza.

Cabe pensar que los 1.008 habitantes del año 1300 corresponden en su mayoría, a juzgar por los identificados en el Repartimiento, a familias del escalafón económico alto, que no representaría más allá de la tercera parte de la población que, en este caso estaría formada por unas 3.024 personas, varias de las cuales abandonarían la ciudad tras la marcha de los aragoneses y de ellas regresarían muy pocas tras el perdón de Fernando IV ${ }^{56}$.

Entre 1330 y 1337, años de la Cuarta Partición, llegaron a Lorca 2.632 nuevos pobladores que, sin duda, encontraron amplios espacios en los que asentarse y abundantes tierras para cultivar, pero las necesidades eran muy superiores a los medios por lo que hacia falta más gente, de modo que la población lorquina con este aporte no sufriría un incremento sustancioso, pudiendo elevarse la cifra de pobladores muy poco por encima de los 3.000 .

56 Pocos años después de Torrellas, en 1308, un suceso fronterizo permite una nueva aproximación a la demografía lorquina. Juan Domínguez, Deán de la Iglesia de Cartagena, informaba a Ferrer Descortell, bayle general de Orihuela, que el martes, 26 de Marzo, por la noche entraron en tierra de Murcia unos 40 jinetes que al amanecer se encontraban ya en Sangonera con una presa de unas 150 cabezas de ganado mayor, entre vacas y yeguas, y entre 5.000 y 6.000 cabezas de ganado menudo, con todo lo cual, protegidos por una densa niebla, iniciaron el regreso hacia el territorio granadino, perseguidos por los de Murcia que llevaban dos leguas - 11.144 metros- de retraso. Al contingente murciano se sumaron Pedro Ximénez de Lorca y los que "sallieron de Lorca, bien DCCC peones". Una nueva cifra de 800 lorquinos que se enfrentaron junto a los demás con los granadinos que dirigía el hijo de Çaen, posiblemente el mismo Zaen que dirigía a los granadinos que apresaron a los vendimiadores en 1283. Cabe plantearse el porcentaje de población que suponen esos 800 , ya que si todos fueran cabeza de familia, representarían una cantidad de 3.600 habitantes a los que habría que sumar los que no participaron en la batalla y que elevaría. el número. Pero resulta lógico pensar que dentro de los lorquinos que salieron en apellido habría una mayoría de jóvenes entre 15 años, edad en la que se tenía capacidad para empuñar las armas, y 25 años, la mayoría solteros o padres de poca prole, quedando el resto para los de más edad, y es posible que participasen padres e hijos. Por la importancia de la cabalgada granadina debieron salir casi todos los que eran capaces de manejar un arma, como las ballestas, uno de cuyos disparos hirió de muerte al hijo de Çaen, quedando los menores de 15 años, los ancianos y las mujeres en la ciudad de Lorca que, hipotéticamente, contaría con unos 2.500/3.000 habitantes, casi los mismos que en 1300. 1308-III-28, Murcia. FERRER I MALLOL, M.T., Op. cit. Doc. 61. 
Para 1493, lo mismo que para todo el período de poblamiento cristiano, Juan Avellán habla de 1.500 vecinos, es decir 6.750 habitantes, guarismo que no puede corresponder a la realidad por dos cuestiones. La primera es la descripción de Münzer, viajero alemán que pasó por Lorca el día 15 de Octubre de 1494 y que expresaba su parecer sobre lo que tenía ante sus ojos: "Creo que tiene cerca de 800 casas bien defendidas, por estar habitadas continuamente por el ejército" ${ }^{57}$. $Y$ es la otra que en fecha cercana, como es 1498, la población se sitúa en 5.031 habitantes y un espacio de cinco años no es tiempo para que la demografía lorquina perdiese 1.729 habitantes por muchos que se fueran a poblar en las recientemente conquistadas tierras granadinas, salvo catástrofe que no hay constancia que se produjera ${ }^{58}$.

Queda claro, por tanto que la continuidad de los repobladores, pasado un tiempo de estancia en Lorca, no cubre las previsiones de Alfonso $X$ y que tan sólo una porción de los llegados quedará residiendo de continuo en Lorca, de modo que hay que insistir en unas bajas demográficas importantes que llevaron al abandono de extensas zonas de cultivo, circunscritas al ámbito cercano a las defensas muradas de la población y que el resto del territorio fuese paradigma de la desolación y las otrora superficies cultivadas fuesen ahora zona de herbaje para los rebaños y demás fauna adscrita a este tipo de alimentación, tanto doméstica como salvaje. En consecuencia, a falta de datos que permitan desbancar esta hipótesis, en el espacio cronológico centrado en los años de transición del Siglo XIII al XIV, en la fase de dominación aragonesa, la ciudad de Lorca pudo contar con una población total comprendida entre los 2.500 y 3.000 habitantes, más cercana a la primera que a la segunda cifra.

La Sentencia de Torrellas ponía fin a la presencia aragonesa en Lorca y Fernando IV se aprestaba a perdonar a los vecinos de Lorca "todas las cosas que fizieron et dixeron fasta el dia que esta carta es fecha» ${ }^{59}$. Comenzaba una nueva fase, tan agobiante o más que la que ahora se cerraba, pues la Lorca que retorna al dominio de Castilla presenta un panorama muy triste: no había población, ya que muchos de los

57 MÜNZER, J., Viaje por España y Portugal. Madrid, 1991; p. 69. Es de suponer que en cada una de esas no viviera un solo soldado, sino que serian familias y no mayoritariamente militares, pues 800 es un número elevado para un ejército de guarnición en Lorca en 1494, año en el que no tiene objeto el estacionamiento de tal contingente pues la frontera ya sólo era recuerdo. Por ello hay que entender que se trataba de viviendas en la población y volviendo a aplicar el coeficiente de 4'5 resultarían unas 3.600 personas, las mismas que habitaban en las edificaciones vistas por el andariego alemán.

58 Cánovas Cobeño indica refiriéndose a la obra de MÉNDEZ SILVA, Población general de España, editada por segunda vez en 1675, que Lorca "era una población de casi dos mil vecinos», lo que nos lleva otra vez a una aproximación a los 9.000 habitantes del periodo musulmán, aunque para 1675 la cifra es más real. En 1708 eran 2.854 vecinos - 13.643 habitantes-, mientras que en 1755 , los vecinos eran ya 7.295 -32.827 habitantes-y en 1772 poblaban Lorca 9.000 vecinos, unas « 40.000 almas", caso en el que la utilización del coeficiente 4 '5 no va descaminado ya que realizada la operación resultan 40.500 vecinos, 500 más de los dados por CÁNOVAS COBEÑO, F., Op. cit.; pp. 414 y 461.

59 1304-VIII-10, Agreda, confirmada en 1305-III-14, Guadalajara. TORRES FONTES, J., Documentos de Fernando IV. Docs. XXVI y XL. 
que se marcharon con los aragoneses no volvieron temiendo las represalias de sus antiguos vecinos a pesar de las garantías del rey, los bienes escasos y la tierra vacía y yerma, una carencia total de perspectivas, al igual que sucedía en todo el Reino de Murcia. En adelante Lorca no sería más que una fortaleza situada en un territorio frecuentemente visitado por huestes armadas de uno u otro lado de la frontera, como las murcianas que en 1309 conquistan el castillo de Lubrín o las aragonesas que, con menor fortuna, intentaron la conquista de Almería en 1310. En suma, años difíciles y oscuros, pues la vida por "entonces era un mero persistir, sin más variantes que las alternativas fronterizas; la continua sucesión de años, uno tras otro, bajo el mismo desesperanzador horizonte sin que se prevea inmediato cambio... no surgen nuevas necesidades $y$ todo se reduce a resistir, pervivir, sin que ningún avance se consiga» 60 .

\section{JUDÍOS Y MUSULMANES. AUGE Y DECADENCIA DE UNA MINORÍA}

En las páginas anteriores la población cristiana de Lorca, la que configuraba la mayoría de la sociedad, ha sido la protagonista. Ahora, sin repetir los condicionamientos generales que les afectaban en cuanto eran pobladores de Lorca, es tiempo de pasar a estudiar a los dos grupos étnicos que se encontraban en ella. Por lo que respecta a los musulmanes hay que decir que las fuentes existentes guardan el más absoluto silencio, lo que puede ser debido a tres causas. La primera que no había, otra la exención total de impuestos, salvo alcabalas, diezmo y medio diezmo de lo morisco y tributos concejiles que gozaban Lorca y sus habitantes, lo que justificaría la inexistencia de padrones recaudatorios, $y$, tercera que no han llegado hasta nosotros documentos al respecto. En todo caso, hay que indicar que la posición de Lorca, próxima a la frontera, nunca aconsejaba contar con una numerosa población de musulmanes, siempre en contacto con el lado granadino y cuyo control sería problemático en todo momento ${ }^{61}$, de

60 TORRES FONTES, J. y TORRES SUÁREZ, C., Op. cit; pp. 162-163. También Cánovas insiste sobre el particular e indica que «resultó que gran parte de sus moradores, acaso la más numerosa y trabajadora, quedó sin recursos para vivir en el país, viéndose en la necesidad de abandonarlo", y la población que quedó, a causa de «las continuas luchas en que de ordinario estaba ocupada, no podía atender al cultivo de los campos». CÁNOVAS COBEÑO, F., Op. cit.; pp. 243-244. La permanencia de algunos repobladores es continua y sus descendientes ilegan al Siglo XV. Así tenemos a Pedro Calafad y a Jaime Calafad, descendientes de Juan Calafat; Juan Dotón el viejo y Juan Dotón, acaso su hijo, herederos del repoblador Adán Dotón; Fernando Azor, Fernando Azor el mozo, Juan Azor, Pedro Azor el viejo, Pedro Azor el mozo, descendientes de Guillén Azor; también encontramos a Alonso de Chuecos, Domingo de Chuecos, Alonso de Chuecos, Rodrigo de Chuecos, posiblemente emparentados con Juan de Chuecos; Juan Mellado y Pedro Mellado, apeilido ilustre de Lorca, descendientes del poblador Pascual Mellado; Ferrán Pérez de Tudela, criado de Juan Mellado, acaso descendientes de Miguel Pérez de Tudela; Antón de Ribahorada cuyo apellido familiar procede del repoblador Martín de Ribaforada y, finalmente, de la familia Aorero o Avorero procede Juan Aorero, yerno de Medina. A.M.L. Repartimiento de las Parroquias de Santa María y San Jorge. Caja 3, Núm. 3.

$61 \mathrm{Y}$ es que los musulmanes siempre mantendrían un espíritu de revancha latente y nunca aflorado por las escasas posibilidades de éxito. En Lorca ese ánimo opositor a los castellanos ya se manifestó cuando Muhammad ben Ali ben Ahla, miembro de una familia muladí de rancio abolengo "entre la 
manera que tras la experiencia de 1264 en que consiguieron dominar la ciudad pero no la fortaleza, don Alfonso, considerando el potencial éxito de los repartimientos no pondría muchos impedimentos a su salida de la ciudad y bastantes trabas para su establecimiento en ella, como lo prueba el que entre 1268 y 1272 solamente se registra el heredamiento de un musulmán, Alcayd Aben Bez, que recibe en la Segunda Partición una caballería menos cuarta ${ }^{62}$. La población mudéjar lorquina se vería reducida muy considerablemente, como sucedía en otras poblaciones del adelantamiento como Murcia, y si no desapareció por completo sería tan mínima su presencia y actividad en el marco socioeconómico que no ha quedado rastro alguno en los documentos y, así, no resulta exagerado afirmar que la inmensa mayoría de los musulmanes que habitaban en Lorca emigraron en los años inmediatamente posteriores a $1266 \mathrm{y}$ que en 1300 su presencia era ya totalmente residual ${ }^{63}$.

Pese a ello, hay algunos datos que parecen apuntar hacia una presencia de mudéjares en Lorca antes y después de 1300, pues en 1293 la "aljama de Lorca" debía a

gente de Lorca no la había ni más valiente ni más numerosa», se proclamó emir y pasó a defender la independencia del territorio, primero con la dialéctica que le proporcionaba su formación teológica y, después, por medio de las armas: "Cuando sus habitantes entregaron Murcia a los cristianos en el mes de shawal del año 640 - Abril de 1243-, consideró errónea la decisión y manifestó su oposición polemizando con ellos con su lengua y batiéndose contra ellos con su lanza», hasta que se vio forzado a pedir la paz. Muhammad se mantuvo en esa actitud opuesta radicalmente al dominio castellano hasta su muerte acaecida en los primeros días del mes de Mayo de 1247. CARMONA GONZÁLEZ, A., "Textos árabes del Reino de Murcia entre 1243 y 1275. Aspectos jurídicos y políticos». En Glosae, 5-6. Murcia, 1993-94; p. 243.

62 TORRES FONTES, J., Repartimiento de Lorca; p. 13.

63 Desde 1243 la emigración de musulmanes lorquinos hacia Granada, lo mismo que sucedía en las restantes poblaciones del Reino de Murcia, fue constante y alcanzó su punto culminante a raíz de los sucesos de 1264-66, aunque todavía permanecerían musulmanes hasta 1275, año en el que, según Ibn Idari, después de fracasada la revuelta en 1266, los musulmanes de Murcia «entregaron la ciudad a los cristianos y éstos les permitieron salir de ella con garantía de salvaguarda e instalarse en la Arrixaca, donde residieron por espacio de diez años, hasta que les sucedió lo que les sucedió cuando fueron expulsados en el año $673 »-1274-75$ - El texto no deja duda en cuanto a que la salida de los mudéjares murcianos en 1274-75 no fue voluntaria sino que hubo una expulsión, un desalojo forzoso cuyas causas y circunstancias no indica. Por otro lado están las recomendaciones y arengas de los oradores como al-Wansharisi que incitaban a la emigración en masa argumentando que «entre un país donde impera la incredulidad y un país (islámico) donde hay injusticia, es preferible este último", - las frases del magrebí Ibn Miqlas, ya del Siglo XIV, que afirmaba su convicción de que "Dios es enemigo de los infieles y estos son enemigos de los Profetas y Enviados, por ello no se puede aceptar que un musulmán tenga como vecino a quien es enemigo de Dios y del Profeta" y por si eso fuera poco, todavía continua proclamando que «Aquel que se deja seducir por la creencia de que en la tierra de Islam no alcanzará los bienes que tiene en tierra de infieles, ha abandonado todo temor de Dios y toda confianza en Él». CARMONA GONZÁLEZ, A., Textos árabes acerca del Reino de Murcia...; pp. 245 y 248. Lo sucedido en Murcia y la llegada de los expulsados camino de Granada a Lorca, donde contarían lo sucedido, unido a las incitaciones a la emigración realizadas por los muftíes sin duda tendrían repercusiones en Lorca y sus consecuencias no serían otras sino el abandono de la población por todos o casi todos. 
Sancho IV 569 maravedís ${ }^{64}$, pero la ambigüedad del dato no invalida lo dicho y, a falta de mayores precisiones, hay que señalar su continuidad en los Siglos XIV y XV. También se han querido ver como mudéjares habitantes en Lorca a cinco individuos que figuran en el mencionado padrón de 1498: Andrés Habibe, Ça Granada, Pedro de Alhajarín, Arrián Ça y Albarracín, pero esto no puede ser nada más que un error ${ }^{65}$. Finalmente, el carácter residual de la población mudéjar de Lorca se refleja en los padrones de contribuyentes de las morerías del reino correspondientes a los años

64 CÁNOVAS COBEÑO, F., Op. cit; p. 160 . Se trata de la única noticia existente a este respecto, lo que contrasta con los silencios documentales y con la certeza de que Lorca por estos años quedó "reducida a la condición, no de una población regular, sino de una plaza o presidio militar fortificado", en donde los castellanos no querían tener cerca musulmanes pues tenían bastante con los granadinos, lo que encaja en la política seguida por Sancho IV y Alfonso XI que no querían que en las ciudades cabeza de sectores fronterizos hubiese población musulmana en número que pudiese suponer una amenaza. También cabe pensar que él historiador de Lorca utilizase el término «aljama» referido a musulmanes cuando debía estarlo a los judíos, ya que trata de unos y otros conjuntamente. Ibid; p. 244.

65 «Sin contar a Ça Granada, que consta como emigrado, el número de mudéjares, vecinos de Lorca, en 1498 quedaría reducido a cuatro". MARTíNEZ MARTÍNEZ, M., Op. cit.; p. 36. En mi opinión, la identificación de estos nombres como pertenecientes a mudéjares es muy forzada y en algunos casos imposible. El nombre de algunos: Andrés y Pedro es cristiano y si eran de ascendencia musulmana serian conversos o cristianos nuevos y nunca contribuirían como musulmanes ni serían tenídos por tales. Respecto a Arrián --tal vez Adrián- Ça, lo mismo que del emigrado Ça Granada, hay que decir que su origen musulmán es imposible por llevar Ça, vocablo que, como es bien sabido, se trata de una partícula residual del demostrativo latino ipse-ipsa-ipsum, que indicaba la identidad de uno mismo con respecto a los otros, y que actualmente se utiliza en esta misma forma -ça- en Mallorca, de manera que Ça Granada nunca puede ser tildado de musulmán por el Ça que significa la Granada referido a persona y no a la ciudad, y en este caso hay un dato significativo contenido en el padrón antes mencionado en Nota 60, que no lleva fecha, aunque por los nombres en el contenidos, como Martín Fernández Piñero, homónimo del famoso alcaide, o el notario García López y otros, puede ser fechado en la segunda mitad del Siglo XV, donde figura «El fijo de Catalina Sa Granada», avecindado en la parroquia de San Jorge, tal vez este y el que nos ocupa sean la misma persona. (A.M.L. Repartimiento de las Parroquias de Santa María y San Jorge, fol. 6r.). En cuanto a Arrián Ça le falta el apellido. En cualquier caso se trata de algo muy frecuente en la lengua catalana, tal y como aparece en los nombres de repobladores en Murcia y Orihuela, que nada tienen que ver con musulmanes: Berenguer Ça Sala (Berenguer la Sala), Berenguer Ça Cambra (Berenguer la Cambra), Berenguer Ça Riera, Arnalt Ça Riba, Bernardo Ça Gra, Bernardo Ça Sala, Guillen Ça Torre o Ferrer Ça Font. TORRES FONTES, J., Repartimiento de Murcia. Murcia, 1960; pp. 17, 28, 32, 33, 55, 61 y 250. Berenguer Za Burguera, Berenguer Za Sala, Bernat Ça Torre de Valencia, Bernat Zavilla, Bernat Çarriera. TORRES FONTES, J., Repartimiento de Orihuela. Murcia, 1988; pp. 26, 30, 42, 66, 70, 93, 106, 113, 122, 143, 194, 259 y 273. En cuanto a Albarracín su origen musulmán esta fuera de toda duda, pero, en este caso, más parece tratarse de apellido, por cierto muy frecuente en Lorca, que de nombre, caso, por ejemplo, del lorquino Ginés de Albarracín, nominado en el referido Padrón del Siglo XV, o del jurado de Murcia, Martín Díaz de Albarracín, en 1384, que no son musulmanes ni hay motivo para atribuirles una más que dudosa ascendencia islámica; de todas maneras, que una persona lleve un nombre toponímico no quiere decir nada en cuanto a su raza y religión puesto que hoy ya es claro que no todos los que llevan tal apellido son conversos o descendientes de musulmanes o judíos. Por todo elio no creo posible que los considerados musuimanes en tal padrón lo sean. 
1495 a 1501, pues solamente figura una "pecha» en Lorca, referente al año $1496^{66}$, lo que tampoco es indicativo de que la morería lorquina, si la había, estuviese poblada.

En cuanto a los judíos se refiere también hay una carencia documental importante sobre todo en los Siglos XIII y XIV, pues sólo hay datos dispersos para el Siglo XV, lo que no impide pensar que en Lorca, como sucedía en otras poblaciones del adelantamiento murciano, un sector de la población estaba integrado por judíos. Es bien sabido que Fernando III y su hijo Alfonso X se apoyaron en la colaboración de los judíos para afianzar su dominio sobre los territorios que habian incorporado en Andalucía y Murcia, estimulando por ello la inmigración ${ }^{67}$, de manera que en las ciudades recientemente anexionadas en el Reino de Murcia las comunidades judías, amparadas y protegidas por Alfonso $\mathrm{X}$, no sólo verán garantizada su supervivencia sino que recibirán nuevos aportes demográficos ${ }^{68}$.

Como ya expuse en otra parte, no hay motivo para negar que en la Lorca musulmana ya existía una comunidad judía que, junto a la islámica, testificó con su presencia el cambio operado cuando las tropas castellanas, dirigidas por el entonces heredero de Castilla hicieron su entrada en la ciudad para ocupar el alcázar y también presenciaron el cambio operado a raíz de 1266 cuando la hasta entonces plaza musulmana se convirtió en el núcleo fronterizo más importante del nuevo territorio sumado a Castilla, reino al que desde ese momento pertenecerán ${ }^{69}$. La frontera entre Castilla y Granada por el Reino de Murcia separaba dos territorios por muchas y obvias razones diferentes, pero no podía impedir, que a uno y otro lado hubiese varios nexos comunes uno de los cuales es la existencia de comunidades judías, unidas por lazos familiares, de amistad o de relaciones comerciales, ya que no sería raro el caso de

66 LADERO QUESADA, M.A., «Datos demográficos sobre los musulmanes de Granada». En Anuario de Estudios Medievales, 8. Barcelona, 1972-73; p. 487. El criterio del recaudador era anotar las «pechas» de cada aljama y en las cuentas generales el autor calcula cinco personas por "pecha" cuya cuantía era uno o dos castellanos (485 ó 970 maravedís). Aunque «pecha" es un concepto "que no puede ser equiparado con el de vecindad aunque se le aproxime mucho, porque pechaba todo mudéjar que tuviera hacienda propia y apartada, aunque fuese menor de edad». Ibid; p. 487. Del estudio del Dr. Ladero se distingue con claridad que, en 1496, considerando cinco personas por «pecha", había cinco musulmanes que pagaron en Lorca, aunque también puede tratarse de una «pecha" individual y en este caso contribuyese una sola persona con su familia. En todo caso está claro que no hay mención al respecto en 1495 y tampoco en los siguientes años hasta llegar a 1501, por lo que parece posible imaginar que este musulmán o musulmanes que pagaron en Lorca por tener una propiedad en el amplísimo término lorquino, -lo que no quiere decir que viviesen en ella, ya que podían residir, por ejemplo, en Vélez Blanco, Vélez Rubio, etc. y ser dueños de una tierra cercana a Xiquena por la que pagarían en Lorca-, vendieron o perdieron su propiedad y desaparecieron del entorno lorquino.

67 SUÁREZ FERNÁNDEZ, L., Judíos españoles en la Edad Media. Madrid, 1980; p. 98.

68 El ejemplo más claro de lo dicho se encuentra en la ciudad de Murcia en donde la comunidad hebrea constituía ya, en 1267, un grupo de cierta importancia, por lo que el monarca, atendiendo a la idea que había expresado en las Partidas, ordenó su apartamiento de vivienda con respecto a los cristianos y la formación de una judería. TORRES FONTES, J., Repartimiento y población de Murcia en el Siglo XIII. Murcia, 1990; p. 249.

69 VEAS ARTESEROS, F. de A., Los Judíos de Lorca en la Baja Edad Media. Murcia, 1992. 
judíos de Lorca que tuviesen parientes e intereses económicos en las poblaciones de lado granadino con las que mantenían frecuente contacto en el período islámico y que ahora no se verían interrumpidas, si acaso obstaculizadas por la existencia de esa línea invisible que es la divisoria y el peligro que conlleva para todos aquellos que se atrevian a cruzarla por las rutas que desde siempre habian comunicado las diferentes localidades antes unidas en una misma entidad política, étnica y religiosa y ahora separadas. $Y$, al igual que hicieran los musulmanes, aunque a menor escala ya que su número era mucho menor, cabe pensar en una emigración judía hacia otras localidades, como Orihuela, una vez finiquitada la rebelión mudéjar de 1264, que ocasionaría una despoblación en la judería.

Pero no sería un grave problema la emigración para la comunidad judía de Lorca porque muy pronto llegaron nuevos miembros puesto que, en efecto, está comprobado que los judíos se instalan en las poblaciones conquistadas al amparo de las ventajosas condiciones ofertadas por el monarca y que se reflejan en los documentos reales que otorgan exenciones y franquicias que inciden de lleno en las actividades económicas $y$, sobre todo, en los negocios y transacciones mercantiles que llevaban a cabo y, en este contexto, las posibilidades que ofrecía Lorca eran realmente excepcionales, porque la cercanía a la frontera, al margen de otras consideraciones de índole socio-política, abría grandes horizontes para el comercio, ya fuese legal o ilegal, con el otro lado, afluencia a mercados ya conocidos y visitados desde los años de dominio musulmán y ahora bajo jurisdicción granadina ${ }^{70}$. Sin embargo, la parquedad de noticias es angustiosa y para los años inmediatamente posteriores a la anexión solamente contamos, de momento, con dos.

Una corresponde a la Segunda Partición en la que el judío «Mose Avendaño, yerno de Mose Aventuriel»s recibió dos caballerías en la Cuadrilla de Arias Pérez ${ }^{71}$. La

70 El propio Cánovas Cobeño alude a esta realidad cuando indica que «algunos de los judíos que acompañaban a los ejércitos, no como soldados, sino como especuladores y comerciantes, aprovechando toda ocasión para ejercer su industria, no dejarían perder la que se les presentaba con la guarnición cristiana y con los vecinos moros. Retirados del centro de la población y al abrigo de la fortaleza estaban protegidos contra cualquier desmán de los moros, y así tuvo origen lo que se llamó después la Judería». Op. cit; p. 160.

71 Las características del heredamiento - caballería- indica que Mose Abendaño gozaba de una posición económica holgada, cosa que ciertamente vendría avalada por su parentela con Mose Aventuriel, almojarife real en 1281. TORRES FONTES, J., Repartimiento de Lorca; p. 27 y Fueros $y$ Privilegios de Alfonso $X$ el Sabio al Reino de Murcia. Doc. CLIII. Mose Aventuriel quizá sea el origen de una dinastía de judíos que durante dos siglos mantendrá una amplia y continuada presencia en la ciudad y reino de Murcia, sobre todo en las parcelas económicas, familia en la que se distinguen dos ramas principales. Una arranca en Mayr Aventuriel, uno de cuyos hijos, Mose Aventuriel, fue despensero y almojarife de Juan Sánchez Manuel, conde de Carrión, y otro, Zag Aventuriel, que ocupó varios años el cargo de recaudador de las alcabalas del Obispado de Cartagena. La otra parte de Abraham Aventuriel, padre de Zag Aventuriel y abuelo de Mose Aventuriel quienes también se dedicarán estos oficios recaudatorios. Tal vez Abraham y Mayr fuesen hijos de este Mose Aventuriel y, por tanto, cuñados del heredado en Lorca. También se encuentran otros: Salomón Aventuriel, padre de Zag Aventuriel; Yuzaf Aventuriel, Haym Aventuriel y otros del mismo apellido aunque de diversa procedencia: Mose Aventuriel de Albacete, Mose Aventuriel de Chinchilla, Soliman Aventuriel de Murcia. De todos ellos 
otra es una mención contenida en el Fuero de Córdoba que Alfonso X entrega a Lorca para su gobierno y que explicita que «ningund judio nin christiano nueuo non aia mandamiento sobre christiano de Lorca ni de su termino" ${ }^{72}$, y que es prueba de que en Lorca había una comunidad judía en 1271 y en ella, muy posiblemente, se integraría el yerno de Mose Aventuriel y ampliaría la red económica de la dinastía. Por lo demás, ya en 1273, la presencia de judíos por la comarca de Lorca, residieran o no en la ciudad, queda fuera de toda duda ${ }^{73}$.

No ha quedado disposición de Alfonso $X$ ni de sus sucesores, caso de que tal hubiese dado, por la cual especificase el lugar destinado a convertirse en recinto donde habrían de residir los judíos. Mas, sin embargo, de las afirmaciones contenidas en los documentos posteriores en los que los judíos de Lorca aluden a su lugar de residencia como «vezino e morador en el castillo de la juderia de la dicha çibdad» o bien "vezino del castillo desta dicha villa»" ${ }^{4}$, no dejan lugar a dudas. La Judería se encontraba en el interior de la amplísima fortaleza y ahí debió estar desde siempre, lo que justificaría la ausencia de órdenes reales en este sentido, y es cosa nada extraña pues en el Siglo XIII los judíos residentes en los núcleos urbanos más importantes de Castilla moraban en el castillo de cuya defensa defensa se van a ocupar, tal y como sucede en poblaciones tan distintas y tan distantes como Zorita, Haro, Cuenca y Astorga ${ }^{75}$.

Ubicados en ese lugar y comunicados con el resto del recinto del castillo por la «Puerta de la Judería», que con bastante frecuencia atravesarán en idas y venidas, los judíos desarrollarán su vida y ocupaciones, unas veces vinculadas al comercio local y otras a mayor escala, también los habrá dedicados al mundo de la frontera, como alfaqueques y espías, a veces una misma cosa, y también como contrabandistas, y, en fin, aquellos cuyo trabajo está vinculado a las recaudaciones de derechos, como el diezmo y medio diezmo de lo morisco que se cobraba en el "puerto de Lorca", atalayeros y vigilantes de la frontera y quienes consagren su vida al ejercicio de la medicina y farmacia, oficios tradicionalmente vinculados a esta raza ya en tiempos de

hay abundantes datos en el Siglo XIV.VEAS ARTESEROS, F. de A., «Documentos del Siglo XIV». Vol. 2 y 3. C.O.D.O.M. X y XII. Murcia, 1985 y 1990. También ROTH, N., "Los judíos murcianos desde el reinado de Alfonso $X$ al de Enrique Il». En Miscelánea Medieval Murciana, XV. Murcia, 1989; p. 34.

72 1271-VIII-20, Murcia. TORRES FONTES, J., Fueros y Privilegios de Alfonso $X$ el Sabio..., Doc. CXIV.

73 En ese año el Maestre de Santiago arrendó los derechos que la Orden poseía en Lorca y otros lugares a los judíos Bono, Jacobo y Samuel, sus almojarifes, para que se desplazasen a ellos y procediesen a su percepción. TORRES FONTES, J., «Documentos del Siglo XIII». C.O.D.O.M., II. Murcia, 1969. Doc. LV, LVI y LIX.

74 VEAS ARTESEROS, F. de A., Los judíos...; p. 33.

75 Como habitantes de una parte de la fortaleza los judíos de Lorca tendrán también una función militar que se centra en la defensa de, por lo menos, la porción de muralla que delimitaba la judería. Se trata de una actividad que tendrá continuidad y cuando lleguen los tiempos del enfrentamiento entre el alcaide lorquino, Alonso Fajardo, y su primo Pedro Fajardo, adelantado mayor, el primero entregará la guarda y defensa de la fortaleza, principal apoyo con el que contaba, al judío José Rufo. Ibid; p. 34. 
la presencia cristiana e incluso antes, pudiendo encontrar casos de judíos que trabajan en el cultivo de campos y huertas.

Los judíos de Lorca, lo mismo que sus conciudadanos cristianos, pasarán bajo la soberanía aragonesa tras la capitulación de la fortaleza, su lugar de residencia, en Enero de 1301, y tras los primeros momentos de espectativa, incertidumbre y cierto desasosiego ante el futuro que se presentaba al depender de un monarca desconocido, pasarán a la tranquilidad cuando vieron que el rey Jaime cumplía su promesa y confirmaba los privilegios y libertades de Lorca y de sus habitantes ${ }^{76} \mathrm{e}$ intentaba atraerse al mayor número posible de lorquinos dando muestras de una tolerancia modélica que, como es lógico, también les iba a afectar aunque las razones que don Jaime tuviere para ello eran otras ${ }^{77}$. Una vez dominado el Reino de Murcia, el monarca aragonés se dispuso a regulación la nueva situación y a garantizar la seguridad de las comunidades judías así como facilitar sus actividades e incremento demográfico, por lo que, en 1296, concede seguro al ilicitano Isaac Vidal para que pudiese trasladarse con todos sus bienes a vivir a Murcia, con la única condición de que permaneciese bajo su vasallaje y soberanía, mientras que, poco después, otorgaba salvoconducto a los judíos de Cartagena para que pudiesen desplazarse por todo el territorio del adelantamiento murciano con total libertad y franquicia, al tiempo que les perdonaba cualquier delito que hubiesen cometido en tiempo de la soberanía castellana ${ }^{78}$.

La defensa que el rey de Aragón hace de las juderías que encuentra en las poblaciones del Reino de Murcia, quedan plasmadas en las confirmaciones de sus privilegios y libertades, como sucede en Cartagena y $\mathrm{Mula}^{79}$, por las que el soberano pretende evitar la disminución de efectivos que traería la huida de muchos de sus miembros, lo que no es óbice para que estuviese dispuesto a cortar los abusos que los prestamistas judíos cometían en el cobro de intereses de los préstamos que hacían y

76 En efecto, en 1300-XII-29, Lorca, el monarca aragonés prometía proceder a la confirmación de los fueros y privilegios de Lorca una vez que se le entregase el alcázar y en 1300-Y-21, Murcia, así lo hace incluyendo las donaciones que la localidad y sus vecinos hubiesen recibido de los reyes de Castilla. ESTAL GUTIÉRREZ, J.M. del, Op. cit; Doc. 145 y 158.

77 Los judíos en Aragón eran considerados como patrimonio personal del monarca, lo que también sucedería con los residentes en Lorca, por lo que está plenamente justificado el interés de Jaime Il por mantener e incluso aumentar la población de las aljamas que, por otra parte, le proporcionaban grandes ingresos. Agradezco esta aclaración al Doctor Yon Tov Assis, Profesor de la Universidad de Jerusalén.

78 1296-VI-1, Alhama y 1296-VI-3, Lorca. ESTAL GUTIÉRREZ, J.M. del, Op. cit. Doc. 96 y 97.

79 1296-VII-15, Huerta de Lorca, confirma los privilegios a la judería de Cartagena, y 1296-VIII-2, Murcia a la aljama de Mula, cuyos vecinos serán protegidos por Jaime II frente a los atropellos que padecían por parte del comendador santiaguista de Caravaca, Cehegín y Bullas, frey Lope Pays, que retenía ciertos bienes que pertenecían a los hermanos muleños Yuzaf y Abolazar en esas poblaciones. Los judíos de Murcia solicitarán y obtendrán la seguridad del rey «quels jueus e els moros sien salues persones en tot lo seu. E plau al senyor rey". ESTAL GUTIÉRREZ, J.M., Op. cit. Doc. 117, 126, 127,128 y 141 . 
limitase el importe de los mismos ${ }^{80}$, prohibiendo que los intereses de los créditos pudiesen superar los cuatro dineros por cada libra al mes, bajo pena de perder la suma prestada que sería adjudicada por mitad al deudor y al erario público.

Cuantificar la población de la judería de Lorca en 1300 es imposible porque no hay datos. En realidad, solamente existe un documento de excepcional importancia para este aspecto y es el Padrón de la Contribución que los judíos debian pagar para la guerra de Granada ${ }^{81}$. En la distribución de los fondos necesarios para financiar las campañas, los habitantes de la judería lorquina estaban obligados a contribuir según lo siguiente:

\begin{tabular}{|crrrrrr|}
\hline Años & Cantidad & $\mathbf{1 / 3}$ & Contrib. & $\mathbf{2 / 3}$ & Contrib. & Habitantes \\
\hline 1485 & 18.430 & - & - & - & 38 & 171 \\
\hline 1489 & 14.360 & 4.787 & $?$ & 9.573 & 20 & 90 \\
\hline 1490 & 11.785 & 3.929 & $?$ & 7.856 & 16 & 72 \\
\hline
\end{tabular}

En 1485 los judíos de Lorca habían de abonar 38 castellanos, esto es aquellos que disponían de numerario suficiente como para hacer frente a un gasto de 485 maravedís que valía cada castellano, por tanto, en este caso, no ofrece duda que 38 eran los habitantes de la aljama lorquina con esas características, siendo posible volver a instrumentar el coeficiente de 4'5 y obtener un resultado de 171 habitantes integrados en familias con un nivel adquisitivo alto o, por lo menos, muy por encima de la media de la judería. Pero, en los años 1489 y 1490, se produce una sustancial variación, ya que la contribución, aparte de venir cifrada en maravedís y no en castellanos de oro, no se impone totalmente por cabezas sino que se distribuye en dos conceptos, 1/3 sobre la capacidad económica de los afectados y 2/3 por cabezas; en consecuencia, tenemos que, en 1489, la cifra se ha rebajado en 4.070 maravedís, lo que puede ser indicativo de una disminución de la población en la judería o de unas menores necesidades para la campaña. En todo caso, el montante de 9.573 maravedís, correspondiente a los $2 / 3$ recaería sobre 20 judíos, teniendo que pagar a cada uno $478^{\prime} 6$ maravedís, cantidad no muy inferior a la que tuvieron que abonar en 1485 , y en

80 1295-V-11, Orihuela. Con igual energía tratará de cortar de raíz las actitudes de algunos cristianos que buscaban amparo en la religión y en las disposiciones eclesiásticas para no pagar los débitos que tenían contraídos con judíos o mudéjares, por el simple hecho de no ser cristianos. Por ello ordenará a sus oficiales que hagan abonar a todos los acreedores del judío catalán Abraham las sumas que le debían, hubiese o no escritura pública y siempre y cuando les constase la veracidad de las reclamaciones del judío que, por otra parte, no estaba dispuesto a perder su capital. ESTAL GUTIÉRREZ, J.M. del, El Reino de Murcia bajo Aragón (1296-1305). Alicante, 1985. Doc. 31 y 99.

81 Publicado por SUÁREZ FERNÁNDEZ, L., Documentos acerca de la expulsión de los judíos. Valladolid, 1964. Doc. 141. 
este caso, atendiendo solamente a los obligados a pagar los $2 / 3$, tendríamos una población de 90 habitantes para 1489.

En 1490 , la cuantía sigue decreciendo en 6.645 maravedís con respecto a 1485 y en 2.575 si la referencia es 1489 , en total una rebaja de 9.220 maravedís entre los dos años, cifra ciertamente importante. La cantidad de 7.856 maravedís, correspondiente a los $2 / 3$ del montante total, quedaría en manos de 16 judíos para que la abonasen a los plazos reglamentados, correspondiendo a cada uno 491 maravedís, 6 maravedís más de los pagados en 1485 y 13 maravedís más que los abonados en 1489 , de manera que aunque se produce una rebaja global, los más adinerados pagaban más en 1490 que en 1485 . Siguiendo el procedimiento antes empleado obtendremos la cifra de 72 habitantes en la judería lorquina en 1490. Queda por saber cuántos tenían que hacer frente al pago de las cantidades asignadas en $1489-4.787$ maravedís - y 1490 - 3.929 maravedís - al tercio restante que, como queda dicho, se distribuía según la capacidad económica de los afectados, pero eso es tarea imposible ya que no hay datos, aunque no tendrían que ser muchos. Por ello, dejando siempre la puerta abierta a nuevos datos, ya que todas estas cifras son totalmente aproximadas y sujetas a variaciones, una cifra situada entre los 120/250 habitantes para la judería de Lorca a fines del Siglo XV no parece exagerado.

Partiendo de aquí y yendo hacia atrás en el tiempo se podría conjeturar, sólo eso, sobre la ocupación demográfica de la judería de Lorca en 1300 , según los criterios expuestos a lo largo del presente estudio, y establecer una población cercana al centenar de personas, una cifra en absoluto real, acaso ni tan siquiera aproximada y por tanto condicionada a la aparición de nuevos datos, pero que pienso que, a tenor de lo visto, responde a la situación general de la población lorquina en el periodo estudiado.

Hasta aquí el análisis y estudio de la población de Lorca en 1300 , en que se pone de manifiesto, aparte de la carencia de fuentes para abordar el tema en profundidad y con una mayor seguridad, las grandes fluctuaciones que sufría el contingente demográfico de la plaza, muy sometido a vicisitudes de todo tipo. En conjunto, se trata sólo de una aproximación, válida en la medida que se acerque a la realidad, pero no por ello deja de estar a merced de las novedades que futuras investigaciones sobre fuentes nuevas puedan establecer. 

 \\ Congreso
nternacional}

Jaime II

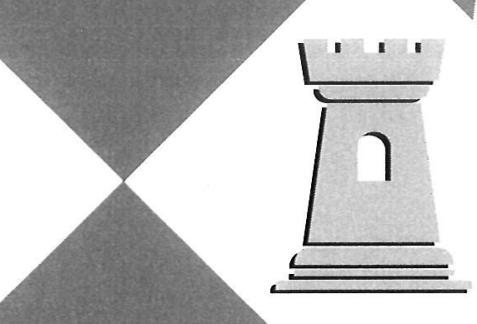

-
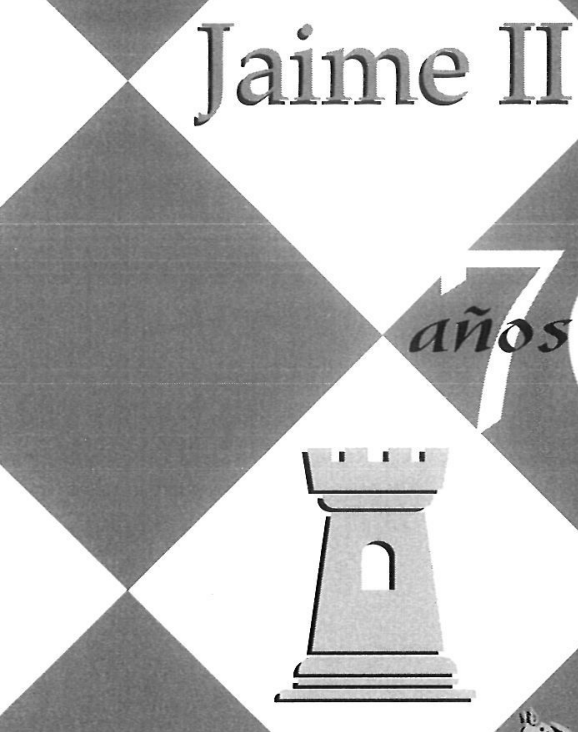

años después
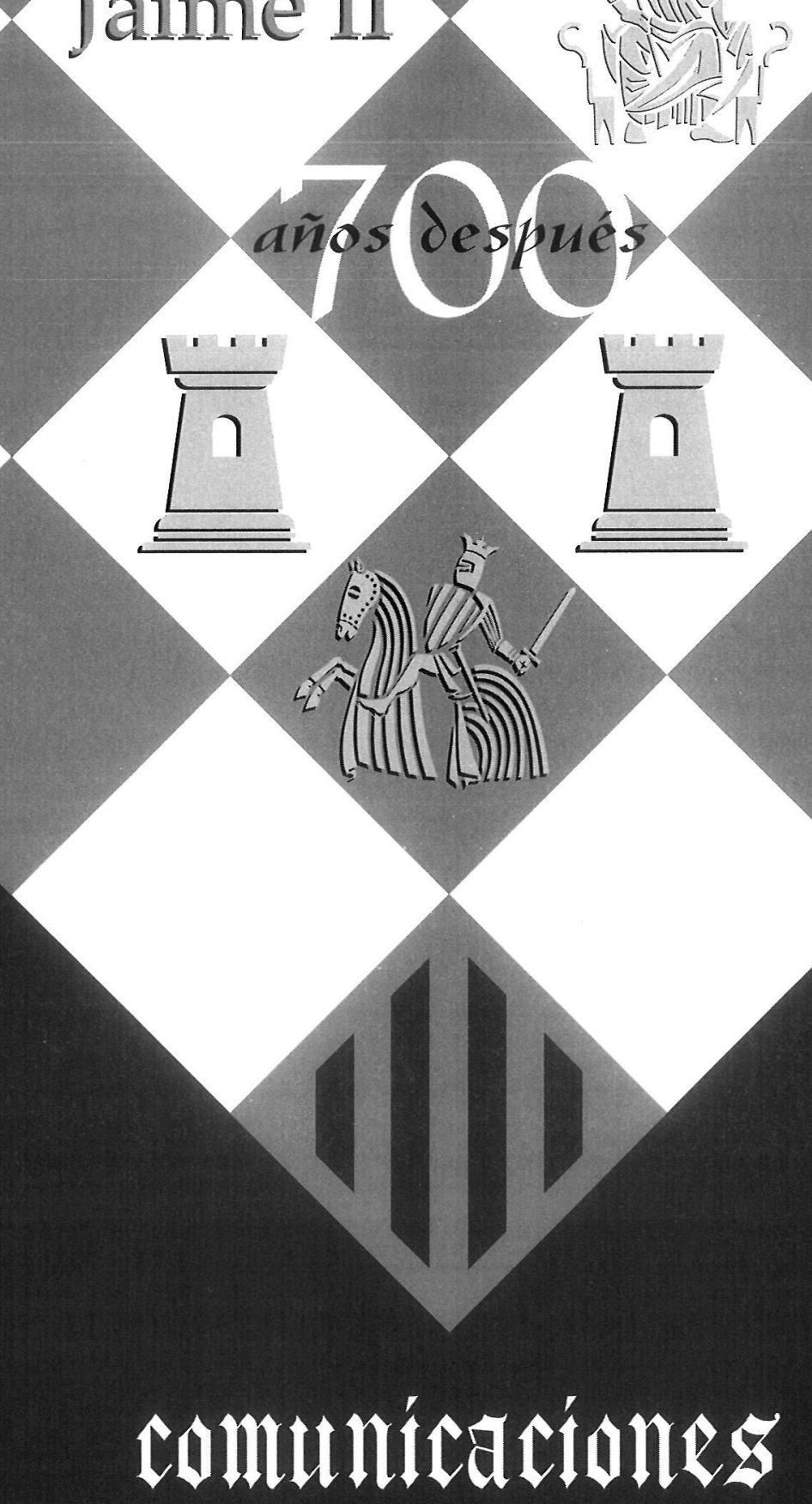



\section{EL CONTEXTO MEDITERRÁNEO}




\title{
LA CONTRIBUCIÓN DE LA PROCURACIÓN DE ORIHUELA EN LA CONQUISTA DE CERDEÑA
}

\author{
Juan Antonio BARRIO BARRIO \\ José Vicente CABEZUELO PLIEGO \\ José HINOJOSA MONTALVO \\ Universidad de Alicante
}

La infeudación del «Regnum Sardiniae et Corsicae» por la Santa Sede a Jaime II iniciaba la intervención de los monarcas aragoneses en la isla, que se prolongó durante las centurias posteriores y que generaron diversas expediciones para someter las frecuentes rebeliones sardas, forzando a la Corona a exigir contribuciones económicas a sus súbditos para llevarlas a cabo y mantener la paz, tarea que no siempre fue fácil de conseguir.

En el marco de la celebración del séptimo centenario de la conquista del reino de Murcia por Jaime II y dentro de la recuperación de la figura del «rey Justo», los autores de esta comunicación pretendemos poner de relieve con esta aportación el nivel de participación de las villas de la Procuración de Orihuela en la conquista sarda y las repercusiones que ésta tuvo en las tierras alicantinas, tema que hasta ahora ha pasado prácticamente desapercibido para los historiadores de la región.

Cuando a principios de la década de 1320 Jaime II inició los preparativos para el asalto final a las islas de Córcega y Cerdeña, se arbitraron por parte de la Corona fórmulas que lograsen una participación efectiva de todas las comunidades del reino de Valencia. Una de las vías utilizada habitualmente era, como es sabido, la solicitud de subvenciones, teóricamente acordes a la capacidad económica de cada una de las localidades, que como contrapartida solían obtener privilegios y exenciones que a larga permitían cubrir el capital desembolsado, generalmente importante.

En el reino de Valencia, al igual que en Aragón, fue el infante Alfonso el encargado de conseguir de los valencianos tales aportes económicos, que en esta primera oca- 
sión podemos calificar de generosos, al menos en lo que se refiere a la capital del reino, que aportó nada menos que 350.000 sueldos reales de Valencia (17.500 libras), mientras que Orihuela, a la sazón villa, contribuyó en 1322 con 20.000 sueldos a la empresa sarda, recibiendo en recompensa diversos privilegios al tiempo que viendo confirmados otros anteriores por parte de Jaime II, predominando los que tienen un claro contenido económico o político, siempre en beneficio del municipio y de sus habitantes. Entre ellos figuran los expedidos el uno de marzo de 1322, en el primero de los cuales el monarca declaraba a los vecinos y sus mercancías francos del pago de lezdas en todos los territorios de la Corona de Aragón ${ }^{1}$. En otro de ellos prohibía a los oficiales reales del municipio todo acto de compraventa o donación del suelo que conllevara la reducción o alteración de las plazas, calles y mercados, en detrimento de la utilidad pública' ${ }^{2}$; mientras que en el último Jaime II confirmaba los fueros, libertades, franquicias y libertades que habian disfrutado hasta entonces los vecinos de Orihuela ${ }^{3}$. Este último privilegio era particularmente importante para los oriolanos, incorporados de forma definitiva a la Corona de Aragón y al reino de Valencia no hacía muchos años, tras la sentencia arbitral de Torrellas en 1304, pero conservando también sus fueros peculiares de la etapa de dominio castellano, ahora ratificados. Esta fue una característica común a las distintas localidades que integraban la Procuración de Orihuela: Alicante, Elche y Guardamar, que los reyes respetaron siempre, la coexistencia de los Furs de València con las particularidades locales. De nuevo el 31 de mayo de 1322 el infante Alfonso confirmará a los oriolanos todos estos fueros otorgados por su padre, Jaime $\mathrm{II}^{4}$, mientras que les ratificaba la inmunidad de todo tipo de impuestos y servicios reales, como portazgos, lezdas, aduanas, etc. ${ }^{5}$. Los privilegios dados a Orihuela son, por lo demás, similares a los del resto de las villas de la Procuración, y ese mismo día el infante Alfonso confirmaba a Elche los fueros, franquicias y demás privilegios concedidos por Jaime II en compensación por la ayuda económica para la empresa de Cerdeña ${ }^{6}$.

Vemos pues un claro interés por parte de los municipios de obtener a cambio de tan elevado subsidio importantes compensaciones en el terreno de lo económico, y es en este contexto en el que hay que situar el nacimiento de una de las principales imposiciones que gravarán en lo económico a los ciudadanos de la procuración de Orihuela, y también del reino de Valencia: nos referimos a las sisas ${ }^{7}$. La consolidación del sistema impositivo de las sisas en el mediodía del reino de Valencia hay que si-

1 ARCHIVO MUNICIPAL DE ORIHUELA (AMO): Libro de privilegios, 2588. $\mathrm{n}^{\circ} \mathrm{XXIII}$. ff. 32v.-33v. ARCHIVO HISTÓRICO NACIONAL (AHN): Códice 1368-B, Privilegia per Serenissimos Reges ciuitati Oriole concesa, ff. 62v.-64r.

2 AMO: Libro de Privilegios, 2588. fff. 33v.-34r. AHN: Privilegia, 1268 B. ff. 64r.-65r,

3 AMO: Libro de Privilegios, 2588. no XXV. f. 34r. AHN: Privilegia, 1368 B. ff. 65r.-66r.

4 AMO: Libro de Privilegios, 2588, $n^{\circ}$ II, f. 41r.

5 AMO: Libro de Privilegios, $1368 \mathrm{~B}, \mathrm{ff}, 78 \mathrm{~V} .-80 \mathrm{r}$.

6 ARCHIVO MUNICIPAL DE ELCHE (AME): Armario 2, Páginas de Oro, $\mathrm{n}^{0}$ 11. (1322, mayo, 31 ).

7 BARRIO BARRIO, J.A.: El ejercicio del poder en un municipio medieval: Orihuela 1308-1479. Alicante, 1993, (tesis microfichada). 
tuarla en el privilegio concedido por Jaime II a finales del año 1321, por el que ordenaba que todas las ciudades y villas que contribuyesen con subvenciones para la campaña de Córcega y Cerdeña debían recibir licencias para imponer tributos e impuestos con el fin de poder reunir fácilmente dichas cantidades y autorizaba al infante Alfonso para otorgar en su nombre privilegios de concesión de tributos ${ }^{8}$. Se sitúa, por tanto, en relación con el problema de la conquista de Cerdeña (1323-1324), y quedó plasmado en las veinte galeras que se armaron en la ciudad de Valencia con las subvenciones que aportó esta ciudad, 350.000 sueldos, y las del resto de las ciudades del reino ${ }^{9}$.

Tal franquicia, que al principio tenía carácter temporal, gravaba la compra y venta de determinados productos en el mercado local, sobre todo los artículos básicos del consumo: pan, vino, carne, pescado, etc. y en la Procuración oriolana fueron autorizadas a imponerlas Alicante, Elche y Guardamar el uno de abril de $1322^{10}$. La primera dió una ayuda económica al monarca de 12.000 sueldos, mientras que la de Elche fue de 8.000 sueldos y de 6.000 la de Guardamar. El 15 de febrero de 1324 vieron prorrogadas dicha concesión de sisas cada una de las tres mencionadas villas en quince, seis y cinco años respectivamente. ${ }^{11}$ En dicho año Alicante se excusaba ante el procurador y el baile general de esa tierra acerca de su participación en tal subsidio. Exponía «el extravío de sus negocios» que había producido las luchas entre el rey Roberto y los genoveses, por lo que solicitaba se rebajase su participación hasta los mencionados 12.000 sueldos así como franquicias comerciales en Córcega y Cerdeña, como ciudades de la talla de Barcelona y Valencia ${ }^{12}$.

Orihuela, que había recibido el privilegio de la sisa en 1312, obtuvo el 31 de mayo de 1322 una prórroga de quince años del mencionado impuesto ${ }^{13}$. En 1324 Jaime II prorrogó a estas villas la duración de la concesión de las sisas durante algunos años más ${ }^{14}$. La ciudad de Valencia, como premio a su importante aportación, recibió en 1322 del infante Alfonso la concesión de un importante privilegio para poder fijar una serie amplia de imposiciones sobre la navegación, el comercio y sobre la compraventa de

8 AO, Priv. I, Alfonso IV., p. 215. (1321, diciembre, 10).

9 RUBIO VELA, A.: «El segle XIV», en História del País Valencià. De la conquesta a la Federació Hispànica. Vol. II. Barcelona, 1989, pp. 197-198. Acerca de la conquista de Cerdeña cfr. ARRIBAS PALAU, A.: La conquista de Cerdeña por Jaime Il de Aragón. Barcelona, 1952.

10 HINOJOSA MONTALVO J., BARRIO BARRIO, J.A.: "Las sisas en la Gobernación de Orihuela durante la Baja Edad Media", Anuario de Estudios Medievales, 22, Barcelona, 1992, pp. 535-579.

11 ACA, C, reg. 225, f. 191r.

12 ARRIBAS PALAU, A.: La conquista de Cerdeña ..., p. 181.

13 ESTAL, J.M.: Colección documental ..., doc. n. 92. (1322, mayo, 31).

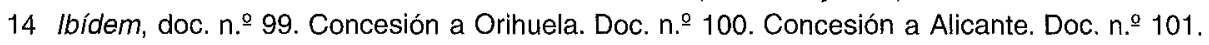
Concesión a Elche. Doc. n. 102. Concesión a Guardamar. Todos los documentos tienen la misma fecha, 1324, febrero, 15. La prórroga de estos años se añadía a los quince ya otorgados. Orihuela cinco años, Elche seis, y Guardamar cinco. Alicante recibió un privilegio especial para poder duplicar la cuantía del valor de la sisa por el tiempo ya concedido de quince años. Finalmente, tras los privilegios de 1324 la concesión de las sisas en la Gobernación quedaba así: Alicante (1322-1337), Orihuela (1322-1342), Guardamar (1322-1342) y Elche (1322-1343). 
determinados productos ${ }^{15}$. La contribución final de las ciudades del reino de Valencia se cifró en los 350.000 sueldos aportados por la capital y los 46.000 de las villas de la Procuración de Orihuela ${ }^{16}$.

La solicitud de vituallas también era habitual y Orihuela, Elche, Guardamar y Alicante, las principales poblaciones del meridión valenciano, fueron requeridas por Jaime II a fin de que prestasen un subsidio en trigo y cebada para la conquista de Cerdeña ${ }^{17}$, lo que provocó las quejas de estas localidades, dado que su política de abastecimiento del mercado local, siempre en frágil equilibrio, podía quedar gravemente afectada. Recordemos que Jaime Il había solicitado en 1321 a la Procuración de Orihuela un subsidio de 3.000 cahices de cereal, cantidad que el procurador Simó de Bell.lloch debía distribuir entre las comunidades. Si bien, las distintas poblaciones se mostraron reticentes en satisfacer tal cantidad por varias razones. Argumentaban lo excesivo de la misma - no se recogía ni en dos años-, que las mejores tierras de la huerta se encontraban en poder de los mudéjares "que allí son poblats", la incertidumbre de los años venideros, así como que todo el peso del subsidio recaía sobre la ciudad, ya que ni caballeros ni hòmens de paratje contribuirían al poseer privilegio de exención. Todas las comunidades expusieron este razonamiento, que debía ser más que cierto ya que fue ratificado por el propio Simó de Bell. lloch ${ }^{18}$.

Además de la población cristiana, para entonces ya mayoritaria en los núcleos urbanos de la Procuración oriolana, contribuyeron también al subsidio de Cerdeña moros y judíos en proporción que por el momento desconocemos. De los judíos tan sólo nos ha quedado una noticia de julio de 1322 por la que sabemos que el rey notificó al baile general del reino, Jaume Andreu, que había autorizado a la aljama judía de Orihuela a imponer sisas con el fin de que pudiera recaudar la mencionada ayuda y otras cantidades que se le habían solicitado a la aljama ${ }^{19}$. Como vemos, las soluciones dadas por los hebreos son las mismas que las de los cristianos, la aplicación de sisas, algo normal si tenemos en cuenta que la minoría judía vivía inserta dentro del sistema feudal cristiano. El problema para ellos era que esta carga solicitada para la conquista de Cerdeña se añadía a las continuas y numerosas peticiones monetarias que continuamente les estaba haciendo el rey, para quienes los judíos no dejaban de ser "nostre tresor", con lo cual la situación económica de las aljamas solía ser bastante precaria.

No menos dramática debía ser la situación de los mudéjares, ya en un proceso de retroceso demográfico claramente perceptible en el primer tercio del siglo XIV como consecuencia de las emigraciones hacia el reino de Granada y que pocos años después se acentuaría con las expediciones del caudillo Ridwan en 1331 y 1332 . Al menos

15 AO, Priv. I y II. Privilegios del infante Alfonso. (1322, febrero, 26), pp. 215-218.

16 ARRIBAS PALAU, A.: La conquista de Cerdeña ..., p. 185.

17 ARRIBAS PALAU, A.: La conquista de Cerdeña ..., p. 54.

18 ARRIBAS PALAU, A.: La conquista de Cerdeña ..., p. 190. Cf. docs. 125bis y 126 del de Estal Alicante de villa a ciudad.

19 ACA, C, reg. 222, f. 105r-v. (1322, julio, 21). 
así parece deducirse de la petición hecha el 6 de febrero de 1328 por el Consell de Orihuela a Alfonso IV para que condonase una parte del servicio de 5.000 sueldos que había solicitado a la aljama mudéjar de la villa con motivo de su coronación. Le recordaban que su padre, Jaime II, les había rebajado dicha cantidad de 5.000 a 2.000 sueldos atendiendo a su precaria situación económica, y, lo que era mucho más grave, a causa de las pechas originadas por la conquista de Cerdeña, muchos moros se habían marchado de la aljama oriolana a vivir a Elche, Crevillente o Abanilla, corriendo el riesgo de que la morería se despoblara ${ }^{20}$. $\mathrm{M}^{\mathrm{a}}$. T. Ferrer recoge la conmoción que entre los sarracenos causaron los impuestos especiales pedidos en 1322 y 1324 para la conquista de Cerdeña en las morerías de Orihuela y Elche. En esta última el éxodo a Granada y Berbería hizo que el rey escribiera el 10 de marzo de 1324 a los viejos y moros ilicitanos interrogándoles por la causa que les llevaba a emigrar, comprometiéndose a que los oficiales reales los tratasen bien y los defendieran, pero aunque en Orihuela se rebajó de 5.000 a 2.000 sueldos la cantidad pedida, ello no impidió que las salidas de población sarracena de la Procuración continuasen en estos años ${ }^{21}$.

Todo apunta a que fueron años muy duros fiscalmente hablando, pues a la subvención de 1322 hubo que añadir una nueva petición en 1324 a las villas de la Procuración, de la que tan sólo sabemos que Orihuela aportó la cantidad de 10.000 sueldos. Una vez más los peor parados eran los musulmanes, que en el caso de Alicante debían contribuir con 2.000 sueldos, pero en vista de su miseria, el rey hubo de rebajarles la exigencia en un cincuenta por ciento, 1.000 sueldos. En parecida situar ción estaba la exigua comunidad de Orihuela, que en 1328 todavía tenía deudas pendientes por los subsidios que les había exigido Jaime II y pedía al nuevo rey, Alfonso IV, una rebaja de aquellos 5.000 sueldos solicitados hacía años para su coronación, pues muchos moros se habían ido a vivir a otros lugares para no tener que pagar tales cargas, hecho éste que el Consell oriolano se encargó de ratificar en apoyo de la petición de la aljama sarracena de la villa ${ }^{22}$.

Otra consecuencia directa de la campaña sarda y de las dificultades económicas que ello supuso para la monarquía fue la petición hecha por el rey a las villas de las tierras situadas más allá de Jijona de que le adelantasen nuevamente el monedaje, que sería recaudado por el baile general Jaume Andreu y por el baile de Orihuela Jaume Masquefa ${ }^{23}$; problema siempre arduo, pues el realengo iba disminuyendo poco a poco en beneficio del señorío. Vemos, pues, a las minorías musulmana y judía soportando una fuerte presión fiscal, lo que se tradujo a la larga, junto con otros muchos factores, en la extinción de la morería de Orihuela.

20 ACA: cartas reales de Alfonso IV, $n^{\circ}$ 85. FERRER I MALLOL, $M^{a}$ T.: Les aljames sarraïnes de la Governació d'Oriola en el segle XIV. Barcelona, 1988, doc. ํㅜ 81, pp. 56 y 244-245.

21 FERRER I MALLOL, M. ${ }^{\text {T }}$.: Els sarraïns de la Corona catalano-aragonesa en el segle XIV. Segregació i discriminació, Barcelona, 1987, p. 151.

22 ACA, cartas reales de Alfonso IV, $\mathrm{n}^{\circ}$. 86. (1328, febrero, 6). FERRER I MALLOL, Mํ. T.: Les aljames sarraines ..., pp. 164-165.

23 FERRER I MALLOL, M. ${ }^{\text {a }}$ T., Les aljames sarraïnes ..., p. 162. 
La campaña del infante Alfonso en Cerdeña tuvo también algunas repercusiones en la configuración política y en los cargos de gobierno de la Procuración oriolana, debido a la movilidad de algunos de los personajes que ejercían tales funciones y que se habían desplazado a la isla ante el llamamiento real. Por eso el 15 de diciembre de 1323 Jaime II ordenaba a Maimó Sacirera, lugarteniente del procurador general del reino dellà Sexona, que continuara ejerciendo el cargo a pesar de la muerte en Cerdeña de Pere de Queralt, que lo había nombrado para dicha lugartenencia. En lo sucesivo actuaría en nombre de Bernat de Guimerà, hasta que éste regresara de la isla, puesto que había sido nombrado para sustituir al difunto ${ }^{24}$. Pere de Queralt encontró la muerte en Cerdeña, en el sitio a la villa de Iglesias, antes del 28 de octubre de 1323. Parece que le acompañó en la expedición su hijo Guillem. Al difunto Pere de Queralt le sustituyó en la Procuración oriolana el 28 de octubre de 1323 el noble catalán Bernat de Guimerà, que estaba en Cerdeña cuando le llegó el nombramiento de procurador general de Valencia dellà Xixona. La Lugartenencia continuó ejerciéndola el caballero Maimó Sacirera, puesto que Guimerà es posible que ni siquiera llegara a tomar posesión efectiva de la Procuración. Si el gobierno de Bernat de Guimerà fue efímero, puede decirse otro tanto de su sucesor, Bernat Saportella, otro catalán que también estaba en la empresa sarda, que fue nombrado el 28 de marzo de 1324 para la Procuración, pero falleció el 8 de agosto de ese año, siendo sustituido por el cuñado del rey, Guillem Ramón de Montcada, hermano de la reina Elisenda, desde el 5 de septiembre de $1324^{25}$.

Por otra parte, la marcha del infante Alfonso, el procurador general, a Cerdeña en 1323 tuvo consecuencias para el título del procurador, que hasta entonces había sido, literalmente, de: «portantveus general de l'infant pel que fa a l'ofici de la procuració en la part del regne de València dellà Xixona". Al quedar como portavoz su hermano el infante Pere, el título de procurador del territorio pasó a ser de «lloctinent general de portantveus de governador general en el regne de València dellà Xixonas ${ }^{26}$.

Podemos considerar, en definitiva, que la principal consecuencia que la conquista de Cerdeña tuvo para las localidades de la Procuración de Orihuela fue de índole económico, dado que la aportación humana — si la hubo- es imposible de fijar en el estado actual de nuestros conocimientos. Por un lado, la exacción dineraria solicitada por la Corona a las villas, que éstas intentaron cobrarse consiguiendo que se fijara la modalidad impositiva de las sisas. Éstas no eran nuevas en las comarcas meridionales del reino de Valencia, ya que Jaime II había autorizado en 1307 y 1308 a Orihuela, Alicante, Guardamar y Elche a imponer sisas con el fin de hacer frente a los gastos militares del municipio por causa de su situación fronteriza con el reino de Granada.

24 ACA, C, reg. 233, f. 130r-v. FERRER I MALLOL, M. ${ }^{\mathrm{a}}$ T.: Organització i defensa d'un territori fronterer. La Governació d'Oriola en el segle XIV, Barcelona, 1990, doc. $n^{\circ}$ 117, pp. 446-447.

25 FERRER I MALLOL, M. ${ }^{a}$ T.: Organització i defensa ..., pp. 108-110. Acerca del fallecimiento de Saportella cf. CABEZUELO PLIEGO, J. V., «El veneno en la política. La muerte de Bernat Saportella, procurador de Orihuela, a manos de los patricios", inédito.

26 FERRER I MALLOL, M.ํㅜ., Organització $i$ defensa ..., p. 13. Acerca del cambio de denominación en el reino de Valencia cf. CABEZUELO PLIEGO, J. V., Poder público y administración territorial en el reino de Valencia, 1239-1348. El oficio de la Procuración, en prensa. 
No olvidemos, por otra parte, que este impuesto tenía su precedente en otro llamado "Comune", que se percibía en estas localidades cuando pertenecieron al reino de Murcia, hasta $1296^{27}$. A partir de ahora, la sisa se convertirá en una exacción fiscal regular y en la principal fuente de ingresos para los municipios alicantinos del sur del reino de Valencia ${ }^{28}$.

27 VEAS ARTESEROS, M. ${ }^{\text {a }}$ C., Fiscalidad concejil en la Murcia de fines del Medievo, Murcia, 1991.

28 HINOJOSA MONTALVO, J.: «Finanzas y fiscalidad de las ciudades valencianas», IV Semana de Estudios Medievales, León, 1995, en prensa. 



\title{
LOS ANTECEDENTES TRECENTISTAS DEL CORSO MURCIANO. LAS VINCULACIONES DEL CORSARIO MARTÍN SÁNCHEZ CON LAS AUTORIDADES DE VALENCIA EN LAS POSTRIMERÍAS DEL REINADO DE JAIME EL JUSTO
}

\author{
Andrés DÍAZ BORRÁS
}

\section{LOS ANTECEDENTES TRECENTISTAS DEL CORSO MURCIANO}

El mar Mediterráneo ha sido considerado como un gran patio de vecindad al cual se asoman multitud de pueblos, de distintas procedencias, creencias y nacionalidades. No obstante, la convivencia a la que se han visto condenados, frecuentemente, está en el fondo de las relaciones solidarias que, en multitud de ocasiones, se han producido, incluso entre aquellas comarcas colindantes pero separadas por fronteras políticas. Desde el punto de vista marítimo, los vínculos del litoral mediterráneo, en la Edad Media cristiana peninsular, parecen demostrados'. Sin embargo, es cierto que

1 En cualquier caso la columna vertebral de toda la red de vigilancia costera fue la comunica. ción de los avisos. La solidaridad arraigada en todo el litoral era patente. Dentro del reino de Valencia, cuando los avisos pasaban a la capital, con frecuencia se hacia constar que éstos debian llegar, por el norte hasta Tortosa, y por el sur hasta Cartagena. Es decir, haciendo saber la noticia hasta la primera estación costera fuera de la jurisdicción valenciana. A la recíproca, fue normal recibir avisos desde Cataluña y Murcia, aunque de esta última región en mucho menor grado, como consecuencia de su limitada línea litoral y de tratarse de un país extranjero que no siempre se encontraba en buenas relaciones con los países de la Corona de Aragón. Andrés DÍAZ BORRÁS, Problemas marítimos de Valencia a finales de la Edad Media: el corso, la pirateria y el cautiverio en su incidencia sobre la dinámica económica, 1400-1480, p. 243. Valencia, 1988, Edit. microfichada. Sobre este mismo tema vid también Andrés DÍAZ BORRÁS, «Alcanar medieval y el peligro pirático: notas acerca de la solida- 
existen diferencias evidentes entre los lazos culturales y políticos que ligan a los países que componían la comunidad de territorios bajo soberanía del rey de Aragón, por ejemplo, y la asociación que podía existir entre el reino de Valencia y las tierras murcianas. Aunque la penetración catalano-aragonesa había sido considerable, ya desde la conquista cristiana, será solamente después de la ocupación de las comarcas del sur de Valencia, por Jaime el Justo, cuando se consoliden las relaciones de vecindad entre Murcia y el reino de Valencia.

La incorporación de las comarcas de Alicante, Elche, Orihuela y Villena se vio complementada con los deslindes fronterizos y de términos municipales, esclarecidos por la sentencia de Torrellas de 1304, según la cual Yecla y Jumilla pertenecerían al reino de Valencia, al igual que la comarca del Campo de Cartagena ${ }^{2}$, limitando por lo tanto, hasta el extremo la salida castellana al Mediterráneo, una de las máximas aspiraciones de la política anti-castellana de Jaime el Justo ${ }^{3}$. Esta configuración de la frontera valenciano-murciana solamente estará en vigor hasta que una nueva sentencia, la de Elche, en 1305, dejará el Campo de Cartagena del lado de Murcia. En cualquier caso, el poco tiempo que permanecieron unidos ambos territorios junto a las influencias intensas que todo el reino de Murcia recibirá de parte de la Corona de Aragón motivarán una profunda vinculación, como mínimo administrativa, si no también política en lo que se refiere al mundo marítimo del aparejo de barcos.

En este sentido hay que contar con la escasísima tradición marinera del litoral murciano. Ciertamente, se había intentado frenar la expansión de la Corona de Aragón mediante la ocupación castellana de Alicante y Cartagena, a mediados del siglo XIII. Cartagena recibirá el fuero de Córdoba en 1246 y en 1254 se fijarán sus límites territoriales, junto a disposiciones específicas que avalan la hipótesis del potenciamiento de la guerra corsaria y de los aparejos navales ${ }^{4}$. Precisamente, si parece que en los primeros años de la ocupación cristiana del territorio no se produjo una repoblación masiva, siendo la presencia castellana limitada a las guarniciones, en el alcázar de Murcia y los castillos claves de la frontera con Granada o con la Corona de Aragón, es cierto, también, que hubo excepciones significativas a esta regla general. Además de los catalanes que acudieron en época de Jaime el Conquistador, cabe mencionar a los castellanos que Alfonso $X$ asentará en poblaciones como Lorca, Orihuela, Cartagena y Alicante, estas dos últimas con la intención de «potenciar su naturaleza de puertos

ridad litoral desde Peníscola a Tortosa". jer Congrés d'Història d'Alcanar. 750è Aniversari de la Carta Pobla (1239-1989). Alcanar (1989), pp. 69-85. Andrés DÍAZ BORRÁS, «L'estudi de la pirateria a través dels avisaments costaners. Replegament cristià i setge islàmic a la València de la transició a la Modernitat: 1480-1520\%. Anuario de Estudios Medievales, 20 (1990), pp. 275-295.

2 Enric GUINOT RODRÍGUEZ, Els límits del regne. València, 1995, pp. 103-115.

3 Maria Teresa FERRER I MALLOL, "Notes sobre la conquesta del regne de Múrcia per Jaume II (1296-1304)". Homenatge a la memoria del Prof. Dr. Emilio Sáez. Barcelona, 1989, pp. 27-44. Vid. también Juan Manuel del ESTAL, Colección documental del Medievo Alicantino II. Años 1306-1380. Alicante, 1988.

4 J. Gautier DALCHÉ, Historia urbana de León y Castilla en la Edad Media (siglos IX-XIII). Madrid, 1979, p. 162. 
mediterráneos $»^{5}$. En realidad, Alfonso el Sabio habría ido planeando toda una estrategia para el puerto de Cartagena que después el tiempo no permitió cumpliró.

En efecto, a la disminución de la actividad en el puerto de Cartagena se unió una clara tendencia a la despoblación de todo el reino de Murcia, durante el último tercio del siglo XIII. Así las cosas, no es de extrañar que el litoral del sureste se vea recorrido por todo género de enemigos, especialmente granadinos y berberiscos ${ }^{7}$. Esta tónica se mantendrá incluso a lo largo de todo el siglo XIV, cuando la guerra con Jaime el Justo, primero, y la actividad granadina en la frontera, reducirá Cartagena a la condición de un núcleo marítimo de muy limitadas posibilidades y peso específico ${ }^{8}$.

\section{EL CORSARIO MARTÍN SÁNCHEZ Y LA AUTORIDADES DE VALENCIA}

Los años que se encuentran a caballo entre el siglo XIII y XIV fueron, probablemente, años muy complicados para los habitantes de la zona fronteriza que separaba Valencia, Castilla y Granada. La agregación al reino de Valencia de una parte sustanciosa de lo que había sido territorio murciano no significó el final de la incertidumbre. Aunque desde entonces los conflictos armados, los enfrentamientos abiertos, ya no se producirán,-todavía pasarán bastantes años de indefinición e indecisión respecto de la responsabilidad política y administrativa de extensas áreas. Esta inseguridad había de sumarse al inevitable peligro que la cercanía granadina proporcionaba a toda la frontera y, sin duda, contribuirá a que los señores de la tierra, poderosos y singularmente autónomos en Murcia, actúen por su cuenta y riesgo, sin contemplar otros intereses más elevados y lejanos que los suyos propios y los de sus dominios más o menos hurtados a la fiscalización real.

$\mathrm{Si}$ en Murcia los señores de la tierra actuaron objetivamente al margen, en lo posible, de los deseos de la monarquía o de las influencias catalano-aragonesas, los corsarios locales, cuyas dificultades para el aparejo de barcos, después de que Alicante pasara al bando valenciano, eran casi insuperables, no les irán a la zaga. No disponemos de muchas informaciones al respecto, pero los indicios que hemos ex-

5 Salvador de MOXÓ, Repoblación y sociedad en la España medieval. Madrid, 1979, pp. 373374.

6 Juan TORRES FONTES, El concejo de Cartagena en el siglo XIII. Murcia, 1977, pp. XXIXXXXIV, también publicado posteriormente en Colección de Documentos para la Historia de Murcia, $\mathrm{I}$. Alfonso XI (1315-1340). Murcia, 1980. IDEM, «El reino de Murcia en el siglo XIV». Anuario de Estudios Medievales, 7 (1970-1971), pp. 253-278.

7 Juan TORRES FONTES, El concejo de Cartagena..., p. XXXIV.

8 La guerra con Aragón y las posteriores luchas sociales de minorias dinásticas fueron la causa intrapeninsular de que el comercio marítimo castellano apenas tuviese actividad hasta el primer tercio del siglo XIV, cuando Alfonso XI refrendó en 1332 unos acuerdos firmados con Mallorca en 1327. $A$ pesar de la protección real a todos los que armasen barcos en Cartagena, la ciudad fue un misérrimo núcleo marítimo que tenia 176 vecinos en 1381, de los cuales aún perdió casi la mitad hasta los años 1408-1410. $\mathrm{M}^{\mathrm{a}}$ de los Llanos MARTíNEZ CARRILLO, «El reino de Murcia en el sistema económico Mediterráneo de la Baja Edad Media". Anuario de Estudios Medievales, 24 (1994), pp. 247-273, en concreto, p. 250. 
puesto nos permiten presumir que las posibilidades de armar barcos en corso, entre 1300 y 1330 serían muy limitadas en Cartagena o cualquier otro lugar del litoral murciano. Los usos y costumbres de la administración catalana, aunque muy breve en el tiempo, dejará una huella suficientemente perdurable como para que los escasos armadores murcianos la asuman como propia y la empleen en su beneficio.

Este será el caso del corsario Martín Sánxez, de Murcia, personaje del que, afortunadamente, conocemos las suficientes informaciones como para poder seguir su trayectoria aproximada. El primer documento de que disponemos se refiere a la obligación de prestar las suficientes seguridades y fianzas en manos de las autoridades oportunas, por parte de los corsarios que aparejaban barcos armados ${ }^{9}$. Efectivamente, dado que Martín Sánxez, vecino y habitante en la ciudad de Murcia entendía llevar una saetía ${ }^{10}$ o barqua de veinte remos que había aparejado en Valencia, donde, al presente se hallaba amaridada ${ }^{11}$, es decir lista para navegar pero no suficientemente armada, las autoridades reales requerían el cumplimiento de los trámites correspondientes. Es decir, el lugarteniente del Baile General, Guillem Çaplana, en nombre del administrador del patrimonio regio, Joan Scrivà, exigiría que se cumpliesen con las seguridades correspondientes, haciéndose hincapié en la necesidad de que, una vez en Murcia, el armador y patrón de la saetía se presentase ante el Adelantado para que no dejase de estar controlado en sus posibles acciones, permitiéndosele la entrega de las garantías ante el Baile de Xixona, Jaume Andreu' ${ }^{12}$.

Del detenido análisis de este documento se desprende que Sánxez, murciano de

9 Com Martín Sànxez, vehi e habitador de Múrçia, hagués en la ciutat de Múrçia feyta una sagetia o barqua de vint rems, la qual, segons que diu, enten armar en la ciutat de Múrçia, e lo dit Martín Sànxez entengués la dita sagetia o barqua amenar a la dita ciutat de Murçia, e era al Grau de la ciutat de València, amarinada solament. E açò li fos contrastat per l'onrat En Guillem Çaplana, tinentloch de Ihonrat En Johan Scrivà, Batle General de regne de València, per lo Senyor Rey, demanan que donàs seguretat, que la dita barqua menaria al Alcàçar de Múrçia, e presentaria aquella a l'Adelantat de Múrçia, e que entre tant mal o dan no faria a la terra e gents del Senyor Rey o béns d'aquelles o a la terra o gents havents pau e treva ab lo dit Senyor Rey o béns d'aquelles. $E$ açò ab covinences fermançes e seguretats de pena. E lo dit En Martí Sànxez, per ço com la dita obligació fer no poria en la ciutat, donà aquella en poder de l'honrat En Jacme Andreu, Batle en partida del regne de Valencia de Sexona a.n là, segons que.l dit En Jacme Andreu per letra sua feu saber, sots aquesta forma. Archivo del Reino de Valencia (ARV), Real, 611, f. 262v.

10 Antigua embarcación mediterránea de una sola cubierta y dos palos. Durante la Edad Media semejaba una galera pequeña, pues iba a remo y era de poco desplazamiento, pero más adelante se construyeron de más tonelaje y de tres palos con velas, hasta que, al llegar el siglo XVI, navegaban exclusivamente a vela y eran menores que el jabeque. Julián AMICH, Diccionario marítimo. Barcelona, 1983.

11 El trabajo que realiza una tripulación enviada a bordo de un buque abandonado o apresado para ponerlo en condiciones de navegabilidad // En general, dejar un buque listo para hacerse a la mar. Julián AMICH, Diccionario marítimo, Barcelona, 1983.

12 Por lo que se refiere al Baile de Xixona, Jaume Andreu, vid. Maria Teresa FERRER I MALLOL, “La Batlia Generai de la part del regne de València dellà Xixona". Anales de la Universidad de Alicante. Historia Medieval, 6 (1987), pp. 279-309, en concreto pp. 287-288. Vid., también Juan Bautista VILAR, Historia de la ciudad de Orihuela III. Los siglos XIV-XV. Murcia, 1977. 
origen y residencia, deseando aparejar un barco, de no muy grandes proporciones y vocación costera, se habría trasladado a Valencia, dado que en los puertos murcianos, como ya sabemos, la capacidad para construir saetías no debía ser muy grande. Al trasladarse a la capital valenciana las autoridades, que no le pondrán demasiadas dificultades para que cumpliese su propósito, se mostraron especialmente sensibilizadas para que el corsario estuviese suficientemente controlado. Evidentemente, la entrega de garantías y fianzas en metálico era fundamental, pero el hecho de residir fuera del reino de Valencia implicaba que gran parte de sus bienes se hallaban fuera del alcance legal de las autoridades reales. Por ese motivo se hará imprescindible el concurso del Adelantado de Murcia, que así, se responsabilizaría del espacio marítimo murciano al estilo y según los usos vigentes en el reino de Valencia.

El día 7 de julio de 1327 se redactaría un documento en poder de Pere Barberà, notario público de Orihuela, y escribano de la Bailía que regía Jaume Andreu, por el cual se informaba al lugarteniente Guillem Çaplana o al Baile General Joan Scrivà, del cumplimiento de las obligaciones por parte del corsario Martín Sánxez ${ }^{13}$.

Este documento, es el compromiso de Martín Sánxez para con las autoridades valencianas, siendo condición indispensable para que pudiera sacar la sagetía del Grao de Valencia. En primer lugar se comprometía a aparejar la embarcación en tierras de Murcia, pero advierte que esta operación la haría novellament, de nuevo, por lo que cabe interpretar que Martín Sánxez ya vendría actuando anteriormente, más o menos vinculado a la ciudad de Valencia. El propósito del aparejo, que se realizaría en tierras de Murcia, será ir, exclusivamente contra los enemichs de la Creu de Nostre Senyor, en ningún momento se indica que pudiese intervenir contra súbditos cristianos de algún soberano. Sin embargo, para evitar posibles tentaciones se obligará mediante las cauciones mencionadas, en manos del representante real, Jaume Andreu. El propósito del marino murciano era sacar del Grao la saetía solamente amarinada, esto es solamente con cinco marineros, panática y armas, en exclusiva, para ellos y los aparejos del barcos completos. Evidentemente, una saetía de veinte remos requería del concurso de mucha más gente para estar en condiciones de entrar en corso y por lo tanto lo único que podía hacer en esas condiciones era dirigirse, de inmediato hacia el Alcàcer del Camp de Cartagènia.

Una vez en este lugar, Martín Sánxez se comprometía a acudir delante del Adelantado de Murcia para ponerse en sus manos y que fuera él quien autorizase el aparejo del barco armado, pidiéndosele que en el plazo de los dos meses siguientes escribiera una carta al Baile General notificándole la asunción de competencias en este ámbito. Entre tanto ocurría esto, Sánxez se comprometía a no hacer daño a súbditos

13 Al honrat En Johan Scrivà, Batle General del regne de València o a son lochtinent. De mi, En Jacme Andreu, Batle General, en partida del regne de València, per lo Senyor Rey. Salut ab tota honor. Per tenor de la present a Vós certifich que En Martí Sànxez, vehi de Múrçia, se obliga en poder meu e dóna fermança covinent en rahó de una sagetia que novellament ha feyta fer aquí en València de vint rems, la qual enten armar en les partides de Múrçia. E la obligació que aquella feu e la fermança que dóna, en esta rahó, reebé En Pere Barberà, notari públich de Oriola e scrivà de la Batlia del dit loch, la qual diu segons que segueix. ARV, Real, 611, f. 263r. 
de la Corona de Aragón ni a amigos y aliados del rey Jaime el Justo, dejando como fianza 200 morabatinos alfonsinos de oro ${ }^{14}$ y renunciando a todo tipo de fuero o norma legal a que pudiera acogerse, siendo su avalador Domingo Morçellés, vecino de Orihuela, que entregó también 200 morabatinos, aunque al contrario que el corsario no obligaba todos sus bienes, siendo el tope de responsabilidad asumida de 300 morabatinos. Actuarán como testigos tres vecinos de Orihuela, Felip Togores, Jaume de Mosquefa y Sanxo Ponçano ${ }^{15}$.

14 Por una regulación de 1306, Jaime el Justo habría estipulado las cantidades que se tenían que entregar como fianzas y qué tipos de barcos debían hacerlo. Estos últimos serán leños de hasta sesenta remos que pagarán 1.000 morabatinos. Sobre embarcaciones todavía de menor porte no se especificará cuál será la cantidad a entregar, dejándose, usualmente, en manos del Baile General la regulación de este extremo. Vid. Andrés DIAZ BORRÁS, Los orígenes de la piratería islámica en Valencia. La ofensiva musulmana trecentista y la reacción cristiana. Barcelona, 1993, pp. 24 y ss.

15 En Martí Sànxez, vehin de Múrçia, atenent que ell, en la ciutat de València, ha feta fer novellament una sagetia, de vint rems, per la qual enten armar, en les partides de Múrçia, contra los enemichs de la Creu de Nostre Senyor, e la qual sagetia li és comunicat que no pot treer del Grau de la mar de València. E açò per lo Batle General del dit regne de València, temen que ell ab la dita sagetia dan o mal no fos donat e feyt, a la terra del Senyor Rey d'Aragó o gents sues o béns d'aquelles o a la terra e gents havents pau ab lo dit Senyor Rey o béns lurs, e d'açò li fos demanada seguretat e caució. E ell, aquella donar no pogués en poder del dit Batle General, per tal lo dit En Martí Sànxez promés e.s obliga en poder de l'honrat En Jacme Andreu, Batle en partida del regne de València de Sexona a.n llà, que ell, la dita sagetia, la qual entén traure amarinada, solament, del dit Grau de València, ço és ab cinch hòmens e panàtica e vianda e armes a aquells necessària e ab la exàrcia de la dita sagetia parten del dit Grau de València e menarà, dreta via, desús salvant e volent al Alcàcer del Camp de Cartagènia. E quant serà aquí ell se presentarà al Adelantat de Múrçia e li farà a saber com la dita sagetia és alli en lo dit Alcàcer per ço que no puscha ésser treta o armada sens volentat del dit Adelantat. Promés, encara, que dins dos meses, primervinents, lo dit Adelantat haurà feyta fe, ab letra sua, al dit Batle General, que la dita sagetia és en poder seu e que és estada, a ell, presentada per lo dit Marti Sànxez e que, entre tant, ab la dita sagetia ne ab los hòmens que en aquella iran no farà ne darà, ne consentirà que sia donat o feyt mal o dan a la terra o gents del Senyor Rey d'Aragó ne a béns lurs. E si o feya que fos encorregut en pena de doents morabatins alfonsins d'or, al Senyor Rey donadors 10 dan per ell donat, primerament, e complida esmenat e satisfeyt a aquells qui suffer l'aurien. E encara que sia haüd per traydor a fur d'Aragó e per bare a costum de Catalunya, de la qual trayció e bària scusar no.s pogués, ab ses pròpies armes ni ab altres, ans, aytal e per tal fos haüt e tengut en tota cort e en tot loch. E per les dites coses, attendre e complir, obliga en poder del dit En Jacme Andreu, en nom del Senyor Rey, reebent e del notari dejús scrit axí com a pública persona, stipulant e reebent, en nom del Senyor Rey, e d'aquells a qui pertany e pertanyer pot e deu tots sos béns haüts, e per haver on que sien e donat fermança e principal tengut e obligat de la pena dels dits doents morabatins si ell, en la dita peccúnia, encorria, ço és, En Domingo Morçellés, vehí de Oriola, qui present és, 10 qual, de la dita pena, si comesa era, principalment, sia tengut e obligat, la qual obligació, 10 dit Domingo Morçellés, en si reebé e volenterosament fóu e atorga, sots obligació, de tots sos béns, presents e esdevenidors, los quals, principalment, en poder del dit Batle, en nom del Senyor Rey, e del notari dejús scrit estipulant etc., quant és per la dita pena, dels dits treents morabatins, //f. 263v// tantsolament, si comesa sia de certa sciència. E renúncia a fur de València, qui diu que ans sia cobregut lo principal de la fermança e atri, altre dret contra acovinent.

Testimonis En Felip Tegores, Jacme de Masquefa e Sanxo Ponçano, vehïns de Oriola. 
Una vez que Jaume Andreu, representante de los intereses reales, tuviera en su poder el documento mencionado, firmado por Martín Sánxez, y las garantías en metálico estipuladas, con el correspondiente avalador, que curiosamente es valenciano, al igual que los testigos presentes en la redacción del documento ante un notario de Orihuela, solamente quedaba librar al corsario la oportuna credencial para que el Guardia del Grao le dejara sacar el barco cuando se presentase en la ciudad de Valencia. El documento en cuestión no representa ninguna novedad reseñable, excepto una: se pide a Joan Vicent, guardia del Grao, sin duda, que permita la salida de la saetía tripulada no por cinco hombres, como creíamos hasta ahora, sino por ocho, cifra mucho más adecuada para mover una barqua de veinte remos ${ }^{16}$.

El 15 de julio de 1327, una semana después de que se redactara el escrito en Orihuela, el lugarteniente del Baile General, Guillem Çaplana, dará instrucciones a Jaume Andreu, Baile de Xixona, respecto del procedimiento de actuación para un próximo futuro. Se le recomendará que debía permanecer atento ante la posible llegada del documento castellano responsabilizándose del corsario Martín Sánxez. En caso de que el escrito del Adelantado de Murcia llegase debería ser inmediatamente registrado para comprobar las fechas estipuladas y proceder a la devolución de fianzas ${ }^{17}$.

El 25 de agosto de 1327, Martín Sánxez se presentará ante el Baile General con una carta del Concejo de Murcia y otra del honrado Pero López de Ayala ${ }^{18}$. Se trata de

Et per que ell dit Martín Sànxez me requés que de les dites coses vos certifficàs, tramés-vos la present letra closa e sagellada ab mon sagell, en testimoni de veritat, que fo feyta en Oriola, dimarts set dies de juliol, Anno Domini millesimo tricentesimo vicesimo septimo. ARV, Real, 611, f. $263 \mathrm{rv.}$

16 E en après, lo dit lochtinent, feu al dit En Martí Sànxez fer l'albarà seguent: A.N Joan Vicent, etc. Lexats traure de la plaja e Grau de València a.N Martí Sànxez, vehïn de Múrçia, una sagetia o barqua de vint rems, ab la qual ell ha feyta fer, en la ciutat de València, a la qual s'en mena a Múrçia, on la enten armar, axí que ell la dita sagetia hi traga ab sos rems e exàrcia d'aquella e huyt persones tengudes d'aquella e armes e vianda a aquells necesària tro a Múrçia. Data etc. ARV, Real, 611, f. $263 \mathrm{v}$.

17 Idus iulii. Lo dit lochtinent mana que al dit Martí Sànxez fon scrit la letra seguent: Al honrat e savi En Jacme Andreu, Batle General en partida del regne de València de Sexona en llà. De mi En Guillem Caplana, tinentloch del honrat En Johan Scrivà, Batle, etc. Saluts et honor. Com En Martí Sànxez, vehïn de Múrçia se sia obligat en poder nostre, que dins dos meses següents aportarà albarà testimonial de l'Adelantat de Múrçia, per lo qual serà cert que aquella sagetia o barqua, en present trau del Grau de la mar de València e deu manar al Alcàcer de Múrçia, haurà presentada en poder del dit Adelantat segons que en la obligació, en poder nostres, feyta dimarts, VII dies de juliol de l'any present és contengut. Per ço, de part del Senyor Rey, vos requir e, de la mia, prech que si.l dit En Martí Sànxez a vós presentarà e delliurarà letra del dit Adelantat, per la qual apparega lo dit En Marti Sànxez la dita sagetia haver mesa en poder d'aquell, dins lo temps en la obligació contengue, vós, la dita letra, fets registrar a ca vila aprés la dita la obligació, striven lo dia de la obligació, per ço que a avant la veritat del feyt sia sabuda, ço que.l dit En Martí Sànxez, les fermançes, per aquell donades, sien absoltes de la dita obligació si donchs no aparia lo dit Martí Sànxez ésser vengut contra les coses en la dita obligació contengudes. Data Valentia idus iulii, anno, etc. ARV, Real, 611, f. $263 \mathrm{v}$.

18 VIII kalendas september die martis. Lo dit En Martí Sànxez comparech devant lo dit Batle General e presenta a aquell dues letres, la una del consell de Múrçia e l'altra de l'honrat En Pero López d'Ayala, la tenor de les quals és aytal. ARV, Real, 611, f. $163 \mathrm{~V}$. 
los escritos reclamados por las autoridades valencianas para poder permitir el armamento de la saetía, dejando en libertad a los avaladores del aparejo y las fianzas correspondientes. Nosotros contamos con la inestimable conservación de la carta de Pero López de Ayala, redactada a 12 de agosto de $1327^{19}$. En ella, este personaje narrará como Sánxez había llegado al Alcázar de Murcia con una saetía que ya era de treinta y dos remos, en lugar de los veinte que se estipuló en un principio. El arribo del corsario con su barqua se habría producido unos 18 días antes de la redacción del documento. El largo período que pasó entre la llegada de Sánxez y la redacción del escrito se debió a la confusa situación política que atravesaba Murcia.

En efecto, el Baile General había exigido el compromiso del Adelantado del reino murciano para permitir que los avaladores del corsario recuperasen sus fianzas. Sin embargo, Jaume Andreu se negó a conformarse con la carta del Concejo de Murcia, puesto que no había todavía, nombrado oficialmente un Adelantado. El Baile de Xixona reclamó, en cualquier caso que fuera Pero López de Ayala, hombre fuerte del momento, en la frontera mediterránea castellana, la persona que se hiciere cargo, junto al Concejo de Murcia del tema, aduciendo para su insistencia que el Baile General no se conformaría con otra solución ${ }^{20}$. Fue por ese motivo, por el que López de Ayala, a la

19 Al honrado Guillem Çaplana, tinientelugar de Johan Scrivà, Batle General, del regne de València. De mi Pero Lóppez Dayala, vassallo e merçés de mi l/f. 264r// Senyor don Alonso, rey de Castiella. Salut como aquell para quien quiera que diesse Dios mucha honra et endreça buena. Fagvos a saber que Martín Sánxez, vecino de Murçia, traxo al Alcáxar, término del dito lugar, una saetía, de trenta dos remos, e legó aqui con la dicha saetia oy, ha XVIII días poco más o menos, e mostrome una vostra carta por la qual aparesçe que diera fiaderos, que pornia la dicha saetía en el dicho Alcáçar, e que levando ell carta, del Adelantado daqui, a Jayme Andreu, Batle General, en partida del regne de Valencia, de Xixona aquá, que soltasse los fiadores que diera (sic) que diera. E por razón que Adelantado non ay agora en Murçia, de qui ell pueda levar carta, e el dicho Jayme Andreu dize que no soltaria los fiadores sin la dixa carta, por que due que vos gelo enbiastes assí a decir e el dicho Martín Sànxez pidiome que.l diesse mi carta para vos en sta razón, porque vos certifics e vos fag fe, con esta carta, quel dicho Martín Sánxez coxo e tiene, en el dicho Alcáçar, la dicha saetía e la puso aqui en poder del consejo de Murçia et de mi, que esto aqui por el rey mio señor, adido recabdo al consejo e a mi que non sacare ni levará la dicha saetía a nenguna part sin sabidoria nostra, per que della non pueda seer fecho danno a cerca de los amigos de nuestro senyor el rey, ni a sus gentes, ni a sus cosas, de comón el consejo vol lo enbian deser por su carta. E asi ruegovos que devedes dar vuestra carta al dicho Martín Sánxez, por al dicho Jayme Andreu, en quel suelte los fiadores, que dio en su poder e que mande dampnar e cancellar la dicha fiadoría. Et vos faredes drecho e mesura e lo que devedes e yo agradeçer vuestros ruegos. Fecha XII dies de agosto, era de $M$ e CCC e sesenta e cinco annos. ARV, Real, f. 263v 264r.

20 Respecto de Pero López de Ayala todas las informaciones de que disponemos hacer referencia a su conexión con don Juan Manuel, señor para el que ejercerá labores diplomáticas y guerreras, sirviendo, también de intermediario entre Jaime el Justo, el rey de Castilla y el soberano nazarí. Pero López de Ayala actuará como Adelantado, a veces en nombre de don Juan Manuel, a veces en representación del rey de Castilla, en multitud de ocasiones, estando documentado, como mínimo desde 1303. El peculiar status de estos hombres de frontera repercutirá en el comportamiento del que fue, probablemente, su descendiente el Canciller Pero López de Ayala, también documentado unos años más tarde por estas comarcas. Vid. por ejemplo. Maria Teresa FERRER I MALLOL, La frontera amb I'Islam en el segle XIV cristians i sarrains al País Valencià, Barcelona, 1988, pp. 105, 107-108, 111, 
sazón, sin titularse Adelantado de Murcia, el que asumió las responsabilidades del aparejo de Sánxez ante Joan Escrivà.

De este modo fue como Martín Sánxez, después de no pocas vicisitudes, consiguió verse libre de las fianzas que había tenido que depositar en la Bailía de Xixona. No obstante, el futuro de nuestro hombre estaba lejos de Murcia o de Cartagena. Sabemos, por ejemplo, que el corsario se habría asentado en Valencia durante 1334, al menos. En efecto, por un cuadernillo remitido desde la Bailia de Valencia al rey, en el que se anotaban todos los aparejos comprendidos entre marzo de 1334 y enero de 1335 aparecerá Martín Sánxez. Así el 22 de abril de 1334 se anotará un Martín Sanç, que armaba una barcha de 14 remos, con la que había capturado un cautivo cerca de Mostaganem. Más interesante es otro asiento de 30 de septiembre por el que Martín Sancho aparejó una barca de 20 remos, pagando como fianza 200 morabatinos y siendo avalador Pere Rull, residente en la Xerea, uno de los barrios más marineros intramuros de la ciudad ${ }^{21}$.

Probablemente, las dificultades con las que se encontró Martín Sánxez, después de la firma de la paz entre Granada y los territorios cristianos llevaron al corsario a plantearse la posibilidad de desplazar su puerto base nuevamente. Efectivamente, sabemos que en 1334 ya se había trasladado a Mallorca, con su barca de 24 remos, cuyo rey continuaba la guerra contra Granada22.

Como conclusión a todo lo dicho hasta ahora es el momento de establecer un balance de la realidad corsaria murciana, durante el primer tercio del siglo XIV. La primera premisa que conviene manejar, como constatable, es la de la propia existencia de actividad corsaria en la costa murciana. El estado de precariedad en el que vivía el litoral parece incuestionable, hasta el punto de favorecer a los armadores locales su integración en la órbita territorial valenciana, que le resultaría afín si no familiar. Por esos motivos encontramos a Martín Sánxez en Valencia, donde apareja su fusta e intenta conseguir una licencia de corso.

La segunda premisa que se desprende de todo este proceso será la asunción, por parte de las autoridades de la Vega del Segura, de las normativas impuestas desde Valencia, ante la inexistencia de un corpus legal paralelo. De hecho, la integración de parte de las poblaciones murcianas en el reino de Valencia, durante el reinado de

113, 118, 120, 125-126, 145 y 255-256. También Les aljames sarraines de la Governació d'Oriola en el segle XIV. Barcelona, 1988, p. 10. Por último, vid., Organització i defensa d'un territori fronterer. La Governació d'Oriola en el segle XIV. Barcelona, 1990, pp. 46, 51, 62, 74 y ss.

21 Manuel SÁNCHEZ MARTÍNEZ, «El control del corso valenciano (1334) en el marco de la paz entre la Corona de Aragón y los sultanatos de Granada y Fez». Homenaje al Prof. Jacinto Bosch Vilá, 1, Universidad de Granada. Departamento de Estudios Semíticos. Granada (1991), pp. 349-365. María Dolores LÓPEZ PÉREZ, La Corona de Aragón y el Magreb en el siglo XIV (1331-1410). Barcelona, 1995.

22 Maria Teresa FERRER I MALLOL, La frontera amb l'Islam..., pp. 137 y 139. 
Jaime II, habría permitido cierto grado de proximidad de los oficiales de la Vega Alta del Segura respecto de la administración real valenciana. Es más, después de la reintegración a Castilla de Cartagena y algunas villas más, la situación en el reino de Murcia era tan fluida que, ante la inexistencia de personalidades con responsabilidades políticas definidas, se recurrirá, por parte del concejo de Murcia, a los «señores naturales» de la tierra, con objeto de atender las exigencias valencianas, conscientes de que el baile local de Orihuela podría aceptar el aval de López de Ayala.

Por último, Martín Sánxez se verá impelido a abandonar el puerto de Cartagena. Además, desde la década de los treinta, el apoyo que Sánxez pudiera obtener por parte de las autoridades valencianas quedará anulado por las paces firmadas entre el nuevo monarca catalano-aragonés, Alfonso el Benigno, y el rey nazarí. En estas condiciones, Martín Sánxez, que en ningún momento pensó en abandonar su actividad corsaria, se vio libre de cualquier vinculación para trasladar su puerto base, nuevamente, en esta ocasión a Mallorca, donde el rey Jaime III de Mallorca podría garantizar la continuidad de los aparejos.

Martín Sánxez, en suma, no consiguió establecer su puerto base en Cartagena, pero si que logró sus aspiraciones de dedicarse al mundo del corso, constituyendo un valioso antecedente de los armadores que tuvieron, cien años más tarde, los puertos murcianos como base de operaciones en el Mediterráneo ${ }^{23}$. Los corsarios murcianos, en cualquier caso, tuvieron una estrecha vinculación con el reino de Valencia y la tradición marítima catalana en donde, muy probablemente, pueda encontrarse su origen o al menos su potenciación como actividad naval.

23 Andrés DÍAZ BORRÁS, Problemas marítimos de Valencia a finales de la Edad Media: el corso, la piratería y el cautiverio en su incidencia sobre la dinámica económica, 1400-1480. Valencia, 1988 (edit. microfichada de tesis doctoral), pp. 483-491. 


\section{LA DOCUMENTACIÓN DIPLOMÁTICA ENTRE LA CORONA DE ARAGÓN Y EL SULTANATO MAMELUCO DURANTE EL REINADO DE JAIME II: UN EJEMPLO DE LAS TRANSFORMACIONES EN LAS RELACIONES INTERNACIONALES DEL ÁMBITO MEDITERRÁNEO EN LA BAJA EDAD MEDIA}

\section{Gabriel GONZÁLEZ MAURAZOS}

El tema que se pretende abordar en esta comunicación es de capital importancia para conocer los orígenes de las relaciones entre la Corona de Aragón y los Estados islámicos mediterráneos durante la Baja Edad Media. Es una cuestión que ya ha sido abordada por la historiografía contemporánea, si bien ha interesado más a arabistas e historiadores dedicados al estudio de Oriente Medio en época medieval (Heyd ${ }^{1}$, Aziz Suryal Atiya ${ }^{2}$, Labib ${ }^{3}$, Irwin $^{4}$, Holt $^{5}$ ) que a medievalistas especializados en la Corona de Aragón y su expansión territorial y comercial por el Mediterráneo.

La documentación que ha sido utilizada para realizar este estudio es aquella que se halla en el Archivo de la Corona de Aragón y que ha sido publicada, bien de forma íntegra, bien de manera resumida, por Capmany ${ }^{6}$, Aziz Suryal Atiya ${ }^{7}$, y Alarcón y Santón y García de Linares ${ }^{8}$. Cada autor se dejó llevar por diferentes criterios a la hora de

1 Histoire du commerce du Levant au Moyen Âge, II, pp. 30 y ss.

2 Egypt and Aragon. Embassies and Diplomatic Correspondence between 1300 and 1330 A.D.

3 Handelsgeschichte Ägyptens im Spätmittelalter, pp. 78-80.

4 The Middle East in The Middle Ages: The Early Mamluk Sultanate, 1250-1382, pp. 73-74, 9899 y 117.

5 The Age of The Crusaders, p. 166.

6 Antiguos tratados de paces y alianzas, pp. 26-35.

7 Op. cit.

8 Los documentos árabes diplomáticos del Archivo de la Corona de Aragón, pp. 335-368. 
elaborar sus colecciones documentales. Así, frente al criterio filológico seguido por Capmany (recoge la correspondencia que, escrita en catalán por los monarcas aragoneses, fue dirigida a los soberanos de los principales Estados islámicos bajomedievales del Mediterráneo), o por Alarcón y Santón y García de Linares (complementan el trabajo de Capmany al recopilar las cartas que los jefes de Estado del Islam remitieron en lengua árabe a varios monarcas hispánicos), se opone el criterio cronológico empleado por Aziz Suryal Atiya, quien estudia las relaciones diplomáticas entre el Sultanato mameluco y la Corona de Aragón durante el período 1300-1330, en el que se registran un total de ocho embajadas. Se trata de un encuadre puramente formal y arbitrario, pues no se ajusta a ninguna realidad política o documental: no se incluye la actividad diplomática de los primeros años del reinado de Jaime II, desarrollada a finales del siglo XIII, y, por contra, se añaden las embajadas de 1328 y 1330, ya en tiempos de Alfonso IV. El período 1300-1330 tampoco es significativo desde el punto de vista mameluco, pues esta primera actividad diplomática con la Corona de Aragón se desarrolla básicamente a lo largo de los tres sultanatos de al-Nasir Muhammad, esto es, entre los años 1293 y 1341, si bien existe correspondencia anterior. Por tanto, para conocer la génesis de las relaciones diplomáticas entre la Corona de Aragón y el Sultanato mameluco, es preciso tener en consideración la documentación producida en la última década del siglo XIII.

Los trece textos que han sido utilizados para llevar a cabo este estudio han sido todos ellos publicados por los tres autores anteriormente citados. Redactados entre los años 1292 y 1328, componen en su conjunto una secuencia documental, que puede estar incompleta, a juzgar por los grandes paréntesis temporales en los que hay un vacío documental, así como por la alusión que en algunos de ellos se hace a la correspondencia recibida por alguna de las partes pero que hoy nos es desconocida. En cualquier caso, dicha secuencia responde siempre a la misma tónica: el desarrollo de un intercambio de correspondencia entre el monarca aragonés y el sultán mameluco. Cuando sea el primero quien tome la iniciativa a la hora de establecer relaciones diplomáticas con el segundo y solicitarle una serie de concesiones, el soberano musulmán responderá positivamente a las embajadas de Jaime II y en la mayoría de los casos satisfará los ruegos del rey Justo, aunque, recíprocamente, también utilizará el envío de misivas como medio para obtener del monarca aragonés una serie de bienes y privilegios.

No deja de llamar la atención el hecho de que estas iniciales relaciones diplomáticas entre la Corona de Aragón y el Sultanato mameluco estén prácticamente asociadas a las figuras de Jaime II y al-Nasir Muhammad, si bien hay noticias de embajadas anteriores a estos soberanos ${ }^{9}$, al igual que sabemos que hay una continuidad en la actividad diplomática tras la muerte de Jaime II, como atestigua el intercambio de

9 De hecho, las cartas fechadas en 1292 corresponden a embajadas desarrolladas en tiempos del sultán al-Ashraf Khalil. Además, en la carta que el sultán dirige a Jaime II el 9 de agosto de 1292 se menciona la existencia de unas relaciones anteriores entre ambas naciones, siendo rey Alfonso III (véase CAPMANY, Op. cit., p. 27). 
correspondencia que continúa desarrollándose entre Alfonso IV y al-Nasir Muhammad ${ }^{10}$. A continuación, se enumeran por orden cronológico las cartas publicadas que han sido utilizadas para realizar la presente comunicación:

1. 28-I-1292. ACA, carta árabe n 153. En Alarcón y Santón y García de Linares (original árabe y traducción al castellano), pp. 335-344.

2. 9-VIII-1292. En Capmany (traducción castellana del original catalán), pp. 26-31.

3. 6-IV-1300. ACA, carta árabe en papel. En Atiya (extracto del original árabe con traducción al inglés), pp. 17-19.

4. 1-VI-1303. ACA, reg. 334. En Atiya (fragmentos del original catalán), pp. 20-21.

5. 19-V-1304. ACA, cartas árabes. Rollo II. En Alarcón y Santón y García de Linares (original árabe y traducción al castellano), pp. 350-354; y Atiya (extracto del original árabe con traducción al inglés), pp. 22-24.

6. 1-IX-1305. ACA, reg. 334. En Atiya (fragmentos del original catalán), pp. 26-27.

7. 16-11-1306. ACA, cartas árabes. Rollo IV. En Alarcón y Santón y García de Linares (original árabe y traducción al castellano), pp. 355-360; y Atiya (resumen del contenido y edición de una lista de regalos ofrecidos por el sultán a Jaime II, que fueron enviados a Barcelona desde Egipto en esta embajada), pp. 28-32.

8. 8-IX-1314. ACA, reg. 337, fol. 231. En Atiya (fragmentos del original catalán y resumen del contenido), p. 35; y Capmany (traducción castellana del original catalán), pp. 32-35.

9. 17-III-1315. ACA, cartas árabes. Rollo I. En Alarcón y Santón y García de Linares (original árabe y traducción al castellano), pp. 360-365; y Atiya (texto árabe y su traducción al inglés), pp. 36-41.

10. 27-VIII-1318. ACA, reg. 337, fol. 233. En Atiya (sólo se resume su contenido), pp. $42-43$.

11. IX-1322. ACA, reg. 338 , fol. 138. En Atiya (texto catalán original), p. 45.

12. 23-II-1323. ACA, cartas árabes. Rollo VI. En Alarcón y Santón y García de Linares (original árabe y traducción al castellano), pp. 365-368; y Atiya (texto árabe y su traducción al inglés), pp. 47-52.

13. 20-VIII-1327. ACA. Regesta Jacobi, II, reg. 338, fol. 140. En Atiya (texto catalán original), pp. 53-54.

Para iniciar el estudio de estas trece cartas, se pueden agrupar en tres fases cronológicas, utilizando como criterios divisorios los períodos de silencio documental. No obstante, conviene señalar que los temas contenidos en la documentación son bastante homogéneos, por lo que este tipo de clasificación respondería únicamente a la intención de dar una posible explicación a la ausencia de embajadas por una u otra parte en determinados momentos históricos.

10 Son un ejemplo de esto los documentos árabes de 1328 (véase ATIYA, Op. cit., pp. 57-60; ALARCÓN Y SANTÓN y GARCÍA DE LINARES, Op. cit., pp. 368-370) y 1330 (véase Suryal ATIYA, Op. cit., pp. 61-65; ALARCÓN Y SANTÓN y GARCÍA DE LINARES, Op. cit., pp. 370-371). 
Una de esas preocupaciones que está siempre presente en todas las embajadas es el deseo que ambas naciones tienen de mantener los lazos de amistad establecidos a finales del siglo XIII; unos vínculos que pueden buscar como meta el reconocimiento mutuo como potencias y representantes ante el otro de la Cristiandad y el Islam respectivamente. Es por esta razón por lo que la principal preocupación reflejada en la documentación va a ser la seguridad de los súbditos residentes en el territorio de la otra potencia. Un deseo que irá dirigido hacia la protección de los comerciantes, pero, en el caso de Jaime II, se hará con el fin de garantizar el ejercicio del culto cristiano en las ciudades del Sultanato mameluco, así como el acceso a los Santos Lugares por parte de los peregrinos y el derecho a la Iglesia occidental a compartir el Santo Sepulcro con otros ritos cristianos. Por tanto, es evidente que, mientras Jaime II pretende mostrarse como protector de los cristianos orientales que habitan las ciudades del Sultanato mameluco y principal defensor de los intereses de la Iglesia latina en Tierra Santa, la postura adoptada por al-Nasir Muhammad es la de un líder panislámico que considera como su deber la salvaguarda del bienestar de todos los musulmanes, incluidos aquellos que se hallan bajo el dominio de una autoridad cristiana, como es el caso de los mudéjares de la Corona de Aragón: "Hegemony over the rest of the Muhammadan world is here re-claimed for Egypt ${ }^{11}$.

En definitiva, podemos afirmar que con este tipo de política se abre una nueva etapa en las Relaciones Internacionales del mundo mediterráneo medieval: tras una fase de dos siglos de confrontación militar entre la Cristiandad y el Islam en Oriente Medio, motivada por el fenómeno de las Cruzadas, se asiste, tras la toma por las tropas mamelucas de las últimas plazas cruzadas en la costa mediterránea oriental (Acre es conquistada en 1291), a un nuevo período histórico, que se caracterizará por un dominio mameluco en Oriente Medio, incuestionable por los Estados de Europa occidental, que ahora tratarán de acercarse a esta potencia islámica a través del envío de embajadas.

\section{LAS ETAPAS DE LAS RELACIONES EGIPCIO-ARAGONESAS EN EL REINADO DE JAIME II}

\section{Los documentos de 1292}

Entrando ya en el análisis de cada una de las fases en que hemos dividido a la documentación, se puede considerar como primera fase aquella compuesta por las dos primeras cartas, ambas de 1292, las únicas pertenecientes al siglo XIII y ocho años anteriores a la siguiente, que data de 1300 . Pese a poderse tratar del comienzo de las relaciones entre ambas potencias, la carta del 9 de agosto hace referencia a una embajada anterior de Alfonso $1 \mathrm{II}^{12}$. Es posible que ésta se produjera en 1291, poco antes de su muerte, y que la carta que el sultán (en ese momento lo era al-Ashraf

11 ATIYA, Op. cit, p. 52.

12 CAPMANY, Op. cit., p. 27. 
Khalil) dírigió a Jaime II fechada el 28 de enero de 1292, fuese una contestación a la misiva inicial de Alfonso III.

Lo más destacado de esta etapa de las relaciones bilaterales mantenidas entre Egipto y Aragón, protagonizadas en el lado aragonés por los emisarios Romeo de Marimón y Raimundo Alemany, es el espíritu de liderazgo que ya se observa en Jaime II, al incluir a Castilla y Portugal, cuyas casas reales están unidas a la aragonesa por lazos matrimoniales, en los tratados de paz y amistad con los mamelucos. Se establecerá también un pacto contra el rey de Francia, manifestándose con esto lo que va a resultar evidente en la documentación posterior: la pugna que ambas monarquías europeas van a establecer por ser reconocidas como potencias cristianas protectoras de los Santos Lugares y las comunidades cristianas que viven bajo el dominio mameluco. Por ese motivo se desarrollará una intensa actividad diplomática encaminada al reconocimiento por parte del sultán de tal autoridad a una u otra nación.

\section{El período 1300-1306}

La primera carta de cuantas conservamos de esta serie es la que con fecha de 6 de abril de 1300 el sultán al-Nasir Muhammad dirige a Jaime II, si bien menciona en esta misiva una embajada anterior realizada por el monarca aragonés a Egipto, de la que no tenemos constancia documental ${ }^{13}$. Junto al siempre presente deseo de seguridad y bienestar que Jaime II manifiesta a lo largo de todo su reinado para los súbditos aragoneses que habitan o visitan el pais mameluco, se pueden observar una serie de elementos y características comunes en la correspondencia realizada entre los años 1300 y 1306 que nos permiten observar que estamos ante un conjunto de embajadas que integran un ciclo propio dentro de toda la documentación quę estamos analizando.

No obstante, la embajada que al-Nasir envía a Jaime Il en 1300 pone de manifiesto un fenómeno que se está produciendo en Oriente Medio en este momento y que hace que esta carta del sultán de El Cairo tenga un contenido especial: el avance de los mongoles hacia el oeste, que va a poner en jaque el dominio mameluco de Siria, una región que es invadida por las tropas del ilján de Persia Ghazan a finales de 1299, y aunque los mamelucos recuperaron ese territorio en primavera, hoy parece claro que «for a brief period, some four months in all, the Mongol il-khân was de facto the lord of the Holy Land»" ${ }^{14}$. Esta "conquista" de Tierra Santa por los mongoles es convertida inmediatamente por las naciones de Europa occidental en una recuperación del Reino de Jerusalén para la Cristiandad, al haber sido arrebatado de las manos del Islam por Ghazan ${ }^{15}$. Por este motivo, el sultán mameluco tratará de volver a poner de su parte a las potencias cristianas, lanzando una campaña propagandística en la que anuncia sus campañas victoriosas contra el ilján de Persia ${ }^{16}$. No obstante, Jaime II se

13 ATIYA, Op. cit, p. 18, nota 1.

14 SCHEIN, «Gesta Dei per Mongolos 1300», p. 810.

15 lbidem, p. 805

16 lbidem, p. 810, nota 5; ATIYA, Op. cit., p. 17, nota 3. 
dejará llevar por esa corriente de pensamiento que fluye por todo el Occidente europeo y que considera a Ghazan como el conquistador de Jerusalén para la Cristiandad, por lo que escribe al ilján una carta fechada el 19 de mayo de $1300^{17}$, en la que «desea saber, si quiere ayuda suya, qué parte le dará de la Tierra Santa, que mediante la gracia de Dios nuestro Señor ha ganado nuevamente, y de aquella que en adelante ganare y conquistare ${ }^{18}$. De nuevo, queda patente el interés que el monarca aragonés tiene por Tierra Santa, dado el poder y prestigio que da su control de cara al resto de la Cristiandad.

Una vez normalizada la situación en Siria, con la recuperación del control del territorio por parte mameluca, se seguirá la rutina habitual en la correspondencia diplomática entre Egipto y Aragón. El protagonista por parte aragonesa de este ciclo de embajadas es Aymeric Dusay, que va a protagonizar un desafortunado suceso con el embajador mameluco Fahr al-Dîn en el puerto de Alejandría en 1306, ocasionado por la retención de uno de los rehenes cristianos que iba a ser liberado y embarcado rumbo a Barcelona ${ }^{19}$. La respuesta del sultán será el arresto inmediato de todos los aragoneses instalados en Alejandría, lo que será considerado por Jaime II un motivo suficiente para romper las relaciones diplomáticas, puesto que una de las peticiones formuladas por el monarca aragonés en aquella embajada, recogida en la carta fechada el 16 de febrero de 1306, era que se garantizase la seguridad de los mercaderes aragoneses asentados en ese puerto egipcio.

Esto será lo más destacado de esta fase en las relaciones egipcio-aragonesas, junto a la exclusión de Castilla y Portugal en los tratados. Parece ser que Aragón pierde a comienzos del siglo XIV representatividad en el marco ibérico, a juzgar por una carta que en 1300 al-Nasir envía a Alfonso XI de Castilla (realmente el monarca es Fernando IV, pues es el período de la minoría de edad de Alfonso), en respuesta a una misiva remitida por el rey castellano. A partir de este momento, las embajadas de Jaime II al sultán mameluco representarán exclusivamente a la Corona de Aragón.

\section{El período 1314-1327}

El grave incidente ocurrido en 1306 en Alejandría, unido a la deposición de al-Nasir Muhammad por al-Muzzafar Baybars II, ahora nuevo sultán (1308-1310), hace que se enfríe la relación diplomática que es objeto de nuestro estudio.

Sin embargo, en los años siguientes se van a producir dos acontecimientos que van a propiciar la restauración de este intercambio bilateral de embajadas. En Oriente, el retorno al poder de al-Nasir Muhammad en el que va a ser su tercer sultanato (13101341), hace que la más poderosa nación del Levante mediterráneo esté gobernada de nuevo por un jefe de Estado deseoso de ser considerado líder de Dâr al-Islâm, tanto por todos los musulmanes del mundo como por las potencias europeas.

17 Traducida por CAPMANY, Op. cit., pp. 106-109.

18 lbidem, p. 108.

19 Sobre este suceso, véase ATIYA, Op. cit., pp. 33-34. 
Mientras, por parte aragonesa se produce, en 1315, el matrimonio de Jaime II con María de Lusignan, de la casa reinante en Chipre, siendo éstas las terceras nupcias del monarca aragonés. Este enlace concede aún más fuerza al ya importante papel que jugaba Jaime II en el Mediterráneo oriental, «for Marie was a potential heiress to Cyprus and Jerusalem ${ }^{20}$, aunque posteriormente fuera desheredada en favor de uno de sus sobrinos.

Es muy posible que esta nueva situación haga plantearse a Jaime II la posibilidad de reemprender las relaciones con al-Nasir Muhammad. De hecho, un año antes de su matrimonio con la presumible heredera al trono chipriota, en 1314, decide recuperar la amistad del sultán mameluco a través del envío de una embajada que es contestada favorablemente por al-Nasir el 13 de marzo del año siguiente; muestra del agrado con que acoge la iniciativa aragonesa es la lista de regalos, fundamentalmente de carácter textil, incluida en su carta ${ }^{21}$, que es una interesante muestra de los más destacados productos de la industria de lujo mameluca.

En definitiva, se ha abierto una nueva etapa en las relaciones de amistad que Jaime II siempre quiso establecer con los sultanes de El Cairo; una nueva época en la que el rey Justo no contará con un único emisario como en el ciclo anterior, sino que serán distintos los nombres que se registren en la documentación. Sólo el nombre de Arnaldo Sabastida aparecerá en dos de las embajadas (1314 y 1318), y nunca solo, sino acompañado por otro emisario (Guillem de Casanadal y F. de Villafrancha respectivamente). El resto de emisarios serán Berenguer de Castro y Gerardo de Olivaria (embajada de 1322) y Pere de Mijavila (1327). Mediante esta política, es posible que Jaime II pretendiera evitar que los embajadores acumularan un excesivo poder, que les pudiera permitir actuar en función de sus intereses, como pudo llegar a suceder con Aymeric Dusay.

Sin embargo, la cuestión más sobresaliente de este período es de nuevo de índole religiosa, relacionada con el control de los Santos Lugares, amén de la petición de traslado a España de determinadas reliquias; una actitud que no gustó a los cristianos orientales y que fue considerada como un abuso de influencia por parte de Jaime $\mathbf{I}^{22}$. El principal interés que en estos momentos tiene el monarca aragonés sobre Tierra Santa es el control del Santo Sepulcro mediante el encargo de la custodia de este importante lugar sagrado de la Cristiandad a monjes pertenecientes a la Corona de Aragón. Así, en la carta de 1322, solicita la custodia de esta iglesia jerosolimitana para los monjes Dominicos aragoneses, si bien en 1327 los favores del monarca irán dirigidos hacia los Franciscanos ${ }^{23}$.

Sin embargo, la suerte de Jaime II con respecto al control de Tierra Santa pudo haber cambiado ese mismo año, ya que su embajada coincidió en Egipto con una francesa que contaba con la sanción del Papado para representar a la Cristiandad

20 BISSON, The Medieval Crown of Aragon, p. 95.

21 ALARCÓN Y SANTÓN y GARCÍA DE LINARES, Op. cit, pp. 364-365.

22 Sobre el intento aragonés de trasladar reliquias como el cuerpo de Santa Bárbara, véase ATIYA, Op. cit, pp. 44-47.

23 Ibidem, p. 53. 
ante el sultán. Cuando todo parecía que iba a decantarse en favor del rey de Francia, la habilidad de Mijavila, el embajador aragonés, permitió que al-Nasir cambiara de opinión y Jaime II siguiera manteniendo su posición de liderazgo sobre los Santos Lugares y de portavoz de la Cristiandad ante el Sultán. De esta manera quedaba abierto el camino para el futuro monarca aragonés, Alfonso IV, que continuaría con esta política de amistad hacia el sultanato mameluco, tan brillantemente desarrollada por su padre.

\section{CONCLUSIONES}

A lo largo de la presente comunicación hemos analizado los principales puntos que configuraron las relaciones diplomáticas establecidas entre Jaime II de Aragón y los sultanes mamelucos contemporáneos a aquél. Unas relaciones que realmente no son más que uno de los muchos ejemplos registrados de intercambios bilaterales de correspondencia entre potencias del Occidente europeo y el Islam.

Tras la intervención bélica en el Oriente mediterráneo por parte de las naciones del Occidente latino a través de las Cruzadas en los siglos XII y XIII, se llega al surgimiento de un poder islámico eficaz a mediados de esa última centuria: es el Sultanato mameluco Bahrî, que para 1291 ha conseguido arrebatar a los cristianos occidentales todos los territorios de Oriente Medio que estaban en su poder.

La derrota militar obliga a las naciones europeas a buscar otros medios para seguir estando presentes en Oriente, y ello, unido al deseo que los propios mamelucos tienen de establecer contacto con esas naciones para poder cubrir algunas de sus necesidades, impulsará el desarrollo del intercambio de embajadas.

Las relaciones diplomáticas que la Corona de Aragón mantendrá con Egipto serán especialmente intensas pues ambos Estados tienen los ingredientes que les hacen ser mutuamente atractivos: la Corona de Aragón, a través de su expansión mediterránea, se ha convertido en una potencia; de ahí que desee ser influyente en el Mediterráneo oriental, donde ahora cuenta con importantes intereses. Por otro lado, la Corona de Aragón es un Estado que cuenta con una importante población musulmana sometida al dominio cristiano, lo que no deja indiferente al sultán al-Nasir, en su deseos de ser reconocido como líder del Islam por el resto del mundo musulmán. En lo económico, la necesidad que tiene el Sultanato mameluco de barcos y metal, elementos indispensables para una sociedad guerrera, pero de los que carece, impulsa a Egipto a aproximarse a la Corona de Aragón que posee hierro en abundancia y es una potencia naval.

Todas estas necesidades hacen que estos lazos de amistad fragüen pronto y siempre esté presente el deseo de mantenerlos por parte de ambos Estados, dado el beneficio mutuo que ello les conlleva. En ese sentido, estamos sólo ante uno de los varios ejemplos de las nuevas actitudes adoptadas entre Estados cristianos e islámicos dentro del marco mediterráneo. 


\section{BIBLIOGRAFÍA}

ALARCÓN Y SANTÓN, M.A. y GARCÍA DE LINARES, R., Los documentos árabes diplomáticos del Archivo de la Corona de Aragón, Madrid-Granada, 1940.

ATIYA, Aziz Suryal, Egypt and Aragon. Embassies and Diplomatic Correspondence between 1300 and 1330 A.D., Leipzig, 1938.

BISSON, T.N., The Medieval Crown of Aragon. A Short History, Oxford, 1986.

CAPMANY Y MONTPALAU, Antonio de, Antiguos tratados de paces $y$ alianzas entre algunos reyes de Aragón y diferentes príncipes infieles de Asia y África, desde el siglo XIII hasta el XV, Madrid, 1786 (reimpr. facsímil: Valencia, 1974).

HEYD, W., Histoire du Commerce du Levant au Moyen Âge, 2 vols., París, 1885-86. HOLT, P.M., The Age of the Crusaders: The Near East from The Eleventh Century to 1517, Nueva York, 1986.

IRWIN, Robert, The Middle East in The Middle Ages: The Early Mamluk Sultanate, 1250-1382, Londres, 1986.

LABIB, Subhi Y., Handelsgeschichte Ägyptens im Spätmittelalter (1171-1517), Weisbaden, 1964.

SCHEIN, Silvia. "Gesta Dei per Mongolos 1300. The Genesis of a Non-event», The English Historical Review, XCIV (1979), pp. 805-819. 



\title{
DE NUEVO SOBRE LA «GUERRA DEL ESTRECHO»: LA CONTRIBUCIÓN FINANCIERA DEL REINO DE VALENCIA EN LA ÚLTIMA FASE DEL CONFLICTO (1332-1344)
}

\author{
María Dolores LÓPEZ \\ Universidad de Barcelona
}

La lucha por el Estrecho, en la que se vieron involucrados los mariníes, el reino de Granada y Castilla, así como la Corona de Aragón, Portugal y Génova, se circunscribe en un período cronológico que abarca desde 1275 hasta 1344 y se caracteriza por un complejo y cambiante sistema de alianzas entre las diferentes potencias implicadas en el conflicto. El control de las principales plazas situadas en el estrecho, Algeciras, Gibraltar, Tarifa o Ronda, en la península, o Ceuta en el espacio norteafricano, y con ellas las comunicaciones Mediterráneo-Atlántico, se encuentra en la base de un conflicto cuyo desarrollo es bastante bien conocido. La historiografía se ha ocupado ampliamente, aunque de manera desigual, de los acontecimientos bélicos así como de las consecuencias políticas y económicas derivadas de la intervención mariní en la península, si bien la última intervención es la que ha atraído el interés mayoritario de los historiadores'.

La última fase tuvo lugar entre 1332 y 1344 y se vio propiciada por el reforzamiento del poder mariní en la persona de Abu-l-Hasan tras un período de crisis sucesorias y disidencias internas. El tránsito de los siglos XIII al XIV fue un período de empuje castellano, secundado por el apoyo catalano-aragonés, frente a la impotencia evidente de los sultanes mariníes, determinados por los conflictos internos. La subida al poder

1 Una amplia referencia bibliográfica sobre esta cuestión puede verse en M.D. LÓPEZ PÉREZ, La Corona de Aragón y el Magreb en el siglos XIV (1331-1410), Barcelona: Institución Milá y Fontanals, 1995, p. 58. 
de Abu-l-Hasan en 1331 supondrá la reanudación de la expansión mariní de los territorios peninsulares.

La petición de ayuda elevada por el sultán nazarí Muhammad IV a Abu-I-Hasan, en 1332, ante el renovado empuje castellano en las zonas fronterizas, sería el detonante de esta última intervención que se materializó en la toma de Gibraltar. La firma de una tregua con Castilla y la Corona de Aragón, en 1334 y 1335, respectivamente, así como el interés preferente del sultán mariní en la expansión hacia el este magrebí, supusieron un intermedio en la lucha por el control del estrecho, una lucha que se reanudó tras la toma de Tremecén por los marroquíes en 1337.

Ante esta posible expansión territorial magrebí en la península, una expansión terrestre, favorecida por la alianza mariní-nazarí, y una expansión marítima posibilitada por la intensa actividad armadora desarrollada en las atarazanas marroquies, las diferentes potencias peninsulares no podían permanecer impasibles. No entraremos en el desarrollo de los acontecimientos ${ }^{2}$, pero sí es importante remarcar que, ante la gravedad de la situación Castilla y la Corona de Aragón firmaron un tratado de cooperación, el Tratado de Madrid, en 1339, con el objetivo de controlar el área marítima del sur peninsular ante las alarmantes noticias del paso de tropas marroquíes a la península. Según este acuerdo, Castilla debía contribuir a la vigilancia del estrecho con veinte galeras durante cinco meses, desde mayo a septiembre, y con ocho el resto del año, mientras que la corona de Aragón aportaría la mitad de embarcaciones, es decir, diez galeras en la temporada estival y cuatro desde octubre hasta abril. Este número podía aumentar o disminuir según las necesidades de un momento concreto, pero siempre en idéntica proporción $n^{3}$. Desde un punto de vista teórico, los acuerdos de colaboración catalano-aragonesa castellana en materia de defensa marítima aseguraban el mantenimiento de una escuadra compuesta de treinta galeras en los espacios temporales de alto riesgo y de doce durante el período invernal. La documentación posterior certifica, sin embargo, el incumplimiento de los términos estipulados por parte de la Corona de Aragón, pero también de Castilla. Cuestiones coyunturales inherentes a las dificultades de financiación, supeditada en gran medida a los donativos de Cortes, y el desvio de una parte de recursos monetarios hacia otras empresas bélicas, bastarían para explicar la imposibilidad de cumplir con los acuerdos pactados. Paralelamente, la evolución del conflicto desde una inicial e inminente invasión de la península hasta una situación claramente beneficiaria para la Corona de Castilla, a raíz de la derrota musulmana del Salado, en octubre de 1340, bastarían para justificar el paulatino desinterés de la Corona de Aragón más preocupada en la solución de sus propios conflictos internos que en la conquista castellana de la plaza de Algeciras. Con todo, Pedro

2 Analizados en M.D. LÓPEZ PÉREZ, La Corona de Aragón y el Magreb, pp. 55-96.

3 Las cláusulas de este tratado son bien conocidas al haber sido publicadas por P. de Bofarull en su recopilación de documentos del Archivo de la Corona de Aragón [Codoin, VII, doc. 5, pp. 87-96] y por las referencias incluidas en la obra de J. Zurita [Anales de la Corona de Aragón, Zaragoza: Consejo Superior de Investigaciones Científicas, 1973, vols. III, p. 471]. Sobre este acuerdo: M.D. LÓPEZ PÉREZ, La Corona de Aragón y el Magreb, pp. 72-83. 
el Ceremonioso intentará mantener una colaboración de compromiso hasta la finalización definitiva de la cuestión del Estrecho.

Cumplir los compromisos implicaba un fuerte desembolso monetario. La organización de una escuadra de diez galeras durante el período estival y cuatro los restantes meses del año, precisaba de importantes sumas de capital y de un fuerte desembolso inicial, especialmente si no se disponía de un número suficiente y era preciso construir algunos navíos. Los salarios de la tripulación y una adecuada provisión de víveres que garantizara la manutención durante la travesía constituían, asimismo, algunas de las partidas de gastos más importantes; unos gastos que se completaban con el armamento en armas ofensivas y defensivas, tanto de la propia embarcación como de los hombres que la tripulaban, así como el equipamiento de velas, mástiles, timones y entenas. Los mecanismos de financiación utilizados por Pedro el Ceremonioso no difieren sustancialmente de los sistemas habituales empleados por la monarquía catalano-aragonesa del trescientos para financiar sus empresas militares. Los recursos del patrimonio real resultaban cada vez más insuficientes dadas las crecientes necesidades del estado. Las continuas y repetidas alienaciones de las rentas reales efectuadas por los sucesivos monarcas ya desde el siglo XIII y a lo largo del trescientos estuvieron motivadas, sobre todo, por la apertura de sucesivos frentes de guerra y el consiguiente aumento de los gastos bélicos, consecuencia de la política expansionista llevada a cabo por la Corona ${ }^{4}$.

La cuestión marroquí, a la que se superpuso la recuperación para la Corona de los dominios del rey de Mallorca, puso de manifiesto la inviabilidad del monarca de disponer de las cantidades suficientes para cumplir con los compromisos contraídos en el Tratado de Madrid. Para una empresa de esta envergadura el monarca precisaba de una serie de recursos extraordinarios que debían ser otorgados por las Cortes. El grado de cooperación estaba lógicamente en relación directa con el grado de peligrosidad de un ataque del sultán mariní y la disponibilidad de Pedro el Ceremonioso a aceptar las prerrogativas exigidas por los diferentes estamentos a cambio de las subvenciones monetarias. El reino de Valencia, directamente afectado por una posible invasión, marítima y terrestre, del ejército mariní, mostró una pronta disposición a colaborar en la financiación de la flota. En agosto de 1339, la ciudad de Valencia, ante la petición de subsidios realizada por el rey, le otorga la cantidad de 100.000 sueldos $^{5}$.

4 Este proceso de desintegración del patrimonio real y los intentos de reincorporación efectuados a finales del trescientos por Martín el Humano han sido estudiados magistralmente por M.T. FERRER en su artículo «El patrimoni reial i la recuperació dels senyorius jurisdiccionals en els estats catalanoaragonesos a la fi del segle XIV», Anuario de Estudios Medievales 7 (1970-1971), pp. 351-491.

5 M. SÁNCHEZ y S. GASSIOT, "La Cort General de Barcelona (1340) y la contribución catalana a la guerra del Estrecho", Les Corts a Catalunya. Actes del Congrès d'Història Institucional, (Barcelona, 1988), Barcelona: Generalitat de Catalunya, 1991, p. 225. De estos 100.000 sueldos deberían descontarse 22.314 sueldos, 4 dineros adelantados por los jurados al almirante Jofre Gilabert de Cruïlles, quien se encontraba en el Estrecho desde el mes de julio con el primer reemplazo de galeras enviado por la Corona de Aragón. Los restantes 77.685 sueldos, 8 dineros, necesarios para el pago de salarios de las tripulaciones, se obtuvieron a través de la venta por dos años de la imposición sobre las 
El pago efectuado por la universidad valenciana permitió al monarca cubrir una parte de los gastos derivados de la permanencia de la flota en los mares de Tarifa desde julio hasta finales de septiembre de 1339 , si bien a partir de esas fechas, las galeras que continuaron con las labores de vigilancia lo hicieron a cargo económico del rey castellano ${ }^{6}$.

El sostenimiento de un número regular de navíos en el área marítima sur peninsular precisaba de elevadas cantidades que el monarca catalano-aragonés únicamente podía conseguir a través de donativos pactados en las Cortes. La carencia de embarcaciones catalano-aragonesas en el Estrecho durante todo un año, desde octubre de 1339 hasta octubre de 1340, se explicaría, en parte, por una falta de disponibilidad de recursos susceptibles de ser invertidos en el armamento de naves destinadas a la guerra de Marruecos. La victoria de la escuadra musulmana sobre la flota castellana, reforzada por las cuatro galeras catalano-aragonesas al mando de Dalmau de Cruïlles, en abril de 1340 sería el desencadenante para proceder a una rápida convocatoria de Cortes, primero en Valencia y más tarde en Cataluña.

Inmediatamente después de conocerse en la corte las noticias de la derrota, Pedro el Ceremonioso procedía a convocar Cortes en la ciudad de Valencia para mediados del mes de mayo ${ }^{7}$. Los capítulos refrendados por los diferentes estamentos repre-

carnes. Las imposiciones, dado su carácter de contribuciones irregulares instituidas en momentos de necesidades extraordinarias de numerario, debían ser aprobadas por el rey, aunque las universidades gozaban de una total autonomía respecto a las modalidades de recaudación de los impuestos. La propia universidad decidía cuáles debían ser los productos gravados y las tasas a imponer, siempre en relación directa con las necesidades monetarias de ese momento concreto, mientras que el monarca únicamente refrendaba y otorgaba los capítulos de las imposiciones. Así, los emisarios enviados por el rey ante los jurados de Valencia en agosto de 1339 con motivo de la concesión de un subsidio especial, Berenguer de Codinacs y Bernat de Ripoll, tenían suficientes prerrogativas para conceder a la universidad, una vez otorgado el subsidio, plenos poderes con el objeto de crear una imposición sobre aquellos productos que consideraran susceptibles de un mayor rendimiento [Archivo de la Corona de Aragón (en adelante ACA), Cancillería (en adelante C), reg. 1377, f. 28 v. (Barcelona. 29, junio, 1339)]. En las deliberaciones del consejo, sobre los diferentes mecanismos posibles para obtener esa cantidad en el tiempo concertado para el pago, se consideró la posibilidad, junto con la venta de la imposición sobre las carnes, de recurrir a la questia o manleuta. Finalmente se optó por la primera alternativa, siempre teniendo en cuenta que la imposición, que había sido otorgada por el rey con una duración de seis años, había sido ya vendida en sus $2 / 3$ partes, es decir, por cuatro años [Archivo Municipal de Valencia (en adelante AMV), Manuals de Consells, A-3, ff. 299 r.-v. (Valencia. 25, agosto, 1339)]. El comprador de los dos años restantes, por una suma total de 80.000 sueldos, fue Bernat Joan, cambiador y jurado de la ciudad, según se acordó en el consejo de la universidad celebrado el 1 de septiembre de 1339 [AMV, Manuals de Consells, A-3, ff. 300 r.-301 v. (Valencia. 1, septiembre, 1339)].

6 Sobre la flota catalano-aragonesa en el estrecho cf. M.D. LÓPEZ PÉREZ, La Corona de Aragón y el Magreb, pp. 72-83.

7 En las cartas dirigidas a los jurados y prohombres de diferentes villas reales del reino de $\mathrm{Va}$ lencia (Morella, Villareal, Castelló de Burriana, Morvedre, Alzira, Játiva, Jijona, Liria, Cullera y Corbera), el monarca les notifica que, ante las noticias de la pérdida de galeras en el conflicto con el soberano mariní, había decretado la obligatoriedad de todos sus súbditos de prestar la ayuda necesaria. Por 
sentados establecen, en primer lugar, la concesión de un subsidio o almoina, con una duración de 3 años, destinado a la defensa marítima, cuya cuantía debería ser suficiente para mantener veinte galeras durante un período de cuatro meses y otras cinco los ocho meses restantes ${ }^{8}$.

Para obtener las cantidades necesarias se procedió a promulgar unas imposiciones, generales en todo el reino de Valencia, sobre las transacciones efectuadas con toda una serie de productos, alimentarios y manufacturados; una imposición que gravaba, básicamente, tanto la compra como la venta. Asimismo, se impuso una tasa, en el caso de las villas marítimas, sobre la entrada y salida de embarcaciones de sus puertos. Si bien estas ordenaciones tienen un carácter general, los capítulos contemplan la posibilidad de una reducción de las tasas, nunca un aumento, dependiendo de la situación concreta de las diferentes universidades donde se levaban las imposiciones. La tipología de los productos sujetos al pago de gravámenes, así como la imposición de derechos sobre el tráfico mercantil nos hace pensar que en su elaboración se tomó como modelo la propia ciudad de Valencia, e incluso posibles imposiciones decretadas con anterioridad por esta universidad ${ }^{\circ}$. En consecuencia, se trataría de un modelo de base, susceptible de adaptarse a las diferentes condiciones económicas y sociales de cada uno de los lugares obligados al pago del subsidio.

En relación al valor de las tarifas, observamos, en primer lugar, que las tasas impuestas sobre los cereales varían notablemente en relación a la calidad de los granos. El trigo candeal paga a razón de 2 sueldos por cahíz, mientras que el resto - panizo, maíz, cebada, avena y centeno-- abonan justamente la mitad: 12 dineros. Es importante remarcar que la compra de cereales destinados a uso mercantil o para la siembra no pagaba ningún tipo de tasa.

Las carnes, frescas y saladas, son objeto de una amplia reglamentación a nivel de

este motivo requería la presencia de sus representantes en la ciudad de Valencia con los poderes y facultades suficientes para conceder subsidios [ACA, C, reg. 1377, f. 44 r.-v. (Zaragoza. 1, mayo, 1340); M. SÁNCHEZ y S. GASSIOT, La Cort General de Barcelona (1340), p. 226]. Sobre estas Cortes cf. J. MARTÍNEZ ALOY, La Diputación de la Generalidad del reino de Valencia, Valencia, 1930; M. DUALDE, Solidaridad espiritual de Valencia con las victorias cristianas del Salado y Algeciras, Valencia: Instituto Valenciano de Estudios Históricos-Institución Alfonso el Magnánimo, 1950; M.R. MUÑOZ, Orígenes de la Generalidad valenciana, Valencia: Generalitat valenciana, 1987, pp. 47-52. Véase asimismo, de esta última autora, "Las Cortes de 1339, paso previo en la alianza contra los benimerines", Estudios dedicados a Juan Peset Aleixandre, Valencia: Universidad de Valencia, 1982, III, pp. 51-64.

8 Los capítulos aprobados en las Cortes valencianas de 1340, con fecha del 2 de junio, referentes a la concesión del subsidio se conservan en el registro 1377, de la sección de Cancillería del Archivo de la Corona de Aragón, folios 54 v.-63 r. cit. M. SÁNCHEZ y S. GASSIOT, La Cort General de Barcelona (1340), pp. 226 y 235.

9 Por ejemplo, en las Cortes de Valencia de 1329-1330 se decretó la imposición de tasas sobre determinados productos para la obtención de la cantidad ofrecida por los estamentos a Alfonso el Benigno; una cantidad otorgada en ayuda a la Cruzada pactada con Alfonso XI de Castilla contra el sultán de Granada. Un estudio sobre esta cuestión puede verse en M. SÁNCHEZ, "La contribución valenciana a la Cruzada granadina de Alfonso IV de Aragón (1327-1336)", Primer Congreso de Historia del País Valenciano, Valencia: Universidad de Valencia, 1981, II, pp. 579-598. 
tarifas impositivas. La universidad valenciana ejercía un estricto control tanto sobre la venta, que podía realizarse, salvo excepciones, sólo en los establecimientos autorizados, como sobre los precios, fijados por el propio consell de la ciudad. J. Broussolle constata en Barcelona la adopción de idénticas medidas por parte de la municipalidad en materia de productos cárnicos ${ }^{10}$. Estas disposiciones facilitaban en gran medida el cobro de los derechos, que eran abonados a los compradores de la imposición directamente por los carniceros en el momento de procederse al peso de las carnes. Las tarifas eran sumamente variables. Las carnes de carneros, ovejas, cabras y terneros abonaban 1 dinero por cada libra de carne además de una deducción de una libra de peso en el momento de efectuarse la venta de las piezas al carnicero. Idénticas tarifas se aplicaban en las ventas de carne de cerdo, fresca o salada, y animales de caza, como ciervos y jabalíes. La carne de buey y de vaca se tasaba a razón de 1 malla y una reducción de 4 libras en el peso. Los terneros de pequeño tamaño se gravaban con 2 sueldos por pieza, mientras que corderos y cabritos pagaban una cantidad menor -2 dineros por pieza- y si su venta se realizaba a peso 1 dinero por libra.

Los animales de matanza para uso doméstico se gravaban asimismo con unas tasas, cuyo control presentaba mayores dificultades. Los derechos no se establecían en relación al peso, como veíamos en las ventas realizadas directamente en carnicerías, sino que las tarifas eran impuestas por piezas. Así, los bueyes y vacas pagaban a razón de 2 sueldos; los terneros, 18 dineros; los carneros, ovejas y cabras, 12 dineros y los cabritos y corderos 2 dineros, mientras que la carne de cerdo era gravada con una tasa de 12 dineros. En el caso de producirse una venta de la totalidad o una parte de estos productos cárnicos, los propios particulares estaban obligados a pagar un suplemento sobre las tasas anteriores.

A diferencia de los cereales y las carnes, únicamente se gravaba el aceite destinado a la exportación, siempre que fuera extraído por vía marítima. En este caso, el propietario debía abonar a los colectores de la imposición una tasa de 1 dinero por cada arroba.

El vino completaba, junto con las carnes, los cereales y el aceite, el conjunto de productos alimenticios gravados en las sucesivas imposiciones decretadas por motivos económicos diversos en las diferentes universidades valencianas, dado que sus rendimientos eran los más elevados y regulares ${ }^{11}$. La primera de las medidas adoptadas se refiere a la disminución de la capacidad del quarter de vino que pasaba de 30 a 28 libras. Al mismo tiempo, las tarifas diferencian claramente las ventas al mayor y al detalle, así como el destinado a uso particular o mercantil con tarifas que oscilan desde los 4 a los 16 dineros por cada libra del precio total.

La imposición de una tarifa sobre los paños, independientemente de la materia

10 J. BROUSSOLLE, "Les impositions municipales de Barcelone de 1328 à 1462 ", Estudios de Historia Moderna, V (1957), p. 44.

11 Idénticas constataciones pueden hacerse para el caso de las universidades catalanas. J. Broussolle, en su estudio sobre las imposiciones decretadas en Barcelona durante el período comprendido entre 1328 y 1472 , las ha clasificado por este motivo dentro del grupo de las denominadas imposiciones permanentes [Les impositions municipales, pp. 33-59]. 
prima utilizada - lana, lino, estopa, cáñamo, algodón, seda - se concretó en la reducción de 1/40 parte de la pieza y en el pago de una tasa de 6 dineros por cada libra del precio de venta.

Finalmente, en las áreas marítimas, especialmente en el Grao de Valencia, se impone una tasa sobre el tráfico de embarcaciones que cubrían los diferentes trayectos comerciales mediterráneos y, en menor medida, atlánticos. Los capítulos establecen una diferenciación en el valor de las tasas en dependencia a la capacidad de las embarcaciones y la distancia respecto a las plazas de procedencia o destino. Las tarifas más elevadas, que oscilaban entre los 1.000 sueldos de máxima y los 300 de mínima, según el navío, correspondían a la ruta del Levante y de Flandes. A continuación, encontramos la zona circunscrita por los puertos nazaries, Cáller, en Cerdeña, la isla de Sicilia, Túnez y Bugía, situados en el sultanato hafsí y los puertos italianos de Venecia, Pisa, Génova y Nápoles. Los derechos abonados se cifran entre un máximo de 400 sueldos y un mínimo de 100. Esta última tasación, en navíos de idéntica capacidad, se aplica asimismo en la ruta magrebí occidental, que comprendía desde Tedelis, en la zona costera zayyaní, hasta Nife, situada en el Marruecos atlántico. Otra de las zonas delimitadas correspondería a la Provenza, a los mercados de Marsella, Aigues Mortes, Narbona y Colliure con tasas sensiblemente menores, de 23 sueldos, 4 dineros. Finalmente, los trayectos efectuados a lo largo de la costa catalano-balear eran los menos gravados por la imposición: solamente 50 sueldos.

Las diferentes tasas no eran cobradas directamente por los representantes de los diversos estamentos, sino que las imposiciones se vendían por una cantidad preestablecida en subasta pública y era el comprador el encargado de recolectar los derechos correspondientes. Con el objeto de facilitar las ventas y también de evitar posibles fraudes en la recaudación de las sumas obtenidas, se nombraron ocho administradores como representantes de los diferentes estamentos ${ }^{12}$. Para evitar la defraudación se estipuló, asimismo, que la totalidad de los ingresos procedentes de la venta de imposiciones se depositaran en una única taula, al tiempo que se establecía la ilegalidad de realizar ningún pago sin la conformidad de los administradores; los albaranes deberían, en consecuencia, estar refrendados por los sellos de todos y cada uno de los estamentos para que adquirieran validez y pudieran hacerse efectivos. Los poderes otorgados por las Cortes a los administradores son sumamente amplios y no se limitan a las cuestiones referentes a la administración del subsidio. Los capítulos contemplan en este sentido la posibilidad de que ellos mismos tasen en una cantidad fija la cuota de participación en el subsidio de aquellos lugares en que las imposiciones no obtuvieran un precio de venta considerado suficiente, o bien existiera algún tipo de resistencias en el momento de materializar los pagos correspondientes. Estas

12 La elección recayó en Umbert de Tous, de la orden de Montesa, Arnau Bru, rector de la iglesia de San Salvador de Valencia, Jaume Castellar, Gilabert de Noguera, Joan Escrivà, Bartomeu Saranyó, Bonafonat de Vall-llebrera y Pere de Clariana [ACA, C, reg. 1377, f. 63 r.-v. (Valencia. 8, junio, 1340)]. Las tasas debían ser recaudadas en lugares muy distantes entre sí, de manera que se les otorga que puedan nombrar procuradores que desempeñen en su nombre algunas de las tareas [ibídem, f. 64 r.-v. (Valencia. 9, junio, 1340)]. 
prerrogativas se verían refrendadas por la capacidad de los administradores de proceder a la confiscación de bienes, tanto en lugares bajo jurisdicción de la nobleza, laica o eclesiástica, o de la monarquía, en el caso de incumplimiento de los términos acordados sobre el pago del subsidio.

Pero al mismo tiempo, se establecía un férreo control sobre los administradores, quienes deberían rendir cuentas regularmente ante las personas nombradas por las Cortes para este cometido, pero no ante el rey o sus oficiales. Igualmente, se establecia que las cantidades obtenidas a través del subsidio únicamente pudieran ser empleadas en la cuestión de la defensa marítima del estrecho y se prohibía terminantemente que el monarca pudiera disponer directamente de esas sumas.

En definitiva, con estas disposiciones, refrendadas en su totalidad por Pedro el Ceremonioso como condicionante indispensable para la obtención del subsidio, las Cortes se aseguraban un control total y absoluto tanto de la tasación como de la administración del subsidio e impedian cualquier posible injerencia de la monarquía.

A cambio de esta ayuda pecuniaria, el monarca catalano-aragonés no podría exigir ninguna otra exacción mientras durase la recaudación de las cantidades concedidas $^{13}$, al tiempo que confirmaba a perpetuidad los privilegios e inmunidades de los diferentes estamentos ${ }^{14}$.

Tras la conformidad mostrada en las Cortes sobre la concesión del subsidio para la guerra de Marruecos, Pedro el Ceremonioso otorga a los administradores nombrados para la leva de la almoina plenas facultades para recibir las firmas que refrendaban la concesión. De esta manera podía regresar inmediatamente a Cataluña, donde esperaba recibir, al igual que en el reino de Valencia, ayuda monetaria para proceder al armamento de galeras. Ciertas dilaciones en el momento de procurar algunas firmas, como la de Lope de Luna, señor de la ciudad de Segorb, o la del obispo de Tortosa, a pesar de sus intenciones claramente favorables a la imposición de la tasa, significaban importantes retrasos en la recaudación del subsidio ${ }^{15}$. Otros señores, laicos y eclesiásticos, ofrecieron asimismo algunas resistencias en el momento de suscribir los acuerdos tomados en las Cortes viéndose por ello amenazados con la con-

13 Así lo certifica Pedro el Ceremonioso en las cartas dirigidas a la universidad de Valencia [ACA, C, reg. 1377, f. 66 r.-v. (Valencia. 5, junio, 1340)]; a Pere, conde de Ribagorza y Ampurias [ibídem, f. 72 r. (Barcelona. 15, julio, 1340)]; a Teresa de Entenza, viuda de Juan Eiximen de Urrea, Toda Pérez de Urrea, viuda de Artal de Alagón, hija y heredera de Juan Eiximen y de Teresa, y a Juan Eiximen de Urrea, hijo de Artal de Alagón y de Toda Pérez [ibídem, f. 80 r.-v. (Barcelona. 4, agosto, 1340)]; a Lope de Luna, señor de la ciudad de Segorb [ibídem, ff. 95 v.-96 r. (Barcelona. 25, agosto, 1340)]; a Pere, señor de Xèrica, a Pere de Tous, maestre de la orden de Montesa, a Berenguer, obispo de Tortosa, $y$, en general, a las universidades y a los señores laicos y eclesiásticos con posesiones en el reino de Valencia [ibidem, ff. 88 v.-89 r. (Barcelona. 30, agosto, 1340)].

14 ACA, C, reg. 1377, f. 111 r.-v. (Barcelona. 1, octubre, 1340).

15 La firma no se efectuaría hasta finales del mes de julio [ACA, C, reg. 1377, f. 63 r.-v. (Valencia. 8, junio, 1340); ibídem, f. 64 r. (Valencia. 9, junio, 1340); ibídem, f. 69 r.-v. (Barcelona. 7, julio, 1340); ibidem, f. 69 v. (Barcelona. 7, julio, 1340)]. 
fiscación de sus bienes ${ }^{16}$. Las amplias facultades otorgadas a los administradores sobre la posibilidad de efectuar ventas, arrestos y confiscaciones paliaron parcialmente las resistencias mostradas en determinados lugares para la colecta de las sumas correspondientes ${ }^{17}$; unas resistencias especialmente marcadas en los territorios del reino de Valencia ultra Sexonam, donde se vieron obligadas a intervenir las propias autoridades reales ${ }^{18}$.

La pronta expedición de una flota de cuatro galeras y un leño prevista para finales de septiembre y a la que estaban destinados los beneficios inmediatos de la almoina, obligó a proceder con cierta rapidez a los administradores. No se consiguieron las cantidades necesarias en el tiempo preciso, de manera que el monarca tuvo que recurrir a los préstamos particulares para poder cumplir con los plazos establecidos ${ }^{19}$.

La inexistencia de una pronta solución al conflicto bélico con Marruecos y la continuidad de los envíos de galeras al área del Estrecho determinó la necesidad inmediata de una nueva subvención monetaria, decretada en las Cortes celebradas en Valencia en diciembre de 1342, y con una duración de otros tres años. En ese momento particular, los intereses prioritarios de Pedro el Ceremonioso se centraban no tanto en la guerra de Marruecos como en la recuperación de los dominios del rey de Mallorca y en su anexión a la Corona. De hecho, consigue que en el donativo otorgado por las Cortes se incluya una cláusula conforme, en el caso de que fuera necesario, pudiera utilizar una parte de esa cantidad en los preparativos del desembarco en Mallorca, programado para efectuarse en los meses siguientes. La condición requerida era procurar previamente una suma suficiente para armar las diez galeras que deberían cubrir la vigilancia en los mares de Tarifa; el resto podría ser utilizado en la

16 Es el caso de Eiximen de Tovia, señor de Xella, quien es requerído en numerosas ocasiones por Pedro el Ceremonioso para que se adhiera al acuerdo [ACA, C, reg. 1377, f. 89 v. (Barcelona. 31, agosto, 1340); ibidem, f. 89 v.-90 r. (Barcelona. 31, agosto, 1340); ibídem, f. 90 r. (Barcelona. 31, agosto, 1340).

17 ACA, C, reg. 1377, ff. 63 v. -64 r. (Valencia. 9, junio, 1340); ibidem, f. 64 r. (Valencia. 9, junio, 1340).

18 ACA, C, reg. 1377, f. 131 v. (Barcelona. 25, noviembre, 1340); ibídem, f. 132 r. (Barcelona. 15, noviembre, 1340). Sin duda, los problemas más graves se produjeron por la negativa de Eleonora, viuda de Alfonso el Benigno y madrastra de Pedro el Ceremonioso, de proceder al pago de la suma correspondiente por sus posesiones en los territorios de Valencia ultra Sexona, una suma que ascendía a 30.000 sueldos anuales y que le fue requerida en numerosas ocasiones, llegándose incluso a amenazarla con la confiscación de sus bienes [ACA, C, reg. 1378, f. 92 v. (Barcelona. 1, mayo, 1342); ibídem, ff. 92 v.-93 r. (Barcelona. 1, mayo, 1342); ibidem, f. 106 r. (Barcelona. 5, julio, 1342); ibidem, f. 107 v. (Barcelona. 26, julio, 1342)]. La causa final de esta negativa no era tanto una marcada oposición a la política del monarca como una cuestión de enfrentamientos personales ya desde la época de Alfonso el Benigno.

19 El conde de Prades, Ramón Berenguer, adelantó por este motivo la suma de 15.000 libras barcelonesas [ACA, C, reg. 1378, ff. 23 v.-24 r. (Valencia. 1, marzo, 1341)]. La duración del conflicto con Marruecos y los sucesivos armamentos impidieron obtener un sobrante suficiente para proceder a la devolución de ese préstamo, más los intereses generados, en los términos previstos inicialmente y a posponer el pago de la deuda [ibídem, f. 69 v. (Valencia. 30, octubre, 1341); publ.P. DE BOFARULL, Codoin, VII, doc. 37 , p. 152)]. 
ejecución contra el soberano mallorquín ${ }^{20}$. De hecho, la colaboración de algunos nobles y los servicios prestados por éstos y sus huestes en el viaje a Mallorca, en junio de 1343, les eximió del pago adeudado por razón de la almoina; exenciones que iban en detrimento de las sumas dedicadas a la defensa marítima del Estrecho ${ }^{21}$. En los capítulos acordados en Cortes se establecía asimismo que en el momento que finalizara la cuestión mallorquina, las cantidades obtenidas a través de la imposición de la almoina deberían ser invertidas de nuevo en su totalidad en el objetivo primero al que estaba destinada la ayuda, es decir, a la guerra de Marruecos ${ }^{22}$.

La insuficiencia de numerario para sufragar los gastos derivados de ambos conflictos militares obligó al monarca a pedir subsidios extraordinarios. Así, en noviembre de 1343 , los jurados y prohombres de la ciudad de Valencia concedieron al rey una cantidad suplementaria a pagar en períodos cuatrimestrales durante dos años. Las sumas, al igual que las anteriores, se obtendrían a través de las imposiciones decretadas en la ciudad y sus términos jurisdiccionales ${ }^{23}$. Los productos gravados, al igual que observábamos en los capítulos otorgados por las Cortes de 1340, son los alimenticios - cereales, vino y carnes-, la producción textil y el tránsito de embarcaciones comerciales; pero, en este caso específico de la ciudad de Valencia, se incluyen, asimismo, diversas tasas que gravan la exportación de una serie de mercancías, como los cueros, las especias, la plata y la cera ${ }^{24}$.

En general, se observa una fuerte reducción de las tasas impuestas sobre los cereales respecto a las imposiciones decretadas en 1340 para la totalidad del territorio valenciano. Así, el trigo candeal pasa de gravar 24 dineros por cahíz a únicamente 6 dineros; los derechos sobre el resto de los cereales - panizo, maíz y cebada - disminuyen en idéntica proporción: 3 dineros por cahíz frente a los 12 de 1340, es decir, el importe de las tasas disminuye en un porcentaje que oscila en torno al $75 \%$. El consejo de la universidad alude a la gran carestía que sufría el reino de Valencia ese año como una de las causas justificantes de la disminución en la cuantía de la ayu$\mathrm{da}^{25}$. Idénticas características se constatan en las imposiciones sobre el tráfico de

20 ACA, C, reg. 1378, f. 121 r.-v. (Valencia. 3, enero, 1343).

21 En octubre de 1343, tras haber anexionado nuevamente las Baleares a la Corona, Pedro el Ceremonioso ordena que le sean perdonadas a Pere, señor de Xèrica, las 2.398 libras de moneda real valenciana que adeudaba a los administradores de la elemosine. No es un caso único. A Gonçalvo García, señor de Jumella, Xinosa, Motnover, la Daia y Xacarella, se le exime del pago de 3.720 sueldos que debían sus vasallos por estos lugares. Las razones argumentadas responden a la importante ayuda prestada al monarca durante la toma de la isla por éstos y otros nobles con posesiones en el reino de Valencia [ACA, C, reg. 1378, f. 136 r.-v. (Valencia. 21, octubre, 1343); ibidem, ff. 137 r.-138 r. (Valencia. 27, octubre, 1343); ibídem, f. 138 r. (Valencia. 27, octubre, 1343)].

22 ACA, C, reg. 1378, ff. 126 r.-127 r. (Barcelona. 24, marzo, 1343).

23 ACA, C, reg. 1378, ff. 142 v.-143 r. (Valencia. 17, noviembre, 1343).

24 Los capítulos de estas imposiciones, con fecha del 5 de noviembre de 1343 se encuentran en el registro 875 de la sección de Cancillería del Archivo de la Corona de Aragón, folios 194 r.-196 v.

25 Esta misma alegación es utilizada por Pedro el Ceremonioso para denegar las sucesivas peticiones de cereales elevadas por el rey de Castilla destinadas al aprovisionamiento de las tropas ocupadas en el sitio de Algeciras. 
embarcaciones, donde se observa la misma reducción de las tasas del orden de las 3/ 4 partes. Las tarifas sobre las carnes y el vino muestran alguna pequeña variación, pero en general denotan una estabilidad respecto a las tasas anteriores. La imposición sobre la producción textil es la única que sufre un aumento bastante considerable: de los 6 dineros impuestos en 1340 por cada libra del precio de las piezas, pasa a gravarse con una tasa de 8 dineros. Es importante resaltar, en primer lugar, el marcado carácter proteccionista de estos capítulos respecto a la comercialización de paños autóctonos y de producción extranjera en la plaza de Valencia. Sólo las operaciones de compra-venta de piezas de lino, estopa, cáñamo o seda realizadas a ús de vestir, estaban sujetas al pago de derechos; por el contrario, las efectuadas a ús de mercaderia no abonaban las tarifas correspondientes.

A diferencia de las ordenaciones de 1340, los capítulos aprobados por la universidad valenciana incluían, dentro de los productos sujetos a un determinado gravamen, algunas mercancías destinadas a la exportación. Los cueros y las especias abonaban 4 dineros por libra; la tasa impuesta sobre la cera era de menor cuantía: 3 dineros por libra. Es de suponer que las imposiciones sobre estos productos debían ser notablemente rentables dada la creciente actividad mercantil mostrada por la plaza valenciana a lo largo del trescientos. En la ciudad de Valencia convergían las materias primas y los productos manufacturados procedentes de las zonas rurales que limitan con los territorios de la urbe, pero también de las demás áreas de producción peninsulares y del comercio internacional. La plaza valenciana extendía su radio de influencia hacia el interior, hacia Castilla, mientras que las embarcaciones que entraban y salían del Grao se movían a pequeña escala entre Provenza, Baleares y el litoral catalán, valenciano y castellano meridional o en dirección a las costas del Magreb y del reino nazarí, y a larga distancia con los centros comerciales del Mediterráneo oriental. La producción local abastecía en parte las exportaciones de cueros, cera y especias, aunque en gran medida procedían de la reexportación de los cargamentos procedentes de las diferentes áreas en contacto comercial con la plaza valenciana.

En este contexto de intensa actividad mercantil se justifica la rentabilidad de una imposición, que ascendía a 3 dineros por libra, sobre la extracción de la plata, cuya exportación se veía favorecida por el déficit de ciertas operaciones comerciales en determinadas áreas, especialmente del Levante mediterráneo.

Además de la ciudad de Valencia otras comunidades reales concedieron subsidios de diferente cuantía. En total, una suma de 260.000 sueldos, obtenidos igualmente por vía de imposiciones sobre los cereales, el vino las carnes y otras mercancías, repartidas de manera proporcional entre las diferentes universidades ${ }^{26}$.

La totalidad del subsidio, al igual que se estipulaba en los capítulos redactados por la universidad valenciana, sería sufragado en un período de dos años, en pagos

26 Contribuciones de las comunidades reales valencianas a la Guerra del Estrecho: Morella, 78.923 s.; Castalla/Favanella, 972 s. 2 dn.; Játiva, 64.366 s.; Morvedre, 54.237 s. 7 dn.; Alzira, 27.423 s. 5 dn.; Burriana, 13.180 s. 8 dn.; Cullera, 7.403 s.; Castellfabib, 4.021 s. 11 dn.; Alpont, 3.888 s. 9 dn.; Ademuç, 2.448 s. 5 dn.; Penàguila, 1.620 s. 3 dn.; Jijona, 1.529 s. 11 dn. 
cuatrimestrales depositados en la taula de Bernat Joan, en la ciudad de Valencia. Como contraprestación, el monarca se compromete a no exigir durante esos dos años ninguna otra subvención, questia o peita extraordinaria, ni la convocatoria de un ejército con motivo de la ejecución contra el Rosellón y la Cerdaña. Además, en el caso de que antes de los proyectados dos años finalizara este conflicto y la guerra de Marruecos, las cantidades procedentes del subsidio los emplearía en la redención y luición de los castillos, lugares y jurisdicciones alienados en el reino de Valencia desde el inicio del conflicto con el rey de Mallorca.

Estas subvenciones no bastaron para sufragar los enormes gastos derivados de los conflictos bélicos que se desarrollaban simultáneamente en el Estrecho y el Rosellón y Pedro el Ceremonioso se vio en la obligación de recurrir a nuevas peticiones de subsidio, siempre a cambio de ciertas prerrogativas. En febrero de 1344 Pere de Tous, maestre de la orden de Montesa, otorgaba al monarca una subvención de 60.000 sueldos en idénticas condiciones a las decretadas por las universidades anteriores, es decir, en pagos efectuados cada cuatro meses durante un espacio temporal de dos años, y tomando como base los mismos capítulos sobre las imposiciones aprobados en la ciudad de Valencia y las villas reales ${ }^{27}$. La concesión de un privilegio real otorgado por Pedro el Ceremonioso, a cambio de la ayuda monetaria, respecto a la extracción de lana sin licencia de los oficiales reales, justificaría la generosa donación ${ }^{28}$.

Finalmente, la firma de una tregua en marzo de ese mismo año, y la suscripción del tratado por la Corona de Aragón en 1345, daba por finalizado un conflicto que tuvo como consecuencia más evidente el final de la intervención mariní en la península ibérica.

27 ACA, C, reg. 876, f. 33 r.-v. (Barcelona. 5, marzo, 1344); ibidem, reg. 1378, f. 151 v. (Barcelona. 21, marzo, 1344).

28 ACA, C, reg. 876, f. 33 v. (Barcelona. 11, marzo, 1344). La orden de Montesa poseía amplios dominios, dentro del reino de Valencia, en la zona del Maestrazgo, una de las áreas de producción lanera más importantes de la península y donde se aprovisionaban algunas compañías catalano-aragonesas y, sobre todo, italianas. Lugares como San Mateu, Peñíscola, Salzadella, Albocàsser, Onda, Tirig o Adzaneta, entre otros, todos ellos pertenecientes a la orden, figuran entre los principales centros productores identificados por F. Melis, tomando como base los datos procedentes de la documentación del Archivo Datini de Prato, de donde se deriva la importancia económica para la orden de Montesa de esta prerrogativa real [F. MELIS, «La llana de l'Espanya mediterrànea i de la Berberia occidental en els segles XIV-XV", en València, un mercat medieval, A. FURIÓ (ed.), Valencia: Diputación Provincial de Valencia, 1985, pp. 75-80]. 


\title{
LA PERSPECTIVA CATALANO-ARAGONESA DE D. JAIME DE SICILIA
}

\author{
Miguel MARZAL GARCIAA-QUISMONDO
}

El largo reinado de Jaime II, huelga reiterarlo, es sumamente rico en cambios y proyectos. También es muy fecundo en las relaciones externas de la confederación catalano-aragonesa.

Esta riqueza, por supuesto, viene fomentada por la coyuntura que vive Jaime II en el gozne del difícil siglo XIV, pero, en última instancia, es el monarca quien imprime el ritmo a su reinado en respuesta a los retos internacionales. Pretendemos, pues, confirmar cómo su fino instinto político maduró durante su reinado en Sicilia dotándole un olfato político siciliano, una habilidad diplomática italiana y una concepción global mediterránea en el escenario hispánico. Aún más, supo ver en el reinado de Alfonso III, si bien en negativo desde su perspectiva siciliana, un experimento para definir sin riesgos sus propias directrices exteriores.

\section{LOS CONDICIONANTES DE LA EXPERIENCIA POLÍTICA DE D. JAIME}

La formación política de D. Jaime, muy temprana, tuvo en nuestra opinión cuatro referentes definitorios:

\subsection{El expansionismo mediterráneo}

Vocación ya enraizada en la casa de Barcelona en el último cuarto del siglo XIII y asumida en sus proyectos políticos.

Durante un tiempo se pensó que la casa de Barcelona no hacía sino secundar los 
intereses de los mercaderes barceloneses ${ }^{1}$, que habrían gestado un auténtico «imperialismo" a cuyo servicio estaría la Corona ${ }^{2}$. Nuevos documentos, un análisis más profundo y un nuevo enfoque metodológico han alterado completamente esta visión. Desde la comprobación de que los mercaderes barceloneses fueron el soporte y no la inspiración del expansionismo mediterráneo de los monarcas catalano-aragoneses ${ }^{3}$, lo que justifica entre ellos el protagonismo de los armadores sobre los mercaderes ${ }^{4}$, hasta reconocer una simbiosis entre la Corona y la nobleza urbana barcelonesa ${ }^{5}$, en que los monarcas respetaron los intereses de los mercaderes como medio para engrandecer la dinastía ${ }^{6}$, se llegó a la afirmación de que la propia complejidad de la confederación catalano-aragonesa explicaba un complicado expansionismo, en el que, empero, primó el particularismo dinástico ${ }^{7}$, que se yuxtapuso y superó a los intereses económicos ${ }^{8}$.

J. Lalinde Abadía reconoce ${ }^{9}$ que el expansionismo mediterráneo es personal, dinástico y feudal, complejo por los variados intereses que debió integrar la Corona, inscrito en las tensiones güelfo-gibelinas, con cierta participación de la nobleza e incorporación de la burguesía barcelonesa. En efecto, en nuestras propias investigaciones $^{10}$, vemos actuar a Pedro III estimulado por criterios feudales y dinásticos (los eco-

1 Variados han sido los análisis los análisis sobre el «despegue» de Barcelona, pero especialmente brillante la tesis de J.E. RUIZ DOMÉNEC, «La sociedad barcelonesa en los siglos XI y XII» y su artículo «El origen del capital comercial de Barcelona», Miscellanea Barcinonensia, XXXI, (1972), pp. 55-88. Existe un importante elenco historiográfico sobre la progresión, artículos, escenarios, caracteres de este comercio.

2 Tesis de R.S. LÓPEZ, desarrollada por J. Vicens Vives y articulada en el artículo, en colaboración con L. Suárez Fernández y C. Carrére, «La Economía en los Países de la Corona de Aragón en la Baja Edad Media", VI CHCA, ed. Madrid, 1959, pp. 103-135, en su opinión la "ruta africana" fue la columna vertebral de la expansión.

3 Cit. Y. RENOUARD, "Les principaux aspects économiques et sociaux de l'Histoire des pays de la Couronne d'Aragon aux Xlle, XIIle, XIVe siécles», VII CHCA, 1962, pp. 231-264.

4 Este protagonismo acentuó el carácter político del expansionismo, M. del TREPPO, "L'espansione catalano-aragonese nel Mediterraneo", en Nuove questioni di storia medievale, pp. 259-300, Milán, 1969.

5 F. UDINA MARTORELL, «La expansión mediterránea catalano-aragonesa», pp. 206-224, /l Congreso Internacional de Estudios sobre culturas del Mediterráneo Occidental, ed. 1978, distinguió entre "expansión comercial», sostenida por mercaderes y «expansión marítima» promovida por la Corona y la nobleza urbana, que proporcionó los grandes consejeros de Pedro III.

6 V. SALAVERT, “Nuevamente sobre la expansión mediterránea de la corona de Aragón», pp. 359-388, / Congreso..., cit. El autor señala Mạtjorca y Sicilia como prototipos de «reconquista» y «gloria».

7 Cit. G. PISTARINO, «Espansione mediterranea della Corona d'Aragona», pp. 193-207, II Congreso..., cit. Distinguía, además, entre objetivos dinástico-feudales, político-territoriales y económicomercantiles.

8 Afirma J.N. HILLGARTH, «El problema del Imperio catalano-aragonés», AEM, X, (1980), pp. 146-159.

9 La Corona de Aragón en el Mediterráneo Medieval (1229-1479), Zaragoza, 1979.

10 Mi propia Tesis inédita, Proyección de las Vísperas Sicilianas en la politica peninsular española, 1282-1291. 
nómicos, meros coadyuvantes), en los que su hijo, el infante D. Jaime comprendió ser una pieza más.

\subsection{Las circunstancias dinásticas}

La fragilidad de la sucesión en los tronos hispánicos se había hecho patente por las arbitrarias y patrimonialistas disposiciones de Jaime I en Aragón, coincidiendo alarmantemente con el temible dilema sucesorio que las reformas legislativas de Alfonso X habían planteado en Castilla ${ }^{11}$. La actitud de Pedro III de Aragón, contradictoria, no ayudó: siendo infante obligó a su padre, Jaime I, el 20 de noviembre de 1275, reconocer a su primogénito $D$. Alfonso como heredero en caso de mori ${ }^{12}$, instaurando el derecho de representación como en las Partidas; luego, ya rey, en su testamento del 3 de junio de $1282^{13}$, refrendaba la "costumbre de España», esto es, la herencia consecutiva de los hijos varones en vida del rey. Pedro III, pues, nombraba su heredero al infante D. Alfonso y, en caso de morir, a su segundogénito el infante $D$. Jaime. Este testamento, en pleno ejercicio de soberanía, tendría una insospechada relevancia legal.

Desde entonces, dos circunstancias determinaron la situación dinástica del infante D. Jaime:

$1^{\circ}$ La supeditación dinástica a la rama agnaticia, siguiendo las pautas del vasallaje practicado por Jaime II de Mallorca ante su hermano Pedro en 1279 y convirtiéndose D. Jaime en el garante de la sucesoria "costumbre de España", en su calidad de segundogénito. La política de Pedro III para el dominio efectivo del Sistema Ibérico iba a ser una muestra. Viuda la señora de Molina, $D^{\mathrm{a}}$ Blanca, y como única heredera su hija $D^{\mathbf{a}}$ Isabel, desde 1281 el monarca aragonés proponía un matrimonio con uno de sus hijos para incluir el señorío molinés en la órbita aragonesa. En enero de 1282 $\mathrm{D}^{\mathrm{a}}$ Blanca pareció aceptar $^{14}$. Se iniciaron unas negociaciones culminadas el $20 \mathrm{de} \mathrm{abri}^{15}$, en que Molina aceptó el matrimonio con el infante D. Fadrique, la alianza y casi protectorado aragonés. Deliberadamente se posponía a D. Jaime, llamado a una posible sucesión y que podía despertar una violenta reacción en Castilla.

La situación varió radicalmente cuando $\mathrm{D}$. Jaime se convirtió en corregente de Sicilia, lejana para las suspicacias castellanas. Muy ajeno a sus intereses sicilianos D. Jaime

11 Fragilidad analizada por R. GILBERT, «La sucesión al trono en la Monarquía española», Recueils de la Societé Jean Bodin pour l'Histoire comparative des Institutions, XXI, (1969), pp. 447-546.

12 Reg. J.E. MARTÍNEZ FERRANDO, «Índice cronológico de la colección de documentos inéditos del ACA», DGAB, XLII, (1973), p. 88. El 21 de noviembre las Cortes juraban a D. Alfonso.

13 Cit. R. ANDRÉS, Relación de testamentos..., p. 39, pero un estudio más profundo se encuentra en M. DUAL DE SERRANO, «Testamento de Soberanos medievales en el Archivo Real de Valencia», EEMCA, IV, (1951), pp. 436-446.

14 El 18 de enero Pedro III ordenó sufragar los vestidos de Domingo Pérez, embajador de Molina. ACA, Reg. 52, f. 1 v.

15 Ese día el rey de Aragón ratificó todos los compromisos pactados por sus embajadores con Da Blanca, ACA, Reg. 44, f. 228 V. 
se avenía dócilmente a la tortuosa política paterna en el sistema lbérico. El 21 de junio de 1283 Pedro III notificaba a $D^{\mathrm{a}}$ Blanca que $\mathrm{D}$. Jaime había dado plenos poderes al comendador de Alcañiz sobre un asunto «que ella conoce», ¿el proyectado matrimonio? D. Jaime se contempla como una pieza de la diplomacia aragonesa.

$2^{2}$ La ilegitimación de la dinastía aragonesa. La conquista de Sicilia provocó la excomunión de Pedro III por el Papa Martín IV el 18 de noviembre de 1282. Sin embargo, el Papa reservó todo el rigor de su poder hasta coordinar la estrategia con Carlos I de Anjou el 9 de marzo de 1283 en Viterbo ${ }^{16}$, en la que Francia era fundamental. Martín IV se comprometió a utilizar las terribles sanciones espirituales.

El 21 de marzo el Papa fulminó la bula «De insurgentis in» por la que condenaba a Pedro Ill y su dinastía, le priva de sus reinos, libera a sus súbditos de la obediencia y homenaje debidos y somete a sus estados al entredicho ${ }^{17}$, sentencia reiterada en bulas del 15 de abril y 27 de mayo siguientes. Era una seria amenaza por la infeudación de Aragón a la Santa Sede y la función de la Iglesia en la articulación de la comunidad política medieval. Consciente, Martín IV ofreció el trono aragonés a un hijo de Felipe III de Francia. El 1 de septiembre de 1283 el monarca francés declinaba, por cuanto un testamento regio legal había instituido legítimo heredero al infante D. Alfonso, aún, en el seno de la Iglesia ${ }^{18}$. Fulmínante, ese día el Papa declaraba nula la donación de Pedro III a D. Alfonso ${ }^{19}$.

Era una arbitrariedad que Pedro III supo evidenciar con su escrupuloso respeto a las potestades pontificias ${ }^{20}$. Empero, incapaz incluso por la violencia de evitar la publicidad de las bulas pontificias, el monarca vio cómo exacerbaron la crisis latente por su estilo de gobierno y la empresa siciliana, desembocando en una rebelión de la que emanó en octubre de 1283 el Privilegio General y la Unión. Martín IV, entonces, confirmó las sanciones espirituales el 18 de noviembre de 1283 ilegitimando la dinastía aragonesa ${ }^{21}$.

Pedro III comprendió que debía erradicar una subversión tan peligrosa. En el invierno de 1283-84 la corte aragonesa halló en la escrupulosa argumentación legal francesa un arma jurídica insoslayable: el testamento del 3 de junio de 1282 era perfectamente legítimo, anterior a las sanciones y consolidaba como heredero de Aragón

16 Detalla S. RUNCIMAN, Las Visperas Sicilianas, Madrid, 1961, p. 234.

17 Regestada en varios catálogos, tan relevante bula que transcrita y publicada por F. OLIVIER MARTíN, Les Registres de Martín IV (1281-85), París, 1931-35, ํㅜ448, pp. 130-1.

18 Carta de clarificadora exposición de doctrina jurídica de monarca francés, reg. F.J. MIGUEL, Regesta de las letras pontificias del ACA, Madrid, 1984, nº 200, p. 112.

19 A.N. de France, j. 714-5. Reg. J. PAZ, Documentos relativos a España existente en los Archivos de Paris, Madrid, 1934, $\mathrm{n}^{2} 149$.

20 Estrategia estudiada por A. FÁBREGA GRAU, «Actitud de Pedro III el Grande de Aragón ante la propia deposición fulminada por el Papa Martín IV", Miscellanea Historiae Pontificae, XVIII, (1954), pp. 161-178.

21 Reg. A. POTTHOST, Regesta Pontificum Romanorum inde ab anno 1198 ad annum 1304, Berlin, 1875, no 22077, p. 1783; pub. F. OLIVIER MARTÍN, Les Registres de..., obr. cit., no 482, pp. 220 2. Se dirigió a Venecia, Génova, Pisa, Ancona y «resto de las repúblicas marítimas" para cercenar la política mediterránea aragonesa. 
al infante D. Alfonso. Así se argumentó, con extrema habilidad, ante Felipe III de Francia, muy pundonoroso en cuanta a la dignidad y atribuciones de la institución monárquica. La maniobra tuvo éxito, porque Felipe III aceptó una controversia entre juristas franceses y aragoneses, fijada en Perpiñán para febrero de 1284 y destinada a dilucidar los derechos de D. Alfonso. A finales de enero, el infante aragonés nombraba sus defensores al obispo de Valencia D. Jazberto y a D. Pedro costa, su juez y consejero. La controversia, se inició el 11 de febrero ${ }^{22}$. Complementariamente, el infante facultaba a D. Artaldo de Rexach y D. Bernardo de Olorda para exponer sus derechos en la Santa Sede, con la plena cobertura de Pedro III23.

La controversia, bien manipulada por juristas propapales, debió aplacar los escrúpulos de Felipe III: el 21 de febrero aceptaba la corona aragonesa para su hijo Carlos Valois Martín IV, satisfecho, refrendó las condenas a Pedro III el 6 de abril y 18 de mayo de 1284, incluso el 4 de junio ordenó predicar la cruzada contra el monarca aragonés y los sicilianos.

En realidad era una pirueta que de facto demostró la solidez de los derechos del infante D. Alfonso. Pedro III supo responder con otra pirueta: el 4 de octubre de 1284 D. Alfonso cedía sus derechos a su padre, Pedro $\mathrm{III}^{24}$, sorteando todos los anatemas pontificios. Una solemne embajada era enviada a Roma el 12 de diciembre para notificar al Papa sobre la nueva legalidad ${ }^{25}$. En todo caso la suerte dinástica de $D$. Jaime quedaba más unida y subordinada a sus hermano.

\subsection{Sicilia}

Centro de los circuitos comerciales más neurálgicos de la Cristiandad, base estratégica para cualquier proyecto de dominio mediterráneo, símbolo del «dominium» pontificio, era el escenario idóneo para el conflicto güelfo-gibelino. En ella D. Jaime pudo familiarizarse con la más alta política y pulsar la raíz de los intereses que palpitaban en el Mediterráneo. D. Jaime, además, pudo comprobar su débil posición en la tortuosa política siciliana, traducida en una mayor dependencia de Aragón. La experiencia de Pedro III fue reveladora.

22 El 1 de febrero, mediante carta al senescal de Carcasona citó a los juristas franceses el 11. El día 7 el infante dio plenos poderes a sus defensores y el 10 concedía dinero para la misión. Cit. del ACA las tres cartas de G. CARINI, Gil Archivi e le Biblioteche di Spagna, in rapporto alla Stotia d' Italia en generale e di Sicilia in particolare, II. Palermo, 1884, p. 164; J.E. MARTíNEZ FERRANDO, Catálogo de los documentos del Antiguo Reino de Valencia, Madrid, 1934, oㅜ 1857, 1860, 1861, pp. 397-8.

23 Cit. del ACA, G. CARINI, Ibídem, pp. 52-54 y 165-6. El 10 de febrero solicitó la asistencia legal de los más grandes juristas gibelinos italianos, especialmente de Raimundo de Ponte. El 13 de febrero advertía al papa sobre la llegada e intención de la legación.

24 Cit. G. CARINI, Ibídem, p. 173.

25 Seguridad diplomática al comendador franciscano y templario de Azcona y para el canónigo de Tudela Pedro Sánchez otorgada por Pedro III y solicitada al Papa. Ese día Pedro III les entregó credenciales ante el Papa, el colegio de Cardenales y los más destacados líderes gibelinos italianos. Otra vez solicitaba asistencia legal a Raimundo de Ponte y a los juristas gibelinos italianos. Seis documentos en el ACA, Reg. 47, f. 131 a 132 v. 
La conquista de Sicilia había sido fácil y rápida, pero sin entusiasmo siciliano, retraído por el republicanismo mesinés aspirante a una communitas Sicilial siguiendo el ejemplo italiano y por el recelo a un despotismo gibelino ${ }^{26}$. Las levas militares y exacciones fiscales para sostener la guerra, unido al asentamiento de catalanes y aragoneses en tierras confiscadas y su ocupación de los cargos político-administrativos relevantes, alimentaron una sorda resistencia a Pedro $\mathrm{II}^{27}$, que ni siquiera detuvo el Parlamento General de Catanía, donde el 25 de noviembre de 1282 se desmontó el impopular régimen fiscal angevino, ni la victoria naval de Nicotera en octubre.

Pedro III debió confiar sólo en el esfuerzo de sus estados hispánicos. Un eficaz infante D. Alfonso logró, desde el 10 de septiembre de 1282, organizar un sistema de convoyes que partía a Sicilia desde Barcelona y Valencia y que dirigían Cerviano de Narbona, Stefano de Seta, Marinone Lenguard y Ramón Calberto ${ }^{28}$.

Fue una medida prudente, porque desde octubre de 1282 crecían los "traidores", que llegaron a organizar una conspiración en enero de $1283^{29}$. Atizados por las bulas de perdón pontificias y el Parlamento de San Martín de D. Carlos de Salerno, heredero de Carlos I, una rebelión antiaragonesa estalló en marzo de 1283. Las fuerzas catalano-aragonesas se convirtieron en el pilar de todo el entramado de Pedro III en Sicilia. En marzo el infante D. Alfonso activó la construcción de una nuevo flota en las atarazanas de Barcelona y Valencia, mientras ordenaba a Cerviá de Riera reclutar soldados en Cataluña y a Ramón de Riusech en Valencia con destino a Sicilia ${ }^{30}$. Pedro III supo que debía volver a sus estados hispánicos para salvar la empresa siciliana, una experiencia bien asimilada por D. Jaime.

\subsection{La corregencia siciliana (1283-85)}

Pedro III sabía que anclar Sicilia en la órbita catalano-aragonesa iba a exigir una solución especial. Para ella optó por dos vías:

- Da Constanza, la Regina, legítima heredera de los Staufen sicilianos y a quien enseguida implicó el monarca aragonés en la política siciliana ${ }^{31}$. Finalmente, coinci-

26 Cit. M. AMARI, Guerra del Vespro Siciliano, reed. Palermo, 1973, pp. 239-42.

27 Política analizada por A. SCANDURA, «L'Espansionismo della Corona d'Aragona in Sicilia ai tempi di Pietro III il Grande», pp. 389-97, /l Congreso Internacional de Estudios..., cit. en pp. 391-2.

28 Cit. documental de G. CARINI, Gii Archivi..., obr. cit., p. 133 y pub. G. LA MANTIA, Códice diplomático dei Re Aragonesi di Sicilia, 1282 a 1355, I. Palermo 1918, no 20. ACA, Reg. 59, f. 110.

29 Prisión de antiguos destacados líderes antiangevinos en las Vísperas, como Palmiero Abate, Simone Finetta, Ruggier di Maura, Gualterio Caltafione, incluso se sospechó de Alaimo de Lentini, cit. M. AMARI, Guerra del Vespro..., obr. cit., pp. 287-8.

30 ACA, Reg. 60, f. 59 v, 60, 72, 92 v. Cit. parcialmente G. CARINI, Gli Archivi..., obr. cit. pp. 29 y 135-6; reg. parcialmente J.E. MARTÍNEZ FERRANDO, Catálogo del Antiguo..., II, obr. cit., oํ 1699, 1702, 1709, 1720, pp. 362-7; pub. parcialmente LA MANTIA, Códice diplomático dei.., obr. cit, no 24 у 25.

31 El 22 de octubre de 1282 el infante D. Alfonso ordenaba pagar vestidos al alfaquí Samuel, enviado por Pedro III a D ${ }^{\mathrm{a}}$ Constanza, ACA Reg. 71, f. 224 v., reg. J.E. MARTINEZ FERRANDO, Catálogo del Antiguo..., II, obr. cit., $n^{\circ}$ 1597, p. 340. El 28 de octubre Pedro III ordenó a Ramón Marquet 
diendo con las revueltas antiaragonesas de marzo de 1283, Ramón Marquet trasladó a principios de abril a $D^{a}$ Constanza y los infantes D. Jaime, D. Fadrique, Da Violante, desembarcados en Trápani. Era la conexión con la legitimidad Staufen.

- La corregencia y donación de reinos en vida, como hicieran los Capeto, antídoto contra la ilegitimación pontificia ${ }^{32}$. Al abandonar Aragón rumbo a Sicilia en 1282 Pedro III encargó la regencia al infante D. Alfonso y cuando el infante le cedió sus derechos el 4 de octubre de 1284, el 17 de noviembre el monarca le nombró Lugarteniente de Aragón, Valencia y Cataluña ${ }^{33}$.

El sistema se aplicó en Sicilia en torno a $D^{\mathrm{a}}$ Constanza, como reverente legitima-

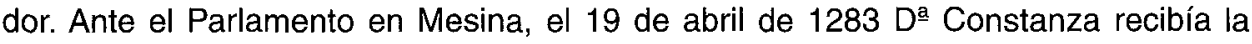
regencia, siendo heredero y corregente el infante $\mathrm{D}$. Jaime ${ }^{34}$. La regencia supo generar una eficaz trama administrativa de catalano-aragoneses y sicilianos, mientras la seguridad, marítima y unida a Aragón se delegaba en Roger de Lauria el 20 de abril como Almirante de Cataluña y Sicilia ${ }^{35}$. Era un camino acertado: D: Jaime sofocó con energía la rebelión de Val de Noto en mayo de 1283 y Roger de Lauria derrotaba a la armada angevina en Malta el 8 de junio.

Sin embargo, el estilo de gobierno de Pedro III era de la más rancia estirpe gibelina: autoritario y centralizador. La Regencia debía reducirse a un testaferro cuya misión debía ser transformar la función de Sicilia: de receptora en dispensadora de recursos para sostener la política mediterránea del rey. Los documentos muestran la constante y directa intervención de Pedro III en Sicilia, con Giovanni Prócida como su «alter ego» ${ }^{36}$. D. Jaime y la Regencia carecieron de autonomía pero convirtieron Sicilia en la pieza útil que Pedro III precisaba, con tres funciones:

1ํ Función táctica como frente militar subsidiario para aliviar la presión sobre Aragón, amenazado de invasión. Los intentos de Carlos I por invadir Sicilia se estrellaron con la gran victoria naval de Roger de Lauria en Nápoles (5 de junio de 1284), en la que apresaba a D. Carlos de Salerno, heredero de Carlos I. La iniciativa no solo pasó a

armar una galera para trasladar a $\mathrm{D}^{\mathrm{a}}$ Constanza y algunos de sus hijos a Sicilia, cit. F. SOLDAILA, L'Almirall Ramón Marquet, Barcelona, 1953, p. 26; el 4 de enero de 1283 D. Alfonso ordenaba unos pagos a tripulantes de naves de la Reina, ACA, Reg. 59, f. 191, reg. J.E. MARTÍNEZ FERRANDO, Ibídem, no 1639, p. 350 .

32 Junto con el testamento y jura en Cortes, en opinión de F. SOLDEVILA, «La pretensa donació dels regnes per Pere el Gran al sen fill Alfons", Homenaje a Vincke, ed. 1962-3, pp. 193-200.

33 ACA, Reg. 43, f. 66 v. Reg. J.E. MARTíNEZ FERRANDO, Catálogo del Antiguo..., obr. cit. no 2055, p. 439; pub. J. LALINDE ABADÍA, Gobernación General en la corona de Aragón, Zaragoza, 1963, no 2, pp. 501-2.

34 Junto con Giovanni Prócida como consejero plenipotenciario, vicario del Reino Guillén Galcerán y justicia Alaimo de Lentini. Bernard DESCLOT, Crónica, ed. M. Coll i Alentorn Barcelona, 1951, p. 202.

35 Se complace en la ceremonia R. MUNTANER, Crónica, reed. F. Soldevila, Barcelona, 1948, p. 117 .

36 El 29 de julio de 1283 el monarca refrendaba todos los actos políticos de Prócida, pub. LA MANTIA, Códice diplomático dei..., obr. cit., $\mathrm{n}^{\circ} 30$, pp. 76-77. El 31 de enero lo convertía en Canciller vitalicio de Sicilia, ACA, Reg. 46, f. 160, pub. Ibídem, no 40, pp. 93-95. 
manos sículo-aragonesas (invaden Calabria), sino que el futuro de los estados angevinos quedaba hipotecado.

En la retaguardia D. Jaime aseguraba la adhesión siciliana. El infante continuó la inteligente política de incorporación de sicilianos a su administración ${ }^{37}$, confirmó la fidelidad de los maestres portulanos, maestre racional y los castillos a Pedro III. En agosto de 1285 hábilmente desmontó una conspiración antiaragonesa, que salpicó a Alaimo de Lentini.

$2^{\circ}$ Función logística, en la que destacó la competencia de D. Jaime. Desde agosto de 1283 parece iniciarse un circuito exportador de trigo entre Sicilia y Barcelona, secundado por La Regencia ${ }^{38}$ y al que D. Jaime incorporaba Mesina ${ }^{39}$. En 1284 Sicilia llegaba a proporcionar dinero a Aragón ${ }^{40}$. Cuando en 1285 se hacía inminente la temible invasión francesa en Aragón, Sicilia pudo aportar dos elementos imprescindibles: abastos y flota.

La fuerte concentración de tropas y las malas cosechas de 1285, provocaron en marzo-abril las revueltas de Barcelona, Gerona y Lérida. En mayo de 1285, Pedro III interrumpía el acarreo de trigo siciliano por particulares para centralizarlo en manos de Bernardo de Segalars ${ }^{41}$. D. Jaime sólo era informado de la orden el 3 de junio, otra muestra de escasa autonomía política.

Contra la armada francesa, Pedro III proyectó una flota defensiva en Cataluña comandada por Ramón Marquet y Berenguer Mallol, y otra ofensiva la siciliana de Roger de Lauria, reforzada con abastos ${ }^{42}$, tropas $^{43}$ y corsarios ${ }^{44}$. El 28 de agosto de 1285 Lauria hundía en Les Formigues la armada francesa y la invasión de Cataluña.

3 Función estratégica. La alta política que monopolizó Pedro III. Aún así desde Sicilia D. Jaime pudo constatar en primera línea las circunstancias de dos escenarios muy importantes.

37 A instancias del rey, D. Jaime recompensaba a Ugo Tallach y Perrone Caltagirone, el 4 de junio de 1284 con oficios en la corte. ACA, Reg. 46, f. 205. Pub. LA MANTIA, Ibídem, no 50, pp. 117-118.

38 El 9 de agosto Pedro III ordenaba permitir la exportación de trigo siciliano al catalán Geraldo de Rocha, ACA, Reg. 46, f. 99 v. El 17 de septiembre los regentes ordenaban a Roger de Lauria permitir la exportación de trigo siciliano. Pub. LA MANTIA, Ibídem, ํo 120, p. 542.

39 Confirmación por el infante de todos sus privilegios a Mesina. Pub. LA MANTIA, Ibídem, $n^{\circ} 38$, pp. 85-89.

40 El 9 de abril Pedro III ordenaba al baile de Barcelona custodiar el dinero procedente de Sicilia, Cit. G. GARINI, Gli Archivi..., obr. cit, p. 29.

41 Facultad concedida el 22 de mayo, ACA, Reg. 56, f. 105. El 21 de mayo el rey había permitido a una nave de Ramón Marquet partir a Sicilia, ACA, Reg. 56, f. 104, pero el día 22 le advirtió que comprase el trigo a Segalars, ACA, Reg. 56, f. 105.

42 Permiso real de exportación de pez para la armada siciliana, el 16 de abril, ACA, Reg. 56, f. 70. El 23 de junio se enviaban víveres y dinero, ACA, Reg. 58, f. 32 v.

43 Salvoconducto, el 30 de junio, a Pedro Íñiguez para ir a Sicilia, ACA, Reg. 57, f. 140.

44 Reavituallamiento para el corsario Attobono de Trápani y compañeros el 5 de mayo, ACA, Reg. 58, f. 23. El 28 de mayo una nave de Marquet transportaba marinería a Sicilia, ACA, Reg. 56, f. $104 \mathrm{v}$. El 23 de octubre el rey ordenó pagar 1400 onzas de oro a los corsarios que acudieron a Sicilia, ACA, Reg. 58, f. 81. 
- Génova, la potencia condicionante de todo el Mediterráneo. Las Vísperas Sicilianas habían acabado con el proyecto de un Imperio angevino de Marsella a Jerusalén (con Sicilia y Constantinopla) y Génova creyó llegado el momento de imponer "su imperialismo". En su consecución después del verano de 1282 se lanzó a una feroz contienda con Pisa. Pedro III comprendió toda la dimensión de tan colosal combate próximo a Sicilia e intentó la inhibición ${ }^{45}$. Empero, desde el 30 de agosto de 1283 Génova controlaba Cerdeá, estación en la ruta de Cataluña a Sicilia. Desde entonces, Pedro III inició un distanciamiento de $\mathrm{Pisa}^{46}$, paralelo a un aproximación a Génova: preocupando la controversia de Perpiñan, el 10 de febrero de 1284 informaba a los linajes genoveses sobre su legitimidad, en tanto que en mayo reconocía los derechos genoveses a exportar trigo siciliano y les dedicaba especial protección ${ }^{47}$.

Cuando la victoria de la Meloria (6 de agosto de 1284) Génova se deshizo de Pisa, sólo apuntaba como rival Barcelona. La consigna fue aplacar una potencia que determinará la política mediterránea aragonesa: el 17 de agosto de 1284 se concedía especial permiso exportador de trigo a los genoveses ${ }^{48}$, mientras el 24 de noviembre y el 19 de noviembre D. Jaime confirmaba los privilegios y exenciones de los genoveses en Sicilia.

- Túnez, Reino vasallo y tributario de el de Sicilia. Era un escenario que interesaba a Pedro III (expedición a Collo), pero una vez rey de Sicilia de nuevo los intereses económicos sostenían los derechos feudales. Desde agosto de 1283 Pedro III inició la intervención ${ }^{49}$, después de la victoria de Lauri en Malta. A pesar de que en julio de 1284 se coronaba como nuevo califa tunecino Abu Hafs, no hubo tampoco entendimiento ${ }^{50}$. Pedro III, entonces acudió a la presión militar (Lauria ocupa Djerba en octubre de 1284, Kerkennah en abril de 1285), la subversión aliándose con Tremecén en octubre de 1284 para oponer a Abu Zacariya contra Abu Hafs y a una alianza antitunecina con Granada, Marruecos y Tremecén. A fines de mayo de 1285 llegaban embajadores de Abu Hafs a Barcelona ${ }^{51}$. el 2 de junio firmaban el tratado de Panigars por el que, entre otros capítulos (ponduk, aduanas, milicias), reconocían a Pedro III rey de Sicilia y un tributo de 33.333 besantes anuales.

45 El 7 de abril de 1283 solicitaba la alianza de la gibelina Pisa, en tanto no implicase a Aragón en la contienda. Cit. C. TRASELLI, I privilegi di Mesina e di Trapani, Palermo, 1949, p. 40.

46 Airada protesta, el 30 de septiembre de 1283, por los ataques corsarios pisanos a mercaderes catalanes, ACA, Reg. 46, f. 110. Las protestas crecerán en meses posteriores.

47 El 7 de mayo ordenaba deponer al pisano Gerardo Bossi, justicia de Val di Mazzara, por perseguir a los genoveses, “amici carissimi» y «nostri especiales amicj». ACA, Reg. 46, f. 192. Pub. LA MANTIA, Códice diplomático dei..., obr. cit., no 46, pp. 110-111.

48 ACA, Reg. 43, f. 22. El 7 de noviembre se recordaba este permiso a Ramón de Sant Liceri.

49 El 9 de agosto desautoriza a dos galeras con trigo siciliano tocar Túnez con destino a Mallorca, ACA, Reg. 46, f. 104. Al tiempo, enviaba a Rodrigo Jiménez de Luna, que volvía en septiembre sin entendimiento pero con una nave de gran valor: ¿el tributo?

50 El 4 de noviembre Pedro III notificaba al vicario y baile de Barcelona como bienes de mercaderes catalanes habían sido requisados en Túnez por orden del nuevo Califa, ACA, Reg. 43, f. 55 v.

51 En cuatro cartas, entre el 25 de mayo y el 4 de junio, ACA, Reg. 58, f. 26 y 28 r y v. Pedro III ordenaba la manutención y traslado de estos embajadores. 


\subsection{La confederación dinástica}

Sicilia tenía un peso específico entre los estados de Pedro III, pues, que una Regencia reducida a mero testaferro no reconocía. Se multiplicaban las ansias de autonomismo: D. Jaime será el portavoz y D. Carlos de Salerno el instrumento.

Con cuidada aparatosidad una revuelta de linchamiento y una condena a muerte amenazaban al Príncipe de Salerno, preso en Montegrijón después de ser capturado en la batalla de Nápoles. Alarmado, enseguida Carlos I inició negociaciones con D. Jaime ${ }^{52}$. So pretexto de garantizar su seguridad D. Jaime trasladó al Príncipe de Salerno a Cefalú, donde le arrancaba un provechoso acuerdo: D. Jaime, D. Fadrique y D. Violante casarían con sendos hijos del Príncipe y serían reconocidos rey de Sicilia $e$ islas adyacentes, duque de Tarento y señora de Calabria respectivamente. como seguro D. Carlos entregaría en rehén tres de sus hijos, ciertos nobles provenzales, un rescate y prometía lograr la paz de Aragón con Francia y el Papado ${ }^{53}$. D. Jaime, así, generaba un orden apropiado en el sur italiano. Carlos I lo rechazó.

Los sucesos, entonces se precipitaron. el 7 de enero de 1285 moría Carlos I. Preso en Sicilia su heredero el Príncipe de Salerno, los estados angevinos parecieron desintegrarse. Sólo las enérgicas medidas de Martín IV, capaces de imponer un gobierno ${ }^{54}$, evitaron la hecatombe, pero el Papa eligió a Honorio IV el 2 de abril, un Savelii, aristocrática y güelfa familia romana. El nuevo Papa no decepcionó: el 31 de mayo de 1285 refutaba la legitimidad de D. Alfonso ${ }^{55}$. En bulas sucesivas otorgó apoyo financiero a la invasión de Cataluña y el 30 de julio ofreció absolución a los sicilianos que abandonasen la causa aragonesa.

Pedro III, ante la inminente invasión francesa, comprendió que debía solventar el encaje de Sicilia en la órbita catalano-aragonesa. El 3 de febrero de 1285 expidió cartas secretas a $D^{a}$ Constanza y $D$. Jaime ${ }^{56}$, cuyo resultado fue que el 12 de febrero $D$. Jaime jurara por heredero de Aragón al infante $\mathrm{D}$. Alfonso, le prestara homenaje y prometiera absoluto apoyo en la defensa de sus derechos ${ }^{57}$. En correspondencia, el 8 de mayo D. Alfonso reconocía la donación del Reino de Sicilia a D. Jaime ${ }^{58}$. No tardó D. Jaime en estrenar su mayor margen político: a pesar de los urgentes requerimientos de Pedro III el 29 y 31 de mayo para entregarle al Príncipe de Salerno. D. Jaime

52 Dos cartas de D. Jaime certifican que existían negociaciones con Carlos I. Pub. LA MANTIA, Códice diplomático dei..., no $159-160$, p. 352.

53 Refiere L. D'ARIENZO, «Documenti sulla prigionia di Carlos || d'Angio, Principe di Salerno», XI CHCA, II, pp. 489-555, ed. Palermo, 1983, p. 495.

54 El 16 de febrero imponía como regentes al conde de Artois y al cardenal de Santa Sabina, reconociendo futuro rey a D. Carlos de Tarento, primogénito del Príncipe de Salerno. Reg. A. POTTHOST, Regesta Pontificum..., obr. cit., $\mathrm{n}^{\mathrm{O}}$ 22213, p. 1793.

55 Ordena retirar licencia a todo eclesiástico que sostuviese al infante A. N. Francia, j. 714-9, reg. J. PAZ, Documentos relativos a..., obr. cit., ำ 161.

56 ACA, Reg. 58, f. 5. Pub. LA MANTIA, Códice diplomático dei..., obr. cit., no 65.

57 Cit. G. CARINI, Gli Archivi..., obr. cit., p. 209.

58 ACA, Reg. 62, f. 152. Pub. LA MANTIA, Códice diplomático dei..., obr. cit., no 79, pp. 150-153. 
únicamente accede al contacto diplomático $0^{59}$ y sólo lo entrega cuando fue seguro el fracaso de la invasión francesa en Cataluña, en octubre de 1285. Sicilia, empero, se mantuvo firme en la adhesión a Aragón.

El estrepitoso fracaso de la invasión convenció a Honorio IV de dos cosas: convenía a la Santa Sede un estado italiano y dependiente como brazo de la Iglesia (estados angevinos) e italianizar al contencioso de las Vísperas (concentración en la recuperación de Sicilia). El Papa promulga disposiciones que alentasen a los sicilianos en el retorno a la obediencia angevina y pontificia, que culminaron el 17 de septiembre de 1285 con la «Constitución de Sicilia» reguladora de un estado angevino más eficaz y popular. El efecto fue fulminante, porque el sur italiano tornó de grado a la obediencia angevina. Era el umbral de la otra época.

Aragón también ayudó a traspasar ese umbral. Cuando preparaba la conquista de Mallorca, Pedro III enferma y, antes de morir, publica el 2 de noviembre de 1285 un nuevo testamento confirmando la división de Aragón, Valencia y Cataluña para D. Alfonso y Sicilia para D. Jaime, pero además hace firmar a D. Alfonso la expresa renuncia a todo derecho sobre Sicilia ${ }^{60}$. Era la confederación dinástica.

\section{EL ARAGONISMO DINÁSTICO DE JAIME DE SICILIA (1285-87)}

Muy al contrario el fracaso de colaboración dinástica entre Pedro III y Jaime II de Mallorca, D. Jaime conocía la extrema inseguridad de su trono siciliano y la necesaria dependencia de Aragón, por lo que se esforzó en un correcto funcionamiento de la confederación dinástica. La realidad impondría un ritmo distinto a los deseos.

\subsection{Los actos de continuismo}

Tanto D. alfonso en Aragón como D. Jaime en Sicilia habían sido fieles testaferros de la política paterna, por los que conocían perfectamente los proyectos de Pedro III y sus designios sobre la confederación dinástica. Ambos hermanos pudieron practicar en puridad un adherente continuismo político. La iniciativa claro, correspondía a Aragón.

La conquista de Mallorca se realizó en el más estricto sentido continuista. Proyectada por Pedro III, D. Alfonso decidió su inmediata realización para lo cual necesitaba el imprescindible concurso de la armada de Roger de Lauria. El almirante prestó su colaboración ${ }^{61}$ después de protagonizar un acto que reforzaba la confederación dinástica: el 25 de noviembre de 1285, ante el almirante, D. Alfonso juraba defender la corona siciliana de $D$. Jaime y acto seguido Roger de Lauria apoyar a ambos en sus

59 En agosto de 1285 Pedro III hacía pública la recepción de tres embajadores del Príncipe de Salerno. ACA, Reg. 57, f. 182. Pub. LA MANTIA, Ibídem, nº 97, pp. 195-6.

60 Cit. ambos documentos, G. CARINI, Gli Archivi..., obr. cit., pp. 204-206 y 182 respectivamente.

61 El 25 de enero Alfonso III ordenaba a los justicias y jurados de Valencia entregar 500 quintales de pez a la armada de Lauria, ACA, Reg. 63, f. 32 v, así como pagarle cierta cantidad que él adelantó para los gastos de la armada en Mallorca, ACA. Reg. 63, f. 33. Reg. ambos A. GALLOFRE, Documentos del reinado de Alfonso III de Aragón, relativos al Reino de Valencia, Valencia 1968, oํ 17 y 18, p. 16. 
respectivos estados ${ }^{62}$. El almirante daba así un sentido siciliano a la conquista de Mallorca.

La conquista, iniciada en noviembre, fue muy fácil y rápida, apenas un mes ${ }^{63}$. Después de someter unos brotes nobiliarios de resistencia, Alfonso III supo reincorporar administrativa y comercialmente Mallorca en los circuitos catalanes ${ }^{64}$. En enero de 1286 se sometía Ibiza.

La recuperación de Mallorca pretendió utilizarse como un medio de reforzar las rutas marítimas que uniesen más estrechamente Aragón y Sicilia: el 22 de febrero de 1286 Alfonso III ofrecía a los líderes gibelinos italianos renovar la alianza como prueba de compromiso ${ }^{65}$; el día 23, mediante el matrimonio con su tía $D^{\mathrm{a}}$ Beatriz, sellaba la alianza con el marqués de Saluzzo en favor de Jaime I de Sicilia ${ }^{66}$; en marzo establecía Alfonso III colaboración con los mercaderes placentinos ${ }^{67}$; el 30 de marzo enviaba a Jaime Barull para renovar alianza con el juez de Arborea (Cerdeña) ${ }^{68}$.

Roger de Lauria articuló finalmente la confederación dinástica. Tomada Mallorca, llegaba a Sicilia a finales de enero de 1286 y quizás coordinó una simbólica ceremonia: el mismo día, 2 de febrero, Alfonso III se coronaba rey de Valencia, mientras Jaime I lo era como rey de Sicilia en la catedral de Palermo por los obispos de Cefalú, Squilacce y Neocastro. El 12 de febrero, Jaime I juraba el mismo documento que Alfonso III el pasado 25 de noviembre.

Enseguida la confederación dinástica tomo cariz de perfecta simbiosis: Aragón aporta la fuerza militar y Sicilia compensa con un lucrativo comercio, siendo los garantes Lauria, Prócida y $D^{a}$ Constanza ${ }^{69}$. El 18 de febrero Jaime I otorga el monopolio de exportación de trigo siciliano a los catalanes, quienes el día 22 reciben nuevos privilegios y un consulado en Sicilia ${ }^{70}$. Ese 22 de febrero, Alfonso III advertía a $\mathrm{D}^{\mathrm{a}}$ Constanza que D. Jaime Pérez (bastardo de Pedro III) pasaba con tropas a Sicilia en servicio de Jaime ${ }^{71}$. Para facilitar el paso el rey ordenaba la prórroga de deudas por $D$. Jaime Pérez y sus hombres ${ }^{72}$. Ambos hermanos, pues, deciden aplicar sus fuerzas confederadas en dos campos:

62 Cit. G. CARINI, Gil Archivi..., obr. cit., p. 208.

63 Efecto de la firma voluntad regia y los sólidos intereses aunados de las burguesías barcelonesa y mallorquina. cit. A. RIERA MELIS, La Corona de Aragón y el Reino de Mallorca en el primer cuarto del siglo XVI, Barcelona, 1986, pp. 69-70.

64 Política detalladamente expuesta por A. SANTAMARÍA ARÁNDEZ, "La política municipal de Alfonso el Liberal en el Reino de Mallorca (1285-1291)", pp. 1271-1299, en La Ciudad Hispánica durante los siglos XIII al XVI, Madrid, 1985, pp. 1280-84.

65 ACA, Reg. 63, f. 69.

66 Largo y clarificador documento, ACA, Reg. 63, f. 72v.-73.

67 El monarca confirmaba a sus oficiales la especial protección a estos mercaderes de Mallorca y, a cambio, éstos conceden un empréstito de 4.000 sueldos reales, ACA, Reg. 66, f. $7 \mathrm{v}$.

68 ACA, Reg. 64, f. 26.

69 La Reina procuraba mantener su influencia en Aragón. El 11 de mayo de 1286 obtenía de Alfonso III una asignación económica para su canónigo Jimén Cuscull. ACA, Reg. 75, f. 7.

70 Pub. LA MANTIA, Códice diplomático dei..., obr. cit., $n^{\circ} 191$ y 192, pp. 306-309.

71 ACA, Reg. 63, f. 65.

72 ACA, Reg. 63, f. 90 v. 
$1^{\circ}$ Militar. Puesto que Alfonso III continuaba en guerra con Francia y sus aliados (hubo un desmayada invasión de Jaime II de Mallorca a Cataluña entre marzo y julio de 1286), Jaime I reactivó el frente marítimo siciliano. Roger de Lauria depredó el Midi francés, mientras Bernardo de Sarriá y Berenguer Villarant cercaban las costas de sur italiano del Tirreno al Adriático.

$2^{2}$ Legitimismo dinástico. Muy seguro de sus derechos, una vez coronado, Alfonso III notificaba a Honorio IV y el Colegio cardenalicio sobre el envío de una embajada para defender sus legítimos derechos ante la Santa Sede ${ }^{73}$, el 1 de marzo de 1286. Subrepticiamente enviaba cartas personales a una parte del Colegio, filoaragonesa, a la que proponía persistir en esa inclinación aragonesista ${ }^{74}$. Mucho más astuto, el 3 de abril, Alfonso III acreditaba ante el Arzobispo de Tarragona a Pons de Monpaó para argumentar desde el Derecho canónico su legitimidad regia, argumentación que expondrían al Papa un clérigo aragonés y otro catalán ${ }^{75}$, muestra inequívoca del monolítico apoyo de la Iglesia catalano-aragonesa a la casa de Barcelona. entretanto, con sendas órdenes del 25 de marzo y 27 de mayo Alfonso Ill mantenía la violencia paterna para que no se publicasen las sentencias pontificias.

En estricto paralelismo actuó Jaime $I$, al que preocupaba la afirmación de soberanía de Honorio IV sobre Sicilia el 2 de enero de $1286^{76}$. Nada más coronarse enviaba a Gilberto de Castellet y Bartolomeo de Neocastro para ofrecer se obediencia al Papa, entre otros gestos de sumisión ${ }^{77}$. Por toda respuesta, Honorio IV exigió volver a la situación anterior a las Vísperas.

\subsection{Los actos de distorsión}

Aún a pesar de que durante los años 1286 y 1287 Alfonso III persiste en la idea de que la confederación dinástica es beneficiosa para sus estados, tres factores ensombrecen progresivamente esta perspectiva hasta principiar los desencuentros con Jaime I.

$1^{\circ}$ La política de Honorio IV, madura y diferenciada de la de Martín IV ya en 1286. Partidario de reeditar el «dominium mundi», la posesión de Sicilia por la Santa Sede era su espacio material y un güelfismo manejable por parte de los estados angevinos (nunca la poderosa Francia) el brazo armado del Papado. Sicilia y la libertad del Príncipe de Salerno, pues eran los supuestos prioritarios de su política y ambos pasaban por Aragón. Una alambicada política pontificia buscó el entendimiento con Alfonso III para separarle de Jaime I y predisponerle sobre la conveniencia de liberar a D. Carlos de Salerno.

73 Ambos documentos, ACA, Reg. 63, f. 92 r y v.

74 Cardenales Latino, Albano, Jerónimo, Mateo, Jordano y Jacopo Colonna. Ese día 1 de marzo, solicitaba el tradicional auxilio jurídico de Raimundo de Ponte. ACA, Reg. 63, f. 94v-95.

75 ACA, Reg. 63, f. 31 v.

76 Ordena no cubrir vacantes, a disposición papal, todas la iglesias sicilianas que perdiesen su titular. Reg. M. PRON, Les Registres d'Honorius N (1285-87), Paris, 1888, $n^{\circ} 490$, col. 347.

77 El 22 de febrero Jaime I recibía en custodia la Orden del Hospital de Santa Mª de Teutónicos de Jerusalén. Reg. LA MANTIA, Códice diplomático dei..., obr. cit., no 143, p. 309. 
Por entonces, fiel a la confederación dinástica, Alfonso III aislaba al Príncipe de Salerno en el castillo de Ciurana y alli, desinformado, desde abril de 1286 acometía unas conversaciones tendentes a confirmar lo pactado con Jaime I en Cefali ${ }^{78}$. Honorio IV actuó enseguida. El 11 de abril de 1286 confirmaba las sanciones contra Alfonso III, Jaime I, D $\mathrm{D}^{\mathrm{a}}$ Constanza y los sicilianos ${ }^{79}$, pero suspendería la aplicación en Aragón si Alfonso III satisfacía los derechos de la Santa Sede (una imposible devolución de Sicilia) o enviaba una embajada a Roma, sabiendo que el aragonés ya la preparaba. Aún más, el 5 de mayo recibía unos enviados de Eduardo I de Inglaterra a quienes confirma que aprobaría sus gestiones mediadoras en Aragón. El 2 de mayo los hijos del Príncipe de Salerno y los eclesiásticos angevinos habían aceptado también la mediación inglesa.

Otras eran las expectativas de Alfonso III respecto a la mediación inglesa: obviar al Papa y la Jaime II de Mallorca y abrir a Francia la sucesión del trono castellano a cambio de que Felipe IV olvidase la reclamación de Sicilia ${ }^{80}$. El 18 de mayo comunicaba al Príncipe de Salerno que Jaime I de Sicilia sólo se avendría a liberarle si renunciaba expresamente a Sicilia ${ }^{81}$. Honorio IV respondió con contundencia: anima a los catalano-aragoneses a la rebelión en favor de $\mathrm{D}$. Carlos de Valois y el 23 de mayo reitera la excomunión de Jaime I por su criminal coronación ${ }^{82}$, como también la de Alfonso III, si bien insiste el reservarse a proceder si era enviada a la embajada.

Alfonso III recapacitó. A través de una carta del Príncipe de Salerno al Papa el 22 de junio, el monarca aragonesa sugería reconocer el ius utile de Sicilia para Jaime I y el ius eminens para el Príncipe. Todo su entramado se vino abajo por la confluencia de tres sucesos adversos: el 24 de junio la Unión amenaza con destronar a Alfonso III (necesitará el refrendo papal); bajo presidencia de Eduardo I la legación francesa exigió la inmediata libertad del Príncipe de Salerno e incluir el asunto de Mallorca; el 21 de junio, enérgico, Jaime I le advirtió que nunca aceptaría una paz que no le reconociese la plena soberanía sobre Sicilia y que no podía garantizar la seguridad de una embajada aragonesa contra este axioma ${ }^{83}$, incluso expresó serias dudas sobre la lealtad de su hermano ${ }^{84}$. Más aún, decidido al sabotaje por entonces Jaime I notificaba al Papa que nunca abandonaría Sicilia.

78 El monarca aragonés el 4 de abril permitía al Príncipe entrevistarse con Jacomo de Bonsó y el Preboste de Marsella, sin duda para acuciarle en la necesidad imperiosa de ocupar enseguida su trono. Pub. L. D'ARIENZO, Documenti sulla prigionia..., obr. cit., $\mathrm{n}^{0}$ 6, p. 510, ACA, Reg. 66, f. 33 v.

79 Reg. A. POTTHAS, Regesta Pontificum..., obr. cit., no 22414, p. 1810; pub. M. PRON, Les Registres..., obr. cit., no 494, col. 348-9.

80 El 5 de mayo el rey aragonés constituía sus embajadores a Pedro Martínez de Artusona y Juan Zapata para tratar la tregua con Francia. Significativamente, el 13 de mayo les son expedidas credenciales ante Eduardo I, Felipe IV de Francia y su madre Da Margarita, así como para $\mathrm{D}^{\mathbf{a}}$ Blanca, madre de los Príncipes de la Cerda, ACA, Reg. 64, f. 179 a 180 v.

81 ACA, Reg. 64, t. 181, pub. L. D’ARIENZO, Documente sulla prigionia..., obr. cit, no 13, pp. 513-4.

82 Reg. A. POTTHAS, Regesta Pontificum..., obr. cit., no 768, col. 557.

83 Pub. G. LA MANTIA, Códice diplomático dei..., obr. cit., nº 147, pp. 320-1.

84 El 21 de junio Alfonso III hubo de asegurar a Jaime I sobre la imposibilidad de que el Príncipe de Salerno se «evadiese», ACA, Reg. 64, f. 183. 
En esta encrucijada, Alfonso III apostó por conciliar las líneas opuestas. Por un lado, en julio de 1286 tomaba medidas para sostener militarmente Sicilia ${ }^{85}$, lo que supuso la recompensa de Jaime I a los intereses mercantiles catalanes ${ }^{86}$, de otro lado buscó rentabilizar la mediación inglesa y la embajada a Roma. La mediación inglesa se agostó en el "congreso" de París, donde Eduardo I sólo arrancó una tregua franco-aragonesa hasta el 29 de septiembre de 1287. Reconociendo su fracaso, Eduardo I insistía en agosto para reconducir las negociaciones ${ }^{87}$.

La embajada a Roma para demostrar la legítima entronización de Alfonso III pareció más fructífera. El 12 de julio el monarca encargaba a Ramón de Muntanyana y Bertrán de Vall obtener el pleno respaldo a su legitimidad por parte de un amplío sector de la nobleza y clero catalano-aragoneses ${ }^{88}$. No creyó el rey encontrar obstáculos en este trámite (pese al proselitismo de la Unión entre las ciudades durante agosto de 1286) y el 21 de agosto advertía a sus partidarios en Roma la próxima llegada de su embajada, noticia que transmitió oficialmente al Papa y el Colegio cardenalicio el 3 de septiembre ${ }^{89}$. Acometidos sus primeros gastos ${ }^{90}$, el 20 de septiembre constituía la legación y extendía cartas de recomendación y asistencia en Roma ${ }^{91}$.

Sicilia, otra vez, fue el escollo. En agosto y septiembre de 1286 se aliaba con Francia y hacía colectas para invadir Sicilia. En respuesta, el 2 de octubre Jaime I hacía que su tía $\mathrm{D}^{\mathrm{a}}$ Beatriz le cediese todos sus derechos a Sicilia ${ }^{92}$, confirmando su legitimidad Staufen, pero además presionó a un Alfonso III acosado por la Unión para revalidar la perfecta sintonía de intereses en octubre ${ }^{93}$. Asi pues, aunque la embajada aragonesa debió partir hacia Roma a principios de noviembre ${ }^{94}$, al tiempo que el 6 de noviembre Honorio IV acreditaba a los arzobispos de Ravenna y Monreale ante Eduardo

85 El 2 de julio ordenaba a Castellfabib y otros lugares pagar cierto tributo con destino a la expedición de Sicilia, ACA, Reg. 68, f. 81. Reg. A. GALLOFRE, Documentos del reinado..., obr. cit., no 310, p. 75 .

86 Estipulaba el pago de un terreno para construir la Lonja de catalanes. Pub. LA MANTIA, Códice diplomático dei..., obr. cit., nº 149, pp. 323-5.

87 El 1 de septiembre de 1286 Alfonso III accedía a entrevistarse con el monarca inglés. ACA, Reg. 66, f. 180.

88 ACA, Reg. 66, f. 151. El 31 de julio repetía el cometido esta vez para el reino de Valencia.

89 Primer documento, ACA, Reg. 66, f. $166 \mathrm{v}$ y el segundo ACA, Reg. 64, f. $183 \mathrm{v}$.

9070 libras tornesas para gastos corrientes y pagos a la Curia pontificia, ACA, Reg. 65, f. 166.

91 Gilabert de Cruilles, Rodrigo Sánchez de Calatayud, Pedro Costa y Ramón de Besalú. El 21 de septiembre el rey los recomendaba a la facción filoaragonesa del Colegio, y el 8 de octubre a Pandulfo Savelli, hermano del Papa. ACA, Reg. 64, f. 187, ambas.

92 Cit. G. CARINI, Gli Archivi..., obr. cit, pp. 209-210.

93 El día 19 el aragonés ordenaba liberar a dos protegidos de Ramón Monterol, notario de Jaime I, ACA, Reg. 64, f. 129 v. Poco después, Alfonso III sugirió entregar a Alamino de Lentíni, conspirador contra Jaime I.

94 El 13 de noviembre se pagó al conde de Urgell el valor de unas bestias perdidas «in uiatico quod fecerunt apud collem panicars in nostro seruitio", ACA, Reg. 65, f. 163. 
I para tratar con los aragoneses ${ }^{95}$, lo cierto es que Alfonso III no tenía voluntad de entretenimiento: el 4 de noviembre tomaba disposiciones para una larga prisión del Príncipe de Salerno. Sicilia era una rémora diplomática.

$2^{\circ}$ Las Baleares. Ocupada Mallorca para apuntalar la ruta a Sicilia, por imperativo geográfico fomentó una orientación al Magreb y Estrecho de Gibraltar ${ }^{96}$, que insensiblemente afectó a la política mediterránea de Alfonso III.

Respecto a Túnez, denunciado el tratado de Panicars por Abu Hafs al morir Pedro III, Alfonso III pergeñó tres rasgos innovadores: la penetración territorial (Roger de Lauria conquistó islas litorales); desplazar a genoveses y pisanos; imponer su primacía a Jaime I por tener Sicilia derechos feudales sobre Túnez ${ }^{97}$. En la primavera de 1286, entretanto, Alfonso III protagonizó una ofensiva diplomática en Marruecos, Granada y Tremecén ${ }^{98}$, con desigual suerte: Tremecén aceptó un auténtico vasallaje; Granada (instigada por Génova) derivó a un conflicto con Aragón en diciembre; mientras, pese a una reiterada insistencia ${ }^{99}$ Marruecos declinaba una colaboración en diciembre.

Estas tendencias esbozadas esa primavera habrían de acentuarse cuando en enero de 1287 Alfonso III conquistó Menorca, con expresa y significativa participación de la armada siciliana ${ }^{100}$. En la perspectiva de Alfonso III las Baleares son el fundamento y Sicilia sólo el coadyuvante en el Mediterráneo.

La posesión de Baleares, empero, tuvo un serio inconveniente: eran base imprescindible para la expansión genovesa hacia Magreb y Flandes. en verano de 1286 la actividad corsaria genovesa contra mercaderes catalanes era intensa y de nada sirvieron los gestos apaciguadores de Alfonso III $^{101}$.

$3^{\circ}$ El autonomismo siciliano. A pesar de la influyente posición coagulante de $D^{a}$ Constanza entre sus hijos ${ }^{102}$, la consolidación del régimen sículo-catalán, la vivificante

95 El 7 de noviembre el Papa ordenaba a sus plenipotenciarios negociar con los aragoneses con flexibilidad e informándole constantemente. Reg. A. POTTHAST, Regesta Pontificum..., obr. cit. n² 22527, p. 1818 .

96 Cit. F. SEVILLANO COLOM, Historia del Puerto de Palma de Mallorca, Palma, 1974, destaca el círculo de vientos y corrientes marítimas Mallorca-lbiza-Valencia-Málaga-Melilla-Túnez-Mallorca, p. 153.

97 Cit. el objetivo Ch. E. DUFOURCQ, L'Espagne catalane..., obr. cit., p. 280.

98 En marzo y abril envió como embajadores a Pere de Deu en Marruecos, ACA, Reg. 64, f 26 , a Ramón de Sant Liceri en Granada, ACA, Reg. 64, f. 177, a Pedro García en Tremecén, ACA, Reg. 66, f. 61, a quien el 1 de mayo el rey aplazó deudas por la legación en Tremecén.

99 Nada obtuvo Pere de Deu y en mayo Alfonso III insistía con Abraham y Samuel Abengalell, sin resultados porque el califa Abu Ya'qub ofrecía un protectorado sobre la presencia catalana en la zona. Aún así el 15 de diciembre daba credenciales a Pere de Deu, los Abengalell y Vidal Porta ante Abu Ya'qub, ACA, Reg. 72, f. 48 v. El 21 de diciembre ordenó a Berenguer Mathoses y Francisco Burquet su traslado. La nueva legación ofrecía seguridad mutua de súbditos y mercancías, alianza y colaboración militar (naves aragonesas por zenefes marroquíes) ACA, Reg. 64, f. 176 r y v. Inútil por la alianza aragonesa con Tremecén, el conflicto con Granada y la conquista de Menorca.

100 Orden a Roger de Lauria, ACA, Reg. 64, f. 184.

101 El 8 de octubre el monarca aragonés advertía a Génova que la embajada destinada a Roma, se detendría en la ciudad Ligur, ACA, Reg. 64, f. 187, sin duda para despejar recelos.

102 El 18 de junio de 1287 Alfonso III entregó rentas y derechos en Tornos a su hermano el infante D. Pedro por orden de Da Constanza, ACA, Reg. 70, f. 171. 
energía económica del trigo siciliano en Aragón ${ }^{103}$ y los servicios de Sicilia en la integración aragonesa en los grandes circuitos económicos y diplomáticos ${ }^{104}$, convencieron a Jaime I que la confederación dinástica debía ser sinalagmática, proporcionada a su función en Sicilia. El traslado el 18 y 19 de febrero de 1287 por Giovanni Prócida de los documentos del 25 de noviembre de 1285 (cesión de todos sus derechos a Sicilia por Alfonso III y la mutua asistencia entre Jaime I y Alfonso III, demostraban un claro sentido reivindicativo.

Jaime I optó por plantear su afirmación sicilianista en dos delicados asuntos: Túnez y el Príncipe de Salerno. Al parecer, Jaime I reclamó a Alfonso III para Sicilia la soberanía feudal sobre Túnez, en tanto que le hacía saber que sólo admitía la libertad del Príncipe según las condiciones de Cefalú y Ciurana. El 27 de febrero de 1287 nombraba sus procuradores ante Alfonso III a Gilberto de Castellet y Bertrán de Canellas, a quienes el 3 de marzo da plenos poderes para tratar con el Príncipe y los regentes angevinos, mientras el 8 de marzo les faculta para tratar sobre Sicilia y Túnez ${ }^{105}$. De nuevo Alfonso III optó por el entendimiento. En marzo, el monarca aragonés enviaba a Sicilia a Conrado Lanza ${ }^{106}$ para negociar compartir el tributo tunecino e imponerlo a Abu Hafs. Jaime I debió aceptar pero el califa tunecino negó rotundamente tributo y vasallaje, por cuanto el 9 de junio suscribía un acuerdo comercial con Génova. De nada sirvió que Alfonso III el 30 de julio de 1287 coronase en Jaca califa tunecino a Abu Malik Abdalwahid, quien aceptaba tributo y vasallaje compartido entre Aragón y Sicilia ${ }^{107}$ : en conminaba sin convicción a Abu Hafs, a través del nuevo cónsul del ponduk catalán Berenguer de Segalars asumir el tributo.

En la cuestión del Príncipe de Salerno, la auténtica batalla diplomática, la confederación dinástica no fue tan resistente. En respuesta a requerimientos de Eduardo I en diciembre de $1286^{108}$, en enero de 1287 Alfonso III destacó a Burdeos a Pedro Martínez de Artasona y en febrero retomaba el diálogo con Roma ${ }^{109}$. A instancias de Pedro Martínez, Alfonso III rehusó enviar una embajada ante Eduardo ${ }^{110}$, hasta conocer las

103 El 8 de enero de 1287 Alfonso III pagaba una deuda a Bonanato di Rippa sobre rentas reales en las partidas de trigo siciliano, ACA, Reg. 64 , f. $48 \mathrm{v}$.

104 El 12 de marzo mercaderes catalanes suscribían sociedad con florentinos, ACA, Reg. 64, f. 162 v. El 30 de marzo el sultán de Babilonia concedía especial protección a los mercaderes catalanes, por lo que Alfonso III le envió a Bertrán de Caldas para sellar alianza, ACA, Reg. 64, f. 175; el monarca concedía permisos exportadores a mercaderes catalanes hacia Mallorca, Sicilia y Túnez el 27 de marzo, ACA, Reg. 70, f. 182.

105 Cit. G. CARINI, Gil Archivi..., obr. cit, p. 212.

106 El 28 de febrero Alfonso III ordenó pagar a Conrado Lanza 4.000 sueldos barceloneses para gastos de su embajada en Sicilia y Túnez. ACA, Reg. 72, f. $48 \mathrm{v}$.

107 Pub. G. LA MANTIA, Códice diplomático deí.., obr. cit, no 168, pp. 377-383.

108 El 18 de diciembre el rey aragonés ordenaba sufragar los gastos de unos embajadores ingleses, ACA, Reg. 72, f. 12 v.

109 El 5 de febrero el monarca aragonés aprestó a Peironeto Crocerio como su enviado ante el Papa, ACA, Reg. 72, f. 52.

110 La carta de Pedro Martínez en ACA, Reg. 64, f. 192 v. El 6 de marzo, en efecto, Alfonso III disculpaba un retraso en la embajada, ACA, Reg. 64, f. 193. 
intenciones pontificias a través de los plenipotenciarios arzobispos de Ravenna y Monreale, que llegaron a Burdeos a fines de Febrero. En efecto, Honorio IV no tardó en hacer diáfanas sus intenciones: el 4 de marzo arrebataba toda iniciativa a la mediación inglesa, y declaraba nulos, por irracionales, los acuerdos de Cefalú-Ciurana para liberar al Príncipe de Salerno. El 20 de marzo, entonces, Alfonso III constituía su embajada, a la que el 21 dio plenos poderes e instrucciones de negociación en Burdeos con los legados pontificios ${ }^{111}$ : junto a la razón aragonesa de ocupar Mallorca y Albarracín, reclamar indemnizaciones por la invasión de 1285 y proteger a los Príncipes de la Cerda contra Sancho IV de Castilla, Alfonso III insistía en hacer reconocer su legitimidad regia por los testamentos de Jaime I y Pedro III, así como hacer aceptar a Jaime I como rey "tenente» de Sicilia (ius útile), quien satisfaría todos los derechos de la Iglesia (soberanía y ius eminens para la Santa Sede).

Era una vía muy poco grata para Jaime I, sobre todo porque desde comienzo de 1287 Honorio IV hacía intensos preparativos bélicos para invadir Sicilia por Agosta, Lentini y Catania. A pesar de la muerte del Papa el 3 de abril, una armada papal y angevina ocupó Agosta el 1 de mayo. Jaime I comprobó entonces la solidez de su régimen: Sicilia se mantuvo fiel y aprestó inmediatamente un ejército y una flota. La invasión angio-pontificia quedó abortada.

Alfonso III comprendió que sin Sicilia la Santa Sede ya no tendría interés en reconocer su legitimidad regia. En junio movilizó sus fuerzas en favor de Sicilia ${ }^{112}$, mientras el 23 de junio Jaime I recuperó Agosta y Roger de Lauria aplastó la armada angevina en Castellamare. Jaime I recibió la confirmación de que Sicilia no debía supeditarse a los exclusivos intereses aragoneses: desautorizó una tregua por dos años pactada por Roger de Lauria con los regentes angevinos (el almirante se apresuró a informar a Alfonso III) y sólo admitió oportuno el desmantelamiento de los estados angevinos. Era un formidable desafío a la diplomacia de Alfonso III.

$4^{\circ}$ Olorón. Desde mediados de 1287 Alfonso III comprende que Jaime I ve su única salvación como rey siciliano aniquilando los estados angevinos, objetivo impensable para la Santa Sede. El monarca aragonés necesita al Papa para detener una Unión que ya sin ambages busca derrocarlo y también precisa clausurar las Vísperas Sicilianas para reordenar su política mediterránea. Frente a Jaime I, Alfonso III decide dar viabilidad a los estados angevinos. El 20 de junio solicitaba al Colegio cardenalicio (luego también personalmente a los cardenales filoaragoneses) su benevolencia para acabar la guerra ${ }^{113}$. Paralizada la Santa Sede por muerte de Honorio IV, el Colegio pareció delegar en Eduardo I.

En efecto, desde el 25 de julio Alfonso III y Eduardo I se entrevistaron en Olorón, junto a los plenipotenciarios pontificios (Ravenna y Monreale) y los sicilianos (Castellet

111 ACA, Reg. 64, f. $194 \mathrm{v}-195$.

112 El 2 de junio acudía a Sicilia para coordinar la estrategia sículo-aragonesa Jaime de Sant Climent, ACA, Reg. 71, f. 55 v; el 17 de junio ordenaba a sus capitanes y a los almirantes Marquet y Mallol colaborar con el enviado siciliano Berenguer de Monteolivo para armar una flota hacia Sicilia, ACA, Reg. 71, f. 60 v; El 29 de junio fomentaba la piratería contra Provenza, ACA, Reg. 70, f. 154.

113 ACA, Reg. 64, f. 196 v. 
y Canellas) ${ }^{114}$. En Olorón se establecieron las condiciones para liberar al Príncipe de Salerno, la alianza anglo-aragonesa y la potestad a Eduardo I para ampliar la tregua franco-aragonesa que expiraba el 29 de septiembre.

Nada más irritante para Jaime I. El 27 de julio un cauto Alfonso III notificaba a su hermano la próxima liberación del Príncipe, noticia transmitida también a Giovanni

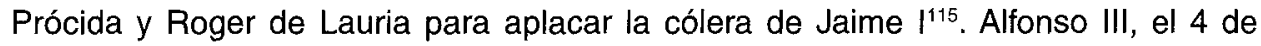
agosto, hizo tres gestos comprometedores para evitar el sabotaje de Jaime I: le entregaba, con permiso de asesinato, a Alaino de Lentini (símbolo de la resistencia al régimen de Jaime I); confirmaba a las ciudades sicilianas que todos los pactos se hacían en pro de Sicilia y reiteraba la denuncia a sus derechos sicilianos como la colaboración naval sículo-aragonesa ${ }^{116}$. El 25 de septiembre advertía que sólo ratificaría una tregua que Jaime I considerase oportuna ${ }^{117}$.

Olorón fracasó por el boicot de la Unión y la oposición de Jaime I de Sicilia, Jaime If de Mallorca, Felipe IV de Francia y el Colegio Cardenalicio, pero se abrió un canal de solución para la Vísperas y una vía de desencuentro con Jaime de Sicilia.

\section{LA ITALIANIZACIÓN POLÍTICA DE JAIME I (1288-1291)}

\subsection{Los nuevos factores}

Olorón, además, desató otro factor determinante: la participación de Francia. Felipe IV había contemplado sin simpatía la ocupación aragonesa de Mallorca, pero cuando el Olorón Alfonso III reclamó vasallajes en Provenza temió un renacimiento occitánico. La directa intervención pareció el antídoto adecuado. El 9 de diciembre de 1287 Felipe IV ordenaba al Senescal de Carcasona secundar los proyectos aragoneses de Jaime Il de Mallorca, por lo que el 26 de diciembre el monarca advertía al mismo Senescal y al Gobernador de Navarra que ya no existía tregua con Aragón ${ }^{118}$. En enero y febrero de 1288 tropas de Jaime II, Carlos de Valois y los plenipotenciarios pontificios se reunían en Rosellón, mientras Felipe IV promovía preparativos navales en Languedoc. Alfonso III temió la edición de una nueva Cruzada y entre enero y abril de 1288 dispuso defensas navales, levas y refuerzo de castillos.

Peor aún, por entonces llegaban ante Alfonso III Guillem Durfort y Conrado Lanza con la noticia de que Jaime I rechazaba la tregua de Roger de Lauría con los regentes angevinos e insistía en que la única solución era el desmantelamiento del poder angevino. Alfonso III desvió esta legación a Eduardo I como prueba de que urgía com-

114 Alfonso III cuidó la presencia siciliana. El 27 de junio ordenó a Jaime Pérez responder de 25.000 sueldos que Roger de Lauria recibió de Jaime I para el ornato y caballos de su embajadores que irían a Olorón. ACA, Reg. 70, f. 146.

115 ACA, Reg. 71 , f. 170

116 Los dos últimos documentos en ACA, Reg. 70, f. $162 \vee$ y Reg. 74, f. 30.

117 ACA, Reg. 64, f. 197.

118 Cit. L. KLÜPFEL, «Die Aüssere politik von Alfons IIl», Aragonensia, pp. 1-174, Leipzig, 191112 , en p. 43. 
prometer a Francia con la tregua ${ }^{119}$. Para evitar sabotajes franceses, el 20 de febrero ambos monarcas pactaron un encuentro secreto de representantes en Perpiñán ${ }^{120}$. Eduardo I evitó el menor compromiso, porque el 22 de febrero era electo nuevo Papa Nicolás IV. El nuevo pontífice no tardó en manifestar la plena continuidad con la política de Honorio IV: en marzo primero descalificó y luego sepultó con sentencias pontificias Olorón ${ }^{121}$; el 13 de marzo a los arzobispos de Rávenna y Monreale unía Rayno de Virterbo para negociar la liberación del Príncipe de Salerno; el 15 de marzo exhortaba a Alfonso III abandonar a Jaime $\mathrm{I}^{122}$, a quien el 25 de exigía la incondicional devolución de Sicilia.

Sin consultar a Jaime I, Alfonso III, convencido de su superioridad agnaticia dinástica, ensayó una contraofensiva en mayo de 1288: nuevos alegatos sobre su legitimidad ante el nuevo $\mathrm{Papa}^{123}$, concertar vistas con Eduardo $\mathrm{I}^{124} \mathrm{y}$ firmar una tregua el 24 de mayo con $D^{a}$ María, esposa del Príncipe de Salerno, idéntica a la establecida por Roger de Lauria ${ }^{125}$.

Sin embargo a nadie interesaba la vía diplomática. Nicolás IV encargaba el 1 de mayo a Eduardo I obtener la liberación del Príncipe de Salerno, pero ese día suscribía empréstitos para recuperar militarmente Sicilia y el día 6 reiteraba durísimas condenas contra Jaime $\mathrm{I}^{126}$. Aún más, el Papa se empeñó en enturbiar una fórmula de entendimiento entre Génova y Aragón en el Estrecho de Gibraltar ${ }^{127}$, amparando a la República el 18 de mayo sí retiraba cualquier apoyo a Jaime $\left.\right|^{128}$. Mientras, el 3 de mayo, en Nimes Felipe IV y Jaime II de Mallorca sellaban una alianza, por la que tropas rosellonesas invadieron el Ampurdán y tropas francesas Aragón desde Navarra.

De otro lado, Jaime I había consolidado una autonomía que le permitía corregir

119 Cit. J. ZURITA, Anales, obr. cit., pp. 333-334.

120 Carta de compromiso en ACA, Reg. 74 y f. 85. Entre abril y mayo se entrevistaron un procurador inglés y Pedro Martínez de Artasona, a quien Alfonso III ordenó pagar 4.000 sueldos turonenses de plata por su legación ante el monarca inglés, ACA, Reg. 79, f. $20 \mathrm{v}$.

121 En sendas bulas de 15 y 29 de marzo. Reg. E. LANGLOIS, Les Registres de Nicolás IV (12881292), París, 1886-1893, no 562 y 566, pp. 113-114.

122 Reg. A. POTTHAST, Regesta Pontificum..., obr. cit., p. 1827.

123 El 24 de mayo el rey ordenaba colectas en el obispado de Lérida para sostener al maestro jurista Ramón de Ponte, al servicio real en Roma, ACA, Reg. 79, f. 53.

124 El 8 de mayo Alfonso III ordenó entregar una generosa suma a un escudero inglés, $A C A$, Reg. $79, f .42 \mathrm{~V}$, sin duda presente en Aragón para organizas las vistas.

125 Cit. L. KLÜPFEL, Die Aüssere politik..., obr. cit., p. 46; J. ZURITA, Anales, obr. cit., p. 343; G. CARINI, Gli Archivi..., obr. cit., p. 223; pub. G. LA MANTIA, Códice diplomático dei..., obr. cit., nº 179, pp. 410-417.

126 Pub. E. LANGLOIS, Les Registres de..., obr. cit., no 597, p. 118.

127 El 20 de septiembre de 1287, muestra de que Génova secundaba el proyecto aragonés de una paz en Granada, para la que en julio de 1287 envió a Adán Abenhacep, ACA, Reg. 71, f. 55 , Alfonso III ordenó delegar en un mercader mallorquín y el genovés Vivaldi firmar una tregua hasta marzo de 1288, ACA, Reg. 64, f. 198 y en agradecimiento protegió la actividad naval genovesa en sus estados, permitiendo la exportación de pez, ACA, Reg. 74, f. 105 v el 28 de marzo de 1288.

128 Reg. A. POTTHAST, Regesta Pontificum..., obr. cit., n²2715, p. 1834; pub. E. LANGLOIS, Les Registres de..., obr. cit., nำ 76, p. 14. 
sus proyectos fraternos, expresando su frontal oposición a la tregua pactada con $D^{\text {a }}$ María el 24 de mayo. Sobresaltado, Alfonso III conminó con dureza a su hermano aceptar la tregua ${ }^{129}$ y para presentarle hechos consumados precipitó para el 1 de agosto, en Santa Cristina, vistas con Eduardo I para decidir la liberación del Príncipe de Salerno ${ }^{130}$, informándolo así enseguida al Papa mediantes dos franciscanos ${ }^{131}$, y favoreciendo una presencia de los arzobispos de Ravenna y Monreale, con Rayno de Viterbo en las negociaciones ${ }^{132}$. Jaime I supo maniobrar. No sólo recordó a los catalanes el valor de Sicilia ${ }^{133}$, sino que, obedeciendo formalmente las admoniciones pacifistas de Alfonso III, envió el 12 de junio una embajada a Roma ${ }^{134}$ con proposiciones tan opuestas a la Santa Sede (conservar el trono frente a la devolución incondicional) que cegó toda vía de entendimiento. Nicolás IV desautorizó toda negociación en torno al Príncipe de Salerno. Eduardo I hubo de suspender los preparativos de las vistas de Santa Cristina, mientras la embajada franciscana aragonesa cosechó en Roma un rotundo fracaso en julio de 1288. Mientras en agosto y septiembre el Papa reactivaba donaciones para atacar Aragón y Sicilia, el 13 de julio, en Lyon se rubricaba una solemne alianza antiaragonesa entre Francia y Castilla.

En esta coyuntura Alfonso III tomó dos medidas extremas: el 20 de agosto notificaba a Jaime I que liberaría al Príncipe de Salerno ${ }^{135}$ y el 28 de agosto permitía en Jaca la coronación de D. Alfonso de la Cerda como rey de Castilla. La ruptura con Castilla implicó un indeseado deterioro de las relaciones con Marruecos (amistado con Castilla), por lo que Alfonso III buscó un contrapeso fomentando las relaciones con Granada a través de los consulados catalanes en Almería y Málaga ${ }^{136}$, con escaso éxito.

Sin embargo, la directa intervención de Francia inquietó sobremanera a Eduardo 1 que veía cómo sus posesiones de Gascuña se situaban en peligrosa línea de expansión francesa. No podía permitirse fallar y activó su mediación. El 15 de septiembre el monarca inglés hace pública y enérgica protesta por el obstruccionismo de Jaime $\mathbf{I}^{137}$, mientras obligaba el compromiso de Alfonso III en la liberación del Príncipe de Salerno el 26 de Septiembre y al Príncipe a aceptar, el 4 de octubre, las condiciones de libe-

129 ACA, Reg. 73, f. 2. Pub. LA MANTIA, Códice diplomático dei..., obr. cit., nº 181, pp. 421-423.

130 En junio Alfonso III acreditó a Gilabert de Cruilles y Ramón de Besahí, concediéndoles ciertas sumas el 17 por gastos de legación ante Eduardo I, ACA, Reg. 79, f. 59 v. cit. las maniobras de Santa Cristina, L. KLUPFEL, Die Aüssere politik..., obr. cit., p. 47.

131 Para ellos solicita la asistencia en Roma de Ramón de Ponte y la facción filoaragonesa del Colegio cardenalicio, ACA, Reg. 77, f. 1.

132 Concesión de salvoconducto a los tres, el 17 de junio, ACA, Reg. 77, f. 3 v y 4.

133 Equiparaba el 17 de julio los privilegios de los catalanes a los genoveses. Pub. LA MANTIA, Códice diplomático dei..., obr. cit., $\mathrm{n}^{\circ}$ 182, pp. 424-426.

134 Reg. A. POTTHAST, Regesta Pontificum..., obr. cit., $n^{\circ} 22742$, p. 1836.

135 Expresamente declinaba el ofrecimiento naval de Jaime I, innecesario por esta medida pacificadora, ACA, Reg. 77, f. 6.

136 Así lo expresó desde el 2 de febrero de 1288 a Guillermo López, ACA, Reg. 74, f. 65.

137 T. RYMER, Foedera, conventiones, literae et cuinscunque generis acta publica inter Reges Angliae et alios quosvis imperatores, reges, pontifices, principes vel comunitales, II, Londres, 1727, pp. 366-7. 
ración que pactasen él y el rey de Aragón. En un gesto teatral, Alfonso III confirmaba estas decisiones a las ciudades sicilianas, obviando a Jaime I y al Papa a través de sus plenipotenciarios y de una embajada directa para la que el monarca aragonés solicita especial protección ${ }^{138}$, que el pontífice concedió el 25 de noviembre una vez que el Príncipe de Salerno fue liberado tras el tratado de Canfranc el 28 de octubre. Así las cosas el 29 de diciembre Alfonso III encargó a Ramón de Riera, a quien acredita el 3 de enero de 1289, preparar la embajada ante el Papa y los regentes angevinos ${ }^{139}$. Sólo entonces, el 25 de enero de 1289 Alfonso III notificó oficialmente a Jaime I la liberación del Príncipe de Salerno ${ }^{140}$.

\subsection{El proyecto de Alfonso III}

Liberado el Príncipe de Salerno la política exterior aragonesa ya no podía ser igual. Sin embargo el rey de Aragón no tardó en comprender el error de intentar clausurar las Vísperas Sicilianas sin la supervisión francesa.

En efecto, en enero de 1289 no sólo Felipe IV apresó sin contemplaciones a los embajadores aragoneses que le informaron de la liberación del Príncipe, sino que le exhortó a coronarse rey de Sicilia ${ }^{141}$. De nada sirvió que Alfonso III advirtiese al noble castellano D. Juan Núñez de Lara (influyente en Francia por su firme apoyo a los príncipes de la Cerda), que el 7 de diciembre de 1288 había reconocido a D. Alfonso de la Cerda (primo de Felipe IV), rey de Castilla ${ }^{142}$, porque cuando entre enero y febrero dispuso la solemne embajada a Roma y ante los regentes angevinos ${ }^{143}$, los embajadores fueron presos en Narbona por instigación francesa. Presionado, el 7 de abril de 1289 Nicolás IV renovó el proceso contra Alfonso III y Jaime I, sin reconocerles el título real ${ }^{144}$. Las dolidas protestas de Alfonso III al Papa ${ }^{145}$, sólo sirvieron para que el 17 de junio el pontífice solicitase la liberación de los embajadores aragoneses a Felipe IV y sólo renovase el proceso a Jaime I.

En perfecta sintonía con la estrategia francesa, mientras Felipe IV apretaba a Aragón, Nicolás IV se lanzaba a la recuperación de Sicilia: el 29 de mayo en Rieti, coronaba al Príncipe de Salerno como Carlos II de Sicilia, vasallo de la Iglesia. Acto seguido estos aliados iniciaban la ofensiva. Mientras, en julio, tropas mallorquinas de

138 ACA, Reg. $77, f 9$.

139 Sendas cartas en ACA, Reg. 79, f. 74 v y ACA, Reg. 77, f. 11 v a 13.

140 ACA, Reg. 78, f. 29.

141 Era contrario a lo pactado en Canfranc. D. Carlos de Salerno, escrupuloso, solicitó la opinjón de Alfonso III, quien se opuso enérgicamente el 26 de enero, ACA, Reg. 77, f. 15.

142 ACA, Reg. 77, f. $17 \vee$ y 18.

143 El 23 de enero eligió a Gilabert de Cruilles y Bernat Guillen de Pinels como embajadores en Roma y a Galcerán de Tímor y Pedro Costa en Sicilia, ACA, Reg. 77, f. 15 r y v; enseguida les concedió plenos poderes, ACA, Reg. 77, f. 16; el 18 de febrero les anejó al jurisperito Pedro de Solsimira, ACA, Reg. 77, f. 20 r y v, además les exhortaba a asecrarse con expertos en Barcelona, Roma y Sicilia, ACA, Reg. 77, f. $17 \mathrm{v}$.

144 Pub. E. LANGLOIS, Les Registres de..., obr. cit., nº 2170 y 2171 , pp. 383-4.

145 ACA, Reg. 77, f. 22 a 23. 
Jaime II invadían Cataluña y las francesas Cerdaña y Aragón, Carlos II y Nicolás IV adoptaban medidas demagógicas de captación para los sicilianos y rompían hostilidades, que provocaron una contraofensiva de Jaime I hasta sitiar Gaeta el 30 de junio.

Poco antes Jaime I recibía la legación aragonesa que Alfonso ll envió al tiempo que la apresaba en Narbona. Todo indica que, siguiendo las astutas sugerencias de Eduardo I, ambos hermanos coordinaron una inteligente acción contra el belicismo papal. Eł 14 de junio Jaime I daba plenos poderes a Gisbert de Castellet y Bertrán de Canellas ${ }^{146}$.

El plan urdido surtió efecto. En plena ofensiva pontificia, el embajador inglés Eudes Grandson recordó al Papa la calamitosa situación de Tierra Santa y la necesaria paz entre cristianos, en tanto que, so pretexto de una solicitud de Alfonso III para socorrer al reino cruzado de Chipre ${ }^{147}$, Jaime I se ofreció para una Cruzada. Impactado, Nicolás IV recomendó a Carlos II, el 18 de agosto, una tregua que el angevino suscribió con Jaime I hasta el 1 de noviembre de 1291 a finales de mes. Era un éxito no sólo porque se detuvo la peligrosa ofensiva, sino porque Nicolás IV se mostró más benévolo hacia Sicilia: el 13 de septiembre de 1289 permitía el comercio con Venecia e inició una relación epistolar continuada con $D^{\mathrm{a}}$ Constanza de Sicilia ${ }^{148}$.

Desde entonces es claro que Nicolás IV está preparando los preliminares de una paz que clausuraría las Vísperas Sicilianas, por los que debía partir de condiciones de negociación muy duras, juego que siguió admirablemente Alfonso III.

El 12 de septiembre de 1289, el Papa recordaba a Carlos II que estaba dispensando de cumplir el tratado de Canfranc, por lo que en octubre el angevino escribía a Alfonso III sobre la imposibilidad de obtener una tregua entre Aragón, Francia y el Papado, por lo que retornaría a prisión según lo pactado en Canfranc, protagonizando el único simulacro de su entrega el 31 de octubre, mientras el 18 de noviembre Nicolás IV incoaba proceso contra los obispos aragoneses, sicilianos y gibelinos italianos. Por entonces, una embajada de Carlos II, que Alfonso III se negó a recibir en persona, proponía la paz si el rey de Aragón renunciaba a Mallorca, Jaime I a Sicilia, Aragón era infeudado a la Santa Sede y la diplomacia aragonesa se subordinaba a Francia ${ }^{149}$.

Alfonso III respondió magistralmente. Demostró la excelente salud de la confederación dinástica sículo-aragonesa ${ }^{150}$, solicitando a Jaime I y sus colaboradores, el 9 de diciembre de 1289 víveres y 40 galeras para detener a los enemigos «vuestros y nuestros». Aún más, demostró al Papa que podía boicotear su ansiada Cruzada: Bizancio otorgó privilegios comerciales a los catalanes; propició acuerdos con Egipto ${ }^{151}$ que

146 Cit. G. CARINI, Gil Archivi..., obr. cit., pp. 232-233.

147 ACA, Reg. 77, f. 24 v a 25.

148 Sólo como muestra, el 20 de junio de 1290 el Papa solicitó a la reina que favoreciese en la exportación de trigo a Roma a Juan Macario, mariscal pontificio enviado a Sicilia. Reg. F.J. MIGUEL, Regesta de las letras..., obr. cit., $\mathrm{n}^{\circ}$ 205, pp. 115-6.

149 Cit. J. ZURITA, Anales, obr. cit., p. 397.

150 El 10 de octubre solicitó a Jaime I un rehén para canjear por Gilabert de Cruilles, ACA, Reg. 80 , f. 65 v.

151 En octubre de 1289 ciertos egipcios visitaban la corte aragonesa, pues el rey ordenaba al baile de Cataluña conocer el «Fuego griego" y construir tres o cuatro lanzaderas para proyectarlo. ACA, Reg. 80, f. 67. 
culminaron con la instalación de un fonduk catalán en Alejandría para abril de 1290; el 27 de enero ofrecía una amplia colaboración a Génova ${ }^{152}$; el 4 de enero de 1290 proponía a Granada alianza política y protección mercantil oficialmente, aunque oficiosamente sugería el rey nazarí combatir a Castilla, igualar los privilegios de catalanes a los genoveses y obtener beneficios en las aduanas y el concurso de los zenetes ${ }^{153}$.

Los gestos no podían ocultar los hechos. Comisionados franceses, aragoneses y de Jaime II de Mallorca se reunieron en enero de 1290, en Perpiñán, para evaluar los daños de la invasión de 1289 y el 3 de febrero llegaban a un acuerdo ${ }^{154}$. De otro lado, para ver los efectos de la ofensiva diplomática y en calculada maniobra, Alfonso III preparaba en febrero de 1290 una nueva embajada a la Santa Sede ${ }^{155}$, coincidiendo con la llegada a Roma de Giovanni Prócida para impetrar la absolución del entredicho pontificio para Sicilia ${ }^{156}$.

Nicolás IV vio llegado el momento de actuar. Evasivamente encargó estudiar los asuntos sicilianos a los cardenales de San Nicolás y Santa Sabina, pero respecto a Aragón advirtió que previo a una negociación era el acuerdo de Alfonso III y Carlos II, esto es, una solución siciliana.

Obedeciendo al Papa, Carlos III tomó la iniciativa de unas vistas que enseguida aceptó Alfonso III el 15 de marzo ${ }^{157}$ para el 23 de abril entre Panigars y la Junquera ${ }^{158}$. en ellas, Alfonso III aceptó una conferencia multilateral para acabar con las Vísperas y se comprometió a lograr la anuencia de Jaime I.

\subsection{La clausura de las Vísperas Sicilianas}

Desde la primavera de 1290, Acre, último bastión cruzado vive un asedio agónico, obsesionando a Nicolás IV. La Cristiandad, además, teme el cierre del Mediterráneo oriental. El contencioso de las Vísperas era un estorbo para diseñar un necesario «nuevo orden».

Acabadas las vistas con Alfonso III, Carlos II acude a París y arranca dos acuerdos decisivos; el 18 de mayo Carlos de Valois, por matrimonio con $D^{a}$ Margarita (hija

152 Credenciales al doctor en leyes Galvany y al caballero Arenys con memorial para exponer en Génova la "liberación" de Sicilia por Pedro III, ofrecer la continuidad de los privilegios genoveses en Mallorca y Sicilia, la mutua neutralidad en conflicto y protección contra la piratería, ACA, Reg. 73, f. 72 v a 73 v.

153 Credenciales y memoriales público y secreto a Abraham Abenamíes en ACA, Reg. 73, f. 70 a 71 .

154 ACA, Reg. 81, f. 8 v y Reg. 73, f. 72 v.

155 Entre los días 7 y 10 de febrero el monarca solicitó la colaboración de nobles romanos y de los cardenales filoaragoneses, el consejo de los eclesiásticos catalano-aragoneses y enunció su misión: legitimidad de su título. ACA, Reg. 73, f. 75 a $77 \mathrm{v}$.

156 Cit. J. ZURITA, Anales, obr. cit, p. 402

157 Para prepararlas envió ante el angevino a Berenguer Puiguert y fray Ramón de Ripoll, ACA, Reg. 82, f. 24 v. Preparativos y seguros a los emisarios angevinos se encuentran el 24 de marzo en ACA, Reg. 81, f. 73 v, 77 v-78 y Reg. 73, f. 79.

158 ACA, Reg. 81 , f. 79 v y 80. 
de Carlos II), obtenía los ducados de Anjou y Maine a cambio de renunciar a sus derechos sobre Aragón; al día siguiente, Felipe IV aceptaba esta renuncia y una paz con Aragón, si era deseo del Papa. En junio de 1290, los nuevos plenipotenciarios pontificios, cardenales San Nicolás y Santa Sabina, llegaban a Montpellier e inmediatamente contactaban con Alfonso 1 II $^{159}$, quien el 7 de junio destacaba a Ramón Cabrera ante la Santa Sede en defensa de sus argumentos legitimistas ${ }^{160}$.

Alfonso III, entonces, comenzó a preparar la espinosa cuestión siciliana. El 17 de mayo, una carta suya a Mesina sugiere que aceptaba una retirada efectiva de Sicilia ${ }^{161}$, por lo que el 19 de mayo enviaba a Bernardo de Bellvis para explicar a Jaime I lo tratado en las vistas con Carlos II ${ }^{162}$. Tortuosos debían ser los proyectos de Alfonso III sobre Sicilia, porque Jaime 1, el 14 de junio, confirmó los plenos poderes en la negociación a Gisbert de Castellet y Bertrán de Canellas, pero además aceptaba casar a su hermana $D^{a}$ Violante con un alto dignatario en Roma para influir sobre el Papa, siguiendo el consejo de Alfonso III $^{163}$. Aún más, los plenipotenciarios sicilianos coordinaron estrategia con el monarca aragonés durante julio, en Valencia, sobre la base de que jamás Sicilia sería devuelta. La advertencia era seria, porque desde el principio los plenipotenciarios pontificios se negaron a tratar con los sicilianos ${ }^{164}$. Sicilia, simplemente, debía volver a 1282. Ese mes de julio, Nicolás IV comisionó a su capellán, maese Raimundo, para exigir a Jaime I la inmediata devolución de Sicilia.

Jaime I buscando evitar un peligroso aislamiento sorprendió con una ambiciosa propuesta: devolvería todos los derechos y bienes eclesiásticos (nunca el Reino) e iría a la Cruzada, pero el Papa respetaría sus derechos regios a Sicilia, le concedería los privilegios de un cruzado (fin de los anatemas), ampararía una tregua de Sicilia con la Iglesia, Francia, Castilla, Jaime II y Carlos II por diez años (es decir, le admite en las negociaciones) y consentiría el matrimonio de Alfonso III con $\mathrm{D}^{\mathrm{a}}$ Leonor de Inglaterra (guiño a la confederación dinástica) ${ }^{165}$. El 10 de agosto, en una bula, Nicolás IV declaraba a Jaime I perseguidor de la Iglesia. No había acuerdo.

Realmente inquieto, Jaime I inició una diplomacia ofensiva desestabilizadora. Génova se había alineado interesadamente con el Papado y exigía la inmediata retirada catalanoaragonesa de Sicilia ${ }^{166}$, por lo que el 3 de julio Jaime I amplió los privilegios genoveses en Sicilia ${ }^{167}$, pero además encargaba a Bertrán de Canellas asentar su matrimonio con

159 Alfonso III, el 6 de junio, les solicita acudan a Gascuña o área de Tolosa y da seguro a sus emisarios para hacer más ágil la comunicación, ACA, Reg. 73, f. 85 r y v.

160 ACA, Reg. 73, f. 84 v.

161 ACA, Reg. 73, f. 82 v.

162 ACA, Reg. 82 , f. 45 v- 46 .

163 Sendas cartas, de plenos poderes (en ACA, Pergaminos de Alfonso II) y proyecto matrimonial, pub. LA MANTIA, Códice diplomático dei..., obr. cit., no 196 a 200, pp. 459-474.

164 Cit. J. ZURITA, Anales, obr. cit., p. 407.

165 Pub. LA MANTIA, Códice diplomático dei..., obr. cit., nº 209, pp. 493-495.

166 Para contrarrestar esta ofensiva el 10 de junio de 1290 Alfonso III revalidó la alianza con Pisa. Cit. L. KLÜPFEL, Die Aüssere politik..., obr. cit., pp. 70-71.

167 Pub. LA MANTIA, Códice diplomático dei.., obr. cit., n² 203, pp. 480-481. 
$D^{a}$ Guillerma de Montcada ${ }^{168}$, reciente heredera de los estados de Bearn, que amenazaban Aragón, Francia e Inglaterra. Desde el verano, además, bombeó víveres ${ }^{169}$ y dinero $^{170}$ a Aragón, forzando la expresa gratitud de Alfonso $1 \mathrm{II}^{171}$. Pese a todo, a través de Conrado Lanza, acreditado el 10 de agosto ${ }^{172}$, el monarca aragonés debió advertir a su hermano sobre su endeble posición diplomática frente a la obcecación pontificia.

De hecho, Alfonso III rediseñaba la política catalano-aragonesa en el Mediterráneo, como si la cuestión siciliana estuviera superada. A la alianza con Granada, unió las intentonas en Marruecos, una embajada a Tremecén en julio de 1290 y el 1 de diciembre otra encargada a Bernardo de Bellvis en Arborea (Córcega) ${ }^{173}$ y Túnez. En Egipto, Berenguer de Sant Liceri y Ramón Alamán gestionaban una alianza ${ }^{174}$, que se concretó en septiembre de 1290. Por fin, el 13 de noviembre Alfonso III confirmaba a Jaime I que el mes próximo iniciaría los preliminares de una paz de la que Sicilia era excluida ${ }^{175}$. Oficiosamente la realidad debía ser otra, porque el aragonés enviaba a Artal de Azlor para una información reservada a Jaime I.

Muy satisfecho, el 18 de noviembre el Papa absolvía de anatemas a Aragón ${ }^{176}$, mientras exigía sumisión a Jaime I y el día 20 renovaba el proceso contra él. Nada parecía detener la paz. El 8 de diciembre de 1290 emisarios aragoneses iniciaban sesiones preparatorias en Montpellier con los plenipotenciarios pontificios, mientras Alfonso III reunía Cortes en Barcelona para someter las condiciones de la paz y elaboración de un tratado. En enero de 1291 disponía una brillante comitiva para la negociación ${ }^{177}$.

\subsection{El Tratado de Tarascón-Brignoles (1291)}

La seguridad de una paz exacerbó la oposición de Génova al impulso marítimo catalán. En enero de 1291 Alfonso III recibía una embajada genovesa ${ }^{178}$ poco

168 ACA, Pergaminos de Alfonso II, no 370. Pub. LA MANTIA, Ibídem, no 202, pp. 477-479.

169 Órdenes de entrega de partidas de trigo siciliano a Artaldo de Bastida o Berenguer de Finestres, el 10 de junio, ACA, Reg. 82, f. 57; reconocimiento de deuda, el 7 de agosto, de Alfonso III por 21.000 sueldos reales de Valencia por transporte de trigo siciliano, ACA, Reg. 82, f. 60; el 15 de noviembre solicitó Alfonso III permiso de exportación de trigo a Jaime I, ACA, Reg. 81, f. 207.

170 Alfonso lil confirma el envío de un emisario para recibir cierto dinero de Jaime l, como acusa recibo de 400 onzas de oro del siciliano a través de Cerviá de Riera, ACA, Reg. 85, f. 23.

171 En carta del 18 de septiembre, ACA, Reg. 73 , f. $88 \mathrm{v}-89$.

172 ACA, Reg. 73, f. 86 v. Similar acreditación se extendía significativamente ante $D^{a}$ Constanza, Roger de Lauria y Giovanni Prócida.

173 ACA, Reg. 73, f. 90 v.

174 El 8 de agosto el rey les reconocía una deuda por esta legación, ACA, Reg. 73, f. 71v-72, aceptando su relación de gastos el 24 de septiembre de 1290, ACA, Reg. 82, f. 71 v.

175 ACA, Reg. 73, f. 89 v.

176 Así lo recordaba ese día Alfonso IIl a los arzobispos de Zaragoza y Tarragona, como al obispo de Barcelona, ACA, Reg. 81, f. 208 r y v.

177 ACA, Reg. 84, f. 2.

178 Dirigida por Francisco de Camilla al que el rey concede un seguro el 15 de enero, ACA, Reg. 84 , f. 12. El 30 de enero ordenaba costear caballos para Francisco y Damián de Camilla, junto con León Spínola, ACA, Reg. 82, f. 12. 
tranquilizadora, porque el 12 de enero excusaba el retraso de envío de embajadores ante los plenipotenciarios pontificios ${ }^{179}$. En sospechosa coincidencia una legación granadina ofrecía mediar entre Alfonso III y Castilla, propuesta muy conveniente para Génova pues trastocaba la estrategia de Alfonso III en el Estrecho de Gibraltar. en este instante, la embajada genovesa exponía la voluntad de su República: Jaime I debía abandonar Sicilia ${ }^{180}$.

Alfonso III buscó conjurar el peligro. El 11 de enero entregaba un memorial a Abraham Abenamies ofreciendo a Granada apoyo logístico y militar aragonés, advirtiendo su aproximación a Marruecos (potencial enemigo nazarí) y reputando inútil la mediación con Castilla por ser Sancho IV un rey taimado y estar próxima la paz de Aragón con ta Santa Sede y Francia ${ }^{181}$. El 23 de enero, de otro lado, expresaba a Génova el deseo de una alianza ${ }^{182}$ y el 30 de enero concedía especiales privilegios mercantiles a genoveses.

Sin embargo, el tiempo corría en contra de los intereses aragoneses, por lo que Alfonso III precipitó el tratado. El 27 de enero dio credenciales a sus representantes y el día 28 concedió seguro a todo emisario que comunicase las partes signatarias del tratado $^{183}$. Las sesiones se iniciaban en Montpellier el 2 de febrero, continuaron en Tarascón y culminaron en Brignoles, buscando aislamiento de presiones, el 19 de febrero.

Fue un tratado prolijo en se deseo de sentenciar todos los contenciosos de la Cristiandad y así fomentar un espíritu cruzado. Alfonso III veía reconocida su legitimidad a cambio de reconocerse vasallo de la Iglesia (pagaría un censo, acudiría con fuerzas militares a Roma en la Navidad de 1291) y acudir a la Cruzada en junio de 1292. Esta generosidad pontificia se compensaba respecto a Sicilia: Alfonso III liberaría todos los rehenes angevinos, pactaría una paz bilateral con Carlos II, cercenaría toda ayuda a Sicilia, instando a Jaime I a abandonar el trono siciliano, incluso le desalojaría al volver de la Cruzada. Por si cabían dudas, Génova ofrecía a Carlos II 70 galeras para recuperar Sicilia ${ }^{184}$.

En realidad los designios del Alfonso III eran otros a los que rubricó. En lo formal manifestó ser un escrupuloso cumplidor del tratado: firmó la paz con Carlos II en abril de 1291, pergeñando una colaboración mediterránea, pues el aragonés utilizó su influencia sobre los givelinos italianos y secundaba los intereses angevinos en Hungría en favor de Carlos II $^{185}$, mientras el angevino reconocía el statu quo de Mallorca (posesión aragonesa) y mediaría ante Génova ${ }^{186}$, crecientemente anticatalana; el 28 de

179 ACA, Reg. 73, f. 91.

180 ACA, Reg. 73, f. 92v-93.

181 Acreditación en ACA, Reg. 84, f. 10 v; el memorial, ACA, Reg. 73, f. 91v-92.

182 ACA, Reg. 73, f. 92 r y v.

183 ACA, Reg. 84, f. 19.

184 Cit. J. ZURITA, Anales, obr. cit., p. 413.

185 ACA, Reg. 73, f. 98.

186 Animado, Alfonso III dispone que la preceptiva embajada que iría a Roma, se detendría en Génova, ACA, Reg. 73, f. 97 v. 
marzo ordenó a bailes y vegueres de Cataluña y Valencia interrumpir la navegación hacia Sicilia y Calabria, incluso a los justicias valencianos la exportación de pez; envió al abad de Poblet para exponer sus terminantes compromisos por la paz de Tarascón.

Lo cierto es que en los cálculos de Alfonso III no entraba el completo abandono de Sicilia ${ }^{187}$. Así lo debió expresar secretamente a Jaime I a través de Gisbert de Castellet, que acompañó al abad de Poblet y lo reiteró mediante Bernat de Ginesbret en una nueva embajada el 22 de abrilis8. Al parecer, Alfonso III preparaba una complicada triquiñuela: el tratado le obligaba a no apoyar a su hermano, pero no estipulaba que Sicilia debiera ser devuelta a los Anjou. Así las cosas, ¿quién sería el "tenente" siciliano de la Santa Sede? Alfonso III recomendaba a su hermano preparar una nave de trigo a Roma, donde la legación aragonesa obtendría resultados convenientes.

\section{LA HERENCIA ALFONSINA DE D. JAIME}

Clausuraba así, satisfactoriamente, las Vísperas Sicilianas Alfonso III disponiéndose entonces a desarrollar su propio programa político, libre de la herencia paterna. Apenas esbozó unas líneas, firmes sin embargo.

$1^{\circ}$ Retención de Baleares mediante un complejo contencioso, amparado en el derecho feudal y de conquista.

$2^{0}$ Reconocer la soberanía pontificia (nunca angevina) sobre Sicilia. La posesión se reservaría a testaferros aragoneses en la calidad que determinasen futuras negociaciones con la Santa Sede.

3 Reforzar los protectorados en Magreb, plataforma de dominio mediterráneo y paso a Gibraltar. El 15 de mayo se rubricaba un nuevo tratado con Tremecén ${ }^{189}$ y en junio con Túnez.

$4^{\circ}$ Consolidar una berroqueña alianza anglo-aragonesa ${ }^{190}$, alternativa al eje franco-castellano surgido en Bayona, aquel 1291.

5 을 Subvertir el «orden peninsular» castellanista, que confirmaba la debilidad aragonesa en la península. La anexión de Albarracín y conspiraciones en Molina, señoríos de una Sistema lbérico que asfixiaba a Aragón, así como la cesión del Reino de Murcia (puertos hacia Gibraltar) por D. Alfonso de la Cerda, son pruebas fehacientes.

La rápida defunción de Alfonso III el 18 de junio de 1291, dejó en proyecto su programa. La suerte de D. Jaime dio un vuelco espectacular al convertirse en el nuevo monarca aragonés. Si llegó con una mentalidad siciliana, la fuerza de los hechos hizo que adoptase la perspectiva catalano-aragonesa de Alfonso III respecto a Sicilia y que asimilase las líneas políticas que su hermano esbozara. Jaime II dio sentido al reinado de Alfonso III.

187 Pub. L. KLÜPFEL, Die Aüssere politik..., obr. cit,, no 8, pp. 159-160.

188 ACA, Reg. 82, f. 183 v.

189 ACA, Reg. 82, f. 186 v.

190 Cit. J. ZURITA, Anales, obr. cit., p. 416. 


\title{
ACTIVITAT PIRÀTICA ENTRE CATALANO- ARAGONESOS I CASTELLANS A LA MEDITERRÀNIA OCCIDENTAL DURANT EL REGNAT DE JAUME II
}

\author{
Josefina MUTGÉ I VIVES \\ Institució Milà i Fontanals (CSIC, Barcelona)
}

\section{INTRODUCCIÓ}

Els freqüents atacs piràtics que es produien al mar foren una de les causes que més varen impedir el normal desenvolupament del comerç a l'Edat Mitjana.

La present comunicació, que pot inserir-se a la Secció sobre el Marc Mediterrani, dintre del Congrés Internacional «Jaume II, set-cents anys després», és una aportació a l'estudi del cors i de la pirateria al Mediterrani Occidental durant el primer quart del segle $\mathrm{XIV}^{2}$.

1 Les abreviatures utilitzades són les següents: $\mathrm{ACA}=$ Arxiu de la Corona d'Aragó; $\mathrm{AHCB}=$ Arxiu Històric de la ciutat de Barcelona; $C=$ Cancelleria; $C C=$ Consell de Cent; $C R=$ Cartes reials; $f$, $\mathrm{ff} .=$ foli, folis; LI. C. = Llibre del Consell de la ciutat de Barcelona; $p ., p p .=$ pàgina, pàgines; reg. = registre; $r_{0}=$ recto; $v_{0}=$ verso.

2 La bibliografia sobre la pirateria i el corsarisme és abundant. A aquest tema, hi prestà especial atenció el I Congreso Internacional de Historia Mediterránea: La Península Ibérica y el Mediterráneo centro-occidental (siglos XII-XV), Barcelona, 1980. A més, entre altres treballs, podem citar, per exemple, els següents: C. TRASSELLI, "Naufragi, pirateria e doppio gioco", Le genti del mare Mediterraneo, Nàpols, 1981, pp. 499-510; A. UNALI, Mariners, pirates i corsaris catalans a l'època medieval, BarceIona, La Magrana, 1986; F. MARTIGNONE, "Fatti di pirateria nel Mediterraneo occidentale nel secolo $X V$ ", /l Congreso Internacional de Estudios sobre las culturas del Mediterraneo Occidental, Barcelona, 1978, pp. 297-307; M. FONTENAY-A. TENENTI, “Course et piratérie méditérranéennes de la fin du Moyen Age au début du XIXe siècle», XV Colloque International d'Histoire Maritime, Paris, 1987; M. MOLLAT, "De la piratérie sauvage à la course réglementée: XIIle-XIVe siècles", Mélanges de l'École Française de Rome. Moyen Age-Temps Modernes, 87 (1975), pp. 7-25. 
Basant-nos en documentació procedent de la secció de cancelleria reial de l'Arxiu de la Corona d'Aragó i de la secció de Consell de Cent de l'Arxiu Històric de la Ciutat de Barcelona, donarem compte d'algunes escomeses de caràcter piràtic que tingueren lloc entre súbdits castellans i catalano-aragonesos. Aquest tipus d'escomeses, amb molta freqüència, es produïen independentment de l'existència de treves, tractats de pau o relacions d'amistat entre els sobirans respectius dels grups contendents ${ }^{3}$.

Per tal de situar els fets que descriurem a continuació, que succeïren l'any 1319 , hem de recordar la trajectòria política entre Castella i la Corona d'Aragó, des dels darrers anys del segle XIII. El tractat de Monteagudo-Soria, signat el 29 de novembre de 1291 entre Jaume II de Catalunya-Aragó i Sanç IV de Castella, significà, dins la Península, la solidificació dels límits entre els regnes castellans i catalano-aragonesos i el renunciament per part dels monarques catalans a tota expansió peninsular enllà d'aquests límits. Aquesta pau, però, havia de durar poc, perquè Jaume II, de seguida, fou conscient que, fins i tot per damunt de l'expansió per la Mediterrània, el principal objectiu del seu regnat havia de ser el trencament dels límits massa estrets dels seus reialmes peninsulars i reivindicar el regne de Múrcia, que Jaume I, després d'haver-lo conquerit als moros i repoblat, lliurà a Castella sense cap contrapartida ${ }^{4}$. Jaume II començà donant el seu suport als Infants de la Cerda contra Sanç IV i la ruptura de la pau de Monteagudo es féu palesa amb la primera expedició de conquesta de Múrcia, que finalitzà a la primeria d'agost de 1296, conquesta que la reina de Castella, llavors Maria de Molina, no es resignà a acceptar, esperant, sens dubte, el moment propici per a reivindicar-la. Aquesta situació política portà com a conseqüència que la rivalitat entre castellans i catalans es tornés a revifar a tots els nivells. Així s'explica que, el 30 d'abril de 1297, Jaume II es queixés als prohomes i govern municipal de Sevilla del fet que pirates i corsaris castellans causessin danys als súbdits catalano-aragonesos, quan ell havia prohibit expressament als pirates de la Corona d'Aragó de perjudicar els castellans. Els advertia que, si els seus pirates no deixaven de fer mal als súbdits catalans, ell també donaria llicència a aquests darrers perquè els ataquessin i enviaria llenys i galeres armades per tal d'escometre les seves gents ${ }^{5}$.

3 La pirateria es distingia del cors, en línies generals, perquè s'efectuava en temps de pau o treva, sense autorització ni justificació; en canvi el cors consistia en la captura d'un vaixell sota el pretext de la possessió d'una carta de marca (Vegeu l'article de M. MOLLAT, «Essai d'orientation pour l'étude de la guerre de course et la piraterie (XIIle-XVe siècles)', Actas del I Congreso Internacional de Historia Mediterránea, citat, pp. 743-749).

4 Cf. F. SOLDEVILA, História de Catalunya, Barcelona, 1963, pp. 403-404; M.T. FERRER I MALLOL, Organització i defensa d'un territori fronterer. La governació d'Oriola en el segle XIV, BarceIona, 1990, pp. 3-4; ÍDEM, «Notes sobre la conquesta del regne de Múrcia per Jaume II (1296-1304)», Homenatge a la memòria del Prof. Dr. Emilio Sáez. Aplec d'estudis dels seus deixebles i col.laboradors, Barcelona, 1989, p. 27.

5 ACA, C, reg. 108, f. 4 v. -5 r. (1297, abril, 30. Només sis anys abans, la situació era ben diferent. Ho demostren dues cartes de Jaume II, datades respectivament el $15 \mathrm{i}$ el 16 de setembre de 1291. A la primera, el monarca demanava a l'adelantat del regne de Múrcia que fes complir la disposició del rei de Castella que prohibia als seus súbdits causar danys als catalano-aragonesos (ACA, C, reg. 90 , f. 39 v.). A la segona de les cartes, Jaume II ordenava als seus cavallers, almogàvers I oficials reials situats 
La rivalitat amb Castella s'incrementà encara més el 1300, amb motiu de la segona expedició a Múrcia de Jaume II (1300-1304), que acabà amb la sentència de Torrellas del 8 d'agost de 1304: Múrcia va ser retornada a Castella i el territori alacantí fou annexat al regne de València 6 .

Uns quants anys més tard, però, la lluita contra el musulmà va unir, una vegada més, els interessos de Castella i de la Corona d'Aragó i s'iniciaria un nou periode de pau. L'any 1308 , els atacs granadins a les costes valencianes, per l'una banda, i la situació difícil per què passava Muhammad III de Granada, per l'altra, decidiren els castellans i els catalano-aragonesos a accelerar llurs esforços per a preparar un pròxim atac al regne de Granada. Per tal de dur a terme aquesta empresa, el mes de desembre d'aquest any de 1308, Jaume II i Ferran IV s'entrevistaren al monestir de Santa Maria de Huerta (Soria) i poc més tard a Alcalá de Henares. En aquesta darrera població determinaren repartir-se l'esmentat regne musulmà que, considerat com a conquesta de Castella, es desprendria de la seva sisena part, o sia el regne d'Almeria, per recompensar l'ajut rebut de la Corona d'Aragó ${ }^{7}$. A més, anteriorment, s'havia concertat el matrimoni entre el primogènit de Jaume II i Elionor, filla de Ferran IV de Castella ${ }^{8}$. Un motiu més d'apropament entre la Corona d'Aragó i Castella es produí l'any 1311, amb motiu del casament acordat entre la filla gran de Jaume II, Maria, i l'infant Pere, germà del monarca castellà Ferran IV ${ }^{9}$. Però tant les expedicions conjuntes contra els musulmans com la política matrimonial acabaren en un fracàs. Les tropes cristianes

a la frontera amb el regne de València, que no es perjudiqués els castellans, en consideració a la relació de parentiu que hi havia entre ell i Sanç de Castella i, també, perquè entre ambdós monarques «nullam fuit dissentio nec est» (ACA, reg. 90, f. 39 v.). Com veiem, doncs, la situació havia canviat en pocs anys.

6 Sobre la conquesta de Múrcia, cf. J.M. del ESTAL, «Conquista y anexión de las tierras de Alicante, Elche, Orihuela y Guardamar al reino de Valencia por Jaime II de Aragón (1296-1308)», a Alicante Medieval en la proyección expansionista de Aragón desde la hegemonía castellana a su incorporación formal al reino de Valencia (1243-1308), Alicante, 1982; íDEM, Corpus documental del reino de Murcia bajo la soberanía de Aragón (1296-1304/5). Colección de documentos medievales alicantinos, I/1, Alicante, 1995; M.T. FERRER I MALLOL, "Notes sobre la conquesta de Murcia per Jaume II (1296-1304)", Homenatge a la memòria del Prof. Emilio Sáez, ja citat, pp. 27-44; J. TORRES FONTES, La delimitación del Sudeste peninsular (Torrellas-Elche, 1304-1305), Murcia, 1951, 21 pp. Sobre l'organització del territori murcià conquerit per Jaume Il, és fonamental l'obra ja citada de M.T. FERRER I MALLOL, Organització i defensa d'un territori fronterer.

7 A. GIMÉNEZ SOLER, “El sitio de Almería en 1309, Barcelona, 1904; Idem, La Corona de Aragón y Granada", Boletín de la Real Academia de Buenas Letras de Barcelona, 3 (1905-1906), pp. 342-343; M.T. FERRER I MALLOL, La frontera amb I'Islam en el segle XIV. Cristians i sarraïns al País Valencià, Barcelona, 1988, pp. 99-101.

8 «Com pau se tractà entre lo senyor rey d'Aragó e lo rey de Castella, ab covinença que.l fill major del rey En Jacme d'Aragó mulleràs ab filla del rey En Ferrando de Castella" (R. MUNTANER, Crònica, capítol CCXLV); Cf. també J. ZURITA, Anales de la Corona de Aragón, ed. llib. V, caps. LXVI i LXVII, ed. preparada por A. CANELLAS LÓPEZ, vol. 2, Zaragoza, 1970; R. OLIVAR BERTRAND, Bodas reales de Aragón con Castilla, Navarra y Portugal, Barcelona, 1949, pp. 77-90.

9 H. FINKE, Acta Aragonensia (3 vols., Berlin und Leipzig, 1908-1922), I, p. 337; R. OLIVAR BERTRAND, Bodas reales de Aragón con Castilla, Navarra y Portugal, Barcelona, 1949, pp. 69-72. El casament tingué lloc el mes de gener de 1312 (R. OLIVAR, Ibídem, pp. 72-73. 
foren vençudes pels musulmans i Pere de Castella, marit de la infanta Maria, va morir prematurament lluitant contra els moros el juliol de $1319^{10}$. Va ser llavors —regnant ja Alfons XI a Castella - quan Jaume II abandonà els afers castellans i començà els preparatius per a dur a terme la conquesta de Sardenya.

Fou en aquests anys d'apropament i de treva amb Castella que es desenvoluparen els episodis que descriurem a continuació.

\section{PIRATERIES DE CASTELlANS CONTRA CATALANO-ARAGONESOS}

Aproximadament els mateixos dies que Castella era vençuda pels moros i, concretament, el 25 de juliol de l'esmentat any de 1319'11, uns mercaders barcelonins, anomenats G. Ferran, Bernat Sestany, P. Percàç, Jaume Samenla, Jaume Colliure, Simó Xifre, Jaume Conill, Joan Batlle i d'altres, havien sortit de Trapani (Sicília) i navegaven cap a Barcelona, repartits en dues coques: n'anaven una part a la coca de P. Sabater i una altra part, a la dels patrons Francesc Desvalls i Jaume Conill. Quan foren en un indret situat entre l'illa de Sardenya i l'illa de "Gaalata» ${ }^{12}$, es varen trobar amb dues altres coques tripulades per súbdits del rei de Castella: el patró de l'una era Pascual Mandeta de Castro i el de l'altra, Juan Gonzálvez de Santander. Aquests, sense tenir en compte la pau existent entre els reis de Castella i d'Aragó, —diu exactament el document- - varen capturar, injustificadament, —aquesta és una de les característiques dels atacs piràtics-, els vaixells dels mercaders catalans. Als mercaders, després de robar-los les mercaderies, se'ls endugueren presos cap a l'esmentada illa de "Gaalata» on els retingueren durant sis dies. Tot això causà als catalans un greu perjudici. Quan Jaume II de Catalunya-Aragó s'assabentà d'aquest fet, com era el seu costum en casos semblants, va ordenar que es fes una relació fidedigna dels esdeveniments i una estimació dels danys causats, amb la qual es va demostrar de manera evident que la invasió i posterior captura del vaixell català foren fetes pels patrons Pascual de Mandeta i Juan Gonzálvez i que el botí obtingut fou el següent:

A P. Percàç i a Jaume Samenla els foren presos onze moros i una mora captius, valorats en 6.000 sous de moneda barcelonesa; cinc sacs de bescuit, formatges, un guant de ferro ${ }^{13}$, valorats en 111 sous barcelonesos.

A G. Ferran i a Bernat Sestany, tres captives gregues i dos sacs de bescuit, valorat tot en 1.280 sous barcelonesos.

A Joan Batlle, dues gerres de tonyina, valorades en 80 sous barcelonesos.

A P. Sabater, dues botes (segurament de vi, per bé que el document no ho especifica), valorades en 16 sous barcelonesos.

10 Cf. A. GIMÉNEZ SOLER, "La Corona de Aragón y Granada», Boletín de la Real Academia de Buenas Letras de Barcelona, 4 (1907-1908), pp. 79-80; M.T. FERRER MALLOL, La frontera amb l'Islam al segle XIV, pp. 117 iss.

11 AHCB, CC, Sèrie I, LI. C., 5, fols. 54 v. -55 v. El mateix document a LI. C., 6. fols. 24 v. -25 v. (1319, desembre, 19).

12 Així consta al document. No hem pogut identificar aquesta illa.

13 Segurament devia ser la part d'una armadura. 
De la coca de Jaume Conill i de Francesc Desvalls, varen prendre'n també 23 persones, entre moros i mores, vint dels quals pertanyien a Jaume Colliure i a Simó Xifre, dos a Riudefoix, que, al seu torn, els havia encarregats a Jaume Colliure, i un que era de Jaume Conill i de Francesc Desvalls, patrons de la coca. Així mateix, varen perdre els 220 sous que havien de cobrar pel noliejament dels dits moros.

A Jaume Colliure, també li foren presos dotze sacs de bescuit i una bota i mitja de vi, valorat tot en 380 sous barcelonesos.

A Bonanat Dezcoll, 4 gerres de tonyina, avaluades en 180 sous barcelonesos.

A Jaume Conill, dos sacs de bescuit i una bota i mitja de vi, per valor de 180 sous barcelonesos.

A més d'això, Francisco Cardino, patró de les coques del rei de Castella, va exigir per la força als mercaders catalans dotze dobles d'or o l'equivalent en monedes d'or i plata, les quals varen donar-li G. Ferran, Bernat Sestany, P. Percàç i Jaume Samenla.

Així doncs, segons l'estimació efectuada per la cort de Jaume II, l'acte piràtic perpetrat pels castellans, és a dir, les mercaderies més l'import del noliejament dels moros i esclaus, que els patrons també varen perdre, atenyia la suma de 19.547 sous barcelonesos i dotze dobles d'or.

Com que les coques atacants havien estat armades a Sevilla, el 19 de desembre de 1319, els consellers de Barcelona s'adreçaren al govern municipal d'aquella ciutat i a l'almirall major del rei de Castella, Alfonso Jofre ${ }^{14}$, $i$ els demanaren que, tenint en compte la pau que hi havia entre els reis de Castella i de Catalunya-Aragó i l'amistat entre els govern municipals de Barcelona i de Sevilla, procuressin que les mercaderies o el seu valor, juntament amb les despeses esmerçades en la seva recuperació, danys $i$ interessos, tot fos restituït als mercaders catalans o al seu procurador, el mercader i ciutadà de Barcelona, Jaume Colliure, el qual fou designat per a dur a terme les gestions encaminades a recobrar les mercaderies que havien estat confiscades a ell $\mathrm{i}$ als altres mercaders compatriotes seus ${ }^{15}$.

L'activitat diplomàtica desplegada pels consellers de Barcelona no acabà aquí. També recorregueren a l'arquebisbe de Sevilla, «reverend Ferrando ${ }^{16}$, a qui demanaven que ajudés Jaume Colliure, el qual, en nom propi i com a procurador dels altres

14 Alfonso Jofre Tenorio fou almirall de Castella des del 1314 al 1340. Era fill de Jofre de Loaysa, un dels primers pobladors de Sevilla, i pertanyia al grup social dels «ricos hombres» (Cf. F. PÉREZEMBID, El almirantazgo de Castilla hasta las capitulaciones de Santa Fe, Sevilla, 1944, pp. 114-122; Vegeu també M. GARCÍA FERNÁNDEZ, El reino de Sevilla en tiempos de Alfonso XI (1321-1350), Sevilla, 1989, p. 277).

15 AHCB, CC, Sèrie I, LI. C., 5, fols. 54 v. -55 v. El mateix document a LI. C., 6, fols. 24 v. -25 v. (1319, desembre, 19).

16 A les obres respectives de P.B. GAMS (Series episcoporum Ecclesiae Catholicae, Leipzig, 1931, p. 73); i de C. EUBEL (Hierarchia Catholica Medii Aevi, Re-impressió, Padua, 1960, I, p. 278), consta que des de l'any 1404 fins el 1323, l'arquebisbe de Sevilla fou Fernando Gutiérrez Tello. En canvi, segons M. GARCÍA FERNÁNDEZ [El reino de Sevilla en tiempos de Alfonso XI (1312-1350), p. 181, nota 59 i p. 285], l'arquebisbe hispalense es deia Fernando Tello, mentre que Fernán Gutiérrez Tello, nebot seu, fou ardiaca de Sevilla i vicari de l'església sevillana pel seu oncle. D'acord amb el document, els magistrats municipals de Barcelona demanaren ajut a l'arquebisbe. 
mercaders damnificats, es dirigia a la ciutat de Sevilla per tal d'entrevistar-se amb el rei de Castella a fi que els fossin retornats els béns retinguts ${ }^{17}$.

En aquests anys, Barcelona tenia ja consolat a Sevilla, i els cònsols d'ultramar, per privilegi de Jaume I, depenien directament del govern municipal de Barcelona. Per això, els consellers de la ciutat no dubtaren gens a demanar també la col-laboració del consolat de catalans a Sevilla. El 19 de desembre de 1319, els consellers s'adreçaren a Arnau Mertell, el qual actuava com a lloctinent del cònsol que llavors era Jaume Llopart, en aquells moments absent de la capital del Guadalquivir ${ }^{18}$. A l'esmentat lloctinent del cònsol, els consellers li deien «com vós siats aquí per ajudar e per defendre en quant puscats los mercaders cathalans e lurs mercaderies e coses e especialment los nostres ciutedans e lurs béns, per ço.us requerim e-us pregam que, curosament e tant com puxats, procurets e ajudets al dit Jacme Copliure, axí en anant davant lo dit rey de Castella e davant lo dit almiray e lo conseyl e els prohomes de Xibília e davant tot altre qui ell vulla, com en procurant e en tractant perquè ells puixen cobrar totes les mercaderies e coses damunt dites, ensemps ab totes les messions, dans e interessos que lo dit Jacme Copliure e los dits mercaders han fets e sostenguts per la dita raó, ne faran ne sostendran d'aquí avant tro el dia que en les dites coses a ells plenerament serà satisfet» ${ }^{19}$.

Jaume II s'interessà especialment en aquest cas «de roberia manifesta, mal exemple i gran pèrdua per als barcelonins", i va escriure al rei de Castella, a l'almirall major castellà, Alfonso Jofre ${ }^{20}$, i al govern de Sevilla sengles cartes, el portador de les quals fou també Jaume Colliure ${ }^{21}$.

Aquest atac piràtic perpetrat pels castellans a mercaders de Barcelona, juntament amb el creixent rumor que a Sevilla s'armaven encara més coques i galeres, destinades a atacar els súbdits del rei catalano-aragonès i els del rei de Sicília, va causar tant de pànic a la marineria catalana que els consellers de Barcelona començaren a alertar tots aquells qui habitaven les costes de la Mediterrània occidental per tal que prenguessin les mesures pertinents: així doncs, a la darreria del 1319, el govern barceloní comunicava aquest fet al rei Frederic de Sicília i l'advertia del perill que suposarien aquests pirates castellans. Li demanaven que, si aquestes coques i galeres anessin en terres del seu domini, les fes detenir, com si de malfactors es tractés, «ja

17 AHCB, CC, Sèrie I, LI. C., 5, fol. 51 r.; i 6, ff. 25 v.-26 r. (1319, desembre, 19).

18 De fet, en aquells moments, el consolat era vacant, perquè el cònsol, Jaume Llopart, a causa de certes desavinences amb els conseliers de Barcelona, se n'havia anat de Sevilla i havia retornat a Barcelona "pels seus afers". Això succeí els darrers dies de 1319 o bé els primers de 1320 . Per aquest motiu, els consellers el varen destituir i, el 10 de febrer de 1320, designaren Guillem de Bellsolell, mercader i ciutadà de Barcelona per a presidir el consolat de catalans de la capital hispalense [Vegeu J. MUTGÉ I VIVES, "Projecció de Barcelona a l'àmbit supraregional: Notícies sobre el consolat de catalans a Sevilla (1282-1327)", nota 38, IV Congrés d'Història de Barcelona, desembre 1995, en premsa].

19 AHCB, CC, Sèrie I, LI. C., 5, f. 55 v.; i 6, f. 26 r. (1319, desembre, 19).

20 Vegeu, més amunt, la nota 14.

21 AHCB, CC, Sèrie I, LI. C., 6, f. 26 r. (1319, desembre, 19). 
que s'havien comportat com veritables raptors i malfactors ${ }^{22}$. Anna Unali23 observa que la dificultat de captura i persecució dels vaixells enemics variava segons la consistència dels adversaris. No era igual defensar-se d'una sola embarcació que d'una petita flota de vaixells, com era el cas de les coques armades a Sevilla. Calia prendre les màximes precaucions. Per això, els consellers de Barcelona feien el mateix advertiment als cònsols de catalans a Sicília: Guillem Despuig, cònsol de Trapani, Guillem Deslledó, cònsol de Palerm, Ramon Ricard, cònsol de Messina i Marc Mateu, cònsol de Siracusa. Els consellers també varen trametre a Sicília un lleny armat, els còmits del qual eren Domènec Descoll i Berenguer Vidal, i una barca armada patronejada per Bernat Bellot i Guillem Bartomeu, amb la comanda específica d'advertir totes les naus, coques o llenys, bé fossin d'homes de Barcelona o d'altres vasalls del sobirà catalano-aragonès, que arribessin a l'illa de Sicilia, del perill que corrien. Els cònsols també eren pregats de donar consell $i$ ajut als dits patrons del lleny $i$ de la barca i d'insistir al rei Frederic de Sicília i als seus oficials en el mateix extrem: que si les coques piràtiques armades de Sevilla arribaven a Sicília, fossin preses ${ }^{24}$. $S$ ha comprovat que aquesta iniciativa d'armar una o més embarcacions guardacostes per a advertir de possibles agressions piràtiques havia de ser posada en pràctica molt freqüentment per les ciutats marítimes ${ }^{25}$.

De la mateixa manera, els consellers de Barcelona es varen adreçar a l'infant Alfons, hereter ja llavors de la Corona i procurador general del rei, a fi que ell, pel seu compte, també alertés al rei Frederic de Sicília del greu perill que representaven els pirates sevillans i que aquest darrer, al seu torn, demanés al castellà de Malta que si els corsaris arribaven a la dita illa els fes prendre. Els consellers barcelonins demanaven així mateix a l'infant Alfons que donés ordre al veguer de Barcelona d'instituir una taxa, a càrrec dels mercaders de Barcelona, per tal de contribuir, entre tots, a pagar les despeses ocasionades per la barca i pel lleny armats que navegaven per la Mediterrània occidental, per tal d'advertir els vaixells catalano-aragonesos de guardar-se dels vaixells

22 «tamquam raptores et malefactores capi faciatis, cum ipsos vere raptores et malefactores sentierimus anno proxime preterito" [AHCB, CC, Sèrie I, LI. C., 5, ff. 66 r., 67 v. (aquesta carta és del començament de 1320 i en ella, com veiem, es fa referència a les pirateries perpetrades l'any anterior)]. La petició formulada pels consellers de Barcelona de fer capturar els corsaris li fou reiterada al rei Frederic el 27 de febrer de 1320; això demostra que el perill continuava. Llavors, demanaren a Arnau de Sarrià i a Miquel Marquet que tinguessin cura de fer arribar al monarca sicilià les cartes, tant les escrites pels mateixos consellers com les del rei Jaume II (Ibídem, LI. C., 6, f. 32 r.-v.). L'esmentat Miquel Marquet era fill del gran Ramon Marquet, vice-almirall de Pere el Gran, el qual va preparar la flota per l'expedició de conquesta de Sicília. Com a recompensa va rebre del rei diverses terres prop de Siracusa i va arrelar a l'illa i segurament ocupà algun càrrec important prop del rei Frederic (Vegeu la genealogia de la família Marquet estudiada per M.T. FERRER I MALLOL a Gran Enciclopèdia Catalana). Més tard, fou conseller de Barcelona (Vegeu, J. MUTGÉ, La ciudad de Barcelona durante el reinado de Alfonso el Benigno (1327-1336), Madrid-Barcelona, CSIC, 1987, pp. 224-225).

23 Mariners, pirates $i$ corsaris catalans a l'època medieval, cit. pp. 130-131.

$24 \mathrm{AHCB}, \mathrm{CC}$, Sèrie I, LI. C., 5, f. 67 v. (1319).

25 Anna UNALI, ob. cit., pp. 131-132. 
castellanss, Aquesta taxa seria fixada per mercaders bons i honrats de la ciutat de Barcelona ${ }^{26}$.

Una altra escomesa de corsaris castellans que també tingué ressò a les cancelleries fou la que varen dur a terme els patrons sevillans Martín Blasco o Vasco y Martín de Saba, el mateix any 1319 i prop de la ciutat de Sciacca, al sud-oest de l'illa de Sicília ${ }^{27}$. La víctima, en aquesta ocasió, fou una nau de dues cobertes de venecians. Aquesta nau havia carregat a Nàpols avellanes, nous, formatges, oli, carn salada i algunes altres mercaderies i es dirigia a Xipre. També portava onze bales de teles, entre les quals es comptaven 94 peces de draps de llana i armes del mercader barceloní Guillem SesOliveres. Els pirates sevillans prengueren totes aquestes teles, deixaren el mercader a Sicilia i ells se'n anaren cap a Mallorca on, amb molta habilitat, aconseguiren que el patró de la nau que, com hem dit, era venecià, escrivís una carta testimonial tot dient que la nau es dirigia a Alexandria. Se li quedaren la nau i li donaren 50 dobles en joies, cosa que varen fer com a pretext per tal de poder retenir les robes. Tot seguit retornaren a Sevilla.

Una vegada més, els consellers de Barcelona varen sol.licitar als membres del govern municipal de Sevilla "els quals tenien com a frares» que procuressin recuperar aquestes robes i que no permetessin que fossin venudes sinó retornades a Guillem Ses-Oliveres, que aniria a cercar-les a Sevilla ${ }^{28}$. La veu d'alarma donada pels consellers de Barcelona a causa d'aquest fet per tot l'àmbit de la Mediterrània occidental portà com a conseqüència que els capitans de les coques de Sevilla fossin detinguts per ordre del procurador del regne de València, llavors Pere de Queralt. Com calia esperar, immediatament el govern municipal de la ciutat de Sevilla va demanar a Jaume II que aquests capitans fossin alliberats $i$ absolts. El rei va voler actuar generosament amb aquests capitans (Nosque, erga, dictos ductores nos generose habere velimus) (recordem que en aquests anys hi havia pau entre la Corona d'Aragó i Castella) i, el 4 de febrer de 1320 , ordenà al procurador del regne de València, l'esmentat Pere de Queralt, que els deslliurés, malgrat que no haguessin pagat els salaris a l'escrivà o a d'altres funcionaris de la ciutat de València, ja que el rei no volia que romanguessin detinguts en llocs on no tenien béns dels quals poguessin respondre. Si encara els quedava algun bé, els podien obligar a pagar salaris justos a aquells a qui els devien. I, si algú els feia pagar preus injustos o immoderats, els haurien de ser restituïts. El rei afegia que aquelles persones que havien robat mercaderies als sevillans, tot aprofitant que aquests estaven sota manlleuta, haurien de ser castigats degudament i obligats a restituir-los. En el cas que als capitans els restés algun diner per a pagar als catalanoaragonesos que varen ser robats, havien de ser retinguts. Altrament, el rei ordenava que fossin alliberats ${ }^{29}$.

26 AHCB, CC, Sèrie I, LI. C., 5, f. 68 r. (1319).

$27 \mathrm{AHCB}, \mathrm{CC}$, Sèrie I, LI. C., 5, f. 31 r. (1319, juliol, 27). El cognom del primer dels pirates apareix en les dues formes Blasco o Vasco.

28 Ibidem.

29 ACA, C, reg. 217, f. 255 r. (1320, febrer, 4. Tarragona). Sobre la trajectòria política de Pere de Queralt, cf. M.T. FERRER, Organització i defensa d'un territori fronterer, cit., pp. 106-110, 292, 302, 
A l'estiu de 1320, l'escrivà d'una de les coques castellanes, anomenat Joan Scut, encara romania capturat en poder del procurador Pere de Queralt. Però, el 28 de juliol de l'esmentat any, Jaume II ordenà a Queralt que el posés en llibertat, sempre que els mercaders catalans haguessin estat rescabalats de llurs pèrdues, malgrat que aquest Joan s'hagués declarat fiador de Martín Blasco o Vasco -l'altre capità pirata detingut pel procurador-, el qual s'havia compromès a tornar a la presó i no ho havia fet ${ }^{30}$. Aquest temor dels catalano-aragonesos als corsaris castellans continuava vigent al començament de l'any 1321. El 21 de febrer d'aquest any, l'infant Alfons, atenent segurament les reiteratives peticions dels consellers de Barcelona, s'adreçava altra vegada al seu oncle Frederic de Sicília per dir-li que hom sabia que les coques castellanes havien d'anar a Sicilia i li demanava que es preparés per a capturar-les i que avisés al castellà de Malta que també ho fes i que ordenés els seus oficials que previnguessin tots els navegants catalano-aragonesos del perill que corrien ${ }^{31}$.

\section{PIRATERIES DE CATALANS CONTRA CAStELlanS}

L'altre episodi piràtic que descriurem tot seguit tingué lloc contemporàniament als que acabem de comentar, però es produí a la inversa. En aquesta ocasió, foren els catalans que varen agredir els castellans, sense motiu. El fet va succeir de la següent manera ${ }^{32}$ : uns cavallers catalans, actuant per ordre del noble Gispert, vescomte de Castellnou ${ }^{33}$, detingueren l'abat de la colegiata de Jerez, Juan García de Gallegos, el qual era fill de Don García Martínez de Gallegos, alcalde major de la ciutat hispalense. Aquest fet fou considerat com una greu ofensa per part del govern municipal de la capital andalusa, per la qual cosa, el 7 d'agost de l'any 1319, l'alcalde major, l'algutzir

307 i docs. 115, 117 i 122. De 1320 a 1322 exercí el càrrec de procurador del regne de València $i$, el 10 de desembre de 1322, Jaume || el designà procurador del regne de València dellà Xixona, càrrec aquest darrer que exerci molt poc, ja que participà en l'expedició de conquesta de Sardenya comanada per l'infant Alfons i morí en el setge de la vila d'Esglésies el mes d'octubre de 1323 (IDEM, Ibídem, p. 107 i doc. 115).

30 ACA, C, reg. 218 , f. 86 v. (1320, juliol, 28. Calataiud).

31 ACA, C, reg. 364, f. 129 v.-130 r. (1321, febrer, 21. Barcelona).

32 La descripció d'aquest esdeveniment es troba a ACA, C, CR de Jaume 11, caixa 99, núm. 12.312. La carta està datada un 12 d'agost, però no hi consta l'any. Creiem poder-la situar en el 1319.

33 Gispert de Castellnou (1284-1321) fou el darrer vescomte de Castelinou (aquest vescomtat estava situat al Sud-oest del Rosselló, al massís dels Aspres). El 1285 es posà al costat de Pere I de Catalunya-Aragó contra Felip III de França I Jaume II de Mallorca, actitud que li valgué la confiscació dels seus béns fins a la pau del 1298. Del 1300 al 1303 fou portantveus del procurador de València. Sostingué una guerra ruïnosa contra Pere de Fenollet, vescomte d'llla (P.PONSICH, «Castellnou, Jaspert de», a Gran Enciclopèdia de Catalunya). El 1309, Gispert de Castellnou comanà els estols combinats de Catalunya i Castella a la campanya d'Almeria. Els esmentats estols ocuparen l'Estret, i Ceuta, en poder del rei de Granada, fou atacada i presa el 21 de juliol de 1309. Així mateix, cal esmentar que la conquesta de Gibraltar fou assolida el 12 de setembre de 1309, gràcies a l'esforç de Guzmán el Bueno qui comptà amb l'ajut de Gispert de Castellnou i dels mariners catalans (A. GIMÉNEZ SOLER, «La Corona de Aragón y Granada», Barcelona, 1908, p. 160. Extret del Boletín de la Real Academia de Buenas Letras de Barcelona, III i IV; F. SOLDEVILA, Història de Catalunya, p. 411). 
i els prohomes de Sevilla es reuniren a l'església de San Andrés i varen fer compareixer davant seu els mercaders catalans i mallorquins que es trobaven a la ciutat de Sevilla, protestaren enèrgicament del fet ocorregut $i$ els amenaçaren de prendre serioses represàlies sobre les persones i els béns dels catalans si no es feia l'esmena i satisfacció corresponent a l'abat de Jerez. El consell de Sevilla acordà que, des d'aquell mateix dia, es comencés a prendre venjança sobre els catalans, però, sortosament per aquests darrers, l'alcalde i l'algutzir s'hi oposaren, de moment. Els mercaders catalans, trobantse en aquesta difícil situació, varen exposar el fet a Jaume II, tot dient-li textualment que, si de la primera se n'havien escapat, de la segona no se n'escaparien, ja que se'ls havia prohibit terminantment de treure els béns que tenien a Sevilla fins que l'abat de Jerez no fos alliberat i rescabalat ${ }^{34}$. La persona designada per a portar la carta a Jaume II fou el cònsol Jaume Llopart, el qual tenia l'encàrrec d'explicar-li totes aquestes coses de paraula i amb més detall, ja que les havia presenciades. Els mercaders demanaven al rei una solució urgent per tal de poder sortir del perill en què es trobaven ${ }^{35}$. Li feien avinent que el pare de l'abat i alcalde major de Sevilla, Don García Martínez de Gallegos, era un «om qui.s té molt tengut de servir a vós, senyor» ${ }^{36}$.

Convé explicar que el llinatge dels Gallego pertanyia al grup dels «caballeros hidalgos", dintre de la baixa noblesa sevillana. Eren oriünds de Galícia i s'establiren a Sevilla des del segle XIII ${ }^{37}$. Durant el segle XIV, aquest cognom estigué vinculat a l'alcaldia hispalense. García Martínez de Gallegos era fill de Gonzalo García de Gallegos. Tant l'un com l'altre varen ostentar el càrrec d' «alcalde mayor» de la ciutat de Sevilla. García Martínez de Gallegos era el pare, com hem dit, de l'abat de Jerez, Juan García de Gallegos ${ }^{38}$. De la documentació consultada es dedueix que aquesta

34 Transcrivim un fragment d'aquesta carta que els mercaders catalans de Sevilla adreçaven a Jaume II: «A la vostra altea, senyor, fem saber que dimecres a VII dies d'agost, que.Is alcaldes majors e l'alguazir e.ls prohomes de Sibília, tenent Consseyl en l'esgieya de Sant Andreu, nos feren venir tots davant eyls e dixeren-nos que.I noble en Gizbert de Casteylnou avia fet pendre e destenir Johan Garcia, abat de Xerez, fil de Don Garcia Martíniz de Galegos, alcalde major de la ciutat de Sibília, de la qual cosa tots los honrrats hòmens de Sibília e tot lo consseyl se tenen per molt desonrrats e agreujats, e.ns an fortmen menassats dien que si d'aquesta cosa no.Is és feta esmena e satisfacció complida a lur honor, que els que las pendran de nostres persones e de nostres avers. Ens digueren que si no fossen los alcaides e l'alguazir que o vedaren, que.l Consseyl avia aut d'acort que lo dia mateix fossen preses [...] en havers e en persones. Encara.ns digueren que.ns guardassem que pus d'aquesta primera erem bé escapats, que no escapariem tant bé a la segona. En axí que.ns an destenguts e fet manament que nós no iscam ne tregam res del nostre de la ciutat de Xibilia tro que.I damunt dit abat de Xerez sia solt e lexat ab totes ses companyes e ses coses complidament..." (ACA, C, CR de Jaume II, caixa 99 , núm. 12.312).

35 «... perquè, senyor, veen-nos en est peril tan gran avem hordenat que-us trametem per missatgé en Jacme Laupart, cònssol per vós en Sibília, qui totes estes coses mils e pus clarament vós contarà, persò car és estat present a totes» (Ibídem).

36 lbidem.

37 Cf. J. GONZÁLEZ, El repartimiento de Sevilla, Madrid, 1951, II, p. 130.

38 Cf. M. GARCÍA FERNÁNDEZ, El reino de Sevilla en tiempos de Alfonso XI (1312-1350), ja citat, pp. 280-283. Vegeu también R. SÁNCHEZ SAUS, Los linajes de la baja nobleza en la Andalucía de los siglos XIII al XV (Sevilla y Jerez de la Frontera), Madrid, 1986, p. 522. Vull fer constar el meu 
agressió perpetrada en la persona de l'abat de Jerez va comportar, com succeïa amb freqüència, la concessió d'una carta de marca o represàlia contra els mercaders catalans, motiu pel qual molts dels dits comerciants varen ser pignorats i marcats a la ciutat de Sevilla ${ }^{39}$. El fet que el personatge formés part de l'estament eclesiàstic va fer que l'agressió de què havia estat objecte transcendís fins la cort pontifícia. Per altra banda, com que a l'hora d'avaluar els danys ocasionats a l'abat, hi havia hagut gran diversitat d'apreciacions tant per part de l'abat com del seu procurador, Jaume II s'adreçà a Raimon «Juvenis", auditor de la cúria romana, per tal que rebés una declaració jurada del mateix abat - que precisament llavors es trobava a la cort papaldels béns que li havien estat robats, a fi que, coneguda la veritat, es pogués actuar amb justícia i se li fes restituir allò que realment li havia estat confiscat ${ }^{40}$.

L'abat fou interrogat $i$, tot i que digué no recordar amb precisió algunes coses, féu les següents declaracions:

1. Que li havia estat robada una quantitat major de dobles d'or i tornesos de plata del que s'havia dit. Creia que li prengueren 525 dobles i no pas 235 i 3.686 tornesos de plata.

2. Li havien estat robades dues espases amb ornaments de plata, valorades en 2.500 morabatins de moneda castellana.

3. L'abat declarà que no creia que fos cert que el valor de les espases sense ornaments que li foren robades estiguessin valorades en 400 morabatins, sinó que valien més.

4. Declarà que era cert que l'anell amb un robí incrustat valia 2.200 morabatins.

5. Una bossa de seda, dues corretges amb ornaments de plata, una espasa grossa, també amb ornaments de plata, tot valorat en 300 morabatins.

6. Un bacinet de plata que valia 100 morabatins.

7. L'abat declarà, així mateix, que li foren robades una darga o escut de cuir pintat i segellat amb el seu segell, dues llances, algunes espases i corretges, el valor de les quals no podia precisar perquè no el recordava.

agraïment al Prof. Dr. Manuel García Fernández per les notícies i la bibliografia que, molt amablement, em va donar sobre la família dels Gallego.

39 ACA, C, CR de Jaume II, caixa 50, núm. 6.219 (1320, juliol, 2): el monarca catalano-aragonès s'adreçava a lauditor de la cúria papal en els següenbts termes: «... super quadam raubariam que facta extitit Johanni Garsie de Gallegos, abbati de Xeres, diocesis Ispalensis, per quosdam milites terre nostre, mandato nobilis vicecomitis Castrinovi, propter quamquidem raubariam pignorati et marchati fuerunt in ispalensis civitatis aliqui mercatores terre nostre, et de dicta raubaria satisfacere habuerunt...".

Sobre les marques o represàlies, vegeu, per exemple: R. de MAS LATRIE, Du droit de marque ou droit de représailles au Moyen Age, Paris, 1875 (Bibliothèque de l'École des Chartes, Vle série, t. II), 123 pp; A. DEL VECCHIO ed. E. CASANOVA, Le rappresaglie nei comuni medievali e specialmente in Firenze, Bologna, Arnaldo Forni, editore, 1894. Reed. anast. Bologna, Zanichelli, 1974. XLV+417 pp.; J. MIRET I SANS, "Les represàlies a Catalunya durant l'Edat Mitjana». Extret de la Revista Jurídica de Catalunya, Barcelona, 1925, 62 pp.; R. de ALBURQUERQUE, As represalias. Estudo de História do Direito português (sécs. XV e XVI), Lisboa, 1972. Tomo I, en 2 vols.

40 ACA, CR de Jaume II, caixa 50, núm. 6.219 (1320, juliol, 2). 
8. Una sobrevesta folrada, una túnica amb botons de plata i una clàmide o capa, de les quals tampoc no manifestà el valor ${ }^{41}$.

No podem aportar cap més document que ens permeti d'explicar com va acabar aquest fet. Però sí que és cert que, una vegada més, de l'acte piràtic efectuat per un noble català, en varen pagar les conseqüències els mercaders compatriotes seus.

Pel que fa a Juan García de Gallegos, consta que, més endavant, el 1331, ocupava una canongia a la Catedral de Sevilla ${ }^{42}$.

41 lbidem.

42 Cf. M. GARCÍA FERNÁNDEZ, El reino de Sevilla en tiempos de Alfonso XI, cit., p. 283, i nota 76 . 


\title{
INTERESES TRANSALPINOS DE JAIME II EN LA ÉPOCA DE LA CONQUISTA DEL REINO DE MURCIA. LA DONACIÓN DE LOS CALATRAVOS AL INFANTE JUAN EN 1304
}

\author{
Pedro Carlos PICATOSTE NAVARRO
}

En el verano de 1296 Jaime II de Aragón ocupa y gobierna el antiguo reino hudita de Murcia, lo que le hace entrar en conflicto con la otra gran fuerza cristiana peninsular, Castilla. Esta guerra por la posesión de las tierras levantinas se mantuvo por espacio de ocho años, hasta que en 1304, con la intervención de Dionís de Portugal, las coronas litigantes firmaron en Torrellas una paz que suponía el reparto del territorio en litigio'. Conseguida la paz con el castellano y el afianzamiento de la frontera sur de la Corona de Aragón ${ }^{2}$, Jaime II acometió nuevas empresas en uno de sus más continuados propósitos: seguir manteniendo la soberanía catalano-aragonesa en tierras de Nápoles y Sicilia, siendo en este terreno el control comercial del Mediterráneo el ob-

1 Acerca de la conquista del reino de Murcia por Jaime II cfr. ESTAL GUTIÉRREZ, J. M. del, Conquista y anexión de las tierras de Alicante, Elche, Orihuela y Guardamar al Reino de Valencia por Jaime II de Aragón (1296-1308), Alicante, 1982. Id., Corpus Documental del reino de Murcia bajo la soberania de Aragón (1296-1304/5). Colección de Documentos Medievales Alicantinos 1/1, Alicante, 1985. Id., El reino de Murcia bajo Aragón (1296-1305). Colección documental del medievo alicantino. Corpus Documental I/2, Alicante, 1990. FERRER i MALLOL, M. ${ }^{\text {a }}$ T., «Notes sobre la conquesta del regne de Múrcia per Jaume II (1296-1304), en Homenatge a la memòria del Prof. Emilio Sáez. Aplec d'estudis dels seus deixebles y col.laboradors, Barcelona, 1989, pp. 27-44. Mientras que al respecto del acuerdo de Torrellas cf. TORRES FONTES, J., La delimitación del sudeste peninsular (tratados de Torrellas-Elche, 1304-1305), Murcia, 1951. ESTAL GUTIÉRREZ, J. M. del, El reino de Murcia bajo Aragón .... $/ 1$, pp. 89-103 y doc. 213.

2 GUINOT i RODRÍGUEZ, E., Els límits del regne. El procés de formació territorial del País Valencià medieval (1238-1500), Valencia, 1995. 
jetivo fundamental ${ }^{3}$. Ello, además, en un momento especialmente delicado en este sector, por cuanto tanto la liga urbana de Barcelona como los mercaderes de la Corona de Aragón y el propio rey Justo se enfrentaban a importantes contratiempos consecuencia del proteccionismo y de la subida de aranceles de los capetos franceses y de su homónimo de Mallorca, que gravaba la actividad comercial en los «antepuertos» de Barcelona y Valencia, vitales para el comercio ultramarino de la Corona de Aragón ${ }^{4}$. Desde el siglo XIII son los mercaderes catalanes los que controlan el comercio en esta zona del Mediterráneo, viéndose consolidada tal preeminencia con el poder y dominio político de la Corona de Aragón en ese momento. Para estos mercaderes el reino de Nápoles era un mercado importante, tanto por el consumo como por ser un punto comercial de primer orden por sus ferias y lugar estratégico en el centro del Mare Nostrum. Se vendía a Nápoles lana, cueros, azafrán, cera, sal y paños catalanes, valencianos y mallorquines ${ }^{5}$. Además, para reafirmar esta actividad comercial los monarcas otorgaron privilegios a los mercaderes catalanes, que forman en la zona numerosas colonias.

Sin duda, en este contexto se producen una serie de hechos que afianzan la presencia aragonesa en ultramar. Uno de estos aspectos es analizado en la presente comunicación. Se trata de la donación efectuada por el maestre de la Orden de Calatrava, García López, en favor del infante Juan, hijo de Jaime II de Aragón, por la que el infante recibe una serie de posesiones en Italia; ello seis meses antes de la firma del tratado de Torrellas, aunque sin relación con él. García López concedía a mediados de febrero de 1304 al infante Juan, quien ya incluso antes de nacer había sido destinado a la carrera religiosa, una serie de posesiones que la Orden tenía en Italia ${ }^{6}$. Nombraba como procurador para encargarse del asunto a fray Joan de Sempere, calatravo también, quien tenía como misión poner en posesión de tales bienes al representante del joven infante, que por razón de su minoría de edad fue nombrado por su padre el rey: se trataba de Enric de Quintavall. El apelativo de familiarem nostrum con el que Jaime II denomina al caballero Quintavall nos hace pensar que se tratase de una persona del círculo real que gozaba de toda la confianza del monarca.

García López de Padilla, según la crónica de Calatrava impresa en Toledo en $1571^{7}$, fue electo maestre en el año 1296 pero no en concordia, ya que otros caballeros de la Orden eligieron antes a Gutierre Pérez. Esta disputa dio lugar a que cada uno de ellos se apoderase de los más pueblos y castillos de la Orden que pudieron, durando la crisis algo menos de cuatro años. Llegó el acuerdo tras la mediación de Roma, mientras tanto las posesiones de la Orden estuvieron bajo la jurisdicción del maestre de Alcántara. La solución daba la razón a García López, corriendo de esto el año de 1301.

3 MIRÓN, B.L., Las reinas de Aragón, sus vidas y sus épocas, Valencia.

4 RIERA i MELIS, A., La Corona de Aragón y el Reino de Mallorca en el primer cuarto del siglo XIV, Madrid-Barcelona 1986.

5 SALRACH MARÉS, J. M. a La Corona de Aragón: plenitud y crisis, Historia 16, Madrid 1996.

6 Apéndice documental, doc. n. $¹$.

7 RADES Y ANDRADA, F. de, Chronica de la orden y Cavalleria de Calatrava, Toledo, 1571. 
Hay que tener en cuenta que en tiempos de este maestre se producen importantes acontecimientos para las órdenes militares en el ámbito europeo. Como sabemos la Iglesia termina condenando a los templarios y sus bienes son confiscados ${ }^{8}$. La orden del Temple tenía un carácter marcadamente militar, si bien lo que provocó su fin fue su inmensa riqueza y la amplitud de su sistema crediticio, que la hicieron demasiado poderosa a ojos de monarquías como la francesa que precipitó su caída. Felipe IV el Hermoso inició el proceso contra los templarios en 1307 y Clemente V, aliado del capeto, los terminó disolviendo cinco años después, pasando sus bienes en Francia tras el expolio regio a los hospitălarios ${ }^{9}$; el poder real se afianza sobre la milicia religiosa con la aquiescencia del Papa. En otros reinos los bienes del Temple se reparten entre órdenes autóctonas o de nueva creación, como Montesa en Aragón o las de Calatrava, Santiago y Alcántara en Castilla; el espíritu de la cruzada y la oposición al Islam eran sus fundamentos ${ }^{10}$.

Una de las consecuencias directas de esta decisión, como hemos visto, es la creación en el reino de Valencia de la Orden de Montesa dependiente de la de Calatrava ${ }^{11 .}$ La crónica antes citada señala de forma explícita que el rey de Aragón participó activamente en la petición al Papa de que los bienes templarios de esta zona bajo su jurisdicción pasasen a depender de Calatrava por medio de una nueva Orden que vigilase esas tierras, todavía frontera de las posibles razzias musulmanas. Jaime II de Aragón junto con Dionís de Portugal se opusieron a la ambición de los hospitalarios sobre las posesiones del Temple. La Orden de Montesa aceptó la regla de Calatrava y del Císter, pero para no someterse directamente a los designios del maestre calatravo, castellano, pasó a depender del monasterio cisterciense de Santes Creus en Tarragona. La petición del rey Jaime la hizo, según la mentada crónica, «por devoción que tuvo a esta orden de Calatrava, y afición particular al Maestre don Garci Lopez". El Papa concedió la petición en el año 1317, fundándose al año siguiente el Convento de San Jorge de la villa de Montesa, siendo su primer maestre Guillen Erill12.

A lo que parece, existieron siempre muy buenas relaciones entre el calatravo García López y la Corona de Aragón, de lo contrario no se explicaría el hecho de que fuese Alcañiz, dentro del reino de Aragón, la población elegida por el maestre para refugiarse cuando años después huyó de Castilla. Sabemos igualmente que en 1328 García López asistió a los fastos de la coronación de Alfonso IV acompañado incluso de «gran cavalleria» ${ }^{13}$, siendo ésta su presencia última en acontecimiento importante antes de

8 MARTÍNEZ dÍEZ, G., Los templarios en la Corona de Castilla, Burgos, 1993.

9 BORDONOVE, G., Les templiers. Histoire et tragedie, París, 1974.

10 RUNCIMAN, S., Historia de las cruzadas, Madrid, 1994.

11 RIGALT y NICOLAS, B., Diccionario histórico de las órdenes de Caballería, Barcelona, 1858. GUINOT RODRÍGUEZ, E., Feudalismo en expansión en el norte valenciano. Antecedentes y desarrollo del señorío de la Orden de Montesa. Siglos XIII y XIV, Castellón, 1986.

12 RIGALT y NICOLAS, B., Diccionario histórico .... Quien por cierto acudió a los actos de coronación de Alfonso el Benigno en la Aljafería de Zaragoza, donde fue armada caballero por en infante Pedro, hermano del rey. ZURITA, J., Anales de la Corona de Aragón, edición preparada por A. CANELLAS LÓPEZ, Zaragoza, 1972, 3, VII, I, pp. 300-301.

13 SOLDEVILA, F., Les quatre grans cròniques, Barcelona, 1971 
renunciar al maestrazgo tras casi tres décadas al frente de la orden de Calatrava. No obstante tal renuncia, García López se quedó con lo que la Orden tenía en la Corona de Aragón y con el castillo y encomienda de Zorita (1329). Parece evidente que Jaime II disfrutaba de un aliado en el seno de una de las órdenes militares más importantes y potentes con gran fuerza en Castilla.

En este estado de cosas es posible que las donaciones acreditadas en los documentos que aportamos pudiesen haber favorecido de modo notable esa "afición particular» por García López en el ánimo de Jaime II.

Los territorios cedidos al Infante Juan, todavía niño, por García López y la orden de Calatrava fueron Santo Angel de la Ossaria, Castelluço, Pons, Albaneti, Troya, Fraguinyano, Sanctus Pantalomeus, Romania, Astol, Foggia, Sancta María de Posse, Brindissi, Salpione, Sancta Maria la Mutata, La Grotayla, Maiolano, Sanctus Nichola, y las «piscarias» de Tarento, Avorna, Alexia, Sancta Elia, Ayora de Matreria et Sanctus Dimine.

El embajador elegido por Jaime II para tomar posesión de estas donaciones fue, lógicamente, alguien que en esos momentos gozaba de toda su confianza, Enric de Quintavall, a quien además de entregarle sus "vices", licencia para nombrar a procuradores, subalternos o removerlos cuando lo considerase oportuno, así como para hacer y deshacer a voluntad ${ }^{14}$, le arropó de toda una labor diplomática encaminada a facilitar su trabajo en aquellas tierras. Los documentos que se envian así lo acreditan. Sin dejar detalle al azar se giran misivas entre el 24 y el 30 de abril de 1304 a todos aquellos, clérigos y laicos, reyes y nobles, que Jaime II consideró personas influyentes que facilitarían la tarea al legado Quintavall. Carlos de Nápoles ${ }^{15}$; Benedicto XI de Roma ${ }^{16}$, quien además había de darle su bendición; Marco, diácono cardenal de Santa María in Portico; Laudulfo, diácono cardenal de Sant Angelo; Francesco, diácono cardenal de Santa María in Cosmedin; a Napoleón, diácono cardenal de San Adrián; al maestro Pedro Hispano, cardenal de la Sabina; Francesco Napoleón, diácono cardenal de Santa Lucía in Sílice ${ }^{17}$; Ramón Berenguer, hijo del rey de Jerusalem y Sicilia; Felipe, príncipe de Tarento; Roberto, duque de Calabria; la reina María de Jerusalen, Sicilia y Hungría ${ }^{18}$; Bartolomé Siginulfo, "comite tolesino», camarero del rey de Sicilia; Bartolomé de Capua «logotero» y protonotario del rey de Sicilia; Sergio Siginulfo, mariscal del rey de Sicilia; Diego de Lavat, caballero del duque de Calabria ${ }^{19}$; García, prior de Santa Cristina y procurador real de la Curia Romana; Vidal de Vilanova Curia Romana ${ }^{20}$; Roberto, duque de Calabria ${ }^{21}$; Pedro, obispo y canciller del rey de Sicilia; Giovanni Pipino, maestro racional del rey de Sicilia; a Roger de Lauria, almirante del

14 ACA, C, reg. 235. f. 60 v. (1304, abril, 30).

15 ACA, C, reg. 235, f. 61r. (1304, abril, 24 y 26).

16 ACA, C, reg. 235, f. 61 r. (1304, abril, 30).

17 ACA, C, reg. 235, f. 61 v. (1304, abril, 30).

18 ACA, C, reg. f. 61 v. (1304, abril, 26).

19 ACA, C, reg. 235, f. 62r. (1304, abril, 26).

20 ACA, C, reg. 235, f. 62r. (1304, abril, 26).

21 ACA, C, reg. 235, f. 62r. (1304, abril, 26). 
rey de Aragón; a Ermengando, conde de Ariano y maestro justiciero del rey de Sicilia; Ramón de Balso, domino Avellini; Guillermo, electo de Salerno, obispo, canciller y consejero del duque de Calabria'22; Manfredo, marqués de Saluciarum; Pedro de Victo "alme urbis perfecto»; y Porçello de filiis Urssi ${ }^{23}$ son objeto de sus cartas. A todos ellos se comunicó la razón del viaje de Quintavall y a todos ellos se solicitó ayuda de todo tipo, consejo y favor para su legado, que en algún caso los había de visitar, en atención a la amistad que se profesaban. La calidad de los receptores de las misivas dice mucho del interés del rey de Aragón por el asunto en cuestión.

Jaime II cuidó, a su vez, el recorrido que su representante había de hacer; con este fin escribió a Beltrán Jordan de la Ylla, senescal del rey de Francia, o a su lugarteniente, para que supiesen que Quintavall pasaría por las tierras del rey francés a la cabeza de una comitiva aragonesa montado en un caballo de pelo negro de su propiedad. Idéntica misiva dirigía el rey de Aragón a Ivo Girardi, rector de Montpellier ${ }^{24}$; al rey de Mallorca; a Ricardo de Cabatesa, senescal del rey Carlos ${ }^{25}$; a Cristiano Spinola y a Françesco Scarsafica ${ }^{26}$.

Por último, Jaime ll ordenó, por medio de documento, a todos sus oficiales y súbditos que ayudasen en aquello para lo que fuesen requeridos a Enric de Quintavall mientras estuviese en tierras de la Corona de Aragón. Como vemos, la amplitud de esta actividad diplomática denota la importancia que el monarca concede a la toma de posesión de estas donaciones de la Orden de Calatrava para su hijo el infante Juan.

Huelga referir que Quintavall fue una persona de toda confianza de Jaime II, así lo denotan los adjetivos empleados en los documentos como "dilectum militem", "familiarem nostrum" "familiarem dicti domini regis Aragonum", etc. Lo que desde luego no era es un desconocido, aunque sea muy poco lo que sepamos sobre él. Le sabemos en calidad de escudero cercano a Jaime II durante la campaña murciana de 1296, de quien obtuvo, en pleno proceso conquistador, unas casas situadas en la ciudad de Murcia y una heredad en el término de dicha ciudad compuesta por viñas y otras posesiones que habían sido propiedad de Pedro lbáñez a quien le fueron confiscadas por ser rebelde al rey de Aragón. Todo ello por los servicios prestados y a perpetuidad con todos los derechos ${ }^{27}$.

Por otra parte, encontramos a Enric de Quintavall en asuntos relacionados con la compra venta de la alquería de Benimeli, en el término de Denia, y de Segària ${ }^{28}$. Estas disposiciones reflejan como Enric de Quintavall compra a Bernat Desclapers dicha

22 ACA.1304, Abril, 26.Alagón.

$23 \mathrm{ACA}, \mathrm{C}$, reg. 235, f. $62 \mathrm{v}$.

24 ACA, C, reg. 235, f. $62 \mathrm{v}$.

25 ACA, C, reg. 235, f. $62 v$.

26 ACA, C, reg. 235, f. 63 r.

27 ACA, C, Reg. 194, f. 247 r-v. (1296, agosto, 3).

28 OLMOS Y CANALDA, E., Inventario de los pergaminos del Archivo de la Catedral de Valencia, Valencia 1961. 
alquería el 12 de agosto de $1306^{29}$, siendo confirmada tal adquisición por el propio Jaime II el día 16 del mismo mes $^{30}$. Vuelve a aparecer en diciembre el caballero Quintavall vendiendo la alquería a Pere Ronda ${ }^{31}$, panicerus domine regine, quien la vende a su vez a Jaime II, que la vuelve a vender al propio Enric de Quintavall el día después. En este documento se especifica que se venden las casas, campos, hierbas, etc. de la alquería de Benimeli entre lo perteneciente a Segària, una montaña, la rambla de Riusech, la alquería de Açenech, el Rafol y el río de Arobulata-Sagra, camino de Laguart ${ }^{32}$. Tales transmisiones se completan en otro documento ${ }^{33}$. En marzo de 1307 Enric de Quintavall se concierta con Bienvenida, hija de Guillem Garcia sobre esta alquería de Benimeli $i^{34}$, aunque desconozcamos como pudo quedar la cosa, pues en 1325 Quintavall recibió como donación del entonces procurador valenciano Bernat de Sarrià el mero y mixto imperio de Benimeli. Volvemos a localizar a Enric de Quintavall en junio de 1328 participando en la negociación que llevó a la nueva redacción de la carta de población de Ayora ${ }^{35}$. La última noticia vinculada con este personaje tiene fecha de cinco años después, 1330, por la que queda encargado junto con Ramon Giner de hacer efectivo el pago determinado por Alfonso IV a los escribanos de la Procuración del reino de Valencia ${ }^{36}$.

29 Ibidem.

30 lbidem.

31 Ibidem.

32 lbidem.

33 lbidem.

34 lbídem.

35 Cf. FERRER i MALLOL, M." T., "La carta de població dels sarraïns de la Vall d'Aiora (1328)", en Sharq al-Andalus, 3, Alicante, 1986, pp. 89-94. GUINOT RODRÍGUEZ, E., Cartes de poblament medievals valencianes, Valencia, 1991, doc. $n .{ }^{\circ} 261$, pp. 495-501.

36 CABEZUELO PLIEGO, J. V., La Curia de la Procuración. Estructura de una magistratura medieval valenciana, en prensa. Gentileza del autor. 


\section{APÉNDICE DOCUMENTAL}

1304, febrero, 15. Valencie.

Donación de los calatravos al infante Juan de ciertas posesiones en Italia. ACA, C, reg. 235, f. 60r.

\section{Domini infantis Joannis ${ }^{37}$}

Carte et littere tradite Enrico de Quintavalle, missa ad partes Neapolis et Romane Curie pro habenda possessione bonorum que magistro Calatrave dedit inclito domino infanti Johanni, nato domini regis, que sunt in Apulia et Principatu et Romani ipsisque colligendis et ministrandis.

Noverint universi presentes litteras inspecturi quod nos cum, frater Garsias Lupi, magister Milicie de Calatrava, Ordinis Cisterciensis, ad devocionis affectum quem illustris et magnificus princeps dominus Jacobus, Dei gracia rex Aragonum, suique progenitores ad nostrum Ordinem habuerunt actenus, dederimus et concesserimus inclito domino infanti Johanni, prefati domini regis Aragonum nato, quandiu sibi fuerit vita comes omnia loca omnesque redittus, responsiones, fructus et universos proventus et iura quos et que ordo predictus de Calatrava recepit aut debet recipe seu recipere consuevit vel usus est recipere per Apuliam et Principatum ac Romanium in locis ipsis que infra scriptis nominibus nuncupantur et in terminis et terris et pertinenciis eorumdem que quidem loca hec sunt videlicet Sanctus Angelus de la Ossaria, Castelluço, Pons, Abbaneti, Troya, Fraguinyano, Sanctus Pantalameus, in Romania, Astol, Fogia, Sancta Maria de Posse, Brundusii, Salpione, Sancta Maria la Mutata, La Grotayla, Maiolano, Sanctus Nichola, eadem piscaria que est in Tarento, due piscaria altera in Avorna et altera in Alexna, Sancta Elia, Aoyra de Matreria et Sanctus Dimitre. Idcirco volentes huiusmodi concessionem nostram ad effectum produci, constituimus, facimus et ordinamus certum nuncium ac procuratorem nostrum vos, fratrem Johannem de Sancto Petro, priorem decimus Valencie, nostri Ordinis, ad inducendum loco nomine et pro parte nostra in possessionem corporalem predictorum omnium et singularium percipiendorum discretum Enrricum de Quintavalie, familiarem dicti domini regis Aragonum, quem idem dominus rex Aragonum nomine et pro parte dicti infantis, nunc pupilli, duxit ad hec cum carta sua specialiter deputandum. Ita siquidem quod ex tunc vasalli dicti Ordinis et alii quicumque astricti vel debentes de predictis vel aliquo predictorum nobis vel Ordini nostro modo aliquo respondere de ipsis omnibus et singulis dicto domino regi Aragonum vel cui voluerit donec dictus infans ad etatem pervenerit pubertatis et ex tunc ipsi infanti vel cui seu quibus voluerit integre respondeant et plenarie satisfaciant, sicut nobis Ordini tenebantur. Nos et enim, ut vasalli ipsi et alii, hec faciant, compleant et attendant per presentem cartam nostram eisdem mandatum facimus specialiter ratum insuper habemus et firmum et in futurum habere promittimus quicquid

37 Letra no contemporánea. 
per dictum fratrem Johannem, nuncium et procuratorem nostrum, circa hec acta fuerint sive gesta. In cuius attamen rei testimonium ad cautelam presentem cartam inde fieri fecimus sigilli nostri pendentis munimine roboratam.

Data Valencie, $\mathrm{XV} \mathbf{I}^{\circ}$ kalendas marcii, anno Domini $\mathrm{M}^{\circ} \mathrm{CCC}^{\circ}$ tercio.

Yo, Garçi la fis escrivir por mandado del maestre. 


\title{
EL PAPEL DE CEUTA EN LA POLÍTICA EXTERIOR DE JAIME II DE ARAGÓN
}

\author{
Rica AMRÁN-TEDGHI
}

\section{INTRODUCCIÓN}

Ceuta, conocida como "Abyla» bajo la dominación fenicia, fue la «Julia Trajecta» de los cartagineses; denominada "Septum" o "Septa» bajo los bizantinos, su nombre es transformado en el de «Sabta» (Cepta) tras la conquista árabe del año 711 .

Frontera natural entre musulmanes norteafricanos y aquellos que habitaron el alAndalus: los Omeyas de Córdoba intentaron tomarla pues comprendieron rápidamente que era la puerta para su expansión territorial en el norte de África. Hammudies, almohades, almorávides, hasáfidas y merinidas ${ }^{2}$, hasta llegar a la conquista portuguesa de la plaza en $1415^{3}$, pasaron por el gobierno local, todos por razones comunes,

1 SUREDA DE BLANES, F., Abyla Herculana, Madrid 1925, p. 55.

GLICK, T.F., Islamic and Christian Spain in the early Middle Ages, Princeston 1979, pp. 31-32.

2 AMRÁN, R., Ceuta y el mundo cristiano mediterráneo durante los siglos XII y XIII, Ceuta 1986, pp. 7-22.

- "Acercamiento a la historia económica de Ceuta, siglos XII y XIII", Actas del Congreso Internacional "El Estrecho» de Gibraltar, UNED, Madrid 1987, pp. 221-230.

3 AMRÁN, R., El norte de África como refugio de judíos y conversos según las crónicas de los reyes de Castilla, siglos XIV-XV, Hesperis (Université de Rabat), (en prensa).

- «Precedentes a la conquista portuguesa de Ceuta", Actes du Congrès International Bartolomeu Dias e sua época, Porto 1989, pp. 117-129.

- «Juifs et musulmans à Ceuta auX XVI-XVII èmes siècles», Communication du Colloque International organisé par le Centre Intenational de Recherche sur les Juifs du Maroc, octobre 1995 (en prensa).

- "La situación de los judíos en el norte de África según el "Libro de los veedores de Ceuta" y "The present state of the jews in the north Africa" ", Hommage à Haïm Vidal Sephiha, SEPHARDICA (ed. Peter Lang), Berlin 1996, pp. 435-443. 
de tipo político y económico, bien específicas: su posición estratégica, la capacidad de su puerto (uno de los mayores del norte de África, durante el periodo medieval), las riquezas marítimas de sus costas y por ser un punto de encuentro indiscutible en las rutas comerciales, para los diferentes países de esta época.

\section{CEUTA Y LAS POTENCIAS DEL OCCIDENTE MEDITERRÁNEO}

Si los diferentes pueblos musulmanes, peninsulares y norteafricanos, desearon una dominación política para llegar a monopolizar la economía de la ciudad, otros países estuvieron más interesados en poseer una hegemonía total o parcial del comercio con la plaza. Es el caso de Génova y Marsella.

Sabemos que las relaciones mercantiles entre cristianos y musulmanes, aunque existente desde antiguo fueron restringidas. La existencia de una lista de mercancías prohibidas son recogidas ya por el III concilio de Laterán, del año $1179^{4}$, y el sínodo de Montpellier de $1195^{5}$. Inocencio III, año 1215, en el IV concilio de Laterán, reforzó las medidas anteriormente adoptadas:

«Excommunicamus praeterea et anathematizamus illos falsos et impios christianos, qui contra ipsum Christum et populum Christianum sarracenis arma, ferrum et lignamina deferunt galearum; eos etiam quui galeas eis vendunt, vel naves, quique in piraticis sarracenorum navibus curam gubernationibus exercent, vel in machinis aut quibuslibet aliis aliquod eis impendunt concilium vel auxilium, in dispendium Terrae Sanctae, ipsarum rerum privatione mulctari et capientium servus fore cessemus...» ${ }^{6}$.

Estas medidas aunque fueron suavizadas bajo Honorio III, el 31 de octubre de 1224, de nuevo se renovaron, el 10 de agosto de este mismo año, con Gregorio X:

«ltem excommunicamus et anathematizamus illos qui equos, arma ferrum vel lignamina deferunt sarracenis, quibus christianos impugnant» ${ }^{7}$.

Sería Urbano IV quien daría un nuevo giro a las susodichas prohibiciones; el 23 de octubre de 1263 redactará su sentencia, repitiendo aquellas normas adoptadas en el IV concilio de Laterán:

4 «Ita quorundam animos occupavit saeve cupiditas ut cum gloriae nomino christiano sarracenis arma, ferrum et ligamina galearum dederant, et pares eis neccessaria suministrabant».

MANSI, I.D., Sacrorum conciliorum et amplissima collectio, reed. 1902, XXII, col. 230.

5 MANSI, XXI, col. 1160.

6 MANSI, XXII, col. 1066.

7 AUVRAY, L., Les registres de Gregorie IX (1239-1241), Paris 1906, no 332. 
«Ecommunicamus praetere et anatahematizamus illos falsos et impios christianos qui contra ipsum Chistum et populum christianum sarracenis arma, ferrum et lignamina deferunt galearum, eos etiam qui galeas eis vendunt...”.

Tras periodos más o menos severos, sería Nicolás IV quien restablecería las antiguas prohibiciones; así leemos, el 23 de agosto de 1291 :

«... arma, ferrum, lignamina, victualia et alia quecumque mercimonia in Alexandiam vel alia loca serracenorum terra Egiptia ${ }^{9}$ deferre vel mittere seu de portubus eorum eisdem deferantur... ${ }^{10}$.

Clemente $\mathrm{V}$ siguió el camino emprendido por sus predecesores, al igual que aquellos que le sucedieron en la silla pontificia Juan XXII y Nicolás IV: dependiendo de la situación política del momento las normas relativas al comercio fueron más o menos severas.

Sobre esto Jaime Vicens Vives nos dice que el comercio con los países cristianos «fue un comercio de tipo normal», y continua: «en cambio el realizado con los musulmanes tuvo desde el principio una faceta especial: hasta cierto punto fue un comercio ilícito, de contrabando" "1.

Los comerciantes al llegar a Ceuta, y a todo el norte de África, en general, debían abonar un impuesto, un $10 \%$ del valor real de la mercancía, en especia o en metáli$\operatorname{co}^{12}$ (a excepción de Génova, la más directa rival de la corona de Aragón, que pagaba un $8 \%{ }^{13}$ ) al que se añadía un $1 \%$ destinado a pagar el gobierno local, denominado «intalaca».

Sin embargo lo más importante era salvaguardar la integridad física de los mercaderes y preservar sus productos de todo tipo de peligros. Para la buena marcha de las relaciones comerciales ceuties se decidió:

10 Seguridad a los individuos que circulaban por la ciudad.

$2^{\circ}$ Responsabilidad de los cónsules sobre los diferentes fondacos ${ }^{14}$.

8 GUIRAUD, J., Les registres d'Urban IV, Paris 1901, $\mathrm{n}^{\circ} 468$.

9 Enviada también a Génova.

LANGLOIS, E., Les registres de Nicolas IV, Paris 1881, $n^{\circ} 6784$.

10 - Les registres de Nicolas $N, n^{\circ} 6784$.

11 VICENS VIVES, J., Historia económica de España, Barcelona 1959, p. 188.

12 MAS LATRIE, M.L., Traités de paix et de commerce divers concernant les relations des chretiens avec les arabes de l'Afrique septentrionale au Moyen Ages, Paris 1866, vol. I, p. 204.

MERCIER, E., Histoire de l'Afrique septentrionale, Paris 1888, II, p. 210.

13 «... ut per omnes terras Moadebeant ire; et in aliqua terra ipsorum nisi de centum octo nullam dare debeant conductionem, except Buzee, ubi decimum debent, quia quartum ipsius decimi debet reverti ad commune Janue,...».

MAS LATRIE, II, p. 108.

14 Tenemos conocimientos de la existencia de dos grandes en la plaza: el de los genoveses y marselleses y el de los súbditos de la corona de Aragón. 
$3^{\text {o }}$ Propiedad de los fondacos, de las iglesias y de los cementerios ${ }^{15}$.

$4^{9}$ Responsabilidad civil personal, en el caso de robo o asesinato a un súbdito musulmán ${ }^{16}$.

$5^{\circ}$ Libertad religiosa ${ }^{17}$.

$6^{0}$ Prohibición de la piratería ${ }^{18}$.

$7^{9}$ Anulación de la antigua costumbre, por la cual se atribuía los restos de un naufragio a aquellos que los encontraban ${ }^{19}$.

Los principales productos que las distintas potencias adquirían en Ceuta eran:

a) Compraban: hierro ${ }^{20}$, pieles $^{21}$, sal $^{22}$, corales ${ }^{23}$, pinturas $^{24}$, azúcar ${ }^{25}$, cera $^{26}$, esclavos ${ }^{27}$, aceite $^{28}$, algodón ${ }^{29}$, etc.

b) Vendían en Ceuta: vino ${ }^{30}$, harina ${ }^{31}, \operatorname{telas}^{32}, \operatorname{sedas}^{33}, \operatorname{armas}^{34}, \operatorname{esclavos}^{35}, \ldots$

15 MAS LATRIE, I, pp. 89-90.

16 MAS LATRIE, I, pp. 90-93.

17 MAS LATRIE, I, pp. 104-105.

18 MAS LATRIE, I, pp. 94-96.

19 Comisión Histórica de las campañas de Marruecos, Acción de España en África, Madrid 1935, I, p. 200.

20 VICENS VIVES, p. 196.

21 MAS LATRIE, I, p. 296.

22 MAS LATRIE, I, p. 217.

GAUL, M., "Para un mapa de la sal hispana en la Edad Media», Homenaje a J. Vicens Vives, I, (1961), pp. 483-497.

23 HEYD, W., Histoire du commerce du Levant au Moyen Ages, Leipzing 1923, 1, pp. 609-610.

24 MAS LATRIE, I, p. 210.

25 MAS LATRIE, I, p. 218.

26 MAS LATRIE, I, p. 218.

27 MAS LATRIE, I, p. 215.

28 Vicens Vives, p. 195.

MAS LATRIE, I, p. 218.

29 VICENS VIVES, p. 196.

30 BLANCARD, L., Documents inedits sur le commerce de Marseille au Moyen Ages, Marsella 1885, I, pp. 72-73.

PERNOUD, R., Histoire du commerce de Marseille, Paris 1949, p. 176.

MAS LATRIE, I, pp. 212-214.

31 Con respecto a Marsella ver: BLANCARD, L., I, p. 90.

32 MAS LATRIE, I, p. 211.

33 LÓPEZ, R.S., The Trade of Medieval Europe, Cambridge Economic History, VII (1950), pp. 257354.

34 MAS LATRIE, I, p. 210.

35 Referente a Marsella, ver: PERNOUD, R., I, p. 177. 


\section{LA CORONA DE ARAGÓN Y CEUTA}

\section{Economía}

Podemos considerar que el apogeo catalano-aragonés comenzó en el siglo $\mathrm{XI}, \mathrm{y}$ que continuaría hasta el año 1330. En 1291, tras firmarse el acuerdo de Monteagudo entre Castilla y Aragón, quedó determinada como zona de influencia de esta última el este del río Mulaya. Bajo ella estaría el Magreb, es decir la zona occidental a la cual se denominó Ifrikiya ${ }^{36}$.

Es a partir de entonces cuando los catalanes intentaron, con mayor ímpetu, tomar la plaza de Ceuta, con la que desde 1227 habian soñado. Las razones de la corona eran claras: la ciudad era la puerta que les abriría las rutas atlánticas, a la vez que paso obligado hacia las del norte de África.

$Y$ es en este punto que vemos reflejado los intereses aragoneses, y que les diferencia del resto de las potencias que llegan a negociar en Ceuta: la conquista física era condición «sine qua non» se podía llegar a crear un área de expansión comercial. Esta ambición se vio truncada solamente en 1415, cuando la plaza es conquistada por los portugueses.

A otros niveles económicos, su agricultura e industria llevaron a la corona de Aragón a ser una de las más ricas y productivas de la Península lbérica, y de ahí su éxito en las rutas comerciales del norte de África: trabajaban la piel, con la que fabricaban desde pergaminos a cinturones, zapatos, y todo tipo de marroquinería en general. En el campo textil se destacaron en la producción de telares, en materia como lino y algodón; tras la conquista de Sicilia en 1282, el desarrollo de la industria textil se hizo de mayor envergadura, y en el que a partir de esos momentos se fabricaron desde los telares más refinados y lujosos hasta los más económicos, aunque de una excelente calidad. La artesanía también fue importante durante estos siglos: vajillas (desde las más corrientes a las delicadas de tradición árabe), cerámicas, etc. A pesar de todo, y por lo cual se hizo famosa sería la industria naval, conocida en todo el mediterráneo como una de las de mayor importancia.

Como vemos por lo brevemente expuesto, la rica producción local llevó a desarrollar mercados locales y a buscar otros en ultramar. Las exportaciones a países peninsulares y de la Europa cristiana eran frecuentes: Castilla, Navarra o Francia, son alguno de los ejemplos. Pero las miras de la corona estuvieron puestas en los países musulmanes con los cuales las posibilidades comerciales creían más provechosas, aunque las sanciones, citadas anteriormente, dificultaron este.

36 Ver especialmente: DUFOURQ, Ch.E., L'Espagne catalane et le Magrib au XIIth et XIV siècles, Paris 1966.

LALINDE ABADÍA, J., La corona de Aragón en el mediterráneo medieval (1229-1497), Zaragoza 1979.

VICENS VIVES, J., pp. 187-194.

VILAR, P., El declive catalán en la baja Edad Media. Hipótesis sobre su economía. Crecimiento y Desarrollo, Barcelona 1964, pp. 325-430. 
Tenemos conocimientos que los principales productos con los cuales negociaron los súbditos de la corona de Aragón en el norte de África y muy especialmente en Ceuta fueron:

a) Exportaron: trigo ${ }^{37}$, vino ${ }^{38}$, frutos $\operatorname{secos}^{39}, \mathrm{miel}^{40}$, lana ${ }^{41}$, cerámicas ${ }^{42}$, esclavos ${ }^{43}$, telas ${ }^{44}$, etc.

b) Importaban: aceite ${ }^{45}$, algodón ${ }^{46}$, hierro ${ }^{47}$, pieles $^{48}, \ldots$

Como vemos hay un mayor número de productos exportados que importados, y de ahí su interés por llegar a la susodicha ciudad.

\section{Política de la corona de Aragón ${ }^{49}$}

T.N. Bisson ${ }^{50}$ define de esta manera a Jaime II: «Si su abuelo (de Jaime II) fue un gran conquistador, y su padre el mayor defensor de la dinastía, Jaime II fue el mejor gobernador (de la corona de Aragón)". Para reafirmar esta idea traemos las dos cartas siguientes relacionadas con la plaza.

Como ejemplo de esta política traemos a estas páginas dos textos relativos a la política de Jaime II en el norte de África, y más particularmente en relación con la plaza de Ceuta.

El primero de ellos fue redactado en Barcelona el 3 de mayo de 1309 por Jaime II, y dirigido a Abou-Rebia Soliman ${ }^{51}$, rey de Marruecos, anunciándole las condiciones para ayudarle a continuar con el sitio de Ceuta, ocupada por aquel entonces por el rey de Granada, ayudado por Génova. Se adjunta también una serie de instrucciones al

37 Tortosa tenía el monopolio en el río Ebro.

38 MAS LATRIE, I, p. 213; VICENS VIVES, p. 195.

39 VICENS VIVES, p. 195.

40 VICENS VIVES, p. 195.

41 VICENS VIVES, p. 195.

VISKO, Ch.J., «El castellano hombre de llanura. La exportación ganadera en el área fronteriza de la Mancha y Extremadura durante la Edad Media», Homenaje a J. Vicens Vives, I (1965), pp. $201-216$.

42 VICENS VIVES, p. 196.

43 VICENS VIVES, pp. 196-198.

LÓPEZ, R.S., The Trade, pp. 261-262.

44 VICENS VIVES, p. 195.

45 VICENS VIVES, p. 195.

46 VICENS VIVES, p. 196.

47 VICENS VIVES, p. 196

48 MAS LATRIE, I, p. 216.

49 BISSON, Th.N., Conservation of coinage, Monetary Explotations and its Restrain in France, Catalonian and Aragon (1000-1225), Oxford 1979, pp. 64-106.

O'CALLAGHAN, J.F., A History of Medieval Spain, London 1975 (especialmente el capítulo denominado "The oversas expansion of the Crown of Aragon», pp. 382-406).

50 BISSON, Th.N., The Medieval Crown of Aragon. A short history, Oxford 1986, pp. 72-173.

51 MAS LATRIE, I, p. 297. 
vizconde de Castelnou, para que este explique a Abou-Rebia el por qué no le había ayudado a atacar con anterioridad la ciudad de Ceuta (en esos momentos en manos del señor de Granada), hasta no haber obtenido el compromiso del rey de Castilla, atado como estaba al último tratado sellado con él, siendo el rey de Granada vasallo del castellano. A través de este texto vemos reconstruida la historia de la corona de Aragón: a la muerte de Pedro III le sucedió su hijo Alfonso III (1285-1291), quien muere repentinamente, pasando el trono entonces a su hermano Jaime II, heredero de Sicilia. Sancho IV el bravo, al que se alió para hacerse con la corona, sin resultado, pues en 1294 rompió su pacto. Sería renovado sólo en la persona de su hijo Fernando IV (1295-1312), con el cual Jaime II llegó a un acuerdo de actuar contra el rey de Granada, aunque todos los derechos de conquista los cedió al castellano, en diciembre de 1308. Como vemos, pocos meses más tarde se decidiría a actuar y ayudar, como había sido la costumbre entre los monarcas del trono aragonés, a los soberanos de Marruecos ${ }^{52}$.

Por el presente acuerdo el aragonés se aliará, a favor o contra, todo «amigo o enemigo" de Abou-Rebia Soliman, y le alquilará a este cada una de las galeras aragoneses por 2.000 doblas cada cuatro meses (pasado estos, pagará sólo 1.000 doblas de cuatro en cuatro meses). Aborrabé deberá dar sueldo a 1.000 caballeros para mantener la guerra contra Ceuta, y a la conquista de estas los bienes muebles serán para Jaime II.

"Al muy alto, è muy noble, è muy poderoso rey, Aborrabe, miramomelin de Mar-/ruecos, don Jayme, por la gracia de Dios rey de Aragon, de Valencia, de Serdenya,/ de Corsega, cuende de Barcelona è de la santa eglesia de Roma senyalero, almirante/ è capitan general, saludes muchas como á rey que mucho amamos de coraçon, è cob-/diciamos que Dios dé mucha de honra, è de buenaventura, è de victoria, contra todos/sus enemigos, è quel lexe complir el su deseo è el su plaçer.l

Rey noble, façemos vos saber que sobre los fechos tractados entre vuestro hermano,/el rey botebet, á qui fue mandadero Bernardo Seguin, amado nuestro, con/noes de los quales vos sedes certificado, segunt nos envio decir el dicho Bernardo/Seguin, è vos place que vengan á buen acabamiento,

52 Abu Yusuf, rey de Marruecos pidió ayuda a Jaime I el conquistador en 1274, para conquistar Ceuta.Quería asediarla por mar, y para ello necesitaba barcos, los cuales poseía el aragonés:

"Manifiesta cosa sia a tots com Nos aben Yusuf Miarammollin Senyor de Marrochs e Feza e Suyamoza, e de ses pertenencias, Senyor dels Benimarins... ab vos noble en Jaume, per la gracia de Deu Rey D'Arago, è de Malloques, è de Valencia, Comte de Barcelona...

E puis que romanga aquella pau entrels votre fills è los nostres, en tal manera que Vos nos façats ayuda à pendre Cepta, è que nos enviets deu naus armades è deu galees,...».

MAS LATRIE, I, p. 285.

Nos aporta luces sobre el tema el trabajo de:

GASPAR REMIRO, M., El negocio de Ceuta entre Jaime II de Aragón y Aburrebia, sultán de Fez, contra Mohamed III de Granada, Madrid 1925. 
enviamos á vos, el noble è muy/ honrado è amado consellero nuestro, don Jaçpert viçconde de castelnou;el qual vos/enviamos con pleno poder de tractar è ordenar è firmar todas cosas que nos podiamos facer, como á aquel en quien mucho fiamos, è es çertificado de todo nuestro entendi-/miento, porque vos rogamos, rey, que lo creades de quantovos dira de parte nuestra./E porque nos entendiemos por el dicho Bernardo Seguin que vos queriades saber de/nos è por nuestra carta quales eran aquellas cosas que eran tractadas, è las quales/ nos demandavamos ques complissen, mandamos las poner è escribir en esta carta /nuestra, segunt se siguen./

1. Tractado es que los reyes sean amigo de amigo è enemigo de enemigo, contra/ todos los reyes del mundo de los Moros./

2. Item, que el rey Aborrabe dara cascuna galea con todo su complimiento è/ armada para quatro meses, dos mil doblas./

3. Item, pasados acquestos quatro meses primeros, dara mil doblas por galea, de/ quatro en quatro meses, mientras menester las aura./

4. Item, el dito rey Aborrabe dara sueldo para mil cavalleros, para mantener la/ guerra, entro á tanto que aya acabado su entendimiento de Cepta./

5. Item, prometra è jurara en su ley que no aura paç ni tregua nunca con el rey /de Granada, sin voluntad del rey de Aragon./

6. Item, quando sea presa Cepta, todo el mueble sea del rey d'Aragon, è las/ personas è el lugar sean del rey Aborrabe./

Dada en Barcelona, tres dias andados del mes de Mayo, en e, anyo de Nuestro/ Senyor, de mil trescientos y nueve.-Bernadus de Aversone, mandato regio./

\section{II}

Primerament, lo saludara de part del dit rey d'Arago.

En apres, il recomptara la gran amor è bona voluntat que fo el temps passat entre/la casa de Marrochs è lacasa del dit rey d'Arago, 'e especialment en temps de son avi, / el rey Abenjacob.Apres la mort del quel rey Abeniacob, lo rey Botebet, volent rego-/nescer è refrescar la bona amor que avia ahuda son avi ab lo rey d'Arago, trames sos/missatges al dit rey d'Arago, ço es, en Bernat Segui è ell veyll Abulabez fill de Gau-/ramet, qui requeséren lo dit rey d'arago, de part del dit rey Botebet, que li plagues/que fos aquella amor entre ells, qual era estada entre son avi e ell;encara pregaren,/ è demanaren que li plagues donar ajuda contra el rey de Granada, senialament de/galees per cobrar Cepta del dit rey, qui la li tenia forçada, de la qual cosa allse tenia/fort per minuat, que tant vill rey com aquell fees á ell força;encara retrasqueren los/dits missatges al dit rey d'Arago, que gran vergonya li era tant vill hom con aquell/ tengues terra prop de tant noble rey com ell, è en sa presencia.

Apres recomptada la missatgeria, compliment è sabia per los dits missatges del/ rey Botebet, 10 rey d'Arago respos, que ver era que tots temps era estaba bona amor è/pau entre la casa de Marrochs è la sua, è 
senyaladament en temp's del rey Abenjacob,/de qui el dit rey d'Arago havia membrança, è que li plahia molt que aquella fos man-/ tenguda entre ells tots temps, á que era apparellat de fer en sos fets tot ço que ell/ pogues, axi com per amic leyal, guardant pero sa fe è sa leyaltat, la qual tots temps/ guardaren sos predecessors á tots sos amics. E aço deya per la amor è la convinença /que era entre ell è el rey de Castella, la qual era aytal que el rey de Castella, el temps/ que fou pau ab lo dit rey d'Arago, lo reques el prega que volgues quel rey de Granadal fos en aquella pau, axi com a vassayl del dit rey de Castella;è el rey d'Arago otorga / ho, per honor del dit rey de Castella.

$\grave{E}$ axi, per aquesta raho, el rey d'aragono podla otorgar la ajuda quels dits missatges/ demanaven contra el rey de Granada, mas que el dit senyor rey d'Arago, per amor è/ per honor del dit rey Botebet, è per que pogues satisfer á voluntat, è per lo retreyt/ que li fayen los missatges de part del rey Botebet, se trebayleria de tractar è procurar/ ab lo rey de Castella quel solves d'aquella covinença.Per la qual cosa, lo dit rey/ d'Arago trames encontinent un dels maiors de son conseyl al rey de Castella.

E feta aquesta resposta, fo fet alcun tractament de la ajuda que demanavan los dits/ missatges de part del rey Botebet, è de co que aquell rey Botebet degues fer al dit rey/ d'Arago, del qual s'en porta un ecrit en Bernat Segui, è romas ne altre en poder del/ dit rey d'Arago. $\grave{E}$ apres d'aço, patiren s'en los dits missatges;è á pochs dies ans que/ s'en fossen tornats, agueren ardir cert quel dit Botebet era mort, è que era rey/ Aborrabe. ̇̇ jaç sia quel dit rey d'Arago agues despagament de la mort del dit rey, pero hac gran pagament quan ohi que era rey Aborrabe, qui era son frare, è nebot' d'aquell mateix rey Abenjacob, amic seu.

En apres, en Bernat Segui ab l'altre companyo seu, axi con aquell qui volia recaptar/ ço per que era vengunt, torna, è dix al dit rey d'Arago si li plahia que el pogues dir/ aquella bona resposta á son senyor el rey Aborrabe, que el sabia per cert que á ell/ plauria aço mateix que plahia al rey Botebet.

Ė el senyor rey respos li que li plahia/ molt que lui pogues dir secretament, è que ell è el rey de Castella se devie veureensemps dins breus dies, è que faria tot son poder que pogues fer la ajuda complidament/ quel rey Aborrabe hauria ops d'ell.

$\dot{E}$ apres d'aço, lo dit rey d'Arago è el rey de Castella hagueren vistes;è en aquell/ temps, vench en Pere Marti d'Orta al dit rey, ab la carta del dit rei Aborrabe, per la/ qual se mostrava que al rey Aborrabe plahia esser en amor è en convinença ab lo dit/ senyor rey;è aporta aytambe carta d'en Bernat Segui, en la qual se contenia clara-/ment que el rey Aborrabe vulia è li plahia molt que ço que era tractat entrel dit senyor/ rey è el rey Botebet fos entre ells, è vengues à compliment. Per la qual cosa, lo rey d'Arago fermant se en la carta del dit rey Aborrabe, è en ço quel dit en Bernat Segui/ li trames á dir, se trebaylla molt fortament que acabas ab lo rey de Castella qu'el/ solves 
d'aquella covinença, è no tant solament acaba aço, mas/ encara qu'el dit rey de Castella mateix fees guerra al rey de Granada la qual comença/ á pochs dies./

$E$ tantost, lo rey d'Arago d'amunt dit, veent que les galees nos' podien fer dins pocs/ dies, ne l'aparallament que y fa mester, mana fer gran quantitat de galees, per complir/ ço quel rey Aborrabe demanava, è que les pogues haver tant tost com los tractamens/ fossen endressats. Evolch lo dit rey d'Arago que un conseller seu, don Gonçalvo/ Garcia, ab qui havia tractat d'aquests fets en Bernat Segui, trameses un missatge al/ dit en Bernat Segui, que procuras quel tractament vengues á acabament de part del/ rey Aborrabe, que de la parte de ça tot era endreçatè acabat./

Lo qual missatge fo á en Bernat Segui, è ell respos al dit rey d'Arago è al dit con-/seller seu que el rey Aborrabe, è tots aquells de son conseyl, havien ahut gran plaer/ d'aquelles noves com les ahiren, è qua plahia molt al rey Aborrabe que aquests trae-/tamens venguessen á compliment, è que era apparellant è volenteros de complir e/ guardar totes aquelles coses que fermades serien entre ell è el dit rey d'Arago, è que/ guardaria encara mellor la amor è les convinences que no havien fet negun de sos pre-/decessors, perço com una vegada son avi lo rey Aben jacob se empres ab los Crestians/ contra los Andaluços, è puys desempara los Crestians 'fo ab los Andaluços;'è que el no ho entenia á fer axi que abans hauria pau ab Jueus, que Deus confona! que no/ hauria ab los Andaluços. Ė perço demanava è vulia lo dit rey Aborrabe qu'el senyor/ rey d'Arago li trameses un hom honrat de son conseyl, ab/plen poder de tractar è fermar sobre los tractaments d'amunt dits, los quals lo dit rey dÀrago li feés saber/ per sa carta declaradament./

$\dot{E}$ sobre aço, vench ab volentat del dit rey Aborrabe en Ramon Torro, parent d'en Bernat Segui.È tantost, lo senyor rey trames un cavaller de son conseyl, ab una/ galea lo qual ha nom Artal Daçlor,al dit rey Aborrabe, 10 qual anant son cami, fe a Cartagenia, hon hac ardit que avia galees del rey de Granada en mar, è no hac d'acort que passas á abant;ans trames lo dit Ramon Torro á en Bernat Segui ab una barcha, è perço, car no poch passar, tornasen al dit rey d'Arago./

De la qual cosa, lo senyor rey com la ohi fo molt despagat, è amntinent ordona que/ fossen armades galees è leyns tro á setse, les quals trames contra la dita armada del/ rey de Granada'è ordena aytambe qu'el noble en Jacpert vescomte de Castennou anas/ per missatge ab les dites galees al dit rey Aborrabe perço que pus segurament, è pus/ honrada, pogues anar, è encara que les galees anassen contra Cepta en serven del dit/ rey Aborrabe, è que destrenguessen Cepta que socors de gents ne de vianda ne y/ pogues entrar; è entretant los dit rey dẢrago fo apparellar major quantitat de galees./

E mana encara al dit noble en Ja'pert, que fos dàvant lo rey Aborrabe per trer á / compliment los tractamens d'amunt dits, è donali plen poder de fer totes aquelles/ coses, è tractar 'fermar, quel dit rey d'Arago podria fer./ 
È axi requira è deman al dit rey Aborrabe que ell complescha è ferm è fassa complir/ los tractaments d'amunt dits, pus lo dit rey d'Arago, quant á la sua part es, hal començat á fer ço que ops era è es á aquests fets./

Item, parria raho que, pus lo senyor rey mou la guerra per lo rey de Marrochs, è li/ ajuda á destruir sos enemichs, que com el haura acabat son enteniment de Cepta, ço/ que sera tost, quel dit rey ajut al rey d'Arago de galees è de moneda á fer la guerra all rey de Granada;è aço comena el senyor rey á en Jacpert;mas pero finalment, que/ per aquest capitol no romangues./ $/ x^{53}$.

La segunda carta, $1^{\circ}$ de mayo de 1323 , de Jaime II a Abou-Said-Othman, rey de Marruecos, podemos divisar en ella tres partes bien definidas:

1. Reclamación por parte del aragonés de ciertos compromisos que el anterior rey de Marruecos, Abu Said, había incumplido, en relación con lo acordado a la toma de Ceuta (de manos del rey de Granada).

2. Pedía un préstamo de dinero y hombres (caballeros aragoneses, que les servían en Marruecos), necesario en esos momentos a Jaime II por la guerra que se produjo en Cerdeña y Córcega.

3. Renovar los acuerdos de paz y de comercio.

"Al molt alt, è molt noble, è molt poderos, Buçayt, rey de Marrochs è del Garb, en/ Jacme, per la gracia de Deu, rey d'Arago, de Valencia, de Sardenya è de Corsega,/ è compte de Barchelona, è de la santa egleya de Roma senyaler, almiral è capitan/ general, salut, axi com á rey per á qui volriem honor è bonaventura./

Rey, fem vos saber que, per alguns afers, trametem á la vostra presencia l'amat è/ feel nostre en a Romeu de Corbera, conseller è de casa nostra, que aquesta carta vos/ part nostra. On rey, vos pregam que vos lo dit missatge nostre vullats benignament/ reebre, è ohir, è creure á ell firmament, è sens tot dupte de tot ço queus dira per/ part nostra, è grahir vos ho hem molt./

Dada en Barcelona, primer dia del mes de Maig, en l'any de Nostre Senyor mil/ trescents vint è tres -Bernardus de Aversone, mandato regio./

\section{II}

1 Primerament, salut de part del senyor rey d'Arago lo dit rey de Marrochs, $a b /$ cuvinents paraules, è digili de son bon estament, è demanli del seu./ 2 En apres, deja continuar se missatgeria en aquesta forma: dient/i que certa/ cosa es que entre les cases lurs, d'Arago è de Marrochs, ha estada en temps passad/ entrels predecessors dels dits reys, è encara entrel dit senyor rey d'Arago, amor è/ amistat bona, è convinençes de pau è de ajuda de la una

53 MAS LATRIE, I, pp. 297-298. 
casa á la altra;è senyalada-/ ment foaren acquestes coses entrel dit senyor rey d'Arago è el rey Aborrabe, en tant/ encara quel senyor rey d'Arago qui havia pau ab lo rey de Granada, qui lavors eral li volch esser enemich è s'empres contra ell per lo dit rey Aborrabe, è feu ajuda á el/ contral dit rey de Granada, qui li tenia forçada Cepta, de galees en gran quantitat; hi trames en elles lo noble ça en rera en Jaçpert, veçcomte de castellnou, quin fo/ davant lo dit rey Aborrabe, è puys ab les galees fo el fet de Cepta, com fo cobrada ál la senyora del dit Aborrabe.E jassia que de part del dit rey Aborrabe fossen al dit/ rey d'Arago atorgades alcunes coses, aixi de ajuda de sou de cavallers, per mantenir/ la guerra del dit rey de Granada, è de pagar de galees, com del moble de Cepta,/ empero no fo cumplit, è el dit rey Aborrabe hac son enteniment de Cepta;ne encara/ de ço que per acquesta raho fo assignat sobrel dret dels mercaderss qui venen á la terra/ del dit rey de Marrochs, non fo res pagat ni satisfet al dit rey d'Arago./

$3 \dot{E}$ com ara lo dit senyor rey d'Arago, segons que creu que ha entes lo dit rey/ de Marrochs, haia grans fets è fort senyalats á gran honor sua è de son regne, per/ acquesta del regne seu de Sardenya è de Corsega, per raho de la qual con-/ questa, segons que ell pot be pensar, li ha convengut è li cove á fer molt grans messions/ è despeses;perço lo dit senyor rey, esguardant la bona amor è amistat que ha estat è / sera, Deu volent, entre les cases d'Arago è de Marrochs, è confiant que en aytal è/tant assenyalant fet, lo dit rey de Marrochs li sera bon amich è li ajudara, ha volgut/ trametre é ell en Romeu de Corbera. 4 Per quelprega que ell, esguardant les coses d'amunt dites, è specialment com/lo dit senyor rey d'Arago ha ajudat, è es appereylat de ajudar á ell è á la sua casa,/ en semblant cas è en major, que vula è li placia de accorrerli d'aquella quantitat de/ moneda que pertanga al dit rey de Marrochs, è que sia de pendreal dit rey d'Arago,/ è ell grahir lin ha molt;è en aço, lo dit rey de Marrochs li dara á conexer la bona/ voluntat è la amor que li ha, è el rey d'Arago faria per ell, en semblant cas, è en/ maior, ço que fos honor sua è be de son regne./

$5 \dot{E}$ sil dit rey de Marrochs atorga que ajudara al dit senyor d'Arago, mas que vol/ saber de quina quantitat seria pagat lo rey d'Arago, diga lo dit en Romeu que be pot/ pensar lo dit rey de Marrochs quina ajuda se pertany á aytal rey com ell es, de fer/ á aytal princep com es lo rey d'Arago, è en tan grans affers, è aixi que ell hi faça/ segons qu'el senyor rey d'Arago espera è confia d'ell. É si ell volia qu'el dit missatge/ expressas la quantitat de que enten lo dit senyor rey d'Arago, pot dir que semblaria/ que elmenys degues esser la dita ajuda de quaranta mille dobles d'or;è sobre aço faça/ sa puja de obtenir è haver aquella maior quantitat que puga. Ė finalment, si als no/ podia, quen preses tro á quantitat de deu mille dobles./

6 Si lo dit rey de Marrochs, per aventura, demanara que pus ell fa la dita ajuda, / que en vol que totes les coses d'amunt dites, è ço que pugues esser demanat per les/ dites covinençes, li sien diffinides è absoltes, respona lo missatge queu fara volenter, è qu'en ha poder./ 
7 Encara, sil dit rey de Marrochs demanara è volra que pau è amistat sia reno-/ vellada, è convinences fetes entrel senyor rey d'Arago è ell, diga lo dit Reomue quel/ senyor rey d'Arago, si ell li es bon amich en aquesta ajuda, es aperellat de donar hi loch/tota hora que á ell placia. È si li demanaven ell si ha poder sobre aço, respondera que/ hoc, è, ab que la ajuda sia covinent, ell la fermar de part del rey d'Arago. Ė en aquell/ cas, mostras la carta del poder que s'en porta;è la forma de la pau fos aytal qual se / conte en la forma del procuratori./

8 Item, dira al dit rey de Marrochs que com alcuns cavallers naturals del dit rey/d'Arago, qui son en son serviy, entena lo dit senyor rey haver en son serviy, en aquest/ fet de la conquest de Sardenya, pregalo que li placia de donar llicencia á ells que/ puguen venir al serviy del dit rey d'Arago, aquells, ço es á saber quel missatge li/ nomenara. $\dot{E}$ d'açol' prega, per lo prechs que ja li ha fetsab carta sua, que li tramete/ en Jacme Segui, ab cent homensá cavayl á la genetia./

9 Item, si demanen ajuda de galees, puga ho prometre, lo rey de Marrochs donant/ per cascuna galea, ab tot son compliment è armada, per quetre meses, tres mille/ dobles d'or; è passats los quatre meses primers, que do dos mil dobles d'or per galeal de quatre meses, mentre mester les haura./2,54.

El punto de vista más interesante, a nuestro parecer es el segundo, en el que se nos habla de las milicias cristianas aragonesas, al servicio del rey de Marruecos.

Dos elementos que influyen enormemente en la sociedad son el comercio y la guerra, y cuando estos se combinan, como en el caso presente, muchísimo mejor; estas milicias, modernamente las llamaríamos grupos de «mercenarios».

Desde un punto de vista militar los ejércitos cristianos eran más fuertes, sólidos y pesados, que las tropas musulmanas, caracterizadas por una mayor agilidad y movilidad. Los dos tipos de ejército, juntos podrían llegar a formar uno perfecto ${ }^{55}$. Y de ahí la presencia de pequeños grupos de musulmanes en las tropas cristianas (cosa no muy frecuente), y de caballeros cristianos, en los musulmanes, especialmente del norte de África.

La razón por la que los soldados cristianos llegan a África es por destierro de sus países natales respectivos: lo único que sabían hacer para ganar su sustento era guerrear y esto fue a lo que se dedicaron. La organización interna no demandaba grandes condiciones, aceptando a todo individuo que portaba caballo y armas; cada grupo poseía un "alcaide ${ }^{56}$, el cual los dirigía. Países como Génova y Pisa alquilaban sus ejércitos de mercenarios al mejor postor; las coronas peninsulares, por el contrario,

54 MAS LATRIE, I, pp. 315-317.

55 GIMÉNEZ SOLER, A., "Caballeros cristianos en África y africanos en España», Revue Hispanique, XII (1905), pp. 299-372; XVI (1907), pp. 56-59.

AMRÁN, R., Ceuta y el mundo cristiano, pp. 21-22.

56 Bernardo Segui era el «alcaide» de las milicias aragonesas, que citamos en la primera de las cartas aportados en estas páginas. 
quizás por la situación de guerra latente, no lo hicieron. Podemos considerar la llegada de estos "caballeros hispanos" como una especie de emigración individual.

El otro dato abordado en este segundo punto es la guerra por la toma de Cerdeña y Córcega, las cuales les habían sido prometidas a Jaime II tras su renuncia a Sicilia. Los problemas internos de la corona y la guerra contra los musulmanes habían pospuesto veinte años su posesión, dominadas por los pisanos.

En junio de 1323 sale de puerto la flota aragonesa dirigidas por el hijo del rey de Portugal, Alfonso (el futuro Alfonso IV, 1325-1357, enemistado con su padre); en 1325 los pisanos habían sido expulsados de la isla ${ }^{57}$.

El establecimiento del gobierno aragonés en Cerdeña inicia una larga guerra comercial en el occidente mediterráneo entre ellos y Génova; estos últimos hasta el momento había mantenido en estos lugares su supremacía.

Queremos acordar que esta "lucha» ya había sido iniciado, aunque de forma más discreta en el norte de África, cuando genoveses y aragoneses intentaron monopolizar el comercio de la ciudad entre los siglos XII y XIII58.

\section{CONCLUSIONES}

Los dos textos presentados nos demuestran:

1. La importancia del norte de África, y más especialmente de Ceuta en los planes económicos de Jaime II. Es el primer eslabón para la extensión comercial en la zona.

2. El interés de la corona por poseer el monopolio comercial de la ciudad.

3. Que la crisis suscitada entre Génova y Aragón tras la conquista de Cerdeña, ya había tenido sus antecedentes en épocas anteriores, y en relación a la ciudad de Ceuta, causa de su antigua rivalidad por ostentar un dominio en el plano económico de la plaza.

57 O'CALLAGHAN, pp. 406-407.

58 Ver:

AMRÁN, R., Ceuta y el mundo cristiano, pp. 9-12, pp. 23-27.

-, «Acercamiento a la historia económica de Ceuta, siglos XII y XIII", Actas del Congreso International, El Estrecho de Gibraltar, UNED, pp. 221-230.

- "Un documento sobre el comercio realizado por judios en la ciudad de Ceuta", Estudios de Historia Medieval, Universidad de Valladolid, Valladolid 1991, pp. 25-28. 


\title{
NOTÍCIES DE GENOVESOS AL REGNE DE MÚRCIA AL TOMBANT DEL SEGLE XIII
}

\author{
Roser SALICRÚ I LLUCH \\ Institució Milà i Fontanals (CSIC, Barcelona)
}

La presència genovesa 0 , si es prefereix, la presència de genovesos al regne de Múrcia al tombant del segle XIII, a l'entorn dels anys que emmarquen la intervenció de Jaume II en aquelles terres, ha d'integrar-se tant en les coordenades i en la conjuntura de l'enfrontament entre la Corona d'Aragó i la de Castella com en les coordenades del propi regne de Múrcia, però no pot analitzar-se deixant de banda les coordenades mediterrànies, sia pensant en l'expansió comercial genovesa, sia pensant en la lluita per al domini de la Mediterrània i, per extensió, en l'enfrontament emergent que, des d'aleshores i al llarg de tota la Baixa Edat Mitjana, encararia catalans i genovesos.

Les notícies que hem recollit i que intentarem analitzar són notícies procedents, quasi exclusivament, dels registres de Cancelleria de l'Arxiu de la Corona d'Aragó'. Són, per tant, notícies que fan referència al domini catalano-aragonès d'aquelles terres que, des que havien estat preses als musulmans, havien format part de la corona de Castella; en conseqüència, en el moment cronològic en què sorgeixen, són notícies que poden $i$ han ser llegides i interpretades des de l'òptica de les relacions entre la Corona d'Aragó i Gènova, des de l'òptica de llurs respectives aspiracions i expansions mediterrànies. Però també poden servir, a nivell retrospectiu, per avaluar la presència genovesa al regne de Múrcia en la fase anterior, en l'etapa de ple domini castellà del

* Abreviatures utilitzades: $\mathrm{ACA}=$ Arxiu de la Corona d'Aragó; $\mathrm{C} .=$ Cancelleria; $\mathrm{CR}=$ Cartes Reials; f., $\mathrm{ft} .=$ foli, folis; $r$ = recto; reg. = registre; $v=$ verso.

L'elaboració d'aquesta comunicació ha gaudit del suport de la CIRIT i de la Direcció General de Coordinació i Seguiment Sectorial de la Generalitat de Catalunya, per mitjà d'un «Ajut Ferran Soldevila a treballs d'investigació sobre la història i la historiografia catalanes (convocatòria 1995)». 
regne, en la mesura que, lògicament, moltes vegades, el que fan és posar de manifest la continuïtat de la presència, de l'establiment, de la residència o de les possessions i, a voltes, de les activitats i del comerç, de ciutadans i mercaders lígurs o de procedència lígur en terres murcianes $\mathrm{i}$, fins aleshores, castellanes.

Pel que fa a l'àmbit cronològic, coincidint amb la intervenció jaumina, aquestes notícies se centren, fonamentalment, entre 1296 i la primera dècada del segle XIV, tot i algunes «incursions» en les dues dècades posteriors, però són sempre anteriors a l'inici de la conquesta de Sardenya.

Com és ben sabut, la presència genovesa a la Península Ibèrica, a la darrera dècada del segle XIII, estava ben consolidada.

Si pensem en el sultanat nassarita de Granada, només cal recordar, per exemple, l'acord comercial amb la República que data de 1278-1279 i que, justament, fou ratificat a la segona meitat de la dècada dels noranta ${ }^{2}$, coincidint amb la intervenció de Jaume II al regne de Múrcia.

Si pensem en Castella, només cal recordar, tal com consta al que és conegut com a Libro de los privilegios de la nación genovesa, en el privilegi que, des de 1251, ja havia donat als genovesos barri per comerciar a Sevilla, que havia regulat les seves obligacions i els havia concedit diversos drets i mercès; en la confirmació, l'octubre de 1281, d'algunes franqueses que ja els havien estat concedides per Ferran III; 0 , finalment, anant una mica més enllà, en la confirmació, a la darreria de 1316, del privilegi d'exempció del pagament de l'alcabala de les bèsties ${ }^{3}$. I pel que fa, estrictament, al regne de Múrcia, sabem que alguns genovesos ja foren repobladors de la capital; entre més d'una vintena d'italians, alguns d'ells de procedència indeterminada, al repartiment de Múrcia hi apareixen, com a mínim, tres lígurs ${ }^{4}$. Durant l'expedició de Jaume la

1 He d'agrair, molt sincerament, a la Dra. M.T. Ferrer i Mallol l'amabilitat amb què ha contribuït a posar-me-les a l'abast.

2 Vegeu, essencialment, B. GARÍ, «Génova y Granada en el siglo XIII: Los acuerdos de 1279 y 1298», Saggi e Documenti VI (1985), pp. 173-206; idem, "El reino de Granada y la política comercial genovesa en la Península lbérica en la segunda mitad del siglo XIIl", dins Relaciones exteriores del Reino de Granada. IV Coloquio de Historia Medieval Andaluza, Almeria, 1988, pp. 287-296; i també, de la mateixa autora, "Genova e la Castiglia nel Trecento", dins La Storia dei Genovesi. Atti del Convegno di Studi sui Ceti Dirigenti nelle Istituzioni della Repubblica di Genova. 1986. VII volume, [Gènova], [1987], pp. 369-389, i "Why Almeria? An Islamic port in the compass of Genoa", Journal of Medieval History 18 (1992), pp. 211-231.

3 Cf. I. GONZÁLEZ GALLEGO, «El Libro de los Privilegios de la Nación Genovesa», Historia. Instituciones. Documentos 1 (1974), pp. 275-358, documents II, III i IV; sobre la presència genovesa a Castella a partir del segle XIII vegeu també, per exemple, M. GONZÁLEZ JIMÉNEZ, "Genoveses en Sevilla (siglos XIII-XV)", dins Presencia italiana en Andalucía. Siglos XIV-XVII. Actas del / Coloquio Hispano-Italiano, Sevilla, 1985, pp. 115-130, o M.Á. LADERO QUESADA, «Los genoveses en Sevilla y su región (siglos XIII-XVI). Elementos de permanencia y arraigo», dins Los mudéjares de Castilla y otros estudios de Historia Medieval Andaluza, Granada, 1989, pp. 283-312.

4 En Genovès, Ducho Genovès i Albertín Genovès; vegeu J. TORRES FONTES, Repartimiento y repoblación de Murcia en el siglo XIII, Múrcia, 1990 (segona edició), pp. 238-239; M. GUAL CAMARENA, "La Corona de Aragón en la repoblación murciana", dins VII Congreso de Historia de la Corona de Aragón, vol. II, Barcelona, 1962, p. 309. Encara que l'estudi se centri en el segle XV, vegeu 
Múrcia, alguns dels seus proveïdors ja havien estat, també, mercaders genovesos: Geraldo Gambaforte li havia venut 590 quinters de vi a Alacant i, probablement, també eren genovesos els «Simonet de Medulo» $i$ «Conrad de Junta» que li deixaren, també a Alacant, 13.000 besants $^{5}$. Tres dècades després, en el moment de la intervenció de Jaume II, trobem documentats genovesos establerts o negociant, com a mínim, a Múrcia, Oriola, Alacant, Cartagena, Guardamar, Asp, Monòver i, sobretot, Elx, però probablement perquè, aquí, la particularitat del curs dels esdeveniments féu que fos el lloc on deixaren més traces a la documentació reial.

$\mathrm{Si}$, finalment, girem la mirada cap a la Corona d'Aragó, podem remuntar la presència de genovesos en terres catalanes, així com de la de catalans a Gènova, fins a la primeria del segle $\mathrm{XII}^{6}$, quan es començà a gestar la situació de privilegi fiscal de què els

també les pàgines de presentació (pp. 71-76) de J. TORRES FONTES, «Genoveses en Murcia (Siglo XV)», Miscelánea Medieval Murciana II (1976). Sobre la projecció mediterrània del regne de Múrcia, J. TORRES FONTES, "Los puertos de Cartagena y Alicante en la segunda mitad del siglo XIIl», dins XI Congresso di Storia della Corona d'Aragona, vol. IV, Palerm, 1984, pp. 347-366; Á.L. MOLINA MOLINA, «Proyección mediterránea del reino de Murcia en la Edad Media», Miscelánea Medieval Murciana XVII (1992), pp. 59-75; Mª de los LI. MARTÍNEZ CARRILLO, «El reino de Murcia en el sistema económico mediterráneo de la Baja Edad Media", Anuario de Estudios Medievales 24 (1994), pp. 247-273; i J. HINOJOSA MONTALVO, “El puerto de Alicante durante la Baja Edad Media», Anales de la Universidad de Alicante 4-5 (1988), pp. 151-166, per bé que se centri, essencialment, en el segle XV. Aquí, l'origen italià (toscà, genovès?) de la família del conegut cer Jacobo de las Leyes (cf. J. TORRES, Repartimiento, p. 239), pare, segons el mateix autor, del també famós corsari Bonajunta de las Leyes, que es dedicava, des de 1295, quan en rebé l'encàrrec de Juan Sánchez de Ayala, adelantat de Múrcia de don Juan Manuel, a atacar embarcacions catalano-aragoneses (cf. idem, Los puertos, pp. 356-357, i Á.L. MOLINA, Proyección, p. 66), ens permet destacar algunes de les accions del corsari que han deixat traça a la cancelleria catalano-aragonesa. A la primeria de maig de 1297, Jaume II comunicava al procurador de Múrcia, Jaume Pere, que un vel de Mallorca, Pere Cortès, s'havia queixat que Bonajunta, veí de Múrcia, amb un lleny armat, havia pres a Eivissa una barca que sortia de Mallorca i que anava a Salé; Cortès hi tenia un sarraí blanc, anomenat Azmet, que enviava allí al seu fill Bernat, i Bonajunta l'havia pres i portat a Múrcia; si era cert, el procurador l'hi havia de fer restituir (ACA, C., reg. 108, f. 12v). A la primeria de juliol del mateix any, hi ha noves notícies dels actes de cors de Bonajunta, amb un galió armat a Múrcia, a Eivissa (ACA, C., reg. 108, f. 135r). A mitjan maig de 1298, el rei seguia fent referència, en aquest cas a Jaume de Xèrica, de les queixes de Bernat Espinach $i$ d'altres mallorquins a qui havia "robat sense causa justa» béns i mercaderies a les mars d'Eivissa; el rei manà al procurador que obligués el murcià a restituir-les o a fer-ne esmena (ACA, C., reg. 111, $f$. 228r). A la primeria de 1303, en canvi, les queixes arribaven del rei de Portugal, perquè Bonajunta, amb gent d'Elx, d'Alacant i de València, havia comès atacs piràtics contra alguns dels seus súbdits, per valor de 750 lliures de moneda portuguesa (ACA, C., reg. 127, ff. 11v i 80r). A mitjan desembre del mateix any, s'avaluaven els danys ocasionats al portuguès Joan Yvanyes i al seu soci en 4000 sous reials, i entre els pirates hi havia també un Simone de Legibus (ACA, C., reg. 130, f. 231v).

5 Cf. M.T. FERRER I MALLOL, «Els italians a terres catalanes (segles XII-XV)», Anuario de Estudios Medievales 10 (1980), p. 434, que remet a J. MIRET I SANS, Itinerari de Jaume I «el Conqueridor', Barcelona, 1918, pp. 394-395.

6 Vegeu M.T. FERRER, Els italians, pp. 393-466, en especial «Els genovesos», pp. 428-447, i G. PISTARINO, "Genova e l'Occitania nel secolo XII", dins Actes du I Congrès Historique Provence-Ligurie, Ais-Marsella-Bordighera, 1966, pp. 
genovesos havien de gaudir, a la Corona d'Aragó, al llarg de tota l'Edat Mitjana'.

Al llarg del segle XIII, entre la Corona d'Aragó i la República de Gènova prevalgueren les bones relacions polítiques; si bé la conquesta de Sicília per part de Pere el Gran no alterà la situación ${ }^{8}$, des de la darreria de la dotzena centúria començà a operar-se el canvi de relacions i l'obertura d'aquella rivalitat que esdevindria endèmica. Tot i que pugui considerar-se que el fet que assenyala el punt de ruptura definitiu amb Gènova és, a la darreria del regnat de Jaume II, la conquesta de Sardenya (1323-1324) ${ }^{9}$, el punt d'inflexió cal recular-lo algunes dècades, fins a la darreria del segle XIII $i$, en conseqüència, en paral.Jel amb el moment que ens ocupa.

Geo Pistarino utilitzà, com a baròmetre d'aquest canvi de conjuntura i, en conseqüència, del canvi de visió dels catalans a Gènova, els testimonis que fan referència a les Vespres Sicilianes ${ }^{10}$. $\mathrm{Si}$, d'entrada, el fet fou observat amb un cert fervor, aviat suscità una preocupació creixent, en relació directa amb la consolidació del govern catalano-aragonès a l'illa i amb la infeudació de Còrsega i Sardenya. Un cop instal.lats a Sicília, els catalans, que havien esdevingut uns competidors massa moltestos pels genovesos, es convertiren, també, en paraules de Ferrer, en una amenaça massa propera ${ }^{11}$. Com sentencià Pistarino, con la rivolta del Vespro in Sicilia nel 1282 e con la concessione papale della Sardegna e della Corsica in feudo alla monarchia aragonese nel 1297 è cominciata la grande lotta fra catalani e genovesi per il predominio del Mediterraneo occidentale ${ }^{12}$. Després de la que l'autor considera la sostanziale cordialità di rapporti durante $i$ secoli XII e XIII, s'obre, entre la darreria del segle XIII i la primeria del XIV, l'antagonisme che è destinato a durare e ad approfondirsi sino all'inizio dell'età moderna ${ }^{13}$, antagonisme que cal atribuir a raons tant de naturalesa

7 Com assenyalava Pistarino, la posició de privilegi de què gaudiren els mercaders genovesos en terres catalanes respecte a altres mercaders es remunta al segle XII i cal enquadrar-la en l'hàbil política d'infiltració a Occitània i a la Península lbèrica del comú genovès, l'ajut del qual als diversos sobirans tenia com a contrapartida, gairebé sempre, concessions i exempcions comercials i fiscals; vegeu G. PISTARINO, Genova e l'Occitania, M.T. FERRER, Els italians, i S. FOSSATI RAITERI, «Privilegis genovesos a les terres catalano-aragoneses en els primers vint anys del segle XV i l'impost dels tres diners per lliura», Estudis d'Història Medieval V (1972), pp. 101-113.

8 Com destacava Soldevila, Pere el Gran concedí a les colònies genoveses establertes a Sicília privilegis comerciais tan importants que, quan el seu fill Jaume volgué afavorir els mercaders catalans, els concedí els mateixos privilegis de què ja gaudien els lígurs (F. SOLDEVILA, «Jaume I, Pere el Gran», dins Biografies Catalanes, vol. V, Barcelona, 1955, pp. 149-150; cf. M.T. FERRER, Els italians, p. 435).

9 Vegeu, essencialment, al respecte, V. SALAVERT Y ROCA, Cerdeña y la expansión mediterránea de la Corona de Aragón (1297-1314), Madrid, 1956, 2 volums, i A. ARRIBAS PALAU, La conquista de Cerdeña por Jaime II de Aragón, Barcelona, 1952.

10 G. PISTARINO, «Genova e Barcellona: incontro e scontro di due civiltà», dins Atti del / Congresso Storico Liguria-Catalogna [1969], Bordighera, 1974, pp. 81-122.

11 M.T. FERRER, Els italians, p. 435.

12 G. PISTARINO, Genova e Barcellona, p. 90. Vegeu també G. JEHEL, «Angevins, génois et siciliens aux temps des Vêpres (1276-1337)", dins XI Congresso di Storia della Corona d'Aragona. Palermo-Trapani-Erice 25-30 aprile 1982, vol. III, Palerm, 1984, pp. 257-277, que també assenyala que «les rapports entre Gênes et Aragon se dégradent entre 1290 et 1300 (p. 267).

13 G. PISTARINO, Genova e Barcellona, p. 99. 
econòmica com de naturalesa política i que, sempre en paraules seves, s'alimenta de dos motius fonamentals: en primer lloc, de la penetrazione genovese in Castiglia, già largamente in atto nel secolo XIII, con la quale i genovesi cercano di aggirare da mezzogiorno e da occidente la Catalogna e l'Aragona; en segon lloc, de la dinamica della politica aragonese, dallinsurrezione del Vespro in poi, per la costituzione di quella "diagonale insulare», tra le Baleari, la Sardegna e la Sicilia, il cui scopo non riguarda l'Oriente e la via delle spezie, ma si rivolge all'egemonia politica "nell'ambito del Mediterraneo occidentale, in quell'area che ha come punti terminali Tunisi, la Sicilia e la fascia costiera della penisola italiana fino a Genova ${ }^{14}$.

Per tant, en aquestes coordenades aquí obertes, només, sumàriament ${ }^{15}$, l'anàlisi de la presència genovesa al regne de Múrcia al tombant del segle XIII pot transformarse en un observatori privilegiat de les actituds genoveses i catalano-aragoneses en el moment en què s'està operant la inflexió en la dinàmica de les relacions i en què comencen a cristal-litzar i a posar-se de manifest els episodis d'aquella pugna plurisecular.

Les actituds que aquests genovesos establerts o negociant a Múrcia prengueren davant de l'ofensiva catalano-aragonesa no foren pas homogènies, i cal jutjar-les com a casos individuals.

A Januino de Quinto, per exemple, establert a Elx des d'abans de la intervenció de Jaume II, Jaume Pere, procurador del regne de Múrcia, li confiscà les propietats, o almenys una vinya que fou lliurada a mestre Pere Ballester, perquè, durant el setge, s'havia quedat a la vila; però, com que pogué demostrar que ho havia hagut de fer obligat i coaccionat, posteriorment n'hi fou restituïda la possessión ${ }^{16}$.

En canvi, un altre genovès de la mateixa procedència, Oto o Otín de Quinto, també establert a Elx, féu costat, almenys d'entrada, a les tropes catalano-aragoneses, ja que, durant el setge, Jaume II ja havia ordenat als seus oficials que obliguessin els seus deutors a pagar-li allò que li devien ${ }^{17}$. Uns mesos després, a mitjan febrer de 1298 , sabem que ell i dos mercaders genovesos més, Giovanni Ceba i Guglielmo Barcell, es dedicaven a avituallar el monarca ${ }^{18}$. Tanmateix, després es passà a la causa castellana. A mitjan 1301, aleshores com a veí de Múrcia, ja tenia problemes per

14 Ibídem, pp. 108-109; la darrera cita és extreta de F. GIUNTA, Aragonesi e Catalani nel Mediterraneo, II, La presenza catalana nel Levante dalle origini a Giacomo II. Palerm, 1959, p. 8.

15 Remeto, al respecte, a la molt més detallada i pertinent aportació, aquí mateix, sobre el marc mediterrani, d'Antoni Riera i Melis.

16 ACA, C., reg. 109, f. 238v. A la primeria de març de 1300 , sabem que Januino havia mort, per malaltia, in viatico quod nos proxime fecimus in Sicilia; com que havia fet testament, Jaume II ordenà als justícies de Múrcia i d'Elx que emparessin tots els seus béns fins que arribés el testament, per evitar que, mentrestant, fossin depredats (ACA, C., reg. 115, f. 348v).

17 ACA, C., reg. 340 , f. $187 \mathrm{r}$.

18 Gómez Fernández, «amo» de don Juan Manuel, havia pres a llur nunci, Guerço Selvayno, durant la treva, diversos bocs i moltons destinats al servei reial. Se n'havien queixat, però no havien aconseguit que els en fos reintegrat el preu estimat. A súplica dels tres mercaders, Jaume II va ordenar a Jaume Pere, procurador del regne, que requerís a don Juan Manuel que el fes pagar i que, si no hi accedia, el fes satisfer amb les seves rendes. ACA, C., reg. 107, f. 223r-v. 
conservar les seves possessions a la ciutat ${ }^{19} \mathrm{i}$, finalment, a mitjan 1303 , sabem que les seves propietats al terme de Múrcia li havien estat confiscades propter rebellione ipsius ${ }^{20}$.

Un altre genovès, Francesquí o Francesquí David de Mazzara, veí d'Alacant, també tingué problemes amb la Corona, encara que, en aquest cas, posteriors a la conquesta catalana de la vila. Tot i que, d'entrada, hagués pogut gaudir de la protecció reial ${ }^{21}$, el maig de 1303 el monarca ja ordenava al justícia d'Alacant que el prengués i el lliurés a Sanç López i a Pericó, de la família de l'algutzirir2. Un cop pres, Francesquí fou conduït a València i lliurat a Bertran de Canelles, procurador del regne de València, i, a la darreria de desembre de 1304, havia estat condemnat ${ }^{23}$. Posteriorment, per la mateixa causa o per altres motius, Francesquí David havia estat pres al castell d'Uixó; però, a la primeria de 1307, havia aconseguit fugir-ne i vivia a Ricot, de manera que Jaume II ordenà al comanador que el prengués i el lliurés a l'alcaid del castell d'Uixó24. Tanmateix, també aconseguí esvair-se de Ricot i tornar a escapar de les mans de la justícia: segons informacions d'alguns mercaders, s'havia refugiat, finalment, a Almeria, on sembla que es trobava en el moment de la croada, collaborant amb els nassarites en la construcció de ginys de guerra; segons una carta del jutge de la cort reial Guillem de Jàfer al monarca, si hom el prenia viu havia d'esbrinar-se, abans que morís, com havia sortit de la presó d'Uixó, cosa que se suposava que havia fet (malgrat tots els deutes que sabem que tenia!) mitjançant suborn ${ }^{25}$.

19 ACA, C., reg. 118, f. 8v. Jaume If escriví a Bernat de Sarrià, procurador del regne de Múrcia, o al seu lloctinent, per manar-los que, si era cert que eren seus, defensessin el genovès en la possessió dels seus béns $i$ impedissin que fos molestat. Ottinus havia exposat al rei que tenia béns i possessions a Múrcia i als seus termes que foren de l'orde de l'Hospital i que hom n'hi discutia la possessió.

20 Una heretat seva del terme de Múrcia fou concedida a Guillem Ça Muntada, per serveis prestats. ACA, C., reg. 201, ff. 12v-13r; ed. J.M. del ESTAL, El reino de Murcia bajo Aragón (1296-1305), Alacant, 1990, doc. 261. D'aquest Otín de Quinto en coneixem altres dades, relacionades amb un plet amb un mallorquí resident a València, Guillem Espaer, a qui de Quinto havia ferit a Elx amb una espasa; a mitjan maig de 1303 Berenguer de Puigmoltó ja havia dictat sentència, que després fou apel.lada (ACA, C., reg. 128, f. 139r); a la primeria de 1304, el rei Jaume ordenava al procurador de Múrcia que examinés el procés i hi procedís d'acord (ACA, C., reg. 131, f. 17V), però l'afer no es resolgué definitivament abans de mitjan 1308 (ACA, C., reg. 142, f. 152v).

21 A la primeria d'abril de 1303, s'havia queixat al rei perquè Felip de Sant Joan li devia diners mercaderies que havia rebut de deutors seus o en forma de comandes però no els hi volia pagar; Jaume II ordenà al justícia d'Alacant que ho investigués (ACA, C., reg. 127, f. 61r). Però, aleshores, anteriorment, el rei ja havia hagut de citar a declarar, tant contra Francesquí com contra la seva sogra Teresa, unes dones que havien presentat queixes en contra llur (ACA, C., reg. 127, f. 61v).

22 ACA, C., reg. 127, f. 121r.

23 ACA, C., reg. 134, ff. 145r i 188v. Hi havia pel mig una qüestió d'un esponsalici fals i diversos deutes, àdhuc amb un mercader de Montpeller (ACA, C., reg. 136, ff. 191r-192r). La sogra de Francesquí, Teresa, mare de la seva esposa Elvira, també havia estat condemnada; l'agost de 1308 també era presa, fos o no des de la condemna d'uns anys abans, a la cort de València, però, segons sembla, s'hi movia lliurement, «com vol»; per això Jaume II ordenà al justícia, Arnau de Font, que la fes custodiar millor, ja que devia «molts diners" que no volia o que no podia pagar (ACA, C., reg. 142, f. 164r).

24 ACA, C., reg. 140, f. 88r.

25 ACA, C., CR Jaume II, caixa 106, núm. 13.098. 
També podria ser genovès, encara que la documentació no ho indiqui, el veí d'Elx Ranieri Conventi, amb possessions a Elx i a Oriola. Amb el pretext de les cartes reials que Jaume II havia expedit a instància i en favor seu i de dos altres veïns d'Elx (Pero Garcia de León i Garcia Suera), on es deia que, si el pacte amb don Juan Manuel exigia que els fossin restituïdes, havien de ser-los tornades les heretats i possessions que els havien estat confiscades per la revolta, els tres d'Elx havien aconseguit que Jaume Pere, procurador del regne de Múrcia, prengués a Pere Verdú, de la casa reial, les possessions d'aquells que el rei li havia lliurat al terme d'Oriola. Davant les queixes de Verdú, Jaume II aclarí al procurador que el pacte no s'estenia a les possessions de fora d'Elx i que, per tant, havia de restituir a Verdú els béns d'Oriola ${ }^{26}$.

Probable parent seu i també probable genovès, era un altre veí d'Elx, Guido Conventi, que, per manament de Bernat de Sarrià, hagué de sortir o fou expulsat del regne de Múrcia com a sospitós; a mitjan agost de 1305, enmig de l'onada de devolucions dels béns confiscats a Castella, d'anul-lació de les vendes obligatòries dels béns dels expulsats i de reclamacions de béns dels súbdits de Jaume II, el rei donà ordres a Gombau d'Entença perquè també fos anul-lada la venda que Conventi havia hagut de fer dels seus béns ${ }^{27}$.

Al costat d'aquests genovesos «rebels», tanmateix, també en trobem un reguitzell que es dedicaren a fornir vitualles a Jaume II o a alguns dels seus oficials, encara que no necessàriament per aprovisionar l'exèrcit.

Ja hem esmentat l'apropiament indegut per part dels oficials de don Juan Manuel de diversos moltons i bocs propietat de Ceba, Barcell i Quinto destinats al servei reial ${ }^{28}$.

Abans de la primeria d'abril de 1298, mentre el rei era a Alacant, també havia fet comprar blat als genovesos Francesco de Podio i Antonio Traversa ${ }^{29}$.

I, a mitjan febrer de 1304, Bernat de Sarrià devia diners a un altre genovès, Gil de Quarto; de Quarto s'havia queixat al procurador del regne de València, Bertran de Canelles, perquè, mentre Bernat de Sarrià era procurador, li havia comprat, a Oriola,

26 ACA, C., reg. 106, ff. 75v i 75v-76r. Dues cartes, una a Jaume Pere i l'altra al batlle, justícia i jurats d'Oriola. L'afer no degué solucionar-se tan fàcilment, almenys pel que feia a Conventi. Gairebé tres anys després, a mitjan juliol de 1300 , amb Conventi i Verdú ja difunts, Jaume II manava a Bernat de Sarrià, a instància de Pere Roderic Danzano, procurador d'Isabel, vídua de Rainer, que fes executar la sentència que Obert de Cap de Pont, jutge de la cúria reial, havia dictat sobre el plet entre ell, com a procurador d'Isabel, i Bernat Ses Preses, procurador dels marmessors de Pere Verdú (ACA, C., reg. 117, f. 307r). Un altre Rainer Convent, veí d'Elx, podria haver estat fill homònim del primer; havia estat acusat de negligència per no evitar la fuga d'un sarraí que era pres sota la seva custòdia i que fou trobat culpable d'haver mantingut relacions sexuals amb una dona cristiana. A mitjan setembre de 1313, Jaume II li concedí la remissió (ACA, C., reg. 210, f. 89r).

27 ACA, C., reg. 136, f. 164r (citat per M.T. FERRER I MALLOL, Organització i defensa d'un territori fronterer. La Governació d'Oriola en el segle XIV, Barcelona, 1990, pp. 59-60, nota 62) i ACA, C., reg. 134, f. $177 \mathrm{v}$.

28 Vegeu la nota $18 \mathrm{i}$ el text corresponent.

29 ACA, C., reg. 110 , f. 73 r. 
civada per al seu cavall $i$ ara es negava a pagar-la-hi. El rei Jaume ordenà a Canelles que, si era així, obligués Bernat a pagar al genovès allò que li devia ${ }^{30}$.

També podria ser, probablement, genovès, encara que les nostres fonts no ho esmentin, el Lanfranco o Nanfranco Bocar a qui, el maig de 1296, Jaume II concedí llicència perquè pogués estar-se a Elx i a qualsevol altre lloc de la seva terra -llevat del regne de Mallorca i les illes de Menorca i Eivissa- amb els seus béns, a la vegada que ordenava als oficials reials que obliguessin els seus deutors a pagar-lo ${ }^{31}$; el favor reial a aquest italià s'explica, segurament, pel seu paper com a prestamista de la corona, que queda en evidència durant el setge d'El $x^{32}$.

El ventall de noms de genovesos que, en aquelles dates, negociaven o estaven establerts al regne de Múrcia és, però, més ampli.

El juny de 1296, per exemple, des del setge d'Elx, Jaume II havia concedit llicència a Giovanni Embrono, ciutadà de Gènova, per sortir de Guardamar amb mercaderies seves i dels seus socis ${ }^{33}$.

El gener de 1301, al port de Cartagena també hi havia un lleny de genovesos, amb

30 ACA, C., reg. 131, ff. 77v-78r. Gil de Quarto també tenia negocis, aleshores, amb les aljames sarraïnes d'Elx, Asp i Monòver. Els sarraïns vells d'aquestes aljames estaven endeutats amb ell i, tot i que tenia en poder seu un instrument escrit en àrab que en donava testimoni, es negaven a pagarlo. Se n'havia queixat al rei i Jaume ordenà a Pere de Montagut, procurador de Múrcia, que els obligués a fer-ho (ACA, C., reg. 131, f. $77 \mathrm{v}$ ).

31 ACA, C., reg. 340, f. 104v. 2 documents.

32 ACA, C., reg. 340, f. 146r. El deute (2003 sous barcelonins, 111 florins d'or, 39 dobles mines d'or, 35 dobles de rexet) li fou assignat sobre les rendes de la batllia de València. Encara que consti com a ciutadà de València, també devia ser d'origen, almenys, italià, el Bonacaso Lagrigerium per mitjà del qual Roger de Llúria havia fet comprar a Múrcia, a la darreria de 1297, «per l'armada que fa el rei», lorigas seu coopertas ferreas de cavall i altres armes per portar a València; el monarca ordenà a Jaume Pere, procurador del regne de Múrcia, que permetés la treta (ACA, C., reg. 106, f. 104v).

33 Així ho notificà a l'alcaid del Iloc, Galceran de Rosanes (ACA, C., reg. 340, f. 133r). Un document molt malmès del mateix registre, i pràcticament illegible en microfilm, expedit també des del setge d'Elx, el 30 de juny (ACA, C., reg. 340, f. 185r), sembla fer referència a aquest mateix mercader (Johannes Brunio Brune) i relacionar-lo amb Elx i Crevillent; per algun problema de caràcter comercial, Embrono defensa i presenta al rei un privilegi segons el qual els genovesos sint franchi in regno Murcie. Aquesta tan obscura i una altra de més tardana, de 1317, són les dues úniques notícies que hem localitzat sobre el tracte fiscal dels genovesos al regne de Múrcia en aquelles dates primerenques, una qüestió que, el 1317, era conflictiva. A mitjan mes de maig d'aquell any, hi havia a Barcelona, on es trobava el rei, l'ambaixador i jurista genovès Giovanni de Galuciis o Galucio, membre d'una destacada família de jutges genovesa (vegeu G. PETTI BALBI, Simon Boccanegra e la Genova del'300, Gènova, 1991, pp. 184-194, tot i que difícilment el nostre Giovanni sigui identificable, per raons cronològiques, amb l'homònim que il.lustra l'autora), que, de part del comune, reclamava que fossin observats als seus conciutadans, al regne de Múrcia, els privilegis d'immunitas de non solvendis lezdis, pedagiis i altres drets reials que havia mostrat al monarca; segons sembla, ni Joan Rolf, batlle reial in parte regni Valencie, ni la resta d'oficials d'aquelles terres no els observaven i els genovesos pretenien que el rei els manés que ho fessin. El rei manifestà a Rolf que, ex quibusdam probabilibus causis, viderimus in consilio nostro dubium an predicta privilegia in dicta parte regni predicti observari deberent, però, tanmateix, volentes nos erga dictum comunem gerere generose, li manà que, de moment, mentre enllestia la informació, observés els privilegis als genovesos (ACA, C., reg. 214, f. 59v). 
part de la tripulació castellana de Sevilla i d'altres llocs, i, a bord, s'hi havia produït una insurrecciói ${ }^{34}$.

Un altre mercader de Gènova que corria habitualment per aquelles terres era Guglielmo di Pontremoli; a mitjan gener de 1301, havia estat denunciat «per algunes paraules» i s'havia fet enquesta contra ell. Però Guillem de Vilaragut, lloctinent de Bernat de Sarrià, procedia contra ell il.legalment, de manera que el rei Jaume li ordenà que ho fes segons fur i, sense admetre dilacions, el castigués si era culpable, però el deixés estar si no ho era ${ }^{35}$. Poc després, el febrer d'aquell mateix any, trobem més dades d'aquest lígur. Sabem, llavors, que havia estat condemnat a exiliar-se, però que havia obtingut gràcia per quedar-se fins que pogués recuperar un deute d'alguns del regne; el deute era, probablement, el que ell assegurava que tenien amb ell diversos veïns d'Oriola ei obligati nomine fideiussorio in quantitate peccunie ratione annone seu cibate que ab ei fuit, ut asserit, occupata. El rei Jaume manà al justícia de la vila que vengués els béns d'aquests que tenia en penyora, o bé que deixés que Pontremoli els retingués en pagament d'aquella quantitat ${ }^{36}$.

Un darrer genovès que negociava $\mathrm{i}$, en aquest cas, era veí del regne de Múrcia $\mathrm{i}$, en concret, d'Elx, era Giovanni de Brandis; el setembre de 1304 havia anat, amb el seu lleny, al Port de l'Aljub, i Ferrer Descortell l'hi havia fet emparar ${ }^{37}$.

34 ACA, C., reg. 118, f. 4r. Carta a Romeu de Marimon, alcaid de Cartagena. Els castellans havien ferit el patró i han abuda gran barayla entre si. El rei Jaume, que n'havia estat informat, ordenà a l'alcaid que retingués el lleny al port fins que no s'hagués esbrinat la veritat, motiu pel qual li envià un seu porter.

35 ACA, C., reg. 118, f. $2 v$.

36 En aquells moments, Bernat de Sarrià li tenia ocupat un cavall i es negava a restituir-l'hi; el monarca li ordenà que ho fes. ACA, C., reg. 118, 14v (3 documents).

37 ACA, C., reg. 133 , f. 88v. Podria haver estat també genovès el veí d'Elx Rotlan Salvanyo (Salvago?) que havia administrat els béns de la comtessa, mare de don Juan? (ACA, C., reg. 138, ff. 212v-213r). Al llarg del període que ens ocupa, també ens han aparegut notícies i noms d'altres genovesos en altres punts de la Corona d'Aragó. A la darreria de febrer de 1298, Francesquí Grimaldi, per exemple, havia tret del port de Palomera de Mallorca, per força i amb engany, la galera de Pasqual d'Areto, també genovès, carregada de grana, cera i altres mercaderies de mercaders de la terra i d'altres; el còmit, els notxers i la major part de la tripulació hi havien consentit. S'havien dirigit cap a terres granadines i, per això, Jaume Il demanà al rej de Granada, i després escriví a l'arrais d'Almeria, que el fes prendre amb les mercaderies robades (ACA, C., reg. 107, ff. 260r i 262v). Pel que fa al regne de València, el 1304, per exemple, fou concedida llicència al genovès Cristiano Spinola perquè els seus factors, Ranieri de Vedereto i Tommaso Costati, en poguessin treure pega, sèu i dos cavalls amb la galera de Cristiano, que era a aquelles parts, per dur-la cap a Gènova (ACA, C., reg. 201, f. 121v, 2 documents); poc abans, el rei Jaume havia ordenat a Bernat de Libià, batlle general del regne de València, que obligués els cristians i jueus de la ciutat i regne de València que devien diners a Raineri, factor de Cristiano, per mercaderies que aquest els havia lliurat, a pagar-li allò que li devien, a desgrat de què, prèviament, alguns d'ells haguessin obtingut un allargament de deutes de la corona (ACA, C., reg. 134, f. 235v). Aquesta situació de privilegi de Cristiano Spinola i dels seus factors pot relacionarse amb el paper que aquest tingué com a principal confident o informador de Jaume Il sobre l'actitud i les intencions del comune genovès durant l'estira i arronsa diplomàtic amb la República mentre el monarca intentava aplanar-se el camí per la conquesta de Sardenya, tan detalladament analitzat per Salavert (vegeu les entrades que en dóna l'índex de V. SALAVERT, Cerdeña, vol. I). 
Malgrat que, com dèiem, les actituds de tots aquests genovesos que hem anat trobant respecte a la intervenció de Jaume II al regne de Múrcia poguessin ser merament personals $\mathrm{i}$ individuals, quasi en paral.lel podem anar observant algunes de les primeres guspires d'aquella rivalitat que seria secular, guspires que afecten individualment als genovesos del regne de Múrcia però que fan referència a tota la "nació genovesa». Són, gairebé sempre, repercussions d'incidents marítims que acaben convertint-se en «afers d'estat» i que ja comencen a enterbolir, de la mateixa manera que ho farien durant les dues centúries següents, les relacions oficials entre la Corona d'Aragó i la república de Gènova.

Un dels primers detonants que se'ns presenten són els danys ocasionats pels atacs piràtics del genovès Rosso de Finale a mitjan 1301, amb un lleny armat i prop del Cap de Creus, a mercaders de Barcelona, Girona i d'altres llocs que tornaven cap a Barcelona procedents de la fira de Perpinyà. El monarca catalano-aragonès s'adreçà al comú de Gènova perquè fes restituir als mercaders damnificats les mercaderies o el seu valor. Però, mentrestant, ordenà a tots els oficials de la Corona que emparessin tots els béns de genovesos que trobessin a llurs jurisdiccions. Com que el comune respongué amb dilacions i no es preocupà de fer justícia, el rei Jaume concedí als daminificats, finalment, llicència de marca contra béns de genovesos - a no ser que tinguessin guiatge - a tots els seus regnes, fins a la quantitat de 2350 lliures de Barcelona i durant nou mesos ${ }^{38}$.

Fruit, potser, dels actes piràtics del mateix Rosso de Finale, tot i que la documentació només esmenti, genèricament, alguns genovesos, a la primeria de 1302 , un ciutadà de València, Jaume Farfall, en favor del qual Jaume II havia escrit al comú lígur sense que aquest accedís a procedir-hi, també rebé llicència de penyorar béns de genovesos fins que «els homes del comú» li fessin satisfacció dels danys i injúries ${ }^{39}$.

La primavera del mateix any, els oficials reials reberen nova ordre d'emparar els béns de genovesos que trobessin a llurs jurisdiccions, sempre i quan no tinguessin guiatge, a favor d'un altre súbdit de la Corona, Bernat de Peramola, fill del difunt Jaume de Peramola, que l'any anterior havia estat damnificat per genovesos a les parts de Sicília ${ }^{40}$.

Finalment, els darrers dies de juny de 1302, sabem que, poc abans, tres galeres armades de genovesos, de tres Spinola (Guietus, Baldus i Guami), "exercint pirateria», també havien atacat les naus de Berenguer Romeu i de Ramon Verniols, enduentse'n tots els béns i mercaderies que transportaven; els danys ascendien a 932 unces d'or i 15 tarins, segons constava per testimonis, i, en conseqüència, Jaume II adreçà una nova reclamació a la República lígur per tal que els fes satisfer aquestes quantitats ${ }^{41}$.

38 Des del 2 de gener, data del document, fins a la següent festa de Sant Miquel de Setembre; ACA, C., reg. 119, ff. 11v-12r, 33r-34r (carta al comú de Gènova amb detall de totes les mercaderies preses), $79 \mathrm{v}$ i 80v-81r, i ACA, C., reg. 120, f. 199r. Les accions de Rosso de Finale (el lleny del qual havia estat armat per diversos genovesos de Noli) són analitzades amb més detall, aquí mateix, per l'aportació del Dr. Antoni Riera i Melis.

39 ACA, C., reg. 120, ff. 245v-246r i ACA, C., reg. 123, f. 85r-v.

40 ACA, C., reg. 123 , f. $87 \mathrm{v}$.

41 ACA, C., reg. 124, f. 225r-v. 
L'evident manca de voluntat de fer justícia del Comune i l'escalada de tensió impulsà a Jaume II, finalment, a la darreria de 1302, a acabar, fins i tot, amb les garanties de què disposaven els genovesos guiats, que fins aleshores havien quedat protegits de les empares i marques, fet que tingué repercussions concretes al regne de Múrcia. L'onze de desembre, una ordre del monarca comunicava a Bernat de Sarrià, procurador del regne, que Eimeric Dusay havia resultat perjudicat per genovesos a Pisa i que, en conseqüència, li havia concedit llicència per confiscar béns de genovesos. Si, fins aleshores, els genovesos guiats havien romàs immunes a aquesta mena de disposicions, aquesta vegada llur salvaguarda només fou temporal: els genovesos que hi havia en el regne de Múrcia, que estaven sota protecció reial, tindrien dos mesos per sortir-ne i, acabat aquest termini, llurs béns també podrien ser confiscats ${ }^{42}$.

Aquests incidents, dels més primerencs coneguts ${ }^{43}$, ja són una mostra dels fets $\mathrm{I}$ actituds que serien endèmics al llarg de les dues centúries futures, amb el valor afegit d'estar situats en els anys de l'emergència de la rivalitat catalano-lígur. En aquells segles a venir, les relacions amb Gènova alternarien i encavalcarien la guerra oberta i una pau oficial però constantment transgredida. En temps de guerra oberta, o bé en episodis com els que acabem de veure, les relacions directes entre Gènova i la Corona d'Aragó quedarien, oficialment, suspeses, encara que l'intercanvi de productes essencials pogués continuar, sovint a través de tercers. Llavors, les colònies de genovesos es veien obligades a tornar ràpidament, com en aquest darrer cas, a les seves terres, si hi eren a temps i no quedaven presoners ${ }^{44}$. Sovint, només un acte de pirateria ja era suficient per provocar una ruptura. Hem vist que succeí en els primers anys del segle XIV, i es repetí, de nou, a la darreria de 1322, en un cas que també ens interessa per les repercussions que tingué en terres alacantines.

Des de mitjan novembre de 1321, almenys al regne de València dellà Xixona, a causa de danys ocasionats per genovesos a súbdits catalano-aragonesos, ja es procedia a l'empara de béns de lígurs. Per aquest motiu, el batlle Jaume Andreu havia emparat a Manuele Pessagno, olim almirall del rei de Portugal ${ }^{45}$, tot el que era seu:

42 ACA, C., reg. 126, f. 175 bis $r$.

43 M.T. FERRER, Els italians, n'esmenta indirectament alguns, a través de la creació d'impostos extraordinaris per indemnitzar les preses, de la segona meitat del segle XIII (pp. 439-440), i també l'empresonament de genovesos del desembre de 1322 - que veurem tot seguit- a causa de danys ocasionats a mercaders barcelonins (p. 436); considera, tanmateix, que, malgrat els nombrosos i inevitables casos de pirateria, les bones relacions polítiques entre catalans i genovesos prevalgueren al llarg del segle XIII i del començament del XIV, i facilitaren els contactes comercials (p. 435).

44 Ibídem, pp. 435-436.

45 Encara ho era, com després consta al segon dels documents esmentats tres notes més avall; el primer dels dos, el guiatge que veurem tot seguit, només diu que era genovès i, com el document de l'empara, parent del cardenal Fieschi. Sobre els Pessagno i el seu paper com a almiralls del rei de Portugal, L.T. BELGRANO, "Documenti e genealogia dei Pessagno genovesi, ammiragli del Portogallo", Atti della Società Ligure di Storia Patria XV (1881), pp. 241-315. El març de 1310 el monarca també havia concedit salconduït de dos mesos a un altre genovès, Ranieri de Grimaldi, almirall del rei de França, per anar del regne de Múrcia a Gènova amb vint-i-cinc cavalls, muls i rossins (ACA, C., reg. 206, ff. 101v-102r). 
diners, joies i altres béns per valor de més de 1500 o 1700 florins. El rei, en consideració del rei de Portugal i del cardenal Luca Fieschi (també genovès i, segons el document, parent seu) ${ }^{46}$, ordenà al batlle que aixequés l'empara, sempre i quan els béns de Pessagno no sobrepassessin la quantitat de 2000 florins $^{47}$. A precs dels mateixos rei de Portugal i cardenal genovès, el rei també concedí guiatge de quatre mesos a Pessagno juntament amb la seva muller, fills i família, immunitat respecte a les marques contra genovesos $i$ llicència per treure de les seves terres un cavall i dos rossins ${ }^{48}$.

Un any després, fet independent o vinculat a l'empara anterior, el rei havia manat als seus oficials, a causa dels danys causats per genovesos a mercaders de Barcelona, que fossin empresonats tots els genovesos que trobessin en llurs jurisdiccions. Aquestes ordres també havien arribat a les terres dellà Xixona i els oficials locals havien procedit conforme a elles. Això havia motivat queixes dels jurats i de la universitat d'Alacant al rei, que al-legaven que, contra els privilegis de la vila, pretenien també prendre els genovesos que hi anaven a mercadejar ${ }^{49}$. El monarca, afirmant que les seves ordres havien estat dictades pretextu dampnorum per januensium tunc non nullis fidelibus nostris de civitatis Barchinone illatorum et non sit nec fuerit intencionis nostre dicte ville Alacantis super dicto prejudicari privilegio, ordenà que vigore dicti mandati nostri seu alias ad capiendum dictos januenses vel alios quoscumque causa mercandi ad dictam villam Alacantis accedentes contra formam dicti privilegii minime procedatis ${ }^{50}$.

Però les queixes dels jurats i universitat d'Alacant sobre la manca d'observació de llurs privilegis, que no només feien referència a aquest aspecte ${ }^{51}$, tingueren altres efectes.

En primer lloc, motivaren una ordre general del monarca al portant-veus de procurador, al batlle, als justícies, batlles i a la resta d'oficials, perquè observetis dicte

46 Sobre els Fieschi, vegeu, per exemple, M. TRAXINO, «I Fieschi», dins Dibattito su Quattro Famiglie del Grande Patriziato Genovese. Atti del Convegno. Genova, 15 novembre 1991, Gènova, 1992, pp. 12-33, o també G. PETTI BALBI, «I Fieschi e il loro territorio nella Liguria Orientale», dins La Storia dei Genovesi... III volume, [Gènova], [1984], pp. 105-129, i idem, “Simon Boccanegra», «Fieschi», pp. 151-156, a banda del molt més difícil de localitzar F. FEDERICl, Della famiglia Fiesca, Gènova, 1620. En concret sobre el cardenal Fieschi, que fou enterrat a la catedral de Gènova, A. GAGLIANO CANDELA, «II Cardinale Luca Fieschi nella cultura e nell'arte», dins La Storia dei Genovesi... X volume, pp. 155-196. Luca Fieschi fou destinatari, sempre entre altres personatges, d'algunes cartes de Jaume II en moments anteriors a la conquesta de Sardenya; vegeu V. SALAVERT, Cerdeña, vol. I, pp. 244, 260 (on és anomenat carisimo consanguineo) i 407.

47 ACA, C., reg. 221, f. $120 \mathrm{~V}$.

48 ACA, C., reg. 221, ff. 120 r i $132 \mathrm{~V}$.

49 «intenditis contra formam privilegiorum eidem ville Alacantis concessorum capere januenses ad dictam villam causa mercandi convenientes"; ACA, C., reg. 178, f. 148v.

50 Es tracta, potser, d'una referència al privilegi de la fira que, el 1296, el propi rei Jaume havia concedit a la vila i que protegia tant els mercaders com els béns que hi acudissin amb finalitats comercials? Vegeu J.M. del ESTAL, “Erección por Jaime II de una feria medieval en Alicante», Revista del Instituto de Estudios Alicantinos 16 (1976), pp. 153-174.

51 També s'havien queixat al rei, per exemple, que s'havia comès frau en la provisió d'alguns oficis de la vila, que, com el de carceller, havien de ser ocupats, anualment, per veïns de la vila i no ho havien estat, contra forma dels privilegis; ACA, C., reg. 178, f. 148v. 
universitati Alacantis et termini sui privilegia supradicta nec contra formam et usum ipsorum eosdem aliquatenus adgravetis, destacant, però, clarament, que els havien estat concedits pels reis de Castella i confirmats, després, per Jaume ${ }^{52}$.

I, en segon terme, i sobretot, propiciaren que, acte seguit, responent a una súplica de la pròpia universitat perquè, per augment i utilitat de la vila, el monarca guiés i assegurés tant els genovesos aleshores residents a Mallorca com a altres qualssevol genovesos que volguessin establir-se a Alacant, Jaume II guià i assegurà januenses quoscumque ad dictam villam Alacantis causa populandi et suum domicilium constituendi venire volentis. Però allò que més ens interessa és que aquests genovesos, un cop domiciliats efectivament a Alacant, no només podrien estar-s'hi i residir-hi salvament i segura $i$ anar $i$ tornar per totes les terres de la Corona com la resta de veïns i habitants de la vila, sinó que, a més, quedarien protegits d'alicuius pignorandi licencie subditis nostris contra januenses concesse ${ }^{53}$.

Aquests darrers episodis posen de manifest fins a quin punt els alacantins defensaven i es mostraven zelosos de les seves prerrogatives, però també fins a quin punt conservaven la consciència de l'origen d'aquestes, sense perdre la memòria històrica: els privilegis concedits pels reis de Castella i confirmats pel monarca catalanoaragonès.

Però, a més, també evidencien, per un costat, el recolzament del monarca al port d'Alacant, amb reconeixement implícit de la importància del paper que hi tenien o que es considerava que hi podien tenir els genovesos si es vetllava adequadament; i, a la vegada, per un altre costat, fins a quin punt els lígurs ja podien tenir difícil, en aquells moments, preludiant els esdeveniments futurs, la presència en terres de la Corona, ja que el guiatge contra qualsevol marques o empares contra genovesos es considerava un esquer suficient perquè acudissin a poblar la vila $i$, d'aquesta manera, poguessin contribuir a activar el paper del seu port a la Mediterrània.

52 ACA, C., reg. 178, f. 146v.

53 ACA, C., reg. 222, f. 138r. 



\title{
RELACIONES POLÍTICAS Y COMERCIALES DE JAIME II DE ARAGÓN
}

\author{
Consuelo VARA IZQUIERDA \\ Licenciada en Geografía Historia
}

La complejidad que supone el estudio sobre la: figura, época, y sociedad del Monarca JAIME II —de Aragón- exige centrar la comunicación, en temas concretos, aunque interrelacionados unos con otros. Para ello, hemos elegido, RELACIONES EXTERIORES E INTERIORES (ámbito peninsular). Corona de Castilla, Reinos, Murcia, Valencia y las consiguientes repercusiones que tuvieron éstas.

No pretendo, realizar una investigación exhaustiva, que a mi juicio sería muy amplia, al mismo tiempo que interesante.

No sólo podemos referirnos a la figura del gran Rey JAIME II — de la Corona de Aragón-, sino que tendremos que remitir a los hechos históricos, acaecidos con anterioridad; que sin embargo de no haber ocurrido, el rey ya citado, no podría haber llevado a cabo su política.

Ante la densidad del tema central: JAIME II, decidí, ante todo darle un carácter general y la vez concreto de las relaciones mantenidas por el ya citado monarca con las diferentes Coronas y Reinos.

El hecho de basarme en POLÍTICA, (interior y exterior) radica - ante todo- en la representación de un importante LEGADO; para la posterior política, sociedad y economía en la que se basarán sus predecesores ya que tendrá grandes repercusiones de diferentes niveles.

Si nos centramos -más- en las RELACIONES EXTERIORES, deberíamos hacer una pequeña síntesis y división, que se irá viendo a lo largo de mi modesta comunicación.

En un principio, podíamos hablar de las no buenas relaciones que tuvo «la Corona de Aragón», UBIETO A., cita ${ }^{1}$ textualmente «... La Corona de Aragón no tuvo relacio-

1 UBIETO, A., Introducción a la Historia de España, Ed. Teide, Barcelona 1983, pp. 207 y 208. 
nes cordiales con los reyes de Francia»... «Los problemas planteados con respeto a la Provenza y Touluse». Con respecto a la primera el mismo antes citado dice ${ }^{2} \ldots$ «La solución llegó por medio de un remedio no esperado... Los Condes de Provenza durante los primeros años del S. XIII siguen perteneciendo a la Casa Real de la Corona de Aragón... sin embargo a la muerte de J. Ramón Berenguer V (1217-1245) le sucede su hija Beatriz que casa con Carlos de Anjou" ${ }^{3}$.

«Item: Todo lo que Casa de Túnez debe del tiempo pasado al Rey Carlos.

Item: Le pagará todo lo que apresaron de la nave que fue enviada a Túnez, del Reino de Valencia, cargada de Sarracenos, y de otras mercaderías.

(2) Era Carlos I de Anjou, Rey de Nápoles y de Sicilia desde 1268, en que murió degollado Conradino, hasta 1281 en que el Rey D. Pedro III de Aragón se apoderó de aquella Isla y Corona por el derecho de su mujer Doña Constanza. En 1276 el Rey Omar Muley se hizo tributario del Rey Carlos, que con poderoso ejército había ido en socorro de S. Luis».

Con respecto a la política mediterránea, podemos decir que la resistencia opuesta a la presencia catalana en Sicilia, va a obligar a que los Reyes de Aragón busquen fórmulas que les permitan mantener los privilegios adquiridos con anterioridad. Se dará pretendencia a la inducción militar, es decir, incluir la defensa de Sicilia y lucha contra el enemigo: Francia.

Según José Luis Martín ${ }^{4} .$. «La muerte de Alfonso «El Franco» obligó a reconstituir el sistema de alianzas de 1282 ... «Jaime Il», renuncia a Sicilia, a cambio obtendría la Investidura Pontificia sobre las Islas de Córcega y Cerdeña...», muy importante éste para su política.

Debido al aumento de la competencia genovesa y pisana en el comercio con Túnez, en 1323 el rey tendrá que hacer efectivas un derecho sobre Cerdeña.

Podremos observar en el documento siguiente lo, referido con anterioridad ${ }^{5}$.

\section{EMBAJADA DEL REY DE ARAGÓN DON JAIME SEGUNDO}

"Al Rey de Túnez, para pedirle satisfacción de ciertos daños, causados por su Almirante y otros Oficiales a vasallos de los Dominios de su Corona. Su fecha en la Villa de Montblanch a 15 de Abril del año 1307".

2 Ibid., pp. 210 y 211.

3 Documentos: “Antiguas Paces y Alianzas, con Principes infieles», pp. 52 y 53.

4 MARTÍN, J.L., Revista de Historia de España no 4, Historia 16, Año V, diciembre 1980, pp. 44 y 45 .

5 «Antiguas Paces y Alianzas con Principes infieles», pp. 53 y 54. 


\section{PODER REAL}

"Sepan todos quantos esta Carta verán: Que Nos D. Jaime, por la gracia de Dios, Rey de Aragón, de Valencia, de Cerdeña, y de Córsega, Conde de Barcelona, y de la Santa Iglesia de Roma, para ir ante la presencia del muy noble Rey de Túnez (Mahomet Amiramuzlemin) y pedirle y requerirle, en nombre $y$ de parte nuestra, y recibir por Nos, quatro mil besantes y mas, que él y sus oficiales se han retenido del medio derecho de la Aduana de Túnez que pagan en ella los Catalanes: el qual dicho Rey nos consignó por razón de cierta suma de moneda en que nos es responsable por nuestra nave, llamada la Stantona, y efectos que contenía, la qual se perdió en la tierra del dicho Rey en lugar de Grigia (Gigel); y además la cantidad de dos mil ciento y ochenta y nueve besantes, y más, que nuestros Mensageros y Procuradores han hecho de gastos y de gratificación á sus oficiales hasta hoy, para percibir y cobrar el referido medio derecho.

También os hacemos Procurador y Mensagero nuestro, para pedir, cobrar, y tomar todo lo que á Nos resta que cobrar de dicha suma de moneda; y asimismo para requerir al referido Rey de Túnez, en nombre y de parte nuestra, que nos sea dada por él resarcimiento y satisfacción de los daños y males, causados por el Almirante del dicho Rey de Túnez, resarcimiento y por sus gentes, á las nuestras y á sus cosas, en qualquiera manera, desde que subsiste la tregua entre él y Nos hasta hoy; y además, para pedir y requerir al mismo Rey de Túnez el resarcimiento y restitución de la nave de Bernardo Marquet vecino nuestro de Barcelona, y de todos los efectos que contenía, que por culpa de Sarracenos de dicho Rey, que en ella venian de Alexandría á Túnez, se perdió la otra vez en Trípoli de Berbería, tierra suya; y el casco, la xarcia, y los géneros han venido en poder de los Oficiales de dicho Rey de Túnez, y de sus gentes del referido lugar de Trípolì.

Por lo ya expuesto, así aseguraba a Cataluña en el control del Mediterráneo Occidental y permitía de esta forma defender la ruta comercial que sin embargo habrá que tener en cuenta lo ya citado, para comprender la política llevada en la Corona de Castilla y las posteriores conquistas.

Con respecto a la Corona de Castilla, (y posterior Reino de Murcia) Jaime II, se aprovechará de la Crisis Dinástica. Las circunstancias, eran caóticas; y Jaime II, se servirá de los Infantes, de la Cerda y de la división y lucha entre nobles Castellanos por el poder (a la muerte de Sancho VI). La facción derrotada ofrecería su apoyo al monarca aragonés, el cual más tarde conseguiría ocupar la mayor parte del reino murciano.

El Documento siguiente, nos aclarará la explicación anterior ${ }^{6}$.

6 RAMOS OLIVEIRA, A., Historia de España. La Edad Media, Ed. Oasis, México 1974. 
"Después de la muerte del Rey Don Sancho se movieron grandes alteraciones... en los reinos de Castilla y León... ciudades y villas no querian obediencia ni prestar fidelidad al rey don Fernando... Y unos seguian la opinión de Don Alonso hijo de don Fernando de la Cerda».

Sin embargo otra sublevación de nobles aragoneses, le obliga a FIRMAR LA PAZ CON CASTILLA, ello no significó una ruptura para la política mediterránea de la Corona.

En opinión de Juan Manuel de Estal ${ }^{7}$... «Jaime II, consciente de que los territorios más indicados en sus aspiraciones de expansión eran sobre todo los que integraban el Reino de Murcia y éstos eran los que había hecho donar en los Pactos (Calatayud (1289) Ariza (1269) Serón (1286). no quiso atacar, sino que se dirigió en persona -al reino de Murcia - haciéndose antes entregar por el infante D. Alfonso los «instrumentos" de los homenajes y los recaudos" ${ }^{8}$.

"de los homenajes que los naturales del de este reino le habian hecho y los recaudos necesarios para que todos le obedeciesen por rey".

En Serón el 3 de febrero de 1296 "Don Alonso de la Cerda por la gracia de Dios rey de Castilla, de Toledo, de León, de Galicia, de Sevilla, de Córdoba, de Jaén... al Consejo e a los homes buenos de Oriola... vos mandamos que obedezcades al rey de Aragón e lo tengades por senyor verdadero e natural... porque, nos ayamos dado el regno de Murcia con todos sus términos e pertenencias assi como a nos pertenece e lo auer deuemos por cualquier manera por nuestras cartas selladas con nuestra bulla de plomo colgada al muy noble Jaymes por la gratia de Dios rey de Aragón por las grandes e muchas mercedes e placeres e en muchas de maneras que recibiemos de sus antecessores.

Dada en Seron tres días de febrero Era de mill e trescientos XXXIII, 1296, anyos. Yo Aparizio Pérez por mandado del rey la escriuy".

Podemos decir, que todo el Reino de Murcia paso a dominio de la Corona de Aragón, excepto las villas y castillos de Lorca y Alcalá, que al final, acabaron por someterse al monarca aragonés, en el año 1300. Con ello, se produce el FIN DE LA CONQUISTA ARAGONESA DE TODO EL REINO DE MURCIA.

Hay que destacar, la importancia que tuvo de la misma forma el Reino de Valencia y su posterior conquista, también llevada a cabo por el propio JAIME II. Este inicia el Gobierno de la Corona de Aragón en 1291, a la muerte de su hermano Alfonso III en las Cortes de Zaragoza tras jurarle fidelidad, prestar homenaje y aclamarlo como soberano los ricos-hombres y caballeros ${ }^{9}$.

7 ESTAL, J.M. del, Conquista y anexión de las tierras de Alicante, Elche, Orihuela y Guardamar, al Reino de Valencia por Jaime // de Aragón (1286-1308), Alicante 1982.

8 Ibid., nota $\mathrm{n}^{\circ} 22$.

9 A.C.A. Premiscum Alfonsi et Jacobi II. Memorial Hist. Español. T. III, Madrid 1852. Cortes de Zaragoza, pp. 426-253. (Documento citado en la Conquista y anexión... ESTAL, S.N., p. 112, nota no 11). 
"Aragón "E los richs homens e los mesnaders et los cavalers et los infançons e los procuradors de les ciutats et de les viles Daragó juraren al dit Senyor Rey en JACME per la gracia de Deu Rey Daragó et de Sicilia et de Mayorcha et deValencia et Comte de Barcelona per Rey et Senyor natural, et quel servirien el obeyrien ben et leyalment, axi con lurs Antecesors feren als seus».

Con respecto a la conquista —en sí- a la que nos referimos con más detalle luego, deberíamos decir que un principio JAIME II pensó no que sería necesario recurrir a las armas ya que le sería entregado sin más la villa y el Castillo, sin embargo, la respuesta recibida por parte del ALCAYDE DEL CASTILLO, fue negativa, y se vio obligado para la obtención de las fortificaciones, que decía era de sus jurisdicción y soberanía. Ramón Muntaner, nos lo relata así ${ }^{10}$.

"en lo primer lloc on ell (Jaime II) venc del Regne de Múrcia fo ALACANT, e combaté la vila e la pres,e puis muntá al Castell, qui és dels bells castells del món, e pensà'l de combatre tant fort, que sus per la muntaya a amunt el senyor aquell lloc, per foça d'armes, esvaïren lo castell’".

Pero Jaime II, se adueño del Castillo de Alicante, tras una reñida lucha, dando muerte alcayde del mismo. Lo antes expuesto, es el relato denominado «Tradicional» por Juan Manuel del Estal ${ }^{11}$, admitido por los historiadores como verosímil, acerca de las conquista del Castillo y Villa de Alicante.

"Sapien quantos esta carta veuran com nos en Jaume Perez senyor de Segorb e Procurador del Regne de Murcia per lo senyor Data en Alacant a tres dies de octubre anno a nativitate domini Millesimo ducentesimo monagesimo septimo" "In christi dei nomine noverint universi quod nos Jacobus dei gratia rex».

Fue conquistado éste, el 22 de abril de 1290 y Jaime II procedió a proveer los "cargos municipales" de mayor urgencia, por ejemplo: bayle, alcayde, justicia... etc.; colocando al frente a caballeros leales y seguidores suyos; como por ej.: Pedro de Urtx, Raimundo de Capiath y Otras ${ }^{12}$. «Raymundo de Urgio, alcayde Castride Alacant significamus vobisquos Nos mandamus... vobis 336 rovas farine ad opus munition is et stabilitionis Castri de Alacant"...

10 Crónica de MUNTANER, R., CLXXXVIII; edit. SOLDEVILLA, Barcelona 1971, pp. 834-835 (citado por Juan Manuel del Estal en: Conquista y anexión de las tierras de Alicante, Elche, Orihuela y Guardamar al Reino de Valencia por Jaime I/ (1296-1308), Alicante 1982. Caja de Ahorros Provincial, pp. 197-198.

11 Ibid. (Juan Manuel del Estal, pp. 167-170).

12 Ibid., pp. 197-198. (Citado por Juan Manuel del Estal; notas 32 y 33). A.C.A., p. 340; fel G.R.). 
"Data apud Alacant decimo kalendas madii, anno domini millesimo ducentesimo nonagesimo sexto ( $A C A, R g .340$, fol. 6 r.), prueba inequívoca de haberla conquistado".

Con respeto a la política social - a la que no hemos hecho referencia- hay que decir, aunque nos parezca inverosímil y paradójico, Jaime II se ocupó en la misma conquista (a lo que de forma continuada hemos aludimos) de los distíntos grupos étnicos y confesiones que configuraban la denominada Villa de Alicante, (castellanos-aragoneses, sarracenos y judíos).

\section{SÍNTESIS}

En resumen, deberíamos decir que habría que tener en cuenta las fuentes historiográficas silenciadas, debido al carácter inédito de las mismas, que nos hablan de aquel período, consistente en su mayor parte en las CARTAS DEL REY JAIME II, a diferentes príncipes de distintos Reinos y Coronas, extra y peninsulares.

Sin embargo, los documentos conservados más fiables, se encuentran en el Archivo de la Corona de Aragón (A.C.A), existiendo una rica colección de Privilegios.

Es difícil estudiar una tema tan complejo sin previa documentación bibliográfica actual; ya que no podemos aceptar sólo el relato de las Crónicas, como por ejemplo la del caetano MUNTANER.

Con respecto a la figura del rey citado constantemente a lo largo de nuestro trabajo; diremos que fue un monarca que llevó a cabo una buena política, tanto de relaciones comerciales exteriores como con la Corona de Castilla; siendo por tanto un gran estratega a la vez que un luchador incansable e invencible ya que conseguía todo aquello propuesto.

En relación a la política comercial entre Valencia e Italia (después de la conquista), las relaciones, marchan según lo hacen los acontecimientos políticos, sociales y económicos, sin embargo existía una clara inclinación - por parte valenciana- de ayuda a los italianos. Los datos que tenemos por ahora son incompletos, aunque los resultados obtenidos son buenos.

Si nos referimos a las rutas Marítimas, diremos que la más importante se dirigía de Valencia a los puertos italianos. Las más frecuentadas serán las que bordean el Mediterráneo Occidental (desde el Estrecho de Gibraltar a Melilla); es la navegación denominada de "Cabotaje».

La segunda, es la llamada «Ruta de las Islas», que realiza la corriente inversa la antes citada.

Toda la información expuesta, relativa a Relaciones Comerciales pertenece al insigne profesor Magnánimo: Hinojosa Montalvo, José en «las Relaciones Comerciales entre Valencia e Italia durante el Reinado de Alfonso el Magná-(Coses Vedades)». 


\section{BIBLIOGRAFÍA}

A.C.A., Prumiscuum Alfonsi // et Jacobi II, Publ. memorial hist. Español, T. III. Madrid 1852, pp. 432-434 y 432-453. «Vistas de D. Jaime II de Aragón y Don Sancho N de Castilla en Mariza y Monteagudo».

BENAVIDES, A., Memorias de Fernando IV de Castilla, (Contiene la Crónica de dicho Rey). Madrid, 1860.

BRAUDEL, E., El mediterráneo y el mundo mediterráneo en la época de Felipe II.

CABANES PECCURT, Ma Desamparados, Coses y verdades en 1381, Valencia 1972.

CASCALES F., Discursos históricos de la muy noble y muy leal ciudad de Murcia y su reino. $2^{\circ}$ ed. Murcia 1775 . ( $2^{\circ}$ impresión añadida e ilustrada con notas críticas, ed. $4^{\circ}$, Murcia 1980).

X C.H.C.A., «Jaime I su época». Alicante en la politica territorial de las dos Jaimes de Aragón, Comunicación al X.C.H.C.A., Zaragoza 1980, pp. 65-66.

CORTÉS MUÑOZ, F., "Aportación al estudio de las instituciones, mercantiles de la Valencia feral. La condición jurídica de los mercaderes", en Boletín de la Sociedad Castellonense de Cultura XXIV, pp. 218-225.

ESTAL, J.M. del, Conquista y anexión de las tierras de Alicante, Elche, Orihuela y Guardamar al Reino de Valencia por Jaime I/ de Aragón (1296-1308), Alicante 1982 (Caja de Ahorros Provincial).

ESTAL, J.M. del, Papel relevante el «Castrum de Alacant». Según una procisión real inédita de Pedro el Ceremonioso, conservada en el archivo municipal de Alicante. A.E.A.C. número especial.

FERRER NAVARRO, R., Panorámica comercial de Valencia y su puerta a finales del S. XIV, Notas para su estudio. Tesis Doctoral (Valencia, 1972).

GARCÍA SANZ, A., Comandas comerciales barcelonesas de la Baja. Edad Media, Barcelona 1973.

GÓMEZ CAMAÑO, J.L., Páginas de la historia de la Farmacia, Sociedad Nestlé A.E.P.P., Barcelona 1982.

GONZÁLEZ MíNGUEZ, C., Fernando IV de Castilla, Victoria 1976.

HEERS, J., Types de nacires et specialisation des trafics en mediterranée e la fin de mopen Afe. Paris 1958.

HINOJOSA MONTALVO, J. Valencia y el comercio de exportación durante la primera década del siglo XV (Coses vedades). Tesis Doctoral, Valencia 1972.

HISTORIA del Mundo en la Edad Media V.II, desde el S. XII hasta el Renacimiento. (Bajo la dirección de C.W. PreVité OrtOn. Editorial Ramón Sopena, Barcelona 1978. LLINÁRS, J., La música a través de la Historia. Julián Llinárs. 64 pt il. Salvat Editores, Madrid 1982.

MARTIN, J.L., Revista de la Historia de España no 4, Historia 16, Año V, diciembre 1986.

MUNTANER, R., Crónica, C. CXLII, ed. Soldevila, F., Les quatre grans croniques, Barcelona 1971. 
PILES ROS, L., Apuntes para la historia económica comercial de Valencia durante el S. XV. Valencia 1969.

PUGA ORTIZ, J.Mํ.., Torres y Fortificaciones de la Provincia de Alicante, A.E.A.C., Alicante 1992.

RAMOS OLIVERA, A., Historia de España: La Edad Media, Ed. Oasis, México 1974. SANTAMARÍA ARÁNDANEZ, A., Aportación al estudio de la economía de Valencia durante el S. XV, Valencia 1966.

SOLDEVILA, F., Historia de Catalunya, I., Barcelona 1962, 20 ed., pp. 384/404-00.

TORRES FONTES, J., Murcia Castellano. Historia de Murcia V.F., Murcia 1981.

UBIETO, A., "La reconquista del reino de Valencia y Murcia", Ponencia $X$ Congreso de Historia, Corona de Aragón, Zaragoza 1976.

UBIETO, A., Jaime / y su época, pp. 164-165, Zaragoza 1979.

UBIETO, A. y otros, Introducción a la Historia de España, Editorial Teide, Barcelona 1983.

VICENS, J. y SUÁREZ, L., «La economía de la Corona de Aragón en la B.E.M.», en VI Congreso Historia, Corona de Aragón, Madrid 1959.

VICENS, J.; SUÁREZ, L. y CARRERE, Cl., "La economía de los países de la Corona de Aragón en la Baja Edad Media» en el VI Congreso de la Corona de Aragón, Madrid 1959. 


\title{
NOVES DADES SOBRE LES RELACIONS ENTRE EL SOLDÀ DEL CAIRE AL-NĀSIR MUHAMMAD IBN SAYF AL-DİN QALÁWON I EL REI JAUME II
}

\author{
Mercè VILADRICH \\ Universitat de Barcelona
}

Al-Nāṣir Muḥammad ibn Sayt al-dīn Qalāwūn accedeix al poder suprem de la cort mameluca en tres períodes: entre el 692/1293 i el 693/1294, quan encara no tenia 10 anys; després, entre el 698/1299 i el 708/1309; i, la tercera vegada, per establir una de les autocràcies més fortes que han caracteritzat el poder polític mameluc, i més persistents, ja que va prollongar-se des del $709 / 1310$ fins al $741 / 1341^{1}$.

1 Sobre els esdeveniments que caracteritzaren la seva època, vegeu IRWIN, R., The Middle East in the middle ages. The early Mamluk Sultanate 1250-1382. Londres, Sidney: Croom Helm, 1986, amb nombroses referències bibliogràfiques sobre els aspectes més variats de la història del soldanat mameluc. Vegeu també HOLT, P.M., «Mamlūks». A: Encyclopédie de I'Islam, El , vol. VI, Leiden-París, 1987, pp. 305-315. Aquest autor ha publicat recentment un estudi sobre qüestions diplomàtiques immediatament anteriors a l'època que estudiem: HOLT, P.M., Early Mamluk Diplomacy (1260-1290). Treatises of Baybars and Qalāwūn with Christian Rules. Leiden: E.J. Brill, 1995. Sobre el tercer soldanat d'al-Nășir Muḥammad vegeu LEVANONI, A., A Turning point in Mam/uk History. The Third Reign of alNaşir Muhammad Ibn Qalāwūn (1310-1341). Leiden: E.J. Brill, 1995.

Pel que fa a les fonts historiogràfiques àrabs, suggerim consultar les obres següents:

LITTLE, D.P., History and Historiography of the Mamluks. Londres: Variorum Reprints, 1986.

L'historiador egipci, Taqi al-Dīn Ahmad ibn 'Alī al-Maqrīzī. Aquest autor, nascut al Caire el 766/ 1364 i mort el 845/1442, jurista de la cancelleria del soldanat i mestre de tradicions, va redactar, després d'una estada de cinc anys a la Meca, una descripció d'Egipte (Hițț) i una Crònica de les dinasties aiúbida i mameluca (Kitāb al-sulak) que cobreix el període comprès entre el 1166 i el 1441. Existeix una edició deguda a ZIYADA, M.M. et al., Kitäb al-sulūk li-macrifat duwal al-mulūk. 6 vol. El Caire: 1956. QUATREMĖRE, E. va publicar una traducció a partir del ms. de París (BN, Arabe 1727): Histoire des sultans mamlouks de l'Égypte. 2 vol. París: 1845. 
El procés diplomàtic entre el soldà al-Nāșir Muḥammad $i$ Jaume II va ser força enrevessat. Malgrat la seva complexitat, a hores d'ara disposem d'estudis que han aconseguit aclarir els entrebancs de les trobades diplomàtiques i que ofereixen descripcions exhaustives i prou acurades d'aquests esdeveniments, establertes a partir de l'edició de la documentació llatina i catalana conservada, majoritàriament, a l'Arxiu de la Corona d'Aragó ${ }^{2}$. Ens plau, doncs, afegir a aquestes informacions un document àrab inèdit, i que en part complementa les notícies conegudes fins ara.

L'Arxiu de la Corona d'Aragó guarda quatre cartes àrabs a través de les quals es van trametre les respostes del soldà Muhammad ibn Sayf al-dīn Qalāwūn a les

BLOCHET, E., «Moufazzal ibn Abil-Fazail. Histoire des sultans mamluks». A: Patrologia Orientalis. Vol. 14, 1920; vol. 20, 1929.

Abū-l-Fidā'. Al-muhtaşar fi ahbār al-bašar. 4 vol. Istanbul: 1869-1870. Trad. parcial HOLT, P. M. The Memoirs of a Syrian Prince. Wiesbaden: 1983.

Ibn al-Șuqā̄i, Tălĭ kitāb wafayāt al-acyān. SUBLET, J. (ed. i trad.). Damasc: 1974.

Ibn al-Dawādāri. Kanz al-durar wa-jāmic al-ghurar. Vol. VIII. HAARMANN, U. (ed.). El Caire/Freiburg: 1391/1979.

Al-Ğazari. La Chronique de Damas d'al-Jazari (années 689-698 H). Trad. SAUVAGET, J. París: 1949.

Ibn al-Furăt. Tarikh al-duwal wa'l-mulūk. Vol. VIII. ZURAYQ, Q.; IZZ AL-DIN, N. (ed.). EL Caire: 19391941.

Ibn al-Tagrībirdī. Al-nujūm al-zähira fi mulūk Mişr wa'l-Qāhira. Vol. 8. El Caire (sense data).

Anònim. A: Beiträge zur Geschichte der Mamluksultane. ZETTERSTEEN, K.V. (ed.). Leiden: 1929.

2 Vegeu MASIÀ DE ROS, A., La Corona de Aragón y los estados del norte de África. Política de Jaime II y Alfonso IV en Egipto, Ifriquía y Tremecén. Barcelona: Instituto Español de Estudios Mediterráneos, 1951. Amb relació al procés diplomàtic amb Egipte, l'obra publica un magnífic apèndix documental, amb textos cadbals per entendre les sis ambaixades de Jaume II al Caire, els anys 1303, $1305,1314,1318,1322$ i 1327. A més a més, dedica una atenció especial als fets ocorreguts a Alexandria el 1305, quan es produi l'enfrontament dels ambaixadors Eimeric i Fahr al-Dĩn. Vegeu pp. 58-77 i apèndix. L'estudi de MASIÀ DE ROS permet esbrinar la via accidentada per la qual la llista de regals que editem va arribar al seu destí final a Barcelona.

En data més recent GIUNTA, F. va reproduir la narració dels fets establerta per MASIÀ a Aragonesi e catalani nel Mediterraneo. II: La presenza catalana nel levante dalle origini a Giacomo II. Palerm: U. Manfredi Editore, 1959. Trad. cast.: Aragoneses y catalanes en el Mediterráneo. Barcelona: Ariel, 1989. Vegeu pp. 86-122. Ambdós autors donen nombroses referències bibliogràfiques.

Altres estudiosos havien fet referència al procés diplomàtic entre Jaume II i Muhammad ibn Qalāwūn. Encara que la descripció dels fets no hi és completa, cal tenir en compte l'obra de GOLUBOVICH, P.G., Biblioteca Bio-Bibliografica della Terra Santa e dell'Oriente Francescano. 3 vol. Florència: 19061913. GOLUBOVICH edita, acompanyades de versió italiana, les cartes catalanes de les ambaixades del juny del 1303, setembre de 1305, 1318, agost del 1327, i resumeix el contingut de les ambaixades del 1314 i el 1322. Vegeu vol. 3, pp. 73-85, 185-87, 232-236 i 309-317.

D'altra banda, ANTONI DE CAPMANY va traduir al castellà la carta d'una ambaixada catalana al soldà d'Egipte Muammad, datada a Lleida el 1314. Vegeu CAPMANY, A. de, Antiguos tratados de paces y alianzas entre algunos reyes de Aragón y dirigentes principales infieles de Asia y África, desde el siglo XIII hasta el XV. Madrid: 1786. Reed. facs. València: 1974, pp. 32-35. CAPMANY esmenta un registre de l'Arxiu Reial Jacobí II, titulat Legationum Jacobii II, ab anno 1318 ad 1327, fol. 138, on consta l'ambaixada al Caire, de l'any 1322, en què s'enviaren també alguns regals. Vegeu pp. 34-35. 
sol.licituds del rei Jaume II, documents en llengua àrab que corresponen a ambaixades egípcies dels anys 703/1304,705/1306, 714/1315 i 723/1323, i que també han estat editades ${ }^{3}$.

A la segona carta, que ha estat publicada i traduïda al castellà per ALARCÓN i GARCÍA DE LINARES - que tracta de l'arribada a Egipte de l'ambaixador de sa majestat, Aul Eimeric ${ }^{4}$, i de les actuacions que el soldà proposa dur a terme en favor del rei cristià-, s'informa de la tramesa d'uns regals que el soldà del Caire envia al rei a través del príncep Fahr al-Dīn i que, segons el contingut de la missiva, es detallen de forma específica en una llista a part. La carta i l'enviament de regals són resposta a l'ambaixada de Jaume II del 1305, encapçalada per Eimeric, en un segon viatge d'aquest a Egipte ${ }^{5}$. ALARCÓN i GARCÍA DE LINARES van editar i traduir el document principal $^{6}$, datat l'1 de šacbān de l'any 705/26 de febrer de 1306 . Trobaren a faltar, però, la llista dels presents del soldà al rei Jaume, que creiem poder identificar entre els papers de la caixa IV dels documents àrabs de l'Arxiu de la Corona d'Aragó. El document al que fem referència (avui a la caixa IV de documents àrabs, núm. 163) ${ }^{7}$ datat els primers dies de ša ${ }^{c} b a ̄ n ~ 705 / f e b r e r-m a r c ̧ ~ 1306$, conté una llista de regals oferts a Jaume II per part del soldà mameluc Al-Nāșir Muḥammad ibn Sayf al-dīn Qalāwūn, el segon dels fills de Qalāwūn que van ocupar el carreg de soldà. Mentre preparem l'edició del text àrab del document, la seva traducció i l'estudi del significat dels termes específics que designen els objectes de la llista, donem una descripció del document $i$ del seu contingut.

\section{DESCRIPCIÓ}

Es tracta de tres fulls de paper enganxats, d'una amplada uniforme de $14 \mathrm{~cm}$ i de llargades distintes $(23,41 \mathrm{i} 20 \mathrm{~cm})$. El paper és fi, de color groguenc, tinta negra i

3 Les cartes han estat editades i traduïdes al castellà per ALARCÓN, M.A. i GARCÍA DE LINARES, R., Los documentos árabes diplomáticos del Archivo de la Corona de Aragón. Madrid: 1940. Vegeu pp. 350-368. La carta de l'any 1315 conté una llista de regals. A més a més, ALARCÓN i GARCíA DE LINARES editen altres cartes d'Al-Nāşir Muhammad, dues adreçades a l'infant Alfons de Castella (699/1300), una amb llista de regals; vegeu pp. 344-354. Unes altres dues missives són adreçades a Alfons IV d'Aragó (728/1328); vegeu pp. 368-371. Vegeu també HOLT, P.M., «Al-Nāșir Muhammad's letter to a Spanish ruler in 699/1300\%. A: Al-Masāq. 3, 1990, pp. 23-29.

4 Aul Eimeric era un ciutadà noble de Barcelona, amic personal del rei. Havia anat a Egipte anteriorment, encapçalant l'ambaixada del 1303. CAPMANY esmenta altres membres de la seva família, amb el cognom Dusay, que van ocupar càrrecs importants com a representants de la ciutat de BarceIona, a CAPMANY, A. de, Memorias históricas sobre la Marina, Comercio y Artes de la antigua ciudad de Barcelona. 3 vol. Barcelona: Cambra Oficial de Comerç i Navegació, 1961-1963. Vegeu vol. 2, pp. 69,70 i 89.

5 El document català enviat per Jaume II a al-Nâșir Muḩammad ha estat editat per MASIÀ DE ROS, núm. 28, pp. 292-293. Recordem que la resposta a aquest document és la segona carta editada per ALARCÓN i GARCÍA DE LINARES, on s'esmenta l'ambaixador barceloní amb el nom d'Aul Eimeric.

$6 \mathrm{Pp} .355 \mathrm{i}$ seg. Correspon al rotllo àrab núm. IV de l'Arxiu de la Corona d'Aragó.

7 Signatura antiga de l'Arxiu, núm. 19; Inventari Ribera, núm. 154; Inventari Vernet, núm. 163. 
cal-ligrafia oriental. Hi ha escrites algunes vocals i signes auxiliars. L'estat de conservació és bo i s'han enganxat unes bandes de paper al dors per protegir el diploma. És evident que es tracta d'un escrit independent del rotllo de paper que conté la carta, encara que els estils cal.ligràfics d'ambdós instruments són prou semblants i fàcilment identificables com a obres de la cancelleria mameluca.

\section{ESTUDI}

Pel que fa als regals, la tramesa consta, en primer lloc, de 20 peces de teixit.

El costum de regalar vestimenta a les persones estimades o respectades és molt antic al Pròxim Orient, encara que al-Maqrīzī, l'historiador egipci gairebé coetani dels fets que descrivim, atribueixi al califa Hārūn al-Rašĩd l'inici d'aquesta pràctica. DOZY crida l'atenció sobre l'honor que representa, per a qualsevol súbdit, rebre un regal d'indumentària del seu senyor. Fins $i$ tot, hi ha un terme genèric clàssic per designarlo, hilca-tašriff en època més moderna-, que significa «roba honorífica» ${ }^{8}$.

Entre els teixits regalats a Jaume II creiem que, des del punt de vista terminològic, crida especialment l'atenció la peça designada amb la paraula kanğğā, d'origen xinès i introduïda a l'àrab a través del persa. Cal recordar que, entre d'altres, aquesta peça de roba duu țirāz, és a dir, els brodats propis d'un teixit destinat a vestir un rei ${ }^{9}$. D'altra banda, s'han conservat fins els nostres dies diverses peces de roba amb el țirāz del soldà Nāșir al-Dunyā wa'l-Dĩn Muḥammad ibn Qalāwūn, una de les quals és de fabricació xinesa ${ }^{10}$.

L'indument masculí i femení cairota en temps dels mamelucs, destaca per la seva complexitat i per l'evolució soferta des dels temps del Profeta, així com per l'ús de sedes estampades i vistoses en el vestir. Aquestes teles s'han fabricat, al llarg de tota l'edat mitjana, a les localitats artesanals egípcies, com ara Alexandria, Ajmīm, Antinoa, al-'Ažm, Banšăă, Damietta, Dabīq, Dumaira, Erment, al-Farama, Tinnīs i Tuna, conegudes per la producció de teles fines, robes de seda i de lli, estampades amb fil d'or, amb representacions florals o bé amb escenes de cacera, festes, concerts, danses, lluites i combats ${ }^{11}$.

8 DOZY assenyala que el regal de Hārūn al-Rašĩd anava destinat a Yaşyā el Barmekida. Sobre la tradició dels regals de roba, vegeu DOZY, R., Dictionnaire détaillédes noms de vêtements chez les arabes. Amsterdam: 1845, p. 14 i nota 4.

9 "Ibn Khaldūn is very well informed about the institution of the tiräz; according to him, the majesty of the ruler found expression in his name or the royal badge ('alāma) being put in the border (țirāz) of the materials, which were used for his robes of silk or brocade, and the inscription was worked into the web of the material with gold thread or bright coloured yarn, wich stood out against the background of the material. The royal robes were thus distinguished to mark out the royal wearer, or him who received the garment from the ruler as a mark of special favour, to show him honour or appoint him to one of the higher offices in the kingdom». Vegeu «Ṭirāz». A: El, vol. VIII. p. 785.

10 Vegeu "Tirāā". A: El, p. 786.

11 Sobre la producció tèxtil a Egipte i el Pròxim Orient, cal remetre a la consulta dels clàssics i a la bibliografia que esmenten sobre arts manuals i economia domèstica a l'edat mitjana. Vegeu:

MIGEON, G., Manuel d'art musulman, 2 vol. París: Auguste Picard, 1927. Vegeu vol. 2. Arts plastiques 
A vegades els historiadors àrabs clàssics descriuen escenes de donacions de regals, de roba i d'altres objectes com ara punyals, armes o cavalls. La llista de regals d'alNāșir Muahmmad a Jaume II es acompleta amb la fusta de incens, uns arcs de mà ${ }^{2}$, una pomada en un vas de vidre i, tal vegada, un xiulet. És a bastament conegut l'interès de Jaume II i de la seva família més propera per les manifestacions externes de luxe, a través del vestir i de l'ús d'objectes personals opulents, que eren inventariats amb certa periodicitat a la cort catalana ${ }^{13}$. Entre els regals arribats del Caire i els objectes valuosos de la cambra reial hi ha certes coincidències, com ara algunes peces de roba, les botzines o els xiulets, les ampolletes de bàlsam i tota mena d'armes, encara que res no podem afirmar sobre la destinació final dels regals del soldà ${ }^{14}$. L'obsequi d'atuells valuosos de tota mena era una pràctica habitual del rei Jaume II envers els membres de la seva família $i$ els seus servidors més fidels ${ }^{15}$.

Al document objecte d'estudi no s'esmenten ni el nom del soldà ni el nom del rei, fet que ben segur ha entorpit la identificació com a llista de regals que manca a la carta del $1306^{16}$. Efectivament, la data que conté correspon a l'ambaixada de la primeria

et industriels, pp. 279-348. Vegeu també HEYD, W., Histoire du commercedu levant au moyen-âge. Supplément: Articles d'échange entre l'Orient et l'Occident: «Soie», pp. 670-674; “Fils d'or et d'argent», pp. 677-678; «Tissus", pp. 693-701.

12 Alguns destinats a la caçera i d'altres d'aplicació bèlḤlica. Cal recordar que les armes com ara arcs, artinets, fonèvols, gates, gosses, etc. són armes de soldat i no pas de l'armament personal cavalleresc.

13 Vegeu -com a testimoniatge de l'opulència de la cort catalana d'aleshores- les obres que indiquem tot seguit: MARTORELL I TRABAL, F., «Inventari dels béns de la Cambra reyal en temps de Jaume II". A: Anuari de I'Institut d'Estudis Catalans. 1911-1912, pp. 553-567; GONZÁLEZ HURTEBISE, E., Libros de la Tesorería de la Casa Real de Aragón. Barcelona: 1911; i MARTÍNEZ FERRANDO, J., «Datos sobre el vestuario de Jaime II de Aragón». A: Anales y Boletín de los Museos de Arte de Barcelona. 1945. pp. 5-17.

14 Vegeu MASIÀ DE ROS, p. 107. No hem trobat referència a l'entrada dels regals del soldà d'Egipte a la cambra reial de Jaume II. Això no obstant, entre els objectes d'aquesta se'n troben de procedència egípcia i tunisiana, com ara uns bacins pochs de coure de obre d'Alexandria, un traveser ab cuberta de bort d'Alexandia, una pessa de bort d'Alexandria de seda llistada ab camp vermell, iii draps de seda e ii borts d'Alexandria, vii barrats de Tuniç, una pessa de drap appelat bort d'Alexandria a semblant de manil... Vegeu l'inventari del 1323 dels objectes de Jaume II publicat per MARTORELL, F., «Inventari dels béns de la Cambra reyal...". pp. 553-567.

15 Vegeu el diplomatari dels documents d'entrada i sortida d'objectes preciosos de la cambra reial, publicat per MARTÍNEZ FERRANDO, J.E., "La Cámara Real en el reinado de Jaime II (12911327). Relación de entradas y salidas de objetos artísticos". A: Anales y Boletín de los Museos de Arte de Barcelona, XI, 1953-1954. En un altre treball, aquest autor assenyala: «De esta clase de objetos preciosos de ornato de la persona... hizo don Jaime frecuentes repartos, entre sus hijos y la reina, asi como también a otros personajes predilectos. Nos referimos a los cinturones y correas forrados de seda en los que iban "cabadas" perlas y piedras preciosas, carners (zurrones), marsupias (bolsos), orcleria (¿pendientes?), anillos, bocinas, paternosters, espadas y cuchillos...". Vegeu Datos sobre el vestuario de Jaime I/ de Aragón, pp. 13-14. Indica també que el registre de Cancelleria Reial 279 , fol. $1 \mathrm{v}, 44$ i 247 conté la descripció de nombroses armes.

16 D'altra banda, no deixa de ser contradictori que un rei immers en un procés conqueridor contra els musulmans de la península lbèrica rebi un tractament tan afalagador. En qualsevol cas és ben conegut l'interès del soldanat mameluc de ser proveït pels mercaders occidentals. 
de šacbăn del 705/febrer-març del 1306, moment en què Eimeric es disposava a tornar a casa.

Eimeric, però, no va portar els regals a Barcelona i tampoc no va lliurar personalment cap dels dos documents esmentats, sinó que va refugiar-se a Sicíia, irritat pels fets d'Alexandria i pel fracàs envers els objectius del seu rei ${ }^{17}$. D'acord amb la descripció de l'episodi que dona MASIÀ DE ROS, Jaume Il, quan tingué notícia d'aquests incidents, i de la retenció dels captius cristians, va fer certes indagacions a l'entorn del que havia succeït. Eimeric va donar, a través de Pere de Munels, canceller i conseller del rei, una versió pròpia dels fets - d'interès cabdal a l'hora d'esbrinar que se'n va fer dels regals i de la llista que editem-, disculpa en la qual Eimeric assenyalava els esforços personals que havia dedicat a la missió diplomàtica i la inversió generosa en el repartiment de presents als ministres del soldà, entre els quals acusa directament Fahr al-Din per la seva cobdícia.

MASIÀ DE ROS ${ }^{18}$ edita la carta d'Eimeric a Pere de Munels, en la qual l'ambaixador fa saber al rei que li arribaran, juntament amb els documents escrits i a través dels seus companys de viatge, alguns objectes que li envia el soldà del Caire. La valoració que en fa Eimeric és més aviat pobra:

«La pau senyer que es en sarrahinesch e encara la carta quel Soudan tramet al senyor Rey, ab alcunes altres coses que son asats poques, li tramet per los dits frares Lop de Liuranes e per Frare G. de Villalba e per en Pere Duzay frare meu; e els senyor li diran largament les falcies ni les desleyaltats $a b$ que nos son anatz ni con falsament man robat tot quan avia; ni tot quan jo avia pogut trobar a manlevar; e si mes nagues trobat; mes $n$ agueren ahut..." (MASIÀ DE ROS, pp. 297-298).

Així, doncs, varen ser els dos frares $i$, en Pere, el germà d'Eimeric, els qui van arribar finalment a Barcelona, amb la carta, els regals i la llista.

Juntament amb la petició de disculpa enviada des de Sicília, Eimeric va suggerir al rei Jaume II d'enviar quatre o cinc navilis per interrompre el trànsit comercial dels ports mediterranis amb Alexandria:

17 Després d'haver obtingut algunes concessions del soldà amb motiu de la segona ambaixada del 1305 (com ara l'autorització als cristians a practicar la litúrgia lliurement en terres orientals, la fi de les persecucions, la lliure circulació de pelegrins i la llibertat d'alguns presoners), Eimeric havia de tornar a Barcelona amb l'emir Faḩr al-Dīn cUțmān i un grup de captius catalans alliberats. Poc abans de salpar d'Alexandria, alguns d'aquests captius van ser retinguts i tornats a empresonar. Eimeric, irritat a causa dels enganys i la dilació del procés, va salpar abandonant immediatament l'ambaixador Fahr al-Dīn en una platja alexandrina i va fugir d'Egipte en direcció a Sicília amb els presoners alliberats, els regals del soldà i els documents que aquest havia entregat a Fahr al-Din (el text d'un tractat de pau que Eimeric considerava humiliant per al rei Jaume, la carta diplomàtica i la llista d'objectes que ara publiquem). Les pàgines 100-105 de l'obra de MASIÀ DE ROS són cabdals per conèixer les peripècies de tot aquest tràngol diplomàtic (vegeu supra nota 3 ).

18 Vegeu MASIÀ DE ROS, doc. núm. 31, pp. 296-97. 
«... cor es I dels pus grans mals que hom los puixa fer que hom destrenga que crestia noy vaj; per ço senyer cor tota la terra ha gran profit del anar dels crestians; $E$ que no porien viure sens ço que crestians lur porten" (MASIÀ DE ROS, p. 298).

La valoració d'Eimeric posa de manifest que el soldanat mameluc travessa una situació difícil al principi del segle XIV, crisi econòmica descrita pels historiadors contemporanis i perceptible també als ulls de l'ambaixador Eimeric ${ }^{19}$.

Sospitant la vàlua que informacions d'aquest caire podien tenir a l'hora de definir les estratègies bèl.liques i comercials catalanes al Pròxim Orient, destaquem el paper d'observador de la situació del soldanat egipci que juga l'ambaixador de Barcelona. Per la nostra banda, hem recuperat un text àrab de l'Arxiu de la Corona d'Aragó, que completa els editats fins ara, i que s'escau en el context del conflicte diplomàtic entre Jaume II i el soldanat mameluc.

19 Vegeu les anàlisis d'ASTHOR, E., A Social and Economic History of the Near East in the Middle Ages. Londres: 1976; Studies on the Levantine Trade in the Middle Ages. Londres: Variorum Reprints, 1978; Levantine Trade in the Later Middle Ages. Princeton: 1983; i Technology, Industry and Trade. The Levant versus Europe, 1250-1500. Londres: Variorum Reprints, 1992. 


$$
\text { . }
$$




\section{LA CORONA DE ARAGÓN Y LOS ESTADOS PENINSULARES}





\title{
ACTUACIONES DE JAIME II EN LAS ENCOMIENDAS HOSPITALARIAS DE LA CASTELLANÍA DE AMPOSTA: UNA APROXIMACIÓN*
}

\author{
Carlos BARQUERO GOÑI
}

\section{INTRODUCCIÓN}

Las relaciones de Jaime II con la Orden Militar del Hospital o de San Juan ya han sido bien estudiadas por Anthony Luttrell y, más recientemente, por María Bonet. Por ello, con esta comunicación nos proponemos tan sólo ampliar un poco el panorama presentado por estos autores en un nivel más inferior. Pretendemos realizar una aproximación inicial a las medidas tomadas por Jaime II en relación con las encomiendas, que eran las unidades administrativas básicas de la Orden, para acercarnos así a los problemas más comunes que aquejaban a los hospitalarios aragoneses a fines del siglo XIII y comienzos del XIV. Debido a las limitaciones de espacio, hemos decidido excluir de nuestro estudio a las encomiendas que se desgajaron en 1319 de la principal circunscripción hospitalaria de la Corona de Aragón, la Castellanía de Amposta, para pasar a formar el priorato de Cataluña'.

Como fuente principal, hemos utilizado el archivo de la propia Castellanía de Amposta, conservado hoy en el Archivo Histórico Nacional. También hemos consultado los documentos de Jaime II referentes a encomiendas valencianas del Hospital que se encuentran entre los fondos de la Orden de Montesa del mismo Archivo. Sin embargo, hemos procurado contrastar esta información con el abundante material

* La presente comunicación ha sido realizada con la ayuda de una beca postdoctoral de la Fundación de Caja de Madrid.

1 A. LUTTRELL, The Hospitallers in Cyprus, Rhodes, Greece and the West, Londres, 1978, XI pp. 2-12. M. BONET DONATO, La Orden del Hospital en la Corona de Aragón, Madrid, 1994, pp. 59-66. J. MIRETY SANS, Les cases de Templers y Hospitalers en Catalunya, Barcelona, 1910, pp. 388-9. 
publicado procedente del Archivo de la Corona de Aragón. Somos conscientes de que este último Archivo guarda mucha más documentación sobre el tema, que habrá que consultar en su momento para un análisis más detallado, completo y sistemático.

\section{CONFIRMACIONES DE PRIVILEGIOS A LAS ENCOMIENDAS}

En primer lugar, debemos señalar que tras haber confirmado los privilegios de la Orden, Jaime II ordenaba explícitamente a sus oficiales que los observasen en algunas encomiendas. Sabemos que así lo hizo en 1292 al menos para las bailías de Cervera del Maestre y de Aliaga, aunque es probable que redactara otros documentos parecidos en beneficio de más encomiendas ${ }^{2}$.

\section{JAIME II Y LAS AGRESIONES SUFRIDAS POR LAS ENCOMIENDAS}

Alguna vez Jaime II tuvo que ordenar a sus oficiales que protegieran a las encomiendas hospitalarias. En 1293 mandó al justicia y jurados de Ejea de los Caballeros que defendieran al comendador y a los hombres del Hospital de Pilot ${ }^{3}$. Los hospitalarios necesitaban realmente esta protección porque da la impresión de que durante aquella época sus encomiendas estaban sufriendo continuas presiones por parte, sobre todo, de elementos de la nobleza laica. El caso del comendador de Torrente de Cinca con Fraga y sus señores, los Moncada, es bastante aleccionador a este respecto.

Al parecer, en 1295 algunos habitantes de este lugar hospitalario hicieron ciertas injurias a unos judíos de Fraga. Entonces el baile de Fraga con una comitiva de hombres de la localidad atacó a Torrente de Cinca, haciendo tres prisioneros. Jaime II tuvo que mandar a doña Teresa de Moncada, viuda de Ramón de Moncada y señora de Fraga, que reparase todos los daños infringidos al comendador y hombres de Torrente de Cinca, y liberase a los tres prisioneros. En realidad, la causa profunda del enfrentamiento era la pretensión de Fraga de que Torrente y Torralba estuvieran sujetas a su jurisdicción. Parece que en un principio Jaime II apoyó esta idea, pero en 1295, a propuesta del comendador de Torrente de Cinca, ordenó al sobrejuntero de Huesca que no obligase a los hombres de Torrente y de Torralba a aceptar la jurisdicción del señor de Fraga, Guillermo de Moncada, hasta que no le constase la veracidad de aquella pretensión. El conflicto se prolongó algunos años más. Una sentencia judicial adjudicó la jurisdicción civil y criminal de Torrente al Hospital, pero cuando en 1300 un musulmán de la villa forzó fraudulentamente una casa y el comendador de Torrente se negó a entregarlo a la jurisdicción de Fraga, Guillermo de Moncada, señor de Fraga, capturó a tres musulmanes de la villa de Torrente de Cinca. La Orden recurrió entonces a Jaime II, quien mandó a Guillermo de Moncada que liberase a los tres musulmanes ${ }^{4}$.

2 Archivo Histórico Nacional, Sección de Órdenes Militares, carpeta 483, no 153 y carpeta 586, no 128 .

3 J. DELAVILLE LE ROULX, Cartulaire général de l'Ordre des Hospitaliers de $S$. Jean de Jérusalem, 1100-1310, París, 1894-1906, III p. 619, ํำ 4215.

4 AHN, OOMM, carpeta $691, n^{\circ} 26, n^{\circ} 27$ y $n^{\circ} 32$. 
En 1309 el conflicto volvió a recrudecerse. El comendador de Torrente había hecho azotar a una musulmana por haber cometido un hurto. Entonces Guillermo de Moncada envió a algunos hombres armados de Fraga a Torrente de Cinca, quienes hicieron una entrada violenta alli. Jaime II tuvo que volver a intervenir, ordenando a Guillermo de Moncada que diera la debida satisfacción y enmienda al comendador y hombres de Torrente por todos los daños sufridos 5 .

Un caso parecido en otra encomienda ocurrió en 1304, cuando Vallesio de Ancillion quitó ciertos bienes de la bailía de Barbastro a los hospitalarios. Entonces el rey mandó al sobrejuntero de Ribagorza que le obligara a devolverlos ${ }^{6}$.

Especial importancia parecen tener las agresiones relacionadas con cuestiones ganaderas. Con frecuencia los ataques de miembros de la nobleza a las encomiendas sanjuanistas tenían como objetivo el robo de ganado, y el monarca tuvo que tomar repetidas medidas al respecto. En 1291 ordenó al sobrejuntero de Huesca que forzara a P. Romeo de Puyo de Cinca a restituir a los hospitalarios de Mallén el ganado que les había arrebatado haciendo una incursión sobre sus tierras. En 1293 Guillermo de Moncada, señor de Fraga, y algunos hombres de Tortosa robaron muchas cabezas de ganado del término sanjuanista de Cervera del Maestre, que condujeron al término de la ciudad de Tortosa. El rey tuvo que ordenar al comendador templario y a los hombres de Tortosa que restituyeran aquellos animales a los hombres del Hospital. Finalmente, en 1295 el monarca forzó a Artal de Luna y a Pedro de Ayerbe a devolver los ganados robados a los hospitalarios de Mallén?

Las intrusiones en el uso de los pastos de las encomiendas constituían otra fuente de problemas que requerían la atención de Jaime II. Bien informados estamos del conflicto suscitado en los últimos años del reinado por una dehesa ubicada en Pitarque y dependiente de la encomienda sanjuanista de Aliaga. En 1324 Jaime II, a petición de Jordano Royo, arrendador de la bailía de Aliaga, mandó a sus oficiales que mantuvieran a los hombres de Pitarque en la posesión de una dehesa boyal que les había concedido el Castellán de Amposta. Sin embargo, el noble Alfonso Fernández y los habitantes de Hijar, Belchite y La Puebla de Hijar, quienes disfrutaban del derecho de pasto en el término de Pitarch, consideraron que aquella dehesa ocupaba la mayor parte de dicho término en su perjuicio. Como el Justicia de Aragón, Jimeno Pérez de Salanueva, no quería pronunciarse sobre aquella cuestión con el pretexto de la carta real de 1324 que acabamos de citar, consiguieron que en 1327 el monarca ordenara al Justicia que procediera en aquella causa según el fuero sin que aquel documento sirviera de impedimento. Sin embargo, en octubre de aquel mismo año el procurador del Hospital demostró al rey que aquella dehesa no ocupaba la mayor parte del término de Pitarque, sino que el valle elegido por el Castellán para tal fin no llegaba a media legua de longitud y media milla de ancho. Por ello Jaime II mandó a Jimeno Pérez de

5 AHN, OOMM, carpeta 691, $\mathrm{n}^{\circ} 34$.

6 DELAVILLE, Cartulaire, IV, p. 77, ํํ 4637.

7 DELAVILLE, Cartulaire, III, p. 602, n 4178. AHN, OOMM, carpeta 522, $n^{\circ}$ 506. F. de MOXOY MONTOLIU, La casa de Luna (1276-1348), Munster, 1990, p. 294 y p. 132, nota 9. 
Salanueva que, respetando la magnitud de Pitarque y la condición de sus habitantes, decidiera brevemente lo que debiera hacerse sobre aquella dehesa ${ }^{8}$.

Otra fuente de problemas para las encomiendas hospitalarias lo podía constituir el abastecimiento de sal. La bailía sanjuanista de Aliaga se aprovisionaba de sal en las salinas de Segura en virtud de un privilegio de Jaime I. Sin embargo, en 1308 el custodio de las salinas reales de Arcos de las Salinas obligó al comendador y a los hombres de Aliaga a usar su sal y no otra. Ellos recurrieron entonces a Jaime II, quien mandó a Bartolomé Tarin, sobrejuntero de Zaragoza, que le certificara la veracidad de las alegaciones presentadas por los de Aliaga para que el monarca pudiera decidir. En efecto, Bartolomé Tarin informó al rey de que el comendador y los hombres de Aliaga, Villarroya de los Pinares y Fortanete habían utilizado un privilegio de Jaime I de 1276 que no estaba derogado por falta de uso. En consecuencia, en 1309 Jaime II ordenó al procurador y baile de Aragón, al custodio de las salinas de Arcos y a todos sus oficiales que permitieran al comendador y a los habitantes de los lugares citados utilizar la sal de Segura'.

Una última fuente de conflictos para las encomiendas de la Castellanía que exigió la intervención del monarca fueron las cuestiones relativas al uso del agua. En 1293, a petición del comendador de Barbastro, el rey mandó al justicia de Barbastro que forzase a Ozende, dama de Castellazo, a que permitiera a los hospitalarios de Barbastro reparar la azuda que alimentaba a sus molinos en Barbastro. En 1296 fray Raimundo de Ripellis, gran comendador del Hospital en España, se quejaba a Jaime II porque el baile de Tortosa no permitía a la Orden y a los hombres de Ulldecona el uso del agua del río de la Sénia que venía por una acequia nueva del término de Ulldecona, a pesar de que los comendadores sanjuanistas y los habitantes de Ulldecona siempre habían usado el agua de dicho río para regar sus tierras y mover sus molinos. El monarca encomendó la resolución de la causa a Raimundo de Toylano, juez de su curia, y a Andrea de Alliecar, canónigo de la Catedral de Tarazona ${ }^{10}$.

Sin embargo, en este tema no siempre eran las encomiendas hospitalarias las agredidas. En 1317 los hombres de Peñíscola protestaron al rey porque el comendador de Ulldecona o los habitantes de dicha localidad habían construido cierta acequia por la que fluía agua del río de la Sénia, de manera que los de Peñíscola no recibían la mitad del agua que les correspondía de aquel río en el verano y en las épocas de sequía. En consecuencia, Jaime II mandó al comendador de Uildecona que destruyera aquella acequia"1.

\section{IV. «FUGAS» DE VASALLOS DE LAS ENCOMIENDAS}

Un tema interesante que aparece bastante en la documentación de Jaime II referente a las encomiendas de la Castellanía de Amposta es el de la pérdida de vasallos

8 AHN, OOMM, carpeta $620, n^{0} 59$.

9 AHN, OOMM, carpeta $619, n^{0} 46$ y carpeta $620, n^{\circ} 55$.

10 DELAVILLE, Cartulaire, III, p. $635, n^{\circ} 4230$ y p. $692, n^{\circ} 4327$.

11 AHN, OOMM, carpeta 528, nº 693. 
que se van a habitar otras poblaciones vecinas. Algunos nobles recibían como vasallos suyos a los habitantes de lugares sanjuanistas en grave perjuicio del Hospital. Sabemos que esto llegó a ser un grave problema para la encomienda de Torrente de Cinca. En 1309 el procurador de la Orden se quejó al rey porque Guillermo de Moncada, senescal de Cataluña, y Guillermo de Entenza así lo hacían cọn los hombres del Hospital de Torrente de Cinca. Jaime II tuvo que ordenar a los dos nobles que liberasen de su vasallaje a aquellos hombres si no vivían en lugares de su señorío. Un problema parecido lo encontramos en 1314. El concejo de Ejea de los Caballeros impedía a los freires sanjuanistas cobrar derechos a los hombres del lugar hospitalario de Pilot por los bienes que tenían en aquella localidad cuando transferían sus domicilios a Ejea. El monarca mandó entonces al justicia y al concejo de Ejea que obligaran a aquellos hombres de Pilot a contribuir a la Orden por esos bienes mientras retuvieran su posesión ${ }^{12}$.

\section{DISPUTAS POR CUESTIONES DE LÍMITES TERRITORIALES}

Otra fuente de continuos problemas para las encomiendas de la Castellanía durante el reinado de Jaime II era la delimitación de sus términos frente a los poderes vecinos. En 1300 el rey ordenó al baile, justicia, jurados y hombres de Morella que terminasen la disputa pendiente entre ellos y los hombres del castillo hospitalario de Cervera del Maestre relativa a los límites entre ambos territorios. En 1305 el mismo monarca encomendó al Justicia de Aragón y a Gilles de Jaca, baile general de Aragón, la resolución del pleito que enfrentaba a la Orden con Guillermo de Moncada por los límites de Caspe y Fraga. Jaime II mandó en 1307 al justicia de Calatayud que obligase a los habitantes de Milmarcos, en Castilla, a dejar el disfrute de una parte del territorio fronterizo de Campillo de Aragón al comendador sanjuanista de Calatayud. Finalmente, tras una queja del procurador del Hospital, el rey ordenó en 1321 al vicario de Tortosa y de la Ribera del Ebro que no permitiera que los habitantes de Torrente de la Galera ocuparan parte de los términos de Ulldecona ${ }^{13}$.

\section{PROBLEMAS SUSCITADOS EN ANTIGUAS ENCOMIENDAS TEMPLARIAS}

Como es conocido, en 1317 el Papa Juan XXIl otorgó a la Orden de San Juan las antiguas posesiones del Temple en Aragón y Cataluña, mientras que casi todos los bienes hospitalarios y templarios en Valencia fueron asignados a la nueva Orden de Montesa. De esta manera la Castellanía de Amposta recibió un buen número de antiguas encomiendas templarias. Sin embargo, los bienes del Temple habían permanecido secuestrados durante una década bajo la administración real ${ }^{14}$. Probablemente

12 AHN, OOMM, carpeta $691, n^{\circ} 35$ y $n^{\circ} 36$; carpeta $658, n^{\circ} 100$.

13 DELAVILLE, Cartulaire, III, p. 817, nº 4519; IV, p. 135, no 4731 y p. 157, nº 4770. AHN, Sección de Códices, 662 B, pp. 203-204.

14 M.L. LEDESMA RUBIO, Templarios y Hospitalarios en el Reino de Aragón, Zaragoza, 1982, pp. 219-235. 
este factor contribuyó a difuminar los antiguos derechos templarios en aquellas bailías. El hecho es que encontramos varios indicios de que los hospitalarios tuvieron dificultades para ocupar el vacío de poder dejado por los templarios en sus encomiendas y se hizo necesaria la intervención de Jaime II en varias ocasiones. El fenómeno lo hemos encontrado documentado en las bailías de Horta de San Juan, de Monzón y del Temple de Zaragoza.

En el caso de Horta se trataba de un problema de límites territoriales. Los hospitalarios tuvieron que esforzarse por volver a clarificar los términos de Horta, difuminados durante el periodo de administración real de la bailía. En 1294 el rey había conseguido los derechos del Temple en Tortosa a través de una permuta ${ }^{15}$. Con este motivo los términos de Horta de San Juan y de Miravet fueron amojonados. Sin embargo, en la época de la disolución de aquella Orden Bernardo de Podio, ciudadano de Tortosa y propietario del castillo de Pauls, derruyó aquellos mojones. Cuando los hospitalarios se hicieron cargo de los bienes templarios, el comendador sanjuanista de Horta pleiteó con Bernardo de Podio y logró una sentencia favorable del infante don Jaime para que los mojones fueran repuestos. En 1320 Jaime II encomendó a Bernardo de Locustaria, vicario de Tortosa, y al arcipreste de Morella la tarea de comprobar si aquellos mojones estaban colocados en el mismo sitio donde habían sido puestos en la época de la permuta de Tortosa. Ese mismo año el monarca mandaba a Bernardo de Podio que respetara aquella mojonera ${ }^{16}$.

Inmediatamente después se suscitó otra disputa entre Pedro de San Minato y el comendador de Horta por los términos de Castells y Horta. En junio de 1321 Jaime II confió la resolución del pleito primero al oficial Geraldo de Guardia y a Guillermo de Cereto, ciudadano de Tortosa. Sin embargo, al mes siguiente el rey encargaba a Domingo de Pulcrotalio, arcipreste de Morella, y a Guillermo Molinero, jurisperito de Lérida, que finalizaran la causa y levantaran los mojones necesarios para delimitar los términos. A pesar de ello, la disputa se prolongó durante algunos años más. En 1322 Jaime Il ordenó a su escriba, Pedro Lupeti, que fuera a los términos de Horta y de Castells para reconstruir los hitos de la delimitación hecha en época de los templarios que encontrara destruidos. Todavía más de un año después el monarca mandaba al caballero Bernardo de Puente y a Pedro Talbeci, juez de su curia, que resolvieran el pleito entre la ciudad de Tortosa y Pedro de San Minato, y el comendador y los hombres de Horta sobre los límites de sus términos ${ }^{17}$.

En el caso de Monzón los hospitalarios se encontraron con que no se les reconocía algunos de los derechos que, según ellos, habían disfrutado los templarios. Los Concejos de Lérida, Zaragoza y Huesca tomaban prendas a los hombres del Hospital porque a sus ciudadanos se les exigía el cobro de un peaje al pasar sus mercancías por Monzón, como se hacía en época de los templarios. En 1320 Jaime II tuvo que mandar a los concejos mencionados que dejaran de tomar prendas con ese motivo y

15 E. GUINOT, Feudalismo en expansión en el norte valenciano, Castellón, 1986, p. 28.

$16 \mathrm{AHN}$, OOMM, carpeta $672, \mathrm{n}^{\mathrm{0}} 13$ y $\mathrm{n}^{\mathrm{0}} 15$.

17 AHN, OOMM, carpeta 486, $n^{\circ} 249$; carpeta $672, n^{\circ} 16, n^{\circ} 17$ y $n^{\circ} 18$. 
ordenó al vicario de Lérida y de Pallars, y al sobrejuntero de Zaragoza que defendieran al Hospital en su disfrute del cobro de peaje en Monzón. Por la misma época también se suscitó un pleito sobre si era el rey o la Orden del Temple quien había recibido las caloñas de los homicidios en Monzón y su bailía antes de la disolución de dicha Orden. Con este motivo fueron hechas algunas prendas al Hospital. En 1322 Jaime II mandó al justicia de Aragón, don Jimeno Pérez de Salanueva, que terminara este proceso ${ }^{18}$.

Por su parte, el colector del tributo real de la cena en la antigua casa del Temple de Zaragoza seguía exigiendo al comendador sanjuanista que se había hecho cargo de ella los 200 sueldos jaqueses que correspondían a los hombres de Alfocea en esa cena, cuando el monarca todavía no había devuelto aquel lugar al Hospital. En 1319 Jaime II tuvo que ordenarle que no demandara esta cantidad hasta que él no hubiera entregado Alfocea a la Orden ${ }^{19}$.

\section{LAS ENCOMIENDAS COMO UNIDADES FISCALES}

Buena parte de la documentación de Jaime II que hemos hallado referente a encomiendas de la Castellanía de Amposta trata de cuestiones tributarias. Da la impresión de que las bailías hospitalarias constituian unidades fiscales a efectos del cobro de impuestos. En especial, la contribución debida por las encomiendas al rey sobre la que estamos mejor informados es el derecho de cena. En 1297 el monarca mandaba al comendador de Mallén que pagase su parte dentro del derecho de cena impuesto a Mallén. Simultáneamente ordenaba al recaudador del tributo, Artaud de Luna, que forzara a abonarlo al comendador de Mallén. En 1298 Jaime Il estableció las cantidades que debían entregarle las encomiendas sanjuanistas de Valencia, Mallén, Villafamés, Aliaga y Zaragoza en concepto de cena durante el año 1299. En 1300 el monarca ordenaba a Pedro Martí, escriba regio, y a su sustituto Pedro de Claperis, ciudadano de Valencia, que exigieran al comendador de la casa del Hospital de Valencia y a los hombres de Villafamés las cenas de aquel año, a pesar de que un mandato anterior suyo les había ordenado que no lo hicieran. Finalmente, en 1301 Jaime II mandó a los comendadores sanjuanistas de Calatayud y de Añón que le abonasen cada uno 400 sueldos jaqueses en concepto de cena. De todas formas, ocasionalmente alguna encomienda de la Castellanía conseguía la exención. En 1312 el monarca otorgó a los hombres de Ulldecona que no pagaran cenas al procurador de Cataluña mientras su hermanastro, fray Sancho de Aragón, tuviera la bailía de Amposta ${ }^{20}$.

Las cantidades producidas por estas cenas podían ser concedidas a algún noble por el rey. Así, en 1320 Jaime Il asignó a Pedro de Luna una renta anual de 500 suel-

18 F. CASTILLÓN CORTADA, "Los sanjuanistas de Monzón (Huesca) (1319-1351)", Cuadernos de Historia "Jerónimo Zurita", 47-48 (1983), pp. 147-148 y p. 170.

19 AHN, Códices, 659 B, p. 53.

20 DELAVILLE, Cartulaire, III, p. 718, no 4379 y p. 741, no 4416; IV, p. 1, no 4526. AHN, OOMM, carpeta 524, $\mathrm{n}^{\circ} 551$. J. MIRET $Y$ SANS, Les cases..., p. 412. 
dos jaqueses proveniente de la cena que el comendador hospitalario de Zaragoza y los hombres de la Almunia de doña Godina, Cabañas y Alpartil debían pagarle cada año. Sin embargo, a veces los beneficiarios eran miembros de la Orden, como el comendador de Samper de Calanda y de Zaragoza en 1305. En 1308 Jaime II otorgó a Teresa Artal de Alagón, monja del monasterio sanjuanista de Sijena, una renta vitalicia de 300 sueldos jaqueses anuales provenientes de la cena que el comendador hospitalario de Barbastro estaba obligado a abonarle ${ }^{21}$.

Las encomiendas de la Castellanía también debían pagar otro impuesto, el de monedaje. En 1301 el rey anunció a los recaudadores de este tributo que él había concedido a su hermanastro Sancho de Aragón, miembro de la Orden de San Juan, el derecho de percibir 5.000 sueldos de Barcelona sobre el primer monedaje que tuvieran que pagar los hombres del Hospital en el reino de Valencia o, a falta de éste, sobre el monedaje de las bailías sanjuanistas de Aliaga, Caspe y Samper de Calanda ${ }^{22}$.

\section{CONTROLES REGIOS EN LA DESIGNACIÓN DE COMENDADORES}

Desde 1317 los comendadores hospitalarios estaban obligados a prestar juramento y homenaje al rey antes de comenzar a administrar sus encomiendas. En efecto, sabemos que Jaime II así lo exigió en 1319 y 1321. Además, en el caso especial de Sijena parece que Jaime II se reservó la elección del comendador en $1324^{23}$.

\section{SOLICITUDES DE DOCUMENTACIÓN A LAS ENCOMIENDAS}

El papel de algunas casas del Hospital como depósitos de documentación regia en esta época es conocido ${ }^{24}$. Sabemos que Jaime II pidió documentos conservados en encomiendas de la Castellanía de Amposta. En 1312 solicitó a Ramón de Ampurias, lugarteniente del Maestre en la Castellanía, la escritura de donación por el rey Pedro III de Castro-pintano a Martí de Alaet. El documento estaba guardado, junto con otros, en la casa del Hospital de Huesca ${ }^{25}$.

En efecto, parece que los hospitalarios eran celosos guardianes de archivos en sus encomiendas. Tras la fundación de la Orden de Montesa, el rey tuvo que ordenar

21 F. de MOXÓ, La casa..., pp. 429-430, no 152. DELAVILLE, Cartulaire, IV, p. 115, nº 4695. R. SAINZ DE LA MAZA LASOLI, El monasterio de Sijena. Catálogo de documentos del Archivo de la Corona de Aragón. I (1208-1348), Barcelona, 1994, p. 88, nº 260.

22 DELAVILLE, Cartulaire, IV, p. 11, no 4541.

23 S. PAULI, Codice diplomatico del sacro militare ordine Gerosolimitano, Lucca, 1733-1737, II, pp. 54-55. F. de MOXO, La casa..., pp. 422-423, $\mathrm{n}^{\circ}$ 142. J. VINCKE, Documenta selecta mutuas civitatis Arago-Cathalaunicae et ecclesiae relationes illustrantia, Barcelona, 1936, p. 260, no 361. J.E. MARTÍNEZ FERRANDO, Jaime // de Aragón. Su vida familiar, Barcelona, 1948, II, p. 299, № 413 y p. 306, no 423.

24 F. UDINA MARTORELL, Guia histórica y descriptiva del Archivo de la Corona de Aragón, Madrid, 1986, pp. 28-31. J.M. del ESTAL, El reino de Murcia bajo Aragón (1296-1305). Corpus documental I/2, Alicante, 1990, pp. 94-95, nº 97. DELAVILLE, Cartulaire, IV, p. 221, nº 4874. R. SÁINZ DE LA MAZA LASOLI, El monasterio de Sijena..., p. 88, n 259.

25 J. MIRET Y SANS, Les cases..., p. 417. 
a los comendadores sanjuanistas de Aliaga y de Amposta que hicieran entrega de la documentación referente a los antiguos bienes hospitalarios que ahora pasaban a Montesa en $1320^{26}$.

\section{OTRAS ACTUACIONES DEL REY EN ENCOMIENDAS DE LA CASTELLANÍA}

Además de los temas vistos hasta ahora, que eran los más frecuentes, las actuaciones de Jaime II en encomiendas de la Castellanía de Amposta podían tener otros motivos muy variados ${ }^{27}$. Quizá debamos señalar aquí que la intervención del monarca aragonés en el reino de Murcia también afectó a las encomiendas sanjuanistas, aunque parece que su participación fue reducida. En 1296 Jaime II prohibió al justicia y jurados de Burriana que obligaran a los hombres que el Hospital tenía en la localidad a participar en la expedición. Sin embargo, en 1300 el trigo y la cebada almacenado en las encomiendas de la Orden en el reino de Valencia sirvió para aprovisionar a los castillos fronterizos del reino de Murcia por orden del rey ${ }^{28}$.

\section{CONCLUSIÓN}

En definitiva, parece que las encomiendas atravesaban un periodo bastante conflictivo y que el intervencionismo regio alcanzaba en ellas hasta asuntos aparentemente menores.

26 AHN, OOMM, carpeta $485, n^{\circ} 216$ y $n^{\circ} 225$ bis.

27 DELAVILLE, Cartulaire, III, p. 680, nำ 4306, III, p. 736, nº 4410 y IV, p. 187, n² 4811. J. DELAVILLE LE ROULX, “Les Archives de l'Ordre de L'Hôpital dans la Péninsule lbérique», Nouvelles Archives des Missions Scientifiques et Littéraires, IV (1893), p. 195.

28 DELAVILLE, Cartulaire, III, p. 683, no 4312 y p. $798, n^{\circ} 4489$. 



\title{
JAIME II Y LA «CONSTITUCIÓN» DE LA CORONA DE ARAGÓN
}

\author{
José María DE FRANCISCO OLMOS \\ Universidad Complutense de Madrid
}

Durante mucho tiempo, la figura de Jaime II en sus aspectos constitucionales ha sido ensombrecida por la de su nieto, Pedro IV el Ceremonioso, al que tradicionalmente se atribuyen muchas de las modificaciones constitucionales que en realidad pertenecen por derecho a Jaime II. Veremos brevemente como el rey acepta y consolida el "pacto» con el reino que se realiza mediante las ceremonias de coronación, como se intentará mitificar la figura del rey y la dinastía, y por fin la manera de asegurar la sucesión y consolidar la figura del primogénito dentro de la administración de la Corona, hecho trascendental en el que nos detendremos con mayor amplitud.

\section{LA CORONACIÓN Y SUS CEREMONIAS}

- El uso del título real de Aragón. Jaime II no usó el título de rey hasta después de tomar posesión del reino y jurar sus fueros, cosa que hizo durante las cortes de Zaragoza (1291), aunque sin ser solemnemente coronado ya que Jaime ya había sido ungido rey de Sicilia, y no consideró oportuno repetir las ceremonias'.

No hay duda de que Jaime quería evitar los problemas que había tenido Alfonso III por titularse rey antes de las ceremonias de toma de posesión y jura, a lo que había

1 Jaime II no fue coronado en Aragón, ya que anteriormente había sido ungido y coronado como rey de Sicilia. El hecho de no repetir las ceremonias se debió a dos razones: una que la unción no es reiterable, dado su carácter es en sí irrepetible; por otra parte las ceremonias de la coronación en Aragón estaban muy mediatizadas por su especial relación con la Santa Sede, ya que el reino era feudatario del Papado y en esos momentos las relaciones de Jaime II con Roma eran extremadamente tirantes, a lo que hay que añadir que al haber depuesto los papas a los reyes de la Casa de Barcelona tras la invasión de Sicilia la coronación podría haberse considerado una provocación. 
que añadir que la Santa Sede había privado de sus estados y título a Pedro III y sus sucesores, por lo que Jaime II decidió actuar en este tema con el mayor de los cuidados, partiendo de la base de que su «honor» personal quedaba a salvo ya que a todos los efectos podía usar el título real de Sicilia.

- El derecho de sucesión y la integridad de la herencia. Asimismo Jaime II declaró recibir la Corona no por el testamento de su hermano, sino por derecho sucesorio, rechazando la política de particiones ${ }^{2}$. Un objetivo que llevará a sus últimas consecuencias en 1319, durante las cortes de Tarragona, al aprobar en ellas el llamado Privilegio de Unión, por el cual se consagraba la indivisibilidad de la Corona de Aragón, desde entonces el rey debía jurar mantener la unidad y si faltaba a su juramento los estados podían resistirle por la fuerza. Este juramento de indivisibilidad será prestado el día de la coronación del monarca, formando parte del conjunto de promesas solemnes del soberano ante los representantes de la Corona ${ }^{3}$.

- Las protestaciones. Igual que hacían sus antepasados desde la época de Pedro III el rey realizó una protesta formal, afirmando que «no recibía la corona con reconocimiento que por el reino debiese hacer a la Sede Apostólica, conservando su derecho cuanto a ser libre y exempto, como lo había sido y lo era en lo temporal ${ }^{4}$. Con este acto de nuevo Jaime II intenta mostrar sus independencia respecto de otros poderes, en este caso el Papado.

- El juramento. Al no coronarse nuevamente Jaime II no tiene que enfrentarse al problema de si el juramento de los fueros debía hacerse antes o después de la coronación; lo que sí sabemos es que el rey realizó el juramento como primer acto de las Cortes de Zaragoza, como ya mencionamos. Este acto institucional era importantísimo e ineludible, simbolizando la continuidad y vigencia de las ideas contractuales entre el rey y el reino ${ }^{5}$. Y Jaime II entenderá este juramento no como una cortapisa a su poder

2 Alfonso III en su testamento (10-III-1287) dejó como heredero de la Corona a su hermano Jaime, siempre y cuando abandonara el trono siciliano, en caso contrario debía sucederle su otro hermano, Federico. Jaime no aceptó este testamento y tras presentarse en Barcelona reclamó el trono por derecho de primogenitura y en virtud del testamento de Pedro III (3-VI-1282), que le nombraba heredero en caso de morir el primogénito Alfonso. Esta protesta y declaración de derechos la volvió a realizar ante las Cortes de Zaragoza cuando juró los fueros (Jerónimo ZURITA, Anales de la Corona de Aragón. Zaragoza, 1592, libro IV, capítulos CXXII y CXXIII. Edición de Ángel CANELLAS, Zaragoza 1970, tomo II, pp. 416-422).

3 Bonifacio PALACIOS, La Coronación de los Reyes de Aragón 1204-1410, Valencia, 1975, pp. 188-193.

4 Este texto recogido de J. BLANCAS, Coronaciones de los serenísimos reyes de Aragón, con dos tratados del modo de celebrar Cortes, Zaragoza, 1641, p. 25; es el único testimonio que nos habla de este acto, ya que no' se conserva el documento notarial que el rey debió hacer para que se oficializase su protesta, como lo hicieron antes de él Pedro III y Alfonso III, cuyas actas notariales sí se conservan.

5 De nuevo hay que esperar al reinado de Pedro IV para que la costumbre se convierta en ley, siendo sancionada por el rey en las Cortes de Zaragoza de 1348. De ese momento el Privilegio General y su Declaración por Jaime Il pasan a formar parte integrante del Fuero de Aragón. Ver P. SAVALL y S. PENEN, Fueros, observancias y actos de Corte del reino de Aragón, Zaragoza, 1866 (reedición Zaragoza 1991), tomo I, pp. 21, 25 y 26. 
sino como una nueva arma para luchar contra los que intenten reducir su campo de acción, como lo veremos en el siguiente apartado.

\section{EL MITO DE LOS FUEROS Y EL MITO DEL REY}

Jaime II decide aceptar "los fueros" como base de su actuación interior en la Corona, no luchar contra ellos, de esta manera se convierte en principal defensor de éstos, arrebatando a los nobles la bandera del foralismo; y desde esta perspectiva pudo reducir mejor a la nobleza (altercados de 1301 y 1325 especialmente) y a las ciudades cuando sus pretensiones eran excesivas.

Ahora es el rey quien acude a las Cortes y al Justicia para reclamar el cumplimiento de los fueros contra las exigencias de los nobles, y consigue sus objetivos, las sentencias del Justicia se convierten en inapelables. Los fueros se convierten así en la primera fuente legal de la Corona, a la que tanto el rey como los súbditos deben someterse, alcanzando la categoría de mito, en tanto en cuanto aparece en la conciencia general la teoría de que en Aragón antes fueron los fueros y después el rey, y que éste sólo lo era verdaderamente cuando los juraba, pudiendo ser depuestos si los incumplían ${ }^{6}$.

Inmediatamente el rey se lanzaría a consolidar, como contrapeso de lo anterior, el mito del rey, sacralizando su persona y actos, y en general cuanto le rodea para elevarse por encima de sus súbditos sublimando su majestad con el fin de robustecer su poder y autoridad, mediatizados precisamente por el juramento que se ha visto obligado a hacer antes de tomar posesión de sus estados. Paradójicamente, en la base del nacimiento del mito regio está el prestigio que la monarquía obtiene ante el pueblo al arrebatar a una nobleza egoísta la bandera de los fueros y de la legalidad?

\section{EL PRIMOGÉNITO Y LA SUCESIÓN}

La Figura del Primogénito va a ser uno de las más beneficiadas por la política de Jaime II, que asegurará la adscripción a su figura de la gobernación general, e incluso impondrá el derecho de representación.

- Se consolida el «juramento del primogénito» con unas características formales que venían estructuradas desde 1228. El acto es normalmente preceptuado por el rey, siendo prestado por «todo el reino", es decir, barones, caballeros, representantes de las ciudades y demás municipios. Es habitual la ausencia de los eclesiásticos. En to-

6 En estos momentos surge la idea de adoptar un emblema para representar al reino, se elabora un escudo del reino de Sobrarbe, unido a la leyenda del origen de los Fueros y del Justicia de Aragón, se recuperará la legendaria cruz de Íñigo Arista, y la cruz de San Jorge con cuatro cabezas de moros que recordaban la gran batalla de Alcoraz y la conquista de Huesca, uniendo todos estos símbolos a los palos rojos de la dinastía catalana. Se formó así el escudo del reino. Ver J.A. SESMA MUÑOZ, “El sentimiento nacionalista en la Corona de Aragón y el nacimiento de la España moderna”, en Realidad e Imágenes del poder (Coordina Adeline Rucquoi), Valladolid, 1988, p. 226.

7 B. PALACIOS, La Coronación..., ob. cit., pp. 196-200. 
dos los casos el rey ordena que los súbditos presten juramento de fidelidad y homenaje por este orden. El vínculo que estos actos crean entre el futuro rey y el pueblo que los presta no es ciertamente el del vasallaje feudal propiamente dicho, que, como se sabe, llevaba la contrapartida de una recompensa y era, además, soluble a la voluntad del vasallo. Precisamente esto era lo que se trataba de evitar, se buscaba consolidar el reconocimiento por los súbditos del vínculo que el día de la sucesión uniría naturalmente a éstos con su «señor natural», el rey. Era una promesa de cara al futuro, que unas veces incluía los compromisos propios de la fidelidad jurada (1228) y otras no (1257). Queda claro así que lo esencial del acto no son los compromisos de fidelidad, sino garantizar en todo cuanto fuera posible la promesa de reconocer al sucesor. De ahí también que, al revés de lo que ocurre en el vasallaje propiamente dicho, el homenaje siga al juramento, tanto si éste incluye lo relativo a la fidelidad como si solamente contiene la promesa de aceptación del sucesor como rey en el futuro. En este último caso la naturaleza del homenaje no ofrece dudas.

En cuanto al juramento en sí se usó siempre (excepto en el caso de Valencia al infante Alfonso en 1257) la fórmula de "fidelidad jurada» que se usaba comúnmente en Occidente para consolidar el homenaje y el vasallaje feudal. Tal vez el papel instrumental, de refuerzo, que dicha fórmula desempeñaba en su utilización original facilitó la adaptación de la misma a otros usos, como el de reforzar el reconocimiento del sucesor.

En cuanto a sus efectos jurídicos, hay que ponerlos en relación con su eficacia coercitiva en la medida en que el juramento y el homenaje eran una garantía contemplada y regulada por la ley ${ }^{8}$.

- La procuración general y su adscripción al heredero. Tras su llegada al trono y el nacimiento de sus hijos varones, Jaime II hace que su primogénito D. Jaime (nacido en 1296) fuera jurado como primogénito en las Cortes de Zaragoza de 1301, y al año siguiente (con apenas seis) fue nombrado procurador general en Aragón y Cataluña. Era la primera vez que este cargo se asignaba a un menor, con la trascendencia que ello conllevaba, ya que dejaba claro la intención de unir este oficio a la condición de primogénito de la Corona. Obviamente el infante no pudo ejercer sus funciones, porque lo que su padre nombró varios "gerens vices" para que actuaran en su nombre ${ }^{9}$. En 1309 el rey nombra a su hijo como procurador general de Valencia ${ }^{10}$, con lo que el infante consigue ya la procuración general de la Corona. El que un cargo tan importante haya sido conferido al primogénito siendo un menor implica que el rey no ha buscado las cualidades de la persona para regir la administración, sino solamente las

8 En el de 1228 se dice que el homenaje era de manos y de boca. Ver Bonifacio PALACIOS, «La práctica del juramento y el desarrollo constitucional aragonés hasta Jaime I", en Cuadernos de Historia Medieval, 1, UAM, Madrid, 1979, pp. 36-39.

9 Tales como Bernardo de Fonollar para Cataluña (ACA, AR. Reg. 231, fol. 19) y Arnaldo de Luna para Aragón (ACA, AR. Reg. 231, fol. 12v.).

10 Ya que lo manifiesta explícitamente en el exordio correspondiente al nombramiento de Artal de Orta como su «gerens vices" en dicho reino (ACA, AR. Reg. 232, fol. 319). 
condiciones concurrentes en él independientes de toda idoneidad, que no puede ser sino la primogenitura, y eso revela una intención manifiesta de adscripción ${ }^{11}$.

El infante, al alcanzar la mayoría de edad, juró, ante las cortes de Zaragoza (19 de mayo de 1311), guardar los fueros, privilegios y libertades del reino, aprobando y ratificando la confirmación del privilegio general que el rey su padre había concedido y los otros privilegios ${ }^{12}$.

Tras hacer esto, pudo entrar en la plena posesión de la procuración, que gestionó con notable éxito si hemos de creer las cartas que su padre le envió felicitándole ${ }^{13}$, gracias principalmente a sus buenos consejeros, tales como Bernardo de Fenollar (su mayordomo y lugarteniente en el cargo), Artaldo de Alagón (su senyalero, alférez, desde 1312), Gonzalo García, Esteban de Roda, Pedro de Pomar, Blas Maça de Vergua, Pero Sánchez de Calatayud y otros.

Pero su actuación, a partir de 1318, se volvió excesivamente rigurosa (tal vez por el empeoramiento de su estado físico), lo que llevó a Jaime II a desautorizarle en varias ocasiones, aunque sin apartarle del cargo, e incluso encomendándole importantes asuntos, tales como la resolución de uñ conflicto entre la ciudad de Valencia y don Artaldo de Luna, que el rey no podía atender por estar negociando las «cosas» de Sicilia ${ }^{14}$.

El comportamiento del infante era cada vez más extraño, a veces desaparecía durante días retirándose a lugares solitarios (actitud que le reprochaba el rey como impropia de un heredero con graves responsabilidades en el gobierno de la Corona), esquivaba el trato con el rey (incluso durante una grave enfermedad de éste) y la celebración de su boda (concertada con Leonor de Castilla desde hacía tiempo). Todo esto llevó al rey a escribir al papa, y éste envió una larga carta al infante aconsejándole abandonar sus malos hábitos de forma cordial ${ }^{15}$.

Nada se arregló, y el tiempo transcurría, se prepararon los esponsales, que tuvieron lugar el 18 de octubre ${ }^{16}$, y ese mismo día el infante desapareció de la corte. Finalménte el 22 de diciembre de 1319 renunció formalmente a todos sus derechos de primogenitura, como le exigió el rey, tomando el hábito de la orden de San Juan del Hospital ${ }^{17}$.

11 Jesús LALINDE ABADÍA, La Gobernación General en la Corona de Aragón. Madrid-Zaragoza, 1963, p. 52.

12 J. ZURITA, Anales..., Libro V, capítulo 90 (tomo II, p. 742).

13 ACA, Reg. 337, fol. 328v. (Poblet, 23 de junio de 1313).

14 ACA, Reg. 244, fol. 317. (Barcelona, 3 de julio de 1318).

15 Colección de bulas papales, Leg. 30. Juan XXII, n 33. Avlgnon, 19 de agosto de 1319, publicada por J.E. MARTÍNEZ FERRANDO, Jaime // de Aragón, Barcelona, 1948, tomo II, n² 292, pp. 213-214.

16 Unos días después, el 22, Jaime ll envió una larga carta a la reina de Castilla, doña María de Molina, explicando la extraña conducta del infante y todas las quejas que tenía contra él que muestra, mejor que ningún relato, las esperanzas defraudadas de Jaime II. ACA, Reg. 245, fol. 198v., publicada por J.E. MARTÍNEZ FERRANDO, ob. cit., tomo II, no 299, pp. 220-221.

17 Jaime II había intentado por todos los medios evitar esta decisión, como consta en los documentos notariales que dan fe de la renuncia del primogénito (ACA, Reg. 348, fol. 22v, Pergaminos de

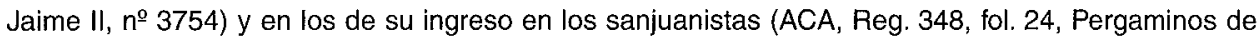
Jaime II, $n^{\circ} 3755$ ). 
Jaime II insistió en que su hijo optara por la orden de San Juan, ya que aquellos que vestían su hábito eran considerados profesos en el mismo día de recibirlo y, por lo tanto, no podían volverse atrás de su decisión. El rey no quería más vacilaciones ni problemas $^{18}$.

Inmediatamente, el monarca convocó cortes generales, donde fueron leidos los documentos notariales antes mencionados, siendo declarado primogénito y heredero del trono el infante don Alfonso, conde de Urgel ${ }^{19}$, segundogénito del rey. Don Alfonso fue nombrado inmediatamente (de hecho en el mismo mes de diciembre) Procurador general, cargo que antes tenía su hermano, ya que como nuevo heredero «ut segundogenito ad primogenitura sui germani predicta subrogato, suplebit in omnibus officium regiminis regnorum ${ }^{20}$. También se ampliaron notablemente sus dotaciones territoriales ${ }^{21}$.

D. Alfonso cumplió sus funciones de forma muy grata a su padre, como éste lo expresa en una carta al tesorero real, Pedro March, felicitándose por la manera en que don Alfonso había llevado el proceso abierto contra Ramón Folch, vizconde de Cardona ${ }^{22}$. Tanto es así que en 1321 el rey amplia notablemente sus poderes al permitirle ejercer plenamente su oficio y terminar completamente los negocios que trate en apelación, aún cuando el rey esté presente ${ }^{23}$. En 1323 el infante recibe facultad

J. ZURITA, Anales..., libro VI, capítulo XXXII (tomo III, pp. 117-122), dedica varias páginas a contar con detalle los hechos narrados anteriormente.

18 De hecho los primeros meses tras su profesión el ahora venerable fray Jaime mostró extrañas actitudes, e incluso pareció querer recuperar su posición en la Corona. Poco después cambió el hábito sanjuanista por el de la orden de Montesa, pasando a residir en Santes Creus (1320). Su vida fue luego bastante azarosa, en 1323 se encuentra en Valencia «en malas compañías», lo que lleva al rey a ordenar a su hijo Pedro, conde de Ribagorza, que se llevara a Jaime, de buen grado o por la fuerza, de la ciudad, siendo posteriormente retenido en Santes Creus de manera permanente, falleciendo en julio de 1334.

19 Alfonso era conde de Urgel y vizconde de Ager desde su matrimonio con Teresa de Entenza en 1314, cumpliendo así el testamento del conde Ermengol de Urgel, que dispuso la boda de su hija con Alfonso y la venta de sus estados al rey por 100.000 libras jaquesas.

20 Carta de Jaime 11 al rey de Mallorca informándole de la renuncia de su primogénito. ACA, AR. Reg. 348 , fol. 40 . «el segundogénito, subrogado en la primogenitura de su hermano, le suplió totalmente en el oficio del gobierno de los reinos".

También reconoce este hecho el mismo Pedro IV, en la «Crónica de Pere el Ceremoniós» libro I, cap. XLII (p. 1017 de la Ed. de F. SOLDEVILA en Els Quatre Grans Cròniques).

21 Además de Urgel y Ager, el infante tenía los castillos de Perrúa, Gual, Fels y la tenencia de la castellanía de Benabarre (ACA, Reg. 25, fol. 277r.); así como la baronía de Josa y la tierra de Lavança, con los castillos de Josa, Fornols, Ossera, Esplugas de Lavança, Ciscar, Pardina, Cornellana y Montergull. A los que se añadió el castilla y villa de Albalate de Cinca en 1318 (A. SINUES y A. UBIETO, El patrimonio real en Aragón durante la Edad Media, Zaragoza, 1986, documento 53, p. 35), y sobre todo el castillo y villa de Luna en 1320 (ACA, Pergaminos de Jaime II, $n=3828$ ). Dato citado por J. ZURITA, Anales..., libro VI, capítulo XXXVI (tomo III, pp. 133-134).

22 ACA, Reg. 339, fol. 373 (Valencia, 10 de abril de 1321).

23 ACA, AR. Reg. 233, fol. 23v. Texto publicado por J. LALINDE, ob. cit, documento XXIV, pp. 517-518. 
plena para destituir y nombrar a sus «gerentes vices», que hasta entonces eran nombrados directamente por el rey, mientras ahora el monarca simplemente se reserva el «placet». Así, a finales del reinado de Jaime II, el prímogénito, como Procurador General, ha extendido su poder a todos los territorios de la Corona (incluida Cerdeña) y ha conseguido controlar a todos los oficiales que dependen de él, creándose una posición de privilegio en la Corona a la que sólo le falta la asignación explícita por ley del cargo al primogénito ${ }^{24}$.

Puede decirse que el sistema de la procuración general es el resultado de la convergencia de dos líneas, que son la tendencia a la centralización administrativa y la inclinación natural de los reyes a asegurar la sucesión, promocionando al primogénito mediante su inserción en la cúspide de la administración pública.

- El derecho de representación. El derecho de representación en Aragón fue reconocido en la mayoría de los testamentos reales, pero no se plantea el problema como tal hasta el reinado de Jaime $\mathrm{l}$, cuando el rey promete $(20-\mathrm{X} \mid-1275)$ a su primogénito el infante Pedro que hará jurar al hijo de éste, Alfonso, como heredero del heredero ${ }^{25}$.

Tanto el rey Jaime I como don Pedro, deseando evitar los problemas sucesorios que se estaban desarrollando en Castilla, decidieron promover la jura de Alfonso (primogénito de don Pedro, nacido en 1265) como heredero del trono ante la inminente partida de Don Pedro a Castilla con refuerzos para frenar la invasión musulmana. Era el juramento del primogénito del primogénito, primera muestra de la aceptación «institucional» del derecho de representación en Aragón y de la posición de fuerza que en estos momentos tenía el infante en la Corona. De este modo, a instancias de su hijo, el rey Jaime en un documento de 19-XI-1275 daba poder al infante para que, si moría antes que él, dejase los reinos de Argón y Valencia y el condado de Barcelona a su primogénito Alfonso y a sus otros hijos en defecto de aquél. Igualmente, el rey se comprometía a observar y hacer observar en todo esta disposición, de manera que, una vez muerto él, los reinos pasasen al heredero designado por el infante ${ }^{26}$. Partien-

24 Este último paso se dará en 1366, cuando en las Cortes de Calatayud se promulgue el Fuero «Statuimus», según el cual se dispone que el Primogénito del Rey pueda regir el oficio de la Gobernación o Procuración General, y usar y ejercer la jurisdicción civil y criminal del mismo después que tuviere 14 años y jurara respetar los fueros.

Esta ley enfrentaría a Pedro IV con su heredero Juan en 1386; en esos momentos ambos se encontraban enfrentados por motivos personales y su distinta orientación política, por lo que el rey quiso despojar a su hijo de la Gobernación General. El Duque Juan se opuso y firmó de derecho ante el justicia de Aragón contra su padre, y le fue recibida la «iurisfirma». El Fuero de 1366 lo dejaba claro, el Primogénito era Gobernador General tras cumplir 14 años y jurar respetar los fueros, y lo era por la Ley; no por designación del Rey, que no podía destituirle de un cargo que no le había dado, sino que lo tenía por derecho.

25 El documento regio está en ACA, Pergaminos de Jaime I, no 2253, y en Reg. 20, fol. 300v. Publicado por CODOIN-ACA, VI, documento LIII; Ver B. PALACIOS MARTÍN, «La práctica del juramento...", ob. cit., pp. 35-36.

26 ACA, Reg. 20, fol. 300v. Publicado por Ferrán SOLDEVILA, Pere el Gran. L'Infant, Barcelona, Institut d'Estudis Catalans, Memories de la Secció Històrico Arqueològica, XI, 1950. Apéndice, documento 55, pp. 472-473. 
do de esta situación de reconocimiento de derechos del infante Pedro, el rey Jaime emitió el documento antes comentado del 20-XI, donde prometía al infante que antes de que éste partiera en servicio de Dios para ayudar a Castilla, haría jurar y hacer homenaje por sus reinos a su hijo mayor, el infante Alfonso, para que lo tuvieran por rey y señor después de la muerte de ambos ${ }^{27}$. Este documento fue una simple declaración de intenciones, ya que dicha jura no se realizó, al no partir inmediatamente el infante con las tropas preparadas para apoyar a los castellanos, pero el precedente estaba claro.

Cincuenta años después tuvo lugar la institucionalización de este hecho. Durante la campaña sarda dirigida por el primogénito de Jaime II, D. Alfonso, ocupó de forma interina el cargo de procurador general su hermano, el infante Pedro, pues bien en esos momentos pidió al rey ser declarado infante heredero, alegando la posibilidad de que su hermano muriera en Cerdeña, la corta edad del hijo de éste (el futuro Pedro el Ceremonioso), y la mala salud del propio Jaime II.

Don Pedro, era el hijo preferido del rey, tenía un nutrido grupo de simpatizantes entre la corte y la nobleza, disponía de cuantiosas rentas (había recibido el condado de Ribagorza en 1322) y había mostrado sus cualidades de gobierno en la procuración. Jaime II dudó durante algún tiempo, pero tras la vuelta de don Alfonso, el rey convocó Cortes en Zaragoza (1325) y ordenó jurar como heredero de sus reinos, en casó de morir el primogénito, al futuro Pedro el Ceremonioso primogénito de éste ${ }^{28}$, es el llamado juramento del primogénito del primogénito. Se consolidaba así el derecho de representación en Aragón, que por primera vez se había esbozado en 1275 por Jaime I. Aunque no sin la protesta del conde Pedro de Ribagorza, hijo menor del rey. Poco después, en su testamento de 1327 Jaime II reconoce explícitamente el derecho de representación, aunque sólo en favor de su primogénito Alfonso y de sus descendientes varones; en defecto de estos, sucede su segundogénito, a cuyos descendientes no se les reconocen el derecho de representación, pasando el orden sucesorio al tercer hijo de Jaime II.

\section{CONCLUSIÓN}

Con todas estas medidas Jaime $\|$ buscó la consolidación definitiva de la Corona de Aragón, su indisolubilidad, una sucesión pacífica y reglada (derecho de representación y adscripción de la procuración general al primogénito consiguiendo que lo que hasta entonces era una simple entrega de poderes coyunturales se transforme en derecho consuetudinario y en parte de la administración cotidiana de la Corona) así

27 ACA, Reg. 20, fol. 300v. 20 de noviembre de 1275. A. BALLESTEROS, Alfonso $X$ el Sabio, Madrid-Barcelona 1964, p. 776; B. PALACIOS, «El juramento...», ob. cit., p. 35.

28 J. ZURITA, Anales..., libro VI, cap. LXII (tomo III, pp. 230-231) y «Crónica de Pere el Ceremoniós", libro I, cap. XLII. El documento completo del juramento (15 de septiembre) lo publica D. GIRONA I LLAGOSTERA, «Itinerari de l'infant Pere (1319-1336)», en Estudis Universitaris Catalans, 18 (1933), pp. 346-350. 
como una delimitación clara del «pacto» entre el rey y el reino que se formaliza en los actos de coronación, reforzando los poderes del monarca alentando el mito del rey.

En este período se dan los pasos necesarios para consolidar de manera definitiva la figura del heredero dentro del organigrama «constitucional» de la Corona de Aragón, entregándole unos poderes, en razón de su posición en la sucesión al trono, que le colocan en una posición inigualable dentro de la Corona, y con una capacidad de maniobra que no tienen ninguno de los herederos de los reinos de la Europa Occidental.

Ahora bien, esta entrega de poderes que consolida y fortalece la figura del heredero convirtiéndole en el principal colaborador del rey conlleva también sus problemas: en primer lugar la asignación de este importante oficio cuando el rey no tiene un hijo varón ${ }^{29}, y$ en segundo la posible confrontación de políticas entre el rey y el heredero que podría desembocar en un conflicto de grandes dimensiones ${ }^{30}$.

En cualquier caso desde este momento se potencia esta figura, y seguirá en ascenso, salvo algún breve período, hasta el reinado de Juan II, cuando su hijo y heredero Fernando el Católico se convierte en su principal colaborador y prácticamente co-regente, para luego vaciarse de contenido en el reinado de los Reyes Católicos.

29 Hay que recordar los años en que Pedro IV tuvo como única posible heredera a su hija Constanza, y los esfuerzos que hizo entonces por modificar la Procuración; y también el problema que se planteó durante el reinado de Martín I, ya que la asignación de la Gobernación General podía significar en sí misma la designación del heredero al trono en un momento en que había varios candidatos a él.

30 Ya hemos comentado brevemente el enfrentamiento de 1386 entre Pedro IV y el Duque Juan; pero más importante fue el de Juan II con Carlos de Viana, que nunca fue Gobernador General al no cumplir el requisito de jurar los fueros, ya que el rey lo evitó al no convocar Cortes para realizar el acto; lo que fue un motivo más de enfrentamiento entre ambos. 



\title{
SOBRE EL CONCEPTO Y LA EVOLUCIÓN DE LA FRONTERA EN LOS REINOS HISPÁNICOS PENINSULARES. ENTRE ÚBEDA Y SEPÚLVEDA
}

\author{
Antonio LINAGE CONDE \\ Adela TARIFA FERNÁNDEZ
}

\section{LA FRONTERA}

A propósito de la acuñación de los Estados Unidos se ha insistido en que la clave de «la sencillez rústica, pero sólida y auténtica de su vida de frontera», una frontera cuyo desplazamiento iba "conformando y cargando, en su avance, individualismo, democracia y nacionalismo»'. Opinión que aquí traemos a introductoria colación, pese a su lejanía geográfica y la tan distinta circunstancia vital de nuestra España medieval, para sentar desde un principio el convencimiento que tenemos de haber sido igualmente la frontera, configurada y modificada ésta al lentísimo paso de la Reconquista, el elemento decisivo de nuestro paralelo hacerse.

Frontera junto a la cual hay que considerar decisivamente la faja desértica ubicada, simplificando por la historiografía predominante, en el valle del Duero; pero que puede extenderse, sin pérdida de contacto con la realidad, de Oporto a Barcelona. Una tierra de nadie que se ha llamado desierto estratégico, epíteto que no es posible aceptar sin someterlo a alguna reflexión. Por cuya vía habremos ineludiblemente de encontrarnos la cuestión de su posible índole fronteriza en sentido amplio, sus conexiones con la frontera en todo caso. Dentro de esa su índole determinante para captar la entraña del moldearse hispano que confesó en él don Claudio Sánchez Albornoz al justificar la oceánica desmesura de su respuesta a la negación desdeñosa,

1 Cfr. R.F. LAFUENTE, sobre La cultura de la queja, de Robert Hughes, ABC literario, núm. 137, 17-6-1994, p. 14. 
un tanto hecha de pasada por don Ramón Menéndez Pidal², a la búsqueda de ese "secreto de los grandes problemas españoles» que Ortega y Gasset no pudo por menos de radicar en la Edad Media ${ }^{3}$.

De 1846 a 1853 publicó Alejandro Herculano su Historia de Portugal ${ }^{4}$, lanzando en ella como novedad su visión del desierto medieval del Duero. A pesar de lo cual, los historiadores que siguieron no insistieron apenas en la sugerencia, hasta el apuntalamiento, desde luego el más decisivo de los suyos, del propio Sánchez-Albornoz, ya en 1966, en el crepúsculo de su exilio bonaerense. Con un apoyo sólido en el interludio, el del bibliotecario bordelés de la Sorbona, excesivamente crítico con los papeles de este lado de los Pirineos, Louis Barrau-Dihigo, nacido en 1876, un año antes de que el historiador lusitano muriera solitario en su quinta del Valle de Lobos. En 1921 publicaría aquél sus Recherches sur I'histoire politique du royaume asturien, $718-910^{5}$.

Sin embargo, Diego de Colmenares, en su Historia de la insigne ciudad de Segovia y compendio de las historias de Castilla, aludía en $1637^{6}$, si bien para manifestar su disconformidad, a «lo que en nuestros tiempos se ha escrito ${ }^{7}$ inadvertidamente de que nuestra ciudad y su comarca estaba desierta por esos años".

Así las cosas, calibrar el grado de densidad desertizante de la población que quedó, no nos compete aquí. Sino matizar si el desierto fue o no en alguna medida frontera.

\section{DE LA DESPOBLACIÓN A LA REPOBLACIÓN}

Siendo ante todo preciso distinguir entre la etapa desertizada y la del poblamiento inicial.

Durante la primera, el panorama demográfico no era otro que el de grupos de pastores con algunos labradores y los consabidos ermitaños en los reductos predestinados a la geografía monástica.

Cuando la repoblación comienza ya es otro cantar. $Y$ notemos que a veces ese inicio, aparte de ser débil en sí, se dejaba atrás una buena porción de tierra que se-

2 Despoblación y repoblación del valle del Duero, Buenos Aires, 1966.

3 Sin perjuicio de la posible discusión fecunda de las consideraciones de éste acerca de «la anormalidad permanente de la historia española» - «ensaye quien quiera la lectura paralela de nuestras crónicas medievales y las francesas"- y sobre todo la definición con la cual concluye de haber sido «la historia de España entera, y salvo fugaces jornadas, la historia de una decadencia». Posteriormente citaremos los pasajes concretos orteguianos de donde están tomadas estas referencias.

4 Véase $5^{\mathrm{a}}$ edición, III, 1891, p. 183.

5 «Revue Hispanique»52, 144; tirada aparte el mismo año en Tours.

6 Ed. Academia de San Quirce de Segovia, 1969, I, 12, pp. 195-6.

7 Basa su disconformidad en la confusión de lo reivindicatorio - límites del obispado de Simancas, cuyo titular, Ilderedo, se titulaba de Segovia, pero sólo lo podía ser in partibus (véase nuestra noticia sobre él en «Dictionnaire d'histoire et géographie ecclésiastiques»)- - y lo real. Sobre donde pudo haberse escrito «inadvertidamente» el asunto del desierto, damos importancia a la oralidad. Eran bien escasos los medios de difusión gráfica, y no superarían el peso de aquella. 
guía eremada. Pensemos en la de Sepúlveda, por Fernán González, el año 940, que por eso fray Justo Pérez de Urbel la llamó salto de tigre. En esas circunstancias, a la tierra de nadie sucedió otra que ya empezaba a tener dueños, pero bajo la espada de Damocles de la inseguridad. $Y$ entonces es cuando se habla de guerreros -0 caballeros - pastores y aparecen fortificaciones plantadas en la inmensidad poco ha vacía y ahora sólo con islotes en lucha por el arraigo ${ }^{8}$. Así las cosas, diríamos que esta tierra tendente a la vuelta a la vida suplantaba a la frontera, al fin y al cabo hacía sus veces «los dos se mantuvieron en el yermo o desierto que hay entre las comarcas musulmanas y cristianas», según rezaba Ibn Al-Qûtîya9 .

Pero lo cierto es, que tanto una como otra situación pueden tildarse de antifronterizas. Un paisaje histórico que sería elocuente cotejar con el de los territorios europeos de dispares destinos entonces y hasta el futuro lejano.

\section{EN POS DE LA CLAVE}

Los que tuvimos como tierra nativa la de Sepúlveda, ya antes de conocer la hipótesis de la despoblación, en la niñez, notábamos la intuición de un vacio inexplicado, vislumbrado sólo a medias; de manera que, el tener noticia de aquella, sensorialmente nos pereció como si las piezas de un rompecabezas se acoplaban.

Mas, ¿sería lícito inquirir algún significado?

Para Ortega y Gasset, la falta o debilidad del feudalismo en España, el equivalente de "las minorías de superior intelecto" en las sociedades modernas, dio lugar a la formación de reinos con monarca y plebe - ésta, entre otras incapacidades, aquejada de la de organizar un estado de prolongada consistencia- pero sin suficiente número de nobles; y por esos caminos llegó a sostener que no hubo verdadera Reconquista, al contrario de otras partes en que hubo Cruzadas $^{10}$. A propósito de esta preterición de la Reconquista se nos ocurre sin embargo, de momento, objetar que precisamente lo larguísimo de su duración, si bien no fue incompatible con la continuidad de la lucha por la fuerza misma de las cosas, tiene también otra vertiente, de persistencia en el propósito de imponer la civilización propia, una recuperación en este caso de la España perdida.

Pero, ya en nuestro argumento, esas reflexiones que el genial pensador y literato empezó a escribir en El Sol el año 1920, su España invertebrada, ¿no habrían podido aplicarse a la falta de frontera, y al desierto de ella causante, acaso en una relación de causalidad más íntima con la invertebración postulada?

8 L.M. VILLAR GARCÍA, La Extremadura castellano-leonesa. Guerreros, clérigos y campesinos, 711-1252 (Valladolid, 1986); D. CONTE BRAGADO, Introducción a la arqueología del cañón del Duratón (Segovia, 1993), 181-94.

9 Versión de J. RIVERA, Colección de obras arábigas de historia y geografía (Academia de la Historia) 1, p. 74.

10 Texto en «Obras Completas» (6⿳a ed., Madrid, 1966) 3, pp. 109-12.

11 Tal como, por ejemplo, la reconstruye M. MARTÍNEZ MARTÍNEZ, «Organización y evolución de una sociedad de frontera: el reino de Murcia, ss. XIII-XIV», Medievalismo 5 (1995) 31-88. 
Lo cierto es que en el septentrión, la presencia del desierto supliendo a la frontera, determinó luego, llegada la hora repobladora de él, la aparición de una frontera peculiar en las avanzadas de la misma, muy diversa de la que después, al sur de la tierra despoblada, iría delimitando sucesivamente ${ }^{11}$ los dominios de la cruz y de la media luna, aunque en algún caso fueran protagonistas de un nuevo poblamiento, también del todo distinto. Por lo cual precisamente, no nos parece caprichosa la repartición de estas páginas entre sendos ejemplos de ambas situaciones.

Y la caracterización de la tal frontera peculiar se produce primero acuñándose una noción jurídica de la misma.

\section{LA SIGNIFICACIÓN DEL FUERO DE SEPÚLVEDA O DE EXTREMADURA}

Al repoblar Sepúlveda, Fernán González la concedió un Fuero. Ello equivalía a darla un régimen jurídico particular, determinado por la necesidad de atraer gentes a la nueva frontera. Una frontera que ahora lo seguía siendo con el desierto, pero en una posición avanzada y peligrosa. De manera que, en la óptica de sus pobladores no podían entrar ni la convivencia ni la retirada asequible, como ocurriría después en otros puestos y lineas, entre poblaciones nada más queremos decir.

El texto del Fuero fernandino no se conserva. En el año 1076 lo confirmó Alfonso VI, de cuyo texto conservamos una copia ${ }^{12}$.

Antes y después, el Derecho de Sepúlveda se enriqueció con nuevas normas, hasta llegar a ser un ordenamiento juridico bastante completo, que fue puesto por escrito el año 1300 .

Los historiadores del Derecho venían discutiendo la precedencia cronológica entre este Fuero y otros de la misma familia, pero teniendo sólo en cuenta las redacciones escritas. Fue Rafael Gibert el que llamó la atención hacia la necesidad de tener en cuenta la elaboración consuetudinaria de las normas que posteriormente fueron escritas. De ahí que, en los preceptos sepulvedanos que integran la redacción de 1300, los tenga forzosamente que haber de datación muy diversa, por lo general precisarlo de no fácil conjetura.

Así las cosas, debemos fijarnos en el título primero titulado «que toda Extremadura sea tenida de venir a Sepúlveda a fuero", y cuyo contenido se limita a reiterar la concesión del término de la Villa a sus vecinos presentes y futuros. Pero lo que quiere decir es que se había creado un derecho de la frontera peligrosa y avanzada con el desierto, cuya acuñación fue el Fuero de Sepúlveda. De ahí la primacía de éste, con independencia de problemas redaccionales. $Y$ el dato es decisivo cual comprobante de ese peculiar concepto jurídico de la también particular frontera en cuestión.

Una situación que ¿dejó de darse absolutamente cuando unas y otras tierras limitaban fronterizamente sin la medianería del desierto?

12 E. SÁEZ y otros, Los Fueros de Sepúlveda (Segovia, 1953). 


\section{ÚBEDA ¿EN LA ÚLTIMA FRONTERA?}

Y llegados de uno a otro extremo pocos ejemplos más paradigmáticos para cuestionar concepto y significado de frontera, en el cotejo anunciado, que esta ciudad andaluza, en la «Extremadura castellana», mitad meseta-plaza, mitad borde-almena, en el castillo peninsular del medievo invertebrado. Pero nunca desierto, en el sentido humano más estricto. Porque desiertos puede haberlos de muchos tipos, y todos tiene en común esa vaga sensación de vacío antes aludida para la primera «despoblación» sepulvedana.

Aquí es obligado reiterar la transcendencia de aquella reflexión inicial: el lento paso de la Reconquista como elemento decisivo para entender nuestro pasado, y desde luego presente. Porque ¿es acaso tangencial que a la hora del cotejo en la repoblación cristiana de estas dos Extremaduras hayan transcurrido casi dos siglos? Con todo lo que el paso del tiempo trajo para unos y otros, transmutados destinos de vencedores en vencidos.

Así el privilegio de ejercitar la visión retrospectiva que es concedido al historiador permite constatar a la vuelta de cada meandro que nada fue ni será definitivo cuando lo construyen hombres, inexactos por definición. Mutables infinitamente, en la aparente inmutabilidad en que el tópico suele envolver desde el desconocimiento a los siglos más remotos del medievo hispano.

Notemos pues que el "desierto" se convierte en elemento diferencial aparente: es el exceso de ocupación humana en la vieja Ebbdete mora el principal problema de los monarcas cristianos. Es la falta de repobladores cristinos, a la inversa, lo que retrasa más de un siglo su definitiva conquista, fracasadas una y otra vez desde el reinado de Alfonso $\mathrm{VI}$, por más que las crónicas cristianas del momento adornen el valor épico de sus guerreros, las avanzadillas sobre lo que era ya populoso núcleo urbano de la media luna ${ }^{13}$. ¿Cómo entender sino, ejemplificando lo más notable, que tras la gloriosa « $\ldots$ batalla que llamaron de las Navas de Tolosa, y también de Úbeda, por haber tenido principio en aquellas y fin en ésta...", cuando los cristianos asolan la villa, pasando a cuchillo «... el octavo día después de la batalla de Navas sesenta mil infieles (?) dentro de los muros de Úbeda...», esta ciudad vuelva a manos musulmanas? ${ }^{14}$. Naturalmente algo

13 Las crónicas musulmanas aportan pocos datos sobre el rango que tuvo Úbeda en los primeros tiempos de la reconquista. Sabido es que la dominan los Yamaríes por un tiempo, y que fue en aumento la intolerancia hacia los mozárabes, mientras los moros levantan fuertes murallas. Úbeda, dependiente de Toledo en la división provincial Yusuf el Jehir (746) progresó bastante durante el Califato. Después de la muerte de Almanzor se recrudece la intolerancia contra los cristianos, tomando conciencia del papel de fortín defensivo que le tocaba desempeñar, como lugar de acogida a musulmanes que escapaba de avanzadillas cristianas en su entorno más próximo. Puede verse: M. RUIZ PRIETO, Historia de Úbeda (1909), pp. 14-15; J. PASQUAU GUERRERO, Biografía de Úbeda, Úbeda, 1984, pp. 13-19, y A. CAZABÁN LAGUNA, Apuntes para la historia de Úbeda, Úbeda, 1992 (ed. facsímil), pp. 13-23.

14 Sin duda el año 1212 marca un hito fundamental en el avance cristiano hacia el sur. Después de incursiones anteriores, como la de Fray Fernando Escarza, apoyada por el arzobispado de Toledo y las tropas reales, fueron los días del triunfo de la Santa Cruz en Navas los más decisivos para el futuro de ambos bandos. Caerán sucesivamente Vilches, Baños, Ferraz, Tolosa...; luego tocó la vez a 
fue distinto en el Sur, pasados doscientos años desde la repoblación de Sepúlveda. Entre otras muchas razones porque El Islam era duro rival para cristianos que idealizaban el celibato, al menos teóricamente, y que convertían el oficio de las armas en privilegio de unos pocos, por mucho que no imperasen modelos feudales rígidos.

¿Faltaron nobles, como aventuró Ortega y Gasset, para acelerar el proceso...? Es posible, y de ello se benefició parte de la plebe, ascendida a rango de hidalguía con la urgencia del momento, convertida a la larga en la más pesada losa que inmovilizó a la monarquía. Pero fundamentalmente faltaron hombres, a secas. Una enfermedad que acabó siendo endémica, luego de terminada la Reconquista, y que tantos «desiertos invertebrados» generó.

Se comprende que ahora el desierto-frontera no sea más que un símbolo. Un mito. Es más ¿existió frontera más allá de las murallas de Úbeda desde julio de 1233 ? Se nos antoja acaso aquella frontera como algo artificial, incómodo a ambas partes. Permaneció mucha población musulmana en el lado de la cruz, y, en pos de intereses comunes, se "disimuló" un permanente trasiego de uno a otro lado. Pero claro que quedaba algo siempre presente: miedo y violencia, prontos a estallar cuando algo externo rompía el monótono transcurrir de los días; por mucho que el Rey Santo fuese un modelo de monarca cuasi ideal, conjugadas en él las virtudes cristianas de la piedad y la tolerancia con otras más próximas al que con el paso de los años perfilaría Maquiavelo ${ }^{15}$.

Úbeda. Independientemente de la dosis de lirismo o fantasía que encontremos en los cronistas cristianos para narrar el suceso, y de ciertas imprecisiones puntuales en la fecha exacta (las fuentes alude a su cerco el viernes 20 de julio, y su rendición el lunes 23), algo de verdad debe existir en las negociaciones que luego siguieron, ofreciendo los moros comprar su libertad pagando «mil veces mil maravedís de plata al contado...", antes de que, consultado el Papa, los cristianos decidan destruirla, pasando a cuchillo a muchos de sus pobladores. Incapaces sin embargo de repoblarla y defenderla, los cristianos volverán a perder Úbeda. Pero el final de esta frontera mora era ya inminente. Sobre el tema, entre otros: FRANCISCO DE BILCHES, Santos y Santuarios del Obispado de Jaén y Baeza, Madrid, 1636, fl. 130; M. DE JIMENA JURADO, Anales eclesiásticos del Obispado de Jaén, Madrid, 1643, fls. 119-122. (Ed.facsímil, con estudio preliminar de J. Rodríguez Molina, y M.J. Osorio Pérez), Granada, 1991.

15 Hemos abordado el perfil humano del Rey Santo en nuestro trabajo «Úbeda fronteriza y cristiana en la historiografía giennense», Congreso internacional "la frontera oriental nazarí como sujeto histórico", Murcia, 1994 (en prensa). de modo más monográfico: A. TARIFA FERNÁNDEZ y M.J. PAREJO DELGADO, “Fernando III y su época en la historiografía giennense», Actas IV jornadas de historia militar, Sevilla, 1994, pp. 521-540. Una notable diferencia respecto al cambio de mentalidad el el ocaso del XVIII ofrece el Deán MARTÍNEZ DE MAZAS, limitando rasgos épicos, y tópicos quizás, de la figura de Fernando III, como desaparecen exageradas alusiones a todo lo sobrenatural: Retrato al natural de la Ciudad y término de Jaén, su estado antiguo y moderno, su población, agricultura y comercio, Jaén, 1794 (ed. facsímil, 1975), pp. 97-8. Puede verse: M.J. PAREJO DELGADO, Baeza y Úbeda en la baja Edad Media, Granada, 1988, pp. 28-30; y F. GARCÍA FITZ, “Las conquistas de Andalucía en la cronística castellana del siglo XIII. La mentalidad historiográfica en los relatos de la conquista», V Coloquio internacional medieval de Córdoba, 1988, pp. 51-61. 
En todo caso Úbeda enlaza su destino de ciudad-frontera con el septentrión, y recibe en 1240 el Fuero de Cuenca; noble gesto, que posibilita sea repoblada, con bastante dificultad, por cristianos, sobre todo de Castilla ${ }^{16}$.

Generosidad regia que nadie duda tiene justificación en el riesgo de vivir situaciones fronterizas; Fuero pues de frontera, ideado también aquí para atraer pobladores, para facilitar convivencias y limar asperezas, para premiar al guerrero. Úbeda compró libertades a precio de sangre. Y las mantuvo hasta que fue útil a la monarquía ${ }^{17}$. El sueño acabó cuando cayó Granada. Pero volvamos a la Úbeda-frontera recién conquistada por Fernando III. ¿Qué quedaba allí de lo que un día las tropas de Tarif encontraron? ¿Valdría la pena acaso dar la voz por un momento a viejos cronistas del pasado?:

«... y trataron (Tarif y Muza) en particular sobre todo lo que convenía para proseguir y acabar la conquista... y se resolvieron de tomar la vía de Castilla... y comenzaron a marchar por la rivera de un rio caudaloso (que)... es llamado de los moradores chistianos de aquellas tierras Betis... y guiaron su camino azia la mano izquierda, y llegaron a una ciudad pequeña, llamada por propio nombre en español Úbeda... y habiéndola cercado, sus moradores, de buena conformidad, sin hazer ninguna resistencia, abrieron las puertas...» ${ }^{18}$.

«... era Úbeda plaza fuerte, pertrechada con gente y municiones, como frontera que era de Baeza... más volviendo la primavera, y el Rey Santo a la conquista... cercó segunda vez a úbeda, y la combatió por tantas partes y con tal brío, que desmayó el orgullo de los moros, y se vieron forzados a entregar luego la ciudad... y si bien no se dice el modo, se puede entender haver sido el mismo que en las ziudades grandes, pues lo era Úbeda... ${ }^{19}$.

16 M. PESET y J. GUTIÉRREZ CUADRADO, EI Fuero de Úbeda (estudio preliminar), Valencia, 1979, pp. 156-57. J. RODRÍGUEZ MOLINA, «Las órdenes militares de Calatrava y Santiago en el alto Guadalquivir (ss. XIII al XIV)», CEM, Granada, 1974, pp. 70 y ss.

17 J. HIGUERAS MALDONADO, Documentos latinos de Úbeda, I.E.G., Jaén, 1975. Doc. 1, pp. 15-20, y doc. 3, pp. 33-37; PESET y GUTIÉRREZ, Op. cit., pp. 363-70. La proximidad a la frontera tuvo, entre otros inconvenientes, el peligro de cautividad. El destino de los cautivos era la venta en almoneda, cotizándose entre 12-17 doblas. Esta venta de cautivos pasa por la pluma de los cronistas del XVII con bastante frecuencia para justificar la reconquista y repoblación cristiana. Puede verse al respecto A. LINAGE CONDE y A. TARIFA FERNÁNDEZ, «Mentalidad, guerra y religión en la obra de Francisco de Bilches: una visión hagiográfica de la frontera hispano-musulmana", Actas Congreso internacional: "La sociedad de la frontera", Alcalá la Real, 1995 (en prensa). Precisamente el Condestable de Castilla Ruy López Dávalos, natural de Úbeda, fue hecho prisionero por los musulmanes en 1379. En casos de este tipo se recurría al canje con otro personaje importante. En GUERRERO NAVARRETE, Proceso y sentencia contra Ruy López Dávalos, I.E.G., Jaén, 1982, p. 9.

18 A. ABENTARIQUE TARIF, Pérdida y conquista de España (763), Libro I, Cap. XIV, fls. 63-64, Obra apócrifa del que se declara su traductor, Miguel de Luna, Granada, 1589.

19 F. BILCHES, Op. cit., pp. 129-30. 
¿Qué encontramos entre aquella aldea visigoda que encontraría Tarif, y esta gran urbe musulmana que describe el padre Bilches? Admitidas todas las reservas que puedan hacerse a las fuentes ${ }^{20}$, entre ambas situaciones media un abismo. Y no podemos simplificar alegando sólo cuestiones cronológicas. Progresó espectacularmente con los musulmanes por ser frontera; como cimentó luego ese auge, tras la conquista cristiana, por seguir siéndolo, ahora al amparo del Fuero.

Superadas las primeras dificultades para establecer sus límites municipales, especialmente tensas con Baeza y las Órdenes de Santiago y Calatrava, los «Señores» del Fuero de Úbeda, primeros guerreros-repobladores cristianos, se agarran con fuerza a los privilegios. Son el germen de una oligarquía violenta, envidiosa, díscola, que hará derramar sangre en las calles, cuando escaseen ya las cabezas de moros rebeldes. Pequeñas familias hidalgas, con ínsulas de grandeza, exenta de impuestos, excepto para mantener torres y murallas a su costa. $Y$ dispuestas siempre a la guerra. Serán a la postre su nobleza, afianzada de modo firme tras la Sentencia arbitraria de 1446, hasta arrancar a la Corona el reconocimiento postrero de no pechar, a no ser con el simbólico gesto de 5 maravedís. Ellos son «frontera» por antonomasia. Pero también el "desierto" del Sur... porque ya dijimos que desiertos hay muchos. Ellos hicieron posible vivir en Úbeda sin dominio musulmán. Ellos hicieron también que «vivir» en Úbeda fuera muy difícil. Difícil para los "moradores», "siervos", «jornaleros" y "mancebos». Para "hortelanos» y "pastores"..., "paniaguados" todos. Más aún para la comunidad mudéjar, siempre laboriosos, pobres entre los pobres, quizás sólo por eso tolerados. Insoportable en fin para aquella importante comunidad judía, envilecida en tratos artesanales y comerciales, que a duras penas sobrevivió tras los muros del Alcázar en los años de hambre hasta su expulsión.

Cierto que Úbeda progresa como ciudad-frontera, pese a las continuadas banderías de la nobleza. Pero desde 1233 hasta que el avance contra el Reino de Granada se intensifica, la ciudad ve nacer y morir muchas esperanzas, siempre en pie de guerra. Contribuye activamente en la conquista de Córdoba. Los Messias, Dábalos, Tráperas, Porceles, Sanmartines, Arandas, Orozco..., entre otros linajes, levantan a su costa torres, y «La ciudad con el común hizo las murallas todas, $\backslash$ con las torres que faltaban, $\backslash$ con sus ayudas y sobras $\backslash$ Está muy fortificada.... ${ }^{21}$. Desde Úbeda, con apoyo de los maestres de las Órdenes militares, parte el infante don Pedro, en 1313, para tomar el castillo de Alicún. Más tarde el de Belmez y Tíscar, Siles. Nobles de Úbeda están en

20 La obra del morisco granadino Miguel de Luna, intérprete de arábigo al servicio de Felipe II, bebe de viejas crónicas musulmanas y cristianas. Traducida varias veces, pasó del éxito a la denostación. Pese a todo conviene volver a ella más serenamente. Sobre el tema puede verse el trabajo de F. MARQUÉS DE VILLANUEVA, "La voluntad de leyenda de Miguel de Luna», en Revista de Filología Hispánica, T. XXX, 1981 ( $\mathrm{n}^{\circ}$ 2), pp. 359-95. También D. CABANELLAS RODRíGUEZ, El morisco granadino Alonso del Castillo, Granada, 1965. La mentalidad de Bilches, un jesuita baezano hijo de la época, no aporta ninguna sorpresa al lector. Hemos tocado el tema en nuestro trabajo "Mentalidad, guerra y religión...», Op. cit.

21 Forma parte del poema atribuido por algunos al ubetense Jorge de Mercado, en el que se describe el proceso de fortificación y defensa de Úbeda tras su definitiva conquísta. En A. CAZABÁN LAGUNA, Apuntes para la historia de Úbeda (1887), Ed. facsímil, Úbeda, 1992, pp. 40-44. 
la batalla del Salado, y en la toma de Algeciras. Luego será Enrique II quien premie a sus nobles por la fidelidad a su causa, en años turbulentos de guerras civiles, cuando Pedro I de Castilla «... fiso destruir la ciudad de Úbeda con los moros...". Pero las cosas van cambiando desde que cae Huelma, cuando el término de Úbeda ya queda en retaguardia ${ }^{22}$.

Con la toma de Granada, cansada Úbeda de aportar hombres, trigo y dinero a la Corona, sus privilegios, como ciudad de fuero de frontera, tienen ya los días contados. Precisamente entonces cerraran definitivamente las casas de sus barrios judíos. Todo un símbolo ${ }^{23}$.

Así entramos en el más temido de los desiertos: el mental. Fue éste el que alejó a Úbeda, como a los demás pueblos de España de la modernidad. El que nos invertebró acaso para siempre ¿y no es peor que el estratégico del Duero? ¿y no valdría la pena debatir sobre la pervivencia de esa frontera-desierto hoy, 700 años después...?

Aunque esta ciudad prospere en el XVI, un siglo "corto", sería discutible afirmar que comenzó para Úbeda una «Edad de Oro», después de que en 1507 el corregidor Gil de Mogollón aprovecha las luchas de bandos para derribar parte de su alcázar, un signo ya inútil de independencia, molesto a la monarquía. En todo caso se cambió libertad por prosperidad ${ }^{24}$. Acaso no sabían que, como dijo Domínguez Ortiz, «las épocas de plenitud son transitorias «. Sin duda más transitorias cuando se barren fronteras que no son desiertos. Cuando desaparecen las Extremaduras.

Sepúlveda, Extremadura primera. Úbeda, ya en la postrera. Allí nos podría servir como emblema su Fuero. Aquí perdido el suyo, como se perdieron los cuadernos de repartimiento, nos quedan todavía bastantes casas judias en pie, desconocidas y silenciadas de forma increíble para la macrohistoria.

Hoy, en un congreso de Fronteras, ¿habría que pedir a los más sabios que recuperasen la costumbre de indagar en el detalle de la historia local? Suele ser ejercicio incomodo, sobre todo porque cuando aplicamos la lupa a la microhistoria descubrimos que conviene usar anteojos, como los de Quevedo, con más frecuencia.

Creemos que la «invertebración» de España, en el sentido más genérico, acaso perdura porque lo hacen los desiertos mentales. Que no son generalmente las fronte-

22 Tocamos el tema en el estudio introductorio de Úbeda en 1752, según las Respuestas Generales del Catastro de Ensenada, Tabapress, Madrid, 1994, pp. 14 y ss. M.A. LADERO QUESADA, Los mudéjares de Castilla en la Baja Edad Media, H.I.D., Sevilla, 1978, y La Orden de Santiago en Andalucía. Bienes, rentas y vasallos a finales del siglo XV, Sevilia, 1975, y J. RODRÍGUEZ MOLINA, Las Órdenes militares de Calatrava y Santiago en el alto Guadalquivir, Granada, 1974, pp. 70 y ss.

23 Vale la pena mencionar el encomiable esfuerzo de recuperación y mantenimiento de los barrios judíos ubetenses que viene realizando desde hace años don José Ángel Almagro Alises. La historia hablará de su solitaria y tenaz labor en este ámbito.

24 Pedro Mártir de Anglería escribió por entonces al conde de Tendilla: «... me cuentas como en una novedad que en Úbeda todo anda revuelto, que entre sí se destrozan y aniquilan con mutuas carnicerías los dos partidos, el de Molina y el de La Cueva...". ¿Entraba la ciudad en lo que se ha llamado su gran siglo? Puede verse: E. TORAL PEÑARANDA, Úbeda (1442-1590), Jaén, 1975, p. XXXV; H. KENINSTON, Francisco de los Cobos, Secretario de Carlos V, Madrid, 1980, pp. 2-6, y PAREJO D. y TARIFA FERNÁNDEZ, Estudios sobre Úbeda, Sevilla, 1991, pp. 31-35. 
ras desiertos, pero sí desiertos todas las fronteras que se alzan violentamente. Por ello entre Úbeda y Sepúlveda parecen diluirse fronteras. Y es que, como ya apuntamos, marcadas las diferencias de ambas situaciones en tiempo y espacio, las nociones jurídicas del Fuero sepulvedano, y la presencia de repobladores del norte en el sur, en «fronteras peligrosas", permite encontrar cierto paralelismo entre tanta y tan compleja diversidad enriquecedora de nuestros Reinos Peninsulares. 
LA FRONTERA EN LOS REINOS DE MURCIA, VALENCIA Y GRANADA 



\title{
CAPÍTULOS ENTRE MURCIA Y ORIHUELA. RELACIONES DE FRONTERA (1427)
}

\author{
Clara ALARCÓN RUIZ \\ Julio NAVARRO MOLTÓ \\ Rafaela VIDAL FERNÁNDEZ
}

Este estudio persigue mostrar un ejemplo más de la compleja y azarosa vida fronteriza, situación que sufrieron y/o «aprovecharon» como nadie los habitantes del adelantamiento murciano. Estos tuvieron que adaptarse a la problemática derivada de la existencia de las tres fronteras por las que se encontraban rodeados casi por completo: la aragonesa, la granadina y la mediterránea.

Pero antes de adentrarnos en profundidad en el desarrollo de esta cuestión, procedamos en primer lugar a la contextualización del documento en el que basamos esta comunicación.

En 1427 había transcurrido algo más de una centuria desde que Murcia acordase nueva frontera con Aragón; fue concretamente a partir de la sentencia de Torrellas, y la reforma en Elche, donde Guardamar, Orihuela, Elche y Novelda pasan a manos del monarca aragonés. El reino de Murcia había perdido su zona norte y Castilla una parte importante de su litoral.

Sin embargo, los limes que se establecen son bastante imprecisos, por lo que en adelante fueron numerosas las ocasiones en que representantes de ambos reinos tuvieron que reunirse para definir con mayor claridad la línea fronteriza, ya que su imprecisión era motivo constante de conflictos'.

Nos parece importante, al tratar el tema del reparto del territorio murciano, dirigir la mirada más allá del exclusivo punto de vista político. Murcia y Orihuela quedaban ahora

1 MARTÍNEZ CARRILLO, Mª . LI., Revolución urbana y autoridad monárquica en Murcia durante la Baja Edad Media (1395-1420). Murcia, 1980, p. 203. 
englobadas en dos unidades políticas diferentes al convertirse en cabeza del sistema fronterizo castellano y aragonés respectivamente. Las dos ciudades hermanas eran ahora "centros polarizadores de dos áreas enfrentadas e incompatibles»?2.

Pero además, se había establecido desde el punto de vista geográfico, una frontera artificial. Los pasillos orográficos que durante largo tiempo habían unido y facilitado las relaciones entre estas localidades vecinas, quedaban ahora partido por unos acuerdos totalmente arbitrarios ${ }^{3}$. Se llega a hablar de frontera «antigeográfica». En definitiva, «la política se impuso a lo que la naturaleza y el quehacer de los hombres habían unido" ${ }^{4}$.

Ciertos cronistas oriolanos también se hacen eco de esta circunstancia, es el caso de Gisbert y Ballesteros que, en su obra «Historia de Orihuela», lamenta las contiendas y reyertas que frecuentemente se dieron entre murcianos y oriolanos, "selladas no pocas veces, con la sangre de quienes siempre han debido considerarse como hermanos, como hijos de una misma vega y ligadas aunque no quieran por los mismos intereses» 5 .

El documento, además de hacer alusión a la frontera aragonesa, también se refiere a la que el reino murciano mantiene con Granada, frontera que permanece sin variaciones importantes durante más de dos centurias, desde 1266 a $1486^{6}$.

Se trata de una extensa "tierra de nadie" donde la escasez de población es la característica dominante. Circunstancia esta que queda reflejada en el siguiente texto que recoge Torres Fontes: "desde Xiquena, nueve leguas de tierra despoblada, e toda a peligro de moros" ${ }^{7}$. Parcas palabras pero extraordinariamente clarificadoras, como lo son de la misma manera las reflexiones que sobre esta cuestión realiza Rodríguez Llopis y que nos parece interesante destacar aquí; dice el autor que «el despoblamiento se constituye en la consecuencia lógica de una sociedad que vive para la guerra; la población se contrae para mejor defenderse, y en ello encuentra su pervivencia...." .

Grave problema este vacío humano del que hablamos para la defensa del territorio, por lo que hubo de adoptar una serie de medidas para subsanarlo. Una de ellas fue la concesión del privilegio del derecho de asilo a «homicianos». Así la frontera se convierte en "refugio de malhechores, violadores y homicidas" ${ }^{9}$, sin olvidarnos de los nobles desterrados de la corte.

2 VILAR, J.B., Historia de la ciudad de Orihuela. T. III. Los siglos XIV y XV en Orihuela. Murcia, 1977, p. 307.

3 MARTÍNEZ CARRILLO, M${ }^{a}$. LI., Op. cit, p. 195.

4 Historia de España. Dirigida por J.M‥ Jover Zamora. T. XIII. I. Madrid, 1990, p. 484.

5 GISBERT Y BALLESTEROS, D., Historia de Orihuela. Orihuela, 1903.

6 TORRES FONTES, J., "La actividad bélica granadina en la frontera murciana (ss. XIII-XV)». Príncipe de Viana, 3 (1986). Homenaje a J.M $M^{a}$. Lacarra, pp. 721-739, p. 721.

7 TORRES FONTES, J., «Enrique IV y la frontera de Granada. (Las treguas de 1458, 1460, y 1461)". Homenaje al profesor Carriazo. Sevilla, 1973, pp. 345-380, p. 346.

8 RODRÍGUEZ LLOPIS, M., Señoríos y feudalismo en el reino de Murcia. Univ. de Murcia, 1986, p. 51 .

9 JIMÉNEZ ALCÁZAR, J.F., Huércal y Overa: de enclaves nazaries a villas cristianas (12441571). Huercal-Overa, 1996, p. 29. 
Por otra parte, aunque sin abandonar la frontera entre el reino nasrí de Granada y el castellano en su sector murciano, no debemos pensar en la existencia de una clara y precisa línea divisoria entre ambos. Los verdaderos límites quedaban marcados por un rosario de torres y atalayas, de puntos fuertes que se extienden a lo largo de esa tierra de nadie ${ }^{10}$.

Hasta aquí, algunas puntualizaciones de carácter general sobre los dos sectores fronterizos; completaremos estos datos con una visión política y diplomática global de los tres reinos - granadino, castellano y aragonés- en el momento en que se redacta el documento objeto de este estudio, esto es, abril de 1427.

A Granada la hallamos sumida en un proceso de inestabilidad del que ya no podrá salir. Muhammad VIII y su tío Muhammad IX, apoyados por Alamines y Abencerrajes respectivamente, las dos facciones más poderosas en el reino nazarí durante el siglo $X V^{11}$, llevan practicando el juego del derrocamiento desde hace varios años. A comienzos de 1427 llega el turno de gobierno a Muhammad VIII, que tuvo que abandonarlo en beneficio de su tío, conocido como el Izquierdo, antes de finalizar el año. Nos encontramos inmersos en una guerra civil que conducirá al emirato a su propia destrucción.

En Castilla también se lucha por el poder; esta vez la pugna se desarrolla entre don Álvaro de Luna, los infantes de Aragón y las ligas nobiliarias. Distintas facciones pero un sólo objetivo: riqueza y, sobre todo, poder. Frente a estos Juan II, indolente soberano que deja las riendas de su política en manos de su valido.

Por su parte, Aragón cuenta con la figura, que no con la presencia, de Alfonso $V$ el Magnánimo, más interesado en ampliar las fronteras de su Corona por mar que por tierra $^{12}$. Al mismo tiempo, se observa el crecimiento de la alta nobleza aragonesa ante la ausencia de toda autoridad regia.

Centrándonos en el adelantamiento murciano, la figura indiscutible es el que denomina Cascales «belicosisimo caballero» ${ }^{13}$; se trata del segundo Alonso Yáñez Fajardo. Como adelantado mayor, cargo al que accede en 1424, le incumbía «el mantenimiento de la paz pública en su circunscripción, preservando el territorio y sus pobladores de todo mal o daño, como asomadas o revueltas ${ }^{14}$. $Y$ a éste fin dedicó su vida, pero con tal empeño y exhibiendo tan espléndidas cualidades guerreras y políticas, que le hicieron merecedor, en 1430 , del cargo de capitán mayor «de la frontera de la guerra de los moros" ${ }^{15}$.

Este es el panorama interno que presentan los tres reinos, pero la cuestión que nos interesa destacar aquí es la política que cada uno de ellos despliega con respecto a los demás. Hablemos pues, de política exterior, de diplomacia.

10 JIMÉNEZ ALCÁZAR, J.F., Lorca: ciudad y término. Lorca, 1994, p. 150.

11 TAPIA GARRIDO, J.A., Historia de la Vera Antigua. Almería, 1987, p. 235.

12 VILAR, J.B., Op. cit., p. 307.

13 TAPIA GARRIDO, J.A., Op. cit, p. 111.

14 GARCÍA DE VALDEAVELLANO, L., Curso de las instituciones españolas. Madrid, 1977, p. 510.

15 TORRES FONTES, J., "Los Fajardo en los siglos XIV y XV». M.M.M., IV, 1978, Univ. de Murcia, pp. 107-175, p. 137. 
Como punto de partida, resaltar la privilegiada situación de Castilla en el panorama peninsular y su peso cada vez mayor en el acontecer político de los reinos hispánicos. A pesar de su manifiesta superioridad militar, la inestabilidad interna que atravesaba, ya hemos comentado, era motivo de peso para no desplegar una firme política defensiva contra el enemigo musulmán. Por otra parte, de éste tenía asegurado el cobro del tributo anual o parias.

Por lo que respecta a Aragón ya hablamos de las preferencias extrapeninsulares mostradas por su monarca, lo que le llevará a buscar relaciones pacíficas en el interior de la península, sobre todo con Granada; manifestación de ello son, por ejemplo, el envío de emisarios o la firma de acuerdos comerciales ${ }^{16}$.

El mantenimiento de la paz y el establecimiento de buenas relaciones parece ser el objetivo de los tres monarcas, lo que se plasmó en la firma de una serie de acuerdos entre los mismos. Como ya hemos apuntado anteriormente, en enero de 1427 el trono de Granada cambia de manos lo que implica que la tregua firmada en 1426 entre el monarca granadino depuesto y Castilla deja de tener vigor; con toda premura los soberanos de ambos reinos, en un intento de evitar el estallido de incidentes, se disponen a negociar una nueva tregua, la cual va a tener comienzo oficial el 16 de febrero de $1427^{17}$.

Habría que destacar cómo el juego político de treguas entre Aragón y Granada, Granada y Castilla o entre Aragón y Castilla venían a crear en el Sureste peninsular una situación interesante. Por ejemplo, en momentos en los que Granada tiene rota la tregua con Castilla, pero no con Aragón, cómo ocurrió en 1407, los aragoneses - concretamente los oriolanos - no pueden atender, al menos oficialmente, la llamada de ayuda que les llega desde el adelantamiento murciano, aunque como apunta Bellot: «muchos caballeros vendrán a la deshilada» ${ }^{18}$.

Pero acercándonos de nuevo a los territorios fronterizos, aquí se debían hacer valer las treguas acordadas entre los monarcas. Cuestión ésta sin duda, harto difícil; y es que como apunta Carriazo, en la frontera ni la guerra era guerra, ni la paz era paz, ni siquiera las treguas eran treguas, en el pleno sentido del concepto ${ }^{19}$.

El estado normal de la frontera en tiempos de paz venía marcado por las constantes algaras, cabalgadas e incursiones más o menos profundas que llevaban a cabo fronteros de uno u otro lado. Situación ésta que algunos autores han venido a denominar de "semibeligerancia, guerra atenuada $"^{20} 0$ "guerra chica ${ }^{21}$.

16 TORRES FONTES, J., "Relaciones castellano-granadinas (1427-1430)». IV Coloquio de His" toria Medieval Andaluza. I.E.A., 1988, p. 86.

17 TORRES FONTES, J., “Las relaciones castellano-granadinas desde 1416 a 1432. !. Las treguas de 1417 a 1426». Cuadernos de Estudios Medievales, VI-VII, pp. 297-312, p. 311.

18 CARRIAZO ARROQUIA, J.M., "Un alcalde entre los cristianos y los moros en la frontera de Granada". En la frontera de Granada. Homenaje al profesor Carriazo. Sevilla, 1971, pp. 87-142, p. 138.

19 Ibídem, p. 139.

20 lbídem.

21 TORRES FONTES, J., “La actividad bélica... », p. 732. 
Innumerables situaciones conflictivas que en ningún caso ponían en peligro la vigencia de la treguas. En este contexto político se hallaban las Coronas castellana, aragonesa y granadina a finales de la década de 1420-30. Precisamente en 1427, y como concreción de la tregua firmada en febrero de este año, se acuerdan entre Murcia, Orihuela y el sector fronterizo oriental de Granada --Vera, Huércal y los Vélez- unos capítulos en los que el adelantado murciano como máximo representante de la Corona castellana en su demarcación, intenta... poner remedio a los grandes males e daños e pérdidas, ofensas e injusticias e agravios... ${ }^{22}$ que acontecian como consecuencia de las frecuentes correrías que almogávares de los tres sectores citados llevaban a cabo. Es obligación de Alonso Yáñez Fajardo II «apuntalar» en el ámbito fronterizo suroriental las buenas relaciones que a nivel general se desean mantener.

Por otra parte y, como claramente se expresa en nuestro documento, los almogávares granadinos no limitan sus acciones a territorio murciano sino que penetran en Aragón, concretamente en la gobernación de Orihuela; y es que la distancia entre esta villa y los puntos más avanzados del reino de Granada no supera los 120 kms. ${ }^{23}$; a esta circunstancia se añade una orografía favorable -recordemos que la depresión prelitoral une Andalucía con Levante-, además de la existencia de numerosas aljamas en territorio cristiano que prestaban información y ayuda oportuna a los que venían de Granada.

Era habitual la represalia por parte de los oriolanos que se aventuraban hasta tierras de Granada con la finalidad del robo y cautiverio. La contestación granadina no se hacía esperar «pero en vez de verificarla en la gobernación de Orihuela lo hacían en el reino de Murcia, como territorio más cercano a su frontera» ${ }^{24}$.

Es precisamente este constante trasiego de almogávares que recorren en todas direcciones el territorio murciano, ocasionándose por ello muchas muertes e otros males $^{25}$, lo que denuncia e intenta subsanar Alonso Yáñez Fajardo Il a través de estos capítulos. Sus disposiciones giran en torno a uno de los males endémicos que soportan los habitantes de la frontera: el cautiverio. El temor a ser sorprendidos por el enemigo, hizo que el ambiente normal que se respiraba en los lugares próximos a la frontera estuviera impregnado de una gran tensión e inquietud. $Y$ es que la frecuencia de los cautiverios aumentaba a la par que avanzaba el siglo; circunstancia que se aprecia con claridad en las condiciones impuestas en la firma de las treguas entre castellanos y granadinos, en las que cada vez es mayor el número de cautivos cristianos que se exigía fueran puestos en libertad ${ }^{26}$. La captura de enemigos se había convertido en un negocio que reportaba «pingües" beneficios por lo elevado de los rescates;

22 Ver Apéndice Documental.

23 MARTÍNEZ CARRILLO, Ma LL., Op. cit., p. 208.

24 TORRES FONTES, J., "Notas sobre los fieles del rastro y alfaqueques murcianos». M.E.A.H., $X(1969)$, pp. 89-105, p. 99.

25 Ver apéndice documental.

26 TORRES FONTES, J., «La frontera de Granada en el siglo XV y sus repercusiones en Murcia y Orihuela: Ios cautivos". Homenaje a J.M?. Lacarra. Vol. IV, Zaragoza, 1977, pp. 191-211, p. 192. 
no es de extrañar, por tanto, que fueran muchos los que convirtieran esta arriesgada actividad en su forma de vida.

El número de cristianos que sufrieron cautiverio, fue bastante superior al de musulmanes. Varias son las causas. La primera de ellas y la más importante es de orden económico. La mayor parte de los moros cautivos eran reducidos a esclavitud o canjeados por cristianos, eran muy pocos los que volvían a su lugar de origen tras haber recibido su captor un rescate en metálico. Con los cristianos ocurría lo contrario; las familias de los cautivos, con grandes dificultades en muchas ocasiones, lograban reunir las cantidades exigidas. Obtienen los musulmanes, de esta forma mayores beneficios que sus compañeros de oficio del otro lado de la frontera ${ }^{27}$.

Una segunda causa la encontramos en la desigualdad del dispositivo defensivo desplegado entre castellanos y granadinos. El sector oriental del reino nazarí presenta a lo largo de su frontera "un poblamiento concentrado muy denso, con muchos enclaves de pequeña y mediana importancia ${ }^{28}$, por lo que las incursiones por sorpresa resultan más difíciles de realizar que en los extensos despoblados castellanos.

Asaltos, correrías y violencias de todo tipo son el resultado del largo período en el que se mantuvo el límite entre el musulmán y el cristiano en el sureste peninsular. Pero durante este espacio de tiempo también se fueron generando toda una serie de instituciones tendentes a acabar o a mitigar en lo posible estas acciones. A una de ellas hace alusión nuestro documento, se habla en el de seguir el rastro ${ }^{29}$, los encargados de esto eran los llamados fieles del rastro, oficiales concejiles cuya tarea consistía en perseguir a los malhechores que entraban en su territorio. Su labor concluía cuando los presuntos autores del delito habían sido capturados o podía entregarse el rastro a los encargados de ello en la jurisdicción vecina ${ }^{30}$.

Conocido el paradero de los cautivos entraba en escena el alfaqueque. El oficio de la alfaquequería resulta ser la más clara evidencia de la frontera como generadora de instituciones; prueba de ello es que este personaje ya actuaba mucho antes de que estuviese instituido el oficio como tal. Así cuando en Las Partidas aparece el cargo de alfaqueque la intención de Alfonso $X$ «no es tan solo el resultado de una inquietud legislativa sino un atemperarse con la realidad fronteriza castellana» ${ }^{31}$.

Estos alfaqueques y «exeas» estaban encargados de llevar a cabo el canje o redención de cautivos, además de la recuperación de ganados u otras cosas robadas. Solían portar una carta concejil, una especie de acreditación o salvoconducto - normalmente aceptado por las diversas partes en liza- que les permitía la libre circulación y el paso a través de la frontera.

27 TORRES FONTES, J., «La frontera, sus hombres y sus instituciones». Murgetana, 57 (1987), pp. $71-116$, p. 100.

28 JiMÉNEZ ALCÁZAR, J.F., Huércal y Overa: de enclaves nazaries..., p. 13.

29 Ver apéndice documental.

30 TORRES FONTES, J., «Notas sobre los fieles...", p. 91.

31 TORRES FONTES, J., "Los alfaqueques castellanos en la frontera de Granada». Homenaje a Agustín Millares Carló. Las Palmas de Gran Canaria, 1975, pp. 99-116, p. 99. 
Pero quien realmente pone en movimiento toda esta maquinaria fronteriza es el adelantado. Alonso Yáñez Fajardo II se erige en arbitro de las situaciones conflictivas que acontecen en el sector fronterizo suroriental; a él compete establecer las disposiciones de los capítulos, disponiendo la persecución de los malhechores, demandando a los culpables la devolución de lo sustraído o bien una compensación en metálico, estableciendo el plazo en el tienen que llevarse a efecto las citadas devoluciones y compensaciones, etc.

Las relaciones fronterizas que tradicionalmente han suscitado mayor interés por parte de los investigadores son las que tienen como protagonistas a dos culturas, dos religiones diferentes; es por ello que los estudios en este campo se han centrado en la frontera entre Castilla y Granada. Sin embargo, la zona de contacto entre Aragón y Castilla en el adelantamiento murciano es un foco muy interesante para mostrar como a lo largo de la historia las divisiones territoriales artificiales, resultado de decisiones políticas, han afectado a la dinámica de una zona, tanto que incluso actualmente los problemas, aunque de otra índole siguen manteniéndose.

Murcia sigue sintiendo la cercanía oriolana como algo propio y Orihuela siente Alicante mucho más lejana tanto en la distancia física como en el arraigo histórico. 


\section{APÉNDICE DOCUMENTAL}

\section{7, abril, 15. (Orihuela)}

Carta de Alfonso Yáñez Fajardo al baile general del reino de Valencia y éste a los oficiales del concejo de Orihuela para la aprobación de unos capítulos. Inserta: 1427abril-17. Carta confirmando la aceptación de dichos capítulos. (A.M.O. Libro $\mathrm{n}^{\circ} 20$, fols. 90-93).

Don Pero Maça de Liçana conseller e mayordomi del molt alt senyor rey e gobernador de la gobernaçio de la vila d'Oriola en Antich Albarades justiçi de la dita vila en lo criminal en Antoni de Galbe e en Jaume Rocamora e en Bernat Despuig jurats de la dita vila vist sus capitols tramesos e fermats per part del adelantat e regidors e qonsell de la ciutat de Murçia los quals capitols son estants portats e presentats el molt honorable miser Johan Mercader baile general del regne de Valencia e per lo dit honorable baile enviats als dit gobernador e justiçi e jurats de la dita vila per Johan Peres de Bonmati scriba e notari del dit adelantat e qonsell de la dita ciutat dimarts qui es comptante quinze dies del mes de abril del any de la Nativitate de nostre senyor mil e quatrocens e vint e set por los quales capitols se mostren fermats de la ma e nom per part dit adelantat e de Lope Alfonso e de Pero Martinez de Ahuera regidors del dit qonsell de la dita ciutat de Murçia per tal nos dit gobernador lo ant aceptant los dits capitols fermats aquells de nostre propi nom e ma segons en la fi de aquells es contengut. E nosalters aixi mateix justiçi e jurats e qonsell de la dita vila aceptant los dits capitols donan poder an Jaume de Rius bacheller en leys e an Barthomeu Mosen de Castanyesa misatgers nomenats en los dits capitols que en nom nostre e de la dita universitat fermen los dits capitols e sots scriuen de sos propis noms e mans segons en la fi d'aquells es contengut los quals capitols son de la tenor seguent.

En el nombre de Dios.

Alfonso Yañez Fajardo adelantado mayor del regno de Murçia e Pero Martines de Ahuera e Lope Alfonso de Lorca regidores de la muy noble çibdat de Murçia, en nombre del conçejo,regidores, caballeros, escuderos, ofiçiales e omes buenos de la dicha çibdat, de la una parte en nombre de todo el dicho regno,realengo e señorios. E e de la otra parte Jayme de Rius, bachiller en leyes, e Bartolome Monsy de Castañiesa, habitadores e mensajeros del gobernador e justiçia e jurados de la villa de Orihuela, en nombre de los dichos gobernador,justiçia e jurados e conçejo e universidat de la dicha villa e de su gobernaçion,realengo e señorios. Por oviar e poner remedio a los grandes males e daños e perdidas, ofensas e injustiçias e agravios que son acaesçidos e suelen e se esperan acaesçer en los dichos regno e gobernaçion e en sus terminos, por causa e ocasion de las entradas que los moros del regno e señorio de Granada fasen por los terminos deste regno de Castilla deste dicho adelantamiento a los terminos de la dicha gobernaçion.E otrosy por las entradas que los vezinos de la dicha gobernaçion e otros fasen a la dicha tierra e señorio de Granada por termino de Castilla deste dicho adelantamiento fasiendose por alli guerra los unos a los otros, sobre lo 
qual son acaesçidas muchas muertes e otros males e se han sostenido muchos trabajos e muchas costas e despensas. Por esta rason ordenaron los capitulos siguientes.

Primeramente, que firmados estos dichos capitulos por los señores reyes de Castilla e de Aragon e por el rey de Granada, quel dicho adelantado aperçiba luego por sus cartas a los cabdillos e alcaydes e aljamas de Vera,e Veles e de Huerca e sus conquistas e de los otros lugares del dicho regno de Granada que son en la frontera deste dicho adelantamiento, que no entren por los dichos terminos del dicho adelantamiento a cativar omes ni faser otros males ni muertes a los dichos terminos de Orihuela e su gobernaçion, ni por alli a otros lugares del regno de Aragon.E otrosy que los de la dicha villa de Orihuela e de su gobernaçion, que no entraran por los dichos terminos de Murçia e de su adelantamiento a cativar moros ni a faser otros males ni muertes a las dichas conquistas de Vera e de Veles e Huerca, ni por alli a otras partes del dicho regno de Granada de aqui adelante, çerteficandoles que qualquier o qualesquier personas christianos o moros de amas las partes que fueren tomados en pasando,entrando o saliendo o estando seran luego muertos por justiçia e tornada la presa a la parte dabnificada.E si no fueren tomados, sera seguido el rastro, e sera demandado el robo e toma por el dicho adelantado a qualquier de las dos partes de Orihuela e su gobernaçion e de los dichos lugares e conquistas de Granada, e fara prendas e pagara a los dabnificados.E otrosy, quel dicho gobernador sea tenido de faser semejante aperçebimiento a todos los lugares de su gobernaçion e a los otros lugares comarcantes a ella.

Item que luego quel dicho adelantado o sus ofiçiales fueren çerteficados de algun salto o muertes o cativerios o robos que sean fechos por los dichos moros del dicho regno de Granada o por otras personas, en el termino de la dicha villa de Orihuela o en su gobernaçion, o por alli a otros lugares del dicho regno de Aragon, e fuere puesto el rastro de los malhechores en este termino de Murçia e en su adelantamiento, quel dicho adelantado o sus ofiçiales fagan tomar e seguir el rastro. E que si no fueren tomados los malhechores, demandara el dicho adelantado a los moros de la conquista donde entrare el rastro, o donde se sopiere que fue levado el robo, que lo paguen o su estimaçion sabida con gran deligençia la verdat del dicho daño, aunque por rastro no se falle. E si oviere muertes, que se pague por cada muerte quarenta doblas para la parte de los dabnificados, e las personas vivas que sean tornadas en toda manera, aunque sean trasportadas en otros regnos e señorios, en tal que se falle por verdat que por tierra sean levados o tomados pasando por el dicho adelantamiento por tierra en todo o en parte.E si los moros no lo cumplieren asi dentro en veinte dias del dia que fueren requeridos, quel dicho adelantado fara prendas bastantes por ello en los moros e las dara e entregara a los dichos gobernador e villa de Orihuela dentro en dos meses. E si dentro en el dicho plaso no lo fisiere, que los dichos gobernador e villa de Orihuela puedan faser prendas por ello en personas e bienes de la dicha çibdat de Murçia e de su adelantamiento fasta ser satisfechos de los dichos daños. E que desta guisa se entienda quel dicho adelantado ha de enmendar e satisfaçer a los moros de las dichas conquistas de las muertes e cativerios que resçibieren e les fueren fechos 
por parte de la dicha villa de Orihuela e su gobernaçion por el dicho adelantamiento.E que estas cosas suso dichas se fagan e cumplan a buena entençion e sin engaño de ninguna de las partes. E que el dicho adelantado aya cargo de faser firmar estos dichos capitulos al señor rey de Castilla e al rey de Granada,e el dicho gobernador al señor rey de Aragon, e que dure del dia que fueren confirmados en tres años complidos $e$ dende adelante en tanto tiempo quanto a todas las dichas partes plasera.

1427-abril-17. En hoy XVII dies d'abril en l'any de la Nativitate de nostre senyor mil e quatrecents e XXVII complits (?) en Johan Peres de Bonmati scriua public e notari del adelantat de la çiutat de Murçia e presenta als justiçi e jurats de la dita vila d'Oriola e en presençi del honorable miser Johan Mercader baile general de regne de Valençia dita carta del dit adelantat qui es de la tenor seguent.

A los mucho honorables el justiçia e jurados e consegeros de la vila de Orihuela.

Mucho honorables el justiçia e jurados e consegeros de la vila de Orihuela. Alfonso Yañez Fajardo, adelantado mayor del regno de Murçia, vos envio mucho a saludar como aquellos por quien de buena voluntat faga las cosas que a honra vuestra cumpla.Reçebi los capitulos que, de parte del senyor baylle e gobernador e vuestra, me fueron enviados con Johan Peres de Bonmati, mi scriuano, firmados de los nombres de don Pero Maza e de Jaime de Rius, bachiller, e Bartolome Mosin de Castanyesa, segun por ellos parecia et oi cosas quel dicho mi scriuano, de parte de los dichos bayle e gobernador e vuestra, me dixo. Las quales, por mi entendidas, le respondi segun que el vos dira plega a vos de lo oir e cierto de lo que acerca dello de parte mia el vos dixere e explicare. E Dios vos haya en su santa guarda.Scripta disisiete dias de abril.Alfonso Yañez. 


\title{
CASTRIL: DE ḤIȘN FRONTERO A SEÑORÍO BAJOMEDIEVAL
}

\author{
Concha ALFARO BAENA \\ Universidad de Granada
}

Los estudios referidos a la tierras fronterizas entre el reino nazarí de Granada y la corona de Castilla son muy numerosos, y prácticamente han abarcado todos sus sectores. Las más modernas corrientes investigadoras introducen en esta temática nuevos análisis de la problemática social y económica de estos territorios, que vienen a completar el ya tradicional punto de vista político. $Y$ es que, realmente, la frontera es algo más que guerras y treguas, cabalgadas, cautiverios y rescates, conquistas y reconquistas.

Es indudable que para llevar a cabo esta labor también ha sido necesaria la utilización de nuevas fuentes de conocimiento. La documentación escrita, tanto cristiana como musulmana, ha proporcionado la mayor parte de las noticias que hasta hoy se conocen de este complejo mundo que es la frontera. Pero los esperanzadores resultados que la arqueología está proporcionando para el estudio de lo que fue el reino nazarí de Granada, y sobre todo para el mundo rural ${ }^{1}$, nos obligan a su aplicación en los estudios fronterizos. Sirva como ejemplo, los importantes sistemas defensivos con que cuenta, que apenas han sido objeto de estudio por parte de los Historiadores del Arte; o del gran número de despoblados originados por los avances y retrocesos de la línea y su consiguiente inestabilidad, cuyo estudio se hace hoy en día imprescindible.

Proponemos aquí el análisis de un pequeño territorio que pasó a formar parte de la frontera granadino-jiennense desde principios del siglo XIII: el Hiișn Qastāl. Para ello hemos utilizado la importante colección documental referida a esta zona, dada a

1 Al respecto merecen especial mención los trabajos que se han llevado a cabo por el profesor Antonio Malpica Cuello en la costa de Granada, el profesor Tomás Quesada Quesada en el sector fronterizo de Sierra Mágina y la profesora Carmen Trillo San José en la Alpujarra granadina. 
conocer y estudiada por el profesor Juan de Mata Carriazo y Arroquia. Otra parte importante de los documentos consultados proceden del Archivo General de Simancas, especialmente el Repartimiento de $\mathbf{1 5 2 7}^{2}$, que proporciona importantes datos para el período posterior a la conquista cristiana. Incluimos también las aportaciones que hasta este momento hemos obtenido de las fuentes arqueológicas.

Castril (Qastāi) se localiza en el extremo nororiental de la provincia granadina en las estribaciones montañosas de la Sierra de Cazorla que en esta zona es conocida como Sierra de Castril. Alcanza altitudes de hasta $2.000 \mathrm{~m}$, si bien en dirección S se suaviza hasta los $900 \mathrm{mts}$. La vegetación dominante corresponde a la especie Quercus, sobre todo encinas, que en las zonas más húmedas deja paso al quejigo. Las áreas más altas de la sierra se encuentran pobladas de un bosque de coníferas con especies tales como el pino laricio y un denso matorral de tipo mediterráneo. Cuenta también con importantes pastizales de alta montaña en cotas superiores a los 1.500-1.700 $\mathrm{m}$, que presentan la enorme ventaja de poder ser aprovechados una vez que han desaparecido las nieves, es decir a partir de mayo o junio, cuando ya están prácticamente agotados los de las zonas más bajas. Esto dió lugar, al menos desde época medieval, a una importante corriente trashumante a través del puerto de Tíscar ${ }^{3}$. La existencia de un curso permanente de agua, el río Castril ( $W \bar{a} d \bar{l}-J$-Qastā $/ \bar{h}$ ), bien canalizado y aprovechado a través de una compleja red de acequias, molinos y albercas ha permitido el riego de extensas zonas de tierra y por consiguiente el establecimiento de una importante agricultura de regadío y de huerta que convivía con la de secano.

La frontera oriental del Reino de Granada quedó definida en el sector que nosotros estudiamos desde principios del siglo XIII, coincidiendo con el avance de Fernando III por tierras jienenses y murcianas. En 1231 el monarca hizo donación al arzobispo de Toledo D. Rodrigo Jiménez de Rada un amplio territorio que tenía como área de expansión las hoyas de Guadix y Baza 4 . Para ello pronto los cristianos se hicieron con todos los castillos de la cabecera del río Guadiana Menor - Cuenca, Chiellas, Torres de Alicún, Cebas, Cuevas de Almizdra y Cúllar--, entrada natural desde el Guadalquivir hacia estas tierras. En el sector murciano ocurre algo similar, ya que en 1243 pasa también a poder cristiano junto con el resto del Reino. Un año antes la Orden de Santiago había recibido de Fernando III Segura de la Sierra, siguiendo la misma política que con el Adelantamiento de Cazorla. De esta manera a la vez que era premiada por sus acciones militares permitía el establecimiento de una base fuerte que hiciese frente a los granadinos en su intento de apoderarse del reino murciano. Los

2 Este documento fue el objeto de nuestra Memoria de Licenciatura, en la actualidad en prensa.

3 Antonio MALPICA CUELLO, «Fiscalidad y comercio de la sal en el reino de Granada en la Edad Media», Das Salz in der Rechtsund Handelsgeschichte. Internationaler Salzgeschichtekongres, 1990, pp. 65-94.

4 "Que él(el arzobispo de Toledo) había rogado y suplicado humildemente que no se anulase en sus días la antigua autoridad de loas arzobispos de Toledo, a todos los cuales se habia permitido atacar hasta recuperarlas las dos ciudades de Baza y Guadix...". Alonso de PALENCIA, Crónica de Enrique N, trad. A. PAZ Y MELIA. B.A.E. CCLVII-CCLIX, Madrid, 1973-1975, p. 103. 
santiaguistas que ya ocupaban Huéscar se hacen con Galera, Orce y Castilléjar, que les son donados por privilegio real de 1243.

Salvo en determinados momentos en que cristianos y musulmanes alcanzan alguna paz estable los enfrentamientos fronterizos marcan la actividad de esta zona durante los dos siglos siguientes. De esta manera el área bastetana no conoció descanso alguno, manteniendo un estado de alerta permanente que llevó al establecimiento de uno de los más importantes sistemas defensivos de todo el reino.

Las primeras noticias que tenemos de Castril se refieren a Lezas. Se trata de un despoblado de época musulmana localizado en el pago de mismo nombre en el tramo alto del río Castril ${ }^{5}$. Situado a media ladera y en la margen derecha del río presenta fácil acceso desde éste. Está en una zona muy fértil, rodeada de pastos y donde aún hoy es posible distinguir restos de abancalamientos y terrazas de cultivo. En el siglo $\mathrm{XVI}$ contaba este lugar con el aporte del agua proveniente de un arroyo Royo de Lezas, que hoy se encuentra seco ${ }^{6}$. No son visibles, en cambio, estructuras de muros, salvo algunas canalizaciones de agua y en el perfil de un corte de sembrado han aparecido restos de enterramientos cubiertos en su parte superior por unas lajas de piedra. A pesar del grado de destrucción que presentan y de la necesidad de proceder a su excavación y estudio, no descartamos que sean de época árabe. La cerámica procedente de este yacimiento ha proporcionado restos de sigillata que permiten apuntar la presencia romana en éste área y ponerla en relación con otros yacimientos aparecidos en el curso del río Castrili. En su mayor parte, la cerámica arroja una cronología en torno a los siglos XI y XII. No existe ningún fragmento susceptible de ser datado con posterioridad y es escasa la presencia de cerámica a mano que permita establecer una datación anterior.

A propósito de este lugar tenemos constancia del topónimo Lezar en una donación que en 1294 hace Sancho IV a don Gonzalo García Gudiel y posteriormente, en 1384, en una sentencia por el pleito que mantenían Ubeda y la mitra de Toledo sobre los lugares de Quesada y sus límites con Cazorla. En ella aparece citada como una aldea:

«e dende a las aldeas de la dicha villa, quales son leçar, çebas, que parten con Castril, lugar del rei de Granada»."

Parece clara, por tanto, la correspondencia entre yacimiento y topónimo dado su proximidad a Cebas y Castril, junto a las que aparece citada en la fuentes, y la no

5 M.I.G.N., hoja 929 , San Clemente, 1:50.000, $0^{\circ} 54^{\prime}-0^{\circ} 55^{\prime} / 37^{\circ} 51^{\prime}-37^{\circ} 50^{\prime}$

6 "Primeramente una haça en el Leças que es del camino arriba, que tiene seys hanegas sacadas, que es linde de Alcotroy y del royo de Leças y con el rio". A.G.S.-G.A., leg. 1315, fols. 145, 146 y 227.

7 Milagros SOLER CERVANTES, “Proyecto de estudio de poblamiento en la prehistoria reciente en la Depresión de Baza-Huéscar», Campaña de Prospección de 1991, Investigaciones Arqueológicas en Andalucia, 1985-1992, Huelva, 1993, pp. 815-821.

8 Juan de Mata CARRIAZOY ARROQUIA, Colección Diplomática de Quesada, Jaén, 1975, Doc. núm. 31, pp. 57-66. 
existencia en todo el área de algún topónimo similar. Los restos del despoblado medieval existentes en este pago nos llevan a confirmar que era éste el lugar donado a don Gonzalo García Gudiel. Por último en el reparto de tierras que se hace en 1527 al objeto de animar la repoblación de la zona, se entregaron en este pago un total de treinta y cinco fanegas y media a cuatro vecinos, de las que únicamente una y media correspondían a monte y por tanto estaban pendientes de roturar.

Más temprana es la cronología que nos ofrece el hișn Qastāl, donde han aparecido algunos fragmentos pertenecientes al período emiral. No obstante, el grueso de la cerámica de este yacimiento se data en los siglos XII a XVI, coincidiendo con las noticias que nos ofrecen las fuentes escritas. El castillo se ubica en un espolón rocoso - conocido como las Peñas -9 en la margen izquierda del río dominando todo su valle. Este lugar ha sido objeto del sistemático expolio de furtivos que en varias ocasiones han procedido a realizar excavaciones dentro del recinto, a lo que debemos añadir la presencia de algunas construcciones modernas que han acelerado su destrucción. A pesar de ello es posible distinguir algunos de sus elementos más significativos. De planta irregular tiende hacia un rectángulo y sobre una base de materiales calizos se pueden observar restos de muros de mampostería en el extremo $\mathrm{N}$ y $\mathrm{SE}$, donde además se encuentra una torre y otra que emerge. En la zona $S$ se encuentran los restos de dos aljibes, uno dentro de otro, que aún presentan restos de enlucido. No se han podido contabilizar el número de torres con que contaría la fortaleza pero debió ser elevado ${ }^{10}$.

La única descripción con que contamos de esta fortaleza la realizó en el s. XII alZurhī, en los siguientes términos:

«A poniente de este monte sale el río llamado Guadiana [Menor], que baja hacia la fortaleza llamada Castril (Qastäl). En el patio de dicha fortaleza se encuentra la gran piedra de la que mana agua y que es una piedra lisa que se alza enormemente sobre el suelo. En su parte superior hay una fuente de la que brota tal cantidad de agua que podría mover ocho piedras [de molino]. En el estanque [que se forma] existen muchos peces de color amarillo con lunares rojo, que poseen dientes caninos y molares. Ni en el mar ni en los ríos existen peces más finos que éstos. Quien los contempla correteando entre las cavidades de las rocas se imagina que son espadas [centelleantes] o destellos de relámpago. Luego el agua se esparce entre los peñascos y desciende hasta el Guadiana [Menor] hasta que se junta con el Guadalquivir"'".

Este castillo hay que ponerlo en relación con el sistema defensivo de la zona oriental del reino. En concreto formaría parte de un tercer cinturón en torno madīnat Basţa y por su condición fronteriza desarrollaría una importante labor de vigilancia y defensa

9 "Yten un colmenar que esta baxo de las Peñas de la fortaleza". A.G.S.-R.G.S., leg. 1315, fols. 145,146 y 227.

10 Antonio MALPICA CUELLO, Poblamiento y Castillos en Granada. Barcelona, 1996.

11 Dolores BRAMONS, El mundo en el siglo XII. Estudio de la versión castellana y del original árabe de un geografía universal, «El tratado de al-Zuhrī», Barcelona, 1991, p. 173. 
de los pasos que a través de la sierra comunicaban tierras cristianas y musulmanas. A su vez se encontraba en contacto visual con las atalayas que salpicaban el territorio y que conectaban con Baza. Sabemos que para su mantenimiento contaba con un habiz consistente en un aljibe y un inmueble en las inmediaciones de la ciudad de Baza. La cuarta parte del usufructo que se obtenía de estos bienes eran destinados al hiş̦n Qastāl que compartía esta renta con los caballeros pobres de Baza, los estudiantes de esta ciudad más necesitados y el propio administrador del habiz que recibía otra cuarta parte ${ }^{12}$.

Un núcleo habitado se asentaba en las laderas de este prominente rocoso, formado por un grupo de casas que disponían de su propia muralla ${ }^{13}$. Así pues nos encontramos con lo que los cronistas cristianos denominan villa fronteriza, ubicada en un lugar elevado dominando el valle del río y protegida por su propia muralla, dentro de la cual y en lugar destacado se encontraba la fortaleza que contaba también con su propio muro defensivo. A ella acudiría a refugiarse la población en caso de peligro.

En cuanto a las casas sabemos por el texto de 1527 que algunos de los nuevos pobladores procedieron a la construcción de sus propias moradas en este momento, lo cual nos induce a pensar que o bien la población musulmana que habitaba el lugar anteriormente fuese sensiblemente menor, o bien que las casas que se habían conservado, por sus peculiares características, no fuesen del agrado y la comodidad de los recién llegados. Estos decidirian bien hacerse una nueva, bien adaptar las que les fueron entregadas.

Otro de los lugares que encontramos en fecha temprana en la documentación cristiana es Cebas. Aparece citado en diversas ocasiones como uno de los castillos de la cabecera del Guadiana Menor que en 1245 estaban en poder de los cristianos ${ }^{14}$, en otros casos se le da el calificativo de aldea ${ }^{15}$. Nosotros no hemos podido confirmar la existencia de una fortaleza en el paraje que con este nombre se encuentra en las inmediaciones de Castril. Efectivamente, a unos 5 kilómetros al $\mathrm{O}$ de esta población y en la margen derecha del río se localiza el pago conocido como Campo Cebas ${ }^{16}$. Una parte importante de este terreno participa del relieve montañoso de la Sierra de Castril, donde hasta principios del siglo XVI el bosque debió ocupar una parte destacada de su superficie. Conforme desciende hacia el río se suaviza la pendiente dando lugar a una extensa llanura apta para los cultivos de secano.

Tradicionalmente Cebas ha sido lugar de frontera y paso hacia la vertiente $\mathrm{N}$ de la

12 Vicent LAGARDĖRE, Campagnes et paysans d'Al-Andalus (VIII-XVe S.), Paris, 1993, p. 281.

13 "Yten vna casa que alinda con la de Juan Abad y con Diego Amador y el adarue de la villa». A.G.S.-G.A., leg. 1315 , fols. 145,146 y 227.

14 Juan de Mata CARRIAZO Y ARROQUIA, Colección Diplomática de Quesada..., Doc. núm. 8 , p. 11.

15 Archivo de la Real Chancillería de Granada, cab. 506, leg. 1106, pieza 3. Pleito del Concejo de Cazorla con Fernando de Zatra sobre la mojonera de los términos de Castril.

16 «Que el campo de Cebas es una llanura situada al pie de la sierra de Castril, poblado de cortijos y, las tierras que no se labran, de monte". Tomás LÓPEZ, Diccionario geográfico de Andalucía: Granada. Ed. Cristina SEGURA GRAIÑNO y Juan Carlos DE MIGUEL, Granada, 1990, p. 53. 
Sierra de Castril con la que mantiene fácil comunicación a través del camino, que cruzándola, llega al núcleo de Los Almiceranes. Pero también el camino Real de Pozo Alcón a Castril, que no pasa por lo que hoy es el núcleo de los cortijos, sí lo hace por lo que se conoce como el Campo, al $S$ de Cebas.

Su cercanía a Quesada hicieron de esta zona lugar de influencia del Adelantamiento de Cazorla, siendo de hecho la frontera por excelencia. En la delimitación de términos que se hizo en 1384 entre los lugares de Quesada y Cazorla, el Adelantamiento tenía su límite hacia el SE en «la enzina santa questa entre Cebas e Castril»17, esta última perteneciente al rey de Granada. La tan próxima presencia de los granadinos debió ser un obstáculo que impidiera a Cazorla el uso y aprovechamiento de estos términos hasta que la fortaleza de Castril pasase a poder cristiano. Sin embargo Fernando de Zafra, nuevo señor de Castril desde 1490, defendió sus derechos sobre estos territorios y consiguió este mismo año la confirmación de una sentencia que reconocía la pertenencia de estos términos a Castril desde tiempo inmemorial ${ }^{18}$. Lo que estaba en cuestión era una importante zona de pastos a la que tradicionalmente acudían los pastores de Ubeda y a la que no estaban dispuestos a renunciar, según se desprende de la declaración tomada a los testigos del pleito en 1494:

«Preguntado sy supo del dicho ganado que se traxo de Diego de Baeça, vesino e regidor de Ubeda e que se tomo en el Campo Çevas dixo que lo ha oydo desir publicamente en esta villa. Preguntado sy el dicho Campo Çevas es parte donde se tomo el dicho ganado del dicho Diego de Baeça sy es mas adentro hasia Castril de los dichos mojones que declaro querian los moros de Baça e Castril segund derechos, dixo que el dicho Campo Çevas es en medio poco mas o menos de entre los dichos mojones querian los dicho moros por suyos... e que sabe que quando yvan a dar los dichos rastros a los dichos moros e los tomavan no los queryan reçibir salvo por los dichos mojones que ellos desian "'19.

Desde este momento se inició el que es conocido como pleito de La Marmota que duró unos cinco años y que puede ser considerado como uno de los más interesantes conflictos de términos en el oriente granadino tras la llegada de los cristianos.

17 Juan de Mata CARRIAZO Y ARROQUIA, Colección Diplomática de Quesada..., Doc. núm. 31 , pp. $57-66$.

18 «... fallaramos que la dicha villa de Castril y su procurador, en su nombre propio conplidamente su yntençion conviene a saber los terminos que la dicha demanda contenidos averlos poseydo de tiempo ynmemorial a esta parte el conçejo, alcayde e vesinos de la dicha villa de Castril, asy en los tiempos que las ayan los moros como despues que fue de xristianos paçificamente usando de los dichos terminos e arrendandolos e llevando los frutos dellos e prendando a los vesinos de la dicha villa de Caçorla cada e quando en los dichos terminos entrauan». A.G.S.-R.G.S., VII-1490, fol. 311.

19 A.R.Ch.Gr., cab. 506, leg. 1106, pieza 3. Pleito del Concejo de Cazorla con Fernando de Zafra sobre la mojonera de los términos de Castril. 


\section{LA FORMACIÓN DEL SEÑORÍO DE CASTRIL}

Tras la campaña de 1488 la mayor parte de la alquerías de la hoya de Baza habían pasado a poder de los cristianos, situándose la frontera, prácticamente en la misma vega de la ciudad. Así pues, era lógico que el próximo objetivo fuese Baza, ya que si finalmente esta ciudad era ganada se rendirían el resto de las grandes ciudades de la zona oriental que permanecían fieles a El Zagal, Almería y Guadix, y por tanto se completaría la ocupación de todo este territorio del reino granadino ${ }^{20}$.

En mayo de 1489 se inician las operaciones militares desde Jaén, tomando el camino hacia Quesada y Tíscar, para entrar en la hoya de Baza a través del curso del río Guadiana Menor. Instalado el real en Sotogordo, una parte de los contingentes se dirigieron hacia el Campo Cuenca, en las inmediaciones de Castril, desde donde entraron en la fortaleza que fue la primera de toda la zona en rendirse ${ }^{21}$. A principios de diciembre Baza capituló después de un penoso asedio de seis meses.

Las primeras noticias que disponemos de Castril, ya en manos cristianas, datan de 1490 y nos señalan que el lugar quedó despoblado como consecuencia de la guerra:

"Castril quando era poblada dizen que valia hasta çiento fanegas de pan de renta e que tiene muy buena sierra que abran en ella cada un año veynte mill cabeças de ganado que pagaran de doze vna que son dozientas $e$ quarenta cabeças, agora por la pas valdra mas»"22.

No obstante, parece seguro que permaneció un pequeño grupo de población mudéjar dedicado a la ganadería, actividad ésta que no requiere una importante fuerza de trabajo. Sin embargo si pudo haber un abandono por parte de aquellas personas que vivian de la agricultura.

Castril fue pronto enajenada a favor del secretario real, Fernando de Zafra, quien por merced la recibió por juro de heredad el 16 de febrero de 1490 como pago a «los muchos e buenos e señalados e leales serviçios... que nos avedes fecho e fazedes cada dia, espeçialmente en la guerra de los moros....233. Se trataba de una concesión peculiar que nos impide hablar de un "señorío pleno», ya que no le fueron reconoci-

20 "Especialmente determinaron de poner sitio sobre la cibdad de Baza; porque fue platicado en su consejo, que si aquella cibdad se ganase, seria menos trabajosa la conquista de las cibdades é castillos que en aquellas partes quedaban por conquistar'. Hernando DEL PULGAR, Crónica de los muy altos e poderosos Don Fernando é Doña Isabel rey e reyna de Castilla é de Leon é de Sicilia, Ed. Cayetano Rosell, Crónica de los Reyes de Castilla, III, B.A.E., LXX, Madrid, 153, p. 481.

21 Juan de Mata CARRIAZO Y ARROQUIA, "Los relieves de la Guerra de Granada en el Coro de Toledo", En la frontera de Granada. Homenaje al profesor Carriazo, vol. l, p. 362.

22 A.G.S.-Diversos de Castilla, leg. 44, p. 24.

23 A.G.S.-R.G.S., $11-1490$, fol. 25. 
dos ni la facultad de juzgar ni la potestad sobre los moradores ${ }^{24}$. Únicamente se especificaba la posesión militar de la fortaleza y del dominio territorial e incluso cuando en muchos casos es la Corona la que se quedaba para sí el control de las fuentes de riqueza, en este caso es el secretario Zafra quiene tiene el domino absoluto de "todo ello desde la hoja del monte hasta la piedra del río" ${ }^{25}$. El 13 de septiembre de ese año concedía Carta-Puebla a los pobladores y moradores del lugar ${ }^{26}$, en un intento de animar a la repoblación con cristianos viejos.

Que en Castril permaneció un grupo de mudéjares lo confirma la presencia de Abd Allah el Cotrob, musulmán que había ayudado a los cristianos a entrar en este lugar y que ahora es nombrado su alcalde y alguacil, además de recibir importantes propiedades tanto en Castril ${ }^{27}$ como en otros lugares de la hoya de Baza ${ }^{28}$. Pero además el propio texto de la Carta Puebla lo señala:

«No han de criar puercos en las huertas ó lugares de los moros, é si criaren sus haciendas de los dichos moros, puedan matar en pena».

«Ha de quedar el horno para el alfaquí é para la mezquita»²9.

El señor de Castril fijó en doscientos los vecinos que podrían avecindarse y a los cuales entregarían huertas e tierras para pan y viñas, es decir tierras de secano y regadío. Se les permitía construir una casa y además Fernando de Zafra les ayudaba a cada uno con mil maravedíes que debían ser devueltos al cabo de cuatro años. Este plazo se fijaba también para poder vender las tierras que les eran entregadas, siempre a vecinos del mismo lugar y nunca a forasteros. Además se les imponía como única carga durante los primeros cuatro años el diezmo de los frutos que obtuvieran y a partir del quinto año deberían entregar el quinto de todas las cosas de labranza y crianza.

En cuanto a los pastos se distinguían las zonas de llano en las cuales se podía pacer "sin derechos y la sierra con derechos" ${ }^{30}$, lo cual significaba su arrendamiento,

24 En 1502 los reyes le otorgan por merced vitalicia la jurisdicción civil y criminal de esta villa que no se había contemplado en la concesión de 1490. A.G.S.-R.G.S., II-1502, sin foliar, en Enrique PÉREZ BOYERO, «Hernando de Zafra: secretario real, oligarca granadino y señor de vasallos», Miscelánea Medieval Murciana, vol. XVIII (1993-1994), pp. 175-207.

25 A.G.S.-R.G.S., II-1490, fol. 25.

26 Copia de la escritura de transacción otorgada en 10 de noviembre de 1893, entre los actuales dueños de los bienes procedentes del antiguo señorío de la Villa de Castril y hacendados y vecinos de la misma villa. Granada, Imprenta de Vda. e Hijos de P.V. Sabatel, 1895. Agradecemos a D. Vicente González Barberán que nos facilitara esta escritura.

27 A.G.S.-G.A., leg. 1315., fols. 145, 146 y 227.

28 Miguel Ángel LADERO QUESADA, Granada después de la conquista: repobladores y mudéjares. Granada $1993\left(2^{a}\right)$, p. 134.

29 Copia de la escritura de transacción otorgada...

30 Copia de la escritura de transacción otorgada... 


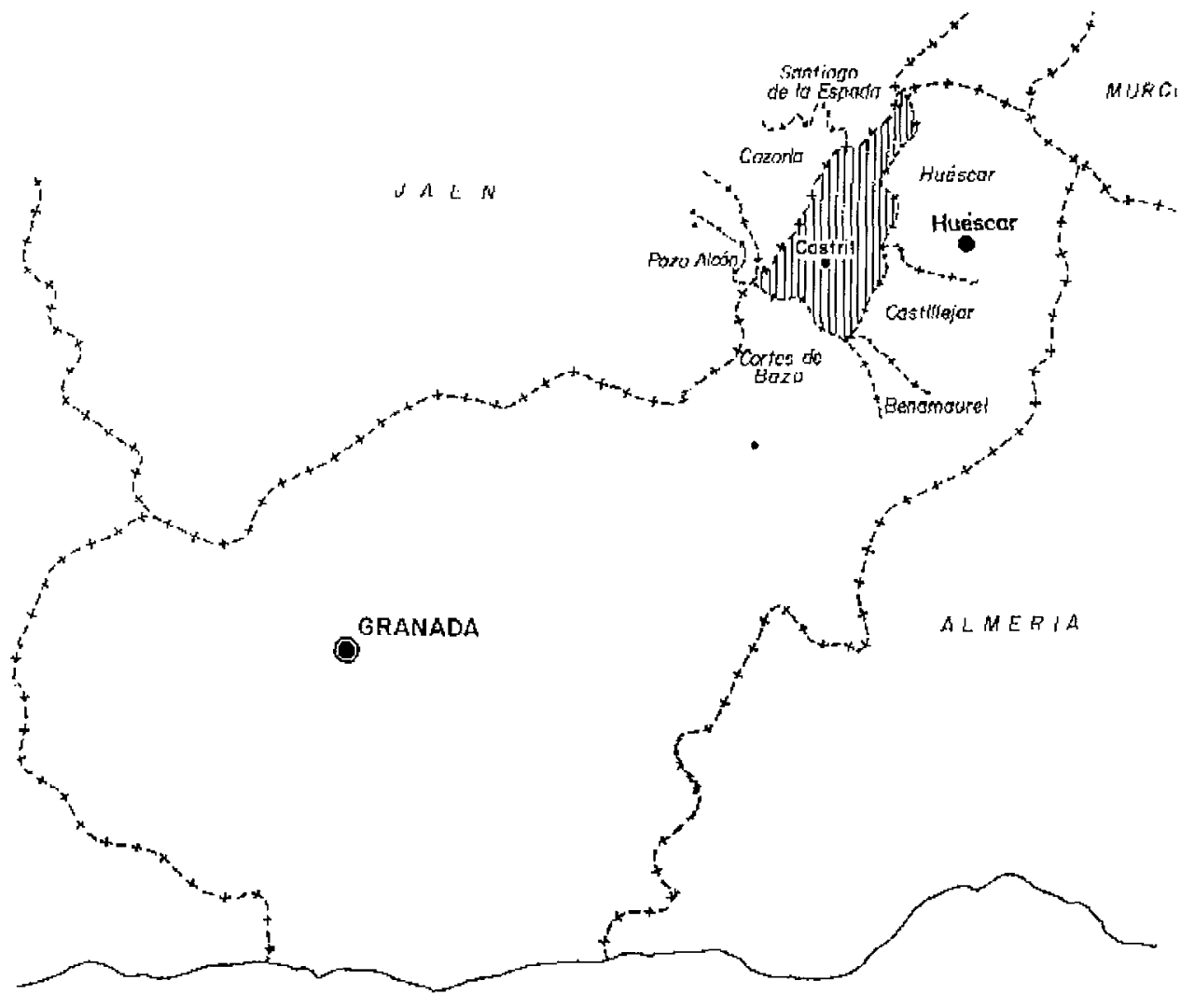

que el secretario real inició pronto, a fin de obtener alguna rentabilidad de sus nuevos dominios ${ }^{31}$. Si bien sabemos que agricultura y ganadería convivían antes de la llegada de los cristianos, y que de esta última se obtenían importantes beneficios, no sabemos si la presión del fisco nazarí llevó a los musulmanes a arrendar sus pastos a los cristianos del otro lado de la frontera como ocurría frecuentemente en las zonas de Málaga $^{32}$ y Jaén ${ }^{33}$. Además esta actividad parece estar estrechamente asociada a la importante explotación salinera existente en torno al río Guadiana Menor, cuya sal sería aprovechada para alimento del ganado ${ }^{34}$.

31 «Sepades que Juan Lopez Çatyco vesino de la çibdad de Huesca nos fizo relaçion disiendo que algunas personas e conçejos deven e son obligados de dar e pagar ciertas quantias de maravedis de la renta y hervajes de los terminos de Castril que el diz que tiene arrendado de Fernando de Çafra nuestro secretario cuya es la dicha Castril’. A.G.S.-R.G.S., 1496-11, fol. 30.

32 Manuel ACIÉN ALMANSA, La vida fronteriza en la zona meridional de la Serranía de Ronda (1470-1501), Granada, 1974, (Memoria de Licenciatura, inédita), p. 75.

33 Tomás QUESADA QUESADA, La Serranía de Mágina en la Baja Edad Media. Una tierra fronteriza con el Reino Nazari de Granada. Granada, 1989, p. 262.

34 Antonio MALPICA CUELLO, «Fiscalidad y comercio de la sal...», p. 89. 
No obstante, para llevar a cabo sus planes, Fernando de Zafra debió delimitar los términos de su señorío, tanto hacia el $E$ como hacia el $O$ a raíz de la gran pugna que se desató entre los nuevos señoríos de la hoya de Baza. En 1491 los Reyes Católicos decidieron el mantenimiento de la comunidad de pastos, norma de tradición musulmana que permitía la libre circulación del ganado. Su principal consecuencia fue el inicio de largos pleitos entre estas villas para delimitar los términos que correspondían a cada una de ellas, con la intención velada de impedir que los ganados de los lugares vecinos penetrasen en sus tierras a pastar.

Ya vimos el pleito de La Marmota que consiguió legitimar una sentencia dada en 1384 que incorporaba la importante zona de Cebas al término de Castril. Algo similar ocurrió con la denominada Hoya de la Puerca, actualmente en la provincia de Jaén en los terrenos ocupados por el Embalse de la Bolera, donde se encontraba el paso fronterizo de los dos reinos ${ }^{35}$ y que al menos hasta el siglo XVIII formaba parte del término de Castrili ${ }^{36}$.

Para evitar problemas con el Condestable de Navarra, nuevo propietario de Huéscar, en el límite $O$ del término, Zafra solicitó de los Reyes una carta de amparo sobre «terminos e prados e pastos e montes e dehesas e abrebaderos de la villa de Castril fazia la parte de la villa de Huéscar ${ }^{37}$, según le correspondían desde que estaba en poder de los musulmanes. En cuanto al pleito con Castilléjar, es de fechas posteriores, 1548, y en el se cuestionaba la propiedad de un área de

nominada Campo del Rey, rico también en pastos, que era tenido como suyo por los vecinos de esta villa, pero donde también acudían con frecuencia los hatos de Castril a pacer ${ }^{38}$.

No tenemos noticias de cual fue la respuesta a la Carta-Puebla de 1490 y el alcance que tuvo este primer intento repoblador. Sin embargo contamos con un reparto de tierras llevado a cabo en 1527 por los herederos de Zafra, que afectó a 65 «... veçinos viejos de esta villa de Castril que se entienden los que estan aqui antes del primero dia de henero de $1527{ }^{39}$. Todo parece indicar que se trata de un nuevo Repartimiento, independiente del llevado a cabo en 1490, por el cual los beneficiarios reciben tierras de secano, regadío, casas o en su defecto solares y, majuelos.

Incluye este reparto un conjunto de cláusulas que pretenden ordenar la repoblación e impedir que ésta se convierta en un medio fácil de obtención de riqueza. De esta manera se obligaba a los vecinos a esperar un mínimo de cinco años para poder

35 "Yten otra aça en la Oya de la Puerca, linderos la mojonera del Campo de Cámara y por la otra parte Juan Garcia y Fernan Lopez, que tiene setenta hanegas sacadas y de ensanche diez hanegas que estan de monte, entre lo labrado y los dichos mojones de Campo de Camara y de esta villa, entiendase que es alinde de ella Aça Grande en el pecho frontero». A.G.S.-R.G.S., G.A., leg. 1315, fols. 145,146 y 227.

36 Tomás LÓPEZ, Diccionario geográfico de Andalucía..., p. 52.

37 A.G.S.-R.G.S., II-1497, fol. 237, en Concepción ALFARO BAENA, La formación de un señorio en el Reino de Granada. El caso de Castril. Granada, 1993. (Memoria de Licenciatura, en prensa).

38 A.R.Ch.Gr., 3/478/11.

39 A.G.S.-G.A., leg. 1315. fol. 146. 
vender las propiedades que le eran entregadas, debían pagar el terrazgo de los frutos que obtuvieran "de cada nueve fanegas una ${ }^{40}$. Para las tierras de monte se establecian condiciones muy específicas de tal manera que quedaba expresamente prohibida su compra o venta si no estaban roturadas.

En cada donación se detallan las fanegas comprendidas en cada lote indicándose la localización del pago y sus límites. También se hace referencia específica a las fanegas que son de monte y que están pendientes de roturar. Se incluye la suma total de las fanegas y las casas y huertas con sus respectivos lindes.

En líneas generales del estudio de este documento se puede concluir que fueron entregadas un total de $2.888,5$ fanegas de tierra en treinta y un pagos distintos, de las cuales $1.604,5$ correspondían a secano, 553,5 a regadío y 730,5 participa de ambos en una proporción que no hemos podido determinar. Las zonas de regadío estan mucho más fragmentadas y sus parcelas serían de un tamaño mucho menor que las de secano, en donde prevalecía una mayor homogeneidad.

Hemos podido constatar la no existencia de grandes disparidadęs, de tal manera que aunque una pequeña minoría se beneficia del reparto, en líneas generales, tanto el tamaño como al calidad de las tierras que reciben son similares.

El total de la superficie roturada y ganada al monte apenas llega al $12 \%$ y se halla repartida en propoción a la extensión de cada pago. No obedece, tanto a su distribución geográfica como a la cantidad que corresponde a cada poblador a una necesidad de aumentar la superficie de cultivo por falta de tierras. Más bien hay que buscar la causa de este hecho en la progresiva adaptación del territorio disponible a aquellos cultivos más propios de la economía castellana. Estas tierras que ahora se incorporan son destinadas en su mayor parte al cultivo de cereales, si bien la presencia de hortalizas, frutales y plantas textiles seguía siendo importante ${ }^{41}$.

En definitiva tenemos que hablar de una nueva reorganización económica de este lugar, que relega a un segundo plano la ganadería en favor de la agricultura, ya que el aumento de la producción agrícola permitía la obtención de mayores beneficios para el señor de la villa.

40 A.G.S.-G.A., leg. 1315, fol. 146.

41 Concepción ALFARO BAENA, La formación de un señorio en el Reino de Granada. El caso de Castril. Granada, 1993. (Memoria de Licenciatura, en prensa). 



\title{
PRESENCIA DE NAVARROS Y VASCOS EN LA REPOBLACIÓN DE MURCIA
}

\author{
Ángeles GARCÍA DE LA BORBOLLA
}

Departamento de Historia. Universidad de Navarra

La victoria de las Navas de Tolosa implicó de manera directa a todos los reinos peninsulares en la lucha contra el Islam. A partir de este momento, los castellanos enfocan su área de actuación hacia el fértil valle del Guadalquivir, teniendo como apéndices de sus conquistas hacia el oeste el reino de Niebla y hacia el este el Reino de Murcia. Mientras tanto el monarca aragonés centrará sus esfuerzos reconquistadores en la zona levantina.

Por su parte Sancho el Fuerte, a quien vemos combatiendo en 1212 en las estribaciones montañosas de Sierra Morena, reorientrá su política exterior hacia lo que era la gran empresa plenomedieval y el espíritu que imbuía a todos estos hombres: la recuperación de los territorios en manos de los infieles. Para ello y a pesar de que Navarra no contaba con zonas limítrofes con Al-Andalus, pero si con una sólida base económica que le permitirá hacerse con territorios en la Frontera (ej. comarca de Linares, 1213).

La actividad que en un primer momento impulsó este monarca navarro se vería acompañada por un proceso paralelo de despliegue demográfico y social que desborda los límites geográficos de estas regiones y que desde la Rioja y siguiendo la vertebración del Sistema Ibérico, se dirige hacia el Levante.

\section{LA DOMINACIÓN POLÍTICO-MILITAR: LA CONQUISTA}

La incorporación del reino de Murcia a la corona castellana no se inicia con una campaña militar sino con un compromiso firmado en la villa de Alcaraz en abril de 1243. A partir de ese momento gran parte del reino murciano entra en un régimen de protectorado, reconociendo a su hasta ahora enemigo más poderosos y cercano, 
Castilla, la soberanía así como la tenencia de las principales fortalezas que le permitiera garantizar la defensa del territorio y la concesión de la mitad de las rentas públicas. Por otra parte, la población autóctona conservaría no sólo sus costumbres y tradiciones sino también su gobierno y religión.

Desde la muerte de lbn Hud, protagonista de la sublevación frente al poder almohade de la Península, se suceden una serie de gobiernos inestables bajo un clima de anarquía y fragmentación política. El fracaso de las tentativas de Muhammad lbn Hud por lograr una nueva reunificación del reino, así como las amenazas por una parte del reino vecino de Granada, donde Al-Ahmar acababa de tomar Almería, y por otra de la avanzada hacia el sur del monarca aragonés Jaime I, conquistador de Valencia, llevan al emir murciano, que no contaba con fuerzas militares suficientes que le garantizasen su protección, a buscarla en el exterior. Y será Castilla, la que presentaba condiciones más idóneas. Suponiendo al mismo tiempo para el reino de Fernando III la toma de un territorio sin necesidad de desgaste militar.

Sin embargo, el tratado por el cual se entregaban según cuenta la Crónica General la cibdad de Murcia e todos los castillos que son desde Alicante fasta Lorca e fasta Chinchilla no fue signado por todos los arraeces del reino: Lorca, Mula y Cartagena no aceptan esta pleitesía ${ }^{2}$, así como Orihuela, Elche, Alicante, Aledo y Ricote. Esto suponía un grave obstáculo para la incorporación pacífica del reino que al menos exigía el dominio de las plazas principales. De este modo, a partir de la firma del tratado de Alcaraz se inicia un periodo en el que el dominio castellano se fue extendiendo por estas tierras bajo condiciones muy diferentes: Mula y Cartagena acaban rindiéndose a las huestes alfonsíes bajo ninguna condición y con la consiguiente expulsión de su población ${ }^{3}$; Lorca, tras un largo asedio y con la muerte de su gobernador, capitula y acepta el pacto, como también lo hacen Orihuela y Alicante una vez son tomadas por las armas.

Tras estas campañas dirigidas por el infante castellano y que finalizan en 1257 , era necesario el afianzamiento del dominio sobre estas nuevas tierras, que como a lo largo de años anteriores quedaba garantizado emprendiendo una labor de repoblación del territorio.

El ideario político de Alfonso iba dirigido a conseguir un doble objetivo: la paz y seguridad en las zonas reconquistadas. Situación que se puso gravemente en entredicho hacia 1264, año de la sublevación mudéjar en Al-Andalus, que aunque fracasó desde un primer momento en Lorca y Orihuela no fue así en Murcia. Este episodio ocasionará la intervención militar del monarca aragonés, suegro de Alfonso, en el solar

1 J. TORRES FONTES, La Reconquista de Murcia en 1266 por Jaime I de Aragón. Murcia, 1967.

2 Et dessta guisa apoderaron los moros al infante don Alfonso, en boz del rey don Fernando su padre en todo el reyno de Murçia, ssaluo Lorca et Cartagena et Mula que no quisieron dar ni entrar en la pleitesia que los otros: et ganaron y poco ca a la çima ouieronlo a Jazer mal SU grado (ed. R. MENÉNDEZ PIDAL Primera Crónica General de España. Madrid 1955. n² 1.060. Esta obra se citará CGE).

3 Et corrio Mula et Lorca et Cartagena et esos logares rebeldes que se le non querien dar et tirolas et astragolas todas... et el infante don Alffonso echo todos los moros ende. CGE $n^{0} 1.065$. 
murciano. Las fuerzas del castellano resultaban insuficientes, con lo cual se ve obligado a acudir a Jaime I, que a pesar de contar con la oposición de gran parte de la nobleza acude y somete a Murcia ${ }^{4}$ empleando sus dotes diplomáticas más que las armas. Esta participación activa en la política castellana le lleva a aconsejar al infante castellano en la entrevista que mantuvieron en Tarazona durante las Navidades de 1270: «lo que debéis de hacer es que queden en la ciudad cien hombres de valor....que vivan allí con suficiente patrimonio" nada más alejado de las ideas de Alfonso ${ }^{5}$.

\section{LA APARICIÓN DE UNA NUEVA SOCIEDAD: REPOBLACIÓN Y REPARTIMIENTOS}

La expansión militar que había permitido a las tropas castellanas, en tan sólo unos años, llegar al litoral mediterráneo, iba acompañada por una labor repobladora dirigida por los propios soberanos que se traduce en la instalación de contingentes de población cristiana llegados a estas tierras y que se presentan como elementos indispensables para su defensa, pues la repoblación de un territorio era la mejor garantía de su conservación.

Del mismo modo, esto suponía el paso de una sociedad a otra. De un mundo poblado, urbanizado y gobernado por el poder musulmán que supo forjar durante siglos una brillante civilización, a otro en el que nace una sociedad nueva que se integra con mayor o menor resistencia dentro de los reinos cristianos. Sociedad compuesta por gentes de diferentes orígenes y por tanto culturas, de diversas condiciones socio-profesionales y por tanto económicas. En definitiva este trasvase de población implicaba una restructuración social y una reorganización de tierras que impidiesen un colapso económico-social y pusiese en crisis el poder cristiano en el lugar reconquistado.

Pero Alfonso carecia de medios humanos suficientes para llevar desde el primer momento una repoblación intensiva; recordemos que de manera paralela se está produciendo la conquista y repoblación de Andalucía, lo que ocasionará una repoblación lenta y en varias fases en el territorio murciano. Todas las villas fueron objetos de sucesivos repartos de tierras, los más tardíos tienen su explicación en la conquista del reino por el aragonés Jaime II, durante la minoría de Fernando IV de Castilla. Los restantes pueden tener varias explicaciones: la movilidad inicial de los repobladores que se dirigen hacia las tierras andaluzas; la necesidad de atraer nuevos pobladores ante la emigración de los mudéjares al reino de Granada. Por ejemplo en el caso de Lorca, su carácter fronterizo obliga a trasladar población hacia la villa desde puntos muy expuestos a ataques granadinos.

Sin embargo, la tarea se presentaba urgente debido a la amenaza constante que

4 Datum in obsidione Murcie nonas januarii anno Domini MCCLX quinto (documento fechado por el afio de la Encarnación). (J. MIRET Y SANS. Itinerari de Jaume l «El Conqueridor», Barcelona, 1918 , p. 382).

5 Sobre las diferencias entre Jaime I y Alfonso $X$ en la repoblación de Murcia, vid. J. TORRES FONTES, Jaime I y Alfonso X. Dos criterios de repoblación, VII Congreso de Historia de la Corona de Aragón, Barcelona, 1962, pp. 329-340. 
ejercían sus poderosos vecinos: Granada y Aragón. Esta condición fronteriza no resultaba un factor muy atractivo para los nuevos pobladores, que al abandonar sus lugares de orígenes buscaban tierras donde asentarse que les garantizasen un medio de vida más fácil y productivo.

Según M. González Jiménez en su obra Alfonso X (1252-1284), la repoblación del reino de Murcia conoció dos fases: una primera desde 1244 a 1264, con una limitada presencia cristiana reducida a las guarniciones militares de las principales fortalezas aunque un tanto mayor en las poblaciones conquistadas militarmente. De esta primera fase destacaremos la repoblación de Cartagena (1246) y Alicante (1252), de las que no se ha conservado el texto de su repartimiento. Ambas villas, importantes baluartes defensivos dada su situación costera, capitularon y recibieron el fuero de Córdoba $^{6}$. Una segunda etapa se abre en 1266, tras ser sofocado el levantamiento de los mudéjares en Al-Andalus, y se extiende más allá del reinado de Alfonso $X$ (hasta Fernando IV y Alfonso XI).

Con la repoblación del reino de Murcia se iniciaba al mismo tiempo su castellanización, a pesar de que nos encontraremos ante una realidad que merece ser señalada, nos referimos al importante peso demográfico que supusieron catalanoaragoneses en el conjunto de nuevos pobladores llegados a estas tierras. Tomemos algunos ejemplos significativos:

J.M. Lacarra que cifró la población global de Murcia, tras todos los repartos, en 2.835 , contabilizó un total de $1.238(48 \%)$ procedentes de la corona aragonesa, siendo incluso mayor el número de catalanes, 1.108, que el de aragoneses, 105. Frente a unos 517 castellanos $(18 \%)^{7}$.

Para el caso de Orihuela, J. Torres Fontes en su artículo La procedencia de los repobladores en el repartimiento de Orihuela, «Miscelánea Medieval Murciana», 1986, Vol. XIII, establece los siguientes porcentajes sobre el origen de los pobladores que se beneficiaron de los sucesivos repartos de tierras orolianas: catalanes: $266(24,40 \%)$; aragoneses : $192(17,61 \%)$; valencianos: $48(4,40 \%)$; no peninsulares: $12(1,10 \%)$; castellanos: $238(21,83 \%)$; navarros: $70(6,42 \%)$; extranjeros $5(0,45 \%)$; indeterminados; $259(23,76 \%)$.

En definitiva, si políticamente Murcia pertenece al reino de Castilla es sin duda un

6 En el caso de Murcia en 1257 se realiza el primer reparto de una zona al margen del Segura, situada a unos diez kilómetros del este de su muralla, "Las Condominas», unas 450 tahúllas de 200 alfabas de valor. En Orihuela no se inician los repartimientos hasta 1264 y en Lorca se documentan concesiones de donadíos en fechas tempranas, pero su repoblación no comienza hasta 1257.

7 Estos porcentajes varían si tomamos en cuenta que el número total de pobladores es menor: entre 2.380-2.400, tal como J. TORRES FONTES expone en su obra Huerta y campo de Murcia en el siglo XIII, Murcia, 1971. Alterando del mismo modo los dados en el siglo XVIII por F. CASCALES en sus Discursos históricos.

Hacia 1272 el porcentaje de catalano-aragoneses era de $55,9 \%$ frente a $23,6 \%$ de castellanos, en un total de 1974 pobladores: 951 catalanes; 91 aragoneses; 60 valencianos; 1 mallorquín y 467 castellanos. (D. MENJOT, Murcie (1243-milieu XV siècle). Une ville mediterranéenne perisphérique dans la Castille du Bas Moyen Age. Tesis doctoral, Niza, 1990). 
reducto de pobladores de la corona de Aragón, muchos de los cuales habían formado parte de las huestes de Jaime I y para otros supuso un nuevo terreno de expansión, pues la conquista de Valencia quedaba ya muy lejos ${ }^{3}$.

La ocupación del solar fue gradual mediante sucesivos repartos minuciosos y metódicos que conocen y respetan la organización musulmana precedente ${ }^{9}$. Como en el caso andaluz se distribuyeron tierras tanto en donadíos, aunque su número es muy reducido limitándose a miembros de la familia real o nobles y que tienden a desaparecer, y en heredamientos, cuyas tierras se encontraban dispersas entre las diferentes cuadrillas con el fin de evitar la concentración de grandes propiedades en pocas manos.

Cada poblador según su categoría social, existían tres categorías de caballero y tres de peones, recibe un número de alfabas (valor en renta de las tierras) pero con diferentes extensiones o tahúllas, ya que la variedad de tierras impedía establecer un canon distributivo fijo.

\section{VASCOS Y NAVARROS EN MURCIA EN EL SIGLO XIII}

En este epígrafe nos centraremos en determinar la participación de gentes de origen navarro y vasco, a partir del estudio del libro de Repartimiento de Murcia que junto al de Lorca y Orihuela son los que se han conservado hasta nuestros días. Cuantificaremos sus porcentajes a partir del análisis sobre los nombres locativos que nos desvelan la identidad social del individuo, y que actúa de elemento diferenciador frente al otro ${ }^{10}$. De este modo el topónimo es un espacio que dota de identidad, que facilita la unión y cohesión en grupos compactos de individuos de diferentes casas pero provenientes de los mismos lugares. En una sociedad nueva, en constante situación de peligro, en tierras que resultaban desconocidas, sería una tendencia lógica y natural el reagrupamiento con aquellos identificados por el apellido como vezinos que iban llegando en sucesivas oleadas.

Sin embargo, incluso antes de que se comiencen a asentar estos emigrantes procedentes de las tierras navarras y vascas, encontramos en las fuentes la participación activa de grandes y a quien vemos participar en las campañas que realiza el infante

8 ...e poblada la tierra de los mas cristianos que podia aver e senaladamente fazia mucho para poblar de cristianos la cibdat de Murcia e la villa de Orihuela o la villa de Lorca, e porque no podía aver gentes de la su tierra que les poblasen, vinieron e poblaron muchos catalanes de los que eran venidos a poblar el reino de Valencia. (Crónica del rey Don Alfonso Décimo. Biblioteca de Autores Españoles, LX, p. 11).

9 En Murcia se efectúan cinco repartos desde su conquista hasta 1272. En Orihuela, seis particiones, cinco de las cuales son castellanas. Desde 1265 a 1314. En Lorca de 1265 a 1270, su carácter fronterizo se evidencia en su población mayoritariamente militar. Siendo sus categorías: caballero, adalid, almogávares a caballo, almocadenes, ballesteros y peón.

10 La antroponimia occidental utiliza un sistema descriptivo, que hace referencia ya sea al lugar de origen, a su filiación, a su profesión, o a sus caracteres físicos o morales que permite saber cuales son las creencias, las costumbres, los usos, la organización política, las lenguas y los trabajos de los habitantes así como sus particularidades geográficas y geológicas del país. (E. VROONEM, Anthroponymie universelle comparée. Bruselas, 1967). 
entre 1243 y 1257 en Murcia ${ }^{11}$. En estas mismas campañas encontramos documentada la presencia de otros nobles cuyos linajes son originarios de estas tierras: Don Roy López de Mendoza, noble alavés, muy ligado al infante Alfonso junto al que combate en Murcia, Mula y Lorca ${ }^{12}$.

Pero quizás debemos detenernos en esta relación de grandes personajes de origen navarro y vasco que participan tanto en las campañas militares acompañando al infante, en un personaje de gran trascendencia no sólo en la conquista sino también en los años posteriores participando en la organización del territorio murciano. Nos referimos a Don Gil García de Azagra. Su apellido hace clara referencia a su origen navarro ${ }^{13}$. Fue el más activo de los designados por Alfonso $X$ pata llevar a cabo los repartimientos de Murcia $^{14}$.

11 Don Diego participa también en la conquista de Jaén (1246) y de Sevilla (1248) donde recibirá importantes bienes. La subida al trono de Alfonso $X$ supone un cambio importante en las relaciones con esta casa nobiliaria que acaban con la desnaturalización del reino, pasando entonces al servicio del monarca aragonés. (J. GONZÁLEZ, Reinado y diplomas de Fernando III. Córdoba, 1983. T. I pp. 133-137).

12 Roy López de Mendoza es nieto de Íñigo de Mendoza, quien participó en las Navas de Tolosa. En los privilegios alfonsíes aparece nombrada como almirante mayor de la mar. F. CASCALES, embiò su flota sobre Cartagena con Rui Lopez de Mendoza su Almirante i por tierra a Don Gil García de Azagra y a Diego Lopez de Salcedo Merino mayor de Castilla Estos últimos personajes también presentan un claro origen navarro el primero y alavés el segundo. López de Mendoza fue nombrado repartidor de la vega sevillana. (J. GONZÁLEZ, El Repartimiento de Sevilla Madrid, 1951. T. I, p. 241 y T. II, p. 13) e por poblar e asosegar la noble dicha cibdad de Sevilla .

13 Azagra se localiza en las tierras de la ribera en la Navarra meridional.

El espacio geohistórico de Navarra se puede dividir en tres sectores: la "Navarra nuclear", los confines trasmontanos y las tierras nuevas y riberas. El primero se corresponde al solar originario de la monarquía pamplonesa, que abarca las cuencas y valles intrapirenáicos dispuestos en torno a la Cuenca de Pamplona. Los confines trasmontanos engloban el espacio traspirenaico y atlántico del actual territorio foral y, por último, las tierras nuevas y riberas se identifican con la amplia franja espacial dispuesta sobre las tierras exteriores de la cordillera pirenáica hasta la comarca tudelana. (J. PAVON BENITO, El poblamiento medieval navarro. Base socioeconómica del espacio monárquico. Pamplona, 1996. Tesis inédita en prensa).

14 Don Gil García de Azagra. ZURITA en su España Sagrada, XLII, 324, lo señala como uno de los ricos hombres que acompañan a Jaime I en 1225 en el sitio de Peñíscola, donde aparece como confirmante de dos documentos. Su padre combatió al lado de Jaime I el Conquistador lo cual le valió el recibir numerosas mercedes y heredades. Casado con doña Toda Ladrón que era pariente de doña Teresa Gil de Vidaurre, una de las mujeres de Jaime I, lo que explicaría su participación activa en la política aragonesa.

Tras servir hacia 1260 al rey de Aragón pasa al servicio del monarca castellano en 1263, donde entre sus episodios más destacados sería el ataque y reconquista de Cartagena en 1265 donde asumió la jefatura junto a Diego López de Salcedo. Seguidamente lo encontramos con las tropas castellanas y las aragonesas de Jaime I en la reconquista de Murcia.

Desde mayo de 1262 a mayo de 1272 aparece como confirmante de los privilegios rodados de Alfonso $X$, ocupando un lugar destacado entre los de su categoría.

Realmente fue el verdadero rector de las particiones, ya que documentamos actuaciones en las que movido por su propia voluntad incrementaba ciertos heredamientos o realizaba cambios de lugar. 


\subsection{Navarros}

En pocos años, de 1243 a 1273 se lleva a cabo un repartimiento perfectamente organizado y orientado a cubrir deficiencias, ausencias no justificadas (sobre todo a partir de la tercera partición de 1266) y a compensar a los nuevos pobladores. Es Murcia el foco principal de atracción de pobladores cristianos ansiosos por tomar posesión de ricas tierras como lo era su huerta. Sin embargo, al ser esta una repoblación coetánea a la efectuada en tierras andaluzas, pocos eran las gentes que Castilla podía ofrecer. La proximidad de reinos como el de Aragón y la reciente repoblación valenciana y mallorquina abría las puertas a gentes aragonesas, catalanas y navarras que «buscan en la aventura de la emigración las esperanzas y posibilidades que podía proporcionarles el Sureste» (J. Torres Fontes vid. nota 7).

A la hora de presentar la cuantificación exacta de pobladores que se instalan en el solar murciano encontramos divergencias numéricas entre los 21 navarros contabilizados por José María Lacarra y los 19 por Denis Menjot ${ }^{15}$ en una población total de 1.974 repobladores entre 1266 y 1272.

Sin embargo, un análisis pormenorizado de las fuentes, es decir de las sucesivas particiones que contiene el Libro de Repartimiento, permite establecer la cifra de 27 pobladores de origen navarro, como atestiguan sus apellidos toponímicos, que bien pueden indicar su origen regional o su origen geográfico preciso.

A este respecto y en relación con el primero de estos casos, nos encontramos con la presencia de siete individuos cuyo nombre va seguido del etnónimo "navarro", todos ellos beneficiados con tierras en la tercera y cuarta partición de acuerdo su con-

Su labor fue reconocida y premiada desde un primer momento por Alfonso X, con la concesión de un donadío que superaba incluso al de la reina Violante y al del infante don Manuel, unas 710 tahúllas: 470 en Cudiaçibir; 50 en Adufa; 80 en Benitahas; 110 en Alfarellas (Libro del Repartimiento de Murcia, f. 1, 3, 4, 6, 8, 10, 16). A esto debemos añadir en 1272, 26 tahúllas en Rabad Algidid. También recibió unas casa, probablemente de las mejores, situadas cerca de Santa María, con hornos, baños y tiendas que a su muerte fueron entregadas a don García Martínez para que sirvieran de morada a los obispos de Cartagena y que luego utilizaran los prelados de Murcia.

Por su categoría no es nada extraño que tubiera servidores como el caso de Zulemán Catorce, su almojarife; Pedro Martínez; Martín Jiménez (caballero); García Pérez, todos ellos beneficiados por privilegios.

Su fallecimiento tendría lugar ente finales de 1272 o inicios de 1273. (J. TORRES FONTES, Vid. nota 7).

15 Quizás esta diferencia de las cifras se deban a que D. MENJOT establece un total de 322 pobladores indeterminados frente al $17 \%$ dado por LACARRA, entre los que, tras un estudio exhaustivo, es probable identificar a algún navarro. Para este último autor, los navarros estarían dentro del grupo que clasifica como «otros» que suponen un $2 \%$ (68) y que Denis Menjot eleva a $4,1 \%$.

Sin embargo, y a pesar de las disgresiones, los libros de Repartimiento se convierte en una fuente de inestimable valor demográfico, incluso superior a los documentos fiscales o catastros, pues el número de propietarios, de los cuales nos revela sus nombres, responde de manera exacta al número de jefes de familias cristianas del reino. (D. MENJOT. vid. nota 7). 
dición socio-militar, son todos peones (medianos y menores ${ }^{16}$ ), salvo Domingo Navarro que recibe un mayor número de alfabas ${ }^{17}$.

Los peones menores reciben parte de sus pequeñas propiedades en la cuadrilla de Cotillas ${ }^{18}$ : Pascual Navarro y Bartolomé Navarro ${ }^{19}$ y Pedro Navarro ${ }^{20}$ quién es declarado ausente ya en 1266 como también se presupone para Juan Pérez Navarro ${ }^{21}$ pues su heredad la compra en estas fechas el caballero mediano Berenguer de Altariba. La palabra «ausente», tan frecuente en las particiones murcianas es reflejo de ese comportamiento social tan extendido de abandono de las nuevas tierras, ya fuese por ser zona de inseguridad o por no satisfacer las expectativas económicas del recién llegado, y que se convierte en un grave problema, pues la atracción primera de nuevos pobladores era sencilla, lo que realmente resultaba difícil era su permanencia, a pesar de existir la obligación a poblar la tierra un mínimo de cinco años y no poder vender ni enajenar su propiedad. Para ello veremos que Alfonso $X$ en su política repobladora recurre al amejoramiento de los lotes primitivos en los diferentes repartos.

En segundo lugar nos encontramos ante una serie de individuos inscritos en el Libro con su nombre seguido de un topónimo de origen más preciso. Son un total de veinte, entre los que destaca por su condición social y su papel político el ya nombrado Don Gil García de Azagra (vid. nota 14).

Si tomamos como punto de partida la ribera tudelana se observa una mayoritaria procedencia de gentes de este espacio: del propio núcleo de Tudela provienen los

16 Los peones menores recibían una alfaba y seis ochavas en esta partición; y los medianos una alfaba y media. Entre estos últimos encontramos dos personajes Lope Navarro (peón mediano) y Lope Navarro de Alcalá (peón menor). Este segundo presenta un doble topónimo quizás con la finalidad de diferenciarse del anterior. Pues ambos reciben tierras en la misma cuadrilla. Billora, o bien indicaba su último lugar de procedencia. En esta misma cuadrilla encontramos un poblador probablemente navarro, Pedro Navarret. Libro de repartimiento de Murcia, de TORRES FONTES, Murcia, 1991 (que se abreviará como $L R M$ ) f. 63.

17 Domingo Navarro, LRM f. 64.

Tahúlla es la medida de superficie para toda la tierra de riego, equivale a $1 / 6$ de una fanega o a $1 / 9$ de una hectárea. Una tahúlla son cuatro cuartas u ocho ochavas; la alfaba es una medida de valoración por tanto variable según la tierra. En general en tierra de albar equivale a ocho tahúllas (J. TORRES FONTES, vid. nota 7).

18 Se localiza en el actual azarbe de Cutillas, dependiente de la acequia menor de Alquibla de Mediodía. Aquí se formo una cuadrilla que destaca dentro del repartimiento por ser muy numerosa y por la variedad de oficios de sus componentes, que son en su mayoría menestrales y peones. Sus tierras no eran de gran calidad y se distribuyen entre un total de 233 pobladores. (J. TORRES FONTES, vid. nota 7).

Podemos hablar de una "concentración» de navarros que reciben parte de sus heredamiento en esta cuadrilla, un total de seis. Este agrupamiento de gentes de un mismo lugar de origen aceleraría el proceso de afianzamiento de la población, pues sería más rápido el proceso de creación de lazos de vecindad y originando grupos compactos de colonos, e incluso es probable sirvieran de foco de atracción de gentes de sus lugares de origen, pero sobre todo eran garantía de cierta estabilidad del poblamiento en una sociedad de gentes nuevas.

19 LRM f. 40.

20 LRM f. 41.

21 LRM f. 50. 
peones: Aemar de Tudela ${ }^{22}$ y Domingo Tudela ${ }^{23}$; de esta comarca son también originarios Martín Fernández de Fitero ${ }^{24}$, Pedro Ruiz de Corella ${ }^{25}$ y Gonzalo de Corella ${ }^{26}$, personajes de mayor rango militar y elevada condición social. Continuando con los pobladores procedentes de las tierras bañadas por el Ebro, contabilizamos la presencia, que podemos calificar como numerosa en relación al porcentaje global, de cuatro cabezas de familia, cuyo municipio de origen era Caparroso ${ }^{27}$ y tres del municipio vecino de Peralta ${ }^{28}$.

Estas gentes nos permiten dibujar claramente la dirección de un flujo migratorio que desde las tierras de la ribera, es decir la zona más meridional de Navarra, que recoje los elementos demográficos deseosos de emprender esa aventura que era la repoblación, pasan a la Rioja y descienden siguiendo la vertebración del sistema lbérico hacia las tierras del Levante. Gentes en su mayoría de dedicación agrícola que se adaptan a unos nuevos campos que se presentaban a sus ojos como de una gran riqueza, es la huerta murciana.

De los rebordes occidentales de la "Navarra nuclear", se certifica la presencia de dos pobladores procedentes del burgo de Estella, quizás burgueses francos de los cuales se señala en la documentación su oficio (cuchillero y blanquero) y que nos permite diferenciarlos pues ambos tienen el mismo nombre: Pedro Guillén de Estella ${ }^{29}$. Así como del valle de la Solana, es el caso de García Martínez de la Solana ${ }^{30}$.

$22 L R M$ f. 50.

23 LRM f. 39.

24 Martín como peón menor recibe una alfaba y seis ochavas en la cuadrilla de Cuiaçibit, pero luego logra incrementar sus lotes con las tres alfabas y cinco ochavas que posee en Cotillas. $L R M$ f. 8,33 .

25 Recibe un donadío en la tercera partición con valor de 58 alfabas (107 tahúllas) LRM f. I,2,9. Aparece como testigo en documentos de la quinta partición, lo cual indica su continuidad de poblamiento, (LRM f. 90, 94, 96) y en esta misma fecha, 1272 , el rey le da en heredamiento un casar de molinos en la acequia de Aquibla, seguramente en pago a sus servicios.

26 Gonzalo de Corella es caballero mayor y aparece como cuadrillero de Benetucer y Benifiar, sus posesiones tiene el valor de 19 alfabas y 6 ochavas (LRM f. 20, 22), también permanece como poblador «estable» pues recibe tierras en el reparto del Campo de Cartagena (LRM f. 98). La concesión de nuevas tierras era posible al existir tanto tierras abandonadas por los "ausentes» como las que las fuentes llaman «tierras vagadas» propiedades de antiguos propietarios musulmanes que emigraron sobre todo a partir 1266 al reino nazarita o hacia el norte de África.

27 Sancho de Caparroso. Carpintero ( $L R M \mathrm{f}$. 70); los peones medianos Pedro Serrano de Caparroso ( $L R M$ f. 63) y Pascual de Caparroso ( $L R M$ f. 63, 91), vecino este último, del labrador Don Martín de Caparroso en la collación de Santa María ( $L R M$ f. 91).

28 Son caballeros beneficiados en la tercera partición: Gil de Peralta (LRM f. 11, 26, 98) y Domingo Pérez de Peralta ( $L R M$ f. 28). Y en la quinta partición el teniente del maestre don Ramón, Jimén García de Peralta (LRM f. 84, 85, 99).

29 Ambos reciben tierras en la cuadrilla de Cotilla, que como ya hemos dicho más arriba se caracterizaba por el gran número de menestrales que la componian lo cual nos permite estudiar la dedicación profesional de estos primeros pobladores tanto en sus lugares de origen como en los de destino. Individuos necesarios para satisfacer las necesidades de una nueva población. ( $L R M$ f. 35, 35, 38, 45).

30 Heredero por compra et non fueron escriptos en padron, que posee unas once alfabas y media. (LRM f. 23). 
Por último de la fachada oriental de Pamplona, de donde es originario Martín Sánchez de Pamplona probablemente uno de los primeros pobladores pues es declarado ausente en $1266^{31}$, encontramos emigrantes de orígenes más dispersos: Íñigo de Aibar, quien formaría parte de esos primigenios repobladores que abandonaron las tierras que les fueron dadas, ya fuese para volver a su lugar de origen, o lo que resulta más probable, debido a la gran distancia que los separaba de su municipio, para dirigirse más hacia el sur, hacia las tierras andaluzas que también demandaban población, pues en 1266 el texto dice en la absencia de Yennego d'Ayvar... ${ }^{32}$; ausente en 1272 es declarado Juan López Eslava ${ }^{33}$; y por último del extremo nororiental de las tierras navarras, del valle del Roncal, procede Domingo Sancho Roncalés ${ }^{34}$.

Frente a este grupo de pobladores de origen navarro fácilmente identificables, hay nombres que por ser muy comunes no permiten una identificación precisa. Tal puede ser el caso de Íñigo Jiménez de Lorca y Juan López de Lorca ${ }^{35}$. O bien el de Domingo Monteagudo, peón menor, que junto a su mujer e hijos se ve beneficiado con tierras en la tercera partición ${ }^{36}$.

En el caso que el poblador no aparezca registrado por su apellido topónimo debemos acudir para su posible identificación, al patronímico, formado por el nombre del padre (patrilinealidad ${ }^{37}$ ) más los sufijos -ez, -aiz, -oz, -iz. Sirven quizás como ejemplos más significativos los casos de l̃ñiguez ${ }^{38}$.

31 LRM f. 45, 46.

32 LRM f. 50, 51, 54.

33 LRM f. 47, 88. Este personaje recibe en 1266 un donadío de casa de la reina en Benicotó de 30 alfabas y una y media en huerto. Esta heredad de Benicotó fue entregada casi en su totalidad en concepto de donadío a los servidores de la casa de la reina doña Violante. (J. TORRES FONTES, vid. nota 7).

34 LRMf. 62, peón mayor que recibe las tierras de su heredamiento en la cuadrilla de Benivivas, que se caracteriza por asignarle a todos los pobladores una cantidad mayor de tierra arbolada y otra menor de albar. (J. TORRES FONTES, vid. nota 7).

35 El primero de ellos resulta ser una importante figura en la vida política-religiosa de Murcia hacia el año 1300, debido a la resolución de pleitos con el obispo y el cabildo de la ciudad. LRM f. 64 y LRM f. 85. Ambos individuos pueden proceder de la vecina Lorca, villa del reino de Murcia que por su carácter fronterizo con el reino granadino no presentaba unas condiciones de vida muy favorables por tanto es una hipótesis bastante probable, o bien del municipio de Lorca en el valle de la Solana, pues el nombre de Íñigo resulta ser un indicativo importante.

36 Este personaje y su familia puede ser originario del municipio de la zona más meridional del reino navarro, colindante con Aragón, o por el contrario del municipio próximo a Murcia, cerro donde existía una importante fortaleza defensiva desde 1078 y que en 1268 pertenecía al donadío de doña Violante con sus viñas y secano.

37 La tendencia a la patrilinealidad del apellido, es decir a recibir el apellido del padre, se debe a la influencia los grupos repobladores castellanos-leoneses. Estos individuos conservan su identidad (referencia a un espacio) y aún más, la refuerzan. Esta práctica cada vez más general de una filiación más personal frente a la espacial y patrifilial más que matrilineal, consecuencia de la influencia castellana, se constata en la edad Moderna en el solar navarro. (A. ZABALZA y A. MORENO, Identidad social y espacio en la Navarra Pirenaica, Pamplona, 1996).

38 Jimeno íñiguez, LRM f. 55; Pedro Íñiguez, LRM f. 26; María İniguez, LRM f. 6; Martín Íñiguez, LRM f. 97. 
En último lugar haremos referencias a estos beneficiados de los repartimientos de tierras en el reino murciano cuyos nombres son de clara tradición navarra: Íñigo ${ }^{39}$, Velasco (Blasco $)^{40}$ o Fortún ${ }^{41}$. Ejemplos todos muy significativos pero que no permiten el realizár una afirmación rigurosa sin riesgo a equivocarnos, pues la difusión de los nombres en estos siglos bajomedievales era práctica frecuente. De este modo encontramos individuos cuyo nombre es de claro origen catalán, Guillén seguido de uno navarro, Fortún (LRM f. 61, 95).

El grupo de estos últimos que presentan mayor dificultad a la hora de precisar su procedencia geográfica son un total de doce que elevaría la suma global de pobladores navarros a treinta y nueve, aunque volvemos a señalar que los últimos presentan un margen de duda.

\subsection{Vascos}

Hasta aquí nos hemos ocupado de los navarros que las fuentes nos permiten identificar como nuevos pobladores en el solar murciano, pasando ahora a aquellos que llegaban de las tierras vascas. Su número es claramente inferior, debido tanto a que su lugar de origen está más alejado y cuyas condiciones geográficas, un territorio de pequeñas dimensiones de carácter montañoso, se presentan menos favorables para la movilización de su población. Ésta puede ser la razón de que el protagonismo de los vascos en la repoblación murciana quede asumido de manera mayoritaria por los alaveses, los más próximos y con fácil acceso a Castilla.

En primer lugar analizaremos aquellos individuos de los que podemos determinar su origen gracias a que su nombre aparece junto a un apellido topónimo de un municipio alavés, no todos ellos son repobladores tal como veremos: Heredia ${ }^{42}$; Ayala $^{43}$; San Román ${ }^{44}$;

39 Íñigo López, LRM f. 55 y 98.

40 Velasco Pérez, LRM t. 88; Blasco Pérez, LRM f. 47.

41 Fortún Sánchez, $L R M$ f. 68, 71, 73, 86, 88, 90, 92, 94, 98. Alcalde de Murcia que participa en el reparto de la heredad de Aquibla en la quinta partición, o en el Campo de Cartagena, y en los términos de Benieça y Benibarrira. Poseía un total de 26 alfabas repartidas en diferentes cuadrillas.

Fortún López, LRM $f .83$ y 84 que recibe un total de 20 alfabas.

42 Los cabalieros menores: Juan López de Heredia (LRM f. 56) y Juan Pérez de Heredia (LRMf. 58). Por último Ruy Jiménez de Heredia que recibió en la tercera partición un heredamiento por valor de 20 alfabas, pero que es declarado ausente en 1272 y sus tierras entregadas a Ponce de Villanueva. (LRM f. 20,88).

43 Martín López de Ayala (LRM f. 10).

O Pedro López de Ayala quien no aparece citado en el Libro de Rapartimiento, pero que merece ser destacado pues fue Adelantado Mayor del reino de Murcia durante el reinado de Alfonso XI hasta el año 1325. Este personaje, miembro del linaje nobiliario alavés de Ayala, es abuelo del gran canciller escritor. J. TORRES FONTES El concejo de Murcia en el reinado de Alfonso XI.

44 Pedro López de San Román, peón menor que acude con su mujer e hijos, recibe en la tercera partición tierras en la sierra de Tiñosa, sin regadío y otras de riego en la misma cuadrilla. (LRM f. 64). 
Mendoza ${ }^{45}$; La Guardia ${ }^{46}$ y por último aunque no aparece recogido en el Libro de Repartimiento, pero si fue un beneficiado de los repartos de las tierras de este reino y probablemente poblador, Pedro López de Álava ${ }^{47}$.

En segundo lugar nos encontramos en las fuentes con personajes denominados con un nombre seguido de patronímicos que se han convertido en apellidos de claras referencias alavesas: es el caso de Domingo Hurtado ${ }^{48}$; Ladrón ${ }^{49}$, caballero mayor y vasallo del infante don Manuel que recibe tierras por valor de 20 alfabas en las cuadriIlas de Alfatella y Algualega. Este personaje es objeto de un proceso, pues en 1272 se le declara ausente, mientras él alega lo contrario Ladron dixo que los jurados no le devieran fazer absente porque touo et tenia aqui cauallo et armas suyo; o bien la viuda madre de Ferrán Ladrón ${ }^{50}$.

Estos tres últimos pobladores junto a los seis anteriores, citados en el Libro de Repartimiento, indican la escasa participación de vascos en la repoblación de esta tierra de un gran atractivo agrícola, pero a gran distancia. Además las condiciones física de esta región montañosa no presentaban una salida fácil hacia el exterior, de ahi que el porcentaje absoluto correspondan a gentes de la llanura alavesa que desde 1100 a 1300 experimenta un importante crecimiento demográfico.

\section{CONSIDERACIONES FINALES}

El incremento demográfico de la población navarra y de las tierras meridionales vascas, que culmina en el siglo XIII, perfectamente documentado, contribuye a la explicación de la presencia de vascos y navarros en las costas del Levante. Ya desde comienzos del siglo XII, estos efectivos demográficos se dirigen hacia las zonas ganadas al Islam (ej. Tudela 1119). De este modo, el valle del Ebro, los cursos inferiores del Arga, Aragón y Ega se convierten en ricas tierras receptoras de emigrantes procedentes del norte. Hasta aquí, se cierra una primera etapa, iniciándose una segunda con

45 Lope de Mendoza, su carácter de poblador parece ponerse en duda pues no aparece como beneficiado de los repartos, las únicas noticias que tenemos sobre él son a raíz de un peito a un tal Ladrón. En 1272 Lope, quizás miembro del linaje nobiliario de los Mendoza, junto con sus hombres y otros caballeros está unos días en casa de Ladrón, vecino de la collación de Santa María, quizás se dirigían hacia otro punto más al sur y aprovechan la hospitalidad de este poblador oriundo de su tierra.

46 Municipio cuyo nombre es bastante común, lo cual no nos permite una determinación clara sobre el origen del poblador, aunque en este caso por una parte el hecho de la proximidad a las tierras castellanas del municipio a través de Laguardia como por otra el nombre de Sancho pueden ayudarnos a establecer un posible origen en las tierras vasco-navarras: Sancho Ruiz de la Guardia, peón menor de la cuadrilla de Cudiaçibit (LRM f. 8).

47 En 1266 este almotacén de Alfonso $X$ recibe de manos reales un rafal en la pendiente de Mendigol, con una situación muy favorable al hallarse en la desembocadura de la rambia o cañada que recogía las aguas de la sierra del Puerto.

48 En 1266 recibe un heredamiento de tres alfabas y cuarto en las cuadrillas de la $V$ Alquería y Benicomay. (LRM f. 51).

49 LRM f. 57, 88, 91, 95.

50 LRM f. $65,66,94$. 
las corrientes de emigración hacia el sur, hacia las tierras que desde 1212 se incorporan a los dominios cristianos, Andalucía y Levante.

En este último caso, la presencia de pobladores navarros en Murcia pueda estar en relación con una segunda oleda de migraciones procedente del reino valenciano. No cabe duda que el Levante fuese un segundo punto de inflexión del despliegue de población fuera de los límites navarros. La adaptación y permanencia de estos primeros pobladores no sólo aseguraba la repoblación sino que facilitaba la llegada de muchos más de su mismo lugar de procedencia geográfica. Ya que el asentamiento de algunos y la seguridad cara al futuro servían de llamadas a sus vecinos del lugar de origen.

Próximos estudios sistemáticos y detallados de los libros de Repartimiento de tieras de los municipios de Lorca y Orihuela nos permitirán comprobar y afirmar de nuevo que el reino de Murcia fue receptor del segundo gran salto de la población navarra y vasca que tomando como eje el conjunto orográfico del Sistema Ibérico afluyen directamente o desde escalas intermedias a estas latitudes peninsulares. 



\title{
JAIME II Y LA CRUZADA DE ALMERÍA
}

\author{
Mª Desamparados MARTÍNEZ SAN PEDRO \\ Universidad de Almería
}

\section{EL SITIO DE ALMERÍA SEGÚN LAS CRÓNICAS}

En la segunda mitad de 1309 Jaime II puso sitio a la ciudad de Almería. Las crónicas castellanas y aragonesas contemporáneas de los hechos suelen ser muy concisas dando breves noticias de la preparación del asedio y de su fracaso. Así, la Crónica General de España de 1344 se limita a decir: "E el rey de Castilla fué cercar Algeciras e don Jayme cercó Almería e toviéronlas así cercadas grant tiempo e non plugo a Dios que las tomasen e tornaron cada uno para sus tierras"'. Igual de breve es la Crónica de Alfonso XI: «E en el tienpo de este rey Mahomad, fué el rey don Fernando a çercar a Algezira e tovola çercada siete meses, y en este tienpo el rey don Jaime de Aragón tenía çercada a Almería. E estos reyes de Castilla e Aragón no tomaron ningunos lugares de aquellos que tenían çercados „2. Por su parte, la Crónica Barcinonense relata: "En la fiesta de Santa María de Agosto, año mil trescientos ocho, fué cercada la ciudad de Almería por el señor rey Jacobo y en el mes de enero siguiente se retiro ${ }^{3}$. Como vemos, adelanta en un año los acontecimientos. En la Historia Pinatensis se dice: "Así pues el rey Jacobo, habiendo aparejado una gran armada, asedió estrechamente por mar y tierra la ciudad de Almería, llevando consigo a su mujer Blanca»4.

El catalán Ramón Muntaner dedica al suceso mayor atención que los anteriores. Militar y cronista, no asistió al asedio por hallarse en esas fechas en el Mediterráneo

1 Crónica General de España de 1344, preparada por Diego Catalán y Ma Soledad de Andrés. Madrid, 1970 , p. 324.

2 Gran Crónica de Alfonso XI, preparada por Diego Catalán. Madrid, 1976. Cap. LXVIII, p. 405.

3 Chronicon Barcinonense. Marca Hispánica, 1688, p. 758.

4 Vetus Pinntensis Historia Regum Aragoniae. Ad. de 1876, cap. 38, p. 369. 
oriental con los almogábares de Roger de Flor, pero para escribir su obra debió contar con testimonios directos, puesto que la comenzó en 1325, quince años después del asedio. En uno de sus pasajes comenta que «... el rey de Castilla fue con todo su poder a sitiar Altzehira de Alhadra, y el señor Don Jaime de Aragón la ciudad de Almería que es una ciudad muy importante. $Y$ el sitio, que duró mas de nueve meses, lo mantuvo el señor rey de Aragón con trabucos y manganos y con todos los artefactos adecuados para mantener un sitio, pues el señor rey de Aragón fué allí muy bien pertrechado, con muchos ricoshombres y barones de Cataluña y Aragón. Entre otros, vino con él el infante Don Fernando de Mallorca, muy ricamente pertrechado, con cien caballos armados y muchos hombres de a pie y con galeras y con leños que traían los caballos y víveres y compañías y trabucos, pues el rey de Mallorca quiso que viniera en ayuda del señor rey de Aragón bien equipado de todo, como pertenecía a quien era, uno de los mejores caballeros del mundo. $Y$ asi lo demostró en todos los lances en que tuvo que intervenir durante el sitio, pues entre otros hechos tuvo por tres veces que enfrentarse con los moros y de todo el mundo tuvo que ser loada la caballería del infante don Fernando» ${ }^{5}$.

A pesar de toda esta preparación la toma de Almería no llegó a buen fin por la deslealtad del rey castellano que lo abandonó a su suerte. Bien es verdad que los aragoneses lograron la victoria de San Bartolomé, pues sigue diciendo Muntaner que «... todo el poder de Granada cayó sobre la hueste del rey de Aragón que mucho se sorprendió, pero lejos de desmayar, ordenó al señor infante Don Fernando que estuviera con su compañía cerca de la ciudad de Almería, para que nadie saliera de la ciudad, y que si alguien salía, atacase el sitio mientras ellos combatían a los sarracenos y el señor infante mantendría la defensa» ${ }^{6}$. El rey atacó a los moros y los derrotó celebrándolo al día siguiente, fiesta de San Bartolomé, apóstol.

Cuando el rey de Granada vió la maravilla que el rey de Aragón y los suyos habián logrado, se dio por perdido y envió unos mensajeros al rey aragonés rogándole que levantara el sitio por tres razones: la primera, porque el invierno se venía encima; la segunda, porque no encontraría ayuda pues los castellanos habían abandonado para que él y sus gentes se perdieran, y la tercera e importante, porque le prometía ser en todo tiempo y lugar su aliado contra todos los hombres del mundo y que en su honor libertaría a todos los cautivos cristianos que sumaban un gran número y que era algo más importante que si hubiera tomado dos ciudades de Almería. El rey Don Jaime reflexionó la cuestión, firmó la tregua y mandó embarcar a toda su gente con sus pertenencias de regreso al reino de Valencia?.

Jerónimo Zurita, en el Libro $V$ de sus "Anales del Reyno", describe también la gesta de Jaime II en Almería, relato que posteriormente recogerá Orbaneja, y dicen: «... movió Dios el espíritu valiente y el corazón animoso del rey de Aragón don Jayme

5 MUNTANER, R., Crónica. Madrid, 1970, cap. 246, p. 505.

6 Ibídem, cap. 247, p. 506.

7 Ibídem, cap. 247, pp. 508-509. 
el Segundo y aviendo convocado gran número de cavalleros valencianos, catalanes y aragoneses juntó un grande y copioso exercito.

Procuró antes con el abad de San Juan de la Peña que le diese un braço o alguna reliquia del cuerpo del gran Prelado y Apostol San Indalecio, obispo que fué de la primitiva iglesia de la ciudad de Urci, de cuyas ruinas se fundó Almería, por la gran devoción que tenía hacia el glorioso santo discipulo de Santiago.

Con tan preciosa reliquia y resguardo embarcose el Rey en la playa de la Ciudad de Valencia a 18 de el mes de Julio, hizose a la vela y llegó a el Puerto de el Cabo de Aljud donde se avía de juntar toda la armada. Detuvose el Rey en aquel puerto hasta primero de agosto, donde ordenó su exercito, para ir sobre la ciudad, así por mar como por tierra, lo qual tenía consultado con el Rey de Castilla».

Y continúan diciendo: «... partió el Rey de Cabo de Aljud con su exercito por tierra, acompañado de la Reyna Doña Blanca su mujer y de grandisima nobleza; pusose sobre la ciudad de Almería a 15 de el mes de Agosto, día de la Assumpción de Nuestra Señora; dispusose el campo con grandes prevenciones militares, de máquinas, trabucos, de batería y muchas torres de madera, que se avían labrado solo para este fin; comenzaron a hacer algunas minas y pusieron la Ciudad en gran estrecho combatiendola por mar y por tierra... $\gg^{8}$.

El cerco duró cuatro meses y el 19 de Diciembre el rey de Granada presentaba al de Aragón sus credenciales prometiéndole que si levantaba el cerco pondría en libertad a todos los cautivos y además sería un amigo fiel permitiendo a todos sus vasallos que tratasen y comerciasen con los aragoneses.

Jaime II consideró estos beneficios y consultando a los grandes del Reyno decidió, el 26 de Enero de 1310, levantar el cerco y volver con su ejército a Alicante desde donde pasó a Valencia.

\section{PREPARACIÓN DEL ASEDIO}

En 1308 Jaime II concertó con Fernando IV de Castilla una entrevista, para la que propuso como lugar de reunión "las partidas de Valencia", tierra con mejor caserío y menos fría que la castellana. Pero hubo de aceptar la opinión de don Fernando, que señaló Ariza, en tierras sorianas, vecinas de las aragonesas ${ }^{9}$, para pasar luego al monasterio de Santa María de Huerta.

Procedieron primero a consolidar los lazos de amistad y la paz firmada cuatro años antes en Agreda en la que hubo reparto de tierras, para tratar después la empresa granadina, llegando a las siguientes conclusiones:

8 ZURITA, G., Anales de la Cronica de la Corona de Aragón. Anotado por A. Ubieto Arteta. Valencia, 1967. Lib. V, caps. 78 al 84. PASCUAL Y ORBANEJA, G., Historia de Almería en su antigüedad, origen y grandeza. Ed. facsímil. Almería, 1975, pp. 89-92.

9 JIMÉNEZ SOLER, A., Don Juan Manuel. Zaragoza, 1932, p. 38. 
1. Hacer la guerra por tierra y por mar contra el reino nazarita, hasta su total destrucción. Empezarían en el mes de junio del año siguiente a partir del día de San Juan. Castilla cercaría Algeciras y Gibraltar, y Jaime Il la ciudad de Almería.

2. Como esta conquista pertenecía a Castilla por anteriores tratados entre ambos reinos, Fernando IV cedía a Jaime II, por su participación en la empresa, la sexta parte de las tierras situadas en la zona oriental del reino de Granada, que venían a constituir la zona de Almería, y, si ésta no llegase a tanto, se comprometía a completar dicha sexta parte con otros lugares del reino, a juicio y determinación del arzobispo de Toledo y del obispo de Valencia, y, si valiese más, la sobra, a juicio de los referidos prelados, quedaría para el rey de Castilla.

3. Nunca se haría la paz y tregua con los moros sin consentimiento mutuo y de los principes don Juan y don Pedro ${ }^{10}$.

Para asentar en firme esta concordia se firmaría posteriormente el Tratado de Alcalá de Henares.

Este tratado ponía las bases para la consecución de los objetivos prioritarios de ambos monarcas. Para el castellano era importante el dominio del estrecho de cara a finalizar la reconquista. Para el aragonés el conseguir Almería suponía, de alguna forma, satisfacer sus deseos imperialistas en el Mediterráneo ${ }^{11}$, ya que realmente esta empresa era como un complemento de sus actividades mediterráneas que se orientaban hacia los países islámicos. Hacía ya mucho que el rey de Túnez era tributario del soberano de Aragón; desde 1290 Jaime II, tras un pacto solemne, era protector de los cristianos residentes en Egipto, y, viudo de Blanca de Anjou, volvió a casarse en segundas nupcias con María de Lusignan, presunta heredera del título de Jerusalén. Almería era, pues, solamente el final de una extensa línea que tocaba los dos extremos del Mediterráneo ${ }^{12}$.

\section{INTENTOS DE JAIME II PARA CONSEGUIR LA BULA DE CRUZADA PARA ALMERÍA}

Si importantes eran las relaciones diplomáticas, no lo eran menos las gestiones económicas que era necesario llevar a cabo para recabar fondos y recoger subsidios para la empresa granadina.

El 12 de agosto de 1308 se había convocado, mediante una bula pontificia de Clemente V, el Concilio de Vienne, para tratar los temas de la reconquista de Tierra San-

10 TORRES DELGADO, C., El antiguo reino nazari de Granada (1232-1340). Granada, 1974. pp. 234-235.

11 HILLGARTH en su estudio El problema del imperio catalano-aragonés, considera que hablar de imperialismo en los siglos XIII y XIV puede ser una declaración ciertamente arrogante. Más bien hubo unos determinados proyectos para una limitada hegemonía en el Mediterráneo occidental. Actas del I Congreso Internacional de Historia Mediterránea, 1980, p. 157.

12 SUÁREZ FERNÁNDEZ, L., Historia de España. Edad Media. Madrid, 1970, p. 355. 
ta, la reforma de la Iglesia y el proceso de los Templarios ${ }^{13}$. Jaime II, sospechando que todo el apoyo de la Iglesia se encaminaría hacia la Cruzada de Oriente, inicia un plan estratégico en torno al Pontificado, para atraer la atención del papa hacia su campaña. En marzo de 1309 envía una embajada a Clemente $V$, que se encontraba en Montpellier, al haber sido trasladada la corte pontificia a Avignon, integrada por Ponce, obispo de Lérida, y Bernardo de Fenollar. Su misión era solicitar, además de otras peticiones, el apoyo económico concretado en que la décima concedida para Cerdeña se aplicase a la proyectada empresa granadina ${ }^{14}$. Esto se consiguió fácilmente y los emisarios escriben desde Mondragón comunicando que la embajada había sido positiva:

«... la primera peticio que otorga, que la décima que era ainstada per lo viatge de Cerdenya sia mesa e liurada a vos por lo viatge de Granada»15.

Efectivamente, por un breve de 19 de Marzo, el Papa ordena al obispo de Valencia y al abad del Monasterio Fixense, colectores de las décimas eclesiásticas en el reino de Aragón, que entreguen a su rey las dos terceras partes para la guerra. Por otros dos breves de 24 de Abril manda al obispo de Valencia que publique la cruzada, concediendo indulgencia plenaria en los dominios de Aragón, exceptuando las islas de Córcega y Cerdeña, a los que vayan a la guerra de Granada. Concede también a los clérigos de cualquier dignidad, canónigos, racioneros o curas que vengan a esta guerra, poder hacer suyos los frutos de sus prebendas durante su ausencia. $Y$ por último, concede la décima parte de todas las rentas eclesiásticas por tres años ${ }^{16}$.

Así las cosas, se inician los asedios de Almería y Algeciras por parte de Jaime II y de Fernando IV, respectivamente.

A lo largo de la empresa, Jaime II, al encontrarse falto de dinero para continuar, lo buscará en el país vecino y de nuevo en la curia pontificia.

Por una parte, escribe una carta a su cuñado, el rey Dionís de Portugal, pidiéndole un préstamo para la conquista de Almería, que iba por buen camino, a la vez que le envía otra a su hermana, la reina Isabel de Portugal, exponiéndole el negocio que trataba con su marido y pidiéndole su intervención: «Porque, Reyna vos rogamos muy carament que Vos rogades al dicho rey et guisedes con él que a esta sazón nos acorra de empréstamo et auremos a él et a vos para siempre que agradecer..." ${ }^{17}$.

Por otra parte, envía de nuevo embajadores ante el Papa Clemente $V$, esta vez el militar Fortún Martín y Pedro Marsilio, de la orden de Predicadores y autor de la Cró-

13 MIQUEL ROSELL, F., Regesta de Letras Pontificias del Archivo de la Corona de Aragón. Sección Cancillería Real. Madrid, 1948. 330, p. 174.

14 SALAVERT Y ROCA, V., Cerdeña y la expansión mediterránea de la Corona de Aragón (12971314). II, p. 403.

15 Ibídem, II, p. 425.

16 TAPIA GARRIDO, J.A., Almería musulmana. Almería, 1978. II, p. 187.

17 Archivo de la Corona de Aragón. Registro General in Viagio Almeriae Jacobo Secundo. $1^{a}$ parte, fol. $27 \mathrm{~V}$. 
nica Latina de Jaime I, conocido por sus dotes políticas y diplomáticas. Pretendía Jaime II mejorar las concesiones que anteriormente habia hecho el Pontificado, ya que entre las peticiones de nuevos sobsidios, la más importante era conseguir la décima duplicada de las rentas de los bienes eclesiásticos para poder continuar la cruzada contra los moros de Almería, que ya se había iniciado.

Con fecha 6 de noviembre, Clemente V escribe desde el Priorato de Grosseau a Jaime II, dándole cuenta del resultado de las peticiones de sus nuncios y notificándole que habían sido desestimadas; la petición del subsidio de la Sede Apostólica para continuar la guerra de Granada por estar exhausto el erario de la Santa Sede con motivo de la reconquista de Ferrara y de los dispendios hechos en Tierra Santa y en Chipre; también fue rechazada la petición de la décima duplicada, por no haber sido concedida nunca por la Iglesia, ni en la cruzada contra Federico II de Sicilia ni tampoco en la recuperación del Cuerpo de San Luis del poder de los orientales. Sin embargo, concedía de nuevo las mismas indulgencias que para Tierra Santa al maestre y religiosos hospitalarios de Granada, la absolución de sus reinos de las censuras incurridas por comercio ilícito de víveres y armas con los sarracenos e indulgencia plenaria a quienes tomaran parte en la cruzada de Granada, personalmente o con subsidios $^{18}$.

Jaime II, que, pese a todo, concebía la empresa granadina como el camino más recto hacia Oriente, alimentaba la esperanza de dedicarse después a la recuperación de Tierra Santa, pues como dice Muntaner su objetivo era "acrecentar y multiplicar la santa fe católica»' ${ }^{19}$.

Pero la primera parte de su programa le salió mal. Habiendo abandonado Fernando IV el cerco de Algeciras en noviembre de 1309, Jaime II, para evitar una catástrofe, tuvo que levantar el sitio de Almería poco tiempo después. Muntaner, como hemos visto, considera que si el rey aragonés levantó el cerco fue porque se acercaba el invierno, porque los castellanos habián demostrado una gran deslealtad y porque los esclavos que le entregaron eran una ventaja más considerable que si hubiera tomado dos ciudades como Almería. El Padre Mariana quizás, más realista, dice que Jaime levantó el asedio por la poca esperanza de salir airoso de la empresa. Lo cierto es que el 26 de enero de 1310 Jaime II se retiraba de Almería con el consiguiente desprestigio.

El 15 de febrero, el rey envía al Papa desde Játiva una carta con su consejero Vital de Vilanova, que lleva el encargo de exponerle los motivos urgentes que le habían obligado contra su voluntad a levantar el asedio de Almería, para evitar que tuviera noticias deformadas de lo sucedido por otros conductos ${ }^{20}$, y para dejar una puerta abierta a la amistad y ayuda que ante cualquier nueva campaña pudiera necesitar del Pontífice.

18 MIQUEL ROSELL, F., Regesta de Letras Pontificias del Archivo de la Corona de Aragón. Sección Cancillería Real.Madrid, 1948. 352, p. 185.

19 MUNTANER, R., Crónica. Madrid, 1970. cap. 247, p. 509.

20 Archivo de la Corona de Aragón. Registro General in Viagio Almeriae Jacobo Secundo. $2^{\mathrm{a}}$ parte, fol. 237. 
Efectivamente, un año más tarde, el 16 de octubre de 1311, se inaugura el Concilio de Vienne y Jaime II envía sus embajadores con un programa bien concreto: «Cruzada sí, pero atacando a los sarracenos por todos los frentes, uno de los cuales, el más occidental, es Granada. Empecemos la conquista por la parte occidental y con la gracia de Dios podremos llegar a Tierra Santa» ${ }^{21}$.

Clemente V, aunque alabó la buena disposición del monarca aragonés, contestó a los embajadores que sería mejor no mencionar a Granada, al tratar en el Concilio de los subsidios de Tierra Santa, puesto que franceses e ingleses estaban dispuestos a emprender la cruzada hacia Oriente. A través de esta entrevista conocieron la predisposición del Papa, que se hizo evidente en el Concilio, cuando anunció a la asamblea como una gran alegría, lo que para Aragón era una realidad triste: Felipe IV de Francia dirigiría los ejércitos cruzados hacia Tierra Santa ${ }^{22}$.

La campaña de Granada nuevamente volvía a perderse, esta vez en el Concilio de Vienne. Había que plantear, para poder salir adelante, una nueva estrategia.

\section{PEDRO MARSILIO ESCRIBE SU CRÓNICA}

Estando así las cosas, comienza Pedro Marsilio a traducir el Llibre dels Feyts. Pero ¿qué interés podría tener Pedro Marsilio en traducir las gestas de un rey muerto que ya circulaban en romance? Se han barajado un sinfín de motivaciones, entre las que se cuentan la de halagar al monarca aragonés regalándole el libro de las gestas de su abuelo o la de ensalzar a la Orden de Predicadores, puesto que introduce fragmentos dedicados a ella que en la Crónica catalana no existen ${ }^{23}$. Conociendo el talante de Pedro Marsilio y su categoría intelectual, no cabe duda que contaba con elementos suficientes para llevar a cabo otro tipo de obra, en la que se plasmara mejor su capacidad creadora. Todo ello induce a pensar que su objetivo no estaba en la redacción de la Crónica sino, más bien, en su traducción.

Traducir un texto supone, ahora y siempre, darlo a conocer a un público que desconoce la lengua original del mismo. Probablemente lo que Marsilio pretendía era poner la Crónica de Jaime I en manos de un sector no conocedor del catalán, es decir, ampliar el área de lectura de la Crónica catalana, universalizarla y posiblemente hacerla llegar al mundo eclesiástico y, concretamente, a la curia romana y al Papa. Pedro Marsilio, que conoció personalmente a Clemente $\mathrm{V}$, captaría, sin duda, que al Pontífice le resultaba complicado el catalán. En un carta que Bernardo de Fenollar dirigió a Jaime II aparece explicitado que el Papa «entenía be nostre romanc mas nol sabría legir, mas que tantost lo tornassem en latí que molt volenters lo legiría e hi estudiaría» ${ }^{24}$.

Por otra parte, en varios pasajes de la Crónica latina aparecen fragmentos como

21 FINKE, H., Acta Aragonensia. Berlín und Leipzig, 1908. II, pp. 234-237.

22 MARTÍNEZ SAN PEDRO, Mª̀.D., Crónica Latina de Jaime I. Almería, 1984, p. 44.

23 Ibídem, pp. 29-33.

24 SALAVERT Y ROCA, V., Cerdeña y la expansión mediterránea de la Corona de Aragón (12971314). II, p. 425. 
«... et certe movere vos debet hoc principaliter honor Dei et cristiane fidei promotio» 25 , 0 «... prima ratio es fide» ${ }^{26}$, o también «... petimus necessarium subsidium $»^{27}$, que no existen en el texto catalán y que manifiestan con toda claridad que Marsilio quiso introducir intencionadamente, de un lado la idea de Cruzada y la lucha por la fe y de otro la petición de subsidios y ayudas económicas, todo ello en boca de Jaime $\mathrm{l}$.

Así pues, no parece extraño pensar que Marsilo, estableciendo un paralelismo entre lo que fue y lo que hizo Jaime I, con lo que podría ser y hacer Jaime II, pretendiera atraerse la atención del Pontífice, como ya lo había hecho Ramón Lull con su obra «De acquisitione Terrae Sanctae»28. De esta forma se intentaba desviar la atención de Clemente V, muy centrada en la recuperación de los Santos lugares desde la celebración del Concilio de Vienne, hacia la península y, más concretamente, hacia el Reino de Granada, donde el problema musulmán seguía siendo preocupante y si no se resolvía, no era tanto por falta de estrategas o de planes de ataque eficientes cuanto por falta de fondos económicos.

25 MARTíNEZ SAN PEDRO, Ma.D., Crónica Latina de Jaime I. Almería, 1984, p. 159.

26 Ibídem, p. 194.

27 Ibídem, p. 161.

28 GOÑl GAZTAMBIDE, J., Historia de la Bula de la Cruzada en España. Vitoria, 1958, p. 258. 


\title{
LA ESTRUCTURA CASTRAL SANTIAGUISTA EN LA SIERRA DE SEGURA DURANTE EL SIGLO XIII: APROXIMACIÓN A SU TIPOLOGÍA
}

\author{
Enrique VARELA AGÜÍ \\ Universidad Autónoma de Madrid
}

\begin{abstract}
El propósito de este trabajo se centra en el estudio de la tipología de los emplazamientos castrales en la Sierra de Segura, zona de asentamiento inicial de la Orden de Santiago en el reino de Murcia. El estudio de las estructuras de fortificación y hábitat tiene por objetivo fundamental el análisis de la red castral que los santiaguistas establecieron en dicha zona, intentando diferenciar los distintos tipos de emplazamientos existentes y su relación con la adecuación al medio geográfico, a las valoraciones estratégicas, poblacionales y productivas de la Sierra de Segura.
\end{abstract}

\section{EL MARCO ESPACIAL}

La implantación de la Orden de Santiago a lo largo del Río y la Sierra de Segura tuvo lugar a lo largo de las primera mitad del siglo XIIl como zona natural de expansión santiaguista a raíz de la ocupación por la Orden del Campo de Montiel y venía avalada por la doble intención castellana de llegar hasta el litoral mediterráneo y de penetrar hacia tierras andaluzas'.

En los límites de las actuales provincias de Jaén, Albacete, Granada y Murcia, la impresionante cadena montañosa de dirección soroeste-noreste que conforma la Sierra de Segura, donde las altitudes oscilan entre los 800 y los 1.800 metros, conforma

1 D.W. LOMAX, La Orden de Santiago (1170-1275), Madrid, 1975, pp. 9-16. Vid. asimismo J. GONZÁLEZ, Reinado y diplomas de Fernando III, Tomo I, pp. 182-187. J. TORRES FONTES, CODOM, tomo III, pp. 23-24. 
a la zona en una barrera natural de difícil acceso durante los siglos centrales de la Edad Media.

\section{LA CASTRALIZACIÓN DEL ESPACIO: ANTECEDENTES Y EVOLUCIÓN}

Estas características geomorfológicas del paisaje, unidas al hecho de que se trate de una zona de frontera van a determinar la estructura del poblamiento, caracterizado para este período por los habitats fortificados enclavados en espacios de altura.

\section{2.a. La castralización musulmana}

Pero esta morfología del poblamiento no va ser impuesta ex novo por los santiaguistas en el momento de su asentamiento en la zona, sino que, en la gran mayoría de los casos, los hábitats fortificados son de herencia islámica.

Durante el período de establecimiento musulman, la zona de Segura de la Sierra, por sus condiciones geoestratégicas y por la presión del avance cristiano, se había configurado ya en un espacio ampliamente castralizado ${ }^{2}$. Incluso desde una perspectiva geográfica más amplia se pone de manifiesto el proceso de incastellamento musulmán sufrido durante los siglos XI, XII y XIII ${ }^{3}$.

La organización del poblamiento se articula en torno a una estructura castral en la cual se integran el castillo - Hisn-y un conjunto de pequeños núcleos de hábitat -alquerías- entre los que se establece una relación dialéctica castillo-territorio, de manera que el castillo actúa como centro polarizador de las poblaciones ubicadas en el territorio castral. El poblamiento se dispone en torno a un esquema desconcentrado -no disperso- - y no jerárquico, donde un conjunto de pequeñas comunidades de aldea se sitúan cercanas a los terrenos de cultivo. Sobre esta estructura poblacional se sitúa el Hisn como centro político-administrativo o militar del territorio castral que controla y protege ${ }^{4}$. El hisn puede llevar asociado la existencia de un hábitat permanente al que se la añade la función de refugio en períodos de peligro para las poblaciones vecinas o puede funcionar como refugio temporal sin hábitat permanente ${ }^{5}$. Pero

2 E. de la CRUZ AGUILAR, «El reino Taifa de Segura», Boletín del Instituto de Estudios Gienenses, año XL, julio-sept., 1994, nº 53, tomo II, pp. 883-912. J. VALLVÉ BERMEJO, «La división territorial de la España musulmana. La Cora de Jaén», Al-Andalus XXXIV, pp. 76.

3 Este fenómeno ha sido estudiado para la zona centro-oriental de la península por A. BAZZANA, "Typologie...: Les habitats fortifiés du Sharq Al-Andalus", en Habitats fortifiés et organisation de l'espace en Mediterranée médiévale, Table Ronde tenue à Lyon les 4 et 5 mai 1982, GIS-Maison de I'Orient, 1983, pp. 19-27.

4 Este tipo de relaciones que genera la presencia de un castillo sobre un territorio ha sido puesto de manifiesto por André BAZZANA en "Les structures: fortification et habitat", en Habitats fortifiés et organisation de l'espace en Méditerranée médiévale, op. cit., pp. 161-172.

5 Pueden darse diversos modelos de husun relacionados con la existencia o no de un habitat permanente, concretamente A. BAZZANA en «Typologie...: Les habitats fortifiés du Sharq Al-Andalus", op. cit., p. 27, establece cuatro modelos principales. Al mismo tiempo, dentro ya de la existencia de hábitats permanentes, el mismo autor distingue seis categorias posibles dependiendo del grado de 
dentro del territorio castral, además del hisn, se sitúan otras formas menores de defensa, éstas son las torres de alquería. Estas torres asociadas a un hábitat, constituyen un tipo original de estructuras castrales que caracterizan el paisaje medieval de al-Andalus en época musulmana; su función está ligada a la vigilancia del territorio próximo a la aldea en la que se ubica y participan en la defensa colectiva del territorio castral $^{6}$.

\section{2.b. Ocupación santiaguista de la Sierra de Segura}

La fase de establecimiento de la Orden de Santiago en la Sierra de Segura viene precedida por la ocupación santiaguista del Campo de Montiel, la cual servirá de plataforma de penetración hacia la zona limítrofe de los reinos de Granada y Murcia formando, de esta manera, con la ocupación de la Sierra de Segura, una cuña cristiana entre ambos reinos.

Este proceso se inicia en 1235 con la concesión a la Orden, por parte de Fernando III, de la villa y castillo de Torres ${ }^{7}$; en 1239 recibe el castillo y villa de Hornos $^{8}$, y en 1242 la villa y el castillo de Segura ${ }^{9}$ que, conquistada en 1214 , se convertiría en la cabeza de una nueva y extensa encomienda santiaguista ${ }^{10}$.

El proceso de consolidación del patrimonio santiaguista continuó ampliándose por

fortificación y su relación con un hisn en A. BAZZANA, "Les structures: fortification et habitat", op. cit., p. 172.

6 A. BAZZANA; P. CRESSIER y P. GUICHARD, en Les châteaux ruraux d'Al-Andalus. Historie et archéologie des Husun du sud-est de I'Espagne, Publications de la Casa de Velazquez, série archéologie XI, Madrid 1988, pp. 106-120, plantean la posibilidad de que estas torres, además de la función de vigilancia, posean una función de granero colectivo para la población de la aldea.

7 Mayo 1. Malagón. ... illam villam meam de Torres que est circa Seguram, cum castello suo..., Publ. J. GONZÁLEZ, Fernando III, III, op. cit., pp. 71-73, doc. 554.

8 Noviembre 25. Burgos. ... villam et castellum quod vocatur Furnos, quod est in frontaria de Segura..., Publ. J. GONZÁLEZ, Fernando III, III, op. cit., pp. 197-198, doc. 657.

9 Agosto 21. Burgos. Exceptúa de esta donación las villas, castra, turres seu munitiones et terminos pertenecientes al reino de Murcia, a los concejos de Riopal y Alcaráz y los del reino de Jaén y concejos de Baeza y úbeda. Publ. J. GONZÁLEZ, Fernando III, III, op. cit., pp. 248-250, doc. 700.

10 La importancia de esta nueva encomienda viene refrendada por el hecho de que a partir de 1245 la Encomienda Mayor de Castilla sea trasladada desde Uclés a Segura de la Sierra (D.W. LOMAX, La Orden de Santiago, op. cit., pp. 57 y 122-124). Sobre la encomienda de Segura de la Sierra y la ocupación del territorio, ver J.V. MATELLANES MERCHÁN, "La encomienda santiaguista de Segura de la Sierra (1235-1335)", Actas del II Congreso de Historia de Andalucia, Córdoba, 1994, tomo II, pp. 63-80. M. RODRÍGUEZ LLOPIS, «La evolución del poblamiento en las Sierras de Segura (provincias de Albacete y Jaén) durante la Baja Edad Media», Al-basit, año XII, nº 19, 1986, pp-5-32. ID., "Repoblación y organización social del espacio en los señoríos santiaguistas del reino de Murcia (12351350)», Murgetana, 1986, nº 70, pp. 5-34. C. SEGURA GRAIÑO, «La formación del patrimonio territorial de las Órdenes Militares en el alto valle del Guadalquivir (S. XIII)", Las Órdenes Militares en la Península Ibérica durante la Edad Media, Actas del Congreso Internacional Hispano-Portugués, Barcelona, 1981, pp. 99-112. G. NAVARRO, "La Orden de Santiago y Segura de la Sierra", Boletín del Instituto de Estudios Gienenses, (1967), nº 53, pp. 9-14. 
las tierras del sudeste peninisular, llegando a estar las posesiones bastante dispersas $^{11}$. En 1243 el infante don Alfonso dona a la Orden, por los servicios prestados en la toma de Chinchilla, la villa de Galera con las aldeas o torres de Orce, Castalla, Itur, Las Cuevas de Almizra y Color $^{12}$, al norte de la provincia de Granada. Ese mismo año la Orden da a Gil Gómez la villa y castillo de Paracuellos y lo que posee en Segovia a cambio de los castillos de Hijar, Bueycorto, Guttar y Abejuelas ${ }^{13}$. En otro documento de 1243 el infante Alfonso confirma a la Orden la donación de Segura efectuada por su padre un año antes, en ella se especifican las posesiones que tenía Segura con sus castillos que aparecen citados ${ }^{14}$. Sobre este documento volveremos más adelente por su gran interés para nuestro estudio, pues en él se refleja la estructura castral de la Sierra de Segura.

A lo largo del siglo XIII la donación de propiedades a la Orden continuó en zonas de las actuales provincias de Murcia y Jaén ${ }^{15}$ hasta completar un amplio señorío, lo que provocó la creación de nuevas encomiendas que permitieran un control más efectivo sobre sus dominios fronterizos ${ }^{16}$.

\section{2.c. Valoración estratégica de la Sierra de Segura}

Haciendo un rápido repaso a las posesiones otorgadas a la Orden vemos como estas se estructuran a lo largo de toda la Sierra y el Río Segura en el límite de las actuales provincias de Jaén, Granada, Albacete y Murcia, concentrándose la mayor

11 Las posesiones de la Orden en este sector ocuparon zonas de las actuales provincias de Jaén, Granada, Albacete y Murcia.

12 Febrero 15. Toledo, CODOM III, op. cit., pp. 2-3, doc. 2.

13 Mayo 31. Murcia, M. RIVERA GARRETAS, La encomienda, el priorato y la villa de Uclés en la Edad Media (1174-1310), Madrid-Barcelona 1985, p. 401, doc. 193. De esta forma, la Orden consolidaba sus posesiones meridionales, en la frontera, en detrimento de las que poseía más al norte.

14 Julio 5. Murcia. ... Securam... cum castellis hic connominatis uidelicet: Muratalla, Socouos, Bueycorto, Gutta, Letur, Priego, Feriz, Abeiuela, Litur, Aznar, Abeneyçar, Nerpe, Tayviella, Yeste, Agraya, Catena, Albanchez, Huescar, Mirauet, Vulteyrola, Burgeia, cum omnibus terminis pertinentibus ad hec nominata castra, cum terris, cum uineis, cum montibus et fontibus, cum serris et riuis, cum molendinis et pescariis, cum pratis et pascuis, cum defferis et montaticis, cum salinis et portagiis, cum ingressibus et egressibus et cum omnibus directuris et terminis supradicte ville pertinentibus et cum omnibus aldeis suis tem populatis quam populandis... CODOM, III, op. cit., pp. 4-5, doc. 3.

15 En 1246 Fernando Ill donó a la Orden unas casas en Jaén, quince aranzadas de viña, cuatro de huerta, la torre que fue de Mezquiriel, dos molinos cerca de ella, la torre de Maquif con su término, (Publ. J. GONZÁLEZ, Fernando III, III, op. cit., pp. 301-303, doc. 735). En 1257 Alfonso X da a la Orden Aledo y Totana a cambio de Elda, Callosa y Catral, previamente incorporadas a la Orden (Publ., CODOM III, op. cit., pp. 47-49, doc. 32).

16 El traslado de la Encomienda Mayor a Segura y la amplitud de los dominios que acogía hicieron muy difícil el control y la defensa de la frontera, por lo que, en opinión de Rodríguez Llopis, se hizo inevitable la fragmentación de la encomienda de Segura y la formación de otras nuevas como las encomiendas de Yeste, Taibilla, Socovos y Moratalla. Vid. M. RODRÍGUEZ LLOPIS en Conflictos fronterizos y dependencia señorial: la encomienda santiaguista de Yeste y Taibilla (ss. XIII-XV), Albacete 1982, pp. 37-40. 
parte de los castillos a lo largo del Río Segura. La valoración de este espacio, caracterizado por una particular estructura física plagada de pasillos naturales, depresiones fluviales y abundantes afloramientos rocosos, favorece la definición fronteriza de esta zona. La ocupación de este espacio por parte de la Orden de Santiago marcaba la posibilidad castellana de comunicación entre el interior de la Península y el litoral mediterráneo ${ }^{17}$, de penetración hacia el reino de Granada y de formar entre ambos reinos musulmanes - granadino y murciano- una cuña cristiana que impidiera toda comunicación entre ellos. Estos factores, unidos a otros de carácter económico como la posibilidad de explotación de los abundantes recursos acuíferos, la abundancia de pastos de invierno para los rebaños conquenses ${ }^{18}$, así como el control de las redes del tráfico comercial que desde Granada o Murcia, penetraban hacia Castilla a través de Segura ${ }^{19}$, hacen de este espacio un enclave natural geopolítico de primer orden para los intereses santiaguistas, lo cual determinó que se consolidara un fuerte señorío económico-militar en torno a Segura de la Sierra, centrando en un espacio muy reducido gran cantidad de fortalezas, castillos y torres ${ }^{20}$.

\section{2.d. La estructura castral santiaguista: tipología}

Con el paso de una formación social musulmana a otra cristiana, la estructura castral del territorio de Segura de la Sierra será heredada, en su mayor parte, por los santiaguistas, si bien la evolución del poblamiento y de sus emplazamientos fortificados sufrirá unas transformaciones que más adelante señalaremos.

Volvamos ahora al documento de confirmación de Segura de 1243, ya que a través de él intentaremos analizar la red castral santiaguista en la Sierra de Segura. En el citado documento ${ }^{21}$ se mencionan los numerosos castillos - un total de veinteque pertenecen a la encomienda de Segura de la Sierra. La localización de dichos castillos, en su mayoría, no reviste problemas ${ }^{22}$ si bien hay algunos en donde surgen

17 Vid. F. CALVO GARCÍA-TORNEL, «Política y geografía: la delimitación del Reino de Murcia en la Edad Media", Homenaje al profesor Juan Torres Fontes, Universidad de Murcia, Academia Alfonso X el Sabio, Murcia 1987, vol. I, pp. 193-198.

18 Vid. D.W. LOMAX, La Orden de Santiago (1170-1275), op. cit., pp. 110-111.

19 Vid. J.V. MATELLANES MERCHÁN, La Orden de Santiago y la organización social de la Transierra castellano-leonesa (ss. XII-XIV), Tesis Doctoral inédita leída en 1996. J. GONZÁLEZ, Fernando III, I, op. cit., pp. 184.

20 Vid. J.V. MATELLANES MERCHÁN, La Orden de Santiago y la organización social de la Transierra castellano-leonesa, op. cit. ÍD., «Las fortalezas de Segura de la Sierra: aproximación a un marco de organización del espacio (1235-1350)», en I/l Curso de Cultura Medieval, Aguilar de Campoo, 1992 (en prensa).

21 Ver nota 14.

22 Para la localización de los topónimos nos hemos servido, por una parte, de la prospección de campo y, por otra, con los más problemáticos hemos intentado conciliar las diferentes localizaciones que de ellas se dan en M. RODRÍGUEZ LLOPIS, Conflictos frontrizos y dependencia señorial: la encomienda de Yeste y Taibilla (ss. XIII-XV), op. cit., p. 53., CODOM, III, op. cit., pp. 24-25. J.V. MATELLANES MERCHÁN, La Orden de Santiago y la organización social de la Transierra castellano-leonesa, op. cit. E. DE LA CRUZ AGUILAR, «El reino Taifa de Segura», op. cit., pp. 901-902. 
ciertas dificultades. En la actual provincia de Jaén se sitúan, dominando toda la entrada a la sierra desde el Campo de Montiel, aparte del propio Segura de la Sierra, Albánchez, Catena, junto a Segura, donde se localizan las ruinas del castillo de la Espinareda, y Hornos, emplazamiento avanzado en la frontera del reino de Granada. En la provincia de Granada, y también delimitando la frontera, están: Huéscar, Volteruela (actual Puebla de Don Fadrique), Miravet (actual Miravetes en término de Huéscar) ${ }^{23}$, Burgeya, próximo a Huéscar. En la provincia de Albacete se localizan la mayoría de los "castillos" citados en el documento; siguiendo la dirección del Río Segura nos encontramos con: Graya, cercano al curso de Segura y a los pies de la Sierra de los Lagos ${ }^{24}$; Yeste entre el los ríos Tus y Segura, dominando el valle fluvial de éste último; al sur de la provincia, dominando el curso del Taibilla, nos encontramos con el propio Taibilla (próximo a Casas de la Tercia) limitando con la frontera y controlando los pasos que, a través de la Sierra de las Cabras, venían desde Huéscar ${ }^{25}$, y Nerpio; siguiendo el curso del Taibilla hasta casi su confluencia con el Segura está Aznar, identificable con el actual topónimo de la Dehesa de Itnar, al suroeste de Letur; hacia el este, paralelos al curso del Segura, se encuentran Letur, Abejuela, Férez y Socovos; ya en la orilla izquierda del Segura se encuentran Gutta, actual Villares, y Vicorto donde todavía se localizan restos del "castillo" que más bien es una torre; más al norte, sobre el cauce del Río Mundo, se localizan Hijar y Lietor. Ya en la provincia de Murcia, próximos a la de Albacete, se sitúan Priego, en un cerro al pie del Calar del Incol, en el Arroyo de los Frailes (junto a Casa de Requena, donde se localizan los topónimos Cortijo y Castillo de Pliego); Benizar, donde, sobre el Arroyo de Benizar, se localizan los topónimos de cerro y caseta de la Atalaya ${ }^{26}$, torres de control de los espacios fronterizos; por último, hacia el sureste se encuentra Moratalla.

Todos estos topónimos que acabamos de localizar, son denominados «castillos" en el documento de confirmación, lo cual nos hace plantearnos una serie de cuestiones acerca de la terminología: ¿qué se quiere decir con la denominación "castillos»?, ¿son todos esos "castillos" iguales?, ¿no hay diferencias morfológico-funcionales entre ellos?, ¿qué funciones cumplen cada uno de ellos?... Podríamos seguir haciendonos todavía más preguntas pero las respuestas no son fáciles de concretar27.

Un primer problema que se plantea es el terminológico, y es que bajo la denominación de "castillo" se está acogiendo una serie de construcciones castrales que, en buena medida, son muy diferentes entre sí. Una rápida prospección de campo realizada por la zona de Jaén y Albacete, teniendo en cuenta que los restos conservados de los "castillos" no son muy abundantes, nos ha permitido constatar este hecho, deter-

23 Aquí hemos seguido la localizaciones de Rodriguez Llopis y Matellanes Merchán, si bien Cruz Aguilar propone otras localizaciones para Miravet, una primera lo sitúa próximo a Puebla de Don Fadrique, otra en el término de Santiago de la Espada, y otra en el término de Segura de la Sierra.

24 M.T.N. hoja 888.

25 M.T.N. hoja 909.

26 M.T.N. hoja 889.

27 Para obtener respuesta a todas estas preguntas se haría necesaria la indispensable colaboración arqueológica de la cual lamentablemente carecemos para este estudio. 
minado por la gran diversidad de estructuras existente entre los diferentes «castillos" ${ }^{28}$. Los restos conservados corresponden, en su mayoría, a:

a) Estructuras castrales cuya valoración estructural y funcional fue muy destacada en la Edad Media y que fueron sedes de encomiendas santiaguistas; es el caso de Segura de la Sierra, Yeste, Socovos.

Segura de la Sierra es un tipo paradigmático de habitat fortificado ${ }^{29}$. A una altitud de $1200 \mathrm{~m}$., se eleva sobre un afloramiento rocoso la imponente fortaleza, hoy muy restaurada, a cuyos pies se sitúa la población protegida por una muralla guarnecida con torres ${ }^{30}$. Cabeza de un pequeño reino de Taifa ${ }^{31}$, con la conquista cristiana - de cuyo período datan los restos actuales de la fortaleza ${ }^{32}$ — pasó a ser sede de la encomienda de Segura y pieza clave en la actividad repobladora y defensivo-ofensiva del extenso territorio fronterizo ${ }^{33}$. Yeste es otro ejemplo de habitat fortificado en el que se conjugan la existencia de castillo y villa, englobada ésta última por el castillo dentro de una cerca muraria y situada a los pies de é $\left.\right|^{34}$, que aprovecha los elementos naturales para su protección.

28 La prospección de campo, buscando restos de construcciones castrales, se ha realizado por los lugares de Orcera, Segura de la Sierra, y Hornos, en la provincia de Jaén; La Graya, Yeste, La Dehesa, Letur, Abejuela, Férez, Socovos, Vicorto, Villares, Hijar y Lietor, en la provincia de Albacete. Tan sólo hay restos considerables de estructuras castrales en Segura de la Sierra y su término, término de Orcera (Torres de Santa Catalina), Hornos, Yeste, Socovos, y Vicorto, en el resto de las localidades no se han encontrado restos, o no son dignos de mención.

29 Seguimos aquí la clasificación tipologica de hábitats establecida por A. Bazzana, dentro de la cual Segura estaría dentro de la primera categoría, A. BAZZANA, «Les structures: fortification et habitat», op. cit., p. 172.

30 En una visita efectuada por Francisco de León, comendador de bastimentos del Campo de Montiel, en 1468, se recoge:... Esta villa de Segura es mucho fuerte y está en una cuesta muy alta; $y$ en la ladera está la villa y tiene buena çerca... avrá en esta villa çiento e çincuenta vezinos, y ençima de lo altos desta cuesta está el castillo, que está tan alto que pareçe que está en el çielo... y tiene el muro muy ancho de la fortaleza, e tiene en el tres torres buenas y un cubo... Tiene al un canto della, fazi el canpo, una muy gruesa torre del omenaje..., vid. J. TORRES FONTES, «Los castillos santiaguistas del reino de Murcia en el siglo XV», Anales de la Universidad de Murcia, vol. XXIV, nos 3-4, 1965-66, pp. 34. En L. VILLEGAS DÍAZ, «Relación de los pueblos de Jaén, ordenadas por Felipe II», Boletín del Instituto de Estudios Giennenses, $\mathrm{n}^{\text {os }} 88-89,1976$, pp. 216-217, se dice de Segura:... Está toda la villa çercada y esta çerca toma y abraça la villa con la fortaleça e todas la torres e torrejones que dentro della ay. En esta çerca ay mucha torres y tiene cuatro puertas principales... la fuerça desta villa es la más fuerte y prinçipal que su magetad tiene en estos sus reinos, porque está, como dicho es fundada sobre peña biba por todas partes.

31 Vid. E. DE LA CRUZ AGUILAR, «El reino Taifa de Segura», op. cit., pp. 883-912.

32 Vid. J. ESLAVA GALÁN, "Los castillos de la Sierra de Segura", Boletín del Instituto de Estudios Giennenses, no 137, 1989, pp. 27.

33 Vid. J.V. MATELLANES MERCHÁN, "La encomienda santiaguista de Segura de la Sierra», op. cit., pp. 70-74.

34 ... Esta villa de Yeste es una buena villa de asta tresçientos vecinos e muy bien asentada, avunque es çercada a casa muro... y la otra terçia parte, por lo más llano, tiene buena çerca de tapias con su petril e almenas... Tiene esta villa, en lo más alto della, que es una cuesta, vna fortaleça... $Y$ esta fortaleça tiene dos apartamentos..., vid. J. TORRES FONTES, «Los castillos santiaguistas del 
b) Estructuras de importancia menor que las anteriores pero que mantenían todavía una valoración estructural y funcional destacada, como es el caso de Hornos, castillo enclavado en posición estratégica sobre un colina rocosa a $900 \mathrm{~m}$. de altitud, se yuxtapone sobre la villa a la que rodea, en algunos tramos, mediante una muralla natural de afloramiento rocoso ${ }^{35}$. Otro ejemplo podría ser Letur del cual, si bien no han quedado restos del castillo, si hay descripciones documentales del siglo $\mathrm{XV}^{36}$. Taibilla podría entrar dentro de esta categoría, enclavada sobre un espolón rocoso $-1200 \mathrm{~m}$. de altud-, controlaba los pasos hacia Andalucía Oriental. Reuniendo una estructura castral y un hábitat, ocupa un espacio de altura, en el que en el interior de un albacar se levanta la torre, el despoblado se sitúa en la pendiente noroeste del castillo ${ }^{37}$.

c) Estructuras castrales que se pueden corresponder con torres de aldea cuya complejidad estructural y valoración funcional es mucho menor a las anteriores. $\mathrm{Se}$ limitarían a la vigilancia de los espacios inmediatos, es el caso de Vicorto. Se trata de una torre ${ }^{38}$ apartada de lo que es el actual pueblo, situada sobre una pequeña colina de $600 \mathrm{~m}$. de altitud en el camino que va desde Elche de la Sierra a Férez. La función de esta torre sería la de vigilancia de dicho camino y guarda de los vecinos de la aldea. La aldea y torre de Vicorto se encuentran próximas $(1 \mathrm{~km}$.) a la población de Villares donde estaría la torre de Gutta, que no sería más que una torre de aldea de las mismas características de la de Vicorto.

Analizados un pequeño porcentaje de estos "castillos", parece quedar claro que ni todos son iguales, ni a todos les corresponden las mismas funciones y que, por tanto, debemos ser cautos a la hora de analizar los textos ${ }^{39}$ pues nos pueden lievar a

reino de Murcia en el siglo XV», op. cit., p. 41. Vid. M. RODRÍGUEZ LLOPIS, Conflictos fronterizos $y$ dependencia señorial: la encomienda de Yeste y Taibilla (Siglos XIII-XV), op. cit., pp. 41-46.

35 ... la dicha villa de Hornos está poblada en lo alto, ençima de una gran peña, e que toda la villa está çercada de peña tajada biba toda a el derredor. Que confina con el castilloquestá en la cabeçada del pueblo en lo más alto, de cara de donde sale el sol... E que la dicha villa solamente tiene dos puertas por donde entran e salen a ella..., en L. VILLEGAS DÍAZ, «Relación de los pueblos de Jaén, ordenadas por Felipe II», op. cit., p. 149.

36 ... Y es asentada esta villa sobre una peña muy fuerte y algunas parte es menester reparar la çerca. Tiene esta villa vna fortaleça, que tiene un cortijo de argamasa y de muy buena tapia, y tiene seis torres en el dicho cortijo..., vid. J. TORRES FONTES, «Los castillos santiaguistas en el reino de Murcia en el siglo $X V »$, op. cit., p. 43.

37 P. LILLO CARPIO y A.L. MOLINA MOLINA, «El castillo de Taibilla», Miscelánea Medieval Murciana, 1981, vol.VII, pp. 71-84; A. BAZZANA; P. CRESSIER y P. GUICHARD, Les châteaux ruraux d'Al-Andalus. Historie et archéologie des Husun du sud-est de l'Espagne, Publications de la Casa de Velazquez, série archéologie XI, Madrid 1988, pp. 148-152.

38 Junto a la torre se encuentra un recinto de habitación que no sabriamos decir si data de la misma época.

39 Este problema terminológico ha sido abordado por C. de Ayala Martínez, el cual, a través del análisis documental de algunos textos que aquí hemos mencionado, ha planteado cinco posibles categorías de referencia territorial entre las cuales se encuentran tres específicamente castrales: castra, turres, munitiones. El mismo autor establece una acertada identificación paralela, aunque jaráquicamente diferenciada, entre castillo-villa y torre-aldea; vid. C. DE AYALA MARTíNEZ, Las fortalezas santiaguistas y el territorio conquense, en prensa. 
conclusiones erróneas si el análisis de éstos no se ve acompañado de labores de carácter arqueológico, tan necesarias para un profundo conocimiento de las estructuras castrales en la Península Ibérica ${ }^{40}$.

\section{2.e. La evolución del territorio castral: nuevas categorías espaciales}

Anteriormente veíamos de qué manera se estructuraba el territorio castral de la Sierra de Segura durante el último período de dominación musulmana. Reflejo del antiguo ámbito territorial islámico de Segura, sería la concesión de términos de la que hemos venido hablando hasta ahora, realizada por Fernando III y confirmada por Alfonso $X^{41}$.

La estructura del poblamiento, caracterizada por su castralización, viene determinada por la singularidad orogáfica del territorio y por la proximidad de la frontera. A partir de la ocupación del territorio por parte de la Orden de Santiago y, por tanto, de la implantación de un modelo de organización feudal, se van a producir una serie de modificaciones en la estructura de organización del espacio y del poblamiento ${ }^{42}$, cuyos protagonistas van a ser en buena parte los «castillos" de los que hemos venido hablando.

Si bien, al inicio de la ocupación santiaguista, el poblamiento aldeano no se resintió por el cambio de una formación social a otra ${ }^{43}$, a partir de mediados del siglo XIII el antiguo modelo de articulación espacial islámico — no concentrado y no jerarquizado-- será sustituído por una concentración del poblamiento y una jerarquización del territorio en torno a una serie de núcleos principales.

Sobre un contexto de inestabilidad fronteriza, de huída de la población musulmana y de falta de repobladores cristianos, enmarcado todo ello dentro de la política de centralización llevada a cabo por Alfonso X a partir de mediados de siglo, el poblamiento

40 Referente al estudio arqueológico de los yacimientos castrales, nos parecen ejemplarizantes los trabajos llevados a cabo en el levante y sudeste peninsular por A. Bazzana, P. Guichard y P. Cressier, sirva como ejemplo: A. BAZZANA; P. CRESSIER y P. GUICHARD, Les châteaux ruraux d'Al-Andalus. Historie et archéologie des Husun du sud-est de l'Espagne, op. cit.

41 Vid. E. DE LA CRUZ AGUILAR, «El reino taifa de Segura», op. cit., pp. 900-906; el autor se apoya para refrendar esta posibilidad en la costumbre de conceder los términos tal y como eran en tiempo de los musulmanes y en que, salvo Huéscar y Volteruela, todas las villas incluidas en la concesión recibieron el fuero de Cuenca en su variante segureña.

42 Estas modificación han sido adecuadamente estudiadas por M. RODRÍGUEZ LLOPIS en «La evolución del poblamiento en las sierras de Segura (provincia de Albacete y Jaén) durante la Baja Edad Media», op. cit., pp. 5-32; La villa santiaguista de Lietor en la Baja Edad Media, Instituto de Estudios Albacetenses, 1993, pp. 12-23; Conflictos fronterizos y dependencia señorial: la encomienda santiaguista de Yeste y Taibilla (Siglos XIII-XV), op. cit, pp. 49-61; Señoríos y feudalismo en el reino de Murcia (los dominios de la Orden de Santiago entre 1440-1515), Universidad de Murcia, pp. 39-60.

43 En el sector septentrional de la sierra hubo un abandono de la población musulmana que fue reemplazada por población cristiana. Por el contrario, en el sector oriental se mantuvo la presencia musulmana en las aldeas; vid. M. RODRíGUEZ LLOPIS, «La evolución del poblamiento...», op. cit., pp. 8-9. 
tiende a concentrarse en torno a los habitats fortificados, núcleos de relevancia económica y estratégica que ven como otras entidades de poblamiento menores sufren la despoblación de sus espacios.

Esto es precisamente lo que sucedió en torno a la Sierra de Segura a lo largo del siglo XIII, sobre todo a partir de la elección de Segura en encomienda Mayor. A partir de entonces, una serie de habitats fortificados se van a erigir en polos de atracción, en núcleos de organización defensivo-ofensiva y en centros de actividad económica y poblacional del espacio dependiente.

En torno a un territorio amplio - la Sierra de Segura - se van a estructurar otros ámbitos espaciales menores, nuclearizados en torno a las fortalezas de Segura, Yeste, Socovos y Moratalla que serán las que protagonicen de una manera más coherente la defensa y articulación del espacio. Estas fortalezas tendrán bajo su tutela toda una serie de castillos, torres o munitiones de menor entidad, cuya función estará supeditada al control efectivo del espacio circundante $e^{44}$, tanto contra posibles incursiones, como para la explotación de los recursos naturales y el cobro de montazgos, portazgos ${ }^{45}$, pues no olvidemos que en el documento de confirmación de términos de Segura se le concedían a los santiaguistas los "castillos" cum omnibus terminis pertinentibus ad hec nominata castra, cum terris, cum vineis, cum montibus et fontibus, cum serris et riuis, cum molendinis et pescariis, cum pratis et pascuis, cum deffesis et montaticis, cum salinis et portagiis,...

Volviendo al estudio de la tipología de estos emplazamientos, un elemento que nos puede ayudar a descifrar la categoría castral de los mismos, puede ser el factor repoblación-despoblación.

Si tenemos en cuenta que a lo largo del siglo XIII, una serie de emplazamientos se erigieron en cabezas jerárquicas de un espacio que ordenaban, y que el poblamiento tendió a focalizarse en torno a estos hábitats fortificados, debemos presuponer que estos emplazamientos poseían una valoración morfológico-funcional compleja, como correspondería a su categoría.

Por el contrario, otra serie de estructuras de fortificación y hábitat mucho menos complejas estructural y funcionalmente, (leáse torres de aldea, munitiones) sufrieron un proceso de pérdida de población que les llevó, en algunos casos, a convertirse en despoblados. El rastreo de este proceso nos llevará a poder identificar tales emplazamientos como estructuras castrales menores y tipológicamente subordinadas a otras de carácter más complejo. Este es el caso de Taibilla que sufrió una fuerte despoblación

44 Segura de la Sierra contaba con los castillos de La Puerta, Villarrodrigo, Génave, Siles, Benatae, Hornos, Torres de Albánchez, Orcera, Hornillos y Catena. Yeste con Graya. Taibilla con Nerpio. Socovos con: Letur, Abejuela, Lietor, Hijar, Feréz y Aznar. Moratalla con: Volteruela, Benizar y Priego. Vid. J. TORRES FONTES, «Los castilos santiaguistas del reino de Murcia en el siglo XV», op. cit.

45 EL cobro de portazgo en el castillo de Taibilla ha sido puesto de manifiesto por P. LILLO CARPIO y A.L. MOLINA MOLINA, en "El castillo de Taibilla», Miscelánea Medieval Murciana, vol.VIl, 1981, pp. 71-84. También A. PORRAS ARBOLEDAS en «Los portazgos en León y Castilla durante la Edad Media. Política real y circuitos comerciales", En la España Medieval, 1992, pp. 198, advierte el cobro de portazgos en Segura y Torres de Albánchez. 


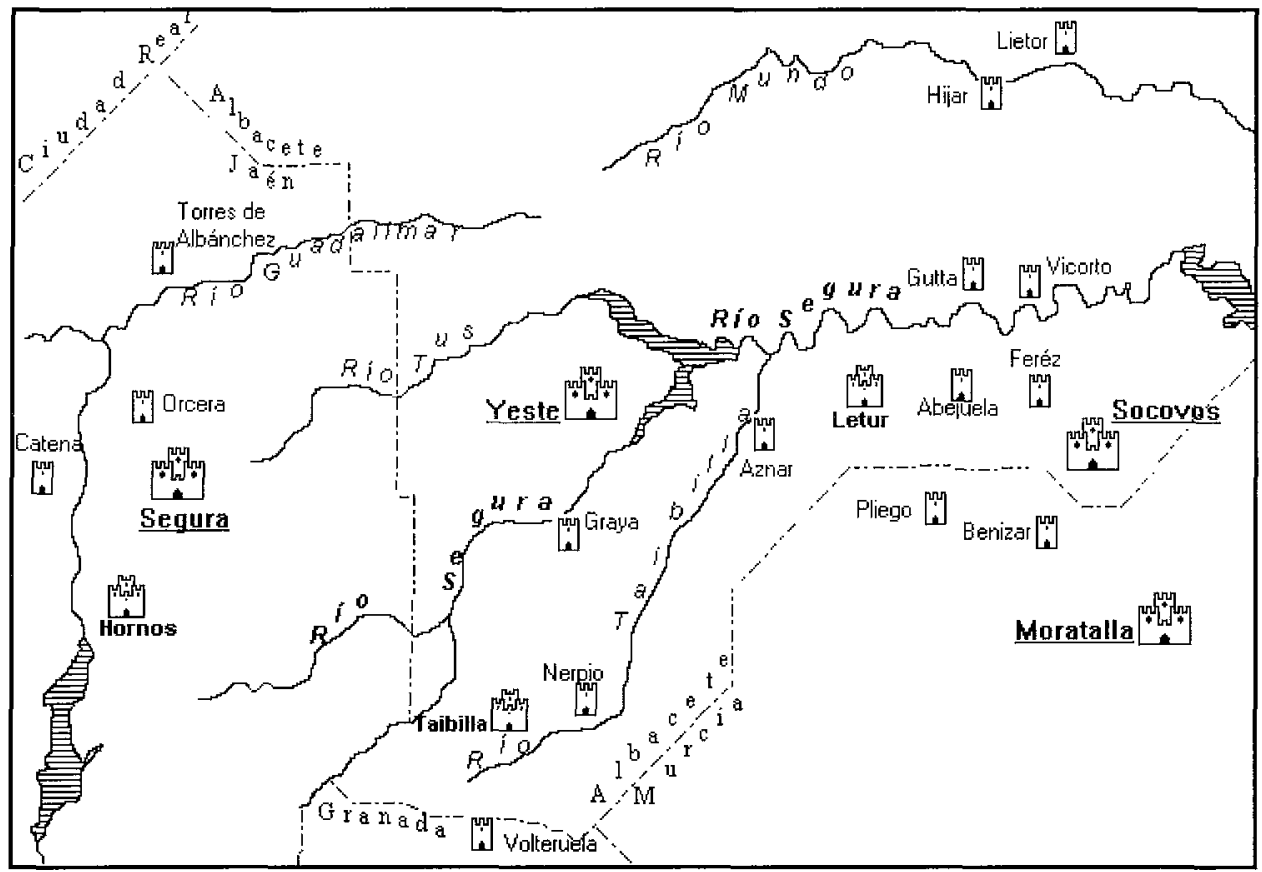

a lo largo del siglo XIV hasta quedar unida a la encomienda de Yeste a principios del $X^{46}$. Hijar - de la cual no quedan restos de ninguna torre o recinto defensivo-, a raíz de la conquista cristiana asistió a una pérdida progresiva de su población lo que le llevó a quedar despoblada a principios del XIV. Lietor sufrió también un proceso paralelo de despoblamiento, aunque no lo llevó al total abandono y pudo ser repoblada en 1335. Más al sur, los lugares de Villares (Gutta), Vicorto, Létur, Feréz también sufrieron la despoblación de su hábitat ${ }^{47}$, y por tanto, la ruina, sobre todo en el caso de Gutta, Feréz, Letur y Lietor, de sus estructuras castrales.

\section{CONCLUSIÓN}

A modo de conclusión queremos hacer una serie de aclaraciones:

Primero, plantear como hipótesis todas las afirmaciones contenidas en este trabajo ya que, como anteriormente hemos dicho, sin un estudio interdisciplinar que contemple las aportaciones necesarias de la historia, la arqueología y la geografía, todas las conclusiones serán parciales y no nos permitirán hacernos un idea lo más aproximada posible de la realidad de la estructura castral santiaguista en la Sierra de Segura.

46 Vid. M. RODRÍGUEZ LLOPIS, Conflictos fronterizos y dependendencia señorial..., op. cit., pp. $39-40$.

47 Letur y Feréz sería repobladas en la segunda mitad del siglo XV, 1454 y 1488, respectivamente, vid. M. RODRÍGUEZ LLOPIS, «La villa santiaguista de Lietor en la Baja Edad Media», op. cit., pp16-23. 
En segundo lugar, y relacionado con lo primero, queremos advertir que la clasificación tipológica que hemos tratado de establecer es meramente aproximativa. De ningún modo hemos hecho un "barrido" sistemático de todas las estructuras castrales situadas en la Sierra de Segura. Nos hemos servido de la documentación para guiarnos a la hora de establecer esta clasificación tipológica, pero no cabe duda de que se nos escapan numerosas torres, atalayas (la abundante toponimia de la zona lo confirma) que también desempeñaron su función en la época medieval y que por ser estructuras de menor entidad quizá no se recogieron en la documentación ${ }^{48}$.

Por último, queremos añadir que en la clasificación tipológica no hemos hablado de un categoría de emplazamiento castral que tuvo su importancia relativa como elemento defensivo. Nos referimos a los refugios naturales: cuevas, abrigos, peñas rocosas, etc., que sin duda fueron utilizados por los habitantes de la Sierra cuando no estaban en disposición de refugiarse en un conjunto castral. Sirva como ejemplo Lietor cuyos habitantes tuvieron como refugio para casos excepcionales, ante la ruina de su fortificación, una cueva existente en la roca, bajo la población misma:

«... visytaron una cueva que se dize la fortaleza, la cual está sobre la barranca del valle y entran por debaxo de la dicha villa, e mandase por junto al muro, por do tyene la entrada a la parte de fuera de la barranca, y entra muy adentro debaxo de la peña, a manera de algarve, donde se solían recoger en los tiempos de necesidad. Es toda obra natural ${ }^{49}$.

48 Un buen ejemplo de ello pueden ser las torres de Santa Catalina, se trata de tres torres - una de ellas mayor que las otras - posiblemente de antiguas alquerías islámicas, situadas a poca distancia de la fortaleza de Segura entre los ríos Trujala y Orcera. Su función en época cristiana podía estar supeditada a la vigilancia de los espacios próximos y poco visibles desde la propia fortaleza de Segura debido a la monticulosidad del terreno. Vid. J. ESLAVA GALÁN, "Los castillos de la Sierra de Segura», op. cit., pp. 22-23.

49 El texto corresponde a una visita realizada a Lietor en el siglo XV, Publ. M. RODRÍGUEZ LLOPIS, La villa santiaguista de Lietor en la Baja Edad Media, Instituto de Estudios Albacetenses, 1993, pp. 22. 


\title{
PER ÇO COM GRAN FRETURA ÉS DE VIANDA EN LA NOSTRA HOST... L'AVITUALLAMENT DE L'EXÈRCIT DE JAUME II EN LA CAMPANYA DE MÚRCIA (1296) ${ }^{*}$
}

\author{
Carles VELA I AULESA \\ Institució Milà i Fontanals (CSIC)
}

El 7 de maig de 1296 Jaume II, que en aquells moments es trobava davant les muralles de la vila d'Oriola assetjant aquesta localitat aleshores murciana, envia una carta a Jaume de Santacreu per tal que trameti per mar a Guardamar tota la farina que trobi a Alacant, sigui qui en sigui el propietari, indicant-li clarament que açò no alonguen en neguna manera, per ço com gran fretura és de vianda en la nostra host, sol 'licitud en el compliment de la qual el conseller no sembla demorar, ja que no tornen a aparèixer entre les lletres reials més referències a fretures de vianda durant la primera etapa de la campanya reial per a l'annexió del regne de Múrcia a la Corona d'Aragó. L'episodi és, doncs, casual, però ens il' lustra a bastament de la importància extraordinària que un aspecte aparentment secundari dels conflictes bèl'lics, l'avituallament, pot tenir. De la constatació d'aquesta importància neix aquesta comunicació en la qual intentarem aprofundir en diversos aspectes de l'aprovisionament de l'exèrcit catalanoaragonès durant els primers moments de la campanya'.

Circumscriurem el període estudiat als dos primers mesos de l'ocupació del regne,

* Aquesta comunicació ha estat possible gràcies a una beca d'investigació atorgada pel Departament d'Ensenyament de la Generalitat de Catalunya i s'inscriu en el Projecte d'investigació La Corona de Aragón y los países islámicos en la Baja Edad Media: el marco político-militar y los intercambios económicos y culturales, dirigit per la Dra. Maria Teresa Ferrer i Mallol i finançat per la DGICYT.

1 Haig d'agrair a la Dra. Maria Teresa Ferrer i Mallol tota la seva col laboració, amb comentaris i suggeriments, que m'ha permès presentar aquesta comunicació. Confio en haver sabut aprofitar tots els seus consells i indicacions. 
des del moment de l'entrada al regne des de València i la conquesta d'Alacant, a mitjan mes d'abril de 1296, fins a l'inici del setge d'Elx, és a dir fins a mitjan mes de juny². L'elecció d'aquest període té els seus motius. Primerament acotar el volum de documentació $i$, per tant, d'informació a l'extensió pròpia d'una comunicació com aquesta que presentem. En segon lloc, la situació bèl' lica a l'inici del setge d'Elx permet afirmar que l'acció militar està pràcticament conclosa, com a mínim la realitzada dins de la campanya reial i des del punt de vista de l'avituallament. Llevat de Lorca, el castell d'Alhama $i$ alguns altres llocs més petits com ara Chuecos, la resta de territoris del regne reconeixen ja la senyoria de Jaume II o estan en tràmits de fer-ho, de manera que podem donar per conquerit el regne que ràpidament passà a ser «reorganitzat a la valenciana», sense oblidar tanmateix la seva idiosincràsia en forma del reconeixement dels privilegis de les viles i de la construcció d'una estructura administrativa i governativa independent ${ }^{3}$.

El sotmetiment del regne de Múrcia, per pacte o per conquesta, havia estat decididament ràpid, afavorit tant per la crítica situació de Castella, ocupada en les disputes pel tron entre Ferran IV i els infants de la Cerda, com per la plena dedicació que hi havia pogut posar Jaume II, que, poc abans d'iniciar la campanya, havia aconseguit tancar la confrontació amb els Anjou, amb França i amb el papat gràcies al tractat d'Anagni de 1295, i havia assolit la firma d'un acord de pau amb el regne de Granada el 1296. A tot plegat, s'hi havia sumat una relativa bona disposició dels murcians, especialment dels d'origen català i aragonès, que no havien oblidat els seus vincles amb la casa de Barcelona.

\section{DESENVOLUPAMENT DE LA CAMPANYA ${ }^{4}$}

Obviarem recordar aquí els detalls dels precedents de la donació a Jaume II del regne de Múrcia, per entrar ja directament en detalls de la preparació de la campanya militar, després que el gener de 1296 l'infant Alfons de la Cerda, com a rei de Castella, hagués donat a Jaume II, pels pactes de Bordalba i de Serón, el regne de Múrcia, el

2 Sobre la campanya per la incorporació del regne de Múrcia a la Corona d'Aragó vegi's, especialment, de FERRER I MALLOL, Maria Teresa, "La conquesta de les comarques meridionals valencianes per Jaume II», en curs de publicació a Quaderns de Migjorn. Revista d'estudis comarcals del sud del País Valencià, Associació cívica per la normalització del valencià, Alacant, i el treball més general de la mateixa autora, «Notes sobre la conquesta del regne de Múrcia per Jaume II (12961304)", a Homenatge a la memòria del Prof. Dr. Emilio Sáez. Aplec d'estudis dels seus deixebles i col/laboradors, Institució Milà i Fontanals (CSIC)-Centre d'Estudis Medievals de Catalunya (Universitat de Barcelona), Barcelona, 1989, pp. 27-44. El treball de DEL ESTAL, Juan-Manuel, (Conquista y anexión de las tierras de Alicante, Elche, Orihuela y Guardamar al Reino de Valencia por Jaime II de Aragón (1296-1308), Publicaciones de la Caja de Ahorros Provincial, Alacant, 1982), vàlid en línies generals per a la reconstrucció de la campanya de Jaume II, força excessivament les fonts per donar una visió numantina de la resistència murciana a la conquesta.

3 FERRER I MALLOL, M.T., "La conquesta de les comarques meridionals valencianes per Jaume ll» i Organització i defensa d'un territori fronterer. La Governació d"Oriola en el segie XIV, Institució Milà i Fontanals (CSIC), Barcelona, 1990, pp. 3-48. 
comtat de Molina i el lloc de Requena, amb el compromís per part del de la Cerda d'actuar, si calia amb les armes, per aconseguir l'entrega al monarca catalanoaragonès d'aquestes terres. El primer pas de l'infant castellà fou trametre ordres, com a rei de Castella, per tal que les diferents autoritats murcianes s'entreguessin a Jaume II voluntàriament, actuacions a les quals, des del febrer, Jaume II n'afegí de pròpies per aconseguir també un sotmetiment voluntari i incruent del regne, mitjançant la tramesa, el 21 de febrer, d'un missatger, Bernat Mercer, ciutadà de València, per entrevistar-se amb diverses personalitats murcianes.

Simultàniament i per tal de complir amb els pactes amb Alfons de la Cerda, Jaume II havia enviat a Ferran IV un missatger per declarar la guerra a Castella, amb l'advertiment que les hostilitats podien començar el $7 \circ 8$ de març, després de 10 dies de pau que el rei catalanoaragonès concedia als castellans. Per altres cartes, manava a Bernat de Sarrià, conseller reial, que ultimés els preparatius per a la conquesta, especialment aconseguint reunir un estol de deu galeres, i que la iniciés amb la presa del castell d'Alacant o d'altres castells, sense perjudicar, tanmateix, els habitants del regne mentre es negociava llur submissió.

Tot i les explícites ordres, l'inici de l'expedició es retardà fins a mitjan abril, possiblement per problemes d'infraestructures, tant de reunir tropes i naus, com d'aconseguir vitualles, ja que encara el 10 d'abril, estant a València, on ha reunit o està reunit gran companya, ha de reclamar que les vitualles que havia sol 'licitat per motiu de la campanya de Múrcia siguin entregades bé a València, bé allà on es trobi l'exèrcit ${ }^{5}$, i encara a València, el 16 del mateix mes, ha d'emetre una carta per protegir les vitualles que, de les parts de Terol, li han d'arribar'.

Creuant, entre el $17 \mathrm{i}$ el 22 d'abril, la frontera valenciana per terra, possiblement per Xixona, i per mar, la host de Jaume II s'ensenyorejà ràpidament de la vila i del castell d'Alacant, després de vèncer, entre el 22 i el 26 d'abril, la resistència del seu alcaid Nicolás Pérez.

Com que Jaume II en tot moment buscava una entrega pacífica del regne, la campanya, presa Alacant, es desvià de la ruta «natural» vers Elx —amb el senyor de la qual, Juan Manuel, no volia encara enfrontar-se, a l'espera d'una sol lució pactada-, i prengué la via de Guardamar, vila que no degué oposar gaire resistència, ja que de la seva conquesta no tenim cap notícia.

Des d'aquest port, les tropes es dirigiren a Oriola, a les muralles de la qual arribaren l'1 de maig després de sojornar tres dies a l'horta d'Almoradí. La vila se sotmeté poc més tard, el 10 de maig, mentre que amb l'alcaid del castell es pactava la rendició per al 21 de juny si aquest no rebia reforços abans, compromís que l'alcaid complí.

Sense esperar a la rendició del castell, les tropes es dirigiren ràpidament a Múrcia. El setge s'inicià el 16 de maig, i la ciutat es va retre tres dies més tard, el 19. Com a

4 Seguim l'explicació de la conquesta del regne de Múrcia del treball esmentat de FERRER I MALLOL, M.T., «La conquesta de les comarques meridionals valencianes per Jaume II". Obviem, per tant, les referències bibliogràfiques i documentals, excepte quan es tracti d'una aportació d'altri.

5 ACA, C, reg. 104, f. 3r.

6 ACA, C, reg. 104, f. $23 \mathrm{v}$. 
Oriola, solament restava «rebel» el castell, encara que seguidament es pactà amb l'alcaid el seu lliurament en un termini de 42 dies, si no era auxiliat per tropes castellanes.

Des de Múrcia Jaume II aprofità, com ja havia fet en menor mesura a Oriola, per negociar $i$ aconseguir el sotmetiment dels principals senyors del regne, especialment dels ordes militars del Temple, de l'Hospital i de Santiago, i de l'arrais de Crevillent. A la majoria el monarca els concedí guiatges per permetre el final reconeixement de la seva senyoria $i$, tot $i$ que en alguns casos alguns castells hagueren de ser presos per les armes, la tònica general fou el reconeixement de Jaume II com a rei de Múrcia.

Al final del mateix mes de maig, Jaume ll es dirigí cap a Mula, que, segons pròpies paraules del monarca, fou expugnada, encara que amb celeritat, ja que el setge s'inicià el 28 de maig i entre el 30 i el 31 del mateix mes ja s'havia retut la vila, que li prestà jurament i homenatge.

Seguidament, el monarca es traslladà a Alhama, la qual assetjà breument fins que concedí al seu alcaid, García Gómez de Lasa, un guiatge per 60 dies. Passà seguidament a assetjar Lorca, la més meridional de les viles murcianes. Entre el $3 \mathrm{i}$ el 7 de juny romangué davant les muralles de Lorca, fins que decidí retornar a Múrcia, possiblement perquè les negociacions per l'entrega de Lorca no avançaven.

Abandonat el front meridional, Jaume II va poder encarregar-se de la rereguarda, on havia deixat els dominis de Juan Manuel pendents d'una solució definitiva en acabada la treva. Com que aquesta havia caducat el 2 de juny, des d'aleshores s'havia posat setge a la ciutat, al qual es traslladà el rei el 12 de juny. Finalment, el 27 de juliol es firmà una treva fins que Juan Manuel fos major d'edat. Tot seguit el monarca retornà a València, donant per acabada la campanya, ja que solament restaven «rebels» Lorca, assetjada, el castell d'Alhama i algunes petites localitats com ara Chuecos.

El regne fou confiat a Jaume Pere, germà natural del rei, amb el càrrec de procurador i amb la finalitat d'acabar la integració del nou domini a les estructures administratives de la Corona d'Aragó i d'aconseguir la rendició de les poques places que encara resistien, tasca en la qual no reeixí, ja que per a la conquesta del castell d'Alhama fou necessària la presència del rei el febrer de 1298, i per a la conquesta de Lorca, el desembre de 1300, ja era procurador en Bernat de Sarrià ${ }^{7}$.

La guerra no havia acabat, ja que el rei, com a mínim, féu acte de presència tres vegades més al regne, a la primeria de juliol de 1297, a l'irrici de 1298 per prendre Alhama i en el pas del 1300 al 1301 per prendre Lorca i intentar-ho amb Mula, que s'havia revoltat i que resistí fins a la pau definitiva de $1304 \mathrm{amb}$ la sentència de Torrellas, que establia la divisió del regne de Múrcia. Però tot i no estar closa la conquesta completa, sí que, a l'estiu de 1296, es pot considerar el regne de Múrcia annexionat a la Corona catalanoaragonesa.

7 Sobre les procuradories de Jaume Pere (1296-1298) i de Bernat de Sarrià (1300-1303), i també sobre la de Jaume de Xèrica (1298-1300), procurador alhora del regne de València, que visqué la revolta de la vila de Mula a l'inici del 1300 , i en general sobre l'octaetèrida de domini catalanoaragonès sobre la totalitat de l'antic regne de Múrcia, vegi's FERRER I MALLOL, M.T. Organització i defensa d'un territori fronterer, pp. 15-48. 
La campanya es pot donar per acabada i amb ella tota la intendència que havia generat, per passar a una situació bèl' lica diferent en la qual les accions armades es reduïren a punts concrets, mentre que la majoria del territori es trobava en pau i per tant aliè a la dinàmica d'un enfrontament armat. Per això mateix, l'avituallament de les hosts que veurem que fins aleshores s'havia muntat, es desmuntà, i es va arribar a l'extrem que el procurador Bernat de Sarrià topà amb la impossibilitat d'assegurar als seus homes l'aprovisionament mínim

Els problemes de Bernat de Sarrià per garantir el proveïment d'aliments i les seves nombroses queixes al monarca ens il'lustren clarament les dificultats que encloïa aquesta tasca i ens retornen al tema d'aquesta comunicació, l'avituallament de l'exèrcit de Jaume II durant la primera campanya murciana, la primavera de 1296. Aquest apunt sobre l'evolució militar de la campanya no ha estat més que l'establiment del marc diacrònic i tòpic en el qual es desenvoluparen els diferents sistemes que l'administració catalanoaragonesa posà en pràctica per tal d'aconseguir que totes les seves tropes, amb la seva diversitat, tinguessin assegurat el mínim manteniment.

\section{LA HOST I EL SEU AVITUALLAMENT}

Si la campanya de Múrcia és el marc geogràfic $i$ cronològic en el qual es desenvolupa la nostra investigació, la host és el receptor d'aquest avituallament, i per tant també l'hem de conèixer prèviament per poder entendre'n l'abastament alimentari.

L'exèrcit, durant tota l'època medieval i fins ben entrada la moderna, no presenta l'homogeneïtat que actualment caracteritza els exèrcits professionals. El primer tret d'heterogeneïtat, que en el cas de les regions frontereres s'accentua, és evidentment l'origen de les tropes. Com Maria Teresa Ferrer i Mallol ha demostrat en l'estudi de l'organització i defensa de la governació d'Oriola en el segle XIV, l'exèrcit en una regió de frontera es componia, o podia compondre's, de quatre tipus diferents de contingents: els oficials reials amb les seves escortes, la host feudal sol licitada pel rei als seus feudaters, les milícies veïnals i els almogàvers ${ }^{9}$.

Les hosts enviades pels nobles feudaters ${ }^{10}$, els ordes militars, les senyories eclesiàstiques i les ciutats i viles reials" ${ }^{11}$ formaren el contingent més nombrós. En

8 FERRER I MALLOL, M.T., Organització i defensa d'un territori fronterer, pp. 23-48.

9 Sobre l'exèrcit reial en tota la conquesta de Múrcia, de 1296 a 1304, vegi's FERRER I MALLOL, M.T., Organització i defensa d'un territori fronterer, pp. 191-193 (sobre guàrdies de castells i escortes), pp. 202-206 (sobre la host reial) i pp. 264-267 (sobre els almogàvers).

10 A tall d'exemple, sabem que l'11 d'abril de 1296 Jaume II convocà a servir a la host amb llur seguici els nobles en Carrós, Berenguer Llançol, Gil Martines d'Entença, Pero Çapata de Tous, Pero Çapata de Morvedre, Ximèn Peres d'Arenós, Martí d'Oblites, Ramon d'Urtx i Guillem de Vilaragut (ACA, C, reg. 104, f. 4V, cf. a FERRER I MALLOL, M.T., Organització i defensa d'un territori fronterer, p. 15).

11 Per documentació diversa sabem que enviaren tropes viles com ara Vilafranca, Montblanc, Piera, Sarral, Manresa, Prades, Cervera, Prats, Santpedor, Montblanc, Alzira, Morvedre, Borriana, Castelló, Morella (FERRER I MALLOL, M. T., Organització i defensa d'un territori fronterer, p. 202), Torroella de Montgrí (ACA, C, reg. 340, f. 88v, 23 de maig de 1296, vegi's infra a «Els sistemes d'avituallament $»)$... 
aquesta campanya s'havia intentat que aquestes hosts vinguessin pagades per a quatre mesos de servei, encara que algunes solament ho foren per dos i altres encara no havien cobrat res en començar l'expedició ${ }^{12}$.

Aquest exèrcit heterogeni presentava alguns problemes de logística que el monarca, com a convocant i cap de la host, havia de preveure i calcular. Dels aspectes militars d'enquadrament dels soldats, no en tractarem en aquesta comunicació, però sí de l'abastament de queviures, un problema aparentment secundari que podia decidir l'èxit o el fracàs d'una expedició.

L'abastament d'un exèrcit ofensiu en època medieval era, com el mateix exèrcit, heterogeni, i depenia de diversos factors, interaccionats els uns amb els altres ${ }^{13}$. El mateix origen i funció de les tropes implicava formes diferents d'abast de queviures. Un exèrcit en campanya tenia unes necessitats diferents que una guàrdia establerta en un castell per a la seva defensa o que un grup d'almogàvers. Aquests darrers, amb un grau de llibertat molt alt dins del conjunt de l'exèrcit, basaven la seva acció militar en el saqueig de les poblacions enemigues de les quals podien, per pillatge, aconseguir part de la seva sustentació, tot i que també era forma normal de «contractar-los», per part del rei o d'algun noble, donar-los les taleques, és a dir els sarrons amb pa que els asseguraven la manutenció ${ }^{14}$. L'exèrcit en campanya, en canvi, i en el cas que ens ocupa, normalment depenia del subministrament gestionat pels oficials reials que la Corona es podia cobrar descomptant-los-el de la quitació ${ }^{15}$, mentre que normalment les guàrdies dels castells, que a Múrcia es regien pel costum d'Espanya, eren

\section{FERRER I MALLOL, M. T., Organització i defensa d'un territori fronterer, p. 202.}

13 Cal diferenciar clarament entre els exèrcits ofensius i els defensius, ja que en els primers és possible la previsió, mentre que en els segons no. Per citar alguns exemples dels primers, són previsions a una campanya militar el pressupost per a la campanya de Sardenya de 1323 de l'infant Alfons (ACA, C, Varia, reg. 416 i ARRIBAS PALAU, Antonio, La conquista de Cerdeña por Jaime // de Aragón, Ins. tituto Español de Estudios Mediterráneos, Barcelona, 1952, pp. 377-379) i el pressupost per a la fallida campanya granadina del mateix Alfons, ja com a rei d'Aragó, redactat el 1329 (ACA, C, Papers per incorporar, caixa 13, n. 3, publicat per GALOPPINI, Laura, "Vino dalla Sardegna per una campagna militare (Granada 1329)", a Archivo Storico Sardo, Deputazione di Storia Patria per la Sardegna, Càller, v. XXXVII, 1992, pp. 51-69, i treballat per SÁNCHEZ MARTÍNEZ, Manuel, «Guerra, avituallamiento del ejército y carestías en la Corona de Aragón: la provisión de cereal para la expedición granadina de Alfonso el Benigno (1329-1333)", a Historia. Instituciones. Documentos, Publicaciones de la Universi.dad de Sevilla, Sevilla, n. 20, pp. 523-549).

14 FERRER I MALLOL, M.T., Organització i defensa d'un territori fronterer, pp. 259-263.

15 En general, sobre l'avitualiament dels exèrcits reials, vegin-se CONTAMINE, Philippe, Guerre, État et Société à la fin du Moyen Âge. Études sur les armées des rois de France, 1337-1494, MoutonÉcole Pratique des Hautes Études, París-L'Haia, 1972, pp. 121-128 i 646-654, i la tesi doctoral de CIFUENTES I COMAMALA, Lluís, Medicina i guerra a l'Europa baix-medieval. La sanitat i la participació dels seus professionals en les expedicions militars de la Corona d'Aragó. 1309-1355 (microfitxes), Publicacions de la Universitat Autònoma de Barcelona, Bellaterra, 1995, pp. 42-48, 146-151, 288-309 i 382-409. Aquest darrer autor cita, per a la campanya de Pere el Cerimoniós per a la reincorporació de Mallorca (1343-1344), la pràctica de descomptar de les soldades les despeses de manutenció (els lliuraments de bescuit) (p. 292). 
mantingudes pel rei (o pel seu senyor), que entregava a l'alcaid la retinença, salari del qual aquest havia d'extreure, entre altres conceptes, la manutenció de la guàrdia ${ }^{16}$.

El tipus de tropa és un paràmetre que calia tenir en compte, però n'hi ha dos més també importants i més genèrics que cal tenir ben presents, tant per a l'estudi d'aquesta campanya com de tota l'època baixmedieval: la forma d'aconseguir l'abastament i la procedència dels queviures necessaris ${ }^{17}$.

Existien dues formes d'aconseguir queviures, l'autoabastament i el subministrament controlat, dirigit i assegurat pel cap de l'expedició; en el cas de les hosts reials, el rei. Igualment, dos podien ser els llocs d'adquisició de la provisió: fora de la zona de conflicte, és a dir que els queviures s'havien d'importar, o en el mateix territori en conflicte, in situ.

Aquests dos parells de possibilitats podien combinar-se entre si i fins i tot conviure en una mateixa expedició militar. Tanmateix, al llarg de l'edat mitjana trobem una lenta evolució cap a la centralització i control de l'avituallament per part del rei o del cap de l'expedició, alhora que l'aprovisionament s'assegura preferentment des de l'exterior per tal d'evitar la inseguretat de buscar els queviures sobre la marxa.

Lautoabastament de les tropes era un sistema fortament conflictiu, ja que afavoria el pillatge, que podia ser altament contraproduent quan les tropes es proveïen en terres que gaudien de la protecció del rei ${ }^{18}$. Davant aquests perills, la tendència des del segle XIII i sobretot al segle XIV fou anar limitant aquest sistema d'avituallament i posar-lo sota el control reial.

L'avantatge del control reial radicava en el fet que permetia fer previsions de despeses, de manera que el monarca podia encarregar als seus oficials la compra o obtenció dels aliments necessaris, podia contactar fins i tot amb mercaders $i$ altres proveïdors de queviures per tal d'assegurar el subministrament, i fins i tot podia fer valer els seus drets per aconseguir, en situacions extremes, l'aliment o el finançament necessari, per exemple desviant cap a una campanya militar rendes o imposicions ${ }^{19}$.

16 FERRER I MALLOL, M.T., Organització $i$ defensa d'un territori fronterer, pp. 176-183, i de la mateixa autora, "La tinença a Costum d'Espanya en els castells de la frontera meridional valenciana (segle XIV)", a Miscel'lània de Textos Medievals, Institució Milà i Fontanals (CSIC), Barcelona, 1988, v. 4 La frontera terrestre i marítima amb l'Islam, pp. 1-102, pp. 1-4 i 18-27.

17 CONTAMINE, Ph., Guerre, État et Société à la fin du Moyen Âge, pp. 121-128.

18 La irrealitzada campanya granadina de 1329, ja esmentada, ens ofereix un bon exemple dels inconvenients de l'autoabastament. La host d'Alfons el Benigne havia de creuar el regne de Múrcia, aleshores dependent de Castella, amb la qual s'estava en pau. Per evitar justament el pillatge de la població murciana quan les tropes creuessin aquest regne, el monarca havia hagut de planejar un sistema per assegurar el proveïment (vegi's aquest projecte infra i a SÁNCHEZ MARTíNEZ, M., "Guerra, avituallamiento del ejército y carestías en la Corona de Aragón», pp. 524-528).

19 Per a exemples d'aquestes pràctiques, vegi's, en general (i per al cas francès), CONTAMINE, Ph., Guerre, État et Société à la fin du Moyen Âge, pp. 121-128 i, per a exemples catalanoaragonesos, GALOPPINI, L., «Vino dalla Sardegna per una campagna militare (Granada 1329)», pp. 51-60; SÁNCHEZ MARTÍNEZ, M., "Guerra, avituallamiento del ejército y carestías en la Corona de Aragón», pp. 528-537, i CIFUENTES I COMAMALA, LI., Medicina i guerra a l'Europa baix-medieval, pp. 42-48, 146-151, 288-309 i 382-409. 
La mateixa perillositat pròpia de l'autoabastament la presentava també el proveïment sobre la marxa, que podia tendir al pillatge o a l'ús de la força, tot i que no era estrany aconseguir la provisió per les zones on passava l'exèrcit simplement comprant-la o per sistemes similars (rendes feudals, préstecs...).

La importació dels aliments era, en canvi, un sistema més segur envers la regió on es desenvolupava la guerra, ja que evitava el pillatge i altres excessos, però tenia l'inconvenient de dependre dels transports, no sempre segurs.

A la Corona d'Aragó, sembla que en campanyes com la de Múrcia la tendència fou el control reial sobre l'avituallament, aconseguit generalment de fora la zona afectada, encara que coexistint amb altres sistemes ${ }^{20}$. L'estudi de Manuel Sánchez Martínez sobre el que havia de ser l'avituallament d'una expedició a Almeria, que mai no s'arribà a realitzar, ens mostra clarament com el monarca, Alfons el Benigne, havia constrü̈t tota una infraestructura per assegurar l'avituallament del seu exèrcit, amb la previsió, a més, que la host, en haver de creuar el regne de Múrcia, de sobirania castellana, provoqués els menors efectes possibles sobre la població «civil»²1. Per aconseguir aquest objectiu, Alfons féu comprar als seus oficials gra arreu dels seus regnes i féu dur-lo a Tortosa on s'havia d'embarcar cap a la governació d'Oriola. Allí s'entregaria a les tropes ració per als sis primers dies dels deu que el procurador d'Oriola, Jofre Gilabert de Cruilles, havia calculat que es tardaria d'anar d'Oriola a Almeria. Un cop partides les tropes, sis naus de 3.000 salmes cadascuna portarien per mar vitualles per a cinc dies més, vitualles que s'entregarien a les tropes al cinquè dia d'haver sortit d'Oriola en un port de la costa granadina. D'aquesta manera s'assegurava el subministrament necessari per a la tropa i, sobretot, la seva "correcciós en creuar el regne murcià, ja que s'estava en pau amb Castella. El pla, tanmateix, finia davant les muralles d'Almeria i no preveia com es mantindria l'exèrcit un cop assetjat el port granadí, però possiblement es considerava que una vegada allà, terra enemiga, el saqueig i nous subministraments per mar serien suficients.

L'exemple de la fallida expedició granadina, posterior a la campanya murciana en solament una trentena d'anys, juntament amb altres indicis de planificació reial de l'avituallament de l'exèrcit en campanya ${ }^{22}$, ens fan sospitar si Jaume II no va preveure també un sistema d'avituallament centralitzat, controlat $i$ assegurat per la seva administració, del qual malauradament no disposem de documentació tant explícita com en el cas de la fallida expedició d'Almeria.

Però abans d'entrar en l'estudi de l'avituallament de la campanya murciana, resta

20 CIFUENTES I COMAMALA, LI., Medicina i guerra a l'Europa baix-medieval, pp. 42-48, 146$151,288-309$ i 382-409.

21 SÁNCHEZ MARTÍNEZ, M., "Guerra, avituallamiento del ejército y carestías en la Corona de Aragón», pp. 524-528.

22 Recordem el ja citat pressupost per a la campanya de Sardenya de l'infant Alfons, publicat i moit parcialment treballat per ARRIBAS PALAU, A., (La conquista de Cerdeña por Jaime /l de Aragón, pp. 178-179 i 377-379). En la tesi inèdita de CIFUENTES I COMAMALA, LI., Medicina i guerra a l'Europa baix-medieval, apareixen constants referències a compres realitzades per oficials reials o similars per avituallar la tropa que ha de partir o que es troba en campanya. 
encara un aspecte fonamental: el finançament. L'avantatge de l'autoabastament i del subministrament in situ per mitjà del pillatge és que no suposa cap despesa extraordinària per al cap de l'expedició, mentre que si aquest ha de buscar, transportar i distribuir les provisions, això genera un dispendi considerable. És en aquest sentit que el monarca es veu sovint obligat a forçar vendes, a fixar preus, a arribar a composicions, a demanar préstecs... La campanya de Múrcia ens forneix un exemple: Jaume II ha de manar a Bernat Ginebret, porter reial, que faci saber als mercaders que han dut vianda en gran quantitat a Guardamar, que els la pagarà bé, de forma que n'hagin cabal i guany, és a dir que, davant el perill que els mercaders girin cua, el monarca prefereix pagar un bon preu i aconseguir totes les provisions que aquests mercaders duen ${ }^{23}$.

Amb aquest darrer cas hem tornat a l'expedició que ens ocupa pròpiament, la murciana de Jaume II, en la qual s'observen totes les possibilitats d'avituallament esmentades, encara que amb una clara tendència al predomini del control reial en forma de l'establiment d'unes xarxes de subministrament de vitualles, portades moltes d'aquestes de regions alienes a l'enfrontament armat.

Això no obstant, com ja hem esmentat, la documentació ens deixa entreveure que també existiren altres formes d'avituallament, fins i tot les més descontrolades, és a dir el pillatge. Vegem-les, abans d'entrar en l'anàlisi de les xarxes esmentades.

\section{ELS SISTEMES D'AVITUALLAMENT EN LA CAMPANYA DE MÚRCIA}

La varietat és, sens dubte, el que caracteritza l'avituallament d'un exèrcit medieval, i el de Jaume II per a la campanya de Múrcia no s'escapa a la norma.

En alguns casos concrets $i$ en situacions específiques, es donava possiblement per sobreentès que eren les mateixes tropes les que devien procurar-se el seu abastament o que ho havia de fer la persona o lloc que les enviava, sense participarhi per res el monarca.

Així, les despeses de trasllat dels cavallers i peons d'un noble feudatari, d'un orde militar, d'una senyoria eclesiàstica o d'una vila reial, fins al camp de batalla o fins al punt de trobada de les tropes abans de començar l'expedició, en aquest cas la ciutat de València ${ }^{24}$, corrien a càrrec de la persona o institució que els enviava. Així es desprèn d'una carta reial de 23 de maig de 1296 per la qual mana al batlle i a la universitat de Torroella de Montgrí que pagui el nòlit de portar armes i vitualles dels peons que aquesta vila va enviar a la host, i les atzembles de carregar-les, suma que encara s'ha d'abonar, un mes després d'iniciada la campanya ${ }^{25}$.

23 ACA, C, reg. 340, f. $70 \mathrm{v}$ (17 de maig de 1296).

24 ACA, C, reg. 104, f. $3 r$ (16 d'abril de 1296). Manament per tal que no es molesti als que porten les vitualles de les parts de Terol mentre vénen cap a València, on Jaume II ha fet congregar la comitiva de cavallers i peons per a la campanya contra Castella.

$25 \mathrm{ACA}, \mathrm{C}$, reg. $340, \mathrm{f} .88 \mathrm{v}$. Aquesta referència al nòlit de dur armes i vitualles ens permet deduir la possibilitat que les viles marítimes enviessin les seves hosts amb els seus arreus per mar, en lloc de per terra. 
Es tracta, evidentment, d'un moment previ a la guerra pròpiament dita i es pot entendre fàcilment que el rei no n'assumís les despeses. En canvi, en un altre cas documentat, el que el rei fa és evitar el compliment d'una obligació que sí que tenia: l'aprovisionament dels castells ${ }^{26}$. El costum d'Espanya, que regia en els castells murcians, establia que els castells fossin mantinguts mitjançant l'entrega de la retinença, suma que havia de servir per als homes, les armes i la provisió del castell ${ }^{27}$. Tot $i$ així, es buscaven sovint alcaids solvents per evitar que en cas de retards en el pagament de la retinença el castell no quedés desprotegit. Tanmateix, en el cas de l'establida d'Oriola el monarca optà per una tercera via per al manteniment del castell: modificar l'ordre de confiscació dels béns dels alzirenys que no havien respost a la convocatòria d'host i dels que havien fugit sense permís, per una ordre de mantenir econòmicament l'establida d'alzirenys (dels alzirenys que havien romàs amb el monarca), que havia deixat per protegir aquest castell ${ }^{28}$. D'aquesta manera, el manteniment del castell d'Oriola, comprès l'abastament de queviures, quedava en mans de la vila d'Alzira.

Un cas relativament similar el representaven els escamots d'almogàvers que es posaren al servei del rei. Tot i que per una carta del rei de 23 de maig de 1296 sabem que pensava donar a deu almugatens 72 roves de farina per les taleques ${ }^{29}$, el fet que aquesta sigui l'única referència trobada a quitacions d'almogàvers en tot el període estudiat de la campanya ens fa creure que l'entrega de taleques de part del rei devia ser extraordinària, i que normalment aquests aconseguien els seus subministraments per altres vies, ja per taleques donades per altres cavallers que el rei, ja sense taleques, la qual cosa els era encara més profitosa, ja que aleshores no havien de donar el setmo a qui els havia donat la taleca ${ }^{30}$.

26 FERRER I MALLOL, M.T., Organització i defensa d'un territori fronterer, pp. 177-179. Podem donar dos exemples d'aquesta obligació per part del monarca. El 27 d'abril de 1296, l'endemà, possiblement de la presa del castell d'Alacant, el rei mana a Jaume de Santacreu que de les vitualles que ha de rebre de Jaume de Guàrdia, procurador del noble Roger de Lloria, enviï 336 roves de farina per a Ramon d'Urtx, nou alcaid de l'esmentat castell (ACA, C, reg. 340, f. 51r, publicat per DEL ESTAL, J.M., Conquista y anexión de las tierras de Alicante, Elche, Orihuela y Guardamar, doc. 11). Deu dies més tard, el 8 de maig, mana a Bernat Ginebret, porter del rei, i a Guillem Arnau, de la casa del rei, que enviïn a Bernat de Pujals, a qui s'ha encomanat el castell de Callosa, les vitualles que s'havien acordat per a l'establida del castell (ACA, C, reg. 340, f. 29r).

27 FERRER I MALLOL, M.T., “La tinença a Costum d'Espanya», pp. 18-27, i Organització i defensa d'un territori fronterer, pp. 177-179.

28 ACA, C, reg. 340, f. 75v-76r (19 de maig de 1296). La confiscació dels béns dels aizirenys fugitius $i$ dels incomplidors del servei d'host havia estat tramesa el 13 de maig (ACA, C, reg. 340, $f$. 61v, cf. a FERRER I MALLOL, M.T., Organització i defensa d'un territori fronterer, p. 202).

29 ACA, C, reg. 340, f. $87 \mathrm{r}$ (publicat per FERRER I MALLOL, M.T., Organització $i$ defensa d'un territori fronterer, p. 337, doc. 5). Coincidim amb Maria Teresa Ferrer que la quitació que apareix al document s'ha d'interpretar com a taleques.

30 Respecte a la normativa de l'entrega del setmo al rei o a aquell qui els ha donat taleca, disposem d'una carta de juny de 1304 en la qual Jaume II demana a Ferrer Des-Cortell, batlle general del regne de Múrcia, que observi el costum i no demani el setmo a uns almogàvers que han rebut taleques de fra Berenguer de Cardona, mestre dels templers a Aragó i Catalunya (FERRER I MALLOL, M.T., Organització i defensa d'un territori fronterer, p. 259 i pp. 369-370, doc. 40). 
Observant conjuntament els tres casos esmentats, l'autoabastament se'ns apareix com una pràctica limitada a alguns àmbits concrets: el desplaçament fins al punt de trobada de l'exèrcit, els escamots d'almogàvers i alguns casos extraordinaris com la conversió de l'empara dels béns dels alzirenys en el manteniment de la host establerta a Oriola... No sembla, doncs, el sistema més emprat.

Des de la perspectiva de la procedència dels queviures, també el control reial $i$, per tant, el predomini de la importació, resulten majoritaris, però tot i així, documentem casos d'abastament sobre la marxa, fins $i$ tot del mateix monarca, de la mateixa manera que l'exemple ja esmentat dels peons torroellencs ens mostra com aquests s'autoabastaren «important» o, més exactament, «portant» els seus queviures de Torroella de Montgrí.

L'endarreriment, tot just abans d'iniciar-se el setge d'Oriola, de l'abastament previst per mar, mentre el monarca és encara a l'horta d'Almoradí ultimant detalls, és sens dubte el que provocà la carta que el 29 d'abril dirigeix als jurats de Guardamar manantlos que recullin tot el blat que trobin entre els veïns i que el lliurin al seu porter Bernat Ginebret ${ }^{31}$.

En aquest cas és evident que el rei busca avituallar-se amb blat de la zona on es troba, però cal situar aquesta requesta dins el context de la fretura amb què vuit dies més tard es trobarà en ple setge d'Oriola. Si tenim present que tres dies després d'enviar la carta esmentada als jurats de Guardamar, n'envia una altra al batlle de Tortosa manant-li que impel 'leixi els mercaders que es van comprometre a subministrar gra, a carregar-lo a la nau de Pere Bussot, qui I'ha de portar cap a Alacant ${ }^{32}$, podem deduir que el que es produí fou un endarreriment de les trameses de blat tal com estaven previstes, o potser simplement l'arribada d'una quantitat menor a la prevista ${ }^{33}$.

De fet, com veurem més endavant, sembla que durant tota la campanya existí un problema d'endarreriment dels queviures, que constantment havien de ser reclamats o se n'havia de demanar l'entrega sense demora, i en aquest sentit, aquesta recollida de blat a Guardamar no seria més que l'intent de solucionar alguna trava en l'abastament exterior tal com devia tenir-lo pensat Jaume II.

Però la recollida de blat a Guardamar no és l'únic cas d'ús de vitualles locals durant la campanya. Bernat de Sarrià havia entregat a Berenguer Morrelles, jurat d'Oriola, 1.700 turonesos d'argent per tal que aquest comprés blat per al rei, blat que havia de

31 ACA,$C$, reg. 340, f. $2 v$ (29 d'abril de 1296). També els fa lliurar el blat que el mateix rei deixà a l'església i els fa saber que tant aquest blat com l'altre els el farà pagar muy bien pel seu conseller Bernat de Sarrià quan aquest arribi a Guardamar.

32 ACA, C, reg. 340, f. $12 \mathrm{v}$ (2 de maig de 1296).

33 Sabem que per aquestes dates alguns vaixells ja havien arribat davant les costes guardamarenques, per l'ordre de desemparança que el monarca envia a Bernat Ginebret dels béns de Francesc de Pròixida que havien arribat a Guardamar amb la nau de Pere Guillem, dels quals en Ginebret s'havia emparat (ACA, C, reg. 340, f. 19r, 3 de maig de 1296). 
ser mòlt per Bernat de Súria, porter del rei. Desconeixem quan fou fet l'encàrrec al jurat oriolà, però sabem que el 20 de maig el rei manava a Bernat de Súria de passar comptes al dit Berenguer Morrelles, qui li havia d'entregar el que tingués, fossin encara els turonesos, fos blat o fos farina ${ }^{34}$. També en aquest cas cal relacionar les presses del monarca per arreglar comptes amb el d'Oriola, amb la carta que tres dies abans el rei havia enviat a Bernat Ginebret a Guardamar manant-li que aconseguís que els mercaders que havien arribat per mar amb vitualles, li les venguessin, pagant el que calgués ${ }^{35}$. Amb tota probabilitat el monarca es tornava a trobar, tot just iniciat el setge d'una ciutat important com Múrcia, amb el fet que el subministrament que havia muntat no acabava de ser prou regular i eficient i per tant havia de recórrer a les autoritats locals per assegurar-se l'aprovisionament.

No són aquests casos els únics que documentem de recurs a la producció local. Estant l'exèrcit a Guardamar, alguns veïns de la vila havien proveït la host de moltó. Concretament coneixem el cas d'Ivanyes Domingo i Guillem Miró, dos veïns de Guardamar que vengueren 37 moltons i mig a l'exèrcit a raó de 6 sous i mig el moltó ${ }^{36}$.

Un darrer exemple ens mostrarà com el monarca comptava o havia de comptar amb la producció agrícola i ramadera local, per exemple, per abastar els seus castells. Cap al final de juny de 1296 rep 100 cafissos del lloc d'Albudeite, prestats a Jaume II pel noble Sanç d'Antillón, per abastar el castell de Mula ${ }^{37}$.

Enfront d'aquests pocs casos documentats, les nombroses referències d'arribades de vianda per via marítima o terrestre de fora del regne de Múrcia ens mostren, tanmateix, que el monarca va comptar amb la producció local més com un complement que no com la base de l'avituallament de la seva tropa. Solament estadísticament, davant dels quatre casos esmentats de compra o recollida d'aliments en viles del regne de Múrcia, la documentació consultada ens ofereix un centenar de referències contemporànies d'importació de vitualles al regne de Múrcia des de tots els regnes de la Corona.

Evidentment, de semblant desproporció documental no es pot deduir necessàriament una desproporció real, però de la seva anàlisi sí que s'observa que Jaume II havia previst o intentat preveure un subministrament de vitualles constant $\mathbf{i}$ equilibrat per mitjà de l'establiment d'una xarxa d'importació i distribució d'aliments.

34 ACA, C, reg. 340, f. 79 .

35 ACA, C, reg. 340, f. $70 \mathrm{v}$ (17 de maig de 1296). Jaume II ha sabut que havien arribat uns quants mercaders al port de Guardamar carregats de vitualles que ell necessita. Com que vol que els mercaders en treguin benefici, mana al seu porter Bernat Ginebret que faci anar al seu campament als dos o tres mercaders que hagin portat més vitualles, per acordar amb ells el preu d'aquestes provisions. Fins $\mathrm{i}$ tot, preveient que els mercaders no gosin venir fins a Monteagudo per la inseguretat del camí, mana que siguin escortats per Galceran de Rosanes, alcaid de Guardamar.

36 ACA, C, cr. Jaume II, caixa 158, núm. 1.351 (30 d'abril de 1296) i ACA, C, cr. Jaume II, caixa 122, núm. 1.460 (30 d'abril de 1296).

37 ACA, C, reg. 340, f. 181r-181v (29 de juny de 1296). El rei mana a Jaume Pere, procurador del regne de Múrcia, que dugui els 100 cafissos de blat que li donarà l'alcaid d'Albudeite fins a Mula i que per fer-ho compti amb la seva companya $i$ amb la de Múrcia, ciutat que, com a mínim, ha d'aportar 100 atzembles i 200 homes de peu (ACA, C, reg. 340, f. 181r, 29 de juny de 1296). 
En aquesta xarxa, o més exactament en les dues xarxes que crearà, una per a l'aprovisionament de carn, l'altra per al de cereals i vi, les provisions s'obtenien principalment de l'exterior.

El recurs a la compra o obtenció fora de la zona en conflicte no ha d'estranyar de cap manera i és de sentit comú: hom no pot refiar-se d'obtenir les vitualles en un territori que està conquerint i que no sap amb exactitud quan tardarà a conquerir. En aquest sentit cal fixar-se que el recurs a productes locals el documentem en moments excepcionals, quan la fretura circumstancial davant les muralles d'Oriola, i en dates tardanes, quan ja la capital i la majoria del regne es troben en mans catalanoaragoneses o en tràmits per a l'entrega.

\section{EL RÈGIM ALIMENTARI ${ }^{38}$}

Fins ara hem parlat de vitualles, aliments, provisió... sense especificar clarament quines eren. Fóra bo ara de concretar, abans d'entrar en l'anàlisi de les xarxes construïdes per Jaume II per tal d'assegurar el proveïment a l'exèrcit, quina era la composició de la dieta dels soldats, és a dir de què calia abastar l'exèrcit.

Philippe Contamine, en estudiar el règim alimentari dels soldats a la França dels segles XIV i XV, diferencia tres tipus d'alimentació: la d'èpoques d'inactivitat militar, la de campanya i la de setge o de flota en combat ${ }^{39}$. En tots tres tipus la base és idèntica, comuna també a l'alimentació «civil»: pa, vi i carn, acompanyada quan es pot per un complement nutritiu de verdures, llegums... Allò que varia entre un règim alimentari $i$ altre és, doncs, la quantitat i la forma en què es menja: el primer tipus és idèntic al dels "civils", mentre que en el segon s'augmenten les racions ${ }^{40}$, i en el tercer se substitueixen els productes frescos per «conserves», és a dir el pa per bescuit i la carn per carn salada o fumada.

Amb vista a un avituallament centralitzat o mínimament controlat, el monarca havia d'assegurar l'arribada dels tres ingredients bàsics: blat, vi i carn. Aquests podien arribar de diverses maneres, especialment el blat, que podia arribar en gra, mòlt o panificat, i la carn, que es podia subministrar bé viva bé salada o fumada. Enfront d'aquests productes "transportables", les verdures i altres complements alimentaris s'aconseguien normalment sobre la marxa, ja fos per la seva ràpida caducitat, ja pel seu ús ocasional.

A totes aquestes vitualles de consum humà, calia afegir una altra vitualla imprescindible: el pinso dels cavalls. La importància de la cavalleria en els exèrcits medievals convertia l'alimentació d'aquestes bèsties en fonamental per a l'èxit de la campanya,

$38 \mathrm{Hem}$ d'agrair en la redacció d'aquest apartat els comentaris del Dr. Antoni Riera Melis, que esperem haver aprofitat convenientment.

39 CONTAMINE, Ph., Guerre, État et Société à la fin du Moyen Âge, pp. 646-654.

40 Es considerava imprescindible a l'edat mitjana que la dieta d'un soldat en campanya augmentés quantitativament i qualitativa per poder fer front al desgast físic del combat. Quantitativament servint racions més generoses, especialment de carn, que esdevenia de consum diari imprescindible, però també qualitativament consumint-se exclusivament pa blanc fet de farina de blat. 
de manera que l'aprovisionament de civada i altres pinsos esdevenia tan important com un bon subministrament de pa, vi i carn.

Tornant a la campanya de Múrcia, la documentació conservada ens permet comprovar que aquesta no s'allunyà dels paràmetres propis d'un conflicte bèl 'lic medieval. Així documentem a bastament els quatre productes bàsics: pa, vi, carn i pinso, i fins i tot disposem d'un document que ens permet d'aproximar-nos a la ració diària dels soldats i de llurs montures.

En canvi, de les verdures $\mathrm{i}$ altres productes complementaris de la dieta, no ens apareixen referències, excepció feta d'un encàrrec reial de xarops, sucre $\mathbf{i}$ altres llaminadures, evidentment de consum restringit a la cort ${ }^{41}$. Aquesta manca de documentació és normal si tenim en compte que pràcticament només se'ns han conservat ordres de pagament reials de ramats de moltons i de grans carregaments de cereals i de vi. Aquests pagaments ascendien a sumes considerables que en la seva majoria el rei feia pagar a la ciutat de València per tal de redimir el seu servei $\mathrm{d}^{\prime}$ host $^{42}$, mentre que els productes no documentats, aconseguits in situ, en quantitats menors i molt més econòmics, generaren despeses menors assumides sobre la marxa.

El blat arribava generalment a l'exèrcit en forma de farina. L'escassa conservació del pa un cop cuit, la senzillesa del procés de cocció del pa i el menor volum de la farina respecte al blat en gra afavorien l'enviament de blat mòlt. El blat provenia principalment dels dos punts d'abastament establerts pel rei, València i Tortosa, però a aquests llocs podia haver arribat d'altres contrades ${ }^{43}$, i a més cal afegir-hi el blat portat per alguns mercaders valencians (de Borriana, de Castelló de la Plana, de Gandia, de Dénia, d'Alzira...) que per pròpia iniciativa s'arribaren a Múrcia a vendre el seu blat i d'altres vitualles ${ }^{44}$.

41 El 5 de maig, en ple setge d'Oriola, el reí mana a Bernat Colomet que fi enviï de València 1 quintar de prunes, $50 \|$ de sucre rosat, $20 \|$ de sucre violat, 2 pans de sucre blanc de $40 \|$ I, $25 \|$ de xarop violat, més 25 II de xarop rosat, 1 quarter a mesura de València de vi de magranes, 30 II de midó recent i 20 II de farric. Com que preveu que el portador no sigui capaç de durnho tot sol, mana al mateix Bernat que li lliuri, si cal, una haveria i tot el que faci falta (ACA, C, reg. 340, f. 21r). La dieta reial i també la dels nobles i oficials més propers al rei havia de ser diferent de la dels soldats, com a mínim en quantitat i qualitat. En aquest sentit, sabem que el rei es va fer portar vi especial, el millor vi que Guillem Colom pogués trobar (ACA, C, reg. 340, f. 112, 30 de maig de 1296) i que gaudia dels serveis d'un coc, Joan de Pulla, al qual el rei mana pagar pels serveis prestats (ACA, C, reg. 340 , $\mathfrak{f}$. $93 \mathrm{v}, 24$ de maig de 1296).

42 Sobre el sistema de finançament de l'avituallament de cereals i vi, vegi's infra "La xarxa ma" rítimo-terrestre d'aprovisionament de cereals i vì.

43 Sobre les concentracions de vitualles a València i Tortosa, vegi's infra «La xarxa marítimoterrestre d'aprovisionament de cereals i vi".

44 El tipus de font emprat, ordres de pagament reials, molt pobre en detalls, no permet conèixer amb certesa la procedència dels productes manats de pagar, que deduïm, potser agosaradament, del veïnatge del venedor i de la moneda de compte emprada, reial per als procedents de València i el País 
Per a l'aprovisionament de les galeres que havia noliejat Jaume II hagué també de comprar bescuit, del qual trobem poques referències, possiblement perquè les galeres havien ja sortit del port de València ben proveïdes ${ }^{45}$. Igualment, i tot i que el rei tendia a comprar el blat mòlt, en algunes ocasions adquirí també pa cuit del qual desconeixem la destinación ${ }^{46}$.

Els altres dos cereals que el monarca adquirí en grans quantitats foren l'ordi i la civada, destinats ambdós a l'alimentació de les montures ${ }^{47}$. Tot i que l'ordi, cereal panificable, formava en temps normal part de la dieta humana, els costums militars ja esmentats demanaven el consum de pa blanc de pur blat, de forma que l'ordi que documentem s'ha d'interpretar com un component més del pinso equí. Els components de la dieta dels cavalls tenien una procedència similar a la de la farina, combinant-se els enviaments des de Tortosa i València, controlats per oficials reials, amb les vingudes de mercaders valencians que veien l'oportunitat d'un guany ràpid $i$ segur ${ }^{48}$.

Valencià, barcelonesa per als procedents de Tortosa. L'extrema esquerperia d'aquesta font permet treure'n poques informacions $\mathrm{i}$ insegures. Una de les més interessants, les quantitats de vitualles comprades pel rei, no és possible calcular-la amb fiabilitat per què en cap ordre de pagament s'indica d'on és la mesura, de València, de Barcelona o d'altre lloc. Tot i així, basant-nos en l'homogeneïtat dels preus per unitat, que fan pensar en pesos molt similars, si no idèntics, i prenent els resultats com merament aproximatius, hem sumat pesos i preus de les ordres de pagament de farina -aquestes advertències serveixen per a tots els futurs esments a aquest tipus documental- De les 15 ordres de pagament de farina documentades s'en pot extreure que els mercaders l'enviaven en carregaments que oscil laven entre les 11 i les 357 roves, amb una raó per rova fluctuant entre els 32 i els $44 \mathrm{~d}$. En total es documenta la compra de 1.515 roves i 15 cafissos amb un preu global de 263 il $17 \mathrm{~s} 9 \mathrm{~d}$ (ACA, C, reg. 340, f. 30v (8 de maig de 1296), 38v (11 i 12 de maig), 39r (11 de maig), 85r (23 de maig), 103r (23 de maig) i $111 \mathrm{v}$ (28 de maig)).

45 Jaume II havia fet noliejar a Bernat de Sarrià deu galeres que havien d'oferir les ciutats marítimes de la Corona. D'aquestes, des del punt de vista de l'avituallament, no en tenim notícies. Solament sabem que el 10 de juny de 1296 el rei manà pagar 58 II $7 \mathrm{~s} 1$ d malla de moneda barcelonesa per 76 quintars 3 roves 22 II de bescuit a raó de $45 \mathrm{~d}$ malla la rova, és a dir per $58 \| 7 \mathrm{~s} 1 \mathrm{~d}$ i malla (ACA, C, reg. 340 , f. $125 \mathrm{v}-126 \mathrm{r})$.

46 Documentem solament tres pagaments de pa i pa cuit per valor de $73 \| 10 \mathrm{~s} 10 \mathrm{~d}$, sense que s'indiqui la quantitat de pa venut (ACA, C, reg. 340, f. 39r i 39v (13 de maig de 1296) i 85r (22 de maig).

47 CONTAMINE, Ph., diferencia la dieta equina d'època de pau, basada en la civada i el fenc, de la de campanya, fonamentada en el consum de civada i ordi (Guerre, État et Société à la fin du Moyen Âge, p. 646).

48 Les ordres de pagament d'ordi conservades són 19, amb quantitats d'ordi que oscil 'ien entre els 4 cafissos 1 faneca $i$ els 157 cafissos 4 faneques, que sumen un total de 832 cafissos 4 faneques 1 barcella, a una raó entre els 148 i els 171 d per cafís, és a dir 559 \|I 14 s 3 d pugesa (ACA, C, reg. 340, f. $14 \mathrm{r}-14 \mathrm{v}$ (4 de maig de 1296), 30v (8 de maig), 31v-32r (10 de maig), 39r (11 i 14 de maig), 39v (13, 16, 18 i 19 de maig), 85r (23 de maig), 103r (23 de maig) i 126r (10 i 22 de juny). De civada, en canvi, solament en conservem vuit ordres de pagament, per quantitats que es mouen entre 1 i 57 cafissos, amb un preu per cafís d'entre 159 i $171 \mathrm{~d}$, que suposen una despesa total de 152 II $17 \mathrm{~s} 7 \mathrm{~d}$ malla per 222 cafissos 3 barcelles (ACA, C, reg. 340, f. $14 \mathrm{r}$ (6 de maig de 1296), 30v (8 de maig), 38v (11 i 12 de maig), $39 \mathrm{v}$ (18 de maig) i 103r (23 de maig). El fet que cap mercader no vengui al mateix temps civada i ordi i que les raons d'ambdós productes es moguin dins d'idèntics marges, ens fa pensar si els termes ordi i civada no s'empraren per indicar "pinso» de les cavalleries, potser una barreja d'ambdós productes. 
Tan important com la civada i l'ordi per als cavalls i el blat per als homes era el vi que durant tota la campanya arribà en grans quantitats a terres murcianes. El vi reunia una sèrie de qualitats que el feien fins i tot més imprescindible, ja que pel seu contingut alcohòlic era més higiènic que l'aigua i fins i tot podia funcionar com a antisèptic, alhora que suposava un complement energètic molt important davant la duresa d'una jornada guerrera ${ }^{49}$. Com els anteriors productes, la procedència del vi fou preferentment valenciana i tortosina, tot i que a aquestes ciutats podia haver-hi arribat d'altres punts ${ }^{50}$.

El consum de carn, important sens dubte, es reflecteix poc en la documentació. De carn salada, que indubtablement es consumí, com a mínim a les galeres, fins i tot no en tenim cap referència. De carn fresca, en canvi, en coneixem alguna cosa més.

El principal problema de la carn era el seu transport. Si la carn havia de ser duta a l'exèrcit des de les seves regions d'origen, els moltons eren els més aptes, molt més resistents que braus, vaques o vedells. El bestiar bovi, si se'n volia prendre, s'havia d'aconseguir bé allà mateix on s'estava l'exèrcit, bé a les regions limítrofes valencianes o murcianes ${ }^{51}$.

També d'origen local podien ser els xais, però la majoria venien de lluny, especialment de les terres meridionals d'Aragó i de les interiors del País Valencià, d'on arribaven en grossos ramats d'entre 500 i 2.000 caps $^{52}$.

\section{LA RACIÓ DIÀRIA, UNA APROXIMACIÓ}

Conservem dos manaments reials de repartir racions per a 10 dies entre les tropes, però cap d'ells precisa la composició d'aquesta raciós ${ }^{33}$. Sí que ho fa, tanmateix, un manament dirigit solament a la companya d'un noble anònim: el 28 de juny de 1296 el

49 GALOPPINI, L., “Vino dalla Sardegna per una campagna militare (Granada 1329)», pp. 59-60.

50 Les compres de vi documentades són 26 . Oscil'len entre els 20 i els 2.000 quarters per compra a un preu que es mou entre els 20 i els 26 d per quarter. En conjunt suposen la compra d'11.408'75 quarters de vi per un preu de 990 II 7 s 8 d malla (ACA, C, reg. 340, f. 11r-11v (2 de maig de 1296), $14 \mathrm{r}$ (4 i 6 de maig), 14v (4 i 5 de maig), 30v (8 de maig), 38v (11 i 12 de maig), 39r (14 de maig), 39v $(13,15,16,18$ i 19 de maig), 103r (23 de maig), 126r (10 i 13 de juny).

51 D'Alzira devien provenir les 75 vaques que es compraren a Bernat Roig i Jaume [Cals], veí d'Alzira, lliurades a Ponç de Mataró, majordom del rei, per dos homes de nom il'legible (ACA, $C$, reg. 340 , f. $187 \mathrm{v}, 10$ de juny de 1296, en molt mal estat). I de Gandia les vaques custodiades fins a l'exèrcit per Gonçalvo de Logronyo, que havia de cobrar el servei prestat del que el justícia de Gandia devia al rei per la quarta de la justícia endarrerida (ACA, C, reg. 104, f. 109r, 27 de setembre de 1296).

52 Sobre el subministrament de carn de moltó, vegi's infra “El projecte de Jaume Il: les xarxes d'aprovisionament».

53 ACA, C, reg. 340, f. 74r (19 de maig de 1296, Múrcia) i ACA, C, reg. 340, f. 91v (23 de maig de 1296, Múrcia). Que solament s'hagin conservat aquestes dues cartes per les quals el rei mana a Bernat Ginebret de repartir ració per deu dies entre tots els seus homes, s'explica simplement pel fet que els repartiments anteriors devien fer-se estant Bernat Ginebret i el rei al mateix lloc, per la qual cosa la carta esdevenia innecessària. Més interessant de constatar és que entre els dos manaments no hi ha deu dies de diferència, sinó menys. Que potser la ració es va fer curta o és que no arribà a tothom? 
rei mana als batlles d'Oriola, Pere Rossell i Guillem Paratge ${ }^{54}$, que lliurin a un noble, el nom del qual no es pot llegir, 140 roves, a pes de València, de farina, 168 quarters de vi i 70 cafissos valencians de civada, que han de servir a l'esmentat noble per donar de ració de 10 dies als 28 cavalls armats que aquest ha enviat ${ }^{55}$.

Els càlculs són fàcils: el rei mana que s'entreguin a cada cavall armat 5 roves de farina, 6 quarters de vi i 2 cafissos i mig de civada per als deu dies, és a dir, mitja rova de farina, 0,6 quarters de vi i un quart de cafís de civada per cavall armat i dia, que traduït al sistema mètric suposen $5,325 \mathrm{~kg}$ de farina, 6,462 I de vi i 50,25 । o $37,69 \mathrm{~kg}$ de civada per cavall i per dia. Tanmateix, cal tenir present que aquestes quantitats es refereixen a un cavall armat, que es componia de 5 homes, un cavaller i quatre peons $\mathrm{s}^{56}$, per la qual cosa hem de dividir de nou aquestes xifres, de forma que obtenim una ració diària per home d'1,065 kg de farina ${ }^{57}$ i d'1,35 I de $v^{58}{ }^{58}$, i per cavall, de 50,25 I o 37,69 kg de civada ${ }^{59}$.

54 Sabem que aquests són batlles per una carta de 14 de maig de 1296 per la qual Jaume II els mana que prenguin possessió del seu càrrec i exigeixin les rendes del lloc, a més de recollir tot el blat que trobin als termes d'Oriola i Guardamar i de reservar-l'hi (ACA, C, reg. 340, f. 64v).

$55 \mathrm{ACA}, \mathrm{C}$, reg. $340, \mathrm{f} .174 \mathrm{v}$ (en força mal estat, fins i tot amb fragments il'legibles).

56 SÁNCHEZ MARTÍNEZ, M., «Guerra, avituallamiento del ejército y carestías en la Corona de Aragón", p. 527, nota 13.

57 Per a l'equivalència en grams utilitzem la rova de farina de València segons ALSINA, Cl., i altres (ALSINA, Cl.; FELIU, G. i MARQUET, LI., Pesos, mides i mesures dels Països Catalans, Curial, Barcelona, 1990, pp. 227-228 «Rova»). Si prenem, segons els mateixos autors, la rova valenciana de pes gros, la ració per dia i per cavall armat augmenta a $6,39 \mathrm{~kg}$, i la ració per home i dia a 1,278 kg.

58 Enlloc hem trobat referències directes a l'equivalència actual del quarter de vi valencià. GALOPPINI, L. («Vino dalla Sardegna per una campagna militare (Granada 1329)», p. 59), basant-se en els treballs de MANCA, C., (Aspetti dell'espansione economica catalano-aragonese nel Mediterraneo. // commercio internazionale del sale, Milà, 196, pp. 334-35, i /l libro dei conti di Miquel ça Rovira, Pàdua, 1969 , p. 59) dóna una equivalència de 4'5 I per quarter, sense indicar si és el quarter de València o el de Barcelona. De ser el de València, per cavall armat i dia tocarien 2'7 I i per home i dia 0'54 I, mentre que de ser el de Barcelona, resultarien respectivament 6'75 I i 1'35 I, segons la relació existent entre els quarters valencià i barceloní ( 6 quarters de València = 15 quarters de Barcelona), esmentada per GALOPPINI, L., (p. 68). Seguint aquesta equivalència i la capacitat atribuïda al quarter de Barcelona (3'8 I) per ALSINA, Cl. i altres (Pesos, mides i mesures dels Paisos Catalans, pp. 208-209 «Quarter»), obtenim una ració per cavall de 5'7 | per dia i per home de 1'14 I per dia. Finalment, combinant una cita dels Furs valencians (Furs e ordinations fetes per los gloriosos reys de arago als regnicols del regne de valencia, estampats per En Lambert Palmart, València, 1482) al Diccionari català-valencià-balear (ALCOVER, A.M. i MOLL, F. de B., Diccionari català-valenci-balear, Barcelona, 1969, v. 9, p. 24 «Quarter»), que esmenta que 1 quarter de vi (valencià) té 30 II (quarter de vi contingue trenta liures), i l'equivalència donada al càntir valencià, conegut també per rova de 30 II ( 1 càntir $=10^{\prime} 77 \mathrm{I}$ ) (ALSINA, Cl. i altres, Pesos, mides i mesures dels Països Catalans, pp. 133-134 "Càntir»), obtenim un quarter valencià de $10^{\prime} 77$ I que implica una ració per cavall armat i dia de 6'462 l i per home i dia de 1'2924 l. Ens inclinem per aquesta, però excepte la primera xifra, excessivament baixa, totes les altres podrien ésser vàlides i situen el consum diari per cavall armat al voltant dels 6 I i per home al voltant d'un litre i quart.

59 No dividim el pes per cinc perquè suposem que en un cavall armat solament hi ha un cavall. Per a la reducció de cafissos valencians a litres (1 cafís $=201 \mathrm{I}$ ) usem el treball de ALSINA, Cl. i altres, Pesos, mides i mesures dels Països Catalans, pp. 127-128 "Cafís". Per a l'equivalència entre litres $\mathrm{i}$

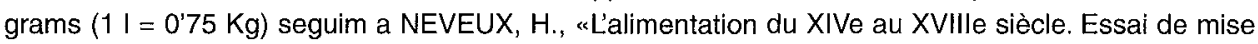
au point», a Revue d'Histoire économique et sociale, v. LI, 1973, p. 372. 
Tot $i$ coincidir els resultats per al vi i la farina amb els pocs càlculs realitzats fins ara de composició quantitativa de la dieta dels soldats ${ }^{60}$, aquestes xifres s'han de prendre com a orientatives, principalment perquè les cinc persones que formaven un cavall armat no hi participaven en condició d'igualtat, sinó que un d'ells, el cavaller, estava socialment per sobre dels altres quatre, els peons, diferència social que s'havia d'apreciar igualment en l'alimentació $i$ en les racions.

Les precaucions que cal tenir amb aquests càlculs, ens les il lustra la ració diària de civada, evidentment desorbitada per a una sola bèstia ${ }^{61}$. És que potser hem d'interpretar que els peons disposaven d'atzembles per traslladar-se que també calia alimentar, o potser el cavaller es desplaçava amb dos cavalls ${ }^{62}$ ?

A més de l'esmentat, dos factors més ens fan ser previnguts sobre la valoració a

60 Les xifres obtingudes concorden força amb les d'altres autors. Segons les Ordinacions de Pere el Cerimoniós (BOFARULL, P. de, CoDoln ACA, Barcelona, v. V, 1850, pp. 171-172), un cafís valencià de gra seria suficient per a un home, és a dir $1,256 \mathrm{~kg}$ de blat, quantitat idèntica a la prevista per a la campanya de Sardenya (ACA, C, Varia, reg. 416, i ARRIBAS PALAU, A., La conquista de Cerdeña por Jaime // de Aragón, p. 160 i p. 379, ap. XIX). SÁNCHEZ MARTÍNEZ, M., obté una ració un xic inferior en el projecte de campanya contra Granada, $1,155 \mathrm{~kg}$ diaris per persona ("Guerra, avituallamiento del ejército y carestías en la Corona de Aragón", p. 527). Semblants són les xifres obtingudes per PRESTWICH, M., ("Victualling estimates for English garrisons in Scotland during the early fourteenth century", a English Historical Review, n. LXXXII, 1967, pp. 536-543): per a una guarnició a Berwick el $1300,1,244 \mathrm{~kg}$ de gra. Evidentment es tracta de gra i no de farina, però les xifres s'acosten força. Tampoc la ració obtinguda per CONTAMINE, Ph., per a un exèrcit en campanya d'entre 48.000 i 50.000 homes, del final del segle $X V, 1,27 \mathrm{~kg}$ de pa, quantitat similar tot $i$ tenint present la diferència entre donar la ració en pa o en farina. L'únic exemple de CONTAMINE, Ph., valorat en farina, per a una guarnició provençal del primer quart del segle XIV, també s'acosta a les nostres xifres: $1 \mathrm{~kg}$ de farina (Guerre, État et Société à la fin du Moyen Âge, pp. 651-653). Per al vi són menys les racions calculades. Les racions estudiades per CONTAMINE, Ph., (pp. 651-653) oscil'len entre 0,44 I diaris en situació de setge i 203 I per a l'esmentada guarnició provençal, i documenta 2 I diaris per a un soldat en campanya. Dividint el total encarregat per a 4 mesos per a la campanya fallida contra Granada segons GALOPPINI, L., $13.500 \mathrm{HI}$ (p. 59), per als 6.500 homes que SÁNCHEZ MARTÍNEZ, M., creu que formarien l'exèrcit (p. 527), s'obté una ració diària d'1,73l. Els marges entre els quals es mouen tots aquests càlculs inclouen, doncs, la ració que documentem per a Múrcia.

61 Per a la campanya de Sardenya de l'infant Alfons s'havia previst una ració diària de civada de 13,4 I o 10,05 kg (ACA, C, Varia, reg. 416, i ARRIBAS PALAU, A., La conquista de Cerdeña por Jaime /l de Aragón, p. 160 i p. 379, ap. XIX), similar a la fixada a les Ordinacions de Pere el Cerimoniós (BOFARULL, P. de, CoDoln ACA, Barcelona, v. V, 1850, pp. 171-172) de 12,56 l o 9,421 kg. CONTAMINE, Ph., (Guerre, État et Société à la fin du Moyen Âge, p. 646) documenta racions de $10107,5 \mathrm{~kg}$ per a mitjan segle XIV i per al final del segle XV a França, i de $181013,5 \mathrm{~kg}$ per a Escòcia pels voltants del 1300. També una xifra alta és documentada per GAIER, Cl., («L'approvisionnement et le régime alimentaire des troupes dans le Duché de Limbourg et les terres d'Outre-Meuse vers 1400", a Le Moyen Age, 1968, pp. 557-558) per a Limburg: 16,6 I o 12,5 kg. Però tot i ser més altes que les documentades per a la Corona d'Aragó, són molt inferiors als 50,25 l o $37,69 \mathrm{~kg}$ que documentem per a Múrcia.

62 La hipòtesi de dos cavalls per cavaller armat podria explicar perquè la civada prevista per a la campanya de Granada de 1329 serveix, segons els càlculs de SÁNCHEZ MARTÍNEZ, M., («Guerra, avituallamiento del ejército y carestías en la Corona de Aragón", p. 528), per a 3.250 montures, el doble del nombre de cavallers previstos: 1.000 cavalls armats i 500 cavallers de la genetia. 
donar a aquesta ració. En primer lloc no sabem amb exactitud si aquesta ració fou donada per a uns homes que estaven en campanya o si era per a una guarnició, tot i que el document deixa entreveure que es tracta de soldats en campanya. Segons un o altre cas, la ració seria evidentment diferent.

En segon lloc, cal fer constar que en aquesta ració manca un aliment sempre present en les dietes de la tropa: la carn, a més de possibles acompanyaments vegetals.

La distribució de la carn, com es veurà, per un sistema diferent a la dels cereals i el vi explica que aquella no aparegui, però alhora desvirtua la ració en eliminar-ne el component essencial.

\section{EL PROJECTE DE JAUME II: LES XARXES D'APROVISIONAMENT}

Ens hem referit repetidament al llarg de la comunicació a xarxes d'aprovisionament controlades pel monarca i encarregades de subministrar amb assiduïtat a l'exèrcit els productes bàsics de la seva dieta, i tanmateix en cap dels documents fins ara esmentats ni en els que citarem trobaríem una sola referència a una xarxa d'aprovisionament pensada, muntada i gestionada com a tal. En què es basa, doncs, la nostra insistència en la seva existència?

Primerament, podem parlar d'una demostració indirecta des del moment que per a la majoria de les campanyes dels monarques catalanoaragonesos de la primera meitat del s. XIV s'han documentat pressupostos i previsions per a la realització de campanyes ofensives ${ }^{63}$. Pressupostos i previsions permeten parlar d'una planificació de l'aprovisionament en el sentit que aquest darrer s'intenta d'assegurar mitjançant la disposició dels elements necessaris: s'estableixen unes quantitats a comprar, uns oficials o particulars per comprar-les, uns punts de concentració de les compres, uns altres oficials o particulars rebedors de les compres i, si s'escau, manipuladors, per exemple molent el gra o panificant la farina; encara uns altres oficials o particulars encarregats del transport per mar o per terra d'aquests queviures fins a la zona del conflicte, uns ports o ciutats on ser rebuts aquests queviures, uns responsables de la rebuda, centralització i distribució posterior ${ }^{34}$... Tot plegat crea un entramat de persones, vitualles i mitjans de transport que podem anomenar «xarxa d'aprovisionament».

Però que per a les primeres campanyes tres-centistes catalanoaragoneses existeixi

63 Vegi's GALOPPINI, L., "Vino dalla Sardegna per una campagna militare (Granada 1329)»; SÁNCHEZ MARTÍNEZ, M., "Guerra, avituallamiento del ejército y carestías en la Corona de Aragón»; CIFUENTES I COMAMALA, LI., Medicina i guerra a l'Europa baix-medieval, pp. 42-48, 146-151, 288309 i 382-409, i ARRIBAS PALAU, A., La conquista de Cerdeña por Jaime /l de Aragón, pp. 178-179 i $377-379$.

64 La irrealitzada i repetidament citada campanya granadina d'Alfons el Benigne ens mostra clarament l'existència d'aquestes xarxes encara que solament sigui en la seva fase preparatòria; a més de fixar les quantitats a comprar de cada vianda, dissenya, en paraules de SÁNCHEZ MARTÍNEZ, M., un «somero marco administrativo": compradors de blat i de civada, rebedors del blat, encarregats de moldre'l, de fer-ne farina, de fer-ne bescuits, noliejadors de les galeres per dur la civada i el bescuit... («Guerra, avituallamiento del ejército y carestías en la Corona de Aragón», p. 527). 
aquesta logística, no és un argument suficient que demostri que per a la campanya de Múrcia també hagués necessàriament d'existir. Cal, doncs, donada la manca (o el desconeixement) de documents equiparables al pressupost per a la campanya granadina de 1329, buscar altres indicis, potser menys clars i directes, d'aquestes xarxes, indicis que creiem haver trobat en el buidatge de les lletres emeses per la cort catalanoaragonesa durant els dos mesos estudiats de la campanya murciana. Indicis, que trobem, creiem, perquè justament la xarxa no fou suficientment efectiva i els plans establerts no es compliren amb prou exactitud. De fet, d'haver-se complert, possiblement no disposaríem de la documentació que tenim, ja que aquesta es generà en gran part per esmenar les irregularitats sobre els plans establerts; és a dir, per posar un exemple, si sabem que Pere Bussot finalment envià la seva nau carregada de farina a Guardamar, és perquè calgué modificar l'ordre inicial, que preveia l'enviament a Alacant, a causa de l'endarreriment en la mòlta del gra $i$ en el carregament de la farina.

De la documentació, se'n dedueixen dues xarxes independents, una de terrestre especialitzada en el subministrament de carn de moltó, $i$ una de maritimoterrestre dedicada bàsicament a l'abastament de cereals i vi.

La primera d'aquestes xarxes és la que ens ha deixat un volum menor de documentació i per tant és la que desconeixem més. A grans trets, la xarxa unia el camp de batalla amb dues de les principals regions ramaderes ovines dels dominis de Jaume II, l'Aragó meridional i l'interior del País Valencià, generalment passant abans per la ciutat de València. Una vegada arribats al seu destí, les bèsties s'entregaven a un carnisser que les sacrificava i en repartia les racions entre la tropa. L'organigrama de la xarxa es concloïa amb un sistema de finançament de les arribades de moltons basat en les composicions entre les universitats de les zones d'origen i el monarca, de forma que aquest darrer solament havia de fer front a algunes despeses secundàries de la vinguda del bestiar, portat normalment per les mateixes aldees que el subministraven, i a les despeses originades per la repartició entre la tropa.

Els xais que Jaume II sol 'licità de les regions esmentades foren, com a mínim, 4.000: 2.000 de les aldees de Daroca i Terol, 1.500 de les de Calataiud i 500 dels homes d'Alpont. Tot $i$ tenir l'inici de la campanya de Múrcia previst per a la primeria de març, no va ser fins al començament d'abril que el rei va arribar a una composició amb les aldees de Daroca i Terol per tal que aquestes li enviessin els 2.000 moltons esmentats ${ }^{65} i$ altrament devia

65 El rei mana als homes de Daroca (i els de Terol) que entreguin a Garci Garcés de Arazuri, justícia de Daroca, els 2.000 moltons que ell i el missatger de les aldees han acordat que aquestes entreguin. El justícia durà el bestiar a València i el rei mana que no se l'entretingui, ja que amb ell ha de donar ració als cavallers i peons que està congregant a València (ACA, C, reg. 340, f. 15r, 13 d'abril de 1296). El mateix dia el rei féu un salconduit per als que portessin el bestiar de Daroca i Terol fins a València (ACA, C, reg. 340, f. 15v). Els de Daroca i Terol, de fet, havien d'aportar blat i moltons a l'exèrcit, però en aquesta ocasió havien remès el blat per moltons, que el rei necessitava més (ACA, C, reg. 340, f. $18 \mathrm{v}, 15$ d'abril de 1296). 
fer amb Calataiud ${ }^{66}$, amb Alpont ${ }^{67}$ i possiblement amb altres universitats, de les quals no tenim notícia. Tanmateix, malgrat els acords, els de Daroca no feien arribar el bestiar a Garci Garcés de Arazuri, justícia de Daroca, qui els havia de dur a València, on s'estava reunint la host, i el monarca va haver-lo de reclamar. Tot i la reclamació, els moltons no arribaren a temps, és a dir, abans de començar la campanya ${ }^{68}$.

Cap al final del mes de maig, des de Múrcia, el rei ha d'enviar a València el seu porter Miquel de Novals, amb l'encàrrec de prendre els moltons d'Aragó (Daroca i Terol), quan aquests arribin ${ }^{69}$. Tots els indicis apunten que aquests encara tardaren a arribar a València fins a mitjan mes de juny, ja que és aleshores quan el monarca envia un seguit de cartes fixant la ruta que el bestiar ha de seguir des de València fins a Elx: Xàtiva, Cocentaina, Xixona, Alacant ${ }^{70}$.

Semblant retardament el va sofrir també la tramesa de 1.500 moltons des de les aldees de Calataiud. Els xais no comencen a dirigir-se cap a l'exèrcit fins el 10 de juny, quan el rei encarrega a Pero Sanches, justícia de Calataiud, que prengui els moltons que la universitat li dona $i$ que els transmeti ràpidament que a la host fan falta vitualles ${ }^{71}$.

No fou tan greu amb Alpont, amb qui s'arribà a l'acord el 6 de maig, una quinzena després d'haver començat la campanya ${ }^{72}$.

Si aquests dos enviaments s'endarreriren tant, com va poder Jaume II alimentar amb moltó la seva host entre abril i juny? Dues respostes existeixen, cadascuna complementària amb l'altra. La primera, que desconeixem si Calataiud, per exemple, no havia ja enviat algun altre ramat a l'exèrcit. La segona, que Jaume II va poder, va haver d'acudir a altres subministradors locals, murcians i sud-valencians, possiblement no previstos, que, com a mínim, li varen vendre 1.237 moltons i mig abans del 25 de maig ${ }^{73}$, és a dir, abans que arribés el gros de les cabanyes aragonesos esmentades.

66 El 10 de juny, ben avançada la campanya, el rei manava al justícia de Calataiud, Pero Sanches, que li enviés urgentment els 1.500 moltons que la universitat de Calataiud li havia donat $(A C A, C$, reg. 340, f. 128r). Desconeixem si existí una altra donació anterior, però si aquesta era la primera, el retard era important.

67 El 6 de maig el rei dóna per pagats, descomptant-los de la qüèstia o de qualsevol subsidi que gravi la vila, els 500 moltons que els homes d'Alpont li han venut i que els hi durà l'alpontí Gil Abat (ACA,$C$, reg. 340 , f. 19v). No és pròpiament una composició, però tampoc una compra «normal» com les que el rei haurà de fer a Múrcia (vegi's infra).

$68 \mathrm{Ni}$ els de Calataiud (vegi's supra), ni els d'Alpont (vegi's supra), ni els de Daroca arribaren a temps. Aquests darrers eren encara esperats el 24 de maig, quan el rei mana que es faciliti a Miquel de Novals, porter del rei, el transport per tal que pugui dur els moltons, que han de venir d'Aragó, de València a l'exèrcit (ACA, C, reg. 340, f. 101v).

69 ACA, C, reg. 340, f. 101v (24 de maig de 1296).

70 Jaume II mana a cada una d'aquestes viles que enviï a Miquel de Novals una familia per guiar el bestiar fins a la següent vila (ACA, C, reg. 340, f. 139v, 14 de juny de 1296).

$71 \mathrm{ACA}, \mathrm{C}$, reg. 340, f. 128r. Desconeixem tanmateix si existí algun lliurament anterior.

72 ACA, C, reg. 340 , f. $19 \mathrm{v}$ (6 de maig de 1296).

73 La compra de moltó més important documentada és la realitzada a Nadal Ros i lvanyes Garcia: 1.000 moltons per $7.500 \mathrm{~s}$ barcelonesos, és a dir a $7 \mathrm{~s}$ malla per moltó, compra comparable pel volum als ramats que s'esperaven d'Aragó (ACA, C, reg. 340, f. 66r, 16 de maig de 1296). Creiem que aquest 
A diferència dels moltons subministrats per les universitats aragoneses, aquest darrer bestiar fou venut a un preu que oscil là entre els $6,5 \mathrm{i}$ els 8 diners per moltó i que suposà una despesa global de $460 \| 3 \mathrm{~s} 9 \mathrm{~d}$, que seria el mínim dispendi realitzat per Jaume II per complementar les retardades vingudes de bestiar aragonès.

Vinguessin d'on vinguessin els xais, sabem que Jaume II disposava, a mitjan mes de maig, de moltons, ja que envia a Pero Çapata de Tous, Eiximèn Peres d'Andilla i Gonçalvo Eiximenis a Alacant amb les seves families per prendre-hi el bestiar que el rei hi té i dur-lo a Oriola ${ }^{74}$. No és l'única referència conservada de transport intern de bestiar. El 22 de maig Arnau Bonet, d'Oriola, rep un salconduit perquè du bestiar a Múrcia, on es troba el rei amb l'exèrcit.

Resumint, les poques notícies conservades sembla que mostren com el rei va preveure un sistema de proveïment de carn de moltó a base de l'enviament des de zones productores d'ovins de quantitats de moltons obtingudes per composició amb les autoritats locals. El sistema, tanmateix, no acabà de funcionar per retards en l'entrega del bestiar i va caldre complementar-lo amb compres a comerciants, assumides, majoritàriament, per la Corona.

Independentment de la procedència darrera dels moltons, el rei va establir una persona encarregada de rebre els moltons vius, de matar-los i de distribuir-ne la carn entre els soldats. Aquesta persona era a l'inici del mes de juny el carnisser de València Borraç d'Olesa ${ }^{75}$, substituït a mitjan mes per Antic d'Olesa ${ }^{76}$. Com trobarem en la distribució de pa, vi i pinso per als cavalls, la xarxa de proveïment confluïa en darrer terme en una única persona (i el seu equip, familia o companya), que era l'encarregada de fer les racions i de repartir-les a la tropa, centralitzant d'aquesta manera el proveïment i la distribució posterior.

Malauradament, i a diferència del que ocorre amb el restant avituallament, no tenim prou dades per arribar a conèixer quina era la ració base, ni si la carn fou suficient per

bestiar s'aconseguí, tot i ésser pagat amb moneda barcelonesa, de Múrcia o fins i tot de Castella, on Ivanyes Garcia mercadejava amb autorització reial (ACA, C, reg. 340, f. 159v, 23 de juny de 1296: que pueda mercar e estar en jurisdicción nuestra con mercaduras e cosas suyas e entrar en Castiella $\theta$ d'allí tornar con mercaduras e cosas suyas). Més petites són les compres a Ivanyes Domingo i Guillem Miró, veïns de Guardamar, de 37 moltons i mig a raó de 6 s malla el moltó (243 s 9 d) (ACA, C, cr. Jaume II, caixa 158, núm. 1.351, 30 d'abril de 1296); a Pere de Torrents i Miquel Messeguer, veïns d'Alzira, de 140 xais a raó de $7 \mathrm{~s}$ reials unitat (980 s) (ACA, C, reg. 340, f. 26v, 7 de maig de 1296), i a Berenguer Amigó de 60 xais a raó de $8 \mathrm{~s}$ de Barcelona cadascun (480 s) (ACA, C, reg. 340, f. 96v, 25 de maig de 1296). Existeix la possibilitat que aquests dos darrers duguessin els seus xais per mar, en lloc de per terra, si ens atenem al fet que se'ls pagà amb l'import de la redempció de la host de la ciutat de València, com tots els cereals i el vi que venien per mar (vegi's infra "La xarxa marítimoterrestre d'aprovisionament de cereals i vi»), però no sembla massa probable que fos així.

74 ACA, C, reg. 340, f. 45r ([12] de maig de 1296).

75 ACA, C, reg. 340, f. $115 \mathrm{v}$ (1 de juny de 1296). El rei mana a Miquel de Novals que entregui els xais a aquest carnisser.

76 ACA, C, reg. 340, f. 140r (13 de juny de 1296). Jaume II mana a Miquel de Novals que entregui els moltons al carnisser Antic d'Olesa. Potser Borraç i Antic són la mateixa persona? 
a tota la tropa i per a tots els dies, ni molts d'altres detalls més enllà de l'arribada dels moltons vius a terres murcianes i de l'entrega al carnisser repartidor ${ }^{77}$.

\section{LA XARXA MARITIMOTERRESTRE D'APROVISIONAMENT DE CEREALS I VI}

L'aprovisionament de cereals i de vi es va preveure per unes altres vies que el de moltons, amb una infraestructura més elaborada i amb un finançament específic, però amb un funcionament deficient comparable.

També com en el cas dels moltons, els cereals i el vi s'anaren a buscar fora del regne de Múrcia. S'assenyalaren dos punts de recollida i concentració de queviures, dos ports importants: Tortosa, on es concentraren els productes procedents del Principat i de la vall de l'Ebre, i València, abastada possiblement per la producció del regne. D'aquestes localitats, les vitualles havien d'arribar, fos per via marítima o terrestre, fins a, en un primer moment, Alacant, un dels ports murcians més importants, i, posteriorment, a Guardamar, convertida en centre de l'aprovisionament cerealístic i vínic, i on s'estava el porter reial Bernat Ginebret, recollidor i repartidor d'aquest tipus de queviures. Des d'aquesta localitat pa, vi i pinso es feren arribar allà on fou l'exèrcit, ara per mar, ara per terra, segons fos més ràpid o més convenient. Per acabar de tancar aquesta xarxa, quasi totes les despeses ocasionades es feren assumir a la ciutat de València, que havia establert amb Jaume II un acord per redimir el seu servei d'host per l'elevada suma pecuniària de 90.000 sous reials.

Aquesta seria, a grans trets, la segona xarxa que Jaume ll construí per tal d'assegurarse el subministrament i que, com l'anterior, tampoc no acabà de funcionar perfectament: el subministrament no fou suficientment regular, es va haver de canviar Alacant per Guardamar com a centre d'operacions, la tropa va arribar a passar fretura de vianda... Observem amb detall aquesta xarxa amb els seus defectes i les seves virtuts.

Les raons de l'elecció de Tortosa com a punt de concentració de queviures semblen clares: és el port en el qual es creuen les rutes marítimes del Principat amb la de la vall de l'Ebre. En aquest port s'havia delegat a Pere Bussot l'encàrrec d'aconseguir blat, farina i potser altres vitualles, de carregar-ho tot a la seva nau i de dur-ho a Alacant. També s'havia delegat en ell la prerrogativa de pactar amb els mercaders subministradors el preu del blat venut al monarca. Tanmateix en aquesta tasca, potser per imperícia, potser perquè la seva missió coincidí amb una mala collita, potser perquè els mercaders no es fiaven que el rei pagués realment el preu acordat, va caldre que Jaume II demanés al batlle de Tortosa que aquest ajudés a en Bussot a aconseguir i carregar el blat ${ }^{78}$. Tampoc no fou suficient l'ajut del batlle, i finalment Jaume II va haver

77 Que el rei mani a Pero Çapata de Tous, Eiximèn Peres d'Andilla i Gonçalvo Eiximenis que li duguin d'Alacant a Oriola bestiar, i a Arnald Bonet que el dugui d'Oriola (possiblement) a Múrcia, ens fa creure si no existirien com amb els cereals i el vi, "punts" de recollida de bestiar, que en un primer moment seria Alacant i que una volta conquerida Oriola ho seria aquesta vila, i potser encara després Múrcia, i finalment l'assetjada Elx, on Miquel de Novals ha d'enviar els moltons.

$78 \mathrm{ACA}, \mathrm{C}$, reg. 340, f. 12v (2 de maig de 1296). El rei confirma al batlle que havia delegat en Pere Bussot la compra i trasllat del blat i que aquest havia estat l'encarregat de convenir el preu. Finalment el rei mana al batlle que ajudi en Bussot en aquesta tasca. 
de convenir amb Berenguer de Finestres la quantitat de blat a carregar i el seu preu ${ }^{79}$. Tot i que desconeixem per a quan preveia el monarca catalanoaragonès l'arribada del blat tortosí, les evidents dificultats del començament del mes de maig, més d'altres que desconeixem, endarreriren l'arribada fins més enllà de la darrera setmana de maig, quan el monarca mana a Pere Bussot que no trameti el blat a Alacant sinó a Guardamar $^{80}$.

Verdes com semblen les negociacions a l'inici del mes de maig, no creiem que el monarca confiés en el blat tortosí més que com una reserva o un segon avituallament després d'acabar el procedent de València, però també sembla evident que s'endarrerí més del previst, fins al punt que fou necessari canviar de plans i fixar un nou port d'arribada, Guardamar, que des del final del mes d'abril s'havia convertit en el centre de rebuda i redistribució de queviures en substitució d'Alacant, massa allunyat del front.

València se'ns mostra, doncs, com la ciutat d'on havia de venir l'avituallament en els primers moments de la campanya ${ }^{81}$. Les vitualles havien d'arribar a València del seu propi regne, però també de zones limítrofes ${ }^{82}$, de manera molt similar al que s'havia pensat fer amb els moltons aragonesos.

A mitjan mes d'abril, les reserves de queviures devien ja ser suficients i per això començà la campanya. Alhora, en la documentació desapareixen fins a la primeria de maig referències a l'avituallament de cereals i de vi.

L'equivalent a València d'en Pere Bussot fou en Bernat Colomet, però aquest afegí a la de recol lector una altra tasca important: pagador de les compres juntament amb Bernat de Segalar, tasca que analitzarem més endavant. Una altra diferència entre Pere Bussot i Bernat Colomet és que des de València i altres ports menys importants del regne partiren mercaders "emprenedors" que es dirigien directament als ports murcians per vendre als oficials reials gra, farina, vi... La proximitat del regne de Múrcia, al qual es podia arribar fàcilment tant per terra com per mar, devia ésser la raó d'aquest accés directe, sense intermediaris, als punts de concentració de queviures per a l'exèrcit: Alacant i Guardamar.

Del regne de València, la majoria de vitualles arribaven al de Múrcia per mar, però també s'hi accedí per terra, especialment les donacions o vendes de queviures de

79 ACA, C, reg. 340, f. $27 \mathrm{~V}$, ([8] de maig de 1296). Jaume II avisa Bussot que ha convingut amb Berenguer de Finestres la quantitat de blat que ell, Pere Bussot, ha de carregar i dur ràpidament a Alacant.

80 Per diverses cartes comunica a Ramon d'Urtg, alcaid d'Alacant, a Bernat de Sarrià, a Bernat Colomet $\mathbf{i}$ als còmits de les galeres que porten vitualles a Guardamar des de València, que si veuen la nau d'en Bussot que es dirigeix cap a Alacant, que diguin a aquest que es desviï a Guardamar (ACA, C, reg. 340, f. 101v-102v, 24 de maig de 1296).

81 ACA , C, reg. 104, f. 3 r (10 d'abril de 1296). Recorda el rei als seus súbdits del regne de València que ha demanat vitualles per a la guerra amb Castella $\mathbf{i}$ que les espera a València $O$ allà on es trobi l'exèrcit. El rei volia, doncs, tenir els subministraments abans d'iniciar la campanya. Més encara, el monarca retardà possiblement la campanya prevista per al març al final de l'abril a causa de l'endarreriment en els enviaments de queviures a València.

82 ACA, C, reg. 104, f. 23v (16 d'abril de 1296). El rei mana als seus súbdits que no molestin les vitualles que han de venir de les parts de Terol. 
Roger de Llúria al rei Jaume II. Les extenses propietats de l'italià a Cocentaina, ben a prop de la frontera murciana, propiciaren que l'almirall fos possiblement un dels principals subministradors de l'exèrcit en els primers moments. Les primeres vitualles que esmenta Jaume II un cop iniciada la campanya són les que s'esperen rebre a Alacant enviades per Jaume de Guàrdia, procurador de Roger de Llúria, des de Cocentaina via Xixona ${ }^{83}$. Aquesta ruta sabem que se seguirà usant fins a mitjan mes de maig ${ }^{84}$, però sempre en segon terme respecte de la marítima. Cal tenir present que la ruta terrestre entre València i Alacant, la primera vila murciana important, és molt muntanyosa.

Més activa fou, doncs, la ruta marítima. Tot i la presència d'alguns pirates per les proximitats ${ }^{85}$, era més ràpida i segura, o solament prou per tal que l'usessin fins i tot els oficials reials per enviar-se queviures els uns als altres, d'Alacant a Guardamar o d'aquesta vila a algun dels caps de pont per a les campanyes interiors, Águilas i el Cap de l'Aljub.

Però tornem encara als punts de recollida de blat, vi $i$ civada. En un primer moment fou Alacant la vila presa com a centre d'avituallament de l'exèrcit. La seva elecció resulta lògica ja que era la primera gran vila i el primer port important que s'havia de conquerir. Per a la funció de coordinador de l'avituallament s'escollí Jaume de Santacreu, que trobem establert a Alacant des de la mateixa conquesta de la vila fins a mitjan mes de maig. A ell s'encarrega la tasca de rebre les vitualles que Jaume de Guàrdia, procurador de Roger de Llúria, li ha de dur. D'aquestes, 336 roves de farina les ha d'entregar al nou alcaid d'Alacant, Ramon d'Urtx, per aprovisionar el castell, mentre que la resta l'ha de reenviar cap a Guardamar, que des del 26 d'abril s'ha convertit en el centre d'aprovisionament de la campanya ${ }^{86}$. Relegada a un paper de segon ordre, Alacant seguirà tanmateix rebent i subministrant queviures a Guardamar i l'exèrcit com a mínim fins a mitjan maig ${ }^{87}$.

El canvi d'Alacant per Guardamar, cal relacionar-lo amb la situació legal i militar en què queden els dominis dels Manuel, Juan i Violant, amb els quals, com hem vist, el

83 ACA , C, reg. 340, f.51v (26 d'abril de 1296). No s'indica que les vitualles vinguin de Cocentaina i per terra, però es dedueix per cartes posteriors. Amb aquestes vitualles s'ha d'abastar el castell d'Alacant (ACA, C, reg. 340, f. 51r, 27 d'abril de 1296, publicat un dels documents per DEL ESTAL, J.M., Conquista y anexión de las tierras de Alicante, Elche, Orihuela y Guardamar, pp. 331-332, doc. 11).

84 Un segon (com a mínim) carregament de queviures havia de venir a mitjan mes de maig de Cocentaina a Alacant passant per Xixona, tramès per Jaume de Guàrdia. Aquesta carregament, segons una primera ordre, havia d'aturar-se a Xixona, on seria pesat, però una contraordre de 13 de maig, provocada per la preparació del setge de Múrcia, que requeria l'emmagatzematge de queviures, establia que les vitualles passessin de llarg de Xixona i que un cop a Alacant fossin ràpidament reenviades a Oriola per Jaume de Santacreu (ACA, C, reg. 340, f. 59r, 13 de maig de 1296).

85 El 23 de juny de 1296 el rei ha de fer pagar de nou (o no) a Jaume Marquès, Joan Català $i$ Bonanat Redon, 17 II $2 \mathrm{~s}$ reials que se'ls deuen per 8 saques de farina de blat comprades per Bernat Ginebret, ja que (o tot i que) uns lladres sevillans els havien atracat (ACA, C, reg. 340, f. 159r-159v, en mal estat de conservació i no es llegeix si s'havien de pagar de nou les saques de blat o no),

86 ACA, C, reg. 340 , f. 51r-51v (26 i 27 d'abril de 1296).

87 Vegi's infra el paper d'Alacant en el nou organigrama de l'avituallament. 
rei estableix una treva per negociar el seu reconeixement com a sobirà de Múrcia. Convertides Elx $\mathrm{i}$ les localitats veïnes en una barrera entre Alacant $\mathrm{i}$ les dues principals ciutats murcianes, Múrcia i Oriola, el rei es veu obligat, si no ho tenia ja pensat, a canviar de centre d'avituallament. El port escollit és el de Guardamar, el més proper a Oriola. Des de ben aviat, doncs, Guardamar, tot i ser un port poc segur, es converteix en el punt de reunió de les galeres reials i de les naus dels mercaders que porten els queviures.

Alacant, per la seva situació geogràfica, perd, doncs, protagonisme en la guerra. Tanmateix, Jaume de Santacreu hi roman com a mínim fins a mitjan mes de maig, encarregat de fer arribar fins a Guardamar els aliments que es recullin o arribin a Alacant. Així, durant la fretura davant les murades d'Oriola, el rei li mana carregar en barques tot el blat que trobi, reial o d'altri, i dur-lo a Guardamar ${ }^{88}$. En dues ocasions més veiem actuar Jaume relacionat amb vitualles, el 13 de maig quan ha de reenviarne novament unes que li arribaran per terra via Xixona de part de Jaume de Guàrdia ${ }^{89}$, i el 17 del mateix mes quan ha de rebre i reenviar les vitualles ja descarregades del lleny d'en Beces ${ }^{90}$.

D'aquests casos esmentats, se'n desprenen dues conclusions: la primera, que Jaume de Santacreu romangué en el seu «càrrec» de recollidor de les vitualles a Alacant, tot i que Guardamar havia esdevingut ja el centre d'aprovisionament, i la segona, que Jaume II no devia haver previst un canvi tan ràpid de centre d'aprovisionament, ja que a mitjan mes de maig encara arribaven queviures directament a Alacant que havien de ser ràpidament reenviats a Guardamar. Un altre cas ens confirmarà aquesta idea: el fet que a la nau d'en Bussot se li encarregués d'anar a Alacant i no a Guardamar, quan se sabia que no podria arribar al regne de Múrcia en iniciar-se la campanya, sinó més tard ${ }^{91}$.

Guardamar es convertí, doncs, per la força dels fets, en el nou centre d'aprovisionament, tasca que no abandonà en tota la campanya, malgrat que el front es desplacés a Oriola, Múrcia, Lorca o Elx. Potser prendre un port natural perfecte com el de Cartagena, tot i que una mica més allunyat d'Oriola, hauria estat més lògic, però la mala comunicació de Cartagena amb l'interior, la capitulació més tardana i l'aparentment extrema facilitat de la conquesta de Guardamar degueren afavorir l'elecció.

Les primeres notícies que tenim de Guardamar com a centre de recollida de queviures són del 29 d'abril, quan Jaume II, des de l'horta d'Almoradí, nomena el seu porter Bernat Ginebret rebedor de les vitualles ${ }^{92}$. Dos dies abans el rei i possiblement

88 ACA, C, reg. 340, f. 26 r (7 de maig de 1296).

89 ACA, C, reg. $340, f, 59 r$, vegi's supra la ressenya.

90 ACA, C, reg. 340, f. 70v. El mateix dia el rei mana a Ramon de Cupiac, batlle d'Alacant, que pari el descarregament del lleny d'en Beces, que el faci partir ràpidament a Guardamar i que la vianda descarregada la doni a Jaume de Santacreu per tal que aquest l'enviï també a Guardamar (ACA, C, reg. 340, f. $70 \mathrm{v}$ ).

91 Sobre el canvi de ruta, vegi's supra.

92 ACA, C, reg. 340, f. $2 v$ 
part de l'exèrcit i les vitualles havien arribat a Guardamar. En previsió de possibles atacs durant el trajecte fins a Oriola, Jaume II havia deixat blat a l'església de la vila; d'aquí sortirà la primera tasca coneguda de Bernat Ginebret com a coordinador de l'aprovisionament: rebre aquest blat de mans dels jurats de Guardamar, augmentat amb tot el blat que els guardamarencs poguessin tenir a casa seva, i enviar-lo després al rei ${ }^{93}$. El mateix dia 29 d'abril el rei també li encomana rebre de Romeu Dalmau totes les vitualles que aquest té excepte el bescuit, tasca en la qual Bernat Ginebret serà ajudat per Guillem Arnau, de la casa del rei ${ }^{94}$.

Les primeres missions reials ens ajuden a perfilar les funcions del càrrec de Bernat Ginebret, que complementem amb altres notícies. En Bernat recollia, buscava ${ }^{95}$, comprava ${ }^{96}$, enviava, per mar o per terra, noliejava ${ }^{97}$, repartia i racionava les vitualles de l'exèrcit ${ }^{98}$, mes mai les pagava, és a dir que controlava tot el proveïment de vitualles excepte en l'aspecte econòmic final de pagament, reservat a dos altres personatges, Bernat Colomet i Bernat de Segalar, dels quals parlarem més endavant quan tractem el finançament de l'avituallament. Una altra tasca pròpia d'en Ginebret va ser l'aprovisionament de tropes establertes en castells, com ara el de Callosa ${ }^{99}$ o el de Guardamar, tot i que aquesta tasca la compartia amb altres oficials reials. L'esmentat cas de l'aprovisionament del castell de Guardamar ens dóna una mostra de com podia finançar-se l'avituallament d'un castell per part del seu alcaid, en aquest cas Galceran de Rosanes. A aquest s'havia assignat el quint de les cavalcades realitzades al regne de Múrcia, i amb el que rebés per aquest concepte el rei li havia demanat que pagués a Bernat Ginebret el necessari per avituallar el lloc de Guardamar ${ }^{100}$.

Tornem, tanmateix, a la campanya militar. Tot i que aquesta avanci per terres oriolanes fins a les envistes d'aquesta vila, Bernat Ginebret roman a Guardamar, des d'on viu la fretura d'aliments que obliga el rei a encomanar a Jaume de Santacreu, el 7 de maig, que prengui tot el blat que trobi a Alacant i l'enviï ràpidament a Bernat Ginebret a Guardamar ${ }^{101}$. Els problemes de proveïment no devien ser nous, perquè quatre dies abans el rei havia actuat a favor de Francesc de Pròixida en el conflicte

93 ACA, C, reg. 340, f. $2 \mathrm{v}$.

94 ACA, C, reg. 340, f. 3v (29 d'abril de 1296).

95 El 19 de maig de 1296 ha de buscar a Guardamar tota la farina, vi i ordi que trobi i prendre'l per al rei (ACA, C, reg. 340, f. 74r).

96 Bernat Ginebret ha de tractar amb els mercaders que han vingut amb les seves barques carregades de queviures davant de Guardamar, de manera que el rei pugui comprar-los tots els queviures (ACA, C, reg. 340, f. 70v, 17 de maig de 1296).

97 El 23 de juny de 1296 el rei mana que es pagui a Guillem de Torrent, barquer de València, el nòlit de 1.450 quarters de vi i 4240425 quarters de vi cuit. El preu del nòlit l'han de decidir els cònsols de la mar de València i la barca fou noliejada per Bernat Ginebret (ACA, C, reg. 340, f. 169r).

98 Ordres de repartir ració a tothom per a 10 dies del 19 i del 23 de maig (ACA, C, reg. 340, f. 74r i $91 \mathrm{v}$, respectivament).

99 Bernat Ginebret ha d'enviar a Bernat de Pujals, alcaid de Callosa, les vitualles ja decidides per a l'establida del castell de Callosa (ACA, C, reg. 340, f. 29r, 8 de maig de 1296).

100 ACA, C, reg. 340 , f. 80 r (21 de maig de 1296).

101 ACA, C, reg. 340, f. 26r. 
que l'enfrontava amb en Ginebret. Aquest s'havia emparat de les vitualles propietat del primer portades a Guardamar en la barca de Pere Guillem, ciutadà de València ${ }^{102}$.

Els problemes sembla que no se solucionaran en tota la campanya, ja que el monarca repetirà amb freqüència les sol'licituds un xic desesperades d'abastament. Tanmateix, cal tenir en compte que les requestes reials coincideixen sempre amb els jorns tot just anteriors a l'inici dels setges, és a dir que el rei reclama a en Ginebret aprovisionar-lo com sigui el 29 d'abril, dos dies abans de començar el setge d'Oriola ${ }^{103}$, el 17 de maig, l'endemà de començar el curt setge de Múrcia ${ }^{104}$, i el 23 de maig, cinc dies abans d'iniciar el setge de Mula ${ }^{105}$.

A mesura que la campanya s'internava i s'allunyava de Guardamar, el proveïment des d'aquesta localitat resultava més dificultós. Per solucionar aquest problema s'adoptaren dues solucions. La primera fou estabir un «subcentre» d'avituallament a Oriola mentre es conqueria Múrcia i es preparava l'expedició de Mula. En aquesta ocasió s'encarregà de la tasca primerament als dos batlles d'Oriola, Pere Rossell i Guillem Paratge, que havien de recollir tot el blat que trobessin als termes d'Oriola i Guardamar i reservar-lo després per al monarca ${ }^{106}$, i en segon lloc al jurat oriolà Berenguer Morrelles, a qui s'entregaren 1.700 turonesos d'argent per tal que comprés blat, i a Bernat de Súria, que l'havia de moldre. D'aquests dos, el primer no complí el seu

102 El rei mana a en Bernat que ho desempari (ACA, C, reg. 340, f. 19r, 3 de maig de 1296).

103 Que en Bernat aplegui tot el blat que trobi a Guardamar (ACA, C, reg. 340, f. 2v).

104 Que en Bernat obtingui tots els queviures que han portat els mercaders desplaçats fins a Guardamar (ACA, C, reg. 340, f. 70v). Tres dies abans, el 14, el rei havia apressat els dos nous batlies d'Oriola, Pere Rossell i Guillem Miró, a obtenir tot el blat que poguessin trobar a Oriola i Guardamar (ACA, C, reg. 340, f. 64v).

105 Que en Bernat doni ració completa per 10 dies a tothom de l'exèrcit i que després reuneixi tots els queviures i els carregui a les galeres reials a punt en qualsevol moment per partir (ACA, $C$, reg. $340, f .101 \mathrm{v}$ ). El mateix dia el rei mana a Bernat Colomet que li trametés dues galeres a València per tal que les carregui de vitualles i encontinent les retorni a Águilas (el rei prepara aleshores la conquesta de Mula, Alhama i, sobretot, Lorca) (ACA, C, reg. 340, f. 102r, 23 de maig). L'endemà de trametre aquestes ordres, el rei, que encara espera la nau d'en Bussot, mana a Ramon d'Urtg, alcaid d'Alacant, que si veu la nau d'aquell, que la reenviï directament a Guardamar (ACA, C, reg. 340, f. 101v, 24 de maig). Al mateix temps respon una carta de Bernat de Sarrià i li fa saber que té la intenció de deixar Múrcia per anar contra Lorca i que per aquest motiu necessita vitualles. Per aconseguir-les en Sarrià en primer lloc ha d'enviar dues galeres a Guardamar, que s'omplin de queviures i s'enviïn tot seguit cap a Águilas (són les dues galeres de les quals ja havia avisat en Ginebret), en segon lloc ha de fer tornar a València dues galeres més per tal de carregar-les de nou de vitualles (les que ha anunciat a Bernat Colomet). Si aquestes galeres es trobessin en Bussot, que l'enviïn directament a Guardamar, i si en Bussot no pogués navegar, per qualsevol motiu, que l'ajudin prenent-li la càrrega i tornant ràpidament cap a Águilas, però si en Bussot pot arribar sol (a Guardamar), que les galeres, una vegada carregades a València, tornin igualment a Águilas (ACA, C, reg. 340, f. 101r, 24 de maig, a 102r-102v, una altra lletra en els mateixos termes informant Bernat de Ginebret, i a 102v, una altra per als còmits de les dues galeres que han de tornar a València). Tanmateix, el monarca mig desmunta tota aquesta logística l'endemà quan demana a en Ginebret que no enviï encara les naus a Águilas, com li havia manat, sinó que les retingui a Guardamar (ACA, C, reg. 340, f. 105, 25 de maig).

106 ACA, C, reg. 340 , f. $64 \mathrm{v}$ (14 de maig de 1296). 
encàrrec correctament i fou necessària la intervenció del monarca per accelerar-ne el compliment en un moment en què el monarca es preparava per dirigir-se a Mula ${ }^{107}$.

La segona solució trobada al problema de l'allunyament del front de batalla de Guardamar, solució possiblement ja prevista quan es planejà l'expedició, fou establir caps de pont més propers a l'escenari del conflicte. D'aquesta manera Bernat Ginebret assegurà des de Guardamar l'avituallament del setge de Lorca des del port d'Águilas i el del setge d'Elx des del port del Cap de l'Aljub, l'actual Santa Pola. En aquests casos s'usava l'armada enrolada, però si calia Bernat Ginebret noliejava també barques de particulars ${ }^{108}$.

Cal destacar en relació amb aquesta segona solució la importància que té el transport per mar, molt més emprat que el terrestre, excepte per dur els queviures de la costa a l'interior, que evidentment s'ha de fer amb atzembles. Fins i tot en un trajecte tan curt com el de Guardamar al Cap de l'Aljub, que no arriba a la vintena de quilòmetres, s'usaren els vaixells en lloc de les atzembles. La raó de l'elecció del transport per mar cal buscar-la en la seguretat que el mar donava. La terra, amb les companyies d'almogàvers i les hosts feudals errant-hi, era més insegura ${ }^{109}$.

Resumint l'evolució del proveïment de l'exèrcit durant la campanya de Múrcia (llevat de la carn de moltó), el rei establí dos punts de recollida de queviures, València i Tortosa. D'aquestes ciutats, tant per terra com per mar, havia d'arribar el subministrament gestionat pels oficials reials en aquestes viles, complementat amb el que venia directament de Cocentaina, donat per l'almirall Roger de Llúria, i amb aquell que mercaders valencians «emprenedors» duguessin directament. En un primer moment s'escollí Alacant com a punt de redistribució dels queviures, però la peculiar situació jurídica dels dominis de Juan Manuel i altres senyors castellans obligaren a traslladar el centre d'avituallament a la vila de Guardamar, cap de pont per a l'avituallament dels setges d'Oriola i Múrcia. En aquest moment, l'avituallament tal com estava previst no acabà de funcionar correctament, la qual cosa obligà Jaume II a apressar els seus oficials a València, Tortosa, Alacant i Guardamar per tal que aconseguissin, d'on fos, els queviures $\mathrm{i}$ els hi trametessin. La desaparició de referències a fretures fa pensar

107 ACA, C, reg. 340, f. $79 r$ (20 de maig de 1296). El rei mana a Berenguer Morrelles que reti comptes a Bernat de Súria dels 1.700 turonesos amb els quals havia de comprar blat. Que retorni a Bernat de Súria el que tingui, moneda, blat o farina. Dos dies més tard Bernat de Súria rep l'encàrrec de dur al rei en atzembles tota la farina que hi hagi a Oriola (ACA, C, reg. 340, f. 90r, 21 de maig de 1296).

108 Bernat Ginebret noliejà una barca per dur vi (ACA, C, reg. 340, f. 169r, 23 de juny de 1296), però amb la redempció de València es pagaren altres nòlits de Guardamar a Águilas o al Cap de l'Aljub (f. 126r, 20 de juny), I fins i tot un primer a Águilas i tot seguit al Cap de l'Aljub (f. 126r, 18 de juny) i altres nòlits de destinació desconeguda (f. $13 \mathrm{v}-14 \mathrm{r}$ (4 i 5 de maig), $15 \mathrm{v}$ (4 de maig) i 100r-100v (24 de maig).

109 Un exemple il'lustrarà clarament la inseguretat de les comunicacions terrestres. A mitjan juny un grup d'almogàvers granadins sota l'adalil de Purchena Çahat Allechari, i tot i haver-hi pau firmada entre Aragó i Granada, van assaltar 5 moros de Cocentaina que portaven vianda a la host reial, van matar-ne un i es varen endur 8 semovents (bestias mulares). El rei se'n queixà al rei granadí i als seus oficials (ACA, C, reg. 340, f. 141r-141v, 15 de juny). 
que se solucionà momentàniament el problema, però la inconstància en el subministrament no s'acabaria de solucionar tot al llarg de la campanya, de manera que abans de les dues grans campanyes que encara restaven, la de Lorca i la d'Elx, el rei hauria de tornar a insistir per tal que li asseguressin el proveïment. Aquest li arribaria en el setge d'aquestes dues localitats principalment per via marítima des del port més proper, Águilas, i el Cap de l'Aljub, respectivament. Però per al setge de Mula, massa llunyana de la costa, el proveïment seguiria arribant de Guardamar via Oriola i Múrcia, però buscant-se un complement de blat des d'Oriola per tal de fer front a les necessitats de l'exèrcit. L'èxit final del conjunt de la campanya, malgrat que Lorca no arribés a caure fins més tard, ens ha de recordar que, tot i les deficiències i una certa improvisació en l'abastament, aquest fou suficient.

Un darrer aspecte roman encara per comentar: l'econòmic. Com finançà Jaume II aquesta xarxa que posava en relació tots els seus dominis? Com ja hem vist més amunt, la conversió de drets reials en aportacions en espècie o en metàl lic fou, entre altres, un dels sistemes, i l'avituallament de cereals i vi seguí aquest camí, però amb una certa originalitat. Tot el finançament de l'avituallament es va adscriure a la suma que la ciutat de València havia de pagar per redimir els seus habitants del servei d'host ${ }^{110}$.

La redempció s'havia valorat en $100.000 \mathrm{~s}$, que per gràcia reial foren reduïts a 90.000 , amb els quals el rei preveia que es podrien pagar tant les vitualles per al seu exèrcit com els sous dels almogàvers i d'altres soldats ${ }^{111}$. Per pagar a la host escollí l'escrivà de ració de la casa de la reina Blanca, Bernat de Segalar, i el seu conseller Bernat Colomet. Aquest era, alhora, com hem vist, l'encarregat d'administrar el subministrament de vitualles des de València, una manera eficaç d'assegurar que cobrarien als mercaders valencians que li venguessin vitualles.

Les dificultats per al cobrament de la redempció començaren ben d'hora. El 8 de maig, Jaume II ja havia d'insistir als jurats i prohoms de la ciutat de València perquè paguessin a Bernat Colomet per tal que aquest pogués comprar i enviar la farina $i$ altres vitualles que manquen a l'exèrcit que assetjava Oriola ${ }^{112}$. La ciutat no va ésser massa receptiva a la demanda i això portà el monarca a prendre mesures més directes:

110 Terol, Daroca, Calataiud... redimiren el servei d'host en espècies (vegi's supra), mentre que altres ciutats redimiren el seu servei en moneda, per exemple Barbastre (ACA, C, reg. 340, f. 37r, 11 de maig de 1296: el rei es queixa als prohoms i la universitat de Barbastre que encara no han pagat a Blas de Novales els $5.000 \mathrm{~s}$ jaquesos que han de pagar per la composició), però no sabem de cap altre cas que el valor de la redempció es dediqués a l'avituallament.

111 ACA , C, reg. 340 , f. $3 r$ (29 d'abril de 1296). El rei els demana que paguin perquè compta amb els diners per finançar l'avituallament $i$ les soldades. Han de pagar a Bernat Colomet i Bernat de Segalar.

112 ACA, C, reg. 340, f. 28r (8 de maig de 1296). El mateix dia el rei ja havia de demanar a Guillem Escrivà, ciutadà de València, que intercedís davant el consell de la ciutat per tal que aquesta pagués a Bernat Colomet i aquest pogués comprar i enviar a l'exèrcit la farina i altres vitualles que mancaven a l'exèrcit que assetjava Oriola (f. $27 \mathrm{r}$-27v). El mateix dia, encara, el rei havia manat a Bernat de Segalar que avancés a Bernat Colomet $16.000 \mathrm{~s}$ reials per tal de fer front a les necessitats més immediates de farina i pa cuit (f. 27v) (recordem que aquesta sol'licitud, en ple setge d'Oriola, coincideix amb la insistència a Pere Bussot que s'afanyi). 
autoritzar els seus oficials a València a prendre en préstec a nom de la ciutat aquelles sumes que els fessin falta per poder pagar als mercaders als quals ja s'havien comprat les vitualles ${ }^{113}$.

La insistència reial aconseguí que els jurats acabessin pagant, però no tot, i al final del mes de maig aquests presentaren un problema al pagament total de la suma establerta. Els jurats, emparant-se en els privilegis de Jaume I, es negaven a pagar $8.000 \mathrm{~s}$ que, segons ells, corresponien a les persones franques. El rei no acceptà ni el raonament ni la queixa dels jurats valencians i els manà que paguessin els $8.000 \mathrm{~s}$ que restaven per donar per pagada tota la redempción ${ }^{114}$.

D'aquesta manera, cap al final del mes de maig es devien acabar les entrades per fer front a l'avituallament, però no en canvi les despeses, de forma que, possiblement contra pronòstic, el rei va haver de recórrer a l'empenyorament. La suma buscada fou de $100.000 \mathrm{~s}$ altra vegada $\mathrm{i}$ els procuradors anomenats foren Berenguer de Finestres, ciutadà de València ${ }^{115}$, i Bernat Colomet. Aquests havien d'aconseguir el préstec de qualsevol persona sobre els drets $i$ rendes de la ciutat $i$ del regne de València, empenyorant-los o venent-los a un 0 dos anys ${ }^{116}$.

Per referències indirectes sembla que el préstec fou finalment aconseguit, si no en el seu valor total, sí com a mínim en part, però també s'aconseguí una altra font de finançament, uns altres $100.000 \mathrm{~s}$ lliurats al rei pel seu conseller Berenguer de Vilaragut ${ }^{117}$.

Tot i disposar d'aquestes informacions sobre quant es tenia previst per al finançament de la provisió, és impossible arribar a establir, ni aproximativament, quant s'arribà realment a abonar. De les ordres de pagament sortides de la cancelleria reial solament podem establir que com a mínim es dedicaren a la compra i trasllat de queviures (nòlits) 43.916 s 11 d pugesa, xifra llunyana dels 200.000 o $300.000 \mathrm{~s}$ de moneda valenciana que entre les vitualles $i$ les soldades es podien gastar.

Resumint sobre la qüestió del finançament, veiem com tampoc els càlculs i les previsions no es compliren i com Jaume II va haver de recórrer a noves fonts d'ingressos per tal de fer front a la necessitat peremptòria de queviures quan encara quedaven

113 ACA, C, reg. 340, f. 89 r (23 de maig de 1296).

114 ACA, C, reg. 340, f. 111r (28 de maig de 1296). Que el rei no cedís, a més de respondre a la real inconsistència de les demandes dels de València, mostra que aquest no podia deixar perdre ni un dobler.

115 Aquest ja havia ajudat el monarca a arribar a un acord amb els mercaders de Tortosa per vendre i carregar el blat a la nau d'en Bussot (ACA, C, reg. 340, f. 27v, [8] de maig de 1296).

116 ACA, C, reg. 340, f. 112r (31 de maig de 1296). El rei mana a Pere de Ripoll, ciutadà de València i administrador del batlle general de València, Pere de Llibià, que no impedeixi a Berenguer de Finestres i a Bernat Colomet obtenir els $100.000 \mathrm{~s}$, encara que afecti drets i similars de la batllia.

117 ACA, C, reg. 340, f. 150r (17 de juny de 1296, en mal estat de conservació). Jaume II mana a Berenguer de Finestres i Bernat Colomet que li comprin amb els diners manllevats una quantitat il'legible de quarters de vi per tal d'enviar-lo al Cap de l'Aljub. Tanmateix, si Pere de Montmeló pot comprar el vi amb els 100.000 s lliurats per Berenguer de Vilaragut, conseller del rei, que no usin els diners manllevats. 
ben bé dos mesos de campanya davant les murades d'Elx. Tot i així, el resultat final satisfactori de la campanya, amb la definitiva annexió del regne murcià a la Corona d'Aragó, prova que els problemes foren superats prou satisfactòriament.

\section{CONCLUSIÓ}

Al voltant de la conquesta i annexió del regne de Múrcia es construiren un seguit d'estructures i relacions per tal d'aconseguir que cavallers i peons percebessin la seva ració diària de pa, vi i carn, i que cavalls i altres quadrúpedes rebessin la seva de civada. L'obtenció per mitjans propis de l'aliment jugà un paper important, però el protagonisme se'l va endur el subministrament gestionat pel rei. Aquest darrer, des del moment de decidir la conquesta manu militari del regne murcià, començà a crear sistemes i xarxes d'aprovisionament amb tots els mitjans que tenia al seu abast. Creà una "administració" dedicada a aquest aspecte de la campanya, amb compradors, recollidors, repartidors de racions, pagadors..., i muntà una xarxa que havia d'assegurar l'arribada constant de queviures d'arreu dels seus dominis. Tot per tal d'evitar que una manca de viandes influís en el resultat de l'expedició. Però les estructures creades no acabaren de funcionar exactament com ell havia previst, i fins va caldre improvisar algunes solucions urgents, com ara requisar, pagant-los, tots els queviures d'Alacant, Guardamar i Oriola, quan aquests feren falta al front. Tanmateix, tot i aquests apedaçaments d'última hora, en línies generals les previsions reials s'acompliren i també l'objectiu final, l'annexió de Múrcia a la Corona d'Aragó, i aquest fet ens confirma que malgrat alguns errors de càlcul, Jaume II i la seva casa se n'assortiren de planejar l'avituallament de l'exèrcit per a la primera campanya de la guerra amb Castella pel regne de Múrcia. 


\section{LAS REPERCUSIONES DE LA INTERVENCIÓN DE JAIME ॥ EN EL REINO DE MURCIA}





\title{
LOS ORÍGENES DEL PLEITO DEL OBISPADO DE ORIHUELA (SIGLOS XIII-XIV)
}

\author{
Antonio CARRASCO RODRÍGUEZ
}

Universidad de Alicante

En 1243, el infante D. Alfonso -en representación de su padre Fernando III el Santo- y el emir murciano Ibn Hud pactaron en Alcaraz el protectorado castellano sobre las tierras del antiguo reino hudita.

La ocupación de este territorio propició el encuentro de los castellanos con los catalano-aragoneses de Jaime I. Por ello, la revisión de los acuerdos de Tudillén y Cazola se plasmó en 1244 en el tratado de Almizra, en el que se redefinieron las áreas de influencia y conquista de ambas potencias, quedando las tierras del sur de la actual provincia de Alicante en territorio castellano.

$Y$ de inmediato, D. Alfonso asumió la tarea de reorganizar las tierras recién conquistadas. Así, desde el punto de vista espiritual, planteó la necesidad de restaurar la antigua sede episcopal cartaginense. Sus deseos gozaron de una acogida muy favorable en Roma, pero toparon con los intereses de Jaime I, quien antes de emprender su labor reconquistadora, había prometido a los catalanes restituir el obispado de Valencia a la jurisdicción del metropolitano tarraconense y las tierras comprendidas entre Denia y Orihuela a la del prelado de Barcelona'. El asunto se complicó aún más cuando las sedes de Toledo y Tarragona reclamaron para sí la sufraganeidad de la futura diócesis de Cartagena.

Al fin, las repetidas instancias del primogénito castellano surtieron efecto, de modo

1 VILAR, J.B., Orihuela musulmana. Historia de la ciudad de Orihuela, t. II, Murcia, 1976, p. 131. Las citadas tierras pertenecían a la jurisdicción eclesiástica de la mitra de Barcelona en virtud de un acuerdo suscrito en el año 1058 por Alí ibn Muyahid, emir de Denia y señor de las Baleares, con Ramón Berenguer I. En él, el conde-marqués catalán reconocía solemnemente a Alí como soberano de Denia y las Baleares; y a cambio, el musulmán facultaba al prelado barcelonés para ordenar a los obispos, proveer los demás cargos eclesiásticos, y entender en el gobierno y dirección de tales iglesias. 
que Inocencio IV, el 31 de julio de 1250, decretó el restablecimiento de la sede cartaginense, y poco después, el 6 de agosto siguiente, propuso una fórmula de compromiso a la cuestión de la sufraganeidad, declararla exenta, esto es, directamente dependiente de la Santa Sede 2 .

Durante los años transcurridos entre el acuerdo de Alcaraz y la muerte de Ibn Hud hacia 1259, la totalidad del emirato, que había aceptado el protectorado castellano, vivió en una situación de precario equilibrio político. No obstante, tras el fallecimiento del emir y aprovechando el rompimiendo de Granada con Castilla, en 1264, los mudéjares murcianos, confabulados con nazaríes y norteafricanos, se sublevaron contra el dominio cristiano. Ocupado el ya rey Alfonso X el Sabio en combatir la sedición andaluza, no tuvo más opción que solicitar la ayuda de Jaime I para sofocar la insurrección murciana. Tras ordenar una primera intervención a su hijo Pedro, en noviembre de 1265 se puso al frente de un gran ejército y emprendió la marcha hacia el sur. No halló gran oposición en las tierras alicantinas de modo que en enero del año siguiente pudo iniciar el sitio de la ciudad de Murcia, que se rindió el 2 de febrero. Así, tras aplastar la rebelión y asentar en el reino murciano a algunos repobladores catalanes y aragoneses, lo devolvió a Alfonso $X$, sin que en nada se modificasen las líneas de frontera civiles y eclesiásticas ${ }^{3}$.

Años más tarde, bajo el episcopado de Diego Martínez Magaz, asistimos al primer suceso relevante de la iglesia de Orihuela tras la dominación musulmana; un hecho que, al fin y al cabo, constituiría la base prístina de las futuras aspiraciones episcopales de la población del Bajo Segura. Por real privilegio dado en Córdoba el 27 de mayo de 1281, Alfonso X estableció que la iglesia de El Salvador y Santa María fuese la mayor de la villa —la iglesia arciprestal- y tuviese, por tanto, primacía sobre las demás parroquias o "collaçiones" 4 .

Asimismo, hemos de destacar también al obispo Magaz porque fue el principal impulsor de la traslación de la sede episcopal de Cartagena a Murcia. Los motivos aducidos por el prelado y el cabildo cartaginenses eran fundamentalmente pastorales. La hasta entonces sede episcopal, por su situación costera, sufría continuas agresiones de los sarracenos. Y, además, se hallaba aislada del resto de la diócesis, ya que el campo y los caminos entre dicha ciudad y la sierra de Carrascoy se hallaban infestados de ladrones que dificultaban un acceso seguro a ella. Se hacía, por tanto, necesaria para la atención espiritual de los feligreses la traslación de la sede episcopal a otra ciudad, que fuera populosa e insigne, que se hallase en una mejor ubicación espacial dentro de la diócesis, y que ofreciese mejores vías de comunicación. Obviamente, la ciudad elegida tenía que ser Murcia. Las primeras instancias del prelado y el capítulo fueron dirigidas al pontífice Nicolás III, pero sus peticiones no tuvieron el resultado apetecido hasta que una bula de Nicolás IV, dada el 13 de septiembre de

2 ALDEA, Q. y otros, Diccionario de Historia Eclesiástica de España, Madrid, 1972, p. 998.

3 Todos estos hechos son narrados con detalle por BALLESTEROS-BERETTA, A., Alfonso $X$ el Sabio, Barcelona, 1963, pp. 388-403, y también por VILAR, J.B., op. cit., pp. 199-206.

4 Archivo Municipal de Orihuela, Libro Becerro de Privilegios Reales. También es citado en GISBERT Y BALLESTEROS, E., Historia de Orihuela, t. I, Orihuela, 1901, pp. 493-495. 
1289, decretó la traslación. Ésta fue aprobada por el rey Sancho IV el Bravo en dos cartas fechadas el 26 y el 29 de mayo de $1291^{5}$.

Con toda seguridad, la noticia no debió caer muy bien en Orihuela, puesto que a partir de entonces, Murcia, su enemiga capital desde tiempo inmemorial, pasaba a ser la sede del obispado, y a ella habrían de acudir los oriolanos a solucionar sus cuestiones de orden eclesiástico ${ }^{6}$.

El 25 de abril de 1295 falleció en Toledo el monarca castellano Sancho IV. Y pese a que en su testamento, con claridad, había señalado como heredero a su primogénito Fernando - menor de edad-, y a su mujer, María de Molina, le había encargado la gobernación del reino, su sucesión no fue tan sencilla. El matrimonio del rey Sancho IV y María de Molina, ilícito por razón de parentesco, no había sido reconocido por la Santa Sede, por lo que la condición de bastardo de Fernando lo incapacitaba para reinar. Por ello, los infantes de la Cerda -Alfonso y Juan-, que se hallaban en Aragón, reclamaron para sí la corona castellana.

Alfonso de la Cerda y Jaime II el Justo de Aragón firmaron un acuerdo en Bordalva, el 21 de enero de 1296. En él, el rey aragonés se comprometía a ayudar al infante en su guerra contra Fernando IV el Emplazado. A cambio se concertó la cesión a la Corona de Aragón del Reino de Murcia, del cual formaba parte, como sabemos, la ciudad de Orihuela y el sur de la actual provincia de Alicante ${ }^{7}$. La coalición contaba además con el apoyo de los musulmanes granadinos, del rey Dionís de Portugal, y del rey de Navarra Felipe IV, todos los cuales tenían problemas fronterizos con Castilla.

En cumplimiento de lo pactado, Jaime II marchó con un gran ejército hacia tierras levantinas. Tomó diversas plazas, entre ellas Alicante y Orihuela, cuyos habitantes le prestaron juramento de sumisión y homenaje en la iglesia arciprestal el 11 de mayo ${ }^{8}$.

5 DÍAZ CASSOU, P., Serie de los obispos de Cartagena, Madrid, 1895, pp. 22-25. FITA, F., «La Catedral de Murcia en 1291" y «Bosquejo histórico de la sede Cartaginense, por el obispo D. Diego de Comontes", en Boletín de la Real Academia de la Historia, t. III, cuad. 5 (1883), pp. 268-275 y 276 293. GISBERT Y BALLESTEROS, E., op. cit., t. I, pp. 525-527.

6 VILAR, J.B., op. cit., pp. 69-70 nos muestra el origen de esa enemistad capital. Hacia el año 825 , Abd al Rahman II hubo de hacer frente a una de las frecuentes contiendas tribales que enfrentaban a yemeníes y sirios en la cora de Tudmir. Tras derrotar a los sediciosos y para prevenir futuras discordias, pensó en trasladar los organismos administrativos de la cora — que se haliaban repartidos entre Orihuela y Hellín - a una nueva ciudad fundada por él, que, situada en las inmediaciones de la urbe orcelitana, en adelante la desplazaría como capital de la región. La citada ciudad, a la que no faltaban algunos precedentes prerromanos, recibió el nombre de Murcia - Mursiya- En el 831, la ciudad estaba ya construida y en ella se instaló, por orden del emir, el gobernador Ibn Labid.

7 Tenemos constancia de tal donación gracias a una carta dada en Serón (Soria) el 3 de febrero de 1296 por el propio Alfonso de la Cerda para Jaime II de Aragón que se halla en el Archivo Municipal de Orihuela, Libro Becerro de Privilegios Reales, f. 9v-10, publicada por MARTÍNEZ MORELLÁ, V., Cartas de los reyes de Castilla a Orihuela, 1265-1295, Alicante, 1954, p. 87; también aparece en TORRES FONTES, J., Colección de Documentos para la Historia del Reino de Murcia, II, Murcia, 1969, pp. 118-119,

8 Archivo Municipal de Orihuela, Libro Becerro de Privilegios Reales, f. 15-16v, publicada por TORRES FONTES, J., op. cit., $n^{\circ}$ CXX, p. 122; y por ESTAL, J.M. del, «Nuevos datos sobre el asedio y conquista de Orihuela por Jaime II de Aragón", en Revista del C.E.U. de Alicante, 2 (1977), pp. 99-109. 
Después se adueñó de prácticamente todos los lugares, poblaciones y castillos del reino de Murcia. Y por fin, el 12 de agosto se apoderó de la capital de este reino.

Pero en 1301 fueron legitimados los hijos de María de Molina, con lo que Alfonso de la Cerda perdió su condición de pretendiente a la Corona de Castilla, y Jaime II el pretexto para su intervención.

La amenaza de sublevación de los unionistas aragoneses y el afianzamiento del poder de María de Molina, que logró apartar de la coalición a los monarcas de Portugal y Navarra, a los musulmanes y al infante Juan de la Cerda, aconsejaron al rey aragonés entablar negociaciones con Castilla.

Dada la multitud de intereses creados y de partes afectadas se hizo necesaria la intervención de tres árbitros. Por Castilla fue designado el infante D. Juan Manuel - hijo de Alfonso X-; por la Corona de Aragón, D. Ximeno de Lema -prelado de Zaragoza-; y como mediador entre ambos, D. Dionís - rey de Portugal-. Y el 8 de agosto de 1304, en Torrellas — cerca de Tarazona - sentenciaron por vía de compromiso que Cartagena, Guardamar, Alicante, Elche —con su puerto de mar y todos los lugares cercanos-, Elda, Novelda y Orihuela —con todos su términos-, pertenecieran en adelante a la Corona de Aragón; que Murcia, Molina, Monteagudo, Alhama y Lorca, y los demás términos y lugares del reino de Murcia fuesen restituidos a la monarquía castellana; y que el señorío de Villena quedase en propiedad del infante D. Juan Manuel. Y para que el convenio tuviese validez, el día siguiente ambos reyes -Fernando IV y Jaime II— lo ratificaron en Campillo.

Aunque se hizo la paz entre ambas coronas, no quedó solucionado el asunto. El 26 de febrero de 1305 los dos monarcas se reunieron en el monasterio cisterciense de Huerta. En la entrevista, Jaime II propuso ceder graciosamente Cartagena a Castilla a condición de que Fernando IV diese la villa de Alarcón a D. Juan -el hijo de D. Juan Manuel-.

Y después, para la ejecución del fallo arbitral, fueron nombrados comisarios Diego García de Toledo — privado del rey de Castilla - y Gonzalo García — miembro del Consejo Real de Aragón-. Las negociaciones se celebraron en Elche y tuvieron su desenlace el 19 de marzo de ese mismo año. El acta de avenencia y partición hizo más precisas las líneas de frontera, y situó el límite entre los reinos de Valencia y Murcia en las poblaciones del Pilar de la Horadada y San Pedro del Pinatar respectivamente. $Y$ una vez que fue aprobada por los dos monarcas el 6 de diciembre del mencionado año, se hizo efectiva la nueva delimitación de los términos de Orihuela y Murcia y, por consiguiente, de las Coronas de Castilla y Aragón ${ }^{10}$.

La incorporación formal de los nuevos territorios se produjo bajo la nueva denomi-

9 En el Archivo de la Catedral de Orihuela, Actas Capitulares, Libro II, «Copia del proces de la Cathredal de la Esglesia de Oriola", ff. 208v-214v, hallamos copias de la Sentencias Arbitrales de Torrellas y de Elche realizadas por Francisco Vilanova, notario y escribano de la Sala del Magnífico Consell de la ciudad de Orihuela. J.M. del ESTAL analiza ambos fallos arbitrales en El Reino de Murcia bajo Aragón (1296-1304/5). Colección de Documentos Medievales Alicantinos. 1/1, Alicante, 1985, pp. 89-103.

10 GISBERT Y BALLESTEROS, E., op. cit., t. II, pp. 15-19. 
nación administrativa de Reino de Valencia ultra Sexonam. El gobierno se encargó a un llochtinent de Procurador, y para la gestión económica se creó la Bailía General de Orihuela, población en la que se fijó la capital de la Procuración ${ }^{11}$.

Un informe del capítulo de El Salvador, presentado el 5 de octubre de 1525 por el síndico Gil Gómez al gobernador del reino de Valencia más allá de Jijona, D. Pedro Maza de Lizana, evidencia de una manera tan sencilla como clara cómo ambas ciuda"des quedaron fronterizas, y con diferentes lenguas y opiniones: "per ço los de Murcia parlen castella e los de Oriola valencia los uns se nomenen castellans los altres valencians los uns son de la Corona Real de Castella los altres de la Corona Real de Arago tots vasalls de S. M. empero regits e governats ab diverses leys furs e privilegis pratiques e costums en la ciutat de Murcia esta lo port de Castella hon hi paguen los drets de moxariffat aduanes e altres drets reales los quals fan pagar als de Oriola entrant y exint en la dita ciutat de Murcia y per lo semblant en Oriola esta la taula dels drets reals del Regne de Valencia per als que van a Murcia". Y también el cariz de sus relaciones a partir de las sentencias de Torrellas y Elche: «entrant los uns en lo terme dels altres a fer cavalcades y cativarse com a enemichs capitals matant-se en batalles los uns als altres' ${ }^{12}$.

Pero el reajuste de los límites políticos no conllevó uno paralelo de los eclesiásticos. Y mientras los territorios del reino de Valencia ultra Sexonam quedaron bajo la soberanía de la Corona de Aragón, siguieron dependiendo en el orden espiritual del castellano obispo de Cartagena ${ }^{13}$.

Por tanto, es en esta falta de coincidencia entre los límites civiles y eclesiásticos donde hallamos el origen de las reclamaciones episcopales oriolanas. Desde este momento, ni el capítulo de la iglesia de El Salvador, ni el Consell de Orihuela, bien por separado, bien conjuntamente - lo que ocurriría la mayoría de las ocasiones-, cejarían en su empeño de lograr la creación de un obispado con sede en la ciudad del Bajo Segura, y cuya diócesis estuviese conformada por los territorios del reino de Valencia que muy a disgusto se hallaban sometidos a la autoridad episcopal murciana ${ }^{14}$.

11 DEL ESTAL, J.M., Orihuela, de villa a ciudad, Alicante, 1996, pp. 39-41. La Procuración ha sido analizada recientemente por CABEZUELO PLIEGO, J.V., Poder público y administración territorial en el Reino de Valencia, 1239-1348. El oficio de la Procuración. En prensa. Alicante, 1997.

12 Archivo de la Catedral de Orihuela, Actas Capitulares, libro I "Papeles y bulas conducentes a la catedralia", ff. $267 \mathrm{v}-268$.

13 BELLOT, P., Anales de Orihuela (siglos XIV-XVI), Orihuela, 1956, v. II, p. 33. Mosén Bellot califica de "descuido" el hecho de que, en las negociaciones de Torrellas y Elche, Jaime II no completara la partición del territorio con un deslinde de obispados, "Costó este descuido innumerables ducados, infinitas pesadumbres, muchos entredichos y descomuniones, que como casi todos los obispos eran castellanos, por cualquier mínima ocasión echaban mano a las armas espirituales...".

14 Sobre los territorios que pertenecian a la diócesis de Cartagena, puede consultarse la obra de MERINO ÁLVAREZ, A., Geografía histórica del territorio de la actual provincia de Murcia, Madrid, 1915, p. 54. Por otra parte, diferentes factores motivaron las reivindicaciones separatistas oriolanas: el abandono pastoral de las tierras valencianas situadas al sur de Jijona por los prelados castellanos, o las disciminaciones y abusos que habian de sufrir los pobladores de dicho territorio cuando tenían que personarse en la curia episcopal para tratar cuestiones de jurisdicción eclesiástica. 
Tenaz aspiración independentista que, como comprobaremos, compartieron y fomentaron los diferentes monarcas de la Corona de Aragón, entre otros motivos, para evitar los frecuentes incidentes fronterizos murciano-oriolanos y, sobre todo, el hecho de que las rentas eclesiásticas de sus territorios más meridionales pasaran a acrecentar las arcas del obispado de Cartagena, una Iglesia castellana ${ }^{15}$.

De cualquier forma, hay que hacer notar que Orihuela no fue la primera población elegida para ser la sede episcopal de la pretendida diócesis. Aunque el proyecto no prosperó, el mismo Jaime II, el 22 de noviembre de 1317, propuso al papa Juan XXII la erección de un nuevo obispado con capital en Játiva ${ }^{16}$. Tras este fracaso inicial, las futuras solicitudes de los reyes aragoneses a la Sede Apostólica ya sí fueron encaminadas hacia la consecución del título episcopal para el oppidum del Bajo Segura.

Jaime II falleció el 2 de noviembre de $1327^{17}$. Le sucedió su hijo, Alfonso IV el Benigno, tras renunciar en su favor el primogénito, su hermano Juan, para profesar en la orden militar de San Juan de Jerusalén. Alfonso, viudo de $D^{a}$. Teresa de Entenza y de Antillón, contrajo segundas nupcias con $D^{a}$. Leonor de Castilla. Ésta siguió una política «farnesiana», intentando conseguir privilegios para sus hijos en perjuicio del heredero al trono, el que más tarde sería Pedro $\mathrm{IV}^{18}$. Al primero de ellos, el infante $\mathrm{D}$. Fernando, el rey le donó, por real privilegio dado en Valencia el 28 de diciembre de 1328, las poblaciones de Tortosa, Albarracín, Orihuela, Callosa de Segura, Guardamar, Alicante, Monforte, Elda, Novelda, La Mola y Aspe, creándose así el señorío de Orihuela ${ }^{19}$.

Los años siguientes no fueron años tranquilos para los territorios del señorío. D. Fernando los indujo a participar en todas sus campañas belicosas, tanto contra su hermanastro, Pedro IV el Ceremonioso, en un primer momento, como contra Pedro I el Cruel, rey de Castilla, en la guerra que enfrentó a ambos monarcas ${ }^{20}$.

Los primeros roces de la iglesia oriolana con Murcia que hemos logrado constatar tuvieron lugar en el año 1353. El arcipreste, Jaime de Bobadilla, acusó ante el justicia y los jurados de la villa a Jaime Maestre — racional del infante- de haber vendido los censales que se habían de destinar a la compra de cirios y el mantenimiento de las lámparas, a las capellanías y a otras obras pías, para cobrar 5.000 sueldos que por amortizaciones debía dicha iglesia. Las citadas autoridades seculares declararon no

15 VILAR, J.B., Los siglos XIV y XV en Orihuela. Historia de la Ciudad de Orihuela, t. II, Murcia, 1977 , p. 370 . J.B. Vilar expone estas mismas razones pero afirma, en nuestra opinión erróneamente, que las tensas relaciones de frontera «no lograron relegar por completo la cordialidad que tradicionalmente presidió las relaciones de Murcia y Orihuela".

16 MANSILLA, D., "La reorganización eclesiástica española del siglo XVI. I. Aragón-Cataluña", en Anthologica Annua, 4 (1956), p. 102.

17 GISBERT Y BALLESTEROS, E., op. cit, t. II, p. 52.

18 CHIARRI MARTÍN, M.L., Orihuela y la guerra de las Germanías, Murcia, 1963, p. 19.

19 El texto íntegro de la donación lo podemos consultar en GISBERT Y BALLESTEROS, E, op. cit., t. II, pp. 696-701.

20 Sobre este enfrentamiento es indispensable consultar la obra de CABEZUELO PLIEGO, J.V., La Guerra de los Dos Pedros en tierras alicantinas, Alicante, 1991. 
tener jurisdicción sobre el referido racional. La respuesta no agradó al clero oriolano, de modo que elevó una queja al obispo, Alonso de Vargas. Éste, tras analizar el cariz de la situación, lanzó contra la villa el que sería el primero de una larga serie de entredichos que contra ella serían fulminados a lo largo del tiempo de dependencia de los prelados cartaginenses. El período de irregularidad espiritual duró poco, pues la diligente intervención del baile general, Juan Ximénez de Perencisa, consiguió que el provisor del obispado, Juan Martínez de Canales, alzara la censura ${ }^{21}$.

No obstante, es dentro del marco de la Guerra de los Dos Pedros donde hallamos el primer rompimiento abierto de Orihuela con el supraescrito obispo de Cartagena, Alonso de Vargas. Hacia mediados de 1357, al conocer que Pedro el Crue/ hacía preparativos para atacar Orihuela, el Consell dispuso, entre otras medidas defensivas, la reparación de los muros y baluartes. Y como el obispo se negó a construir el lienzo de muralla próximo al granero episcopal del diezmo, haciendo caso omiso a las peticiones de la villa, la citada corporación municipal decidió actuar por su cuenta y riesgo, y procedió a la incautación de trigo del prelado por valor de 3.000 sueldos, cantidad que sería suficiente para cubrir los gastos de la obra.

Agravió al obispo esta iniciativa por lo que, además de quejarse ante D. Fernando, lanzó contra toda la población un nuevo entredicho. Decidió el señor de Orihuela que lo mejor era complacer al obispo, y por ello ordenó al Consell que devolviera al prelado la especie incautada para que así fuese conmutada la pena. Pero tan pronto marchó el infante a su villa de Albarracín, volvió el Consell a instar a Alonso de Vargas a que sin más demora sufragase la construcción del tramo de muralla que le correspondía pues, de no hacerlo, le secuestrarían todas sus rentas. Al no obtener respuesta favorable del mitrado, los oficiales concejiles hicieron efectiva su amenaza. Conscientes de la imperiosa necesidad de obtener dinero para reforzar las defensas, incautaron todo el grano episcopal y lo vendieron en la misma villa. Indignado el pastor con tal actitud de su rebaño, protestó alegando que la mercancía podría haber sido vendida fuera de Orihuela con mayores beneficios, pero se abstuvo de poner entredicho ${ }^{22}$. No finalizaron ahí, por supuesto, las diferencias entre el prelado y Orihuela. Tal fue el talante de Alonso de Vargas que llegó a tomar las armas contra sus diocesanos valencianos y participó en el cerco y asalto de Orihuela ${ }^{23}$.

Si bien la conquista de Orihuela por los castellanos, acaecida el 7 de junio de 1365, fue un hecho de gran relevancia en el transcurso de la contienda de los reyes homónimos, aún tuvo mayor trascendencia si tenemos en cuenta el favor que ganó la

21 GISBERTY BALLESTEROS, E., op. cit, t. Il, pp. 93-94. Según Gisbert, este suceso hizo surgir en la mente de los oriolanos la idea de obtener su separación de la diócesis de Cartagena. No les bastaba con arrancar la concesión de un vicariato, que les permitiera zanjar sus cuestiones de índole eclesiástica con independencia de la autoridad del obispo murciano.

22 Archivo Municipal de Orihuela, Libro de Cartas Reales, 1358, f. 66. Esta cuestión es tratada además en VILAR, J.B., Los siglos XIV y XV..., pp. 370-371; en GISBERT Y BALLESTEROS, E., op. cit., t. II, p. 140; y en GEA MARTÍNEZ, J.R., Páginas de la Historia de Orihuela. El pleito del Obispado. 1383-1564, Orihuela, 1900, pp. 10-11.

23 DÍAZ CASSOU, P., op. cit., pp. 37-38. 
villa, por su comportamiento valeroso y fiel, en la consideración de los sucesivos monarcas de la Corona aragonesa, que casi siempre escucharon con buena disposición sus reivindicaciones episcopales ${ }^{24}$.

Por otra parte, antes de proseguir el relato de las tensas relaciones entre los prelados cartaginenses y el clero y el pueblo oriolanos, hemos de destacar que hacia mediados de 1363, y a instigación de Pedro IV el Ceremonioso, fue asesinado el infante D. Fernando. Y por real privilegio datado el 10 de julio del año siguiente, el citado rey anexionó Orihuela y su hinterland a la Corona de Aragón y juró que jamás volvería separarla de ella. Y aún más, el 10 de septiembre de 1366, en virtud de otro privilegio dado en Barcelona, el mismo Pedro IV estableció que, en lo sucesivo, dicha villa ya no podría ser sometida a la jurisdicción del gobernador de la ciudad de Valencia, ni a la de ningún otro, sino que dispondría de un gobernador propio e independiente. Nacía así la gobernación del Reino de Valencia ultra Sexonam, con capital en Orihuela ${ }^{25}$.

El único incidente digno de destacar, a nivel espiritual, entre Orihuela y el siguiente obispo de Cartagena, Nicolás de Aguilar, fue la fulminación de un nuevo entredicho contra la citada villa en el año 1371 . El referido prelado ordenó a 120 oriolanos que acudieran a Murcia, a la curia episcopal, a testificar. El Consell les mandó que no fuesen porque iba contra los privilegios de la villa el hecho de que vecinos de ella tuviesen que ir a prestar declaración a reino extraño. La reacción del obispo no se hizo esperar: excomulgó a los 120 reclamados, citó a otros 300, y lanzó el interdicto. El Consell envió a la corte a un procurador llamado Juan de Fontes para que informase a Pedro IV de las censuras fulminadas contra los oriolanos.

La representación de Fontes tuvo éxito pues poco tiempo después, ya en 1372, llegó a la villa del Bajo Segura Fr. Francisco Mateu, inquisidor de la Corona de Aragón, quien, ejerciendo como tal, realizó diversos procesos. Y además, el rey ordenó al gobernador, Bernardo de Senesterra ${ }^{26}$, que se incautasen bienes del obispo por el valor de los daños que, contra los fueros, éste había infligido al Consell. Y así procedió el representante real.

Conocedor de tal acción, el deán y vicario general del obispado, Pedro Puixmarín, amenazó con excomulgar al gobernador a menos que restituyese la cantidad apropia-

24 GISBERT Y BALLESTEROS, E., op. cit., pp. 265-278 ofrece una completísima descripción del cerco de Orihuela. Por otra parte, el privilegio real dado en Barcelona el 18 de julio de 1380 por Pedro IV - Hamado el Morabatin - nos pone de manifiesto con todo lujo de detalles, algunos de ellos incluso escabrosos, la fiereza y la valentía de los oriolanos a la hora de hacer frente a los ataques castellanos. Este privilegio sería presentado como mérito en la mayoría de las peticiones del capítulo de El Salvador y el Consel/ de Orihuela relacionadas con sus aspiraciones episcopales. Podemos hallarlo íntegro o en alusiones en el Archivo de la Catedral de Orihuela, Actas Capitulares, libro I "Papeles y bulas conducentes a la Catedralia", ff. 75-76v, 267-267v, y libro II "Copia del proces de la Cathredal de la Esglesia de Oriola", ff. 10v-13, 231v-232, $247 \mathrm{v}$ y 259v-261; y editado, comentado y traducido en GISBERT Y BALLESTEROS, E., op. cit., pp. 385-394.

25 Se conserva una copia de este último privilegio en el Archivo de la Catedral de Orihuela, Actas Capitulares, libro I "Papeles y bulas conducentes a la Catedralia», ff. 71v-74v.

26 GISBERT Y BALLESTEROS, E., op. cit., t. II, cap. VI, pp. 311-332 publica un "catálogo de gobernadores ' del reino de Valencia más allá de Jijona. 
da, pero no pudo hacer efectivo su ultimátum porque el obispo se hallaba fuera de la diócesis, en Avignon - localidad en la que residía la Curia Romana-. No obstante, temiendo el gobernador que «en las parroquias de Murcia le descomulgarian cada dia tres veses a el y a su teniente y Assessor y a Juan de Fontes», le escribió al provisor y vicario general explicándole que, por la fidelidad que le debían al Ceremonioso, no podría devolverle las rentas hasta que todos los oficiales reales fuesen absueltos. A lo que Puixmarín contestó que «a iure y por decreto sinodal estavan descomulgados y la tierra entredicha si no restituian al obispo los frutos que le havian llevado".

Aunque mosén Bellot — fuente utilizada ${ }^{27}$ — no recoge el final de la cuestión, suponemos que se llegó a un acuerdo antes del siguiente entredicho, que se produjo en 1375.

Tras el fallecimiento de Nicolás de Aguilar, fue electo obispo de Cartagena el francés Guillén Gimiel quien casi de inmediato, el 7 de mayo de ese mismo año, presidió un sínodo en el que se aprobaron varias constituciones entre las que destacaba una que hacía referencia a "los que usurpan y toman los diezmos y los derechos de la eglesia", en clara respuesta a las frecuentes apropiaciones de los bienes episcopales que solía realizar el Consell oriolano ${ }^{28}$.

El entredicho referido se produjo a raíz de la llegada a Orihuela de Antón Dolcet, clérigo beneficiado en la iglesia de San Jorge de Lorca. Éste debía entregar ciertas cartas del mitrado al arcipreste de El Salvador. No obstante, por causas que se desconocen fue detenido y encarcelado en las prisiones del Consell.

Enterado Gimiel de los hechos, realizó diversas gestiones para conseguir su liberación; pero al resultar vanas todas sus instancias, decidió excomulgar a quienes habían intervenido en la detención del prebendado y lanzar el entredicho sobre la villa.

Ignorando el motivo de tan grave censura, el Consell envió a Murcia a un procurador llamado Ruidoms para que se entrevistase con el prelado. El francés le respondió que no le había agradado tener que fulminar a la villa con el interdicto, pero que se había visto obligado a ello porque el justicia oriolano había metido en prisión a un tonsurado. Y añadió que a menos que lo soltasen, no alzaría la censura.

Tras conocer la posición del obispo, el Consell le envió dos nuevos emisarios, Guillem Belloch y Vicente Zaragoza, quienes le manifestaron que el justicia no tenía preso a ningún tonsurado, y que aún en el caso de tenerlo, el pueblo no tenía culpa de ello.

Tampoco atendió en esta ocasión el obispo cartaginense a la citada petición. $E$ intentando agravar la situación, prohibió a los murcianos que tuviesen trato con los excomulgados. No obstante, sin temor a las condenas espirituales, el concejo murciano desoyó las amenazas del prelado, alegando en su contra las órdenes del rey Enrique II de Castilla de que mantuviesen relaciones pacíficas con los súbditos de la Corona aragonesa, con vistas a favorecer los intereses mercantiles de la ciudad ${ }^{29}$.

No conocemos cómo terminó la cuestión pero, por otra parte, es realmente interesante comprobar que, ya en esta época, los intereses temporales se sobreponían a los espirituales, y que importaba más a la población oriolana la defensa de sus intere-

27 BELLOT, P., op. cit., vol. II, cap. V, p. 466.

28 DÍAZ CASSOU, P., op. cit., p. 41.

29 BELLOT, P., op. cit., vol. II, p. 474. VILAR, J.B., Los siglos XIV y XV.., pp. 371-372. 
ses y aspiraciones episcopales que las frecuentes y largas temporadas de privación de servicios religiosos ${ }^{30}$.

El desarrollo del pontificado de Guillén Gímiel fue poco pacífico; las fricciones y los agravios entre ambas partes estuvieron a la orden del día. Aún en 1383, último año del francés al frente de la mitra cartaginense, se produjo un hecho de amplias repercusiones $^{31}$.

En las Cortes celebradas en Monzón ese año, el síndico de Orihuela, Berenguer Vimbaldi, solicitó a Pedro IV que concediese a Ginés Silvestre un beneficio en la iglesia de Santiago de la referida villa. El monarca, teniendo en consideración los heroicos servicios que le prestara el caballero Domingo Silvestre - padre del tal Ginésen la pasada guerra con Castilla, accedió a la petición.

Entonces, Silvestre pretendió permutar dicha prebenda con un clérigo de Murcia, que había obtenido otra en la parroquia de San Miguel. Pero mientras el murciano accedió sin ningún impedimento al mencionado beneficio de la iglesia de Santiago, Silvestre sí halló dificultades a la hora de completar la permuta. Después de que se le negara la posesión de la prebenda, tuvo que huir de la ciudad vecina y rival porque lo quisieron matar al conocer su condición de oriolano.

Sumamente indignado, el Consel/ de Orihuela se puso de acuerdo con el de Alicante, y ambos organismos comisionaron respectivamente a Francés Fabriques y a Jaime Franco para que marcharan a la corte a presentar al monarca sus quejas y reivindicaciones. $Y$ así hicieron, y con el apoyo del influyente D. Guillén de Rocafull, pidieron a Pedro IV que suplicase al pontífice Bonifacio IX la desmembración de la gobernación del reino de Valencia ultra Sexonam de la jurisdicción de la diócesis de Cartagena y la erección de un nuevo obispado con sede en Orihuela ${ }^{32}$.

Posteriormente, fueron enviados a la corte regia y a Roma, con la misma pretensión, nuevos síndicos del capítulo de El Salvador y del Consell de Orihuela: Pedro de Galbe, Jaime de Rocamora, Francisco Desprats, mosén Jaime Torres, y muchos otros. Pero no consiguieron resultados que colmaran sus expectativas.

Aún tendría que pasar la población del Bajo Segura por muchas vicisitudes, como la erección de la iglesia de El Salvador en Colegiata en 1413, o dos intentos fracasados de crear el obispado propio e independiente, en 1442 y 1510. Pero Orihuela no encabezaría su propia diócesis hasta el 14 de julio de 1564, fecha en que Pío IV atendería la suplicación de otro monarca, éste ya de España, Felipe II, el Rey Prudente.

30 El entredicho eclesiástico conllevaba privaciones tan notorias como la imposibilidad de cumplir con el precepto dominical, de recibir los sacramentos, de contraer matrimonio, o de dar sepultura a los muertos en suelo sagrado.

31 Esta controversia es analizada por los diversos autores. GEA MARTÍNEZ, J.R., op. cit., pp. 1112. VILAR, J.B., Los siglos XIV y XV.., p. 372. GISBERT Y BALLESTEROS, E., op. cit., t. II, p. 411. CHIARRI MARTÍN, M.L., op. cit., p. 27.

32 BELLOT, P., op. cit., vol. I, p. 130, reproduce la súplica de los procuradores oriolanos: «/tem, Señor, per quant son molts y intolerables los agravis que rebem dels bisbes de Cartagena axi en temps de guerra com en temps de pas, placia a Vuestra Magestat si es pot intercedir ab lo papa que dividixca esta partida del reyne del bisbat de Cartagena y intituexca en ella un bisbat y que lo que sera dat pera governarlo se nomene bisbe de Oriola". 


\title{
¿TORRELLAS O TORRIJOS? EN TORNO A LA UBICACIÓN DE LA SENTENCIA ARBITRAL DE 1304
}

\author{
Francisco DE MOXÓ Y MONTOLÍU \\ Universidad San Pablo CEU (Madrid)
}

Fruto de largos años de trabajo sobre la documentación del Archivo de la Corona de Aragón, ha aparecido no hace mucho la nueva obra en dos volúmenes de $D^{a}$ Angeles Masiá de Ros «Relación castellano-aragonesa desde Jaime II a Pedro de Ceremonioso», publicada por el Consejo Superior de Investigaciones Científicas en 1994. Una contribución importante sin duda al estudio del entramado de esas relaciones, en un período en que las situaciones conflictivas alternaron con otras de amistad y colaboración.

Momento de máximo interés en dicha relación lo constituyeron las negociaciones que, tras unos años de confrontación bélica, condujeron a la Sentencia arbitral de Torrellas en 1304 y sus consecuencias posteriores, que determinaron el paso de buena parte de la actual provincia de Alicante del dominio castellano al aragonés. Al tratar de ello, y en base a la abundantísima documentación aportada, la Sra. Masiá ha considerado necesario corregir la tradicional denominación geográfica de «Torrellas», aceptada desde Zurita hasta nuestros días como lugar de ubicación de la Sentencia, sustituyéndola por la, a su juicio más correcta de acuerdo con los documentos, de "Torrijos"'. Cabe preguntarse en vista de ello si no nos hallaremos ante un caso de error toponímico semejante al de aquel Tratado de Cazorla o Cazola, que afectó también casualmente a la cuestión de los límites entre Aragón y Castilla, y fue resuelto correctamente a favor de Cazola por D. Julio González².

La documentación habla claramente en tres ocasiones del «lugar de Torrijos», cerca

1 A. MASIÁ, o. c., vol. I, p. 120. ZURITA, Anales, V, 66.

2 J. GONZÁLEZ, El reino de Castilla en la época de Alfonso VIII, Madrid 1960, vol. I, p. 814 , ก. 39 . 
de Tarazona. La primera en una carta de Jaime II al infante don Juan de Castilla, fechada en Calatayud el 15 de marzo de 1304, pidiendo la restitución, a instancias de unos «hombres de Torrijos, un lugar nuestro que es cabe Tarazona", de lo que les fue robado por "homnes de Castilla de cavallo e de pie ${ }^{3}$. La segunda en un documento fechado en el propio Torrijos el 8 de agosto de 1304, conteniendo la sentencia arbitral pronunciada por los reyes de Aragón y Portugal entre Fernando IV de Castilla y don Alfonso de la Cerda sobre las pretensiones de éste a la corona castellana ${ }^{4}$. Y la tercera, en un traslado. hecho en Zaragoza el 21 de agosto del mismo año del compromiso de arbitraje hecho el 20 de abril de 1304 por los dichos Fernando IV y Alfonso en don Dionís de Portugal y Jaime II respectivamente, y de la sentencia arbitral de 8 de agosto del documento anterior ${ }^{5}$.

Ninguno de los tres documentos contiene pues la Sentencia sobre límites dada el mismo 8 de agosto por los árbitros D. Dionís, el infante D. Juan y el obispo de Zaragoza D. Ximeno de Luna en Torrijos o Torrellas ${ }^{6}$. publicada ya repetidas veces por Benavides, el Prof. Torres Fontes y el Prof. Del Estal'. Sentencia sin embargo que habla también de «Torrijos" (aunque Del Estal entre paréntesis corrija por «Torrellas») presión toponímica propuesta por la Sra. Masiá parece cobrar nuevo vigor. El caso es que su observación ha tenido la virtud de acuciar nuestra reflexión sobre el problema, para cuya solución se ofrecen las hipótesis que vamos a exponer a continuación.

\section{Se trata de otro lugar, "Torrijos», distinto del de «Torrellas» señalado por Zurita}

Es cierto que, si no exactamente «Torrijos», los topónimos «Torrijo» o «Torrijos» los vemos aparecer, precisamente en Aragón, en Torrijo de la Cañada (al N. O. de Calatayud y no lejos del límite con Castilla), Torrijo del Campo (entre Calatayud y Teruel), y un Torrijos al sur de Teruel. Pero ninguno de ellos está junto a la ciudad de Tarazona, como repiten los documentos citados ${ }^{9}$, en cuyas cercanías no existe ningún lugar con ese nombre, y sí el tradicional desde Zurita de Torrellas. Además Zurita, como aragonés, está bien informado sobre las poblaciones de su tierra, y no equivocaría su nombre fácilmente de haberse tratado en realidad de Torrijos.

3 A. MASIÁ, o. c., vol. II, p. 91, doc. $61 / 182, n^{\circ} 2$.

4 Ibídem, p. 175, doc. 96/275, no 1.

5 Ibídem, p. 175, doc. 69/215.

6 Este tercer documento figura por error, en la regesta de A. MASIÁ, como «Sentencia arbitral sobre los límites del reino de Murcia", es decir, la Sentencia arbitral de 8 de agosto de la que aquí tratamos. La coincidencia de la fecha ha podido inducir al error. Ver vol. Y, p. 22, nota 215.

7 Los documentos que contienen la Sentencia, así como las diversas publicaciones que reproducen la misma, vienen indicados por J.M. DEL ESTAL en El reino de Murcia bajo Aragón (12961305), Corpus documental I/1, doc. 213, pp. 362 ss. También en A. MASIÁ, vol. I, p. 122, nota 215, aunque con la confusión indicada.

8 J.M. DEL ESTAL, o. c., p. 368.

9 "Cabe Taraçona" (doc. $1^{\circ}$ ), "cerca de la ciudad de Taraçona" (doc. $2^{\circ}$ ), "cerca de Taraçona" (doc. $\left.3^{\circ}\right)$. 
Por otra parte, el entorno geopolítico de la Sentencia se corresponde totalmente con la ubicación de la Torrellas actual. Al día siguiente de la Sentencia se celebran las vistas reales en El Campillo, situado muy cerca de Torrellas, como testifica, además de Zurita, el documento de 9 de agosto de 1304 aportado por la propia Angeles Masiá ${ }^{10}$.

El Campillo llamado "Susano" había sido ya en 1204 lugar de encuentro de los monarcas Pedro II de Aragón y Alfonso VIII de Castilla; y de nuevo en 1281 de Pedro III y su cuñado Alfonso $X$. Debo a la amabilidad de $D^{\text {a }}$ Teresa Ainaga, del Centro de Estudios Turiasonenses de la Institución "Fernando el Católico", un mapa topográfico detalladísimo del actual término municipal de Tarazona (colindante con el de Torrellas) en el que, además de un «Campillo» al N.E. y muy próximo a la ciudad, con cota de altura $480 \mathrm{~m}$., figura otro mucho más próximo a Torrellas y con cota $766 \mathrm{~m}$., que sin duda sería el «Campillo Susano» de esas entrevistas reales. En este último está situado hoy, además, el «Corral del Campillo», lugar para cercar ganado, con vestigios de edificación que probablemente se remonte a tiempo antiguos.

Por otra parte, Juan Martínez de Luna, abuelo del futuro papa y hermano de uno de los tres árbitros, el obispo zaragozano don Ximeno de Luna, era desde 1301 teniente de Los Fayos, lugar contiguo a Torrellas donde según Zurita, buen conocedor y ensalzador de la historia y miembros de la Casa de Luna, se pronunció la Sentencia ${ }^{11}$.

De modo que esta primera hipótesis parece descartable.

\section{2a el mismo lugar de Torrellas, con denominación geográfica equivocada por errata de los notario o escribanos a sus órdenes}

Hipótesis no totalmente descartable, pero que se hace muy difícil de aceptar si tenemos en cuenta que, en dos de los tres documentos apostados por la Sra. Masiá, y en la Sentencia que reproducen los demás autores, figura un «Pedro Martínez» como «escribano del senior rey d'Aragón e por autoridad suya notario público qui a todas estas cosas present fuim ${ }^{12}$; resultando impensable que, en diversos documentos de esa importancia, ignorase el verdadero nombre del lugar donde se otorgaban y en que él mismo estaba presente. El trasladado en Zaragoza lo fue por un Pedro López «auctoritate regis notarius publicus qui hoc translatum sumptum fideliter ab originali suo ac de verbo ad verbum cum eodem comparatum escribi fecit et clausit»13. El texto de la Sentencia que reproduce Del Estal pertenece a un traslado hecho en Barcelona el 10 de junio de 1361 por el notario público y escribano Berenguer de Fonolleda, por orden del notario público real Francisco de Sant Climent ${ }^{14}$. Aparte de que es contradictorio que notarios públicos catalanes, por lo que diremos en la hipótesis siguiente, se equivocasen en el sentido de cambiar «Torrellas» por «Torrijos», sigue teniendo un peso fundamental el hecho de la coincidencia de los cuatro documentos en el topónimo «Torrijos".

\footnotetext{
10 A. MASIÁ, o. c., vol. II, p. 110, doc. 70/219 (ACA, CRD Jaime II, caja 12, n. 263-332).

11 Ver mi obra La Casa de Luna, Münster 1990, p. 366, doc. 73 (3 sept. 1303).

12 DEL ESTAL, o. c., p. 369. MASIÁ, vol. II, pp. 110 y 176 (no «Nunnes" sino "Martínez»).

13 A. MASIÁ, o. c., vol. II, p. 110, doc. 69/215 (transcripción defectuosa).

14 DEL ESTAL, o. c., p. 369.
} 


\section{3a Es el mismo lugar, pero con denominación vacilante entre «Torrellas» y «Torrijos»}

A primera vista tampoco parece descartable esta hipótesis, abonable además por el hecho de darse con frecuencia en aquellos siglos - y aun en el nuestro- las duplicidades toponímicas gráficas o lingüísticas, más tratándose de lugares situados en zonas fronterizas. Y finalmente, no estaba muy lejos, en territorio de la actual Navarra, el lugar de Tudillén, sede del célebre Tratado (por cierto asimismo de límites) entre Alfonso VII y Ramón Berenguer IV su cuñado, que también vemos mencionado en crónicas y documentos como "Tudején" ${ }^{15}$. Además, es bien conocida la facilidad con que Zurita «transmutaba» los topónimos, en sus «Anales».

Ello nos lleva a un breve "excursus» filológico que puede aportar luz a la cuestión.

Como señala el Prof. Lapesa en su «Historia de la Lengua Española» ${ }^{16}$, la «l |» peninsular nacida de «C ' $\mid$ » 0 «I + yod» pasó a la grafía «j» en Castilla en época muy temprana. Así tenemos:

$\begin{array}{lll}\text { Latín } & \text { Otras lenguas peninsulares } & \text { Castellan } \\ \text { Auricula } & \text { Orella } & \text { Oreja } \\ \text { Malleolum } & \text { Mallol (cat.) } & \text { Majuelo } \\ \text { Mulier } & \text { Muller } & \text { Mujer } \\ \text { Cuniculus } & \text { Conill (cat.) } & \text { Conejo } \\ \text { Oculus } & \text { Ollo, ull } & \text { Ojo } \\ & \text { (ollos aún en Mio Cid) } & \\ \text { Melior } & \text { Milhor, Millor } & \text { Mejor } \\ \text { Folia } & \text { Folla, Full } & \text { Hoja } \\ \text { Similare } & \text { Semellar } & \text { Semejar } \\ \text { Filius } & \text { Fillo, Fill } & \text { Hijo } \\ \text { Butticulum (-a) } & \text { Botella } & \text { Botijo } \\ & \text { (cast. tard. de «Bouteille») } & \end{array}$

Esa " J» tenía un sonido suave, como la inglesa o francesa. El sonido fuerte de la «J» actual se hacia mediante la «X» hasta el siglo XVI: «Mexico», «Exercicios», "Xavier» se pronunciaban "Mejico", «Ejercicios", «Javier».

En el Renacimiento se recuperó la "X» latina con el sonido que ahora tiene y entonces la «J», suave al principio como decíamos, pasó a tener el sonido fuerte actual, antes propio de la " $X$ » e inexistente en latín, en que la «J» y la "Y» se confundían: obsérvese que en italiano no existe la « $\mathrm{J} »$ ni fonéticamente ni gráficamente.

En Aragón se da la grafía « \», adquiriendo el sonido gutural fuerte como en Castilla, sonido procedente (o paralelo al) de la fonética vasca contigua al Alto Aragón, a la Rioja y a Castilla la Vieja: y lo encontramos en "Torrijo» y otros topónimos similares

15 J. GÓNZALEZ, o.c., p. 775, nota 58

16 R. LAPESA, Historia de la lengua española (2a de.), Madrid 1950, p. 132. 
antes citados ${ }^{17}$. En cambio la grafía y sonido «LL», aunque los encontramos también en algunos topónimos aragoneses-medievales no derivados de «Torre», como Novellas (hoy Novillas), Armiellas (?) Villiella (Villel?), Las Cellas, Cella y Maella, los vemos persistir sobre todo en muchos topónimos de Cataluña y Valencia, como Almacellas, Garriguella, Godella y Morella y particularmente los derivados de «Torre» como Torrellas de Llobregat, Torrellas de Foix, Torroella de Montgrí o de Figueres y Sant Martí de Torroella cerca de Manresa ${ }^{18}$.

Supuesto todo esto, en nuestro caso parece que más bien hemos de inclinarnos al "Torrijos» de los documentos que al "Torrellas" de Zurita como nombre de la localidad en el siglo XIV, aunque, en cuanto a la pronunciación de la «J» en esa época, se asemejaría entonces más a la «LL» según hemos expuesto, lo que facilitaría la transformación de un topónimo en el otro. Pero queda todavía la dificultad de la gran divergencia vocálica (I-O en un caso, E-A en el otro), lo que hace difícil establecer la derivación de «Torrijos» a «Torrellas», en sentido además contrario al de la evolución histórico-fonética castellano-aragonesa, como vemos en los diversos «Torrijo» o “Castejón» existentes hoy en Aragón.

Es verdad que Zurita no era muy escrupuloso en la fiel reproducción de los topónimos no aragoneses. Pero lo extraño en nuestro caso es que transforme un topónimo claramente aragonés "Torrijos», como lee en los documentos que el conoce tan bien, en "Torrellas". Si le llama así, parece que es porque, aunque vea otra cosa en los documentos, sabe que así se llama el lugar en el tiempo en que escribe los «Anales».

Todas estas consideraciones nos conducen a una cuarta hipótesis que, aun careciendo por ahora de una prueba incontestable que la convierta en certeza, nos atrevemos a proponer como solución, a nuestro juicio la más probable, al problema.

\section{4a. Es el mismo lugar de Torrijos que, en el tiempo comprendido entre la Sen- tencia arbitral de 1304 y la época de redacción de los Anales de Zurita, pasó a denominarse Torrellas}

Ello pudo deberse, a mi juicio, a una de estas dos causas:

17 Ver R. MENÉNDEZ PIDAL, Orígenes del español, Madrid 1929. Lo mismo podemos apreciar en la diversa grafía y fonética de los "Castejones" aragoneses (de Sobrarbe, de las Armas, de Monegros, de Sos, de Tornos, de Valdejasa, del Puente) y los «Castellós» levantinos (d’Espuny, de Farfany, de la Plana, de Rugart).

18 G. BLEIBERG, Diccionario geográfico de España, Madrid 1958; P. ADIEGO y M. LAGUENS, Album geográfico-histórico del reino de Aragón (SS. XVI-XIX). Cartografía del reino de Aragón, Zaragoza 1987, VIII. Índice alfabético (pp. 141-146), Mapas de J.B. Labaña en las pp. 65 (1641), 67 (1646), 91 (1675) y 99 (1700); Gran Geografía comarcal de Catalunya, dir. Max Cahner ( $2^{\varrho}$ ed.) Barcelona 1991-1996, en los índices de topónimos de los tomos 6,9 y 13 y en los tres tomos del Atles topogràfic de Catalunya (1995). En mi obra La Casa de Luna ver topónimos aragoneses medievales en Ap.B. (p. 544) (Novellas, Armiellas, Villiella) y en doc. 116 A (Novellas), C (Las Cellas), I (Noviellas). 
a) o al influjo fonético, lento y pacífico, de la denominación de lugares no muy lejanos, como Novallas, el citado de Novellas (hoy Novillas), Fontellas y aun de los mismos Tudela y Corella ${ }^{19}$.

b) o a una refundación del lugar, destruido en alguna de las confrontaciones que devastaron esa zona fronteriza. Ya con ocasión de la guerra entre Castilla y Aragón que precedió a la Sentencia, nuestra localidad sufrió robos, como vimos denunciaba el primer documento. Además tenemos el testimonio de otro lugar muy cercano en el documento del año anterior a la Sentencia, dado en Valencia por Jaime II, en el que aparecen los hombres de Los Fayos pidiendo la remisión de las pechas debidas a Juan Martínez de Luna "propter guerram que erat inter regna Aragonie et Castelle in que dampnificati fuistis»20. Pero la más devastadora fue la guerra «de los dos Pedros», con la incursión castellana de 1357 que condujo a la toma de Tarazona. En un trabajo publicado hace unos años en los "Anales de la Universidad de Alicante", me ocupé de estas devastaciones bélicas, entre las que merece señalarse el hecho, aunque en otra zona fronteriza, de los habitantes de Munébrega y Bubierca, dispuestos a pegar fuego a sus villas respectivas si los enemigos amenazaban ocuparlas. Datos tenemos también de la despoblación de varios lugares fronterizos como Alhama, Cervera, Añón y la mitad de Torijo, el lugar ya citado al N.O. de Calatayud y de nombre semejante al nuestro ${ }^{21}$. No sería pues nada extraño que a éste le sucediese algo parecido con ocasión de la ofensiva castellana hasta la vecina Tarazona.

¿Quienes pudieron cambiar el nombre, más aragonés, de Torrijos por el más levantino de Torrellas, dándole este nuevo, aunque por otra parte semejante nombre, posiblemente después de su destrucción y refundación? Dos circunstancias se ofrecen a mi juicio para que ello pudiere suceder:

1) Varios obispos de la muy próxima Tarazona, en el período que aquí contemplamos, procedían de Cataluña o de zonas muy próximas a ella o tuvieron relación con Cataluña: Pedro Arnau de Torres (1317-1321), natural de la villa de Torres, hoy llamada "Torres del Obispo", cercana a la provincia de Lérida; Fernando Pérez Calvillo (13911397), íntimo del Papa Luna y creado cardenal por éste, que fue antes obispo de Vich y también administrador apostólico de Tarragona; Berenguer de Ribalta (1404-1405), también en tiempo de Benedicto XIII; el fidelísimo a éste Francesc Climent, obispo de

19 Cambios de nombre de una localidad mucho más dispares han tenido lugar en la Península, como el de Mayorga en Valencia de Campos y Valencia de Don Juan, y el más afín al caso que estudiamos de Torrejón de la Ribera (distinto, aunque cercano, al de Ardoz) en San Fernando el Real o de Henares (ver P. ILLANA, "San Fernando de Henares. 250 aniversario» en Historia 16, 242 (jun. 1996). Al fin y al cabo, en nuestro caso el cambio no es tan total, pues la raíz del topónimo se conserva intacta, sino solamente de un diminutivo de tipo aragonés (Torrijos) a un diminutivo de tipo catalánvalenciano (Torrellas), con la misma raíz verbal.

20 Ver La Casa de Luna, p. 366, doc. 73 (3 sept. 1303).

21 Ver mi artículo «Notas sobre la economía fronteriza castellano-aragonesa en la Baja Edad Media”, en Anales de la Univ. de Alicante, 6 (1987), pp. 330-331. 
Malloca, administrador de Tarazona de 1405 a 1407 a la vez que obispo de Tortosa y más tarde arzobispo de Zaragoza y obispo de Barcelona; el valenciano Juan de Valterra entre 1407 y 1433; y por fin un Moncada y un Ortí en el mismo siglo XVI22.

2) La época de don Antón de Luna en los tiempos de Caspe, quien, como es sabido, tomó partido por el Conde de Urgel, teniendo numerosos parientes catalanes (entre ellos el propio conde D. Jaime del que fue contrapariente), ya que casó en segundas nupcias con Leonor de Cervelló, y su hermana Beatriz fue la segunda esposa del conde de Cardona Hugo Folch II, casado luego en terceras con Isabel de Urgel ${ }^{23}$.

Ya hemos visto cómo los Luna, desde Juan Martínez de Luna (al que siguió Fernán López de Luna) fueron señores del muy próximo los Fayos, donde tenemos documentado un castillo y del que quizás Torrellas no fue sino una dependiencia, salvo que perteneciera al señorío de los obispos de Tarazona. Además, Juan Martínez de Luna (a+.1309), contemporáneo de la Sentencia, aparece con frecuencia en Valencia posiblemente camino de Librilla en el reino de Murcia, diócesis de Cartagena, cuyo señorío le había concedido Jaime I en documento fechado en Murcia el 1 de febrero de $1301^{24}$. Y si Librilla dejó de pertenecer a los Luna por efecto de la Sentencia, no así Los Fayos, cuya posesión pudo continuar en la familia hasta los tiempos de D. Antón.

En cualquier momento estos personajes, en nuestra hipótesis preferiblemente los posteriores a la devastación en 1357, u otros catalanes o valencianos parientes suyos o bajo su dependencia, pudieron presidir la refundación o reconstrucción de la antigua Torrijos y darle el nuevo y semejante, pero más catalinazante diminutivo de Torrellas que tenía ya al llegar los tiempos de Zurita. Esto explicaría satisfactoriamente la discrepancia entre éste y la documentación.

En Torrellas enseñan hoy una casa de más noble apariencia donde, según la tradición del lugar, se pronunció la Sentencia. Esto podría ofrecer alguna dificultad a nuestra hipótesis, si no fuera por la no siempre fiable seguridad de estas noticias de origen popular. Además, en los ejemplos citados más arriba, vemos cómo el castillo o casa principal se mantuvo a veces indemne en medio de la devastación, sirviendo de refugio a los pobladores.

Sabemos que nuestra hipótesis es sólo eso, una hipótesis, aunque a nuestro juicio, como hemos intentado demostrar, la más probable, por más que carezcamos por el momento de pruebas históricas definitivas. Es muy posible que éstas, tratándose de un lugar modesto a pesar de la importancia histórica que, en aquellos días de agosto de un ya lejano 1304, adquirió, con consecuencias relevantes y prolongadas para el futuro peninsular, nunca se lleguen a encontrar; y que debamos dejar aquí nuestra investigación porque, siguiendo el prudente consejo de Don Quijote cuando se le preguntó por la realidad de Dulcinea, "estas no son de las cosas cuya averiguación se ha de llevar hasta el cabo» 25 .

22 Q. ALDEA; T. MARÍN y J. VIVES, DHEE, IV (1975), pp. 25-26 (Tarazona. Episcopologio).

23 F. DE MOXÓ, El Papa Luna, un imposible empeño. Estudio político-económico, vol. Il, Colecc. Aragón 73 (1986), p. 92, tabla VI.

24 Ver La Casa de Luna, pp. 163, 169, 229 y doc. 62. También Ap. II, D.

25 Don Quijote, $2^{a}$ Parte, cap. XXXII. 



\title{
LA FERIA DE ALICANTE (1296-1804)
}

\author{
Enrique CUTILLAS BERNAL
}

Quienes nos enfrentamos al tema de la Feria de Alicante pasamos algunos momentos de asombro al comprobar cómo la concesión de un Privilegio tan importante para cualquier villa o ciudad, fue relegado al olvido, desaprovechándose los grandes beneficios que podían obtener de la feria las gentes de la entonces villa de Alicante.

Resulta difícil comprender que, en tan sólo doscientos años, la Feria de Alicante tuviera que cambiar de fecha cuatro veces, mientras que otras ferias seguían celebrándose en la primera fecha concedida. Y no sólo esto, porque también variaría su emplazamiento y titularidad repetidas veces, hasta el punto de que el historiador llega a dudar si hubo una o tres ferias, si las celebraciones fueron constantes o estuvo desaparecida durante largos períodos.

Hoy nuestra ponencia aporta nueva documentación que permite esclarecer el devenir de la Feria nacida hace ahora setecientos años, la poca inclinación ferial de Alicante y cómo las clases dirigentes de la Ciudad, manipulando la organización en favor de sus intereses personales, consiguieron hacerla fracasar en reiteradas ocasiones, hasta hacerla desaparecer durante largos períodos al provocar la huida de feriantes a otras poblaciones donde no existían presiones fiscales y económicas.

\section{EL NACIMIENTO DE LA FERIA}

Sobre su inicio, la documentación nos demuestra que en 1296

«... el rey don Jaime de Aragón concedía Privilegio perpetuo de Feria para agosto... francos los géneros de todo derecho»'.

1 A.M.A. Arm. 1, Lib. 50, Fol. 101. 
No debió conseguir el éxito esperado, porque el Consell solicitaba 87 años más tarde que les fuera concedida otra fecha ante la falta de asistencia de feriantes:

«... el señor rey don Pedro de Aragón, dispensó en doze de abril de mil trescientos ochenta y tres, el cambio de fecha, pasando a celebrarse... al mes de diciembre»?2.

Los feriantes seguían sin acudir a la feria alicantina y 76 años después, nuevamente el Consell solicitaba un nuevo cambio de fecha:

«... el tres de abril de mil quatrocientos cincuenta y nueve... el señor rey don Juan de Aragón (entre otras cosas) confirmó el citado privilegio de Feria... variando el tiempo de la feria del mes de diciembre que entonces se celebraba al de octubre ${ }^{3}$.

Ya convertida Alicante en ciudad, el 2 de enero de 1496, se cumplen ahora cinco siglos, el rey Fernando "confirmó los dos Privilegios antecedentes con franqueza de todos derechos...»"

Los primeros años tras la concesión de Jaime Il y las cuatro décadas siguientes a la confirmación de Fernando el Católico, debieron ser los dos períodos de mayor rendimiento ferial, pues la Ciudad reconocía años después que la celebración, «tubo su continuado y vio la mencionada feria por toda la serie de las Eras... durante el mes de octubre»5.

Esta afirmación nos parece exagerada. Por lo menos deformada, pues no volvemos a tener noticia de la feria (como tal feria de Alicante) hasta el último tercio del siglo XVIII.

$Y$ no es que dejara de celebrarse, pero si sufriría transformaciones importantes a partir de 1530, pasando a celebrarse en el Monasterio de la Santa Faz y en los aledaños de San Nicolás, para dar servicio a las gentes de la Ciudad y a los cercanos caseríos de San Juan, Muchamiel y demás partidas de la Huerta. La primitiva feria de Alicante se convirtió en la Feria de la Santa Faz.

\section{LA FERIA EN EL CASERÍO}

Escasa y poco detallada es la documentación que nos aparece sobre la feria del día de la Santa Faz, y las más antiguas citas documentales nos presentan un mercado heterogéneo, con un sólo día de duración. Es algo que encontramos lógico al ser ese, el tiempo que los visitantes permanecían en el caserío.

2 A.M.A. Arm. 1, Lib. 50, Fol. 101.

3 A.M.A. Supra.

4 A.M.A. lbíd.

5 A.M.A. Arm. 1, Lib. 50, Fol.102. 
Pero antes de adentrarnos en el tema, vamos a distinguir tres tipos de feria bajo la advocación de la Santa Faz: la primera, se instalaba en el caserío durante el día de la fiesta; otra que se colocaba primitivamente en las puertas del Ayuntamiento y la Colegial, para aprovechar la afluencia de gentes que acudían para acompañar a la Peregrina; y la tercera, mucho más tardía, que conseguiría la Ciudad en el último tercio del siglo XVIII, también bajo el título de feria de la Santa Faz, pero con ocho días de duración e instalada en Alicante. Su situación fue variable y el éxito efímero.

Por eso debemos tener cuidado para no confundir unas con otras, pues todas ellas nos vienen en los documentos como feria de la Santa Faz.

Pero centrémonos en la más antigua, y que perdura hasta nuestros días: la que se instala en el caserío el día de la romería.

La falta de documentos no nos permite conocer su nacimiento, pero es plausible que naciera sustituyendo a la primitiva feria, al calor de la Peregrina, posiblemente algunos años después de las primeras romerías, cuando la afluencia de devotos permitiera a los feriantes obtener algunas ganancias que compensaran los desplazamientos y los riesgos que estos conllevaban.

Durante el siglo XVI y primer tercio del XVII debieron producirse desplazamientos rápidos e inseguros, instalándose a la salida del sol para marcharse antes de anochecer, pues estaba totalmente prohibido en los momentos de peligro de asaltos, circular de noche por la Huerta. E incluso a mediados del XVI, las mujeres y niños debían abandonar sus casas y sus bienes para refugiarse por las noches en el Monasterio:

“... que de ninguna manera fuera de las torres, Yglesia o Monasterio, quede mujer ni niño a dormir, ni pueda venir ni estar en la dicha guarta asta que esté descubierto y assigurada la dicha guerta... y senyalar personas en la huerta que tengan cargo de visitarla para ver si se retrahen a donde está dicho" ${ }^{6}$.

Con estas condiciones los feriantes no podrían establecerse en los alrededores del Monasterio la noche anterior, ni continuar después de ponerse el sol, el día 17 de marzo. El incumplimiento no sólo conllevaba determinadas sanciones económicas, ya que también estaba prohibido que fueran rescatados en caso de caer en manos de corsarios:

«Que de ninguna manera se pueda rescatar ninguno que se tomare de cualquier condición, que se fuere de las dichas torres, Yglesia o Monasterio, de lo qual se hará provissión y crida, con las penas que pareciere, y modificación de la crida contenida»? ${ }^{7}$.

No se debe olvidar que el peligro berberisco era constante y los desembarcos en

6 A.M.A. Arm. 1, Lib. 9, Fols. 66 y ss.

7 Supra. 
las cercanas playas menudearon hasta casi mediado el siglo XVII. No en vano en mayo de 1638, la abadesa sor Philipa Cisternes, firmaba haber recibido de

«Pedro Borgonión, síndico de dicho Con(ven)to una arrova y media de pólvora, trescientas balas, un roll de cuerdas de arcabús, todo lo qual dise dicho síndico, le ha dado la Ciudad para en caso de necesidad de moros, tenga para poder tirar los escuriles y mosquetes que están en la torre de dicho convento" ${ }^{8}$.

El peligro se mantendría al acecho en los años siguientes, pues se ordenaba doblar las guardias y refuerzos ${ }^{9}$.

A partir de mediados el siglo XVII, los peligrosos ataques corsarios fueron espaciándose hasta quedar la situación más tranquila, lo que valdría a los feriantes, el poder acudir en mayor número, configurándose así la feria tal como hoy la conocemos.

Pero así y todo, en estos primeros años el servicio comercial que prestaban los feriantes no pudo ser muy grande. Sin duda se establecieron paradas que procuraban los géneros más necesarios a los visitantes y gentes de la huerta, pero tenemos constancia de que las mismas religiosas obtenían mercancías por otros medios, incluso en los mismos barcos que los transportaban. Al menos esto se deduce de una orden de los jurados, fechada el 23 de noviembre de 1551, por la que obligaban a las monjas a pagar al arrendador de los derechos de la sisa mayor, los derechos correspondientes a las mercancías que habían comprado las religiosas Clarisas del Monasterio de la Santa Faz, mercancías que:

«... fueron desembarcadas y luego se arrepintieron y volvieron a embarcar en el mismo buque... $\gg^{10}$.

También estaría en relación la importancia de la feria con el número de visitantes que ese día se desplazaba al Monasterio, sin duda grande para la población de aquellos años, pero que, según datos de una rogativa que pasaría a la historia como multitudinaria, se habrían reunido 800 personas ${ }^{11}$. Es más, en la tardía fecha de 1763, sólo habitaban en el caserío de Santa Faz 29 vecinos.

Sí tenemos noticias de la feria que se celebraba el día 17 de marzo en los siglos primeros; sólo nos indican su existencia y pocos datos más aportan, comenzando a dar noticias documentadas a principios del siglo XVIII.

En 1701 la ciudad de Murcia había enviado a Alicante un bando que hacía saber la ratificación de Felipe $V$ del antiguo privilegio de feria para aquella ciudad, comunicando a los feriantes alicantinos las fechas en que se efectuaría para su posible asis-

8 A.M.A. Arm. 5, Lib. 16, Fol. 151.

9 Ibíd. Fol. 206.

10 A.M.A. Arm. 5, Lib. 67, Fol. 1.

11 A.M.A. Arm. 5, Caja n 24, s/fol. 
tencia. Ante esta noticia los jurats alicantinos escribían días más tarde a los de Murcia solicitando información de las prerrogativas concedidas por la Corona y si el nuevo monarca les había respetado todos los privilegios o había abolido algunos.

El 15 de marzo de 1702, los regidores de la capital del Segura respondían a las autoridades municipales alicantinas que el monarca se había servido:

«... confirmar y aprovar a esta Ciudad, por Real Despacho de 19 de noviembre del año próximo pasado, todos sus privilegios, gracias, franquezas, livertades y prerrogativas, y entre ellas que se buelba a restablecer y zelebrar en esta Ciudad, una feria que tenía principio desde el día 25 de agosto y los 15 dias siguientes, de cada un año, con todas las franquezas y calidades que expresa la zitada real confirmación, y el privilegio original que obtubo esta Ciudad del Señor Rey don Alfonso el décimo, su data a 19 de maio de $1304 \ldots \gg^{12}$.

Nacía así la idea entre los jurats alicantinos de conseguir una feria que debería celebrarse el día de la Santa Faz no sólo como hasta entonces se venía haciendo, con un día de duración, sino alargándola hasta ocho días más.

Para conseguir estos propósitos daban los jurats orden a don José Caballero, su procurador en la Corte, para que intentara conseguir que se celebrara la feria durante ocho días a partir del 17 de marzo, ya que la actual feria de la Santa Faz «por introducción solo tiene uno...»"13.

Con fecha 17 de abril de 1702, los jurats escribían nuevamente al citado procurador instándole a que la solicitud pareciera pedida por las monjas, para que:

"se comprehenda que las señoras Religiosas, son las que desean tener ocho días de mercado franco de todo género de mercaderías, ropas, ganados y demás cossas comerciables, y que nuestra obligación, solicita por su consuelo. $Y$ assí en todo casso salga la concesión a instancia de la abadesa y monjas, $y$ se pida el informe con el sobreescrito de Mercado franco, porque no comprehendan essos Señores del Consejo, que es esta gracia, de perjuicio a los derechos reales que se cobran en esta Ciudad" ${ }^{14}$.

Una muestra más de la utilización que para sus intereses hizo la Ciudad de la fundación del Monasterio.

Lo que no esperaban los jurats cuando decidieron solicitar la feria a nombre de las Clarisas, sería que estas elevaran al Consejo de Aragón un memorial, para que no se concediera la ampliación de la feria, en beneficio de la paz y tranquilidad de un lugar de meditación como era el Monasterio.

12 A.M.A. Arm. 11, Lib. 28, Fol. 10.

13 A.M.A. Arm. 11, Lib. 27, Fol. 28.

14 A.M.A. Arm. 11, Lib. 27, Fol. 31 v. 
Ante la petición de las religiosas, el Consejo de Aragón denegaba la solicitud del Ayuntamiento. El 5 de junio del mismo año, don José Caballero, escribía desde Madrid justificando la negativa del Consejo:

“Ante el memorial que se presentó por la abadesa y convento de la Santísima Faz, respecto a la pretensión de feria... hizo bien el escribano de no presentar el suyo, pedido por la Ciudad» ${ }^{15}$.

No se arredraron los jurados alicantinos y pese a serles denegada la ampliación de la feria, fueron permitiendo una mayor libertad de estancia a los feriantes, hasta el punto que en 1718 se instalaban por tres días, con las consiguientes quejas de las religiosas, que escribían este año al Gobernador pidiendo que evitara la ampliación. La respuesta de éste justificaba la decisión de los regidores, porque los feriantes tenían necesidad de terminar de vender sus mercancías.

Además, el control y organización de la feria no debía ser muy estricto. No consta en estos años mención alguna a la organización y adjudicación de puestos, siendo permanentes las quejas del arrendador de la sisa de la puerta de tierra, doliéndose por la falta de observancia de los Capítulos de arrendamiento:

«... como la falta de manifiestos que no le dan los mercaderes de las ropas de seda que introducen por los correos y de las gentes que se introducen para la feria de la Santa Faz»16.

La pertenencia de los terrenos en los que se situaban las paradas de los feriantes haría surgir problemas jurisdiccionales con la vecina universidad de San Juan; y en los momentos de segregación, se agudizarían las disputas.

En 1766, Pascual Fita denunciaba ante la Ciudad que el día nueve de abril anterior, durante la feria de la Santa Faz, se habían introducido los alcaldes pedáneos, diputados de justicia de San Juan, obligando a algunos feriantes a pagar licencia de venta. Uno de los feriantes al no haber vendido aún, no pudo abonar lo pedido, siendo detenido y amenazado con armas por los pedáneos quienes «le destrozaron el puesto de juguetes" ${ }^{17}$.

El denunciante exponía las quejas que habían presentado los vendedores, quienes pedían justicia a la Ciudad y su intervención para evitar los altercados que estuvieron a punto de producirse ante el amotinamiento de las gentes que rodearon a los de San Juan.

La denuncia sería elevada a la Real Audiencia y ésta por Real Provisión de 30 de julio citaba a los pedáneos de San Juan y a otros testigos:

15 A.M.A. Arm. 11, Lib. 27, Fol. 45.

16 A.M.A. Arm. 9, Lib. 12, Fol. 74.

17 A.M.A. Arm. 1, Lib. 41, Fol. 128. 
«para verificar los excesos de los referidos alcaldes en averse introducido en la Feria de la Santísima Faz, que se celebra en el territorio de esta Ciudad y procedido a exigir algunas cantidades de los feriantes y prender a quien se resistía» ${ }^{18}$.

La causa se fallaba el 15 de diciembre de 1766, condenando a los alcaldes a pagar las costas, ordenándoles que no podían exigir cantidad alguna en la citada feria ${ }^{19}$.

La falta de organización daría lugar a que en la feria apareciera la picaresca. Si en años atrás se quejaba de ciertas anomalías el arrendador de la sisa de puerta de tierra, en 1772, el señor Merchent denunciaba ante el Cabildo «que en la feria de la Santissima Faz que se celebraba en una de las partidas de esta jurisdicción», había observado el pasado año, cómo el arrendador de pesos y medidas suministraba medidas de caña a los feriantes de paño «que se establecen en la parte de levante del barranco", teniendo que obligarle a que las diera de madera con el sello de la Ciu$\operatorname{dad}^{20}$.

Aunque San Juan en aquellos momentos estaba unido a Alicante por acuerdos económicos, la zona donde el arrendador repartía las medidas antirreglamentarias era término del lugar de San Juan y esto provocaría numerosos incidentes como el de 1766.

En la feria de 1772 el alcalde mayor de Alicante encontró ejerciendo jurisdicción en la Santa Faz al segundo diputado de justicia de San Juan, remitiéndole preso a la Ciudad ${ }^{21}$.

Hasta entonces los feriantes se instalaban en las paradas sin otro canon que el costo de los operarios municipales que montaban los puestos y otro tanto que voluntariamente y por tradición entregaban a las religiosas como limosna, quedando en manos de la Ciudad los repesos y faenas propias del fiel ejecutor. Pero en 1771, un feriante iba a dar a los regidores nuevas ideas para conseguir dinero por los terrenos.

En febrero de 1771 José Richart, tratante vecino de esta Ciudad solicitaba:

«... una de esas paradas de listonería de la feria de la Santísima Faz, juridisción de esta Ciudad... que él ha visto en otras poblaciones en que se celebran ferias de porte, que los respectivos Ayuntamientos distribuyen los puestos a los feriantes para formar sus tiendas ${ }^{22}$.

El solicitante pedía se le concediera un puesto para la siguiente feria, estando dispuesto a abonar la cantidad exigida.

La ocasión podía proporcionar fondos a las arcas municipales y estos siempre eran necesarios, pero sobre todo ese año, en que los diputados del Comercio habían con-

18 A.M.A. Arm. 9, Lib. 56, Fol. 161.

19 A.M.A. Arm. 1, Lib. 41, Fol. 257.

20 A.M.A. Arm. 9, Lib. 66, Fol. 193 v.

21 Ibíd. Fol. 211.

22 A.M.A. Arm. 9, Lib. 65, Fol. 32 v. 
seguido una Real Provisión, fechada en Madrid el 11 de abril de 1771 en la que se ordenaba al "Justicia, Ayuntamiento y Junta de Propios de Mar» que a partir de ese año cesase el derecho de la sisa de puerta de tierra, debiendo dejar libre la entrada de todos los géneros ${ }^{23}$.

En la feria del año siguiente los regidores decidieron organizar los puestos y cobrar un canon por la cesión del suelo, con las consiguientes quejas de los feriantes, por las pérdidas que esto les ocasionaba.

El cese del tributo de la puerta de tierra haría renacer entre los regidores la vieja idea de conseguir que la feria de la Santa Faz se alargara hasta ocho días, algo que había fracasado a principio de siglo, por la negativa de las religiosas.

Y no sólo eso, porque el afán de obtener ingresos llevaría a los regidores a ocuparse de otros temas. Por Resolución Capitular de 9 de marzo de 1771, al tener conocimiento de que en San Vicente y Santa Faz, se habían levantado, "casas unidas y en forma de población» y que sus dueños las alquilaban para viviendas o tiendas, sin que abonaran el Equivalente, acordaban enterarse de los alquileres para gravarlos con el citado impuesto ${ }^{24}$.

Las innovaciones realizadas por los regidores en la feria de 1772 cobrando a los feriantes la superficie ocupada mientras que ellos mismos tenían que levantar la parada por su cuenta, incluso proveerse de maderas para ello, daría lugar a una mayor desorganización y quejas a los frailes del Monasterio, quienes expusieron el caso a la abadesa.

Días antes de la feria de 1773, la Comunidad del Monasterio escribía al Gobernador, exponiendo el notable perjuicio que sufrían los feriantes:

«... al acerse por sí las paradas para sus venderías, tanto por los transportes de madera, repartimiento de sitios, y a los que vengan forasteros, encontrarse sin tener donde poder vender. $Y$ teniendo proporción la Comunidad de acer por sus donados, las paradas sin perjuicio del público, ni contra lo dispuesto por la resolución de su Magestad, y si beneficio de los mismos feriantes que enquentran echas las paradas sin más que reconocer el trabajo de nuestros hermanos... se sirva concederles su permiso para que agan acer por su quenta las paradas, dando V프 Exa. su comisión al Padre Procurador de este Monasterio, para que con facultades de $V^{a}$ Exa. reparta los puestos para evitar disputas y etiquetas ${ }^{25}$.

El gobernador las autorizaba, sin perjuicio de los derechos y regalías de la Ciudad y de los feriantes, con tal de que todo se ejecutara «en los sitios, paradas, methodo y modo", que beneficiara a los feriantes, al tiempo que prohibía a las monjas que exi-

23 A.M.A. Arm. 9, Lib. 64, Fol. 258 v.

24 A.M.A. Arm. 9, Lib. 65, Fol. 37.

25 A.M.A. Arm. 1, Lib. 51, Fol. 144. 
gieran «otro premio ni interés, ni aún con precepto de limosna que el del legítimo importe del trabajo y costo de hacerlas ${ }^{26}$.

La concesión de organizar la feria a las religiosas, fue un duro golpe para los regidores. No sólo por las pérdidas económicas que representaba, sino por perder algo que siempre habían considerado de su total dominio, y porque veían decrecer sus prerrogativas como patronos del Monasterio y por tanto el dominio de la Comunidad.

Las diferencias por esta concesión del gobernador duraría largos años. De nada sirvieron las alegaciones de los regidores al gobernador, llegando el litigio a ser presentado en la Corte.

Cinco años más tarde, las religiosas seguían organizando las paradas de los feriantes, pero el caso no estaba cerrado. Ante la denuncia de los regidores al Consejo por la actuación del gobernador y corregidor de la Ciudad, éste presentaba su informe el 28 de julio de 1778 en Madrid. Dos días más tarde el procurador de la Ciudad en la Corte remitía al Ayuntamiento copia del citado informe, demostrando los derechos del corregidor en la feria:

"La feria de la Santa Faz, en todos tiempos ha sido dispuesto y arreglada por el Corregidor de esta Ciudad, sin la menor intervención de los regidores, en quanto al señalamiento de sitios y terreno para las paradas de feriantes, quedando sólo a cargo y cuidado de los regidores y diputados del común, últimamente los repesos y demás pertenecientes al fiel executor de mes. Y si en tiempo de mi antecesor el conde de Baillencour asistían los regidores, fue por comicción, encargo o mandato de dicho Governador....27

Don Jorge Dunant, como corregidor de Alicante, rechazaba las acusaciones del Ayuntamiento y demostraba que la petición de los regidores como organizadores de la feria carecía de fundamento y perjudicaba la celebración de ella al dar motivos de descontento a los feriantes, que terminarían por no acudir a ella. Porque no se les podían cobrar impuestos por los terrenos, ya que:

«los feriantes únicamente contribuyeron por el trabajo de los operarios que se ocuparon en la formación de las paradas y la limosna regular que siempre se ha hecho desde antiguo a las monjas del citado Monasterio ${ }^{28}$.

La imposibilidad por parte de los regidores de organizar la feria, atribución concedida a las religiosas, endurecería más las relaciones entre la Comunidad y los patronos, lo que sería aprovechado por las autoridades de San Juan, que estaban dispuestas a segregarse de la Ciudad.

26 Supra.

27 A.M.A. Arm. 12, Lib. 34, Fols. 124, 126 y 127.

28 Supra. 
El 8 de abril de 1777 un memorial de Bautista Planelles, arrendador en San Juan del peso y medidas, solicitaba del Ayuntamiento de Alicante que no se le pusiera impedimento a sus funciones en la feria de la Santa Faz.

No se haría esperar la respuesta y se le hacía saber que el derecho de pesos y medidas era de la Ciudad y estaba arrendado, sin que San Juan tuviera nada que ver en ello:

«... que los de cántaro de vino, media arrova de azeite y barchilla, pertenecen por mitad a la Real Hacienda y a esta Ciudad. Que los arrendadores de los referidos derehos se hallan en posesión de percibir todos los que causan derechos, pesos y medidas en todo el recinto de la feria de la Santísima Faz»29.

Las cosas se complicarían en junio de 1779 , cuando San Juan conseguía la deseada segregación.

El 13 de marzo de 1780 el síndico procurador general informaba a los regidores que al haber ganado San Juan la segregación de Alicante, existía el posible peligro de que en los próximos días de feria de la Santa Faz, pretendieran ejercer jurisdicción «a la otra parte del convento y en la que se llama del barranquet». Para evitarlo acordaban que todos los géneros que se vendieran, lo hicieran dentro de las calles del caserío ${ }^{30}$.

San Juan se había independizado de Alicante, al convertirse en Universidad en 1590, concediéndoles unos términos propios mediante delimitación realizada en 1593, y quedando dentro de ellos «hasta un cuarto de legua que hay de esta con la dicha Ciudad ${ }^{31}$.

Cuando en 1614 por intereses económicos la joven universidad volvía a unirse a Alicante, las cosas permanecieron tranquilas, hasta que la última segregación de 1779 les recordó que el Ayuntamiento alicantino tenía apropiado parte de ese cuarto de legua, en el que estaba incluido el Monasterio.

No se conformarían los de San Juan con las decisiones de la Ciudad para instalar los puestos dentro de sus límites, por lo que se quejarían a la Real Audiencia, alegando sus derechos.

El fallo de la Audiencia les sería favorable, al demostrar que en 1593 había quedado dentro del término de San Juan:

«El convento y caserío de la Santa Faz (donde) de inmemorial se celebra una feria» ${ }^{32}$.

29 A.M.A. Arm. 9, Lib. 72, Fol. 132.

30 A.M.A. Arm. 9, Lib. 75, Fol. 86.

31 A.M.A. Arm. 1, Lib. 59, Fol. 91.

32 Ibíd. Fols. 66 y ss. 
También dejaba claro que en la feria, los vendedores no sólo habían ocupado la plaza, «sino también el barranquet, tocando al expresado convento» ${ }^{33}$.

El 28 de marzo, un Real Despacho ordenaba a la Ciudad que no hiciese innovación alguna en la feria que debía celebrarse el día 6 de abril próximo, según pedían los síndicos y procurador de San Juan, debiendo celebrarse como de costumbre, bajo pena de 500 libras $^{34}$.

A los regidores alicantinos no les quedaba otra alternativa que acatar lo ordenado, pero acordando que en atención a que el terreno que hasta entonces venía ocupando la feria era perteneciente a la Ciudad, se comunicara a los de San Juan, que se inhibieran de ejercer jurisdicción para «evitar las consecuencias, si se confunden juridisciones ${ }^{35}$.

La respuesta de las autoridades de San Juan, no dejaba dudas. Pese a saber que su término llegaba hasta un cuarto de legua dentro del cual quedaba el convento por ese año aceptaban llegar «sólo hasta la pared del convento», sin que ello significara que no reclamaran el cuarto de legua en los años posteriores ${ }^{36}$.

No se conformarían los regidores alicantinos y elevaron nueva instancia a la Real Audiencia, pero el fallo favorecería de nuevo a San Juan, al concederles llegar hasta la pared trasera del Monasterio.

La polémica había terminado con descontento para todos, hasta para las religiosas, pues a partir de ese año ya no tenemos constancia de que siguieran organizando la feria, posiblemente por encontrarse ante dos juridiscciones... En este ambiente seguiría celebrándose la fiesta de la Santa Faz, al menos hasta 1804, último año trabajado. La jurisdicción compartida no parece que suscitara nuevos problemas, bien fuera por común acuerdo o bien porque alguna de las partes hiciera dejación de sus derechos.

En 1793 por Resolución Capitular se suspendía la feria por estar declarada la guerra con Francia ${ }^{37}$, intentando evitar posibles disturbios entre los alicantinos y la población francesa asentada en la Ciudad. La idea era bien acogida por el alcalde ordinario de la universidad de San Juan, quien escribía para informarse:

«Acaba de llegar a mi noticia que $\mathrm{V}^{\mathrm{a}} \mathrm{S}^{\mathrm{a}}$, ha mandado publicarse un bando en esa Ciudad prohibiendo por este año la feria de la Santa Faz, y como ésta se celebra igualmente en el territorio y juridisción de esta universidad, deseo saber, si la providencia de $V^{\mathfrak{a}} \mathrm{S}^{\mathrm{a}}$, es cierta para hacer yo lo mismo en dicha universidad, pues en las actuales circunstancias, quiero uniformar mis procedimientos con los de $\mathrm{V}^{\mathrm{a}} \mathrm{S}^{\mathrm{a}}$, evitando todo genero de ocasión en que pueda acumularse concurso de gentes ${ }^{38}$.

34 A.M.A. Arm. 9, Lib. 75, Fol. 108 y Arm. 1, Lib. 59, Fol. 62.

35 A.M.A. Arm. 9, Lib. 75, Fol. 108.

36 A.M.A. Arm. 1, Lib. 59, Fol. 91.

37 A.M.A. Arm. 9, Lib. 88, Fol. 42 v.

38 A.M.A. Arm. 12, Lib. 49, Fol. 34. 
La calma parecía reinar entre las autoridades de San Juan y Alicante, pero estos últimos tendrían nuevos sobresaltos al recibir noticia de que en el caserío de la Santa Faz se intentaba nombrar un alguacil sin contar con la Ciudad. Los regidores reconocían que eso no debía llevarse a cabo, porque «supondría un primer paso para la segregación $»^{39}$.

Si hasta ahora hemos expuesto la evolución de lo que consideramos realmente la feria de la Santa Faz hasta finales del siglo XVIII, no podemos dejar de referirnos a "otra feria», que con el mismo nombre se celebraba en la plaza del Mar y atrio del Ayuntamiento, cercana a las paradas que se montaban junto a San Nicolás. Esta, como la que se celebraba en el Monasterio, y otra que posteriormente obtendría la Ciudad, recibieron la denominación de ferias de la Santa Faz.

Hablemos de estas dos aunque lo hagamos de forma sucinta ya que, como arriba señalamos, el tener todas el mismo nombre pueden llevar a confusiones.

Al mismo tiempo que se celebraba la feria en el cercano caserío y para aprovechar la afluencia de público a la Colegial y las Casas de la Ciudad cuando iba a salir la Peregrina, se instalaban por la mañana del día 17 de marzo una serie de paradas que aprovisionaban al público de las más heterogéneas mercancías. Se trataría de un pequeño núcleo comercial atraído por los posibles clientes que se disponían para la romería y por tratarse de un día festivo en la Ciudad. Desde un principio parece ser que su duración junto a las puertas de San Nicolás y en los atrios del Ayuntamiento, sólo era de un día. Posteriormente, cuando los regidores ampliaron a tres días la feria del caserío, pese a las quejas de la Comunidad, también fueron concedidos dos días más para estas paradas:

«... hizo saber la costumbre que consecuentemente a la feria de la Santísima Faz, ay y ha havido de aserse en esta Ciudad las paradas de la plaza del Mar y atrio de las Casas Consistoriales, por los dos días sucesivos, y que para el efecto estava dispuesta la madera.... ${ }^{40}$.

Este nexo entre las dos ferias en un mismo día y con la misma denominación llevaría a equívocos que hicieron confundir una con otra. Posteriormente se enredaría aún más la diferenciación pues nacería otra feria, que arrancaba también bajo la advocación de la Santa Faz. Veamos cómo nace.

En líneas anteriores pudimos comprobar como en 1771, el tratante José Richart proponía a los regidores el cobro de las paradas a los feriantes.

Ese mismo año la Ciudad se veía privada de otra fuente de ingresos al ser abolida la sisa de la puerta de tierra, quedando los géneros libres de entrada; la presión que venían ejerciendo sobre la feria del caserío las autoridades de San Juan... todo un cúmulo de causas que llevarían a los regidores a reconsiderar la posibilidad de conseguir autorización para la feria que había sido denegada en 1702.

39 A.M.A. Arm. 9, Lib. 93, Fol. 126.

40 A.M.A. Arm. 9, Lib. 90, Fol. 85. 
El 27 de abril de 1771 la Ciudad elevaba memorial al Consejo:

«deseando sus Señorías promover la pública utilidad de esta población y considerando ser conducente a este fin, que la feria de la SSma Faz, se extienda a ocho días más, en esta Ciudad y separadamente se establezca un día de mercado cada semana... ${ }^{41}$.

Para conseguir este proyecto se comisionaba a los señores Pobil y Caturla, quienes debían instruirse en los privilegios que el Ayuntamiento tenía concedidos para esos fines. Los citados comisionados recomendaban al Cabildo que como primer paso se debía solicitar con justificación al Consejo, señalando que la mejor fecha para la feria «era desde 16 de julio hasta el final de mes y para el día semanal de mercado, el mejor día el lunes» ${ }^{42}$.

Aunque pueda resultar extraño (ya quedó demostrado anteriormente), Alicante carecía de una tradición ferial continuada, pese a tener concedido este privilegio desde el siglo XIII.

En las justificaciones que enviaron Pobil y Caturla, se demostraba esa antigüedad. El primer privilegio había sido concedido por el rey don Jaime, y como fecha para su celebración se les señalaba el mes de agosto, siendo la concesión a perpetuidad, franca de todos los derechos para los géneros que entrasen a la venta.

No tendría éxito la fecha asignada y tras solicitarlo al rey don Pedro de Aragón quedaría confirmada, trasladando la celebración al mes de diciembre, sin que los feriantes sintieran estímulo para frecuentarla. Nuevamente se pediría al rey don Juan de Aragón el cambio de fecha, y el monarca concedía en 1459, que la feria se pasara al mes de octubre.

El 2 de enero de 1496, Fernando el Católico confirmaba todos los privilegios, con franquezas de todos los derechos anteriores. La feria continuó celebrándose en el mes de octubre con mayor o menor suerte, hasta que otras localidades comenzaron a realizar:

«en igual oportunidad de tiempo las ferias de Concentaina y Onteniente, que por su inmediación a aquella Ciudad, arrastraban el concurso a ellas. Que esta novedad impelía a la citada ciudad de Alicante, diputados y síndico personero del Común a restablecer la feria desde diez y seis de julio hasta último del mismo, por ser ocasión de hallarse vacantes otras de este Reyno y seguirse a los principios de agosto la de Orihuela y subcesibamente la de Murcia y Lorca» ${ }^{43}$.

Por estos motivos el Ayuntamiento de Alicante solicitaba del Consejo que aprobara el traslado de la antigua feria al mes de julio y que se le autorizara a tener un día de

41 A.M.A. Arm. 9, Lib. 64, Fol. 65 v.

42 Ibíd. Fol. 69.

43 A.M.A. Arm. 1, Lib. 50, Fol. 101. 
mercado los lunes de cada semana, al igual que lo tenían otras poblaciones del reino, debiendo gozar de franqueza absoluta a todos los géneros sujetos a contribuciones y derechos municipales.

Antes de decidirse el Consejo a otorgar lo solicitado, mandaría informarse de los beneficios o perjuicios que pudiera ocasionar la concesión de la feria solicitada a otras ferias y mercados cercanos y si la Real Hacienda podía sentirse dañada con la concesión. Ante los informes favorables, por Real Resolución de 17 de septiembre de 1772, se concedía a Alicante los privilegios que anteriormente tenía sobre la feria, otorgándole al mismo tiempo la gracia de un día de mercado el lunes de cada semana y ambos en calidad de francos, pero:

«sin perjuicio del derecho de alcavalas que está impuesto sobre los mismos géneros y cobran los diputados del Comercio de aquella Ciudad, para importe del pago de veinte y un mil pesos del cupo del Equivalente de las mismas alcavalas, que se le reparte anualmente con separación de el de los demás vecinos, y estaban obligados a depositar por tercios en la Thesorería del ejercito de dicho Reino, cuia integridad no puede ofenderse con la esención que pretende la espresada Ciudad» ${ }^{44}$.

Los regidores habían intentado conseguir que los géneros que entrasen en la feria y día de mercado quedaran libres hasta del derecho de alcabalas, que cobraban los diputados del comercio como parte del Equivalente que tenían asignado. No debemos olvidar que estos diputados del comercio habían sido los causantes de que la Ciudad perdiera la fuente de ingresos que tenían en la sisa de la puerta de tierra ${ }^{45}$.

Pero esta misma exención ya la habían intentado al solicitar la feria de 1702, porque ese era el motivo que llevó a los regidores de entonces a pedir la feria a nombre de la Comunidad de religiosas del Monasterio, para que no pensaran:

"essos señores del Consejo que es esta gracia de perjuicio a los derechos Reales que se cobra en esta Ciudad ${ }^{46}$.

El anterior privilegio era confirmado el 2 de diciembre de $1772^{47}$, pasando acto seguido a prepararse la feria de 1773 , sin poder imaginarse que mientras ellos tejían sus proyectos, las monjas del Monasterio iban a conseguir del gobernador-corregidor una autorización para organizar las paradas de la feria del caserío, rompiendo los planes que sobre esa feria tenían los regidores.

La nueva feria comenzaba a funcionar en los últimos días del mes de julio de 1773

44 Ibíd. Fol. $104 \mathrm{v}$.

45 A.M.A. Arm. 9, Lib. 64, Fol. 258 v.

46 A.M.A. Arm. 11, Lib. 27, Fol. 31.

47 A.M.A. Arm. 5, Caja n 40, s/fol. 
en el mismo lugar en el que se colocaban las paradas en el día de la Peregrina, "en el atrio de las Casas Consistoriales" ${ }^{48}$.

Tampoco esta vez acompañaría el éxito a la feria alicantina, pues muy pronto sufriría continuos cambios en su emplazamiento, pasando del primero, a la plaza de Ramiro, luego a la plaza del Mar, y posteriormente volver a su lugar de origen en los atrios de las Casas Consistoriales.

Similar porvenir aguardaba al día elegido para mercado, pues habiendo comenzado el lunes, muy pronto sería trasladado al martes, por la falta de abastecedores, hasta el punto de que don José Antonio Romero, corregidor de Alicante en 1796 se quejaba «de la suma decadencia a que havía llegado, sin presentarse forastero alguno»49.

Puede resultar extraño el continuo fracaso de las ferias en Alicante a lo largo de los siglos, posiblemente ocasionado por la mala organización y por la competencia de otras ferias mas llamativas para los vendedores.

También pudo deberse a causas internas, pues en este último período se detectan serias diferencias entre el gobernador y algunos grupos de regidores.

En 1796 tuvieron lugar fuertes presiones de los regidores para evitar la entrada de ciertos géneros forasteros. Se procuraría fomentar el malestar entre los gremios, para que estos embarazaran la llegada de mercaderías, e incluso el alcalde mayor ordenaba encarcelar a algunos vecinos de las poblaciones cercanas, cuando intentaban llegar con sus mercancías para venderlas en el mercado o durante la feria.

En representación elevada a la Audiencia de Valencia por el corregidor de Alicante en 1796, éste denunciaba como la causa de que ningún forastero acudiera al mercado ciertos abusos cometidos:

«... por instancia del clavario del gremio de sarrieros se embargaron a un vecino de Monforte, ciertos capazos, suponiendo aquél, que su ordenanza gremial, tendría el privativo laboreo de dicha especie de manufacturas y que los maestros del oficio reportarían perjuicio en la introducción de dichos obrajes en el mercado. $Y$ en efecto con acuerdo del alcalde mayor, providencia la detención que ya de antemano había hecho por sí mismo el clavario ${ }^{50}$.

Atropellos de este tipo fueron efectuados por los diferentes gremios, deseosos de conservar sus prerrogativas y apoyados por el alcalde $u$ otros regidores, pese a que alguno alzaba su voz en contra de estas anomalías y solicitaba del corregidor que:

«mándase continuar el mercado público en los días señalados a beneficio del común y con admisión de todo género,no siendo de ilícito comercio manufacturas y frutos,según y con la manera que se practica en los demás

48 A.M.A. Arm. 9, Lib. 93, Fol. 122.

49 A.M.A. Arm. 1, Lib. 73, Fol. 239.

50 A.M.A. Arm. 1, Lib. 73, Fol. 240. 
pueblos del Reyno... y que a fin de que los traginantes y conductores forasteros no fuesen molestados con embargos que los empobrecen y retraen de concurrir ${ }^{51}$.

Las requisas quedaban depositadas en manos del regidor diputado de mes y aunque como en esta ocasión el corregidor, tras consultar con los abogados de Ayuntamiento decretaba la devolución de los géneros a los afectados, sin costa alguna para ellos, la realidad mostraba que las detenciones de los forasteros siguieron presentes, propiciando que cada vez acudieran menos vendedores al mercado y a la feria.

Una prueba más de como los regidores actuaban al margen de la ley en beneficio de sus intereses, nos aparece en un Real Decreto de la Audiencia, en el que se ordenaba al Ayuntamiento que respetaran las normas que disponía la Real Provisión del Consejo de 1772 , referente a la feria y mercado:

«... sin permitir que a pretesto de gavelas, ni pagos de derechos gremiales se coarte la introducción y venta de los géneros de lícito comercio con la franqueza correspondiente, en beneficio del Común de aquel pueblo, en los días de mercado de cada semana»52.

Como era costumbre, cuando en Cabildo de 25 de noviembre de 1796 fue leído el fallo de la Audiencia, se prometió acatamiento a la resolución, pero todo serían vanas promesas.

Los abusos reiteradamente permitidos, la disparidad de criterios y una mala organización, terminarían con la feria de ocho días que se celebraba en la ciudad, bajo la advocación de la Santa Faz primero, con la virgen del Carmen después.

Esperamos que con lo aquí expuesto se hayan disipado las dudas que hasta ahora existían, al creer que hubo una feria de la Santa Faz, que se celebraba en el Caserío y luego, por motivos desconocidos, se había trasladado a la Ciudad. Como queda dicho, la feria del Monasterio se celebró allí desde que la gente empezó a acudir en romeria, salvo en contadas ocasiones en que fue suspendida, o en caso de guerra. En la misma fecha se situaba otra en San Nicolás y Casas de la Ciudad, primero de un día de duración y luego con dos días más. Finalmente tendríamos la tercera feria solicitada también como ampliación de la de Santa Faz, pero ésta sería recuperación de antiguos privilegios que tenía concedidos la Ciudad, y se celebraba en la segunda quincena de julio.

51 Ibíd. Fol. $240 \mathrm{v}$.

52 ibíd. Fol. 243. 


\title{
DERECHOS Y PRIVILEGIOS DE LOS MUDÉJARES DE LAS TIERRAS ALICANTINAS EN LA DOCUMENTACIÓN DE JAIME II
}

\author{
Mª Magdalena MARTíNEZ ALMIRA
}

El interés suscitado, recientemente, en torno al modus vivendi de los mudéjares, tras la irrupción de cristianos en las tierras andalusíes, ha dado lugar a aportaciones valiosas que han sacado a la luz el entramado jurídico de una comunidad obligada a readaptar sus ancestrales tradiciones a las exigencias derivadas de una convivencia pacífica.

La abundante legislación medieval promulgada por los monarcas castellanos y aragoneses sigue siendo fuente inagotable para historiadores y juristas en orden al conocimiento de las instituciones jurídicas reguladoras de la economía, sociedad y política de las comunidades mudéjares.

Ahora bien, en el ámbito de la Corona de Aragón los estudios realizados han tenido, por el momento, como principal protagonista a Jaime I quien, como conquistador de la mayor parte de las tierras catalano-aragonesas, hubo de iniciar la tarea de adecuación normativa e institucional a las exigencias de las gentes que poblablan estos lugares'. Pero si difícil hubo de ser la labor iniciada por el Conquistador, no quedó exenta de complicaciones la política de relaciones intercomunitarias que, en la misma

1 En relación al respeto a las instituciones véase la importante aportación documental relativa a las comunidades mudéjares del Reino de Valencia, siendo de obligada consulta la documentación aportada por BURNS en su obra Socitat i documentaciò en el Regnat de València. Diplomatarium l: Introducciò, vol. 1, $1^{\mathrm{a}}$ ed. Valencia, 1988; en relación con las cartas de población otorgadas a las comunidades musulmanas de los pueblos circundantes a Valencia véase FEBRER ROMAGUERA, M.N., Cartas pueblas de las morerías valencianas y documentación complementaria, Zaragoza, 1991; HUICI MIRANDA, A. y CABANES PECOURT, Mà.D., Documentos de Jaime / de Aragón, Valencia, 1976, 2 vols. 
línea, llevaron a término sus sucesores y, en concreto, la del monarca Jaime II; éste, acosado por las vicisitudes de la política castellana, de los reyes de Granada y de los de Berbería se vio obligado a realizar grandes esfuerzos legislativos para seguir manteniendo el ideal de la unidad del Reino.

Pero al lector interesado en el análisis del organigrama jurídico concerniente a las comunidades mudéjares durante el reinado de Jaime II no se le ofrecen obras unitarias, si bien día a día los trabajos monográficos al respecto son cada vez mayores. El objeto de este trabajo es configurar un esquema sintético de las instituciones jurídicas que, a través de los documentos conservados, constate el respeto a determinados derechos inherentes a los mudéjares de Sharq Al-Andalus. Este marco institucional permitirá completar el panorama jurídico relativo a los musulmanes y que hasta el día de hoy no ha sido abordado de forma global.

\section{I. ÁMBITO ESPACIAL Y TEMPORAL EN LA CONFIGURACIÓN DE LOS DERE- CHOS Y PRIVILEGIOS}

La política desarrollada por Jaime II en favor de los mudéjares que permanecieron en territorio levantino, y concretamente en las tierras de Alicante, obedece en primer lugar, a una serie de circunstancias espaciales y temporales motivadas por el respeto a la política del rey castellano Alfonso $X$ el Sabio. Los deseos expansionistas de los monarcas castellanos y aragoneses, que en cada momento ocuparon el poder, encontraron un vehículo favorable en las necesidades que apremiaban a los contigentes poblacionales asentados en los distintos territorios. El objeto principal de la política real fue intentar ganar adeptos a causas comunes, como el bienestar de los súbditos y la paz en sus territorios; estas causas fueron enarboladas como banderas contra la intransigencia religiosa. Es por ello que, en muchas ocasiones, los monarcas, de una $\mathrm{u}$ otra corona, pretendieran ganar el favor de las pequeñas comunidades religiosas a partir de concesiones graciosas con las que conseguir el apoyo de facto para acometer nuevas empresas reconquistadoras. El resultado favorable de esta política fue siempre premiado con el reconocimiento y la concesión de derechos personales y patrimoniales. De este modo se garantizaba el mantenimiento de privilegios reales que, por razón de igualdad y equiparación entre comunidades distintas, se poseian desde antaño.

Todas estas consideraciones quedan de manifiesto en la documentación del monarca Jaime II; éste, desde 1296 hasta la fecha de su muerte, promulga numerosos documentos ratificando y confirmando los derechos de las pequeñas comunidades confesionales murcianas que habían obtenido. Por ello se hace necesario la remisión a los documentos de Alfonso X el Sabio, del Infante don Sancho y de Jaime I para tierras levantinas en general y alicantinas en particular; todos ellos fueron artífices del panorama legistativo heredado por Jaime II para la población mudéjar.

Así pues el trazado del esquema institucional en torno a unos ejes espaciales y temporales de dicha legislación precisa determinar con respecto a este segundo elemento, el tiempo, el momento exacto en que se inicia la política legislativa destinada 
a asegurar la pacífica convivencia entre musulmanes y cristianos. En este sentido podría tomarse como hito inicial el año en que tiene lugar la donación, reconocida publicamente, del reino de Murcia por Alfonso de la Cerda en 1296; ésta actuación política justifica la presencia del monarca en una amplia zona del levante peninsular desde Alicante, pasando por Orihuela, hasta llegar a las tierras de Lorca y Mula².

Pero durante el reinado de Jaime II el Justo, se suceden toda una serie de acontecimientos que irrumpen en el desarrollo lineal de la política del monarca; es, por tanto, con la sentencia de Torrellas, en 1304, cuando se establecen definitivamente los límites espaciales y temporales de la política de Jaime II en la Gobernación y posterior Procuración de Orihuela ${ }^{3}$ y tierras alicantinas ${ }^{4}$; mediante esta política, escasamente innovadora y mayoritariamente conservadora, como se retoman los antiguos derechos de los musulmanes alicantinos, adaptándolos a las nuevas exigencias del momento político y social.

\section{SENTIDO DE LOS TÉRMINOS DERECHOS Y PRIVILEGIOS SEGÚN LOS DO- CUMENTOS REFERIDOS A LA POBLACIÓN MUDÉJAR}

Uno de los primeros aspectos a destacar es el carácter totalizador que los términos derechos y privilegios poseen en relación a las personas integradas en las comunidades islámicas levantinas. Porque, en efecto, estos vocablos comprenden una serie de derechos inherentes a la persona y a su patrimonio, pudiendo diferenciar, a través de las fuentes, las instituciones jurídicas que se pretenden salvaguardar de forma legítima.

Debe advertirse, sin embargo, que son escasos los documentos de Jaime II en los que aparece el término derechos; más bien los derechos, en sentido genérico, se concretan en la documentación a partir del reconocimiento de privilegios, franquicias, libertades, donaciones, mercedes, buenos usos y costumbres en favor de los mudéjares. Así pues puede constatarse desde el momento en que el monarca aragonés hace acto de presencia en territorio castellano; tal ocurre en el documento fechado el 11 de mayo de 1296 en favor de los habitantes de Orihuela ${ }^{5}$, donde estos derechos, sin

2 Véase sobre la presencia del rey Jaime II en tierras murcianas y las vicisitudes de su campaña: Historia de la Región Murciana, t. III, Murcia (1980), pp. 377-384.

3 La consiguiente formación de la gobernación de Orihuela bajo dominio aragonés supone la configuración de un nuevo marco espacial en el que quedaban incluídas las tierras alicantinas. Sobre este aspecto remítase el lector a TORRES FONTES, J., "Los mudéjares murcianos en el siglo XIII", en Murgetana, 17 (1961), p. 79; RODRÍGUEZ LLOPIS, M., “La expansión territorial castellana sobre la Cuenca del Segura (1235-1325)", en Miscelánea Medieval Murciana, XII, Murcia (1985), pp. 113114.

4 Las provisiones reales de los años 1296 y 1297 y el Acta de anexión o carta magna reativa a la incorporación formal del Camp d'Alacant al reino de Valencia en 1308. Puede verse J.M. del ESTAL, "Anexión del Campo d'Alacant al reino de Valencia. Por Jaime II de Aragón (1308)" (Comunicación al I Congres d'Estudis del Camp d'Alacant. Alicante, 29.III.82), Alicante, 1983, pp. 229-278.

5 ESTAL, J.M., del, Privilegios otorgados a la ciudad de Alicante, Edición facsímil, Madrid, 1984, p. 21. 
embargo, se reconocen traducidos en privilegios, franquicias, libertades, donaciones, mercedes, buenos usos y costumbres, de forma general en favor de todos los súbditos del lugar; igual sucede en la carta-privilegio de Jaime II fechada el 23 del citado año en favor de la villa de Alicante ${ }^{6}$. No obstante esta generalización, en cuanto a los destinatarios de los derechos y privilegios, no se da en documentos posteriores, donde ya se hace mención expresa de los beneficiados. Así sucede ante el sitio de Lorca el 15 de julio de 1296 o en Mula dieciocho días más tarde7; en el primer caso el rey precisa los mismos "derechos" alterando tan solo el nombre de los destinatarios y manifiesta su voluntad a los predictis hominibus dicte Ciuitatis Cartaienensis et terminorum suorum/, christianis et judeis et sarracenis ${ }^{8}$. Y del mismo modo ocurre tras la toma de Elche por parte del monarca Jaime II mediante documento fechado el 20 de agosto de 1296 en Valencia; en esta ocasión se dirige a los moradores de la aljama en idénticos términos: per nos et nostros confirmamus vobis, predictis sarracenis ville de Elts, terminorum eius et vestris, perpetuo omnia privilegia, franchitates, libertates, donaciones, mercedes, gracias, bonos usus et consuetudines, quas et que habuistis et habetis a novilibus infante dompno Manuel, quondam et comitissa ac Johanne Manuelis usque ad tempora odierna?

\section{ALCANCE DE LAS CONCESIONES DE JAIME II EN FAVOR DE LA POBLA- CIÓN MUSULMANA}

La presencia castellana en el Reino de Murcia ha permitido a historiadores y juristas trazar en los últimos años un esquema bastante completo del sistema impositivo y garantías jurídicas dirigidas tanto a la población cristiana como a las minorías religiosas sometidas a vínculos reales y señoriales en este marco geográfico ${ }^{10}$.

6 ESTAL, J.M. del, Corpus documental del Reino de Murcia bajo la soberanía de Aragón (12961304/5). Colección de Documentos Medievales Alicantinos, I/1, Alicante, 1985, doc. 120, p. 228 y el traslado notarial doc. 118, p. 223.

7 ESTAL, J.M. del, «Confirmación de Fueros a la ciudad y Reino de Murcia por Jaime ll de Aragón (1296-1304). Anexo documental inédito", en Miscelánea Medieval Murciana, 9, (Murcia 1982), doc. 23, p. 258.

8 ESTAL, J.M. del, "Confirmación de los fueros a la ciudad y reino de Murcia (1296-1304)", op. cit. p. 282.

9 FERRER i MALLOL, Mำ T., Les aljames sarraïnes de la governació d'Oriola en el segle XIV, Barcelona, 1988, doc. 18, p. 194.

10 Sobre el modelo de derechos y obligaciones del conjunto poblacional bajo dominio castellano es de obligada consulta en primer término el organigrama trazado por el profesor Torres Fontes a partir de un esquema globalizador que intenta redistribuir y definir los impuestos relativos a rentas reales, exenciones y franquezas; véase al respecto TORRES FONTES, J., "Documentos del siglo XIII» en CODOM, vol, II, Murcia, 1969, pp. LVII-LXXVI; y en concreto para el señorío de Alguazas, Murgetana, 17(1947), pp. 81-97. El citado autor ofrece también un clarificador panorama sobre el sistema impositivo directo e indirecto en Actas del IV Simposio Internacional de Mudejarismo: economía (Teruel 1719 septiembre de 1987), Teruel, 1992, pp. 387-393. Sobre el contenido y orígenes de los principales tributos exigibles a la población mudéjar véase POCKLINGTON, R., «Nuevos arabismos en los textos 
Por el contrario, el conjunto de derechos y obligaciones, así como el resto de privilegios concedidos en favor de los mudéjares, bajo dominio aragonés, solo ha recibido un trato puntual en relación con determinadas núcleos de población objeto de estudios monográficos ${ }^{11}$. Es por ello que se impone la necesidad de realizar una aproximación global al contenido y valor jurídico de los derechos y privilegios respetados por Jaime el Justo en favor de contingentes poblacionales minoritarios.

La labor del monarca aragonés consistió, a la luz de la documentación conservada, en regular una serie de instituciones peculiares de la comunidad islámica, que ya habrían sido objeto de interés desde los tiempos de Alfonso X. Esa política real justifica la obligada remisión a los documentos alfonsíes para comprender la sensibilidad y el respeto del monarca aragonés hacia la población mudéjar en los primeros años de su presencia en tierras levantinas. Por tanto, y a priori, debe señalarse que no se trata tanto de una creación «ex novo» de derechos sino, por el contrario, de una serie de preceptos resultantes, por un lado de la legislación no derogada en favor de las minorías $^{12}$, por otro, de la propia iniciativa del monarca, quien extrapola a tierras alicantinas y oriholanas soluciones jurídicas ya establecidas en otros ámbitos del reino de Valencia; al propio tiempo, habría también que considerar los privilegios concedi-

alfonsíes murcianos», en Miscelánea Medieval Murciana, 11 (Murcia 1984), pp. 261-293. Finalmente véase RODRÍGUEZ LLOPIS, M., «Población y fiscalidad en las comunidades mudéjares del Reino de Murcia (siglo XV)", en Actas del III Simposio Internacional de Mudejarismo, Teruel, 1984, pp. 39-53.

11 Es este el caso del esquema que sobre derechos y privilegios traza el profesor Hinojosa Montalvo en relación con la morería de Elche (La morería de Elche en la Edad Media, Serie Estudios Mudéjares, Teruel, 1994). Y de igual modo sucede en relación a Crevillente, debiéndo remitirse el lector a los artículos publicados, por el citado autor, bajo el título "Crevillente: una comunidad mudéjar en la gobernación de Orihuela», en Actas del IV Simposio Internacional de Mudejarismo, Teruel, 1993, pp. 307-318 y «La gestión de la renta feudal en Crevillente durante el siglo XV», en Actas del IV Simposio Internacional de Mudejarismo, Teruel, 1993, pp. 319-338. Ya en un marco mucho más amplio desde el punto de vista temporal y espacial, por cuanto abarca todo el Reino de Valencia, destáquense las aportaciones de FERRER i MALLOL, Ma. T., Organització i defensa d'un territori fronterer. $L a$ Governació d'Oriola en el segle XIV, Barcelona, 1990. Al lector puede serle también de valor instrumental la obra de Burns, quien elabora un estudio minucioso del sistema de derechos, privilegios y exenciones durante el reinado de Jaime I, lo que podría extrapolarse, en determinados aspectos, al ámbito alicantino; véase Medieval Colonialism, Postcrusade Exploitation of Islamic Valencia. Princenton, New Jersey, 1975. En este mismo sentido resulta también de interés la aportación de Hinojosa Montalvo sobre "Señorio y fiscalidad Mudéjar en el reino de Valencia» en Actas del V Simposio Internacional de Mudejarismo, Teruel, 13-15 septiembre, 1990, Teruel, 1991, pp. 105-133.

12 Es este el caso de la documentación de Alfonso $X$ y del Infante don Sancho donde se recogen inumerables preceptos jurídicos que perduran hasta el reinado de Jaime II; situación jurídica que mantenemos al margen de los avatares ocasionados tras las revueltas de los mudéjares durante el reinado de los monarcas castellanos y cuyos efectos negativos hacia los mudéjares tuvieron que ser corregidos en los años inmediatamente posteriores por motivos puramente económicos; y así se mantendrán hasta la llegada del monarca aragonés. Sobre esta documentación véase, ESTAL, J.M. del, Alicante, de villa a ciudad (1252-1490). Colección Documental del Medievo Alicantino, t. III (12521490), Alicante, 1990, doc. 1 al 129. 
dos a los musulmanes por razones de la reciprocidad pactada con los reyes del Norte de África ${ }^{13}$.

\section{DERECHOS RECONOCIDOS EN FAVOR DE LA POBLACIÓN MUDÉJAR}

Las campañas militares llevadas a cabo por el rey Jaime II motivaron, en la mayoría de las ocasiones, un éxodo de la población autóctona por el temor de aquellas gentes a verse desprovistas de su anterior status jurídico; la consideración social de la población mudéjar era el resultado de una política equitativa e igualitaria desarrollada por el monarca Alfonso $X$ el Sabio en los primeros años de su presencia en estas tierras y que se mantuvo posteriormente ${ }^{14}$. El monarca aragonés, sensibilizado ante la situación poblacional, hará una serie de concesiones que, tomadas de la legislación real castellana, devuelvan la confianza a los antiguos moradores de los señoríos ${ }^{15}$ y de las tierras ocupadas ${ }^{16}$.

\subsection{Seguridad personal, de residencia y tránsito}

Aún en el marco general de las concesiones realizadas por Jaime II tras el asedio de los lugares castellanos, merece especial atención destacar que algunas de ellas poseen un contenido especial para la población mudéjar, puesto que constituyen el punto de partida del reconocimiento de su situación particular como minoría religiosa, con sus propias intituciones y costumbres. La libertad, entendida como derecho fundamental de las personas, y la libertad de tránsito para ellas y sus bienes son dos importantes derechos reconocidos por el rey en sendos documentos fechados al inicio de su conquista en los que expresamente el monarca cita a la población mudé-

13 Al respecto véanse los doc.1, 4, 10, 12, 15, 24, 27, 82, 83bis, 91, 116, 131, 132, 145, 147, 148, 150, 156, 157, publicados por ALARCÓN Y SANTÓN, M.A. y GARCÍA DE LINARES, R., Los documentos árabes diplomáticos del Archivo de la Corona de Aragón, Madrid, 1940. Se trata de una serie de documentos traducidos del árabe e intercambiados entre monarcas del Norte de África y Jaime II; en ellos la reciprocidad se eríge en la nota dominante de la política magrebí (e incluso egipcia) en materia de tránsito de personas, establecimiento de lugares para el culto, redención de cautivos y tráfico comercial.

14 Así consta en un documento del citado monarca con fecha de 15 de julio de 1296, por el que se confirman determinados privilegios en favor de la población mudéjar de Cartagena. Véase, ESTAL, J.M. del, Confirmación de los fueros, op. cit. doc. XXI, p. 282.

15 Es este el caso de los privilegiods y franquezas confirmados en favor de los habitantes de Elche; véase TORRES FONTES, J., "Documentos del siglo XIII", en CODOM, II, op. cit. doc. CXXIII, p. 126.

16 Así sucede en relación con el arráez de la Arrixaca de Murcia durante el período de ocupación aragonesa a quien se le garantiza su estancia y posesiones; véase ESTAL, J.M. del, Confirmación de Fueros a la ciudad y Reino de Murcia, pp. 264 y 265/266. Es este también el caso de la confirmación de los fueros y franquicias en favor de los sarracenos del entorno cartagenero (ESTAL, J.M. del, op. cit. p. 282). Igual ocurre con el reconcocimiento de los derechos concedidos anteriormente por monarcas castellanos en favor de los sarracenos de Mula (ESTAL, J.M. del, ibid. p. 260). 
$\operatorname{jar}^{17}$. Buena prueba de la postura tolerante hacia estas gentes es el documento fechado el 4 de mayo de 1296 en el sitio de Orihuela, permitiendo la libertad de desplazamiento y fijación de residencia en tierras alicantinas en los siguientes términos: Rogamos vos [al ra'is de Crevillente] e vos requirimos que los sobredihos moros nuestros/ de Alicant e de los otros nuestros logares que son en Crivillen lexedes yr salvamente seguri pora Alicant/con todas sus cosas e sus bienes ${ }^{18}$. En esta misma línea se pronuncia el monarca en un documento fechado el 19 de mayo de 1296 en favor de los sarracenos de Alguazas, asegurándo su libertad a tots los sarrayns e cascun daquels ${ }^{19}$. $Y$ finalmente un tercer documento otorgado por Jaime II, preludiando el respeto hacia la libertad de los mudéjares, es el otorgado al día siguiente, 20 de mayo, en favor de: todos los Moros del regno nuestro de Murcia de aqualesquier logares sean la sua gracial e bona voluntad ${ }^{20}$.

La actitud tolerante hacia el libre desplazamiento de los mudéjares también es una constante que llega a ser exigida como condición para el mantenimiento de buenas relaciones con los reyes musulmanes del otro lado del Mediterráneo; así se desprende de los tratados firmados en febrero de 1323 con el Abu-I-Fatah Muhammad ibn Qalawn de Egipto o el documento fechado en mayo de 1326 entre Muhammad IV de Granada y Jaime II, en el que se exige el respeto, en distintas esferas, hacia los mudéjares residentes en tierras argonesas ${ }^{21}$.

Otro derecho inherente a la presencia y permanencia de los musulmanes en territorio cristiano es el relativo a la propia seguridad de los mudéjares en tierras alicantinas y oriholanas, y que fué objeto de regulación por parte del monarca Jaime II. No se trata en este caso de la seguridad de tránsito por razón de comercio ${ }^{22}$, sino de la seguridad personal y general reconocida en favor de los habitantes del Reino, esto es cristianos, judíos y sarracenos. El primer documento que hace mención a este derecho personal, en favor de los musulmanes, está fechado el 17 de mayo de 1296 y tiene por objeto garantizar la seguridad de plures Sarraceni, qui fuerunt capti in Çetino et Lorquino, inter quos/sunt aliqui Sarraceni qui sunt de locis uocatis Algustes ${ }^{23}$. Con posterioridad, el 19 de mayo, mantiene el monarca la misma postura hacia los mudéjares del Reino de Murcia ${ }^{24}$. En las mismas fechas, en el documento del 22 de mayo

17 Véase el documento dado ante en el campamento de Lorca el 3 de junio de 1296 (ESTAL, J.M., del, Confirmación de los fueros a la ciudad y reino de Murcia, op. cit. p. 269) y la ratificación ante los muros del castillo de Lorca el 5 de junio de 1296 (ESTAL, J.M. del, Confirmación de los fueros a la ciudad y reino de Murcia, op. cit. p. 271).

18 ESTAL. J.M. del, Alicante, de villa a ciudad, op. cit. doc. 30 , p. 175

19 ESTAL, J.M. del, Confirmación de Fueros a la ciudad y reino de Murcia, op. cit. doc. IV, p. 264.

20 ESTAL, J.M. del, Confirmación de los Fueros a la ciudad y reino de Murcia, op. cit. doc. V pp. 264/5.

21 ALARCÓN y SANTÓN, A. Los documentos árabes, op. cit. doc. 150, pp. 365-368 y doc. 27 , pp. 55-58 respectivamente.

22 Esta posibilidad es un derecho derivado del mismo ejercicio profesional y que por tanto se exige como condición de reciprocidad para el libre tránsito de personas (mercaderes) y mercancías.

23 ESTAL, J.M. del, Corpus documental, op. cit. doc. 64, p. 175.

24 ESTAL, J.M. del, Confirmación de los Fueros, op. cit. doc. IV, p. 264. 
de 1296, Jaime II se dirige a los mudéjares alicantinos en los siguientes términos: Unde cum Nos assecurauerimus Sarracenos de Alacant et alios qui ad dominum nostrum uenire uellint/in personis et rebuis eorum ${ }^{25}$. Este posicionamiento del rey aragonés se mantiene como símbolo de su política tolerante hacia las minorías religiosas en otros documentos y así se advierte, por ejemplo, en favor de los sarracenos de Petrer el 2 de junio de $1296^{26}$. Las mismas libertades son esgrimidas en el documento expedido para Cartagena desde el sitio de Lorca donde expresamente dice: Uolentes uos uniuersos et singulos homines Ciuitatis Cartagenensis, tam christianos/scilicet quam, judeos ac sarracenos prosequi gracijs et fauore, guidamus et assecuramus uoos per uniuersas ${ }^{27}$. Y esta misma fórmula jurídica en favor del derecho a la libertad de los sarracenos, es reiterada años más tarde, concretamente en 1316, cuando Jaime II vuelve a garantizar la seguridad de los sarracenos, en este caso de la villa y arrabal de Elche, en los siguientes términos: dicimus et mandamus quatenus motus illicitos hominum insurgencium modo predicto vel alias irracionabiliter contra sarracenos predictos sic cohibnbere curetis quod sarraceni ipsi cum bonios eorum sub nostra deffensione securi permaneant a gravaminibus quorumcumque ${ }^{28}$.

\subsection{Derechos reconocidos de carácter judicial y procesal}

Otro derecho reconocido a los sarracenos como consecuencia del respeto hacia sus costumbres es el ejercicio de su propia jurisdicción; estaba basado en particularidades que la comunidad islámica presentaba en materia legal por su carácter confesional. Es por ello que en materia jurisdiccional Jaime II asegura la supremacía de la ley islámica en la resolución de conflictos entre musulmanes, permitiendo no sólo la aplicación de la sunna, sino también la actuación judicial de funcionarios como el "alamín" o el «alcalde de los moros». Este derecho a los propios funcionarios se recoge en un documento fechado el 24 de mayo en favor de las gentes de la villa de Alicante, donde se dice: vobis universis et singulis sarracenis aliame sarracenorum de Alacant, quod in causis vestris iudicemini per alaminum vestrum, iuxta çunnam sarracenorum prout est actenus melius fieri assuetum ${ }^{29}$.

25 ESTAL, J.M. del, Alicante, de villa a ciudad, op. cit. doc. 41, p. 183

26 ESTAL, J.M. del, Confirmación de los Fueros, op. cit., doc. XI, pp. $271 / 2$.

27 El documento está fechado el 3 de junio de 1296 en el Campamento ante el Castillo de Lorca. Véase ESTAL, J.M. del, “Confirmación de Fueros a la ciudad y reino de Murcia por Jaime ll de Aragón (1296-1304)" Anexo documental inédito, en Miscelánea Medieval Murciana, IX, Murcia, 1982, p. 269.

28 FERRER i MALLOL, Mª T., La frontera amb l'slam, op. cit. p. 265.

29 Este primer texto es complementario de otro documento en el que se priva al antiguo defensor del castillo de Alicante de sus competencias jurisdiccionales sobre los sarracenos en los siguientes términos: Mandamus etiam uobis quod dictis Sarracenis in aliquo uos non intrometatis/sed ipsos porcurarj permitattis per Baiulum nostrum de Alacant, situación que es corregida por el monarca al día siguiente reconociendo las competencias del alamín. Sobre este asunto véase ESTAL, J.M. del, Alicante, de villa a ciudad, op. cit. documento de 23 de mayo de 1296, p. 185 y documento de 24 de mayo de 1296, p. 186. 
La posibilidad de ejercer los mudéjares su propia jurisdicción se detecta desde los tiempos de Alfonso $X$, e incluso aparece también en el señorío ilicitano del Infante don Juan Manuel. En el primer caso el monarca castellano entre sus medidas legislativas reconoce esta posible jurisdicción para los mudéjares, dejando_constancia de ello en un documento fechado el 19 de mayo de 1257 dirigido a los alcaldes de Cartagena ${ }^{30}$. En cuanto a Elche el Infante don Juan Manuel admitirá la competencia del «alcalde moro" según la ley, exceptuando los derechos del almoxarifatgo que tengo por bien que los jutgue todavía el mío almoxerifi.

\subsection{Derechos de contendio patrimonial y mercantil}

La necesidad que a efectos repobladores suponía la fijación de residencia de los mudéjares en las nuevas tierras sometidas a la soberanía del monarca aragonés comportaba para estas gentes el respeto al disfrute de sus bienes.

Así pues, los bienes de los musulmanes fueron protegidos en las mismas condiciones que su integridad personal, tal y como venía sucediendo desde los tiempos de Alfonso $\mathrm{X}$ el Sabio. Esta situación se pone de relieve en un documento fechado el $5 \mathrm{de}$ junio de 1296 ante los muros del castillo de Lorca Jaime Il garantiza y ordena el respeto hacia los bienes y personas de Petrer en los siguientes términos: Nos guidasse et assecurasse ac sub nostra protectione et guidatico speciali/recepisse Sarracenos de Petrer et omnes res eorum per omnia loca dominij nostri, in ueniendi, stando ac etiam redeundo... Quare uobis dicimus et mandamus, quatenus dictis Sarracenis/ predictum guidaticum et assecuramentum obseruetis et contra ipsa non ueniatis nec aliquem contrauenire permittatis laliqua ratione ${ }^{\beta 2}$. Y en términos análogos se pronuncia un documento fechado en 1301 en favor de los mudéjares de Elda y Novelda ${ }^{33}$.

Pero la protección patrimonial no fue algo novedoso para los súbditos musulmanes del rey Jaime, sino que tiene dos claros precedentes alfonsíes; el primero de ellos en un texto en el que el rey castellano ya habría dispuesto: que todos aquellos que no quieran seguir en nuestra aveniencia, que pueden irse libremente del reino con sus bienes muebles y ajuar propio y que, si en el plazo de treinta días resolvieron volver a nuestra merced y devoción que no pierdan sus bienes raíces ${ }^{34}$; y el segundo en un documento fechado el 8 de abril de 1272 y que tiene por objeto la repoblación de Orihuela con moros a los que se les permite: que vengan /saluos et seguros con sus mugeres et sus /fiios et con todo lo suyo. Además, conviene señalar que la permisividad del monarca en relación con las propiedades de los mudéjares será un incentivo no sólo para que estas gentes vengan a repoblar sino para que den a su residencia un

30 TORRES FONTES, J., "Fueros y privilegios de Alfonso $X$ el Sabio al reino de Murcia», CODOM, III, op. cit. doc. XL, p. 57.

31 Véase TORRES FONTES, J., "Documentos del siglo XIII", CODOM, II, op. cit. doc. LXXV, p. 69 .

32 ESTAL, J.M. del, Confirmación de fueros, op. cit. p. 271.

33 ESTAL, J.M. del, El Reino de Murcia bajo Aragón, op. cit. doc. 196, p. 179.

34 ESTAL, J.M. del, Confirmación de fueros, op. cit. p. 25. 
carácter permanente ${ }^{35}$; esta última circunstancia permitirá asegurar unos rendimientos económicos favorables al nuevo Reino, habida cuenta del carácter imprescindible de unas gentes dedicadas, por lo general, a la agricultura, las manufacturas y el comercio.

La parcela de derechos y privilegios que se aborda en el ámbito comercial es la más escasa en cuanto a documentos se refiere. Las referencias que se conservan se encuandran en la política mercantil general de las tierras levantinas.

La libertad de tráfico comercial es objeto de regulación por parte del monarca aragonés con carácter general para todos los ciudadanos, sin distinción de colectivos. Así se regoge en un documento fechado el 11 de mayo de 1296 en favor de la villa de Orihuela ${ }^{36}$. Días más tarde, el 3 de junio de 1296 en el campamento de Lorca, lo hará en favor de los habitantes de Cartagena ${ }^{37}$. $Y$ con posterioridad para los habitantes de Alicante (según un traslado notarial fechado el 23 de julio de 1296, y realizado por Johannes Raolff). En este último se contiene una aprobación y confirmación hacia uobis dictis hominibus et uniuersitati d'Alacant et successoribus uestris in perpetuum preiuilegis et/franquitates (...) tam per mare scilicet quam per teram, ex omnibus mercibus et aliis rebus uestris ab omni lezda, pedagiis/penso, mensuratico, passatico et ribatico pro dictis rebus et merciius exsoluendis ${ }^{38}$.

El comercio de productos entre musulmanes y cristianos en territorio cristiano va a ser otra de las fuentes de obtención de derechos y privilegios para los musulmanes. El respeto que el rey Jaime II demuestra hacia el ejercicio de estas actividades que los musulmanes venían ejerciendo hasta su llegada comporta el reconocimiento del libre tráfico de mercancías, sujeto, sin embargo, a los derechos y obligaciones de la legislación cristiana. Así, por ejemplo, en un documento dado en favor de los sarracenos de Guardamar, el 20 de febrero de 1298, se les garantiza vobis uniuersis et singulos sarracenis, qui apud locu de Guardamar veneritis /pupilare, quod habeatis mercatum ibidem et perpetum ${ }^{39}$.

El mantenimiento de aquellas actividades comerciales pasaba incluso por la continuidad de la política mercantil marítima con países del norte de África. Esta particular circunstancia, a la luz de la documentación conservada, va a suponer un serio contratiempo en la política del rey aragonés para con los mudéjares, puesto que en muchas ocasiones la concesión de derechos a estas gentes estuvo condicionada por

35 Es este el caso constatado en un documento en favor del respeto hacia los bienes de un sarraceno de Crevillente, con fecha de 13 de mayo de 1296. Véase ESTAL, J.M. del, Corpus Documental de Reino de Murcia, op. cit. doc. 43, p. 156.

36 ESTAL, J.M. del, Privilegios otorgados a la ciudad de Alicante, op. cit. doc. 1, pp. 21/2.

37 ESTAL, J.M. del, Confirmación de fueros a la ciudad y reino de Murcia, op. cit. p. 269. Son varios los documentos en los que esta libertad es garantizada a los mercaderes por Jaime II; véase el apéndice documental de la obra citada y en concreto los docs. IV, V, VI, VIII, IX, X, XII, XXI, XXIII, XXIV, XXV y XXVIII.

38 ESTAL, J.M. del, Alicante, de villa a ciudad, op. cit. doc. 46, p. 187.

39 ESTAL, J.M. del, Corpus documental, op. cit. 162, p. 295. 
las presiones provinientes de los reyes de Berbería, que no dudaban incluso en tomar cautivos con fines coactivos ${ }^{40}$.

En cualquier caso, el monarca aragonés dedica su atención a dos aspectos fundamentales en relación con el tráfico comercial. El primero de ellos es la regulación y concesión de derechos y franquicias sobre el tráfico de mercancías en el interior de la gobernación de Orihuela con carácter general; en segundo lugar el reconocimiento de derechos en favor de la seguridad viaria y de tránsito para mercaderes musulmanes en tierras cristianas.

Los derechos sobre el tráfico comercial, reconocidos en favor de la población musulmana en tiempos de Jaime II, se centran en la regulación de esta materia cuando los intercambios entre musulmanes y cristianos o viceversa se producen en territorio cristiano. De este modo se justifica la seguridad que garantiza el monarca castellano, en beneficio de las relaciones internacionales del momento. Derechos reconocidos son, por ejemplo, la posibilidad de establecer "alhóndigas» y designar cónsules que practiquen integramente sus costumbres y usos ${ }^{41}$. $Y$ esta política será garantizada en aras a unas relaciones de reciprocidad defendidas, incluso, por los reyes del Norte de África ${ }^{42}$.

\section{PRIVILEGIOS REALES Y EXENCIONES EN RELACIÓN CON LAS COMUNIDA- DES MUDÉJARES}

\subsection{Obligaciones militares}

El reconocimiento del derecho a residir y permanecer en territorio cristiano va a obligar a los musulmanes a cumplir unas serie de exigencias en favor del monarca como contrapartida por ese respeto a sus derechos. El reclutamiento forzoso es la prerrogativa real de mayor trascendencia, exigible en virtud de sus incursiones por los antiguos territorios castellanos. La participación de los mudéjares en el ejército del monarca aragonés se da siempre en condiciones de igualdad en relación a los contingentes poblacionales en cuyo seno viven; y así se constata en los documentos conservados en relación con los asedios de poblaciones como Alhama o

40 Sobre este aspecto remítase el lector a los documentos de ALARCÓN, A. y GARCÍA DE LLINARES, R.: Los documentos árabes diplomáticos del Archivo de la Corona de Aragón. Al respecto véase not. 13 .

41 ALARCÓN y SANTÓN, Los documentos árabes, op. cit. doc. 1, pp. 1-3. Documento fechado en Orihuela el 15 de mayo de 1296.

42 ALARCÓN y SANTÓN, A., Los documentos árabes, op. cit. doc. 10, pp. 23/25. Sobre esa misma reciprocidad véase doc. 116, pp. 247-253; este documento es un tratado de paz con el rey de Ifriquiya donde se contiene un rigurosa regulación de las actividades comerciales entre gentes de ambos reinados. $Y$ consúltese el tratado de paz de Jaime II con el rey de Egipto, en análogas circunstancias a los anteriores (op. cit., doc. 145, pp. 334-344). 
Elche, donde la exención de esta obligación afecta por igual tanto a cristianos como sarracenos ${ }^{43}$.

\subsection{Obligaciones fiscales}

\section{A. Tributaciones personales}

La especial consideración que se tiene con la población mudéjar no alcanza a eximirla de determinados impuestos cuya regulación se fecha desde los tiempos de los monarcas castellanos. Así sucede, por ejemplo, en relación al impuesto de la capitación por ser éste un impuesto personal de obligado cumplimiento, e incluso previsto por la propia legislación islámica ${ }^{44}$. De este modo se justifica el hecho de que los mudéjares acatasen, de forma respetuosa, la obligación tributaria que a razón de capite quinque solidos et quatuor denarios anno quolibet in reparacione murorum dicti loci ${ }^{45}$ aportaban desde tiempos castellanos el día de San Martín ${ }^{46}$. Este mismo impuesto ya había sido objeto de regulación durante el reinado de Alfonso $X$ en favor de los mudéjares de las aljamas, huerta u otros castillos del término de Alicante, Nompot (Monforte) Agost, Busot y Aguas, y así queda constancia en la documentación consultada ${ }^{47}$. En este sentido es de señalar que según esta documentación sólo los moros exáricos estuvieran sujetos a la alfenrra, denominada también alfatra ${ }^{48}$.

43 Véase FERRER i MALLOL, Mª.T., La frontera amb l'/slam, op. cit. pp. 228/9, donde se exige la prestación de servicios militares a los musulmanes para el sitio de Alhama; y un documento publicado por la misma autora en favor de los sarracenos de Elche eximiéndoles de participar en el ejército salvo en el caso de invasión del reino de Murcia (FERRER i MALLOL, M…T., Les aljames sarraïnes, doc. 21, p. 196). ESTAL, J.M. del, Alicante de villa a ciudad, op. cit. doc. 5-8, p. 211 y del citado autor véase también los documentos relativos al reclutamiento y exención de esta obligación en favor de los habitantes de distintos lugares del Reino levantino, en El Reino de Murcia hajo Aragón (1296-1305). Colección documental del medievo alicantino, 1/2, Alicante, 1990, doc.128, 146, 160, 209, 247.

$44 \mathrm{Ibn}$ Khaldun, por ejemplo, suministra una justificación religiosa de determinados impuestos conforme al modelo que del sistema impositivo ofrece en la Muqaddima. Véase IBN KHALDUN, Discours sur l'histoire universelle (Al-Muqaddima), trad. par Vincent Monteil, t. II, Beyrouth, 1968, p. 570.

45 ESTAL, J.M. del, Alicante de villa a ciudad, op. cit., doc. 127, pp. 306/7 y doc. 128, pp. 307/8; y véase el precedente en el doc. de 11 de mayo de 1296 en ESTAL, J.M., del, Concesión de fueros, op. cit. p. 263.

46 Como así lo constata la legislación alfonsí del período inmediato anterior. Véase ESTAL, J.M. del, Privilegios otorgados a la ciudad de Alicante, Madrid, 1984, doc. 39, fechado en Córdoba el 30 de junio de 1260, p. 45: Et agora tenemos por bien/et mandamos que todos los moros moradores en Alicant o en la/huerta o en los castiellos del termino d'Alicant los que son axa/riques de los christianos o los que son tenderos o los menestrales que nos/den cada anno un moravedí alffonsi de pecho, et los otros que viven por/su açada o por mar o por otra manera qualsequier, que nos/den cada anno medio morvadi alffonsí.

47 Véanse TORRES FONTES, J., CODOM, IIl, op. cit, documentos LI, LIV, LV fechados en los años 1260 el primero y 1261 los dos segundos; en ellos no solo se regula la cuantía síno la fecha de entrega y la posibilidad de disponer de estos ingresos por parte del Concejo de la ciudad.

48 Véase sobre sus orígenes POCKLINTON, R., "Nuevos arabismos», op. cit. pp. 273/274. 
Además, los derechos reconocidos en favor de la población mudéjar comportan, por lo general y como contrapartida, determinadas obligaciones exigidas a los musulmanes como reconocimiento de la soberanía del monarca aragonés. Este es el caso del impuesto del monedaje, principal tributo por razón de potestad soberana. La exigencia de este impuesto a la población mudejar se contiene en un documento fechado el 24 de abril de 1301 donde se dice: fidelibus suis Christianis, Judeis et Sarracenis/ etc.; y mas adelante: Ideo vobis et singulis vestrum firmiter precipiendo mandamus, quatenus predictis quil, collectores et receptores electi fuerint ad dictum monetaticum colligendum sub forma superius ${ }^{49}$. Con posterioridad, el 27 de abril de 1318 y mediante una Carta dirigida al portant-veus del procurador general del reino de Valencia, Jaime II confirma: Idcirco per presentes concedimus uobis et omnibus et singuis habitantibus in parte regni predicti, tam christianis quam Sarracenis, quod adueniente tempore quo primum Monetaticum post istud nobis tenebimini soluere $e^{50}$; quedando constancia mediante este documento de la necesidad de lograr un equilibrio entre concesiones y exigencias hacia las gentes que permanecieron en territorio cristiano.

Otra obligación tributaria recogida por las fuentes se refiere al pago del impuesto de cena. Así, por ejemplo en 1301 el monarca exige este impuesto de carácter anual a los mudéjares de Orihuela en estos términos: mandamos que el dito dia nos dedes por Cena sicyentos solidos de reales de Murcia ${ }^{51}$ y lo mismo hace el 27 de enero del año siguiente al exigir el mismo impuesto a los: Fidelibus suis Sarracenis de Eltx, etc. ${ }^{52}$; si bien en este último caso el impuesto se exige en su modalidad de tributo periódico y no por hecho circunstancial del paso del monarca y su esposa por aquellas tierras, como se deduce del documento oriholano.

Ahora bien, Jaime II no sólo declara en sus documentos la libertad e inmunidad hacia los singulos sarracenos habitantes et habitatores in dicto loco de Alacant et orta eiusdem ${ }^{53}$, sino que proclama abiertamente una serie de exenciones mediante las siguientes palabras: cum nos exigeremus vel exigi faceremus a sarracenis degentibus in villa seu orta de Alacant alfardam, questiam sive peytam, nos, cum dicti saraceni, tempore quod dictus locus de Alacant era regis Castelle ${ }^{54}$. El mantenimiento de esta situación, anterior incluso al reinado del monarca aragonés, se justifica ante las demostraciones de fidelidad que estas gentes manifiestan hacia el rey aragonés; y por tanto la actitud del monarca debe ser entendida como muestra de gratitud e indulgen-

49 ESTAL, J.M. del, Alicante, de villa a ciudad, op. cit., doc. 70, pp. 222/3.

50 ESTAL, J.M. del, Alicante, de villa a ciudad, (1252-1490). Igualmente véase del mismo autor Colección Documental del medievo Alicantino, t. III (1252-1490), Alicante, 1990, p. 295.

51 ESTAL, J.M. del, Alicante, de villa a ciudad, op. cit. doc. 64, p. 215.

52 Ibid. op. cit. en la nota anterior, doc. 73, p. 227.

53 ESTAL, J.M. del, Alicante, de villa a ciudad, (1252-1490) y Colección Documental del medievo Alicantino, t. III (1252-1490), Alicante, 1990, pp. 307/8.

54 Ibid. op. cit., en la nota anterior. 
cia hacia los sectores sociales que tradicionalmente eran considerados menos favorecidas: el campesinado y los menestrales ${ }^{55}$.

\section{B. Privilegios y exenciones respecto a los impuestos patrimoniales}

Las garantías y privilegios que ofrece el monarca en relación con las propiedades de los mudéjares permiten al soberano recabar una serie de rentas o tributos que, en última instancia, irían a engrosar las arcas del Reino. Aunque también es cierto que en ocasiones parte de estas rentas o tributos iban a parar a la propia aljama encargada de distribuir las distintas cantidades en aquellas partidas más deficitarias o necesitadas ${ }^{56}$.

En el terreno patrimonial, y desde un punto de vista fiscal, los mudéjares exáricos están exentos ad contribuendum et peytandum in questiis et aliis servitutibus regalibus ${ }^{57}$ y también lo estan de "alfarda"(sic. $)^{58}$. Un precedente sobre este aspecto lo ofrece un texto de 1265 atribuido a don Juan Manuel y dirigido a los moros de Elche donde se dice: $E$ los moros que fuesen en Elig en su término que non den los pechos e los diezmos e los derechos, assi como los davan, nin les pongamos otra costumbre sino la que era ante entre nos e ellos ${ }^{59}$.

La obligación impositiva se suaviza en muchas ocasiones mediante exenciones temporales o permanentes que permiten presagiar un estructurado sistema fiscal. Así lo recogen una serie de documentos que regulan exenciones como el pago de la algarfa ${ }^{60}$ para los moros de Elche ${ }^{61}$ y el impuesto de la

55 Un precedente de este documento es el fechado en 1 de abril de 1324 dirigido al bayle de la Procuración de Orihuela, pero de igual modo dirigido en favor de los compellitis sarracenos agricultores dictos exarichos. Véase ESTAL, J.M. del, Alicante, de villa a ciudad, op. cit. doc.127, p. 306.

56 Vid. FERRER i MALLOL, Ma.T., Les aljames sarraines, op. cit. doc. 47, p. 216.

57 ESTAL, J.M. del, Alicante, de villa a ciudad, op. cit. doc. 127, p. 307.

58 ESTAL, J.M. del, op. cit. doc. 128, p. 308. Sobre el contenido de estos tributos en la legislación cristiana y sus precedentes véase POCKLINGTON, R., "Nuevos arabismos en los textos alfonsíes murcianos", en Miscelánea Medieval Murciana, Murcia, 1984, pp. 261-293. Véase sobre su carácter de impuesto por el uso del agua BURNS, J.I., Medieval colonialism, op. cit. pp. 121-137. Sobre la trascendencia del sistema impositivo y su significado para la población islámica andalusí véase «La sofra (sujra)» en Sharq Al-Andalus, 3 (1986), pp. 33-37.

59 TORRES FONTES, J., “Documentos del siglo XIIl», CODOM, II, op. cit. p. 21.

60 No hay referencias en la documentación consultada sobre el contenido de este impuesto. Aunque desconocemos su significado, pudiera tratarse, a tenor de su raíz de procedencia [ga/ra/fa] de un impuesto sobre la extracción del agua para el riego. Sobre el término véase CORRIENTE, F., Dicionario Árabe-Español, Madrid, 1977, p. 553 y voz garafa en Student's Arabic-English dictionary, Beirout, 1986, p. 422.

61 FERRER I MALLOL, Ma. T., Les aljames sarraïnes, op. cit. doc. 22, p. 197. 
tarchana ${ }^{62}$. Estas exenciones sobre impuestos patrimoniales se concedían, bien para propiciar el establecimiento de los musulmanes en estas tierras bien para asegurar su permanencia. Jaime II concedió también a los mudéjares franquicias y privilegios ${ }^{63}$ para el pago de determinados impuestos y así sucede en relación con el cabezaje y alfarda, a tenor de sus posibilidades económicas ${ }^{64}$, o perdona retrasos en el cumplimiento de obligaciones tributarias, como sucede en relación con el almagran que debían los moros de Elche ${ }^{65}$.

$Y$ para concluir debe resaltarse el carácter personal e instransmisible de la obligación triburaria en el cumplimiento de estas imposiciones. Esta circunstancia queda ratificada en un documento real fechado el 21 de junio de 1318 en favor de los sarracenos de Elche ${ }^{66}$; en el se prohibe expresamente la privación de libertad de terceras personas para asegurar y realizar las deudas de sus padres.

62 Impuesto del que no se sabe con certeza sus orígenes y objeto, siendo diversas las interpretaciones sobre su contenido. Para el Profesor Carmona González pudiera tratarse de un antiguo impuesto islámico propio sólo del Norte de África y de al-Andalus que gravaba las fiestas y determinadas diversiones, siendo el perceptor de este impuesto el tarqun (según opinión del autor en base a un trabajo monográfico sobre Ibn al-Hatib de Murcia, en curso de publicación). En el mismo sentido véase el documento citado véase FERRER i MALLOL, $\mathrm{M}^{\mathrm{a}}$.T., Les aljames sarraïnes, op. cit. doc.23, p. 197 e HINOJOSA MONTALVO, J., La morería de Elche, op. cit. p. 19.

63 Principalmente moratorias, como sucede en el documento fechado el 21 de abril de 1312 en favor de los musulmanes de Elche. FERRER i MALLOL, Mª.T., op. cit. doc. 38. pp. 208/9.

64 Es este el caso de la franquicia concedida en favor de: quicumque sarracenus barranmius venerit ad dictum locum de Elchio seu termino suo, (FERRER i MALLOL, Mํ. T., Les aljames sarraïnes, op. cit. doc. 26, p. 199).

65 Sobre este impuesto véase BURNS, J.I., Medieval colonisalism, op. cit. pp. 104/7; POCKLINGTON, R., "Nuevos arabismos», op. cit. pp. 281/4 y el doc. 64, p. 231 en la obra FERRER i MALLOL, Mํ.T. (Les aljames sarraïnes, op. cit.).

66 Al respecto véase FERRER i MALLOL, Ma.T., Les aljames sarraïnes, op. cit. doc. 60, p. 228. 

DON JUAN MANUELY ARNAU DE VILANOVA:

LA CULTURA Y LA CIENCIA EN TIEMPOS DE JAIME II 


\title{
HESPER, EL VESPROY EL VESPERTILIO: ELEMENTOS DE CONTINUIDAD ENTRE EL MILENARISMO STAÚFICO $Y$ EL CICLO PROFÉTICO DEL IMPERIO ARAGONÉS
}

\author{
Manuel Alejandro RODRÍGUEZ DE LA PEÑA \\ Universidad Autónoma de Madrid
}

El fenómeno de la profecía política alcanzó a lo largo del siglo XIII una relevancia sin precedentes en el marco de la controversia teórica entre los publicistas defensores de las diferentes posiciones de los poderes políticos de la época'. La publicística del siglo XIII desarrolló sus controversias fundamentalmente en dos niveles: 1/ el enfrentamiento entre las posiciones hierocráticas del Sacerdotium y las soberanistas del Regnum y $2 /$ la disputa por el dominium Mundi entre las Monarquías de Occidente, disputa íntimamente ligada al surgimiento de una conciencia protonacional en el seno de éstas.

Aunque el ciclo profético del Imperio aragonés está inscrito en este segundo nivel, las peculiares circunstancias en que tuvo lugar su alumbramiento le confirieron un marcado perfil gibelino más propio del escenario de enfrentamiento entre Hierocracia y Monarquía, perfil que únicamente tiene explicación a la luz de la herencia política staúfica ímplicita en el nacimiento de la vocación imperial del Casal d'Aragó.

1 A este respecto, la figura de Joaquín de Fiore (1135-1202) como prestigiadora del profetismo escatológico marca un hito en la influencia política del milenarismo. Aunque hay precedentes anteriores de utilización política de la profecía (son los casos de Raúl GLABER y su De divina Quaternitate, Godofredo de MONMOUTH y la Prophetia Merlini o el del ciclo escatológico de la Primera Cruzada estudiado por Paul ALPHANDÉRY en La Chretienté et l'idee de Croisade, 1954, pp. 160-208) no sería hasta el siglo XIII cuando se produjera su eclosión definitiva como uno de los factores formadores de ideología política (cf. Hans M. SCHALLER, «Endzeit-Erwartung und Antichrist-Vorstellungen in der Politik des 13. Jahrhunderts", Festschrift für Hermann Heimpel, Gotinga, 1971, p. 924). 
Por ello, es preciso proceder a una delimitación de aquellos elementos del ciclo profético catalán que, procedentes de la mística imperial de la Casa de Suabia, arrojen luz sobre la particular idiosincrasia del programa político universalista de los reyes que sucedieron a Jaime I en el trono aragonés.

La principal dificultad de esta tarea radica en la díficil diferenciación entre elementos pertenecientes a la tradición milenarista propiamente imperial y elementos joaquinitas, pese al claro carácter hierocrático de estos últimos.

La razón de esta dificultad estriba en el hecho de que ambos ciclos proféticos compartieron un mismo lenguaje simbólico y una misma herencia escatológica de raigambre bíblica, difiriendo tan sólo en la interpretación última de los hechos anunciados. Es esta interpretación y la significación política que le es otorgada, la que normalmente delatará las tendencias güelfas o gibelinas del que formula las profecías ${ }^{2}$.

Sin embargo, como veremos más adelante, es posible identificar algunas figuras alegóricas propias del ciclo escatológico de los Staufen, figuras que, quizá debido a su origen pagano, no aparecen en la tradición joaquinita. Estas figuras alegóricas son la expresión plástica de algunos arquetipos fundamentales de la ideología imperial staúfica y su recepción en el corpus de profecías catalanas resulta altamente significativo a la hora de establecer posibles líneas de continuidad entre el proyecto imperial de la regia stirps de Waiblingen y el de la dinastía catalano-aragonesa.

\section{CARACTERIZACIÓN DE LA INFLUENCIA JOAQUINITA EN EL CICLO PROFÉ- TICO CATALANO-ARAGONÉS}

Marjorie Reeves ha establecido que la evidencia de influencia joaquinita en un texto de profecía política medieval no consiste en atestiguar la creencia del autor en el carácter profético de Joaquín de Fiore o su adhesión a la teoría de las Tres Edades del Mundo, sino más bien en una determinada visión de la historia basada en la expectación milenarista ante una inminente Era de iluminación y beatitud, un auténtico tempus gratiae previo a la venida de Cristo $^{3}$.

De esta forma, podemos' hablar perfectamente de influencia joaquinita en un gran número de autores de los siglos XIII y XIV sin por ello hacer de ellos adeptos de las doctrinas trinitarias del Evangelio Eterno ${ }^{4}$. En este contexto debemos enmarcar la penetración en Aragón del joaquinismo.

Alain Milhou ha señalado como principales introductores de los ciclos proféticos

2 En particular esto es válido para las pseudo-profecías realizadas ex eventu, es decir, aquellas acerca de hechos ya ocurridos sobre los que el profeta proyecta una predicción que los reinterpreta y sitúa en un marco espacio-temporal más amplio.

3 Cf. Marjorie REEVES, «The originality and influence of Joachim of Fiore», Traditio, XXXVI, 1980, p. 298; es esta creencia la que diferencia el joaquinismo de otros movimientos milenaristas anteriores, pues éstos situaban siempre la Edad de la perfección en un tiempo posterior al Juicio Final.

4 Este sería el caso, entre otros, de San Buenaventura, Roger Bacon, Juan de París, Dante o Gerhold de Reichenberg (M. REEVES, op. cit., pp. 299-304). 
milenaristas en España a los franciscanos catalanes imprégnes de joachimisme ${ }^{5}$. En esta dirección, sin duda fue Arnaldo de Vilanova, hombre cercano a la espiritualidad beguina, la figura que primero recogió el pensamiento del abad de Calabria en Aragón, siendo su influencia decisiva para la posterior expansión de las ideas joaquinitas al sur de los Pirineos ${ }^{6}$. Esta influencia es atestiguada por los cánones del concilio de Tarragona de 1317, que revelan la preocupación que despertaba en la jerarquía eclesiástica el gran número de sus seguidores fraticelos y beguinos ${ }^{7}$.

Las concepciones filosóficas del sabio catalán se apoyaban en la formación de un homo novus que alcanzaría la perfección física (gracias a la medicina y la alquimia, que alcanzan en su pensamiento una dimensión escatológica) y espiritual en la Tertia Aetas anunciada por Joaquín de Fiore ${ }^{8}$.

En este sentido, no es un hecho casual el que las meditaciones milenaristas de Arnaldo de Vilanova comenzaran con un comentario al De semine scripturarum de Joaquín de Fiore ${ }^{9}$. Pronto le seguiría la Expositio super Apocalypsi ${ }^{10}$, fuertemente imbuida de las tesis trinitarias joaquinitas. Ambas obras fueron presentadas por su autor ante el papa Clemente $V$ en Burdeos.

Estas obras proféticas del visionario catalán no se limitaron a reproducir las pautas hierocráticas de las predicciones de Joaquín de Fiore ${ }^{11}$, sino que las pusieron al servicio de los designios seculares del Casal d'Aragó.

No en vano, Arnaldo de Vilanova era ante todo un hombre estrechamente ligado a la Corona catalano-aragonesa. Había sido el médico personal de Pedro III y en el momento de la redacción de estas dos obras (1297-1302) era consiliarium et familiarem del Rey Jaime $\mathrm{II}^{12}$, para el que había desempeñado labores diplomáticas en la corte de Francia. Por ello, no es aventurado afirmar que se erigía en portavoz de los más

5 Cf. Alain MILHOU, «La Chauve-Soris, le Nouveau David et le Roi Cache (trois images de lempereur des dernier temps dans le monde ibérique)", Melanges de la Casa de Velazquez, XVIII, 1982 , p. 62.

6 Cf. M. REEVES, The influence of Prophecy in the Later Middle Ages: a study in Joachimism, Oxford, 1969, p. 221: In Aragon and Catalonia the chief carriers of Joachimist ideas may well have been the works of Arnold of Villanova...

7 Cf. José María POU Y MARTÍ, Visionarios, beguinos y fraticelos catalanes (siglos XIII-XIV), Vich, 1930, p. 100; 198-220.

8 Cf. MÉNENDEZ PELAYO, Historia de los Heterodoxos españoles, III, p. 479, Madrid, 1986 (4ª ed.), y Morton W. BLOOMFIELD, “Joachim of Flora: a critical survey on his canon, teachings, sources, biography and influence», Traditio, XIII, 1957, p. 301.

9 Códice 3824 de la Biblioteca Vaticana (cf. Menéndez Pelayo, op. cit., p. 491).

10 Códice 5740 de la Biblioteca Vaticana (cf. Menéndez Pelayo, op. cit., p. 492).

11 Robert E. Lerner opina que Joaquín de Fiore fue ante todo un propagandista de la Hierocracia; la figura central de su ciclo profético era un Papa angélico que debería ser simul Regem et sacerdotem secundum ordinem Melchisedech (Concordia Novi et Veteri Testamenti, IV); era la versión escatológica de una imagen que acuñó en lo político Inocencio III (cf. "Joachim of Fiore as a link between St. Bernard and Innocent III on the figural significance of Melchisedech", Mediaeval Studies, 42,1980 ). Reeves (cf. op. cit., p. 63) señala que el favor mostrado por los papas hacia el abad fue strikingly consistent.

12 A.C.A., Reg. $n^{\circ}$ 193, fol. 69v; Lérida, Abril de 1302. 
íntimos anhelos de su soberano cuando proclamaba que la dinastía aragonesa estaba llamada a la Monarchia Mundi.

En efecto, el comentario de Vilanova a la profecía joaquinita Vae Mundo in centum annis anunciaba ${ }^{13}$ que surgiría de España un Rey que destruiría la machometicae pravitas y que, tras someter África y Egipto, alcanzaría la Monarquia ${ }^{14}$ del orbe.

Pero no fue esta la principal innovación introducida por el visionario catalán en el esquema joaquinita. De hecho, con ello no hacía sino aplicar a España el viejo arquetipo milenarista del emperador de los últimos tiempos, arquetipo que ya había sido incorporado a lo largo del siglo XIII a los ciclos proféticos joaquinitas (aunque no estaba presente en la obra original del abad de Fiore, que únicamente contemplaba la figura del Papa angélico ${ }^{15}$ ).

La importancia de la novedad introducida por la profecía vilanoviana radica en su utilización de una imagen alegórica cargada de significado: la figura del Vespertilio. Esta figura, cuyas implicaciones serán analizadas en profundidad más adelante, era la imagen del Murciélago que Jaime I había dado a Valencia y Mallorca como emblema, el Rat penat que simbolizaba de algún modo al Casal d'Aragó en la mentalidad popular ${ }^{16}$.

Sin embargo, el emblema de Jaime el Conquistador no era un Murciélago sino en la imaginación popular ${ }^{17}$. Se trataba en realidad de un Drac alat, el Dragón de San Jorge ${ }^{18}$, que Arnaldo de Vilanova asimiló al Dragón Alado del Apocalipsis ${ }^{19}$. Esta elección simbólica no fue casual pues enlazaba directamente con la tradición escatológica staúfica y, lo que es aún más importante, situaba claramente a la profecía en el ámbito del ciclo profético imperial más opuesto al mensaje hierocrático joaquinita ${ }^{20}$.

13 Hyspania, nutrix machometicae pravitatis, reciproca furia laniabitur nam in invicem ipsius regna consurgent... subjiciensque Africam et Caput Bestiae conterens accipiet Monarchiam et in posteris humiliet Nili habitatores (apud Pou Martí, op. cit., p. 55).

14 A la luz de la teoría política medieval hay que interpretar la frase de Vilanova accipiet Monarchiam en el sentido de una aspiración al Imperio universal. El concepto Monarchia se reservaba en el lenguaje medieval exclusivamente para designar a los estados mundiales (aunque lo fueran sólo conceptualmente, como en el caso del Imperio Romano Germánico), mientras que el resto de las formaciones políticas recibían el nombre de Regnum.

15 La figura del emperador de los últimos tiempos era propia del ciclo escatológico imperial bizantino, siendo aplicada repetidamente a la Casa de Suabia por sus partidarios a través de la idea de un Tercer Federico. Los joaquinitas respondieron recuperando la idea de un Segundo Carlomagno (que sería francés y no alemán) anunciado como el fiel ejecutor de los designios del Papa Angélico, de la misma forma que la Francia de los Capetos actuaba en esos años como la obediente hija de la Iglesia. Hasta que se produjo esta recepción la figura del emperador de los últimos tiempos representaba para los joaquinitas una alegoría del Anticristo (cf. Marjorie REEVES, «Joachimist influences on the idea of a Last World Emperor», Traditio, XVII, 1961, p. 328).

16 Cf. A. MILHOU, art. cit., pp. 63-69.

17 No sería hasta el siglo XVII el que la transformación del Dragón en Murciélago se hiciera oficial en la heráldica (cf. A. MILHOU, loc. cit.).

18 Proclamado solemnemente en 1344 como emblema de la Corona de Aragón.

19 Cf. A. MILHOU, loc. cit., y J.M. POU MARTÍ, op. cit., pp. 56-59.

20 R. Manselli cuestiona abiertamente que Vilanova estuviera influenciado por el joaquinismo (cf. La Religiosità d'Arnaldo de Villanova, Roma, 1951, pp. 20-23). 
En el marco de una estricta simbología profética la elección vilanoviana del Dragón alado como símbolo era de una enorme trascendencia. De hecho, la sexta y la séptima capita Draconis del Apocalipsis habían sido interpretadas por Joaquín de Fiore y los joaquinitas como símbolos respectivos del anunciador del Anticristo y del propio Antichristus pessimus ${ }^{21}$.

Teniendo en cuenta que era opinión comúnmente aceptada entre los joaquinitas que Federico II había sido la sexta cabeza del Dragón ${ }^{22}$ y que de su sangre nacería el Anticristo (asimilado al Tercer Federico esperado por los gibelinos) ${ }^{23}$, se puede calibrar el trasfondo de la imagen utilizada por Vilanova quien era, no lo olvidemos, amigo y consejero del Rey Federico III de Sicilia ${ }^{24}$, un Staufen por linea materna muy mal visto en la Curia.

La elección de la imagen del Dragón por Vilanova es indicativa de una consciente opción gibelina poco conciliable con la simbología joaquinita. La imagen vilanoviana sólo cobra pleno sentido a la luz de su obra profética fundamental, el De adventu Antichristi et fine Mund ${ }^{25}$ (año 1299), donde se desata en invectivas contra el clero, clama por la reforma de la Iglesia y anuncia la venida del Anticristo para 1345. Esta faceta destructora, purificadora y, en último término, reformadora, es la que encarnaba el Dragón apocalíptico en el pensamiento escatológico gibelino.

En los ciclos proféticos imperiales el Tercer Federico siempre asumía una función destructora, de reforma violenta y traumática de la Iglesia. Así, el hereje dominico fray Arnoldo de Suabia proclamaba en su De correctione Ecclesiae (año 1248) la venida de un emperador de los últimos tiempos que reformaría a sangre y fuego la depravada Iglesia romana dentro de una necesaria Sexta Era de tribulación ${ }^{26}$.

De un modo similar, el mensaje vilanoviano contenido en el De adventu Antichristi era tan subversivamente anti-hierocrático que los teólogos de la Universidad de París consiguieron hacerle encarcelar (pese a su condición de embajador de Aragón) orde-

21 Cf. M. REEVES, "The idea of a Last World Emperor", art. cit., p. 324.

22 Cf. Ernst H. KANTOROWICz, Kaiser Friedrich der Zweite, Munich, 1927, c. I: Joaquín de Fiore anunció a los pocos días del nacimiento de Federico Il que la emperatriz Constanza acababa de dar a luz al tirano universal que anegaria el mundo en un océano de sangre tras regir las naciones con vara de hierro. En las obras pseudo-joaquinitas Super Hieremiam (publ. en Venecia, 1516, fol. 11v) y Praemissiones (ms. Vat. lat. 4959, fol. 2v) se repite esta identificación con la sexta cabeza del Dragón, así como en las Distinctiones de Tomás de Pavía (año 1260, publ. Archivum Franciscanum historicum, XVI, 1923, pp. 27-28).

23 Así lo afirma el tratado pseudo-joaquinita Vaticinium Sibillae Erithreae (año 1252, ed. HolderEgger, en Neues Archiv der Gesellschaft für altere deutsche Geschichtskunde, XV, 1889, p. 168); cf. M. REEVES, art. cit., p. 326, n. 8.

24 P. DIEPGEN, Arnold von Vilanova als Politiker und Laientheologe, Berlín, 1909.

25 Códice 3824 de la Biblioteca Vaticana.

26 Cf. Crónica de Alberto de Stade, M. G. H., Scriptores, XVI, p. 371; M. REEVES, art. cit., p. 326, n. 9; Por otro lado, Robert Graves ha señalado que el Murciélago del escudo de Mallorca está tomado del Khufaash de los sufíes andalusíes cuyo significado es de ruina y destrucción (vid. su introducción a The Sufis de Idries Shah, 1964). 
nando posteriormente el papa Bonifacio VIII que se quemara la obra y se le encarcelara de nuevo en Aviñón ${ }^{27}$.

También de influencia joaquinita son dos anónimos proféticos catalanes de mediados del siglo XIV: los Versos profètics y la Summula super concordia Novi et Veteri Testamentip. Ambos muestran una concepción histórica inspirada en el Evangelio Eterno que incluye la predicción de un glorioso status Mundi tertius, pero difieren, sin embargo, en su inclinación política.

Así, mientras que el autor de los Versos profètics enmarca su visión en el esquema tradicional de Joaquín de Fiore, anunciando las calamidades que sobrevendrán a la Iglesia por obra de un pseudo-profeta elevado al solio pontificio ${ }^{29}$, la Summula, por el contrario, es una obra al servicio de la exaltación mesiánica del Casal d'Aragó.

El desconocido franciscano catalán que compiló la Summula hacia $1368^{30}$ utiliza hábilmente la estructura discursiva del Liber Concordie joaquinita de extrapolación al presente de los hitos temporales del Antiguo Testamento ${ }^{31}$ para insertar en su interior una predicción ex eventu inspirada en la famosa profecía bíblica de las Cuatro Monarquías del Mundo de Daniel (cap. XI).

A pesar de que Reeves califica al autor de la Summula como un perfecto discípulo de Joaquín de Fiore ${ }^{32}$, 10 cierto es que la interpolación introducida por el fraile en la obra joaquinita sigue decididamente la estela de Vilanova.

De otro modo no se puede interpretar la comparación alegórica que realiza entre Alejandro Magno y Pedro III el Grande, comparación por la cual el papel desempeñado por la Macedonia imperial (designada por el profeta Daniel como el macho cabrío) sería ocupado en el siglo XIII por Cataluña ${ }^{33}$, quedando relegados Sicilia y Carlos de Anjou a la triste posición de Persia y el Rey Darío, quienes son vencidos poc en persona por el Rey de Aragón en semblanza de las victorias obtenidas por Alejandro ${ }^{34}$.

27 Cf. MENÉNDEZ PELAYO, op. cit., p. 497.

28 Ambos contenidos en el ms. de la B. N. de Madrid no 6972 (cf. Pere BOHIGAS, «Profecies catalanes dels segles XIV i XV: assaig bibliogràfic", Butlletí de la Biblioteca de Catalunya, VI, 1920-22, pp. 6-7; REEVEs, The influence of Prophecy, op. cit., p. 223.

29 Pseudo propheta culmine Sedis pontificatur, regnabit ficto lumine in seculo sublimatur, clerus perdet Imperium reptans expoliatus ( $v$ v. 24-26, apud Pere Bohigas, loc. cit.). Las únicas concesiones realizadas por el autor a su patria son una apelación a la Virtus yspanis (v. 23) y la sustitución del emperador de los últimos tiempos por los barbari pagani como figura maléfica, único punto en que se aleja del modelo joaquinita.

30 Fecha avanzada por M. REEVES, loc. cit., p. 223.

31 Para Reeves el autor de la Summula es the clearest evidence of a Spanish Joachite who was searching the writings of Joachim at this time and adapting them to contemporary needs (loc. cit., $p$. 223). No otra cosa hizo Arnaldo de Vilanova.

32 ... we see him as a full disciple of Joachim; op. cit., p. 224.

33 ... sicut Persia tangit Ciciliam ita Macedonia Cataloniam (fol. 37, apud. P. Bohigas, art. cit., p. 8). Muntaner avanza esta idea cuando afirma que el Rey Pedro III és lo pus alt hom de cor que anc nasqués d'Alexandri e ençá (cf. Crònica, c. LXXII).

34 Así lo confirma la traducción catalana de la Summula, llamada Refundició compendiada (ms. no 336 de la B. Mun. de Carpentras, apud. P. Bohigas, art. cit., p. 9). 
Pero las visiones imperiales del franciscano catalán no se quedaban ahí. También anunciaba el sometimiento de los reinos hispánicos a la hegemonía de la Casa de Aragón, de la misma forma que Grecia lo había estado a la de Macedonia ${ }^{35}$. Estas profecías realizadas ex eventu, casi un siglo después del Vespro, pueden ser un síntoma de la voluntad de construir en el siglo XIV una plataforma escatológica legitimadora de la conciencia imperial catalana.

Ahora bien, no todo el ciclo profético catalano-aragonés siguió el camino de exaltación monárquica que había iniciado Arnaldo de Vilanova. Hubo obras que se mantuvieron dentro de los márgenes del joaquinismo más estricto. Algunas, incluso, se sumaron con entusiasmo a la publicística más furiosamente güelfa para denunciar al Casal d'Aragó como la estirpe del Anticristo, siendo así fieles continuadoras del ideario hierocrático del abad.

Dentro de la más pura ortodoxia joaquinita ${ }^{36}$ destacan tres obras del ciclo catalán: el anónimo De Statibus Ecclesiae secundum Apocalypsim ${ }^{37}$ (c. 1318), el De Triplici Statu Mundi de Francisco de Eiximenis $(1398)^{38}$ y, sobre todo, las obras del franciscano provenzal Juan de Rocatallada.

La faceta profética del místico franciscano Francisco de Eiximenis plantea, no obstante, algunos problemas de filiación ideológica. Sin lugar a dudas la impronta joaquinita en su obra es evidente, en particular la influencia de Ubertino de Casale ${ }^{39}$, reflejada en la aparición de lugares comunes de los espirituales como las Tres Edades del Mundo y la Reformatio Ecclesiae.

Sin embargo, se aprecian algunos puntos de díficil explicación. El hecho de que fray Eiximenis, pese a su cercanía a la dinastía aragonesa (que había ejercido un continuado mecenazgo sobre su carrera ${ }^{40}$ ), fuera acusado en 1391 por el Rey de predecir para el año 1400 el fin de todas las Monarquías de la Cristiandad a excepción de un triunfante Reino de Francia es cuanto menos desconcertante ${ }^{41}$.

Esta profecía típicamente güelfa, habitualmente incluida en los anuncios de la venida del Segundo Carlomagno ${ }^{42}$, encaja únicamente en un perfil político inclinado hacia posturas de abierta simpatía hacia la entente formada por Francia y Aviñón. Eiximenis

35 ... unde sicut Regnum graecorum, Regnum ispanorum (fol. 37, loc. cit.).

36 Reeves los califica como genuine joaquites (loc. cit., p. 224).

37 Obra conocida a través de los 42 artículos extraídos de su seno por la Inquisición, artículos descubiertos por J.M. Pou y Martí (cf. Visionarios, op. cit., pp. 255-8).

38 Martí de Barcelona ha negado la autoría de esta obra a Eiximenis (cf. «Fra Fr. Eximeniç», Estudis Franciscans, 1928). Sin embargo, la defienden Massó, Pou y Martí y Atanasio López.

39 Cf. M. REEVES, op. cit., p. 222.

40 Desde el Infante Martín al propio Pedro III (cf. M. J. PELÁEZ, «Francisco de Eiximenis y la sociedad eclesiástica de su tiempo", Estudis Franciscanis, 1977, p. 459).

41 Cf. P. BOHIGAS, Profecies catalanes, art. cit., p. 16. Este hecho se conoce a través de una carta del Rey Juan I de Aragón a Pere d'Artés de 17 de Noviembre de 1391. La fecha dada por Eiximenis para el inicio del milenio coincide con la de Rocatallada.

42 Vid. M. REEVES, op. cit., capítulo III: The Second Charlemagne, pp. 320-331. De hecho, Eiximenis incorporó esta profecía hierocrática de la venida de un emperador de los Ultimos Tiempos, subordinado al Papa angélico, que conquistaría Jerusalén. 
se vio pronto obligado a presentar sus excusas al Rey ${ }^{43}$ y denunciaría posteriormente en su Regiment de Princeps como fantasies a las profecías que circulaban sobre el final de los tiempos ${ }^{44}$.

Además, está la cuestión de la imposible conciliación entre el apoyo dado en el De Triplici Statu Mundi a la posición del papa Urbano VI (que era la encarnación de lo anti-francés en ese momento) y la profecía francófila antes mencionada. Estas extrañas piruetas dadas por el franciscano catalán tienen díficil explicación.

Explicación aún más díficil si atendemos al hecho de que en otra de sus obras, el Primer del Crestiá, Eiximenis se destaca como un abanderado del imperialismo escatológico aragonés. En este tratado afirma sin ambages que ha sido profetizado del Casal aragonés que llegará a conseguir la Monarquía Universal ${ }^{45}$, pues Dios lo habría elegido para grandes tareas, entre ellas la de culminar la Cruzada que destruirá toda la secta de Mahoma ${ }^{46}$.

Esta obra imbuida de la tradición escatológica más genuinamente imperial ha llevado a algún autor a calificar a Eiximenis como a un incondicional de la Monarquía aragonesa, en el cual el sentimiento imperialista catalán arriba a su máximo esplen$d o r^{47}$. Pero, ¿cómo conciliar entonces estas afirmaciones con el mensaje del De Triplici Statu Mund?

Quizá la respuesta la haya ofrecido Ángel López-Amo cuando atribuye a rasgos de indecisión en lo doctrinal y a una falta de voluntad para llevar a su conducta las convicciones de su mente los vaivenes políticos del gran místico franciscano ${ }^{48}$. En efecto, fue en el reino de Aragón donde primero se condenó abiertamente como hereje a Joaquín de Fiore (año 1342) ${ }^{49}$ y era ciertamente aventurado para Eiximenis mostrar inclinaciones de este tipo.

Menor ambigüedad ofrecen los planteamientos de Juan de Rocatallada, radicalmente inclinados hacia las posiciones de Francia y el Pontificado. El fraile de Aurillac, apasionado joaquinita y seguidor de las doctrinas del enigmático visionario fraticelo Pierre Jean d'Olivi ${ }^{50}$, fue uno de los más prolíficos autores proféticos de la Edad Media, destacando entre sus obras el Liber Secretorum Eventuum y el Vade mecum in Tribulatione.

43 El 12 de Diciembre de ese mismo año (cf. P. BOHIGAS, loc. cit., p. 16),

44 Cf. Regiment, cap. 473; vid. P. BOHIGAS, Profecies catalanes, art. cit., p. 17.

45 D'aquesta Casa ès profetat que deu aconseguir Monarchia quasi sobre tot lo Món (Primer del Crestià, Va 247; ed. J. Torras i Bages, La tradició catalana, Barcelona, 1924, p. 323).

46 Car és Casa que Déu ha elegida a fort grandes obres a fer, e a fort meravelloses (Primer del Crestià, op. cit., ed. cit., V' 247).

47 Cf. M. J. PELÁEZ, “Los conceptos França y Espanya en el pensamiento literario y jurídicopolítico de Francesc de Eiximenis», Bulletin Hispanique, 82, 1980, p. 355.

48 Cf. "El pensamiento político de Eximeniç», A. H. D. E., XXIII, 1946, p. 46.

49 Ese año el obispo de Mallorca incluía al abad en su Summa de Haeresibus. Hasta ese momento sólo habían sido condenadas algunas ideas del visionario (el trinitarismo en el concilio de Letrán de 1215, por ejemplo) pero nunca su persona; Reeves, op. cit., p. 69.

50 Cf. M. REEVES, The influence of Prophecy, op. cit., p. 225. 
A pesar de haber sufrido doce años de prisión a manos de la Inquisición Rocatallada se nos aparece como un ferviente devoto de la Iglesia romana. Así, no duda en sus Visiones de 1345 en atribuir a la dinastía aragonesa la continuidad de la simiente venenosa y diabólica de Federico II, afirmando que Pedro III el Grande fue el segundo Anticristo y Federico III de Sicilia el cuarto, de quien nacería el Antichristus magnus ${ }^{51}$. Por contra, en su Vade mecum anuncia que el Rey de Francia será elegido emperador y someterá el totus orbis como fiel ejecutor de las ordenes del Papa angélico ${ }^{52}$.

En estas obras Juan de Rocatallada se hace eco de las ideas del joaquinismo francés primigenio, en particular del Liber de Flore, donde aparece por vez primera la idea de la colaboración con el Papa angélico de un Rex generosus de la línea de los Capeto. Sin embargo, en palabras de Reeves, fue Rocatallada el primero en convertir esta imagen en un completo programa de joaquinismo político al servicio de la Monarquía francesa ${ }^{53}$.

Del mayor interés es su comentario al opúsculo pseudojoaquinita conocido como Oraculum Cyrilli. En él realiza una acabada caracterización de la Casa de Aragón como la dinastía del Escorpión, instrumento del Anticristo y fuente de todos los males políticos del siglo por su condición de sucesores de los Staufen, esa raza maldita, herética y luciférica ${ }^{54}$. Aparecía así como un hecho evidente para Rocatallada la conexión política staúfico-aragonesa. Esta percepción, aunque sea por parte de un enemigo de Aragón, no deja de ser por ello indicativa de la existencia de una opinión extendida al respecto.

\section{PRESENCIA DE FIGURAS ALEGÓRICAS STAÚfICAS EN LA ESCATOLOGÍA IMPERIAL ARAGONESA; POSIBLES LÍNEAS DE CONTINUIDAD SIMBÓLICA E IDEOLÓGICA}

Ha sido Alain Milhou el primer investigador en conceder la importancia debida a la trascendental figura alegórica del Vespertilio en el marco del ciclo profético catalán ${ }^{55}$. Desgraciadamente, no profundizó por completo en las implicaciones que se derivan de su instrumentación como símbolo.

No obstante, ha dejado apuntada la principal vía de explicación del asunto al señalar que, junto a la influencia joaquinita, el imperialismo catalán encontró su justificación en las profecías escatológicas aplicadas a Federico II, profecías que habrían llegado al reino de Aragón a través del matrimonio de Constanza de Sicilia con Pedro III,

51 Cf. P. BOHIGAS, Profecies catalanes, art. cit., p. 9.

52 Cf. E. JACOB, «John of Roquetaillade», Bulletin of John Rylands Library, XXXIX, 1956-7, pp. 75-96 y P. Bohigas, art. cit., p. 10.

53 Cf. M. REEVES, op. cit., p. 321 . Este programa no era sino la translación escatológica del pensamiento político de Pierre Dubois, quien proclamó la misión cósmica encomendada por Dios al Rey Cristianisimo en su De Recuperatione Terre Sancte.

54 Cf. J. BIGNAMI-ODIER, Etudes sur Jean de Roquetaillade, París, 1952, pp. 53-109.

55 Cf. La Chauve-Soris, le Nouveau David et le Roi Cache, art. cit. 
un enlace que convirtió al monarca aragonés en el heredero de las ambiciones gibelinas universales de la Casa imperial de Suabia ${ }^{56}$.

Los síntomas de la formación de una incipiente escatología, reflejo de la toma de conciencia imperial catalana, abundan en el último cuarto del siglo XIII. La Crònica de Ramón Muntaner ${ }^{57}$ o el Llibre dels Feits de Jaime I son buenos ejemplos de ello. En este sentido, la obra autobiográfica del Rey Conquistador nos ofrece el primer testimonio del ciclo profético imperial: la visió del menoret. El sueño profético de un franciscano (como no podía ser de otro modo) de Navarra anunciaba al Rey Jaime que un Rei d'Aragó que ha nom Jacme habría de restaurar tots los crestians en Espanya $a^{58}$.

A estos primeros indicios de una escatología autóctona hay que sumar el papel decisivo que sin duda jugó la transmisión de la mentalidad staúfica a través de los exiliados de Sicilia que llegaron a Aragón con Constanza ${ }^{59}$.

La recepción de la mística escatológica staúfica en la corte aragonesa se centró básicamente en dos figuras alegóricas: la imagen hespérica y la efigie del Dragón como símbolo mesiánico de la Realeza.

No exageramos al afirmar que la imagen hespérica fue la plasmación literaria más acabada, en un lenguaje mítico-simbólico, de esa translatio Imperii que, de alguna forma, se produjo entre los Staufen sicilianos y los hispánicos (entendiendo por estos últimos a ambas ramas, la castellana y la aragonesa, nacidas de los matrimonios de Beatriz de Suabia y Constanza de Sicilia con sendos monarcas ibéricos) ${ }^{60}$.

Tras la muerte del Rey Manfredo en la batalla de Benevento (1266), esta translatio apareció como algo evidente para algunos círculos gibelinos italianos y

56 Limperialisme catalan, qui s'était rendu maître de la Sicile dès 1282, pouvait trouver sa justification dans les prophéties eschatologiques jadis appliquées à l'empereur Frédéric II de Hohenstaufen, Roi de Sicile et de Jérusalem; en effect, per le mariage de Pierre III avec Constance, le petite fille de Fréderic, les rois d'Aragon avaient hérité des ambitions gibellines universelles de celuici... (A. MILHOU, art. cit., p. 62).

57 Muntaner hace exclamar al Papa: Que cascun cavaller d'aquells de Catalunya són diables encarnats... aquestes són gents ab qui conquistariem lo Món, e metria'n hom abaix tots los infeels (cf. Crònica, c. CXLIX, p. 7, t. II, ed. M. Gustà, Barcelona, 1979).

58 Cf. Llibre dels Feits, c. CCCLXXXIX, p. 326, ed. Ferrán Soldevilla, Barcelona, 1982; esta profecía era aplicable también a Jaime II ¿fruto de una interpolación posterior?

59 Helene Wieruszowski considera di grande importanza el papel jugado en la corte aragonesa por estos exiliados, destacando figuras como las de Juan de Prócida, Roger de Lauria, Conrado y Manfredo Lancia, Francisco Trogisio, Nicolás de Aspello... ("La corte di Pietro d’Aragona", en Politics and Culture in Spain and Italy, Roma, 1971, p. 201).

$60 \mathrm{El}$ fecho del /mperio en que se vio envuelto Alfonso $X$ no es un fenómeno que se pueda desligar del Vespro siciliano y los inicios del imperialismo aragonés. De hecho, Pedro III no hizo sino recoger el testigo en Italia del liderazgo gibelino ejercido allí por el Rey de Castilla entre 1268 y 1280. Por otro lado, el Rey Sabio fue objeto de una campaña similar a la sufrida posteriormente por Aragón: un joaquinita tan destacado como Gerardo del Borgo San Domnino (autor de la Introducción al Evangelio Eterno) le tildó de ser el Anticristo en 1258 (vid. Antonio BALLESTEROS, Alfonso X, Barcelona, 1984). 
alemanes ${ }^{61}$. Apenas dos años después circulaba en Alemania e Italia la profecía Regnabit Menfridus que anunciaba el advenimiento de un Tertius Fridericus, nomine orientalis, que destruiría al León francés (cuya encarnación era Carlos de Anjou) ${ }^{62}$. Aunque el Federico del Oriente al que se alude en la profecía era un alemán, el hijo del landgrave de Turingia ${ }^{63}$, se vaticinaba en ella que la destrucción de Francia sólo se produciría tras una confederación de Alemania con los reinos españoles: Theutonici et Hyspani confederabuntur et Regnum Francie redigent in nichilum ${ }^{64}$.

Una docena de años después un canónigo gibelino de Colonia, Alejandro de Roes (célebre por sus obras políticas en defensa de un Imperio Universal germánico) al poco tiempo de haber dado continuidad a la profecía del Tercer Federico en su De translatione Imperii $(1281)^{65}$, componía un extraño epigrama satírico, el Prologus in Pavonem (1285).

En este breve opúsculo Alejandro de Roes realiza una alegoría animal del Concilio de Lyon (1245), en la que el Papa Inocencio IV, simbolizado por un Pavo, arrebata injustamente el Imperium sobre los animales al Aquila (el emperador Federico II) con el fin de entregárselo al intrigante Gallus (el Rey de Francia). El final de la sátira consiste en una profecía en la que Alejandro de Roes, un enemigo declarado del papa Martín IV y de Francia, anuncia que la injusticia cometida con el Aquila será vengada por los falcones peregrinos (los españoles) ${ }^{66}$.

Ahora bien, este anuncio, aunque tiene de por sí grandes implicaciones, sólo cobra toda su significación a la luz del enigmático último verso del poema: quos illis Grecus, Calaber transmisit et Hesper ${ }^{67}$. El editor, Herbert Grundmann, interpretó esta alusión

61 Ello es fácilmente comprobable asomándose a las crónicas gibelinas del norte de ltalia compuestas en esos años. Los Anales lanuenses, los Anales de Oberto Stanconi, los Anales lacobi Aurie o los Anales Placentini Gibellini confirman esta impresión (publ. en los M. G. H., Annales Italiae, t. XVIII, Hannover, 1863, pp. 228-574).

62 Cf. Chronica Minor Auctore Minorita Erphordiensi, M. G. H., XXIV, p. 207. Esta profecía, originada en un ámbito gibelino italiano, fue llevada a Alemania por el cardenal-obispo de Porto (cf. M. REEVES, The influence of Prophecy, op. cit., p. 313). De similar contenido era la profecía antifrancesa Gallorum levitas, gestada en esos años.

63 Cuya madre era una Staufen; cf. M. BLOOMFIELD y M. REEVES, «The Penetration of Joachism into Northern Europe», Speculum, 29, 1954, p. 790.

64 Cf. Chronica Minor, loc. cit.; Esta profecía no hacía sino recoger las esperanzas depositadas por los gibelinos ítalianos en Castilla y Aragón, las únicas potencias europeas que tras la batalla de Tagliacozzo desafiaban aún al bloque güelfo-angevino.

65 De huius Frederici germine radix peccatrix erumpet Frederico nomine qui clerum in Germania et etiam Romanam Ecclesiam valde humiliabit et tribulabit vehementer (ed. H. Grundmann, «Die schriften des Alexander von Roes", Kritischen Studientexte der M. G. H., IV, Weimar, 1949, p. 30).

66 Ut qui nolebant Aquila regnante modeste,

conregnare sibi contenti finibus illis,

Quos natura deditm discant moriendo rebelles

Bubones, milvos et falcones peregrinos... (ed. H. Grundmann, Die schriften des Alexander von Roes, op. cit., vv. 268-271, p. 122). La identificación de los falcones con los hispani es realizada por el propio Alejandro de Roes es el proemio al poema.

67 Prologus in Pavonem, v. 272, p. 122, ed. cit. 
al Hesper como un anuncio, concebido abiertamente como un vaticinium ex eventu, de las Vísperas sicilianas ${ }^{68}$.

Era ésta la primera vez que se realizaba el fácil juego de palabras alegórico entre el acontecimiento del Vespro y el nombre que la mitología clásica había otorgado a la península ibérica. No obstante, la elección de la noción Hesperia como figura alegórica no se debió únicamente a una similitud semántica y formal con el término latino para la tarde, sino al conjunto de connotaciones que tenía en la literatura pagana clásica como sinónimo del Occidente más extremo, del Poniente ignoto sede del Jardín de las Hespérides y de los Campos Elíseos.

En efecto, la publicística staúfica ya había utilizado la imagen hespérica en su escatología más primigenia. El médico de la corte siciliana, Pedro de Eboli, al glosar el nacimiento de Federico It en su De rebus Siculis carmen (1195) y profetizar los triunfos que alcanzaría, menciona que su nativitas se había producido ab Experia ${ }^{69} y$ califica a su madre, la reina Constanza, como Experiam diem, la luz del Occidente (v. 1063). Y, dentro del ciclo escatológico imperial bizantino (que tanta influencia ejerció en el staúfico), se anunciaba desde el siglo XII la conquista de Jerusalén por parte de un Rey de cabellos rubios, al que se denomina Estrella del Poniente ${ }^{70}$.

Alain Milhou menciona a este respecto una profecía castellana de finales del siglo XIII atribuida al sabio árabe Acham Turuley que anuncia la venida de un Rey mesiánico en los últimos fines de Poniente ${ }^{71}$. Siendo España el país más occidental de la Cristiandad era lógico que la imagen hespérica se convirtiera pronto en un motivo recurrente para el ciclo profético catalán.

De esta forma, la ya mencionada Refundició denomina de forma reiterada Rei Pere de Ponent a Pedro III, aludiendo a un misteri de Ponent iniciado por el monarca aragonés al conquistar Sicilia y a culminar con el sant passage a Jerusalén ${ }^{72}$. El nomen orientalis del Tercer Federico alemán iba a dejar así paso al misteri de Ponent aragonés.

La imagen del Vespertilio de Arnaldo de Vilanova tuvo la virtud de aúnar gráficamente en un único símbolo esta idea del monarca mesiánico venido de Occidente con la figura staúfica del Dragón. De ahí su posterior difusión.

Al igual que el Aguila era comúnmente interpretada como símbolo del Imperio romano en general y de Alemania en particular, el Dragón (cuyas connotaciones eran

68 En la introducción a su edición de las obras de Alejandro de Roes, Grundmann señala que los versos 270-272 son un prophetisch anspielen del Sizialianische Vesper (cf. Die schriften des Alexander von Roes, op. cit., p. 12). Por otro lado, en su traducción del poema intercambia claramente el término Hesper por Spanien.

69 Venit ab Experia nativi palma triumphi (cf. «De rebus Siculis carmen», ed. L.A. Muratori, v. 1363, Rerum Italicarum Scriptores, XXXI, 1094, p. 177). Muratori indica que el término Experia o Hesper se aplica por igual a Italia o España, tierras occidentales.

70 Cf. Paul ALPHANDÉRY, La Chretiente et lidée de Croisade, París, 1954, II, p. 91.

71 Cf. ms. de la B. N. de Madrid, nº 18725; A. MILHOU, Le Chauve Soris, art. cit.

72 Cf. Refunfició compendiada de la Summa Concordiae Veteris et Novi Testamenti, op. cit., apud Pere Bohigas, Profecies catalanes, art. cit., pp. 8-9. 
claramente diabólicas para la escatología de la Iglesia), se había convertido de alguna forma en el emblema de los Staufen. Así, el ciclo legendario gibelino narraba que la reina Constanza, había soñado ${ }^{73}$ poco antes de dar a luz que de su vientre iba a surgir un Dragón cuyo fuego abrasaría toda Italia. El apelativo filius Draconis sería repetidamente aplicado en el futuro a Federico II tanto por parte de sus enemigos ${ }^{74}$ como por sus fieles. $Y$ es que en la mentalidad mitológica germánica el Dragón no tenía las mismas connotaciones negativas que en la judeo-cristiana. Wolfram von Eschenbach, por ejemplo, relata que la madre de Parsifal, Herzeloïde, había soñado también que iba a dar a luz a un Dragón ${ }^{75}$.

El infante aragonés don Pedro, miembro de la Orden franciscana, recogió en el año 1347 la imagen vilanoviana del Vespertilio y la insertó en la estructura de la Prophetia Tripolitana, una visión tenida por un monje cisterciense en Tierra Santa, cuya primera versión circuló hacia $1240^{76}$.

El emperador de los últimos tiempos conquistador de Jerusalén anunciado por el monje libanés se convierte en la versión latina de don Pedro en el Vespertilio ${ }^{77}$. En su glosa en catalán el Infante minorita va aún más lejos y vaticina que la Rata pinyada (el Vespertilio) destroira les mosques d'Espanya e sotsmetra a si Affrica e pendra la senyoria general del Mon, ço es l'Imperi ${ }^{78}$. El programa imperial aragonés era así recogido en su integridad por quien, reuniendo en su persona la doble condición de infante y franciscano, era el más indicado para formularlo en clave escatológica.

Dos secuelas tardías de la imagen del Vespertilio se encuentran en el Primer del Crestiá de Francisco de Eiximenis, donde aparece una difusa alusión a la Rata pennada ${ }^{79}$, y en la Explicació d'alguns secrets de l'Escriptura (año 1449), que hace del Rey aragonés Alfonso IV la última encarnación del Vespertilio ${ }^{80}$, del que dice ser el fill de l'Aguila ¿Tendría conciencia el anónimo autor del origen alemán del Murciélago aragonés?

73 Cf. Ernst H. KANTOROWICZ, Kaiser Friedrich der Zweite, op. cit., c. I.

74 Una profecía joaquinita de 1264 llama a Federico II Draco repletus furore; Para Reeves es un testimonio de la popularidad del Dragon-symbol (cf. The influence of Prophecy, op. cit., p. 51).

75 Aspecto apuntado por KANTOROWICZ; loc. cit.

76 Esta profecía conoció una larga y exitosa serie de reediciones en 1240, 1287, 1289, 1291 y 1297 siendo esta última la que glosa el Infante argonés; cf. Robert E. LERNER, «Medieval Prophecy and religious dissent», Past and Present, 72, 1976, pp. 12-13.

77 ... cedrus alta Libani succidentur et Tripolis in brevi destruetur et aconcapietur et maris Saturnus insidiabitur Jovi et Vespertilio fugavit eum (apud P. BOHIGAS, Profecies catalanes, art. cit., p. 11, n. 3).

78 Ms. de la B. Mun. de Carpentras, $n^{\circ}$ 336, f. 76r, apud P. BOHIGAS, art. cit., p. 11.

79 Cf. POU Y MARTÍ, Visionarios, op. cit., pp. 397-415; Milhou, La Chauve Soris, art. cit.; esta alusión de Eiximenis indica su conocimiento del significado de la alegoría, pero no que compartiera el mensaje ímplicito en ella.

80 Cf. P. BOHIGAS, art. cit., p. 24. 
. 


$$
\text { . }
$$ 


